\title{
Nadgrobni spomenici na području povijesne Zagrebačke biskupije od XV. do XVIII. stoljeća
}

Žvorc, Maja

Doctoral thesis / Disertacija

2021

Degree Grantor / Ustanova koja je dodijelila akademski / stručni stupanj: University of Zagreb, Faculty of Humanities and Social Sciences / Sveučilište u Zagrebu, Filozofski fakultet

https://doi.org/10.17234/diss.2021.8279

Permanent link / Trajna poveznica: https://urn.nsk.hr/urn:nbn:hr:131:431146

Rights / Prava: In copyright/Zaštićeno autorskim pravom.

Download date / Datum preuzimanja: 2023-04-26

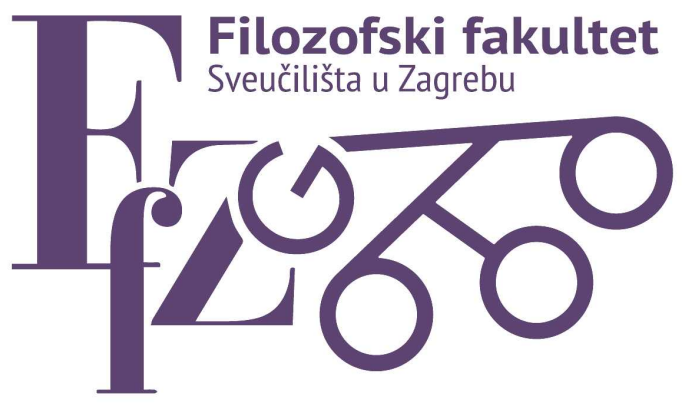

Repository / Repozitorij:

ODRAZ - open repository of the University of Zagreb

Faculty of Humanities and Social Sciences
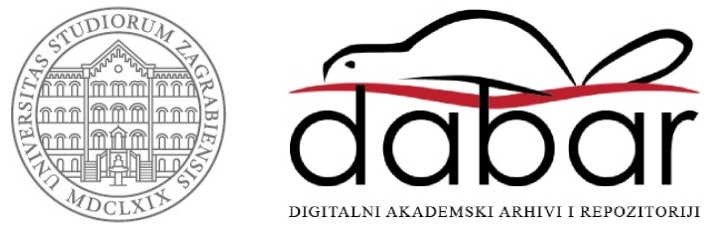


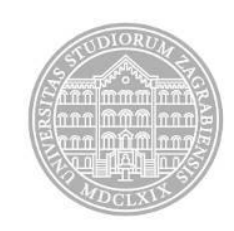

Sveučilište u Zagrebu

Filozofski fakultet

Maja Žvorc

\section{NADGROBNI SPOMENICI NA PODRUČJU POVIJESNE ZAGREBAČKE BISKUPIJE OD XV. DO XVIII. STOLJEĆA}

DOKTORSKI RAD

Mentorica:

dr. sc. Sanja Cvetnić

Zagreb, 2021. 



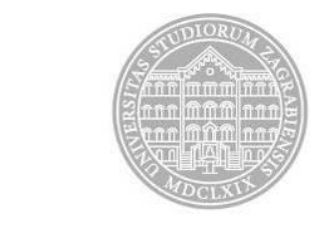

University of Zagreb

Faculty of Humanities and Social Sciences

Maja Žvorc

\section{TOMB MONUMENTS IN THE HISTORICAL DIOCESE OF ZAGREB FROM THE $15^{\mathrm{TH}}$ TO $18^{\mathrm{TH}}$ CENTURY}

DOCTORAL DISSERTATION

Supervisor:

Sanja Cvetnić, PhD

Zagreb, 2021 



\section{Životopis mentorice}

Sanja Cvetnić rođena je 1961. u Zagrebu, gdje je završila Klasičnu gimnaziju (1980.) i diplomirala povijest umjetnosti i komparativnu književnost na Filozofskom fakultetu Sveučilišta u Zagrebu 1986. godine. Na istom je fakultetu magistrirala 1992. godine radom Djela slikarske škole iz Bassana u Strossmayerovoj galeriji u Zagrebu (mentor prof. dr. sc. Radovan Ivančević) te doktorirala 1998. godine disertacijom Slikarstvo u drugoj polovici XVII. i početkom XVIII. stoljeća u Zagrebu (mentor prof. dr. sc. Vladimir Marković). Na Facoltà di Lettere e Filosofia u Bologni diplomirala je interdisciplinarni studij Discipline delle arti, della musica e dello spettacolo (D.A.M.S.) sa završnim radom o slikaru Federicu Benkoviću (1992.). Od 1990. do 2000. godine zaposlena je kao kustos talijanske zbirke Strossmayerove galerije starih majstora Hrvatske akademije znanosti i umjetnosti, a potom na Filozofskom fakultetu Sveučilišta u Zagrebu kao viši asistent (2000.), docent (2001.), izvanredni (2005.) i na posljetku kao redoviti profesor (2009.), potvrđena u trajno zvanje (20. svibnja 2014.). Od jeseni 2002. do jeseni 2004. godine obavljala je dužnost pročelnice Odsjeka za povijest umjetnosti, a od 2004. do danas predstojnica je Katedre za umjetnost renesanse i baroka. Od 2004. do 2011. bila je voditeljica smjera Umjetnost renesanse i baroka na poslijediplomskom doktorskom studiju Odsjeka za povijest umjetnosti Filozofskog fakulteta Sveučilišta u Zagrebu, gdje je i mentorica. Od akademske godine 2004./2005. do 2007./2008. predavala je predmet Umjetnost baroka na Filozofskom fakultetu Sveučilišta u Sarajevu kao vanjski suradnik, a akademske godine 2014./2015. održala kolegij Migrazioni e traduzioni delle immagini na Sveučilištu Ca' Foscari u Veneciji. Objavila je preko sto izvornih znanstvenih radova iz područja umjetnosti renesanse, manirizma i baroka, ikonografije i pučke umjetnosti te samostalne publikacije. 



\section{Zahvala}

Zahvaljujem svima koji su mi olakšali samotnjački posao izrade disertacije, bilo svojim savjetima, slušanjem »mojih tegoba« ili upućenom toplom riječju. Prvenstveno želim zahvaliti mentorici dr. sc. Sanji Cvetnić na njezinom razumijevanju, strpljivosti, usmjeravanju i savjetima. Njezina nesebičnosti prema drugima i zarazni entuzijazam prema struci uvijek su me inspirirali. Zahvaljujem svim kolegama unutar i izvan institucija koji su podijelili sa mnom svoje znanje i uvelike mi olakšali rad. Naposljetku, najveća zahvala upućena je mojoj obitelji, posebice roditeljima koji su me najviše poučili vlastitim primjerom. Bez njihove bezuvjetne podrške i prijateljstva ničeg ovog ne bi bilo. 



\section{Sažetak}

Nadgrobni spomenici predstavljaju specifičnu granu skulpturalne umjetnosti u kojoj se isprepliće svjetovni i vjerski sadržaj. Svojim likovnim i tekstualnim sadržajem ispunjavaju trostruku ulogu: čuvaju uspomenu na pokojnika (komemorativna funkcija), ukazuju na njegov društveni položaj (reprezentativna uloga) i odražavaju vjerovanje u spasenje i uskrsnuće duše (eshatološka funkcija). Nadgrobnici predstavljaju važan segment kiparsko-klesarske produkcije ranoga novog vijeka na području kontinentalne Hrvatske, posebice one XV. i XVI. stoljeća. U dosadašnjoj literaturi obrađeni su pretežito pozitivistički (topografski su pobrojani i opisani), a veća pozornost (rasprave o stilu, autorstvu, mogućim uzorima i slično) pridana je samo najreprezentativnijim ostvarenjima. Cilj je ovoga istraživanja dati sintetičan pristup nadgrobnim spomenicima kao skulptorskom zadatku koji će obuhvatiti stilsku analizu djelā, postanak, razvoj i značenje njihovih likovno-ikonografskih obrazaca, utjecaj suvremenih medija (slikarstva, kiparstva, grafike, arhitekture) te kontekst nastanka (pitanje autorstva i naručitelja). Osnovni korpus čine nadgrobni spomenici podignuti između XV. i XVIII. stoljeća na prostoru povijesne Zagrebačke biskupije koji sadrže barem jedan likovni motiv. U njegovoj obradi primijenjene su povijesno-umjetničke (autopsija djela, likovno-ikonografska analiza, stilska analiza i komparativna analiza) i povijesne metode (arhivsko istraživanje) u svrhu atribucije, datacije, kontekstualizacije i valorizacije nadgrobnikā. Očuvana spomenička građa predstavlja heterogenu skupinu koja varira likovnom složenošću i kvalitetom izrade, no najbolja ostvarenja idu u korak sa suvremenih stilskim previranjima i svjedoče o visokoj kulturološkoj osviještenosti naručitelja i dometima umjetničkoga stvaralaštva.

Ključne riječi: nadgrobni spomenik, povijesna Zagrebačka biskupija, rani novi vijek, kiparstvo, nadgrobna ploča, epitaf, lik pokojnika, obiteljski grb, funeralni motivi 



\section{Summary}

Tomb monuments represent a specific branch of sculptural art in which secular and religious content intertwine. With their inscriptions and visual imagery, they fulfil a threefold function: they keep the memory of the deceased (commemorative function), display the deceased person's social status (representative function), and reflect the contemporary belief in salvation and resurrection of the soul (eschatological function). Tombs represent an important segment of the early-modern-period sculptural production in continental Croatia, especially that of the $15^{\text {th }}$ and $16^{\text {th }}$ centuries. So far, researchers have mostly dealt with the topic in a positivist manner, listing the monuments topographically and describing their appearance, devoting greater attention only to the most representative examples. This study aims to provide a more synoptic approach to tombs as a sculptural task that will include: monuments' stylistic, iconographic, and comparative analysis; the context of their commission and production; possible visual and iconological sources and models; and the influence of contemporary visual media on monuments' stylistic and formal development.

The study comprises tomb monuments that were erected in the historical Diocese of Zagreb from the $15^{\text {th }}$ to the $18^{\text {th }}$ century, but only those that contain at least one figural motif. Throughout centuries, tombs were frequently removed from church interiors, mostly because of (re)constructions and renovations. Consequently, an unknown number of them has been lost. In an attempt to reconstruct the original corpus to the greatest extent possible, the study includes monuments that have not been preserved but whose appearance has been documented in written and/or visual sources. In the corpus analysis, art-historical (close examination; physical description; stylistic, iconographic, and comparative analysis) and historical methods (archival research) have been used with the goal of contextualising and assessing the monuments within the framework of Croatian and Central European earlymodern-period sculptural art.

The borders of the historical Diocese of Zagreb changed greatly throughout the early modern period, mainly because of the war against the Ottoman Empire. The study covers the area that the diocese occupied at the end of the $18^{\text {th }}$ century, which is the territory of the present-day Metropolitan Archdiocese of Zagreb and the Diocese of Požega (today part of the Archdiocese of Đakovo-Osijek). The largest number of tomb monuments has been preserved in Prigorje and Hrvatsko Zagorje, an area that falls within the borders of »remnants of the once great and renowned Kingdom of Croatia« (Latin reliquiae reliquiarum olim magni et inclyti regni Croatiae), which remained under the jurisdiction of the Croatian-Slavonian Parliament during the Ottoman conquests. A smaller number of monuments has been 
preserved in Podravina, Moslavina, Banovina, and western Slavonia. The reason for this lies in the Ottoman invasion that began in the late $15^{\text {th }}$ century and its consequences. Primarily, in the areas that were under Ottoman rule (western Slavonia, south-western Moslavina, and Banovina), an unknown number of tombs has been lost due to the demolition and conversion of Roman-Catholic churches as well as the Islamic aniconic approach to art. Furthermore, the area along the border with the Ottoman Empire was gradually organised into the Military Frontier, a buffer zone that originally served to repel Ottoman attacks but was eventually transformed into a Habsburg military province.

The smallest number of monuments dates from the $15^{\text {th }}$ century (seven preserved, three documented), which can be attributed to the Ottoman military invasion that began in the second half of the century and the aforementioned renovation of church interiors. Their numbers doubled in the $16^{\text {th }}$ century (sixteen preserved, four documented), regardless of the fact that the fifteen hundreds were burdened by warfare, demographic decline, and economic recession. It seems that the imminent Ottoman threat and general insecurity of life acted as an incentive for people to erect tombs, which served as the last material testimony of their earthly life. The largest number of monuments dates from the $17^{\text {th }}$ century (thirty-eight preserved, one documented). During this period the Croatian Kingdom began to gradually recover economically and politically, which had a positive effect on artistic production. Despite the general social and economic upward trajectory, the number of erected monuments began to decline in the seventeen hundreds (fifteen preserved, one documented). This was most likely due to continuous attempts to end the practice of burials inside churches and to open up new, public cemeteries outside of towns and settlements for health and safety reasons.

In the historical Diocese of Zagreb, two types of tomb monuments have been preserved - tomb slabs and epitaphs. Tomb slabs (French dalle funéraire, German Grabplatte, Italian lastra tombale) are laid on the floor and cover an individual grave or the entrance to a crypt. Consequently, they are rectangular in shape and usually coffin-sized. Epitaphs (French monument funéraire plaqué, German Epitaph, Italian epitaffio), on the other hand, are embedded in the wall. As they are not so closely connected with the burial lot, they vary in size and shape. Based on the visual motifs they contain, the tomb slabs and epitaphs found in the (Arch)diocese of Zagreb can be divided into three following categories: I) tombs with an effigy of the deceased, II) tombs with a family coat of arms, and III) tombs with funerary motifs. 
In the first group, the figure of the deceased is employed in two ways. It is either used as an independent, main figural motif or it is incorporated into a more complex composition as a figure kneeling in prayer before Christ on the cross. Tombs that include only the effigy of the deceased were used in the diocese throughout the whole early modern period, prevailing as the dominant form of tomb sculpture in the $15^{\text {th }}$ and $16^{\text {th }}$ centuries. Drawing on the medieval tradition, the early monuments showed the deceased as recumbent figures (French gisant), with their heads resting against a pillow and hands folded in prayer. They represented the blessed dead who awaited resurrection and the Second Coming of Christ. In the $16^{\text {th }}$ century, the figures of the deceased began to assume a more life-like appearance. Positioned in contrapposto and one arm akimbo, they resembled more the living than the dead. This change was reinforced in the $17^{\text {th }}$ century with the introduction of epitaph as the new type of tomb monument that was placed vertically in the church wall. The way the deceased were depicted on tomb slabs was more or less copied and transferred onto epitaphs. Although the representation au vif-which often drew its inspiration from contemporary portraiturebecame predominant, the motif of gisant continued to be used until the end of the $17^{\text {th }}$ century. Monuments with the solitary effigy of the deceased were predominately commissioned for church dignitaries and noblemen. The former were shown in liturgical garments, and the latter in full-body armour. Only several examples of effigies erected for women have been preserved or documented in historical sources. An even greater rarity represent two slabs that carry the gisant of a child, as children were usually buried in family crypts and did not have monuments of their own.

The first tomb monument preserved in the historical Diocese of Zagreb that contains the image of the deceased kneeling and praying before Christ on the cross dates from the mid$16^{\text {th }}$ century. Such depictions were employed until the beginning of the $18^{\text {th }}$ century and can be found on epitaphs erected in the memory of members of the nobility. Compositionally, they contain the en-face figure of the crucified Christ, who is flanked by the kneeling figure of the deceased (French prians) shown in half-profile or three-quarter view. The deceased are sometimes accompanied by their loved ones, namely their spouses and children. In such cases, the figures are always shown in accordance with the hierarchical perspective: men are positioned to the right, and women to the left of Christ. The image of the deceased kneeling before a sacred person has its origin in votive paintings, with which the faithful offered to fulfil a vow they had made or express their gratitude for a favour they had already been granted. The depiction of Christ crucified on the cross - who died for people's sins and then 
rose from the dead—-symbolizes the deceaseds' faith in spiritual deliverance and the salvation of their soul.

Heraldic tombs, which comprise the second major group in the corpus, were used in the Zagreb (Arch)diocese throughout the whole early modern period. They contain a family coat of arms and an inscription, which initially ran along the monuments' edges but was later inscribed in blocks above and/or below the family arms. During the sixteen and especially the seventeen hundreds, the inscriptions became so extensive that they occupied most of the monuments' surface. Coats of arms also became more complex in design with time. Those dating from the $15^{\text {th }}$ and $16^{\text {th }}$ centuries comprised only an escutcheon (shield) carrying the family emblem, out of which some were adorned with a helmet, crest, and mantling. Seventeenth- and eighteenth-century coats of arms were more decorated and always included heraldic achievements such as the helmet, mantling, crown (coronet), crest and sometimes supporters and a motto. At the beginning of the $17^{\text {th }}$ century, a new type of heraldic tombs appeared under the influence of contemporary architecture-epitaphs shaped as an aedicule. In the historical Diocese of Zagreb, heraldic tomb monuments were erected primarily for male members of the nobility and secondarily for clergymen (bishops and canons). By choosing the coat of arms as the main visual motif, the commissioners wanted to stress that they belonged to a particular family, which was the nucleus of the early-modern-period society. As coats of arms could be received only by people of noble birth, heraldic tomb monuments also served as proof of the deceased person's social status.

The last group in the corpus consists of tomb slabs and epitaphs that carry funerary motifs. It should be noted that such motifs were often employed on monuments from two previously described groups - those that contain the effigy of the deceased and family coat of arms - but only as accompanying iconographic elements. The most common motifs that appear in the historical Diocese of Zagreb are the human skull, skeleton, and hourglass. They symbolised the transcience of time and the inevitability of death, serving as a warning to the observer to take heed not of their earthly possessions but of the thing that mattered the mosttheir soul.

As a general rule, tomb monuments were erected by immediate family membersspouses, children, and siblings - after the death of a loved one. In rare cases were they commissioned by members of the extended family, such as nephews or in-laws. It was mostly in situations when the deceased did not have a family of their own, either because of their service (ecclesiastical or military) or as a turn of life events. In only exceptional cases were monuments erected by people who were not blood-related to the deceased, but were bound by 
friendship and/or partnership ties. The deceased sometimes paid for the erection of tombs themselves already during their lifetime. It was to spare their descendants of the obligation and to ensure that their grave would be marked with a monument, especially one to their liking.

When ordering a monument, commissioners turned to both local and foreign craftsmen. Only four artists whose works have been preserved or documented in the diocese are known by name. They are Johannes Fiorentinus (workshop active c. 1495 - c. 1525), Adriaen van Conflans (Brussels, 1535 - Amsterdam, 1607), Ivan Komersteiner (?, mid-17th century - Zagreb, 1694/95), and Josip Buk (?, first half of the $18^{\text {th }}$ century - ?). Fiorentinus and Buk signed their work, whereas the authorship of Conflans and Komersteiner are known from archival sources. The latter two were considered to be prominent artists in their respective fields - Conflans as a portrait painter at the Viennese court, and Komersteiner as the leading early-Baroque sculptor in continental Croatia. Naturally, not all clients could afford the best craftsmen. Quite the contrary, most of the tomb monuments preserved in the observed area were executed by sculptors of more modest skill. Using comparative analysis, some tombs have been attributed to workshops active in present-day Slovenia, which developed their distinctive style, but whose masters have remained unknown by name.

Form and content-wise, tomb sculpture is marked by conventions and tradition. The typology, compositional solutions, and iconography of early-modern-period monuments were derived from their medieval counterparts, and they continued to be used with very few alterations throughout the period. However, the monuments do show stylistic changes, which were in line with the ones emerging and forming in the visual art and architecture of continental Croatia. These changes-noticeable in the way volume is shaped, different treatment of the surface, the interplay between light and shade, choice of ornament, use of different materials, and so on-did not appear as a unified and solidified stylistic formation, but rather as an influx of separate individual features, which could be accepted without disrupting the dignity and solemnity tomb monuments needed to possess. Monuments preserved in the diocese that date from the $15^{\text {th }}$ century still show a great influence of the lateGothic style. The Renaissance began to spread only at the end of the century and held its sway throughout the fifteen hundreds. The $17^{\text {th }}$ century was marked by a stylistic pluralism in which the characteristic of the late Renaissance, Mannerism, and early Baroque intertwined, sometimes even on a single monument. Although the first signs of Baroque appeared in the first half of the $17^{\text {th }}$ century, it did not establish itself as the dominant style until the turn of the century. 
The study also shortly discusses early-modern-period family chapels that were used for burials as well as the funeral ceremonies that followed the death of an individual. Family chapels were erected by the members of the nobility next to the parish churches over which they had patronage or next to the churches of monastic orders, such as the Paulines, Franciscans, and Jesuits. Since they were separated from the rest of the churches' interior, the chapels provided a more intimate space for personal prayer and contemplation, but they also served to preserve and perpetuate the family's memory as they were decorated with familial insignia and coats of arms. Most of the chapels in the diocese were rectangular in plan, with only a few centrally planned. In the second half of the $18^{\text {th }}$ century, the chapels seized to be built as part of churches and were erected as independent, free-standing mausolea.

Funeral ceremonies had a similar function as tomb monuments. On the one hand, their liturgical part was to ensure that the deceased was cleansed from their sins and admitted to the Kingdom of Heaven. On the other hand, they provided an opportunity for the family to laud and glorify the family member they had lost, contributing and improving their own status in the process. Obsequies comprised a wide range of activities, which included: preparation of the deceased person's body for the funeral, vigil over and mourning of the deceased, solemn procession to the place of burial, service for the deceased, funeral speech, and the burial of the body. Churches at which burials took place were richly decorated for the occasion. Their walls were covered in dark cloth, against which were attached insignia and coats of arms, while their interior was illuminated by numerous burning torches and candles. The centrepiece of the funeral apparati was the catafalque, a raised bier used to support the coffin with the body of the deceased, which was placed in the central nave. Catafalques raised for illustrious people, such as state or church dignitaries, were elaborate and highly decorated constructions that resembled a ciborium or tempietto and were known as castra doloris (Latin »castles of grief «). As all of the devices used in the ceremonies were ephemeral, the proof of their existence and use can be found mainly in written and visual sources, namely contemporary descriptions and engravings.

In conclusion, the corpus of early-modern-period tomb monuments preserved in the historical Diocese of Zagreb represents a heterogeneous group, the constituents of which vary in morphological complexity and quality of workmanship. The tombs' quality depended on the commissioners' financial status and their wishes, directly influencing various aspects of the erected monument, such as its material, size, compositional complexity, and craftsmanship. For commissioners who had limited funds, it was more important to mark the burial place of the deceased person and to maintain their memory than to create top-quality 
works of art. However, the clients who belonged to the highest social strata tried to follow contemporary cultural and stylistic trends-in which they mainly succeeded-and the monuments they had erected can be counted among the most successful works of earlymodern-period sculpture in the historic Diocese of Zagreb.

Keywords: tomb monument, historical Diocese of Zagreb, early modern period, sculpture, tomb slab, epitaph, effigy of the deceased, family coat of arms, funerary motifs 

Sadržaj

I. RASPRAVA | 1

1. UVOD 1

1.1 Tema i ciljevi istraživanja | 4

1.2 Materijali i metode istraživanja | 8

1.3 Pregled dosadašnje literature | 9

2. RAZVOJ, TIPOLOGIJA I TERMINOLOGIJA NADGROBNE SKULPTURE | 13

3. NADGROBNI SPOMENICI NA PODRUČJU POVIJESNE ZAGREBAČKE BISKUPIJE | 20

3.1. Nadgrobnici s figuralnim prikazom pokojnika $\quad 28$

3.1.1. Nadgrobnici s likom pokojnika kao osnovnim motivom $\quad 29$

3.1.1.1. Nadgrobne ploče crkvenih dostojanstvenika | 32

3.1.1.2. Nadgrobne ploče plemkinja i djece | 45

3.1.1.3. Viteške nadgrobne ploče i epitafi | 51

3.1.2. Epitafi s prikazom Raspetoga i adoranata $\quad 94$

3.2. Nadgrobnici s obiteljskim grbom | 133

3.3. Nadgrobnici s motivima funeralne ikonografije | 183

4. POKOJNICI, NARUČITELJI I UMJETNICI | 192

5. STILSKE ZNAČAJKE NADGROBNIH SPOMENIKA | 201

6. GROBNE KAPELE | 209

7. POSMRTNE SVEČANOSTI | 217

II. ZAKLJUČAK | 233

III. KATALOG | 237

1. ZAGREBAČKA NADBISKUPIJA $\mid 238$

2. VARAŽDINSKA BISKUPIJA | 336

3. BJELOVARSKO-KRIŽEVAČKA BISKUPIJA | 382

4. SISAČKA BISKUPIJA | 384

5. POŽEŠKA BISKUPIJA | 394

IV. POPIS ARHIVSKIH IZVORA I LITERATURE | 405

V. POPIS SLIKOVNIH PRILOGA I NJIHOVIH IZVORA | 427

VI. ŽIVOTOPIS I POPIS OBJAVLJENIH RADOVA AUTORICE | 439 



\section{RASPRAVA}

\section{UVOD}

U kršćanstvu se od samih početaka primjenjivala praksa pokapanja tijela preminulih kao naslijeđe židovske tradicije. ${ }^{1}$ U početnim stoljećima pokojnici su se sahranjivali na nekropolama izvan gradskih zidina uz grobove mučenika (martirije) oko kojih su podizali grobnice i spomenike. ${ }^{2}$ Kršćani su vjerovali da će im ukop uz tijela svetaca (ad sanctos) ili mučenikā (ad martyres) pružiti tjelesnu i duhovnu zaštitu, odnosno da će svete osobe osigurati njihove grobove od oskvrnuća, a duše zaštiti nakon smrti. ${ }^{3} \mathrm{U}$ V. stoljeću iznad martirija počele su se podizati bazilike koje su objedinile dotad odvojene grobove u jedinstvenu cjelinu. ${ }^{4} \mathrm{Na}$ taj način nastale su grobljanske crkve extra muros, koje su zbog grobova svetaca ubrzo postale hodočasničkim odredištima. Njihov pandan unutar gradskih zidina bile su katedrale koje su predstavljale središte episkopalne administracije. ${ }^{5}$ Razlika između gradskih i grobljanskih crkava počela je nestajati tijekom srednjega vijeka (od VIII. stoljeća nadalje) kada su se posmrtni ostatci svetaca počeli prenositi u crkve smještene unutar gradskoga tkiva. ${ }^{6}$ Motivirani željom da budu pokopani u blizini svetih osoba-zaštitnika, vjernici su nastavili sahranjivati ostatke svojih najbližnjih unutar gradskih crkava. Translacija mučeničkih relikvija tako je otvorila put pokapanju običnih vjernika u crkvama podignutima u živom tkivu gradova.

Premda su svi vjernici htjeli biti pokopani što bliže relikvijama pohranjenima $u$ svetištu, sahranjivanje unutar crkava bilo je dozvoljeno samo pripadnicima klera (biskupima, opatima, svećenicima) i visokoga plemstva koji su bili dobročinitelji i pokrovitelji Crkve. Zaključcima crkvenih sabora održanih u Bragi (561.), Mainzu (813.) i Triburu (895.) te nepriznatoga sabora u Nantesu (900.), vjernicima je dozvoljeno pokapanje mrtvih uz crkvu,

\footnotetext{
${ }^{1}$ Usp. Josip Frančišković, Crkva sv. Franje u Senju (Povjesno-liturgička razmatranja), u: Bogoslovska smotra = Ephemerides theologicae Zagrabiense XIX/4, Zagreb: Hrvatsko bogoslovska akademija, 1932., str. 411-423, 419.

${ }^{2}$ Usp. Željko Demo, Opatovina: tragovi povijesti izgubljene u sadašnjosti. Rezultati arheoloških iskopavanja pred crkvom svetog Franje u Zagrebu 2002. godine, Zagreb: Arheološki muzej, 2007., str. 49; Josip Frančišković, nav. dj., 1932., 419; Slavko Šterk i Boris Mašić, Mors porta vitae = Smrt vrata života: stara zagrebačka groblja i pogrebi, Zagreb: Muzej grada Zagreba, 2014., str. 52.

${ }^{3}$ Usp. Philippe Ariès, The Hour of Our Death, New York: Alfred A. Knopf, 1981., str. 32-33. Prevela Helen Weaver; Erwin Panofsky, Tomb Sculpture: Four Lectures on Its Changing Aspects from Ancient Egypt to Bernini, London: Phaidon Press, 1992. [1964.], str. 46. Uredio H. W. Janson; Slavko Šterk i Boris Mašić, nav. dj., 2014., str. 52.

${ }^{4}$ Usp. Philippe Ariès, nav. dj., 1981., str. 34; Nenad Cambi, Antika, Zagreb: Naklada Ljevak, 2002., str. $227-$ 228; Slavko Šterk i Boris Mašić, nav. dj., 2014., str. 52.

${ }^{5}$ Usp. Philippe Ariès, nav. dj., 1981., str. 35; Slavko Šterk i Boris Mašić, nav. dj., 2014., str. 52.

${ }^{6}$ Usp. Philippe Ariès, nav. dj., 1981., str. 36-37; Nenad Cambi, nav. dj., 2002., str. 231; Željko Demo, nav. dj., 2007., str. 49; Igor Fisković, O grobnim spomenicima u srednjovjekovnoj Dalmaciji, u: Dometi: znanstvenokulturna smotra Matice hrvatske, Ogranka u Rijeci 5, Rijeka: Izdavački centar Rijeka, 1984.b, str. 33-53, 45.
} 
ali isključivo uz njezine vanjske zidove. ${ }^{7}$ Na tom mjestu nastala su crkvena groblja, na kojima se sahranjivao veći dio stanovništva. Zabrane pokapanja u unutrašnjosti crkava redovito su se ponavljale kroz povijest, no u praksi se često nisu poštivale. U vrijeme poslijetridentske obnove, crkvene vlasti ponovno su pokušale zabraniti takvu vrstu ukopa uvidjevši da ona je postala privilegijom bogatih, visokorođenih i utjecajnih, a ne pobožnih i zaslužnih čiji bi ukop unutar Hrama Božjega bio poučan i poticajan. Na provincijalnom saboru u Rouenu (1581.) definirane su tri skupine osoba koje smiju biti pokopane unutar crkve:

»I. Oni koji su posvetili svoj život Bogu, posebice muškarci [redovnice samo u slučaju nužde] jer su njihova tijela odabrana kao hram Krista i Duha Svetoga.

II. Oni koji su primili počast i priznanje unutar Crkve [zaređeni svećenici] ili u svijetu [bogati i utjecajni] jer su oni poslanici Božji i instrument Duha Svetoga.

III. Oni koji su se svojom plemenitošću, djelima i postignućima istaknuli u službi Boga ili općega dobra. $\ll^{8}$

Mjesto ukopa na crkvenim grobljima najčešće se obilježavalo zemljanim humkom i/ili drvenim križem koji se nije obnavljao, zbog čega je znanje o točnom mjestu groba i njegovom vlasniku bilo razmjerno kratkoročno. ${ }^{9}$ Grobovi unutar crkava, s druge strane, imali su trajniji biljeg jer su obilježavani nadgrobnim spomenicima izrađenima u drvu, kamenu, štuku ili metalu. Zemaljski ostaci vjernika polagani su u pojedinačne grobove ili zajedničke kripte, a njihovo mjesto obilježeno je nadgrobnikom postavljenim iznad ili u (ne)posrednoj blizini grobnice. Nadgrobni spomenici varirali su u skladu s društvenim položajem, imovinskim stanjem i htijenjem pokojnikā od jednostavnijih rješenja u obliku ploča položenih na crkveni pod ili ugrađenih u zidnu masu do skulpturalno složenih rješenja uklopljenih u arhitekturu crkve ili postavljenih slobodno u prostoru. (Detaljnija analiza tipologije nadgrobnih spomenika i njihove geneze razložena je u sljedećem poglavlju.)

Najuglednije mjesto za ukop unutar crkve bilo je svetište. ${ }^{10}$ Razlog tome ležao je u već navedenom vjerovanju o zaštitničkim moćima svetačkih relikvija koje su se čuvale uz glavni oltar, ali i vjerovanju da će na dan Posljednjeg suda prvo ustati svetci, a potom »oni koji su im

\footnotetext{
${ }^{7}$ Usp. Philippe Ariès, nav. dj., 1981., str. 46.

${ }^{8} \gg 1$. Those who have dedicated their lives to God, especially the men [nuns only in cases of necessity], because their bodies have been chosen as temples of Christ and of the Holy Spirit. 2. Those who have received honours and dignities in the church [ordained clergymen] or in the world [the rich and powerful], because they are the ministers of God and the instrument of the Holy Spirit, and finally 3. Those who by their nobility, their actions, and their merits have distinguished themselves in the service of God and of the common good.« Philippe Ariès, nav. dj., 1981., str. 47. Prijevod autoričin.

${ }^{9}$ Usp. Philippe Ariès, nav. dj., 1981., str. 269; Željko Demo, nav. dj., 2007., str. 52; Siniša Krznar, Arheološka slika kasnosrednjovjekovnih groblja na prostoru sjeverne Hrvatske, doktorski rad, Zagreb: Filozofski fakultet Sveučilišta u Zagrebu, 2012., str. 24.

${ }^{10}$ Usp. Philippe Ariès, nav. dj., 1981., str. 79; Željko Demo, nav. dj., 2007., str. 50.
} 
blizu«, što je među vjernicima poticalo želju da njihovi zemaljski ostatci budu sahranjeni što bliže onima svetih osoba. ${ }^{11}$ Svako mjesto ukopa imalo je svoju cijenu. Ona smještena u istočnom dijelu crkve bila su najskuplja, a mogli su ih si priuštiti samo najimućniji članovi društva. Što je grobno mjesto bilo udaljenije od oltara, to je bilo manje prestižno, a time i jeftinije. Izuzev svetišta, pripadnici plemstva pokapali su se u obiteljskim kapelama podignutima uz tijelo crkve, koja su tako postala mjestom uspostavljanja obiteljskoga identiteta i čuvanja memorije. ${ }^{12}$

Osim župnih crkava, pravo pokapanja imale su područne kapele, samostani i hospitali. ${ }^{13}$ Pripadnici svih triju staleža često su se običavali pokapati u crkvama samostanskih redova, posebice onih prosjačkih poput franjevaca, dominikanaca i karmelićana. ${ }^{14}$ Sahranjivanjem u samostanskim crkvama obitelji pokojnikā pokušavale su osigurati što dulju skrb o grobu i duši preminuloga jer su redovnici - osim što su sudjelovali u provedbi sprovoda i posmrtnih svečanosti - redovito držali bdjenja i mise zadušnice. Pripadnici plemstva pomno su odabirali crkvu u kojoj će biti sahranjeni ovisno o njezinom ugledu ali i vlastitim novčanim mogućnostima. ${ }^{15}$ Međutim, odnos između plemićkoga odabira i ugleda crkve bio je obostran: kada bi uglednik izabrao neku crkvu kao mjesto svojega posljednjeg počivališta, ona je dobivala na značaju i ugledu privlačeći druge vjernike. Jedan takav primjer predstavlja nekadašnja pavlinska crkva Blažene Djevice Marije u Lepoglavi koja je nakon što je tamo pokopan Ivaniš (Ivan) Korvin (Budim, 1473. - Krapina, 1504.), nezakoniti sin hrvatsko-ugarskoga kralja Matije Korvina (vladao 1458. - 1490.), postala svojevrsni campo santo hrvatskih velikaša.

Zabrinut zdravstvenim posljedicama koje su groblja i kripte smještene u tkivu naselja mogle imati na lokalno stanovništvo, car i kralj Josip II. (Beč, 1741. - Beč, 1790.) donio je uredbu (1781.) kojom je zabranio pokapanje unutar crkava i na župnim grobljima te naredio da se otvore nova, javna groblja izvan naselja. ${ }^{16}$ Unatoč carevoj odredbi, vjernici su se nastavili pokapati u crkvama i na obližnjim grobljima gotovo do sredine XIX. stoljeća. Jedna od zadnjih odredaba kojom su dokinuta i posljednja crkvena groblja donesena je 1867. godine

\footnotetext{
${ }^{11}$ Siniša Krznar, nav. dj., 2012., str. 26. Tijela pokojnikā morala su biti sahranjena najmanje jedan metar od oltara. Usporedi dalje: Josip Frančišković, nav. dj., 1932., str. 420; Šterk i Mašić, nav. dj., 2014., str. 32.

${ }^{12}$ Usp. Philippe Ariès, nav. dj., 1981., str. 290; Howard Colvin, Architecture and the After-Life, New Haven, London: Yale University Press, 1991., str. 190-191.

${ }^{13}$ Usp. Željko Demo, nav. dj., 2007, str. 49; Siniša Krznar, nav. dj., 2012., str. 23.

${ }^{14}$ Usp. Philippe Ariès, nav. dj., 1981., str. 83. Laicima je omogućeno da budu pokopani unutar franjevačkih i dominikanskih samostana dvjema papinskim bulama iz 1227. i 1250. godine. Usp. Howard Colvin, nav. dj., 1991., str. 190.

${ }^{15}$ Usp. Siniša Krznar, nav. dj., 2012., str. 30, 32.

${ }^{16}$ Usp. Siniša Krznar, nav. dj., 2012., str. 23.
} 
kada je kraljevska dvorska kancelarija u Beču naredila da se zatvore sve kripte kojima se pristupa iz crkve. ${ }^{17}$ Napuštanjem običaja pokapanja u crkvi, članovi plemićkih i imućnih građanskih obitelji počeli su podizati grobne kapele i monumentalne grobnice (mauzoleje) na vlastitim posjedima ili novopodignutim, javnim grobljima izvan naselja na kojima se pokapalo pučanstvo.

\subsection{TEMA I CILJEVI ISTRAŽIVANJA}

Nadgrobni spomenici čine posebnu skupinu kiparskih djela koja sadrže značajke svjetovne i crkvene umjetnosti. Budući da obilježavaju mjesto ukopa i prenose sjećanje na pokojnika kasnijim naraštajima, imaju komemorativnu i reprezentativnu funkciju. Međutim, njihovi likovni prikazi i natpisi odražavaju pokojnikovu vjeru u spasenje putem Kristove žrtve, što pokazuje da u sebi sadrže i eshatološku sastavnicu. ${ }^{18}$ Osnovni katalog likovnih djela i topografski opseg ovoga istraživanja čine nadgrobni spomenici podignuti na prostoru povijesne Zagrebačke biskupije od početka XV. do kraja XVIII. stoljeća. Istraživanje je prvenstveno usmjereno na spomenike koji osim natpisa sadrže likovne motive ili prikaze jer oni predstavljaju okosnicu povijesno-umjetničke struke i omogućuju praćenje likovnoga razvoja nadgrobnikā kao grane skulpturalne umjetnosti (detaljnim proučavanjem nadgrobnih natpisa bavi se zasebna, pomoćna povijesna znanost epigrafija). Rad obuhvaća i temu grobnih kapela koje su pripadnici plemićkih obitelji podizali uz župne i samostanske crkve jer imaju sličnu namjenu kao i nadgrobni spomenici: svojim ikonografskim sadržajem one su komemorirale i glorificirale mrtve pretke, a živućim članovima pružale su mjesto osobne molitve i kontemplacije. Sažeto su prikazane i posmrtne svečanosti koje su uslijedile nakon smrti pojedinca i trajale do polaganja njegova tijela u grob jer predstavljaju svojevrsnu sponu između smrti osobe i čina podizanja njezina nadgrobnika kao posljednjega biljega na ovozemaljskom svijetu.

Cilj ovoga istraživanja je uspostaviti korpus ranonovovjekovnih nadgrobnih spomenika na području povijesne Zagrebačke biskupije i obraditi ga na sintetičan način koji će obuhvatiti: stilsku, ikonografsku i komparativnu analizu djelā; otkrivanje potankosti ili produbljivanje postojećih saznanja o kontekstu narudžaba pojedinih spomenika (pitanje naručitelja, autorstva, vremena izrade i izvornoga smještaja); utvrđivanje likovno-ikonoloških obrazaca i njihove simbolike, izvorā, razvoja i utjecaja suvremenih medija; te naposljetku

\footnotetext{
${ }^{17}$ Usp. Vjekoslav Noršić, Povijest župe sv. Anastazije u Samoboru, Zagreb: Društvo za povjesnicu Zagrebačke nadbiskupije »Tkalčić«, 2005., str. 96. Priredio Stjepan Razum.

${ }^{18}$ Usp. Philippe Ariès, nav. dj., 1981., str. 214.
} 
valorizaciju nadgrobnika kao kiparskih ostvarenja u kontekstu hrvatske i srednjoeuropske likovne umjetnosti od XV. do XVIII. stoljeća.

Prilikom definiranja vremenskoga razdoblja koje je obuhvaćeno istraživanjem, rani novi vijek nametnuo se kao sigurnija vremenska odrednica od uobičajene stilske periodizacije koja se primjenjuje u povijesti umjetnosti za to razdoblje (gotika, renesansa, manirizam, barok) zbog stilske raznovrsnosti odnosno nedovoljne stilske određenosti pojedinih nadgrobnih spomenika. Razdoblje ranoga novog vijeka velikim je dijelom bilo obilježeno borbama protiv Osmanskoga Carstva, čiji je prodor na hrvatske prostore započeo padom Bosanskoga Kraljevstva (1463.). Druga polovina XV. i XVI. stoljeće ispunjeni su neprestanim ratovanjem protiv i napredovanjem osmanske vojske, koji su rezultirali demografskim padom, siromaštvom, nesigurnošću življenja i gospodarskim nazadovanjem. ${ }^{19}$ Zagrebačka biskupija i plemstvo oslabljeni su gubitkom posjeda i podanika, što se negativno odrazilo na intenzitet umjetničke djelatnosti i broj narudžaba. Plemićke obitelji najviše su ulagale u izgradnju, održavanje i obnavljanje tvrđava i obrambenih sustava kako bi se što uspješnije obranile od neprijateljskih napada. Prodor osmanskih snaga zaustavljen je početkom XVII. stoljeća potpisivanjem Žitvanskoga mira (1606.), no borba za vraćanje izgubljenih područja potrajala je još cijelo stoljeće. Završetak Bečkoga (Velikoga) rata (1683. - 1699.) i potpisivanje mirovnoga sporazuma u Sremskim Karlovcima (1699.) označili su početak mirnijeg razdoblja tijekom kojega su se Crkva i plemstvo mogli posvetiti obnovi. Slavonija je vraćena pod upravu Bečkoga dvora koji je na njezino područje doseljavao strano plemstvo, hrvatske plemićke obitelji na svojim su »usitnjenim posjedima» podizale palače $i$ dvorce, ${ }^{20}$ a Katolička crkva nastavila je djelovati kao glavni naručitelj i pokretač umjetničkih zbivanja. $^{21}$

Granice povijesne Zagrebačke biskupije znatno su se mijenjale tijekom razmatrana četiri stoljeća. Biskupija je zahvaćala najveću površinu početkom XV. stoljeća kada je, osim područja današnje Zagrebačke metropolije i Požeške biskupije, na sjeveru obuhvaćala Prekmurje i Prekodravlje (današnja Mađarska), a na jugu Dubičku, Sansku i Vrbasku županiju (današnja sjeverozapadna Bosna) (Slika 1). ${ }^{22}$ Prodiranjem osmanskih snaga krajem XV. i tijekom XVI. stoljeća, Kraljevine Hrvatska i Slavonija postupno su gubile teritorij, čime se smanjivao i prostor Zagrebačke biskupije jer se biskup nije mogao pravomoćno pastoralno

\footnotetext{
${ }^{19}$ Usp. Milan Pelc, Renesansa, Zagreb: Naklada Ljevak, 2007., str. 9-11.

${ }^{20}$ Anđela Horvat, Barok u kontinentalnoj Hrvatskoj, u: Barok u Hrvatskoj, Zagreb: Sveučilišna naklada Liber, Odjel za povijest umjetnosti Centra za povijesne znanosti, Društvo povjesničara umjetnosti, 1982.a, str. 3-381, 13. Napisali Anđela Horvat, Radmila Matejčić i Kruno Prijatelj.

${ }^{21}$ Usp. Milan Pelc, Povijest umjetnosti u Hrvatskoj, Zagreb: Naklada Ljevak, 2012., str. 265-266.

${ }^{22}$ Usp. Andrija Lukinović, Zagreb: devetstoljetna biskupija, Zagreb: Glas Koncila, 1995., str. 27.
} 


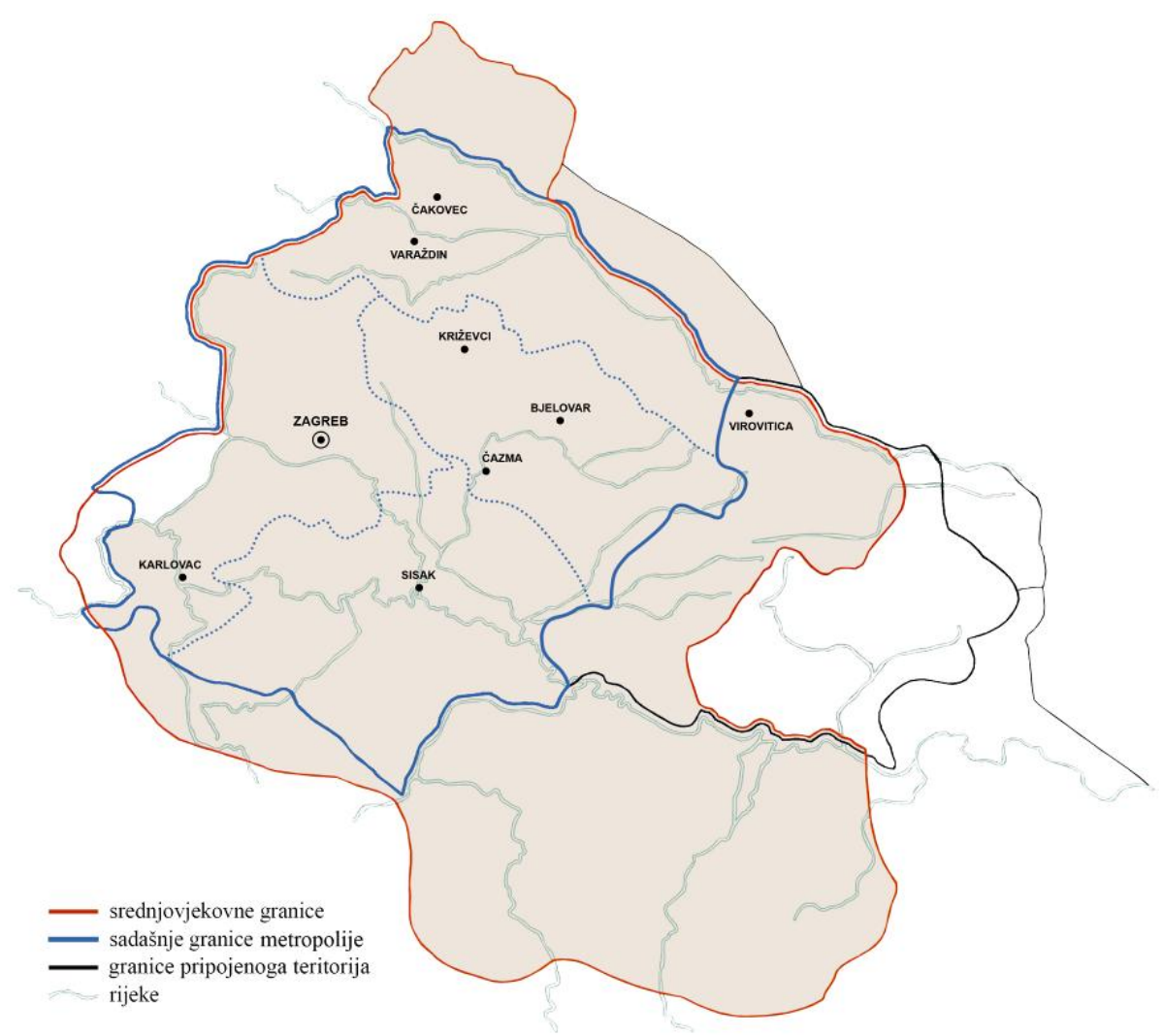

Slika 1. Granice Zagrebačke biskupije u XV. stoljeću ${ }^{23}$

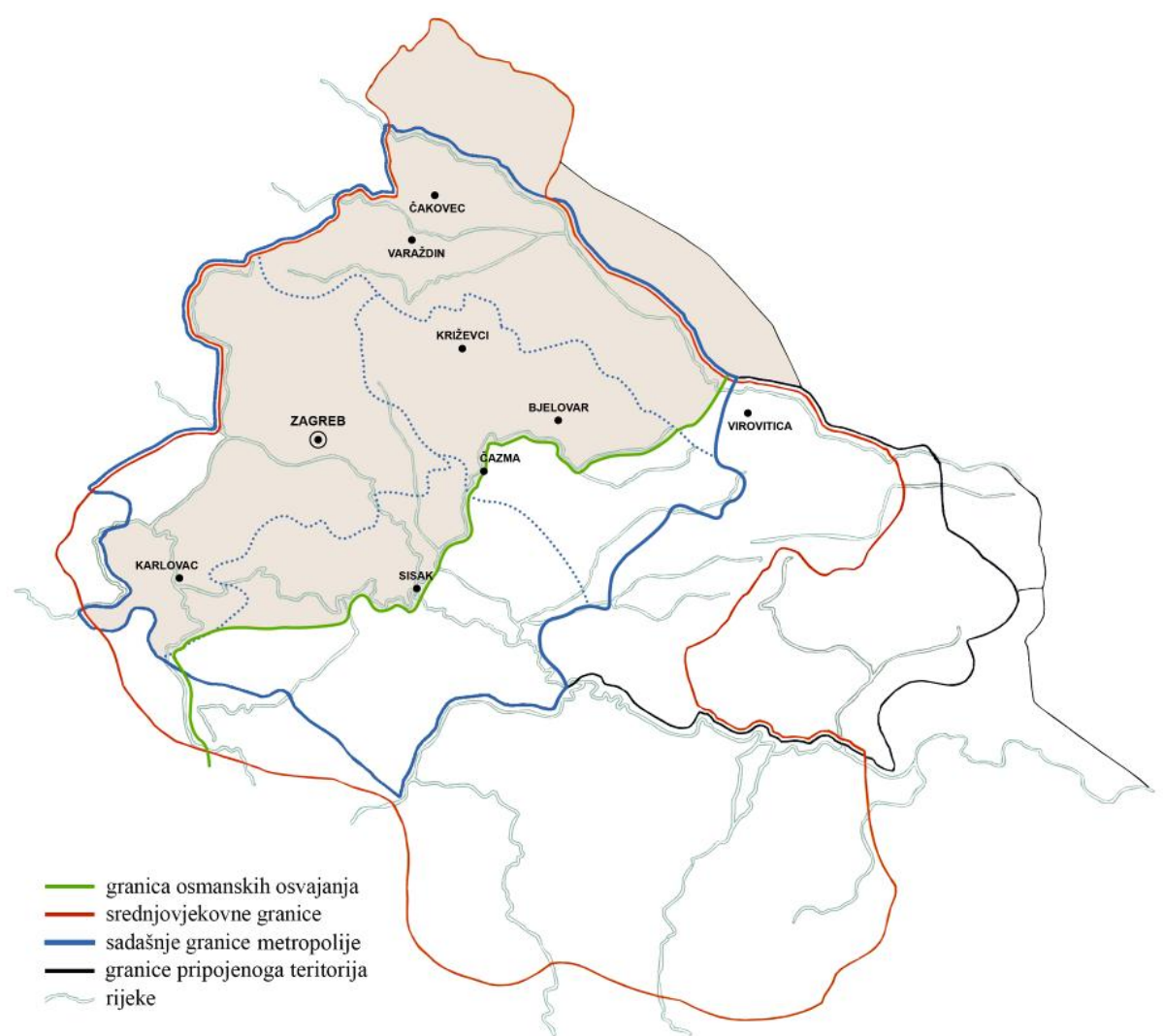

Slika 2. Granice Zagrebačke biskupije u XVI. stoljeću

${ }^{23}$ Osnova svih karata preuzeta je iz knjige Andrije Lukinovića, Zagreb: devetstoljetna biskupija, Zagreb: Glas Koncila, 1995. Karte je doradila autorica. 


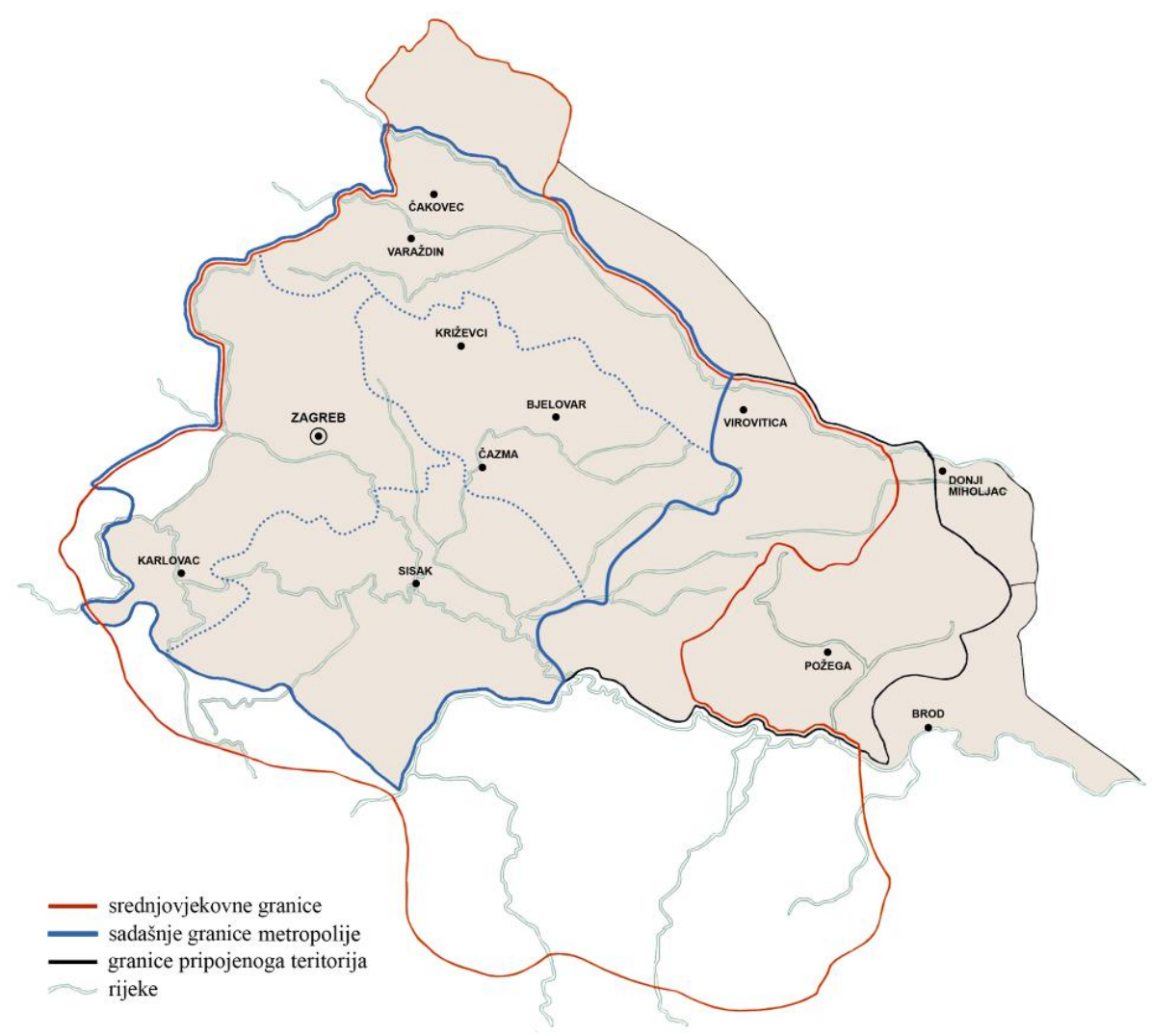

Slika 3. Granice Zagrebačke biskupije u XVII. stoljeću

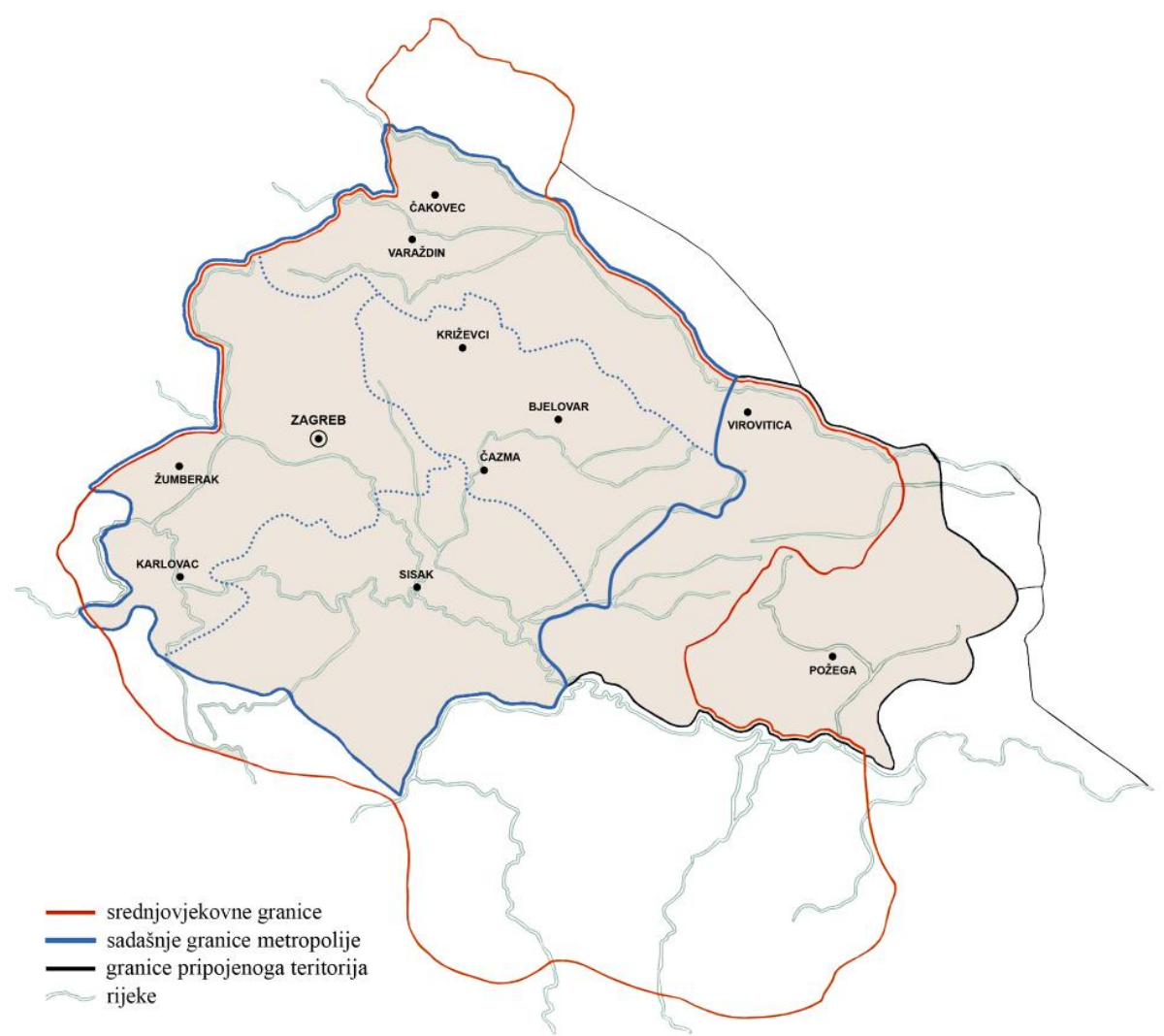

Slika 4. Granice Zagrebačke biskupije krajem XVIII. stoljeća 
skrbiti o vjernicima na području pod osmanskom vlašću. Do kraja XVI. stoljeća neosvojeni dio Hrvatske sveden je na uski pojas uz granicu prema habsburškim nasljednim zemljama koji se prostirao od rijeka Mure i Drave na sjeveru do sjevernoga Jadrana na jugu, u historiografiji poznat kao reliquiae reliquiarum olim magni et inclyti regni Croatiae (»ostatci ostataka nekoć velikoga i slavnoga Kraljevstva Hrvatskoga«) (Slika 2). ${ }^{24}$ Nakon što su Lika i Slavonija oslobođeni Bečkim (Velikim) ratom (1683. - 1699.), Zagrebačka biskupija proširila se na središnju Slavoniju do Donjega Miholjca na Dravi i Babine Grede na Savi, koja je prije provale Osmanlija pripadala Pečuškoj biskupiji (Slika 3). ${ }^{25}$ Međutim, krajem XVIII. stoljeća Donjomiholjački dekanat pripojen je Pečuškoj, a Brodski dekanat Đakovačkoj biskupiji (1780.), s time da je Prekmurje već prethodno (1777.) pripojeno novoosnovanoj Sombateljskoj, a Prekodravlje Vesprimskoj biskupiji. Desetak godina poslije (1790.) dvije žumberačke župe vraćene su iz Ljubljanske biskupije pod jurisdikciju zagrebačkoga biskupa (Slika 4). ${ }^{26}$ Opisane granice nisu se mijenjale više od dvjesto godina, sve do osnivanja novih biskupija sa sjedištima u Požegi i Varaždinu (1997.) te Bjelovaru i Sisku (2009.) koje su izdvojene iz sastava Zagrebačke - tada već - nadbiskupije. ${ }^{27}$ Ovim istraživanjem obuhvaćeno je područje kojim se povijesna Zagrebačka biskupija prostirala krajem XVIII. stoljeća, odnosno područje današnje Zagrebačke metropolije i Požeške biskupije.

\subsection{MATERIJALI I METODE ISTRAŽIVANJA}

Glavni likovni materijal koji je korišten u istraživanju su ranonovovjekovni nadgrobnici očuvani na području povijesne Zagrebačke biskupije. U njegovoj obradi primijenjene su povijesno-umjetničke (autopsija djela, likovno-ikonografska analiza, stilska analiza i komparativna analiza) i povijesne metode (arhivsko istraživanje) u svrhu atribucije, datacije, kontekstualizacije i valorizacije nadgrobnikā. Kao dodatan komparativan materijal upotrijebljeni su nadgrobni spomenici susjednih područja koja dijele povijesne, političke, društvene i kulturne veze s kontinentalnom Hrvatskom (Ugarska, slovenska i austrijska Štajerska) kao i suvremena umjetnička djela sličnih kompozicijskih rješenja izvedena u drugoj tehnici (slikarstvo, grafika).

Terenskim obilaskom nadgrobnih spomenika koji se nalaze in situ ili su pohranjeni u muzejskim zbirkama provedena je autopsija djelā koja obuhvaća bilježenje dimenzija, materijala, tehnike izrade i konzervatorskoga stanja te izradu fotodokumentacije. Nakon

\footnotetext{
${ }^{24}$ Crta razgraničenja vodila je od Virovitice preko Čazme i Siska do Karlovca.

${ }^{25}$ Usp. Andrija Lukinović, nav. dj., 1995., str. 28.

26 Isto.

${ }^{27}$ Biskupija je uzdignuta na stupanj nadbiskupije 1852. godine bulom Ubi primum placuit pape Pija IX. 
autopsije slijedi detaljna likovno-ikonografska analiza kojom se opisuju motivi i teme te iščitava njihovo značenje i simbolika. Uspoređivanjem pojedinih likovnih rješenja unutar zastupljenoga korpusa, ali i njihovim uspoređivanjem s rješenjima nadgrobnih spomenika susjednih područja i drugim likovnim djelima, ustanovljeni su likovni obrasci koji su u to vrijeme bili u optjecaju. Stilska analiza djela usmjerena je prema čitanju značajki određenoga stilskog razdoblja (gotičkoga, renesansnoga, manirističkoga ili baroknoga stila, njihovih izvedenica ili mješavina) i osobnoga stila umjetnika. Prvi pristup primijenjen je u određivanju vremena izrade pojedinoga nadgrobnika kada je ono nepoznato ili upitno, a drugi u pripisivanju djela određenom umjetniku, radionici ili krugu. Budući da većina nadgrobnih spomenika sadrži natpis na kojem je uklesana godina smrti pokojnika, okvirno vrijeme njihove izrade u većini je slučajeva poznato. Međutim, autorstvo nadgrobnika poznato je u samo nekoliko slučajeva i stilska analiza potkrijepljena domaćim ili inozemnim komparativnim primjerima ponekad predstavlja jedini način da se spomenici izvuku iz anonimnosti i pripišu pojedinoj ruci ili radionici.

Arhivskim istraživanjem i iščitavanjem epigrafskih natpisa na spomenicima produbljena su dosadašnja saznanja o potankostima narudžbe pojedinih nadgrobnih spomenika, poput vremena njihova nastanka, autorstva ili izvornoga smještaja. S obzirom na to da su spomenici izvorno bili postavljeni unutar crkvenih građevina - ili još uvijek jesu pozornost je usmjerena na istraživanje kanonskih vizitacija i župnih spomenica. Arhivskim istraživanjem obuhvaćeni su i fondovi obitelji pokojnikā zbog oporučnih pisama u kojima su potpisnici često navodili svoje želje povezane s mjestom ukopa i načinom provedbe sprovoda.

\subsection{PREGLED DOSADAŠNJE LITERATURE}

U domaćoj literaturi nadgrobni spomenici dosad nisu sustavno i cjelovito znanstveno obrađeni. Prikazani su u različitim pregledima hrvatske kulturne baštine u kojima su zbog ograničenja svojstvenih takvoj vrsti rada predstavljeni samo najvažniji primjeri ili kao zasebne studije slučaja, no dosad nije objavljeno opsežnije djelo koje bi se bavilo nadgrobnicima kao središnjim problemom povijesno-umjetničkoga istraživanja. Osnovnu referentnu literaturu o nadgrobnim spomenicima na području kontinentalne Hrvatske predstavljaju studije Gjure Szabe. Riječ je o njegovim izvještajima o radu Zemaljskoga povjerenstva za očuvanje umjetnih i historičkih spomenika u Kraljevinama Hrvatskoj i Slavoniji (1912., 1914., 1919.), članku Ljudi iz kamena (1938.) i knjizi Kroz Hrvatsko zagorje 
(1939.). ${ }^{28}$ Szabo je većinu nadgrobnika obradio kataloški bilježeći njihovu lokaciju, osnovni izgled i (ponegdje) natpis, bez detaljnije formalne, stilske ili ikonografske analize, no njegova djelā predstavljaju osnovu koja je kasnijim istraživačima služila kao polazišna točka. Jedan od njih bio je Ljubo Karaman (1948., 1950.) koji je prvi postavio pitanje autorstva domaćih nadgrobnih spomenika i njihove recepcije kao ostvarenja provincijalizirane umjetnosti naspram umjetnosti velikih centara. ${ }^{29}$ Anđela Horvat također se $u$ znatnoj mjeri služila Szabinim djelima. Prva se detaljnije posvetila nadgrobnim spomenicima i njihovim stilskim odrednicama te im posvetila zasebno poglavlje u dvama pregledima kulturne baštine kontinentalne Hrvatske, Između gotike i baroka (1975.) i Barok u kontinentalnoj Hrvatskoj (1982.). ${ }^{30}$ U preglednim knjigama Renesansa (2007.) i Povijest umjetnosti u Hrvatskoj (2012.)

Milan Pelc je na sličan, sintetičan način obradio nadgrobnike kao zasebnu granu kiparske umjetnosti, no ponovno uključujući samo najvažnija ostvarenja. ${ }^{31}$

Pojedini autori istražili su pojedinačne nadgrobne spomenike i o njima objavili tematske članke. Izuzev već navedenih Anđele Horvat (1958., 1979.) ${ }^{32}$ i Milana Pelca (2006., 2009. $)^{33}$ koji su pisali o najboljim ostvarenjima gotičkoga i renesansnoga stila među nadgrobnim spomenicima, nadgrobnim pločama Nikole $(† 1477$.$) i Lovre Iločkih († 1524$.$) te$

\footnotetext{
${ }^{28}$ Gjuro Szabo, Izvještaj o radu zemaljskoga povjerenstva za očuvanje umjetnih $i$ historičkih spomenika $u$ kraljevinama Hrvatskoj i Slavoniji u godini 1911., u: Vjesnik Hrvatskoga arheološkog društva XII/ 1, Zagreb: Hrvatsko arheološko društvo, 1912., str. 202-259 (Poglavlje III. Spomenici kotara Klanjec i Pregrada, 207259); Gjuro Szabo, Spomenici kotara Krapina i Zlatar, u: Vjesnik Hrvatskoga arheološkog društva XIII/1, Zagreb: Hrvatsko arheološko društvo, 1914., str. 103-204; Gjuro Szabo, Spomenici kotara Ivanec, u: Vjesnik Hrvatskoga arheološkog društva XIV/1, Zagreb: Hrvatsko arheološko društvo, 1919., str. 22-97; Gjuro Szabo, Ljudi iz kamena, u: Jutarnji list XXVII/9668, Zagreb: Tipografija, 24. XII. 1938., str. 5; Gjuro Szabo, Kroz Hrvatsko zagorje, Zagreb: Vasić i Horvat, 1939.

${ }^{29}$ Ljubo Karaman, O umjetnosti srednjega vijeka u Hrvatskoj i Slavoniji, u: Historijski zbornik I/1-4, Zagreb: Društvo za hrvatsku povjesnicu, 1948., str. 103-127; Ljubo Karaman, O umjetnosti srednjega vijeka, u: Historijski zbornik III/1-4, Zagreb: Društvo za hrvatsku povjesnicu, 1950., str. 125-174.

${ }^{30}$ Anđela Horvat, Između gotike i baroka: umjetnost kontinentalnog dijela Hrvatske od oko 1500. do oko 1700., Zagreb: Društvo povjesničara umjetnosti SR Hrvatske, 1975.; Anđela Horvat, Barok u kontinentalnoj Hrvatskoj, u: Barok u Hrvatskoj, Zagreb: Sveučilišna naklada Liber, Odjel za povijest umjetnosti Centra za povijesne znanosti, Društvo povjesničara umjetnosti, 1982.a, str. 3-381. Napisali Anđela Horvat, Radmila Matejčić i Kruno Prijatelj.

${ }^{31}$ Milan Pelc, Renesansa, Zagreb: Naklada Ljevak, 2007.; Milan Pelc, Povijest umjetnosti u Hrvatskoj, Zagreb: Naklada Ljevak, 2012.

32 Anđela Horvat, Ilok: ili - ne znamo dovoljno što imamo, u: Bulletin Instituta za likovne umjetnosti Jugoslavenske akademije znanosti i umjetnosti VI/1, Zagreb: Jugoslavenska akademija znanosti i umjetnosti, 1958., str. 15-21, 78; Anđela Horvat, Dva epitafa u Iloku, u: Zbornik za likovne umetnosti 15, Novi Sad: Matica srpska, Odelenje za likovne umetnosti, 1979.a, str. 307-315.

${ }^{33}$ Milan Pelc, Ugarske kiparske radionice i renesansa u sjevernoj Hrvatskoj, u: Radovi Instituta za povijest umjetnosti 30, Zagreb: Institut za povijest umjetnosti, 2006., str. 67-80; Milan Pelc, Iločki renesansni fragmenti, u: Sic ars deprenditur arte: zbornik u čast Vladimira Markovića, Zagreb: Institut za povijest umjetnosti, Odsjek za povijest umjetnosti Filozofskog fakulteta Sveučilišta u Zagrebu, 2009.a, str. 307-317. Uredili Sanja Cvetnić, Milan Pelc, Daniel Premerl; Milan Pelc, Krhotine renesanse u Slavoniji, u: Slavonija, Baranja i Srijem: vrela europske civilizacije, sv. 2, Zagreb: Galerija Klovićevi dvori, 2009.b, str. 313-317. Uredio Božo Biškupić.
} 
zagrebačkoga biskupa Luke de Szegeda ${ }^{34}(\dagger 1510$.$) , njima pripadaju i Igor Fisković (1984.) { }^{35}$ koji je pisao o srednjovjekovnim i renesansnim nadgrobnicima na području jadranske Hrvatske s posebnim osvrtom na svetačke grobnice, Marijana Schneider (1958., 1959., 1972., 1972.-1973., 1973. $)^{36}$ koja je uglavnom pisala o nadgrobnicima kontinentalne Hrvatske te Zorislav Horvat (1988., 1996., 2002., 2005.) ${ }^{37}$ i Marija Šercer (2003., 2008., 2011.) ${ }^{38}$ koji se podjednako bave spomenicima primorske i kontinentalne Hrvatske. Milan Pelc (2010.) ujedno je pisao o odabranim srednjovjekovnim i ranonovovjekovnim nadgrobnim pločama s likom pokojnika - s posebnim osvrtom na navedenu likovnu skupinu nadgrobnika koji su nastali u okrilju zagrebačke katedrale - kao vrijednim povijesnim, kulturološkim i povijesnoumjetničkim materijalnim svjedočanstvima onoga vremena. ${ }^{39}$

\footnotetext{
${ }^{34}$ U hrvatskoj literaturi navedeni je biskup uglavnom poznat kao Luka Baratin. Ivan Bojničić (1901.) pogrešno je uveo to prezime u hrvatsku historiografiju na osnovu istraživanja S. Borovszkog (1900.). Budući da je Luka bio iz Segedina i potpisivao se kao Luca de Zeged, ispravnije je koristiti to prezime. Usp. Árpád Mikó, All' antica djela i njihovi stvaraoci и Budimu i Zagrebu za Matije Korvina i Jagelovića (1480-1526), u: Hrvatska / Mađarska: stoljetne književne i likovno-umjetničke veze = Horvátország / Magyarország: évszázados irodalmi és képzömüvészeti kapcsolatok, Zagreb: Croatian Writers' Association, 1995., str. 53-60, 56-57. Uredila Jadranka Damjanov.

${ }^{35}$ Igor Fisković, Nadgrobna plastika humanističkog doba na našem primorju, u: Dometi: znanstveno-kulturna smotra Matice hrvatske, Ogranka u Rijeci 1-2-3, Rijeka: Izdavački centar Rijeka, 1984.a, str. 73-104; Igor Fisković, O grobnim spomenicima u srednjovjekovnoj Dalmaciji, u: Dometi: znanstveno-kulturna smotra Matice hrvatske, Ogranka u Rijeci 5, Rijeka: Izdavački centar Rijeka, 1984.b, str. 33-53.

${ }^{36}$ Marijana Schneider, Jedan se spomenik vratio kući..., u: Vijesti Društva muzejsko-konzervatorskih radnika NR Hrvatske VII/4, Zagreb: Društvo muzejsko-konzervatorskih radnika NR Hrvatske, 1958., str. 108-110; Marijana Schneider, O epitafiju Ivana Hrvoja i Eve Dreffell u Plešivici, u: Bulletin Instituta za likovne umjetnosti Jugoslavenske akademije znanosti i umjetnosti VII/3, Zagreb: Jugoslavenska akademija znanosti i umjetnosti, 1959., str. 177-182; Marijana Schneider, Dva dječja kostima s nadgrobnih ploča iz Vojne krajine (s pregledom dječje nošnje u zapadnoj Evropi od 1600. do 1650.), u: Spomenica Josipa Matasovića (1892-1962.), Zagreb: Povijesno društvo Hrvatske, 1972., str. 181-199. Uredio Igor Karaman; Marijana Schneider, Zrinski $i$ Frankopani u likovnoj umjetnosti, u: Historijski zbornik 25-26, Zagreb: Povijesno društvo Hrvatske, 1972.-1973., str. 251-271; Marijana Schneider, Odraz seljačke bune 1573. godine u likovnoj umjetnosti, u: Radovi Zavoda za hrvatsku povijest 5, Zagreb: Institut za hrvatsku povijest Sveučilišta u Zagrebu, 1973., str. 271-286.

${ }^{37}$ Zorislav Horvat, O nekim osobinama gotičkih nadgrobnih ploča s grbovima u kontinentalnom dijelu SR Hrvatske, u: Bulletin Razreda za likovne umjetnosti Jugoslavenske akademije znanosti i umjetnosti LIX/1, Zagreb: Jugoslavenska akademija znanosti i umjetnosti, 1988., str. 41-68; Zorislav Horvat, Heraldički štitovi gotičke arhitekture kontinentalne Hrvatske, Zagreb: Društvo povjesničara umjetnosti Hrvatske, 1996.; Zorislav Horvat, Sačuvani nadgrobni spomenici nekih Senjana i osoba značajnih za povijest Senja - u Senju i drugdje, u: Senjski zbornik: prilozi za geografiju, etnologiju, gospodarstvo, povijest i kulturu XXIX/1, Senj: Gradski muzej, Senjsko muzejsko društvo, 2002., str. 47-86; Zorislav Horvat, Pregled sačuvanih nadgrobnih ploča Krčkih knezova Frankopana, u: Senjski zbornik: prilozi za geografiju, etnologiju, gospodarstvo, povijest i kulturu XXXII/1, Senj: Gradski muzej, Senjsko muzejsko društvo, 2005., str. 25-58.

${ }^{38}$ Marija Šercer, Ulomak nadgrobne ploče Franje Berislavića Grabarskog, u: Informatica museologica IIIIV/34, Zagreb: Muzejsko dokumentacijski centar, 2003., str. 103-106; Marija Šercer, Nadgrobna ploča Stjepana II. Frankopana, u: Modruški zbornik 2, Modruš: Katedra Čakavskog sabora Modruše, 2008., str. 37-52; Marija Šercer, Žene Frankopanke, u: Modruški zbornik 4-5, Modruš: Katedra Čakavskog sabora Modruše, 2011., str. $21-81$.

${ }^{39}$ Milan Pelc, Spomenici potonuloga svijeta. Nadgrobne ploče s likom pokojnika u sjevernoj Hrvatskoj u pisanim i tiskanim vrelima do konca 19. st., u: Umjetnost i naručitelj. Zbornik radova znanstvenoga skupa »Dani Cvita Fiskovića održanog 2008. godine, Zagreb: Institut za povijest umjetnosti, Odsjek za povijest umjetnosti Filozofskog fakulteta Sveučilišta u Zagrebu, 2010., str. 61-71. Uredila Jasenka Gudelj.
} 
Među referentnom literaturom potrebno je istaknuti i katalog izložbe Mors porta vitae = Smrt vrata života (2014.) održane u Muzeju grada Zagreba koja tematizira smrt, njezino poimanje, posmrtne svečanosti i razvoj grobljā tijekom zagrebačke prošlosti. ${ }^{40}$ Od katalogā potrebno je navesti i one Zbirke kamenih spomenika Hrvatskoga povijesnog muzeja (1969., 2002.) koja sadrži većinu sačuvanih nadgrobnika iz XV. stoljeća s područja zagrebačke povijesne biskupije. ${ }^{41}$

Posebno mjesto u proučavanju nadgrobnih spomenika u Hrvatskoj zauzima knjiga Nadpisi sredovječni $i$ novovjeki na crkvah, javnih $i$ privatnih sgradah itd. u Hrvatskoj $i$ Slavoniji (objavljena postumno 1891.) Ivana Kukuljevića Sakcinskoga. ${ }^{42}$ Iako su više dokumentarnoga nego povijesno-umjetničkoga karaktera, Nadpisi predstavljaju glavno priručno djelo u proučavanju natpisa na spomenicima, posebice onima koji su s vremenom istrošeni, oštećeni ili - u najgorem slučaju - uništeni, ali i bitnu okosnicu u pripremi za terensko istraživanje budući da su spomenici sistematski navedeni prema gradovima u kojima se nalaze.

U kontekstu strane stručne literature, polazišna knjiga o nadgrobnoj plastici je Tomb Sculpture (1964.) Erwina Panofskoga. U ovom pionirskom djelu, Panofsky je prikazao razvoj nadgrobnih spomenika od Egipta do baroka povezujući promjene $\mathrm{u}$ poimanju smrti $\mathrm{s}$ promjenama u likovnom jeziku. ${ }^{43}$ Iako današnji stručnjaci nadopunjuju i drugačije intoniraju pojedine Panofskyjeve teze, ${ }^{44}$ njegova knjiga još uvijek posjeduje neosporni autoritet na području nadgrobne skulpturalne umjetnosti. Drugo nezaobilazno djelo je knjiga L'Homme devant la mort (1977.), prevedena na engleski s naslovom The Hour of Our Death (1981.), francuskoga autora Philippea Arièsa. ${ }^{45}$ Iako je Ariès više usmjeren na eshatologiju i proučavanje promjene odnosa zapadnoga društva prema ovozemaljskom životu i onome nakon smrti, knjiga obiluje opažanjima i zaključcima koji se odnose na iščitavanje ikonografije i značenja nadgrobnih spomenika.

\footnotetext{
40 Slavko Šterk i Boris Mašić, Mors porta vitae = Smrt vrata života: stara zagrebačka groblja i pogrebi, Zagreb: Muzej grada Zagreba, 2014.

${ }^{41}$ Josip Brunšmid, Kameni spomenici hrvatskoga narodnoga muzeja u Zagrebu. Dio II. Spomenici srednjega $i$ novoga vijeka, u: Vjesnik Hrvatskoga arheološkog društva XII/ 1, Zagreb: Hrvatsko arheološko društvo, 1912. str. 129-197; Mirko Valentić, Kameni spomenici Hrvatske XIII-XIX stoljeća, Zagreb: Povijesni muzej Hrvatske, 1969.; Mirko Valentić i Lada Prister, Zbirka kamenih spomenika, II. dopunjeno izdanje, Zagreb: Hrvatski povijesni muzej, 2002.

${ }^{42}$ Ivan Kukuljević Sakcinski, Nadpisi sredovječni $i$ novovjeki na crkvah, javnih i privatnih sgradah itd. $u$ Hrvatskoj i Slavoniji, Zagreb: Knjižara Jugoslavenske akademije, Knjižara Dioničke tiskare, 1891.

${ }^{43}$ Erwin Panofsky, Tomb Sculpture: Four Lectures on Its Changing Aspects from Ancient Egypt to Bernini, London: Phaidon Press, 1992. [1964.]. Uredio H. W. Janson.

${ }^{44}$ Ann Adams i Jessica Barker (ur.), Revisiting the monument: Fifty years since Panofsky's »Tomb sculpture«, London: Research Forum of the Courtauld Institute of Art, 2016.

${ }^{45}$ Philippe Ariès, The Hour of Our Death, New York: Alfred A. Knopf, 1981. Prevela Helen Weaver.
} 


\section{RAZVOJ, TIPOLOGIJA I TERMINOLOGIJA NADGROBNE SKULPTURE}

U vrijeme kasne antike, kada su se vjernici još uvijek pokapali na nekropolama uz grobove svetaca i mučenika, grobovi imućnih vjernika obilježavani su stelama ili su njihova tijela polagana u kamene sarkofage koji su potom zakopani u tlo ili postavljeni unutar mauzoleja. ${ }^{46}$ Podizanjem prvih grobljanskih crkava u kojima su tijela pokojnika sahranjivana ispod popločenja broda ili u zatvorenim kriptama, stele više nisu odgovarale potrebama vjernikā te su postupno izašle iz uporabe. ${ }^{47}$ Kameni sarkofazi, s druge strane, nastavili su se upotrebljavati do XIII. stoljeća kada su zamijenjeni drvenim ljesovima (crkveni i svjetovni velikodostojnici nastavili su se pokapati u metalnim sarkofazima). ${ }^{48}$ Nakon što je u njih položeno tijelo pokojnika, uglavnom su se zakopali ispod crkvenoga poda, a oni istaknutih pojedinaca postavljeni su na zidove pomoću konzola ili su uklopljeni u arkosolije (lat. arcus "luk«, solium »škrinja, sarkofag«), plitke grobne niše zaključene polukružnim lukom koje su rastvarale unutarnje i vanjske zidove crkava. ${ }^{49}$

U visokom i kasnom srednjem vijeku nadgrobna plastika doživjela je procvat transformacijom starih i pojavom novih vrsta nadgrobnih spomenika. Ranokršćanski se arkosolij tako razvio u složeni oblik zidne grobnice u niši (eng. altar tomb, fr. enfeu, njem. Bobengrab, Nischengrab, tal. arcosolio). Sarkofag je preoblikovan u pravokutno postolje čije su bočne i prednja strana ukrašeni arhitektonskim elementima, figuralnim prikazima ili motivima funeralne ikonografije, a od XIII. stoljeća nadalje na njemu najčešće počiva lik pokojnika koji leži (eng. recumbent effigy, fr. gisant, njem. Liegefigur) izveden u reljefu ili punoj skulpturi. Zid niše - posebice luneta - često je ukrašen arhitektonskim motivima i figuralnim prikazima izvedenima u reljefu, mozaiku ili fresci, a njezin luk ponekad je naglašen timpanom ili baldahinom. ${ }^{50}$ Budući da svojim izgledom podsjeća na oltarnu menzu s retablom, ova se vrsta nadgrobnika u engleskoj stručnoj literaturi naziva oltarnom grobnicom, iako nema liturgijsku funkciju oltara. ${ }^{51}$ Prvi primjeri grobnica u niši pojavili su se u Francuskoj odakle su se proširili ostatkom Europe, a posebnu popularnost stekli su u Italiji u vrijeme renesanse postajući oblikovno još složeniji. ${ }^{52}$ Jedan od poznatijih primjera je grobnica

\footnotetext{
${ }^{46}$ Usp. Jutta Dresken-Weiland, Christian Sarcophagi from Rome, u: The Routledge Handbook of Early Christian Art, Abingdon: Routledge, 2018., str. 39-55, 51. Uredili Robin M. Jensen i Mark D. Ellison.

${ }^{47}$ Usp. Erwin Panofsky, nav. dj., 1992. [1964.], str. 48-49.

${ }^{48}$ Usp. Philippe Ariès, nav. dj., 1981., str. 203-205.

${ }^{49}$ Usp. Philippe Ariès, nav. dj., 1981., str. 235-236.

${ }^{50}$ Usp. Philippe Ariès, nav. dj., 1981., str. 236.

${ }^{51}$ Usp. Erwin Panofsky, nav. dj., 1992. [1964.], str. 53.

${ }^{52}$ Usp. Erwin Panofsky, nav. dj., 1992. [1964.], str. 53, 76-77.
} 
Leonarda Brunija (1444. - 1447.) u firentinskoj crkvi Santa Croce koju je izradio arhitekt i kipar Bernardo Rossellino (Settignano, 1409. - Firenca, 1464.) (Slika 5).

U XI. stoljeću pojavila se nova vrsta nadgrobnoga spomenika koja je brzo stekla široku primjenu, a to su nadgrobne ploče (eng. tomb slab, njem. Grabplatte, fr. dalle funéraire, tal. lastra tombale). Postavljene iznad groba pokojnika, one obilježavaju dio crkvenoga poda ispod kojega se nalazi tijelo vjernika. ${ }^{53}$ Budući da su služile kao pokrov groba, pravokutnoga su oblika i uglavnom veličine lijesa. Prve nadgrobne ploče klesane su u kamenu, a sadržavale su jednostavnu ornamentiranu dekoraciju i motive poput križeva, vaza s cvijećem i životinja. ${ }^{54}$ Krajem XI. stoljeća pojavile su se ploče s prikazom pokojnika (Slika 6), a izrađivane su u bronci, mozaiku i - najčešće - kamenu. Prema Erwinu Panofskom (1964.), takvi prikazi pokojnika nastali su po uzoru na ranokršćanske funeralne mozaike s područja sjeverne Afrike i Španjolske koji prikazuju orante okružene cvijećem, drvećem i pticama, simbolizirajući beate uzišle u nebeski Jeruzalem. ${ }^{55}$ Panofsky objašnjava da su srednjovjekovne ploče prvo bile izvedene u tehnici mozaika, nalik njihovim ranokršćanskim uzorima, a da su potom klesane u kamenu odnosno lijevane u bronci. Današnji stručnjaci odbacuju njegovu tezu smatrajući da je uvjetovana idejom o očuvanju tradicije i kontinuiranom prenošenju likovnih rješenja. ${ }^{56}$ Tumače da je kiparska produkcija XII. stoljeća bila dovoljno razvijena i zrela da proizvede vlastita rješenja te da su srednjovjekovni kipari mogli crpiti inspiraciju - ako im je ona i bila potrebna - iz antičke grobne skulpture bez posredništva ranokršćanskih mozaika. Ujedno navode da brojne kamene i brončane ploče prethode najstarijim očuvanim mozaicima, stoga smatraju da je izglednije da su se sve tri tehnike upotrebljavale istovremeno, odnosno da nijedna nije prethodila drugoj. Neovisno o njihovom podrijetlu, nadgrobne ploče s motivom gisanta, lika ležećega pokojnika, postale su dominantan oblik nadgrobne plastike u visokom i kasnom srednjem vijeku, a primjenjivale su se do XVII. stoljeća.

Tijekom XI. i XII. stoljeća figura pokojnika na nadgrobnim pločama postupno je rasla u volumenu od plitkoga do visokoga reljefa, naposljetku postajući toliko izdignuta da je otežavala kretanje svećenikā i vjernikā unutar crkava. Prema Erwinu Panofskom (1964.), kao rješenje razvila se nova vrsta nadgrobnoga spomenika - tumba. ${ }^{57}$ Prve tumbe (eng. tumba, fr. tombeau, njem. Hochgrab, Tumba) pojavile su se u XII. stoljeću, a nastale su podizanjem

\footnotetext{
${ }^{53}$ Usp. Philippe Ariès, nav. dj., 1981., str. 237-238; Erwin Panofsky, nav. dj., 1992. [1964.], str. 47.

${ }^{54}$ Usp. Erwin Panofsky, nav. dj., 1992. [1964.], str. 49-50.

${ }_{55}^{5}$ Usp. Erwin Panofsky, nav. dj., 1992. [1964.], str. 47, 50-51.

${ }^{56}$ Usp. Shirin Fozi, From the "pictorial" to the »statuesque«: Two Romanesque effigies and the problem of plastic form, u: Revisting the monumet: Fifty years since Panofsky's »Tomb sculpture«, London: Research Forum of the Courtauld Institute of Art, 2016., str. 30-48, 36-37. Uredili Ann Adams i Jessica Barker.

${ }^{57}$ Usp. Erwin Panofsky, nav. dj., 1992. [1964.], str. 53.
} 


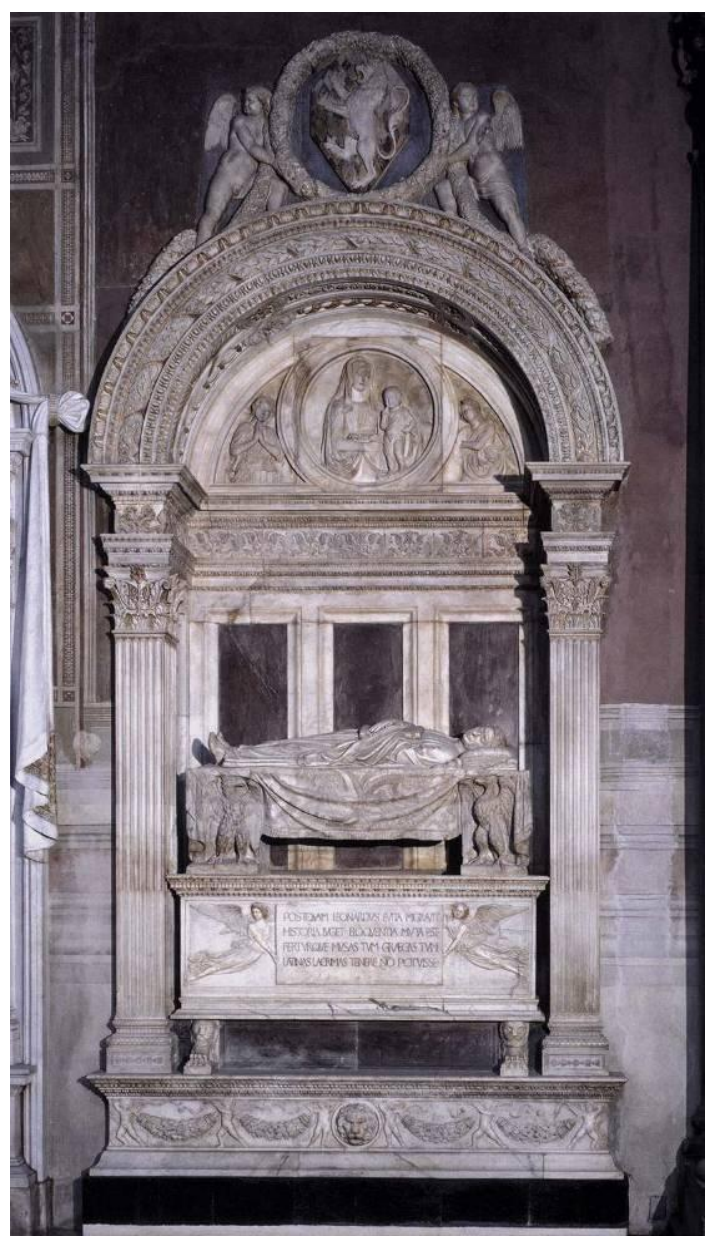

Slika 5. Bernardo Rossellino, Nadgrobni spomenik Leonarda Brunija, 1444. - 1447., Firenca, crkva Santa Croce

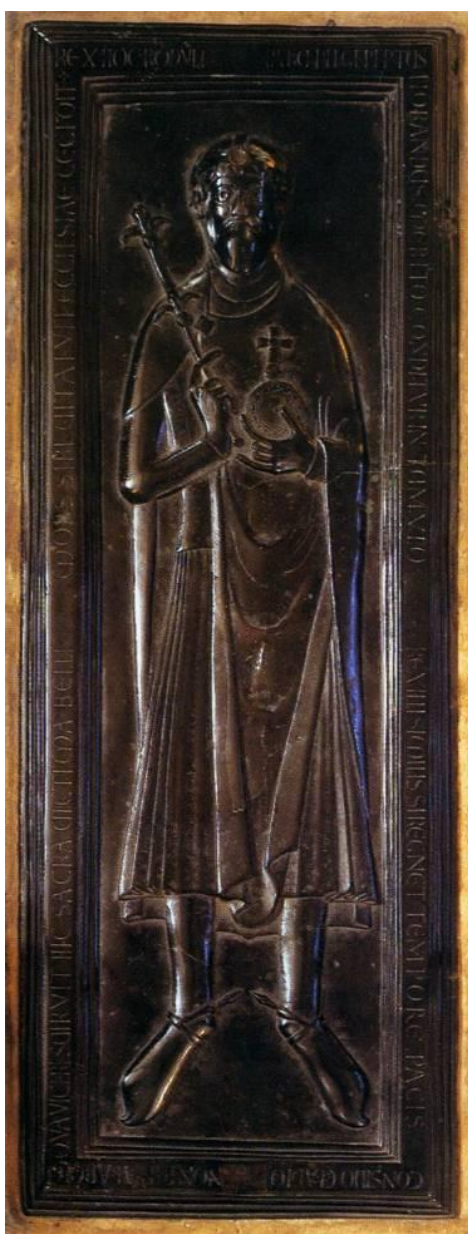

Slika 6. Nadgrobna ploča Rudolfa Švapskoga, o. 1080. 1084., Merseburg, katedrala sv. Ivana Krstitelja i sv. Lovre

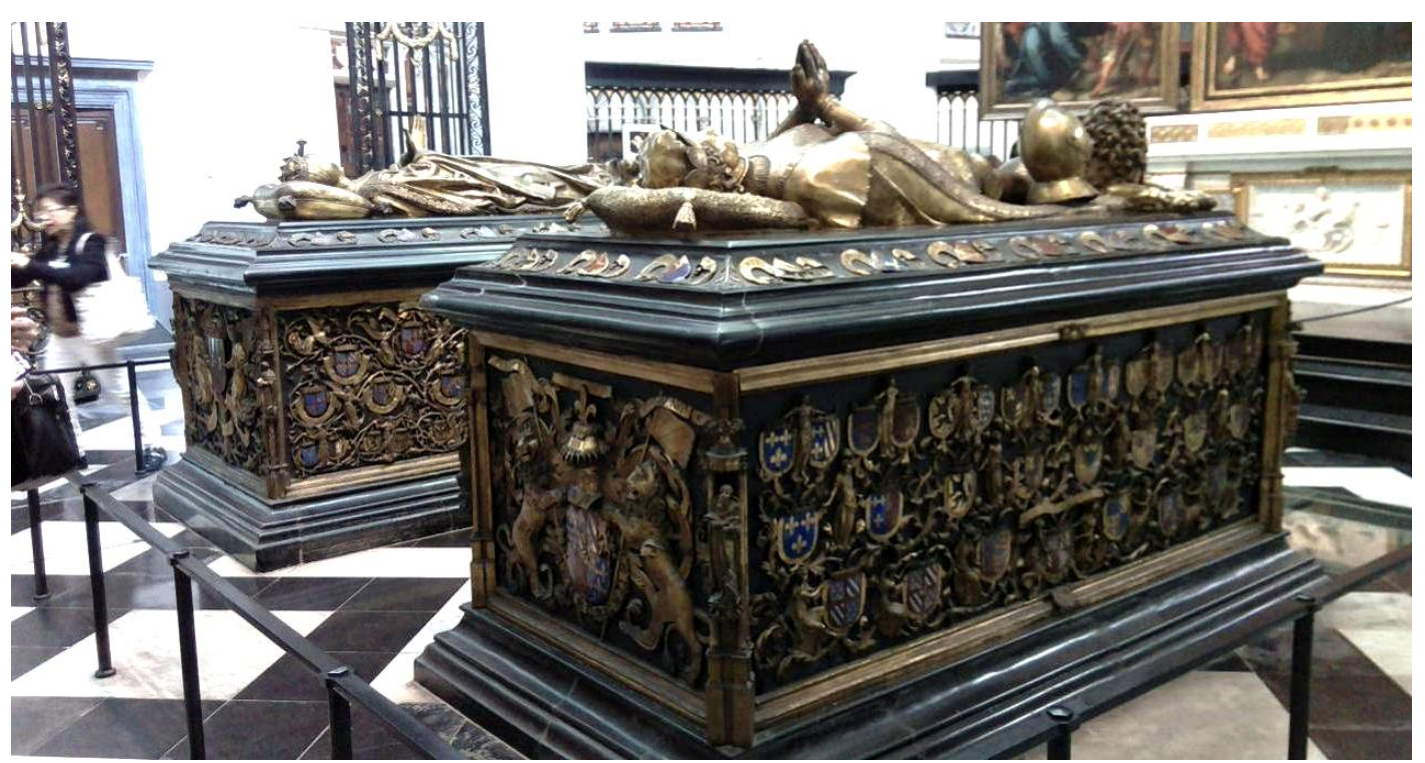

Slika 7. Tumbe Karla Smjeloga (†1477.) i njegove kćeri Marije od Burgundije (†1482.), Brugge, crkva Naše Gospe 
nadgrobne ploče s crkvenoga poda na pravokutno postolje ukrašeno arhitektonskim elementima, figuralnim prikazima ili pojedinačnim motivima poput obiteljskih grbova (Slika 7). ${ }^{58}$ Postavljene su slobodno u prostoru crkve, a mogu biti natkrivene baldahinom. Formom nalikuju antičkim sarkofazima, no za razliku od njih, tijelo pokojnika nije pohranjeno unutar samoga spomenika, nego se nalazi u grobnici ispod njega. Reprezentativna su vrsta nadgrobnika koji su si mogli priuštiti samo najimućniji pripadnici društva poput vladarskih obitelji, visokoga plemstva i najviših crkvenih dužnosnika. ${ }^{59} \mathrm{U}$ vrijeme ranoga novog vijeka tumbe su se razvile u monumentalne grobnice kompleksne forme i ikonografije koje su osim skulpture pokojnika - izvedene u ležećoj, poluležećoj ili klečećoj pozi uključivale figure svetih osoba, anđela, personifikacija, žalobnika i drugo. Jedan takav primjer predstavlja nadgrobni spomenik francuskoga kralja Luja XII. (Blois, 1462. - Pariz, 1515.) i njegove supruge Ane Bretonske (Nantes, 1477. - Blois, 1514.) postavljen u opatijskoj crkvi u St. Denisu (Slika 8).

Posljednja vrsta nadgrobnoga spomenika koja se razvila krajem srednjega vijeka je epitaf (eng. epitaph, fr. monument funéraire plaqué, njem. Epitaph, tal. epitaffio). Nastao je u XIV. stoljeću podizanjem nadgrobne ploče s poda i njezinim ugrađivanjem u zidnu masu. ${ }^{60}$ Budući da ne pokriva grob kao nadgrobna ploča i nije neposredno vezan uz grobno mjesto, može biti raznovrsnih oblika, veličina i materijala (kamen, bronca, drvo, tapiserija, freska, sgrafitto). ${ }^{61}$ Prvi epitafi imali su jednostavan oblik ploče koja je ponekad bila uokvirena edikulom, a primijenjena likovna rješenja varirala su od najjednostavnijih, poput natpisa $\mathrm{s}$ obiteljskim grbom, do složenih, poput portreta pokojnika (Slika 9), Raspeća s adorantima, Uskrsnuća, Presvetoga Trojstva, sacra conversazione i slično. U XVI. i XVII. stoljeću epitafi su prerasli u velike zidne grobnice složenoga arhitektonskog okvira upotpunjenoga skulpturom, koje su nalikovale oltarnim retablima (Slika 10). ${ }^{62}$

Ukratko, u srednjem vijeku razvile su se četiri vrste nadgrobnih spomenika koje su se nastavile upotrebljavati u ranom novom vijeku: I) arkosolij odnosno grobnica u niši, II) nadgrobna ploča, III) tumba i IV) epitaf. Ranonovovjekovne grobnice u niši

\footnotetext{
${ }^{58}$ Usp. Philippe Ariès, nav. dj., 1981., str. 239; Erwin Panofsky, nav. dj., 1992. [1964.], str. 53-58.

${ }^{59}$ Usp. Gerhard Winkler, Zur Typologie und Ikonographie der sepulkralen Kunst des 16. Jahrhunderts in Österreich, u: Renaissance in Österreich: Geschichte - Wissenschaft - Kunst, Horn: Verlag Ferdinand Berger \& Soehne, 1974., str. 213-222, 215. Uredio Rupert Feuchtmueller.

${ }^{60}$ Usp. Erwin Panofsky, nav. dj., 1992. [1964.], str. 58-59.

${ }^{61}$ Usp. Renate Kohn, Zwischen standesgemäßem Repräsentationsbedürfnis und Sorge um das Seelenheil. Die Entwicklung des frühneuzeitlichen Grabdenkmals, u: Macht und Memoria. Begräbniskultur europäischer Oberschichten in der frühen Neuzeit, Köln, Weimer, Wien: Böhlau Verlag, 2005., str. 19-46, 24. Uredio Mark Hengerer; Gerhard Winkler, nav. dj., 1974., str. 218.

${ }^{62}$ Usp. Gerhard Winkler, nav. dj., 1974., str. 217.
} 


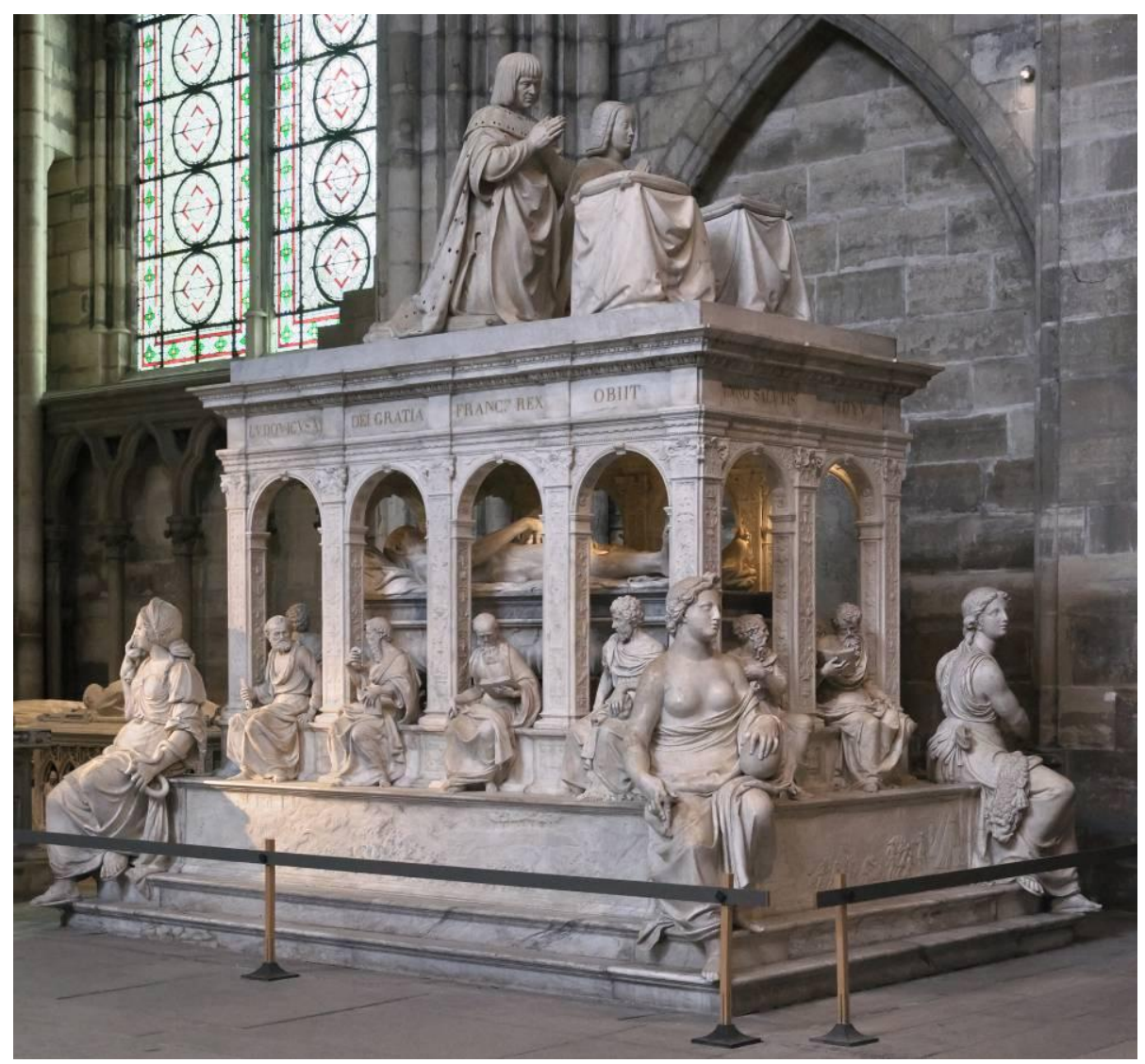

Slika 8. Nadgrobni spomenik Luja XII. i Ane Bretonske, 1515. - 1531., St. Denis, opatijska crkva

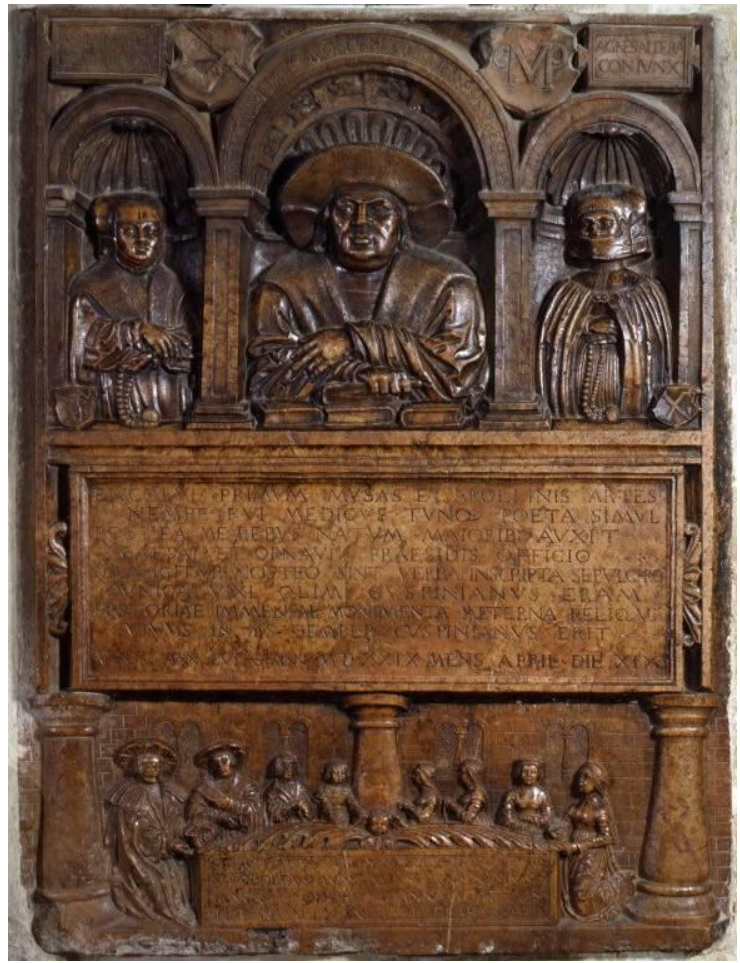

Slika 9. Epitaf Johannesa Cuspinianusa (†1529.), Beč, katedrala sv. Stjepana

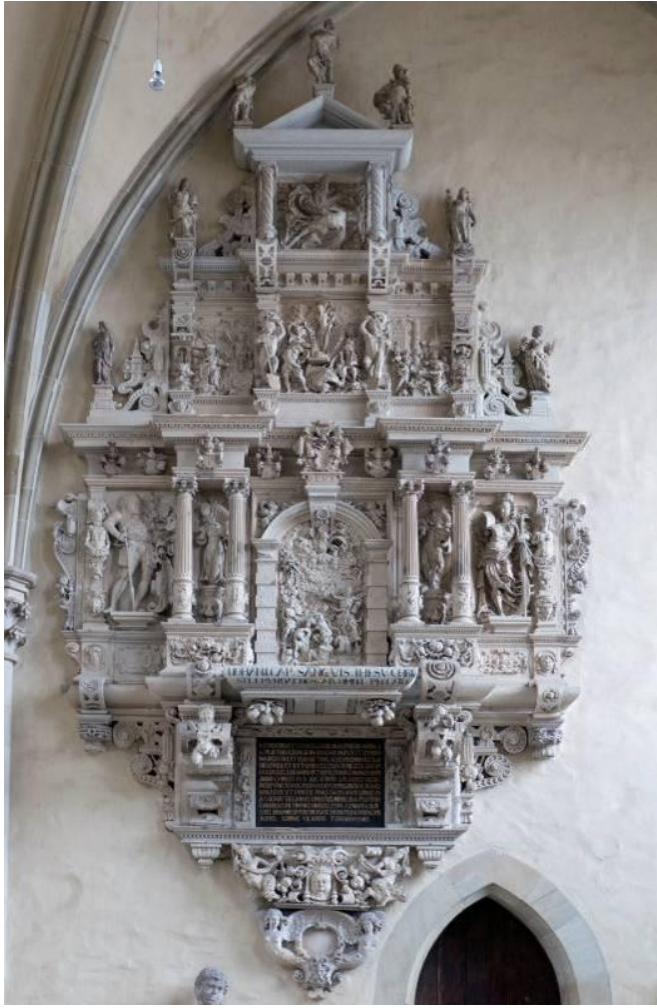

Slika 10. Hans Klintzsch, Epitaf Wernera von Plothowa, 1590. - 1591., Magdeburg, katedrala sv. Katarine i sv. Mauricija 


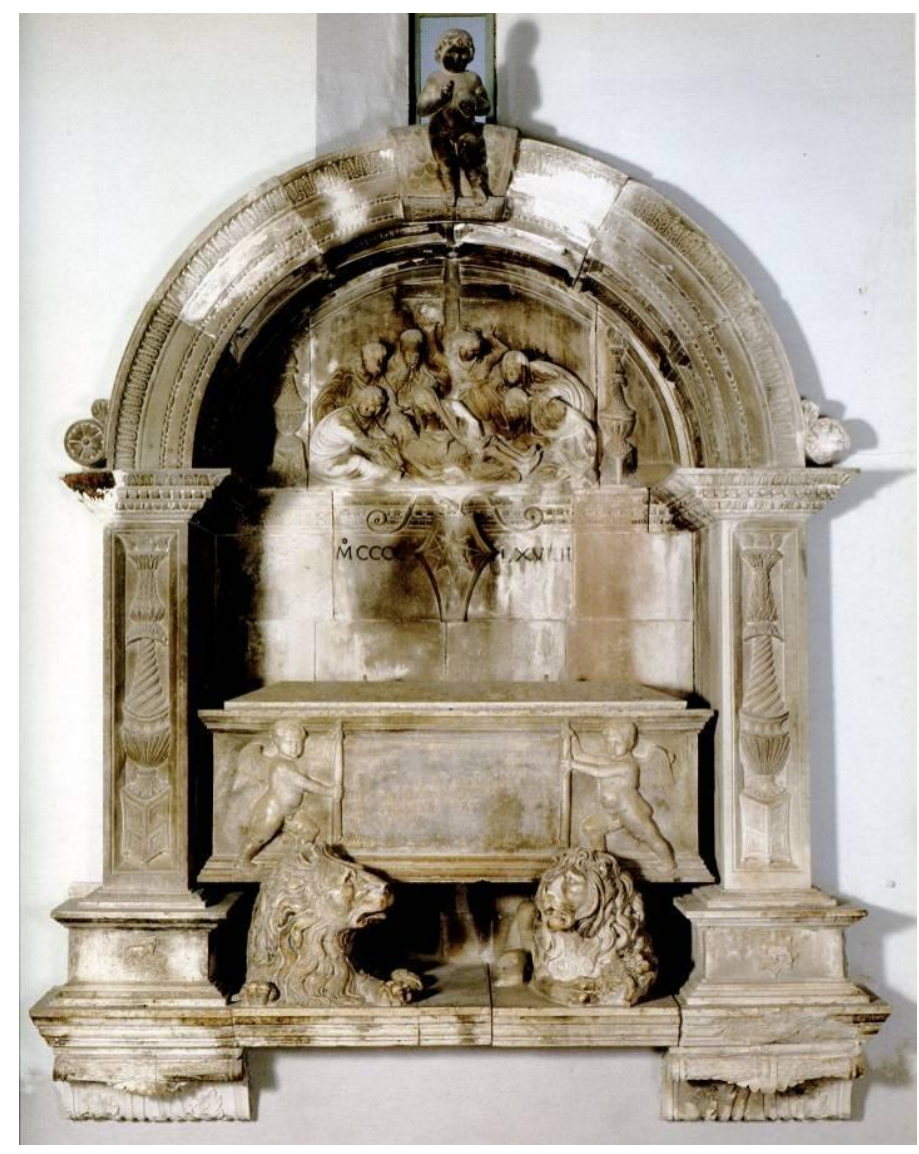

Slika 11. Nikola Firentinac, Nadgrobni spomenik Ivana Sobote (Subotića), 1469., Trogir, crkva sv. Dominika

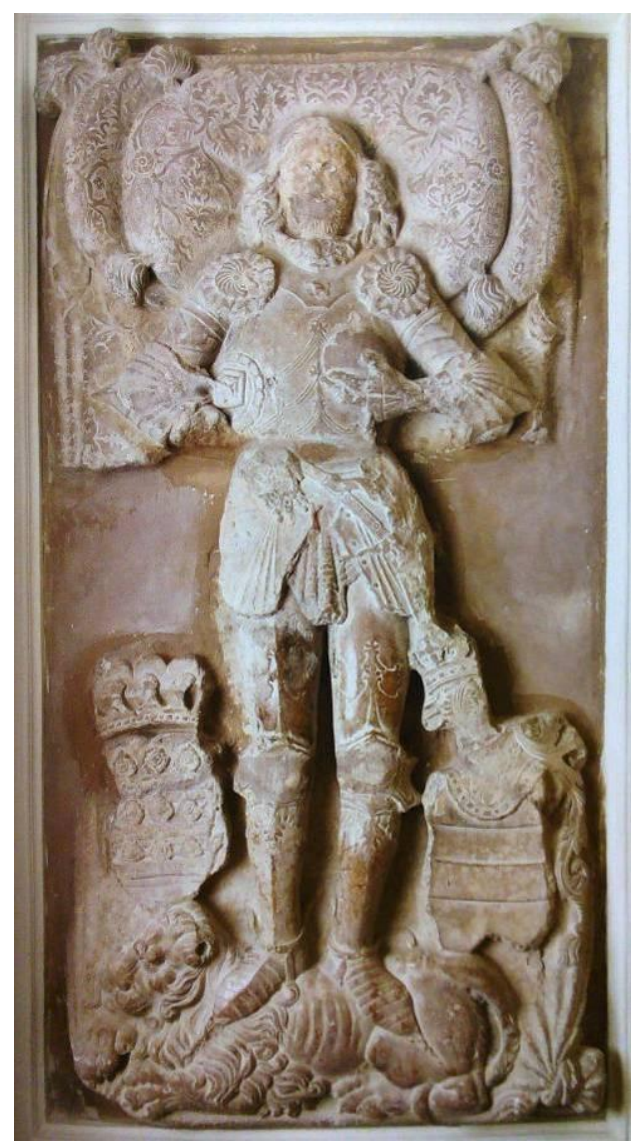

Slika 12. Nadgrobni spomenik Nikole Iločkoga (†1477.), Ilok, crkva sv. Ivana Kapistrana

rasprostranjene su diljem jadranske Hrvatske, a jedno od najboljih ostvarenja je grobnica Ivana Sobote (Sobotića) (? - Trogir, 1467.) iz crkve sv. Dominika u Trogiru koju je izradio Nikola Firentinac (Firenca, ? - Šibenik, 1507.) (Slika 11). Primjerak tumbe nije sačuvan ni na prostoru kontinentalne ni jadranske Hrvatske. Milan Pelc (2009.) upozorio je, doduše, na mogućnost da je nadgrobnik Nikole Iločkoga (Palota?, nakon 1410. - Ilok, 1477.) iz crkve sv. Ivana Kapistrana u Iloku (Slika 12) zapravo poklopac tumbe jer rubovi ploče nisu ravno odsječeni, kao što su kod drugih nadgrobnih ploča koje su umetnute u otvor u podu, nego su profilirani i prekriveni draperijom. ${ }^{63}$ Na području povijesne Zagrebačke biskupije koja je u središtu ovoga istraživanja sačuvani su samo primjerci nadgrobnih ploča i epitafa.

Osnovna razlika između nadgrobnih ploča i epitafa leži u njihovome smještaju nadgrobne ploče položene su u ravnini crkvenoga poda, a epitafi su ugrađeni u zidnu masu. Većina hrvatskih istraživača koristi se ovim terminima u skladu s opisanom razlikom. Anđela Horvat u svojim je radovima upotrebljavala dodatan termin epitafij za nadgrobne spomenike

\footnotetext{
${ }^{63}$ Usp. Milan Pelc, nav. dj., 2009.a, str. 413.
} 
koji sadržavaju lik pokojnika, neovisno o tome jesu li se izvorno nalazili na podu ili zidu. ${ }^{64}$ Iako nigdje nije izričito navela, moguće je da se koristila ovim terminom kako bi razlikovala nadgrobnike s likom pokojnika od natpisa na samim spomenicima, što je drugo značenje riječi epitaf. Marijana Schneider u svojim je radovima također upotrebljavala termin epitafij, no samo za one nadgrobne spomenike koji su ugrađeni u zidnu masu. Štoviše, u članku $O$ epitafiju Ivana Hrvoja i Eve Dreffell u Plešivici (1959.) točno je navela razliku između nadgrobnih ploča i epitafa, objasnivši da su ploče "prvobitno bile postavljene na podu nad grobom«, a da se epitafi »ne nalaze nad grobom, već [su] uspravno uzidani negdje u stijeni«. ${ }^{65} \mathrm{U}$ ovome radu, termin epitaf upotrijebljen je isključivo za vrstu nadgrobnoga spomenika. Za drugo značenje istoga termina koji označuje natpis na nadgrobniku korištena je opća imenica natpis. Termin epitafij nije upotrebljavan zbog nejasnosti njegova značenja.

\footnotetext{
${ }^{64}$ Usp. Anđela Horvat, nav. dj., 1975., str. 344-353; Anđela Horvat, nav. dj., 1982.a, str. 265.

${ }^{65}$ Marijana Schneider, nav. dj., 1959., str. 177.
} 


\section{NADGROBNI SPOMENICI NA PODRUČJU POVIJESNE ZAGREBAČKE BISKUPIJE}

U kršćanskoj eshatologiji, grobovi predstavljaju privremeno počivalište, svojevrsni cubiculum, duša vjernikā u kojima one odmaraju iščekujući drugi dolazak Krista i vlastito uskrsnuće. ${ }^{66}$ Prema prvoj Pavlovoj poslanici Korinćanima, svi vjernici koji su umrli u Kristu poput njega će uskrsnuti: „Budući da je po čovjeku došla smrt, po Čovjeku dolazi i uskrsnuće mrtvih. Jer kao što u Adamu svi umiru, tako će u Kristu svi oživjeti. Svaki u svom redu: prvenac Krist, potom u vrijeme njegova dolaska, Kristovi pripadnici.« (1 Kor 15, 21-23) Kao biljeg mjesta počivanja zemaljskih ostataka pokojnikā i njihovih duša do trenutka uskrsnuća, nadgrobni spomenici svojim sadržajem - bilo natpisom kojim, primjerice, pozivaju promatrača da moli za dušu pokojnika ili likovnim prikazom poput Raspeća - ukazuju na vjeru u nastavak života nakon smrti, u uskrsnuće. Osim opisane eshatološke sastavnice, nadgrobnici imaju i komemorativno-reprezentativnu funkciju. Svojim sadržajem (tekstualnim i/ili likovnim), složenošću forme i kvalitetom izvedbe ukazuju na društveni položaj, ugled i moć pokojnika te čuvaju uspomenu na njega. Iako nam se s današnjega stajališta može činiti da su ove dvije funkcije nadgrobnih spomenika međusobno oprečne, one su za srednjovjekovnoga i novovjekovnoga vjernika bile komplementarne, a u pozadini svega nalazila se ljudska potreba za trajanjem - onim eshatološkim i zemaljskim. ${ }^{67}$

Budući da su ukop u unutrašnjosti crkve i izrada nadgrobnoga spomenika zahtijevali znatan novčani izdatak, njih su si mogli priuštiti samo imućniji članovi društva. Sukladno tome, na području povijesne Zagrebačke biskupije sačuvano je najviše nadgrobnika crkvenih dostojanstvenika i - pretežito muških - pripadnika plemstva, a najčešće su ih podizali članovi obitelji pokojnikā. S druge strane, očuvano je svega nekoliko nadgrobnika koji su postavljeni u spomen na pripadnike građanskoga sloja.

\footnotetext{
${ }^{66}$ Usp. Minou Schraven, Festive Funerals in Early Modern Italy: The Art and Culture of Conspicuous Commemoration, Surrey: Ashgate Publishing Limited; Burlington: Ashgate Publishing Company, $2014 .$, str. 7.

${ }^{67}$ Usp. Philippe Ariès, nav. dj., 1981., str. 214. Eshatološka i komemorativno-reprezentativna funkcija nadgrobnih spomenika može se usporediti s onime što Erwin Panofsky naziva prospektivnim odnosno anticipirajućim te retrospektivnim odnosno komemorativnim aspektom nadgrobnika. Prema Panofskom, spomenici s izraženim prospektivnim (anticipirajućim) značenjem orijentirani su na život koji slijedi nakon smrti, a oni retrospektivnoga (komemorativnoga) značenja na ovozemaljski život pokojnika. Usp. Erwin Panofsky, nav. dj., 1992. [1964.], str. 19-21. Iako Panofsky ove dvije sastavnice često razmatra kao međusobno isključive, današnji stručnjaci prepoznaju da većina srednjovjekovnih i novovjekovnih nadgrobnih spomenika sadrži primjese obiju, s većim naglaskom na jednu ili drugu sastavnicu. Usp. Robert Marcoux, Memory, Presence and the Medieval Tomb, u: Revisiting the monument: Fifty years since Panofsky's »Tomb sculpture«, London: Research Forum of the Courtauld Institute of Art, 2016., str. 49-67. Uredili Ann Adams i Jessica Barker.
} 
Prije nego što se u narednim odlomcima osvrnemo na prostornu rasprostranjenost $\mathrm{i}$ vremensku protežnost spomenikā, potrebno je istaknuti dva kriterija koja su utjecala na oblikovanje kataloga djelā obuhvaćenih istraživanjem. Prvi je povijesno-umjetnički na osnovi kojega su uključeni samo oni nadgrobnici koji osim natpisa sadrže neki likovni motiv ili prikaz. Pregled i katalog stoga ne obuhvaćaju spomenike koji sadrže samo nadgrobni natpis. Drugi kriterij odnosi se na fragmentarnu očuvanost korpusa. Slijedom stoljećā nadgrobnici su nerijetko uklanjani iz crkvenih interijera, bacani i uništavani. U pokušaju da se izvorni korpus rekonstruira $\mathrm{u}$ što većem opsegu, pregled i katalog tako su dopunjeni izgubljenim nadgrobnicima o kojima su sačuvani podatci (arhivski, iz literature ili vizualni).

Jedan od najčešćih razloga uništavanja nadgrobnih spomenika koji je podjednako zahvatio sva područja povijesne Zagrebačke biskupije su kontinuirane obnove i pregradnje crkava. U njima su najviše stradavale nadgrobne ploče jer su se zbog položaja na crkvenom podu brzo trošile. Izvađene ploče u najboljem su slučaju ugrađene u zidove crkava i tako sačuvane. One manje sretne sudbine razlomljene su i iskorištene kao sekundarni građevinski materijal ili su jednostavno bačene. Iako se u stručnoj literaturi mogu naći navodi da je velik broj nadgrobnika stradao u "preradikalnim restauracijama crkava koncem 19. stoljeća«, ${ }^{68}$ potrebno je istaknuti da su nadgrobni spomenici uklanjani i u prethodnim razdobljima. Jedan primjer predstavlja nekadašnja pavlinska crkva u Remetama koja je nekoć bila popločena brojnim nadgrobnim pločama. U kratkom prikazu povijesti remetinskoga samostana, Ivan Krstitelj Krapac (1870.) vrlo se kritički osvrnuo na činjenicu da su u drugoj polovini XVIII. stoljeća nadgrobne ploče u crkvi podignute, preokrenute i upotrijebljene za novo popločenje:

»Razumieva se, da je tu bilo liepih spomenikah, ostatakah literarnih i t. d. ali vandalizam prijašnjih stoljećah, uz nehajstvo domaće uništio je skoro i poslednju uspomenu na davnu prošlost. Koliko je već to nehajstvo, budi mi dozvoljeno pro coronide da spomenem, kad su grobne ploče remetske crkve upotriebljene g. 1768. s drugim kamenjem za crkveni $\operatorname{tarac} ! \ll^{69}$

$\mathrm{Na}$ prostoru povijesne Zagrebačke biskupije, najveća koncentracija nadgrobnih spomenika sačuvana je na području Prigorja i Hrvatskoga zagorja, odnosno na prostoru današnje Zagrebačke nadbiskupije i zapadnoga dijela Varaždinske biskupije (Slika 13). Zanimljivo je uočiti da je riječ o području koje se nalazi unutar granica »ostatka ostataka nekoć velikoga i slavnoga kraljevstva Hrvatskoga«, dijela današnje Hrvatske koji je ostao pod

\footnotetext{
${ }^{68}$ Anđela Horvat, nav. dj., 1975., str. 341. Usporedi i: Milan Pelc, nav. dj., 2007., str. 303.

${ }^{69}$ Ivan Krstitelj Krapac, Samostan remetski: Historička crta, u: Zagrebački katolički list: crkveno-bogoslovni časopis XXI/4, Zagreb: Tiskom Dragutina Albrechta, 27. I. 1870., str. 25-28, 28. Kurziv dodan.
} 


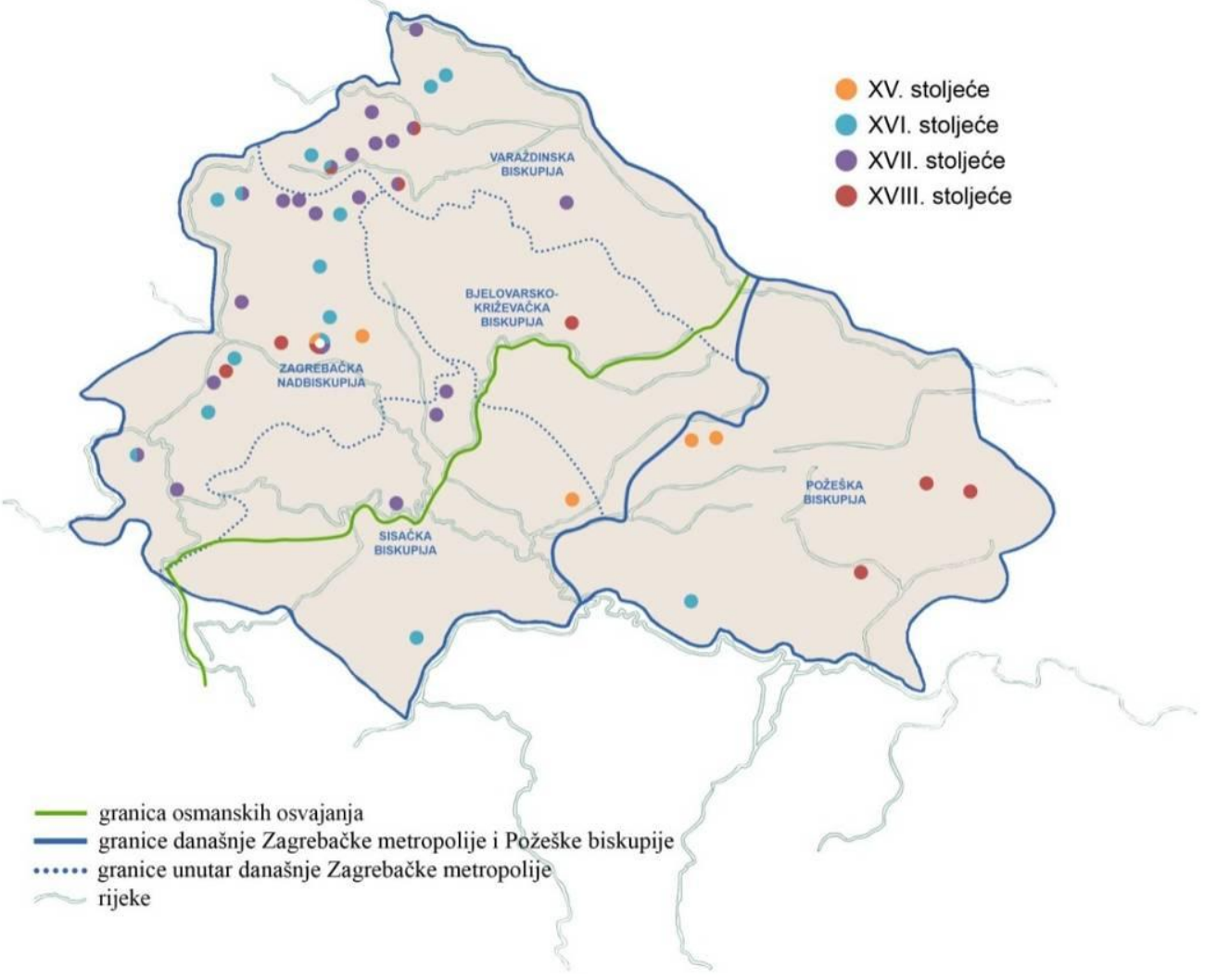

Slika 13. Prostorna rasprostranjenost nadgrobnika od XV. do XVIII. stoljeća na području povijesne Zagrebačke biskupije

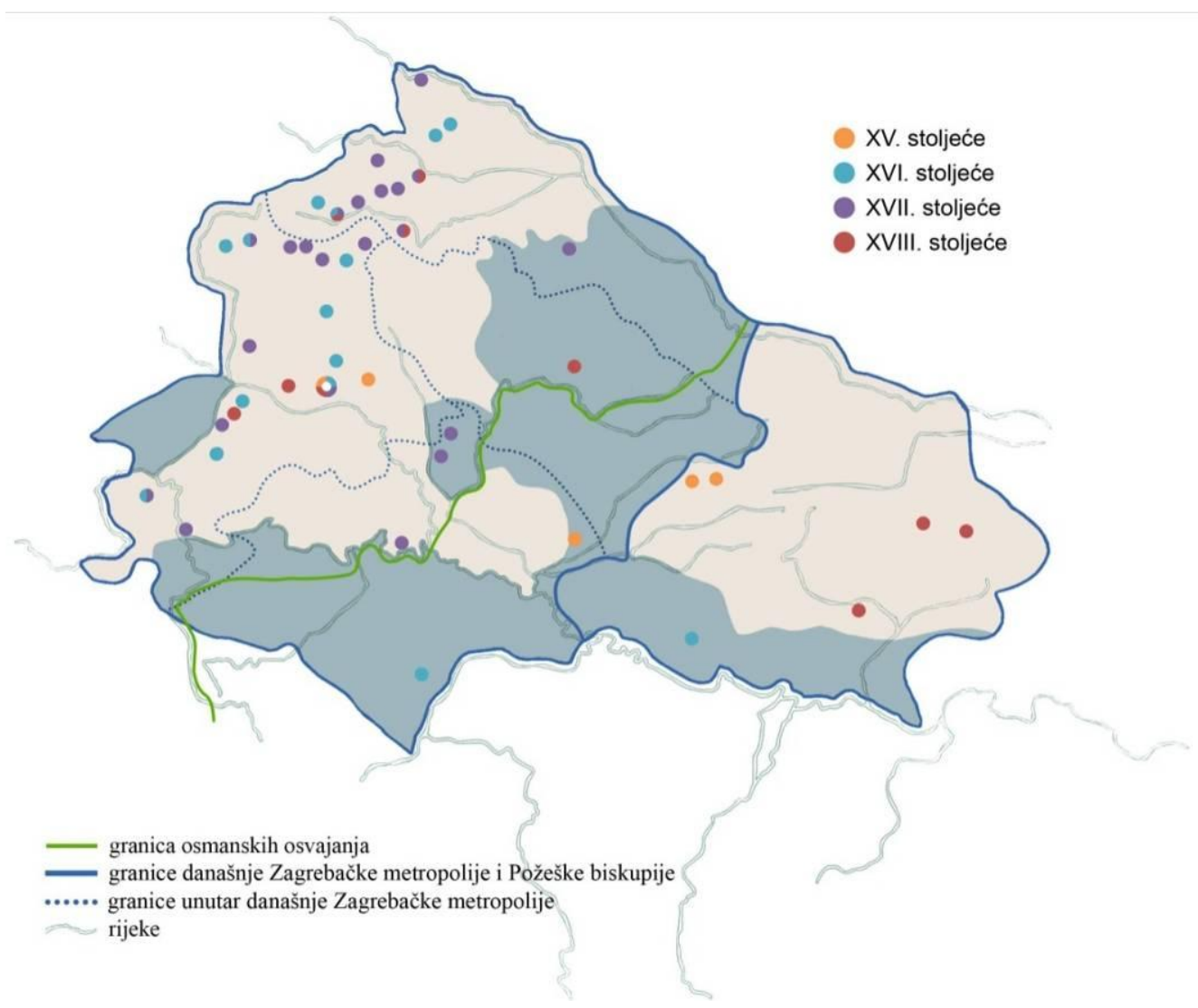

Slika 14. Područja povijesne Zagrebačke biskupije u sastavu Vojne krajine (osjenčano) 
vlašću Hrvatsko-slavonskoga sabora nakon osmanskih osvajanja. Manji broj nadgrobnika sačuvan je na prostoru Podravine, Moslavine, Banovine i zapadne Slavonije, a razlog tome leži upravo u prodoru Osmanlija koji je započeo krajem XV. stoljeća i posljedicama istoga. Prvenstveno, na područjima koja su bila pod osmanskom vlašću (zapadna Slavonija, jugozapadna Moslavina i Banovina) nepoznat broj nadgrobnika izgubljen je zbog rušenja i prenamjene crkava kao i islamskoga anikoničnog pristupa prema ljudskome liku. Nadalje, pogranično područje prema Osmanskom Carstvu postupno je organizirano u Vojnu krajinu, obrambeni pojas koji je izvorno služio za odbijanje osmanskih napada, a s vremenom je pretvoren $u$ habsburšku ratnu provinciju. Podravina i Moslavina većim su dijelom bile $u$ sastavu Varaždinske krajine odnosno nakon preustrojstva Vojne krajine sredinom XVIII. stoljeća Križevačke i Đurđevačke pukovnije, područje Banovine bilo je u sastavu Banske krajine odnosno Prve i druge pukovnije, a južni dio zapadne Slavonije u sastavu Slavonske krajine odnosno Gradiške pukovnije (Slika 14). ${ }^{70}$ Odlukom sabora održanoga u Brucku na Muri 1578. godine, Vojna krajina izuzeta je od vlasti Hrvatskoga sabora i bana te je stavljena pod upravu Dvorskoga ratnog vijeća u Grazu, što je značilo da hrvatski plemići više nisu mogli polagati pravo na svoje nekadašnje posjede koji su ušli u sastav krajine. Jedina je iznimka bila Banska krajina koja je odlukom cara i kralja Leopolda I. (Beč, 1640. - Beč, 1705.) vraćena pod vlast Sabora i bana 1703. godine. S obzirom na to da su se plemići najčešće pokapali u crkvama koje su se nalazile nedaleko njihovih feudalnih posjeda i nad kojima su imali patronat, ${ }^{71}$ a biskupi i kanonici u okrilju zagrebačke katedrale, ne začuđuje što je na području nekadašnje Vojne krajine sačuvan malen broj nadgrobnih spomenika. Nadgrobnike koji jesu očuvani na tom prostoru uglavnom su podigli časnici koji su služili u krajini, bilo za sebe ili za članove svoje obitelji.

Lokaliteti koji prednjače u broju podignutih nadgrobnih spomenika su zagrebačka prvostolnica i nekadašnja pavlinska crkva u Lepoglavi. Zagrebačka katedrala Uznesenja Blažene Djevice Marije i svetih Stjepana i Ladislava posljednje je počivalište trideset i dva

\footnotetext{
${ }^{70}$ Usp. Vojna krajina. Hrvatska enciklopedija, mrežno izdanje. Leksikografski zavod Miroslav Krleža, 2020. Pristupljeno 9. 8. 2020. <http://www.enciklopedija.hr/Natuknica.aspx?ID=65199>.

${ }^{71}$ C̆lanovi obitelji Zrinski pokapali su se, primjerice, u pavlinskoj samostanskoj crkvi sv. Jelene u Šenkovcu nedaleko njihovoga najvećeg feudalnog posjeda u Čakovcu; Draškovići u župnoj crkvi u Bednji nedaleko dvorca Trakošćana te u nekadašnjoj isusovačkoj crkvi, danas katedrali Uznesenja Blažene Djevice Marije na nebo u Varaždinu, gdje su podigli palaču; Ratkaji u župnoj crkvi sv. Jurja u Desiniću nedaleko Velikoga tabora; Keglevići u župnoj crkvi u Pregradi gdje su imali tri dvora - Kostelgrad, Goricu i Dubravu - te u župnoj crkvi sv. Nikole u Krapini, čiji su bili feudalni vlasnici; Patačići u župnim crkvama u Zajezdi i Vidovcu gdje su imali posjede te u nekadašnjoj franjevačkoj, danas župnoj crkvi u Remetincu kod Novoga Marofa gdje su imali stalnu obiteljsku rezidenciju; a Erdődyjevi u župnoj crkvi u Jastrebarskom, središnjem posjedu hrvatske grane obitelji, i u franjevačkoj samostanskoj crkvi u Klanjcu, gdje je ban Toma II. Bakač Erdődy obnovio srednjovjekovni dvorac Cesargrad (Novi dvori klanječki).
} 
biskupa, dva nadbiskupa, jednoga kardinala, osamnaest kanonika i četiri bana. ${ }^{72}$ Kao stolna crkva Zagrebačke biskupije - odnosno od 1852. godine nadbiskupije - katedrala je predstavljala prestižno mjesto ukopa ne samo za crkvene nego i svjetovne velikodostojnike, na što kaptol nije uvijek gledao blagonaklono. Kada je Ana Katarina Zrinski rođ. Frankapan (Bosiljevo, o. 1652. - Graz, 1673.) tražila od biskupa Petra III. Petretića (Sošice, 1604. - ?, 1667.) i zbora kanonika odobrenje da sahrani svojega brata podgenerala Jurja IV. Frankapana Tržačkoga (Bosiljevo?, o. 1620. - Karlovac, 1661.) u katedrali, kaptol joj je to u načelu dozvolio, no uz napomenu da ne bi bilo dolično da se »stolna crkva pretvori u gostionu i krčmu junaka ${ }^{73}{ }^{73}$ Preminuli je podgeneral naposljetku pokopan u crkvi sv. Katarine prema želji njegove supruge Marije Frankapan rođ. Forgách, gdje mu je i postavljen brončani epitaf (Slika 148). ${ }^{74}$ Od nadgrobnika koji su podignuti u unutrašnjosti zagrebačke katedrale od XV. do XVIII. stoljeća in situ su ostala samo tri spomenika, a to su epitafi bana Tome II. Erdődyja $\left(\dagger 1624\right.$.) (Slika 102) ${ }^{75}$ bana Nikole III. Erdődyja $\left(\dagger 1693\right.$.) $\left(\right.$ Slika 146) ${ }^{76}$ i kanonika Nikole Gotala (†1723.) (Slika 162). ${ }^{77}$ Preostali sačuvani nadgrobnici i njihovi ulomci pohranjeni su u Muzeju grada Zagreba, Hrvatskom povijesnom muzeju i Dijecezanskom muzeju Zagrebačke nadbiskupije.

Nekadašnji pavlinski samostan Blažene Djevice Marije u Lepoglavi bio je jedan od najznačajnijih i najuglednijih samostana u Hrvatskoj pavlinskoj provinciji. Od 1577. do ukinuća reda 1786. godine bio je sjedištem vrhovnoga poglavara (generala) reda te rasadište znanosti, prosvjete, kulture i umjetnosti. ${ }^{78}$ Kao što je navedeno, nakon što je u samostanskoj crkvi prema vlastitoj želji pokopan Ivaniš (Ivan) Korvin (†1504.), nezakoniti sin kralja Matije Korvina i pretendent na hrvatsko-ugarsko prijestolje, lepoglavska je crkva postala počasnim mjestom ukopa pripadnikā hrvatsko-ugarskoga plemstva. Osim Korvinove nadgrobne ploče (Slika 35) ${ }^{79}$ u crkvi su postavljeni nadgrobni spomenici Ivana Petheőa de Gerse (1673.) (Slika 153), ${ }^{80}$ Barbare Zaboky rođ. Gereczy (†1678.) (Slika 166), ${ }^{81}$ Ladislava III. Patačića (1710.) (Slika 107), ${ }^{82}$ obitelji Češković (1711.) (Slika 66) ${ }^{83}$ i Sigismunda Ratkaja (1722.)

\footnotetext{
${ }^{72}$ Usp. Slavko Šterk i Boris Mašić, nav. dj., 2014., str. 84.

73 Emilij Laszowski, Grobovi Zrinskih i Frankopana u Zagrebu i Remetama (O 268. obljetnici smrti naših hrvatskih mučenika), u: Jutarnji list XXVIII/9792, Zagreb: Tipografija, 30. IV. 1939., str. 17.

${ }^{74}$ Kat. br. 47.

${ }^{75}$ Kat. br. 37.

${ }^{76}$ Kat. br. 43. Epitaf je izvorno bio postavljen na zidu južne apside iznad epitafa Tome II. Erdődyja, no tijekom obnove katedrale krajem XIX. stoljeća premješten je na južni zid broda, gdje se nalazi i danas.

${ }^{77}$ Kat. br. 46.

${ }^{78}$ Usp. Kamilo Dočkal, Povijest pavlinskog samostana Blažene Djevice Marije u Lepoglavi, Zagreb: Glas Koncila, 2014., str. 141-142.

${ }^{79}$ Kat. br. 54.

${ }^{80}$ Kat. br. 55.

${ }^{81}$ Kat. br. 56.

${ }^{82}$ Kat. br. 57.
} 
(Slika 161). ${ }^{84} \mathrm{U}$ crkvi su pokopani i članovi drugih velikaških obitelji (Drašković, Keglević, Čikulin, Orehovečki, Druškovečki i Stipišić), no nisu sačuvani nadgrobnici kojima su obilježena njihova ukopna mjesta. ${ }^{85}$

Što se tiče vremenske zastupljenosti, najmanji broj nadgrobnih spomenika datira iz XV. stoljeća (Slika 15). Sačuvano ih je sedam, a povijesni izvori bilježe postojanje još tri nadgrobnika s likovnim motivima. Razlog malom broju očuvanih spomenika djelomično leži u prodoru osmanskih snaga koji je započeo u drugoj polovini stoljeća, ali i prethodno spomenutim pregradnjama crkava. Potonju tezu potkrjepljuje činjenica da nijedan nadgrobnik iz toga razdoblja nije sačuvan in situ, nego su svi pohranjeni u muzejskim zbirkama. Iz XVI. stoljeća, koje je obilježeno napredovanjem osmanskih snaga, demografskim padom i gospodarskim nazadovanjem, datira dvostruko veći broj nadgrobnika (Slika 16). Šesnaest ih je očuvano, a još četiri su dokumentirana u izvorima. Najveći broj spomenika zabilježen je u XVII. stoljeću (Slika 17), kada se Hrvatsko Kraljevstvo postupno oporavlja i počinje vraćati izgubljeni teritorij. Iz navedenoga razdoblja sačuvano je trideset i osam nadgrobnika, a likovni izvori svjedoče o postojanju još jednoga. S obzirom na to da su XVI. i XVII. stoljeće obremenjeni ratovanjem, moglo bi se očekivati da će broj spomenika podignutih u to vrijeme biti manji u usporedbi s XV. i XVIII. stoljećem. Međutim, čini se da je nesigurnost življenja intenzivirana sveprisutnom osmanskom opasnošću poticala vjernike da podižu nadgrobnike kao posljednje materijalno svjedočanstvo njihovoga ovozemaljskog života kojim će doprinijeti spasenju duše, ali i očuvati individualnu i obiteljsku memoriju. Tijekom XVIII. stoljeća Hrvatsko se Kraljevstvo gospodarski oporavilo, što se pozitivno odrazilo i na umjetničku produkciju. Doduše, unatoč gospodarskom i društvenom oporavku, broj nadgrobnih spomenika podignutih u to vrijeme (Slika 18) razmjerno je manji od onoga tijekom prethodnoga stoljeća (očuvano je petnaest spomenika, a dokumentiran još jedan). Tome su najvjerojatnije doprinijeli kontinuirani pokušaji vladarā da iz zdravstvenih razloga okončaju praksu pokapanja u crkvama i na okolnim grobljima te otvore nova, javna groblja izvan naseljā.

Na području povijesne Zagrebačke biskupije, među sačuvanom građom zastupljene su dvije vrste nadgrobnih spomenika - nadgrobne ploče i epitafi. Oni se u osnovi razlikuju prema veličini i smještaju. Nadgrobne ploče položene su na pod i pokrivaju pojedinačni grob ili ulaz u kriptu, stoga su najčešće pravokutnoga oblika veličine lijesa. Epitafi su, s druge

\footnotetext{
${ }^{83}$ Kat. br. 58 .

${ }^{84}$ Kat. br. 59.

${ }^{85} \mathrm{Za}$ podroban popis osoba pokopanih u lepoglavskoj crkvi vidi: Kamilo Dočkal, nav. dj., 2014., str. $265-307$.
} 


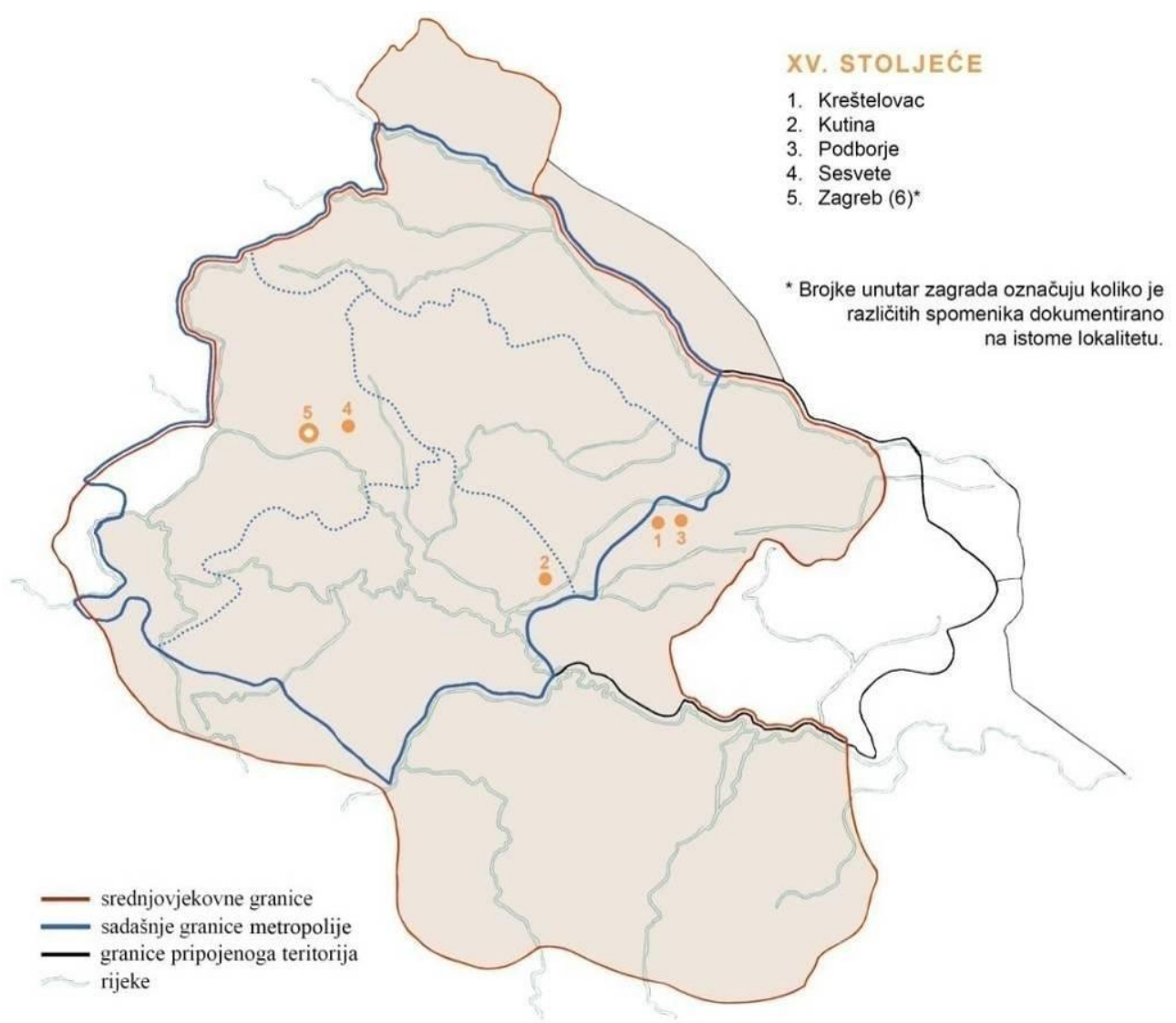

Slika 15. Lokaliteti nadgrobnih spomenika iz XV. stoljeća

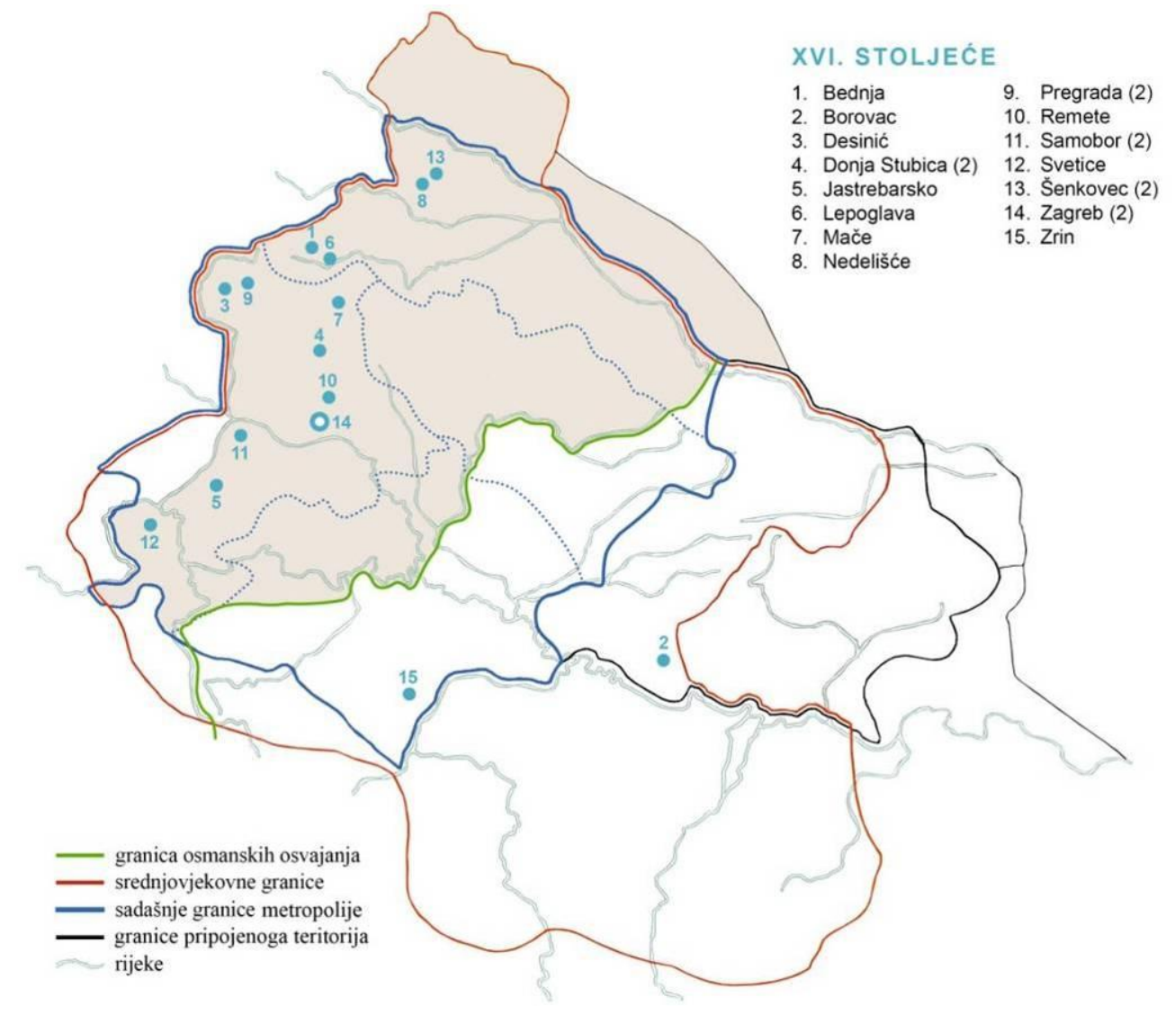

Slika 16. Lokaliteti nadgrobnih spomenika iz XVI. stoljeća 


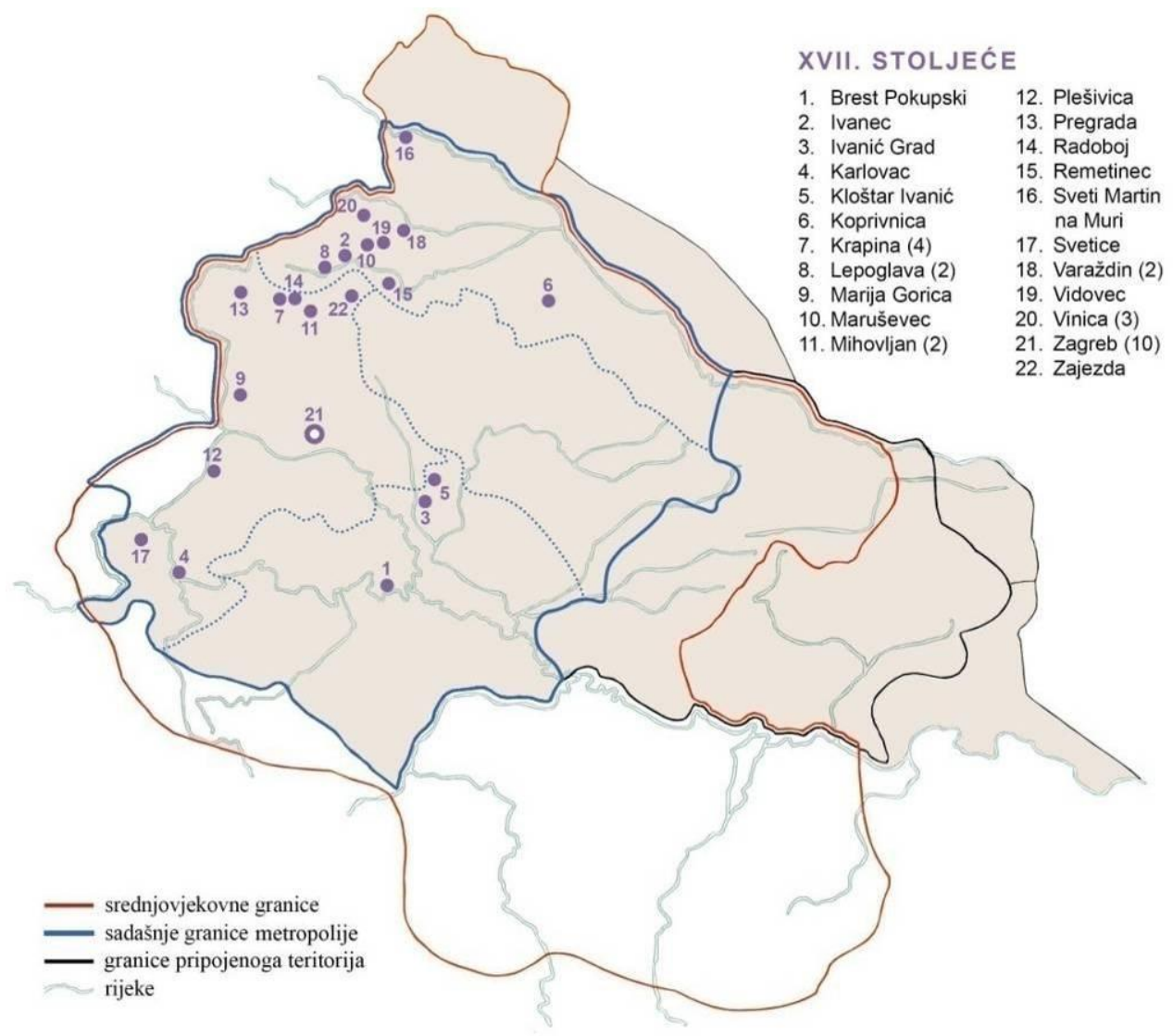

Slika 17. Lokaliteti nadgrobnih spomenika iz XVII. stoljeća

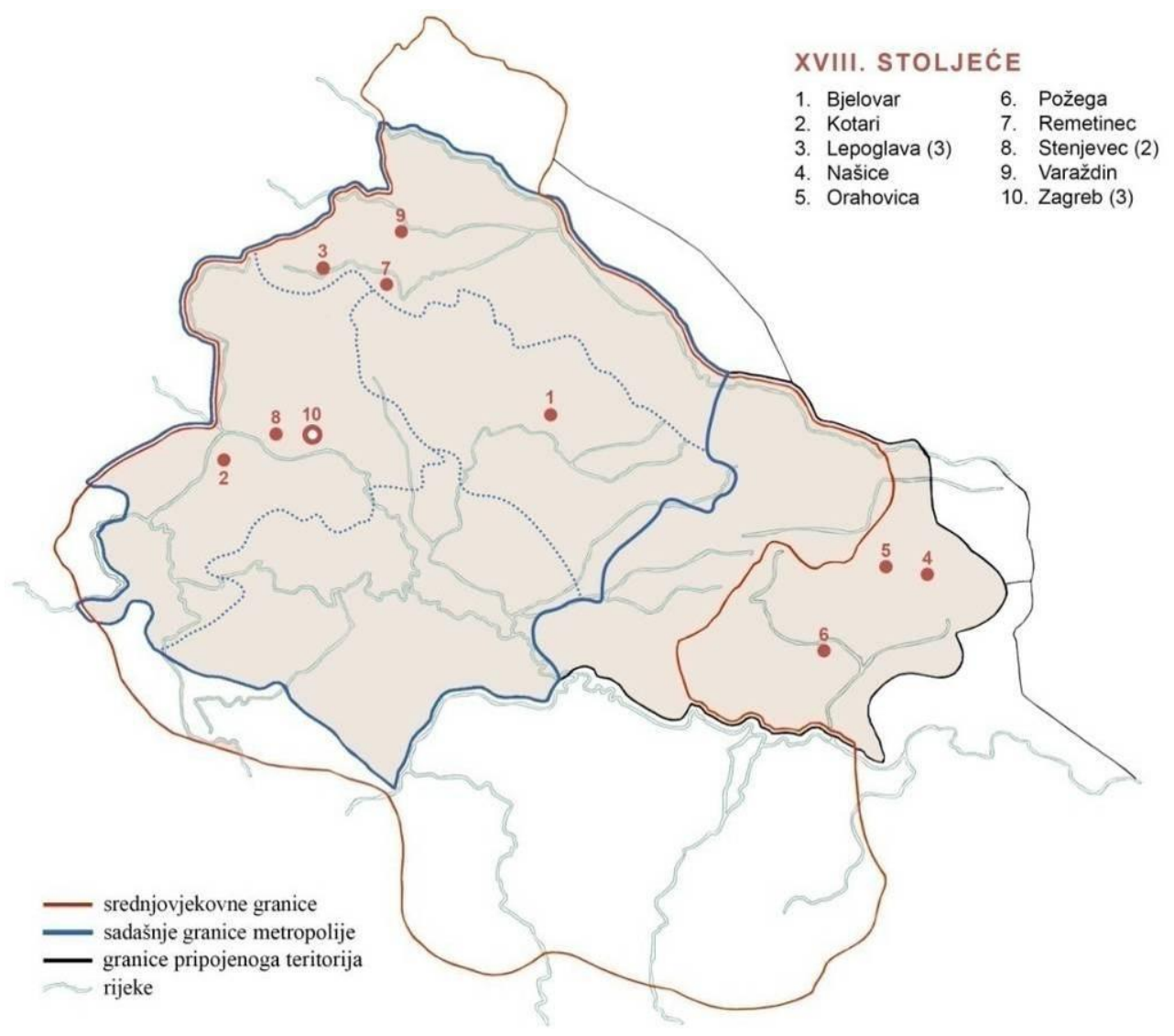

Slika 18. Lokaliteti nadgrobnih spomenika iz XVIII. stoljeća 
strane, ugrađeni u zidnu masu i nisu usko povezani s ukopnim mjestom, stoga variraju veličinom i oblikom. Na osnovi primijenjenih likovnih motiva, sačuvane nagrobnike možemo podijeliti na tri skupine: I) nadgrobnike s figuralnim prikazom pokojnika; II) nadgrobnike s obiteljskim grbom; te III) nadgrobnike s motivima funeralne ikonografije. Potrebno je istaknuti da većina nadgrobnih spomenika s likom pokojnika sadrži i obiteljski grb, no s obzirom na to da je motiv pokojnika sadržajno i likovno značajniji od motiva grba, ti su spomenici svrstani u prvu skupinu. U nastavku rasprave nadgrobnici su opisani i analizirani u skladu s likovnom grupom kojoj pripadaju.

\subsection{NADGROBNICI S FIGURALNIM PRIKAZOM POKOJNIKA}

Na prostoru Zagrebačke (nad)biskupije sačuvano je tridesetak nadgrobnih spomenika s likom pokojnika iz razdoblja novoga vijeka. Najveći broj očuvan je na području Hrvatskoga zagorja (Bednja, Desinić, Donja Stubica, Ivanec, Lepoglava, Marija Gorica, Maruševec, Pregrada, Vinica) te grada Zagreba (Gradec, Kaptol, Stenjevec) i njegove okolice (Sesvete). Primjerci su očuvani i sjeverno od navedenoga područja na prostoru Međimurja (Šenkovec, Sveti Martin na Muri), grada Varaždina i Podravine (Koprivnica), zapadno na području Žumberačkoga gorja (Jastrebarsko, Plešivica, Samobor) te istočno na području Moslavine (Ivanić-Grad) i zapadne Slavonije (Našice). Slično cjelokupnom korpusu, najveći broj spomenika datira iz XVI. i XVII. stoljeća. Iz XV. stoljeća sačuvani su pretežito ulomci, a iz XVIII. stoljeća, kada broj nadgrobnih spomenika općenito opada, tek nekoliko primjeraka.

Među sačuvanim nadgrobnim spomenicima možemo razlikovati dva osnovna likovna rješenja: nadgrobnike na kojima je lik pokojnika jedini figuralni motiv i one na kojima je uklopljen u složeniji figuralni prikaz kao adorant koji kleči pred Kristom na križu. Nadgrobne ploče sa samostalnim likom pokojnika primjenjivale su se kontinuirano od XV. do početka XVIII. stoljeća, a prevladavale su kao dominantan oblik nadgrobne plastike u XV. i XVI. stoljeću. Iz XV. stoljeća u najvećem su broju sačuvane nadgrobne ploče crkvenih dostojanstvenika odjevenih u misno ruho, a iz XVI. stoljeća ploče plemića odjevenih u viteški oklop. U drugoj polovini XVI. stoljeća pojavili su se prvi epitafi na kojima su pokojnici prikazani s članovima obitelji u molitvi pred Raspetim, a njihov broj porastao je u XVII. stoljeću. U istom stoljeću pojavili su se i prvi epitafi koji sadržavaju samostalan prikaz vitezapokojnika kao nastavak tradicije viteških nadgrobnih ploča, a nastavili su se primjenjivati i u XVIII. stoljeću. Među nadgrobnim spomenicima od XVI. do XVIII. stoljeća brojčano su najzastupljeniji oni koji su podignuti za muške članove plemstva. Nadgrobnici s likovima 
plemkinja izrađivani su u znatno manjem broju, a kao prava rijetkost sačuvane su dvije nadgrobne ploče djece. $\mathrm{S}$ obzirom na povezanost spomenika $\mathrm{s}$ osobom - u čemu su nadgrobnici srodni ikonografiji portreta i možemo ih ikonografski razmatrati kao »portrete za vječnost « - njihova analiza u nastavku slijedi dva načela: razdiobu prema njihovom likovnom rješenju i onu prema naručiteljima odnosno osobama za koje su podizani.

\subsubsection{NADGROBNICI S LIKOM POKOJNIKA KAO OSNOVNIM MOTIVOM}

Kao što je navedeno u poglavlju o tipologiji nadgrobnih spomenika, prve nadgrobne ploče s likom pokojnika pojavile su se krajem XI. stoljeća. ${ }^{86}$ Već u XII. stoljeću stekle su široku primjenu diljem cijele Europe, a tijekom visokoga i kasnoga srednjeg vijeka bile su najčešći oblik nadgrobne plastike. Na prvim nadgrobnim pločama likovi pokojnika prikazani su kao živuće osobe, impostacije i pada draperije koji sugeriraju da osoba stoji (Slika 6). Prema Erwinu Panofskom (1964.), takvi prikazi rezultirali su likovno-sadržajnim paradoksom jer su likovi pokojnika prikazani u stojećem stavu polagani vodoravno na crkveni pod. ${ }^{87}$ Jedan od načina na koji su srednjovjekovni kipari doskočili tom problemu jest da su osmislili prve gisante (eng. recumbent effigy, njem. Liegefigur), nadgrobne spomenike na kojima su pokojnici prikazani kako leže. To su postigli promjenom odnosno prilagodbom forme: promjenom impostacije tijela koje daje dojam da je polegnuto, a ne da stoji; dodavanjem motiva jastuka ispod glave pokojnika; oblikovanjem draperije koja izgleda kao da je položena preko ležećega tijela; te primirivanjem gesta pokojnikā i zatvaranjem njihovih očiju. ${ }^{88}$ Prvi gisanti pojavili su se krajem XII. stoljeća u Francuskoj, a jedan od najranijih primjera su nadgrobni spomenici engleskoga kralja Henrika II. (Le Mans, 1133. - Chinon, 1189.) i njegove supruge Eleonore Akvitanske (?, 1122./1124. - Poitiers, 1204.) (Slika 19) koji su pokopani u benediktinskoj opatiji Fontevrault u francuskoj pokrajini Anjou. ${ }^{89}$

Tijekom kasnoga srednjeg vijeka, u nadgrobnoj plastici dominirao je prikaz pokojnika kao mrtve osobe koja leži. Širom primjenom epitafa kao nove vrste nadgrobnoga spomenika koji je ugrađen okomito u stijenu, od XIV. stoljeća nadalje pokojnici se ponovno sve učestalije prikazuju kao živuće osobe. ${ }^{90}$ Njihove su oči otvorene, lica čak ponekad nasmiješena, a tijela prikazana $u$ stojećem stavu. Ista promjena može se zapaziti i na

\footnotetext{
${ }^{86}$ Usp. Erwin Panofsky, nav. dj., 1992. [1964.], str. 47, 50-51.

${ }^{87}$ Usp. Erwin Panofsky, nav. dj., 1992. [1964.], str. 55.

${ }^{88}$ Isto.

${ }^{89}$ Usp. Erwin Panofsky, nav. dj., 1992. [1964.], str. 57.

${ }^{90}$ Usp. Sergej Vrišer, Renesančni viteški nadgrobniki v Sloveniji, u: Zbornik za umetnostno zgodovino VII, Ljubljana: Slovensko umetnostnozgodovinsko društvo, Filozofska fakulteta Univerze v Ljubljani, 1965., str. 195-204, 196.
} 


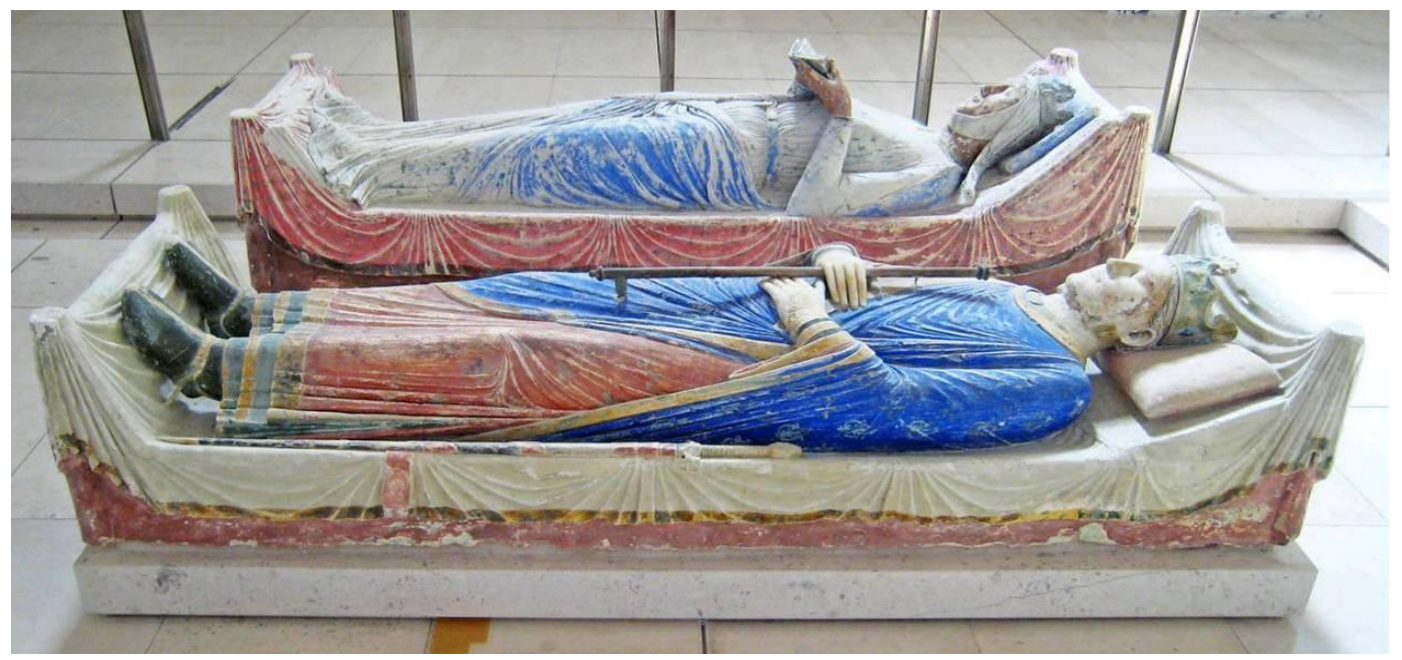

Slika 19. Nadgrobni spomenici Henrika II. (†1189.) i Eleonore Akvitanske (†1204.), Fontevrault, benediktinska opatija

nadgrobnicima Zagrebačke povijesne biskupije, samo što je ona nastupila nešto kasnije, u XVI. stoljeću. Prilikom razmatranja tipova prikaza pokojnika - kao mrtve osobe koja leži i živuće koja stoji - potrebno je istaknuti da je riječ o konstruktima koje su stručnjaci osmislili kako bi lakše analizirali i obradili likovni korpus. Opisani razvoj do određene je mjere generaliziran jer smjena dvaju tipova nije bila u potpunosti linearna, jednako kao što njihova upotreba nije bila međusobno isključiva. Prikazi pokojnika kao mrtve odnosno živuće osobe često su se primjenjivali na djelima nastalima u isto vrijeme. Štoviše, kipari su nerijetko kombinirali elemente obaju tipova i uklapali ih u jedinstvene spomenike hibridnoga rješenja. Tako i na području Zagrebačke (nad)biskupije možemo pronaći nadgrobnike s likom pokojnika u stojećem stavu čija glava počiva na jastuku, kao što je primjerice nadgrobna ploča Nikole IV. Zrinskoga (†1566.) (Slika 46). ${ }^{91}$ Stoga opisane tipove i njihovu podjelu treba razmatrati fluidno, kako su se oni i primjenjivali.

Likovni prikazi pokojnika koji leže mirno položena tijela i glave oslonjene na jastuk podsjećaju na tijela mrtvaca postavljena na odar. Međutim, za vjernike srednjega i novoga vijeka oni nisu predstavljali istinski mrtve osobe. U skladu s kršćanskim naukom o spasenju i uskrsnuću pojedinca, takvi prikazi simbolizirali su beate, blaženike koji su usnuli smrtni san čekajući ponovni dolazak Krista. ${ }^{92} \mathrm{Na}$ dan Posljednjeg suda, oni će se probuditi, uskrsnuti i nastaviti vječni život u Raju. Osnovne postavke kršćanske eshatologije zrcalile su se i u načinu na koji su nadgrobne ploče postavljane u prostoru. Polagane su na pod tako da su noge

\footnotetext{
${ }^{91}$ Kat. br. 65.

${ }^{92}$ Usp. Philippe Ariès, nav. dj., 1981., str. 241-242, 245; Emilijan Cevc, Kiparstvo na Slovenskem med gotiko in barokom, Ljubljana: Slovenska matica, 1981., str. 307, bilj. 72; Željko Demo, nav. dj., 2007., str. 50-51; Gerhard Winkler, nav. dj., 1974., str. 214.
} 
pokojnika bile okrenute prema oltaru, a glava prema zapadu kako bi vjernici na dan Posljednjega suda mogli ugledati Krista koji će se pojaviti s prvim jutarnjim svjetlom. ${ }^{93} \mathrm{Na}$ području povijesne Zagrebačke biskupije nijedna nadgrobna ploča s likom pokojnika nije sačuvana in situ, stoga o njihovoj izvornoj orijentaciji možemo samo iznositi pretpostavke. Ako se i nalaze u crkvi u kojoj su izvorno bile postavljene, ploče nikad nisu položene iznad grobnice pokojnika, nego su ugrađene u zidnu masu kako bi se zaštitile od mogućih oštećenja.

Odjeća u kojoj su pokojnici prikazani jedan je od pokazatelja njihovoga društvenog položaja i službe koju su obnašali tijekom ovozemaljskoga života. Crkveni prelati tako su odjeveni u liturgijsko ruho koje ukazuje na njihov svećenički poziv, plemići u viteške oklope koji svjedoče o njihovoj ulozi vojskovođa ili mentene karakteristične za hrvatsko-ugarsko plemstvo toga razdoblja, a plemkinje u višeslojne haljine. Izuzev odjeće koja odražava njihov društveni status, pokojnici su prikazani sa simbolima svojega položaja i časti. Župnici tako često drže kalež s Presvetim, biskupi nose pastoral i mitru, a vojskovođe pridržavaju mač odnosno sablju ili zapovjedničku palicu. Vrlo čest dodatak figuralnom prikazu pokojnikā je i obiteljski grb koji je dokaz njihovoga plemenitog podrijetla, ali ujedno služi prezentaciji obitelji kojoj su pripadali.

Smjenom stoljeća mijenjale su se i oblikovne značajke nadgrobnikā koje su pratile općenite stilske promjene. Budući da je tijelo pokojnika likovno i sadržajno najvažniji motiv u ovoj skupini spomenika, najveće promjene povezane su upravo s njime. Impostacija tijela mijenjala se od ukočene, krute poze prikazane u strogom frontalnom položaju u opušteni kontrapost isklesan u tričetvrt ili poluprofilu s perspektivnim skraćenjima dijelova tijela. ${ }^{94}$ Razvojem i popularizacijom renesansnoga portreta, lica pokojnika prestaju biti tipizirana i zadobivaju portretne karakteristike. ${ }^{95}$ Mijenjao se i odnos lika pokojnika prema njegovom arhitektonskom okviru od skulpture podređene arhitekturi prema figuri koja se oslobađa svojega okvira i izlazi iz njega. ${ }^{96}$ Leksik arhitektonskih elemenata također se promijenio iz gotičkoga (šiljasti lukovi, filijale) u renesansi i barokni (stupovi/pilastri all' antica, polukružni lukovi, motiv školjke, akant, putti, kerubini). Plastičnost oblika postpuno je rasla od plošnoga prema visokom reljefu, a horror vacui ustupio je mjesto pročišćavanju forme i odbacivanju

\footnotetext{
${ }^{93}$ Usp. Željko Demo, nav. dj., 2007., str. 50; Siniša Krznar, nav. dj., 2012., str. 33.

${ }^{94}$ Usp. Jolán Balogh, Die Kunst der Renaissance in Ungarn, u: Matthias Corvinus und die Renaissance in Ungarn 1458-1541, Schallaburg '82, 8. Mai - 1. November 1982, Wien: Amt der Niederösterreichischen Landesregierung, 1982., str. 81-107, 93. Uredio Gottfried Stangler; Emilijan Cevc, nav. dj., 1981., str. 100; Marjan Marlot, Celjski nadgrobniki 15. in 16. stoletja, u: Zbornik za umetnostno zgodovino VII/3-4, Ljubljana: Slovensko umetnostnozgodovinsko društvo, 1928., str. 73-85, 78; Sergej Vrišer, nav. dj., 1965., str. 195-204, 199, 202; Gerhard Winkler, nav. dj., 1974., str. 213.

${ }^{95}$ Usp. Philippe Ariès, nav. dj., 1981., str. 260.

${ }^{96}$ Usp. Jolán Balogh, nav. dj., 1982., str. 92-93; Gerhard Winkler, nav. dj., 1974., str. 213.
} 
suvišne dekorativnosti. ${ }^{97}$ Tijekom stoljećā nije se mijenjao samo način oblikovanja likovnih motiva već i teksta. Natpisi ispisani na gotici koji su tekli uz rub nadgrobnika postpuno su se izdvojili u zaseban tekst pisan humanistikom smješten u bloku iznad ili ispod figuralnoga prikaza. ${ }^{98}$ Opisane promjene mogu se pratiti i na nadgrobnim spomenicima Zagrebačke povijesne biskupije s određenim odstupanjima uvjetovanima kašnjenjem u prihvaćanju pojedinih stilskih oblika, primjenom mješovitih rješenja, ali i vraćanjem ranijim oblicima kao svjesnom odabiru naručitelja.

\subsubsection{NADGROBNE PLOČE CRKVENIH DOSTOJANSTVENIKA}

Među nadgrobnicima XV. stoljeća općenito, u najvećem su broju sačuvane nadgrobne ploče crkvenih dostojanstvenika (biskupa, kanonika i župnika) s područja grada Zagreba i okolice. Na njima su pokojnici prikazani u strogom frontalnom položaju, mirno položena tijela, ruku sklopljenih na prsima ili trbuhu. Odjeveni su u liturgijsko ruho koje, prema riječima srednjovjekovnoga traktatista Wilhelmusa Durandusa (Guillaume Durand, William Durand; o. 1230. - 1296.), predstavlja Božji oklop (»vestibus sacris quasi armis«). ${ }^{99}$ Sagledana u takvome svjetlu, ova je vrsta nadgrobnika svojevrstan pandan viteškim nadgrobnicima na kojima su svjetovni velikodostojnici odjeveni u prave, viteške oklope.

Iz razdoblja XV. stoljeća u cijelosti je sačuvana samo jedna nadgrobna ploča sa samostalnim likom pokojnika. Riječ je o nadgrobnoj ploči granešinskoga župnika Matije $(\dagger 1472 \text {.) (Slika 20 })^{100}$ koja se nekoć nalazila u kapeli sv. Fabijana i Sebastijana prigrađenoj uz sakristiju župne crkve sv. Marka u Zagrebu. Nakon što je kapela porušena u SchmidtBolléovoj restauraciji crkve (1876.), ploča je predana tadašnjem Narodnom muzeju u Zagrebu koji ju je potom darovao Muzeju grada Zagreba. ${ }^{101}$ Pokojnikov lik isklesan je u središnjem dijelu nadgrobnika u plitkome reljefu, a okružen je nadgrobnim natpisom izvedenim u

\footnotetext{
${ }^{97}$ Usp. Emilijan Cevc, nav. dj., 1981., str. 148; Marjan Marlot, nav. dj., 1928., str. 78.

${ }^{98}$ Usp. Jolán Balogh, nav. dj., 1982., str. 92, 677; Emilijan Cevc, nav. dj., 1981., str. 32; Gerhard Winkler, nav. dj., 1974., str. 214.

${ }_{99}$ Cititrano u: Andreas Zajic, "Zu ewiger gedächtnis aufgericht«. Grabdenkmäler als Quelle für Memoria und Repräsentation von Adel und Bürgertum im Spätmittelalter und in der Frühen Neuzeit. Das Beispiel Niederösterreich, Wien, München: Oldenbourg, 2004., str. 171.

${ }^{100}$ Kamen vapnenac, $198 \times 95 \times 19 \mathrm{~cm}$, Zagreb, Muzej grada Zagreba, izvorno u crkvi sv. Marka u Zagrebu. Kat. br. 49. Pojedini istraživači netočno pripisuju nadgrobnik Franji Polaru na osnovi pogrešno iščitanoga natpisa s ploče koji je prvi objavio Ivan Kukuljević Sakcinski (1891.), a poslije prenio Ivan Krstitelj Tkalčić (1894.). Kukuljević i Tkalčić pročitali su toponom Granešinopolje (»Kranesinopolye«) kao osobno ime Franjo Polar (»Francisco Polar«). Usp. Ivan Kukuljević Sakcinski, nav. dj., 1891., str. 323, br. 1112; Ivan Krstitelj Tkalčić, Povjestni spomenici slob. kralj. grada Zagreba priestolnice kraljevine Dalmatinsko-HrvatskoSlavonske, Svezak drugi, U Zagrebu: Brzotiskom K. Albrechta, 1894., str. xii, 532. Navedenu identifikaciju preuzeo je: Zorislav Horvat, Srednjovjekovna crkva sv. Marka, u: Crkva sv. Marka u Zagrebu: arhitektura, povijest, obnova, Zagreb: Hrvatski restauratorski zavod, 2013., str. 11-36, 31. Uredio Petar Puhmajer. Za raspravu o pogrešnoj identifikaciji pokojnika i naručitelja nadgrobnika vidi: Milan Pelc, nav. dj., 2010., str. 62.

${ }^{101}$ Usp. Josip Brunšmid, nav. dj., 1912., str. 180, 182; Mirko Valentić, nav. dj., 1969., str. 201.
} 


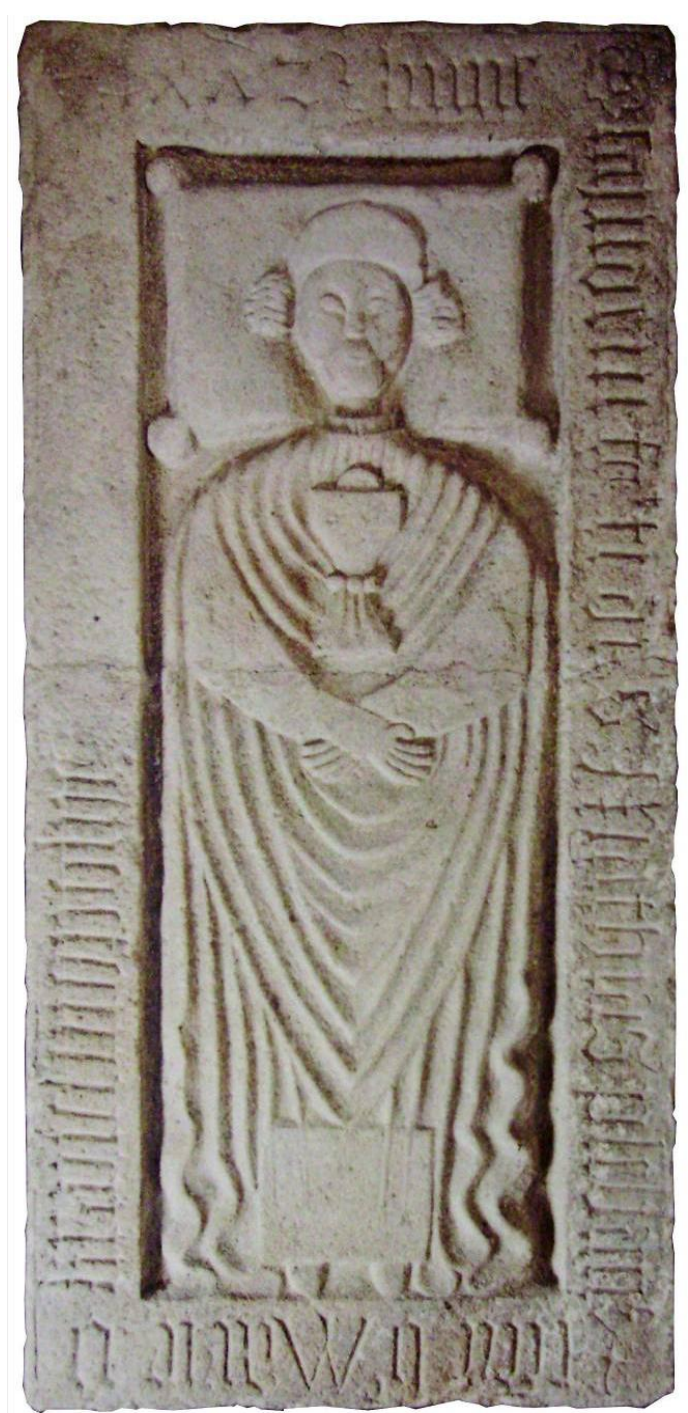

Slika 20. Nadgrobna ploča granešinskoga župnika Matije (†1472.), Zagreb, Muzej grada Zagreba

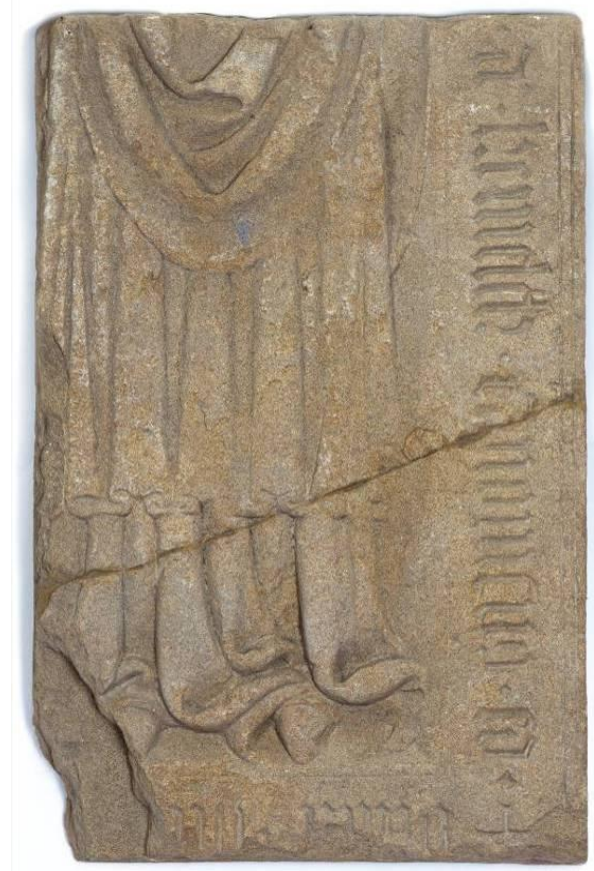

Slika 21. Nadgrobna ploča kanonika Benedikta, nakon 1475., Zagreb, Hrvatski povijesni muzej

gotičkoj majuskuli koji teče uz rubove ploče. Glava mu je oslonjena na jastuk s resama, a ruke drži prekrižene na trbuhu. Odjeven je u albu i misnicu, a na glavi nosi baretu ispod koje proviruje nekoliko pramenova kose. Na pokojnikovim prsima položen je kalež s Presvetim, a na cjevanicama knjiga - atributi koji ukazuju na njegov svećenički poziv. Prema Ljubi Karamanu (1948., 1950.), plošnost forme, shematiziranje oblika, linearan tretman draperije i rustična obrada površine pokazatelji su da autora nadgrobnika treba tražiti među pučkim umjetnicima domaće, provincijalizirane sredine. ${ }^{102}$ Navedena plošnost i linearnost forme te uočljiv horror vacui daju spomeniku gotička obilježja. Josip Brunšmid (1912.) pripisao je nadgrobnik majstoru Petru, sinu klesara Stjepana de Wolsperga, na osnovi dokumenata kojima kanonik Matija imenuje Petra i njegovu suprugu Jelenu svojim baštinicima i daruje im

\footnotetext{
${ }^{102}$ Usp. Ljubo Karaman, nav. dj., 1948., str. 107; Ljubo Karaman, nav. dj., 1950., str. 146.
} 
kuću. ${ }^{103}$ Iako su neki istraživači prihvatili ovaj prijedlog atribucije (Kampuš i Karaman 1994., Pelc 2010.), ${ }^{104}$ on nije naišao na šire prihvaćanje zbog pomanjkanja dokaza koji bi povezali Petra de Wolsperga sa samim nadgrobnikom.

Nekoliko godina nakon nadgrobnika granešinskoga župnika izrađena je nadgrobna ploča kanonika Benedikta (nakon 1475.) (Slika 21) ${ }^{105}$ koja se nekoć nalazila u župnoj crkvi Svih Svetih u Sesvetama. Uklonjena je iz crkve 1973. godine prilikom njezina preuređenja, a župa ju je poklonila Hrvatskom povijesnom muzeju u Zagrebu. ${ }^{106}$ Očuvana je donja polovica ploče na kojoj je vidljivo tijelo pokojnika izvedeno u strogo frontalnom položaju u plitkome reljefu. Odjeven je u misnu ruho koje pada u plošnim, linijski izvedenim naborima, a na nogama nosi šiljate cipele. U usporedbi s nadgrobnom pločom župnika Matije, ovaj je nadgrobnik rad vještijega majstora, no još uvijek gotičkoga senzibiliteta koji se može iščitati iz njegova dekorativnoga tretmana draperije koje zakriva tijelo.

Sličnih oblikovno-stilskih karakteristika je i ulomak nadgrobne ploče crkvenoga dostojanstvenika (XV. st.) (Slika 22) ${ }^{107}$ koja se najvjerojatnije izvorno nalazila u zagrebačkoj prvostolnici, a danas je pohranjena u Hrvatskom povijesnom muzeju. ${ }^{108}$ Očuvan je uski pojas uz desni rub ploče koji prikazuje pokojnika odjevena u misno ruho koje pada u dugim, ravnim, plošno izvedenim naborima. Na osnovi položaja lijevoga lakta i obrisa jastuka vidljivoga u gornjem dijelu spomenika, možemo pretpostaviti da su pokojnikove ruke počivale na prsima, a glava na jastuku.

S kraja XV. stoljeća sačuvan je još jedan ulomak nadgrobnika s likom pokojnika koji se izvorno nalazio u zagrebačkoj katedrali. Riječ je o nadgrobnoj ploči Ivana i Blaža iz Moravča (1495.) (Slika 23) ${ }^{109}$ koja je bila postavljena u kapeli sv. Ladislava pred oltarom sv. Pavla. ${ }^{110}$ Sačuvan je donji dio nadgrobnika na kojem se vidi rub liturgijskoga ruha u koji je pokojnik odjeven, obiteljski grb ${ }^{111}$ i natpis izveden u klasičnoj majuskuli. Premda je natpis

\footnotetext{
${ }^{103}$ Usp. Josip Brunšmid, nav. dj., 1912., str. 182.

${ }^{104}$ Usp. Ivan Kampuš i Ljubo Karaman, Tisućljetni Zagreb: od davnih naselja do suvremenog grada, Zagreb: Školska knjiga, 1994., str. 38; Milan Pelc, nav. dj., 2010., str. 62.

${ }^{105}$ Kamen pješčenjak, $85 \times 50 \times 10 \mathrm{~cm}$, Zagreb, Hrvatski povijesni muzej, izvorno u crkvi Svih svetih u Sesvetama. Kat. br. 24.

${ }^{106}$ Usp. Lada Prister, Zbirka kamenih spomenika, u: Museum 1846.-1996., katalog izložbe, Zagreb: Hrvatski povijesni muzej, 1996., str. 20-25, 22. Uredila Maja Škiljan; Mirko Valentić i Lada Prister, nav. dj., 2002., str. 51.

107 Kamen pješčenjak, $183 \times 23 \times 13 \mathrm{~cm}$, Zagreb, Hrvatski povijesni muzej, izvorno u katedrali Uznesenja Blažene Djevice Marije i sv. Stjepana i Ladislava u Zagrebu. Kat. br. 30.

${ }^{108}$ Usp. Mirko Valentić, nav. dj., 1969., str. 30; Mirko Valentić i Lada Prister, nav. dj., 2002., str. $25-26$.

${ }^{109}$ Crveni vapnenac, $116 \times 99 \times 11 \mathrm{~cm}$, Zagreb, Muzej grada Zagreba, izvorno u katedrali Uznesenja Blažene Djevice Marije i sv. Stjepana i Ladislava u Zagrebu. Kat. br. 33.

${ }^{110}$ Usp. Ivan Krstitelj Tkalčić, Prvostolna crkva zagrebačka nekoć i sada, Zagreb: Knjigotiskara Karla Albrechta, 1885., str. 67.

${ }^{111} \mathrm{Na}$ štitu je predočena šaka koja drži ukrasnu vrpcu. Prema Ljudevitu Ivančanu i Gjuri Szabi (1929.), na vrpci je bio natpis »Corloa«. Usp. Ljudevit Ivančan i Gjuro Szabo, Spomen-kamen kanonika Vukoslavića - nadgrobna ploča Blaža od Moravča (1495.), u: Narodna starina VIII/19, Zagreb: Josip Matasović, 1929., str. 105-108, 106.
} 


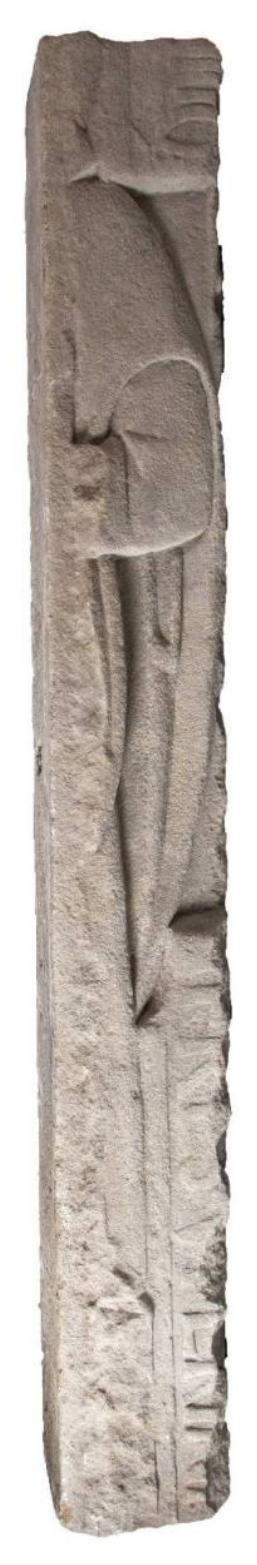

Slika 22. Nadgrobna ploča crkvenoga dostojanstvenika, XV. st., Zagreb, Hrvatski povijesni muzej

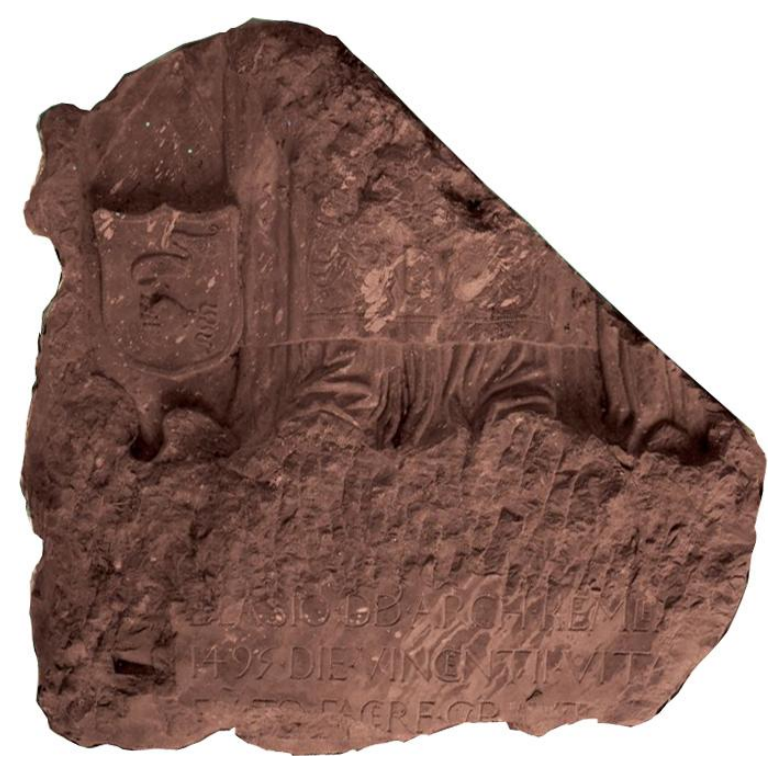

Slika 23. Nadgrobna ploča Ivana i Blaža iz Moravča, 1495., Zagreb, Muzej grada Zagreba

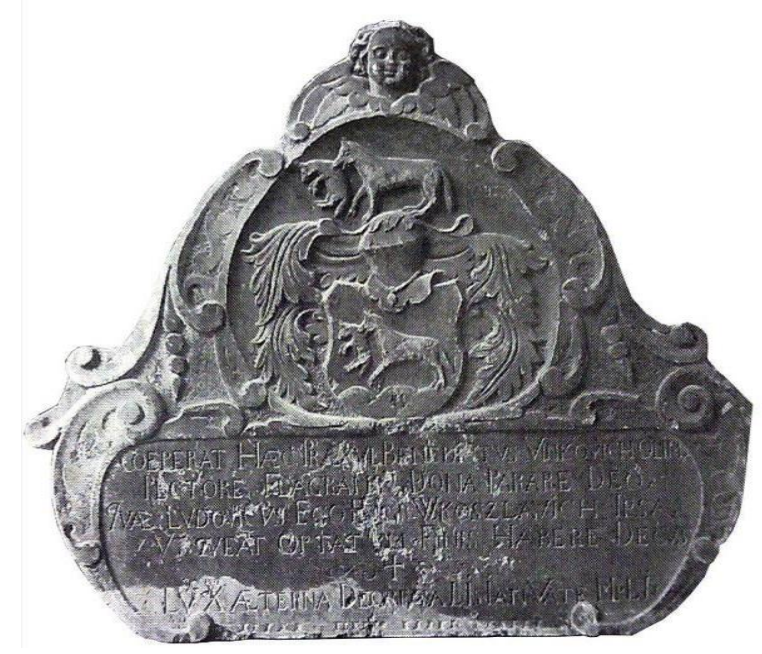

Slika 24. Spomen-ploča kanonika Ljudevita Vukoslavića, 1673., Zagreb, Muzej grada Zagreba

zbog oštećenja tek djelomično čitljiv, na osnovi povijesnih izvora koji bilježe njegov cjeloviti navod znamo da je nadgrobnik postavio gorički arhiđakon i zagrebački kanonik Ivan Moravčanin za sebe i svojega brata Blaža (»SIBI SUOQUE FRATRI«), kalničkoga arhiđakona i zagrebačkoga kanonika, nakon Blaževe smrti 1495. godine. ${ }^{112}$ Naličje ulomka ima vlastitu priču koja svjedoči sudbini brojnih nadgrobnih ploča. Naime, sredinom XVII. stoljeća katedralu je zahvatio veliki požar zbog kojeg se srušio svod iznad kora u punoj širini

\footnotetext{
${ }^{112}$ Usp. Ivan Kukuljević Sakcinski, Prvostolna crkva zagrebačka: opisana s gledišta povjesnice, umjetnosti $i$ starinah, Zagreb: Narodna tiskara Ljudevita Gaja, 1856., str. 25; Ivan Kukuljević Sakcinski, nav. dj., 1891., str. 325, br. 1120; Ivan Krstitelj Tkalčić, nav. dj., 1885., str. 67.
} 
crkve. ${ }^{113}$ Urušeni svod oštetio je korsku pregradu, biskupsko prijestolje, orgulje, šest oltara (uključujući oltar sv. Pavla) i nadgrobnu ploču braće iz Moravča. U obnovi katedrale koja je uslijedila nakon požara, ploča je izvađena i iskorištena kao građevni materijal za obnovu glavnoga, takozvanoga Vinkovićeva portala (izgrađen 1640. - 1643.). Na naličju sačuvanoga ulomka isklesan je grb i natpis kanonika Ljudevita Vukoslavića (Slika 24) ${ }^{114}$ koji je bio zaslužan za dovršetak obnove portala, a kamen je ugrađen iznad arhivolta ispod središnje skulpture Isusa Krista. ${ }^{115}$ Portal, uključujući nadgrobnu ploču braće iz Moravča odnosno Vukoslavićevu spomen-ploču, demontiran je tijekom Schmidt-Bolléove obnove katedrale.

Početkom XVI. stoljeća, u okrilju zagrebačke katedrale nastao je najreprezentativniji primjerak nadgrobne ploče s likom usnuloga pokojnika koji ujedno predstavlja i jedno od najznačajnijih renesansnih skulpturalnih djela na području kontinentalne Hrvatske uopće. ${ }^{116}$ Riječ je o nadgrobnoj ploči zagrebačkoga biskupa Luke de Szegeda (Szeged, Mađarska, ? - Čazma, 1510.; biskupovao 1500. - 1510.) (Slika 25) ${ }^{117}$ koja se izvorno nalazila u svetištu uz oltar biskupova sveca zaštitnika sv. Luke. ${ }^{118}$ Najvjerojatnije je izvađena početkom XVIII. stoljeća kada je u svetištu mijenjan pod (1703.) te je razlomljena na nekoliko dijelova koji su, nalik ulomcima nadgrobne ploče braće iz Moravča, nanovo upotrijebljeni, no u ovome slučaju kao podloga za novo popločenje. ${ }^{119}$ Ulomci nadgrobnika pronađeni su tijekom obnova koje su uslijedile nakon dva velika potresa koji su oštetili katedralu - onoga koji je 9. studenoga 1880. zahvatio cijelu sjeverozapadnu Hrvatsku te nedavnoga koji je 22. ožujka 2020. pogodio Zagreb i okolicu. Nakon prvoga potresa pronađena su četiri ulomka koja su predana Povijesnom muzeju Hrvatske (danas Hrvatski povijesni muzej), ${ }^{120}$ a nakon drugoga dodatna četiri koja pripadaju Dijecezanskom muzeju Zagrebačke nadbiskupije. ${ }^{121}$

\footnotetext{
${ }^{113}$ Usp. Lelja Dobronić, Biskupski i kaptolski Zagreb, Zagreb: Školska knjiga, 1991., str. 42-45.

${ }^{114}$ Vukoslavićev grb sastoji se od štita s motivom vuka koji u zubima nosi janje. Štit je urešen plaštem i kacigom $\mathrm{s}$ nakitom u obliku ponovljena motiva vuka s janjetom. Natpis koji se nalazi ispod grba glasi: „COEPERAT HÆC PRÆSVL BENEDICTVS VINKOVICH OLIM / PECTORE FLAGRANTI DOMA PARARE DEO / QUÆ LVDOVICVS EGO FECI WKOSZLAVICH IPSA/ VT QVÆT OPTATVM FINIS HABERE DECVS / † / LVX ÆTERNA DEO REGALIS IANVA TEMPU.«

${ }^{115}$ Usp. Lelja Dobronić, Renesansa u Zagrebu, Zagreb: Institut za povijest umjetnosti, 1994., str. 36-38; Ljudevit Ivančan i Gjuro Szabo, nav. dj., str. 108.

${ }^{116}$ Usp. Milan Pelc, nav. dj., 2007., str. 303; Mirko Valentić i Lada Prister, nav. dj., 2002., str. 27.

${ }^{117}$ Vapnenačka breča, dimenzije ulomaka pohranjenih u Hrvatskom povijesnom muzeju: gornji ulomci $56 \times 103 \times 13$ cm, donji ulomci $40 \times 60 \times 13 \mathrm{~cm}$, Zagreb, Hrvatski povijesni muzej, Dijecezanski muzej Zagrebačke nadbiskupije, izvorno u katedrali Uznesenja Blažene Djevice Marije i sv. Stjepana i Ladislava u Zagrebu. Kat br. 34.

${ }^{118}$ Usp. Ivan Kukuljević Sakcinski, nav. dj., 1856., str. 23; Ivan Kukuljević Sakcinski, nav. dj., 1891., str. 327, br. 1129; Ivan Krstitelj Tkalčić, nav. dj., 1885., str. 56.

${ }^{119}$ Usp. Josip Brunšmid, nav. dj., 1912., str. 183-184; Lelja Dobronić, nav. dj., 1994., str. 74; Mirko Valentić, nav. dj., 1969., str. 31; Mirko Valetnić i Lada Prister, nav. dj., 2002., str. 26-27.

${ }^{120}$ Usp. Josip Brunšmid, nav. dj., 1912., str. 183; Mirko Valentić, nav. dj., 1969., str. 31; Mirko Valentić i Lada Prister, nav. dj., 2002., str. 27.

${ }^{121}$ Usp. Ivan Tašev, Izniman nalaza u svetištu nakon potresa: Nadgrobna ploča biskupa Luke Baratina nositelja razvoja renesanse, u: Glas Koncila 23, mrežno izdanje. Nadbiskupski duhovni stol, 2020. Pristupljeno
} 


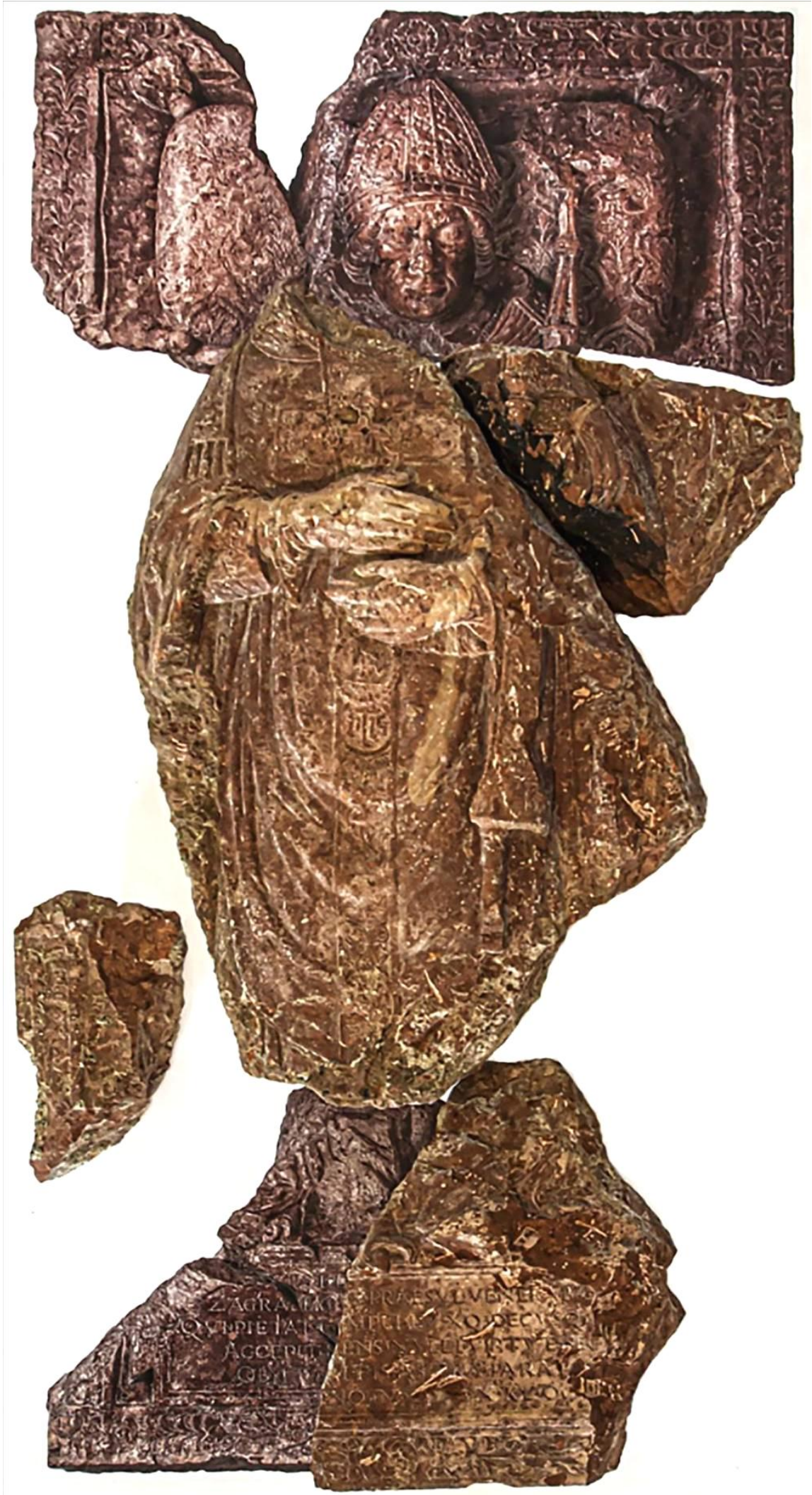

Slika 25. Johannes Fiorentinus (?), Nadgrobna ploča biskupa Luke de Szegeda $(\dagger 1510$.$) , Zagreb, Hrvatski povijesni muzej i Dijecezanski muzej$ Zagrebačke nadbiskupije

18. 8. 2020. <https://www.glas-koncila.hr/izniman-nalaz-u-svetistu-katedrale-nakon-potresa-nadgrobna-plocabiskupa-luke-baratina-nositelja-razvoja-renesanse/> 


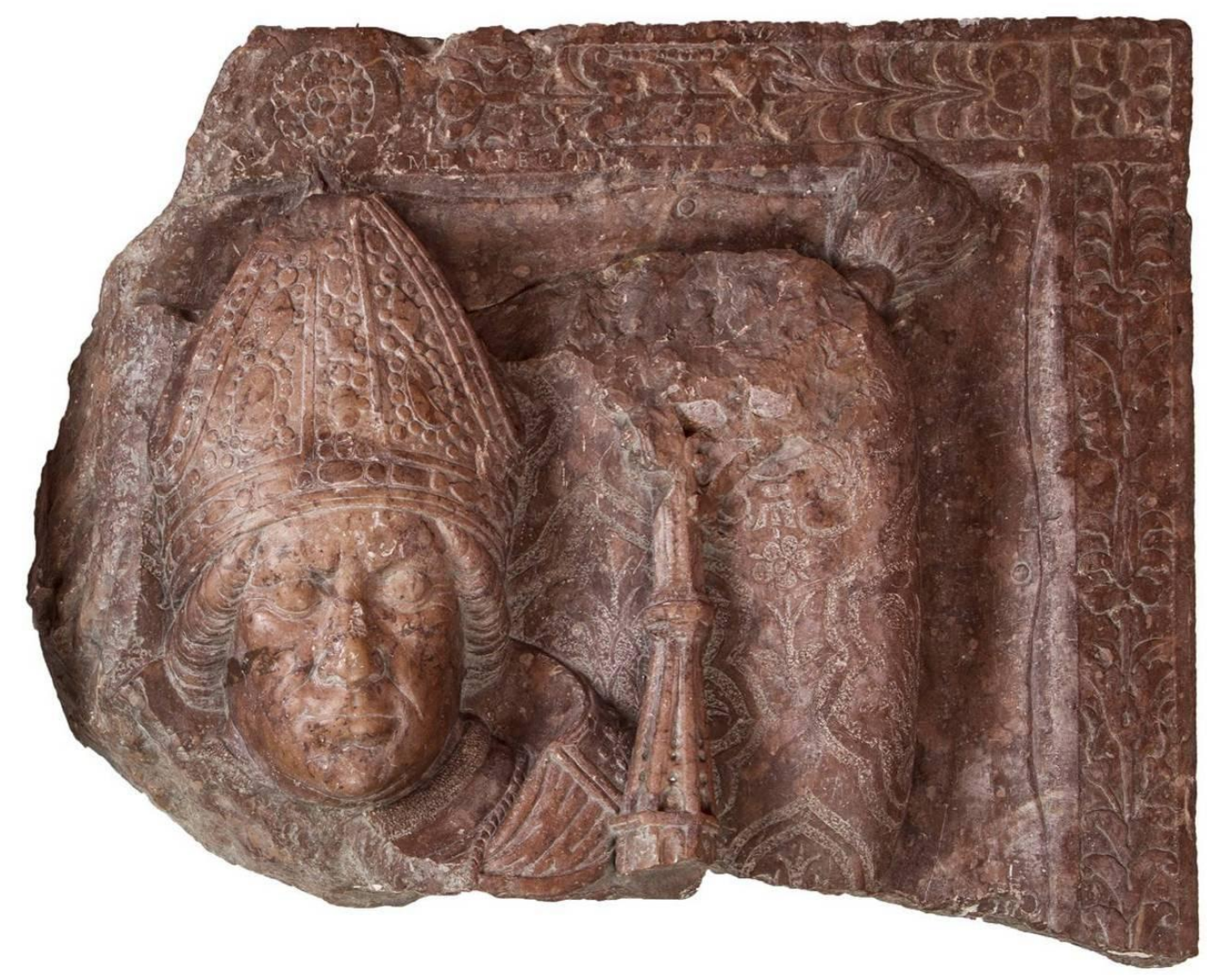

Slika 26. Johannes Fiorentinus (?), Nadgrobna ploča biskupa Luke de Szegeda (†1510.) gornji ulomak, Zagreb, Hrvatski povijesni muzej

Nadgrobna ploča predočuje biskupa de Szegeda odjevena u pontifikalno ruho koji počiva glave položene na jastuk. Prikazan je kao golobradi sredovječni muškarac kratke kovrčave kose te izražajnih individualiziranih crta lica koje mu daju portretne karakteristike. Odjeven je u albu izvezenih rukava povrh koje nosi misnicu s motivom križa. Premda su nabori tkanine plitki, draperija je oblikovana realistično dajući dojam da je položena preko tijela koje leži. Biskup na glavi nosi mitru ukrašenu dragim kamenjem, oko vrata pektoral, a na rukama pontifikalne rukavice. Ruke su mu položene na prsa; desna počiva na pektoralu, a u lijevoj drži patenu. Preko lijeve podlaktice nosi naručnik (manipul), kojom ujedno pridržava pastoral otkinuta vrha. Uz rubove ploče teče uska dekorativna traka ukrašena vegetabilnim motivima koja uokviruje cijeli nadgrobnik. Biskupovo tijelo položeno je na podstavu koja je čavlićima pričvršćena uz unutarnji rub dekorativnoga okvira, stvarajući time iluziju da je pokojnik položen unutar lijesa. Ispod tijela pokojnika nalazi se tabula ansata (lat. "ploča s drškama«) s nadgrobnim natpisom isklesanim u klasičnoj majuskuli. Prema pisanju Baltazara 
Adama Krčelića (1770.), na ploči se nalazio i biskupov grb, štit s motivom grifona koji gazi krunu, izliven u bronci. ${ }^{122}$

Izvedba pokojnikova lica te minuciozni detalji njegove odjeće i atributa svjedoče o iznimnom verističkom pristupu autora ovoga nadgrobnika. Dosadašnji istraživači složili su se da klesarski snažna i realistična izvedba »odaje visokokvalitetnog renesansnog umjetnika «, ${ }^{123}$ no još uvijek se nisu usuglasili oko njegovoga identiteta. Iznad biskupove glave, na unutarnjem rubu dekorativnoga okvira uklesan je natpis: »IOA[...] [...]S ME FECIT« (Slika 26). Na osnovi očuvanoga dijela moguće je zaključiti da se autor zvao Ivan (Ioannis), no njegovo prezime još uvijek nije utvrđeno sa sigurnošću. Josip Brunšmid (1912.) prvi je iznio dva prijedloga atribucije. Prema njegovu mišljenju, uklesani natpis mogao bi se odnositi na Ivana Nicze iz Firence (Ioannes Niczae Florentius), drvorezbara koji je 1507. godine izradio drvene korske klupe za zagrebačku katedralu po narudžbi Luke de Szegeda, ili na jednog od najznačajnijih hrvatskih renesansnih kipara, Ivana Duknovića (Giovanni Dalmata, Ioannes Dalmata; Trogir, o. 1440. - ?, nakon 1509.). ${ }^{124}$ Ipak, Brunšmid je objema mogućnostima pristupio s opreznošću, navodeći kako postoje razlozi koji čine obje atribucije neizglednima. Kao protuargument pripisivanju djela Ivanu Niczi naveo je umjetnikovo nepoznavanje rada u kamenu (Nicze je prvenstveno bio drvorezbar), a kao protuargument atribucije Ivanu Duknoviću nepoklapanje godina Dukovnićeva boravka na dvoru kralja Matije Korvina u Budimu (1482. - 1490.) i početka de Szegedova biskupovanja (1500.) odnosno smrti (1510.).

Unatoč Brunšmidovoj sumnji, pojedini istraživači (Jiroušek 1943.; Prijatelj 1956., 1957.; Valentić 1969.; Dobronić 1994.) mišljenja su da je de Szegedovu nadgrobnu ploču izradio Ivan Duknović, interpretirajući ime uklesano na spomeniku kao IOANNIS DALMATICVS. ${ }^{125}$ Kruno Prijatelj (1956., 1957.) najpodrobnije je razložio argumente temeljem kojih je smatrao da je spomenik djelo poznatoga hrvatskog kipara. Prema njegovu mišljenju, de Szegedov nadgrobnik tipološki se i stilski uklapa u Duknovićev opus. Kao početni argument, Prijatelj je istaknuo činjenicu da je Duknović bio dobro upoznat s izradom

\footnotetext{
122 Usp. Baltazar Adam Krčelić, Povijest Stolne crkve zagrebačke, Zagreb: Institut za suvremenu povijest, 1994. str. 240. Preveo Zlatko Šešelj.

${ }^{123}$ Mirko Valentić, nav. dj., 1969., str. 31.

${ }^{124}$ Usp. Josip Brunšmid, nav. dj., 1912., str. 185.

${ }^{125}$ Usp. Lelja Dobronić, nav. dj., 1994., str. 74; Željko Jiroušek, Pregled razvoja likovnih umjetnosti u banskoj Hrvatskoj. Od XII. do kraja XVIII. stoljeća, u: Naša domovina, svezak 2. Hrvatska kultura - politička poviest Hrvata, Zagreb: Izdanje Glavnog ustaškog stana, 1943., str. 680-697, 692; Kruno Prijatelj, Prinosi za monografiju o Ivanu Duknoviću, u: Anali Historijskog instituta u Dubrovniku IV/V, Dubrovnik: Historijski institut Jugoslavenske akademije znanosti i umjetnosti u Dubrovniku, 1956., str. 305-321, 316; Mirko Valentić, nav. dj., 1969., str. 34-35.
} 
ovakvoga tipa nadgrobnoga spomenika (motiv usnuloga pokojnika javlja se na svim Duknovićevim spomenicima koje je izradio u Rimu), jednako kao što je bio upoznat s radom u crvenom mramoru (u tom materijalu izradio je kipove za ljetnu rezidenciju kralja Matije Korvina u Ostrogonu i Heraklov zdenac za kraljevu rezidenciju u Višegradu). Kao stilske razloge naveo je način izvedbe de Szegedova lica (naglašene kosti, nabori iznad usana, oblik nosa, zatvoreni kapci) i pojedine dekorativne elemente (okvir ukrašen vegetabilnim motivima, ukrasni ornament mitre, oblik i dekoracija jastuka) koji imaju uporište u drugim Duknovićevim djelima. Kao dodatan, povijesni razlog pridodao je i vremensko poklapanje početka de Szegedove dužnosti kao bosanskoga biskupa (1487.) ${ }^{126}$ i Duknovićeva boravka na Korvinovu dvoru (1482. - 1490.), ukazujući na mogućnost da su biskup i kipar istovremeno boravili u Budimu gdje su sklopili poznanstvo koje je poslije rezultiralo suradnjom. Poput Josipa Brunšmida (1912.), Ljubo Karaman (1948., 1950.) izrazio je sumnju da je uistinu riječ o Dukovnićevu radu, a sličan stav zauzeli su i kasniji istraživači (Vukičević-Samaržija 1995., Fisković 2004., Pelc 2006.) navodeći kako de Szegedovu licu nedostaje »profinjena suptilnost izraza i mekoća puti « koja je svojstvena Duknovićevim skulpturama. ${ }^{127}$

Anđela Horvat (1975., 1979.) jedina je ozbiljnije razmotrila mogućnost da je de Szegedovu nadgrobnu ploču izradio drvorezbar Ivan Nicze iz Firence, interpretirajući uklesano ime na spomeniku kao IOANNES FIRENTINUS. ${ }^{128}$ Nepoduprt drugim argumentima osim sličnosti imena umjetnika s natpisom na ploči i već navedenom narudžbom biskupa de Szegeda za korskim klupama (1507.), njezin prijedlog nije naišao na veći odjek.

Najnoviji i zasad najizgledniji prijedlog atribucije iznio je Milan Pelc (2006., 2007., 2010., 2012.). Pelc se slaže s Anđelom Horvat da se natpis na de Szegedovoj ploči može iščitati kao »IOANNES FIRENTINUS ME FECIT«, no u imenu umjetnika ne prepoznaje drvorezbara Niczu, nego talijanskoga kipara Johannesa Fiorentinusa koji je krajem XV. i početkom XVI. stoljeća djelovao u Ostrogonu (mađ. Esztergom). ${ }^{129}$ Svoj prijedlog atribucije potkrjepljuje nizom argumenata. Kao prvi navodi činjenicu da se kiparska radionica majstora Johannesa Fiorentinusa specijalizirala za izradu nadgrobnih spomenika. Drugi je repertoar

\footnotetext{
${ }^{126}$ Luka de Szeged imenovan je bosanskim biskupom 1487. godine, csanádskim 1493. godine, a zagrebačkim 1500. godine.

${ }^{127}$ Milan Pelc, nav. dj., 2006., str. 68-69. Usporedi dalje: Igor Fisković, Ulomci grobne ploče zagrebačkoga biskupa (početak XVI. st.), u: Hrvatska renesansa: katalog izložbe, Zagreb: Galerija Klovićevi dvori, 2004., str. 256, br. K. 32. Uredili Miljenko Jurković i Alain Erlande-Brandenburg; Ljubo Karaman, nav. dj., 1948., str. 107; Ljubo Karaman, nav. dj., 1950., str. 168; Diana Vukičević-Samaržija, Likovne pojave na kraju XV. i početkom XVI. stoljeća - gotika u renesansi, u: Zagrebačka biskupija i Zagreb, 1094 - 1994. Zbornik u čast kardinala Franje Kuharića, Zagreb: Nadbiskupija zagrebačka, 1995., str. 551-558, 553-554.

${ }^{128}$ Usp. Anđela Horvat, nav. dj., 1975., str. 44-45; Anđela Horvat, nav. dj., 1979.a, str. 310, bilj. 17.

${ }^{129}$ Usp. Milan Pelc, nav. dj., 2006., str. 71; Milan Pelc, nav. dj., 2007., str. 317; Milan Pelc, nav. dj., 2010., str. 66; Milan Pelc, nav. dj., 2012., str. 236.
} 
motiva koje je radionica primjenjivala, a uključivao je ukrasnu okvirnu traku s vegetabilnim motivima i tablu ansantu, pravokutni okvir s »drškama« i natpisom, koji nalikuju onima na zagrebačkom nadgrobniku. ${ }^{130}$ Posljedni argument je formula kojom je majstor radionice potpisivao svoja djela, »IOANNES FIORENTINVS ME FECIT«, a odgovara sačuvanim dijelovima natpisa na de Szegedovoj ploči. Iako su pojedina ostvarenja radionice neujednačene kiparske kvalitete, Pelc ističe da se djelā izrađena za zahtjevnije naručitelje koje je najvjerojatnije klesao sam majstor - odlikuju verističkim pristupom koji odgovara senzibilitetu autora nadgrobne ploče biskupa de Szegeda, poput muškoga lika iz grba obitelji Désházy na portalu crkve u Mineu (mađ. Menyö; Rumunjska) (1514. - 1515.). ${ }^{131}$

Nadgrobnu ploču Luke de Szegeda i sljedeći sačuvani nadgrobni spomenik crkvenoga prelata na kojem je primijenjeno isto likovno rješenje razdvaja više od jednoga stoljeća. Riječ je o nadgrobnoj ploči zagrebačkoga biskupa Petra III. Petretića (Sočice, o. 1604. - ?, 1667.; biskupovao 1648. - 1667.) (Slika 27), ${ }^{132}$ poznatoga po osnivanju vezilačke radionice koja je izradila Božji grob za zagrebačku prvostolnicu. ${ }^{133}$ Prema povijesnim izvorima, Petretić je pokopan u svetištu zagrebačke katedrale nedaleko oltara sv. Luke, a njegovo grobno mjesto obilježeno je nadgrobnom pločom koja je uklonjena 1703. godine prilikom mijenjanja popločenja prezbiterija. ${ }^{134}$ Očuvan je ulomak nadgrobnika s biskupovim grbom ${ }^{135}$ koji je pronađen prigodom izgradnje južnoga krila bolnice Milosrdne braće 1869. godine, a danas je pohranjen u Muzeju grada Zagreba. ${ }^{136}$ Prema pisanju Ivana Krstitelja Tkalčića (1885.), ploča je osim grba sadržavala i biskupov lik. ${ }^{137} \mathrm{Na}$ osnovi izgleda drugih sačuvanih nadgrobnika, možemo pretpostaviti da je Petretićev lik bio odjeven u misno ruho (albu i misnicu) te da je na glavi nosio mitru, a u rukama držao pastoral.

Prema povijesnim izvorima, u zagrebačkoj su se prvostolnici nalazila još najmanje tri nadgrobnika podignuta u spomen na biskupe koji su bili urešeni njihovim likovima. Jedan od

\footnotetext{
${ }^{130}$ Termin tabula ansanta (lat. ansa »držak, ručka«) označava vrstu natpisne ploče pravokutna oblika koja na okomitim stranicama ima trokutaste »drške«. Bila je iznimno popularna u vrijeme Rimskoga Carstva, a ponovno se počela upotrebljavati tijekom renesanse kada se primjenjivala u svim vizualnim medijima.

${ }^{131}$ Usp. Milan Pelc, nav. dj., 2006., str. 71.

132 Vapnenac, $56 \times 52 \times 20 \mathrm{~cm}$, Zagreb, Muzej grada Zagreba, izvorno u katedrali Uznesenja Blažene Djevice Marije i sv. Stjepana i Ladislava. Kat. br. 40.

${ }^{133}$ Usp. Mijo Korade, Petar Petretić, u: Zagrebački biskupi i nadbiskupi, Zagreb: Školska knjiga, 1995., str. 333-339. Uredio Franko Mirošević.

${ }^{134}$ Usp. Ivan Kukuljević Sakcinski, nav. dj., 1856., str. 23; Ivan Krstitelj Tkalčić, nav. dj., 1885., str. 58.

${ }^{135}$ Grb štita razdijeljen je na tri polja. U gornjem polju prikazan je lovorov vijenac, u donjem (heraldički) desnom muškarac koji drži svijeću, a u donjem lijevom križ podignut na brijegu s tri vrha. Vrh štita urešen je biskupskom mitrom, križem i pastoralom.

${ }^{136}$ Usp. Ivan Kukuljević Sakcinski, nav. dj., 1891., str. 336, br. 1156; Slavko Šterk i Boris Mašić, nav. dj., 2014., str. 85 .

${ }^{137}$ Usp. Ivan Krstitelj Tkalčić, nav. dj., 1885., str. 58. Vidi i: Milan Pelc, nav. dj., 2010., str. 66.
} 


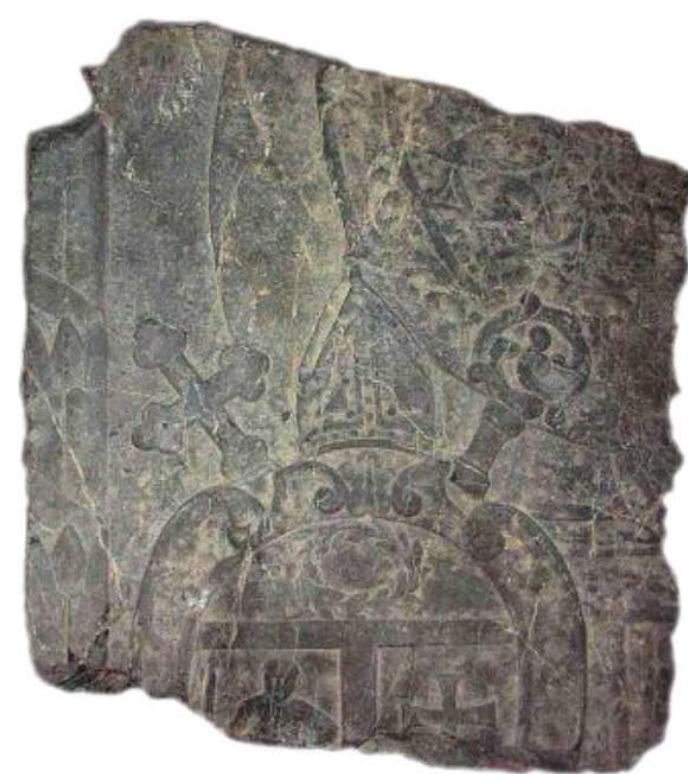

Slika 27. Nadgrobna ploča biskupa Petra III. Petretića (†1667.), Zagreb, Muzej grada Zagreba

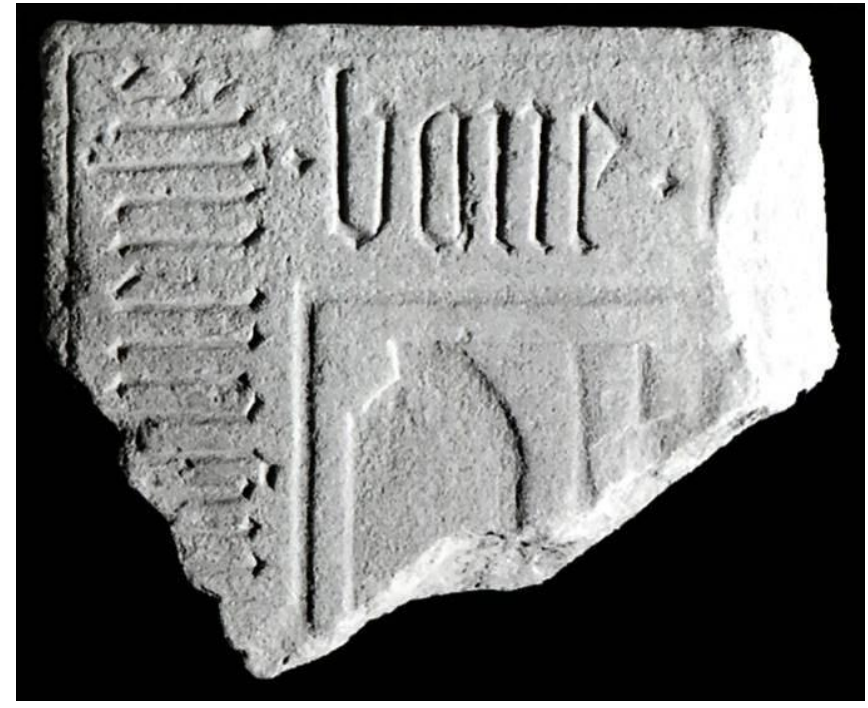

Slika 28. Ulomak nadgrobne ploče, XV. st., Zagreb, Hrvatski povijesni muzej

njih je nadgrobna ploča biskupa Osvalda Thuza od Svetoga Ladislava (de Szentlaszlo) (?, 1438. - Čazma, 1499.; biskupovao 1466. - 1499.), prethodnika Luke de Szegeda. Thuz je pokopan u svetištu pred oltarom Posljednje večere koji je podigao, a iznad groba postavljenja je bijela mramorna ploča koja je sadržavala njegov lik i obiteljski grb. ${ }^{138}$ Nepoznato je što se dogodilo s nadgrobnikom, no najvjerojatnije je doživio istu sudbinu kao i ostale nadgrobne ploče položene u svetištu katedrale koje su izvađene početkom XVIII. stoljeća kada se postavljao novi pod. Preostale dvije nadgrobne ploče pripadale su neznanim biskupima, a pronađene su prilikom obnove katedrale nakon potresa 1880. godine ispod popločenja svetišta. Prema Ivanu Krstitelju Tkalčiću (1885.), obje su sadržavale lik »izklesana biskupa u podpunom ornatu, kako drži ljevom biskupski štap a desnom kalež na prsiuh «. ${ }^{139}$ Na jednoj se mogao djelomično pročitati natpis »ZAGRABIENSIS BONE MEMORIE«, a druga ga nije sadržavala. ${ }^{140}$ Nije poznato što se dogodilo s nadgrobnicima nakon što su pronađeni, no postoji mogućnost da je dio prve ploče danas pohranjen u Hrvatskom povijesnom muzeju. Riječ je o ulomku (Slika 28) ${ }^{141}$ gornjega lijevog kuta nadgrobnika na kojem je vidljiva plitko profilirana niša i nekoliko riječi natpisa u gotičkoj minuskuli (»...biensis / bone«) koji

\footnotetext{
${ }^{138}$ Usp. Josip Brunšmid, nav. dj., 1912., str. 184; Ivan Kukuljević Sakcinski, nav. dj., 1856, str. 22; Ivan Kukuljević Sakcinski, nav. dj., 1891., str. 326, br. 1124; Milan Pelc, nav. dj., 2010., str. 65; Ivan Krstitelj Tkalčić, nav. dj.,1885., str. 55.

${ }^{139}$ Ivan Krstitelj Tkalčić, nav. dj., 1885., str. 54. Vidi i: Milan Pelc, nav. dj., 2010., str. 66.

${ }^{140}$ Isto.

${ }^{141}$ Pješčenjak, $42 \times 46 \times 15 \mathrm{~cm}$, Zagreb, Hrvatski povijesni muzej, izvorno u katedrali Uznesenja Blažene Djevice Marije i sv. Stjepana i Ladislava. Kat. br. 31.
} 
odgovara onome koji je zabilježio Tkalčić. Međutim, s obzirom na fragmentarnu očuvanost ulomka vrlo je teško ustvrditi je li uistinu riječ o istom spomeniku, odnosno je li ostatak nadgrobne ploče iz Hrvatskoga povijesnog muzeja sadržavao lik pokojnika.

Sačuvana građa i povijesni izvori pokazuju da su nadgrobne ploče sa samostalnim likom pokojnika bile široko prihvaćene među crkvenim velikodostojnicima. Ovo se likovno rješenje dugo zadržalo na prostoru Zagrebačke povijesne biskupije, o čemu svjedoči nadgrobna ploča đakovačko-bosanskoga biskupa Nikole III. Ogramića Olovčića (Požega, 1630. - Đakovo, 1701.; biskupovao 1669. - 1701.) (Slika 29) ${ }^{142}$ koja datira s početka XVIII. stoljeća. Biskup Ogramić Olovčić zaslužan je za pripajanje dijelova Slavonije koji su oslobođeni osmanske vlasti Bosanskoj biskupiji i vraćanje sjedišta biskupije u Đakovo, gdje je pod još uvijek nerasvijetljenim okolnostima doživio nasilnu smrt u noći 14. kolovoza 1701. godine, kada su nepoznati počinitelji provalili u kuću u kojoj je boravio i pogubili ga. ${ }^{143}$ Biskup je sahranjen u đakovačkoj katedrali (nekadašnjoj franjevačkoj crkvi), no krajem iste godine njegovo je tijelo preneseno u našičku franjevačku crkvu sv. Antuna Padovanskoga, gdje je pokopano u svetištu. Prema natpisu uklesanom uz rubove ploče, biskupov nećak fra Erazmo Ogramić - koji je poput Nikole bio franjevac - obilježio je stričev grob nadgrobnom pločom koja je barokizacijom crkve (1763. - 1765.) ugrađena u sjeverni zid svetišta, ${ }^{144}$ gdje se nalazi i danas.

$\mathrm{Na}$ nadgrobniku je predočen sredovječan muškarac individualizirana, naborana lica. Za razliku od prethodnih primjera, prikazan je kako stoji, glave i tijela zakrenutih u lijevi poluprofil. Desnu ruku podigao je u gesti blagoslova, a u lijevoj drži pastoral. Odjeven je u albu mesnatih, nezgrapno oblikovanih nabora koji pokušavaju dočarati punoću draperije i vezenu misnicu ukrašenu motivom akanta, a na glavi nosi mitru. Pozadina je ostavljena prazna, uz iznimku biskupova grba ${ }^{145}$ u gornjem lijevom kutu prema kojem je lik usmjeren tijelom i - što je u odnosu na impostaciju prethodno analiziranih likova pokojnika jedinstveno - licem. Pogledom usmjerenim prema gore, biskup Ogramić Olovčić približio se suvremenim

\footnotetext{
${ }^{142}$ Kamen, širina o. 140 cm, Našice, franjevačka crkva sv. Antuna Padovanskoga. Kat. br. 82.

143 Biskup se smjestio u nekadašnjoj sakristiji franjevačke samostanske crkve. Usp. Stjepan Bäuerlein, Fra Nikola Ogramić-Olovčić, biskup đakovački, u: Croatia Sacra XIII-XIV/22-23, Zagreb: Hrvatska bogoslovska akademija, 1944., str. 127-160, 157; Placido Belavić, Našice: povjesničke crtice, Našice: Zavičajni muzej, 1995., str. 28-32; Srećko Majstorović, Našice kroz 700 godina 1229 - 1929, Zagreb: Vicepostulatura, 1973., str. 70-71.

${ }^{144}$ Usp. Paškal Cvekan, Franjevci u Abinim Našicama: Povijesno-kulturni prikaz djelovanja Franjevaca kroz 700 godina postojanja samostana i crkve Svetog Antuna u Abinim Našicama, Našice: Paškal Cvekan, 1981., str. 63; Ratko Ivanušec, Franjevačka crkva sv. Antuna Padovanskog sa samostanom u Našicama: Konzervatorsko istraživanje i obnova, Našice: Franjevački samostan u Našicama, Zavičajni muzej Našice, 2010., str. 15, bilj. 28.

145 Jednostavan štit s motivom lava ukrašen je trima šesterokrakim zvijezdama i galero šeširom širokoga oboda. Prelatski šešir ima po tri kićanke sa svake strane, što predstavlja svojevrstan kuriozitet jer prema heraldičkim pravilima biskupski grbovi ukrašeni su sa sveukupno dvanaest - a ne šest - kićanki.
} 


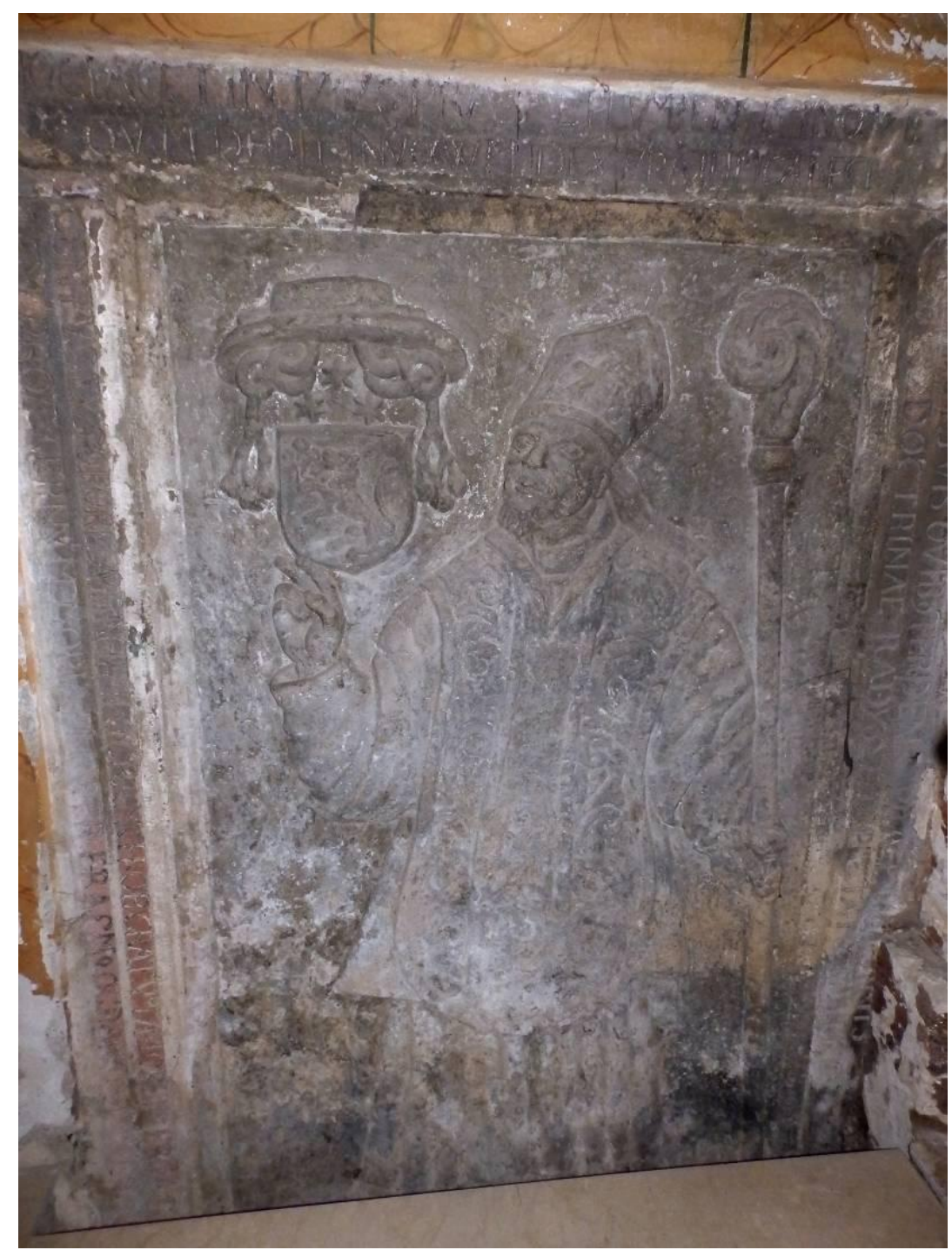

Slika 29. Nadgrobna ploča biskupa Nikole III. Ogramića Olovčića (†1701.), Našice, crkva sv. Antuna Padovanskoga

svetačkim ikonografijama koje povišenim pogledom prate svetačko viđenje (Bogorodicu, zrake svjetlosti ili viđenje nekoga znaka koji im je atribut). U poslijetridentskom - a za Slavoniju i poslijeosmanskom - valu podizanja novih oltara i unosa nove likovne kulture, ikonografija liturgijskih likovnih djela (oltarnih slika, kipova, knjižnih grafika i slično) očito je imala utjecaj i na ikonografiju nadgrobnih ploča. Promjenom impostacije figure pokojnika iz frontalnoga stava u poluprofil i njegovom aktivacijom iz mirno položenoga tijela u ono koje udjeljuje blagoslov, nadgrobnik Nikole III. Ogramića Olovčića udaljio se od tradicionalnoga likovnog rješenja koje je primijenjeno na prethodno razmotrenim nadgrobnim spomenicima. Međutim, odabirom medija nadgrobne ploče s figuralnim prikazom pokojnika u vrijeme kada su epitafi gotovo u potpunosti istisnuli nadgrobne ploče iz uporabe, naručitelj je pokazao poznavanje tradicije nadgrobnih spomenika i svjesno se referirao na nju. 
Nadgrobnu ploču biskupa Ogramića Olovčića tako bismo mogli opisati kao kiparsko ostvarenje suvremenoga baroknog htijenja (promjena impostacije, aktivacija figure pokojnika, poslijetridentska ikonografija, upotreba motiva akanta) koje ima uporište u tradicionalnim oblicima nadgrobnoga kiparstva (odabir nadgrobne ploče kao vrste spomenika, figuralni motiv pokojnika, natpis koji teče uz rubove).

U usporedbi s XV. stoljećem, nadgrobne ploče s likom pokojnika počele su gubiti na popularnosti među crkvenim dostojanstvenicima od druge polovine XVI. stoljeća nadalje. Teško je ustvrditi jesu li u cezurama između nadgrobnikā biskupā Luke de Szegeda (†1510.), Petra III. Petretića (†1667.) i Nikole III. Ogramića Olovčića (†1701.) podizani drugi nadgrobni spomenici istoga rješenja i u kojem broju. No ono što možemo konstatirati jest da se ovo likovno-ikonografsko rješenje održalo i primjenjivalo tijekom gotovo čitavoga novog vijeka kao »usvojeno rješenje velikoga autoriteta« koji je proizlazio iz njegove srednjovjekovne tradicije. ${ }^{146}$

\subsubsection{NADGROBNE PLOČE PLEMKINJA I DJECE}

Prikaz usnuloga pokojnika bilo je ustaljeno likovno-ikonografsko rješenje koje se, osim na nadgrobnicima crkvenih prelata, primjenjivalo i na nadgrobnim pločama podignutima u spomen na pripadnice plemstva. Na području povijesne Zagrebačke biskupije na žalost nije očuvan nijedan cjelovit nadgrobnik s likom pokojnice. Sačuvao se jedino ulomak nadgrobne ploče plemkinje Barbare (XV. st.) (Slika 30 ${ }^{147}$ koji je pohranjen u Hrvatskom povijesnom muzeju. Riječ je o ulomku gornjega dijela ploče na kojem su vidljivi jastuk, pokojničina dijadema ukrašena dragim kamenjem te profilirani rub i natpis u gotičkoj minuskuli. Budući da detaljnost izvedbe dijademe i gotičkih slova upućuje na kvalitetnoga kipara, stručnjaci pretpostavljaju da je pokojnica pripadala imućnoj obitelji koja je takvoga umjetnika mogla i platiti te da je sahranjena u zagrebačkoj katedrali kao prestižnom mjestu ukapanja. ${ }^{148}$ Cjelovit izgled spomenika možemo pretpostaviti usporedbom $\mathrm{s}$ drugim nadgrobnim pločama plemkinja i građanki sačuvanih na području jadranske Hrvatske, poput nadgrobne ploče Elizabete Frankapan rođ. Petheö de Gerse $(† 1513$.$) iz franjevačke crkve na Trsatu (Slika 31)$

\footnotetext{
146 Termin je preuzet iz predavanja dr. sc. Sanje Cvetnić, red. prof. Gotičke i renesanse značajke: razlike u narudžbama $i$ namjeni održanoga na Odsjeku za povijest umjetnosti Filozofskoga fakultetu Sveučilišta u Zagrebu u sklopu kolegija Hrvatska likovna baština »Između gotike i baroka« (ak. god. 2010./2011.).

${ }^{147}$ Kristalični vapnenac, $16 \times 18 \times 6 \mathrm{~cm}$, Zagreb, Hrvatski povijesni muzej, izvorno u katedrali Uznesenja Blažene Djevice Marije i sv. Stjepana i Ladislava u Zagrebu (?). Kat. br. 29.

${ }^{148}$ Usp. Doris Baričević, Skulptura i slikarstvo, katalog S, u: Riznica zagrebačke katedrale = The Treasury of Zagreb Cathedral, katalog izložbe, Zagreb: MTM, 1987. [1983.], str. 55-64, 56. Uredila Zdenka Munk; Mirko Valentić, nav. dj., 1969., str. 26-27, Mirko Valentić i Lada Prister, nav. dj., 2002., str. 25.
} 


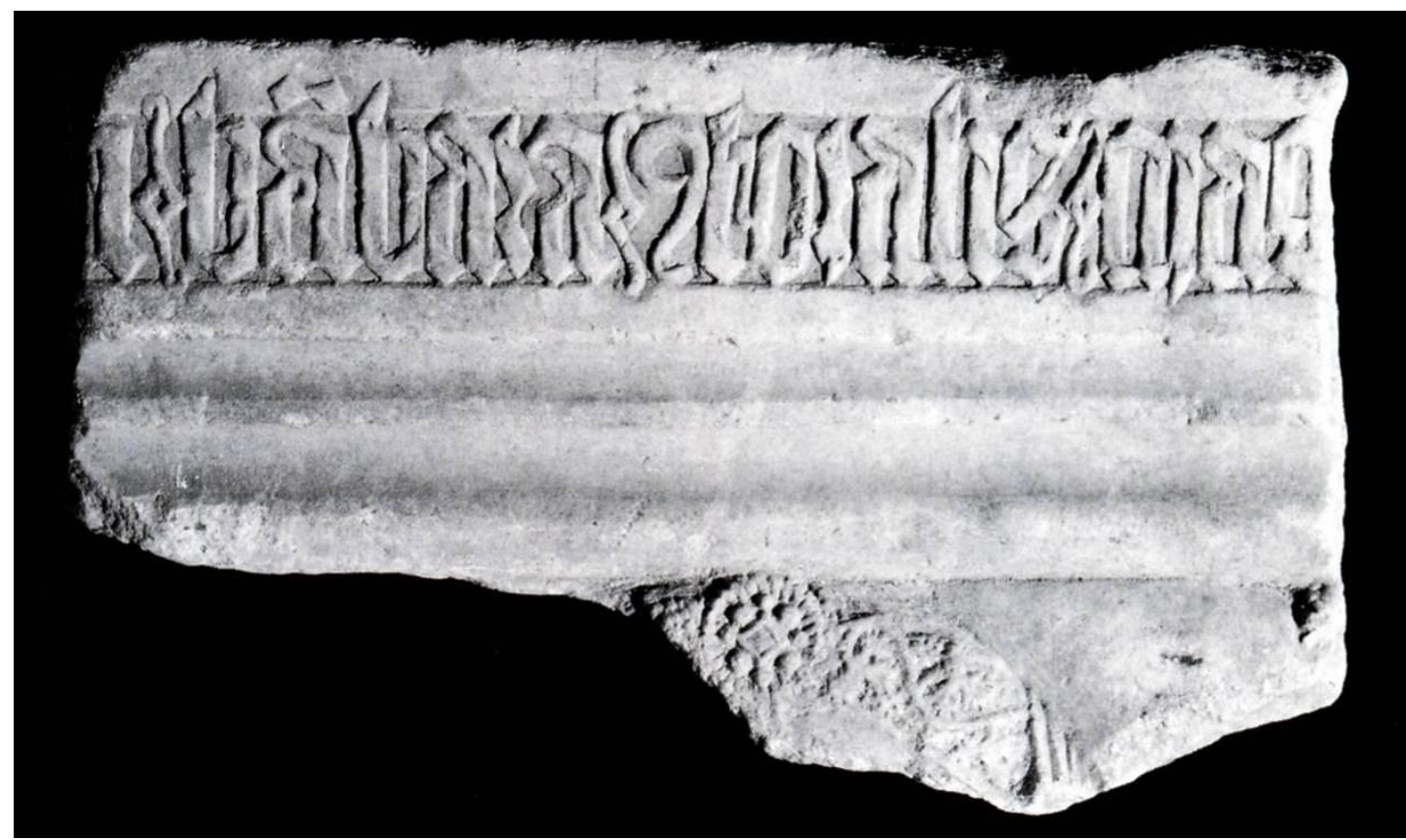

Slika 30. Nadgrobna ploča plemkinje Barbare, XV. st., Zagreb, Hrvatski povijesni muzej

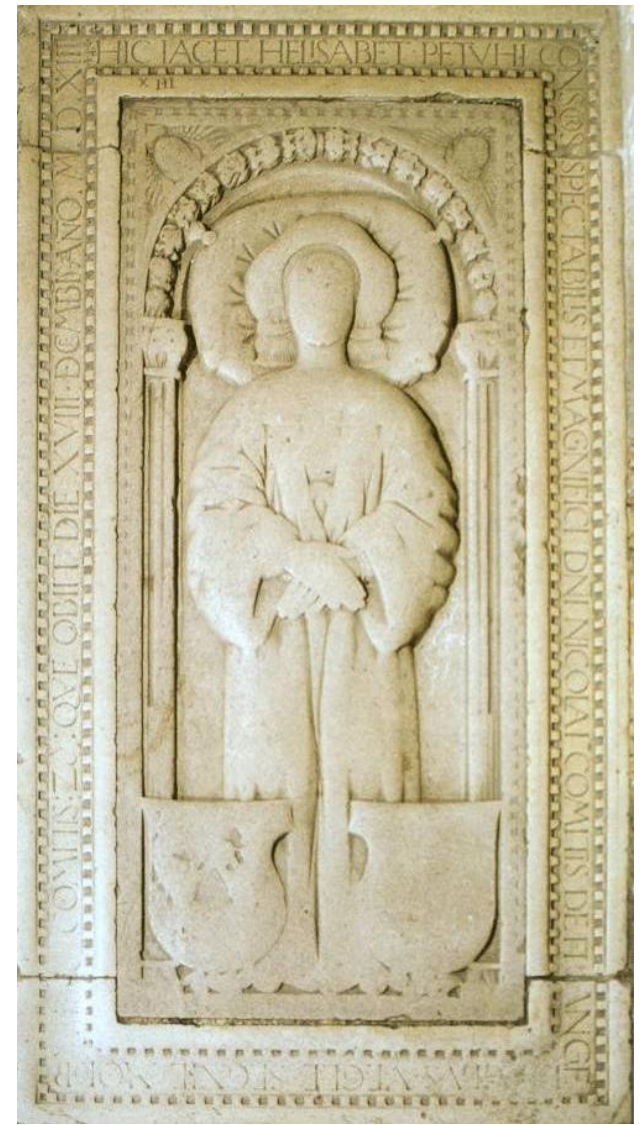

Slika 31. Nadgrobna ploča Elizabete Frankapan rođ. Petheö de Gerse (†1513.), Rijeka, crkva Majke Božje Trsatske

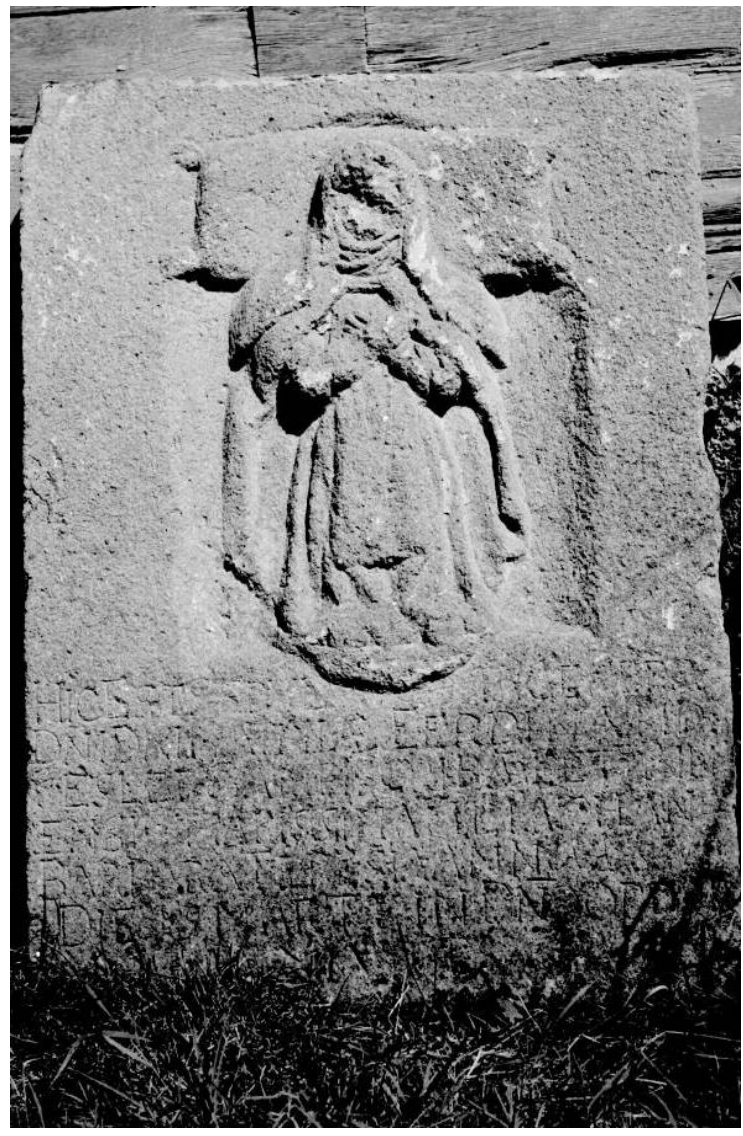

Slika 32. Pokupski Brest, Kapela sv. Barbare, Grobna ploča, 1939., foto: Đuro Griesbach, HAZU, Strossmayerova galerija starih majstora, Schneiderov fotografijski arhiv 
ili Katarine Žuvić (†1527.) iz franjevačke crkve u Poljudu, na kojima su pokojnice odjevene u suvremenu odjeću prikazane mirno položena tijela, glave oslonjene na jastuk, a ruku sklopljenih na krilu.

Dosad nisu pronađeni povijesni izvori koji bi potvrdili da je plemkinja Barbara uistinu pokopana u zagrebačkoj katedrali. Međutim, arhivski spisi bilježe imena drugih plemkinja i građanki koje su posljednje počivalište pronašle u prvostolnici. Prema rukopisu Rafaela Levakovića (Jastrebarsko, 1597. - Zadar, 1649.) o povijesti Zagrebačke crkve, Historiola de fundatione et structura ecclesiae Zagrabiensis, u kapeli sv. Ladislava uz oltar istoimenoga sveca nalazila se nadgrobna ploča Elizabete, kćeri zagrebačkoga župana Valentina, koja je sadržavala pokojničin lik. ${ }^{149}$ Prema Levakovićevu prijepisu uklesanoga natpisa, Elizabeta je preminula 1200. godine (»MCC «). ${ }^{150}$ Ivan Krstitelj Tkalčić (1885.) izrazio je sumnju da je to točna godina pokojničine smrti jer je kapela sv. Ladislava dovršena 1275. godine, sedamdeset i pet godina nakon što je Elizabeta navodno umrla. Smatrajući kako je moguće da je »iza oznake druge stotice [...] bila jošte koja stotica ili bar nekoliko deseticah, kojih je tečajem vremena izbrušeno nogami prohodnikah«, Tkalčić je odredio godinu podizanja kapele sv. Ladislava kao terminus post quem izrade nadgrobnika. ${ }^{151}$ Neovisno o tome je li Elizabeta preminula početkom ili krajem XIII. stoljeća, njezina je nadgrobna ploča jedan od najranije zabilježenih nadgrobnika na području povijesne Zagrebačke biskupije koji je sadržavao lik pokojnika.

$\mathrm{Na}$ razmatranom području zasigurno je podignuto još nadgrobnih ploča s likom pokojnica koje se jednostavno nisu očuvale. Da je tome tako svjedoči fotografijski snimak nadgrobne ploče neznane žene (†1685.) iz kapele sv. Barbare u Brestu Pokupskome (Slika 32) koji je Artur Schneider dao načiniti 1939. godine obilazeći i popisujući umjetničke spomenike Posavine. ${ }^{152}$ Ploča je urešena likom pokojnice koja leži glave oslonjene na jastuk, a ruke drži sklopljene na prsima. Odjevena je u haljinu i ogrtač, a preko glave nosi takozvanu ubradaču, maramu koja pokriva glavu i vrat. Prilikom popisivanja nadgrobnika, Schneider je zabilježio godinu smrti pokojnice (1685.), no ne i njezino ime zbog čega nam je njezin

\footnotetext{
${ }^{149}$ Usp. Ivan Kukuljević Sakcinski, nav. dj., 1856., str. 2; Ivan Krstitelj Tkalčić, nav. dj., 1885., str. 62-63. Vidi i: Milan Pelc, nav. dj., 2010., str. 66.

${ }^{150}$ Puni natpis glasio je: »HIC IACET GENEROSE DNA ELISABETH / FILIA MAGNIFICI VALENTINI COMITIS / ZAGRABIENSIS, OBIIT ANNO MCC.« Citirano u: Ivan Kukuljević Sakcinski, nav. dj., 1856., str. 24; Ivan Krstitelj Tkalčić, nav. dj., 1885., str. 62.

${ }^{151}$ Ivan Krstitelj Tkalčić, nav. dj., 1885., str. 63, bilj. 1.

152 Zagreb, Strossmayerova galerija starih majstora, inv. br. 1518. Usp. Artur Schneider, Popisivanje $i$ fotografijsko snimanje umjetničkih spomenika godine 1939., u: Ljetopis Jugoslavenske akademije znanosti $i$ umjetnosti za godinu 1938/39. Svezak 52, Zagreb: Jugoslavenska akademija znanosti i umjetnosti, 1940., str. 172-186, 174; Anđela Horvat, nav. dj., 1975., str. 350, 352.
} 
identitet nepoznat. Nadgrobna ploča rustičnije je obrade, poput nadgrobne ploče župnika Matije iz Granešine (Slika 20), no za razliku od linearnih i shematiziranih nabora na granešinskom spomeniku, način oblikovanja draperije na nadgrobnoj ploči iz Bresta Pokupskoga otkriva klesara razvijenijega osjećaja za volumen.

$\mathrm{U}$ ranome novom vijeku pojavila se nova vrsta nadgrobnika povezana s posvetom spomenika odnosno odrednicom za koga se spomenici podižu, a to su dječji nadgrobnici. Njihov nastanak proizašao je iz humanističkoga poimanja pojedinca kao neponovljive jedinke, ali i rastuće važnosti obitelji i pripadanju istoj. (Jedna od popratnih pojava potonjega je rastuća primjena nadgrobnika s obiteljskim grbom, o čemu će biti riječ u jednom od narednih potpoglavlja.) Više nije bilo potrebno činiti velika, herojska djela kako bi se živjelo u mislima ljudi. Za to je bila dostatna ljubav obitelji - ona roditelja, braće ili supružnika. ${ }^{153}$

Na području Zagrebačke (nad)biskupije sačuvana su dva dječja gisanta. Riječ je o nadgrobnicima Gottharda von Schrattenbacha $(† 1608 \text {.) (Slika 33 })^{154}$ iz Koprivnice i Marije Ane Weikhard (†1648.) (Slika 34) ${ }^{155}$ iz Poljane u Ivanić-Gradu. Općenito, djeca plemićkih obitelji pokapana su u obiteljskim grobnicama uz svoje najbliže i nisu imala zasebne nadgrobne spomenike. Poznat je primjer Nikole Frankapana Tržačkoga (†1660.), sina jedinca prethodno navedenoga Jurja IV., čiji su posmrtni ostaci preneseni iz Brežica dvije godine nakon njegove smrti i položeni u obiteljsku grobnicu u crkvi sv. Katarine u Zagrebu kako bi mogao počivati uz tijelo svojega netom preminuloga oca. ${ }^{156}$ Iz navedenoga razloga dječji nadgrobni spomenici predstavljaju pravu rijetkost. Čak i na području susjedne Slovenije, gdje su nadgrobni spomenici očuvani u znatno većem broju nego na području Hrvatske, ${ }^{157}$ sačuvano je svega nekoliko dječjih nadgrobnika. ${ }^{158}$ Postojanje navedenih dviju ploča Marijana Schneider (1972.) objasnila je činjenicom da su Gotthard von Schrattenbach i Marija Ana Weikhard bili djeca štajerskih časnika koji su služili u gradovima Vojne krajine Koprivnici i Ivanić-Gradu. Prema njezinome mišljenju, brzo smjenjivanje časnika - a moguće

\footnotetext{
${ }^{153}$ Usp. Philippe Ariès, nav. dj.,1981., str. 230-231.

${ }^{154}$ Kamen pješčenjak, $100 \times 61 \mathrm{~cm}$, Koprivnica, župni dvor, izvorno u crkvi sv. Nikole. Kat. br. 53.

${ }^{155}$ Kamen, $128 \times 77 \mathrm{~cm}$, Poljana, kapela sv. Jakova. Kat. br. 78 .

156 Usp. Miroslav Vanino, Isusovci i hrvatski narod I: Rad u XVI stoljeću, Zagrebački kolegij, Zagreb: Filozofsko-teološki institut Družbe Isusove u Zagrebu, 1969., str. 460.

${ }^{157}$ Istraživači objašnjavaju ovu pojavu činjenicom da se protestantizam jače ukorijenio na slovenskim nego na hrvatskim prostorima. Optužbe protestanata o idolatrijskim prikazima svetaca imale su restriktivan utjecaj na produkciju liturgijskih likovnih djela, stoga su u XVI. i XVII. stoljeća najčešće naručivani upravo nadgrobni spomenici. Usp. Emilijan Cevc, Renesančna plastika na Slovenskem, u: Zbornik za umetnostno zgodovino, Nova vrsta VII, Ljubljana: Umetnostnozgodovinsko društvo SR Slovenije, 1965., str. 119-170, 122, 146.

${ }^{158}$ Među dječjim nadgrobnicima na području Slovenije sačuvane su nadgrobne ploče Nikole Platzera (†1613.) i Filipa Jakova Platzera (†1621.) iz župne crkvi sv. Vida u Glini, nadgrobnik Aleksija Peverella (†1613.) izložen u lapidariju crkve Marije Pomoćnice u Ljubljani i epitaf Andreja von Burgstala (o. 1623.) koji se nekoć nalazio u kapeli sv. Ane u Krupi ob Kolpi, a danas je smješten u crkvi sv. Martina u Metliki. Usp. Emilijan Cevc, nav. dj., 1981., str. 205, 256.
} 


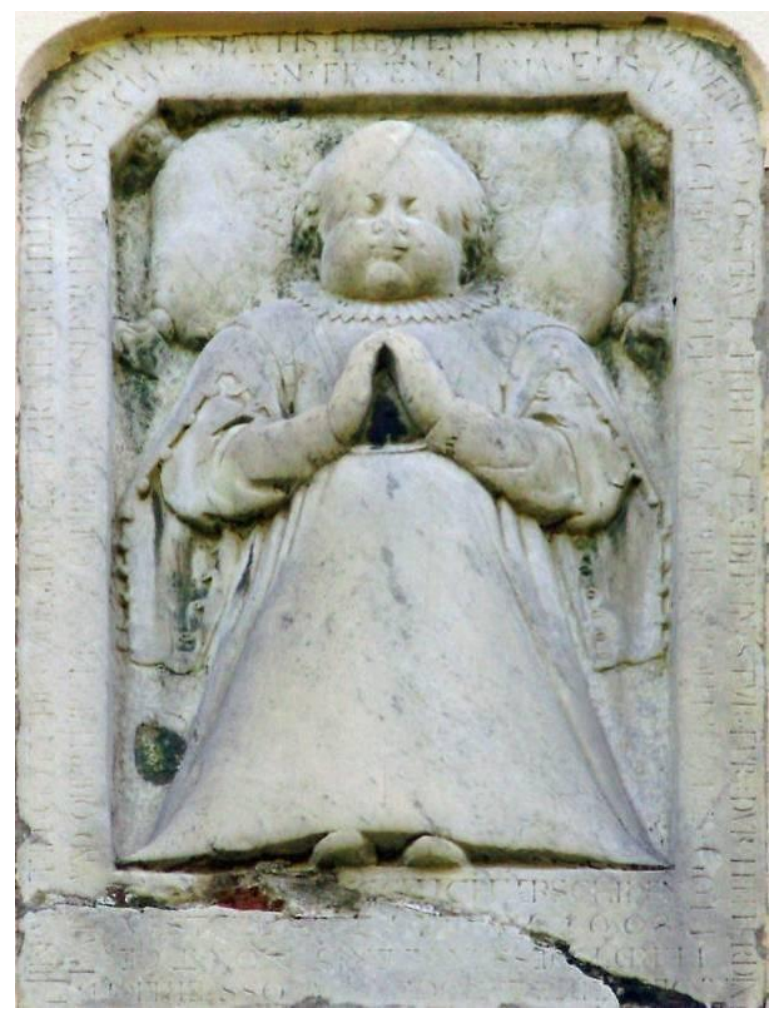

Slika 33. Nadgrobna ploča Gottharda von Schrattenbacha (†1608.), Koprivnica, župni dvor

(desno) Slika 34. Nadgrobna ploča Marije Ane Weikhardt (†1648.), Poljana, Ivanić-Grad, kapela sv. Jakova Starijega

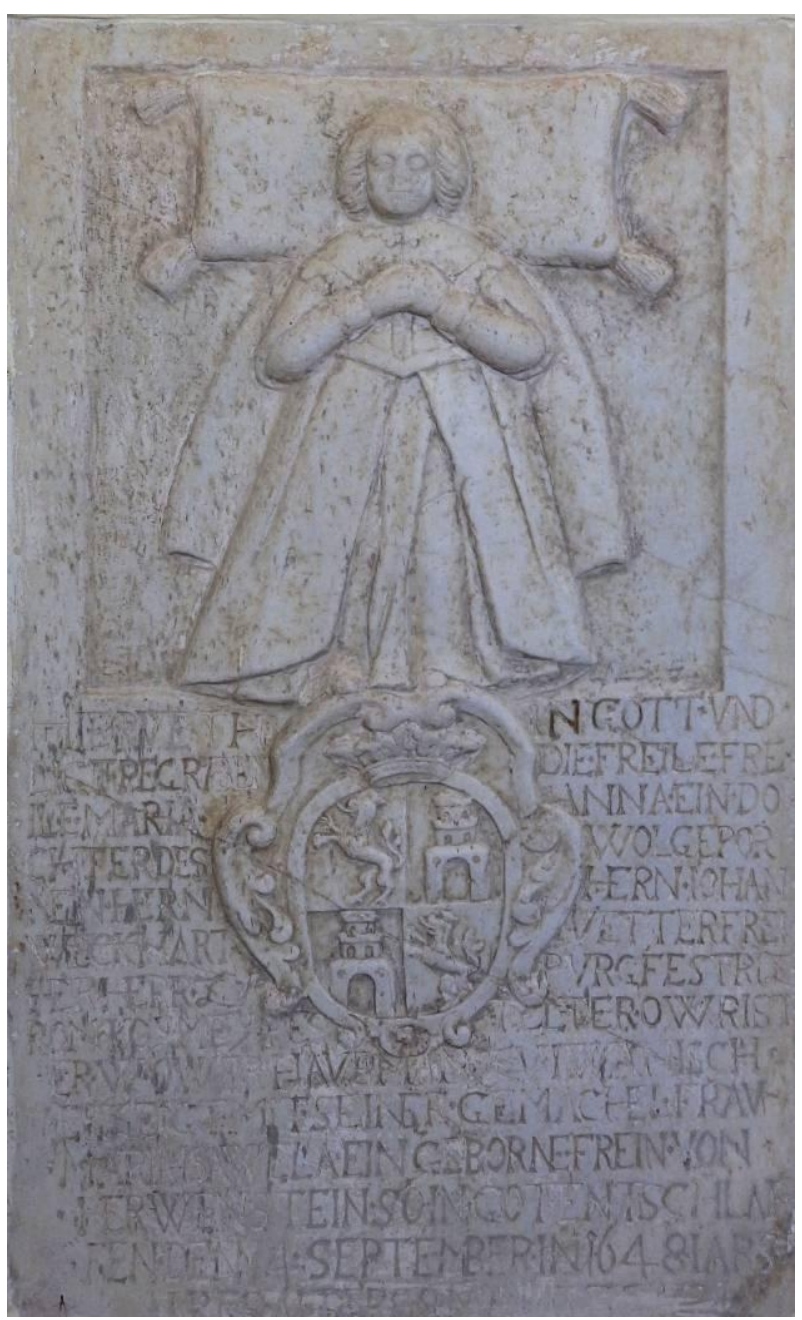

i njihovo strano podrijetlo - »nije [im] dozvoljavalo da stvaraju obiteljske grobnice daleko od svojih stalnih prebivališta«, stoga su bili prisiljeni pokopati svoju djecu u mjestu u kojem su trenutno boravili. ${ }^{159}$

Nadgrobna ploča Gottharda von Schrattenbacha $(\dagger 1608$.) (Slika 33) uzidana je u zapadno pročelje župnoga dvora u Koprivnici, u visini prvoga kata. Prema natpisu, Gotthard je bio sin baruna Heggenberga i Ossterwitza Felixa von Schrattenbacha, člana Dvorskoga ratnog vijeća i pukovnika koji je u Koprivnici obnašao dužnost velikoga kapetana, i Marije Elizabete rođ. Egg. Preminuo je kao dojenče staro svega pet mjeseci. Na nadgrobnoj ploči prikazan je kao dječak punih obraščića i kratke kose. Glava mu je položena na jastuk ukrašen ornamentom i resama, a ruke su mu sklopljene u molitvi na prsima. Odjeven je u haljinu zvonolika oblika ispod koje nosi košulju s nabranim ovratnikom i čipkastim orukvicama, a povrh nje gornju haljinu s razrezanim rukavima na kopčanje. ${ }^{160}$ Najvjerojatnije je bio pokopan

\footnotetext{
${ }^{159}$ Marijana Schneider, nav. dj., 1972., str. 182.

${ }^{160}$ O detaljnijem opisu odjeće vidi: Marijana Schneider, nav. dj., 1972., str. 184-185.
} 
u franjevačkoj samostanskoj crkvi, koja je nakon odlaska franjevaca iz Koprivnice 1613. godine postala župnom crkvom. ${ }^{161} \mathrm{U}$ kanonskoj vizitaciji iz 1716. godine navedeno je da se u predvorju crkve u kapeli sv. Josipa nalazi mala grobnica. ${ }^{162}$ Moguće je da je na njezin otvor bila položena upravo nadgrobna ploča Gottharda von Schrattenbacha. Nadgrobnik je najvjerojatnije odstranjen tijekom jedne od višebrojnih obnova crkve prilikom kojih je mijenjan pod u svetištu i brodu (1746., 1756., 1778.). ${ }^{163}$ Godine 1778. Koprivnicu je zahvatio veliki potres koji je oštetio stari župni dvor građen kanatnom gradnjom i pleterom omazanim blatom. ${ }^{164}$ Sljedeće godine (1779.) na njegovom je mjestu podignut novi zidani dvor, u čije je zapadno pročelje ugrađena izvađena Schrattenbachova ploča.

Nadgrobna ploča Marije Ane Weikhard (†1648.) (Slika 34) nalazi se u grobljanskoj kapeli sv. Jakova Starijega u Poljani, u Ivanić-Gradu. U toj kapeli pokapali su se strani vojnici smješteni u ivanićkom garnizonu. ${ }^{165}$ Marija Ana bila je kći štajerskog grofa i ivanićkoga velikog kapetana Johanna Weikharda Vettera, koji je 1653. godine primio grofovsku titulu von der Lilien, i Marije Izabele rođ. Herberstein. Poput Gottharda von Schrattenbacha, preminula je kao dojenče u starosti od osam mjeseci. Na nadgrobnoj ploči prikazana je u ležećem položaju, glave oslonjene na jastuk i ruku sklopljenih na prsima. Odjevena je u košulju s čipkastim orukvicama i širokim ovratnikom obrubljenim čipkom povrh koje nosi donju haljinu prorezanih dugih rukava i gornju haljinu prorezane prednjice. ${ }^{166} \mathrm{Na}$ glavi nosi kapu koja pokriva pramenove guste kose začešljane prema tjemenu. Podno pokojničinih nogu nalazi se obiteljski grb okružen nadgrobnim natpisom. Zanimljivo je da su na grbu prikazani samo simboli majčine obitelji, roda Herberstein - vuk u skoku i kula s kruništem. ${ }^{167}$ Ploča se

\footnotetext{
${ }^{161}$ Koprivnička crkva nekoliko je puta naizmjence služila kao franjevačka odnosno župna crkva. Nakon što su franjevci prvi put napustili grad zbog osmanske opasnosti (oko 1561.), samostanska crkva postala je župnom i posvećena je Blaženoj Djevici Mariji (1575.). Početkom XVII. stoljeća franjevci su se nakratko vratili u grad (1603. - 1613.) prilikom čega su preuzeli svoju staru crkvu i samostan. Nakon njihova drugoga odlaska, samostanska crkva ponovno je postala župnom. Vrativši se u grad i po treći put (oko 1640.), franjevci su još jednom pokušali vratiti svoj posjed od gradskih vlasti, no bez uspjeha. Naposljetku su odlučili izgraditi novi samostan i crkvu koje su podigli između 1675. i 1685. godine. Usp. Ivy Lentić-Kugli, Kronologija i građa za povijest sakralnih objekata u Koprivnici, u: Koprivnica: grad i spomenici, Zagreb: Odjel za povijest umjetnosti Centra za povijesne znanosti Sveučilišta u Zagrebu, 1986., str. 214-225, 217.

${ }^{162}$ Usp. Rudolf Horvat, Koprivničke crkve i kapele, u: Hrvatska prošlost, Knj. 4., Zagreb: Kulturno-historijsko društvo »Hrvatski rodoljub«, 1943., str. 3-150, 33-34. Uredio Rudolf Horvat; Ivy Lentić-Kugli, nav. dj., 1986., str. 218; Nadbiskupijski arhiv u Zagrebu (dalje NAZ), Kanonske vizitacije (dalje KV), Prot. 178/II (1716.), str. 104.

${ }^{163}$ Usp. Rudolf Horvat, nav. dj., 1943., str. 37-38; Ivy Lentić-Kugli, nav. dj., 1986., str. 218-219; NAZ, KV, Prot. 96/VIII (1746., 1756.), str. 79, 317; Prot. 97/IX (1778.), str. 213.

${ }^{164}$ Stari dvor podignuo je župnik Nikola Poderković 1657. godine. Usp. Ivy Lentić-Kugli, nav. dj., 1986., str. 217, 219.

${ }^{165}$ Usp. Andrija Lukinović, Župa Ivanić-grad, Zagreb: Glas Koncila, 2007., str. 134.

${ }^{166}$ O detaljnijem opisu odjeće vidi: Marijana Schneider, nav. dj., 1972., str. 185.

${ }^{167}$ Usp. Ivan von Bojničić, Der Adel von Kroatien und Slavonien, Nürnberg: Verlag von Bauer und Raspe, 1889., str. 61-62, tab. 45.
} 
u staroj, drvenoj kapeli izvorno nalazila u svetištu, no kada je sredinom XIX. stoljeća stara kapela porušena i sagrađena nova, ploča je premještena i ugrađena u sjeverni zid broda, ${ }^{168}$ gdje se nalazi i danas.

\subsubsection{VITEŠKE NADGROBNE PLOČE I EPITAFI}

Usporedno s nadgrobnim pločama crkvenih dostojanstvenika i plemkinja, na području povijesne Zagrebačke biskupije naručivali su se nadgrobnici s figuralnim prikazom vitezapokojnika. Osobito omiljeni među muškim pripadnicima plemstva, viteški nadgrobnici sadržavaju lik pokojnika koji je odjeven u oklop, a u rukama drži oružje i/ili barjak. Uspjesi i dostignuća preminuloga zabilježena su u nadgrobnom natpisu, a jedan od neizostavnih elemenata je grb koji, kao dokaz plemenitoga podrijetla, ukazuje na pokojnikovu pripadnost obitelji, rodu i društvenome sloju. Isticanje insignija i pokojnikovih zasluga imali su ulogu heroizacije i glorifikacije preminuloga, odražavajući humanistički svjetonazor usredotočen na ovozemaljski život pojedinca i svjetovnu moć. ${ }^{169}$

Figuralni prikaz viteza-pokojnika primjenjivao se na nadgrobnicima zagrebačke (nad)biskupije od XIII. do XVIII. stoljeća. Viteške nadgrobne ploče pretežito su se upotrebljavale do sredine XVII. stoljeća kada su ih postupno zamijenili epitafi istoga likovnog rješenja. Najstariji dokumentirani, no na žalost ne i očuvani, primjer viteškoga nadgrobnika je trinaestostoljetna nadgrobna ploča slavonskoga hercega Kolomana (?, 1208. - Čazma, 1241.). Nakon što je podlegao ranama zadobivenima u bitci protiv Tatara, Koloman je pokopan u nekadašnjoj dominikanskoj, danas župnoj crkvi sv. Marije Magdalene u Čazmi, gradu koji je namjeravao pretvoriti u novu prijestolnicu ujedinjenoga kraljevstva Slavonije, Hrvatske, Dalmacije i Bosne. ${ }^{170}$ Iznad njegovoga groba postavljena je crvena mramorna ploča koja je, prema opisu Ivana Kukuljevića Sakcinskoga (1891.), sadržavala »poprsje viteza u oklopu s kacigom i krunom «. ${ }^{171}$ Nadgrobna je ploča pronađena 1859. godine, no sredinom šezdesetih

\footnotetext{
${ }^{168}$ Usp. Andrija Lukinović, nav. dj., 2007., str. 130, 133-134; NAZ, KV, Prot. 108/IV (1758.), str. 123.

${ }^{169}$ Usp. Emilijan Cevc, nav. dj., 1981., str. 102; Anđela Horvat, nav. dj., 1975., str. 350; Ljubo Karaman, nav. dj., 1950., str. 167.

${ }^{170}$ Usp. Vladimir Peter Goss, Herceg Koloman i umjetnost hrvatskoga prostora, u: Prilozi povijesti umjetnosti u Dalmaciji XLV/1, Split: Književni krug Split, Konzervatorski odjel u Splitu, 2019., str. 129-143, 131.

${ }^{171}$ Ivan Kukuljević Sakcinski, nav. dj., 1981., str. 30, br. 101. Isti opis donosi i: Milan Pelc, nav. dj., 2010., str. 63-64. Pelc pretpostavlja da je Kolomanova nadgrobna ploča sadržavala puni lik pokojnika jer se nadgrobnici s prikazom pokojnika do razine pojasa javljaju tek stotinjak godina kasnije. Manjkavost Kukuljevićeva opisa autor objašnjava fragmentarnom očuvanošću Kolomanove nadgrobne ploče.
} 
godina istoga stoljeća razlomljena je na nekoliko dijelova, a njezini su ulomci ugrađeni u zidnu masu župnoga dvora i sakristije. ${ }^{172}$

Na području povijesne Zagrebačke biskupije nije sačuvan nijedan viteški nadgrobnik koji datira iz XV. stoljeća, no o njihovoj primjeni svjedoče pisani izvori. Ivan Kukuljević Sakcinski (1891.) zabilježio je da je u Podborju (današnji Gornji Daruvar) među ruševinama nekadašnje benediktinske opatije sv. Jelene iskopan nadgrobnik s likom viteza. ${ }^{173}$ Prema Kukuljevićevu prijepisu natpisa, nadgrobnik je podignut u spomen na Stjepana Codharyja (Roha?) de Deche koji je preminuo 1462. godine. ${ }^{174}$ Viteški nadgrobnici upotrebljavali su se u XV. stoljeću i na hrvatskim prostorima koji nisu bili u sastavu tadašnje Zagrebačke biskupije o čemu svjedoče, primjerice, nadgrobnik Nikole V. Iločkoga (†1477.) iz franjevačke crkve sv. Ivana Kapistrana u Iloku (Slika 12) ili nadgrobna ploča Janka Albertija (†1493.) iz splitske prvostolnice.

Najraniji očuvani primjer viteškoga nadgrobnika podignutoga unutar granica Zagrebačke (nad)biskupije je nadgrobna ploča Ivaniša Korvina (Wrocław, Poljska, 1473. Krapina, 1504.) (Slika 35), ${ }^{175}$ slavonskoga hercega, hrvatsko-dalmatinsko-slavonskoga bana (1495. - 1498., 1499. - 1504.) i nezakonitoga sina hrvatsko-ugarskoga kralja Matije Korvina. Svojevremeno jedan od najmoćnijih i najbogatijih plemića Hrvatsko-Ugarskoga Kraljevstva, Ivaniš je preminuo od groznice koju je zadobio na bojnom polju te je, prema vlastitoj želji, sahranjen u nekadašnjoj pavlinskoj crkvi u Lepoglavi. Pokopan je u svetištu crkve, a njegov prijatelj Ivan Gyulay, slavonski banovac, dao je iznad groba postaviti nadgrobnu ploču s Ivaniševim likom (1505.). ${ }^{176}$ Samo pet mjeseci nakon Ivaniševe smrti, u istu je grobnicu

\footnotetext{
${ }^{172}$ Usp. Maja Cepetić, Biskupski posjedi Dubrava, Ivanić i Čazma u 12. i 13. stoljeću: teritorijalna organizacija, naselja i spomenici, doktorski rad, Zagreb: Filozofski fakultet Sveučilišta u Zagrebu, 2015., 308-310. U Gradskome muzeju Čazma pohranjen je ulomak glave ratnika za koji se pretpostavlja da je nekoć bio dio Kolomanove nadgrobne ploče. Zbog fragmentarne očuvanosti ulomka i nedostatka drugih, teško je ustvrditi je li uistinu riječ o dijelu Kolomanove grobnice. Zahvaljujem ravnateljici muzeja Jadranki Kruljac Sever i kustosici dr. sc. Maji Cepetić Rogić na njihovoj usrdnoj pomoći prilikom istraživanja i ustupljenim informacijama o nadgrobnicima s čazmanskoga područja.

${ }^{173}$ Usp. Ivan Kukuljević Sakcinski, nav. dj., 1891., str. 113, br. 376.

${ }^{174}$ Obitelj Roh de Decse imala je brojne posjede u Moslavini, između rijeka Česme i Save, te u gradu Kutini. Smrću posljednjega muškog člana Bernarda Roha $(† 1495$.) svi su obiteljski posjedi oporučno pripali upravitelju zagrebačke biskupije Tomi Bakaču (Ardud, Rumunjska, 1435. - Ostrogon, 1521.). Usp. Josip Buturac, Kutina: uz 200. obljetnicu župne crkve, Zagreb: Kršćanska današnjost, 1977., str. 21-22; Tamás Pálosfalvi, The noble elite in the county of Körös (Križevci) 1400 - 1526, doktorski rad, Budimpešta: MTA Bölcsészettudományi Kutatóközpont Történettudományi Intézet, 2012., str. 222.

${ }^{175}$ Kamen, $190 \times 79 \times 4$ cm, Lepoglava, crkva Bezgrješnog začeća Blažene Djevice Marije. Kat. br. 54 .

${ }^{176}$ Izuzev ploče s likom pokojnika, Ivan Gyulay postavio je i ploču s natpisom koja je s vremenom uništena. Prema povijesnim izvorima natpis na njoj je glasio: »HAEC TENET ARCTA DVCEM TVMBA IOANNEM, / MATHIAE QVI STIRPS INCLYTA REGIS ERAT / STRNVVS HIC ARMIS, PARTAQVE MVNDO TRIUMPHA / PLVRIMA POST VICTOR, DIEM CLAVSIT EXTREMVM / ANNO CHRISTI TERQVINGENTESIMO QVARTO / DIE OCTOBRIS 12. IOANNES DE GYULA FIERI FECIT / 1505.« Usp. Liber Memorabilium Parochiae Lepoglavensis ab Anno 1401 usque 1789. ${ }^{\text {um }}$ (dalje Lib. Mem.), Arhiv
} 
položeno tijelo njegovoga šestogodišnjeg sina jedinca Kristofora $\left(\dagger 1504\right.$.). ${ }^{177}$ Reljefni prikaz na Ivaniševu nadgrobniku već je početkom XIX. stoljeća bio prilično istrošen, stoga je 1824 . godine, na inicijativu grofa Ivana Nepomuka Esterházyja, ploča podignuta s poda i ugrađena u sjeverni zid svetišta, ${ }^{178}$ gdje se nalazi i danas. Na njoj, pokojnik je prikazan u blago raskoračenom stavu koji asocira na kontrapost. U potpunosti je odjeven u viteški oklop, a na glavi nosi kacigu. S mačem opasanim oko struka, u desnoj ruci drži barjak platna omotana oko stijega, a u lijevoj štit sa simbolom obitelji Korvin, vranom koja u kljunu drži prsten. Motiv na štitu danas više nije vidljiv zbog istrošenosti ploče, no njegov je izgled poznat na osnovi crteža iz Spomenice lepoglavske župe. ${ }^{179}$ Svećenici i vjernici koji su stoljećima pohodili lepoglavsku crkvu svojim su stopalima istrošili i druge dijelove Ivaniševa nadgrobnika, stoga je teško raspravljati o detaljima ili kvaliteti izvedbe. No naznaka kontraposta, jednostavni profilirani okvir i pročišćenost forme daju spomeniku renesansne odlike.

Tip viteškoga nadgrobnika s likom pokojnika koji drži barjak koristio se u XVI. stoljeću diljem cijele Hrvatske - od Kvarnera, preko Hrvatskoga zagorja, do istočne Slavonije - što potvrđuju nadgrobne ploče Nikole VI. Frankopana Tržačkoga (†1523.) iz crkve Majke Božje Trsatske u Rijeci i hercega Lovre III. Iločkoga (†1524.), sina navedenoga Nikole V., koji je poput oca pokopan u iločkoj franjevačkoj crkvi. Ovome tipu pripada i nadgrobna ploča grofa Petra II. Erdődyja (?, o. 1504. - Jastrebarsko, 1567.) (Slika 36), ${ }^{180}$ hrvatskodalmatinsko-slavonskoga bana (1557. - 1567.) i savjetnika cara i kralja Maksimilijana II., koji je sahranjen u župnoj crkvi sv. Nikole u Jastrebarskom. Ploča se izvorno nalazila u

Hrvatske akademije znanosti i umjetnosti (dalje Arhiv HAZU), sign. IV. d. 77., fol. 1v; Kamilo Dočkal, nav. dj., 2014., str. 84; Ivan Kukuljević Sakcinski, nav. dj., 1891., str. 120-121, br. 406; Stjepan Ortner, Povjest gradine i trgovišta Krapine, Zagreb: Slob. kr. povelj. trgovište Krapina, 1899., str. 40; Gjuro Szabo, nav. dj., 1919., str. 35.

${ }^{177} \mathrm{U}$ blizini grobnice postavljena je ploča s natpisom koji komemorira mladoga Kristofora: »HIC JACET EXSTINCTVS CRVDELI MORTE IOANNIS / CORVINI NATVS, PRINCIPIS EGREGII, / CHRISTOPHORVS PRINCEPS, CVI NONDVM VENERAT AETAS / MAIOR, SED PVER HIC SANCTIFICATVS OBIT. / CHARA PRECOR GENETRIX MANANTIA LVMINA FLETVM / COMPRIME, SIDEREVM SVSTINET VMBRA PLOVM.« Pavlinski redovnici u nekoliko su navrata mijenjali natpisne ploče položene u blizini Kristoforove i Ivaniševe grobnice (vidi prethodnu bilješku), razmjerno mijenjajući njihov sadržaj. Kada je 1824. godine Ivanišev nadgrobnik premješten na zid, načinjene su nove ploče s natpisom koje su ugrađene u zidnu masu iznad Ivaniševe grobnice. Usp. Kamilo Dočkal, nav. dj., 2014., str. 85-86.

${ }^{178}$ Grobnica Ivaniša Korvina prvi je puta otvorena već 1650. godine te kasnije 1824., 1880. i 1886. godine. Kada je grobnica otvorena 1886. godine, posmrtni ostaci Ivaniša i Kristofora Korvina izvađeni su i preneseni u Arheološki muzej u Zagrebu, gdje su pohranjeni u stakleni lijes. Usp. Lib. Mem., Arhiv HAZU, sign. IV. d. 77., fol. 1v; Kamilo Dočkal, nav. dj., 2014., str. 85-86; Ivo Lentić, Pavlinski samostan i crkva sv. Marije u doba baroka, u: Kaj: časopis za kulturu i prosvjetu XV/5, Zagreb: Kajkavsko spravišče, 1982., str. 36-63, 54; Stjepan Ortner, nav. dj., 1899., str. 47; Gjuro Szabo, nav. dj., 1919., str. 35; Gjuro Szabo, nav. dj., 1939., str. 101.

${ }^{179}$ Usp. Lib. Mem., Arhiv HAZU, sign. IV. d. 77., fol. 1v.

${ }^{180}$ Kamen, $222 \times 90$ cm, Jastrebarsko, crkva sv. Nikole. Kat. br. 4. 


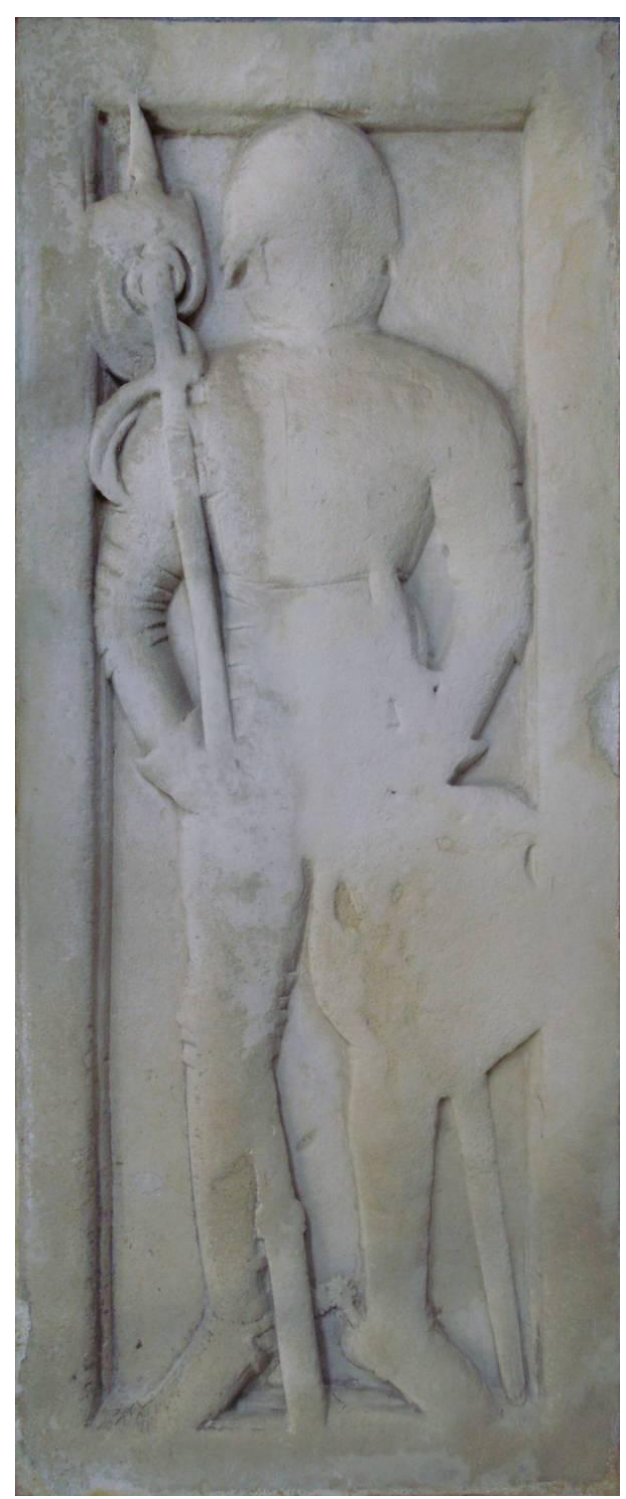

Slika 35. Nadgrobna ploča Ivaniša Korvina, 1505., Lepoglava, crkva Bezgrješnoga začeća Blažene Djevice Marije

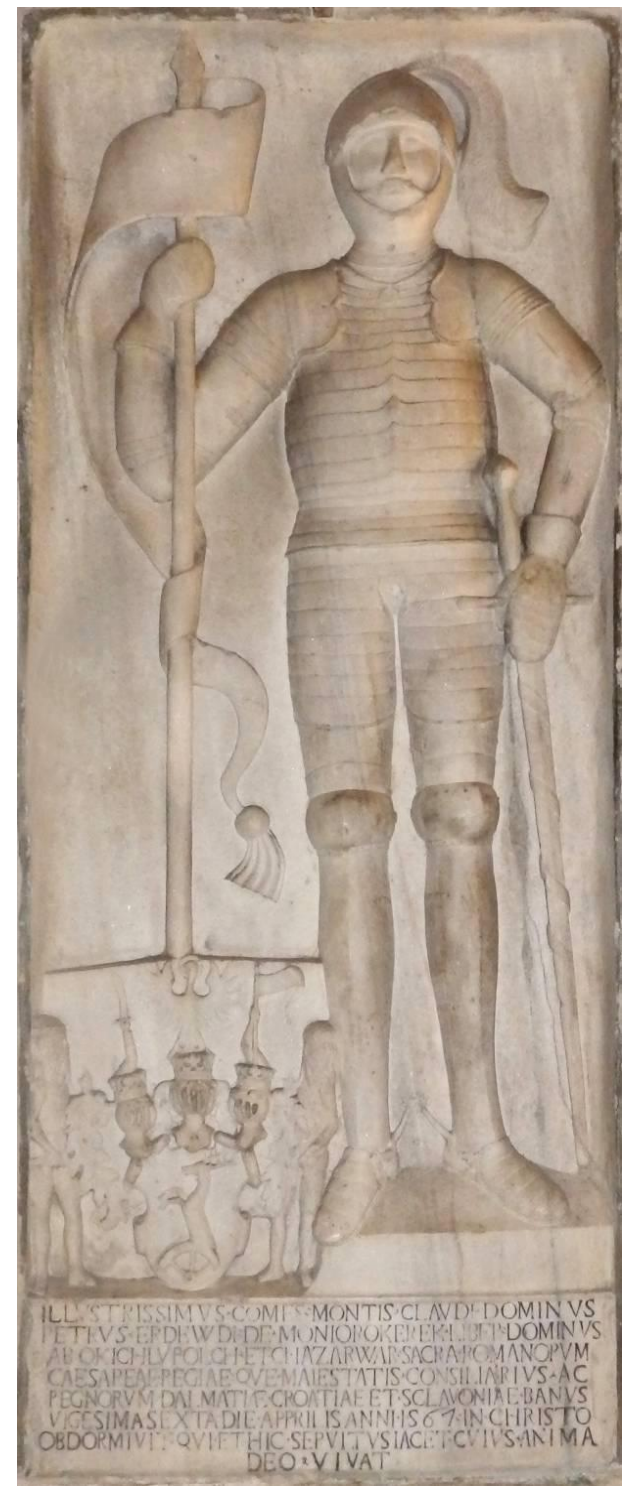

Slika 36. Nadgrobna ploča Petra II. Erdödyja (†1567.), Jastrebarsko, crkva sv. Nikole

prebendarskoj kapeli sv. Petra koju je pokojnik podignuo s južne strane svetišta 1561. godine. ${ }^{181}$ Prilikom izgradnje nove župne crkve (1771. - 1776.), kapela je porušena, a nadgrobnik je ugrađen u južni zid broda uz oltar sv. Roka smještenoga najbliže svetištu i

\footnotetext{
${ }^{181}$ Usp. NAZ, KV, Prot. 122/V (1765.), str. 138; Neven Brandić, Sakralna graditeljska baština Jastrebarskog $i$ okolice, u: Jastrebarsko: 1249. - 1999.: 750 godina grada, Jastrebarsko: Naklada Slap, Gradsko poglavarstvo, 2001., str. 225-278, 230, 241. Uredili Filip Potrebica i Krunoslav Matešić; Emilij Laszowski, Grobnica bana Petra Erdöda u Jastrebarskom, u: Novosti XX/35, Zagreb: [Jugoslavenska štampa], 1926., str. 11; Radoslav Lopašić, Jastrebarsko, u: Vienac: zabavi i pouci XIII/23, Zagreb: Matica hrvatska, 4. VI. 1881., str. 358-361, 360; Dragutin Nežić, Povijest župa i crkvi Jastrebarskog dekanata, Jastrebarsko: Odbor za euharistijski kongres, 1939., str. 9.
} 
ožbukan. Gotovo sto pedeset godina ostao je zakriven slojevima žbuke sve dok nije pronađen 1921. godine prilikom obnove unutrašnjosti crkve. ${ }^{182}$

Likovno rješenje nadgrobne ploče Petra II. Erdődyja nalik je onome nadgrobniku Ivaniša Korvina. Prikazan u stojećem stavu, pokojnik je odjeven u viteški oklop i kacigu s perjanicom. U desnoj ruci drži barjak, a lijevom pridržava mač koji mu visi o boku. Iako su likovno-ikonografskim rješenjem srodni, navedeni se nadgrobnici razlikuju u određenim segmentima. Najuočljiviji je disproporcionalno oblikovano tijelo Petra II. Erdődyja koje u svojoj izduženosti odstupa od klasičnoga kanona. Nadalje, na Petrovoj nadgrobnoj ploči pokojnik drži barjak gotovo pri vrhu koplja zbog čega je njegova ruka izbačena u odnosu na ostatak tijela, odnosno nije položena uz trup kao na Ivaniševu nadgrobniku. Promjenom položaja ruke, figura pokojnika pomaknuta je iz središnje osi prema rubu čineći središte kompozicije sadržajno praznim. U opisanom decentriranju središnjega motiva preminuloga i njegovim izduženim proporcijama, Anđela Horvat (1975.) prepoznala je maniristička obilježja, ${ }^{183}$ no umjetničko htijenje ne možemo posve s razumijevanjem iščitati niti razlučiti zbog skromnije kiparske vještine. Treća stavka po kojoj su Petrov i Ivanišev nadgrobnik drugačiji je obiteljski grb. Reduciran na osnovni element - simbol obitelji - grb na Ivaniševoj nadgrobnoj ploči neupadljivo je ukomponiran u prikaz kao dio pokojnikova štita. Grbu obitelji Erdődy, s druge strane, oblikom je i smještajem pridana veća važnost. Urešen plaštem, kacigama, ukrasima i čuvarima, grb Erdődyjevih ${ }^{184}$ smješten je usporedno s figurom pokojnika i parira mu važnošću. Isticanje grbova na nadgrobnim spomenicima - bilo njihovom veličinom, smještajem ili formom - naglašavalo je pokojnikovu pripadnost određenoj obitelji, ukazujući na onodobne temelje ekonomije i društvenoga uređenja u kojima nije bio važan samo pojedinac nego cijela obitelj. ${ }^{185}$

Krajem XVI. stoljeća izrađen je još jedan spomenik koji pripada istom likovnom tipu kao nagrobnici Ivaniša Korvina i Petra II. Erdődyja. Riječ je nadgrobnoj ploči Gašpara I. Draškovića (?, 1530. - Trakošćan, 1591.) i njegove supruge Katarine rođ. Székely de

\footnotetext{
${ }^{182}$ Usp. Emilij Laszowski, nav. dj., 1926., str. 11; Dragutin Nežić, nav. dj., 1939., str. 10; Agneza Szabo, Grofovi Erdödy, u: Jastrebarsko: 1249. - 1999.: 750 godina grada, Jastrebarsko: Naklada Slap, Gradsko poglavarstvo, 2001., str. 315-323, 316. Uredili Filip Potrebica i Krunoslav Matešić; Agneza Szabo, Jastrebarska grana grofova Erdödy (Erdedi), u: Gazophylacium: časopis za znanost, umjetnost, gospodarstvo i politiku XIV/1-2, Zagreb: Pinta - Udruga za očuvanje, obnovu i korištenje kulturnog blaga Hrvatske, 2009., str. 99-11, 103.

${ }^{183}$ Usp. Anđela Horvat, nav. dj., 1975., str. 156.

${ }^{184}$ Grb se sastoji od štita s motivom jelena i kotača, koji je ukrašen plaštem i trima kacigama s nakitom i krunama. Iznad bočnih kaciga uzdižu se oklopljene ruke (lijeva drži mač, a desna barjak), a iznad središnje orao. Štit s obje strane pridržavaju čuvari - dvojica muškarca duge kose, brade i brkova. Usp. Ivan von Bojničić, nav. dj., 1889., str. 44, tab. 33.

${ }^{185^{5}}$ Usp. Emilijan Cevc, nav. dj., 1981., str. 48.
} 
Kevend (Ormož, 1535. - ?, 1587.) (Slika 37) ${ }^{186}$ koja se nalazi u župnoj crkvi sv. Marije Magdalene u Bednji. Stekavši barunski naslov (1567.) i brojne posjede uključujući Trakošćan, kraljevski kapetan i savjetnik Gašpar I. Drašković položio je temelj bogatstvu, ugledu i moći obitelji. Prema natpisu isklesanom uz rubove ploče, nadgrobnik su podigli Gašparovi i Katarinini sinovi Ivan II. (1550. - 1613.) i Petar Drašković (1555. - 1614.). Izvorno je bio položen na podu svetišta iznad obiteljske kripte, no prilikom obnove crkve 1786. godine podignut je i ugrađen u sjeverni zid svetišta, ${ }^{187}$ gdje je smješten danas.

Na ploči je u niskome reljefu isklesan lik sredovječnoga muškarca odjevena u haljetak, prsni oklop i kacigu s perjanicom. U desnoj ruci drži barjak s grbom obitelji Drašković ${ }^{188}$ koji se u punoj širini spomenika prostire iza pokojnikove glave, dajući dojam da vijori u slobodnom prostoru. Pokojnikova lijeva ruka počiva na balčaku sablje koja mu visi o boku. Unatoč ukočenoj impostaciji lika, skladnost proporcija njegova tijela, perspektivna skraćenja ruku, postupna gradacija reljefa kojom je postignut dojam dubine te vrh perjanice koji izlazi iz okvira figuralnoga prikaza i time ga negira daju spomeniku jasna renesansna obilježja te ukazuju na vješta kipara. O kvaliteti nadgrobnika svjedoči i materijal iz kojega je isklesan, a to je crveni mramor. Budući da su njegova nalazišta bila rijetka, a materijal skup, crveni se mramor koristio za izradu reprezentativnih narudžaba. ${ }^{189} \mathrm{Na}$ području Hrvatsko-Ugarskoga Kraljevstva vadio se u gorjima Mecsek sjeverno od Pečuha i Gerecse u blizini Ostrogona, ${ }^{190}$ stoga postoji mogućnost da je bednjanski nadgrobnik izrađen od pečuškoga ili ostrogonskoga mramora.

Slična likovna rješenja koja sadrže lik pokojnika odjevena u viteški oklop s barjakom u ruci primjenjivala su se u XVI. stoljeću na prostoru Slovenije, Austrije i nekadašnje Ugarske. U Sloveniji su očuvani radovi majstora G. S., poznatoga samo po inicijalima, koji je izradio više ovakvih nadgrobnika, a jedan od njih je nadgrobna ploča vrhovnoga kapetana Hrvatske i Slavonske krajine Ivana Lenkovića (? - Otočec kraj Novoga Mesta, 1569.) (Slika 38)

\footnotetext{
${ }^{186}$ Vapnenačka breča, $225 \times 109$ cm, Bednja, crkva sv. Marije Magdalene. Kat. br. 51.

187 Usp. Vjekoslav Noršić, Bednja, u: Tkalčić: godišnjak Društva za povjesnicu Zagrebačke nadbiskupije = annales Societatis historicae archiepiscopatus Zagrabiensis XIV, Zagreb: Društvo za povjesnicu Zagrebačke nadbiskupije »Tkalčić«, 2010.a, str. 195-240, 208. Rukopis priredio Stjepan Razum. U stručnoj literaturi može se pronaći podatak da je današnja crkva izgrađena ex novo 1822. godine nasuprot staroj koja je stradala u odronu zemlje. Gjuro Szabo (1919.) prvi je objavio taj podatak na osnovi natpisa iz 1862. godine koji je pohranjen u jabuci zvonika, a istraživači nakon njega većinom su ga preuzeli. Tezu o izgradnji nove crkve opovrgnuli su Vjekoslav Noršić (2010.) i Diana Vukičević-Samaržija (1993.). Usp. Gjuro Szabo, nav. dj., 1919., str. 69; Gjuro Szabo, nav. dj., 1939., str. 105; Diana Vukičević-Samaržija, Gotičke crkve Hrvatskog zagorja, Zagreb: Institut za povijest umjetnosti, 1993., str. 218.

${ }^{88}$ Grb se sastoji od štita s motivom krune iz koje izranja grifon koji u desnoj pandži drži kuglu. Usp. Ivan von Bojničić, nav. dj., 1889., str. 40, tab. 30.

${ }^{189}$ Usp. Milan Pelc, nav. dj., 2006., str. 70; Milan Pelc, nav. dj., 2009.a, str. 310.

${ }^{190}$ Usp. Zorislav Horvat, nav. dj., 1988., str. 42-68, 49, 54; Zorislav Horvat, nav. dj., 2005., str. 32; Milan Pelc, nav. dj., 2009.a, str. 310; Milan Pelc, nav. dj., 2009.b, str. 314.
} 


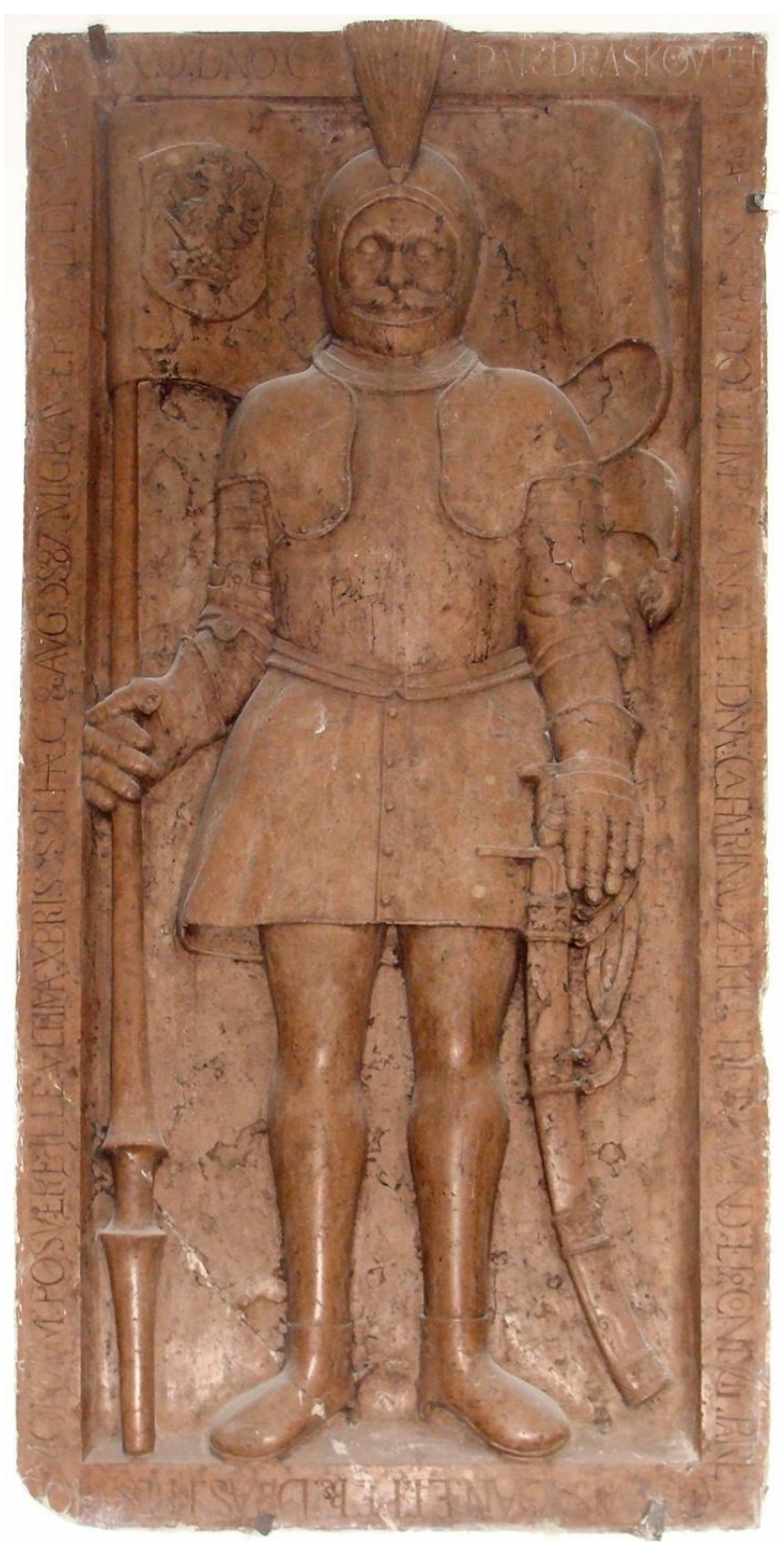

(gore lijevo) Slika 37. Nadgrobna ploča

Gašpara I. Draškovića i Katarine rođ. Székely de Kevend, nakon 1591., Bednja, crkva sv. Marije Magdalene

(gore desno) Slika 38. Majstor G. S., Nadgrobna ploča Ivana Lenkovića (†1569.), Novo Mesto, franjevački samostan sv. Leonarda

(dolje desno) Slika 39. Središnji dio epitafa Georga von Liechtensteina (†1548.), Beč, crkva sv. Mihaela
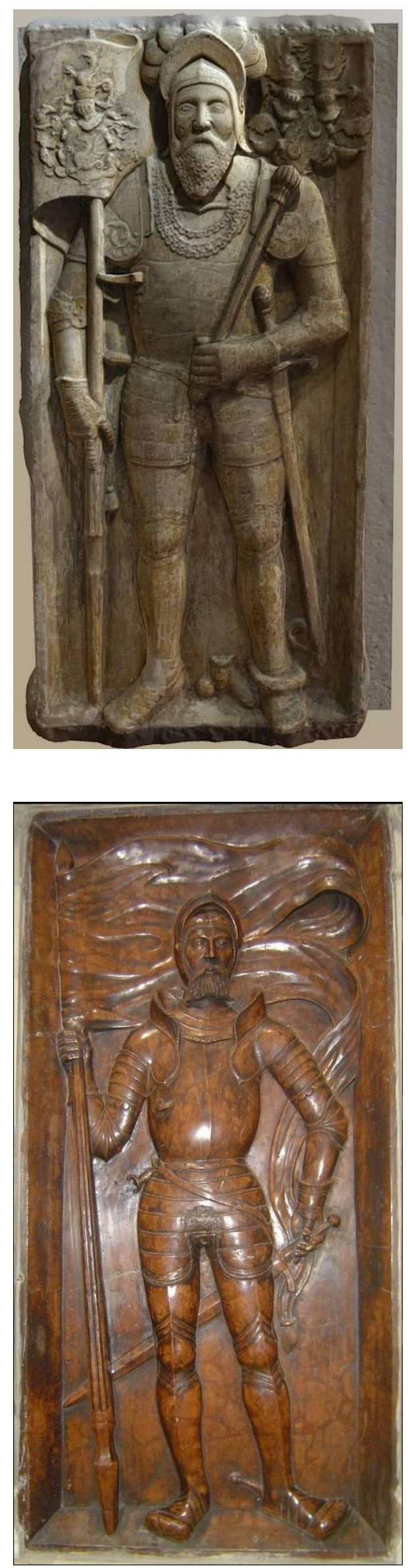
koji je pokopan u franjevačkoj samostanskoj crkvi u Novome Mestu, nedaleko svojih posjeda. ${ }^{191}$ Kao dodatne primjere nadgrobnika srodnoga likovnog rješenja no suverenije izvedbe navodimo nadgrobne ploče Georga von Calausa (†1595.) iz župne crkve sv. Jurja u Ptuju i Gašpara Serédyja (†1553.) iz župne crkve sv. Jurja u Svätom Juru (Slovačka, mađ. Szentgyörgy) te epitaf Georga von Liechtensteina (†1548.) iz crkve sv. Mihaela u Beču (Slika 39).

Usporedno s nadgrobnim pločama - uvjetno nazvanih - vitezova barjaktara, na području Zagrebačke (nad)biskupije u XVI. su se stoljeću primjenjivali viteški nadgrobnici s tradicionalnim rješenjem gisanta, ležeće figure pokojnika. Iz druge polovine XVI. stoljeća sačuvana su dva nadgrobnika koja pripadaju ovoj skupini, a to su nadgrobne ploče Franje Tahyja (?, 1526. - Susedgrad, 1573.) (Slika 40) ${ }^{192}$ i Petra II. Ratkaja Velikotaborskoga (? - ?, 1586.) (Slika 41). ${ }^{193}$

Franjo Tahy bio je vojni zapovjednik te kraljevski konjušnik i savjetnik cara i kralja Maksimilijana II. (Beč, 1527. - Regensburg, 1576.) čiji je spor oko vlasništva susedgradskostubičkoga vlastelinstva s Uršulom Mecknyczer doveo do izbijanja seljačke bune (1573.). Njegova nadgrobna ploča danas je pohranjena u Muzeju seljačkih buna u Gornjoj Stubici, no izvorno se nalazila iznad Tahyjeva groba u obiteljskoj kapeli prigrađenoj sa sjeverne strane svetišta crkve Presvetoga Trojstva u Donjoj Stubici. ${ }^{194}$ Barokizacijom crkve sredinom XVIII. stoljeća kapela je porušena, a ploča je ugrađena u zid između novopodignutoga sjevernoga bočnoga broda i svetišta. ${ }^{195}$ Prije Drugoga svjetskog rata nadgrobnik je ponovno izvađen i sklonjen u spremište zvonika jer su dvije seljanke navodno klečale pred njim i ljubile Tahyjev lik misleći da predstavlja sveca. ${ }^{196}$

\footnotetext{
${ }^{191}$ Detaljnije o slovenskim nadgrobnicima u: Emilijan Cevc, nav. dj., 1981., str. 84-104. Više o nadgrobnoj ploči Ivana Lenkovića u: Sena Sekulić Gvozdanović, Izgradnja, opis i analiza projekta obnove tvrđave Nehaju u Senju, u: Senjski zbornik: prilozi za geografiju, etnologiju, gospodarstvo, povijest i kulturu IV/1, Senj: Gradski muzej Senj, Senjsko muzejsko društvo, 1970., str. 241-261, 257, bilj. 8, 16.

${ }_{192}$ Mramor, gornja natpisna ploča $27 \times 86 \times 12$, ploča s likom pokojnika $183 \times 86 \times 12 \mathrm{~cm}$, donja natpisna ploča $26,5 \times 86 \times 12 \mathrm{~cm}$, Gornja Stubica, Muzej seljačkih buna, izvorno u crkvi Presvetoga Trojstva u Donjoj Stubici. Kat. br. 3 .

${ }^{193}$ Kamen, $232 \times 76$ cm, Desinić, crkva sv. Jurja. Kat. br. 1.

${ }^{194}$ Usp. NAZ, KV, Prot. 1/I (1620.), str. 160; Prot. 57/XIII (1745.), str. 16v; Katarina Horvat Levaj, Župna crkva Presvetog Trojstva u Donjoj Stubici, u: Peristil 38, Zagreb: Društvo povjesničara umjetnosti Hrvatske, 1995., str. 73-82, 76; Ivanka Reberski (ur.), Krapinsko-zagorska županija: sakralna arhitektura s inventarom, feudalna arhitektura, spomen-obilježja, Zagreb: Institut za povijest umjetnosti, Školska knjiga, 2008., sub voce Donja Stubica. Župna crkva Presvetog Trojstva, str. 155, 166 [Katarina Horvat Levaj].

${ }^{195}$ Usp. Katarina Horvat Levaj, nav. dj., 1995., str. 76.

${ }^{196}$ Usp. Marijana Schneider, nav. dj., 1973., str. 276. Ploča je 1955. godine otpremljena u Povijesni muzej u Zagrebu (sada Hrvatski povijesni muzej) za potrebe postavljanja izložbe. Nakon osnutka Muzeja seljačkih buna u dvorcu Oršić u Gornjoj Stubici (1973.), ploča je dopremljena u novoosnovani muzej i postavljena u stalni postav. Usp. Mirko Valentić i Lada Prister, nav. dj., 2002., str. 14.
} 


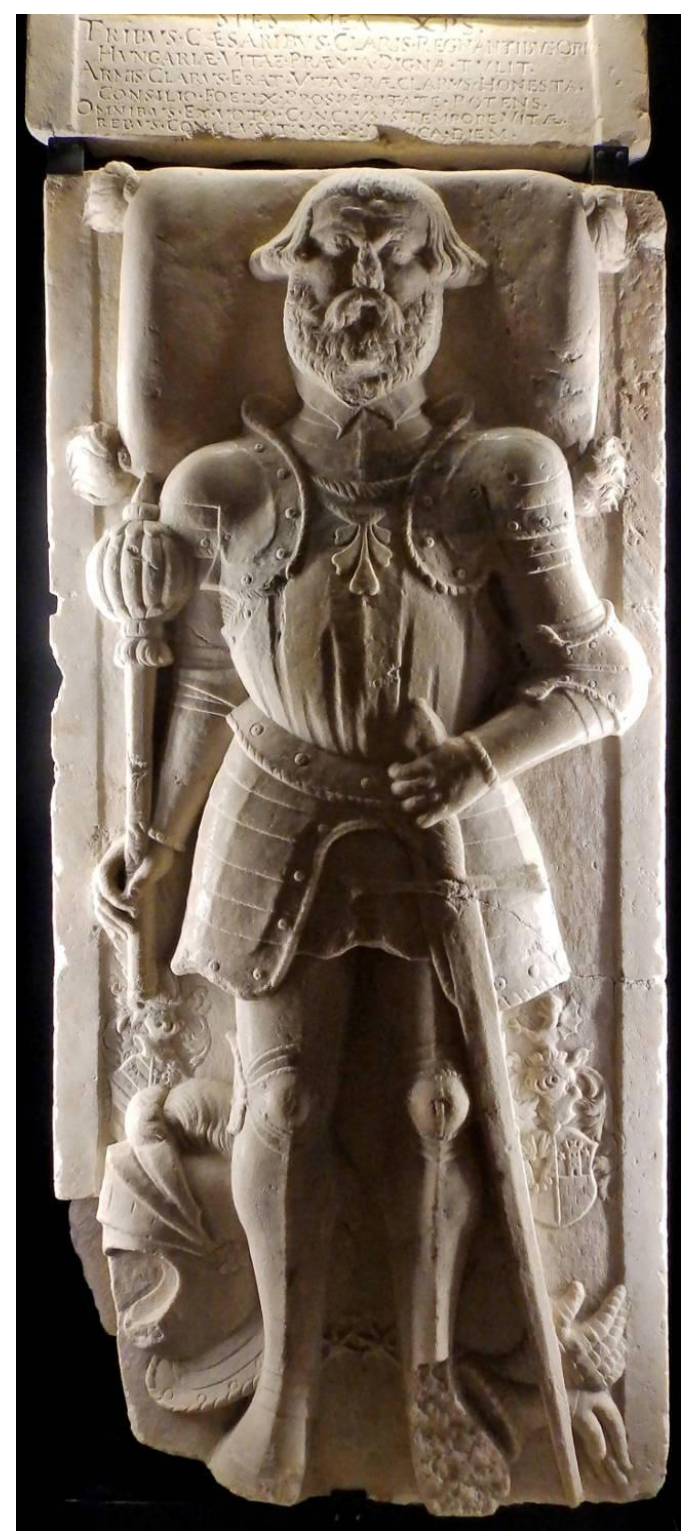

Slika 40. Nadgrobna ploča Franje Tahyja (†1573.), Gornja Stubica, Muzej seljačkih buna

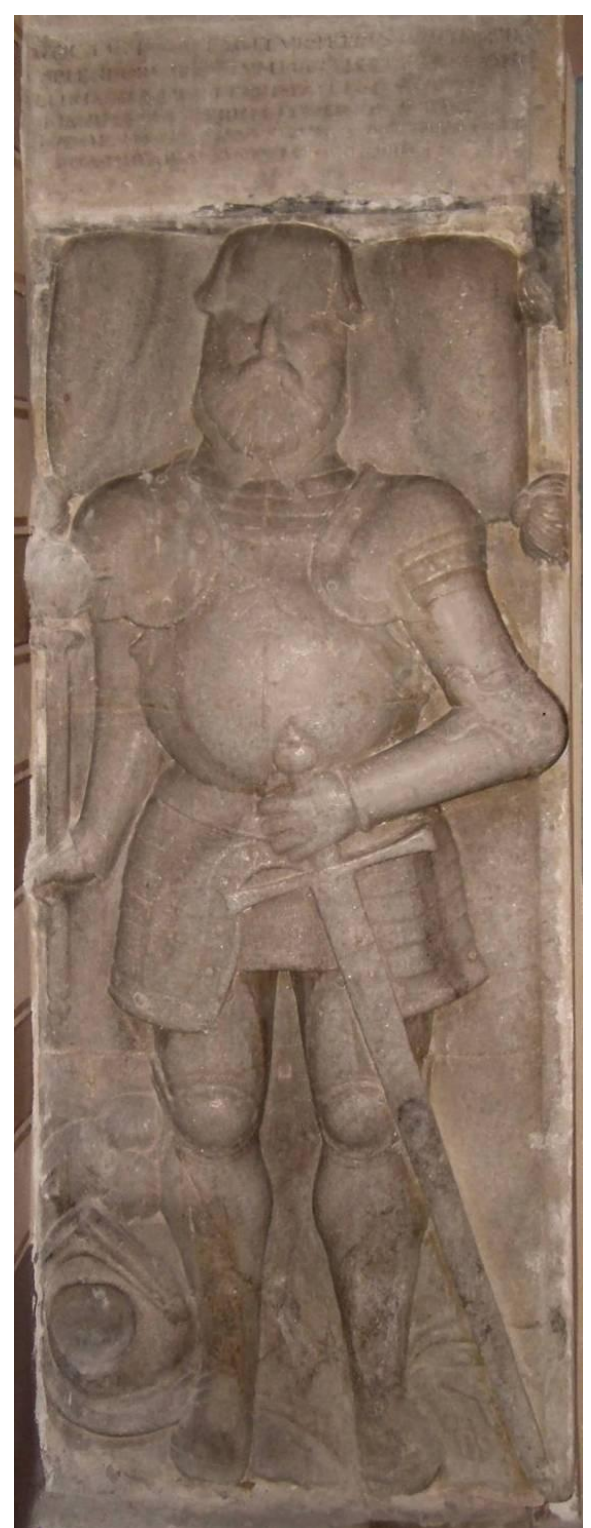

Slika 41. Nadgrobna ploča Petra II. Ratkaja Velikotaborskoga (†1586.), Desinić, crkva sv. Jurja

Nalik Tahyju, barun Petar II. Ratkaj posvetio je život vojnom pozivu, a najveći dio službe proveo je kao kapetan u Vojnoj krajini gdje se istaknuo u borbi protiv Osmanlija. Pokopan je u crkvi sv. Jurja u Desiniću, u kapeli sv. Marije, a iznad njegova groba postavljena je nadgrobna ploča. ${ }^{197}$ Obnovom crkve početkom XX. stoljeća nadgrobnik je premješten i ugrađen u pregradni zid između južne kapele i bočnoga broda. ${ }^{198}$

\footnotetext{
${ }^{197}$ Usp. Danijel Crnić, Župa Desinić, drugo izdanje, Desinić: Župni ured Desinić, 2008., str. 29; Marina Krpan, Hrvatski Ratkaji, u: Kaj: časopis za književnost, umjetnost i kulturu XXV/1-2, Zagreb: Kajkavsko spravišče, 1992., str. 77-88, 81. Gjuro Szabo (1912.) spominje da je ploča početkom XIX. stoljeća navodno donesena u crkvu iz Velikoga Tabora, no ne navodi izvor te informacije. Usp. Gjuro Szabo, nav. dj., 1912., str. 231. Isti podatak upitne točnosti preuzeo je i Artur Schneider. Usp. Artur Schneider, Popisivanje i fotografijsko snimanje umjetničkih spomenika godine 1938,. u: Ljetopis Jugoslavenske akademije znanosti i umjetnosti za godinu 1937/38. Svezak 51, Zagreb: Jugoslavenska akademija znanosti i umjetnosti, 1939., str. 168-180, 172.
} 
Nadgrobnici dvaju zapovjednika likovno su gotovo istovjetni. Pokojnici su prikazani u punom viteškom oklopu. Glave su im položene na jastuk, a kacige odložene s desne strane do nogu. U lijevoj ruci drže mač položen na krilo, a u desnoj topuz polegnut usporedno s tijelom. Za razliku od prethodnih nadgrobnika, pokojnici drže oružje golim rukama, a viteške rukavice odložene su s lijeve strane do nogu, nasuprot kacige. Jedina kompozicijska razlika između Tahyjeva i Ratkajeva nadgrobnika jest ta što na Ratkajevom spomeniku nigdje nije istaknut obiteljski grb. Na Tahyjevoj ploči, s pokojnikove desne strane u razini koljena prikazan je grb obitelji kojoj je pripadao, ${ }^{199}$ a s lijeve strane grb Zrinskih, ${ }^{200}$ obitelji s kojom se orodio oženivši Jelenu, sestru bana i vojskovođe Nikole IV. Zrinskoga. Nadgrobnici se također razlikuju u vrsti materijala u kojem su izvedeni. Tahyjev spomenik isklesan je u bijelom mramoru, a Ratkajev u običnom kamenu. Zbog veće trošnosti materijala, Ratkajev nadgrobnik izgubio je nešto od detalja koje je izvorno imao, čemu svjedoči Griesbachov fotografijski snimak iz 1938. godine (Slika 42).

S obzirom na opisane sličnosti između nadgrobnih ploča Franje Tahyja i Petra II. Ratkaja, ali i njihovu prostorno-vremensku bliskost (plemići su preminuli u razmaku od trinaest godina i pokopani su u crkvama međusobno udaljenima četrdesetak kilometara), postoji mogućnost da ih je izradila ista radionica. U župnoj crkvi Uznesenja Blažene Djevice Marije u Vurberku, naselju smještenom desetak kilometara sjeverno od Ptuja, nalazi se nadgrobni spomenik neznanoga plemića (Slika 43) koji je likovno gotovo istovjetan Tahyjevu i Ratkajevu nadgrobniku. Uz nadgrobnik nije sačuvan natpis, no Emilijan Cevc (1981.) datirao ga je na osnovi stilskih značajki u osamdesete godine XVI. stoljeća, ${ }^{201}$ što vremenski odgovara nadgrobnicima iz Donje Stubice i Desinića. Na sva tri spomenika, pokojnici imaju istu impostaciju i gotovo identično oblikovan oklop. Kao izričite sličnosti ističu se okrugli prsni oklop i štitnici za ramena, konkavno oblikovana lijeva nadlaktica te pomalo nespretno izvijen desni ručni zglob. Navedene podudarnosti upućuju na mogućnost da je sva tri nadgrobnika izradila ista radionica koja je svojim radovima opskrbljivala područje Hrvatskoga zagorja i slovenske Štajerske.

\footnotetext{
${ }^{198}$ Usp. M. S., Obnova rimokatoličke župne crkve u Desiniću, u: Viesti Družtva inžinira i arhitekata u Hrvatskoj i Slavoniji XXIV/4, Zagreb, 1903., str. 49-55.

${ }^{199}$ Grb je djelomično zakriven pokojnikovom kacigom. Štit grba okomito je razdijeljen na dva polja. U prvome polju nalaze se tri dijagonalne grede, a u drugome okrunjeni lav koji u prednjim šapama drži buzdovan. Stit je urešen plaštem, kacigom, krunom i nakitom u obliku krila. Usp. Ivan von Bojničić, nav. dj., 1889., str. 235, tab. 173.

${ }^{200} \mathrm{Na}$ okomito razdijeljenom štitu prikazan je par krila (lijevo) i kula flankirana dvjema petokrakim zvijezdama (desno). Štit je urešen plaštem, kacigom, krunom i nakitom u obliku zmaja. Grb nalikuje onome koji se nalazi na šenkovečkom nadgrobniku obitelji Zrinski. Usp. Ivan von Bojničić, nav. dj., 1889., str. 211, tab. 153.

${ }^{201}$ Usp. Emilijan Cevc, nav. dj., 1981., str. 99. U analizi vurberškoga nadgrobnika, Cevc je naveo mogućnost da je spomenik izradila radionica majstora Hasssova epitafa koja je djelovala na prijelazu XVI. u XVII. stoljeće na području Maribora, Ptuja i njihove okolice. Kao sličnosti je naveo upotrebu ukrasnih voluta i slično oblikovanje obiteljskoga grba, no nije detaljnije zalazio u način oblikovanja tijela.
} 


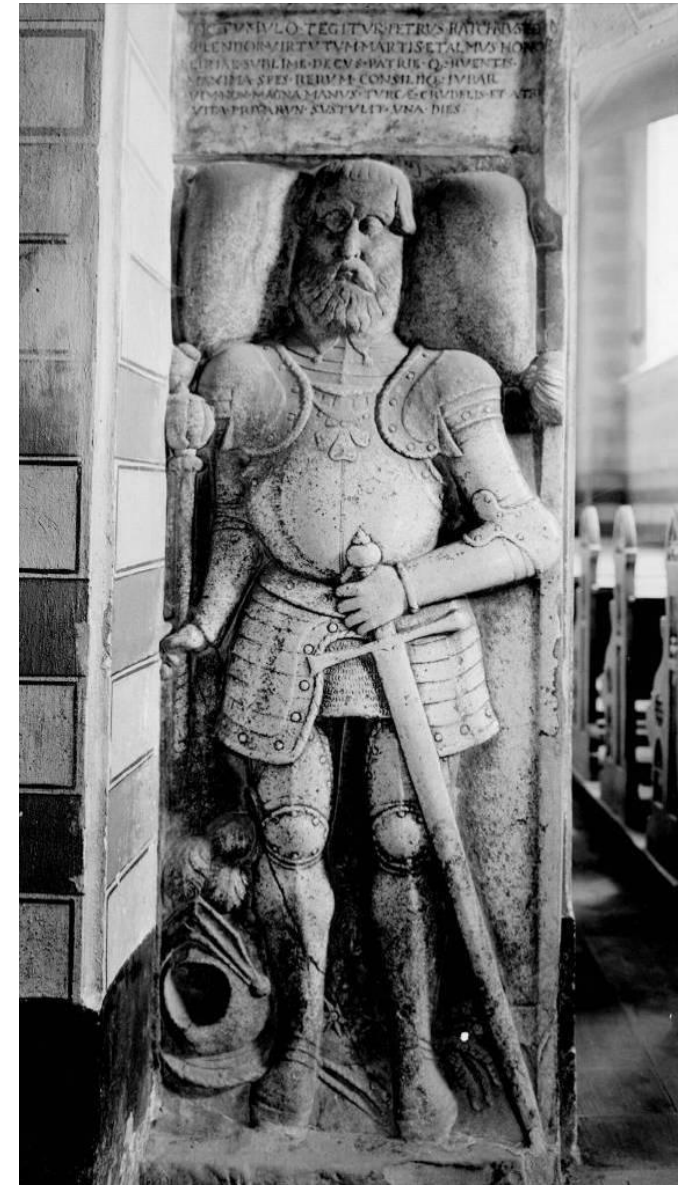

Slika 42. Desinić, Župna crkva, Nadgrobni spomenik Petra II. Rattkay, 1938., foto: Ljudevit Griesbach, HAZU, Strossmayerova galerija starih majstora, Schneiderov fotografijski arhiv

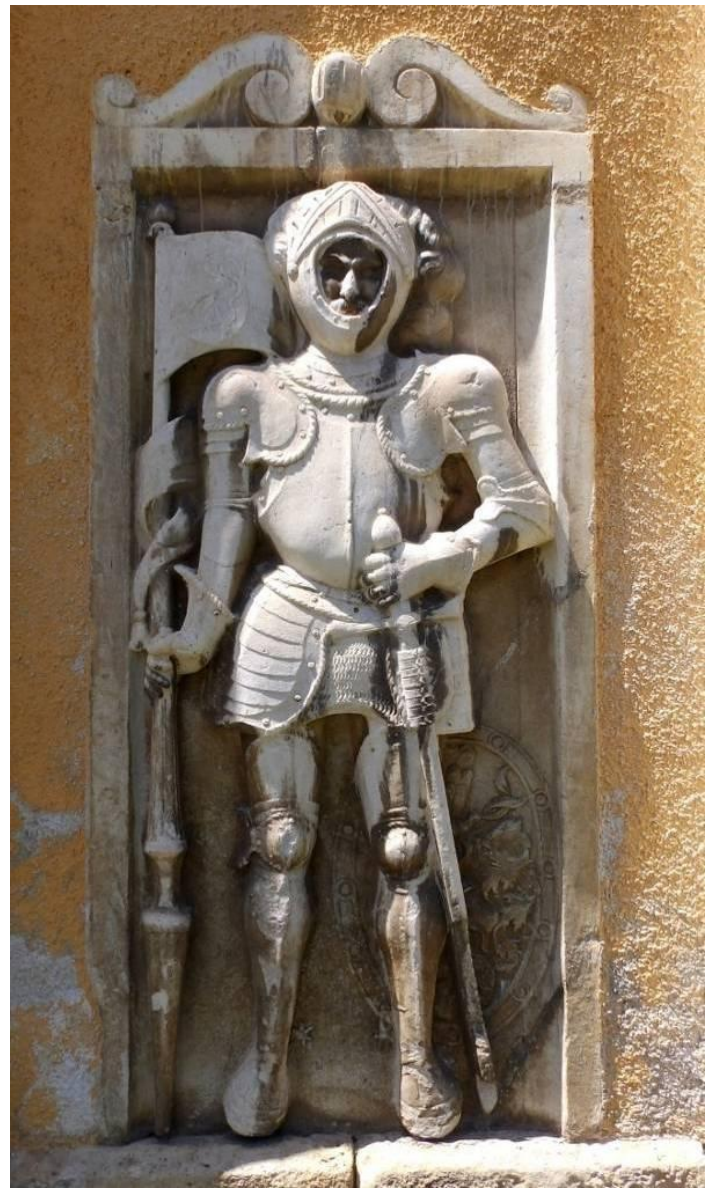

Slika 43. Viteški nadgrobnik, 1580-e, Vurberk, crkva Uznesenja Blažene Djevice Marije

Na Tahyjevu i Ratkajevu nadgrobniku pokojnici su prvi put prikazani bez kacige, jasno vidljivih lica. U srednjem vijeku, lica pokojnikā bila su tipizirana. ${ }^{202}$ Njihov društveni položaj bio je naznačen atributima (žezlo je predstavljalo simbol vladara, mač plemića, topuz zapovjednika, mitra biskupa itd.), a identitet natpisom na spomeniku. Individualizacija ljudskoga životnoga iskustva, za koju je humanizam u renesansnom razdoblju pronašao likovni izraz u portretu kao slikarskoj i kiparskoj temi, potakla je i pojavu da lica na nadgrobnim spomenicima počinju zadobivati portretne karakteristike. ${ }^{203}$ Sačuvani su pojedini nadgrobnici na kojima je čak u natpisu zabilježeno da je figura pokojnika izvedena po uzoru na stvarnu osobu, poput spomenika plemića Franza von Gradenegga (1563.) iz crkve sv. Petra u Brestanici u Sloveniji na kojemu piše da je pokojnik dao izraditi nadgrobnik »NACH

\footnotetext{
${ }^{202}$ Usp. Philippe Ariès, nav. dj., 1981., str. 260; Emilijan Cevc, nav. dj., 1981., str. 154. ${ }^{203}$ Isto.
} 
[S]EINER PILDNUS« (pildnus, njem. »slika, lik«, prema čemu kajk. pelda). ${ }^{204} \mathrm{U}$ stručnoj literaturi za donjostubički se spomenik često pisalo da predstavlja portret Franje Tahyja. ${ }^{205}$ Gjuro Szabo (1938.) s očitim je negodovanjem opisao nadgrobnu ploču ne skrivajući nenaklonost koju je osjećao prema Tahyju kao povijesnoj osobi:

»Mislilo se, da je spomenik postavljen mnogo kasnije poslije smrti Tahyjeve, pa da je lik njegov na ploči tek fantazija, ili tek šematski, nu dostajat će jedan pogled na ploču, da se spozna, da je tu pred nama pravi lik Tahyjev. [...] Glava, naslonjena na jastuk pokazuje nezgrapnog, oporog čovjeka, pa još i u smrti odaje divlji pogled svu nasilnu ćud toga silnika. ${ }^{206}$

Ako usporedimo Tahyjevo lice (Slika 44) - koje navodno oličava njegovu »nasilnu ćud « - s onime na Ratkajevu nadgrobniku (Slika 45), uočit ćemo da ona pripadaju istome tipu. Oba muškarca imaju široko pomalo podbuhlo lice, namršteno čelo i istaknute jagodice te isti stil frizure, brade i brkova. Stoga se postavlja pitanje sadrži li Tahyjevo lice uistinu portretne karakteristike. Budući da je njegov nadgrobnik najvjerojatnije nastao prije Ratkajeva, postoji mogućnost da je izrađen po uzoru na Tahyjev stvarni lik, koji je radionica potom jednostavno ponovila pri izradi Ratkajeva spomenika. Međutim, bez postojanja drugoga suvremenog Tahyjeva portreta s kojim bi se nadgrobnik mogao usporediti ili potkrijepe $u$ arhivskim dokumentima, tako nešto ne možemo tvrditi sa sigurnošću. Izglednije je da je riječ o tipiziranom portretu koji je primijenjen na oba nadgrobnika.

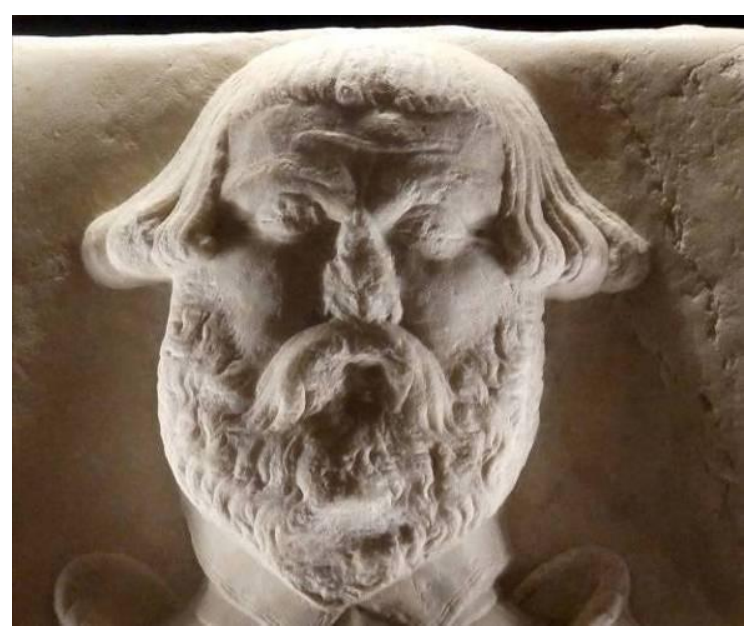

Slika 44. Detalj lica nadgrobne ploče Franje Tahyja (†1573.), Gornja Stubica, Muzej seljačkih buna

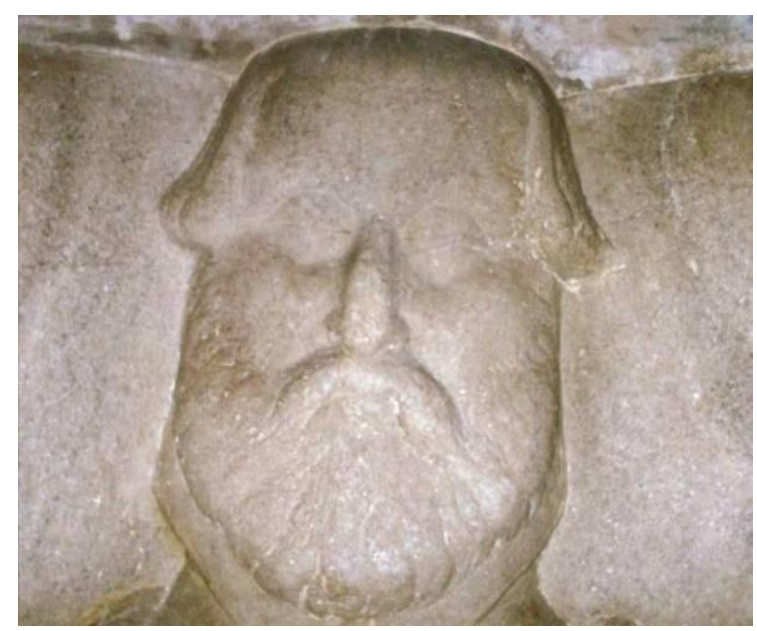

Slika 45. Detalj lica nadgrobne ploče Petra II. Ratkaja Velikotaborskoga (†1586.), Desinić, crkva sv. Jurja

\footnotetext{
${ }^{204}$ Usp. Emilijan Cevc, nav. dj., 1965., str. 138; Emilijan Cevc, nav. dj., 1981., str. 88.

${ }^{205}$ Usp. Milan Pelc, nav. dj., 2007., str. 315; Gjuro Szabo, nav. dj., 1938., str. 5; Gjuro Szabo, nav. dj., 1939: 171; Marijana Schneider, nav. dj., 1973., str. 277.

${ }^{206}$ Gjuro Szabo, nav. dj., 1938., str. 5.
} 
Na području povijesne Zagrebačke biskupije sačuvan je još jedan nadgrobnik koji, uz spomenike Tahyju i Ratkaju, pripada skupini viteških gisanta. Riječ je o nadgrobnoj ploči Zrinskoga (Slika 46) ${ }^{207}$ koja se izvorno nalazila u pavlinskoj crkvi sv. Jelene u Šenkovcu, ${ }^{208}$ a danas je pohranjena u Muzeju Međimurja Čakovec. Stručnjaci još uvijek dvoje za kojega je člana obitelji postavljena, a u optjecaju su tri imena: Nikola IV. (Zrin, 1508. - Siget, 1566.), Juraj V. (Čakovec, 1599. - Požun, 1626.) i Nikola VII. (Čakovec, 1620. - Kuršanec, 1664.). Budući da je pitanje identifikacije povezano s nadgrobnim spomenicima XVII. stoljeća koji još nisu razloženi, rasprava o identitetu pokojnika izložena je u daljnjem dijelu teksta, nakon što su obrađeni svi nadgrobnici relevantnih za razumijevanje navedenoga problema. U ovome dijelu rada osvrnut ćemo se na povijest nadgrobnika, njegovo likovno rješenje i moguće komparativne primjere iz Hrvatske i inozemstva.

Povijest nadgrobnoga spomenika člana obitelji Zrinski svjedoči o načinu brisanja obiteljske memorije nakon smrti posljednjega člana obitelji ili baštinika koji bi istu održavao. Nadgrobnik se izvorno nalazio u grobnoj kapeli - takozvanome mauzoleju - Zrinskih koju je ban Nikola IV. dao podići s južne strane pavlinske crkve u Šenkovcu (o. 1560.). ${ }^{209}$ Godine 1695. izbio je veliki požar koji je oštetio cijeli samostanski sklop, uključujući kapelu kojoj je izgorio krov. ${ }^{210}$ Zahvaljujući naporima zagrebačkoga biskupa Stjepana Želišćevića i priora o. Andrije Weinachta, crkva i samostan obnovljeni su ubrzo nakon požara. Budući da je čakovečka grana obitelji Zrinski tada već izumrla, ${ }^{211}$ pavlini su preuredili njihov mauzolej u kapelu sv. Antuna Padovanskoga. Očistili su kapelu od pepela i nečisti, sa zidova su skinuli ratne trofeje (zastave, bubnjeve, tobolce sa strijelama i lukove), iznijeli su oštećene nadgrobne

\footnotetext{
${ }^{207}$ Mramor, $162 \times 115 \times 22,5 \mathrm{~cm}$, Čakovec, Muzej Međimurja, izvorno u pavlinskoj samostanskoj crkvi sv. Jelene u Šenkovcu. Kat. br. 65.

${ }^{208}$ Od nekadašnjega samostanskog sklopa očuvano je samo svetište crkve koje je preuređeno u kapelu sv. Jelene i temelji grobne kapele obitelji Zrinski.

${ }^{209}$ Rasprava o godini podizanja mauzoleja Zrinskih detaljno je razložena u poglavlju o grobnim kapelama (str. 210-211).

${ }^{210}$ Usp. Josip Bedeković, Natale solum magni ecclesiae doctoris sancti Hieronymi in ruderibus Stridonis occultatum [...], Pars prima, Neostadii Austriae: Ex Typographeo Muelleriano, [1752.], str. 276; Josip Bedeković, Knjiga o sv. Jeronimu, Iliriku i Međimurju, Zagreb, Čakovec, Samobor: Hrvatska akademija znanosti i umjetnosti, Društvo za povjesnicu Zagrebačke nadbiskupije »Tkalčić«, Družba »Braća Hrvatskoga Zmaja«, Ogranak Matice hrvatske u Čakovcu, Zrinska garda Čakovec, Meridijani, 2017., str. 254-255. Preveo Marko Rašić; Kamilo Dočkal, Povijest pavlinskog samostana sv. Jelene u Čakovcu, Zagreb, 1951., Arhiv Hrvatske akademije znanosti i umjetnosti, XVI 29b.7 (rukopis), str. 96, 111; Vladimir Kalšan, Općina Šekovec, Šenkovec: Poglavarstvo Općine Šenkovec, 2008., str. 52; Emilij Laszowski, Zrinski mauzolej u sv. Jeleni kod Čakovca, u: Hrvatsko kolo: književno-naučni zbornik IX/15, Zagreb: Matica hrvatska, 1928., str. 244-259, 249; Tajana Pleše, Izvještaj o provedenim revizijskim arheološkim istraživanjima pavlinskog samostana Blažene Djevice Marije $i$ Svih Svetih u Šenkovcu tijekom 2012. godine, Zagreb: Hrvatski restauratorski zavod, 2013., str. 8-9; Ivan Srša, Rezultati konzervatorskih istraživanja u kapeli svete Jelene u Šenkovcu kraj Čakovca, u: Nepek a Mura Mentén =Völker an der Mur = Ljudi uz Muru = Ljudje ob Muri. Sv. 2, A Nagykanizsan 1997. Majus 15-17. kozott megrendezett nemzetkozi konferencia eloadasai, Zalaegerszeg: Gocseji Muzeum, 1998., str. 123-150, 129-130. Uredila Katalin H. Simon.

${ }^{211}$ Posljednji član obitelji koji je obitavao u Čakovcu bio je Adam Zrinski koji je poginuo u bitci kod Slankamena 1691. godine.
} 
spomenike te su unijeli i postavili oltare (središnji posvećen sv. Antunu Padovanskom i dva bočna posvećena sv. Barbari i sv. Ivanu Nepomuku). ${ }^{212}$ Prema arhivskim izvorima, u kapeli se nalazio i drveni epitaf Nikole IV. Zrinskoga koji je 1574. godine izradio bečki dvorski slikar flamanskoga podrijetla, Adriaen van Conflans (epitaf je detaljnije obrađen u narednom potpoglavlju o nadgrobnicima s prikazom Raspetoga i pokojnika-adoranta). U sklopu obnove crkve, stari drveni tabulat iznad glavnoga broda zamijenjen je zidanim svodom, za koji su postavljeni novi nosači uz zidove lađe. Nadgrobna ploča Zrinskoga, oštećena u požaru, tom je prilikom upotrijebljena kao sekundarni građevinski materijal i ugrađena u temelje nosačā, gdje je pronađena 1928. godine arheološkim iskapanjima lokaliteta pavlinskoga sklopa. ${ }^{213}$

Sačuvani ulomci ploče Zrinskoga prikazuju pokojnika odjevena u puni viteški oklop. Glava mu je položena na jastuk, a na njoj nosi kacigu podignuta vizira koji otkriva pogled na brkato, namršteno lice. Lijevom rukom pridržava balčak mača koji mu visi o boku, a u desnoj drži barjak s grbom obitelji Zrinski. ${ }^{214}$ Platno zastave presavijeno je i položeno na jastuk do pokojnikove glave. Obiteljski grb prikazan je još jednom, lijevo do pokojnikovih nogu, u raskošnijem izdanju urešen plaštem, kacigom i krunom s ukrasom u obliku zmaja. Profilirani rub ploče je prazan, odnosno ne sadrži dekorativne motive ili tekst, stoga možemo pretpostaviti da se nadgrobni natpis nalazio ispod figure preminuloga. Skladnost proporcija pokojnikova tijela, izražajnost njegova lica, uspješno stupnjevanje volumena te minuciozni detalji u izvedbi oklopa i grbova upućuju na vješta renesansna kipara.

Nadgrobna ploča Zrinskoga svojim se osnovnim formalnim karakteristikama (strogom frontalnošću, impostacijom tijela, tipiziranim licem, oblikom zastave i grba te stupnjevanjem volumena) ne razlikuje mnogo od nadgrobnika Gašpara I. Draškovića (Slika 37). Iznimke su lijeva ruka koja je na šenkovečkom spomeniku više izbačena u laktu i, naravno, motiv jastuka koji izostaje na Draškovićevu nadgrobniku. Dodatna poveznica je materijal iz kojega su obje ploče isklesane, a to je crveni mramor. Emilij Laszowski (1924.) iznio je pretpostavku da je nadgrobna ploča Zrinskoga izrađena od mramora koji se vadio u blizini Verone, no bez potkrjepe u povijesnim ili arhivskim izvorima. ${ }^{215} \mathrm{~S}$ obzirom na to da je kontinentalna

\footnotetext{
${ }^{212}$ Usp. Josip Bedeković, nav. dj., 1752., str. 276; Kamilo Dočkal, nav. dj., 1951., str. 96, 111; Vladimir Kalšan, nav. dj., 2008., str. 52; Emilij Laszowski, nav. dj., 1928., str. 249; Tajana Pleše, nav. dj., 2013., str. 8-9; Ivan Srša, nav. dj., 1998., str. 129-130. Nakon što je 1744. godine u kapelu prenesena čudotvorna slika Bogorodice iz pavlinskoga samostana u Sveticama i postavljena na oltar, kapela je posvećena Blaženoj Djevici Mariji.

${ }^{213}$ Istraživanje su proveli članovi družbe »Braća hrvatskoga zmaja« Emilij Laszowski i Stjepan Savić Nosan. Prilikom pronalaska nadgrobnika, Laszowski je zabilježio da su na pojedinim mjestima ploče vidljiva oštećenja od požara, gdje se mramor pretvorio u vapno. Usp. Emilij Laszowski, nav. dj., 1928., str. 259.

214 Štit grba okomito je razdijeljen na dva polja. U prvome polju predočen je par krila, a u drugome kula flankirana dvjema petokrakim zvijezdama. Usp. Ivan von Bojničić, nav. dj., 1889., str. 211, tab. 153.

${ }^{215}$ Usp. Emilij Laszowski, Spomenik bana grofa Nikole Zrinskoga († 1664.), u: Jutarnji list, Zagreb, 12. X. 1924., str. 20.
} 


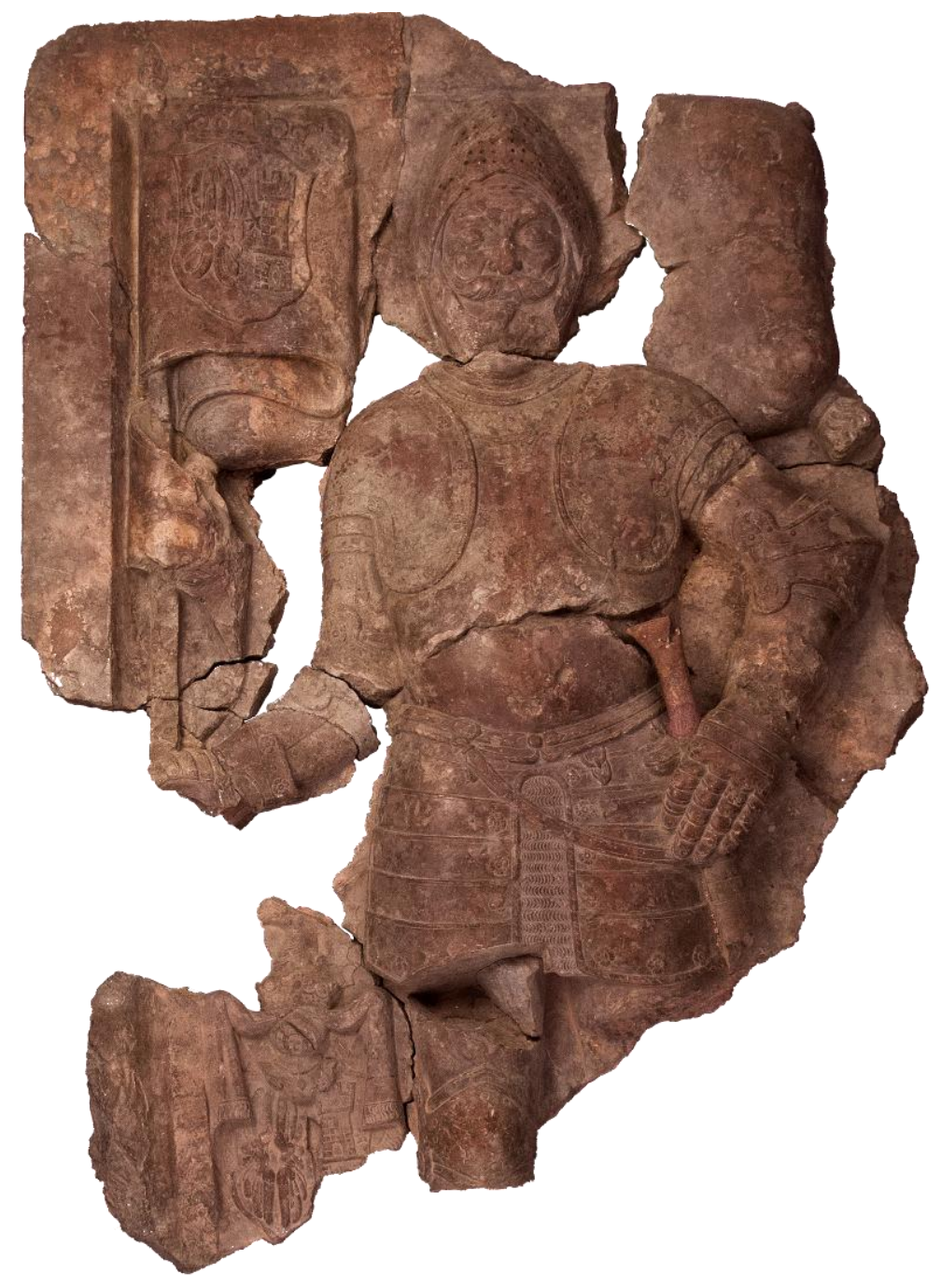

(gore lijevo) Slika 46. Nadgrobna ploča Nikole IV. Zrinskoga (?) (†1566.), Čakovec, Muzej Međimurja

(gore desno) Slika 47. Nadgrobna ploča Jánosa II. Thuróczyja, oko 1558., Levoča, crkva sv. Jakova

(dolje desno) Slika 48. Poklopac tumbe Marka (Horvata) Mišljenovića od Kamičca (†1508.), Nagyvázsony, dvorac Kinizsi
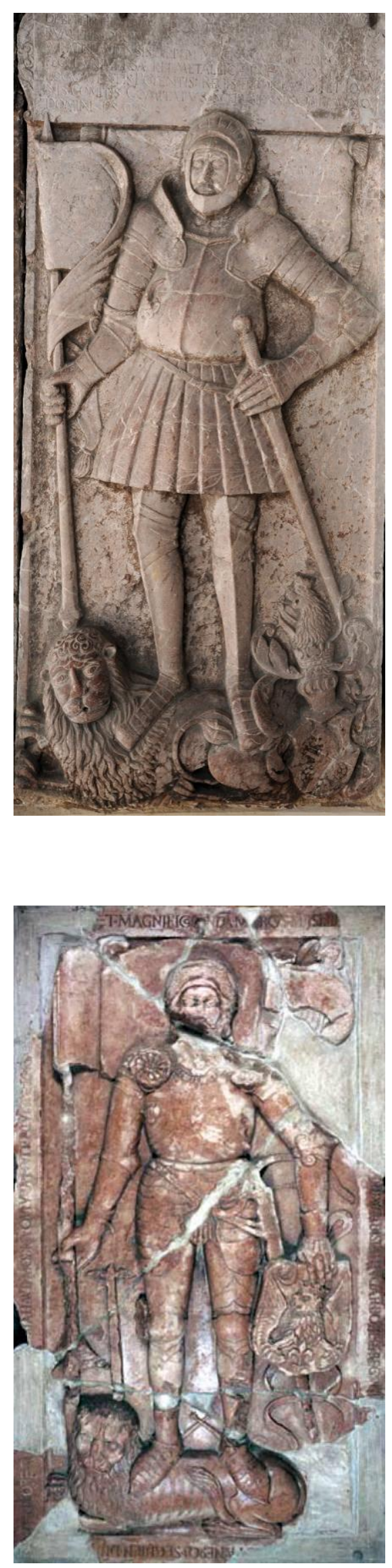
Hrvatska u to vrijeme bila politički, gospodarski i kulturološki više povezana s Ugarskom nego Italijom te da su članovi obitelji Zrinski i Drašković bili okosnica i pokretači hrvatskougarskoga društva, izglednije je da je nadgrobna ploča Zrinskoga, kao i ona Gašpara I. Draškovića, izrađena od pečuškoga ili ostrogonskoga mramora.

$\mathrm{Na}$ šenkovečkom nadgrobniku, impostacija tijela pokojnika daje dojam da je lik prikazan u stojećem stavu, posebice lijeva ruka koja nije priljubljena uz tijelo već je podbočena o bok. Međutim, jastuk na kojem je položena njegova glava i zatvorene oči sugeriraju da pokojnik leži. Takva, uvjetno nazvana, hibridna rješenja koja spajaju oblike različitih tipova prikaza pokojnika - kao živuće osobe koja stoji i mrtve koja leži - nisu bila nimalo neuobičajena u ranom novom vijeku i primjenjivala su se diljem središnje Europe. Na prostoru nekadašnje Ugarske sačuvani su brojni primjeri iz XV. i XVI. stoljeća koji svjedoče o tome, poput nadgrobnih ploča Istvána Máriássyja (†1516.) iz crkve sv. Mihaela arkanđela u Markušovcu, braće Antala i Mihálya Pálóczyja (1519.) iz crkve sv. Elizabete Ugarske u Sáróspataku, Györgya Serédyja (†1557.) iz crkve sv. Egidija u Bardejovu ili gotovo istovjetnih ploča Jánosa II. Thuróczyja (†1508.) (Slika 47) i njegova sina Jánosa V. (†1558.) iz crkve sv. Jakova u Levoči. Isto se rješenje primjenjivalo i na poklopcima tumbi, poput one Istvána II. Báthoryja (†1493.) iz crkve sv. Jurja u Nyírbátoru, hrvatsko-dalmatinskoslavonskoga bana Marka (Horvata) Mišljenovića od Kamičca (†1508.; banovao 1506. 1507.) iz crkve sv. Mihaela u Nagyvázsonyu (danas u dvorcu Kinizsi) (Slika 48) ${ }^{216}$ ili Istvána Dobóa (†1572.) iz crkve sv. Križa u Ruskoj (danas u dvorcu Eger).

Uz nadgrobnu ploču Zrinskoga i Gašpara I. Draškovića, povijesni izvori bilježe postojanje barem još jednoga viteškog nadgrobnika iz druge polovine XVI. stoljeća koji je bio isklesan iz crvenoga mramora. Riječ je o nadgrobnoj ploči kneza i hrvatsko-dalmatinskoslavonskoga bana Franje I. Frankapana Slunjskoga ${ }^{217}$ (Slunj, 1536. - Varaždin, 1572.;

\footnotetext{
${ }^{216}$ Marko (Horvat) Mišljenović od Kamičca (? - Zagreb, 1508.) hrvatskoj je historiografiji poznat tek u osnovnim crtama. Godine 1500. proglašen je kraljevskim peharnikom, 1505. budimskim kapetanom, a od 1505. do 1507. godine obnašao je dužnost hrvatsko-dalmatinskoga bana. Prema želji supruge Benigne Magyar, pokopan je u pavlinskoj crkvi sv. Mihaela u Nagyvázsonyu, uz grob njezina prva supruga Pála Kinizsija (Satchinez, 1431. Smederevo, 1494.). Pál Kinizsi, vojskovođa kralja Matije Korvina, osnovao i podigao navedeni pavlinski samostan između 1480. i 1483. godine s namjerom da samostanska crkva služi kao obiteljsko mjesto pokapanja. Pavlinski sklop porušen je već sredinom XVI. stoljeća, a poklopci tumbi Kinizsija i Mišljenovića nekoliko su puta premještani kako bi se sačuvali. Danas su pohranjeni i izloženi u gradskom dvorcu u Nagyvázsonyu. Usp. Veszprém megye középkori templomai: Szent Mihály pálos kolostorrom, Nagyvázsony. Épitészeti emlékek: A történelmi Magyarország müemlékei, internetska stranica, 2019. Pristupljeno 18. 9. 2020. <https://epitettemlekek.hu/templomok/veszprem-megye/szent-mihaly-palos-kolostorrom-nagyvazsony/>.

${ }^{217}$ U katalogu izložbe Mors porta vitae (2014.) objavljen je nacrt zagrebačke katedrale na kojem su ucrtane nadgrobne ploče koje su se izvorno nalazile u prvostolnici, a danas su pohranjene u Muzeju grada Zagreba. Prema nacrtu, nadgrobna ploča Franje I. Frankapana Slunjskoga jedan je od nagrobnika koji se nalaze u muzeju. Usp. Slavko Šterk i Boris Mašić, nav. dj., 2014., str. 52. Međutim, na upit upućen muzeju dobila sam odgovor da ne postoji zapis o traženom predmetu.
} 
banovao 1567. - 1572.) koji je pokopan u svetištu zagrebačke katedrale uz oltar Uznesenja Blažene Djevice Marije. ${ }^{218}$ Nazivan »mačem i štitom ostatka Ilirije« (ensis et clipeus Illyrici reliquiarum), Franjo I. posvetio je život obrani hrvatskoga teritorija i ratovanju protiv Osmanlija. ${ }^{219}$ Preminuo je u Varaždinu na putu za Moravsku gdje se trebao vjenčati Jelenom Kereczeny, a njegovom smrću izumro je slunjski ogranak obitelji Frankapan. Budući da je umro daleko od obiteljskih posjeda u Primorju i Pokuplju, pokopan je u zagrebačkoj prvostolnici gdje mu je sestra Ana, udovica Nikole Olaha Császára de Lanser, podigla nadgrobni spomenik. ${ }^{220}$ Ploča je najvjerojatnije izvađena 1703. godine - kao i one biskupā Luke de Szegeda i Petra III. Petretića - kada se mijenjalo popločenje svetišta. Prema pisanju Ivana Kukuljevića Sakcinskoga (1856.) i Ivana Krstitelja Tkalčića (1885.), nadgrobnik je sadržavao lik bana odjevena u viteški oklop i opasana sabljom koji kleči. ${ }^{221}$ Ovo likovno rješenje jedinstveno je među nadgrobnim pločama sačuvanima na prostoru povijesne Zagrebačke biskupije, a srodno je prikazu pokojnika-adoranta pred Raspetim koje se u to vrijeme primijenjivalo na epitafima. (Epitafi s figuralnim prikazima detaljnije su razrađeni $\mathrm{u}$ narednom potpoglavlju.) Jedina je razlika što Frankapanova ploča - ako je vjerovati pisanim izvorima - nije sadržavala lik Krista razapetoga na križu, već samo lik preminuloga bana.

Sudeći prema sačuvanom korpusu nadgrobnih spomenika, u XVII. stoljeću postupno se napušta likovno rješenje gisanta te se pokojnici počinju prikazivati kao živuće osobe. Početni u nizu viteških nadgrobnika na kojima je primijenjen novi likovni tip je nadgrobna ploča Nikole I. Mlakovečkoga (?, 1547. - Lapšina, 1603.) (Slika 49). ${ }^{222}$ Mlakovečki je bio zapovjednik tvrđave Bajče (mađ. Bajcsavár) i posade čakovečke utvrde te bliski prijatelj i savjetnik Jurja IV. Zrinskoga (Čakovec ?, 1549. - Vép, 1603.). Nadgrobnik se nekoć nalazio u svetištu crkve sv. Martina u Svetome Martinu na Muri, ${ }^{223}$ a danas je pohranjen u Muzeju Međimurja Čakovec. Nastavljajući se na tradiciju viteških nadgrobnika, prikazuje pokojnika u potpunosti odjevena u viteški oklop, kacige odložene sa strane. Mlakovečki u lijevoj ruci drži sablju koja mu je opasana o bok, a u desnoj topuz. Predočen je kao sredovječni muškarac kratke kose, guste brade i brkova te izražajnih i strogih crta lica koje mu daju portretne

\footnotetext{
${ }^{218}$ Usp. Ivan Kukuljević Sakcinski, nav. dj., 1856., str. 20; Ivan Krstitelj Tkalčić, nav. dj., 1885., str. 57.

219 Trpimir Macan (ur.), Hrvatski biografski leksikon. 4, E-Gm, Zagreb: Leksikografski zavod »Miroslav Krleža«, 1998., sub voce Frankapan, Franjo I. Slunjski [Petar Strčić].

${ }^{220}$ Ovaj podatak zabilježen je na samome spomeniku. Za prijepis natpisa vidi: Ivan Kukuljević Sakcinski, nav. dj., 1856., str. 20; Ivan Krstitelj Tkalčić, nav. dj., 1885., str. 57.

${ }^{221}$ Usp. Ivan Kukuljević Sakcinski, nav. dj., 1856., str. 20; Ivan Krstitelj Tkalčić, nav. dj., 1885., str. 57. Vidi i: Milan Pelc, nav. dj., 2010., str. 66.

${ }^{222}$ Mramor, $200 \times 115 \times 29,5 \mathrm{~cm}$, Čakovec, Muzej Međimurja, izvorno u župnoj crkvi sv. Martina biskupa u Svetom Martinu na Muri. Kat. br. 64.

${ }^{223}$ Usp. Josip Bedeković, nav. dj., 1752., str. 294-295. U kanonskoj vizitaciji iz 1698. godine navedeno je samo da u crkvi postoje tri kripte, jedna ispod kora i dvije u svetištu. Usp. NAZ, KV, Prot. 71/II (1698.), str. 43.
} 
karakteristike. ${ }^{224} \mathrm{U}$ donjem desnom kutu ploče, uz kacigu je prikazan signalni rog koji se na nadgrobnicima uglavnom ne javlja kao samostalan motiv, nego kao dio ratnih trofeja (tal. trofeo d'armi). ${ }^{225}$ Obiteljski grb ${ }^{226}$ umetnut je u bijelom mramoru u gornjem desnom kutu nadgrobnika. Figura Mlakovečkoga svojom se impostacijom ne razlikuje mnogo od onih na nadgrobnicima Franje Tahyja (Slika 40), Petra II. Ratkaja (Slika 41) i Zrinskoga (Slika 46). Međutim, postoje dvije razlike. Prva je što pokojnik stoji u pravom, a ne samo naznačenom kontrapostu, težine oslonjene na lijevu nogu. Druga je što je prikazan u tričetvrt profilu, a ne en face kao što je dotad bilo uobičajeno. Pokojnikova desna ruka čak je djelomično zakrivena tijelom kako bi se dočarala iluzija zakrenutosti tijela. Anđela Horvat (1975.) prepoznala je u ovoj promjeni impostacije nagovještaj baroknoga stila. ${ }^{227}$

Iz XVII. stoljeća sačuvane su još tri nadgrobne ploče koje čine posebnu skupinu jer je na njima primijenjeno gotovo istovjetno likovno rješenje. Riječ je o nadgrobnicima Benedikta Thuróczyja Lubreškoga (? - Vinica, 1616.) (Slika 50 $)^{228}$ iz Vinice, Ivana IV. Petheőa de Gerse (?, 1576. - ?, 1616.) (Slika 51) ${ }^{229}$ iz Ivanca i člana obitelji Vragović (I. polovina XVII. stoljeća) (Slika 52) ${ }^{230}$ iz Maruševca. U skladu s tradicijom, pokojnici su prikazani u oklopu, no na glavi ne nose kacigu već kalpak, pokrivalo za glavu karakteristično za hrvatsko-ugarsko plemstvo. Kacige su odložene s njihove desne strane na niskom profiliranom postamentu, koji predstavlja novitet u kompoziciji nadgrobnih spomenika. U desnoj ruci drže topuz, a u lijevoj sablju, izuzev pokojnika na maruševečkom nadgrobniku koji u lijevoj ruci drži barjak. Motiv zastave ponovljen je i na viničkome nadgrobniku uz desni rub ploče, no zbog oštećenja vidljiv je samo gornji dio platna. Maruševečki nadgrobnik sadrži i motiv lava koji leži iza pokojnikovih nogu. Kao simbol snage, lav je na nadgrobnim spomenicima predstavljao moć pokojnika i služio je kao sredstvo glorifikacije, ${ }^{231}$ a možemo ga pronaći na nadgrobnim pločama Nikole $(\dagger 1477$.) (Slika 12) i Lovre Iločkih $(\dagger 1524$.) kao i

\footnotetext{
${ }^{224}$ Usp. Milan Pelc, nav. dj., 2007., str. 315.

${ }^{225}$ Donji desni kut ploče, na kojem su isklesani kaciga i rog, danas je oštećen, no cjelovit izgled nadgrobnika vidljiv je na crtežu koji je 1824. godine izradio injženjer János Szajdensvartz - najvjerojatnije - za Ladislava II. Feštetića (Ság, 1785. - Beč, 1846.), tadašnjega vlasnika međimurskoga vlastelinstva. Crtež je pohranjen u Mađarskom državnom arhivu u Budimpešti (Magyar Nemzeti Levéltár Országos Levéltára, T - Tervtár, T Családi fondokból kiemelt tervek (1659-2000), T 3 Festetics család (1743-1941), T 3 No 596/7. https://maps.hungaricana.hu/hu/MOLTervtar/7089/view/?bbox=95\%2C-4994\%2C4438\%2C-3088)

${ }^{226}$ Grb se sastoji od štita s motivom lava koji je urešen plaštem, kacigom, krunom i nakitom u obliku lava. Usp. Ivan von Bojničić, nav. dj., 1889., str. 108, tab. 77.

${ }^{227}$ Usp. Anđela Horvat, nav. dj., 1975., str. 191, 353.

${ }^{228}$ Mramor, $181 \times 95,5 \times 11,5 \mathrm{~cm}$, Vinica, crkva sv. Marka Evanđelista, izvorno u staroj crkvi. Kat. br. 72.

${ }^{229}$ Kamen, $221 \times 74 \times 13 \mathrm{~cm}$, Ivanec, crkva sv. Marije Magdalene, izvorno u dvorskoj kapeli sv. Ivana Krstitelja kaštela Ivanec. Kat. br. 52 .

${ }^{230}$ Kamen, $118 \times 100 \times 11 \mathrm{~cm}$, Maruševec, crkva sv. Jurja. Kat. br. 60 .

${ }^{231}$ Usp. Anđela Horvat, nav. dj., 1975., str. 352; Anđela Horvat, nav. dj., 1979.a, str. 311, 313; Slavko Sterk i Boris Mašić, nav. dj., 2014., str. 54.
} 
brojnih drugih ugarskih velikaša (Slike 47 i 48). ${ }^{232} \mathrm{Na}$ sva tri nadgrobnika, pokojnici su prikazani $\mathrm{u}$ sličnoj pozi $\mathrm{s}$ manjim razlikama. Thuróczy Ludbreški stoji $\mathrm{u}$ tek blago naznačenom kontrapostu i prikazan je u punom frontalnom stavu. Petheő de Gerse i Vragović, $\mathrm{s}$ druge strane, stoje u naglašenijem kontrapostu, nalik figuri Nikole I. Mlakovečkoga (Slika 49), a njihova tijela zakrenuta su u blagi tričetvrt profil koji im daje dojam pokrenutosti. ${ }^{233}$ Plemenito podrijetlo pokojnikā potvrđuju obiteljski grbovi koji su zastupljeni na sva tri nadgrobnika. Na nadgrobnoj ploči Thuróczyja Ludbreškoga, grbovi pokojnikove

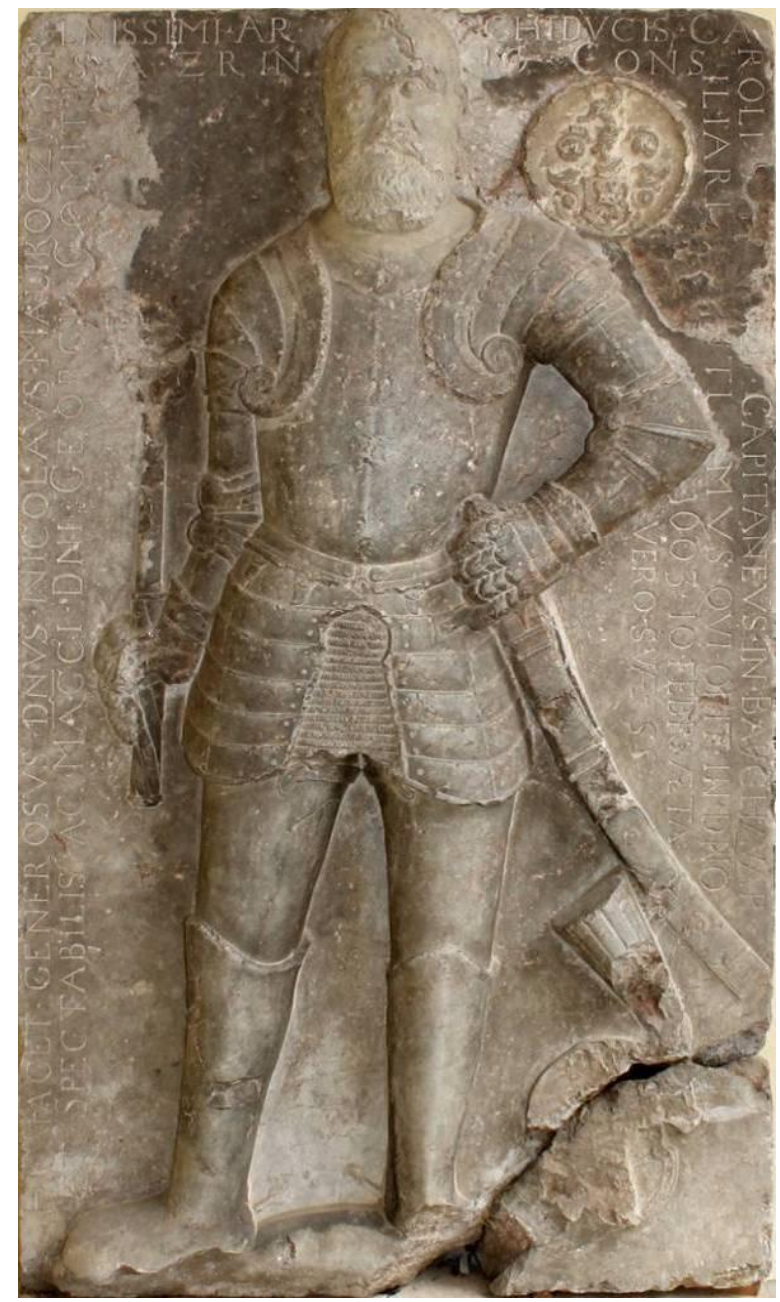

Slika 49. Nadgrobna ploča Nikole I. Mlakovečkoga (†1603.), Čakovec, Muzej Međimurja

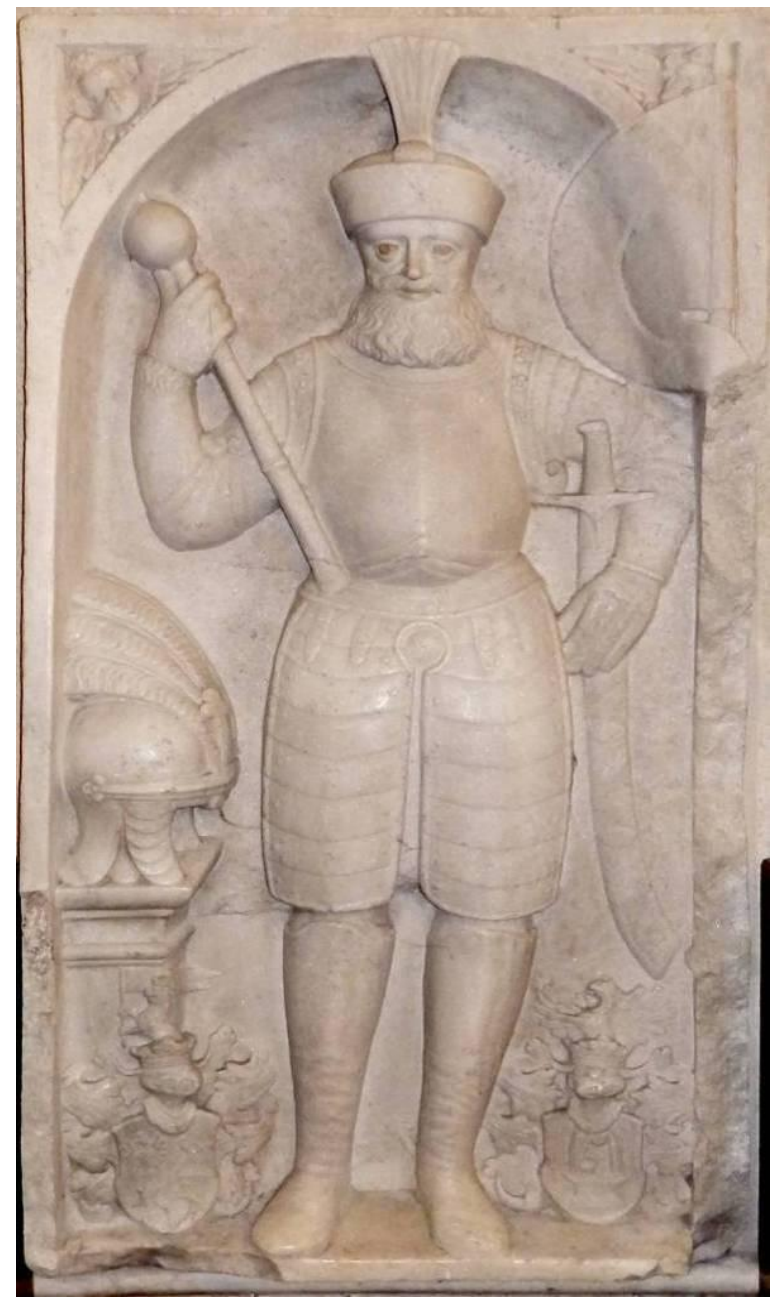

Slika 50. Radionica Majstora Trantnerova epitafa (?), Nadgrobna ploča Benedikta Thuróczyja Ludbreškoga (†1616.), Vinica, crkva sv. Marka evanđelista

${ }^{232}$ Dodatni primjeri nadgrobnika koji sadrže motiv lava su nadgrobne ploče Stjepana Báthoryja $(\dagger 1493$.) iz Nyírbátora, Mirka (†1487.) i Stjepana Zapolje (†1499.) iz Spišske Kapitule, braće Mihaela i Antuna Pálóczyja (1519.) iz Sárospataka te tumbe Janka (†1456.) i Ladislava Hunjadija (†1457.) iz Albe Iulije. Usp. Gottfried Stangler (ur.), nav. dj., 1982., str. 166-168, 681-684 [Jolán Balogh]; Anđela Horvat, nav. dj., 1979.a, str. 312-313. ${ }^{233}$ Usp. Anđela Horvat, nav. dj., 1975., str. 351-352. 


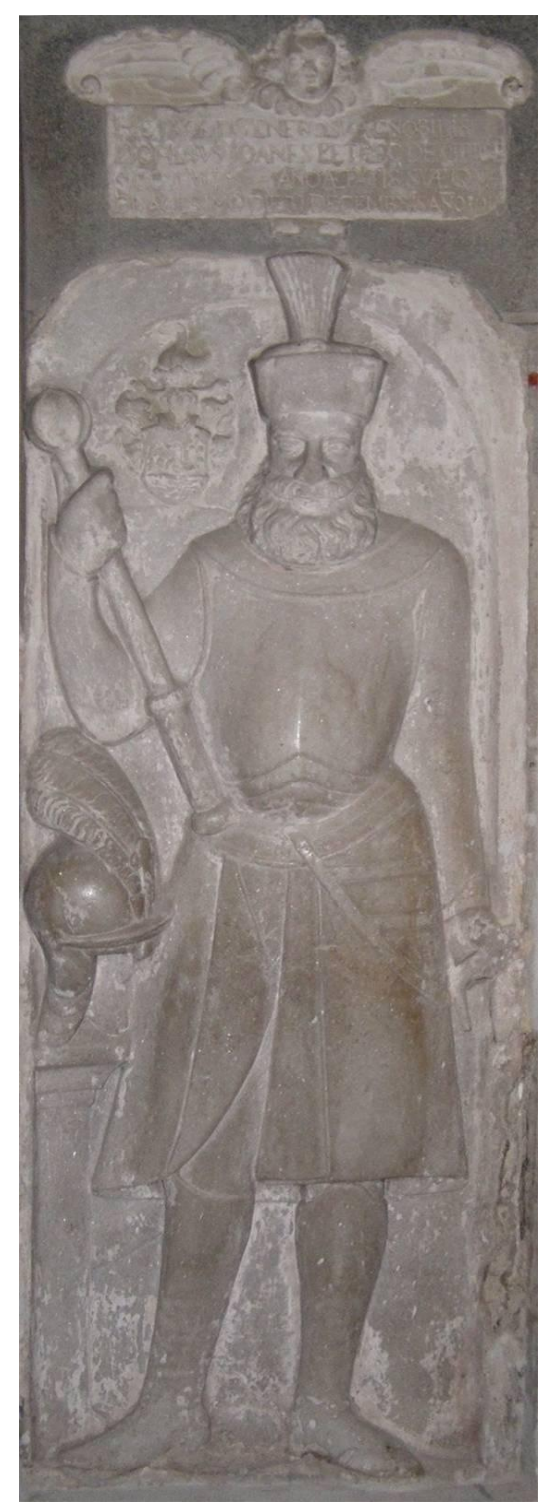

Slika 51. Nadgrobna ploča Ivana IV. Petheöa de Gerse (†1616.), Ivanec, crkva sv. Marije Magdalene

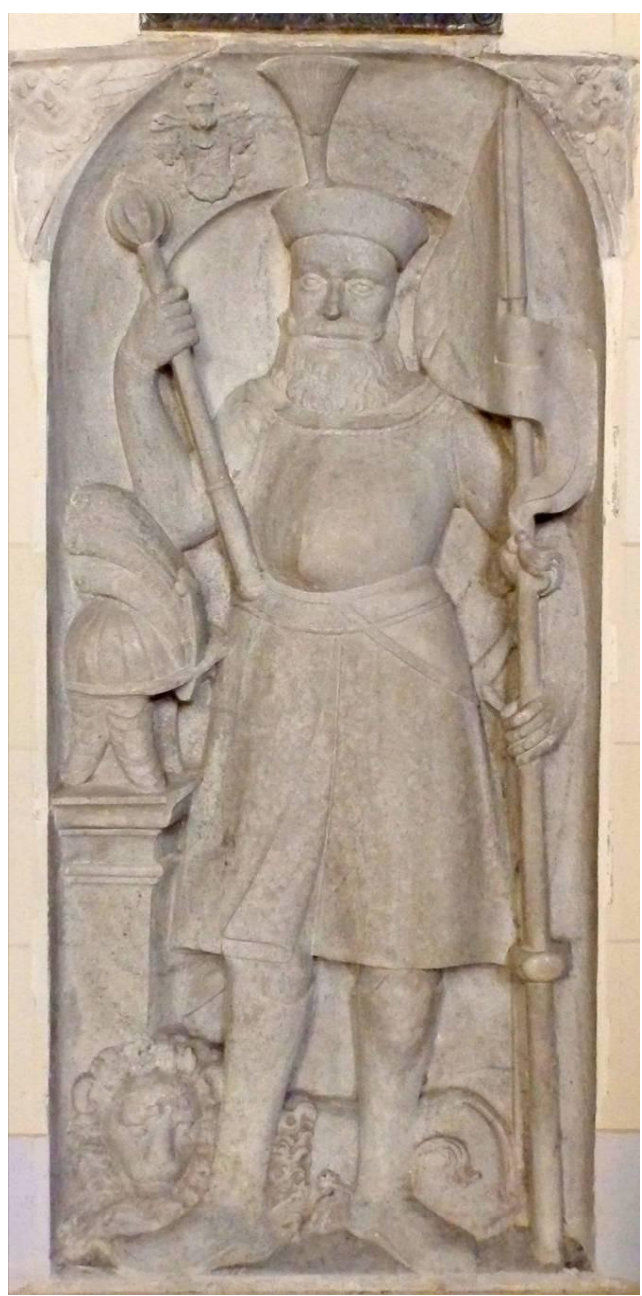

Slika 52. Nadgrobna ploča člana obitelji Vragović, I. polovina XVII. stoljeća, Maruševec, crkva sv. Jurja

obitelji $^{234}$ i one njegove supruge Suzane rođ. Ratkaj Velikotaborske ${ }^{235}$ smješteni su pri dnu nadgrobnika. Na ivanečkom spomeniku, grb obitelji Pethő de Gerse ${ }^{236}$ predočen je s desne strane pokojnikova lica. Grb obitelji Vragovic $^{237}$ isklesan je na maruševečkom nadgrobniku na luku polukružnoga otvora ispod kojega pokojnik stoji.

\footnotetext{
${ }^{234}$ Grb se sastoji od štita ukrašena plaštem, kacigom i krunom s ukrasom u obliku okrunjenoga lava koji u prednjim šapama drži barjak. Štit grba razdijeljen je na četiri jednaka polja. U prvome polju prikazan je okrunjeni orao, u drugome ukrižena viteška rukavica i sablja, u trećemu kruna na brijegu s tri vrha, a u četvrtom jednorog koji se propinje na stražnje noge. Usp. Ivan von Bojničić, nav. dj., 1889., str. 190, tab. 139.

${ }^{235} \mathrm{Grb}$ se sastoji od štita, plašta, kacige i krune $\mathrm{s}$ ukrasom u obliku grifona. Na štitu je prikazan simbol obitelji Ratkaj, bunar. Usp. Ivan von Bojničić, nav. dj., 1889., str. 157, tab. 113.

${ }^{236} \mathrm{Grb}$ se sastoji od štita, plašta, kacige i krune s ukrasom u obliku patke. Na štitu je predočen simbol obitelji patka na vodi omeđena šašem. Usp. Ivan von Bojničić, nav. dj., 1889., str. 145, tab. 104.

${ }^{237} \mathrm{Na}$ štitu grba prikazan je grifon koji u kandžama drži iščupano drvo jabuke, u čijoj se krošnji nalazi šestokraka zvijezda. Štit je ukrašen plaštem, kacigom i krunom s ukrasom u obliku krila s poprečnom gredom. Usp. Ivan von Bojničić, nav. dj., 1889., str. 202, tab. 147.
} 
Smještaj grba obitelji Vragović ukazuje na još jedan element koji je zajednički svim trima spomenicima, a to je da su pokojnici prikazani ispod polukružnoga luka. Arhitektonski okviri na nadgrobnicima - koji su u vrijeme gotike najčešće bili ukrašeni šiljastim lukovima i fijalama, a u vrijeme renesanse i baroka bili izvedeni u obliku polukružnih niša - simbolizirali su portal odnosno vrata kroz koja svaki pokojnik mora proći kada napušta ovozemaljski svijet. $^{238} \mathrm{Na}$ novovjekovnim spomenicima pilastri i lukovi često su ukrašavani klasičnim antičkim ornamentom i motivima kako bi izgledom podsjećali na trijumfalni slavoluk koji je simbolizirao pokojnikovu pobjedu nad smrću. ${ }^{239} \mathrm{Na}$ nadgrobnim pločama Thuróczyja Ludbreškoga i Vragovića ugaona polja luka ukrašena su motivom kerubina. Na sličan način urešeni su portali crkve sv. Katarine u Zagrebu (1620. - 1632.) i crkve sv. Ivana Krstitelja u Varaždinu (1650. - 1655.) koji su suvremeni viničkom i maruševečkom spomeniku.

Nadgrobnik Benedikta Thuróczyja Ludbreškoga (? - Vinica, 1616.) (Slika 50) svojom se kvalitetom izrade i materijala ističe u skupini triju spomenika. Benedikt je pripadao hrvatskom ogranku ugarske plemićke obitelji koja se krajem XVI. stoljeća uzdigla među najistaknutije obitelji Hrvatsko-Ugarskoga Kraljevstva. Obnašao je dužnost hrvatskodalmatinsko-slavonskoga bana (1615. - 1616.) nakon što je Toma II. Erdődy odstupio s toga položaja. Thuróczyjeva nadgrobna ploča isklesana je u bijelom mramoru, a izvorno je bila položena iznad plemićeve grobnice u svetištu župne crkve sv. Marka evanđelista u Vinici. ${ }^{240}$ Nakon što je stara crkva porušena (1808.) i sagrađena nova, nadgrobnik je podignut i ugrađen u sjeverni zid novoga svetišta, gdje se nalazi i danas. ${ }^{241}$ Iako je očigledno riječ o kvalitetnom radu, pojedini dijelovi nadgrobnika pomalo su nezgrapno izvedeni. Primjerice, pokojnik ne drži sablju za balčak, već je obujmljuje oko oštrice te je portretiran bez ušiju. Opisani detalji upućuju na mogućnost da je autor bio kipar manje iskusan u izradi djelā koja uključuju ljudski lik u prirodnoj veličini.

Slovenski povjesničar umjetnosti Emilijan Cevc (1981.) dosad je jedini iznio prijedlog atribucije viničkoga nadgrobnika. Pripisao ga je radionici Majstora epitafa Georga Trantnera koja je početno djelovala u Ptuju, a potom u Slovenskim Konjicama okvirno od 1610. do

\footnotetext{
${ }^{238}$ Usp. Emilijan Cevc, nav. dj., 1965., str. 154.

${ }^{239}$ Usp. Emilijan Cevc, nav. dj., 1981., str. 95.

${ }^{240}$ Usp. Juraj Rattkay, Spomen na kraljeve i banove kraljevstava Dalmacije, Hrvatske $i$ Slavonije od njihovih početaka, pa sve do ove 1652. godine koji je sastavio Juraj Rattkay od Velikog Tabora, zagrebački kanonik $i$ lektor, Zagreb: Hrvatski institut za povijest, 2001., str. 247. Prevela Zrinka Blažević et al. U kanonskim vizitacijama zapisano je da se u svetištu, kapeli i brodu crkve nalaze grobnice (tumuli) u kojima su pokopani članovi različitih velikaških obitelji, no izrijekom je naveden samo epitaf Nikole Istvánffyja (1638.). Usp. NAZ, KV, Prot. 4/IV (1638.), str. 195; Prot. 170/XIa (1771., 1777.), str. 137, 248.

${ }^{241}$ Usp. Anđelko Košćak, Župa sv. Marka Evanđelista - Vinica, Zagreb: Društvo za povjesnicu Zagrebačke nadbiskupije »Tkalčić«, Vinica: Župa Sv. Marka Evanđelista, 2013., str. 62; Biserka Vlahović, Općina Vinica, Vinica: Poglavarstvo općine Vinica, 1997., str. 40, 42; Diana Vukičević-Samaržija, nav. dj., 1993., str. 226.
} 
1650. godine, opskrbljujući kiparskim uradcima Slovensku Štajersku i dio sjeverozapadne Hrvatske. ${ }^{242}$ Radionica je dobila naziv po prvome epitafu koji se može pripisati njezinome djelovanju, a podignut je u spomen na istoimenoga slovenskog plemića koji je pokopan u župnoj crkvi sv. Jurja u Ptuju 1616. godine (Slika 53). Iako među djelima atribuiranima radionici nema nijednoga viteškog nadgrobnika (pretežito je riječ o epitafima s obiteljskim grbovima te prikazom Raspetoga i adoranata), Cevc smatra da se nadgrobna ploča Benedikta Thuróczyja može pripisati istoj radionici zbog istovjetna načina oblikovanja grbova i motiva kerubina. ${ }^{243}$ Ako detalje Thuróczyjeva nadgrobnika (Slika 55) usporedimo s radovima pripisanima radionici, posebice onima iz ranije faze njezina djelovanja poput nadgrobne ploče Anne Zakklin rođ. Keglević (†1616.) iz ptujske župne crkve (Slika 54), uočit ćemo da su grbovi i kerubini na njima uistinu slični. I na viničkom i na slovenskim nadgrobnicima grbovi se sastoje od štita konkavno oblikovanih stranica, kacige s krunom i plašta sačinjena od dva para povijenih listova akanta, a kerubini imaju slična podbuhla lica i kosu oblikovanu kao tri spojena čuperka kovrča (jedan na tjemenu i dva na sljepoočnicama). Budući da među radovima koji su pripisani radionici nema nijedan viteški nadgrobnik, teško je pronaći djelo na kojem bi se način oblikovanja ljudskoga tijela mogao usporediti s onime na Thuróczyjevu nadgrobniku (likovi zastupljeni na nadgrobnicima koje je izradila radionica uglavnom su umanjene figure adoranata i Raspetoga odnosno putti koji pridržavaju grbove). Unatoč tome, Cevcov prijedlog atribucije zasad je jedino usmjerenje koje imamo u razrješenju pitanja autorstva Thuróczyjeva nadgrobnoga spomenika.

Za razliku od viničkoga nadgrobnika, nadgrobna ploča Ivana IV. Petheőa de Gerse (?, 1576. - ?, 1616.) (Slika 51) izvedena je u običnome kamenu. Ivan IV. bio je član hrvatskoga ogranka ugarske barunske obitelji koja je u Hrvatskoj imala posjede u Beli, Ivancu i Jurketincu, a svojedobno je obnašao dužnost podžupana Varaždinske županije. Petheőva nadgrobna ploča izvorno se nalazila u dvorskoj kapeli sv. Ivana Krstitelja koja je bila smještena unutar zidina ivanečkoga kaštela, a prije izgradnje crkve sv. Marije Magdalene služila je kao župna crkva. ${ }^{244}$ Kapela više ne postoji jer je porušena 1844. godine, no prije njezina rušenja nadgrobnik je izvađen i ugrađen u južni zid broda crkve sv. Marije Magdalene, gdje je smješten danas. ${ }^{245}$

\footnotetext{
${ }^{242}$ Usp. Emilijan Cevc, nav. dj., 1981., str. 181-197.

${ }^{243}$ Usp. Emilijan Cevc, nav. dj., 1981., str. 197.

${ }^{244}$ Usp. Marijan Kraš, Ivanec: prilozi povijesti Ivanca do 1940. godine: Ivancu za šest stotu obljetnicu povodom prvoga pisanoga spomena Ivanca 1396.-1996., Varaždin: Zlati Ajngel, 1996., str. 51-52. ${ }^{245}$ Isto.
} 


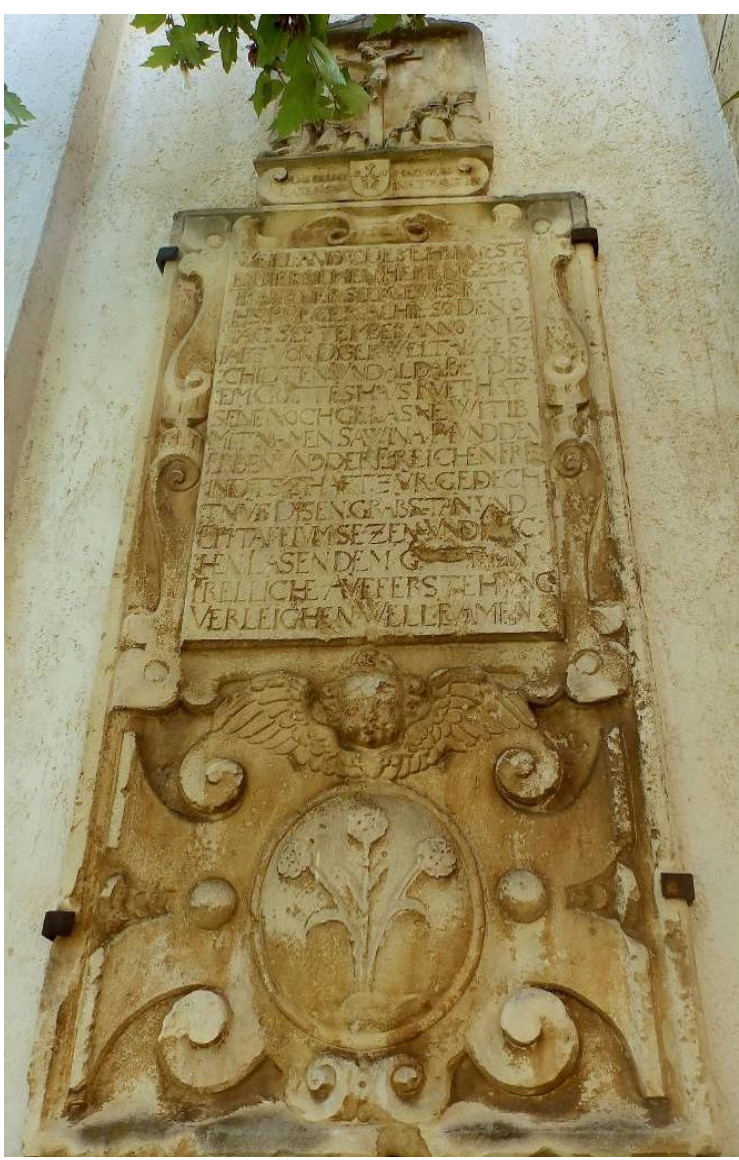

Slika 53. Radionica Majstora Trantnerova epitafa, Epitaf Georga Trantnera ( $† 1612$.), Ptuj, crkva sv. Jurja

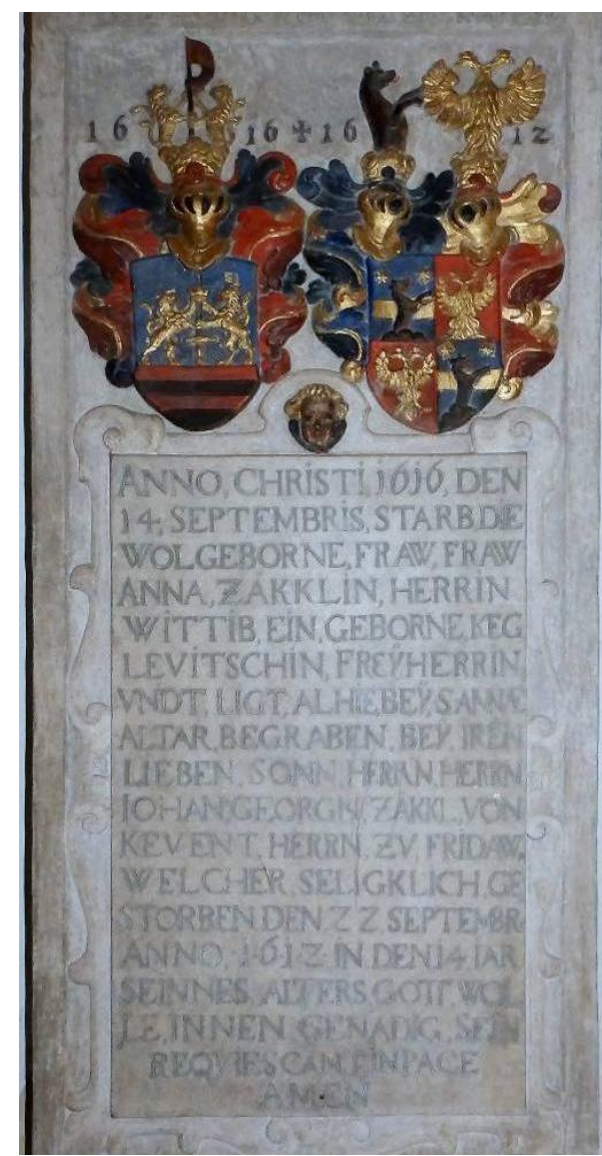

Slika 54. Radionica Majstora Trantnerova epitafa, Nadgrobnik Anne Zakklin rođ. Keglević (†1616.), Ptuj, crkva sv. Jurja
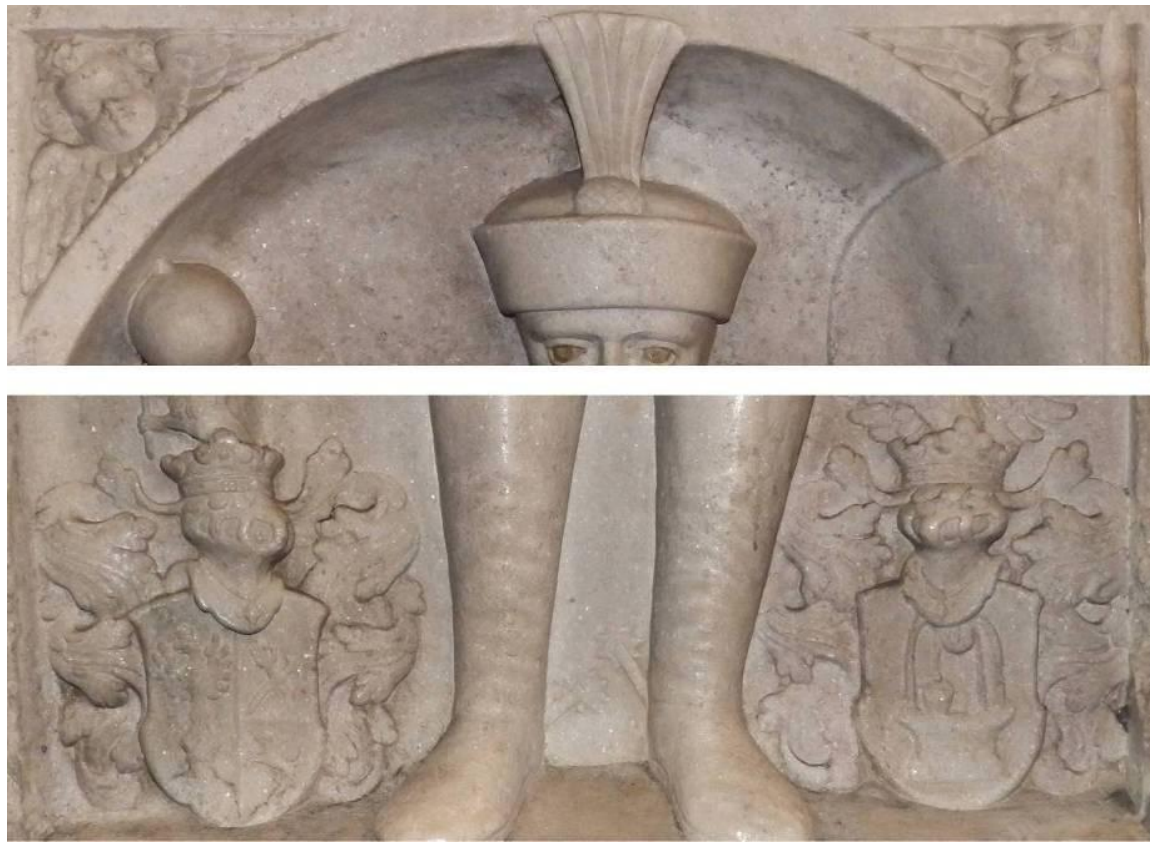

Slika 55.

Radionica

Majstora

Trantnerova

epitafa (?),

Nadgrobna ploča

Benedikta

Thuróczyja

Ludbreškoga

$(† 1616)-$. detalji

kerubina i grbova,

Vinica, crkva sv.

Marka evanđelista 
Poput Petheőva spomenika, nadgrobnik člana obitelji Vragović (Slika 52) isklesan je iz običnoga kamena. Vragovići su bili obitelj ugarskoga podrijetla s posjedima na širem varaždinskom području koja je pripadala srednjem ugarskom plemstvu, a izumrla je početkom XVIII. stoljeća. Nadgrobna ploča posvećena jednome od Vragovića ugrađena je u sjeverni zid svetišta župne crkve sv. Jurja u Maruševcu, u kojoj je obitelj imala grobnicu. ${ }^{246}$ Tamo je najvjerojatnije postavljena 1913. godine kada je prilikom temeljite obnove crkve promijenjen pod. ${ }^{247}$ Likovno je gotovo istovjetna Petheővom nadgrobniku iz Ivanca s kojom dijeli osnovne formalne stavke poput kompozicije, impostacije, tipologije lica i načina obrade površine, ali i detalje poput palca desne ruke koji je uprt o topuz, remenja sablje i nabora na haljetku. Dva se nadgrobnika razlikuju u visini reljefa (maruševečki je nadgrobnik nešto viši od ivanečkoga), izboru oružja koji pokojnici drže u lijevoj ruci (Petheő de Gerse drži sablju, a Vragović barjak) te motivu lava koji izostaje na ivanečkom spomeniku.

Očuvani dio maruševečkoga spomenika ne sadrži nadgrobni natpis zbog čega je teško utvrditi za kojega je člana obitelji podignut. Gjuro Szabo (1919.) prvi je na osnovi sličnosti nadgrobnika s onima u Vinici i Ivancu, za koje se zna da su nastali oko 1616. godine, pretpostavio da spomenik pripada Baltazaru Vragoviću (? - ?, prije 1624.) koji je 1618. godine obnovio i proširio obiteljski dvorac u Maruševcu. ${ }^{248}$ Pojedini istraživači prihvatili su njegov prijedlog identifikacije (Karaman 1950., Schneider 1972. - 1973.), ${ }^{249}$ no drugi su ipak zauzeli oprezniji stav imenujući ploču jednostavno kao nadgrobni spomenik člana obitelji Vragović (Horvat 1975., Čerpinko 2002.). ${ }^{250}$ Budući da najraniji podatci iz župne spomenice i matice umrlih datiraju iz 1740-ih i ne navode koji su Vragovići pokopani u župnoj crkvi prije toga razdoblja, ${ }^{251}$ nadgrobnik bi mogao pripadati bilo kojem muškom članu obitelji koji je obitavao na maruševečkom posjedu tijekom prve četvrtine XVII. stoljeća. Jedan od njih bio je, primjerice, Baltazarov stric Ladislav (? - ?, 1607.) koji je 1588. godine postao zakoniti nasljednik Maruševca. ${ }^{252} \mathrm{~S}$ obzirom na manjak podataka, maruševečki nadgrobnik tako je ipak najsigurnije imenovati samo kao nadgrobni spomenik člana obitelji Vragović.

Likovne sličnosti između viničkoga, ivanečkoga i maruševečkoga nadgrobnog spomenika su neosporne, no s obzirom na to da još uvijek ne znamo točno vrijeme njihova

\footnotetext{
${ }^{246}$ Kanonske vizitacije bilježe da je crkva imala podzemnu grobnicu (kriptu) pri oltaru sv. Josipa. Usp. NAZ, KV, Prot. 162/III. (1681.), str. 342-345; Prot. 164/V. (1691.), 353-355.

${ }^{247}$ Usp. Ivan Čerpinko, Maruševec, Varaždin, Maruševec: TIVA, Općina Maruševec, 2002., str. $31,33$.

${ }^{248}$ Usp. Gjuro Szabo, nav. dj., 1919., str. 89.

${ }^{249}$ Usp. Ljubo Karaman, nav. dj., 1950., str. 167; Marijana Schneider, nav. dj., 1972. - 1973., str. 259.

${ }^{250}$ Usp. Ivan Čerpinko, nav. dj., 2002., str. 32-33; Anđela Horvat, nav. dj., 1975., str. 351-352.

${ }^{251} \mathrm{Na}$ ovome podatku zahvaljujem župniku maruševečke župe vlč. Krunoslavu Milovcu.

${ }^{252}$ Usp. Ivana Šupljika, Gospodari Križovljan-grada: povijest obitelji s posebnim naglaskom na posljednjeg člana Kristofora i njegov posjed u Križovljanju (1724. - 1725.), u: Podravina: časopis za multidisciplinarna istraživanja XIII/25, Samobor: Meridijani, 2014., str. 173-196, 177.
} 
postavljanja, vrlo je teško odrediti koji je možebitno poslužio kao uzor drugim dvama. U slučaju Thuróczyjeva i Petheőva nadgrobnika, godina smrti pokojnika (1616.) može poslužiti kao orijentir u dataciji, no ona se ne mora nužno poklapati s godinom podizanja spomenika. Poznati su primjeri nadgrobnika koji su podignuti čak nekoliko desetljeća nakon smrti pokojnika, poput epitafa Martina Mogorića (†1643.) iz Marije Gorice (Slika 106) koji je postavljen više od trideset godina nakon pokojnikove pogibije (1675.). Iako ne znamo u kojoj su međusobnoj ovisnosti izrađeni i podignuti spomenici u Vinici, Ivancu i Maruševcu, možemo pretpostaviti koji je bio njihov nadređeni likovni uzor, a njega je potrebno potražiti u Požunu, nekadašnjoj prijestolnici Hrvatsko-Ugarskoga Kraljevstva.

Tijekom ranoga novog vijeka, Požun (današnja Bratislava) predstavljao je političko, trgovačko, kulturno i vjersko središte kraljevstva. Ondje su se krunili hrvatsko-ugarski kraljevi (1563. - 1830.) i održavale sjednice zajedničkoga sabora (1536. - 1848.). Novouzdignute obitelji koje nisu imale tradicionalno mjesto pokapanja često su birale požunsku katedralu sv. Martina (Slika 56) kao svoje posljednje počivalište. Ondje su sahranjivani i članovi uglednih obitelji koji su umrli (pre)daleko od obiteljskih grobnih crkava i kapela. ${ }^{253}$ U takvim slučajevima, pokop u Požunu predstavljao je jednostavnije rješenje od

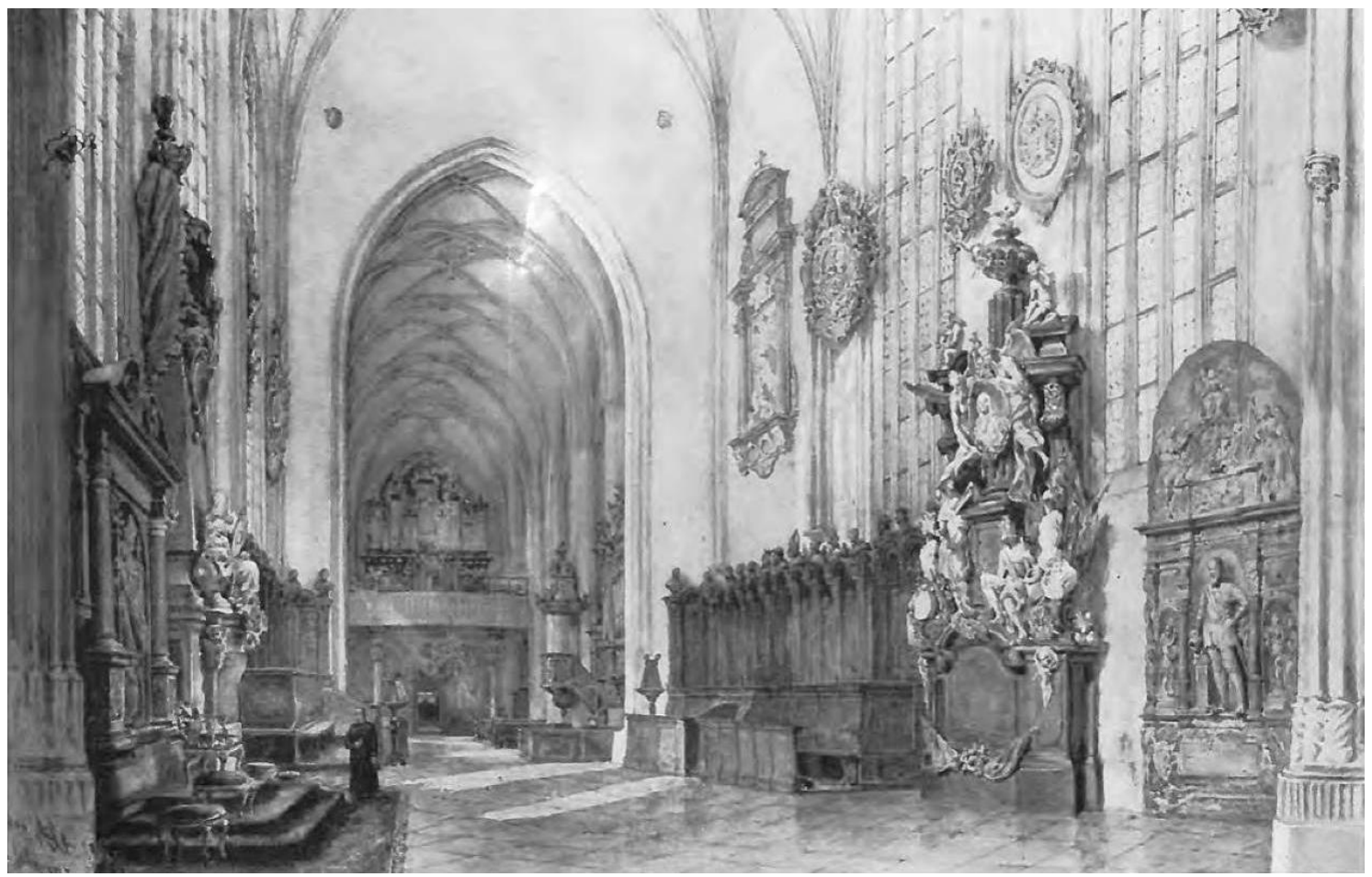

Slika 56. Franz Alt, Unutrašnjost svetišta požunske katedrale sv. Martina, 1848., Beč, Österreichische Nationalbibliothek

\footnotetext{
${ }^{253}$ Usp. Géza Pálffy, Die adelige Funeralkultur und Typen von Grabdenkmälern im Königreich Ungarn im 16. und 17. Jahrhundert, u: Macht und Memoria. Begräbniskultur europäischer Oberschichten in der frühen Neuzeit, Köln, Weimer, Wien: Böhlau Verlag, 2005., str. 483-513, 487-491. Uredio Mark Hengerer.
} 
prijenosa tijela, a katedrala sv. Martina bila je dovoljno prestižno mjesto za to. Iz opisanih razloga ondje su sahranjena i trojica Draškovića koja su preminula u Požunu ili njegovoj okolici - ban Ivan II. (?, o. 1550. - Požun, 1613.), palatin Ivan III. (Trakošćan, 1603. - Óvár, 1648.) i Nikola II. (?, o. 1630. - Požun, 1687.). Za prvu dvojicu podignuti su nadgrobni spomenici koji su očuvani do danas, a za trećega postoje opisi posmrtnoga grba (njem. Totenschild) i zastave koji su bili izloženi u katedrali tijekom i nakon njegova pogreba, no danas su na žalost izgubljeni. ${ }^{254}$

Jedan od najreprezentativnijih nadgrobnih spomenika koji su podignuti u požunskoj prvostolnici je epitaf grofa Nikole (Miklósa) II. Pálffyja od Erdőda (?, 1552. - Hrad Červený Kameň, 1600.) (Slika 57), vojskovođe i vrhovnoga kapetana gradova Požuna, Ostrogona i Novih Zamka. Prema crtežu austrijskoga slikara Franza Alta iz 1848. godine koji prikazuje unutrašnjost požunske katedrale (Slika 56), spomenik je izvorno bio izveden u obliku retabla $\mathrm{s}$ tri niše upotpunjene kipovima pokojnika i para arkanđela povrh kojih se nalazila atika $\mathrm{s}$ grbom obitelji Pálffy i skulpturama muza (nagrobnik je na crtežu prikazan u donjem desnom kutu). ${ }^{255}$ Regotizacijom katedrale u drugoj polovini XIX. stoljeća spomenik je uklonjen, a sačuvana je samo središnja niša sa skulpturom pokojnika koja je uzidana u sjeverni zid svetišta. ${ }^{256}$ Nalik zagorskim nadgrobnicima, Nikola II. Pálffy prikazan je u punom oklopu, lijeve ruke položene na oružju, a kacige odložene sa strane na postamentu. Jedina je razlika što u desnoj ruci ne drži topuz, nego njome pridržava šljem. Prema mađarskome povjesničaru umjetnosti Gézi Galavicsu (1987.), Pállfyjev nadgrobnik svojim likovnim rješenjem uvođenjem motiva postamenta i uklanjanjem elemenata gisanta - predstavlja najveći odmak od tradicionalnoga rješenja viteških nadgrobnika i približava se djelima suvremene portretistike. $^{257}$

Epitaf Nikole II. Pálffya nije prvi spomenik na kojem je primijenjeno novo likovno rješenje. Na području Kraljevine Ugarske, ono je upotrijebljeno na nadgrobniku glavnoga kapetana Gornje Ugarske Hansa Ruebera Pixendorfa (Püchsendorf, Puxendorff; †1584.,) koji je bio postavljen u katedrali sv. Elizabete u Košicama desetak godina prije Pálffyjeva. ${ }^{258}$

\footnotetext{
${ }^{254}$ Usp. Árpád Mikó i Géza Pálffy, A pozsonyi Szent Márton-templom késő reneszánsz és kora barokk siremlékei (16-17. század), u: Müvészettörténeti Értesitö LI/1-2, Budapest: Akademiai Kiado, 2002., str. 107-172, 149-151 (Ivan II.); 160-161 (Ivan III.), 165- 166 (Nikola II.).

${ }^{255}$ Usp. Géza Galavics, A magyar királyi udvar és a késö reneszáns képzömüvészet, u: Magyar reneszánsz udvari kultúra, Budapest: Gondolat, 1987., str. 228-248, 247-248. Uredila Júlia Székely; Árpád Mikó i Géza Pálffy, nav. $d j$., 2002., str. 113, 139-140.

256 Isto.

${ }^{257}$ Usp. Géza Galavics, nav. dj., 1987., str. 248.

${ }^{258}$ Usp. Géza Galavics, nav. dj., 1987., str. 247; Géza Pálffy, nav. dj., 2005., str. 506. Nadgrobni spomenik Hansa Ruebera Pixendorfa doživio je sličnu sudbinu kao onaj Nikole II. Pálffya. Obnovom katedrale uklonjen je iz svetišta, a sačuvana je samo središnja skulptura pokojnika koja je danas izložena u Mađarskoj narodnoj galeriji (Magyar Nemzeti Galeria) u Budimpešti.
} 


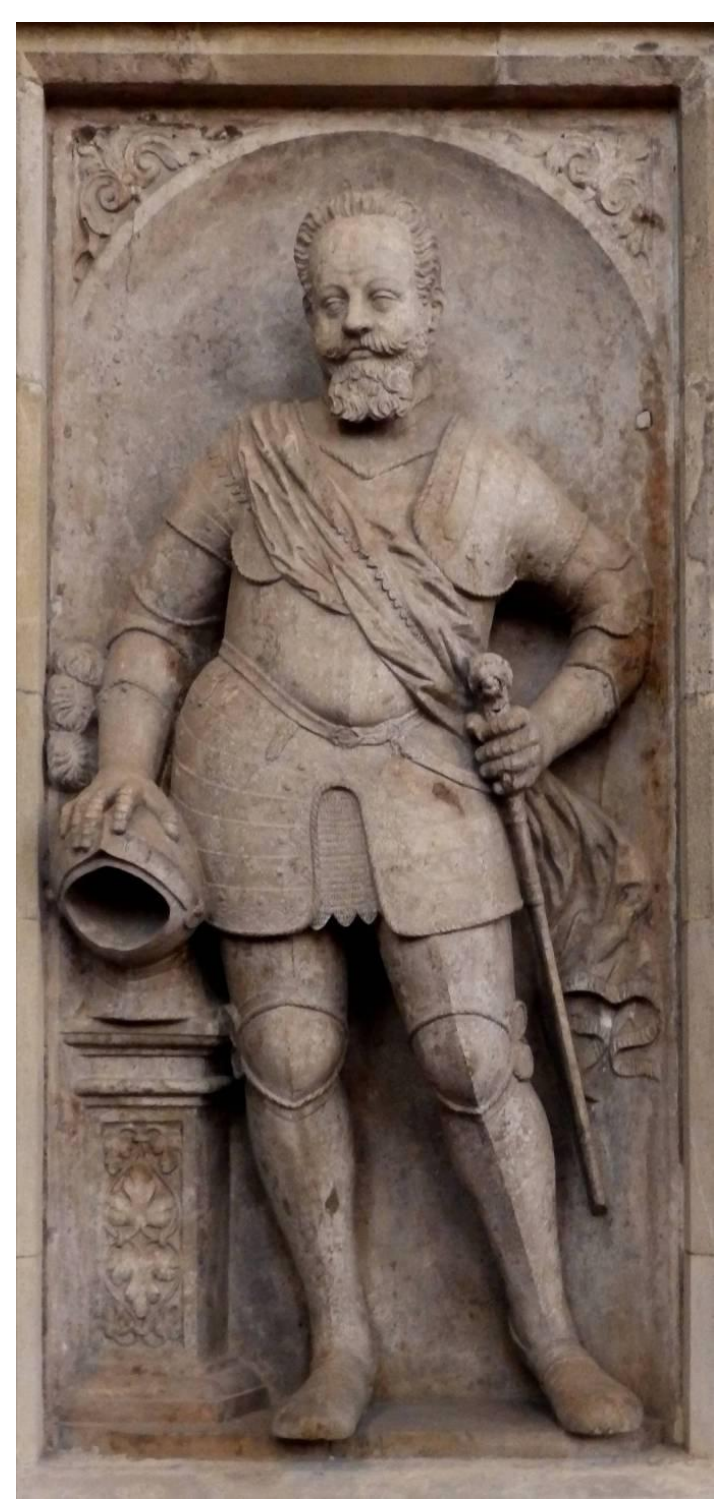

(gore lijevo) Slika 57. Caspar Menneler, Nadgrobni spomenik Nikole II. Pálffyja od Erdöda, 1601., Bratislava, katedrala sv. Martina

(gore desno) Slika 58. Nadgrobnik Petera von Mollarda (†1570.), Beč, crkva sv. Mihaela

(dolje desno) Slika 59. Epitaf Ivana II. Draškovića (†1613.), Bratislava, katedrala sv. Martina
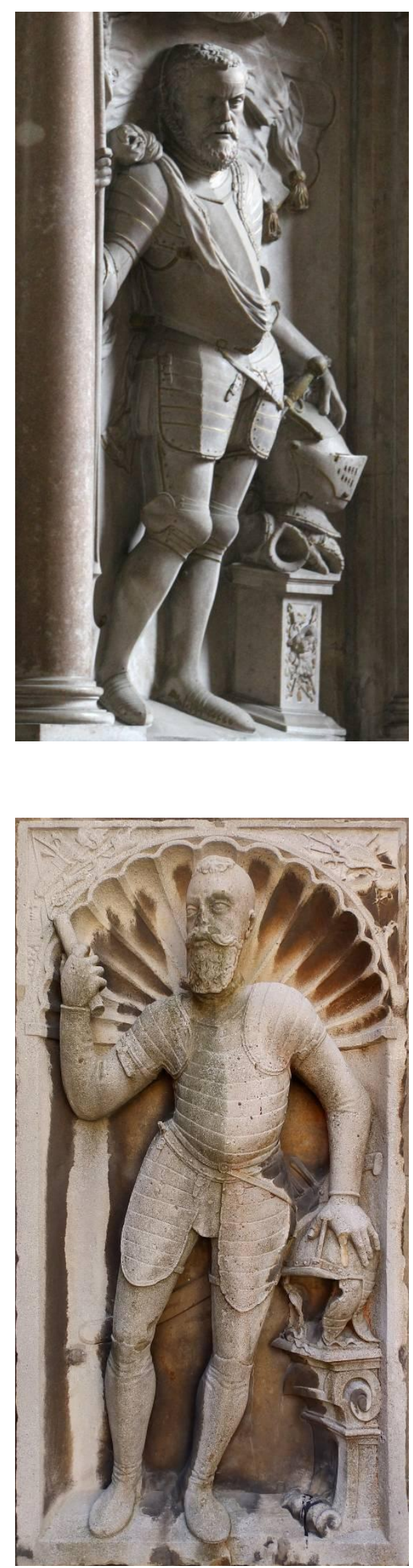
$\mathrm{Na}$ prostoru današnje Austrije, slično rješenje primijenjeno je na skupini još nešto ranijih spomenika iz crkve sv. Mihaela u Beču, poput nadgrobnikā Erasmusa I. von Gera (†1567.), vijećnika Dvorske komore i kapetana Ptuja, ili baruna Petera von Mollarda (†1570.), komornika cara i kralja Maksimilijana II. (Slika 58). Tijekom ranoga novog vijeka, bečke crkve sv. Mihaela i sv. Augustina bile su prestižno mjesto ukopa austrijskoga visokog plemstva velikim dijelom zbog njihove blizine Hofburgu, ${ }^{259}$ stoga postoji mogućnost da je likovno rješenje ugarske skupine nadgrobnika povezano sa spomenicima u Beču. Iako nije bio prvi u nizu, Pálffyjev spomenik neizmjerno je važan jer je poslužio kao uzor brojnim nadgrobnicima podignutima $\mathrm{u}$ spomen na svjetovne velikodostojnike diljem HrvatskoUgarskoga Kraljevstva, poput onih palatina Istvána Illésházyja (†1609.) iz župne crkve u Pezinoku, navedenoga Ivana II. Draškovića (†1613.) iz požunske katedrale sv. Martina (Slika 59), palatina Györgya Thurzóa (†1617.) iz dvorske kapele u Oravskom dvorcu, pa čak i epitafa Tome II. Erdődyja (†1624.) iz zagrebačke katedrale (Slika 102) (potonji spomenik detaljno je prikazan u narednom potpoglavlju). ${ }^{260} \mathrm{~S}$ obzirom na to da kompozicijom prate izgled Pálffyjeva nadgrobnika, ovoj skupini tako možemo pribrojiti i nadgrobne spomenike Benedikta Thuróczyja Ludbreškoga iz Vinice, Ivana Petheőa de Gerse iz Ivanca i Vragovića iz Maruševca.

Prije nego što se osvrnemo na viteške epitafe, potrebno je posvetiti se pitanju identifikacije nadgrobne ploče člana obitelji Zrinski (Slika 46) iz nekadašnje pavlinske samostanske crkve u Šenkovcu, koje je u prethodnom dijelu rasprave stavljeno na stranu. Kao što je objašnjeno, taj problem nije razrađen u sklopu analize samoga nadgrobnika jer je njegovo razumijevanje povezano s nadgrobnim spomenicima nastalima u XVII. stoljeću koji $\mathrm{u}$ tom dijelu elaborata još nisu razrađeni. S obzirom na to da su u ovome dijelu disertacije obrađeni svi relevatni spomenici, u narednim odlomcima pokušat ćemo dati odgovor na postavljeno pitanje.

Sačuvani dijelovi nadgrobnika člana obitelji Zrinski ne sadrže nadgrobni natpis, što je primoralo istraživače da se u odgonetanju pokojnikova identiteta koriste povijesnim izvorima i komparativnim likovnim primjerima. Prema povijesnim podatcima, u obiteljskoj grobnici u pavlinskoj crkvi u Šenkovcu sahranjena su četiri pokoljenja Zrinskih. Od njih, članovi koji su

\footnotetext{
${ }^{259}$ Usp. Mark Hengerer, Zur symbolischen Dimension eines sozialen Phänomens: Adelsgräber in der Residenz (Wien im 17. Jahrhundert), u: Wien im Dreißigjährigen Krieg, Wien: Böhlau, 2001., str. 250-352, 283, 297-298. Uredio Andreas Weigl; Mark Hengerer, Adelsgräber im Wien des 18. Jahrhunderts: Beobachtungen zu einer Archäologie des adeligen Gedächtnisses, u: Macht und Memoria. Begräbnisskultur europäischer Oberschichten in der Frühen Neuzeit, Köln: Böhlau, 2005., str. 381-420, 383-392. Uredio Mark Hengerer.

${ }^{260}$ Usp. Géza Galavics, nav. dj., 1987., str. 248; Árpád Mikó i Géza Pálffy, nav. dj., 2002., str. 113; Géza Pálffy, nav. dj., 2005., str. 506-507, 512.
} 
se svojim djelovanjem dovoljno istakli da bi za njih bio podignut takav reprezentativan spomenik su: Nikola IV. (Zrin, 1508. - Siget, 1566.; banovao 1542. - 1556.), ban i vojskovođa koji je poginuo u opsadi Sigeta; njegov sin Juraj IV. (?,1549. - Vép, 1603.), jedini član obitelji koji je otvoreno prigrlio protestantizam; unuk Juraj V. (Čakovec, 1599. - Požun, 1626.; banovao 1622. - 1626.), ban, kraljev savjetnik i komornik koji se vratio u okrilje Rimokatoličke crkve; i praunuk Nikola VII. (Čakovec, 1620. - Gornji Kuršanec, 1664.; banovao 1647. - 1664.), ban, vojskovođa, diplomat i pjesnik koji je slovio kao velik ljubitelj umjetnosti i kolekcionar. ${ }^{261}$

Dosadašnji istraživači pripisali su nadgrobnik različitim članovima obitelji. Kao prvi koji je pronašao ulomke i opisao ih, Emilij Laszowski (1924., 1928.) smatrao je da spomenik pripada najmlađem Zrinskom od navedenih, Nikoli VII. ${ }^{262}$ Anđela Horvat (1956.) prihvatila je njegovu pretpostavku, no ujedno je ukazala na mogućnost da bi nadgrobnik mogao biti podignut za Jurja V., Nikolina oca. ${ }^{263} \mathrm{Ni}$ Laszowski ni Horvat nisu potkrijepili svoje tvrdnje konkretnim argumentima. Marijana Schneider (1958.) u početku je smatrala da nadgrobna ploča pripada Nikoli VII., ${ }^{264}$ no poslije (1972. - 1973.) se opredijelila za mišljenje da je ipak riječ o nadgrobniku Jurja V., navodeći za to dva argumenta. Prvi je sličnost pokojnikova lica s poznatim Jurinim grafičkim portretima, a drugi činjenica da su viteški nadgrobnici doživjeli »svoj posljednji cvat upravo u prvim desetljećima XVII. stoljeća, što se poklapa s vremenom Jurjeve smrti ${ }^{265}$ Kao potkrijepu drugome argumentu navela je komparativne primjere nadgrobnih ploča Nikole I. Mlakovečkoga (†1603.) (Slika 49), Benedikta Thuróczyja Ludbreškoga (†1616.) (Slika 50), Ivana IV. Petheőa de Gerse $(† 1616$.$) (Slika 51) i Vragovića$ (I. pol. XVII. st.) (Slika 52) koji su svi nastali u prvoj polovini XVII. stoljeća, zaključivši da bi pripisivanjem nadgrobne ploče Nikoli VII. (†1664.) spomenik bio vremenski potpuno osamljen i anakroničan.

Korpus sačuvanih nadgrobnika pokazuje da je tvrdnja Marijane Schneider o maloj vjerojatnosti da šenkovečki spomenik predočava Nikolu VII. Zrinskoga točna. Viteški gisanti prestali su se primjenjivati na području povijesne Zagrebačke biskupije krajem XVI. stoljeća, stoga se čini neizglednim da bi Nikola VII. ili njegovi baštinici naručili spomenik zastarjela izgleda. Međutim, argumenti kojima Schneider potkrijepljuje tezu da je nadgrobnik izvorno

\footnotetext{
${ }^{261}$ Usp. Vladimir Kalšan, Međimurska povijest, Čakovec: Vladimir Kalšan, 2006., str. 72, 86, 96, 119.

${ }^{262}$ Usp. Emilij Laszowski, nav. dj., 1924., str. 20; Emilij Laszowski, nav. dj., 1928., str. 259.

${ }^{263}$ Usp. Anđela Horvat, Spomenici arhitekture i likovnih umjetnosti u Međimurju, Zagreb: [Konzervatorski zavod], 1956., str. 51.

${ }^{264}$ Usp. Marijana Schneider, nav. dj., 1958., str. 108-110.

${ }^{265}$ Marijana Schneider, nav. dj., 1972. - 1973., str. 258.
} 
podignut za Jurja V. podjednako su dvojbeni. Naime, ako lice s nadgrobne ploče (Slika 60) usporedimo s poznatim portretima Jurja V. (Slika 63), može nam se činiti da oni međusobno nalikuju. No, ako to isto lice usporedimo s onime Gašpara I. Draškovića (Slika 61), uočit ćemo da su i ona slična. Srodnost licā na dotičnim nadgrobnicima proizlazi iz činjenice što ona ne predstavljaju pravi portret, već tip portreta. Do istoga ćemo zaključka doći ako usporedimo lica na nadgrobnim pločama Franje Tahyja (Slika 44) i Petra II. Ratkaja (Slika 45) ili onih Benedikta Thuróczyja Ludbreškoga, Ivana IV. Petheőa de Gerse i Vragovića (Slika 62). Dodatno, postoje portreti drugih Zrinskih koji nalikuju nadgrobniku, poput drvoreza Nikole IV. objavljenoga u knjizi Johanna Sommera Vita Jacobi despotae Moldavorum reguli (Wittenberg, 1587.) (Slika 64). ${ }^{266}$ Iz navedenoga možemo zaključiti da sličnost između nadgrobnika i suvremenih portreta nije pouzdana pomoć u identifikaciji. Nadalje, viteški nadgrobnici koje je Schneider navela kao komparativne primjere - onaj Nikole I. Mlakovečkoga, Benedikta Thuróczyja Ludbreškoga, Ivana IV. Petheőa de Gerse i Vragovića - dijele određene sličnosti sa spomenikom Zrinskoga, no prate drugi likovni obrazac. Nadgrobnik Zrinskoga još uvijek pripada viteškim gisantima, a spomenici Thuróczyja Ludbreškoga, Petheőa de Gerse i Vragovića prate novi likovni tip temeljen na suvremenoj portretistici. Nadgrobna ploča iz Šenkovca svojim je likovnim rješenjem sličnija nadgrobnicima Franje Tahyja (†1573.) (Slika 40), Petra II. Ratkaja (†1586.) (Slika 41) i Gašpara I. Draškovića (†1591.) (Slika 37) koji su nastali u posljednjoj četvrtini XVI. stoljeća, od tri do pet desteljeća prije smrti Jurja V.

Od članova obitelji Zrinski koji su mogli naručiti šenkovečki nadgrobnik tako su preostali Nikola IV. i njegov sin Juraj IV. Milan Pelc (2007., 2012.) prvi je naveo da bi ploča mogla pripadati Nikoli IV. koji je poginuo pod Sigetom, no nije detaljnije razložio svoje argumente. ${ }^{267}$ Istoga je mišljenja i Marijana Korunek (2014.) koja je komparativnom analizom isključila mogućnost da je riječ o nadgrobniku Jurja IV. i zaključno ga pripisala Nikoli IV. ${ }^{268}$ U usporedbi je upotrijebila dva para nadgrobnih spomenika sličnih oblikovnih karakteristika. Prvi par čine nadgrobne ploče Franje Tahyja (†1573.) (Slika 40) i Gašpara I. Draškovića (†1591.) (Slika 37), a drugi one Nikole I. Mlakovečkoga (†1603.) (Slika 49) i Ivana III. Zrinskoga (?, 1565. - Vyšší Brod, 1612.). Ivan III. bio je najmlađi sin Nikole IV. kojega je majka Eva Rožmberk nakon suprugove pogibije odvela u Češku, gdje se oženio i umro

\footnotetext{
${ }^{266}$ Usp. Artur Schneider, O nekim manje poznatim portretima Nikole Zrinskog, u: Narodna starina II/5, Zagreb: Josip Matasović, 1923., str. 161-164, 163-164.

${ }^{267}$ Usp. Milan Pelc, nav. dj., 2007., str. 315; Milan Pelc, nav. dj., 2012., str. 236.

${ }^{268}$ Usp. Marijana Korunek, Pavlinski samostan u Šenkovcu i grofovi Zrinski, u: Croatica Christiana periodica XXXVIII/73, Zagreb: Katolički bogoslovni fakultet, 2014., str. 51-70, 67-69.
} 


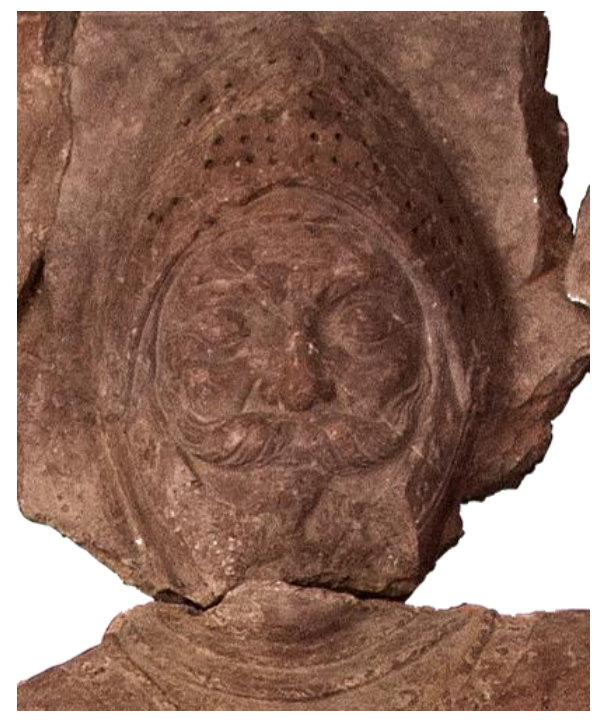

(lijevo) Slika 60.

Detalj lica nadgrobne

ploče Nikole IV.

Zrinskoga (?)

(†1566.), Čakovec,

Muzej Međimurja

(desno) Slika 61.

Detalj lica nadgrobne ploče Gašpara I.

Draškovića (†1591.),

Bednja, crkva sv.

Marije Magdalene
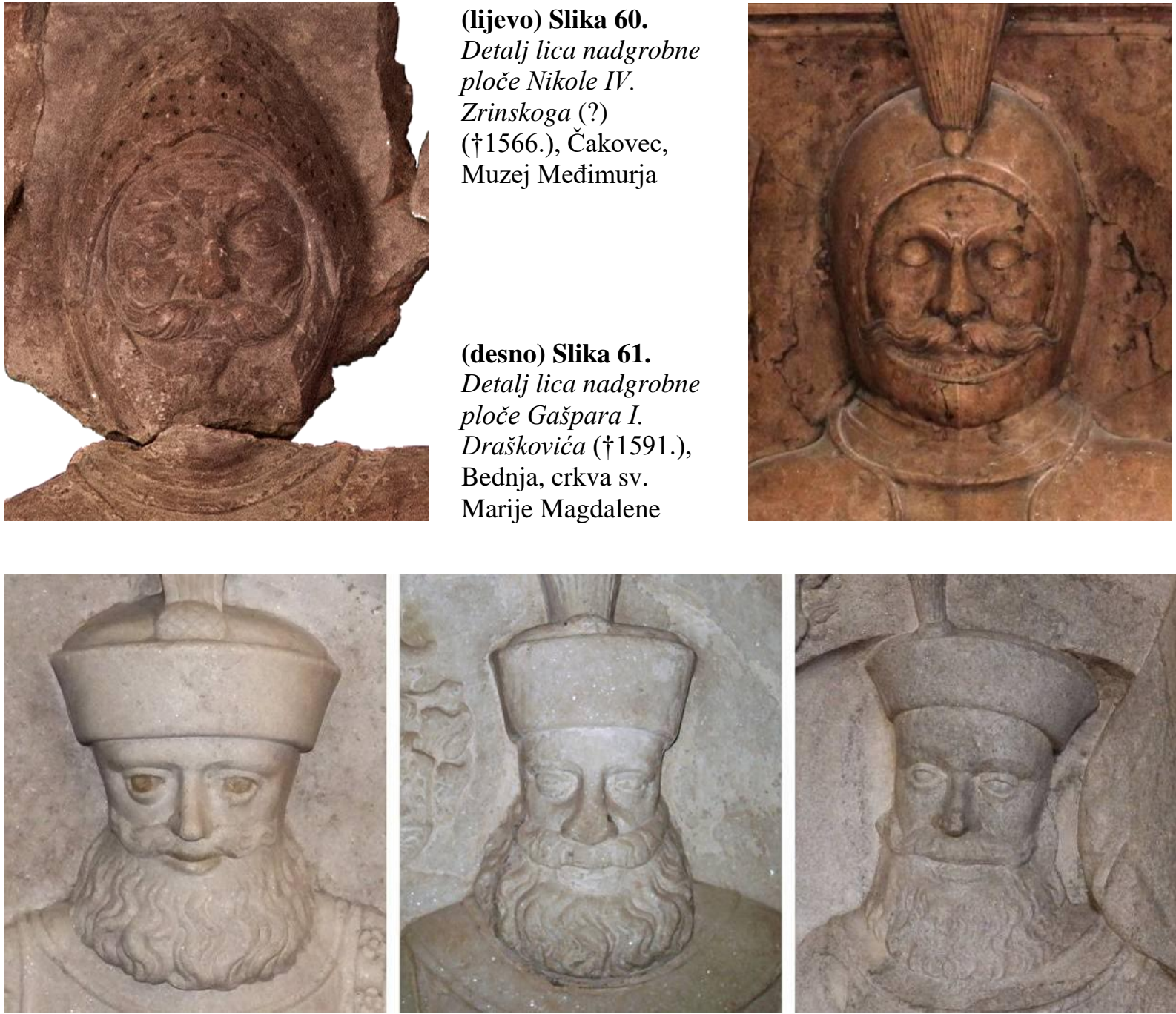

Slika 62. Detalji lica s nadgrobnih ploča (redom): Benedikta Thuróczyja Ludbreškoga (†1616.) iz Vinice, Ivana IV. Petheöa de Gerse (†1616.) iz Ivanca i Vragovića iz Maruševca

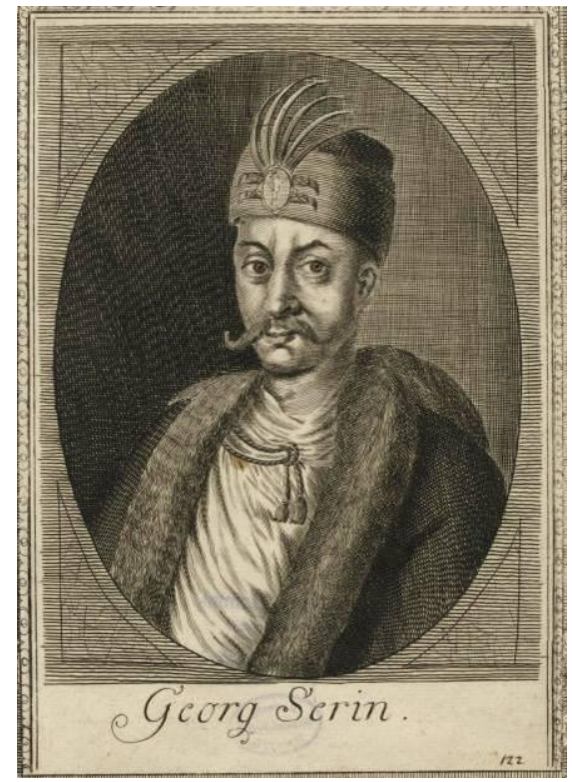

(lijevo) Slika 63.

Portret Jurja V.

Zrinskoga, bakrorez iz

knjige Franza Christopha

Khevenhüllera

»Conterfet

Kupfferstich... deren jenigen regierenden grossen Herren",

Leipzig, 1722.

(desno) Slika 64.

Portret Nikole IV.

Zrinskoga, drvorez iz

knjige Johanna Sommera

»Vita Jacobi despotae

Moldavorum reguli«,

Wittenberg, 1587.

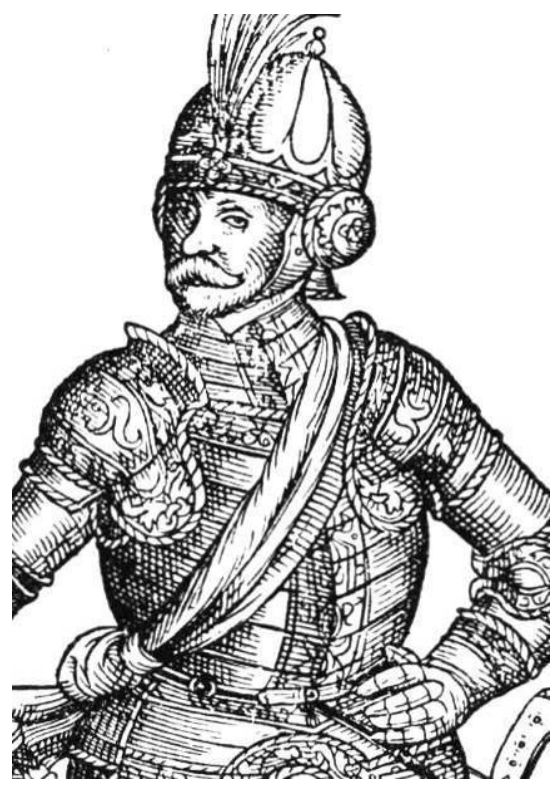


(pokopan je u cistercitskom samostanu u Vyššem Brodu). ${ }^{269}$ Razmatrajući oblikovne značajke šenkovečkoga nadgrobnika, Korunek je zaključila da ga njegova morfologija, plošna obrada te »izrazito idealizirano i stilizirano lice« čine srodnijim Tahyjevu i Draškovićevu nadgrobniku, odnosno da nema dovoljno naglašen volumen i portretne karakteristike poput nadgrobnika Nikole I. Mlakovečkoga i Ivana III. Zrinskoga. ${ }^{270}$ Budući da su Tahy i Drašković bili suvremenici Nikole IV., a Mlakovečki i Ivan III. Jurja IV., autorica je zaključila da ulomci šenkovečkoga nadgrobnika pripadaju Nikoli IV.

Kao generalizirano pravilo, istina je da visina reljefa na nadgrobnim spomenicima smjenom stoljeća raste od niskoga prema visokome. Međutim, taj razvojni slijed nije najpouzdanija smjernica $\mathrm{u}$ dataciji spomenika jer postoji mnogo iznimaka uvjetovanih različitim čimbenicima, poput umješnosti kipara ili želje naručitelja. Primjerice, nadgrobnik Ivana IV. Petheőa de Gerse nastao je u prvoj polovini XVII. stoljeća, a izveden je u plićem reljefu od nadgrobne ploče Zrinskoga. Nadgrobna ploča biskupa Nikole III. Ogramića Olovčića (Slika 29) nastala je još kasnije, početkom XVIII. stoljeća, a isklesana je u najnižem reljefu od svih navedenih. Stoga opažanje Marijane Korunek da šenkovečka ploča pripada Nikoli IV. jer je isklesana u nižem reljefu od one Nikole I. Mlakovečkoga ne nosi dovoljnu težinu. Nadalje, tipizacija lica koju autorica koristi kao drugi argument nije svojstvena samo početnim stoljećima ranoga novog vijeka. $\mathrm{Na}$ području povijesne Zagrebačke biskupije primjenjivala se i u XVII. stoljeću, što dokazuju nadgrobnici Thuróczyja, Petheőa de Gerse i Vragovića (Slika 62). Stoga manja ili veća portretnost lica pokojnika također nije pouzdana smjernica u određivanju vremena nastanka nekoga spomenika. Međutim, Korunek je bila u pravu kada je govorila o sličnom »općem pristupu i morfologiji« između nadgrobne ploče Zrinskoga te onih Gašpara I. Draškovića (†1591.) (Slika 37) i Franje Tahyja (†1573.) (Slika 40), ${ }^{271} \mathrm{~s}$ time da bismo ovome nizu mogli pridodati i nadgrobnu ploču Petra II. Ratkaja (†1586.) (Slika 41). Naime, navedeni nadgrobnici dijele određene oblikovne značajke i tip likovnoga rješenja gisanta, to jest srodni su po primjeni stroge frontalnosti, impostaciji tijela, tipizaciji lica, oblikovanju oklopa te upotrebi motiva jastuka odnosno barjaka. Budući da su nadgrobnici Draškovića, Tahyja i Ratkaja izrađeni u drugoj polovini XVI. stoljeća, izgledno

\footnotetext{
${ }^{269}$ Autorica je u članku pogrešno pripisala nadgrobnu ploču Ivanu II., najstarijem sinu Nikole IV. i Katarine Frankapan koji je umro s nepunih godinu dana 1545. godine. Nikolin najmlađi sin kojega je imao s Evom Rožmberk i koji je većinu života proveo u Češkoj, gdje je i umro, bio je Ivan III. Usp. Károly Széchy, Gróf Zrínyi Miklós 1620-1664, Knjiga 1, Poglavlje 1. Családi hagyományok és vérbeli öröklések, Budimpešta: Magyar Történelmi Társulat, 1902. Mrežno izdanje. Pristupljeno 30. 9. 2020. <https://www.arcanum.hu/hu/online-kiadvanyok/MagyarTortenetiEletrajzok-magyar-torteneti-eletrajzokBE5D/grof-zrinyi-miklos-16201664-5CAF/elso-kotet-5CB0/i-csaladi-hagyomanyok-es-verbeli-oroklesek$5 \mathrm{CBB} />$

${ }^{270}$ Marijana Korunek, nav. dj., 2014., str. 69.

271 Isto.
} 
je da je šenkovečki nadgrobnik nastao u slično vrijeme. Inozemni primjeri nadgrobnika na kojima je primijenjeno isto likovno rješenje kao i na nadgrobnoj ploči Zrinskoga - gisant glave oslonjene na jastuk koji u ruci drži barjak - datiraju s kraja XV. i XVI. stoljeća. ${ }^{272} \mathrm{U}$ sljedećem, XVII. stoljeću to se rješenje napušta, upravo kao što sugerira očuvani korpus nadgrobnih spomenika Zagrebačke povijesne biskupije. Shodne tome, izglednije je da je šenkovečka nadgrobna ploča izvorno postavljena za Nikolu IV. Zrinskoga $(\dagger 1566$.), a ne njegova sina Jurja IV. $(† 1603$.$) .$

$$
* * *
$$

Nakon što su se pojavili na području Zagrebačke povijesne biskupije u drugoj polovini XVI. stoljeća, epitafi su u narednih stotinu godina postali dominantna vrsta nadgrobnoga spomenika. Za razliku od nadgrobnih ploča čiji su oblik i dimenzije bili ograničeni ukopnim mjestom ili ulazom u kriptu koje su pokrivale, epitafi su postavljani na zid i nisu bili neposredno vezani za grob zbog čega su mogli varirati veličinom i oblikom. Tradicionalni motiv viteza-pokojnika koji se primjenjivao na nadgrobnim pločama bez većih je promjena prenesen na epitafe. Epitafi su tako sadržavali lik pokojnika odjevena u viteški oklop s pripadajućim insignijama i obiteljskim grbom koji je određivao njegovu pripadnost rodu i društvenom staležu. Na području Zagrebačke (nad)biskupije sačuvana su dva epitafa sa samostalnim likom viteza-pokojnika, onaj Gottfrieda Falmhaubta (†1641.) iz Varaždina i obitelji Češković (1711.) iz Lepoglave.

Predsjednik Dvorskoga ratnog vijeća i kraljev komornik Gottfried Falmhaubt (Falbenhaubt; ? - Varaždin?, 1641.) služio je kao zapovjednik u Vojnoj krajini, a pokopan je u franjevačkoj crkvi sv. Ivana Krstitelja u Varaždinu, sjedištu Varaždinskoga generalata. Njegov epitaf (Slika 65) ${ }^{273}$ ugrađen je u sjeverni zid svetišta, uz vrata sakristije. U gornjem dijelu spomenika prikazan je pokojnik odjeven u viteški oklop, s kacigom na glavi. Ispod podignutoga vizira vidljivo je njegovo raspoloženo, gotovo nasmijano lice. U desnoj ruci pridržava zapovjedničku palicu, a lijevu drži oslonjenu o bok. Njegova impostacija nalikuje onoj Nikole I. Mlakovečkoga (Slika 49) s početka stoljeća, jedino što Falmhaubt stoji u kontrapostu širega raskoračenog stava i desne ruke postavljene dalje od tijela. Uz pokojnikovu lijevu nogu nalazi se štit ukrašen volutama i krunom na kojem su prikazani simboli obitelji

\footnotetext{
272 Kao podsjetnik navodimo nadgrobne spomenike Istvána II. Báthoryja (†1493.), Marka (Horvata) Mišljenovića od Kamičca (†1508.), Istvána Máriássyja (†1516.), braće Antala i Mihálya Pálóczyja (1519.), Györgya Serédyja (†1557.), Jánosa II. i Jánosa V. Thuróczyja (o. 1558.) te Istvána Dobóa (†1572.). Svi primjeri navedeni su u prethodnom dijelu poglavlja, u formalno-komparativnoj analizi nadgrobne ploče Zrinskoga (str. 66-67).

${ }^{273}$ Mramor, $192 \times 104,5 \times 9$ cm, Varaždin, crkva sv. Ivana Krstitelja. Kat. br. 67.
} 


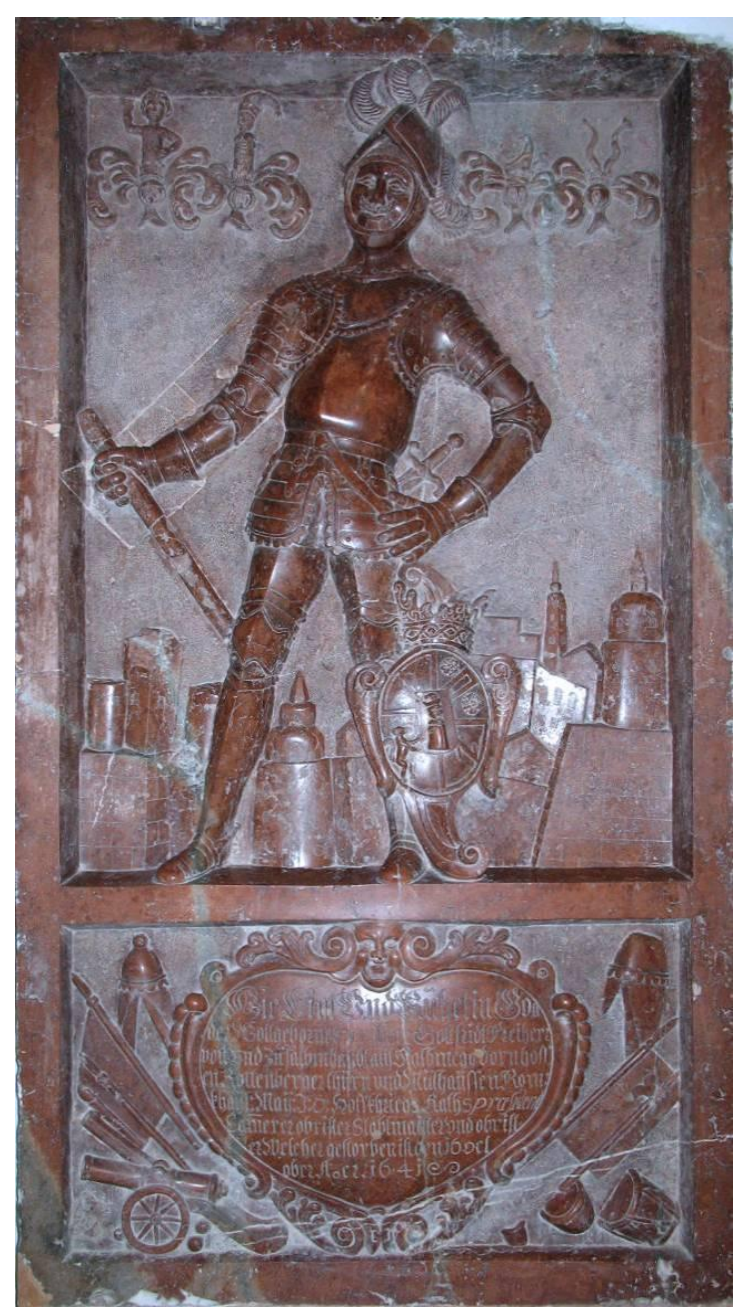

Slika 65. Epitaf Gottfrieda Falmhaubta (†1641.), Varaždin, crkva sv. Ivana Krstitelja

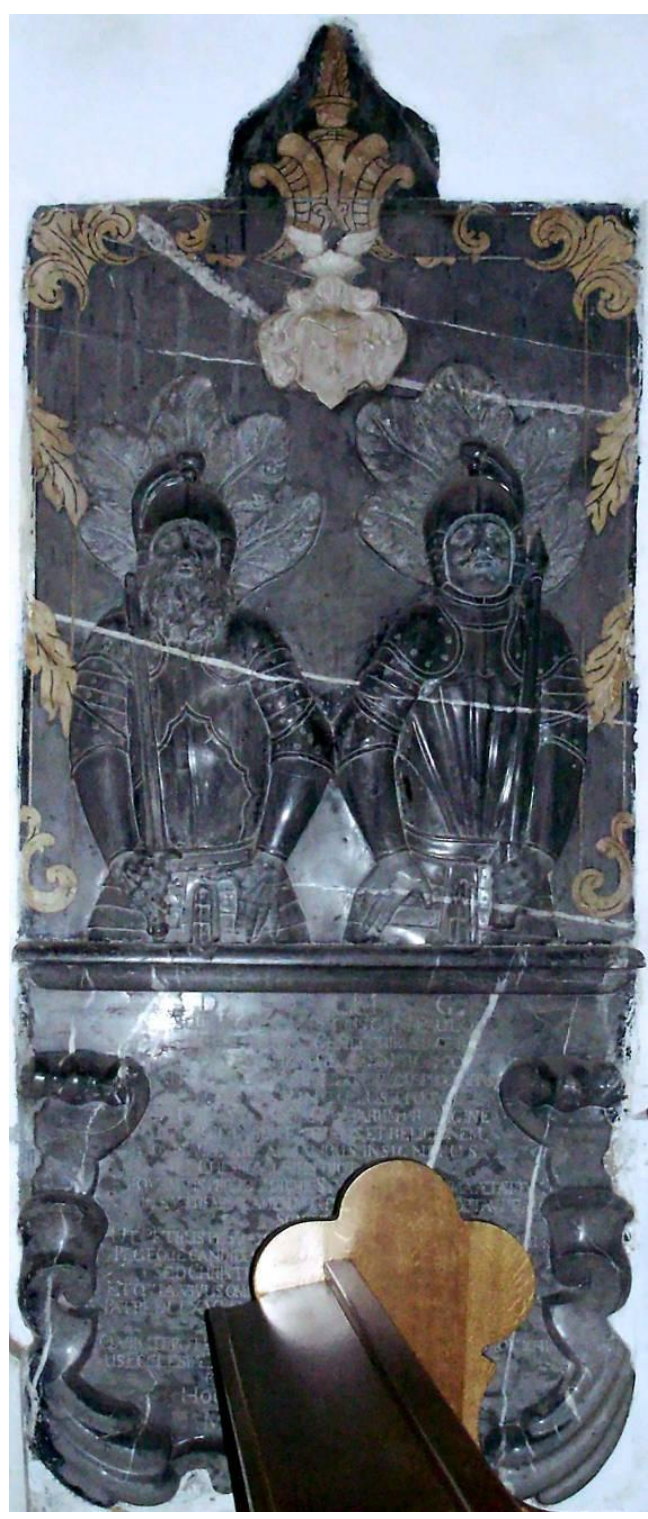

Slika 66. Epitaf obitelji Češković, 1711., Lepoglava, crkva Bezgrješnoga začeća Blažene Djevice Marije

Falmhaubt. ${ }^{274}$ Uz gornji rub epitafa, s lijeve i desne strane pokojnika predočene su po dvije kacige ukrašene plaštevima, krunama i nakitom izvedenim u obliku muškarca, dvorske lude, kune i para rogova (navedeni motivi sastavni su dio grba obitelji Falmhaubt). Iza pokojnika, u niskom reljefu isklesan je capriccio nebeskoga Jeruzalema s mnoštvom tornjeva. Varaždinski epitaf jedini je nadgrobnik sačuvan na području povijesne Zagrebačke biskupije koji sadrži prikaz nebeskoga grada, a njegovoj posebnosti doprinosi i činjenica da su takve vedute

\footnotetext{
${ }^{274}$ Štit grba razdijeljen je na četiri jednaka polja sa srcem štita (štitićem) u sredini. U prvome i četvrtome polju prikazan je znak u obliku slova $N$, u drugome kosa lijeva greda iznad i ispod koje se nalazi po jedna ruža, a u trećemu kuna. U srcu štita predočen je muškarac s kapom. Usp. Johann Siebmacher, Das erneuerte und vermehrte Teutsche Wappenbuch: in welchem deß H. Römischen Reiches hohe Potentaten ... Wappen, Schilde, Helm, Kleinodien ... zu ersehen: Des Neuen Wappenbuchs Fünffter und Letzter Theil, Nürnberg: Fürst, [o. 1665.], str. 19.
} 
učestalije na nadgrobnim spomenicima s prikazom Raspeća i adoranata nego viteškim nadgrobnicima. ${ }^{275} \mathrm{U}$ donjem dijelu spomenika, ispod figuralnoga prikaza nalazi se kartuša urešena maskeronom, viticama repovlja i hrskavicom unutar koje je ispisan nadgrobni natpis na gotici, a okružena je ratnim trofejima (bubnjevima, barjacima, topovima, vojnim šatorima) koji ukazuju na pokojnikov vojni poziv.

Analizirajući varaždinski epitaf, Anđela Horvat (1975., 1982.) prepoznala je u Falmhaubtovoj dinamičnoj pozi naznake baroknoga stila. ${ }^{276}$ Impostacija pokojnikova tijela doista daje liku dojam živosti, no širina njegova raskoračenoga stava čini pozu pomalo nezgrapnom i prenaglašenom. Ako se tome pridodaju neskladne proporcije pokojnikova tijela (trup i glava preveliki su u odnosu na noge), perspektivna neujednačenost koja proizlazi iz upotrebe dvaju očišta (normalnoga za lik pokojnika i povišenoga za vedutu) te upotreba manirističke hrskavice, ovaj spomenik stilski bismo odredili više kao kasnomaniristički nego barokni.

Posljednji viteški nadgrobnik podignut je na području povijesne Zagrebačke biskupije početkom XVIII. stoljeća, a posvećen je obitelji Češković (Slika 66). ${ }^{277}$ Ugrađen je u sjeverni zid broda crkve Bezgrješnoga začeća Blažene Djevice Marije u Lepoglavi, uz oltar sv. Pavla Pustinjaka. Prema natpisu, postavio ga je zagrebački prepošt Pavao Antun Češković (Bednja, 1652. - Zagreb, 1724.) u spomen na svoje roditelje Katarinu i Pavla starijega $(\dagger 1666$.) te brata Pavla mlađega (†1709.) 1711. godine. Izveden u crnome kamenu s bijelim $i$ žutim inkrustacijama, epitaf se sastoji od dva dijela gotovo jednake veličine. Gornja polovica sadrži pravokutni okvir unutar kojega je prikazan par vitezova, a donja polovica nadgrobni natpis. Okvir koji omeđuje portrete dvojice vitezova ukrašen je vegetabilnim motivima i antefiksom u obliku baklje (simbol vječnoga života odnosno života nakon smrti), ${ }^{278}$ koji su izvedeni u inkrustaciji žutoga kamena. Vitezovi su prikazani en face, no za razliku od ostalih nadgrobnika nisu prikazani u punoj visini, već ih kadar reže ispod pāsa. Lijevi je predočen kao stariji muškarac duge brade i brkova koji u desnoj ruci drži mač. Desni, mlađi muškarac ima samo brkove, a u lijevoj ruci drži zapovjedničku palicu. Pretpostavlja se da stariji vitez predstavlja Pavla starijega, a mlađi njegova sina Pavla mlađega. ${ }^{279}$ Pozadina iza pokojnikovih glava ukrašena je dvama lisnatim motivima koji su zamijenili motiv jastuka s viteških gisanta,

\footnotetext{
${ }^{275}$ Usp. Géza Pálffy, nav. dj., 2002., str. 504.

${ }^{276}$ Usp. Anđela Horvat, nav. dj., 1975., str. 353; Anđela Horvat, nav. dj., 1982.a, str. 265.

277 Crni, bijeli i žuti kamen, $255 \times 109 \times 12 \mathrm{~cm}$, Lepoglava, crkva Bezgrješnoga začeća Blažene Djevice Marije. Kat. br. 58.

${ }^{278}$ Usp. Slavko Šterk i Boris Mašić, nav. dj., 2014., str. 55.

${ }^{279}$ Usp. Ivo Lentić, nav. dj., 1982., str. 54.
} 
a povrh njih nalazi se grb obitelji Češković ${ }^{280}$ izveden u inkrustaciji bijeloga kamena. Dvojni portreti na nadgrobnim spomenicima nisu rijetka pojava - jedan primjer predstavlja nadgrobna ploča Martina IV. Frankapana (†1479.) iz franjevačke crkve na Trsatu na kojoj su prikazane Martinove dvije supruge - no ovo je jedini takav primjer očuvan na području povijesne Zagrebačke biskupije. Izuzev načina kadriranja, na epitafu obitelji Češković primijenjeno je isto likovno rješenje koje se primjenjivalo na nadgrobnim spomenicima tijekom srednjega i ranoga novog vijeka, što pokazuje u kojoj je mjeri nadgrobno kiparstvo ukorijenjeno u tradiciji i koliko dugo upotrebljava ustaljene likovne obrasce.

U pregledu Barok u kontinentalnoj Hrvatskoj (1982.), Anđela Horvat svrstala je epitaf Češkovićevih među umjetnička djela baroknoga stila, no nije specificirala njegove stilske odrednice. ${ }^{281}$ Iako kompozicija nadgrobnika prati tradicionalna rješenja i nema izričita stilska obilježja, odraz baroka može se iščitati u realističnoj izvedbi lica pokojnikā, naturalističkoj izvedbi njihovih ruku (posebice onih starijega viteza s istaknutim žilama), svrdlastoj obradi brade starijega viteza te različitoj obradi površine (od uglačane površine većine nadgrobnika do hrapave površine lisnatih motiva).

U posljednjoj četvrtini XVIII. stoljeća nastao je još jedan epitaf koji predstavlja u potpunosti jedinstven primjer na području povijesne Zagrebačke biskupije. Riječ je o epitafu Petra Troila Sermagea od Susedgrada (Brdovec, 1722. - Stenjevec, 1771.) $\left(\right.$ Slika 67) ${ }^{282}$ iz župne crkve Uznesenja Blažene Djevice Marije u Stenjevcu koji se razlikuje od ostalih po tome što portret pokojnika (Slika 68) nije isklesan u reljefu, nego je naslikan na limenoj podlozi. Iako je u ovome pregledu uvršten među viteške nadgrobnike, pokojnik nije odjeven u oklop nego časničku odoru. Naime, tijekom prve polovine XVIII. stoljeća vojnici su postupno prestali koristiti viteške oklope izuzev konjanika koji su nosili samo prsno-leđni oklop, takozvani kiras (eng. cuirass, fr. cuirasse) ${ }^{283}$ Pripadnici ostalih postrojbi nosili su odore koje su pratile građanski stil odijevanja. Odjeća u kojoj je pokojnik portretiran tako predstavlja suvremenu vojnu odoru, upravo kao što je to predstavljao oklop tijekom prethodnih stoljeća. Epitaf se u tom pogledu nadovezuje na tradiciju viteških nadgrobnika i iz toga je razloga uključen u istu skupinu spomenika.

\footnotetext{
${ }^{280}$ Grb se sastoji od štita ukrašena plaštem, kacigom, krunom i nakitom u obliku para raširenih krila. Na štitu je prikazan lav koji prednjim šapama drži mač (jednom šapom drži mač za balčak, a drugom za oštricu). Usp. Ivan von Bojničić, nav. dj., 1889., str. 28, tab. 21.

${ }^{281}$ Usp. Anđela Horvat, nav. dj., 1982.a, str. 266.

282 Mramor, kamen, ulje na bakrenoj ploči, cijeli spomenik $215 \times 94 \times 8 \mathrm{~cm}$, oval s portretom $33 \times 29 \mathrm{~cm}$, Stenjevec, crkva Uznesenja Blažene Djevice Marije. Kat. br. 25.

${ }_{283}$ Usp. Marinko Ogorec, Povijest vojnih odora: Francuska avangarda, u: Hrvatski vojnik: prvi hrvatski vojnostručni magazin 597, mrežno izdanje. Ministarstvo obrane Republike Hrvatske, Samostalna služba za odnose s javnošću i izdavaštvo, Odjel hrvatskih vojnih glasila i izdavaštva, veljača 2020. Pristupljeno 10. 10. 2020. <https://hrvatski-vojnik.hr/povijest-vojnih-odora-francuska-avangarda/>
} 


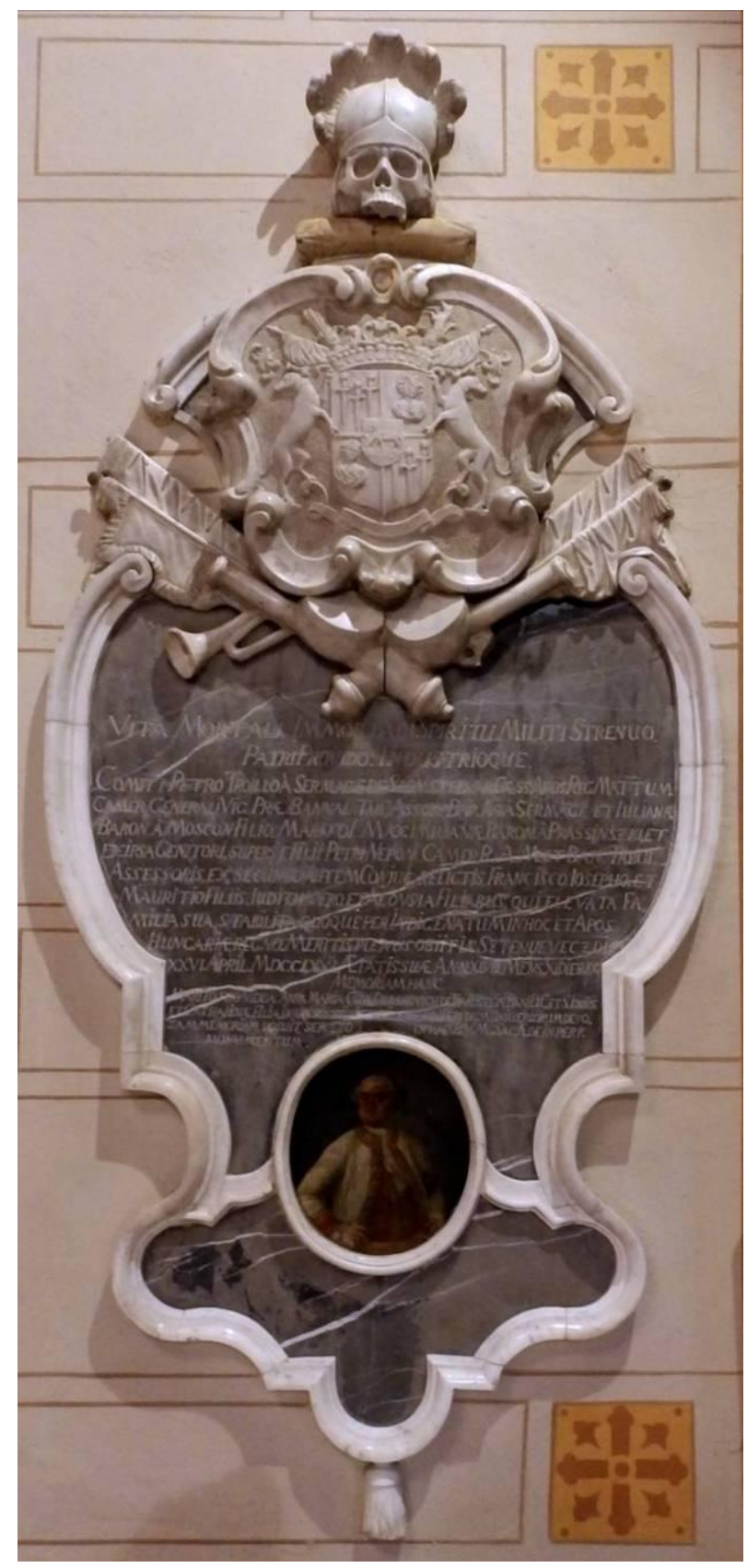

(lijevo) Slika 67. Epitaf Petra Troila Sermagea od Susedgrada, o. 1773., Stenjevec, crkva Uznesenja Blažene Djevice Marije

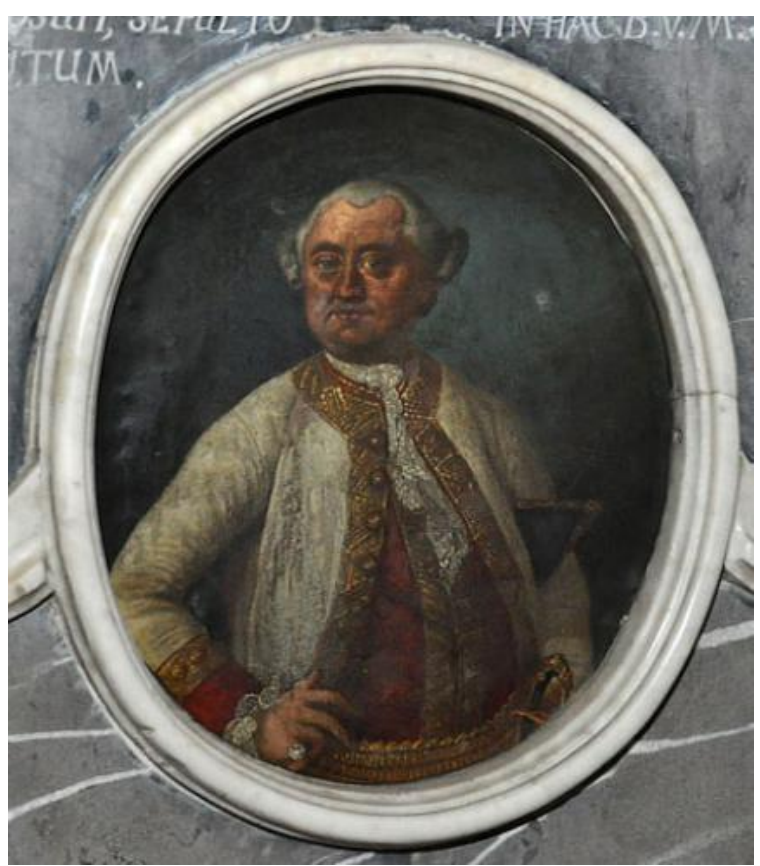

Slika 68. Michael Milluz, Portret Petra Troila Sermagea od Susedgrada, 1773., Stenjevec, crkva Uznesenja Blažene Djevice Marije

Kao sin tajnika karlovačkoga generala koji je doselio iz Francuske u Hrvatsku, Petar Troilo Sermage nastavio je obiteljsku tradiciju služenja u Vojnoj krajini, gdje je stekao čin generala. Sudjelovao je u Ratu za austrijsku baštinu (1740. - 1748.) i Sedmogodišnjem ratu (1756. - 1763.), a godine 1749. primio je grofovsku titulu. Preminuo je u Stenjevcu te je pokopan u tamošnjoj župnoj crkvi gdje mu je supruga Ana Marija rođ. Drašković podigla nadgrobni spomenik. ${ }^{284}$ Postavljen na južnom zidu svetišta, epitaf je izveden u obliku kartuše profiliranoga ruba. U gornjem dijelu kartuše - nalik slici unutar slike - nalazi se druga, manja

${ }^{284}$ Podatak o narudžbi spomenika poznat je iz nadgrobnoga natpisa (»MEMORIAM HANC/ MERITO SUO VIDUA, ANNA MARIA COM. DRASKOVICH DE TRAKOSTEIN...«). Za puni prijepis natpisa vidi kat. br. 25. 
kartuša $\mathrm{s}$ bogato ukrašenim grbom obitelji Sermage. ${ }^{285}$ Povrh nje smještena je lubanja $\mathrm{s}$ kacigom urešenom perjanicom, a ispod ratni trofeji (par ukriženih barjaka s bojnim bubnjevima i trubama). U središnjem dijelu spomenika uklesan je dugi natpis o pokojniku, njegovoj obitelji i dostignućima, a podno natpisa smješten je navedeni portret pokojnika izveden u tehnici ulja na bakrenoj ploči, koji je izradio pictor Michael Milluz iz Beča dvije godine nakon pokojnikove smrti (1773.). ${ }^{286}$ General Sermage prikazan je iznad pojasa, tijela okrenuta u lijevi, a glave u desni tričetvrt profil, pogleda usmjerena prema promatraču. Odjeven je u bijeli kaput sa zlatnim obrubom i pucetima, crveni prsluk i košulju s čipkastim orukvicama. Oko vrata nosi čipkastu maramu, na glavi bijelu periku, a ispod lijeve ruke drži trorogi šešir. Kontrastno usmjerenje tijela i glave portretiranoga, upotreba dvostruke kartuše koja asocira na quadro riportato i alegoričnost lubanje koja poput živućih nosi kacigu dodatno naglašavajući poruku memento mori koju nosi - daju spomeniku jasne odlike baroknoga stila.

Iako epitaf Petra Troila Sermagea predstavlja jedini nadgrobni spomenik na području Zagrebačke (nad)biskupije koji uključuje slikani portret pokojnika, takva vrsta posmrtnoga portreta nije neuobičajena u okvirima europske funeralne umjetnosti. U Poljskoj je, primjerice, od kasnoga XVI. do početka XIX. stoljeća jedan od osnovnih dijelova katafalka bio slikani portret pokojnika koji se pričvršćivao na uznožje lijesa. ${ }^{287}$ Portreti su formatom bili prilagođeni obliku lijesa (najčešće su bili šesterokutna ili osmerokutna oblika), a najvećim su dijelom slikani na metalnoj podlozi (bakru, kositru ili olovu). Pokojnici su uglavnom prikazivani iznad pojasa, en face ili u tričetvrt profilu, u prirodnoj ili neznatno umanjenoj veličini. ${ }^{288}$ Portreti su u početku polagani s lijesom u grob, no sredinom XVII. stoljeća počeli su se postavljati na zidove crkava uz posmrtne grbove, nadgrobne natpise i druge predmete koji su korišteni tijekom posmrtnih svečanosti. Na području Kraljevine Ugarske postojala je

\footnotetext{
${ }^{285}$ Grb je prikazan unutar manje kartuše. Štit grba razdijeljen je na četiri jednaka polja sa srcem štita (štitićem) smještenim u sredini. U prvom i četvrtom polju vodoravno su poredana tri novčića, a ispod svakoga nalazi se po jedan bodež oštricom okrenut prema dolje. U drugom i trećem polju predočeno je poprsje mlade žene. U srcu štita nalazi se jelen koji pase travu. Štit sa svake strane drži po jedan hrt podignut na stražnje noge, a ukrašen je krunom iznad koje se nalazi par ukriženih barjaka i dvije kacige. Lijeva kaciga ukrašena je krilom, a desna motivom psa. Ispod štita nalazi se lenta s pokojnikovim geslom: »ARTE ET MARTE« (Umijećem i srčanošću). Usp. Ivan von Bojničić, nav. dj., 1889., str. 167, tab. 121.

${ }^{286}$ Usp. Anđela Horvat, nav. dj., 1982.a, str. 265; Anđela Horvat, Crkva Uznesenja Blažene Djevice Marije u Stenjevcu, u: Župa Uznesenja Marijina Stenjevec: u povodu 650. obljetnice prvog spomena župe (1334-1984) $i$ 730. obljetnice gradnje crkve Bl. Dj. Marije (1257-1987), Zagreb, Stenjevec: Rkt župa Stenjevec, 1985.a, str. 83-141, 137. Uredili Ivan Buhin i Anđelko Mijatović.

${ }^{287}$ Usp. Bartłomiej Łyczak, The Coffin Portrait and Celebration of Death in Polish-Lithuanian Commonwealth in the Modern Period, u: Ikon: Časopis za ikonografske studije 4, Rijeka: Filozofski fakultet Sveučilišta u Rijeci, 2011., str. 233-241, 235. Uredila Marina Vicelja-Matijašić.

${ }^{288}$ Usp. Bartłomiej Łyczak, nav. dj., 2011., str. 238-240.
} 
slična praksa izlaganja slikanoga portreta preminuloga kao sastavnoga dijela katafalka. ${ }^{289}$ Međutim, na tim portretima pokojnici nisu prikazivani kao žive osobe, nego su predočeni nakon svoje smrti, tijela položenih na odar. S obzirom na to da je portret Petra Troila Sermagea nastao dvije godine nakon generalove smrti, možemo zaključiti da nije bio izložen na odru tijekom posmrtne svečanosti održane u pokojnikovu čast. Međutim, zanimljivo je uočiti sličnosti koje on dijeli s poljskim posmrtnim portretima, poput materijala i tehnike (ulje na bakru) te načina prikazivanja pokojnika.

Prije nego što se posvetimo epitafima na kojima su pokojnici uklopljeni u složeniji figuralni prikaz kao adoranti, kratko ćemo se osvrnuti na ranonovovjekovno portretno slikarstvo i grafiku koji su imali jak utjecaj na nadgrobnu skulpturu, posebice viteške nadgrobnike. Nakon cezure srednjega vijeka, portret se ponovno javio kao tema u europskoj umjetnosti krajem XIV. stoljeća, a doživio je procvat u vrijeme renesanse razvojem individualizma i shvaćanjem pojedinca kao neponovljive jedinke. ${ }^{290}$ Utjecaj suvremenoga portretnog slikarstva na nadgrobne spomenike prvenstveno je vidljiv u promjeni impostacije lika pokojnikā. Njihova ukočena i statična tijela prikazana u strogom frontalnom položaju postupno se opuštaju i prelaze u kontrapost zakrenut u polu ili tričetvrt profil. Od viteških nadgrobnika sačuvanih na području Zagrebačke (nad)biskupije, prve naznake kontraposta javljaju se na nadgrobnim pločama Ivaniša Korvina (†1504.) i Petra II. Erdődyja (†1567.), no prvi pravi kontrapost primijenjen je tek na nadgrobnoj ploči Nikole I. Mlakovečkoga (†1603.) početkom XVII. stoljeća (Slika 69).

Kao što je navedeno, jedan od prvih nadgrobnih spomenika koji pokazuje najveći odmak od tradicionalnoga tipa viteških nadgrobnika i svojim se likovnim rješenjem najviše približava suvremenim portretima jest epitaf Nikole II. Pálffyja (†1600.) (Slika 57) iz požunske prvostolnice. ${ }^{291}$ Izuzev već postojećih promjena u impostaciji lika, najveći novitet na Pálffyjevu nadgrobniku predstavlja postament na kojem je odložena pokojnikova kaciga. Ovo rješenje ima svoje uporište u petnaestostoljetnim portretima vladara i vojskovođa (Slike 70 i 71) na kojima portretirani - odjeveni u viteški oklop - u ruci drže zapovjedničku palicu, a njihovi atributi odloženi su sa strane na stolu ili postamentu (na portretima vladarā najčešće je riječ o kruni, žezlu i jabuci, a na portretima vojskovođā o kacigi). Prateći trendove, pripadnici plemstva prihvatili su nove stilske promjene, kako $\mathrm{u}$ portretnoj umjetnosti (Slike 72 i 73) tako i u nadgrobnoj plastici. Na području povijesne Zagrebačke biskupije

\footnotetext{
${ }^{289}$ Usp. Géza Pálffy, nav. dj., 2005., str. 501-502.

${ }^{290}$ Usp. Josip Bilić (ur.), Likovni leksikon, Zagreb: Leksikografski zavod Miroslav Krleža, 2014., sub voce portet, str. 746.

${ }^{291}$ Usp. Géza Galavics, nav. dj., 1987., str. 246-247.
} 

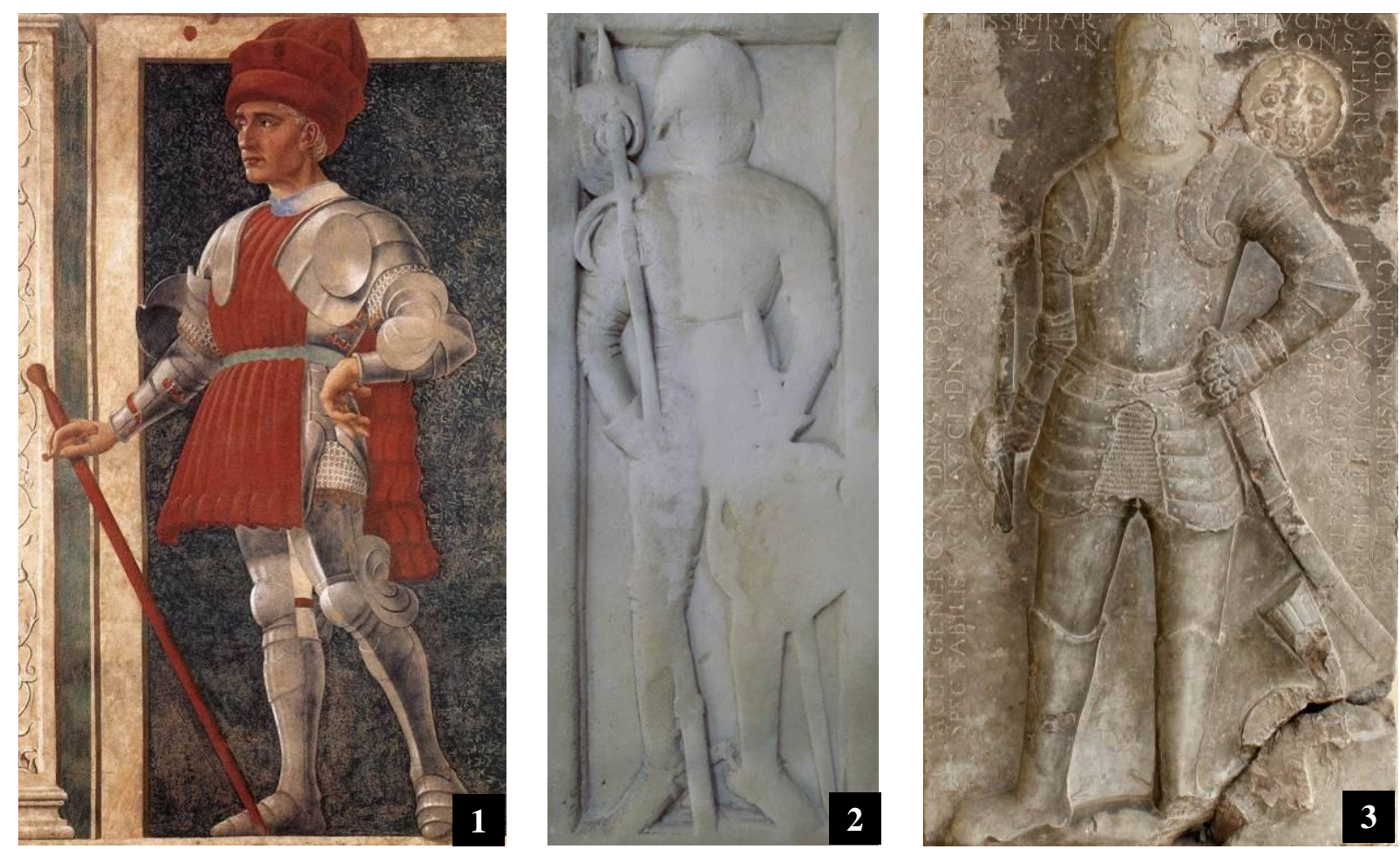

Slika 69. Primjena kontraposta u portretnom slikarstvu i nadgrobnoj plastici

69.1. Andrea del Castagno, Slavne osobe: Farinata degli Uberti, o. 1450., Firenca, Galleria degli Uffizi

69.2. Nadgrobna ploča Ivaniša Korvina, 1505., Lepoglava, crkva Bezgrješnoga začeća Blažene Djevice Marije

69.3. Nadgrobna ploča Nikole I. Mlakovečkoga (†1603.), Čakovec, Muzej Međimurja

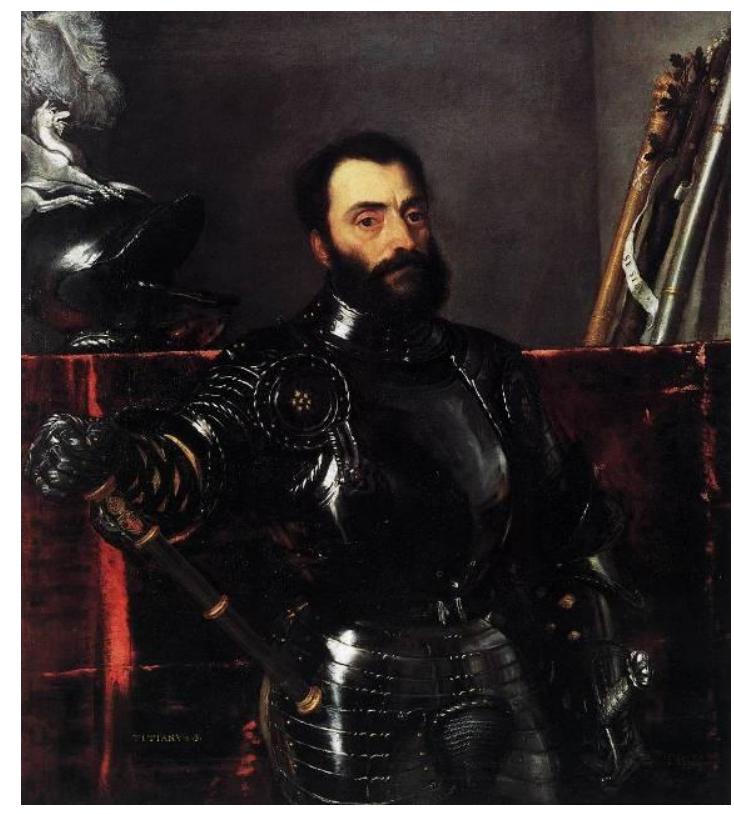

(gore) Slika 70. Tiziano Vecellio, Portret Francesca Marije I. della Rovere, 1536. 1538., Firenca, Galleria degli Uffizi

(desno) Slika 71. Tiziano Vecellio, Portret Filipa II. u oklopu, 1550. - 1551., Madrid, Museo del Prado

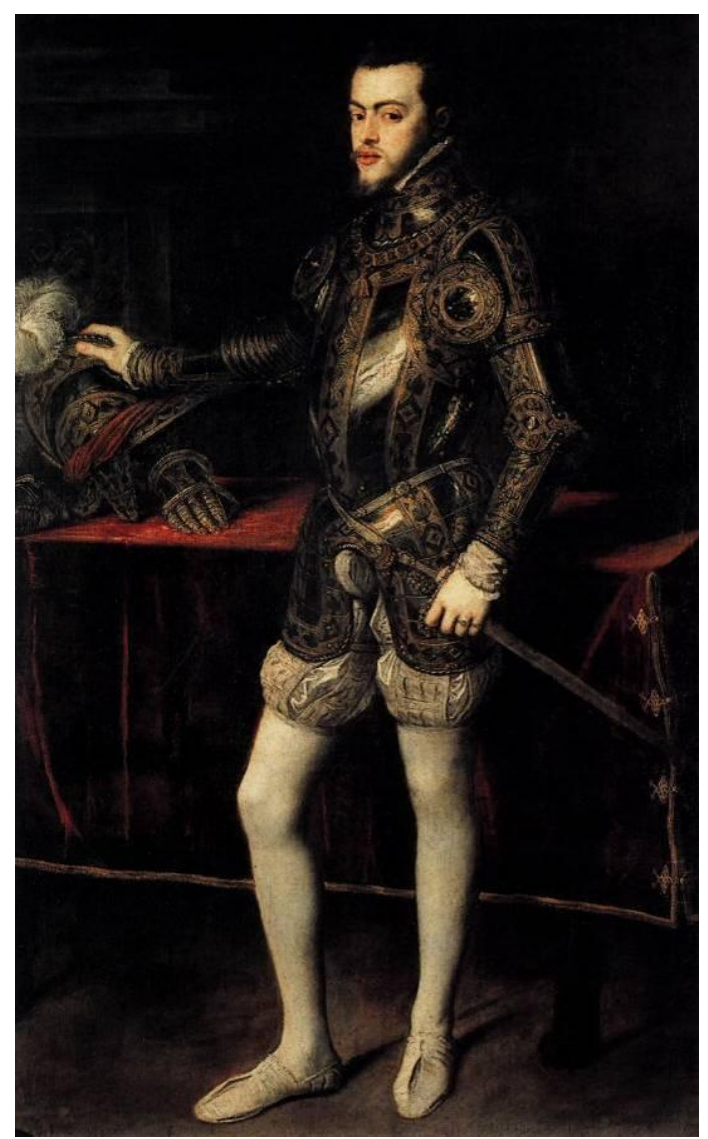


slično likovno rješenje primijenjeno je na nadgrobnim pločama Benedikta Thuróczyja Ludbreškoga (†1616.) (Slika 50), Ivana IV. Petheőa de Gerse (†1616.) (Slika 51) i člana obitelji Vragović (I. pol. XVII. st.) (Slika 52) te epitafu Tome II. Erdődyja (†1624.) (Slika 102).

Tijekom ranoga novog vijeka, pripadnici plemstva naručivali su galerije predaka, vladara i znamenitih osoba (lat. homines illustri) kako bi sačuvali sjećanje na određenu osobu, ali i poslali željenu poruku. Na području Hrvatsko-Ugarskoga Kraljevstva, prve zbirke portreta javile su se u drugoj polovini XVI. stoljeća, no u većem broju nastale su u narednom, XVII. stoljeću. ${ }^{292}$ Među ugarskim plemićkim obiteljima najpoznatije su galerije obitelji Batthyány, Esterházy, Illésházy i Nádasdy, a među hrvatskim one obitelji Drašković, Patačić, Kulmer i Eltz. Portreti u navedenim zbirkama prate promjene u suvremenoj portretistici, a jedini segment u kojem se razlikuju od ostalih diljem monarhije i Europe jest odjeća. Ako nisu odjeveni u viteški oklop (Slika 72), plemići su prikazani u mentenu, dolami i kalpaku (Slika 73), odjeći karakterističnoj za hrvatsko-ugarsko plemstvo toga razdoblja. ${ }^{293}$ Benedikt Thuróczy Ludbreški (Slika 50), Ivan IV. Petheő de Gerse (Slika 51) i Vragović (Slika 52) tako su portretirani s kalpcima na glavi, iako su odjeveni u viteški oklop. Ova razlika prisutna je i na epitafima Zagrebačke (nad)biskupije s prikazom pokojnika kao adoranta pred Raspetim, koji su razloženi u sljedećem potpoglavlju.

Većina galerija portreta izvedena je kao štafelajne slike, a manji dio kao zidne slike ili skulpture. Međutim, medij koji je zbog svoje lake prenosivosti i široke dostupnosti često bio nosilac novih stilskih strujanja i ikonografskih rješenja bila je grafika. ${ }^{294}$ Grafički portreti objavljivani su kao zasebni listovi, serije ili knjižne ilustracije (Slika 74). U ranom novom vijeku popularizirane su knjige sa životopisima hominum illustrium koji su često bili upotpunjeni portretima pripadajućih osoba. Jedna od njih bila je knjiga prvakā austrijske nadvojvodske kuće Augustissimorum Imperatorum, serenissimorum regum atque archiducum, illustrissimorum principum, necnon comitum, baronum, nobilium, aliorumque clarissimorum virorum... autora Jacoba Schrencka von Notzinga koja je prvi put objavljena u Innsbrucku 1601. godine, a opremljena je bakroreznim portretima Giovannija Battiste Fontane i Dominicusa Custosa. ${ }^{295}$ Među »najslavnije muževe« uvršten je i Nikola IV. Zrinski koji je na portretu odjeven u menten, dolamu i kalpak, a oboružan je ratnom sjekirom i

\footnotetext{
${ }^{292}$ Usp. Géza Galavics, nav. dj., 1987., str. 243-244.

${ }^{293}$ Usp. Géza Galavics, nav. dj., 1987., str. 245.

${ }^{294}$ Usp. Géza Galavics, nav. dj., 1987., str. 236.

295 Jedan primjerak knjige nalazio se i u knjižnici Nikole VII. Zrinskoga na njegovom dvoru u Čakovcu, a isti svezak danas je pohranjen u Nacionalnoj i sveučilišnoj knjižnici u Zagrebu (Zbirka rijetkosti, sign. BZ 1).
} 


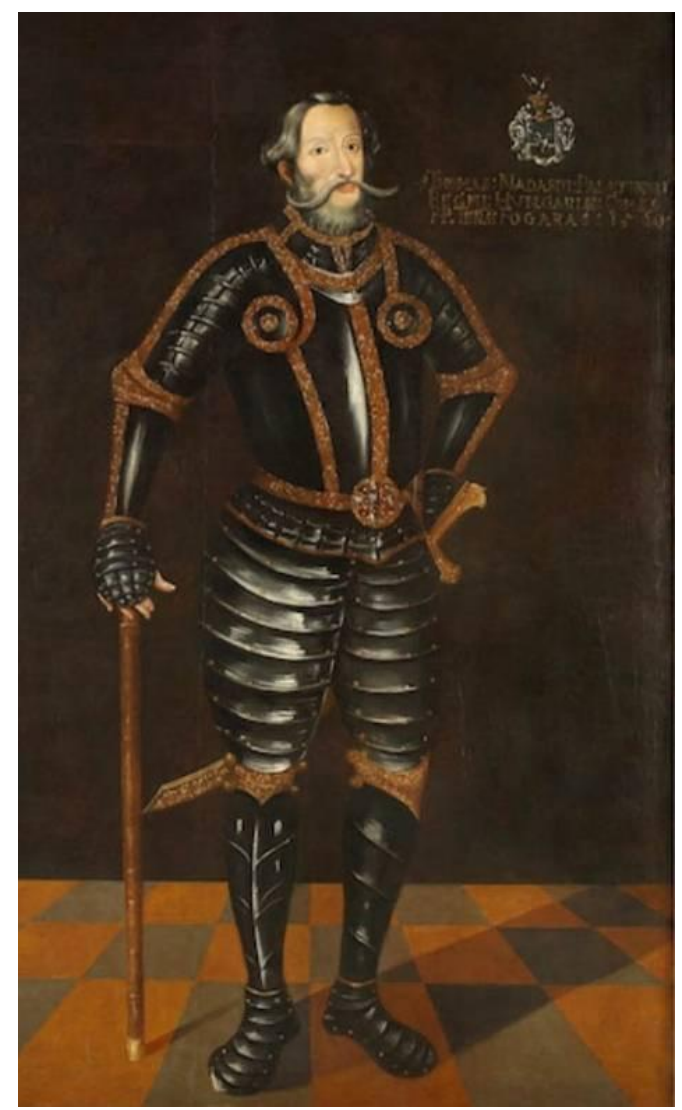

Slika 72. Portret Tamása (Tome) I. Nádasdyja, XVII. st., Budimpešta, Magyar Nemzeti Múzeum

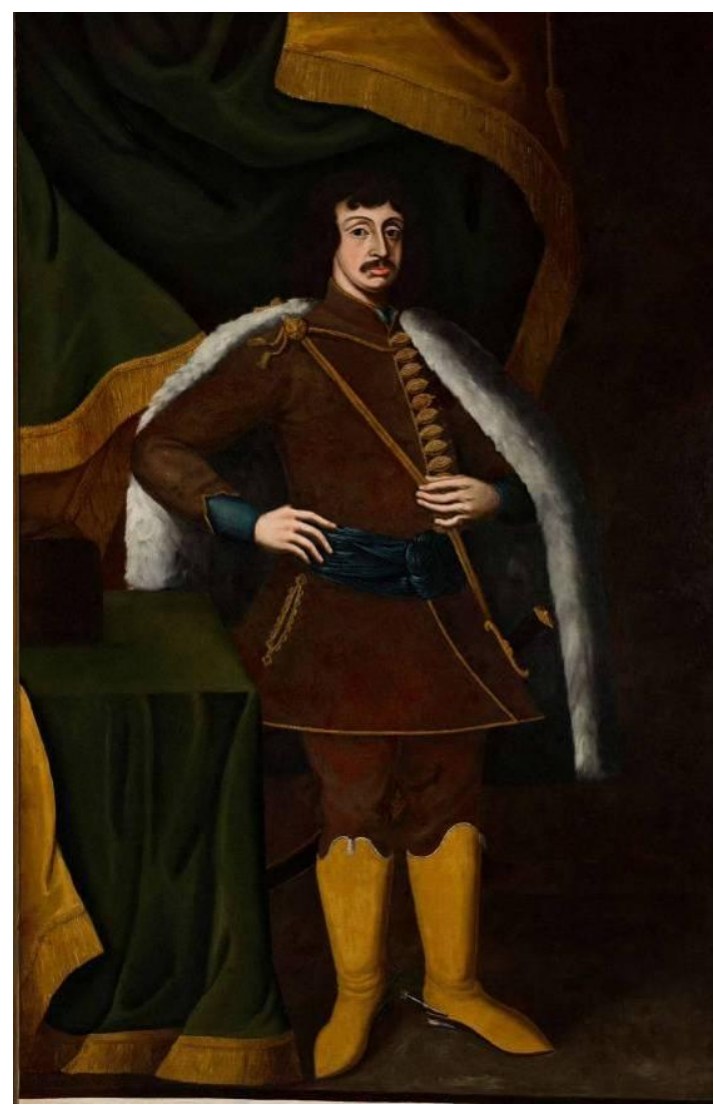

Slika 73. Portret Nikole VII. Zrinskoga, XVII. st., Budimpešta, Magyar Nemzeti Múzeum

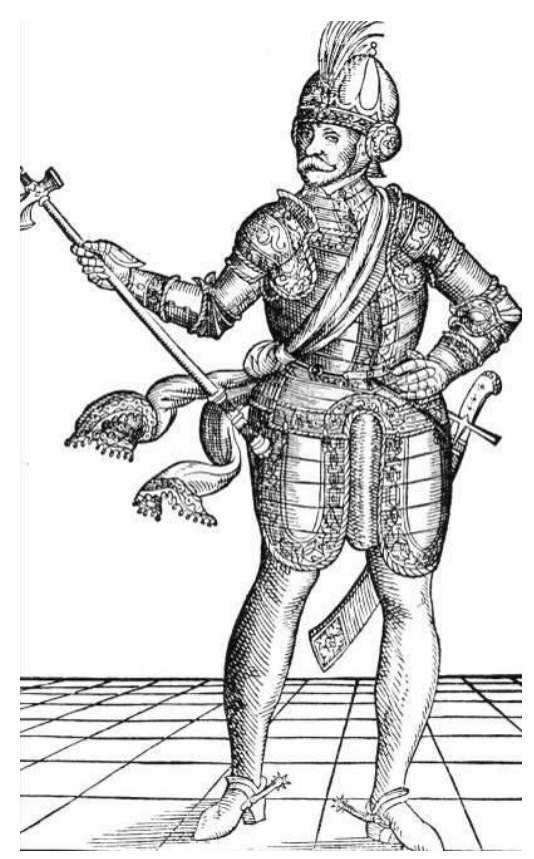

Slika 74. Portret Nikole IV.

Zrinskoga, iz knjige Johanna

Sommera »Vita Jacobi despotae Moldavorum reguli«, Wittenberg, 1587.

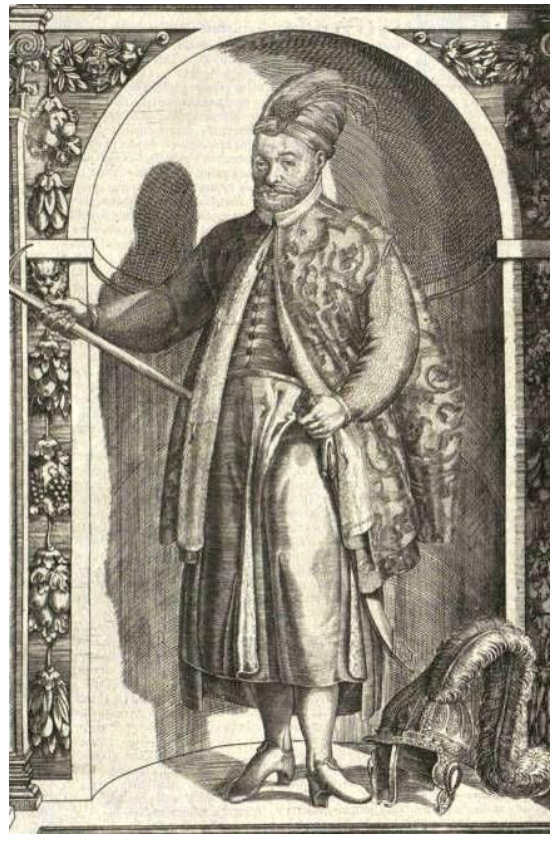

Slika 75. Giovanni Battista

Fontana i Dominicus Custos, Portret Nikole IV. Zrinskoga, iz knjige "Augustissimorum Imperatorum«, Innsbruck, 1601.

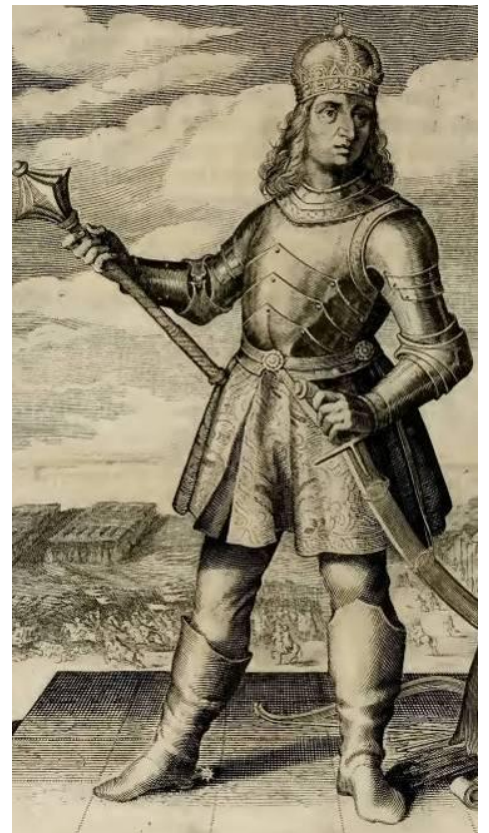

Slika 76. Aegedius II.

Sadeler, Portret kralja Matije Korvina, iz knjige »Mausoleum«, Nürnberg, 1664. 
sabljom (Slika 75). Osim životopisa suvremenih osoba, na području Hrvatsko-Ugarskoga Kraljevstva objavljivane su povijesne knjige s prikazom (hrvatsko-)ugarskih kraljeva i vojskovođa, a jedna od najpopularnijih bila je Mausoleum potentissimorum ac gloriosissimorum Regni Apostolici Regum et primorum militantis Ungariae Ducum (Nürnberg, 1664.) koju je objavio dvorski sudac Franjo (Ferenc) III. Nádasdy. Opremljen grafičkim portretima koje je izradio flamanski grafičar Aegedius II. Sadeler, Mausoleum je poslužio kao uzor brojnim zbirkama povijesnih ali i suvremenih portreta poput onih obitelji Esterházy, Erdődy i Batthyány. ${ }^{296}$ U knjizi, pojedini vladari posjednuti su na prijestolje, no brojni su prikazani u stojećem stavu prateći rješenja suvremene portretistike (Slika 76). Rješenja slična onima na predstavljenim grafičkim portretima upotrijebljena su i na nadgrobnim spomenicima Zagrebačke povijesne biskupije, posebice onima XVII. stoljeća nadgrobnicima Benedikta Thuróczyja Ludbreškoga (†1616.) (Slika 50), Ivana IV. Petheőa de Gerse (†1616.) (Slika 51), Vragovića (Slika 52), Tome II. Erdődyja (†1624.) (Slika 102) i Gottfrieda Falmhaubta $(† 1641$.) (Slika 65).

Posljednja promjena koja je uočljiva na nadgrobnim spomenicima, a proizašla je iz portretne umjetnosti je kadriranje. Dopojasan način kadriranja koji je primijenjen na nadgrobniku obitelji Češković (Slika 66) i Sermage (Slika 67) u portretistiku je uveo Tiziano Veccelio (Pieve di Cadore, 1490. - Venecija, 1576.) portretom urbinskoga vojvode Francesca Marije I. della Rovere (Slika 70). ${ }^{297}$ Upotreba približenoga kadra omogućila je Tizianu da uspostavi komunikaciju između potretiranoga i gledateljā, ali i da aktivno pokaže della Roverovu snagu predvodnika, ratnika i pobjednika. Izniman utjecaj izvršio je i slikarev ciklus uljenih portreta jedanaestorice rimskih careva koji je izradio za mantovanskoga vojvodu Federica II. Gonzagu (1537. - 1538.), a u kojem je primijenio isti način kadriranja. Slikani portreti stradali su u požaru 1734. godine, no srećom Aegidius II. Sadeler prethodno ih je prenio u grafički medij (o. 1593.), zahvaljujući čemu je njihov izgled danas poznat. ${ }^{298}$ Tizianov način kadriranja zaživio je i u kiparstvu, pa tako i u grani nadgrobne plastike, kao što pokazuju epitafi očuvani na području povijesne Zagrebačke biskupije.

\footnotetext{
${ }^{296}$ Usp. Bálint Ugry i Maja Žvorc, The Čakovec Stone Bust Collection: New Identifications, Possible Dating and the Identity of its Commissioner, u: Radovi Instituta za povijest umjetnosti 43, Zagreb: Institut za povijest umjetnosti, 2019., str. 123-138, 127.

${ }^{297}$ Usp. Hilliard T. Goldfarb, Titian: Colore and Ingegno in the Service of Power, u: Titian and Rubens: Power, Politics, and Style, Boston: Isabella Stewart Gardner Museum, 1998., str. 1-28, 5-7. Napisali Hilliard T. Goldfarb, David Freedberg i Manuela B. Mena Marqués.

${ }^{298}$ Usp. Hilliard T. Goldfar, nav. dj., 1998., str. 7.
} 


\subsubsection{EPITAFI S PRIKAZOM RASPETOGA I ADORANATA}

Kao što je navedeno u poglavlju o razvoju i tipologiji nadgrobne skulpture, prvi epitafi pojavili su se u europskoj umjetnosti u XIV. stoljeću. ${ }^{299}$ Budući da nisu neposredno vezani uz ukopno mjesto kao nadgrobne ploče, raznolikiji su veličinom i oblikom. Likovno mogu sadržavati jednostavnije motive, poput obiteljskih grbova i motiva funeralne ikonografije, ali i složene figuralne prikaze, kao portret pokojnika, Presveto Trojstvo, Raspeće, Uskrsnuće, sacra conversazione i slično. Na novovjekovnim epitafima sačuvanima na području Zagrebačke (nad)biskupije koji sadrže složeniji likovni prikaz zastupljena su dva figuralna rješenja. Prvo rješenje sadrži samostalan lik viteza-pokojnika, koje je razloženo u prethodnom potpoglavlju. U drugome rješenju, figura pokojnika pridružena je prikazu Krista razapetoga na križu. U narednim odlomcima opisana je skupina epitafa na kojima je primjenjeno potonje rješenje.

Prikaz pokojnika koji kleči i moli pred Raspetim jedna je od najčešćih ikonografskih situacija na epitafima općenito. ${ }^{300} \mathrm{Na}$ prostoru povijesne Zagrebačke biskupije pojavila se sredinom XVI. stoljeća, a zadržala se do početka XVIII. stoljeća. Kompozicijski sadrži lik Raspetoga prikazanoga en face kojemu je pridružen pokojnik-adorant prikazan u poluprofilu ili tričetvrt profilu. Pokojnici se ponekad nalaze u pratnji svojih najbližnjih, to jest supružnika i djece. U tom slučaju, likovi su uvijek smješteni u skladu s pravilima ikonografske perspektive: muški članovi obitelji prikazani su zdesna, a ženski slijeva Kristu. Takvi prikazi predstavljaju svojevrstan obiteljski portret i služe, među ostalom, očuvanju obiteljske memorije. $^{301}$

Likovno rješenje pokojnika-adoranta ima ishodište u zavjetnim slikama na kojima su naručitelji prikazani kako kleče pred svetom osobom moleći od nje pomoć ili joj zahvaljujući na već udijeljenoj milosti. ${ }^{302} \mathrm{Na}$ nadgrobnim spomenicima općenito, pokojnici su najčešće prikazani kako kleče pred Bogom, Bogorodicom s Djetetom ili Raspetim, a mogu biti u pratnji svetaca zaštitnika koji djeluju kao njihovi zagovornici pred nebeskim sudom. ${ }^{303}$ Kao što je navedeno, na području povijesne Zagrebačke biskupije sačuvani su jedino primjeri epitafā na kojima pokojnici kleče i mole pred Raspetim. Prikaz Krista razapetoga na križu - koji je umro za otkupljenje ljudskih grijeha, a potom uskrsnuo - simbolizira vjeru preminuloga u vlastito

\footnotetext{
${ }^{299}$ Usp. Erwin Panofsky, nav. dj., 1992. [1964.], str. 58-59.

${ }^{300}$ Usp. Emilijan Cevc, nav. dj., 1981., str. 104; Renate Kohn, nav. dj., 2005., str. 26; Géza Pálffy, nav. dj., 2005., str. 504; Andreas Zajic, nav. dj., 2004., str. 176.

${ }^{301}$ Usp. Philippe Ariès, nav. dj., 1981., str. 257.

${ }^{302}$ Usp. Philippe Ariès, nav. dj., 1981., str. 254-255; Emilijan Cevc, nav. dj., 1965., str. 148; Emilijan Cevc, nav. dj., 1981., str. 104.

${ }^{303}$ Usp. Philippe Ariès, nav. dj., 1981., str. 256-257.
} 
spasenje. ${ }^{304}$ Odabirom ove vrste prikaza naručitelji su iskazivali svoju pobožnost i vjeru u duhovno izbavljenje, ali su ujedno htjeli potaknuti promatrača na molitvu kojom će se založiti za njihovu dušu. ${ }^{305}$

Na prostoru Zagrebačke (nad)biskupije, epitafe s prikazom Raspetoga i pokojnikaadoranta podizali su isključivo plemići i plemkinje. Iako ova vrsta nadgrobnika ima naglašeno vjersko značenje, likovi naručitelja uvijek su prikazani u skladu s njihovim društvenim položajem. Žene su tako odjevene u bogatu odjeću i ukrašene nakitom, a muškarci u menten i dolamu ili viteški oklop. Spomenici ujedno sadrže grb obitelji kojoj su pokojnici pripadali tijekom života, potvrđujući njihovo plemenito podrijetlo i pripadnost višem društvenom sloju. Budući da su ugrađeni u zidnu masu u visini očiju i primjetljiviji su u prostoru, epitafi predstavljaju reprezentativniji oblik spomenika od nadgrobnih ploča. ${ }^{306}$ Zbog njihovoga položaja na podu, nadgrobne ploče često su smatrane iskazom poniznosti pokojnikā koji su dozvoljavali da vjernici gaze po njihovom spomeniku. ${ }^{307}$ Poslijetridentski reformisti smatrali su potonju vrstu nadgrobnika jedinom doličnom, a kao jedan od vodećih traktatista o novoj ulozi crkvene arhitekture, milanski kardinal Karlo Boromejski (Arona, 1538. - Milano, 1584.) smatrao je da nadgrobnici ne smiju biti viši od popločenja crkve. ${ }^{308}$

Najraniji epitaf s prikazom Raspetoga i adoranata koji je očuvan na području Zagrebačke (nad)biskupije nalazi se u župnoj crkvi Uznesenja Blažene Djevice Marije u Pregradi (Slika 77). Spomenik koji je danas uzidan u sjeverni zid svetišta zapravo je amalgam triju prethodno zasebnih spomenika. Središnji reljef s prikazom obitelji u molitvi pred Raspetim dio je epitafa Petra II. Keglevića (?, o. 1485. — ?, 1554. ili 1555.), ${ }^{309}$ ploča s natpisom i grbom smještena ispod njega nadgrobnik je Petrova sina Šimuna Keglevića (? Krapina, 1579.), ${ }^{310}$ a arhitrav s lunetom dio je epitafa Jurja Gorupa (? - ?, o. 1680.). ${ }^{311}$ Sva tri spomenika bila su postavljena u staroj, gotičkoj crkvi koja je početkom XIX. stoljeća porušena zbog trošnosti. ${ }^{312}$ Grobnice obitelji Keglević nalazile su se u svetištu, a grobnica

\footnotetext{
${ }^{304}$ Usp. Emilijan Cevc, nav. dj., 1981., str. 104; Renate Kohn, nav. dj., 2005., str. 27.

${ }^{305}$ Usp. Gerhard Winkler, nav. dj., 1974., str. 215; Andreas Zajic, nav. dj., 2004., str. 174-175.

${ }^{306}$ Usp. Andreas Zajic, nav. dj., 2004., str. 162.

${ }^{307}$ Usp. Philippe Ariès, nav. dj., 1981., str. 239.

${ }^{308}$ Isto.

${ }^{309}$ Kamen, $62 \times 113 \times 5$ cm, Pregrada, crkva Uznesenja Blažene Djevice Marije, izvorno u staroj župnoj crkvi. Kat. br. 16.

${ }^{310}$ Kamen, $60 \times 140 \times 5 \mathrm{~cm}$, Pregrada, crkva Uznesenja Blažene Djevice Marije, izvorno u staroj župnoj crkvi. Kat. br. 17.

${ }^{311}$ Kamen, $106 \times 135 \times 5$ cm, Pregrada, crkva Uznesenja Blažene Djevice Marije, izvorno u staroj župnoj crkvi. Kat. br. 18.

${ }^{312}$ Usp. Đurđica Cvitanović, Johann Fuchs projektant Župne crkve u Pregradi, u: Peristil 38, Zagreb: Društvo povjesničara umjetnosti Hrvatske, 1995., str. 121-128, 121-122; Ivan Filipčić, Župa Pregrada: mala
} 


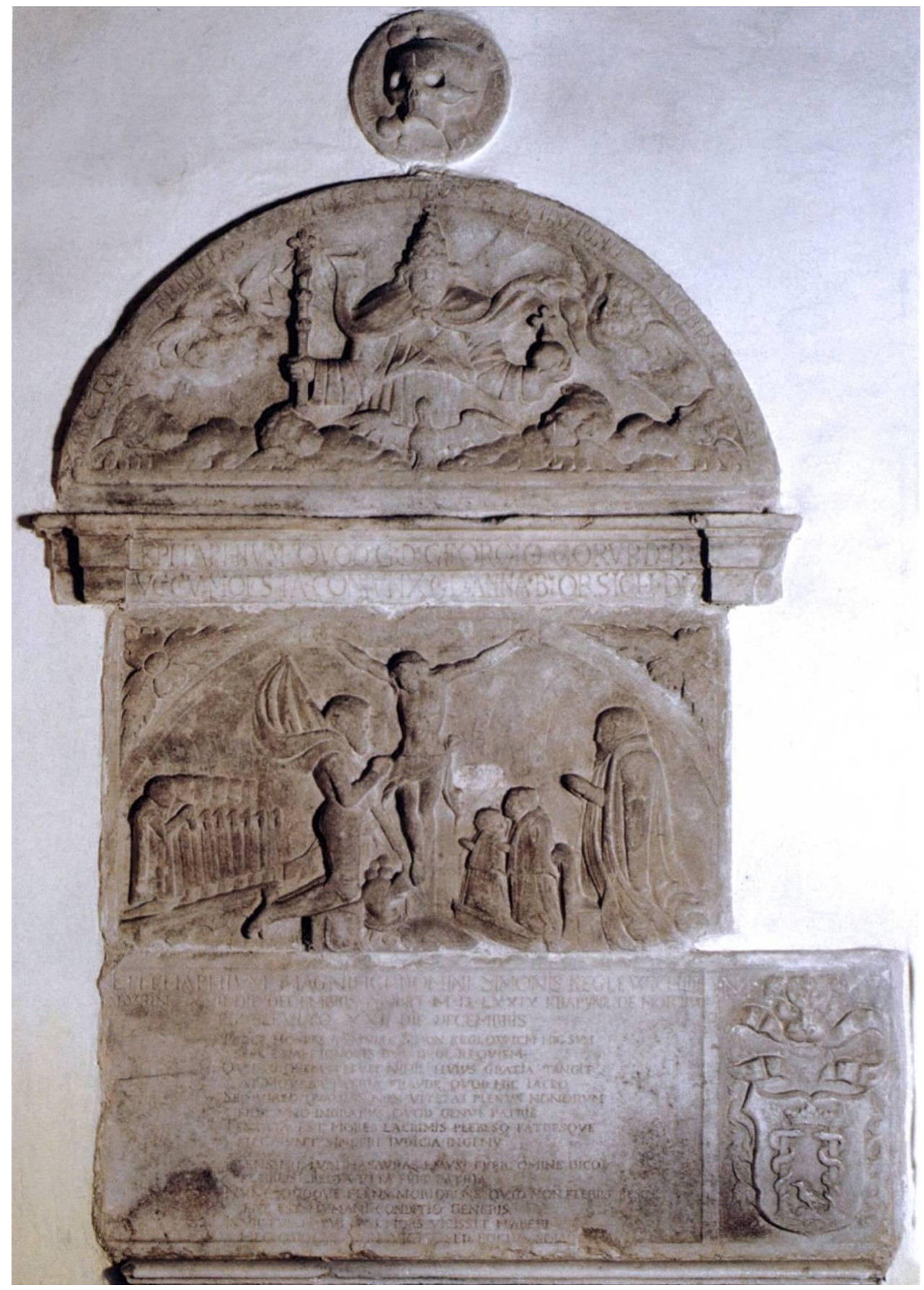

Slika 77. Epitaf Petra II. (†1554./55.) i Šimuna III. Keglevića (†1579.) te Jurja Gorupa (†o. 1680.), Pregrada, crkva Uznesenja Blažene Djevice Marije

obitelji Gorup u brodu stare crkve. ${ }^{313}$ Prije njezina rušenja, nadgrobnici su izvađeni, a podizanjem novoga crkvenog zdanja (1803. - 1818.) dijelovi spomenikā ugrađeni su u zid svetišta kao naizgled jedinstvena cjelina.

monografija o župi Naše Gospe od Kunagore, Zagreb: Kršćanska sadašnjost, Pregrada: ŽU, 1983., str. 20; Anđela Horvat, Pregled spomenika kulture općine Pregrada, u: Kaj: časopis za književnost, umjetnost i kulturu 2-3, Zagreb: Kajkavsko spravišće, 1985.b, str. 167-208, 199.

${ }^{313}$ Usp. NAZ, KV, Prot. 22/IV (1735.), str. 294; Ivan Filipčić, nav. dj., 1983., str. 40, 95. 
Središnji reljef s prikazom obitelji koja kleči i moli pred Raspetim (Slika 78) najstariji je dio spomenika, a podignut je za Petra II. Keglevića (†1554./55.). Petar je bio jedan od najznamenitijih članova obitelji koji je znatno proširio obiteljske posjede i premjestio sjedište obitelji iz Kninske županije u Hrvatsko zagorje. Istaknuo se u bitkama protiv Osmanlija te je obnašao dužnost jajačkoga bana (1521. - 1528.) i hrvatskodalmatinsko-slavonskoga bana (1537. - 1542.). Na epitafu je prikazan s desne strane Krista kao sredovječni muškarac odjeven u viteški oklop s barjakom na desnom ramenu. Na postolju klecala nalazi se štit koji je nekoć sadržavao simbol Keglevićevih - motiv lava. Iza Petra kleče sedmorica njegovih sinova koji su prikazani u istoj pozi. S lijeve strane Raspetoga predočeni su ženski članovi obitelji, Petrova supruga Barbara i njihove dvije kćeri, koje su odjevene u suvremenu odjeću. Iako nije sačuvan nadgrobni natpis koji bi točno naveo za koga je spomenik podignut (on se najvjerojatnije nalazio ispod figuralnoga prikaza), znamo da reljef prikazuje Petra II. Keglevića i njegovu obitelj jer su iznad likova djece uklesani svitci s njihovim imenima. Redom su prikazani: Ivan II. (»IOANNES«), Petar III. (»PETRVS«), Gašpar (»GASPARVS«), Juraj I. (»GEORGIVS«), Franjo I. (»FRANCISCVS«), Nikola (»NICOLAVS«), Šimun III. (»SIMEON«), Ana (»ANNA«) i Suzana (»SVSANA»).

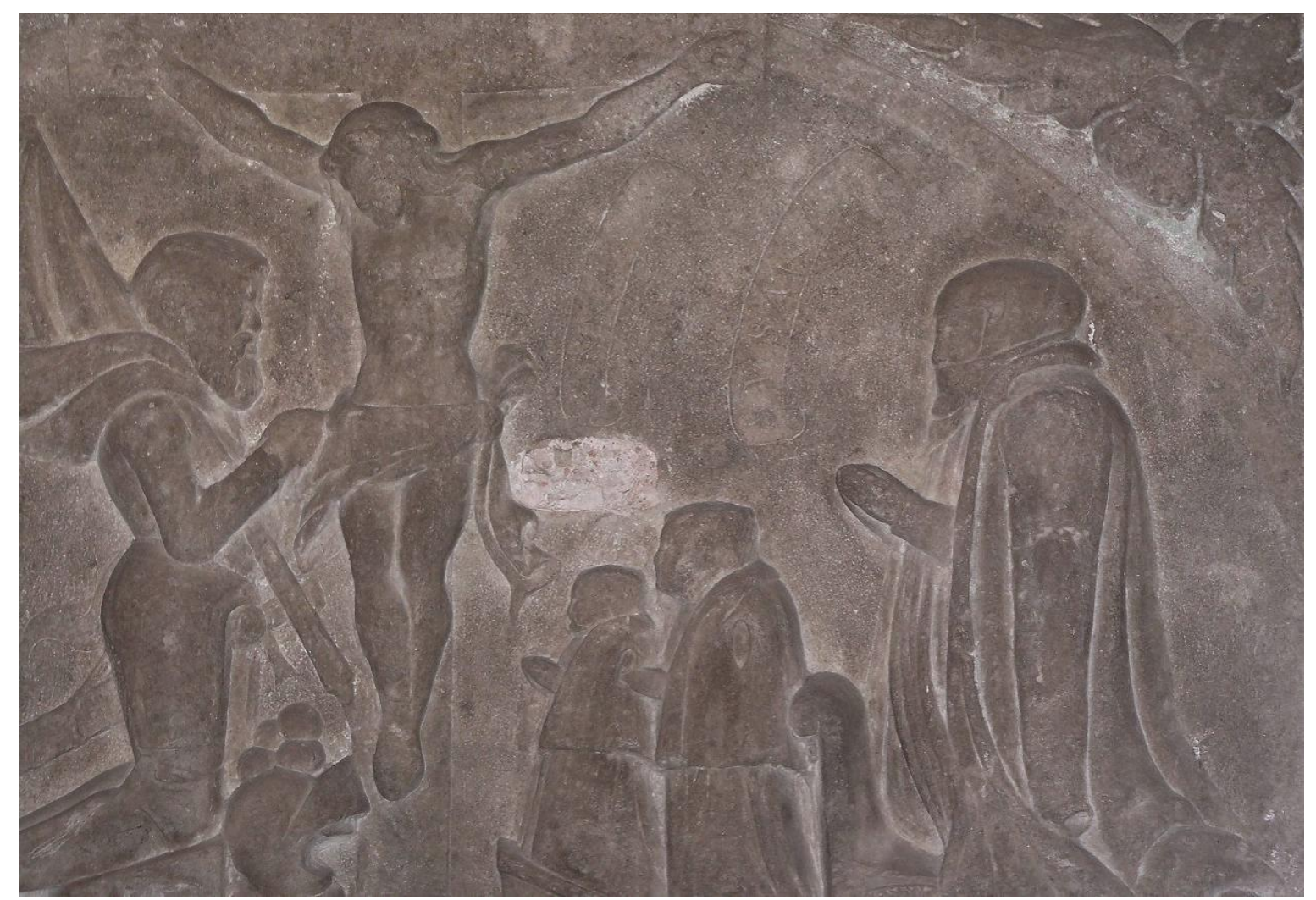

Slika 78. Majstor Hassova epitafa (?), Detalj epitafa Petra II. Keglevića (†1554./55.), Pregrada, crkva Uznesenja Blažene Djevice Marije 
Na prikazu nedostaju lik i ime jednoga od Petrovih mlađih sinova, oni Mateja Keglevića. ${ }^{314}$ Iako su likovi djece svedeni na opetovano riješene figure skromnoga stupnja individualizacije prema spolu i dobi koja je naznačena razlikom u odjeći i veličini likova, Keglevićev nadgrobnik predstavlja svojevrstan obiteljski portret koji je služio očuvanju obiteljske memorije. Epitafi s ovakvom vrstom prikaza brojčano su zastupljeni u susjednoj Štajerskoj, posebice u Mariboru i Ptuju, ${ }^{315}$ a slično likovno rješenje možemo pronaći i na suvremenim zavjetnim slikama poput one obitelji Petheő de Gerse i Choron de Devecser (Slika 79) iz Gradskoga muzeja Varaždin 316 na kojoj članovi imenovanih obitelji mole pred oltarom Raspeća.

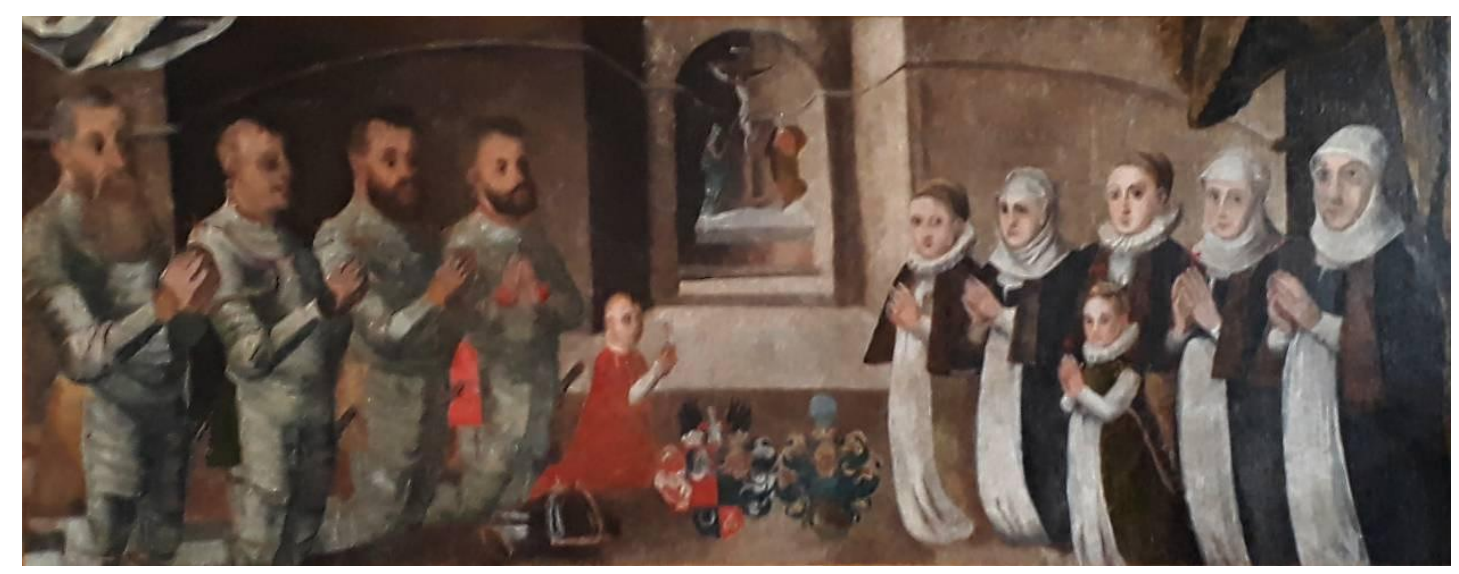

Slika 79. Zavjetna slika obitelji Petheö de Gerse i Choron de Devecser, sredina XVI. stoljeća, Varaždin, Gradski muzej

Opisujući Keglevićev epitaf, Anđela Horvat (1975., 1985.) okarakterizirala je reljef kao maniristički zbog asimetričnosti kompozicije uzrokovane pomicanjem figure Barbare Keglević prema rubu prikaza te neodređenosti prostora koja je dodatno naglašena dijagonalno postavljenim likovima djece. ${ }^{317}$ Navedenim manirističkim značajkama mogli bismo pridodati i izvrtanje ikonografske perspektive koje je vidljivo u promjeni odnosa veličine likova pokojnika i Krista (likovi bračnoga para Keglević veći su u odnosu na lik Raspetoga). Prema Marijani Schneider (1959.), promjena reda veličine likova zrcali humanističko poimanje pojedinca kojem se pridaje sve veća važnost. ${ }^{318}$ Nadalje, opisana inverzija otkriva i samosvijest naručitelja jer pokazuje da on metaforički tumači slavni opis Krista-Čovjeka, koji je s čovjekom »u svemu jednak osim u grijehu« (Heb 4,15), u svoju korist.

\footnotetext{
${ }^{314}$ Usp. Ivan Filipčić, nav. dj., 1983., str. 27.

${ }^{315}$ Usp. Emilijan Cevc, nav. dj., 1981., str. 117-118; Anđela Horvat, nav. dj., 1985.b, str. 199.

${ }^{316}$ Usp. Ljerka Šimunić, Vjera, ufanje, ljubav, u: Vjera, ufanje, ljubav, katalog izložbe, Varaždin: Gradski muzej Varaždin, 2013., str. 6-19, 16. Napisale Ljerka Albus, Ljerka Šimunić i Spomenka Težak.

${ }^{317}$ Usp. Anđela Horvat, nav. dj., 1975., str. 352; Anđela Horvat, nav. dj., 1985.b, str. 199.

${ }^{318}$ Usp. Marijana Schneider, nav. dj., 1959., str. 180.
} 
Keglevićev reljef oblikovno je sličan nadgrobnicima koje je Emilijan Cevc (1981.) pripisao Majstoru Hassova epitafa. ${ }^{319}$ Nazvan po nadgrobniku podignutom za ptujskoga plemića koji je pokopan u gradskoj crkvi sv. Jurja (Slika 80), Majstor Hassova epitafa djelovao je u posljednjoj četvrtini XVI. i početnom desetljeću XVII. stoljeća na području gradova Maribora, Ptuja i njihove okolice (Vurberk, Slovenska Bistrica). Najveći dio djelā atribuiranih kiparu čine upravo epitafi koji sadrže prikaz pokojnika s obitelji u molitvi pred Raspetim (Slike 80 i 81). Uz osnovnu kompoziciju, pregradski i slovenski reljefi posebice su slični u izvedbi likova Krista i pokojnikā. Na objema skupinama spomenika, Kristov torzo izdužen je u odnosu na ostatak tijela, a na njemu su istaknuta rebra i abdomen. Noge Raspetoga savijene su u koljenu, a desna je pribijena preko lijeve. Iako na slovenskim nadgrobnicima nijedan muški lik nije odjeven u viteški oklop nego u suvremenu odjeću, svi imaju sličan profil koji odgovara onome Petra II. Keglevića. Međutim, sličnosti u izvedbi najuočljivije su kod ženskih likova. Na objema skupinama spomenika žene nose ubradače koje zakrivaju donji dio lica i ogrtače koji padaju u dugim, linijski naglašenim naborima. Posebno je zanimljiv detalj prazna rukava na ogrtačima pokojnica koji se ne javlja na drugim

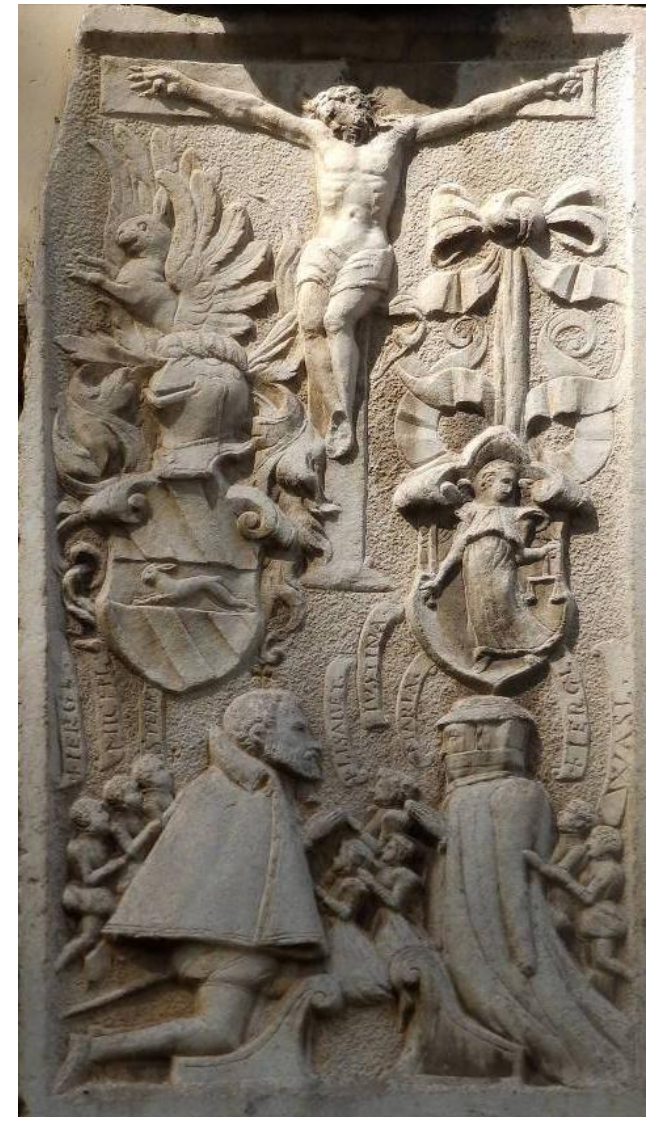

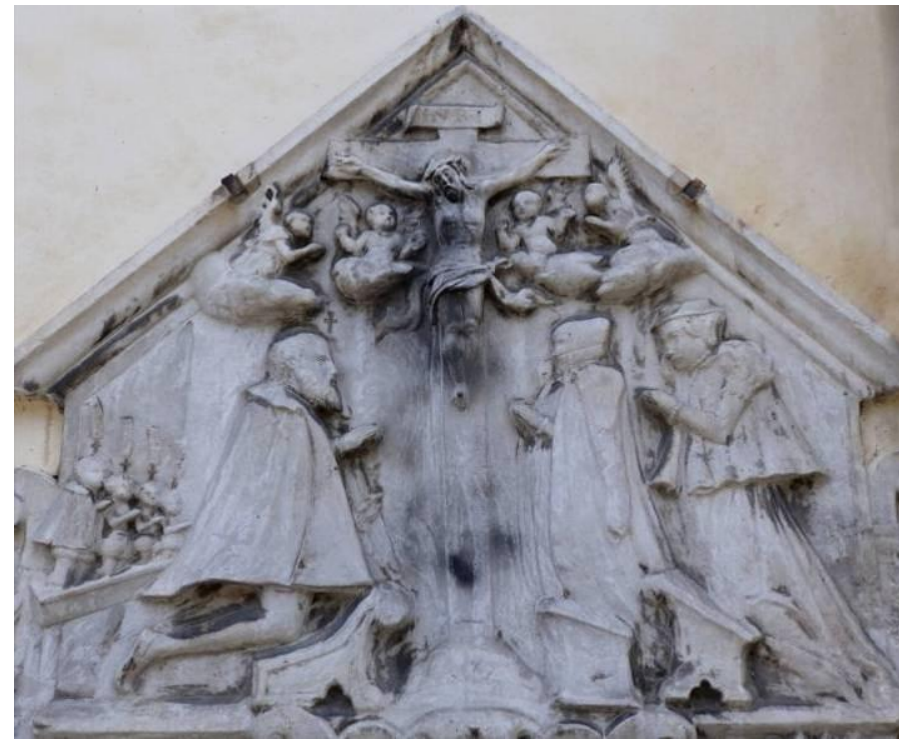

(lijevo) Slika 80. Majstor Hassova epitafa, Detalj epitafa Mateja Hassa (†1587.), Ptuj, crkva sv. Jurja

(gore) Slika 81. Majstor Hassova epitafa, Detalj epitafa Veita Heineggera (†1581.), Maribor, crkva sv. Ivana Krstitelja

\footnotetext{
${ }^{319}$ Usp. Emilijan Cevc, nav. dj., 1981., str. 129-141.
} 
nadgrobnim spomenicima razmatranoga područja. Opisane srodnosti između reljefa Petra II. Keglevića i onih pripisanih Majstoru Hassova epitafa sugeriraju da ih je izradila ista ruka ili radionica. Činjenica jest da godinu Keglevićeve smrti (1554./1555.) i prvi spomenik atribuiran imenovanom majstoru (1581.) dijeli više od dvadeset i pet godina. Međutim, to ne mora značiti da pregradski nadgrobnik nije djelo slovenske radionice jer još uvijek nije točno utvrđeno koje je godine podignut. Prisjetimo se epitafa Martina Mogorića (Slika 106) postavljena više od tri desetljeća nakon pokojnikove pogibije koji pokazuje da se godina smrti pokojnika i podizanja njegova spomenika ne moraju nužno poklapati. Poveznicu između Pregrade i slovenske radionice dodatno učvršćuje epitaf Petrova sina Šimuna III. Keglevića koji je analiziran u narednim odlomcima.

Šimun III. Keglević (†1579.) bio je jedini Petrov sin koji je nastavio obiteljsku lozu. Poput oca, istaknuo se u ratovanju protiv Osmanlija, ali je bio i umješan diplomat. Godine 1572. predstavljao je interese Hrvatskoga sabora pred kraljem, a 1575. - 1576. godine pred nadvojvodom Karlom. Njegov epitaf nalazi se podno reljefa Raspetoga s obitelji Keglević, a sastoji se od podužega natpisa kojem je pridružen grb (Slika 82). Izuzev početna tri retka koja otkrivaju za koga je nadgrobnik podignut i vrijeme pokojnikove smrti, ostatak natpisa sastoji se od stihova preuzetih iz opusa grčkoga humanista, pjesnika i vojnika Michaela Tarchaniote Marullusa (Konstantinopol, 1453. - Volterra, 1500.) i ne sadrži potankosti o narudžbi spomenika. ${ }^{320}$ Desno od natpisa nalazi se polje s obiteljskim grbom povrh kojega je prikazana lavlja glava s inicijalima »M P«. Ivan Filipčić (1983.) zaključio je da se iza inicijala krije Šimunova supruga Magdalena rođ. Petheő de Gerse (†1594.), na osnovi čega je ustvrdio da je ona naručila nadgrobnik za preminuloga muža te da prikazan grb pripada njezinoj obitelji. ${ }^{321}$ Štit na nadgrobniku (Slika 83) sadrži par stabala oko kojih je ovijena po jedna zmija. U podnožju drvā nalazi se vrana, a povrh krošanja kruna. Problem s Filipčićevom tezom o narudžbi spomenika leži u tome što opisani štit ne pripada ni obitelji Keglević ni obitelji Petheő de Gerse. Simbol prve je par okrunjenih lavova, ${ }^{322}$ a druge lav, patka, mjesec s dvije

\footnotetext{
${ }^{320}$ Stihovi su preuzeti iz tri epitafa koje je Marullus posvetio rimskom generalu Germaniku (Rim, 15. pr. Kr. Antiohija, 19.), posinku cara Tiberija; svom ocu Manilu Marullusu, bizantskom vojskovođi koji je morao napustiti dom u Konstantinopolu nakon što je grad pao u osmanske ruke; te Federicu da Montefeltru (Gubbio, 1422. - Ferrara, 1482.), urbinskom vojvodi koji je bio poznat po ratnom umijeću ali i ljubavi prema umjetnosti. Ciljanim preuzimanjem stihova i aludiranjem na osobe kojima su izvorno posvećeni, naručitelj Šimunova nadgrobnoga natpisa htio je sugerirati da je pokojnik posjedovao rimsku vještinu ratovanja, umješnost bizantske aristokracije i manire talijanske dvorske kulture. Usp. Han Lamers, Michele Marullo and the Epitaph of Šmun Keglević (1579): A note on the use and function of Latin inscriptions in Croatia, u: Bibliothèque d'Humanisme et Renaissance LXXVII/2, Geneve: Librairie Droz, 2015., str. 411-421.

${ }^{321}$ Usp. Ivan Filipčić, nav. dj., 1983., str. 27, 29.

${ }^{322}$ Usp. Ivan von Bojničić, nav. dj., 1889., str. 86, tab. 60.
} 


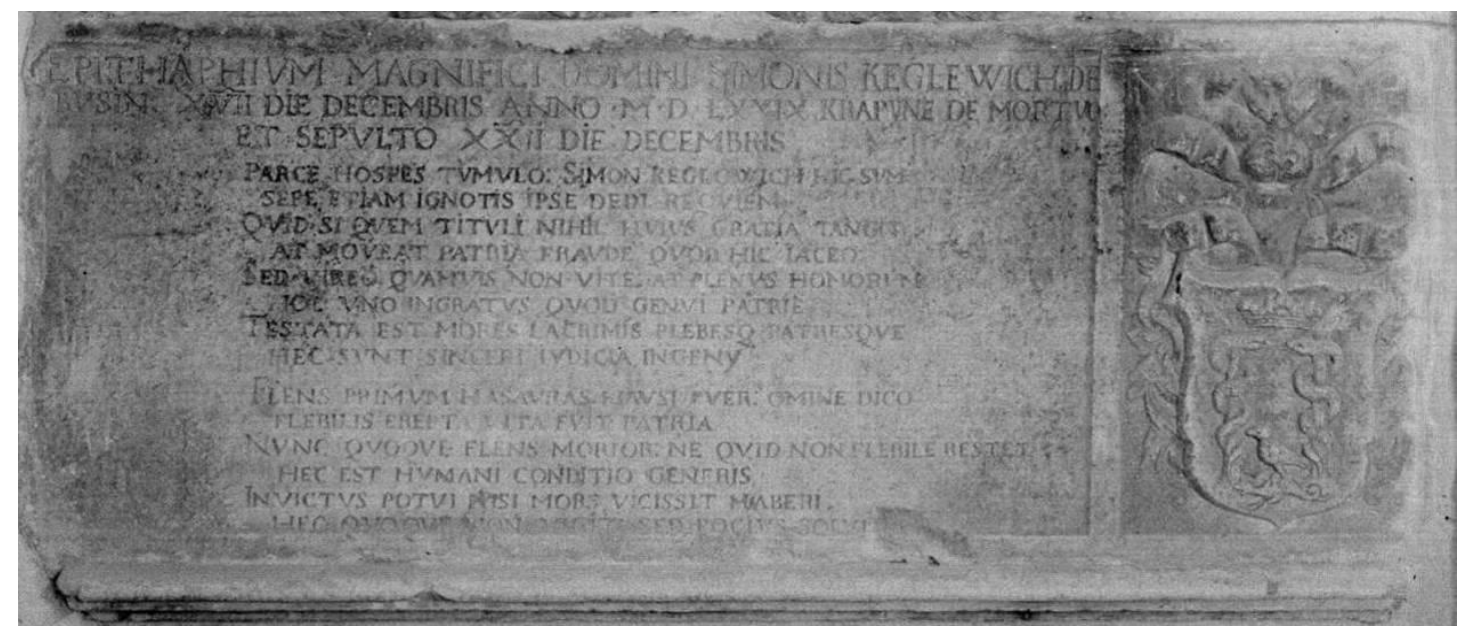

Slika 82. Pregrada, Crkva Uzašašća Bogorodičina, Nadgrobna ploča Jurja Gorupa $i$ Keglevića (detalj), 1938., foto: Ljudevit Griesbach, HAZU, Strossmayerova galerija starih majstora, Schneiderov fotografijski arhiv

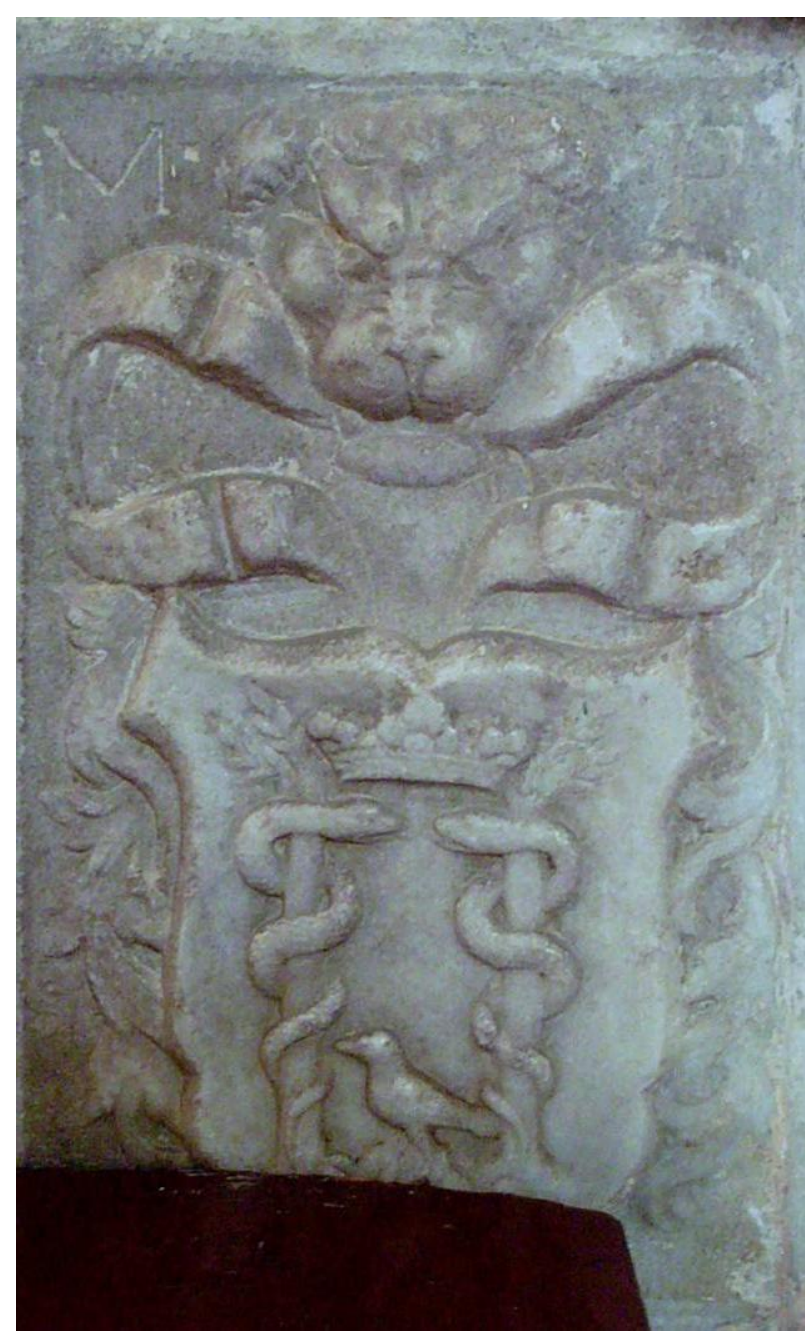

Slika 83. Detalj grba s epitafa Šimuna III. Keglevića (†1579.), Pregrada, župna crkva Uznesenja Blažene Djevice Marije
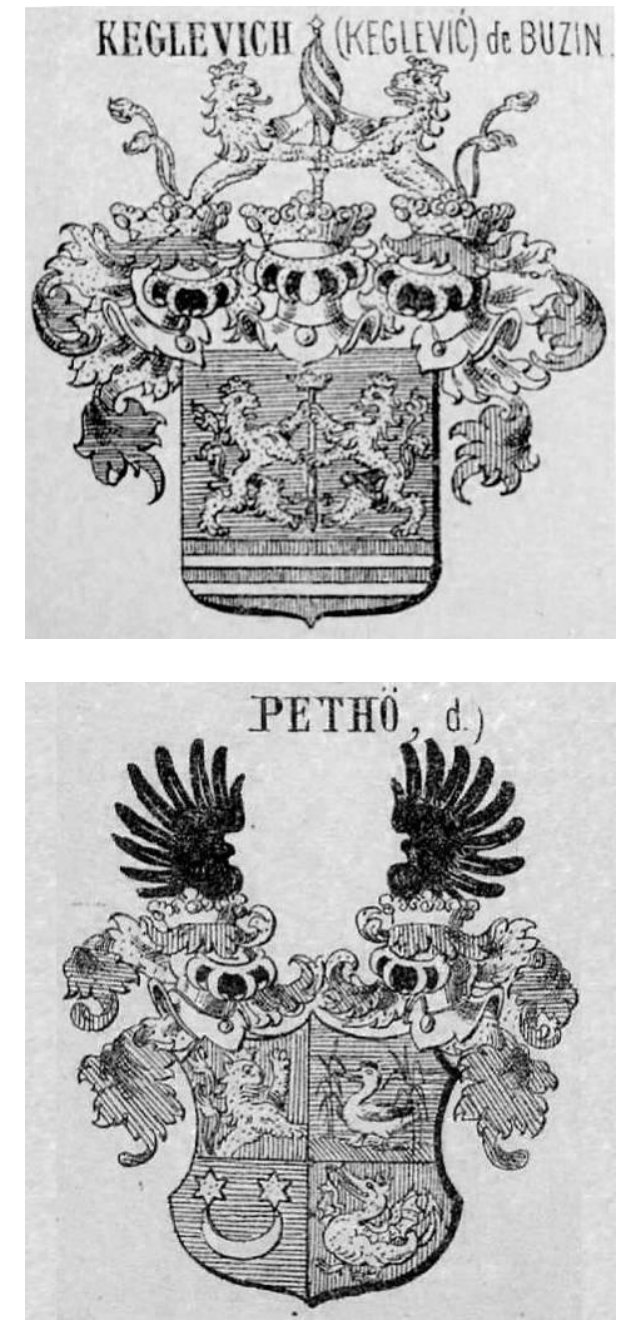

Slika 84. Grbovi obitelji Keglević $i$ Petheö de Gerse, iz grbovnika Ivana von Bojničića »Der Adel von Kroatien und Slavonien«, 1889. 
zvijezde i zmaj (Slika 84). ${ }^{323}$ Premda inicijali uklesani na Šimunovu epitafu odgovaraju onima njegove supruge, postavlja se pitanje zašto bi grofica dala izraditi grb obitelji kojoj ne pripada. U Bojničićevu grbovniku hrvatsko-slavonskoga plemstva (1899.) nijedan grb ne odgovara izgledu onoga na nadgrobniku, što dodatno zapliće pitanje narudžbe ovoga spomenika.

Kao simbol moći, motiv lava karakterističan je za nadgrobnu skulpturu, a najčešće se javlja na spomenicima sa samostalnim likom pokojnika na kojima leži uz noge preminuloga, kao na nadgrobnoj ploči člana obitelji Vragović iz Maruševca (Slika 52). Motiv lavlje glave koji je primijenjen na epitafu Šimuna III. Keglevića, s druge strane, nije toliko učestao. U slučaju pregradskoga nadgrobnika njegova se primjena može povezati s naručiteljem jer je lav simbol obitelji Keglević. Među ptujskim spomenicima koji su pripisani navedenom Majstoru Hassova epitafa postoji nekoliko nadgrobnika koji uključuju motiv lavljih glava. Upotrijebljene su, primjerice, na epitafu Andreja Karnerainda (Slika 85) kao dekorativne konzole, a oblikovno su vrlo srodne onoj u Pregradi. S obzirom na sličnost lavljih glava iz Pregrade i Ptuja, postavlja se pitanje je li nadgrobnik Šimuna III. Keglevića također rad Majstora Hassova epitafa ili ga je izradio kipar koji je preuzeo motiv iz repozitorija slovenskoga majstora, s čijim je radom bio upoznat putem epitafa Petra II. Keglevića.

Iznad reljefnoga prikaza Raspetoga i adoranata nalazi se epitaf posvećen podžupanu Varaždinske županije Jurju Gorupu od Bežanca (†o. 1680.) (Slika 86), a sastoji se od arhitrava i lunete povrh koje je smješten medaljon s lubanjom i ukriženim kostima. Prema natpisu uklesanom na arhitravu, nadgrobnik je podigla pokojnikova supruga Ana Gorup rođ. Oršić od Slavetića. U luneti su prikazani Otac i Duh Sveti okruženi sa šest kerubina. Otac je predočen kao nebeski vladar s atributima najviše crkvene i zemaljske vlasti (tijarom, žezlom i kraljevskom jabukom), a Duh Sveti kao golubica. ${ }^{324}$ Plošno oblikovana i linijski naglašena draperija Očeve odjeće i plašta ukazuje na mogućnost da je njegov lik isklesan prema grafičkome predlošku. Uravnoteženost kompozicije, gotovo zrcalna simetričnost te stroga frontalnost Očeva lika i golubice daju reljefu kasnorenesansne odlike. Uzduž luka lunete uklesan je natpis: »SANCTA TRINITAS VNVS DEVS MISERERE NOBIS« (Sveto Trojstvo, jedan Bože, smiluj nam se). Uz rub medaljona s lubanjom koji je smješten povrh lunete također se nalazi natpis, a riječ je o preinačenom citatu iz Matejeva evanđelja o Isusovom drugom

\footnotetext{
${ }^{323}$ Postoji nekoliko inačica grba obitelji Petheő de Gerse, no sve sadrže neki od simbola navedenih u tekstu. Usp. Ivan von Bojničić, nav. dj., 1889., str. 145, tab. 104.

${ }_{324}$ Usp. Anđelko Badurina (ur.), Leksikon ikonografije, liturgike i simbolike zapadnog kršćanstva, Zagreb: Kršćanska sadašnjost, 1990. [1979.], sub voce Bog, str. 162 [Branko Fučić].
} 


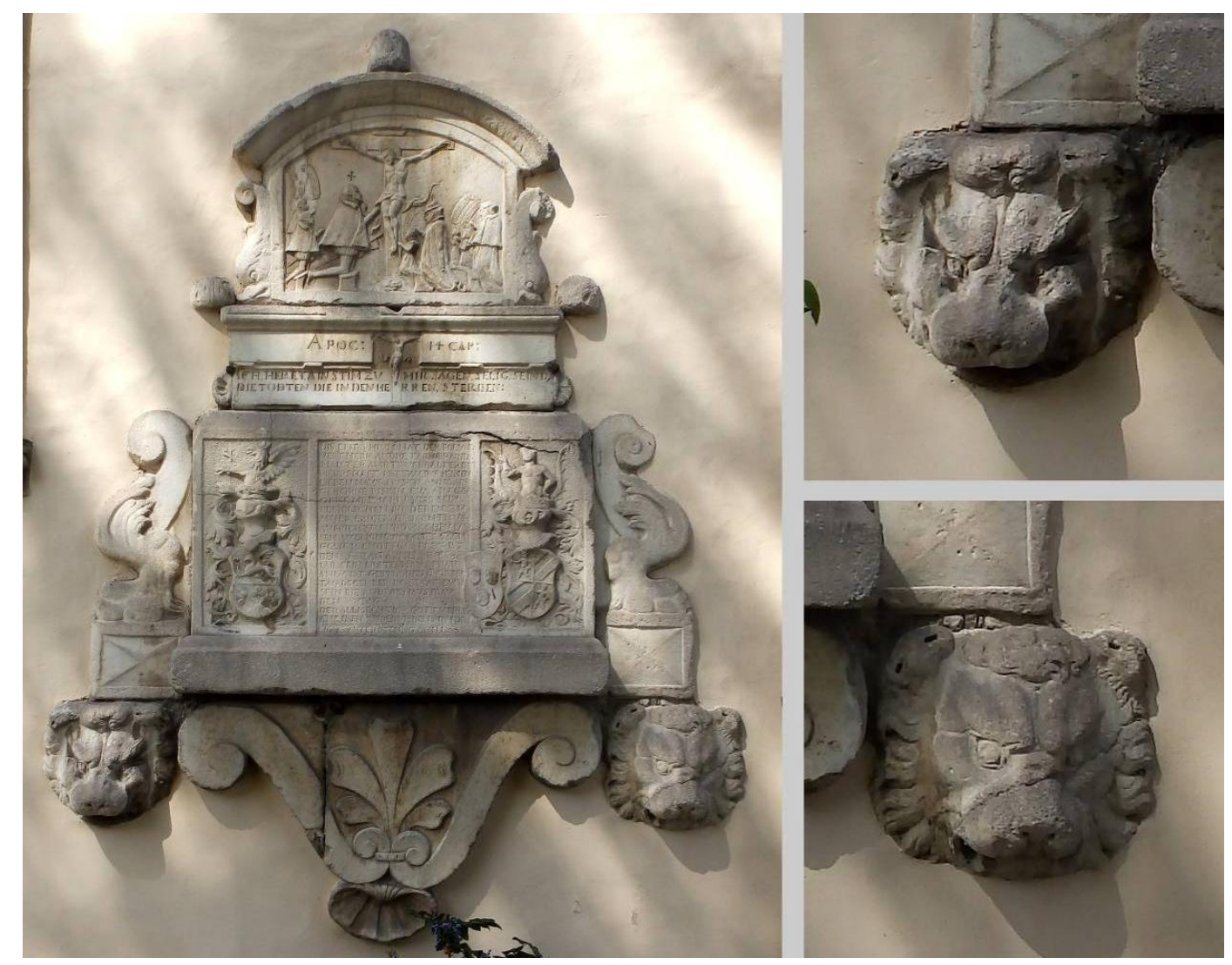

Slika 85. Majstor Hassova epitafa, Epitaf Andreja Karnerainda $(\dagger 1590$.) s detaljem lavljih konzola, Ptuj, crkva sv. Jurja

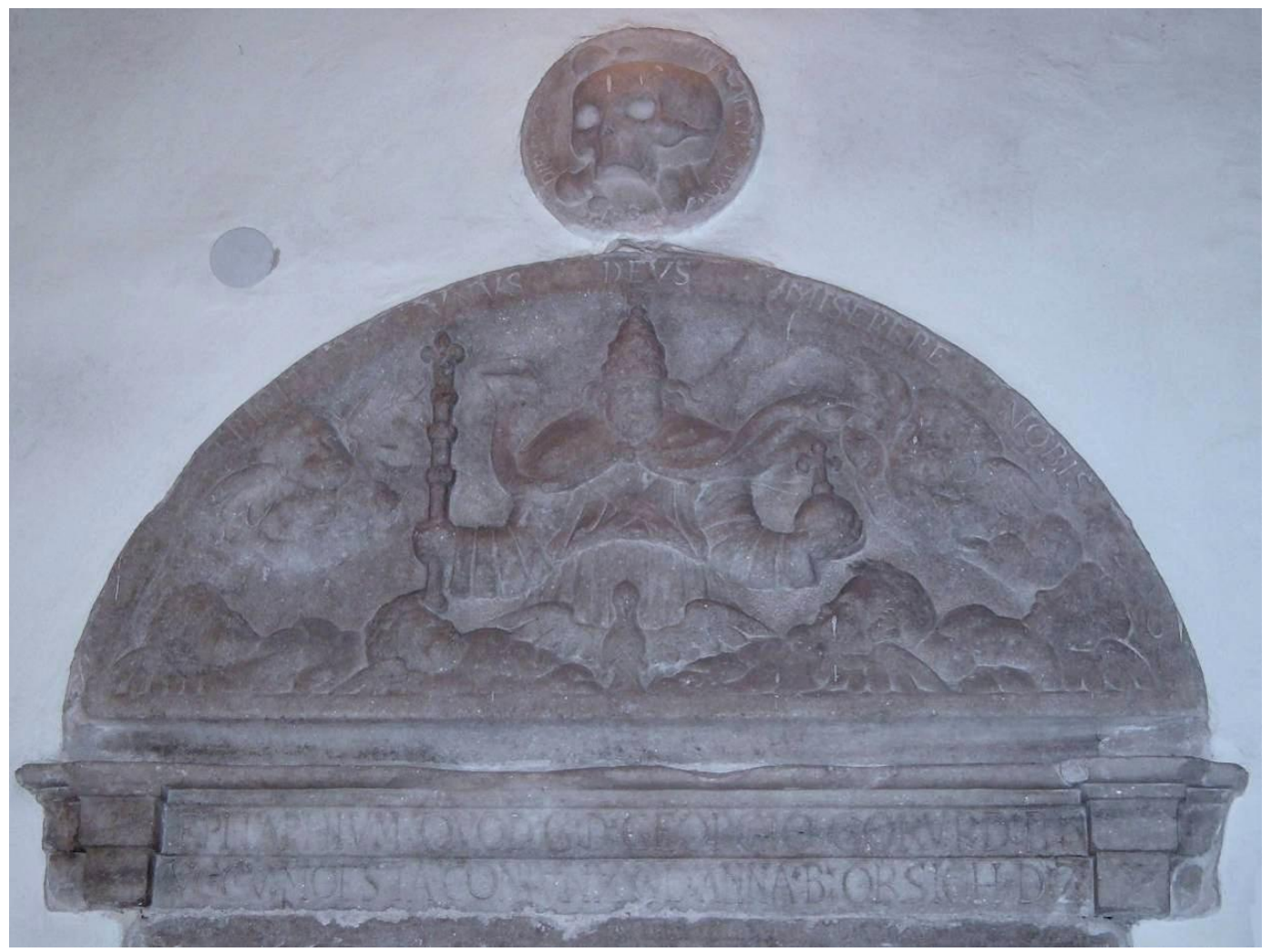

Slika 86. Epitaf Jurja Gorupa (†o. 1680.), Pregrada, crkva Uznesenja Blažene Djevice Marije 
dolasku: »ESTOTE PARATI QVIA NESCITIS DIEM NEQVE HORAM« (Budite pripravni jer ne znate ni dana ni časa. Mt 25, 13). ${ }^{325}$

Iz dosad pronađenih pisanih i likovnih izvora nije poznato kako je epitaf Jurja Gorupa izgledao u cijelosti. Na osnovi sačuvanih dijelova možemo pretpostaviti da je bio koncipiran kao edikula, odnosno da su luneta i arhitrav počivali na nosačima između kojih se nalazio središnji prikaz. Da bi reljef Presvetoga Trojstva iz lunete bio ikonografski potpun, nedostaje mu lik treće božanske osobe - Sina Božjega. U Štajerskoj i Koruškoj postoji niz nadgrobnika koji su, nalik Gorupovu epitafu, zaključeni trokutastim ili zaobljenim zabatom koji sadrži likove Oca i Duha Svetoga. Na njima, zabat se nadovezuje na središnji dio spomenika na kojem je prikazan Raspeti s adorantima, kao na spomenicima Reichardta pl. Liechten steina (1596.) iz crkve sv. Ivana Krstitelja u Ljutomeru (Slika 87), Jakoba Palluea (1626.) iz crkve sv. Egidija u Klagenfurtu ili Barbare Haas (1631.) iz mariborske katedrale sv. Ivana Krstitelja. Na ljutomerskom nadgrobniku uz rub lunete čak je uklesan isti natpis kao i na onome Jurja Gorupa. ${ }^{326} \mathrm{Na}$ osnovi navedenih nadgrobnika možemo pretpostaviti da je središnje polje Gorupova epitafa sadržavalo sličan prikaz Raspetoga s adorantima, nešto nalik reljefu Petra II. Keglevića koji se danas nalazi ispod arhitrava i lunete.

Smjernice u odgonetanju autorstva Gorupova epitafa također je potrebno potražiti na području susjedne Štajerske. Gorupova luneta oblikovno je slična reljefu Boga Oca koji je uzidan u pročelje crkve sv. Petra u Malečniku (Slika 88), nedaleko Maribora. Pretpostavlja se da je malečnička luneta bila dio staroga žrtvenika (kraj XVI. / poč. XVII. st.) koji je barokizacijom crkve iznesen i ukomponiran s elementima drugih oltara u novu cjelinu. ${ }^{327}$ Reljefi iz Pregrade i Malečnika srodni su po osnovnoj kompoziciji - Bog Otac prikazan je en face raširenih ruku te okružen kerubinima zakrenutima u tričetvrt ili poluprofil - ali i plitkom tretmanu površine i linearnoj obradi draperije. Međutim, dva se reljefa u pojedinim segmentima ipak razlikuju. Na malečničkoj luneti lik Oca znatno je monumentalniji u odnosu na predodređen mu okvir, a draperija je ipak nešto voluminoznije oblikovana od one na epitafu Jurja Gorupa, koja je svedena na plitke zareze. Oblikovne razlike kao i nepoklapanje godina nastanka onemogućuju nas da ova dva rada pripišemo istoj ruci ili radionici, no sličnosti koje dijele ukazuju da bi daljnje istraživanje epitafa Jurja Gorupa trebalo biti usmjereno prema proučavanju kiparske djelatnosti na području Štajerske.

\footnotetext{
${ }^{325}$ Redak izvorno glasi: »Vigilate itaque, quia nescitis diem, neque horam « (Bdijte, dakle, jer ne znate ni dana ni časa).

326 Natpis glasi: »SANCTA TRINITAS VNVS DEVS MISERERE NOBIS.« Detaljnije o ljutomerskom spomeniku vidi: Emilijan Cevc, nav. dj., 1981., str. 146-147.

${ }^{327}$ Usp. Emilijan Cevc, nav. dj., 1981., str. 175-177.
} 


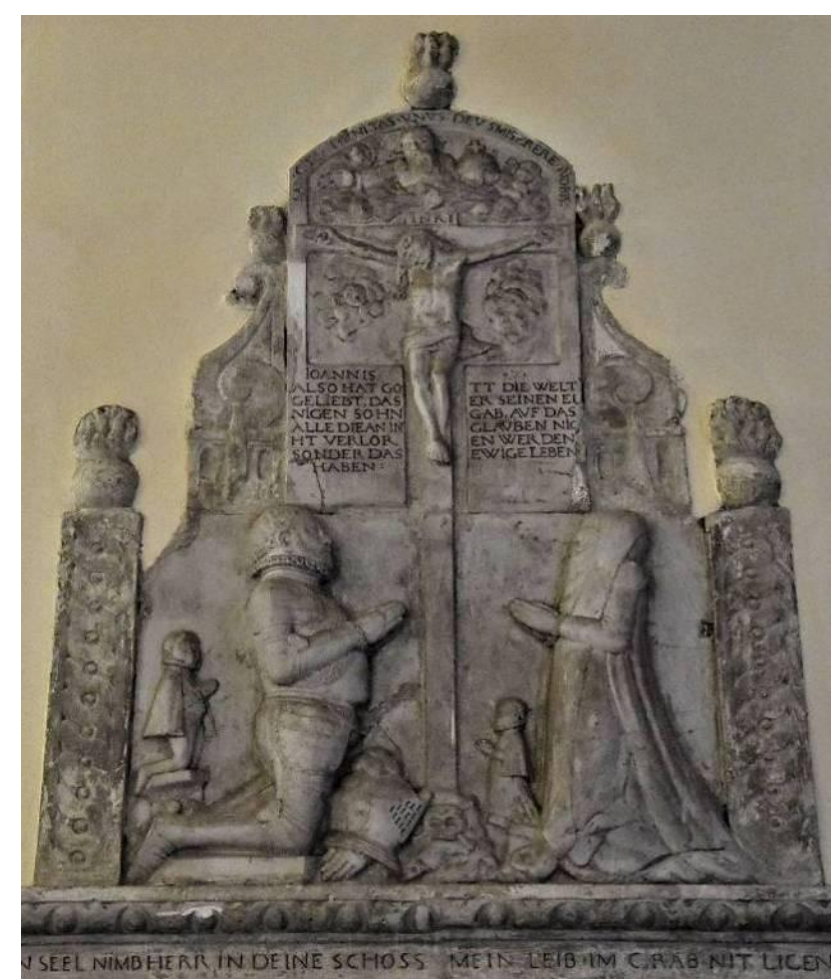

Slika 87. Vincentus Cumini, Epitaf Reichardta pl. Lichtensteina, 1596., Ljutomer, crkva sv. Ivana Krstitelja

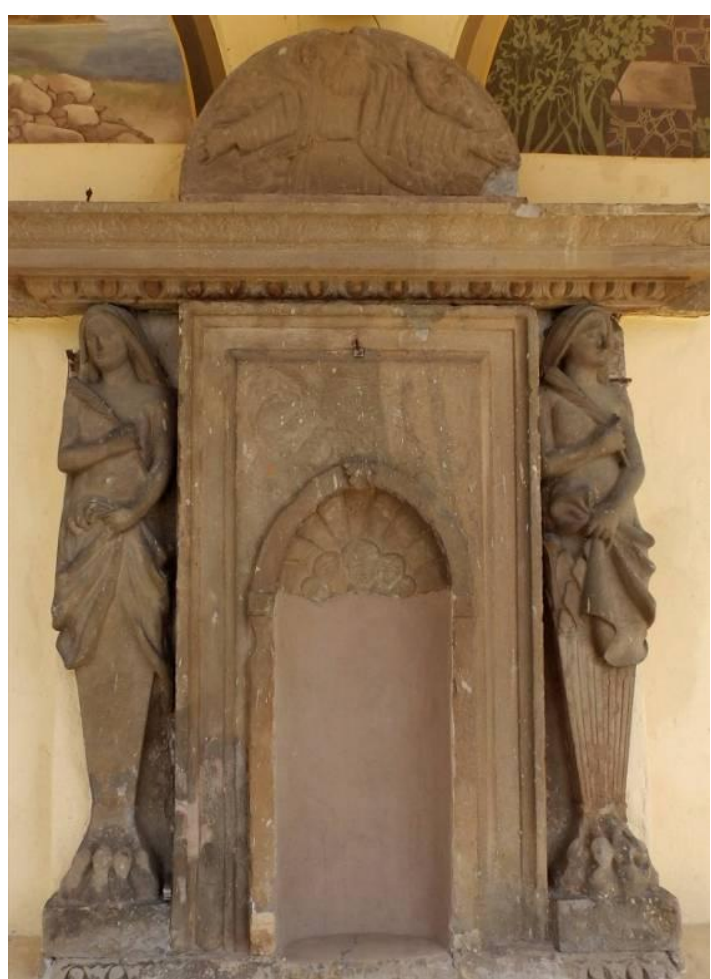

Slika 88. "Oltarna" kompozicija, kraj XVI./poč. XVII. st., Malečnik, crkva sv. Petra

Na području Zagrebačke (nad)biskupije sačuvan je još jedan nadgrobnik s prikazom Raspetoga i adoranata koji datira iz XVI. stoljeća. Riječ je o epitafu Ane Purthin (? - ?, 1589.) (Slika 89) ${ }^{328}$ koji je uzidan u južni zid svetišta kapele sv. Mihaela na Taborcu u Samoboru. Prema natpisu, dao ga je podići Anin suprug koji je ostao neimenovan. Figuralni prikaz Krista razapetoga na križu kojem se priklanjaju pokojnica i njezin suprug nalazi se u gornjem dijelu spomenika (Slika 90). Iako je nadgrobnik podignut za Anu, njezin lik ne nalazi se s desne, ikonografski važnije strane Raspetoga već s lijeve. U skladu s patrijarhalnim ustrojstvom ranonovovjekovnoga društva, mjesto zdesna Kristu namijenjeno je muškom članu obitelji, u ovome slučaju Aninu suprugu. Pri dnu križa položena je lubanja s parom ukriženih kostiju koja ima dvostruku simboliku. S jedne strane, ona simbolizira mjesto Kristova raspeća, brdo Golgotu, čije ime prema Ivanovu evanđelju znači »lubanja« (I noseći svoj križ, iziđe on na mjesto zvano Lubanjsko, hebrejski Golgota. Iv 19, 17). S druge strane, motiv je povezan s Adamom jer je prema srednjovjekovnoj legendi Kristov križ podignut na mjestu Adamova groba. Kosti podno križa tako simboliziraju vjeru da je Krist svojom žrtvom

\footnotetext{
${ }^{328}$ Kamen, $212 \times 75,5 \times 7,5$ cm, Samobor, Taborec, kapela sv. Mihovila. Kat. br. 23.
} 


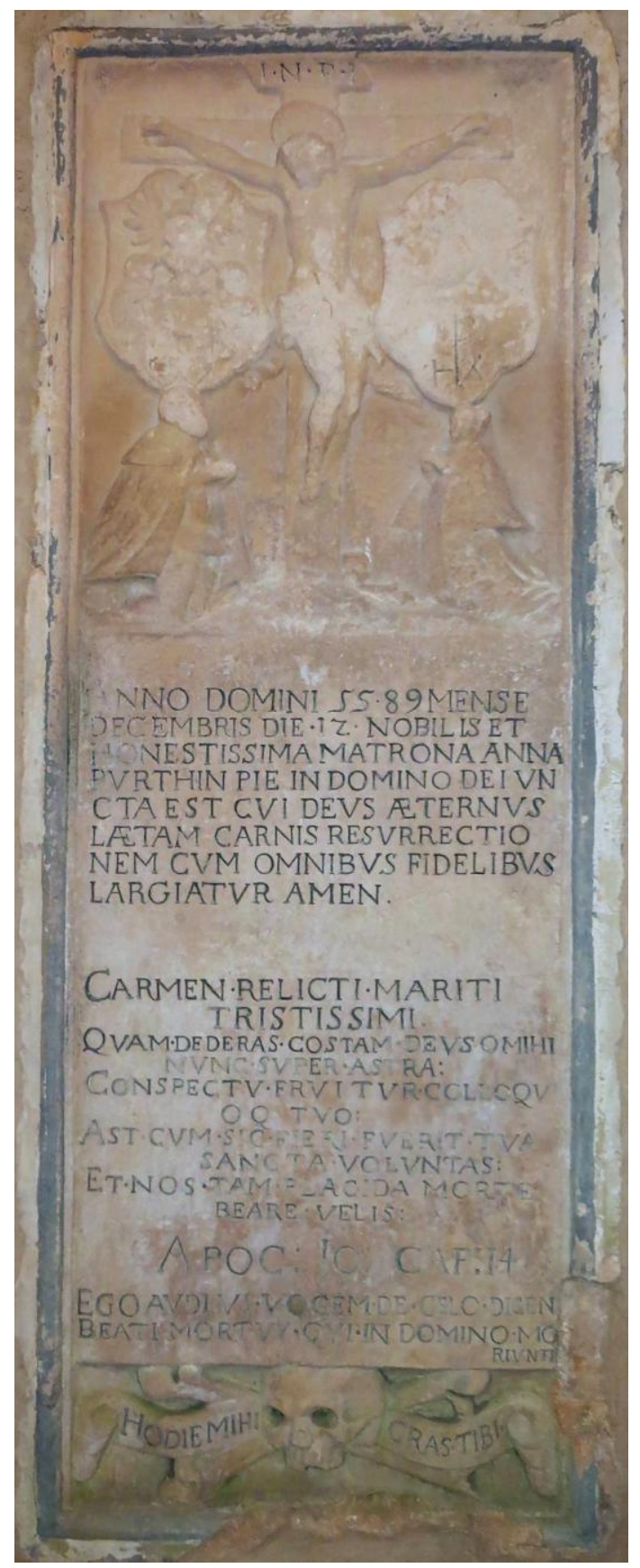

Slika 89. Suradnik Majstora Hassova epitafa (?), Epitaf Ane Purthin (†1589.), Samobor, Taborec, kapela sv. Mihaela

otkupio ljudski rod od Adamova grijeha, ${ }^{329}$ čime se motiv uklapa u i pridodaje eshatološkoj simbolici nadgrobnoga prikaza.

U osnovnim crtama, kompozicija nadgrobnika supružnika Purthin ne razlikuje se mnogo od rješenja primijenjenih na dosad razmotrenim epitafima. Ono po čemu jest drugačiji je važnost koja je pridana motivu obiteljskoga grba. Naime, iznad likova adoranata isklesani

\footnotetext{
${ }^{329}$ Usp. Anđelko Badurina (ur.), nav. dj., 1990. [1979.], sub voce Lubanja, str. 385-386 [Marijan Grgić]; sub voce Raspeće - Adamova lubanja, str. 503 [Anđelko Badurina]; James Hall, Rječnik tema i simbola u umjetnosti, Zagreb: Školska knjiga, 1998., sub voce Raspeće - Lubanja i zmija, str. 282. Preveo Marko Grčić.
} 
su grbovi obitelji Purthin koji se ističu dimenzijama i smještajem. ${ }^{330}$ Gotovo jednake veličine kao same figure pokojnika te postavljeni neposredno s lijeve i desne strane Krista, imaju jednaku sadržajnu važnost kao likovi predočenoga bračnog para. Za usporedbu, prisjetimo se obiteljskoga grba na epitafu Petra II. Keglevića (Slika 78) koji je vrlo suptilno uključen u prizor kao motiv na klecalu pokojnika. Smještanje grbova uz Kristov križ svjedoči o prodoru svjetovnoga u sferu nebeskoga koji je karakterističan za rani novi vijek, a njegova funkcija je glorifikacija obitelj kojoj je pokojnik pripadao tijekom ovozemaljskoga života. ${ }^{331}$

Ispod opisanoga figuralnog prikaza uklesan je natpis o pokojnici kojem slijedi kratka pjesma njezina ožalošćena supruga (»CARMEN RELICTI MARITI TRISTISSIMI«). Natpis završava citatom iz Otkrivenja koji je dio opisa Sudnjega dana, a odražava vjernikovu nadu u spasenje: »EGO AVDIVI VOCEM DE CELO DICENTEM BEATI MORTVY QVI IN DOMINO MORIVNTI [sic]« (Čuo sam glas s neba gdje govori: Blago mrtvima, koji umiru u Gospodinu. Otk 14, 13). Ispod navoda, pri samome dnu epitafa nalazi se lubanja s ukriženim kostima i svitkom na kojem je ispisana latinska uzrečica »HODIE MIHI, CRAS TIBI«, služeći kao podsjetnik na prolaznost života i neizbježnost smrti. Za razliku od nadgrobnika sa samostalnim likom pokojnika, epitafi s prikazom Raspetoga i adoranata često sadrže citate iz Biblije i liturgijskih tekstova. Iako obje vrste spomenika imaju eshatološku funkciju, ona je izraženija u potonjoj skupini zbog figuralnoga prikaza Krista razapetoga na križu. Stoga ne čudi činjenica što su takvi prikazi često popraćeni citatima koji se odnose na uskrsnuće i spasenje duše.

Analizirajući samoborski epitaf, Anđela Horvat (1975.) navela je kako je na epitafu »izražena [...] spiritualna maniristička crta« koja se očituje u postavljanju težišta na figuru Krista i sjetnom natpisu tugujućega udovca. ${ }^{332}$ Navedenome možemo pridodati oblikovne značajke manirizma razvidne u izduženim proporcijama Kristova tijela izvijena u S-liniju i predimenzioniranih obiteljskih grbova koji istiskuju prostor između figura pokojnika i Raspetoga. Unatoč oštećenjima, vrsno oblikovanje Kristove figure (u odnosu na shematično opisane likove adoranata) navodi na pomisao o mogućem suvremenom grafičkom predlošku poput Krista na križu (1584.) flamanskoga grafičara Hieronymusa Wierixa (Antwerpen, 1553. Antwerpen, 1619.) (Slika 91).

\footnotetext{
${ }^{330}$ Grb iznad Anina supruga sadrži štit s lavom ukrašen kacigom, krunom i nakitom u obliku lava. Grb iznad pokojničina lika, s druge strane, u gornjoj polovici sadrži motiv srne, a u donjoj Kristov monogram.

${ }^{331}$ Usp. Emilijan Cevc, nav. dj., 1981., str. 133.

332 Anđela Horvat, nav. dj., 1975., str. 352.
} 
(gore desno) Slika 90. Suradnik Majstora Hassova epitafa (?), Detalj epitafa Ane Purthin (†1589.), Samobor, Taborec, kapela sv. Mihaela

(dolje lijevo) Slika 91. Hieronymus Wierix, Krist na križu (kopija po Martenu de Vosu), 1584., Beč, Graphische Sammlung Albertina

(dolje desno) Slika 92. Suradnik Majstora Hassova epitafa, Detalj epitafa Andreja Praunfalcha

(†1600.), Ptuj, crkva sv. Jurja

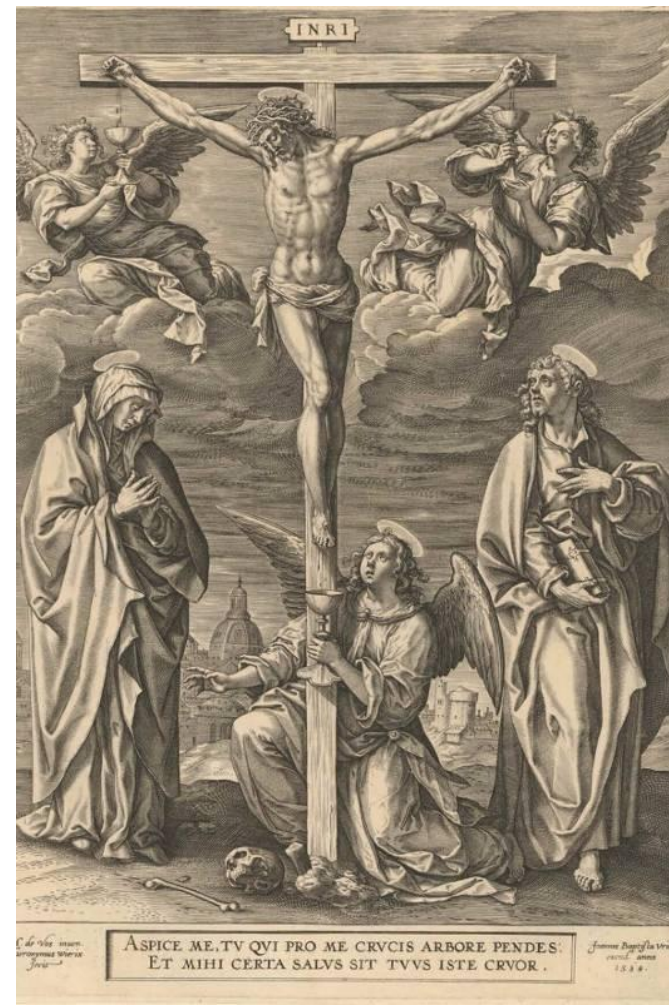

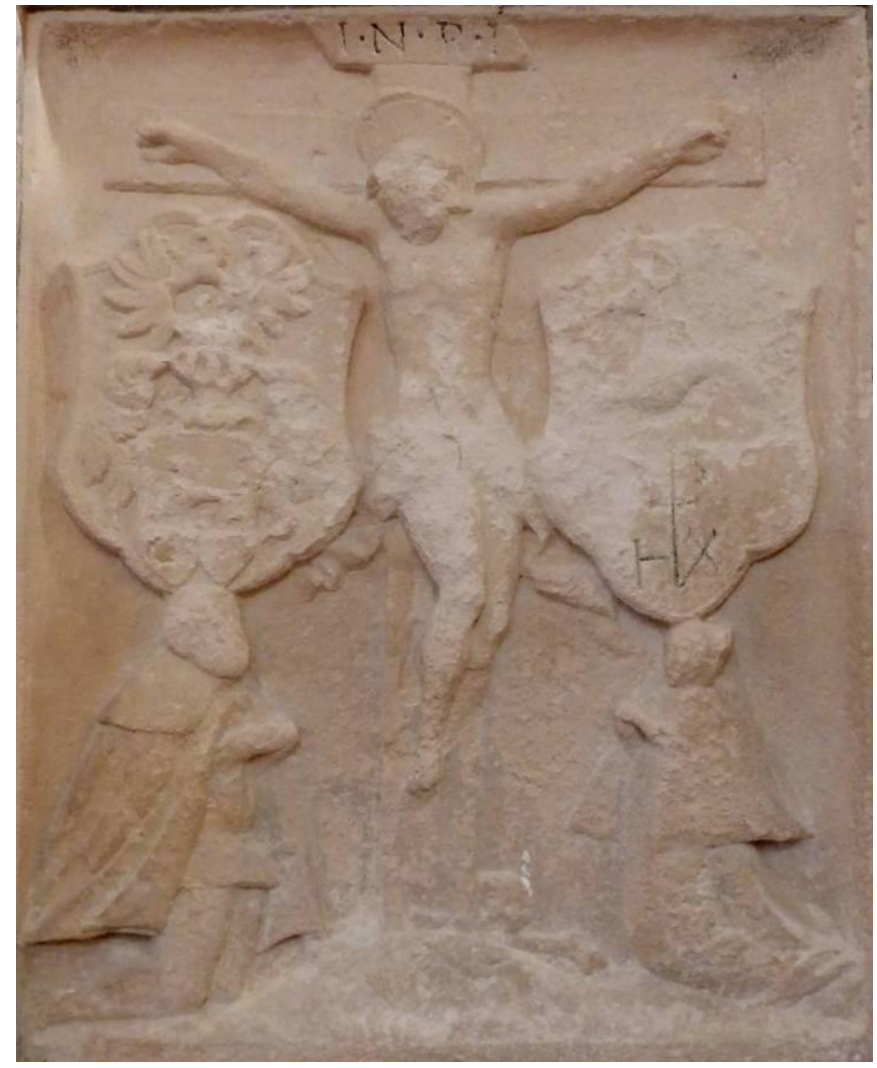

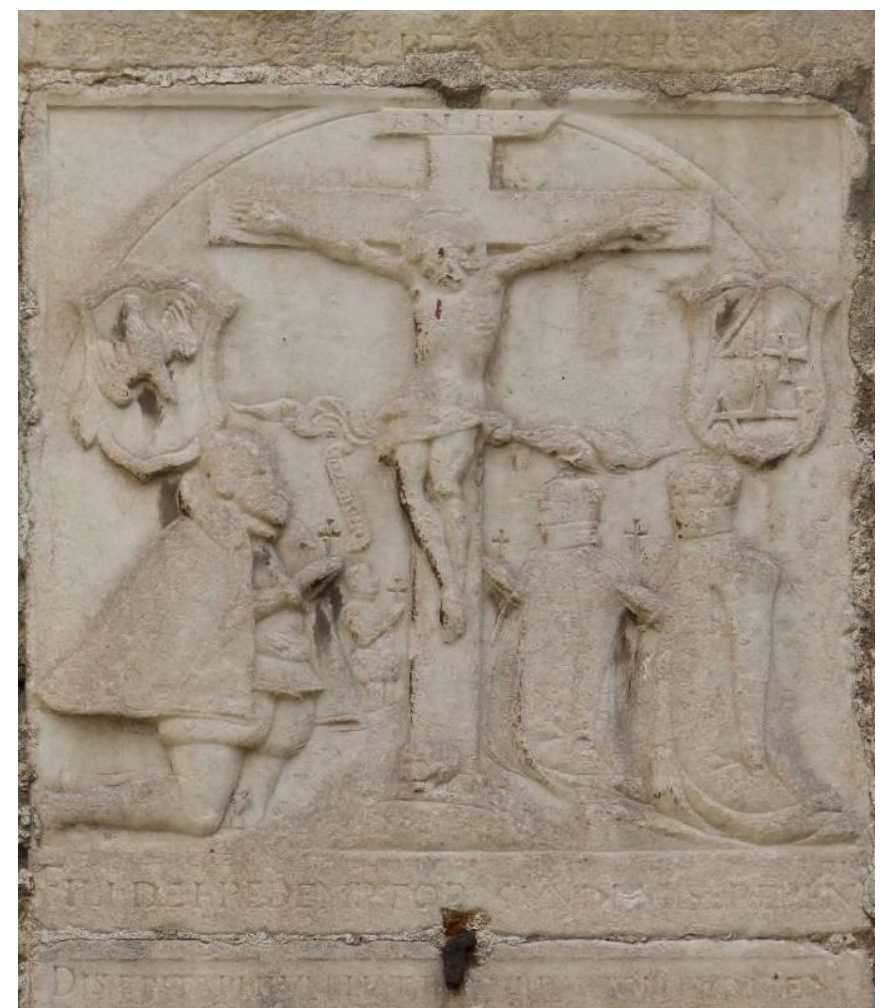


Oblikovno, epitaf Ane Purthin nalikuje nadgrobnim spomenicima koje je izradio Majstor Hassova epitafa, no postoje manje razlike koje ga odjeljuju od ostalih radova pripisanih kiparu. Na samoborskome epitafu, Kristov torzo proporcijama je bolje usklađen u odnosu na ostatak tijela, a likovi adoranata zakrenuti su iz poluprofila u tričetvrt profil, čime je pospješen privid volumena njihova tijela. U opisanim odmacima samoborski nadgrobnik srodan je epitafu Andreja Praunfalcha (†1600.) (Slika 92) iz crkve sv. Jurja u Ptuju koji je Emilijan Cevc (1981.) pripisao suradniku Majstora Hassova epitafa, kiparu koji je djelovao u sklopu odnosno proizašao iz majstorove klesarske radionice. ${ }^{333}$ Osim načina oblikovanja Kristova tijela i impostacije figura pokojnika, samoborski i ptujski spomenik povezuju i druge sličnosti. Na oba nadgrobnika obiteljski grbovi smješteni su iznad likova pokojnika, upotrijebljen je isti oblik štita, muškarci su odjeveni u mentene šiljasto oblikovanih završetaka, a žene nose ubradače koje im prekrivaju donji dio lica. Čak su i rubovi njihovih ogrtača uvijeni na isti način. S obzirom na opisane srodnosti, postoji mogućnost da je samoborski i ptujski spomenik izradio isti kipar koji se obučio kod Majstora Hassova epitafa ili je blisko surađivao s njime.

U crkvi sv. Marka evanđelista u Vinici - istoj onoj u kojoj je postavljena nadgrobna ploča Benedikta Thuróczyja Ludbreškoga (Slika 50) - nalazi se jedini nadgrobnik s područja povijesne Zagrebačke biskupije koji sadrži ikonografski potpun prikaz Raspeća, odnosno na kojem su uz Raspetoga prikazani Bogorodica i sv. Ivan evanđelist. Riječ je o epitafu Franje Keczera od Rad(o)vana (? - ?, poslije 1631.) (Slika 93) $)^{334}$ koji je, prema natpisu na spomeniku, plemić dao podići za sebe i svoju obitelj (»IN SVI SVORVMQVE MEMORIAM «) 1629. godine. Nije poznato gdje se nadgrobnik nalazio u staroj župnoj crkvi, ${ }^{335}$ no njezinom temeljitom pregradnjom početkom XIX. stoljeća ugrađen je u južni zid trijumfalnoga luka unutar jednostavne profilirane edikule. Keczeri su bili plemićka obitelj ugarskoga podrijetla, a Franjo je pripadao ogranku čiji je središnji posjed bio smješten u Rad(o)vanu, zapadno od Osijeka. Rodoslovlje obitelji od XIV. stoljeća nadalje velikim je dijelom neistraženo, no poznato je da su 1631. godine Franjo i Ivan Keczer imali poteškoća s Vlasima koji su obitavali na njihovim posjedima. ${ }^{336} \mathrm{~S}$ obzirom na to da se Franjo spominje $\mathrm{u}$ povijesnim izvorima 1631. godine, dvije godine nakon što je postavio spomenik u viničkoj

\footnotetext{
${ }^{333}$ Usp. Emilijan Cevc, nav. dj., 1981., str. 138-139.

${ }^{334}$ Kamen, $104 \times 43 \mathrm{~cm}$, širina edikule $78 \mathrm{~cm}$, Vinica, crkva sv. Marka Evanđelista, izvorno u staroj župnoj crkvi. Kat. br. 73 .

${ }^{335}$ Godine 1771. vizitator je naveo da se u crkvi nalaze brojni nadgrobni spomenici, no ne i za koga su podignuti. Usp. NAZ, KV, Prot. 170/XIa (1771.), str. 137; Anđelko Košćak, nav. dj., 2013., str. 133.

${ }_{336}$ Usp. Trpimir Macan (ur.), Hrvatski biografski leksikon. 7, Kam - Ko, Zagreb: Leksikografski zavod »Miroslav Krleža«, 2009., sub voce Keczer [Stanko Andrić].
} 


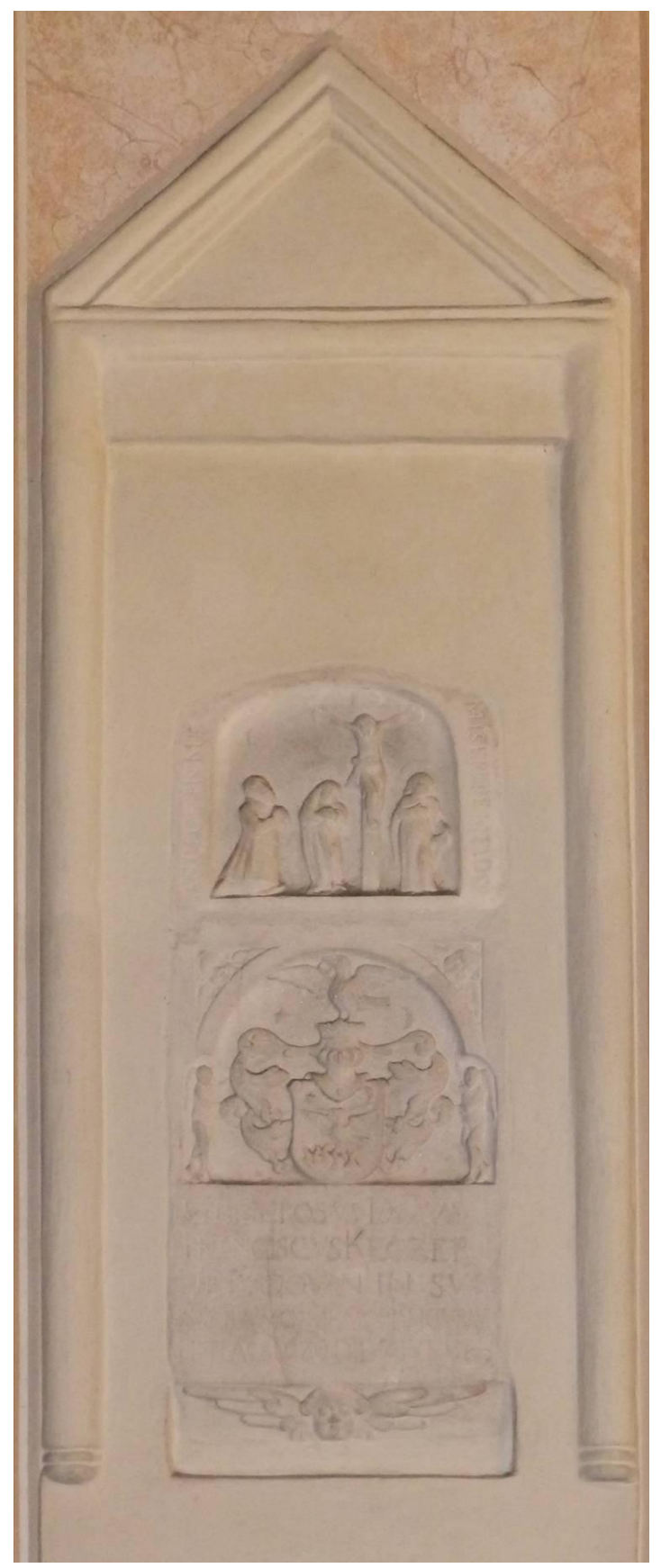

Slika 93. Radionica

Majstora Trantnerova epitafa (?), Epitaf Franje Keczera od Rad(o)vana, 1629., Vinica, crkva sv. Marka evanđelista

crkvi, njegov epitaf jedan je od rijetkih nadgrobnika na području Zagrebačke (nad)biskupije koji je podignut za naručiteljeva života. Ovo nije bila neuobičajena praksa, a svjedoči o želji pojedinca da si osigura spomenik koji će čuvati uspomenu na njega. ${ }^{337}$ Sličan primjer predstavlja nadgrobna ploča Lovre Iločkoga (†1524.) koja je izrađena prije hercegove smrti. Iločki je dao uklesati znamenke stoljeća u kojem je živio (MCCCC), a njegovi nasljednici trebali su dodati posljednje dvije znamenke desetljeća u kojem je umro, što oni iz nepoznatoga razloga nisu učinili. ${ }^{338}$

\footnotetext{
${ }^{337}$ Usp. Emilijan Cevc, nav. dj., 1981., str. 26, 28.

${ }^{338}$ Usp. Anđela Horvat, nav. dj., 1979.a, str. 314; Milan Pelc, nav. dj., 2009.b, str. 314.
} 
Keczerov epitaf sastoji se od navedenoga prikaza Raspeća s pokojnikom-adorantom (Slika 94), podno kojega se nalazi obiteljski grb i natpis zaključen motivom kerubina. Raspeće je izvedeno u plitkom reljefu unutar polukružno zaključene niše. Bogorodica je prikazana zdesna Kristu, obiju ruku prislonjenih na prsa, a pogleda usmjerena prema svome sinu. Sveti Ivan evanđelist stoji s Kristove lijeve strane, u lijevoj ruci drži knjigu, a desnu je nalik Bogorodici - privio na prsa. Do Marije kleči pokojnik odjeven u suvremenu odjeću, a njegov je lik nešto veći u odnosu na ostale. S obiju strana niše uklesan je stih iz Psalama, iz Molitve u pogibelji: »RESPICE IN ME / ET MISERERE MEI DEUS« (Pogledaj me $i$ smiluj mi se, Gospodine. Ps 24, 16). Prikaz Raspeća srodan je bakrorezu Krist na križu (Slika 95) čiji je crtež izradio Antonius II. Wierix (Antwerpen, 1555./59. - 1604.), ${ }^{339}$ jedan od trojice braće koji su bili među najplodnijim antwerpenskim grafičarima tijekom druge polovine XVI. i početka XVII. stoljeća. ${ }^{340}$ Wierixovi su poglavito izrađivali bakroreze sakralne tematike, a njihovi su radovi poslužili kao predlošci brojnim likovnim djelima diljem katoličke Europe, uključujući Hrvatsku. ${ }^{341}$ Sličnosti između Wierixova rješenja i reljefa Raspeća s Keczerova epitafa zamjetne su u impostaciji i gestama Raspetoga, Bogorodice i sv. Ivana evanđelista, posebice u načinu na koji sv. Ivan pridržava knjigu. Vinički reljef, međutim, odstupa od Wierixove invencije u izostanku trnove krune, načinu sklapanja Bogorodičinih ruku i položaju Ivanove glave, što nas sprječava da bakrorez odredimo kao neposredan grafički predložak, no ostavlja otvorenom mogućnost da se autor viničkoga reljefa poslužio njime kao inspiracijom u osmišljavanju kompozicije.

Ispod prikaza Raspeća, na nadgrobniku je unutar trolisnoga okvira isklesan grb obitelji Keczer $^{342}$ u niskome reljefu (Slika 96). Urešen je plaštem, kacigom i krunom s ukrasom, a pridržavaju ga čuvari u obliku anđela. Kutovi središnjega luka okvira ukrašeni su motivima

\footnotetext{
${ }^{339}$ Prema potpisu, Antonius II. Wierix je inventor i izdavač grafike: »Anton. Wierx inuent. \& excud.« Usp. Zsuzsanna van Ruyven-Zeman i Marjolein Leesberg, Hollsteins's Dutch \& Flamish Etchings, Engravings and Woodcuts 1450-1700, Volume LX. The Wierix Family: Part II, Rotterdam: Sound \& Vision Publishers, Amsterdam: Rijskprentenkabinet, 2003., str. 147-148, br. 349.

${ }^{340}$ Antonius je imao dvojicu starije braće, Johannesa (Antwerpen, 1549. - Bruxelles, o. 1620.) i Hieronymusa (Antwerpen, 1553. - 1619.). Njegov sin Antonius III. (Antwerpen, 1596. - 1624.) također je bio uspješan grafičar. Usp. Zsuzsanna van Ruyven-Zeman, The Wierix Family: Introduction, u: Hollsteins's Dutch \& Flamish Etchings, Engravings and Woodcuts 1450-1700, Volume LXIX. The Wierix Family: Introduction and Guide to the Catalogue, Rotterdam: Sound \& Vision Publishers, Amsterdam: Rijskprentenkabinet, 2004., str. xiii-xlv. Sakupile Zsuzsanna van Ruyven-Zeman i Marjolein Leesberg.

${ }^{341}$ Za djela hrvatske likovne baštine nastala po uzoru na grafike obitelji Wierix vidi: Sanja Cvetnić, Ikonografija nakon Tridentskoga sabora i hrvatska likovna baština, Zagreb: FF press, 2007., str. 75-76, 78-80, 118-119.

${ }^{342} \mathrm{Na}$ štitu je prikazan feniks raširenih krila koji se uzdiže iz plamena, a u kljunu drži prsten. S njegove desne strane nalazi se petokraka zvijezda, a s lijeve polumjesec. Isti motiv ponovljen je u ukrasu krune. Usp. Ivan von Bojničić, nav. dj., 1889., str. 86, tab. 60.
} 

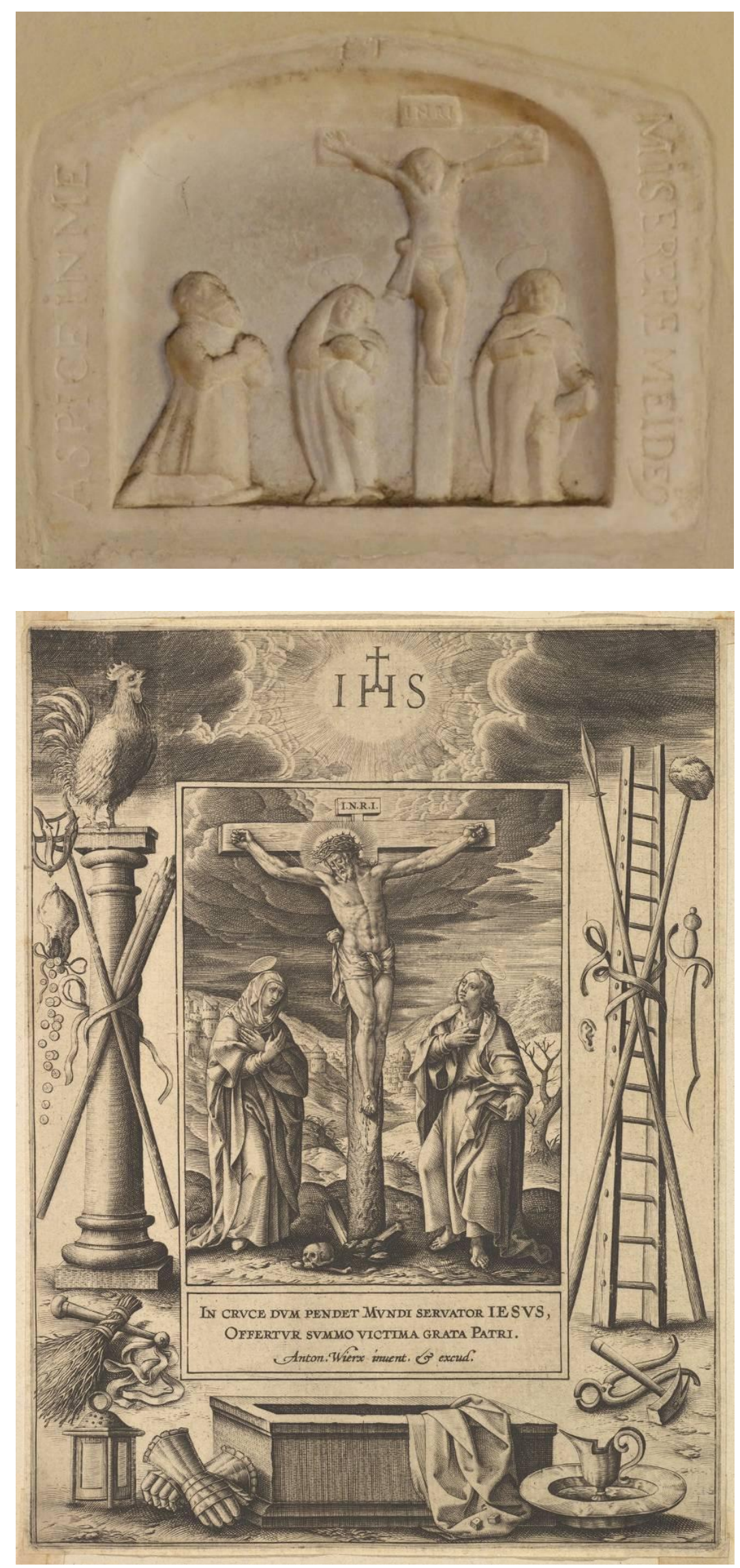

Slika 94. Radionica

Majstora Trantnerova epitafa (?), Epitaf Franje Keczera od Rad(o)vana - detalj Raspeća, 1629., Vinica, crkva sv. Marka evanđelista
Slika 95. Krist na križu (kopija po Antoniusu II. Wierixu), prije 1604., New York, Metropolitan Museum of Art, Department of Prints and Photographs 
kerubina, kao na nadgrobnim pločama Benedikta Thuróczyja Ludbreškoga (Slike 50 i 55) i Vragovića (Slika 52). Ispod grba uklesan je kratki natpis o pokojniku, podno kojega je ponovljen motiv glavice anđela.

Oblikovno, epitaf Franje Keczera možemo povezati s djelima radionice Majstora Trantnerova epitafa, kojoj je Emilijan Cevc (1981.) pripisao autorstvo nadgrobne ploče Benedikta Thuróczyja Ludbreškoga. ${ }^{343}$ Podsjetimo se, radionica je djelovala od okvirno 1610. do 1650. godine početno u Ptuju, a potom u Slovenskim Konjicama. ${ }^{344}$ Njezini se radovi nalaze diljem slovenske Štajerske, a na njima možemo pronaći sve elemente koje sadrži Keczerov spomenik. Na središnjem reljefu epitafa Christopha von Tattenbacha $(\dagger 1627$. (Slika 98) iz grobljanske crkve sv. Ane u Slovenskim Konjicama nalazi se, primjerice, prikaz Raspeća na kojem je impostacija Raspetoga, Bogorodice i sv. Ivana srodna onoj na Keczerovu nadgrobniku. S obzirom na to da je Tattenbachov nadgrobnik većih dimenzija, likovi svetih osoba i pokojnikove obitelji detaljnije su izvedeni, no na njima je zamjetan isti način pojednostavljivanja ljudske fizionomije i linijskoga tretmana draperije kao na Keczerovu spomeniku. Nadalje, na epitafu Jurja iz Kamnice (Georg Gambsis; †1631.) (Slika 97) iz župne crkve u Rogatcu upotrijebljen je isti trolisni okvir s motivima kerubina u ugaonim poljima. ${ }^{345}$ Anđeli na Tattenbachovu, Jurjevu i Keczerovu nadgrobniku gotovo su istovjetno oblikovani - imaju punašne obraze, podbuhli podbradak i široko čelo uokvireno dvama uvojcima kose razdijeljenima po sredini. Slične anđeoske glavice upotrijebljene su i na nadgrobnoj ploči Ane Katarine Wechlser rođ. Haslinger (†1629.) (Slika 99) iz crkve sv. Ane u Vurberku. Opisani kerubini nešto su jednostavnije izvedbe od onih na nadgrobnicima iz početna dva desetljeća aktivnosti radionice - kojima pripada i Thuróczyjeva nadgrobna ploča (Slika 50) - što je Cevc (1981.) objasnio svojevrsnim »nazadovanjem dotad postignutoga razvojnoga stupnja« koje je zamjetno na djelima nastalima tijekom tridesetih godina XVII. stoljeća. ${ }^{346}$ Nadgrobnik Franje Keczera srodan je djelima pripisanima radionici - pa tako i nadgrobnoj ploči Benedikta Thuróczyja Ludbreškoga (Slika 55) - i u načinu oblikovanja grba. Na svim navedenim spomenicima upotrijebljen je isti oblik štita, kacige i krune, a plašt je izveden u obliku para bujnih listova akanta koji proizlaze iz krune i flankiraju štit.

\footnotetext{
${ }^{343}$ Za raspravu o autorstvu Thuróczyjeva nadgrobnika, vidi str. 71-72.

${ }^{344}$ Usp. Emilijan Cevc, nav. dj., 1981., str. 181-197.

${ }^{345}$ Usp. Emilijan Cevc, nav. dj., 1981., str. 183-184.

346 »Tedaj je dal postaviti gospod Matthes Haas materi Barbari v Mariboru (zunanjščina stolnice) epitaf, ki se nam zdi motivno skoraj kot nazadovanje od že dosežene razvojne stopnje.« Emilijan Cevc, nav. dj., 1981., str. 183. Prijevod autoričin.
} 


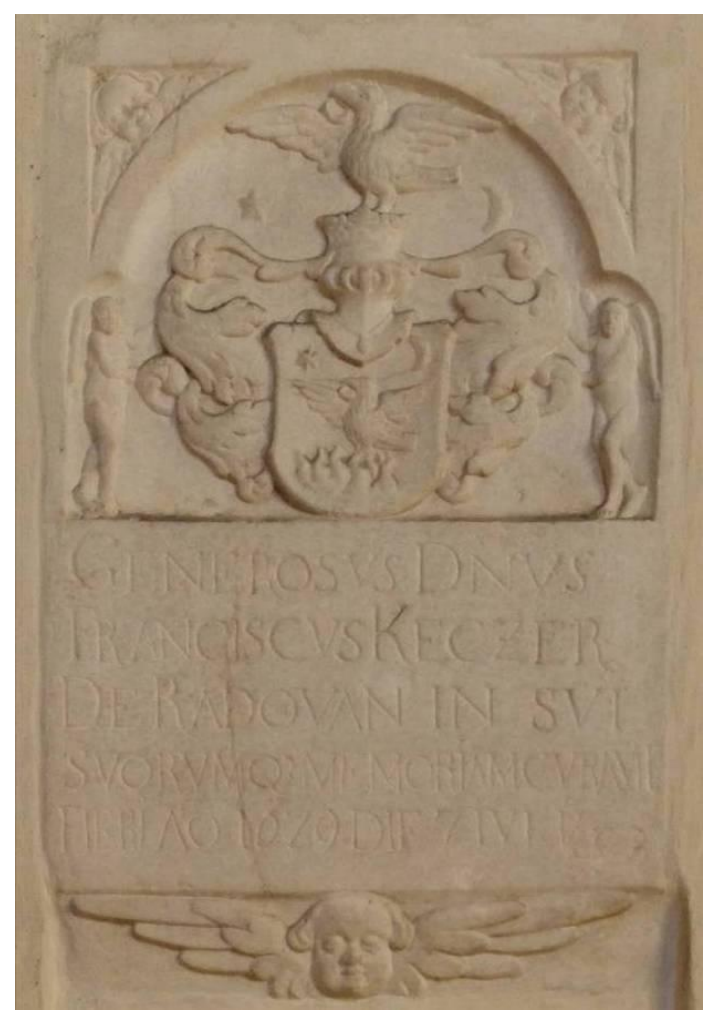

Slika 96. Radionica Majstora Trantnerova epitafa (?), Epitaf Franje Keczera od Rad(o)vana - detalj grba i natpisa, 1629., Vinica, crkva sv. Marka evanđelista

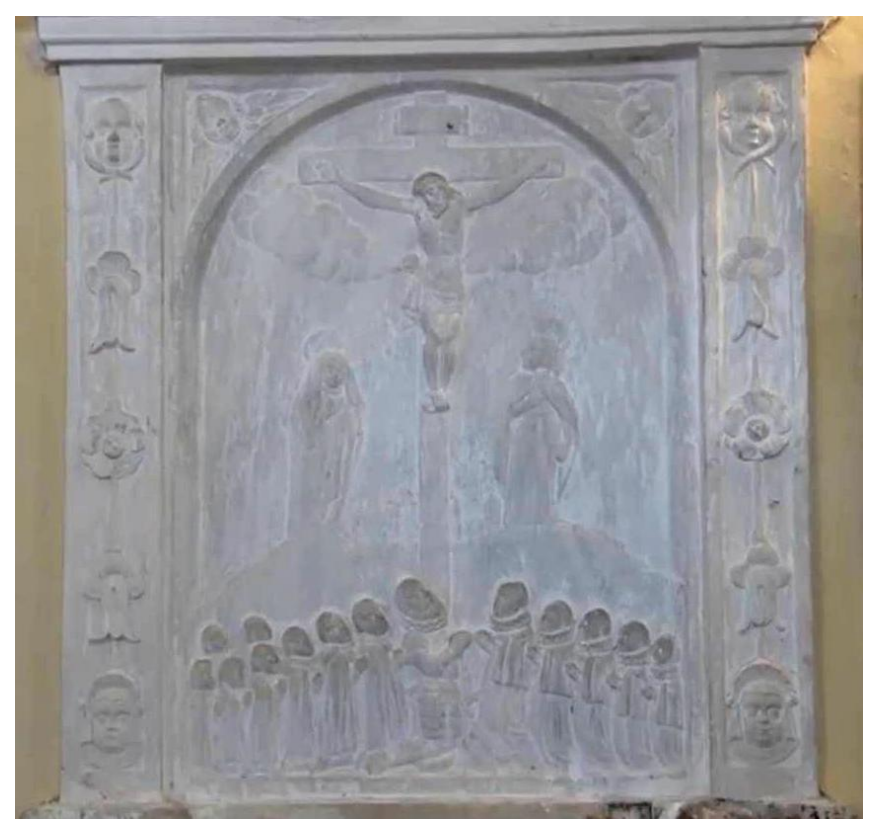

(gore) Slika 98. Radionica Majstora Trantnerova epitafa, Epitaf Christopha von Tattenbacha $(+1627)-$. detalj središnjega reljefa, Slovenske konjice, crkva sv. Ane

(desno) Slika 99. Radionica Majstora Trantnerova epitafa, Nadgrobna ploča Ane Katarine Wechsler rođ. Haslinger (†1629.), Vurberk, crkva sv. Ane

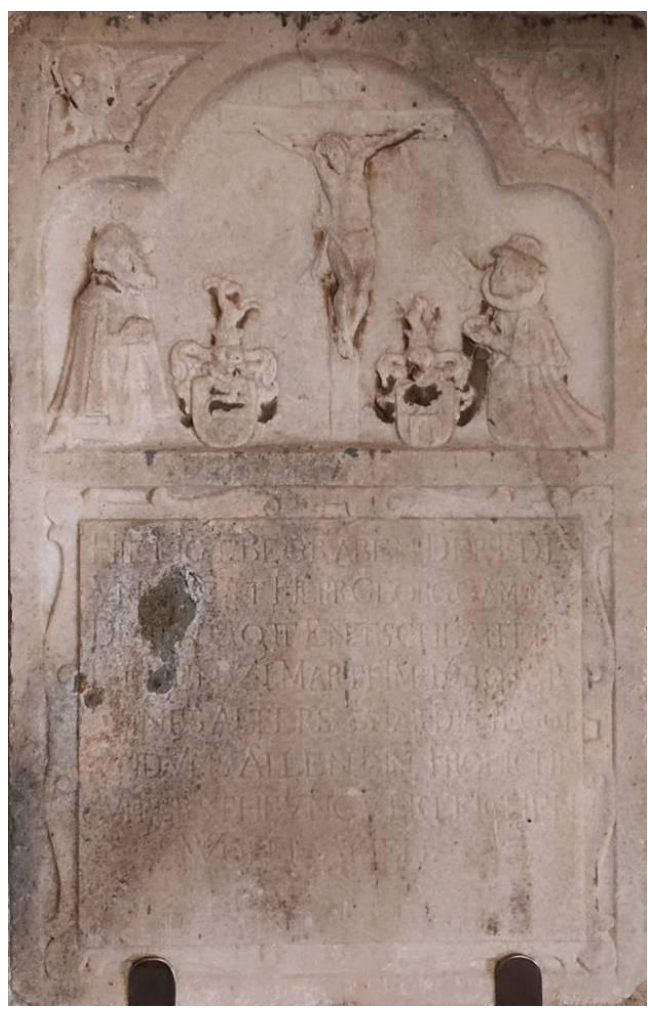

Slika 97. Radionica Majstora Trantnerova epitafa, Epitaf Georga Gambsisa (†1631.), Rogatec, crkva sv. Jerneja (Bartolomeja) 
Krajem XVII. stoljeća podignut je još jedan epitaf pod okolnostima sličnima onima pod kojima je nastao spomenik Ane Purthin. U Plešivici, mjestu smještenom petnaestak kilometara južno od Samobora, žumberački podkapetan Juraj Ivan I. Hrvoj (? - ?, 1704.) podigao je u crkvi sv. Jurja epitaf u spomen na svoju suprugu Evu Hrvoj rod. Dreffel (? - ?, 1672.) (Slika 100). ${ }^{347}$ Obitelj Hrvoj (Hervoy) primila je plemićku titulu u XVI. stoljeću, a glavni obiteljski posjed nalazio se u Prilipju nedaleko Jastrebarskoga. ${ }^{348}$ Godine 1668. Juraj Ivan I. Hrvoj osnovao je darovnicu kojom je proširena stara plešivička crkva ${ }^{349} \mathrm{U}$ sakristiji crkve uredio je obiteljsku grobnicu, a nakon preuranjene smrti supruge Eve na južnome zidu svetišta dao je podići nadgrobnik s njezinim i vlastitim likom koji predstavlja jedan od najbolje sačuvanih i najkvalitetnije izvedenih epitafa s prikazom Raspetoga i adoranata na području Zagrebačke (nad)biskupije. ${ }^{350}$

Nadgrobnik supružnika Hrvoj izveden je u obliku edikule s prekinutim segmentnim zabatom i pravokutnom osnovom s postoljima za nosače. Nosači su izvedeni u obliku profiliranih istaka, bez definiranih baza i kapitela. U središnjem dijelu edikule smješten je reljefni prikaz pokojnikā koji mole pred Raspetim. U zabatnom polju nalazi se kartuša s Kristovim monogramom sv. Bernardina, a u donjem dijelu spomenika, između postoljā nosačā, ploča s nadgrobnim natpisom. Arhitektonski elementi isklesani su iz kamena, a ispune iz bijeloga (središnji reljef) odnosno crnoga mramora (kartuša, ploča s natpisom). Nadgrobnik oblikom podsjeća na jednostavne oltarne retable, pri čemu bi pravokutna osnova analoški odgovarala predeli, središnji prikaz pali, a segmentni zabat s kristogramom atičkom zaključku. Ovakva vrsta nadgrobnih spomenika naglašene sakralne forme i sadržaja javlja se nakon Tridentskoga sabora (1545. - 1563.), a zastupljena je na području cijele Europe. ${ }^{351}$

Središnji reljef Raspetoga s adorantima (Slika 101) kompozicijski prati već ustaljeno rješenje na nadgrobnim spomenicima. U središtu prikaza nalazi se lik Krista razapetoga na križu koji gestom obiju ruku blagoslivlja pokojnike. Na njegovom ispijenom tijelu jasno se ocrtavaju rebra, mišići i tetive koji u mislima promatračã prizivaju Pasiju. Pri dnu križa nalazi se (Adamova) lubanja i par ukriženih kostiju. S Kristove desne i lijeve strane kleče pokojnici odjeveni u suvremenu odjeću. Ruke su im sklopljene u molitvi, a pogled usmjeren prema Kristovu licu. Njihovi likovi razmjerno su veći od figure Raspetoga, čime im je pridana veća

\footnotetext{
${ }^{347}$ Mramor, Kamen pješčenjak, $247 \times 108 \times 9$ cm, Plešivica, crkva sv. Jurja. Kat. br. 15.

${ }^{348}$ Usp. Ivan von Bojničić, nav. dj., 1889., str. 63.

349 Usp. Đurđica Cvitanović, Crkveno graditeljstvo, u: Skriveno blago: iz riznice umjetničkih znamenitosti jastrebarskog kraja. Kulturni i prirodni spomenici Hrvatske: zbirka vodiča časopisa Kaj 8, Zagreb: Zagrebačko spravišče, 1975., str. 1-28, 13; Đurđica Cvitanović, Sakralna arhitektura baroknog razdoblja. Knjiga I. Gorički $i$ gorsko-dubički arhiđakonat. Zagreb: Društvo povjesničara umjetnosti SR Hrvatske, 1985., str. 52, 241.

${ }^{350}$ Usp. Marijana Schneider, nav. dj., 1959., str. 179.

${ }^{351}$ Usp. Howard Colvin, nav. dj., 1991., str. 221.
} 


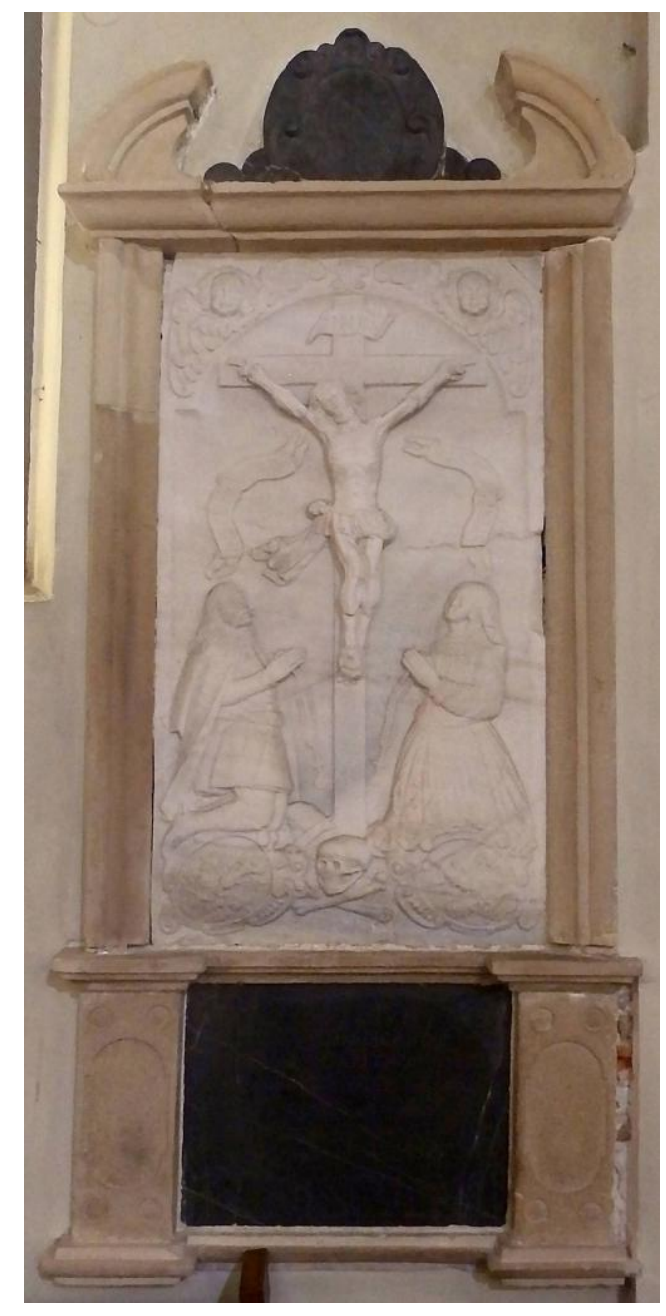

(gore) Slika 100. Epitaf Eve rođ. Dreffel (†1672.) i Jurja Ivana I. Hrvoja (†1704.), Plešivica, crkva sv. Jurja

(desno) Slika 101. Detalj epitafa Eve rođ. Dreffel (†1672.) i Jurja Ivana I. Hrvoja (†1704.), Plešivica, crkva sv. Jurja

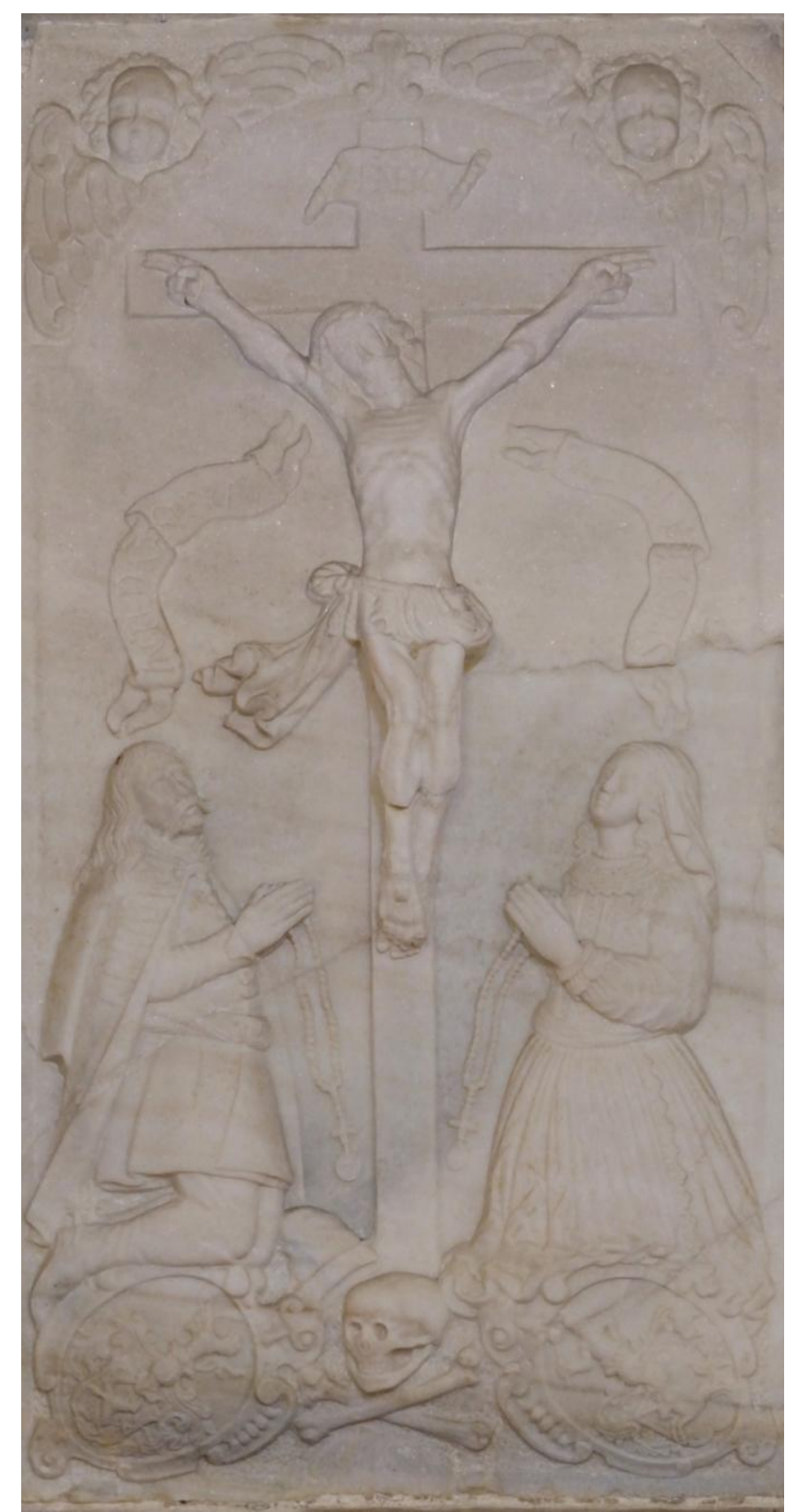

važnost. ${ }^{352}$ Juraj Ivan I. Hrvoj predočen je kao muškarac zrelih godina, duge kose i brkova te skrušena izraza lica. Odjeven je u dolamu, hlače i menten, a njegov kalpak odložen je sa strane, uz podnožje križa. Eva Hrvoj rođ. Dreffel prikazana je kao mlada žena blagih crta lica i duge kovrčave kose prekrivene velom. Odjevena je u bogato izvezenu košulju sa steznikom i suknju. Prema Marijani Schneider (1959.) »karakterističnost [pokojnikovih] lica upućuje na portretnu vjernost «. ${ }^{353}$ Oba supružnika u rukama drže krunicu s križem i medaljonom, a kleče

\footnotetext{
${ }^{352}$ Usp. Marijana Schneider, nav. dj., 1959., str. 180.

${ }^{353}$ Marijana Scheider, nav. dj., 1959., str. 181.
} 
na kartušama unutar kojih su prikazani obiteljski grbovi. ${ }^{354}$ Iznad njihovih glava isklesani su svitci s citatima iz Staroga zavjeta i Rimskoga misala. Iznad Jurja ispisan je navod iz Psalama: »IN TE D[omi]NE SPERAVI« (Tebi se, Gospodine, utječem. Ps, 31, 2), a iznad Eve dio stiha Uskrsne posljednice (Victimae paschali laudes): »SPES MEA CHRISTUS« (Krist, nada moja). ${ }^{355}$ Povrh opisanoga prikaza nadvija se polukružni istak čiji su kutovi ukrašeni dvama kerubinima, nalik nadgrobnicima Benedikta Thuróczyja Ludbreškoga (Slike 50 i 55) i Franje Keczera od Rad(o)vana (Slike 93 i 96) u Vinici te člana obitelji Vragović u Maruševcu (Slika 52).

U članku O epitafiju Ivana Hrvoja $i$ Eve Dreffell u Plešivici (1959.) Marijana Schneider vrlo je detaljno opisala spomenik. ${ }^{356}$ Istaknula je njegove glavne stilske karakteristike te pokušala razjasniti okolnosti narudžbe. Iako je kompozicija središnjega reljefa gotovo zrcalno simetrična, Schneider je primijetila da su pojedini oblici dijagonalno usmjereni:

»...smjer ruku raspetog nastavlja se u glavama adoranata sa zabačenom kosom, odnosno maramom. Iste dijagonalne smjerove slijede linije draperije, podlaktica i sklopljenih ruku i položaj tijela i odijela. Motiv se dijagonala ponavlja u osovinama grbova i u ukrštenim kostima podno križa. « ${ }^{357}$

Autorica je istaknula izražajnost i realističnost oblikovanja licā pokojnikā te - dodali bismo naturalizam u prikazu anatomije Kristova tijela. ${ }^{358}$ Ukazala je na kiparevu vrlo vještu modelaciju kojom je dočarao različite teksture odjeće, poput tankoga vela i čipkastoga ovratnika pokojnice ili teškoga i debeloga ogrtača pokojnika, te uspješno stupnjevanje plastičnosti volumena od gotovo pune skulpture Kristova lika, preko visokoga reljefa figura pokojnikā, do niskoga reljefa svitaka i grbova, čime je postignut dojam dubine. ${ }^{359}$ Iako Schneider nigdje u tekstu nije izrijekom navela, opisane formalne karakteristike obilježje su baroknoga stila.

Nadgrobni natpis ispod središnjega prikaza Raspetoga i adoranata bilježi godine smrti Eve (1672.) i Jurja Ivana I. Hrvoja (1704.), no ne sadrži potankosti o tome kada je epitaf

\footnotetext{
${ }^{354} \mathrm{Na}$ štitu grba Jurja Ivana I. Hrvoja nalaze se lav, koji u desnoj šapi drži sablju, i polumjesec. Štit je ukrašen plaštem, kacigom, krunom i nakitom u obliku ponovljenih motiva lava i polumjeseca. Usp. Ivan von Bojničić, nav. dj., 1889., str. 63, tab. 45. Grb Eve Dreffel sastoji se od štita s motivom jednoroga, plašta, kacige i krune ukrašene motivom viteza koji u desnoj ruci drži topuz, a lijevu drži podbočenu o bok.

${ }^{355}$ Puni stih posljednice glasi: »Surrexit Christus spes mea« (Uskrsnu Krist, nada moja).

${ }^{356}$ Usp. Marijana Schneider, O epitafiju Ivana Hrvoja i Eve Dreffell u Plešivici, u: Bulletin Instituta za likovne umjetnosti Jugoslavenske akademije znanosti $i$ umjetnosti VII/3, Zagreb: Jugoslavenska akademija znanosti i umjetnosti, 1959., str. 177-182.

${ }^{357}$ Marijana Schneider, nav. dj., 1959., str. 180.

${ }^{358}$ Usp. Marijana Schneider, nav. dj., 1959., str. 181.

${ }^{359}$ Isto.
} 
postavljen. Budući da dosad nije pronađen pisani izvor koji bi razjasnio okolnosti narudžbe, godine smrti bračnoga para predstavljaju jedini orijentir u dataciji spomenika. S obzirom na to da su pokojnici preminuli u razmaku od tridesetak godina, nameće se pitanje je li nadgrobnik podignut već nakon Evine smrti ili tek nakon što je preminuo njezin suprug. U navedenom članku Marijana Schneider (1959.) iznijela je pretpostavku da je Juraj Ivan I. dao izraditi središnji reljef neposredno nakon suprugine smrti u želji da »pravovremeno ovjekovječi uspomenu na rano preminulu ženu [te] istodobno pripremi spomenik i sebi«, ${ }^{360}$ a da je ostatak nadgrobnika dovršen nakon što je preminuo. ${ }^{361}$ Svoju je tezu potkrijepila argumentom da reljef dijeli brojne sličnosti s nadgrobnim spomenicima koji datiraju iz XVII. stoljeća, poput primjene ustaljenoga likovnog rješenja, motiva kerubina u ugaonim poljima luka, stilizacije anđeoskih krila, načina obrade kose, oblika svitaka s natpisima te motiva mrtvačke glave s kostima podno križa. ${ }^{362}$ Ovome argumentu pridodala je činjenicu da su oboje Eva i Juraj Ivan I. prikazani u srednjim godinama, u dobi u kojoj su bili u vrijeme Evine smrti, iako je Juraj Ivan I. preminuo više od trideset godina poslije svoje supruge. U pokušaju da precizira godinu izrade središnjega prikaza, autorica je iznijela pretpostavku da je reljef »izrađen u razmaku od oko deset godina iza Evine smrti, koliko je trebalo da bude naručen i izrađen, dakle oko 1680. g. $\ll^{363}$

Tvrdnju Marijane Schenider (1959.) da je središnji reljef epitafa supružnika Hrvoj oblikovno srodan nadgrobnicima XVII. stoljeća potvrđuju usporedbe. Na prikazu je primijenjeno tradicionalno likovno rješenje Raspetoga s adorantima koje se više ne javlja na nadgrobnim spomenicima XVIII. stoljeća s područja Zagrebačke (nad)biskupije. Slično možemo ustvrditi za motive kerubina, natpisnih svitaka i Adamove lubanje koje - ponovno ne nalazimo na očuvanim osamnaestostoljetnim nadgrobnicima. U prilog dataciji reljefa $u$ drugu polovinu XVII. stoljeća ide i činjenica da prikaz sadrži motiv hrskavičaste kartuše e $^{364}$ koji se na području sjeverozapadne Hrvatske poglavito primjenjivao na oltarnim predelama tijekom sedamdesetih i osamdesetih godina XVII. stoljeća. ${ }^{365} \mathrm{~S}$ obzirom na to da još uvijek nisu poznate potankosti narudžbe i izrade reljefa, smatramo da godina smrti Eve Hrvoj rođ. Dreffel (1672.) predstavlja sigurniju vremensku odrednicu u dataciji njegove izrade kao

\footnotetext{
360 Isto.

${ }^{361}$ Usp. Marija Schneider, nav. dj., 1959., str. 182.

362 Isto.

363 Isto.

${ }^{364}$ Riječ je o kartuši obrubljenoj kralješcima, odnosno hrskavičastim elementima. Na plešivičkom prikazu pokojnici kleče na hrskavičastim kartušama koje sadrže grbove obitelji Hrvoj i Dreffel.

${ }^{365}$ Usp. Martina Wolff Zubović, Tipologija i podrijetlo ornamentike na drvenim oltarima XVII. i XVIII. stoljeća na području sjeverozapadne Hrvatske - recepcija, primjena i razvoj motiva, Svezak I., doktorski rad, Zagreb: Filozofski fakultet Sveučilišta u Zagrebu, 2017., str. 35; Svezak II., str. 504.
} 
terminus post quem od 1680. godine koju je predložila Marijana Schneider. Slažemo se da je ostatak nadgrobnika - ili barem natpisna ploča i kartuša s Kristovim monogramom koja je izvedena u istom materijalu - nastao nakon smrti Jurja Ivana I. Hrvoja, kao što je navela Marijana Schneider.

Među nadgrobnicima s prikazom Raspetoga i adoranata preostala su još tri spomenika koja tvore svojevrsnu podskupinu unutar naznačenoga korpusa. Na njima su pokojnici prikazani sami u molitvi pred Raspetim, a odjeveni su u viteški oklop, čime se nadovezuju na tradiciju viteških nadgrobnika. Najstariji spomenik koji pripada ovoj grupi ujedno je jedan od najreprezentativnijih nadgrobnika očuvanih na području povijesne Zagrebačke biskupije općenito. Riječ je o epitafu Tome II. Erdődyja (?, 1558. - Krapina, 1624.) (Slika 102) (66 $^{366}$ koji je postavljen u južnoj apsidi zagrebačke prvostolnice uz oltar posvećen Bogorodici i

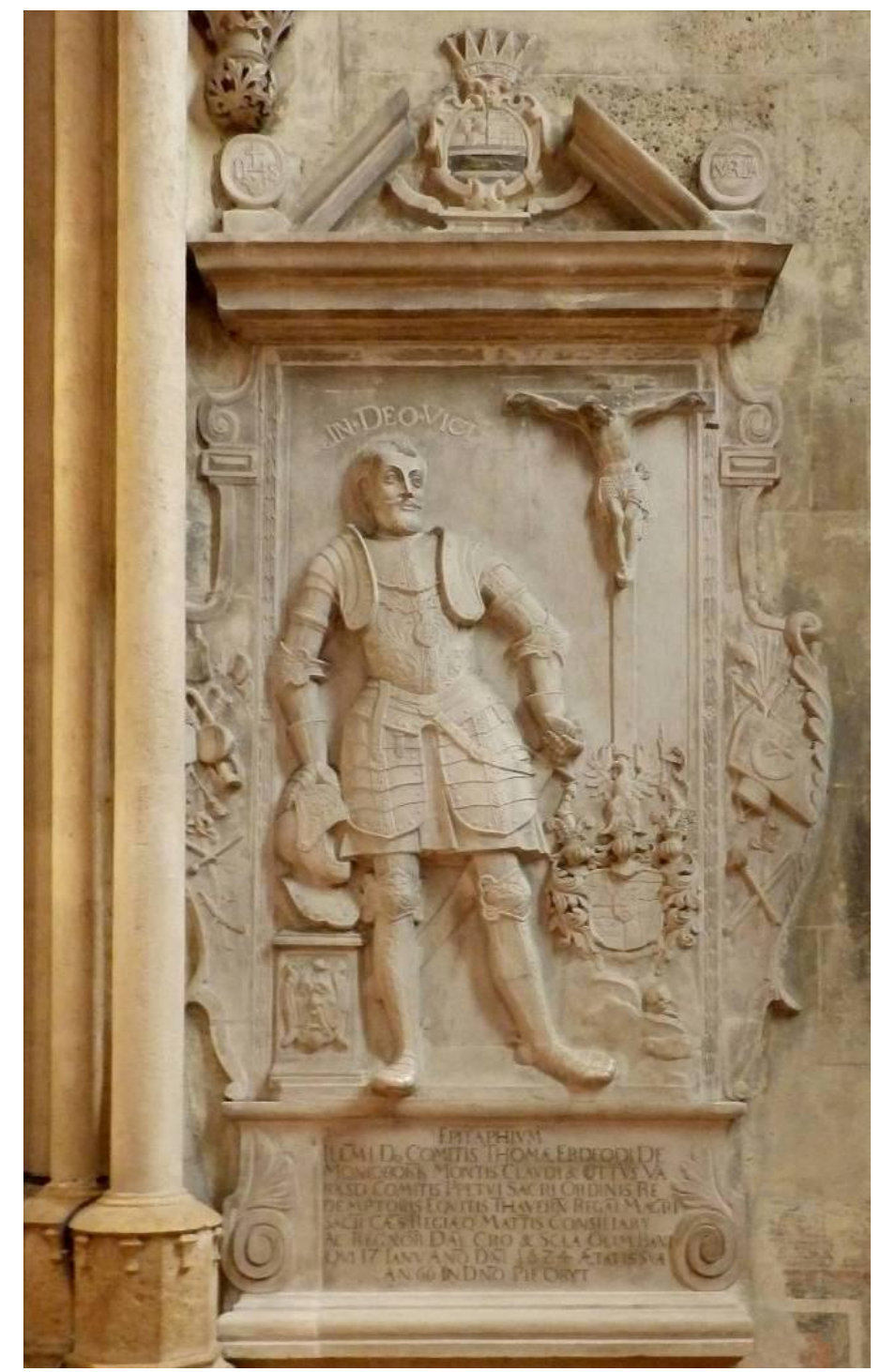

Slika 102. Epitaf Tome II. Erdödyja (†1624.), Zagreb, katedrala Uznesenja Blažene Djevice Marije i sv. Stjepana i Ladislava

\footnotetext{
${ }^{366}$ Mramor, $340 \times 140 \times 14 \mathrm{~cm}$, Zagreb, katedrala Uznesenja Blažene Djevice Marije i sv. Stjepana i Ladislava. Kat. br. 37.
} 
jedan je od tri nadgrobnika u katedrali koji su ostali in situ. Erdődyjev život bio je obilježen borbama protiv Osmanlija, a godine 1593. doprinio je pobjedi europskih snaga nad osmanskom vojskom u bitci kod Siska. Obnašao je dužnosti hrvatsko-dalmatinskoslavonskoga bana (1584. - 1595., 1608. - 1614.), vrhovnoga kraljevskog stolnika (1598.), tavernika za Ugarsku (1603.) i kapetana Kraljevstva (1603. - 1605.). Bio je gorljiv branitelj rimokatoličke vjere što je pokazao na zasjedanju ugarsko-hrvatskoga sabora u Požunu 1608. godine kada se usprotivio zahtjevu ugarskih staleža da se omogući naseljavanje protestanata na području Hrvatske. ${ }^{367}$

Poput nadgrobnika supružnika Hrvoj, epitaf Tome II. Erdődyja izgledom nalikuje jednostavnom oltarnom retablu, ${ }^{368}$ a sastoji se od pravokutnoga postolja, središnjega dijela $\mathrm{s}$ plitkim krilima i zabatnoga zaključka. Na postolju ukrašenom ornamentom repovlja uklesan je natpis koji sadrži podatke o pokojnikovu životu i smrti. Na njemu počiva pravokutni ornamentirani okvir unutar kojega je smješten središnji reljef, a čije bočne stranice su flankirane krilima ukrašenima volutama, viticama repovlja i ratnim trofejima. Povrh okvira nalazi se gređe s prekinutim zabatom i akroterijima izvedenima u obliku medaljona. Unutar zabatnoga polja smješten je grb Trojedne Kraljevine Dalmacije, Hrvatske i Slavonije (1868. 1918.), koji je po svoj prilici dodan u XIX. stoljeću, ${ }^{369}$ a u medaljonima su prikazani simboli Družbe Isusove (Kristov monogram sv. Bernardina sa srcem probodenim trima čavlima) i Marijin monogram (»M[a]RIA«).

Na središnjem reljefu, Erdődy je predočen kao sredovječan muškarac izražajnih crta lica koji stoji pred Raspetim. Odjeven je u puni viteški oklop, a oko vrata nosi orden Reda Otkupitelja. ${ }^{370} \mathrm{U}$ lijevoj ruci drži sablju koja mu visi o boku, a desnom pridržava kacigu koja je položena na postament ukrašen maskeronom. Iznad glave ispisano je banovo konstaninovsko geslo, riječi koje je navodno uskliknuo nakon pobjede nad Osmanlijama kod Siska: »In Deo vici« (U Bogu pobijedih). Pokojnikov pogled usmjeren je prema liku Isusa razapetoga na križu koji je smješten na desnoj strani reljefa (Slika 103). Križ je podignut na stijenju s lubanjom koja simbolizira Golgotu i otkupljenje Adamova grijeha, a podno križa

\footnotetext{
${ }^{367}$ Usp. Trpimir Macan (ur.), nav. dj., 1998., sub voce Erdődy, Toma II [Tatjana Radauš].

${ }^{368}$ Usp. Anđela Horvat, nav. dj., 1975., str. 352.

${ }^{369}$ Usp. Boris Prister, Hrvatski ban Toma Erdödy - vitez Reda Otkupitelja, u: Zbornik radova 2. međunarodnog numizmatičkog kongresa u Hrvatskoj, 15-17. listopada 1998., Opatija: Dobrinić \& Dobrinić, Zagreb: Hrvatsko numizmatičko društvo, 2000., str. 141-155, 142. Uredio Julijan Dobrinić.

${ }^{370}$ U ranijoj hrvatskoj historiografiji često je naveden krivi podatak da je španjolski kralj Filip II. dodijelio Erdődyju orden Reda sv. Spasitelja za njegove zasluge u bitci kod Siska 1593. godine. Kao što je navedeno, Erdődy je primio orden Reda Otkupitelja od mantovanskoga vojvode Ferdinanda Gonzage 1619. godine za zasluge u zaštiti katoličanstva i papinstva. Usp. Boris Prister, nav. dj., 2000., str . 141-142.
} 

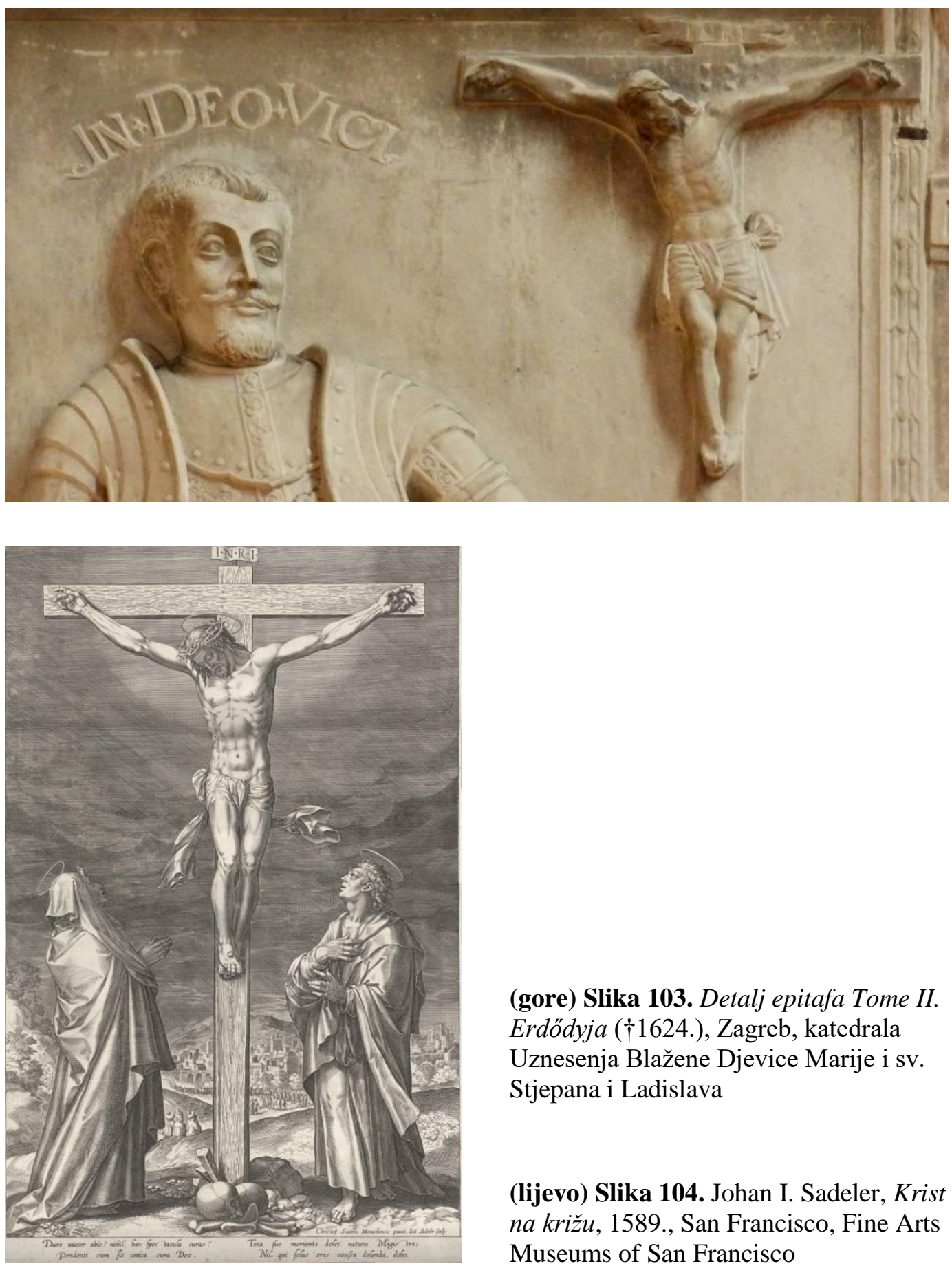

(gore) Slika 103. Detalj epitafa Tome II. Erdödyja (†1624.), Zagreb, katedrala Uznesenja Blažene Djevice Marije i sv. Stjepana i Ladislava

(lijevo) Slika 104. Johan I. Sadeler, Krist na križu, 1589., San Francisco, Fine Arts Museums of San Francisco

smješten je raskošno izveden grb obitelji Erdődy. ${ }^{371}$ Način oblikovanja Kristova tijela (posebice mišićava torza i ruku) upućuje na mogućnost da je njegov lik isklesan po uzoru na suvremene grafičke predloške, poput onoga Johana I. Sadelera (Bruxelles, 1550. - Venecija, 1600./08.) (Slika 104).

\footnotetext{
${ }^{371}$ Štit grba razdijeljen je na četiri jednaka polja, sa srcem štita (štitićem) smještenim u sredini. U prvome polju predočen je okrunjeni orao, $u$ drugome i trećemu dvije šestokrake zvijezde omeđene dvjema vodoravnim gredama, a u četvrtome kula s grudobranom. U srcu štita nalazi se stari grb obitelji Bakač s jelenom i kotačem. Štit je ukrašen plaštem i trima kacigama s krunama i nakitom. Iznad bočnih kaciga uzdižu se oklopljene ruke (lijeva drži mač, a desna barjak), a iznad središnje orao. Usp. Ivan von Bojničić, nav. dj., 1889., str. 44, tab. 33.
} 
Anđela Horvat (1975.) stilski je opisala epitaf kao kasnorenesansno djelo s primjesama manirizma i baroka. ${ }^{372}$ Manirističke odlike prepoznala je u neusklađenosti impostacije likova Raspetoga i pokojnika - potonji tijelom nije usmjeren prema Križu, nego prema promatraču i grotesknom licu maskerona koji je u kontrastu »s banovim licem, koje odiše baroknom vedrinom «. ${ }^{373}$ Značajkama manirističkoga stila pridodali bismo prije svega prostorni opis (»subverziju« prostorne jasnoće »izlaskom« pokojnika u prostor promatrača i dojam stiješnjenosti prostora) te nesrazmjer veličina likova koji je znatno naglašeniji od onoga na prethodnim nadgrobnicima, a proizlazi iz primjene obrnute ikonografske perspektive. Nesklad veličina ne možemo objasniti željom za postizanjem iluzije dubinskoga poniranja jer su oba lika (pokojnika i Raspetoga) smještena $\mathrm{u}$ istom prostornom pojasu. Takvo oblikovanje i razmještaj figura dijeli prostor na lijevu i desnu polovicu koje je teško obuhvatiti u jedinstvenu cjelinu te čini prostor nečitkim, što je još jedna od karakteristika manirizma.

Ako središnji reljef Erdődyjeva epitafa razmotrimo unutar konteksta dosad obrađenih nadgrobnih spomenika, uočit ćemo da je na njemu primijenjeno hibridno likovno rješenje kojim su spojeni elementi epitafā s prikazom Raspetoga i viteških nadgrobnika. Reljef sadrži lik pokojnika i Isusa razapetoga na križu, no za razliku od dosad razmotrenih spomenika pokojnik ne kleči već stoji, impostacijom podsjećajući na figure vitezova sa suvremenih nadgrobnih ploča. Kao što je navedeno u raspravi o viteškim nadgrobnicima i utjecaju slikarstva na nadgrobnu skulpturu, Erdődyjev epitaf srodan je onome Nikole II. Pálffyja (†1600.) (Slika 57) iz požunske katedrale s kojim dijeli sličnosti u impostaciji lika pokojnika i dodatku elementa postamenta s kacigom, koji je preuzet iz suvremenoga portretnog slikarstva. ${ }^{374}$ Reprezentativnost Pálffyjeva nadgrobnika pridonijela je širenju novoga likovnog rješenja koje je na području povijesne Zagrebačke biskupije, osim na Erdődyjevu epitafu, primijenjeno i na nadgrobnim pločama Benedikta Thuróczyja Lubreškoga (†1616.) (Slika 50), Ivana IV. Petheőa de Gerse (†1616.) (Slika 51) i člana obitelji Vragović (Slika 52).

Analizirajući naručiteljsku aktivnost i (samo)oblikovanje herojskoga kulta Tome II. Erdődyja, mađarska povjesničarka umjetnosti Orsolya Bubryák (2008.) uočila je da zagrebački epitaf dijeli sličnosti sa zavjetnom slikom (Slika 105) koju je ban dao izraditi kao zahvalu na Božjoj zaštiti i vodstvu u bitci kod Siska. ${ }^{375}$ Slika slavi Erdődyjevo junaštvo i

\footnotetext{
${ }^{372}$ Usp. Anđela Horvat, nav. dj., 1975., str. 352-353.

373 Anđela Horvat, nav. dj., 1975., str. 353.

${ }^{374}$ Usp. Géza Galavics, nav. dj., 1987., str. 246-248; Árpád Mikó i Géza Pálffy, nav. dj., 2002., str. 113; Géza Pálffy, nav. dj., 2005., str. 506-507, 512.

${ }^{375}$ Usp. Orsolya Bubryák, »In Deo vici«. Kegyesség és reprezentáció Erdödy Tamás (1558-1624) horvát bán müpártolásában, u: Studia Agriensia 27. Hagyomány és megújulás: életpályák és társadalmi mobilitás a
} 
pobjedu nad osmanskim snagama u povijesnoj bitci, a pretpostavlja se da je povod njezinoj narudžbi bilo banovo primanje u viteški Red Otkupitelja. ${ }^{376} \mathrm{U}$ osnovi, zavjetna slika sadrži sve elemente koji su prikazani na Erdődyjevu epitafu. Opremljen verižnom košuljom i mačem, ban kleči pred Kristom razapetim na križu, podno kojega se nalaze grb obitelji Erdődy i štit s maskeronom. Iza bana stoji nekoliko pratitelja koji pridržavaju ostatak njegove vojne opreme (kacigu i topuz), a u pozadini slike odigrava se bitka za Sisak. Ukras grba i maskeron podsjećaju na one sa zagrebačkoga epitafa, a najveća sličnosti između dva djelā zamjetna je u izvedbi Erdődyjeva lica. S obzirom na navedene srodnosti, izgledno je da je Zavjetna slika Tome II. Erdödyja poslužila kao jedan od likovnih izvora u izradi njegovoga nadgrobnog spomenika. ${ }^{377}$

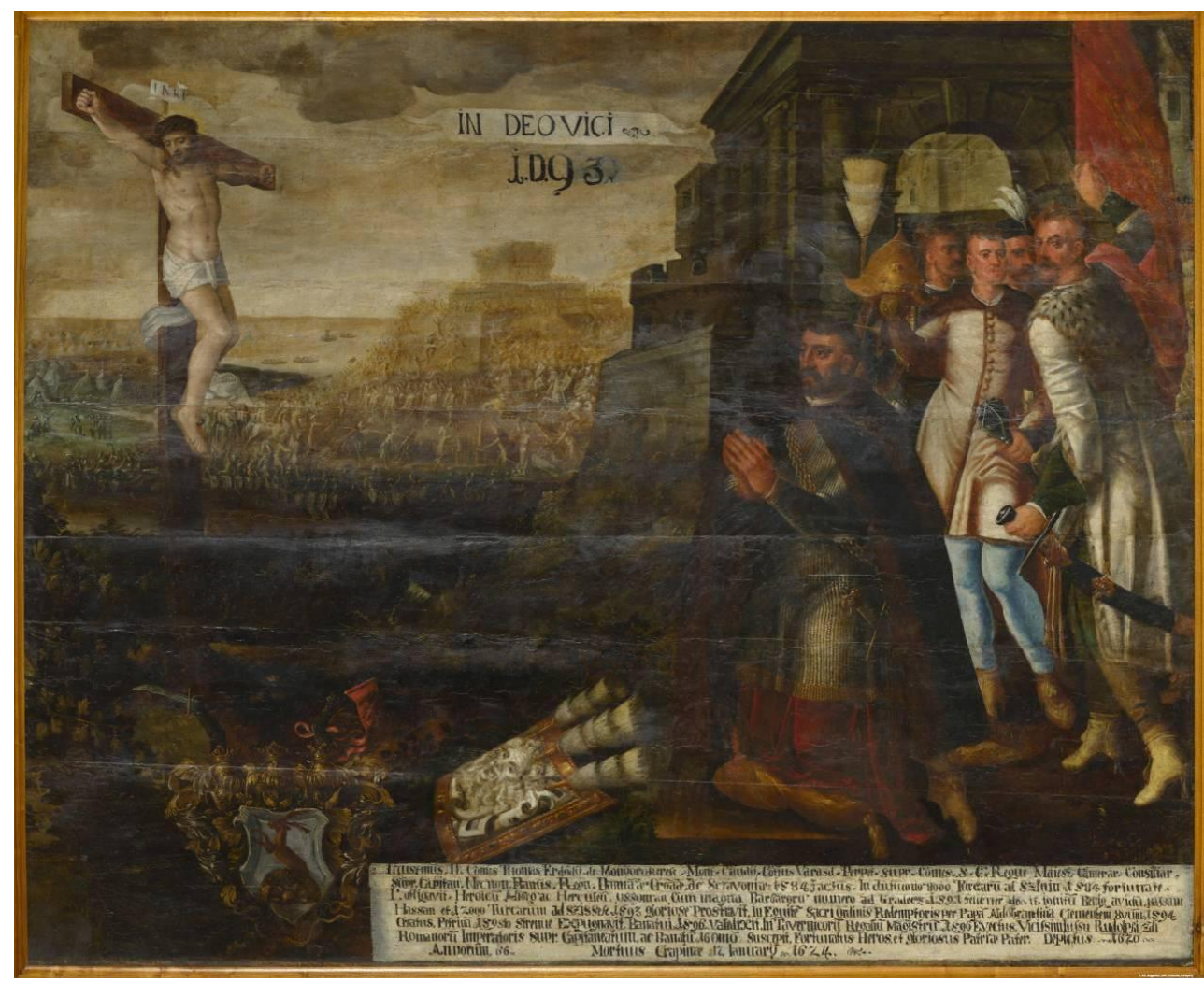

Slika 105. Zavjetnika slika Tome II. Erdődyja, 1620., Bojnice, Slovenské národné múzeum - Múzeum Bojnice

végváriak körében, Eger: Heves Megyei Múzeumi Szervezet, 2008., str. 261-283, 269-270. Uredili Mátyás Berecz i Gábor Veres.

${ }^{376}$ Detaljnije o slici vidi: Orsolya Bubryák, nav. dj., 2008., str. 270-275; Orsolya Bubryák, Athleta Christi. Political Propaganda in the Art Patronage of Tamás Erdödy, Ban of Croatia and Slavonia, u: Acta Historiae Artium Academiae Scientiarum Hungaricae 57, Budapest: Akademiai Kiado, 2016., str. 131-166, 148-153; Zrinka Blažević i Daniel Premerl, »Christianae Reipublicae Propugnator «: Reformnokatolička mitopoetika bana Tome Erdödyja (1558-1624), u: Tridentska baština: katolička obnova i konfesionalizacija u hrvatskim zemljama. Zbornik radova sa znanstvenog skupa održanog u Zagrebu 6. i 7. prosinca 2013., Zagreb: Matica hrvatska, Katolički bogoslovni fakultet, Filozofski fakultet družbe Isusove, 2016., str. 393-408, 398-401. Uredile Zrinka Blažević i Lahorka Plejić Poje.

${ }^{377}$ Usp. Orsolya Bubryák, nav. dj., 2008., str. 269-270. 
Kontekstualizirajući narudžbu Erdődyjeva epitafa, Orsolya Bubryák (2008., 2016.) iznijela je tezu da je spomenik dao izraditi Tomin sin Žigmund I. (?, 1596. - ?, 1639.) nakon očeve smrti. ${ }^{378}$ Kao izvor navela je radove suvremenih kroničara Jurja Ratkaja (Veliki Tabor, 1612. - Zagreb, 1666.), Memoria regum et banorum regnorum Dalmatiae, Croatiae et Sclavoniae (Beč, 1652.), i Gergelya Pethőa (Bela kod Novoga Marofa, o. 1570. - ?, 1629.), Rövid magyar kronika (objavljena postumno u Košicama, 1753.). Iako su oba autora opisala raskošnu posmrtnu svečanost koja je održana prilikom prijenosa banova tijela iz Samobora u Zagreb i ukopa u katedrali, ništa nisu naveli o epitafu ili njegovome naručitelju. ${ }^{379}$ Budući da su nadgrobnike najčešće podizali članovi uže obitelji poput supružnika, djece ili braće, pretpostavka Bubryák da je Erdődyjev epitaf naručio i postavio njegov sin Žigmund I. jest izgledna, no bez potkrijepe u povijesnim izvorima teško je potvrditi njezinu točnost. Razmatrajući mehanizme (samo)reprezentacije Erdődyja kao kršćanskoga heroja, Zrinka Blažević i Daniel Premerl (2016.) istaknuli su mogućnost da su - osim Tominih sinova nadgrobnik podigli isusovci. ${ }^{380}$ Svoju su tezu potkrijepili činjenicom da je Erdődy bio zaštitnik i pomagatelj Družbe Isusove, koja je u znak uzajamnoga poštovanja podigla katafalk za banov pogreb u zagrebačkoj prvostolnici, kao i onom da se na nadgrobniku u zoni zabata nalazi medaljon sa simbolom isusovačkoga reda. U pravilu, pripadnici svećenstva podizali su nadgrobne spomenike za crkvenu braću, rijetko za svjetovne osobe. Kao što je navedeno, u podizanju nadgrobnika najveću je ulogu imalo krvno srodstvo. (Pitanje naručivanja nadgrobnih spomenika razrađeno je u narednome poglavlju.) Znak Družbe Isusove na Erdődyjevu epitafu tako bi se možda trebao više interpretirati kao iskaz banova podržavanja isusovaca kao nositelja Katoličke obnove u vrijeme vjerskih previranja, nego kao dokaz njihove uloge naručiteljā. Međutim, bez potkrijepe u povijesnim dokumentima ili izvorima, ovu tezu ne možemo u potpunosti ni prihvatiti ni odbaciti, jednako kao i onu Orsolye Bubryák.

Posljednja dva primjera epitafa s prikazom Raspetoga i viteza-adoranata slijede ustaljeno likovno rješenje na kojem su pokojnici prikazani kako kleče u molitvi pred Kristom. Prvi je posvećen ogulinskome kapetanu Martinu Mogoriću (? - Perjasica, 1643.) (Slika 106), ${ }^{381}$ a postavljen je u svetištu župne crkve Pohoda Blažene Djevice Marije - nekoć

\footnotetext{
${ }^{378}$ Usp. Oroslya Bubryák, nav. dj., 2008., str. 268; Oroslya Bubryák, nav. dj., 2016., str. 153.

${ }^{379}$ Usp. Juraj Rattkay, nav. dj., 2001., str. 230; Gergely Pethő, Rövid magyar kronika. Sok rendbéli fö historiás Könyvekböl nagy szorgalmatossággal egybe szedettetet és irattatot Petthö Gergelytül, Cassán: Az Akademiai Betükkel Frauenbeim Henrik János által, 1753., str. 202.

${ }^{380}$ Usp. Zrinka Blažević i Daniel Premerl, nav. dj., 2016., str. 403.

381 Kamen, vapnenački pješčenjak, polikromija, 154,5 × $82 \times 22 \mathrm{~cm}$, Marija Gorica, crkva Blažene Djevice Marije od Pohođenja. Kat. br. 12.
} 


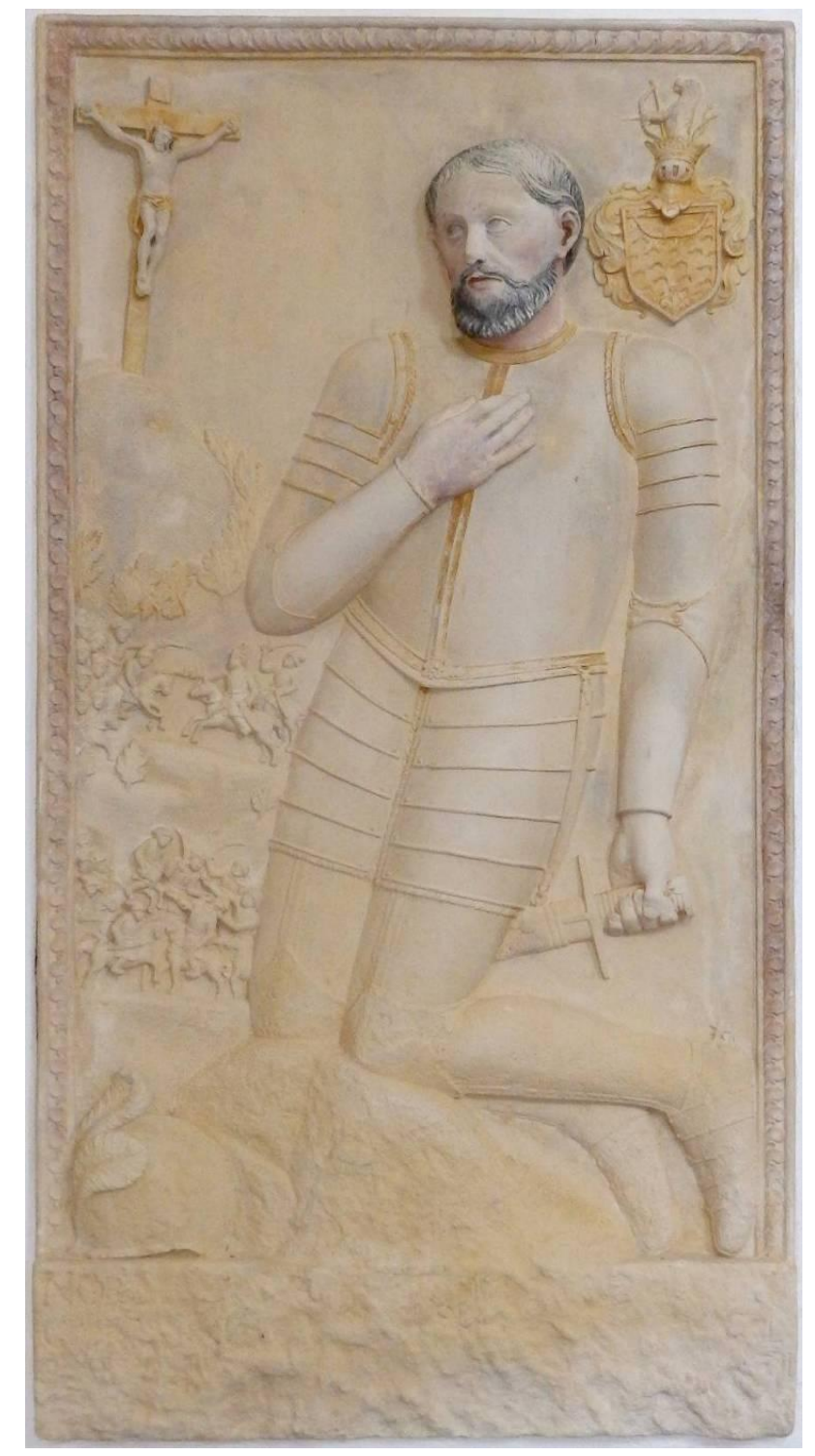

Slika 106. Epitaf Martina

Mogorića, 1675., Marija

Gorica, crkva Pohoda

Blažene Djevice Marije

franjevačke crkve sv. Petra apostola - u Mariji Gorici. Mogorići su bili jedan od brojnih ogranaka obitelji Mogorović, jedne od najstarijih hrvatskih plemićkih obitelji. U XVI. stoljeću nastanjivali su područje Like, no prodorom osmanskih snaga preselili su u okolicu Zagreba. ${ }^{382}$ Obitelj je izumrla u muškoj liniji krajem XVII. stoljeća, a Martin je bio jedan od njezinih posljednjih izdanaka. Poginuo je u bitci protiv Osmanlija podno brda Perjasice 1643. godine, a pokopan je u marijagoričkoj crkvi nedaleko obiteljskoga posjeda u Laduču. ${ }^{383}$ Tijekom XVII. i XVIII. stoljeća crkva u Mariji Gorici razvila se u posjećeno marijansko proštenište,

\footnotetext{
${ }^{382}$ Usp. Ivan von Bojničić, nav. dj., 1889., str. 124.

${ }^{383}$ Usp. Paškal Cvekan, Crkva Majke Božje od Pohođenja u Mariji Gorici, II. dio, u: Zaprešićki godišnjak 5, Zaprešić: Matica hrvatska Zaprešić, 1995.a, str. 30-50, 50. Paškal Cvekan pogrešno je protumačio toponim »MONTE PEROVICZA« uklesan na nadgrobniku kao brdo Perjavicu nedaleko Vrapča. Martin Mogorić sukobio se s Osmanlijama 1643. godine kod brda Perjasice u Kordunu. Usp. Rudolf Horvat, Povijest Hrvatske: od najstarijeg doba do g. 1657. Knj. I, Zagreb: Tiskara Merkur, 1924., str. 400.
} 
što je privuklo brojne lokalne plemiće da je odaberu kao svoje posljednje počivalište. ${ }^{384}$ Mogorićev epitaf nije postavljen neposredno nakon pokojnikove smrti nego tridesetak godina poslije (1675.), a dao ga je izraditi Martinov zet Mihael Vernić. ${ }^{385}$ Okolnosti narudžbe zabilježene su u natpisu na nadgrobniku koji je danas većim dijelom nečitljiv, no moguće ga je rekonstruirati na osnovi prijepisa objavljena u Nadpisima (1891.) Ivana Kukuljevića Sakcinskoga ${ }^{386}$ i fotografijskoga snimka koji je Artur Schneider dao načiniti 1940. godine. ${ }^{387}$

$\mathrm{Na}$ nadgrobniku, lik pokojnika u potpunosti dominira prikazom protežući se gotovo cijelom njegovom visinom. Mogorić je predočen kao muškarac zrelih godina odjeven u puni viteški oklop, a dokaz njegova plemićkoga podrijetla - obiteljski grb - nalazi se u gornjem desnom kutu. ${ }^{388}$ Desnu je ruku položio na prsa, a u lijevoj drži mač. Tijelom i pogledom usmjeren je prema Raspetome koji je prikazan na lijevoj strani reljefa. Križ je podignut na vrhu brda u čijem se podnožju odvija bitka u kojoj je ogulinski kapetan izgubio život. Borba između krajiške i osmanske konjice prikazana je u dva vodoravna niza. U gornjem nizu sukobljene strane jurišaju jedna protiv druge, a krajišnike predvodi Mogorić prepoznatljiv po kacigi ukrašenoj perjanicom. U donjem nizu pokojnik je opkoljen neprijateljskim konjanicima koji mu odsijecaju glavu. Odnos između klečeće figure pokojnika i Raspetoga prostorno je nejasan. Način na koji Mogorić gleda prema Kristu ostavlja dojam da su oba lika smještena u istom prostornom pojasu, no veličina Križa i likova koji se nalaze u podnožju brda sugeriraju da se Raspeti nalazi iza pokojnika. Anđela Horvat (1975.) prepoznala je u ovoj nejasnoći prostornih odnosa značajke manirizma. ${ }^{389}$

Primjenom narativne metode Mogorićev epitaf srodan je Zavjetnoj slici Tome II. Erdődyja (Slika 105) na kojoj je prikazana bitka kod Siska (1593.). Uspješna obrana sisačke utvrde označila je prekretnicu u ratu protiv Osmanskoga Carstva, a Erdődyju je osigurala

\footnotetext{
${ }^{384}$ Usp. Branimir Brgles, Franjevački samostan i crkva Blažene Djevice Marije od Pohođenja u Mariji Gorici, u: Kaj: časopis za književnost, umjetnost, kulturu XLIV/5, Zagreb: Kajkavsko spravišče, 2011., str. 45-56, 48.

${ }^{385}$ Usp. Paškal Cvekan, nav. dj., 1995.a, str. 50.

${ }^{386}$ Usp. Ivan Kukuljević Sakcinski, nav. dj., 1981., str. 41, br. 134.

${ }^{387}$ Usp. Artur Schneider, Popisivanje i fotografijsko snimanje umjetničkih spomenika godine 1940., u: Ljetopis Jugoslavenske akademije znanosti i umjetnosti za godinu 1939/40. Svezak 53, Zagreb: Jugoslavenska akademija znanosti i umjetnosti, 1941., str. 176-184, 181. Snimak je pohranjen u Schneiderovu fotografijskome arhivu koji se čuva u Strossmayerovoj galeriji starih majstora Hrvatske akademije znanosti i umjetnosti (inv. br. 2218).

${ }^{388}$ Štit grba ukrašen je isprekidanim valovitim crtama. U podnožju je prikazan heraldički ljiljan, a u glavi lúk. Štit je ukrašen plaštem, kacigom, krunom i nakitom u obliku lava koji u prednjim šapama drži lúk i strijelu. Grb Martina Mogorića razlikuje se od onoga Tomaša Mogorića iz 1490. godine koji sadrži šestokraku zvijezdu i četiri vodoravne valovite grede. Moguće je da isprekidane linije na Martinovu grbu predstavljaju stilizirane vodoravne grede s Tomaševa grba. Usp. Ivan von Bojničić, nav. dj., 1889., str. 124, tab. 89. U članku u kojem je pokušao rekonstruirati izgled grba obitelji Mogorović, Emilij Laszowski (1897.) netočno je opisao grb Martina Mogorića kao »štit sa dvije poprečne ravne grede; na kacigi rastući lav sa sabljom u desnici«. Usp. Emilij Laszowski, Grb plemena Mogorovića, u: Vjesnik Hrvatskoga arheološkoga društva (N.S.) II/1, Zagreb: Hrvatsko arheološko društvo, 1897., str. 21-25, 24.

${ }^{389}$ Usp. Anđela Horvat, nav. dj., 1975., str. 156.
} 
ugled athletae Christi. Mogorić, s druge strane, nije preživio bitku u kojoj je predočen, niti je bitka kod Perjasice imala važnost one kod Siska. Ipak, Mogorićev epitaf jedinstven je primjer nadgrobnika na području povijesne Zagrebačke biskupije koji uključuje prizor iz pokojnikova ovozemaljskoga života. S obzirom na tu činjenicu, postavlja se pitanje što je potaknulo naručitelja, Mogorićeva zeta Mihaela Vernića, da na nadgrobniku prikaže bitku kod Perjasice. Možemo pretpostaviti da je Vernićeva glavna želja bila ovjekovječiti i glorificirati Mogorićevu zaslugu u obrani Hrvatskoga Kraljevstva od Osmanlija, ali i osnažiti vezu između dviju obitelji. Vernići su bili bogata no u to vrijeme još uvijek mlada plemićka obitelji koja je primila potvrdu plemstva i grbovnicu 1630. godine. $^{390}$ Oženivši se Martinovom kćeri Barbarom Mogorić, Mihael Vernić orodio se ogrankom jedne od najstarijih hrvatskih obitelji, što je svakako pridonijelo ugledu njegova obiteljskoga imena i potvrdi legitimiteta novostečene plemićke titule. Podizanjem nadgrobnoga spomenika preminulom puncu i zapisivanjem vlastita imena uz njegovo, Vernić je dodatno ojačao sponu između svoje i suprugine obitelji.

Epitaf Martina Mogorića jedan je od rijetkih nadgrobnika na kojem su očuvani tragovi polikromije. ${ }^{391}$ Najbolje je sačuvana polikromija pokojnikova lica: put je obojena ružičastim inkarnatom, brada, brkovi i kosa crnom bojom, a usnice crvenom. Na kovanim spojevima oklopa vidljivi su tragovi žute i smeđe boje. Na ostatku spomenika u najvećoj je mjeri očuvano žuto obojenje koje je primijenjeno na križu, Kristovoj perizomi, vegetaciji brda i grbu. Prema podatku iz Župne spomenice, slova natpisa bila su ispisana crvenom bojom. ${ }^{392}$ Tragovi polikromije pronađeni su i na nadgrobnome spomeniku Tome II. Erdődyja iz zagrebačke stolne crkve (Slika 102). Na Erdődyjevu grbu smještenom u donjem desnom kutu spomenika vidljivi su tragovi crvenoga obojenja. Za usporedbu, drveni nadgrobni spomenici kao i većina crkvenoga inventara izrađena u drvu - gotovo su uvijek bili polikromirani. Na području povijesne Zagrebačke biskupije očuvan je samo jedan primjer drvenoga epitafa, koji je polikromiran i pozlaćen. Riječ je o epitafu hrvatsko-dalmatinsko-slavonskoga bana Nikole III. Erdődyja (†1693.) koji je detaljnije obrađen u narednome potpoglavlju. S obzirom na drvene nadgrobnike, postavlja se pitanje u kojoj su se mjeri polikromirali nadgrobni

\footnotetext{
${ }^{390}$ Kralj Ferdinand II. dodijelio je plemićku titulu Jurju Verniću (1597. - 1657.) koji je obnašao dužnost notara ugarske komore. Usp. Ivan von Bojničić, nav. dj., 1889., str. 199.

${ }^{391}$ Hrvatski restauratorski zavod proveo je konzervatorsko-restauratorske radove na epitafu kojima je reljef očišćen, konsolidiran i domodeliran, a polikromija obnovljena. Usp. Krasenka Majer Jurišić, Marija Gorica: Nadgrobna ploča Martina Mogorića. Konzervatorsko-restauratorska istraživanja i prijedlog radova, Zagreb: Hrvatski restauratorski zavod, 2013.

${ }^{392}$ Usp. Krasenka Majer Jurišić, nav. dj., 2013., str. 14, 27.
} 
spomenici isklesani u kamenu, odnosno predstavljaju li nadgrobni spomenici Martina Mogorića i Tome II. Erdődyja iznimku ili pravilo.

Posljednji epitaf s prikazom Raspetoga i adoranta datira s početka XVIII. stoljeća, a podignut je za potpukovnika Križevačke kapetanije grofa Ladislava III. Patačića od Zajezde (?, 1651. - Celje, 1705.) (Slika 107). ${ }^{393}$ Spomenik se nalazi na istočnome zidu kapele Presvetoga Trojstva u lepoglavskoj crkvi Bezgrješnoga začeća Blažene Djevice Marije koju su podigli pokojnik i njegova supruga Barbara Patačić rođ. Vragović. Ladislav je započeo izgradnju kapele 1705. godine, no budući da je za nekoliko mjeseci preminuo, radove je preuzela i dovršila njegova supruga. ${ }^{394}$ Nakon što je kapela podignuta (1706.), Barbara je prenijela suprugove posmrtne ostatke iz kapele sv. Jurja u Purgi Lepoglavskoj, gdje je izvorno pokopan, i pohranila ih u obiteljsku kriptu u novopodignutoj kapeli. Na ploči koja je pokrivala kriptu (danas uništena) dala je uklesati natpis ispisan kronogramom koji je davao godinu Ladislavove smrti (»hIC IaCet LaDIsLaVs pataChIch / VICe CoLoneLLVs CrIsIensIs qVI obIIt / In baLneIs CILIensIbVs xiii 7 brIs $«),{ }^{395}$ a na istočnome zidu postavila je epitaf s muževim likom (1710.). ${ }^{396}$

Epitaf Ladislava III. Patačića izveden je u obliku stilizirane edikule zaključene polukružnim zabatom koja je okružena ratnim trofejima. Središnji dio edikule čini pravokutni okvir unutar kojega je smješten reljefni prikaz pokojnika pred Raspetim. Na okvir naliježu vijenac i zabat s grbovima obitelji Vragović i Patačić, ${ }^{397}$ a pri njegovu dnu nalazi se ovalna ploča s nadgrobnim natpisom. Opisani dijelovi izvedeni su u kombinaciji bijeloga, crvenoga i crnoga mramora. Središnji reljef, vijenac, štitovi grbova i ispuna zabatnoga polja isklesani su u bijelome, pravokutni okvir, luk zabata i ukrasi grbova u crvenome, a ratni trofeji i natpisna ploča u crnome mramoru. Nadgrobnik izgledom podsjeća na sedamnaestostoljetne atektonsko građene retable koji se sastoje od oltarne slike ili kipa obrubljenih pojasom prepletenih vitica

\footnotetext{
${ }^{393}$ Mramor, $302 \times 180 \times 8$ cm, Lepoglava, crkva Bezgrješnoga začeća Blažene Djevice Marije. Kat. br. 57.

${ }^{394}$ Usp. Kamilo Dočkal, nav. dj., 2014., str. 211, 277.

${ }^{395}$ Usp. Lib. Mem., Arhiv HAZU, sign. IV. d. 77., fol. 4r; Kamilo Dočkal, nav. dj., 2014., str. 212, 279; Ljubo Karaman, nav. dj., 1950., str. 167, bilj. 72. Kamilo Dočkal (2014.) primijetio je da su Ivan Kukuljević Sakcinski (1891.) i Gjuro Szabo (1919.) u prijepisu natpisa izostavili riječ »VICe« zbog čega njihov kronogram daje netočnu godinu Patačićeve smrti, 1599. Usp. Ivan Kukuljević Sakcinski, nav. dj., 1891., str. 122, br. 408; Gjuro Szabo, nav. dj., 1919., str. 40.

396 Podatci o okolnostima narudžbe uklesani su na spomeniku: »BARBARAE I VRAGOVICH IAM VIVA DOLORIS IMAGO / FIDA OLIM CONIVVX HÆC MONVMENTA LOCAT. / MDCCX.« Za prijepis ostatka natpisa vidi kat. br. 57.

${ }^{397}$ Grb obitelji Vragović sastoji od štita koji je ukrašen plaštem, kacigom, krunom i nakitom u obliku krila. Na štitu se nalazi grifon koji u kandžama drži drvo jabuke s tri ploda. Usp. Ivan von Bojničić, nav. dj., 1889., str. 202, tab. 147. Na desnoj strani nalazi se grb obitelji Patačić koji se sastoji od štita, plašta, kacige, krune i nakita koji je odlomljen. Štit grba okomito je razdijeljen na dvije polovine. Na heraldičkoj desnoj strani prikazana je djeva ovijena draperijom koja stoji na sidru, a na lijevoj kruna s parom krila. Usp. Ivan von Bojničić, nav. dj., 1889., str. 140-141, tab. 102.
} 


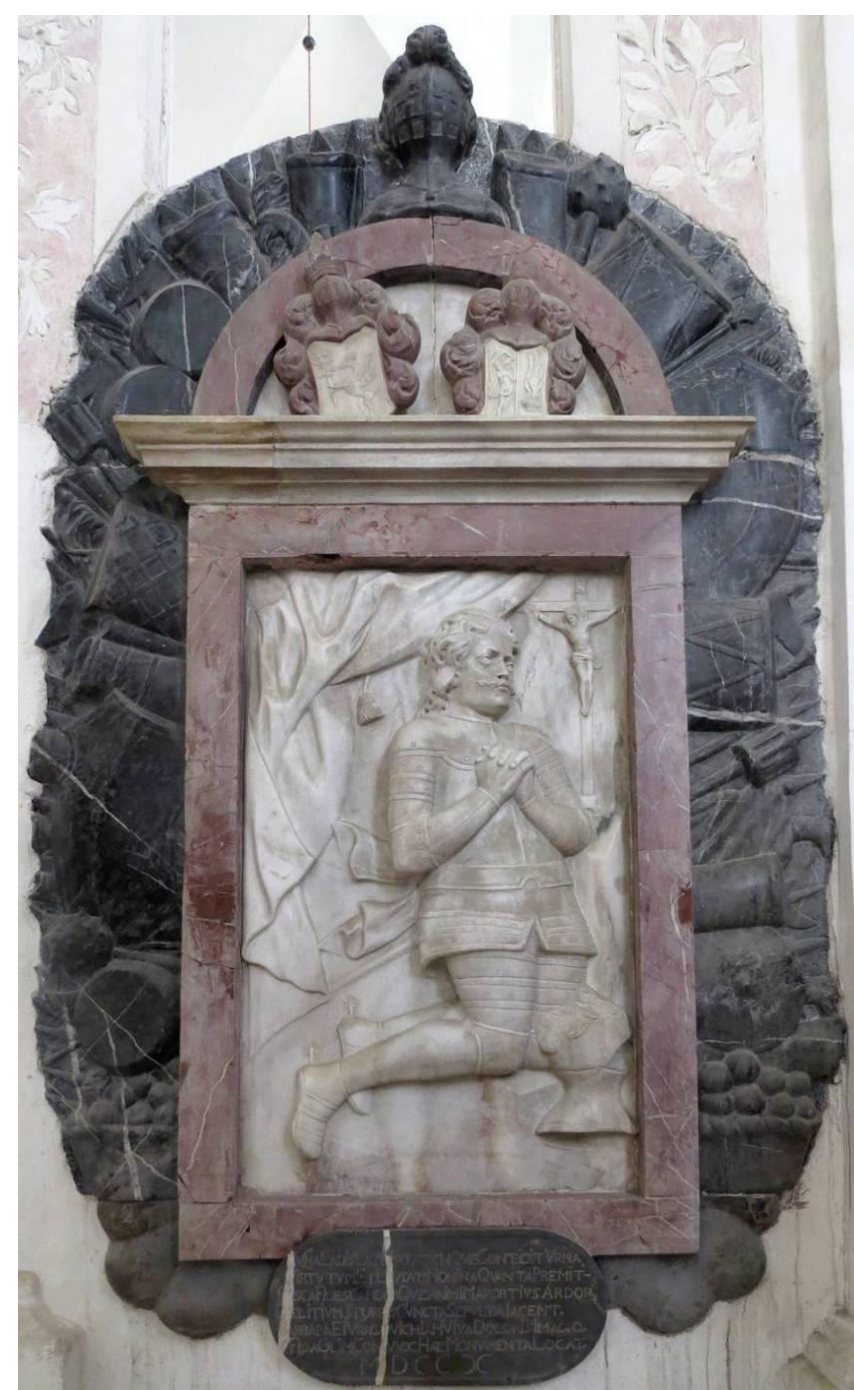

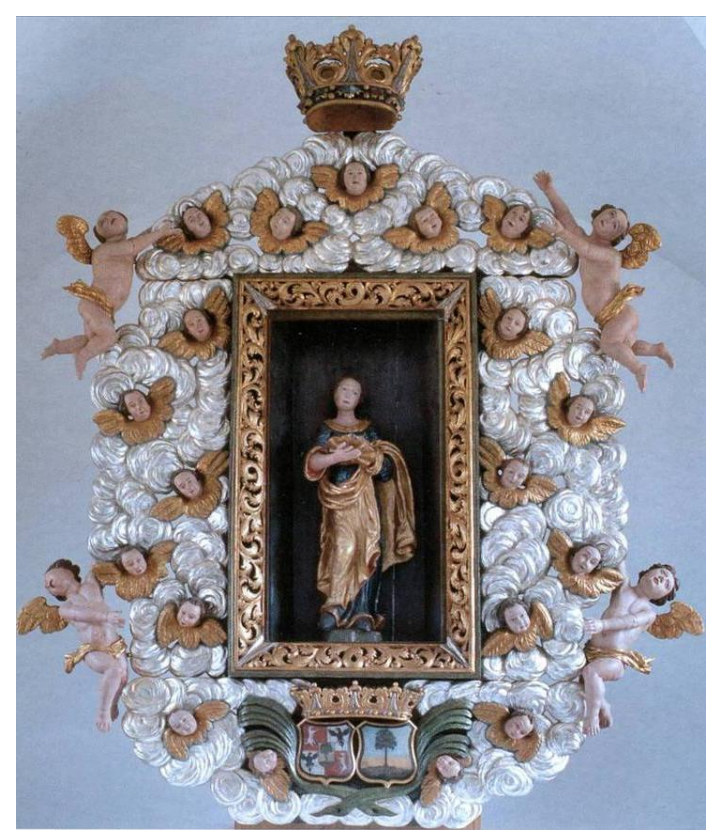

(lijevo) Slika 107. Epitaf Ladislava III. Patačića od Zajezde, 1710., Lepoglava, crkva Bezgrješnoga začeća Blažene Djevice Marije

(gore) Slika 108. Oltar sv. Doroteje, poč. XVIII. stoljeća, Logorište, kapela sv. Doroteje

ili gusto nanizanih oblaka i anđela, poput glavnoga oltara kapele sv. Doroteje u Logorištu kod Karlovca (Slika 108). ${ }^{398}$ Reljef pokojnika i Raspetoga analoški bi odgovarao svetoj slici, a motivi ratnih trofeja prepletu vitica odnosno nebeskome ambijentu koji je okružuje. Jedini dijelovi nadgrobnika koji odskaču od atektonske koncepcije retabla su elementi vijenca i zabata.

Središnji prikaz pokojnika i Raspetoga u osnovnim crtama nalikuje epitafu Martina Mogorića (Slika 106). Odjeven u viteški oklop, pokojnik je prikazan kako kleči pred Raspetim, ruku sklopljenih u molitvi. Portretiran je kao sredovječni muškarac poluduge valovite kose i ozbiljna izraza lica. Njegov je pogled usmjeren prema Kristu razapetome na križu koji je predočen u gornjem desnom kutu reljefa. Raspeti je prikazan u znatno manjoj veličini od lika pokojnika, čime više nalikuje raspelu nego stvarnome prikazu Krista kao na

\footnotetext{
${ }^{398}$ Detaljnije o podjeli i genezi atektonskih koncipiranih retabla vidi: Martina Ožanić, Atektonsko građeni oltari XVIII. stoljeća na području sjeverozapadne Hrvatske, doktorski rad, Zagreb: Filozofski fakultet Sveučilišta u Zagrebu, 2017.
} 
dosad analiziranim nadgrobnicima. Iza pokojnika zastrta je uskovitlana draperija, čija pokrenutost unosi dozu dramatičnosti usuprot svečanoj smirenosti ostatka prizora. Njezini krajnji rubovi prate dijagonalno usmjerenje pokojnikovih nogu i ruku te uspostavljenoga pogleda između pokojnika i Krista. Naglašena dijagonalnost kompozicije, uskovitlanost draperije, stupnjevanje volumena od visokoga prema niskom te realistično oblikovanje Patačićeva lica i svrdlasta obrada njegove kose daju spomeniku jasna barokna obilježja.

Prije nego što prijeđemo na nadgrobnike s obiteljskim grbom kao osnovnim likovnim motivom, nakratko ćemo se osvrnuti na još jedan epitaf koji nije očuvan, ali je dokumentiran u arhivskim izvorima i za koji istraživači pretpostavljaju da je sadržavao lik pokojnikaadoranta. Riječ je epitafu hrvatsko-dalmatinsko-slavonskoga bana i vojskovođe Nikole IV. Zrinskoga (Zrin, 1508. - Siget, 1566.; banovao 1542. - 1566.), istoga onoga kojemu je u ovome radu pripisana nadgrobna ploča s likom viteza (Slika 46) pronađena na lokalitetu nekadašnje pavlinske crkve u Šenkovcu. Naime, u Mađarskom državnom arhivu u Budimpešti pohranjen je dokument (1574.) koji dokazuje da je Nikolin sin Juraj IV. Zrinski (Čakovec ?, 1549. - Vép, 1603.) naručio kod Adriaena van Conflansa (Bruxelles, 1535. - Amsterdam, 1607.), portretnoga slikara flamanskoga podrijetla koji je u to vrijeme boravio na bečkome dvoru, drveni epitaf za svojega oca. ${ }^{399} \mathrm{~S}$ obzirom na to da je cijena nadgrobnika (250 talira) iznosila više od pola Jurjeve godišnje plaće glavnoga rizničara (400 talira) i da je angažiran dvorski slikar, mađarski istraživači (János Kapossy, 1948.; Enikő Buzási, 1990., 2000.) pretpostavljaju da je bila riječ o višedijelnom, bogato ukrašenom i pozlaćenom epitafu koji je sadržavao rezbarene i slikane dijelove. ${ }^{400}$ Povjesničarka umjetnosti Enikő Buzási smatra Jurjev odabir da za oca izradi drveni nadgrobnik pomalo neuobičajenim jer nije bio u skladu s tadašnjom aristokratskom tradicijom i statusom pokojnika, objašnjavajući da je u drugoj polovini XVI. stoljeća drvene epitafe naručivao pretežito građanski sloj, a da je visoko plemstvo - kojem su Nikola i Juraj pripadali - postavljalo nadgrobnike izrađene od kamena odnosno mramora. ${ }^{401}$ Ako ulomci pronađeni u Šenkovcu uistinu predstavljaju dio nadgrobne

\footnotetext{
399 Riječ je o ispravi koju je izdao car Maksimilijan II. (Beč, 1527. - Regensburg, 1576.), a kojom nalaže ugarskoj dvorskoj komori da umjetniku Adriaenu van Conflansu isplati svotu od 250 talira koja će se odbiti od Jurjeve godišnje plaće glavnoga rizničara. Dokument je prvi objavio: János Kapossy, Adriaen van Conflans a Zrínyi epitáfium mestere, u: Magyar Müvészet XV/4, Budapest: Szinyei Merse Pál Tár saság, 1948., str. 180. Usporedi dalje: Ivan Bach, Tri rada stranih umjetnika u Hrvatskoj, u: Peristil: zbornik radova za povijest umjetnosti II/1, Zagreb: Društvo povjesničara umjetnosti Hrvatske, 1957., str. 199-203, 199-200.

${ }^{400}$ Usp. János Kapossy, nav. dj., 1948., str. 80; Enikő Buzási, Zrínyi és a későreneszánsz vitézi allegória: a szigetvári hös festett apoteózisa, u: Collectanea Tiburtiana: Tanulmányok Klaniczay Tibor tiszteletére, Szeged: JATE, 1990., str. 431-442, 433-434. Uredili Géza Galavics, János Herner i Bálint Keserü; Enikő Buzási, $A z$ egykori Zrínyi-epitáfi um és a Zrínyi-kultusz mint a 16. század végi családi reprezentáció forrása, u: TörténelemKép, Szemelvények múlt és müvészet kapcsolatáról Magyarországon, katalog izložbe, Budapest: MNG, 2000., str. 399-402, 399. Uredili Árpád Mikó i Katalin Sinkó.

${ }^{401}$ Isto.
} 
ploče Nikole IV. Zrinskoga, Jurjeva odluka da postavi još jedan, no ovaj put drveni nadgrobnik za svojega oca čini se manje začuđujućom. Uporaba »dvostrukih« nadgrobnika od kojih je jedan pokrivao pokojnikov grob odnosno ulazak u kriptu, a drugi bio postavljen na zidu u blizini ukopnoga mjesta nije bila neuobičajena. Obitelj Patačić imala je sličnu praksu korištenja uparenih nadgrobnika. Jedan takav par nalazi se u njihovoj grobnoj kapeli u remetinečkoj crkvi Kraljice Svete Krunice (Slike 158 i 159) (nadgrobnici su analizirani u narednome potpoglavlju), a drugi u kapeli Presvetoga Trojstva u nekadašnjoj pavlinskoj crkvi u Lepoglavi (Slika 107) (sačuvan je samo epitaf, no arhivski izvori svjedoče o postojanju nadgrobne ploče s posvetnim natpisom).

Razmatrajući suvremene nadgrobne spomenike i portretna djela obitelj Zrinski, Enikő Búzasi (1990., 2000.) pokušala je rekonstruirati izgled Nikolina drvena epitafa. Kao glavni komparativni primjer među nadgrobnicima upotrijebila je epitaf Eleka II. Thurzóa (slvč. Alexej Turzo; ?, o. 1540. - ?, †1594.) iz crkve sv. Jakova u Levoči. ${ }^{402}$ Autorica je odabrala Thurzóv nadgrobnik jer je plemić bio u srodstvu sa Zrinskima (godine 1569. oženio se Jurjevom mlađom sestrom Barbarom), a njegov spomenik predstavlja jedan od ikonografski najsloženijih nadgrobnika sačuvanih iz toga razdoblja. Epitaf se sastoji od dva superponirana prikaza koji uključuju lik preminuloga: u gornjem dijelu spomenika Thurzó je prikazan kako kleči i moli pred Presvetim Trojstvom, a u donjem kako leži na mrtvačkom odru. Búzasi smatra da je Nikolin epitaf sadržavao slične prizore koji su poslije poslužili kao uzor za izradu dviju uljenih slikā - Apoteoze Nikole IV. Zrinskoga (Slika 109) i njegovoga Posmrtnoga portreta (Slika 110). ${ }^{403}$ Prvi rad naručio je Juraj IV. Zrinski nakon očeve pogibije, a prikazuje sigetskoga junaka kako kleči i moli pred Raspetim dok ga personifikacija pobjede ovjenčava lovorovim vijencem. ${ }^{404}$ Búzasi smatra da je opisana ikonografska situacija nastala spajanjem dviju likovnih tradicija: prikaza pokojnika-adoranta u molitvi pred Raspetim koji je zastupljen na nadgrobnim spomenicima i prikaza junaka-pobjednika kao jedne od najčešćih vladarskih alegorija. $^{405} \mathrm{Na}$ Nikolinom Posmrtnom portretu predočena je pokojnika glava, jedini dio

\footnotetext{
${ }^{402}$ Usp. Enikő Buzási, nav. dj., 1990., str. 434-435; Enikő Buzási, nav. dj., 2000., str. 399. Ivan Bach (1957.) smatrao je da je epitaf sadržavao obiteljski portret Zrinskih koji je osim Nikole IV. uključivao portret njegove supruge Katarine i njihove djece. U svojoj argumentaciji Bach se oslonio na suvremene primjere drvenih epitafa s područja Pomurja (Sankt Margarethen im Lungau), smatrajući kako - na osnovi geografske blizine predstavljaju bolji komparativni primjer od nadgrobnih spomenika u Levoči. Usp. Ivan Bach, nav. dj., 1957., str. 200.

${ }^{403}$ Usp. Enikő Buzási, nav. dj., 1990., str. 435; Enikő Buzási, nav. dj., 2000., str. 399

${ }^{404}$ Usp. Enikő Buzási, nav. dj., 2000., str. 401.

${ }^{405}$ Usp. Enikő Buzási, nav. dj., 1990., str. 431-432. Istraživači smatraju da je zavjetna slika Tome II. Erdődyja (Slika 106) nastala po uzoru na sliku Apoteoze Nikole Zrinskoga. Usp. Orsolya Bubryák, nav. dj., 2016., str. 151-152; Enikő Buzási, nav. dj., 1990., str. 439-441.
} 

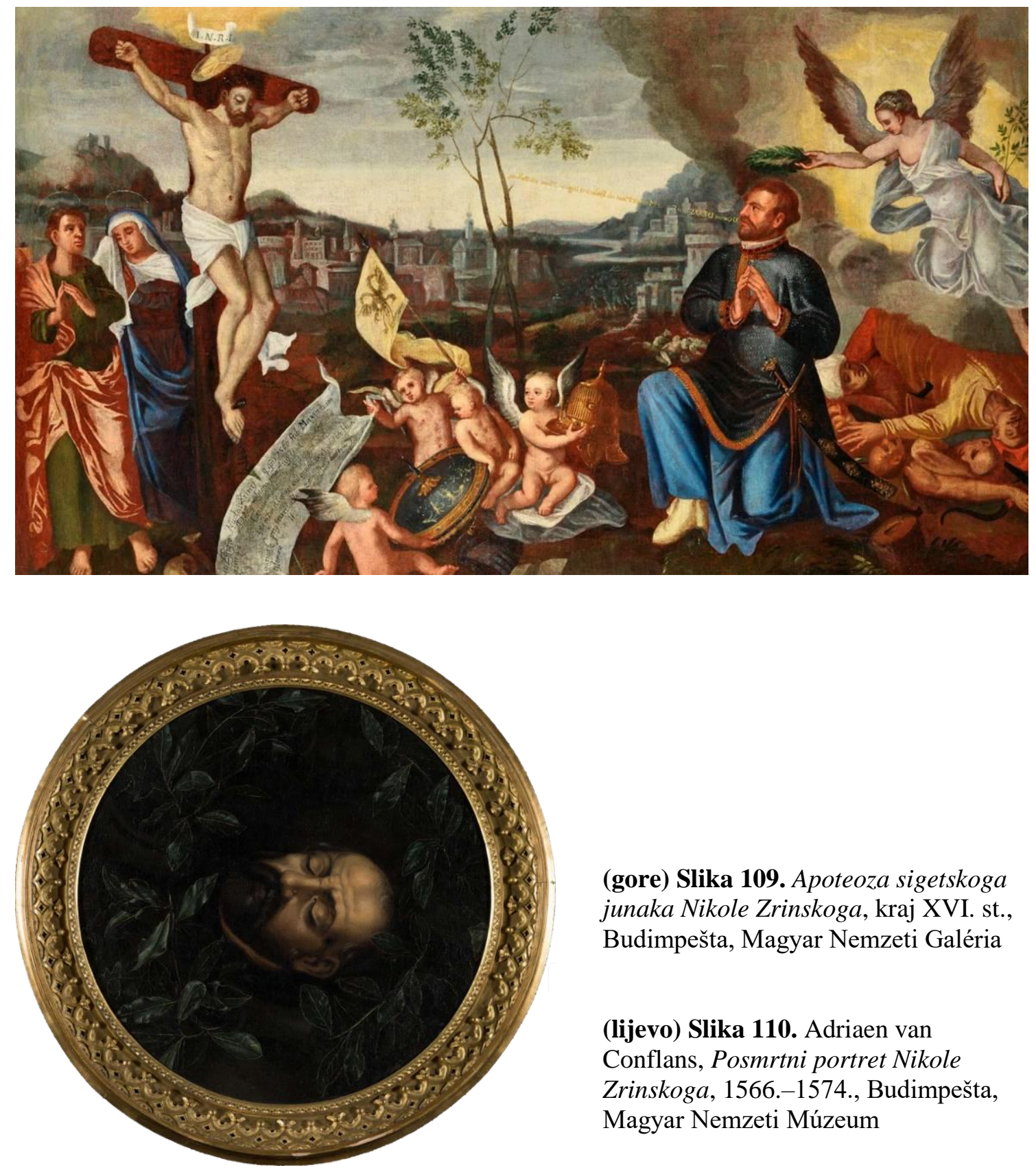

(gore) Slika 109. Apoteoza sigetskoga junaka Nikole Zrinskoga, kraj XVI. st., Budimpešta, Magyar Nemzeti Galéria

(lijevo) Slika 110. Adriaen van Conflans, Posmrtni portret Nikole Zrinskoga, 1566.-1574., Budimpešta, Magyar Nemzeti Múzeum

njegovoga tijela koji je dopremljen s poprišta sigetske bitke i pokopan u Šenkovcu. Naime, nakon Nikoline pogibije, Osmanlije su pronašli njegovo tijelo na bojištu, odrubili mu glavu i poslali je kao pobjednički trofej zapovjedniku carskih četa grofu Salmu u njegovu tabor u Komáromu. ${ }^{406}$ Salm je glavu prenio u obližnji grad Győr, gdje ju je preuzeo Nikolin sin Juraj IV. i odnio je u Šenkovec, gdje ju je sahranio u obiteljskoj grobnoj kapeli.

\footnotetext{
${ }^{406}$ Usp. Géza Galavics, Kult Zrinskih i likovna prezentacija - od obiteljskog mecenatstva do novog tipa javnosti, u: Hrvatska / Mađarska / Europa. Stoljetne likovno-umjetničke veze. Simpozij povjesničara umjetnosti Hrvatske i Mađarske = Horvátország / Magyarország / Európa. Évszázados képzömüvészeti kapcsolatok. Magyar horvát müvészettörténeti szimpozion, Zagreb: Društvo mađarskih znanstvenika i umjetnika u Hrvatskoj, 2000., str. 126146, 127. Uredila Jadranka Damjanov.
} 


\subsection{NADGROBNICI S OBITELJSKIM GRBOM}

Druga velika likovna skupina nadgrobnih spomenika sačuvanih na području povijesne Zagrebačke biskupije su nadgrobnici na kojima obiteljski grb predstavlja osnovni likovni motiv. Nalik spomenicima s likom pokojnika, upotreba grbovnih nadgrobnika nastavila se na srednjovjekovnu tradiciju. Prvi grbovi - a time i grbovni spomenici - pojavili su se početkom XII. stoljeća, a njima su se smjeli koristiti isključivo vladari i plemići. ${ }^{407}$ Grb je predstavljao simbol neke obitelji te je služio kao potvrda njezinoga plemenitog podrijetla, a dodjeljivao ga je vladar posebnom poveljom, takozvanom grbovnicom. Tijekom kasnoga srednjeg vijeka pravo korištenja grbova proširilo se na gradove, općine, crkvene velikodostojnike, udruženja i istaknute građane. ${ }^{408}$

Uz grbovnice, pečate i kovanice, nadgrobni spomenici jedan su od najčešćih likovnih heraldičkih izvora. Na prostoru povijesne Zagrebačke biskupije sačuvano je četrdesetak nadgrobnih ploča i epitafa iz ranoga novog vijeka na kojima je grb primijenjen kao glavni likovni motiv. Nalik spomenicima s likom pokojnika, najveći broj primjeraka očuvan je na području Hrvatskoga zagorja (Krapina, Lepoglava, Mače, Mihovljan, Pregrada, Remetinec, Vinica, Zajezda) i grada Zagreba (Kaptol, Gradec, Remete, Stenjevec). Pojedinačni primjerci sačuvani su i sjeverno od navedenoga područja na prostoru Međimurja (Nedelišće) i grada Varaždina, južno na području Pokuplja (Karlovac, Svetice) i Banovine (Zrin), zapadno na području Žumberačkoga gorja (Kotari, Samobor) te istočno na području Moslavine (Kloštar Ivanić, Kutina) i zapadne odnosno središnje Slavonije (Borovac, Orahovica, Požega). Najveći broj spomenika datira iz XVII. stoljeća. Iz XVI. i XVIII. stoljeća očuvan je manji no podjednak broj nadgrobnika, a iz XV. stoljeća sačuvan je samo jedan primjerak.

$\mathrm{Na}$ području Zagrebačke (nad)biskupije, grbovni nadgrobnici najvećim su dijelom podizani za muške članove plemićkih obitelji, a potom za pripadnike svećenstva (biskupe i kanonike). Odabirom grba kao glavnoga likovnog motiva naručitelji su htjeli naglasiti svoju pripadnost obitelji i rodu, sukladno onodobnom ustroju društva u kome je rodbinsko zajedništvo bilo okvir (ekonomski, sigurnosni, emotivni) pojedinačnih sudbina. ${ }^{409} \mathrm{Ta}$ egzistencijalna mreža čvrstih rodbinskih vezā bila je dovoljno jaka da grb, kao heraldički simbol obitelji, istisne lik pokojnika te postane glavnim nositeljem likovnoga značenja na nadgrobnicima. ${ }^{410}$ Posebnu skupinu unutar ovoga dijela korpusa čine nadgrobne ploče koje su

\footnotetext{
${ }^{407}$ Usp. Vlasta Brajković, Grbovi - grbovnice - rodoslovlja, Zagreb: Povijesni muzej Hrvatske, 1976., str. 7-8. ${ }^{408}$ Isto.

${ }^{409}$ Usp. Emilijan Cevc, nav. dj., 1981., str. 48; Andreas Zajic, nav. dj., 2004., str. 164.

${ }^{410}$ Usp. Emilijan Cevc, nav. dj., 1981., str. 48.
} 
pokrivale zajedničke kripte redovnika u samostanskim crkvama, a obilježene su grbom pripadajuće redovničke obitelji. Nalik obiteljskim grbovima pojedinih rodova, grbovi samostanskih redova simbolizirali su zajednicu unutar koje su pokojnici djelovali i naposljetku umrli.

Sastavni dio svakoga grba je štit stabilna oblika na kojem je predočen jedan ili više likovnih motiva. ${ }^{411}$ Prvi grbovi bili su jednostavne izvedbe, a sadržavali su samo štit sa simbolom. U XIV. stoljeću počeli su se ukrašavati kacigom s nakitom i plaštem, odnosno u slučaju grbova crkvenih velikodostojnika tijarom, mitrom ili prelatskim šeširom, ovisno o položaju njegovoga nositelja. ${ }^{412}$ Budući da nisu smjeli mijenjati izgled štita, umjetnici su se posvetili oblicima grbovnih ukrasa te osmišljavali nove. ${ }^{413}$ Procvatom heraldike u XVI. stoljeću, grbovi su dodatno ukrašavani različitim vrstama kruna, čuvarima i geslima. ${ }^{414}$ Razvoj grba iz likovno jednostavnijega u složeniji oblik možemo pratiti i na nadgrobnicima Zagrebačke povijesne biskupije. Grbovi sa petnaestostoljetnih i šesnaestostoljetnih spomenika jednostavnoga su izgleda. Dio njih sadrži samo štit s obiteljskim simbolom, a pojedini su ukrašeni kacigom s nakitom i plaštem. S druge strane, grbovi na nadgrobnicima iz XVII. i XVIII. stoljeća složenijega su oblika te svi sadrže ukrase poput plašteva, kaciga s nakitom, kruna, prelatskih pokrivala, čuvara i lenti s geslima.

Izuzev grbovnoga znakovlja, nadgrobni spomenici sadrže još jedan, podjednako važan element - natpis. Nadgrobni natpisi u početku su bili kratki, a sadržavali su ime pokojnika, titulu, službu te godinu i dob smrti. ${ }^{415}$ Tijekom srednjega i početka ranoga novog vijeka poglavito su bili uklesani uz rubove nadgrobnika. Od XVI. stoljeća nadalje ispisuju se u blokovima koji su smješteni iznad ili ispod grbovnoga motiva, a ponekad su uklesani unutar ukrasnih okvira ili kartuša. U XVII. i XVIII. stoljeću natpisi postaju sve složeniji te se razvijaju u dugačke nekrologe koji osim osnovnih podataka o pokojniku sadrže zapis o njegovim ovozemaljskim postignućima i vrlinama, ispunjavajući velik dio spomenika. ${ }^{416}$

Najstariji nadgrobnik s obiteljskim grbom koji je sačuvan na prostoru Zagrebačke povijesne biskupije dokazuje da se ova vrsta spomenika primjenjivala na razmatranom

\footnotetext{
${ }^{411}$ Usp. Vlasta Brajković, nav. dj., 1976., str. 7.

${ }^{412}$ Usp. Zorislav Horvat, nav. dj., 1988., str. 41.

${ }^{413}$ Usp. Jolán Balogh, nav. dj., 1982., str. 93, 677; Emilijan Cevc, nav. dj. 1981., str. 78; Zorislav Horvat, nav. dj., 1988., str. 41.

${ }^{414}$ Usp. Vlasta Brajković, nav. dj., 1976., str. 9-10. Čuvari su likovi (ljudi, životinje ili mitološka bića) koji u paru stoje sa svake strane štita i pridržavaju ga. Gesla su ispisana na svicima u obliku početnih slova riječi ili čitavim rečenicama, a smještena su ispod ili iznad štita.

415 Usp. Philippe Ariès, nav. dj., 1981., str. 217-218; Géza Csergheő i Ivan Bojničić, Nadgrobni kamen Radoslava Gorjanskog, u: Viestnik Hrvatskoga arkeologičkoga družtva XI/1, Zagreb: Hrvatsko arkeologičko družtvo, 1889., str. 3-8, 6.

${ }^{416}$ Usp. Philippe Ariès, nav. dj., 1981., str. 223; Géza Csergheő i Ivan Bojničić, nav. dj., 1889., str. 7.
} 
području i prije ranoga novog vijeka. Riječ je o nadgrobnoj ploči gorjanskoga plemića Radoslava (Slika 111) koja je danas ugrađena u unutrašnji zid kapele sv. Martina u zagrebačkoj Laškoj Vesi. Ploča je iskopana na lokalitetu nekadašnjega dominikanskog sklopa (porušen u XVI. stoljeću) prilikom izgradnje sirotišta (1820. - 1826.) koje je dao podići zagrebački biskup Maksimilijan Vrhovac (Karlovac, 1752. - Zagreb, 1827.; biskupovao 1787. - 1827.), na osnovi čega se pretpostavlja da se izvorno nalazila u dominikanskoj crkvi sv. Nikole. ${ }^{417}$ Plemićev grb uklesan je u donjem dijelu nadgrobnika, ${ }^{418}$ a povrh njega predočen je križ na profiliranom postolju. Stručnjaci se spore u vezi pitanja je li ploča nastala u drugoj polovini XIII. (Csergheö i Bojničić 1889., Deželić 1906., Kukuljević Sakcinski 1891., Karaman 1950., Horvat 1988. i 1966.) ili prvoj polovini XIV. stoljeća (Dobronić 1991.), ${ }^{419}$ no ono što je važno za ovu raspravu jest da spomenik potvrđuje da se primjena ranonovovjekovnih grbovnih nadgrobnika nadovezuje na srednjovjekovnu tradiciju.

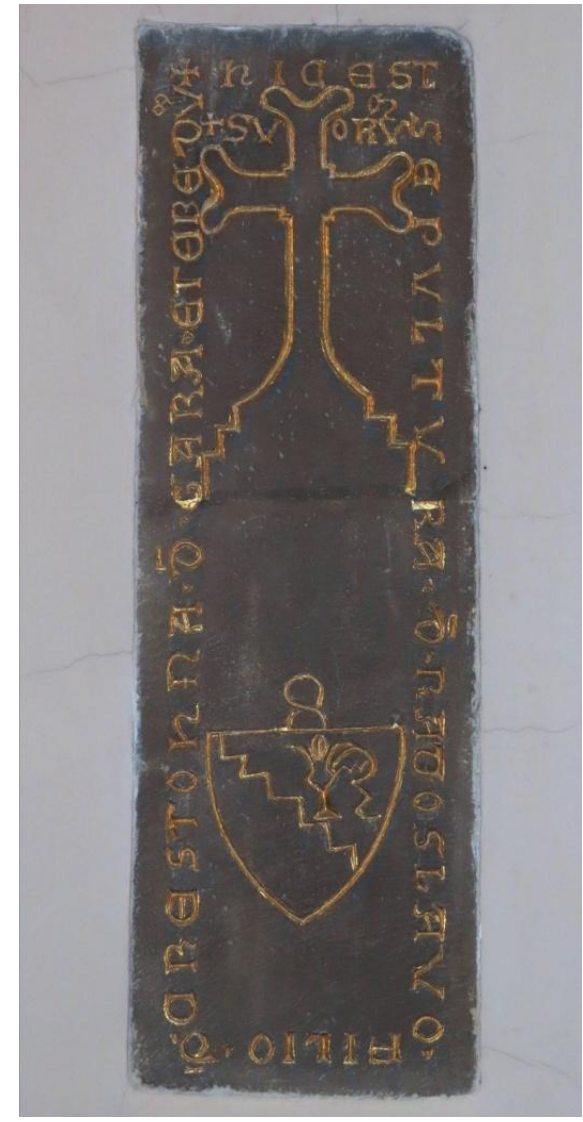

Slika 111. Nadgrobna ploča gorjanskoga plemića Radoslava, XIII./XIV. stoljeće, Zagreb, kapela sv. Martina

\footnotetext{
${ }^{417}$ Usp. Lelja Dobronić, nav. dj., 1991., str. 84; Slavko Šterk i Boris Mašić, nav. dj., 2012., str. 95.

${ }^{418}$ Grb se sastoji od štita dijagonalno podijeljena stubama koje se spuštaju slijeva nadesno. Pri dnu stuba uklesano je slovo $R$ koje simbolizira ime pokojnika. Usp. Ivan von Bojničić, nav. dj., 1889., str. 50, tab. 36.

${ }^{419}$ Usp. Géza Csergheő i Ivan Bojničić, nav. dj., 1889., str. 4-8; Velimir Deželić, Historijski grobovi u Zagrebu, u: Prosvjeta: časopis za pouku i zabavu XIV/23, Zagreb: Antun Scholz, 1906.b, str. 735-740, 736; Ivan Kukuljević Sakcinski, nav. dj., 1891., str. 324, br. 1114; Ljubo Karaman, nav. dj., 1950., str. 142-143; Zorislav Horvat, nav. dj., 1988., str. 42, 45; Zorislav Horvat, nav. dj., 1996., str. 25; Lelja Dobronić, nav. dj., 1991., str. 84.
} 
Jedina petnaestostoljetna nadgrobna ploča s obiteljskim grbom koja je sačuvana na području Zagrebačke (nad)biskupije pripada članu obitelji Roh de Deche (Slika 112). ${ }^{420}$ Izvorno se nalazila u crkvi sv. Marije Snježne u Kutini, a danas je pohranjena u Hrvatskom povijesnom muzeju u Zagrebu. ${ }^{421}$ Imenovana obitelj imala je posjede u povijesnoj Križevačkoj županiji na području rijeke Ilove, a izumrla je u XVI. stoljeću. Ploča je kompozicijski podijeljena na središnje polje u kojem je predočen obiteljski grb i natpis koji teče uz rubove nadgrobnika. Grb se sastoji od štita, kacige s nakitom (krilo s koso postavljenom gredom) i plašta izvedena u obliku lisnatih vitica. Štit je podijeljen na četiri polja jednake veličine koja sadrže obiteljske simbole. Grbovni motivi danas su slabo vidljvi zbog istrošenosti ploče, no njihov je izgled moguće rekonstruirani na osnovi crteža Gjure Szabe (1916.) koji je pohranjen u Arhivu Muzeja Moslavine u Kutini. ${ }^{422}$ Prema Szabinome crtežu, u prvome polju nekoć su se nalazile tri šestokrake zvijezde, u drugome polumjesec i malteški križ, u trećemu ljiljan, a u četvrtome poprečna greda. ${ }^{423}$ Nalik štitu, natpis koji je uklesan uz rubove vrlo je trošan, no mađarski istraživači Pál Engel i Pál Lővei (1991.) prepostavljaju da sadrži ime Ivana Roha de Deche, službenika hrvatsko-dalmatinskoga bana i ugarskoga palatina Nikole II. Gorjanskoga (?, o. 1366. - ?, 1433.), koji je preminuo 1420. godine. $^{424}$

Ploča obitelji Roch de Deche izrađena je od crvenoga mramora koji je bio skupocijen $\mathrm{i}$ dostupan samo imućnijim naručiteljima. Zorislav Horvat (1988., 1996.) pretpostavlja da kamen potječe iz jednoga od ugarskih kamenoloma crvenoga mramora iz okolice Pečuha ili Ostrogona te da je nadgrobnik nastao u budimskoj ili ostrogonskoj radionici, odakle je dopremeljen u Hrvatsku. ${ }^{425}$ Kompozicijska podjela na središnje polje obrubljeno natpisom te primjena određena oblika štita (klinasti), kacige (turnirska) i pisma (gotička majuskula) daju spomeniku jasna gotička obilježja. ${ }^{426}$ Nagrobnici ovakva načina oblikovanja bili su rasprostranjeni diljem Europe, a u najvećem su se broju primjenjivali u XIV. i prvoj polovini

\footnotetext{
${ }^{420}$ Vapnenac, $210 \times 110 \times 20 \mathrm{~cm}$, Zagreb, Hrvatski povijesni muzej, izvorno u crkvi sv. Marije Snježne u Kutini. Kat. br. 77.

${ }^{421}$ Usp. Mirko Valentić, nav. dj., 1969., str. 27-28; Mirko Valentić i Lada Prister, nav. dj., 2002., str. 63.

${ }^{422}$ Usp. Dražen Kovačević, Đuro Szabo - o starinama u Moslavini, u: Zbornik Moslavine IV, Kutina: Muzej Moslavine, 1998., str. 99-110, 106. Uredila Ana Bobovec; Mirko Valentić i Lada Prister, nav. dj., 2002., str. 63.

${ }^{423}$ Grb je istovjetan onome s pečata Ladislava Roha de Deche iz 1484. godine koji je Bojničić objavio u svome grbovniku. Usp. Ivan von Bojničić, nav. dj., 1889., str. 159, tab. 115.

${ }^{424}$ Usp. Pál Engel i Pál Lővei, A gerecsei vörösmárvány használata Zágrábban és környékén a középkorban, u: A Magyar Nemzeti Galéria Évkönyve IX/47-48, Budapest: Magyar Nemzeti Galéria, 1991., str. 47-51, 47. Usporedi dalje: Vlasta Brajković, Grbovi, grbovnice, rodoslovlja: katalog zbirke grbova, grbovnica $i$ rodoslovlja, Zagreb: Hrvatski povijesni muzej, 1995. [1976.]., str. 140. Rukopis uredila Dubravka Peić Čaldarović; Mirko Valentić i Lada Prister, nav. dj., 2002., str. 63.

${ }^{425}$ Usp. Zorislav Horvat, nav. dj., 1988., str. 54-55; Zorislav Horvat, nav. dj., 1996., str. 40.

${ }^{426}$ Isto.
} 


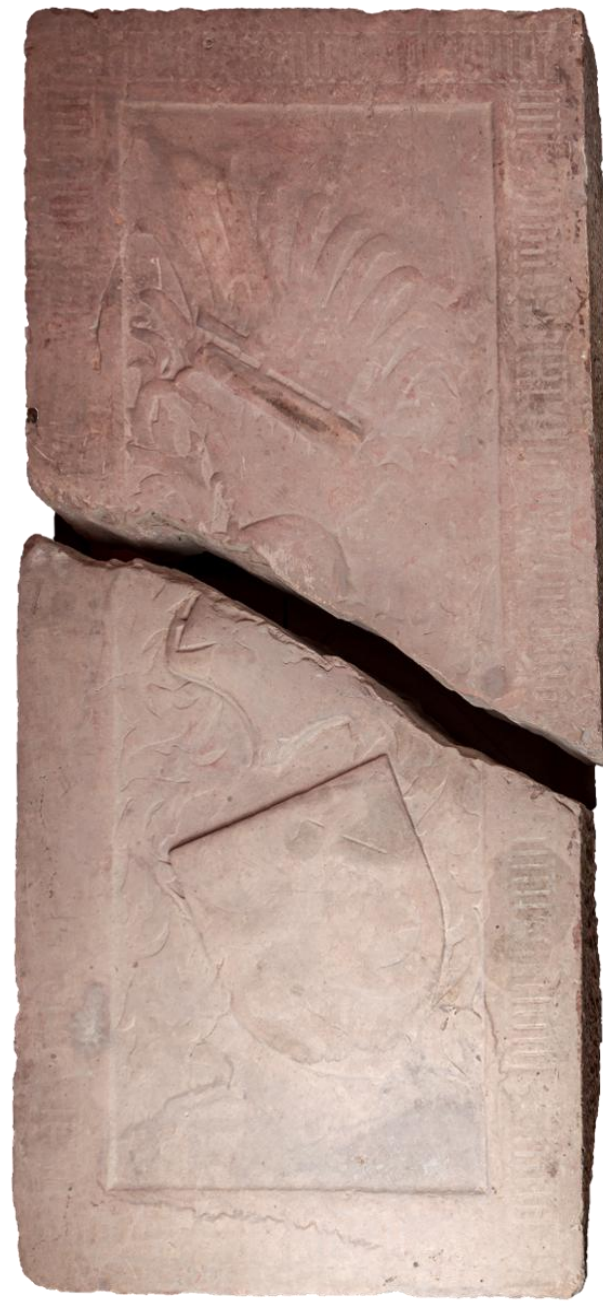

Slika 112. Nadgrobna ploča obitelj

Roh de Deche, I. pol. XV. st., Zagreb, Hrvatski povijesni muzej

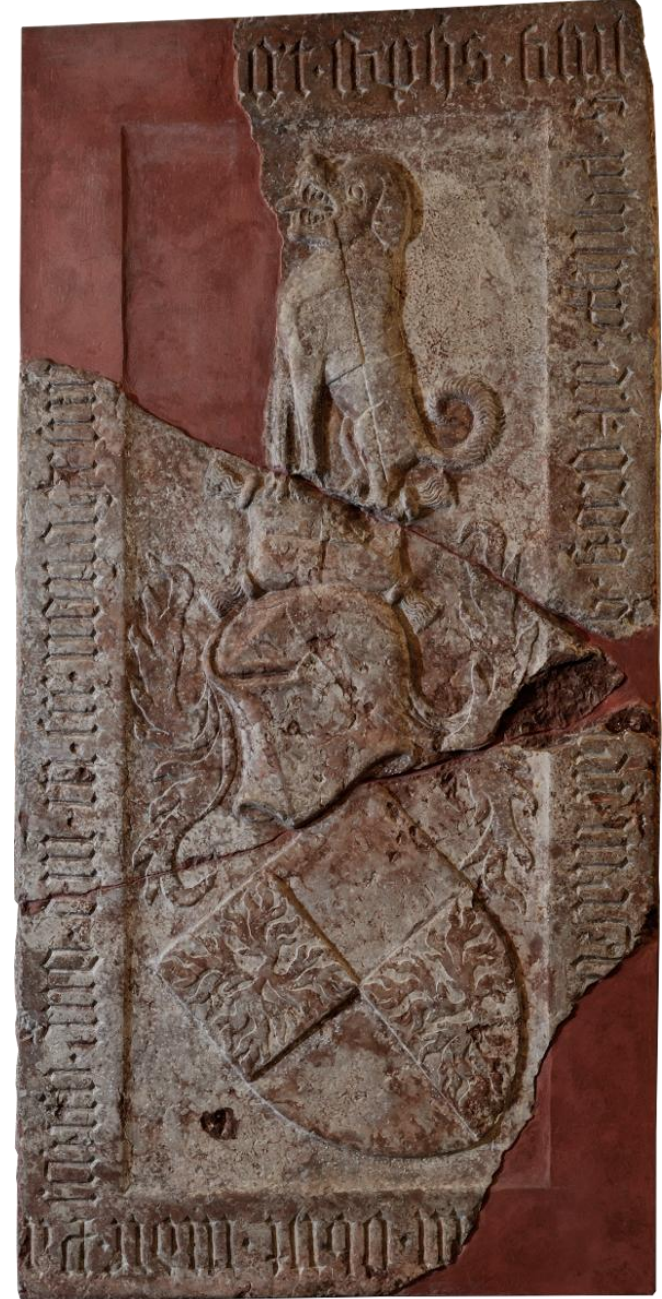

Slika 113. Nadgrobna ploča Filipa IV. Korođskoga (†1394.), Osijek, crkva Svetoga Križa

XV. stoljeća. Likovno srodan primjer predstavlja nadgrobna ploča Filipa IV. Korođskoga (Kórógyji; ? - ?, 1394.) (Slika 113) koja je pronađena uz franjevačku crkvu Svetoga Križa u osječkoj tvrđi. ${ }^{427}$ Nalik nadgrobniku obitelji Roch de Deche, pretpostavlja se da je ploča Korođskoga isklesana od crvenog mramora koji se vadio nedaleko Pečuha te da je nastala $u$ ostrogonskoj radionici. $^{428}$

Pisani izvori potvrđuju da je izvorno postojalo još nadgrobnih ploča s obiteljskim grbom koje su nastale u XV. stoljeću. Ivan Kukuljević Sakcinski (1891.) zabilježio je da je u Dežanovcu nedaleko Daruvara pronađena nadgrobna ploča urešena grbom obitelji

\footnotetext{
${ }^{427}$ Usp. Zlatko Uzelac i Marko Ambroš, Srednjovjekovna župna crkva sv. Trojstva u Osijeku, u: Radovi Instituta za povijest umjetnosti 38, Zagreb: Institut za povijest umjetnosti, 2014., str. 51-62, 57.

${ }^{428}$ Ive Mažuran (1984.) pretpostavio je da je materijal za nadgrobnu ploču Filipa IV. Korođskoga dopremljen iz kamenoloma u gorju Mecsek smještenom sjeverno od Pečuha, a da je u Osijeku predan nekome od lokalnih klesara i kamenorezaca na obradu.Usp. Ive Mažuran, Ulomak nadgrobnog spomenika iz 15. stoljeća nađen u Osijeku, u: Anali zavoda za znanstveni rad u Osijeku, Osijek: Jugoslavenska akademija znanosti i umjetnosti, 1984., str. 195-208, 205.
} 
Grebenski. $^{429}$ Prema natpisu, ploča je pripadala Ladislavu Grebenskom (? - ?, 1490.), potpalatinu Ugarskoga Kraljevstva i županu Križevačke županije, a postavljena je 1489. godine. S obzirom na to da povijesni izvori bilježe da je Ladislav još bio živ 1490. godine, ${ }^{430}$ možemo zaključiti da je spomenik izrađen za njegovoga života. Pišući o povijesti Daruvara i okolice, Gjuro Szabo (1932.) također se kratko osvrnuo na ovaj nadgrobnik. ${ }^{431}$ Budući da se spomeniku već u to vrijeme izgubio trag, Szabo je pisao o njemu na osnovi knjige dvojice budimskih profesora Mathiasa Pillera i Ludwiga Mitterpachera, Iter per Poseganam Sclavoniae provinciam mensibus Junio et Julio anno 1782. (Budim, 1783.). Prema Pilleru i Mitterpacheru, nadgrobnik se nije nalazio u Dežanovcu - kao što je zabilježio Kukuljević Sakcinski (1891.) - nego susjednome Kreštelovcu. ${ }^{432}$ Piller i Mitterpacher sažeto su opisali grb $^{433}$ koji je krasio ploču i zabilježili uklesani natpis, koji je istovjetan Kukuljevićevu prijepisu.

Iz XVI. stoljeća sačuvan je veći, no ipak skroman broj nadgrobnika. Među očuvanim spomenicima likovno je najsloženija nadgrobna ploča kneza Nikole III. Zrinskoga (?, 1488./89. - Zrin, 1534.) (Slika 114) ${ }^{434}$ koji je pokopan u franjevačkoj samostanskoj crkvi sv. Katarine nedaleko sjedišta obitelji u Zrinu. ${ }^{435}$ Padom Banovine pod osmansku vlast samostan je gotovo u potpunosti uništen, a crkva oštećena. Nakon povlačenja osmanskih snaga u XVII. stoljeću, crkva je obnovljena i posvećena sv. Margareti, a nadgrobna ploča izvađena je i ugrađena u zapadno pročelje iznad glavnoga ulaza. ${ }^{436}$ Crkva se koristila do Drugoga svjetskoga rata $\mathrm{u}$ kojem je pretrpjela velika oštećenja te je posljednji put napuštena. Osamdesetih godina XX. stoljeća ploča je izvađena iz pročelja i prenesena u muzejsku zbirku franjevačkoga samostana u Hrvatskoj Kostajnici.

\footnotetext{
${ }^{429}$ Usp. Ivan Kukuljević Sakcinski, nav. dj., 1891., str. 33, br. 109.

${ }^{430}$ Usp. Trpimir Macan (ur.), Hrvatski biografski leksikon. 5, Gn - H, Zagreb: Leksikografski zavod »Miroslav Krleža«, 2002., sub voce Grebenski [Tatjana Radauš].

${ }^{431}$ Usp. Gjuro Szabo, Iz prošlosti Daruvara i okolice, u: Narodna starina XI/28, Zagreb: Josip Matasović, 1932. str. 79-98, 89, 95.

432 Isto.

${ }^{433}$ Prema njihovu opisu, na štitu je bio predočen zupčanik iznad kojega je koračao lav. Usp. Gjuro Szabo, nav. dj., 1932., str. 89.

${ }^{434}$ Kamen, $141 \times 84,5 \times 17,3 \mathrm{~cm}$, Hrvatska Kostajnica, samostan sv. Antuna Padovanskoga, izvorno u crkvi sv. Katarine (kasnije Margarete) kod Zrina. Kat. br. 79.

${ }^{435}$ Nikola III. Zrinski utemeljio je navedeni samostan 1504. godine. Usp. Zorislav Horvat, Arhitektura franjevačkih samostana u dotursko doba na prostoru kontinentalne Hrvatske i Slavonije (arheološki stadij), u: Mir i dobro: umjetničko i kulturno naslijeđe Hrvatske franjevačke provincije sv. Ćirila i Metoda o proslavi stote obljetnice utemeljenja, katalog izložbe, Zagreb: 2000., str. 173-190, 185-186. Uredili Marija Mirković i Franjo Emanuel Hoško; Paškal Cvekan, Kostajnica i franjevci, Hrvatska Kostajnica: Franjevački samostan, 2017. [1982.], str. 44-46.

${ }^{436}$ Usp. Zorislav Horvat, nav. dj., 2000., str. 185-186.
} 


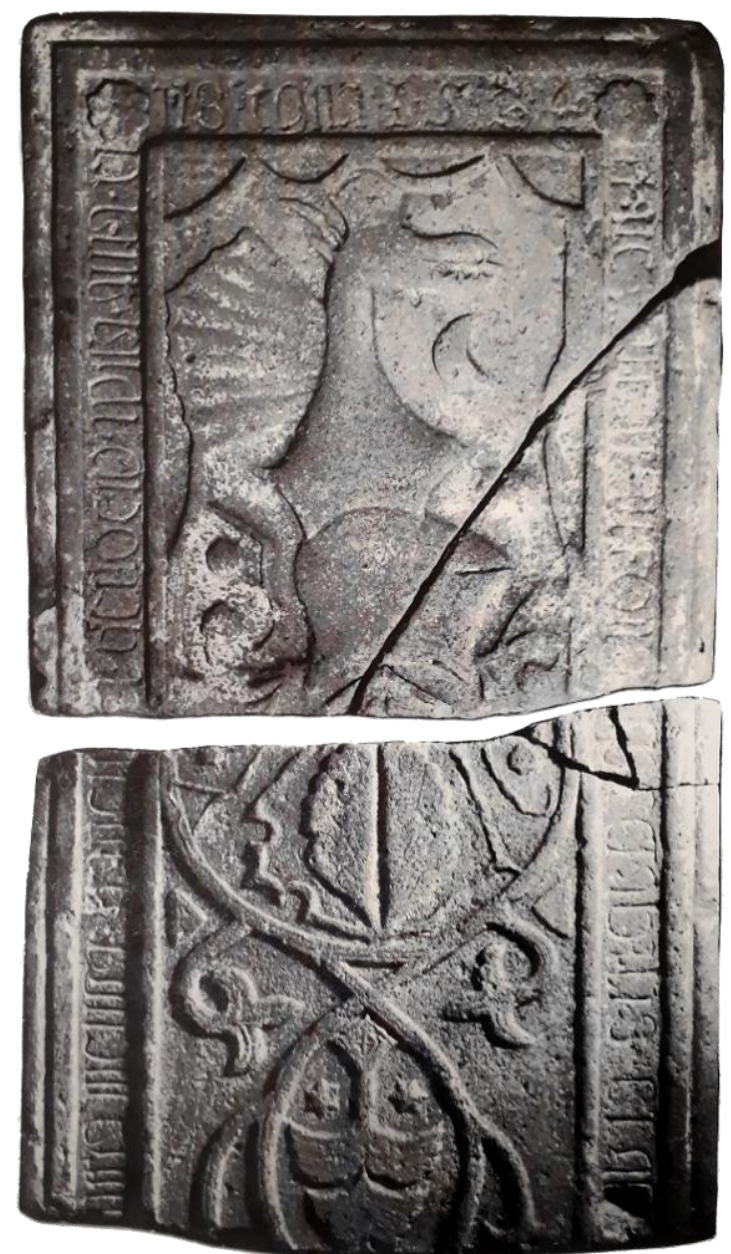

Slika 114. Bihaćka klesarska radionica, Nadgrobna ploča Nikole III. Zrinskoga (†1523.), Hrvatska Kostajnica, Zbirka franjevačkoga samostana

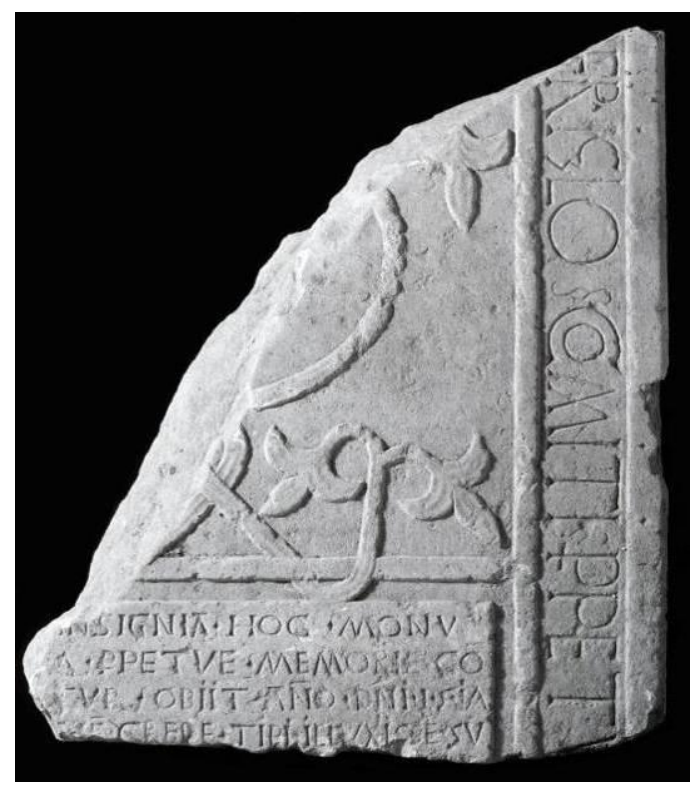

Slika 115. Bihaćka klesarska radionica, Nadgrobna ploča iz Borovca (†1517.), Zagreb, Povijesni muzej Hrvatske

Nalik nadgrobnoj ploči člana obitelji Roh de Deche, nadgrobnik Nikole III. Zrinskoga sastoji se od središnjega polja s grbom i natpisa ispisana uzduž rubova ploče. Grb se sastoji od štita s motivom raširenih krilā, plašta i turnirske kacige s nakitom u obliku zmaja, ${ }^{437} \mathrm{a}$ prikazan je unutar većega heraldičkog štita izvedena u obliku vitica. Vitice se pružaju ispod grba i isprepliću u manji medaljon s motivom topuza i parom šestokrakih zvijezda. Uspoređujući nadgrobnik Zrinskoga s drugim spomenicima nastalima na području hrvatskoga i bosanskoga Pounja, Zorislav Horvat (1988., 1996., 2000.) pripisao ga je bihaćkoj klesarskoj radionici koja je djelovala $u$ prvoj polovini XVI. stoljeća. ${ }^{438} \mathrm{Na}$ svim nadgrobnicima

\footnotetext{
${ }^{437}$ Grb se sastoji od štita, turnirske kacige, plašta i nakita u obliku zmaja. Na štitu je prikazan herladički simbol obitelji, par raširenih krila. Usp. Ivan von Bojničić, nav. dj., 1889., str. 211, tab. 153.

${ }^{438}$ Usp. Zorislav Horvat, nav. dj., 1988., str. 61; Zorislav Horvat, nav. dj., 1996., str. 85; Zorislav Horvat, Srednjovjekovna umjetnost - arheološki stadij, u: Mir i dobro: umjetničko i kulturno naslijeđe Hrvatske franjevačke provincije sv. Cirila i Metoda o proslavi stote obljetnice utemeljenja, katalog izložbe, Zagreb: 2000.,
} 
atribuiranima radionici primijenjena je ista kompozicijska podjela na središnje polje s grbom i natpis koji teče uz rubove, svi su isklesani u niskome reljefu te sadrže heraldičke štitove složenih oblika koji su izvedeni od vitica lisnatih završetaka. Opisujući stil radionice, Horvat je objasnio kako je ona razvila prepoznatljiv likovni izraz koji je, unatoč primjeni renesansih vegetabilnih motiva, još uvijek temeljen na gotičkom načinu oblikovanja. ${ }^{439}$

Sedamdesetak kilometara zapadno od Zrina, ispred kapele sv. Martina u Borovcu kod Novske pronađena je nadgrobna ploča (Slika 115) ${ }^{440}$ koja je oblikovno srodna nadgrobniku kneza Nikole III. Zrinskoga. Župni ured u Gornjim Rajićima darovao ju je Povijesnome muzeju Hrvatske u Zagrebu, gdje je pohranjena i danas. ${ }^{441}$ Sačuvan je donji desni kut nadgrobnika na kojem je vidljiv dio središnjega polja i dijelovi natpisa ispisani u antičkoj kapitali. U središnjem dijelu isklesane su vitice koje su najvjerojatnije - kao na nadgrobnoj ploči Nikole III. Zrinskoga - oblikovale štit koji je sadržavao heraldički simbol obitelji pokojnika, a završavaju petljom i stiliziranim ljiljanima. Na osnovni kompozicijskih sličnosti te načinu oblikovanja vitica, cvjetova ljiljana i slova u natpisu, Zorislav Horvat (1996.) i Marija Šercer (2003.) pripisali su nadgrobnik navedenoj klesarskoj radionici iz Bihaća. ${ }^{442}$

Borovački nadgrobnik razlikuje se od onoga kneza Nikole III. Zrinskoga po tome što sadrži dvostruki natpis - jedan koji teče uz rubove ploče i drugi koji je isklesan u bloku ispod vitica. Natpis u bloku sadrži godinu smrti pokojnika (1517.), a onaj isklesan uz rub njegovu nasljednu titulu (comes perpetuus) i posljednji dio imena (ERISLO). Anđela Horvat (1975.) interpretirala je puni oblik imena kao Periklo, antikno ime koje, prema njezinome mišljenju, uz vitičaste motive i upotrebu antičke kapitale odražava renesansni duh vremena. ${ }^{443}$ Uzevši u obzir lokalni povijesni kontekst, Mirko Valentić i Lada Prister (2002.) zaključili su kako je izglednije da se ime odnosi na člana obitelji Berislavić (lat. Berislo) koja je imala posjede u Požeškoj i Vukovarskoj županiji u XVI. stoljeću. ${ }^{444}$ Nadovezujući se na njihovu pretpostavku, Marija Šercer (2003.) ustvrdila je na osnovi godine smrti pokojnika da je najvjerojatnije riječ o nadgrobnoj ploči Franje Berislavića Grabarskoga (? - ?, 1517.), jajačkoga bana (banovao

\footnotetext{
str. 354-355. Uredili Marija Mirković i Franjo Emanuel Hoško. O potvrdi atribucije nadgrobne ploče Nikole III. Zrinskoga bihaćkoj klesarskoj radionici vidi: Marija Šercer, nav. dj., 2003., str. 104.

${ }^{439}$ Usp. Zorislav Horvat, nav. dj., 1996., str. 91.

${ }^{440}$ Vapnenac, $80 \times 67 \times 14 \mathrm{~cm}$, Zagreb, Hrvatski povijesni muzej, izvorno u kapeli sv. Martina u Borovcu. Kat. br. 80 .

${ }^{441}$ Usp. Mirko Valentić i Lada Prister (2002.) navode podatak da je ploča darovana muzeju 1974. godine, a Marijana Šercer (2003.) 1969. godine. Usp. Mirko Valentić i Lada Prister, nav. dj., 2002., str. 65; Marijana Šercer, nav. dj., 2003., str. 103.

${ }^{442}$ Usp. Zorislav Horvat, nav. dj., 1996., str. 91; Marija Šercer, nav. dj., 2003., str. 104-105.

443 Usp. Anđela Horvat, nav. dj., 1975., str. 49-50. Zorislav Horvat (1996.) preuzeo je njezin prijedlog identifikacije. Usp. Zorislav Horvat, nav. dj., 1996., str. 90-91.

${ }^{444}$ Usp. Mirko Valentić i Lada Prister, nav. dj., 2002., str. 65.
} 
1494. - 1496., 1499. - 1503.) koji je pokopan u franjevačkoj samostanskoj crkvi u Dvorišću. ${ }^{445}$ Premda je pretpostavka Marije Šercer izgledna, s obzirom na fragmentarnu očuvanost nadgrobnika - nedostaje veći dio natpisa i cijeli obiteljski grb - svakom pokušaju identifikacije potrebno je pristupiti s oprezom.

Iz XVI. stoljeća sačuvane su i nadgrobne ploče koje nisu toliko likovno složene kao one iz Zrina i Borovca. Njihovo je rješenje svedeno na osnove - jednostavan grb koji se sastoji od štita s heraldičkim motivom bez dodatnih ukrasa, ispod ili/i iznad kojeg je uklesan nadgrobni natpis. Budući da su bile jednostavnije izvedbe, ovakve nadgrobne ploče bile su jeftinije i dostupnije većem broju naručiteljā, a slijedom toga vjerojatno i brojčano zastupljenije od nadgrobnika sa složenijim likovnim prikazom. Na žalost, tek su rijetke preživjele pregradnje i preuređenja crkava u kojima su se izvorno nalazile, a na području Zagrebačke (nad)biskupije u potpunosti su očuvane samo dvije.

Prva je nadgrobna ploča Mojsija Humskoga (? - ?, 1548.) (Slika 116), ${ }^{446}$ lokalnoga plemića koji je pokopan u župnoj crkvi Bezgrješnoga začeća Blažene Djevice Marije u Maču. U središtu nadgrobnika uklesan je štit složenoga oblika karakteristična za kasnu gotiku ${ }^{447}$ unutar kojega je prikazan lav sa žezlom u prednjim šapama. ${ }^{448}$ Iznad i ispod grba uklesan je natpis koji bilježi za koga je nadgrobnik podignut i godinu pokojnikove smrti. Ploča se izvorno nalazila na podu svetišta, a podignuta je i ugrađena u sjeverni zid svetišne apisde najvjerojatnije prilikom pregradnje crkve između 1777. i 1778. godine kada je mijenjano njezino popločenje. ${ }^{449}$

Druga nadgrobna ploča s jednostavnim grbovnim rješenjem koja je očuvana iz XVI. stoljeća postavljena je za Vuka Dragača (? - ?, 1578.) (Slika 117) ${ }^{450}$ u crkvi Presvetoga Trojstva u Nedelišću. Izvorno je pokrivala ulaz u obiteljsku grobnicu u svetištu crkve, ${ }^{451}$ a danas je ugrađena u južni zid svetišne apside. Sadrži reljefno izveden štit složena kasnogotičkoga oblika - nalik onome s nadgrobne ploče Mojsija Humskoga - na kojem je predočen jelen ranjen strijelom koji izranja iz rijeke. Ispod grba uklesan je natpis koji otkriva

\footnotetext{
${ }^{445}$ Usp. Marija Šercer, nav. dj., 2003., str. 105.

${ }^{446}$ Kamen, $124 \times 71$ cm, Mače, crkva Bezgrješnoga začeća Blažene Djevice Marije. Kat. br. 11.

${ }^{447}$ Usp. Zorislav Horvat, nav. dj., 1996., str. 12-13.

${ }^{448}$ Usp. Vlasta Brajković, nav. dj., 1976., str. 36. Bojničić je zabilježio izgled grba obitelji Humski samo sa simbolom lava, bez dodatka oružja. Usp. Ivan von Bojničić, nav. dj., 1889., str. 64, tab. 46.

${ }^{449}$ Usp. Vjekoslav Noršić, Mače, u: Tkalčić: godišnjak Društva za povjesnicu Zagrebačke nadbiskupije = annales Societatis historicae archiepiscopatus Zagrabiensis VIII, Zagreb: Društvo za povjesnicu Zagrebačke nadbiskupije »Tkalčić«, 2004., str. 259-278, 260-261.

${ }^{450}$ Kamen, $89 \times 51 \times 3 \mathrm{~cm}$, Nedelišće, crkva Presvetoga Trojstva. Kat. br. 61 .

${ }^{451}$ Prema kanonskim vizitacijama, u crkvi su se nalazile dvije kripte, jedna u svetištu i jedna u lađi. Kripta u lađi prvi se put spominje u vizitaciji iz 1698. godine, a ona u svetištu 1779. godine. Usp. NAZ, KV, Prot. 71/II (1698.), str. 1-12; Prot. 81/XII (1779.), str. 1-16.
} 


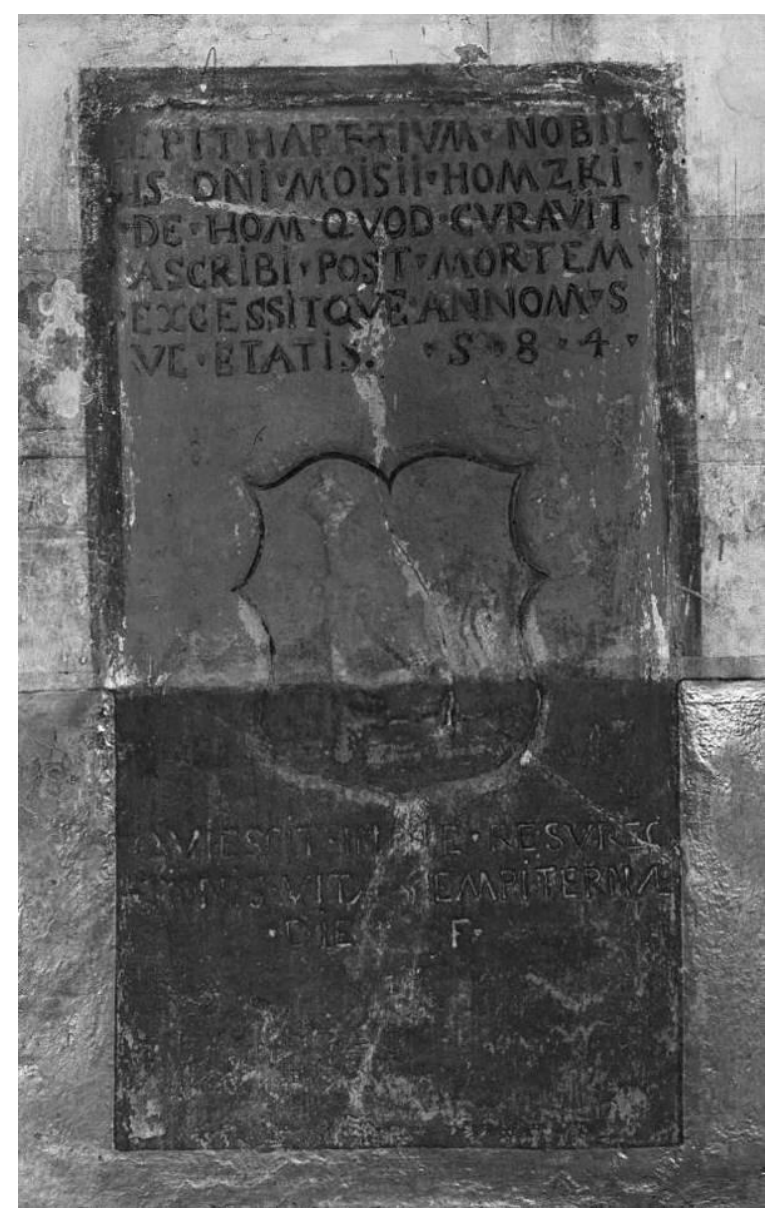

Slika 116. Mače (Zlatar), Crkva Bezgrešnoga začeća Blažene Djevice Marije, Grobna ploča Mojsija Humskoga, 1940., foto: Đuro Griesbach, HAZU, Strossmayerova galerija starih majstora, Schneiderov fotografijski arhiv

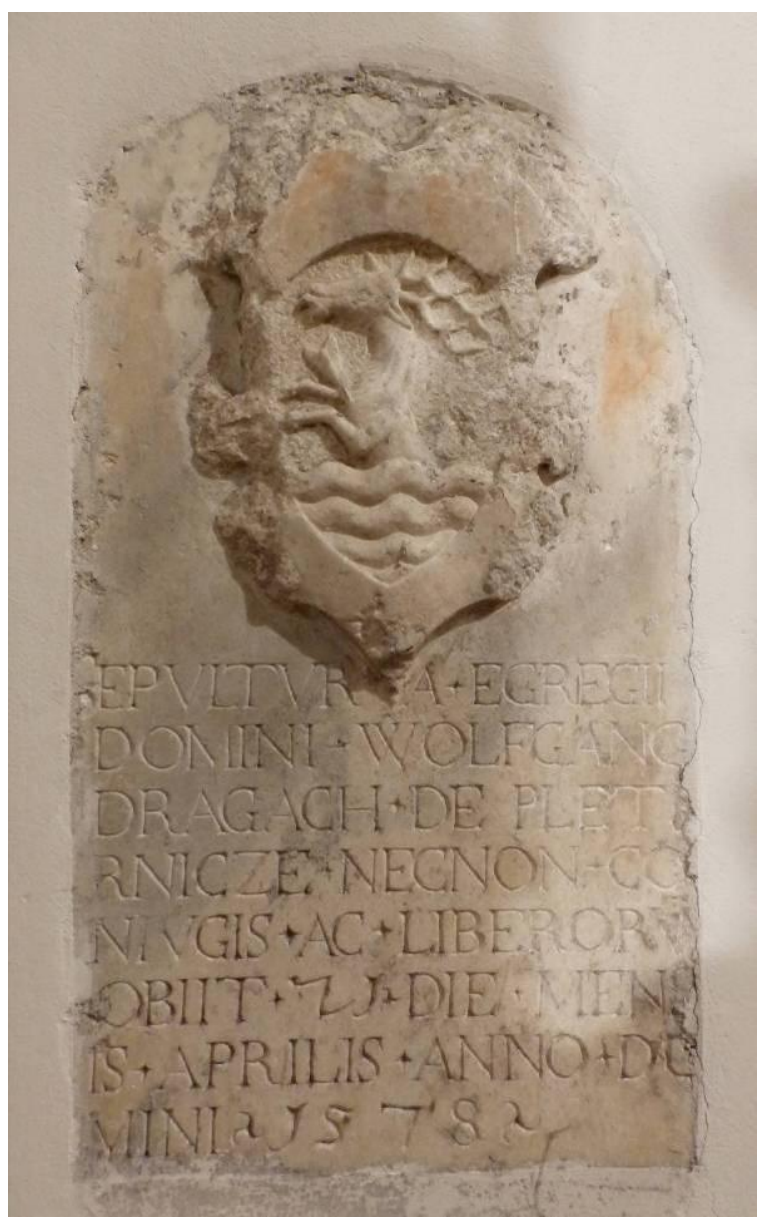

Slika 117. Nadgrobna ploča Vuka Dragača (†1578.), Nedelišće, crkva Presvetoga Trojstva

da je Dragač pokopan uz svoju suprugu i djecu (»SEPULTURA [...] NECNON CONJUGIS AC LIBERORUM«). Prema Juliju Kempfu (1910.), plemić je preselio s obitelji iz rodne Pleternice kod Požege u Međimurje zbog napredovanja osmanskih snaga. ${ }^{452}$

$\mathrm{Na}$ području povijesne Zagrebačke biskupije djelomično su sačuvane još dvije nadgrobne ploče iz XVI. stoljeća za koje znamo da su sadržavale motiv obiteljskoga grba na osnovi pisanih izvora. Prva od njih je nadgrobna ploča Leonarda Grubera (? - ?, 1536.) (Slika 118), ${ }^{453}$ vlasnika samoborskoga grada i naselja Rude, koji je pokopan u kapeli sv. Mihovila na Taborcu u Samoboru. Danas je ugrađena u kamenu ogradu dvorišta, no izvorno je bila položena ispred glavnoga oltara. ${ }^{454}$ Najvjerojatnije je izvađena prilikom barokizacije

\footnotetext{
${ }^{452}$ Usp. Julije Kempf, Požega: zemljopisne bilješke iz okoline i prilozi za povijest Slob. kr. grada Požege i Požeške županije, Požega: Štamparija »Hrvatske tiskare i knjižare«, 1910., str. 129.

${ }^{453}$ Kamen, $40 \times 70$ cm, Samobor, kapela sv. Mihovila na Taborcu. Kat. br. 22.

${ }^{454}$ Usp. Ivan Kukuljević Sakcinski, nav. dj., 1891., str. 225, br. 746. Prema Vjekoslavu Noršiću (2005.), Sakcinski je pogrešno prepisao godinu Gruberove smrti. Umjesto 1536. godine, zapisao je 1436. godinu. Usp. Vjekoslav Noršić, nav. dj., 2005., str. 301.
} 
kapele krajem XVII. stoljeća ili mijenjanjem njezinoga popločenja 1771. godine. ${ }^{455}$ Prema Vjekoslavu Noršiću (rukopis iz 1929.), nadgrobnik je sadržavao natpis koji je tekao uz rubove ploče i grb, koji je već u Noršićevo vrijeme bio teško raspoznatljiv. ${ }^{456}$ Danas je na njemu vidljivo tek nekoliko riječi natpisa (»CLAVSIT ANNO«) i obrisi likovnoga motiva za koji možemo pretpostaviti da predstavlja dio obiteljskoga grba.

Druga nadgrobna ploča nekoć je bila postavljena iznad groba kneza Stjepana IV. (III.) Frankapana Ozaljskoga (? - ?, 1577.) (Slika 119) ${ }^{457}$ koji je prema oporučnoj želji pokopan pred glavnim oltarom kapele Blažene Djevice Marije na Smolčevu vrhu ponad Ozlja, danas poznatom kao Svetice. ${ }^{458}$ Dolaskom pavlina i osnivanjem samostana (1627.), kapela je proširena i preuređena u samostansku crkvu. Nije poznato je li ploča izvađena

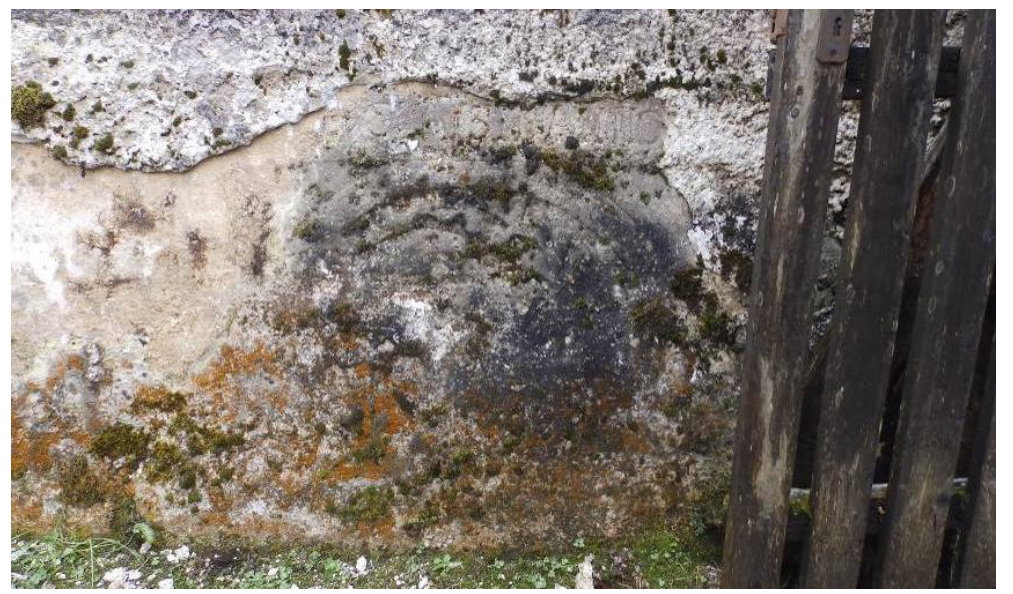

Slika 118. Nadgrobna poča Leonarda Grubera $(\dagger 1536$.$) ,$ Samobor, kapela sv. Mihovila na Taborcu

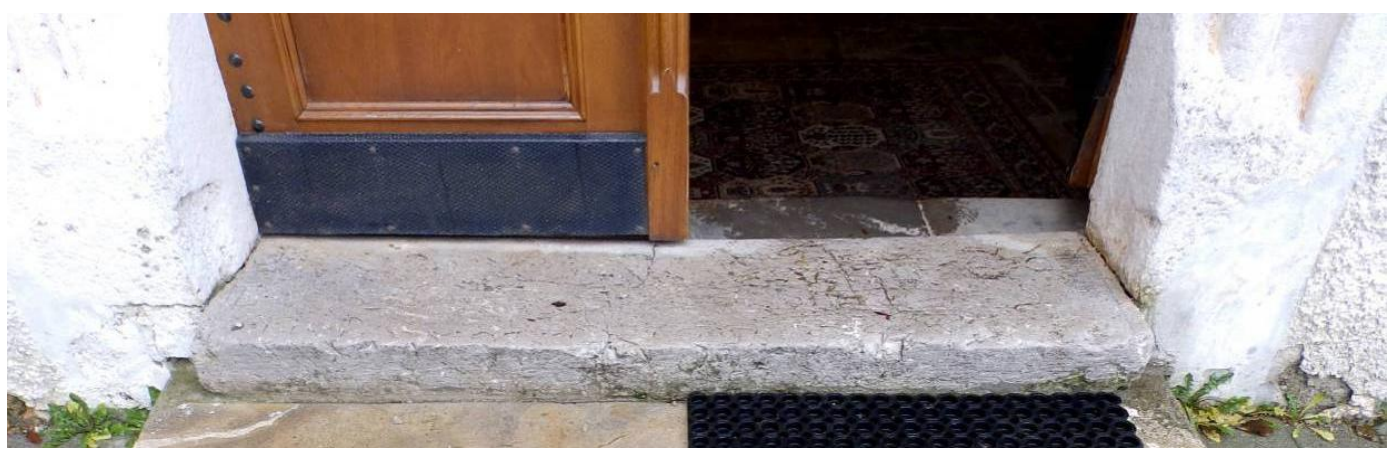

Slika 119. Ulomak nadgrobne ploče Stjepana IV. (III.) Frankapana Ozaljskoga (†1577.), Svetice, crkva rođenja Blažene Djevice Marije

\footnotetext{
${ }^{455}$ U Kukuljevićevo vrijeme, ploča je već bila izvađena i nalazila se u trijemu kapele. Usp. Ivan Kukuljević Sakcinski, nav. dj., 1891., str. 225, br. 746. O pregradnjama kapele vidi: Đurđica Cvitanović, Crkve grada Samobora, u: Kaj: časopis za književnost, umjetnost i kulturu XXX/1, Zagreb: Kajkavsko spravišče, 1997., str. 27-53, 42-45; Vjekoslav Noršić, nav. dj., 2005., str. 284-305.

${ }^{456}$ Usp. Vjekoslav Noršić, nav. dj., 2005., str. 300-301. Prema bilješci pripređivača knjige Stjepana Razuma, Noršićev rukopis o samoborskoj župi nastao je tijekom Prvoga svjetskog rata, a dopunjen je i dovršen 1929. godine. ${ }^{457}$ Kamen, $50 \times 205$ cm, Svetice, crkva Rođenja Blažene Djevice Marije. Kat. br. 27.

${ }^{458}$ Usp. Ivan Kukuljević Sakcinski, Acta Croatica = Listine Hrvatske, Zagreb: Brzotiskom Narodne tiskarnice dra. Ljudevita Gaja, 1863., str. 266; Radoslav Lopašić, Oko Kupe i Korane. Mjestopisne i povjestne crtice, Zagreb: Matica hrvatska, 1895., str. 296, bilj. 1. Dopunio Emilije Laszowski; Zorislav Horvat, nav. dj., 2005., str. $50-51$.
} 
prilikom proširenja crkve ili kasnije sveobuhvatne obnove samostanskoga sklopa zbog oštećenja koja je pretrpio u potresu 1699. godine, ${ }^{459}$ no njezin ulomak postavljen je pred glavni ulaz crkve kao stuba. Redovnici i vjernici koji su stoljećima posjećivali crkvu i prelazili preko njezina praga gotovo su u potpunosti istrošili nadgrobnik. Danas su tek na pojedinim mjestima vidljivi dijelovi natpisa koji je nekoć tekao uz rubove ploče, a jedina riječ koja se može razabrati jest prilog »HIC« koji predstavlja početak formulaičnoga izraza »Hic iacet...« (Ovdje leži...) karakterističnoga za nadgrobne spomenike. Zahvaljujući zapisu Radoslava Lopašića (1895.), znamo da je nadgrobnik krasio grb obitelji Frankapan koji je već u njegovo vrijeme bio slabo vidljiv. ${ }^{460}$

Među očuvanim šesnaestostoljetnim nadgrobnicima s osnovnim motivom grba ne smijemo zaboraviti još jednom navesti epitaf Šimuna III. Keglevića (†1579.) (Slike 82 i 83) iz župne crkve Uznesenja Blažene Djevice Marije u Pregradi. (Nadgrobnik je detaljnije obrađen $\mathrm{u}$ prethodnom potpoglavlju o epitafima s prikazom Raspetoga i adoranata.) Usporedba Keglevićeva epitafa sa suvremenim nadgrobnim spomenicima još jednom potvrđuje kako je - i izvedbom i odabirom motiva - riječ o kvalitetnom renesansnom djelu.

Pisani izvori svjedoče o tome da je na području povijesne Zagrebačke biskupije postojalo još nadgrobnih spomenika s obiteljskim grbom iz XVI. stoljeća koji se do danas nisu očuvali. Jedan od njih je nadgrobnik krbavskoga kneza i hrvatsko-dalmatinskoslavonskoga bana Ivana Karlovića (Udbina, 1485. - Medvedgrad, 1531.; banovao 1521. 1524.) koji je pokopan u svetištu nekadašnje pavlinske crkve u Remetama. Prema zapisu teologa i filozofa Ivana Franje Zdelara (1737.), spomenik je podigla pokojnikova supruga Jelena rođ. Zrinski sa svojom obitelji, a sadržavao je natpis i obiteljski grb povrh kojega je bio ispisan citat iz Knjige o Jobu: »Scio quod Redemptor meus vivit« (Znam da moj Otkupitelj živi. Job 19,25). ${ }^{461}$ Kao što je navedeno u uvodnome dijelu poglavlja, remetsku crkvu krasile su i druge nadgrobne ploče koje su 1768. godine izvađene, preokrenute i iskorištene za novo popločenje crkve. ${ }^{462}$ Nakon razornoga potresa 1880 . godine, ploče su u potpunosti

\footnotetext{
${ }^{459}$ O pregradnjama svetičke crkve vidi: Đurđica Cvitanović, nav. dj., 1982., str. 264-265.

${ }^{460}$ Usp. Radoslav Lopašić, nav. dj., str. 296, bilj. 1. Natpis je već u Lopašićevo vrijeme bio toliko istrošen da je zabilježio da »napisa na njemu [nadgrobniku] nema«.

${ }^{461}$ Ivan Franjo Zdelar, Series banorum Dalmatiae, Croatiae et Slavoniae sub regibus Croatiae, Ungariae et Hungariae-Austriacis, Tyrnaviae: typis Academicis, per. Leopoldum Berger, 1737., str. 108. Citirano i u: Ivan Krstitelj Krapac, nav. dj., 1870., str 26; Ivan Kukuljević Sakcinski, nav. dj., 1891., str. 198, br. 659; Janko Bárle, Remete: povjesni podaci o samostanu, crkvi i župi, Zagreb: Marko Mileusnić, 1914., str. 25. Prema Zdelarovu opisu (1737.), Karlovićev grb sastojao se od štita i čuvara u obliku krokodila. Na štitu su se nalazile tri vodoravne grede povrh kojih je bio predočen labud s tri krune. Jedna kruna bila je postavljena labudu na glavi, druga oko vrata, a treća oko nogu. Za usporedbu s drugim poznatim grbovima obitelji Karlović vidi: Ivan von Bojničić, nav. dj., 1889., str. 30-31, tab. 23.

${ }^{462}$ Usp. Ivan Krstitelj Krapac, nav. dj., 1870., str. 28.
} 
odstranjene. U povijesnom prikazu remetskoga samostanskog sklopa, Janko Bárle (1914.) zabilježio je imena znamenitih osoba koje su sahranjene u nekadašnjoj pavlinskoj crkvi, navodeći da su »svi ti imali [...] nadgrobne ploče s natpisima i grbovima. ${ }^{463} \mathrm{Na}$ žalost, izuzev nadgrobnika Ivana Karlovića, autor nije podrobnije naveo koje su ploče imale samo nadgrobni natpis, a koje su uključivale i obiteljski grb.

Još jedan od izgubljenih šesnaestostoljetnih spomenika za koji znamo da je sadržavao grbovni motiv bio je nadgrobnik Ane Désházy rođ. Bánffy de Alsólendva (Banić od Donje Lendave) (? - Susedgrad, 1533.). Izvorno je bio postavljen iznad obiteljske grobnice u crkvi Presvetoga Trojstva u Donjoj Stubici, u kojoj je pokopan i Franjo Tahy (Slika 40). Nije poznato što se dogodilo s nadgrobnikom, no najvjerojatnije je izvađen i bačen tijekom jedne od pregradnji crkve u XVII. ili XVIII. stoljeću. ${ }^{464}$ Prema Ivanu Kukuljeviću Sakcinskom (1891.), spomenik je sadržavao grb obitelji Bánffy i poduži natpis u kojem su navedeni istaknuti pojedinci iz pokojničine obitelji i one njezina supruga Stjepana Désházyja. ${ }^{465}$ Među krvnim srodstvom Désházyjevih s uglednim velikaškim obiteljima, poput obitelji Hennyngh i Szilagy de Horoghszegh, posebno je istaknuta njihova rodbinska veza s kraljem Matijom Korvinom. Budući da Ana nije imala djece ili živućih roditelja, ${ }^{466}$ nadgrobnik je najvjerojatnije dao postaviti njezin suprug koji je »rodoslovnim« natpisom htio pridonijeti ugledu i statusu obitelji. Prije nego što je ženidbenom vezom postao vlasnikom susedgradskostubičkoga vlastelinstva, Désházy je 1510-ih boravio u Ostrogonu kao upravitelj dvorca kardinala Tome Bakača (?, 1435. - Ostrogon, 1521.). Ondje se upoznao s djelovanjem radionice Johannesa Fiorentinusa, majstora kojem je Milan Pelc (2006.) pripisao autorstvo nadgrobne ploče biskupa Luke de Szegeda (Szeged, ? - Čazma, 1510.) (Slika 25). ${ }^{467}$ Budući da se radionica specijalizirala za nadgrobne ploče s grbovima, postoji mogućnost da je Désházy povjerio izradu suprugina nadgrobnika majstoru Fiorentinusu, kojega je već prethodno angažirao za radove na crkvi u svome rodnome naselju Mineu (mađ. Menyő,

\footnotetext{
${ }^{463}$ Janko Bárle, nav. dj., 1914., str. 84. Prema Bárleu, u remetskoj crkvu pokopane su sljedeće osobe: Pavao Starički (†1377.), Lovro Stoch (†1400.), Fabijan Bickle (†1400.), Pavao Zrinski (†1414.), Poljak neznana imena $(† 1420$.), Kristofor de Florentia (†1424.), Mihael de Goricza (†1424.), Ladislav pl. Lukačević (†1432.) i njegova supruga, Sebastijan Hennyngh (†1460.), Ivan pl. Berivanja (†1460.), Ivan Karlović (†1531.), Gašpar Alapić (†1584.), Franjo Nitray ( $† 1689$.$) i Adam Benedikt Ratkaj ( † 1717$.$) .$

${ }^{464}$ Detaljnije o fazama pregradnje donjostubičke crkve vidi: Katarina Horvat Levaj, Župna crkva Presvetog Trojstva u Donjoj Stubici, u: Peristil 38, Zagreb: Društvo povjesničara umjetnosti Hrvatske, 1995., str. 73-82.

${ }^{465}$ Usp. Ivan Kukuljević Sakcinski, nav. dj., 1981., str. 262, br. 877. U natpisu su navedeni pokojničini roditelji Ivan Bánffy de Alsólendva i Margareta rođ. Hennyngh te djed Ivan Hennyngh Susedgradski. Sa Stjepanove strane imenovani su njegov djed Lászlo (Ladislav) Szilagy de Horoghszegh i teta Erzsébet (Elizabeta) Szilágyi ud. Hunyadi koja je bila majka Matije Korvina. Za potpuni prijepis natpisa vidi kat. br. 2.

${ }^{466}$ Za pojedinosti o životu Ane i Stjepana Désházyja vidi: Trpimir Macan (ur.), nav. dj., 2002., sub voce Hennyngh [Tatjana Radauš].

${ }^{467}$ Usp. Milan Pelc, nav. dj., 2006., str. 70.
} 
današnja Rumunjska). ${ }^{468}$ Naravno, bez potkrijepe u arhivskim izvorima, ovu misao treba razmatrati samo kao otvorenu mogućnost, nikako kao tvrdnju ili tezu.

$$
* * *
$$

Najveći broj nadgrobnih spomenika s obiteljskim grbom sačuvan je iz XVII. stoljeća. Riječ je o dvadesetak nadgrobnika koji sadrže bogato izvedene grbove ukrašene plaštevima, kacigama, krunama i nakitom, a ponekad i čuvarima i geslima. Na njima, natpisi su najčešće izdvojeni u zasebnu cjelinu te su uklesani iznad ili ispod grba unutar ukrasnih okvira odnosno kartuša. U XVII. stoljeću pojavilo se i novo likovno rješenje, a to su grbovni epitafi izvedeni u obliku edikule. Sačuvani nadgrobnici najvećim su dijelom isklesani od kamena, no postoje pojedinačni primjerci koji su lijevani u bronci odnosno izrezbareni u drvu.

Posebno zanimljivu skupinu spomenika iz prve četvrtine XVII. stoljeća čine tri nadgrobne ploče koje su uzidane u potporni zid platoa župne crkve sv. Nikole u Krapini (Slika 120). Izvorno su se nalazile u staroj, barokiziranoj crkvi koja je porušena na prijelazu XIX. u XX. stoljeće, a na čijem je mjestu sagrađena nova neogotička građevina (1901. 1903.). ${ }^{469}$ Na prvoj od ugrađenih ploča (Slika 121) ${ }^{470}$ obiteljski grb i natpis smješteni su u dva zasebna polja nalik kasetama koja su postavljena jedno povrh drugoga. U gornjem polju nalazi se grb sa simbolom obitelji pokojnika - krunom i razlistanom granom na kojoj stoji ptica (Slika 122). ${ }^{471}$ Još uvijek nije utvrđeno kojoj obitelji pripada, a njegov izgled nije zabilježen u grbovnicima hrvatsko-slavonskoga (Ivan von Bojničić, 1899.) ili dalmatinskoga plemstva (Carl G. F. Heyer von Rosenfeld 1873.). U donjem polju nekoć je bio uklesan nadgrobni natpis koji je danas u potpunosti istrošen. Prema Gjuri Szabi (1914.), natpis je bio teško čitljiv već početkom XX. stoljeća. ${ }^{472}$

Druga uzidana ploča podignuta je u spomen na plemkinju Elizabetu Sudić (? - ?, 1620.?) (Slika 123), ${ }^{473}$ a izvorno se nalazila u predvorju stare crkve pred glavnim ulazom. ${ }^{474}$ Prema natpisu, postavio ju je 1620. godine Elizabetin suprug Ivan Logmagi koji je rodom bio iz Dubrovnika (»DE RAGUSEO«). Natpis se nalazi u donjoj polovici spomenika, a uklesan je unutar okvira konkavno oblikovanih stranica koje su u sredini ukrašene parom voluta. Pri dnu

\footnotetext{
${ }^{468}$ Johannes Fiorentinus je izradio za kasnogotičku crkvu portal i krstionicu. Usp. Milan Pelc, nav. dj., 2006., str. $70-71$.

${ }^{469}$ Usp. Gjuro Szabo, nav. dj., 1914., str. 154-155.

${ }^{470}$ Kamen, $173 \times 85 \mathrm{~cm}$, Krapina, crkva sv. Nikole. Kat. br. 8 .

${ }^{471}$ Grb se sastoji od štita, plašta, kacige, krune i nakita. Motiv ptice i razlistane grane koji je prikazan na štitu ponovljen je u nakitu kacige. Usp. Dubravka Peić Čaldarović, Osnove krapinskog grbovnika, u: Krapina: grad povijesti $i$ kulture, Krapina: Grad Krapina, 2004., str. 130-138, 136. Uredila Agneza Szabo.

${ }^{472}$ Usp. Gjuro Szabo, nav. dj., 1914., str. 155.

${ }^{473}$ Kamen, $174 \times 77 \mathrm{~cm}$, Krapina, crkva sv. Nikole. Kat. br. 9.

${ }^{474}$ Usp. Gjuro Szabo, nav. dj., 1914., str. 154.
} 


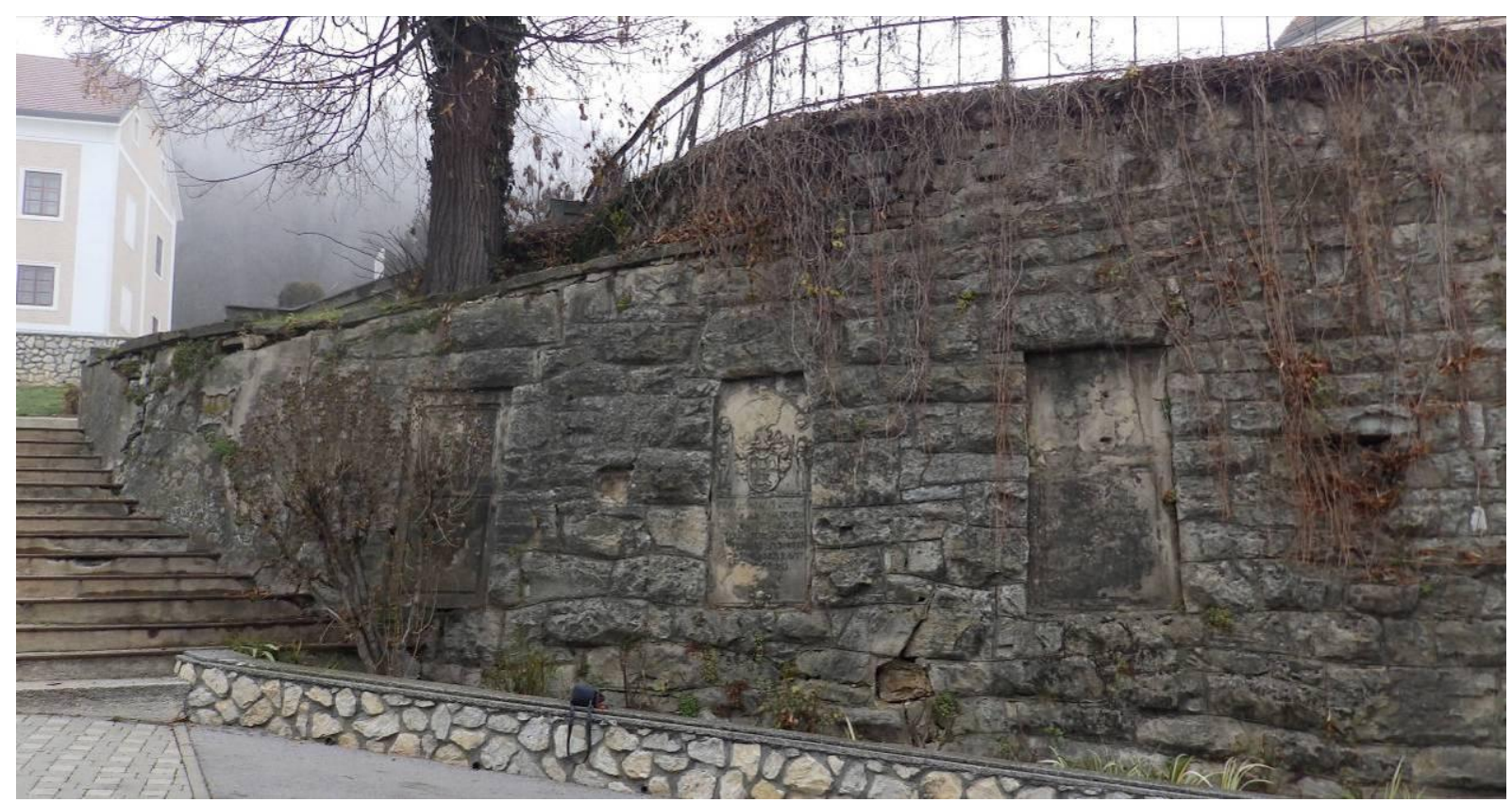

Slika 120. Nadgrobne ploče ugrađene u potporni zid platoa župne crkve sv. Nikole, Krapina
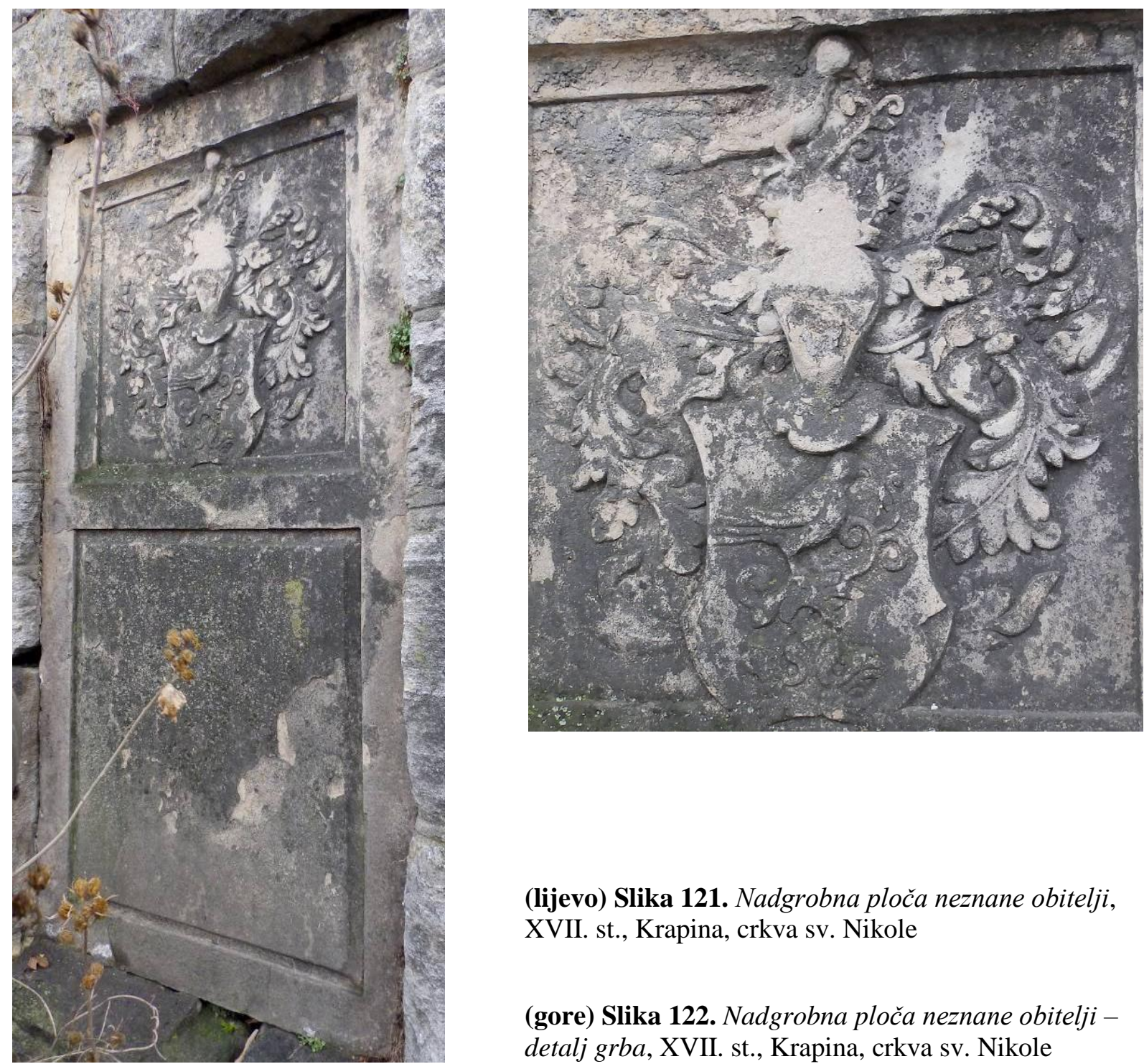

(lijevo) Slika 121. Nadgrobna ploča neznane obitelji, XVII. st., Krapina, crkva sv. Nikole

(gore) Slika 122. Nadgrobna ploča neznane obiteljidetalj grba, XVII. st., Krapina, crkva sv. Nikole 


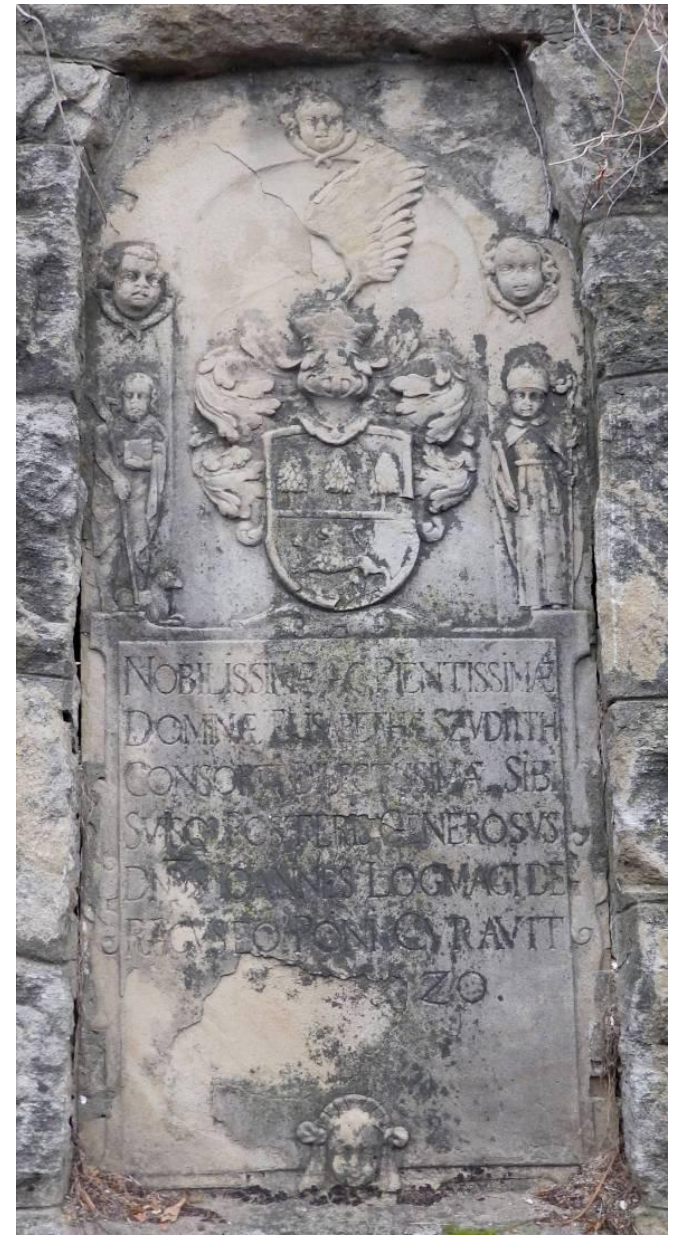

Slika 123. Radionica Majstora

Trantnerova epitafa (?), Nadgrobna ploča Elizabete Sudić, 1620., Krapina, crkva sv. Nikole

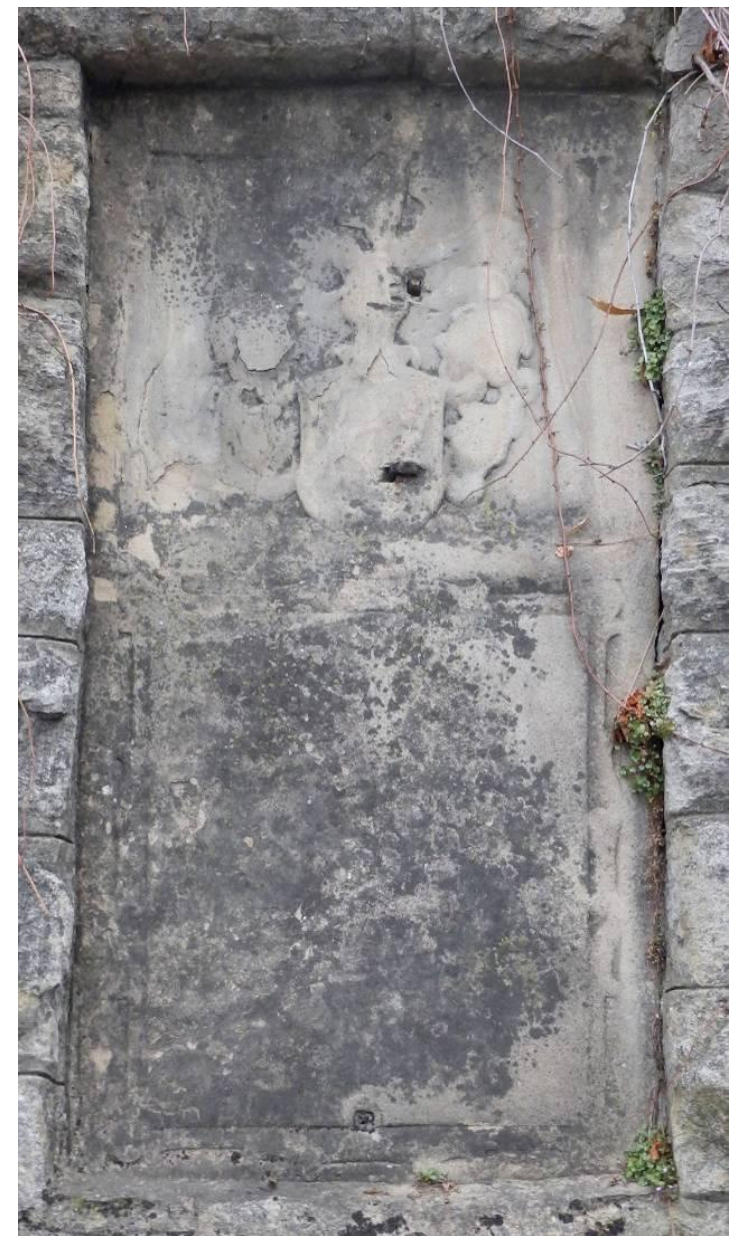

Slika 124. Radionica Majstora Trantnerova epitafa (?), Nadgrobna ploča obitelji Keglević, 1620-e, Krapina, crkva sv. Nikole

okvira prikazan je motiv ženske maske s draperijom i ukrasom za glavu, koji je čest $u$ suvremenoj altaristici. ${ }^{475}$ Sličan motiv primijenjen je, primjerice, na nekadašnjem glavnom oltaru zagrebačke katedrale (1632.) koji je izradio njemački kipar i drvorezbar Hans Ludwig Ackermann. U gornjoj polovici nadgrobnika nalazi se plitka polukružno zaključena niša unutar koje je prikazan grb. ${ }^{476}$ Luk niše ukrašen je trima kerubinima, dvama u petama i jednim u tjemenu luka. Otvor niše flankiran je likovima dvaju svetaca pojednostavljene fizionomije, čija obla lica istaknutih vjeđa nalikuju onima anđela. Na lijevoj strani predočen je naručiteljev svetac zaštitnik, sv. Ivan Krstitelj. U desnoj ruci drži križ ovijen svitkom, u lijevoj knjigu, a do nogu mu počiva janje. Na desnoj strani prikazan je sv. Blaž (Vlaho) odjeven u biskupsko ruho. U lijevoj ruci drži pastoral, a u desnoj upaljenu svijeću koja

\footnotetext{
${ }^{475}$ Usp. Martina Wolff Zubović, nav. dj., Svezak II., 2017., str. 497.

${ }^{476}$ Grb se sastoji od štita, plašta, kacige, krune i nakita u obliku krila. Štit je vodoravno podijeljen na dva polja. U gornjem polju prikazana su tri stabla, a u donjem lav u trku.
} 
simbolizira njegovu posljednju želju upućenu Bogu da pomaže bolesnima. ${ }^{477}$ Sv. Blaž jedan je od četrnaest svetih pomoćnika (lat. quattuordecim auxiliatores) koji se zazivaju protiv bolesti, ${ }^{478}$ no njegova prisutnost na nadgrobniku vjerojatnije je povezana s činjenicom da je zaštitnik Dubrovnika, rodnoga grada naručitelja. Prikazi svetaca kao zagovornika pred nebeskim sudom nisu neuobičajeni na nadgrobnim spomenicima, no uglavnom se javljaju na nadgrobnicima s likom pokojnika (Slika 125). ${ }^{479}$ Nadgrobna ploča Elizabete Sudić jedinstven je primjer nadgrobnika očuvanoga na području Zagrebačke (nad)biskupije koji sadrži prikaz svetaca-zaštitnika, s time da je na njoj kao glavni likovni motiv zastupljen obiteljski grb, a ne lik pokojnika koji je učestaliji na takvoj vrsti prikaza.

Posljednja nadgrobna ploča koja je ugrađena u potporni zid podno krapinske župne crkve (Slika 124) ${ }^{480}$ kompozicijski je slična nadgrobniku Elizabete Sudić. U gornjoj polovici prikazan je obiteljski grb, a u donjoj ukrasni okvir s natpisom. Na grbu se razaznaju njegove osnovne sastavnice - štit, plašt, kaciga i dio nakita - no ne i simbol na štitu, a natpis je u potpunosti istrošen. Prema Gjuri Szabi (1914.), štit je sadržavao simbol obitelji Keglević, lik lava, koja je imala grobnicu u svetištu stare župne crkve. ${ }^{481} \mathrm{Na}$ natpisnoj ploči Szabo je mogao razabrati samo godinu »IDCXX« (slovo »I« najvjerojatnije predstavlja posljednji dio slova »M«) koja označuje godinu smrti pokojnika odnosno postavljanja ploče. ${ }^{482}$ Iako je nadgrobnik prilično istrošen, možemo uočiti da su sastavni dijelovi grba - posebice štit i plašt izveden u obliku lišća akanta - te ukrasni okvir natpisa oblikovani na sličan način kao oni na nadgrobnoj ploči Elizabete Sudić. Oblikovna srodnost kao i prostorno-vremenska bliskost navode na mogućnost da su oba nadgrobnika rad istoga majstora odnosno radionice.

Autorstvo nadgrobnih ploča Elizabete Sudić i obitelji Keglević može se povezati s djelovanjem slovenske radionice Majstora Trantnerova epitafa koja je bila aktivna na području slovenske Štajerske od okvirno 1610. do 1650. godine. Emilijan Cevc (1981.) navedenoj je radionici pripisao izradu nadgrobne ploče Benka Thuróczyja Ludbreškoga (†1616.) (Slika 50) iz crkve sv. Marka evanđelista u Vinici, a u ovome radu pripisan joj je i epitaf Franje Keczera od Rad(o)vana (1629.) (Slika 93) iz iste crkve. Neki od prepoznatljivih motiva koje je radionica primjenjivala su »zavojit okvir« - kako ga je Cevc (1981.) opisao ukrašen parovima voluta unutar kojega je uklesan nadgrobni natpis, grbovni plaštevi izvedeni u obliku povijenih listova akanta te glavice anđela podbuhlih lica, istaknutih vjeđa i kovrčave

\footnotetext{
${ }^{477}$ Usp. Anđelko Badurina (ur.), nav. dj., 1990. [1979.], sub voce Blaž, str. 160 [Marijan Grgić].

${ }^{478}$ Usp. Ante Škrobonja, Sveti od zdravlja: Ilustrirani leksikon svetaca zaštitnika, Zagreb: Kršćanska sadašnjost, 2004., sub voce Blaž, str. 52.

${ }^{479}$ Usp. Philippe Ariès, nav. $d j .$, 1981., str. 257.

${ }^{480}$ Kamen, $186 \times 97$ cm, Krapina, crkva sv. Nikole. Kat. br. 10

${ }^{481}$ Usp. Gjuro Szabo, nav. dj., 1914., str. 155.

${ }^{482}$ Isto.
} 


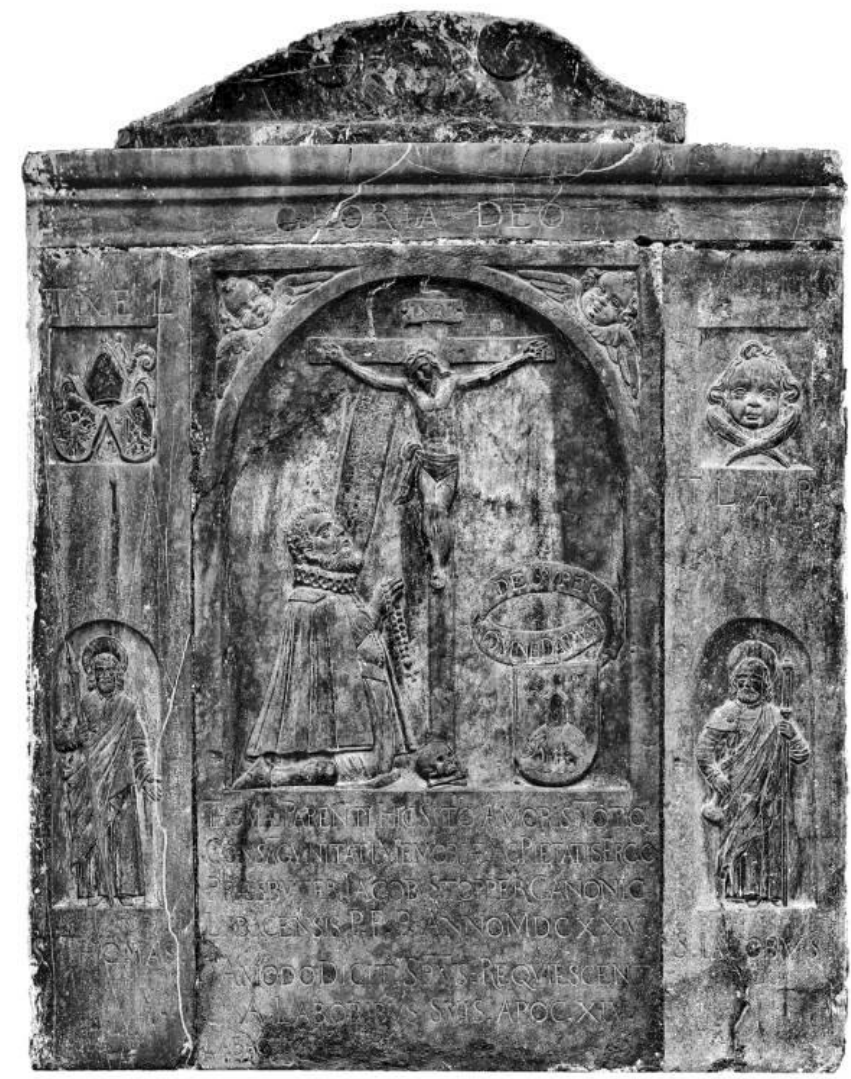

(lijevo) Slika 125. Radionica Majstora Trantnerova epitafa, Epitaf obitelji Stopper, 1626., Mozirje, crkva sv. Jurja

(dolje lijevo) Slika 126. Radionica Majstora Trantnerova epitafa, Epitaf obitelji Stopper-detalj kerubina i sv. Jakova, 1626., Mozirje, crkva sv. Jurja

(dolje desno) Slika 127. Radionica Majstora Trantnerova epitafa (?), Nadgrobna ploča Elizabete Sudić - detalj kerubina i sv. Blaža, 1620., Krapina, crkva sv. Nikole
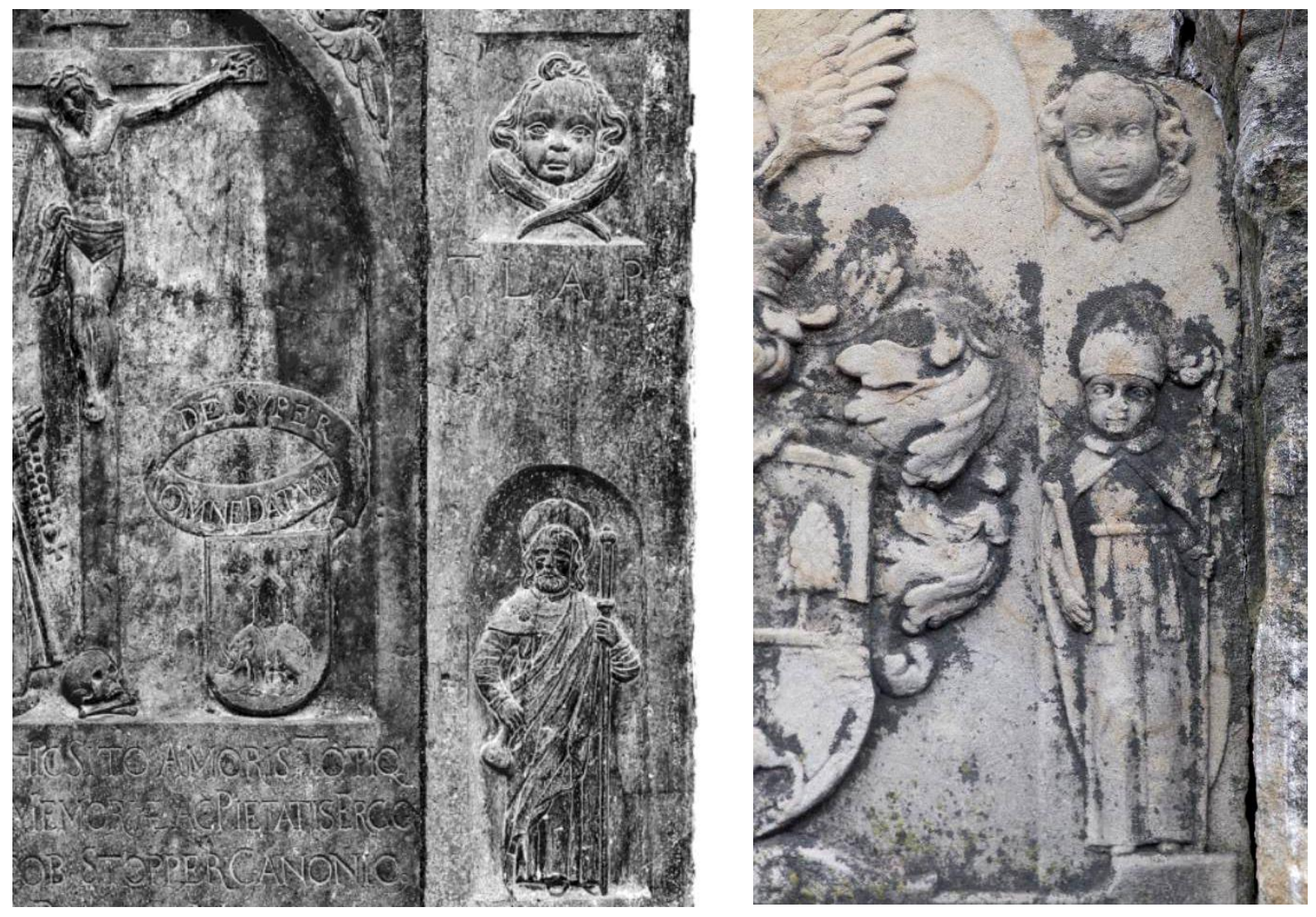
kose (Slike 53, 54, 97, 98 i 99). ${ }^{483}$ Opisani motivi upotrijebljeni su i na nadgrobnim pločama Elizabete Sudić i obitelji Keglević iz Krapine, što upućuje na mogućnost da ih je izradila ista radionica. Stilski i ikonografski vrlo sličan nadgrobnoj ploči Elizabete Sudić jest epitaf koji je radionica izradila za ljubljanskoga kanonika Jakoba Stoppera (Slika 125). ${ }^{484}$ U središnjoj niši epitafa prikazan je pokojnik kako kleči pred Raspetim, a na bočnim istacima isklesane su dvije manje niše s likovima svetaca-zaštitnika naručitelja i njegova oca, za koga je spomenik podignut. ${ }^{485} \mathrm{Na}$ likovima svetih osoba i pokojnika uočljivo je isto pojednostavljivanje ljudske fizionomije i linijski tretman draperije kao i na krapinskome nadgrobniku, jednako kao i srodan način oblikovanja kerubina (Slike 126 i 127).

Na području Moslavine i Hrvatskoga zagorja sačuvane su još dvije nadgrobne ploče koje su oblikovno slične onima iz Krapine. Prva od njih je nadgrobna ploča ivanićkoga kapetana Kristofora Spišića (? - ?, 1614.) (Slika 128) ${ }^{486}$ koji je pokopan u crkvi sv. Ivana Krstitelja u Kloštar Ivaniću. Crkvu su podigli franjevci koji su pristigli u grad na poziv biskupa Luke de Szegeda (Szeged, ? - Čazma, 1510.), no u vrijeme Spišićeve smrti ${ }^{487}$ njome je upravljala Zagrebačka biskupija (1544. - 1639.) jer su redovnici napustili grad zbog osmanske opasnosti. ${ }^{488}$ Spišić je pokopan u svetištu koje je u to vrijeme bilo jedini natkrovljeni dio crkve. ${ }^{489}$ Povratkom franjevaca u Kloštar Ivanić započela je dugotrajna obnova sklopa koja je trajala do kraja XVIII. stoljeća. Spišićeva nadgrobna ploča podignuta je s poda u XIX. stoljeću kada je mijenjano popločenje te je ugrađena u južni zid svetišta, gdje se nalazi i danas. ${ }^{490}$ Crkva i inventar pretrpjeli su velika oštećenja tijekom Drugoga svjetskog rata, no nadgrobnik je srećom ostao neoštećen.

\footnotetext{
${ }^{483}$ Emilijan Cevc koristio je za opisani motiv termin »zavojičasti okvir«. Usp. Emilijan Cevc, nav. dj., 1981., str. $181-184$.

${ }^{484}$ O epitafu vidi: Emilijan Cevc, nav. dj., 1981., str. 194.

${ }^{485} \mathrm{Na}$ lijevoj strani predočen je sv. Toma apostol, zaštitnik naručiteljeva oca Tomaža Stopera, a na lijevoj sv. Jakov, zaštitnik samoga naručitelja.

${ }^{486}$ Kamen, dimenzije nepoznate autorici, Kloštar Ivanić, crkva sv. Ivana Krstitelja. Kat. br. 76.

${ }^{487}$ Prilikom popisivanja i fotografiranja spomenika kulturne baštine, Artur Schneider pogrešno je zabilježio godinu Spišićeve smrti. Umjesto 1614., zapisao je 1694. godinu. Usp. Artur Schneider, Popisivanje i fotografijsko snimanje umjetničkih spomenika godine 1939., u: Ljetopis Jugoslavenske akademije znanosti i umjetnosti za godinu 1938/39. Svezak 52, Zagreb: Jugoslavenska akademija znanosti i umjetnosti, 1940., str. 172-186, 177. Iz povijesnih izvora poznato je da je Kristofor Spišić bio kapetan Ivanića od 1600. do 1601/09. godine, što znači da je živio na prijelazu iz XVI. u XVII. stoljeće. Usp. Leopold Toifl, Baj csavar története stájer levéltári források alapján, u: Weitschawar - Bajcsa-vár. Egy stájer eröditmény Magyarországon a 16. század második felében, Zalaegerszeg: Zala Megyei Múzeumok Igazgatósága, 2002., str. 27-40, 37. Uredila Csilla Kőfalvi. Schneiderovu dataciju Spišićeve nadgrobne ploče preuzeli su i neki kasniji istraživači. Usp. Krasanka Majer Jurišić i Edita Šurina, Schneiderov fotografijski album - svjedok izgubljenog izgleda crkve sv. Ivana Krstitelja u Kloštar Ivaniću, u: Zbornik radova znanstveno-stručnog skupa »Hrvatski povjesničari umjetnosti. Artur Schneider (1879.-1946.)《, Zagreb: Društvo povjesničara umjetnosti Hrvatske, 2016., str. 225-242, 233. Uredila Ljerka Dulibić.

${ }^{488}$ Usp. Paškal Cvekan, Franjevci u Ivaniću, Kloštar Ivanić: Franjevački samostan, 2008. [1979.], str. 26.

${ }^{489}$ Iznad svetišta bio je podginut običan krov, a lađa je bila nenatkrivena. Usp. Paškal Cvekan, nav. dj., 2008. [1979.], str. 46.

${ }^{490}$ Usp. Krasanka Majer Jurišić i Edita Šurina, nav. dj., 2016., str. 233.
} 

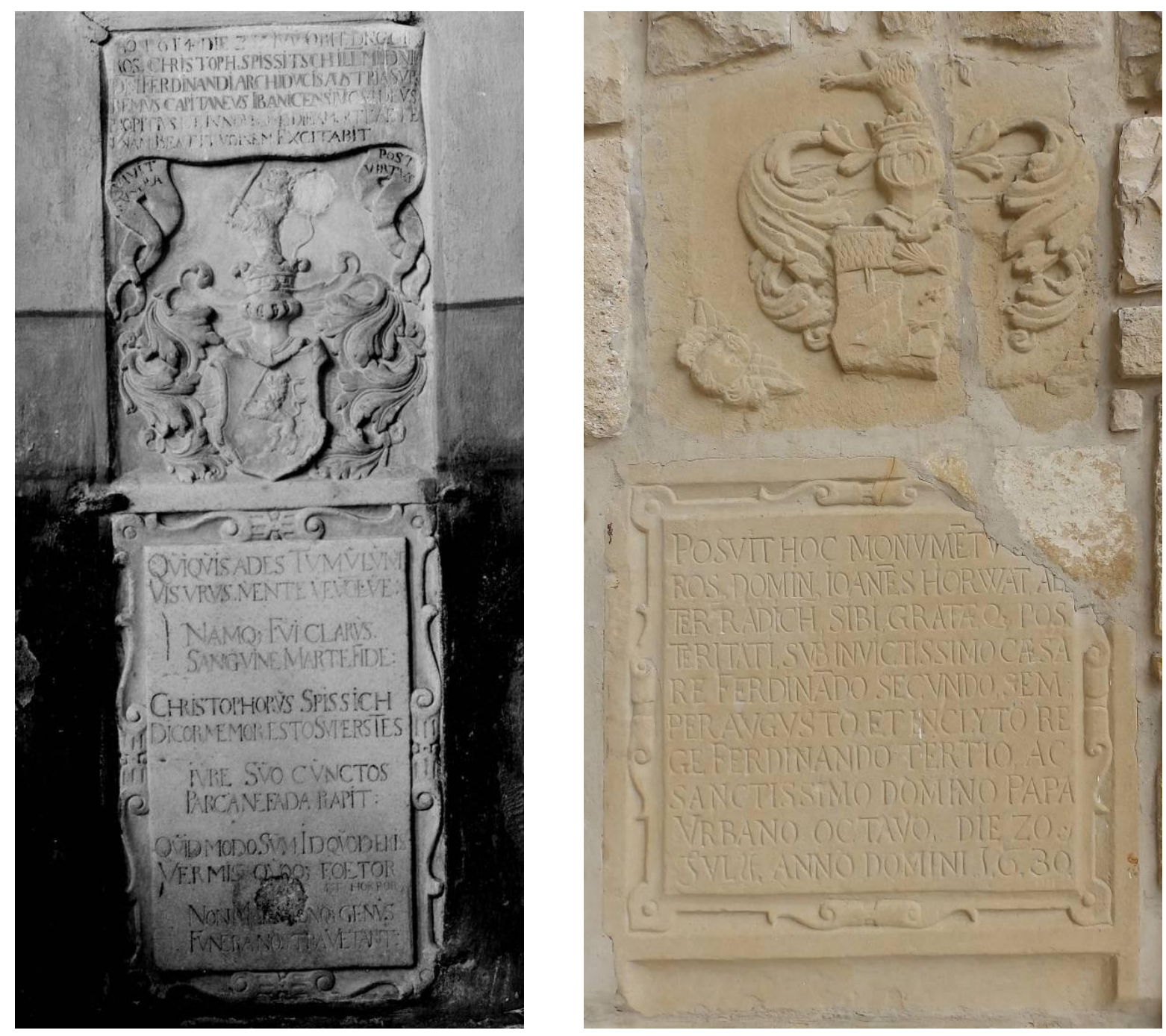

(gore lijevo) Slika 128. Ivanić Kloštar, Crkva sv. Ivana Krstitelja, Grobna ploča ivanićkog kapetana Kristofora Spišića, 1939., foto: Đuro Griesbach, HAZU, Strossmayerova galerija starih majstora, Schneiderov fotografijski arhiv

(gore desno) Slika 129. Radionica Majstora Trantnerova epitafa (?), Nadgrobna ploča Ivana Horvata Radića, 1630., Mihovljan, crkva sv. Mihovila arkanđela

(dolje desno) Slika 130. Mihovljan, Crkva sv. Mihajla, Grobna ploča Ivana Horvata Radića, 1940., foto: Đuro Griesbach, HAZU, Strossmayerova galerija starih majstora, Schneiderov fotografijski arhiv

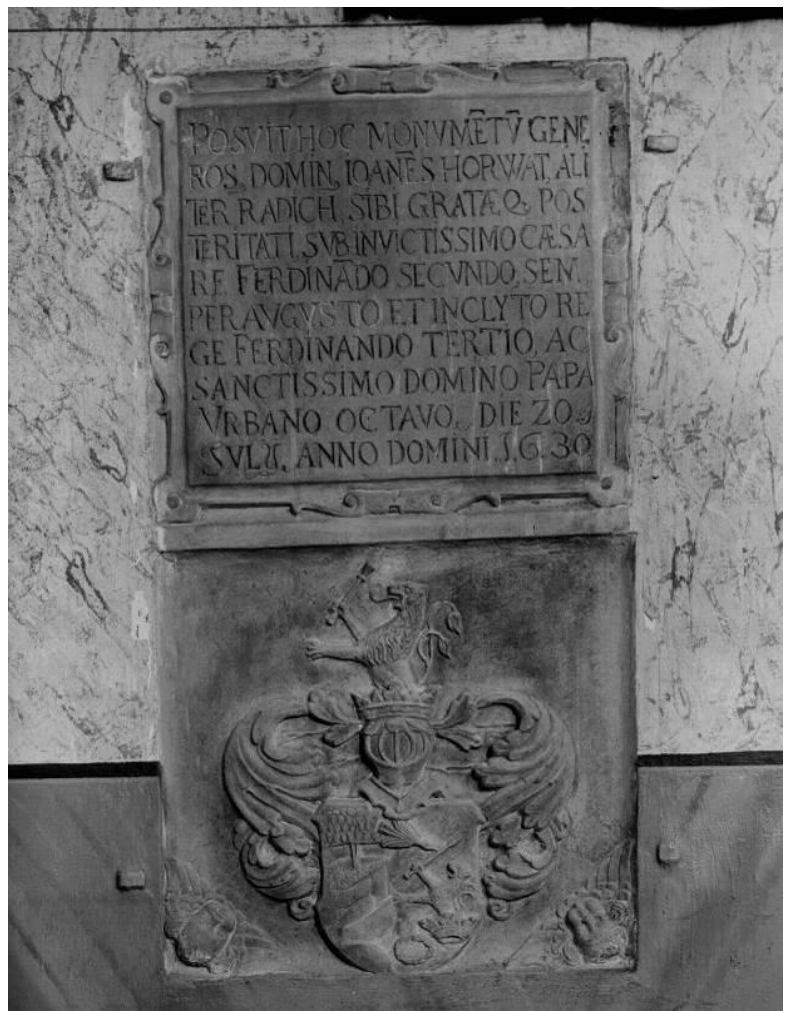


Spišićeva nadgrobna ploča kompozicijski je podijeljena na dva dijela. U gornjoj polovici predočen je grb ${ }^{491}$ povrh kojega se nalazi svitak s rascijepanim krajevima i natpisom za koga je spomenik podignut. Donju polovicu ispunjava ukrasni okvir konkavno oblikovanih stranica urešenih volutama koji sadrži natpis s pojedinostima iz pokojnikova života ispisan u distisima. Kao što je navedeno, način oblikovanja grba (oblik štita, izvedba plašta u obliku akantova lišća, izgled kacige i krune) i ukrasnoga okvira vrlo su slični onima s nadgrobnih ploča Elizabete Sudić (Slika 123) i obitelji Keglević (Slika 124) iz župne crkve u Krapini.

Srodnih oblikovnih značajki je i nadgrobna ploča Ivana Horvata Radića (? - ?, o. 1630.) (Slika 129) ${ }^{492}$ koji je pokopan u crkvi sv. Mihaela arkanđela u Mihovljanu kod Krapine. Ploča je vodoravno podijeljena na dva polja od kojih jedno sadrži grb obitelji Horvat Radić, ${ }^{493}$ a drugo ukrasni okvir s nadgrobnim natpisom. Ploča je izvorno pokrivala obiteljsku grobnicu koja se nalazila u svetištu stare župne crkve, a prema natpisu dao ju je postaviti pokojnik »za sebe i svoje voljeno potomstvo« (SIBI GRATAEQue] POSTERITATI). Mijenjanjem popločenja crkve 1726. godine, nadgrobnik je podignut i ugrađen u zid svetišta s lijeve strane glavnoga oltara. ${ }^{494} \mathrm{U}$ Drugome svjetskom ratu crkva je pretrpjela velika oštećenja i većim je dijelom razrušena. Nadgrobnik je djelomično oštećen, a tijekom izgradnje nove crkve (1972. - 1976.) ugrađen je u južni zid ulaznoga trijema. Usporedba s fotografijom koja je nastala prije oštećenja u Drugome svjetskom ratu (Slika 130) otkriva kako je ploča prilikom ugradnje pogrešno ukomponirana u zid. Naime, polje s grbom izvorno se nalazilo ispod - a ne iznad - natpisne ploče.

Način oblikovanja grba i ukrasnoga okvira na nadgrobniku Ivana Horvata Radića vrlo je sličan onome s nadgrobnih ploča Kristofora Spišića, obitelji Keglević i - posebice Elizabete Sudić, s time da među navedenim spomenicima Spišićev nadgrobnik prednjači kvalitetom izrade. Ako nadgrobne spomenike iz Krapine možemo pripisati djelovanju radionice Majstora Trantnerova epitafa, proširenjem usporedbe nadgrobnike iz Kloštar Ivanića i Mihovljana mogli bismo atribuirati istoj radionici. Već je Emilijan Cevc (1981.)

\footnotetext{
${ }^{491} \mathrm{Na}$ štitu grba predočen je lav s dva repa koji u prednjim šapama drži mač. Štit je ukrašen plaštem, kacigom i krunom koja je urešena ponovljenim motivom lava s mačem. Grb se razlikuje od onih Nikole Spišića (1503.), na kojem se uz lava nalazi i motiv zmaja, i Antuna Spišića (1734.), na kojem je prikazan samo lav bez dodatnih atributa. Usp. Ivan von Bojničić, nav. dj., 1889., str. 173, tab. 126; str. 234, tab. 172.

${ }^{492}$ Kamen pješčenjak, $142 \times 77 \times 2,5 \mathrm{~cm}$, Mihovljan, crkva sv. Mihovila arkanđela. Kat. br. 13.

${ }^{493}$ Grb se sastoji od štita, plašta, kacige, krune i nakita. Na štitu su prikazani bunar (?), vijenac, kruna i lav koji drži žezlo. Motiv lava sa žezlom ponovljen je u nakitu kacige. Predočeni grb razlikuje se od onoga objavljenoga u Bojničićevu grbovniku koji sadrži par lavova sa žezlom u prednjim šapama. Usp. Ivan von Bojničić, nav. dj., 1889., str. 69, tab. 49.

${ }^{494}$ Usp. Usp. Alojz Jembrih, Iz starije povijesti župe Mihovljan, u: Hrvatsko zagorje: časopis za kulturu XVII/14, Donja Stubica: Kajkaviana, 2011., str. 8-36, 9, 11; Gjuro Szabo, nav. dj., 1914., str. 175.
} 
naznačio mogućnost da je nadgrobna ploča Kristofora Spišića rad navedene radionice jer »[o]blik grba i njegovoga ukrasa, jednako kao i okvir natpisne ploče ukazuju na usku ovisnost o Trantnerovu majstoru «. ${ }^{495}$

Na području Hrvatskoga zagorja postoji još jedan nadgrobnik koji je Cevc (1981.) pripisao slovenskoj radionici. Riječ je o epitafu Baltazara I. Patačića (?, 1564. - Zajezda, 1616.) (Slika 131), ${ }^{496}$ sudca Varaždinske županije, koji je pokopan u župnoj crkvi Uznesenja Blažene Djevice Marije u Zajezdi. Baltazarovo tijelo položeno je u obiteljsku grobnicu koja se nalazila u lađi crkve na strani evanđelja nedaleko propovjedaonice, ${ }^{497}$ a njegova supruga Margareta rođ. Babonožić dala je izraditi epitaf koji je ugrađen u sjeverni zid svetišta iznad ulaza u sakristiju. Epitaf sadrži par putta koji pridržavaju grbove obitelji Patačić ${ }^{498}$ i Babonožić. ${ }^{499}$ Ispod grba Patačićevih uklesan je natpis na latinskome jeziku koji sadrži pojedinosti o pokojniku, a ispod grba Babonožićevih natpis na hrvatskom o naručiteljici koja je »do zmerthi pravedno salovala« svojega supruga. ${ }^{500}$ Potrebno je naglasiti kako je to jedan od rijetkih sačuvanih ranovovjekovnih spomenika koji sadrži natpis na hrvatskome jeziku općenito. Razmatrajući djela radionice Trantnerova majstora, Cevc (1981.) je uočio da su oblik grba i putta na Patačićevu epitafu srodni onima koje je primjenjivala radionica. ${ }^{501} \mathrm{Kao}$ jedan od komparativnih primjera naveo je epitaf Barbare Haas (1631.) iz mariborske prvostolnice (Slika 132) koji sadrži slično oblikovane motive grba (oblik štita, kacige i plašta) i putta (impostacija, fizionomija, oblikovanje kose). ${ }^{502}$

Komparativna analiza nadgrobnika nastalih u prvoj polovini XVII. stoljeća na području središnje Hrvatske potvrđuje tezu Emilijana Cevca (1981.) da je radionica Majstora Trantnerova epitafa svojim radovima opskrbljivala $\mathrm{i}$ naručitelje $\mathrm{s}$ hrvatskih prostora. Uz nadgrobnike Benka Thuróczyja Ludbreškoga (†1616.) iz Vinice, Kristofora Spišića (†1614.) iz Kloštar Ivanića i Baltazara I. Patačića (†1616.) iz Zajezde koje je Cevc pripisao radionici, popisu njezinih mogućih radova možemo pridodati nadgrobne ploče Elizabete Sudić (1620.) i

\footnotetext{
495 »Oblik grba in njegovega okrasja, prav tako pa okvir napisne plošče kažejo na ožjo odvisnost od Trantnerjeva mojstra.« Emilijan Cevc, nav. dj., 1981., str. 197. Prijevod autoričin.

${ }^{496}$ Kamen, $49 \times 72$ cm, Zajezda, crkva Uznesenja Blažene Djevice Marije. Kat. br. 50.

${ }^{497}$ Usp. Vjekoslav Noršić, nav. dj., 2010.b, str. 354.

${ }^{498}$ Grb se sastoji od štita, plašta, kacige i krune s ukrasom u obliku krila. Štit je okomito razdijeljen na dvije polovine. Na heraldičkoj desnoj strani prikazana je djeva ovijena draperijom koja stoji na sidru, a na lijevoj krilo. Usp. Ivan von Bojničić, nav. dj., 1889., str. 140-141, tab. 102.

${ }^{499}$ Grb se sastoji od štita, plašta, kacige i krune povrh koje se uzdiže zastava. Na štitu je prikazan jedrenjak. Usp. Ivan von Bojničić, nav. dj., 1889., str. 8, tab. 6.

${ }^{500}$ Za puni prijepis natpisa vidi kat. br. 50.

${ }^{501}$ Usp. Emilijan Cevc, nav. dj., 1981., str. 197.

${ }^{502}$ Isto.
} 
obitelji Keglević (1620-e) iz Krapine, epitaf Franje Keczera od Rad(o)vana (1629.) iz Vinice te nadgrobnu ploču Ivana Horvata Radića (1630.) iz Mihovljana. Svi navedeni spomenici imaju sličan način oblikovanja osnovnih motiva kojima je radionica raspolagala - grbova (Slika 133.1-8), glavica kerubina i ukrasnih okvira.

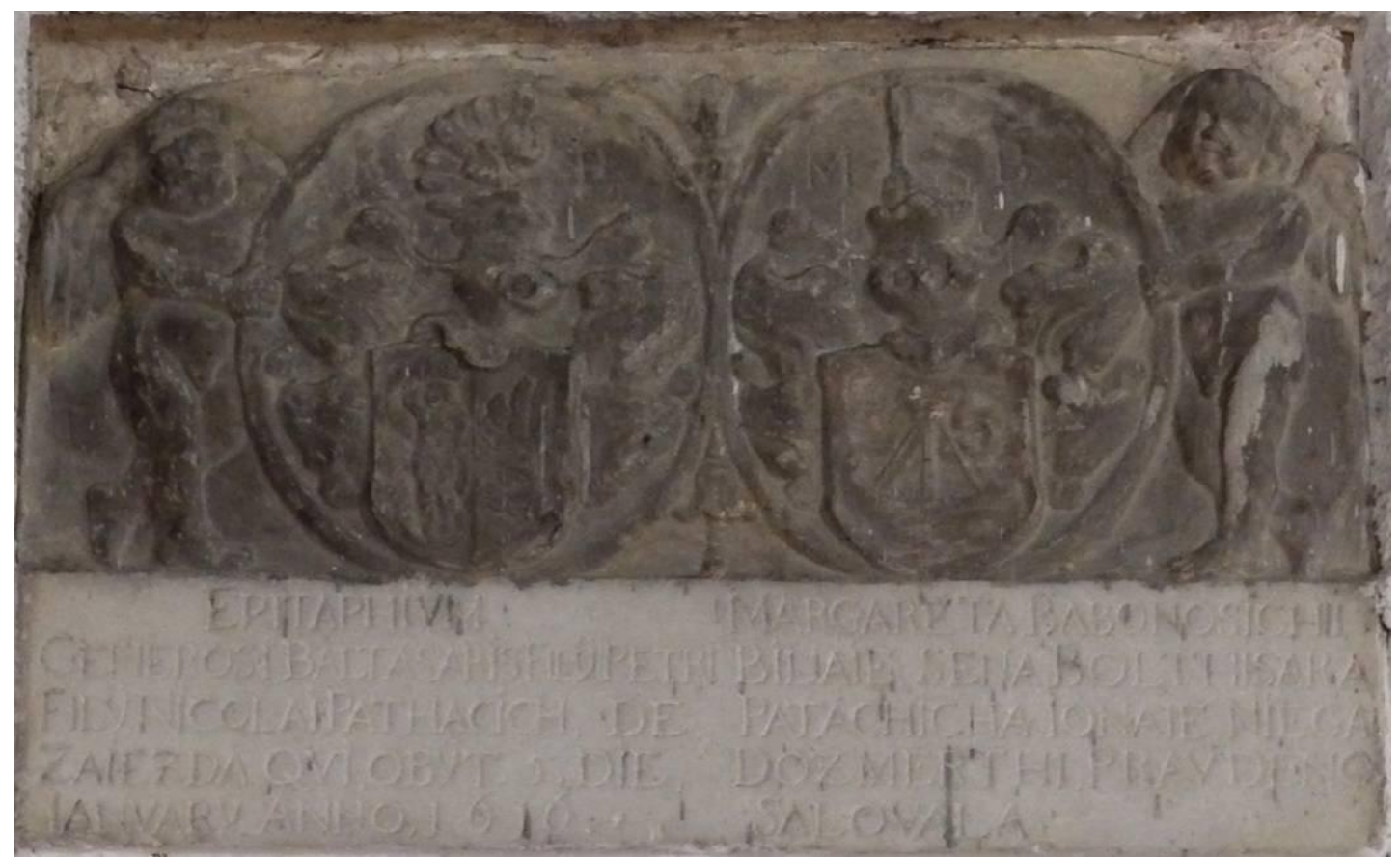

Slika 131. Radionica Majstora Trantnerova epitafa (?), Epitaf Baltazara I. Patačića (†1616.), Zajezda, crkva Uznesenja Blažene Djevice Marije

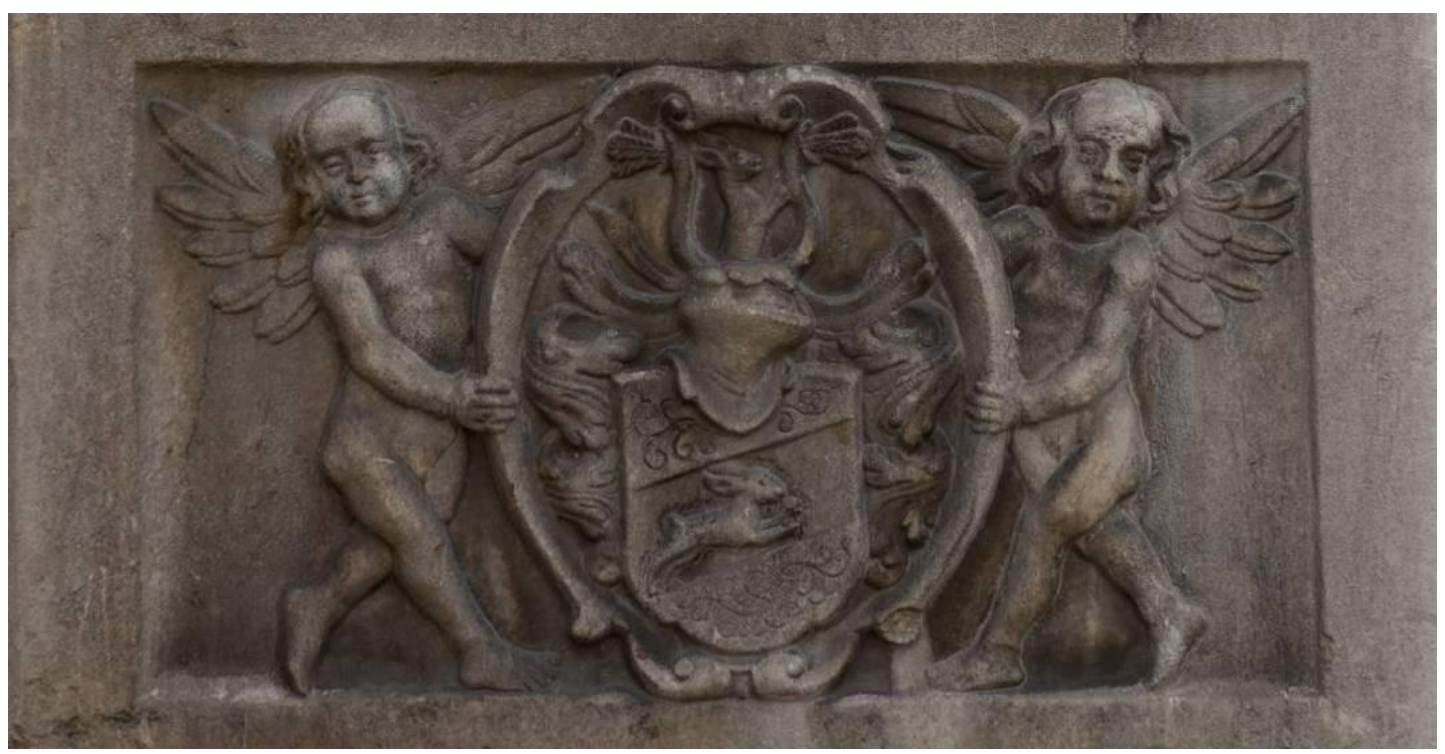

Slika 132. Radionica Majstora Trantnerova epitafa, Epitaf Barbare Haas - detalj para putta s grbom, 1631., Maribor, katedrala sv. Ivana Krsitelja 

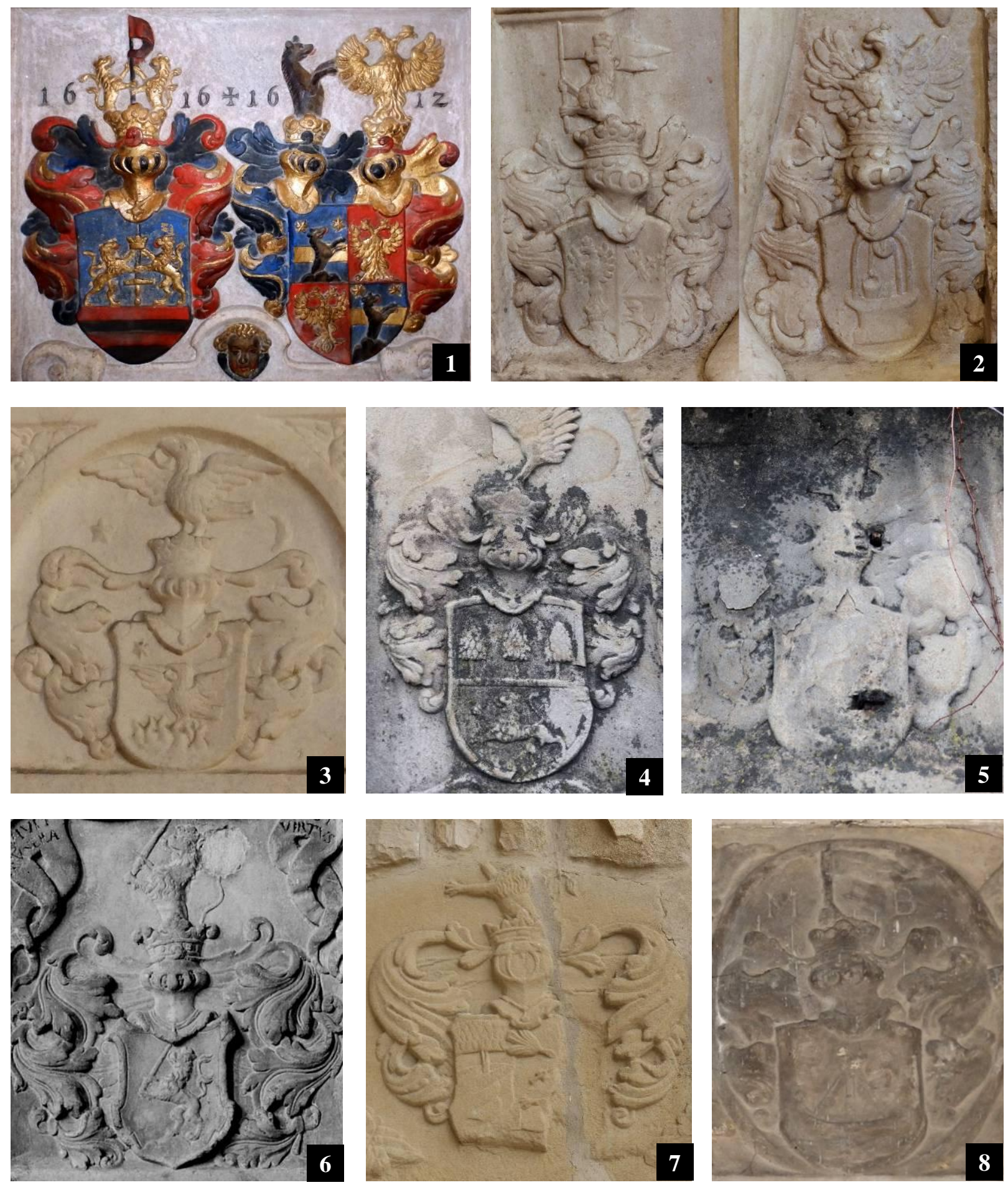

Slika 133. Usporedba izvedbe obiteljskih grbova na nadgrobnim spomenicima

133.1. Nadgrobna ploča Anne Zakklin rođ. Keglević (†1616.), Ptuj, crkva sv. Jurja

133.2. Nadgrobna ploča Benedikta Thuróczyja Ludbreškoga (†1616.), Vinica, crkva sv. Marka evanđelista

133.3. Epitaf Franje Keczera od Rad(o)vana, 1629., Vinica, crkva sv. Marka evanđelista

133.4. Nadgrobna ploča Elizabete Sudić, 1620., Krapina, crkva sv. Nikole

133.5. Nadgrobna ploča obitelji Keglević, 1620-e, Krapina, crkva sv. Nikole

133.6. Nadgrobna ploča Kristofora Spišića (†1614.), Kloštar Ivanić, crkva sv.

133.7. Nadgrobna ploča Ivana Horvata Radića, 1630., Mihovljan, crkva sv. Mihovila arkanđela

133.8. Epitaf Baltazara Patačića (†1616.), Zajezda, crkva Uznesenja Blažene Djevice Marije 
Izuzev nadgrobnika Ivana Horvata Radića, u staroj mihovljanskoj crkvi nalazio se još jedan spomenik - nadgrobna ploča mihovljanskoga župnika Grgura Zebeca (?, o. 1611. ?, 1684.) (Slika 134). ${ }^{503}$ Ploča je izvorno bila položena iznad župnikova groba u svetištu stare crkve, a mijenjanjem popločenja (1726.) uzidana je s lijeve strane glavnoga oltara uz nadgrobnik Ivana Horvata Radića. ${ }^{504}$ Srećom nije pretrpjela veća oštećenja u Drugom svjetskom ratu, a prilikom izgradnje nove crkve (1972. - 1976.) ugrađena je u sjeverni zid ulaznoga trijema, nasuprot Radićevoj. Na njoj je primijenjeno jednostavno likovno rješenje. U gornjem dijelu ploče uklesan je četverolist okružen stiliziranim viticama s cvijećem unutar kojega se nalazi obiteljski grb. ${ }^{505}$ Ispod četverolista ispisan je nadgrobni natpis u kojem je zabilježeno da je spomenik podignuo Grgurov brat Franjo, koji ga je nadživio.

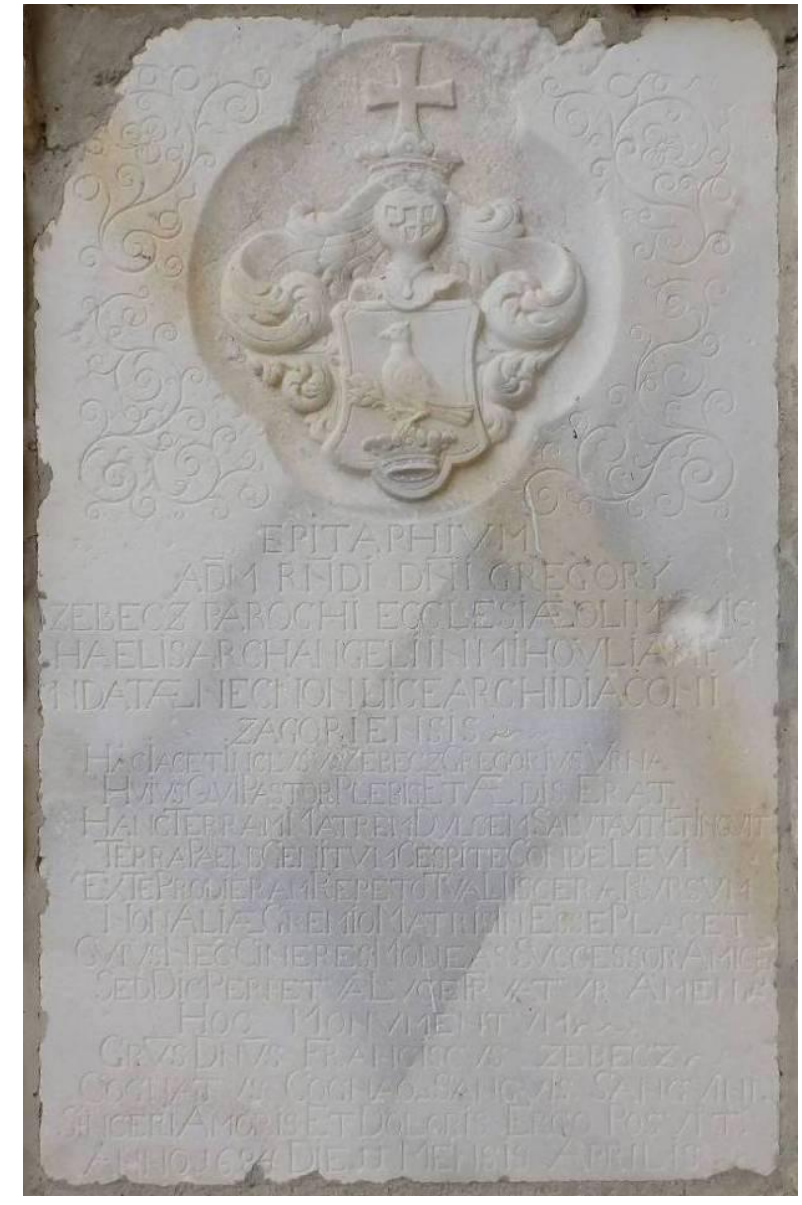

Slika 134. Nadgrobna ploča Grgura Zebeca, 1684., Mihovljan, crkva sv. Mihovila arkanđela

\footnotetext{
${ }^{503}$ Kamen, $136 \times 87 \times 1,5 \mathrm{~cm}$, Mihovljan, crkva sv. Mihovila arkanđela. Kat. br. 14.

${ }^{504}$ Usp. Alojz Jembrih, nav. dj., 2011., str. 9, 11; Gjuro Szabo, nav. dj., 1914., str. 176; Gjuro Szabo, nav. dj., $1939 ., 60-61$.

${ }^{505}$ Grb se sastoji od štita, plašta, kacige, krune i nakita u obliku križa. Na štitu je prikazana ptica koja sjedi na kruni, a u kandži drži klas pšenice. Grgur i njegov brat Franjo primili su potvrdu plemstva od kralja Ferdinanda III. (Graz, 1608. - Beč, 1657.) u vrijeme kada je Grgur služio kao župnik u Svetom Križu Začretju (1647. 1652.). Usp. Stjepan Sirovec, Sveti Križ Začretje: monografija: 1334. - 2004., Sveti Križ Začretje: Župa Svetog Križa, 2005., str. 41.
} 
Slično, kompozicijski jednostavnije rješenje primijenjeno je i na nadgrobnoj ploči obitelji Zmajlović (Slika 135) ${ }^{506}$ koja je postavljena u crkvi rođenja Blažene Djevice Marije u Sveticama. Ploča se nalazi u kapeli sv. Josipa koju je podigao i opremio prefekt ozaljskoga vlastelinstva Kristofor Zmajlović (? - ?, prije 1672.), a pokriva ulaz u obiteljsku grobnicu koju je imenovani plemić dao urediti. ${ }^{507}$ Riječ je o jednoj od rijetkih nadgrobnih ploča s prostora povijesne Zagrebačke biskupije koja je sačuvana in situ. Budući da se još uvijek nalazi na podu, prilično je trošna. U gornjem dijelu naziru se obrisi grba obitelji Zmajlović ${ }^{508}$ koji je uklesan unutar ovala, a njegov potpuni izgled možemo rekonstruirati na osnovi grba koji je objavljen u grbovniku Ivana von Bojničića (Slika 136). ${ }^{509}$ Ispod grba uklesan je natpis,
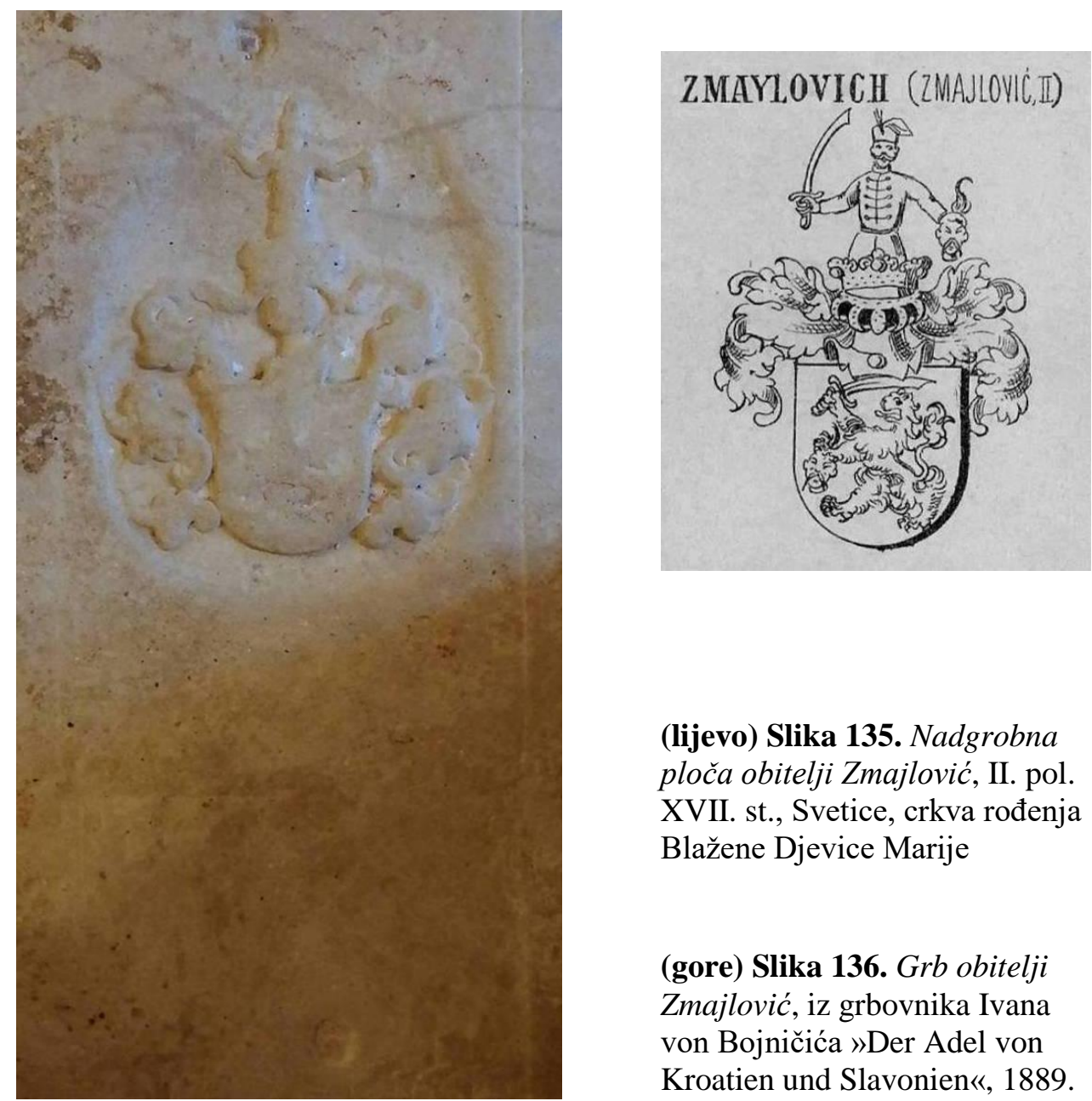

(lijevo) Slika 135. Nadgrobna ploča obitelji Zmajlović, II. pol. XVII. st., Svetice, crkva rođenja Blažene Djevice Marije

(gore) Slika 136. Grb obitelji Zmajlović, iz grbovnika Ivana von Bojničića »Der Adel von Kroatien und Slavonien«, 1889.

\footnotetext{
${ }^{506}$ Kamen, $165 \times 75$ cm, Svetice, crkva rođenja Blažene Djevice Marije. Kat. br. 28 .

${ }^{507}$ Usp. Đurđica Cvitanović, nav. dj., 1985., str. 264-265; Kamilo Dočkal, Samostan bl. Dj. Marije u Sveticama, digitalni transkript, str. 119-120. Pristupljeno 21.12.2020. <https://www.svetice.com/pavlini/>. Izvorni strojopis pohranjen je u Arhivu Hrvatske akademmije znanosti i umjetnosti, sig. XVI.-29c(4).

${ }^{508}$ Grb se sastoji od štita, plašta, kacige, krune i nakita u obliku muškarca koji u desnoj ruci drži sablju, a u lijevoj odsječenu ljudsku glavu. Simbol na štitu slabo je vidljv, no riječ je o lavu koji u prednjoj desnoj šapi drži sablju.

${ }^{509}$ Usp. Ivan von Bojničić, nav. dj., 1889., str. 209-210, tab. 152.
} 
no jedini dio koji se može razabrati jest godina 1666. koja najvjerojatnije predstavlja godinu postavljanja ploče odnosno smrti jednoga od članova obitelji Zmajlović koji je pokopan u svetičkoj crkvi.

Unutar ovoga dijela korpusa, zasebnu skupinu čine grbovni spomenici koji su izvorno bili postavljeni u zagrebačkoj prvostolnici. Obilježavali su ukopna mjesta kanonika, biskupa i banova, a danas su većim dijelom pohranjeni u muzejima. U Hrvatskom povijesnom muzeju u Zagrebu pohranjene su tri takve nadgrobne ploče. Od prve je sačuvan samo ulomak donjega lijevog kuta na kojem je vidljiv dio štita s heraldičkim motivom (krunom?) i natpis uklesan uz rubove (Slika 137). ${ }^{510}$ Natpis sadrži godinu 1619. i ime »IOH[ann]ES« koje se može odnositi na pokojnika ili naručitelja. Nadgrobnik je rustikalne obrade što upućuje na kipara nešto skromnijih mogućnosti. ${ }^{511}$ Nije poznato u kojem se dijelu katedrale izvorno nalazio niti kada je iz nje odstranjen.

Druga nadgrobna ploča pokrivala je grob Baltazara Dvorničića-Napulya (Koprivnica, o. 1560. - Zagreb, 1624.) (Slika 138), ${ }^{512}$ kanonika (1581.) i prepošta zagrebačke katedrale (1613.) koji je ujedno djelovao kao pravnik. Dvorničić je pokopan ispred oltara sv. Franje Serafskoga u sjevernome brodu, ${ }^{513}$ a ploča je najvjerojatnije iznesena iz katedrale tijekom velike obnove koja je uslijedila nakon potresa 1880 . godine. ${ }^{514}$ Sačuvan je veći dio natpisne ploče povrh koje je predočen djelomično očuvan grb obitelji Napuly. ${ }^{515}$ Grb i natpis prikazani su u zasebnim poljima koja su odijeljena trakom ukrašenom renesansnim motivom vitica.

Posljednji nadgrobni spomenik pohranjen u Hrvatskom povijesnom muzeju koji se prvobitno nalazio u katedrali jest nadgrobna ploča Ivana II. Erdődyja (?, 1589. - ?, 1626.) (Slika 139), ${ }^{516}$ egerskoga biskupa, kraljevskoga savjetnika i velikoga župana ugarskih županija Heres i Szolnok. Izvorno je bila položena na podu svetišta uz južni zid apside, ${ }^{517}$

\footnotetext{
${ }^{510}$ Vapnenac, $36 \times 53 \times 22 \mathrm{~cm}$, Zagreb, Hrvatski povijesni muzej, izvorno u katedrali Uznesenja Blažene Djevice Marije i sv. Stjepana i Ladislava. Kat. br. 36.

${ }^{511}$ Usp. Mirko Valentić, nav. dj., 1969., str. 43; Mirko Valentić i Lada Prister, nav. dj., 2002., str. 28.

512 Vapnenac, $165 \times 40 \times 15 \mathrm{~cm}$, Zagreb, Hrvatski povijesni muzej, izvorno u katedrali Uznesenja Blažene Djevice Marije i sv. Stjepana i Ladislava. Kat. br. 38.

${ }^{513}$ Usp. Ivan Kukuljević Sakcinski, nav. dj., 1856., str. 39; Ivan Krstitelj Tkalčić, nav. dj., 1885., str. 96.

${ }^{514}$ Usp. Mirko Valentić i Lada Prister, nav. dj., 2002., str. 29.

${ }^{515}$ Grb se sastoji od štita, kacige i nakita izvedena u obliku para raširenih krila. Štit je okomito raskoljen na dva polja. U prvome polju prikazan je grifon. Motiv drugoga polja oštećen je i teško raspoznatljiv, no na osnovi Bojničićeva grbovnika (1889.) možemo pretpostaviti da je riječ o ruci koja drži tri cvijeta. Usp. Ivan von Bojničić, nav. dj., 1889., str. 128, tab. 93.

${ }^{516}$ Vapnenac, $161 \times 86 \times 14 \mathrm{~cm}$, Zagreb, Hrvatski povijesni muzej, izvorno u katedrali Uznesenja Blažene Djevice Marije i sv. Stjepana i Ladislava. Kat. br. 39.

${ }^{517}$ Usp. Ivan Kukuljević Sakcinski, nav. dj., 1856., str. 20; Ivan Krstitelj Tkalčić, nav. dj., 1885., str. 54.
} 

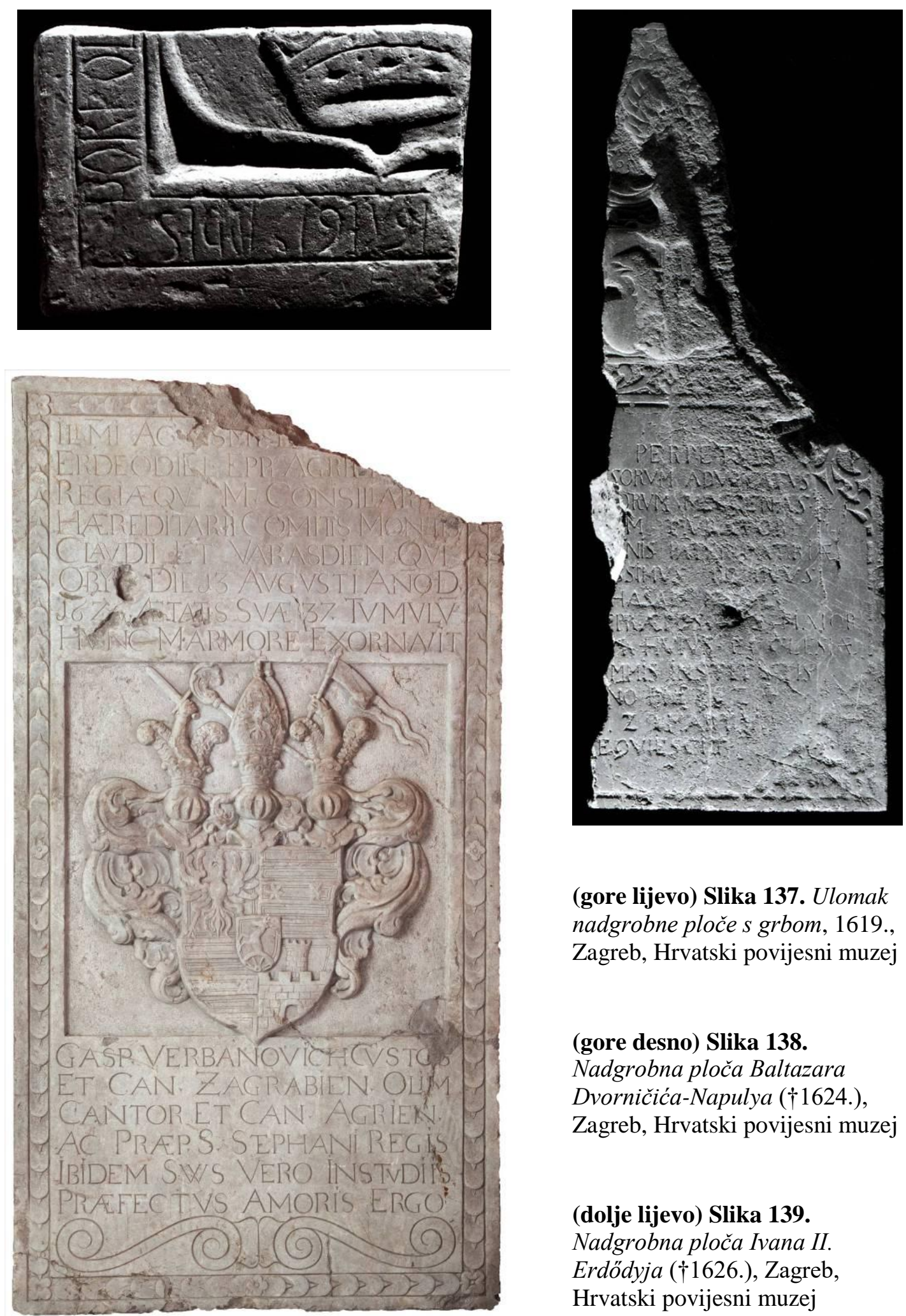

(gore lijevo) Slika 137. Ulomak nadgrobne ploče s grbom, 1619., Zagreb, Hrvatski povijesni muzej

(gore desno) Slika 138.

Nadgrobna ploča Baltazara Dvorničića-Napulya (†1624.), Zagreb, Hrvatski povijesni muzej

(dolje lijevo) Slika 139.

Nadgrobna ploča Ivana II. Erdődyja (†1626.), Zagreb, Hrvatski povijesni muzej 
a uklonjena je prilikom obnove katedrale nakon potresa 1880 . godine. ${ }^{518}$ Prema natpisu, dao ju je postaviti zagrebački kanonik Gašpar Vrbanović s kojim je Erdődy prijateljevao. ${ }^{519} \mathrm{U}$ sredini ploče, unutar pravokutnoga polja reljefno je izveden grb obitelji Erdődy. ${ }^{520}$ Vršak štita i nakita izlaze izvan polja čime negiraju predodređen im okvir, što je odlika ranoga baroka. Povrh i ispod grba uklesan je nadgrobni natpis. Onaj iznad grba sadrži pojedinosti o pokojniku, a onaj ispod o naručitelju. Pri dnu ploče uklesan je par voluta, a njezin rub optočen je ukrasnom vegetabilnom trakom.

Nekoliko nadgrobnih ploča s obiteljskim grbom kao osnovnim motivom pohranjeno je i u Muzeju grada Zagreba. Jedna od njih je nadgrobna ploča Jurja Orehovačkoga (? - ?, 1687.) (Slika 140), ${ }^{521}$ zagrebačkoga kanonika i kantora, koja je pronađena ispod popločenja svetišta u blizini oltara Posljednje večere prilikom obnove katedrale nakon potresa 1880. godine. ${ }^{522} \mathrm{U}$ njezinom središtu predočen je grb obitelji Orehovački ${ }^{523}$ koji pridržavaju dva anđela. Povrh grba nalazi se medaljon unutar kojega je ispisana uzrečica »MEMENTO MORI«. Upozorenje pisane poruke o prolaznosti vremena upotpunjeno je likovnim motivima koji flankiraju medaljon - mrtvačkom lubanjom na lijevoj i pješčanim satom na desnoj strani. Ispod grba prikazani su kerubin i kartuša unutar koje je uklesan nadgrobni natpis. Središnji redak natpisa ispisan je kronogramom koji daje godinu smrti pokojnika, 1687. Prostor između opisanih motiva ispunjen je gustim prepletom vitica i lišća akanta.

Motiv akanta susretali smo i na prethodno analiziranim grbovnim spomenicima, no uvijek kao pomoćni motiv u oblikovanju grba odnosno njegovoga plašta. Na nadgrobnoj ploči Orehovačkoga on je primijenjen kao samostalan ornament. Akant je u ranobarokno kiparstvo kontinentalne Hrvatske uveo kipar i drvorezbar Ivan (Johannes) Komersteiner (?, pol. XVII. st. - Zagreb, 1694./95.). Analizirajući ornamentiku oltarā koji su pripisani majstoru i njegovoj

\footnotetext{
${ }^{518}$ Usp. Mirko Valentić i Lada Prister, nav. dj., 2002., str. 29.

${ }^{519}$ Vrbanović i Erdődy najvjerojatnije su se upoznali na Hrvatskome kolegiju u Bologni, na kojem je Erdődy obnašao dužnost rektora, a Verbanović klerika. Svoje poznanstvo nastavili su u Egeru, gdje su boravili u isto vrijeme. Usp. Mirko Valentić, nav. dj., 1969., str. 45.

${ }^{520}$ Štit grba razdijeljen je na četiri jednaka polja sa srcem štita (štitićem) u sredini. U prvome polju prikazan je okrunjeni orao. Drugo i treće polje razdijeljena su dvjema poprečnim gredama koje omeđuju dvije šestokrake zvijezde. U četvrtom polju predočena je kula s grudobranom. Srce štita je stari grb obitelji Bakač koji sadrži motiv kotača i jelena. Štit je ukrašen plaštem i trima kacigama s krunama. Iznad bočnih kruna uzdižu se oklopljene ruke (lijeva drži mač, a desna barjak), a iznad središnje biskupska mitra i pastoral. Usp. Ivan von Bojničić, nav. dj., 1889., str. 44, tab. 33.

${ }^{521}$ Vapnenac, $178 \times 94 \times 26 \mathrm{~cm}$, Zagreb, Muzej grada Zagreba, izvorno u katedrali Uznesenja Blažene Djevice Marije i sv. Stjepana i Ladislava u Zagrebu. Kat. br. 42.

${ }^{522}$ Usp. Ivan Kukuljević Sakcinski, nav. dj., 1891., str. 338, br. 1161; Ivan Krstitelj Tkalčić, nav. dj., 1885., str. 66-67.

${ }^{523}$ Grb se sastoji od štita, kacige, krune, plašta i nakita. Nakit je izveden u obliku lava koji u šapama drži mač. $\mathrm{Na}$ štitu su predočeni lav i grifon koji stoje na brijegu s tri vrha.
} 


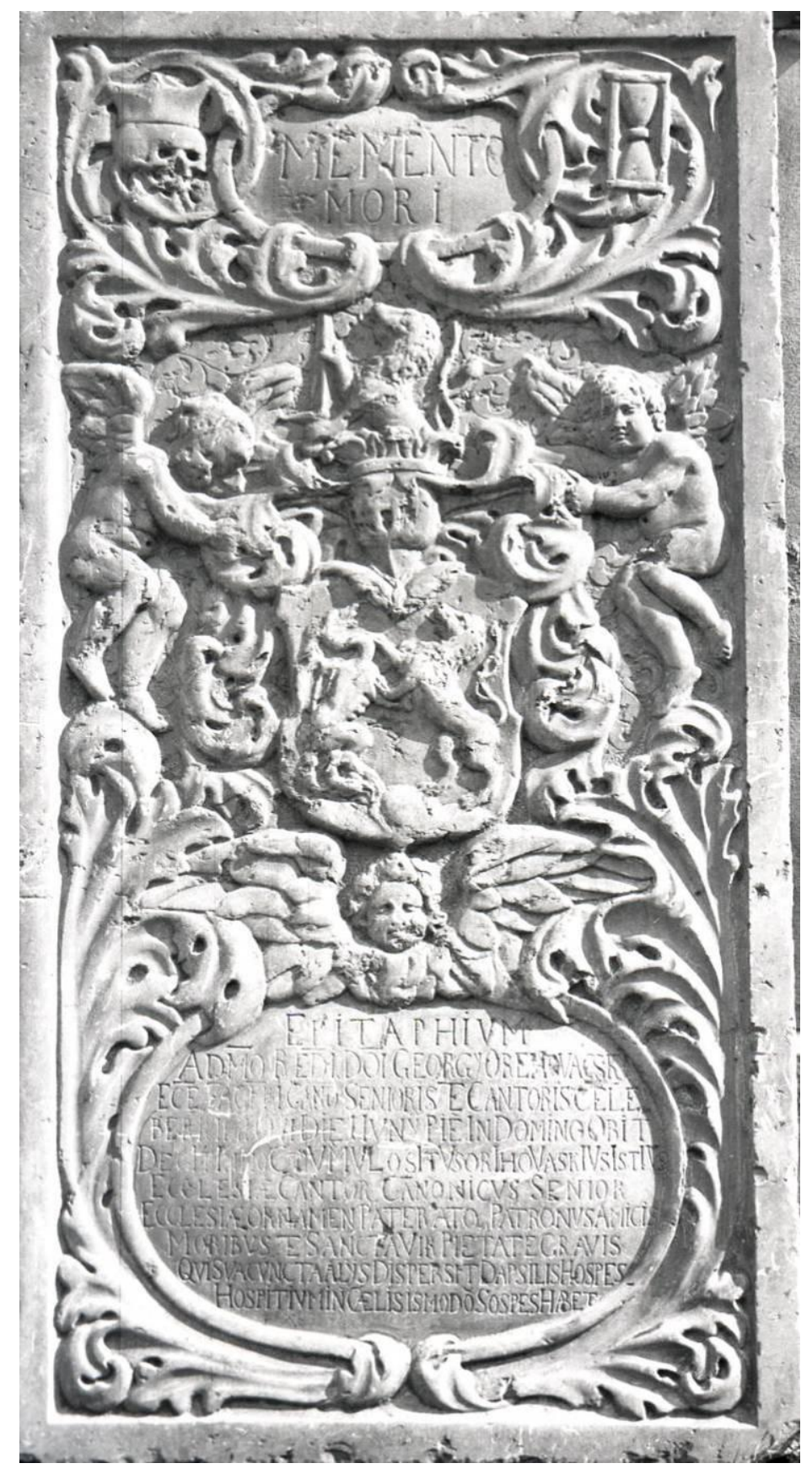

(gore lijevo) Slika 140. Radionica Ivana Komersteinera (?), Nadgrobna ploča Jurja Orehovačkoga (†1687.), Zagreb, Muzej grada Zagreba

(gore desno) Slika 141. Ivan Komersteiner, Oltar sv. Franje Borgie - detalj krila, 1680. - 1684., Zagreb, crkva sv. Katarine

(dolje desno) Slika 142. Radionica Ivana Komersteinera (?), Nadgrobna ploča Jurja Orehovačkoga (†1687.) detalj, Zagreb, Muzej grada Zagreba
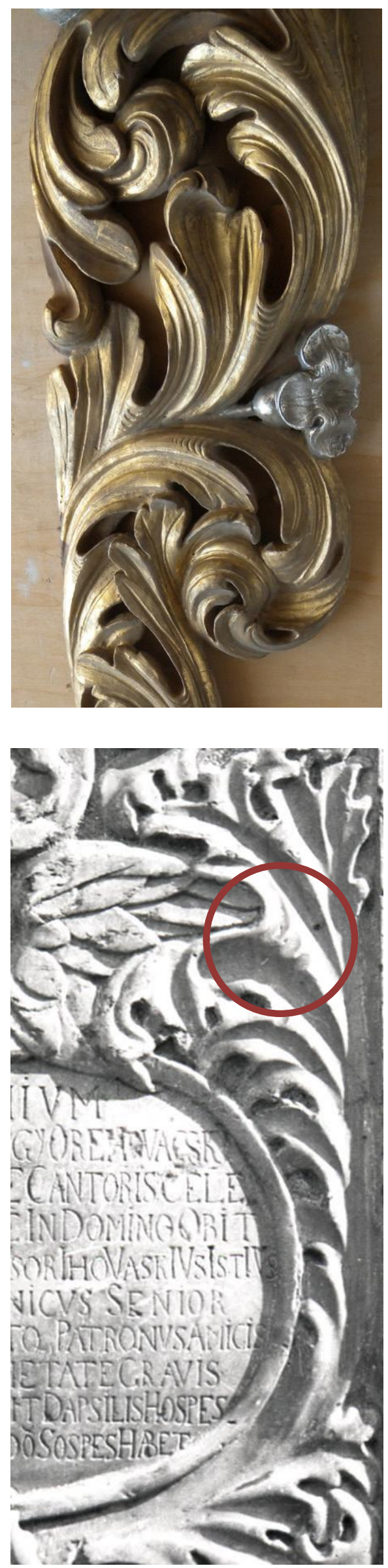
radionici (Slika 141), Marina Wolff Zubović (2017.) opisala je način oblikovanja akanta koji je karakterističan za Komersteinera:

»Bočni izbojci vitice imaju meko zaobljene trodijelne završetke od kojih je srednji najširi. Međusobno su odvojeni uskim i dubokim užljebljenjima u obliku slova $U$, a mjesto njihova spoja naglašeno je malim naborom $\mathrm{s}$ nekoliko polukružnih utora. Taj karakteristični detalj u oblikovanju možemo naći na gotovo svim akantovim viticama koje dekoriraju oltare pripisane Ivanu Komersteineru i radionici, a ishodište im je vjerojatno u onovremenim grafičkim predlošcima. Završni listovi imaju zadebljane vrhove i volutno se uvijaju pod vlastitom težinom, a neki se kovrčaju prema van. ${ }^{524}$

$\mathrm{Na}$ isti način oblikovane su vitice i listovi akanta na nadgrobnoj ploči Jurja Orehovačkoga bočni izbojci imaju trodijelne završetke (od kojih je središnji najširi), a završni listovi volutno su povijeni prema unutra. Štoviše, na spojevima izbojaka lista koji s desne strane flankira glavicu anđela uklesani su polukružni utori (Slika 142) koje je Wolff Zubović opisala kao karakteristične za Komersteinera i njegovu radionicu. Sličnost između radova atribuiranih majstoru i nadgrobne ploče Orehovačkoga uočljiva je i u načinu oblikovanja putta. Anđeli koji nose biskupov grb (Slika 143) vrlo su slični, primjerice, onima na oltaru sv. Franje Borgije (1680. - 1684.) iz crkve sv. Katarine u Zagrebu (Slika 144) ili oltaru sv. Roka (o. 1685.) iz kapele sv. Petra u Gotalovcu. Putti s oltarā i nadgrobnika imaju istu anatomiju tijela (punašan trup, izdužene noge i okruglu glavu) i tipologiju lica (okruglo lice bucmastih obraza, sitne oči, širok prćast nos, uska usta i gustu kosu začešljanu prema naprijed). S obzirom na opisane oblikovne sličnosti, čini se da bi nadgrobnik Jurja Orehovačkoga mogao biti rad majstora Komersteinera odnosno njegove radionice. Pojedini radovi i crtice iz majstorova života idu u prilog toj tezi, a izneseni su u narednim odlomcima.

Iako je bio poznat po raskošno rezbarenim drvenim oltarima, Ivan Komersteiner radio je i u kamenu. ${ }^{525}$ Jedan od takvih radova je mramorna spomen-ploča (Slika 145) koju je izradio za biskupa Aleksandra Ignacija Mikulića (Brokunovec, oko 1650. - Zagreb, 1694.). Ploča se izvorno nalazila na zgradi kaptolske knjižnice koju je biskup podignuo i opremio, ${ }^{526}$ a danas je pohranjena u Hrvatskom povijesnom muzeju. Navodimo Mikulićevu spomen-ploču kao primjer jer je kompozicijski vrlo slična nadgrobniku Orehovačkoga. Naime, sadrži

\footnotetext{
${ }^{524}$ Martina Wolff Zubović, nav. dj., sv. 1, 2017., str. 64.

${ }^{525}$ Komersteinerova djela izvedena u kamenu su: kip sv. Franje Ksaverskoga (1676.) koji je izradio za zagrebačke isusovce, nadgrobna ploča biskupa Martina Borkovića (1692.) (nije sačuvana), spomen-ploča biskupa Mikulića s nekadašnje kaptolske knjižnice (1692.) te kipovi Marije i anđelā postavljeni iznad portala cinktora župne crkve sv. Marije Okićke (1692.). Usp. Doris Baričević, Barokno kiparstvo sjeverne Hrvatske, Zagreb: Institut za povijest umjetnosti, Školska knjiga, 2008., str. 63, 68.

${ }_{526}$ Zgrada knjižnice oslanjala se na Bakačevu kulu, a srušena je reglacijom Kaptola 1907. godine. Usp. Mirko Valentić, nav. dj., 1969., str. 58-60; Mirko Valentić i Lada Prister, nav. dj., 2002., str. 34.
} 

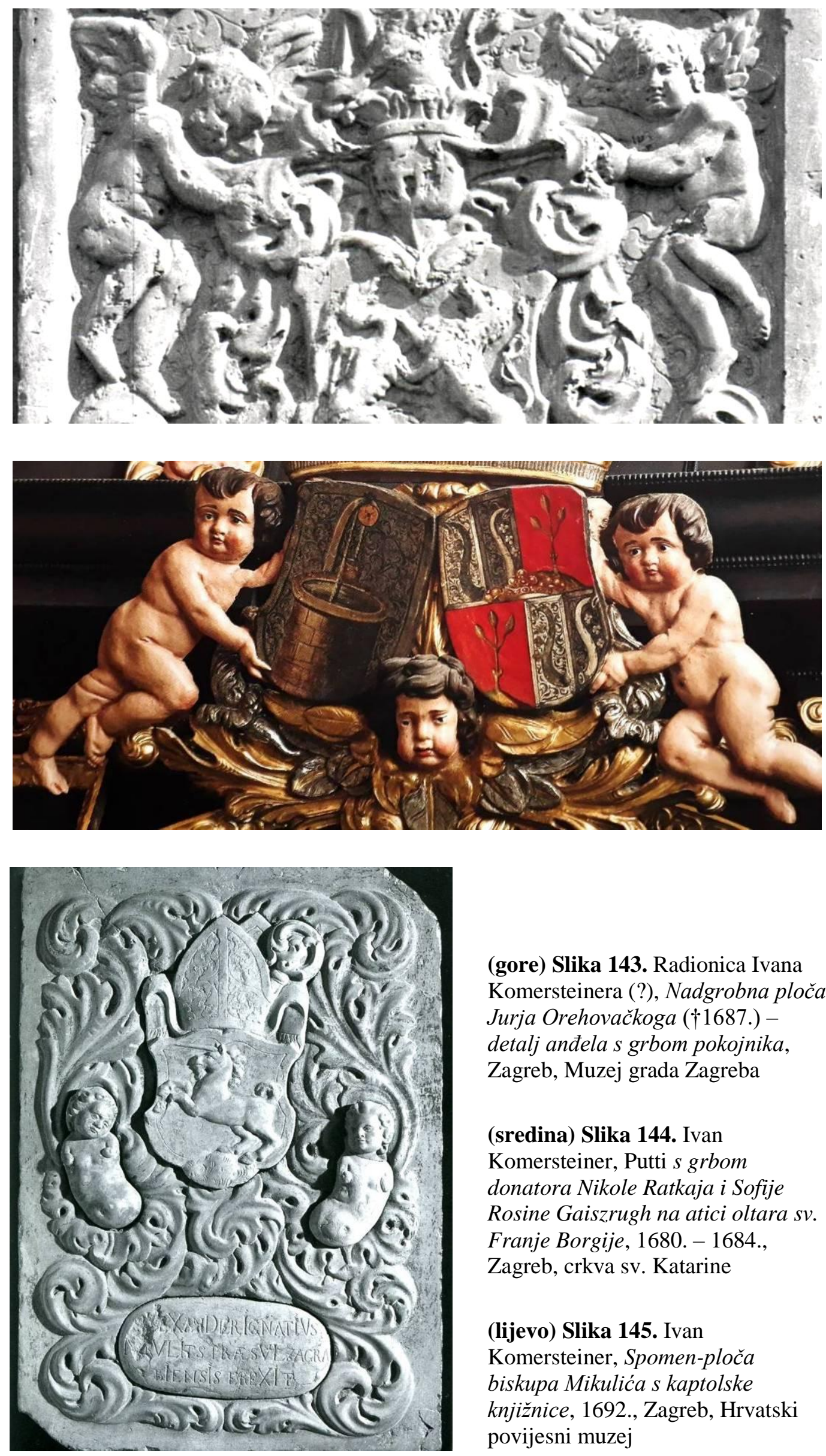

(gore) Slika 143. Radionica Ivana Komersteinera (?), Nadgrobna ploča Jurja Orehovačkoga (†1687.) detalj anđela s grbom pokojnika, Zagreb, Muzej grada Zagreba

(sredina) Slika 144. Ivan Komersteiner, Putti s grbom donatora Nikole Ratkaja i Sofije Rosine Gaiszrugh na atici oltara sv. Franje Borgije, 1680. - 1684., Zagreb, crkva sv. Katarine

(lijevo) Slika 145. Ivan Komersteiner, Spomen-ploča biskupa Mikulića s kaptolske knjižnice, 1692., Zagreb, Hrvatski povijesni muzej 
biskupov grb koji pridržavaju putti (danas nedostaju) ${ }^{527}$ ispod kojega se nalazi ovalni medaljon s posvetnim natpisom, a ostatak ploče ispunjen je prepletom akantova lišća i vitica. Ako usporedimo ornament na dva spomenika, uočit ćemo da je akant na Mikulićevoj spomenploči oblikovan nešto mekše i podatnije od onoga na nadgrobniku, što upućuje na mogućnost da je u izradi nadgrobne ploče Orehovačkoga veći udio imala radionica nego sam majstor.

Izrada nadgrobnih spomenika Komersteineru nije bila strana. Prema spisu izvršenja oporuke Martina Borkovića (1692.), za zagrebačkoga je biskupa isklesao nadgrobnu ploču od crvenoga mramora koji je dopremljen splavima iz Salzburga preko Ljubljane. ${ }^{528}$ Ploča na žalost nije sačuvana te o njoj znamo samo na osnovi arhivskih izvora. Srećom, očuvan je drugi nadgrobnik koji je majstor izradio, a riječ je o epitafu Nikole III. Erdődyja (?, 1630. Aranyosmarót, 1693.; banovao 1680. - 1693.) (Slika 146), ${ }^{529}$ hrvatsko-dalmatinskoslavonskoga bana koji se istaknuo u borbi protiv Osmanlija i znatno pridonio oslobođenju hrvatskih područja od njihove vlasti. Prema sačuvanome ugovoru, nadgrobnik je kod Komersteinera naručio kanonik Ivan Josip Babić (oko 1630. - 1700.). ${ }^{530}$ Erdődy je pokopan u zagrebačkoj prvostolnici uz oltar Majke Božje, u istoj grobnici kao i njegov predak Toma II. Erdődy. Epitaf je izvorno bio postavljen na zidu južne apside iznad Tomina spomenika, a između dvaju nadgrobnika izloženi su Nikolin prsni oklop, kaciga, mač, bansko žezlo i zastava. ${ }^{531}$ Prilikom obnove katedrale nakon potresa 1880. godine, epitaf je premješten na južni zid broda, gdje se nalazi i danas, a pokojnikovi osobni predmeti pohranjeni su u riznici katedrale. $^{532}$

\footnotetext{
${ }^{527}$ Početkom XX. stoljeća kada je ploča predana muzeju anđeli su bili oštećeni, a godine 1968. su ukradeni. Usp. Mirko Valentić, nav. dj., 1969., str. 58, 60.

${ }^{528}$ U dokumentu su za dopremu materijala i izradu nadgrobne ploče definirani sljedeći troškovi: »Pro petra marmorea rubra supra sepulchrum dati Salisburgi fl. Rh. 30 / Ibidem pro ponderatione lapidis et tricesime fl. Rh. 1,40 / Foringa seu deductio lapidis Salisburgo usque Labachum fl. Rh. 65,50 / Deductio Labacho usque Zagrabiam fl. Rh. 9 / Sculptori Ioanni Komerstainer pro elaborato marmore cum bibali fl. Rh. 73 / Lapicidis pro lapidibus circumferentiarum, in quibus eruendis diebus 6 laborarunt fl. Rh. 2,32 / Eisdem pro diebus 10, quibus ad ecclesiam dictos lapides elaborabant fl. Rh. 4 / Laboratoribus 4 qui locum petrae pro illis purgabant fl. Rh. 0,64 / Pro vectura currum 4 qui dictos lapides devexerunt fl. Rh. 1,48 / (summa pro petra marmorea) fl. Rh. 187,34.« Prijepis preuzet iz: Metod Hrg, Oporuka biskupa Martina Borkovića (1667-1687), u: Croatica Christiana periodica X/18, Zagreb: Katolički bogoslovni fakultet, 1986., str. 66-88, 83.

${ }^{529}$ Drvo, polikromija, pozlata, $224 \times 135 \mathrm{~cm}$, Zagreb, katedrala Uznesenja Blažene Djevice Marije i sv. Stjepana i Ladislava. Kat. br. 43.

${ }^{530}$ Usp. Doris Baričević, Kiparstvo manirizma i baroka, u: Sveti trag: devetsto godina umjetnosti zagrebačke nadbiskupije, 1094. - 1994., Zagreb: Muzejsko-galerijski centar, Institut za povijest umjetnosti, Zagrebačka nadbiskupija, 1994., str. 301-340, 325. Uredili Tugomir Lukšić i Ivanka Reberski; Lina Slavica Plukavec, Obnova Ackermannovog oltara, Komersteinerovog spomenika $i$ Sickingerovih kipova $u$ zagrebackoj prvostolnici, u: Tkalčić: godišnjak Društva za povjesnicu Zagrebačke nadbiskupije = annales Societatis historicae archiepiscopatus Zagrabiensis II, Zagreb: Društvo za povjesnicu Zagrebačke nadbiskupije »Tkalčić«, 1998., str. 165-209, 189.

${ }^{531}$ Usp. Ivan Kukuljević Sakcinski, nav. dj., 1856., str. 31-32; Ivan Krstitelj Tkalčić, nav. dj., 1885., str. 72.

${ }^{532}$ Sedamdesetih godina XX. stoljeća nadgrobnik je prenesen u Hrvatski restauratorski zavod u Zagrebu na restauraciju. Nakon obnove, izložen je u Muzeju Mimara na izložbi Sveti trag: devetsto godina umjetnosti
} 


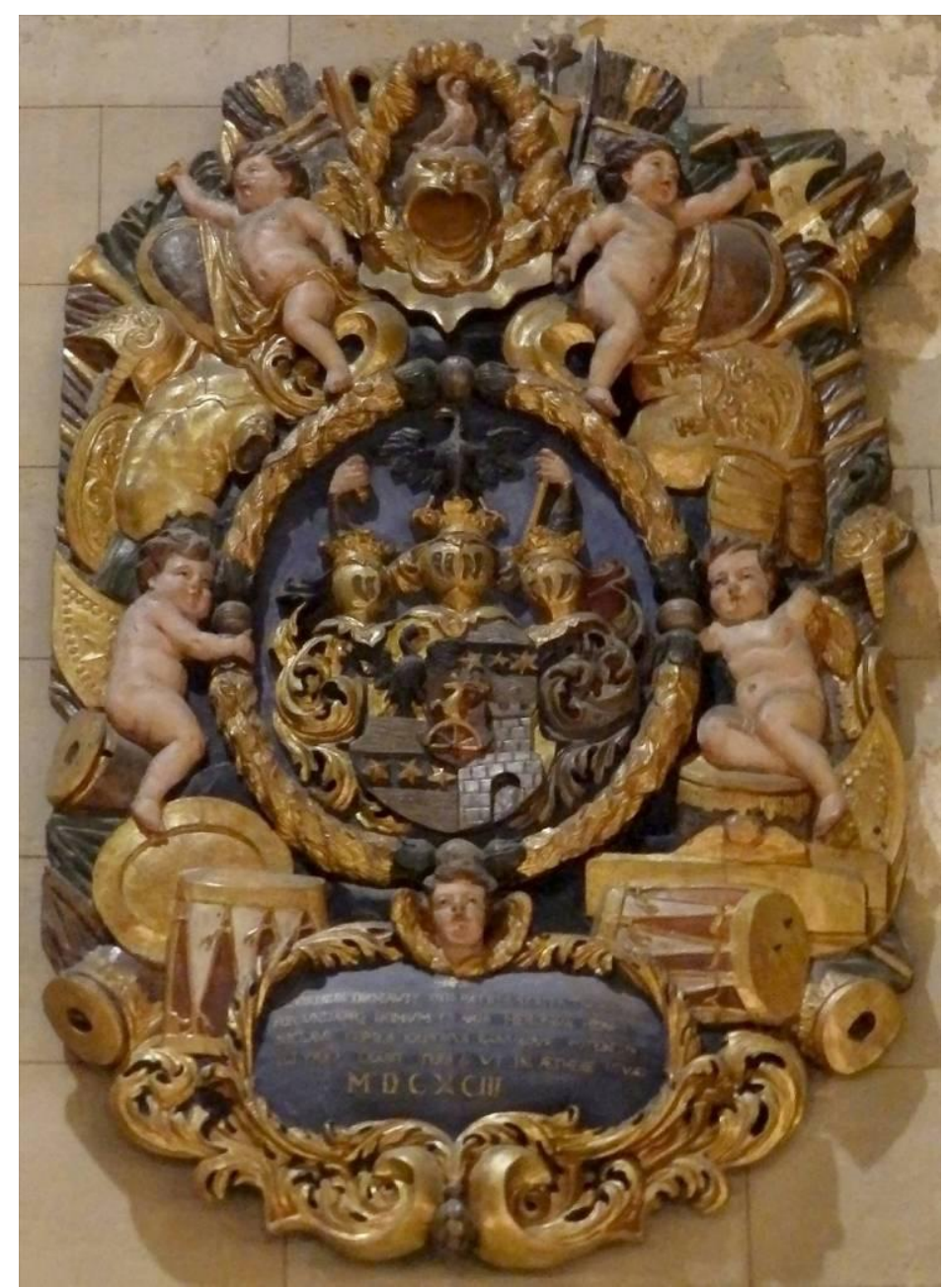

Slika 146. Ivan Komersteiner, Epitaf Nikole III. Erdödyja, 1693., Zagreb, katedrala Uznesenja Blažene Djevice Marije i sv. Stjepana i Ladislava

U središtu Erdődyjeva nadgrobnika prikazan je banov grb ${ }^{533}$ okružen lovorovim vijencem koji pridržavaju dva putta slična onima na nadgrobnoj ploči Jurja Orehovačkoga. Ispod grba nalazi se kartuša ukrašena akantom i motivom kerubina koja sadrži posvetni natpis. Lovorov vijenac okružen je ratnim trofejima poput zastava, oklopa, kaciga, oružja i bubnjeva. Među trofejima, pri vrhu nadgrobnika nalaze se još dva putta iste fizionomije kao oni koji pridržavaju grb. Većina je nadgrobnika pozlaćena izuzev putta koji su obojeni inkarnatom te natpisne kartuše i pozadine grba koji su obojeni plavo. Erdődyjev epitaf jedini je nadgrobni spomenik izrezbaren u drvu koji je sačuvan na području povijesne Zagrebačke biskupije. Drveni nadgrobnici, doduše, nisi bili rijetkost i izvorno ih je bilo više, no nisu se

Zagrebačke nadbiskupije, 1094.-1994., a po završetku izložbe vraćen je u katedralu. Usp. Lina Slavica Plukavec, nav. dj., 1998., str. 187-188.

${ }^{533}$ Štit grba razdijeljen je na četiri jednaka polja sa srcem štita (štitićem) u sredini. U prvome polju, na zlatnoj pozadini prikazan je crni okrunjeni orao. Drugo i treće polje razdijeljeno je dvjema smeđim poprečnim gredama između kojih se nalaze tri zlatne petokrake zvijezde. U četvrtom polju predočena je kula s grudobranom na zlatnoj pozadini. Srce štita predstavlja stari grb obitelji Bakač - na crvenoj pozadini prikazani su kotač i jelen obojeni zlatnom bojom. Štit je ukrašen plaštem i trima kacigama s krunama. Iznad bočnih kruna uzdižu se oklopljene ruke (lijeva drži mač, a desna barjak), a iznad središnje crni orao. Usp. Ivan von Bojničić, nav. dj., 1889., str. 44 , tab. 33 . 
očuvali zbog trošnosti materijala. Kao što je navedeno u prethodnome potpoglavlju, iz arhivskih je izvora poznato da je Juraj IV. Zrinski dao izraditi za svojega oca Nikolu IV. (†1566.) drveni epitaf, koji je postavljen u obiteljskoj grobnoj kapeli podignutoj uz pavlinsku crkvu sv. Jelene u Šenkovcu. Nadgrobnik je najvjerojatnije stradao u požaru koji je 1695. godine zahvatio samostanski sklop, uključujući kapelu Zrinskih.

U Muzeju grada Zagreba pohranjen je još jedan grbovni nadgrobnik koji se izvorno nalazio u prvostolnici. Riječ je o nadgrobnoj ploči zagrebačkoga kanonika (1669.) i naslovnoga šibenskog biskupa (1702.) Ivana Znike (Matenci, 1629. - Zagreb, 1706.) (Slika 147). ${ }^{534}$ Znika je pripadao kulturnom krugu zagrebačkoga biskupa Aleksandra Ignacija Mikulića (Brokunovec, o. 1650. - Zagreb, 1694.), a posebno se istaknuo kao mecena likovne umjetnosti i književnost. ${ }^{535}$ Pridonio je opremanju brojnih crkava uključujući zagrebačku katedralu, što je zabilježeno na samome spomeniku (»CUIVS MORIBUS ET LIBERALITATE / TEMPLA FORA VIÆQ[UE] / IMO TE HÆC BASILICA RESPLENDVERE«). Njegova nadgrobna ploča izvorno se nalazila u južnoj apsidi katedrale ispred oltara sv. Kuzme i Damjana, ${ }^{536}$ a najvjerojatnije je odstranjena u obnovi koja je uslijedila nakon potresa 1880. godine. ${ }^{537}$ Izvedena je u uleknutome refelju, a predočeni motivi vješto su stilizirani. U gornjem dijelu nadgrobnika nalazi se kanonikov obiteljski grb ${ }^{538}$ okružen jednostavnom vrpcom u koju su upleteni motivi koji simboliziraju prolaznost vremena (pješčani sat, dvije lubanje, lopata, motika i dva para ukriženih kostiju). U donjem dijelu ploče predočena je kartuša unutar koje je ispisan nadgrobni natpis.

Nedaleko Znikina nadgrobnika, u zagrebačkoj se katedrali nekoć nalazila i nadgrobna ploča zagrebačkoga kanonika i historiografa Tome Kovačevića (Križevci, 1664. - Zagreb, 1724.), znamenitoga po rukopisima o povijesti zagrebačke biskupije i prvostolnice, kao i zagrebačkim biskupima (Catalogus praesulum et canonicorum Zagrabiensium). Kovačević je

\footnotetext{
${ }^{534}$ Crveni mramor, $205 \times 117 \times 11,5 \mathrm{~cm}$, Zagreb, Hrvatski povijesni muzej, izvorno u katedrali Uznesenja Blažene Djevice Marije u Zagrebu. Kat. br. 44.

${ }^{535}$ Za detaljan prikaz Znikine naručiteljske aktivnost vidi: Danko Šourek, Donatorska i naručiteljska djelatnost zagrebačkoga kanonika Ivana Znike, u: Tkalčić: godišnjak Društva za povjesnicu Zagrebačke nadbiskupije = annales Societatis historicae archiepiscopatus Zagrabiensis IX, Zagreb: Društvo za povjesnicu Zagrebačke nadbiskupije »Tkalčić«, 2005., str. 327-410.

${ }^{536}$ Usp. Ivan Kukuljević Sakcinski, nav. dj., 1856., str. 32-33; Ivan Kukuljević Sakcinski, nav. dj., 1891., str. 346, br. 1189; Ivan Krstitelj Tkalčić, nav. dj., 1885., str. 75-76.

${ }^{537}$ Prema opisu unutrašnjosti katedrale Ivana Kukuljevića Sakcinskoga (1856.), ploča se sredinom XIX. stoljeća još uvijek nalazila na izvornome mjestu. Usp. Ivan Kukuljević Sakcinski, nav. dj., 1856., str. 32-33.

${ }_{538}$ Štit grba razdijeljen je na četiri jednaka polja. U prvom i četvrtom polju prikazani su brijeg s tri vrha $\mathrm{i}$ okrunjeni grifon. Drugo i treće polje razdijeljeno je dvjema poprečnim gredama između kojih se nalaze tri šestokrake zvijezde. Štit je ukrašen plaštem i dvama kacigama. Lijeva kaciga urešena je biskupskom mitrom i pastoralom, a desna krunom s ponovljenim motivom okrunjenoga grifona. Usp. Ivan von Bojničić, nav. dj., 1889., str. 210, tab. 152.
} 


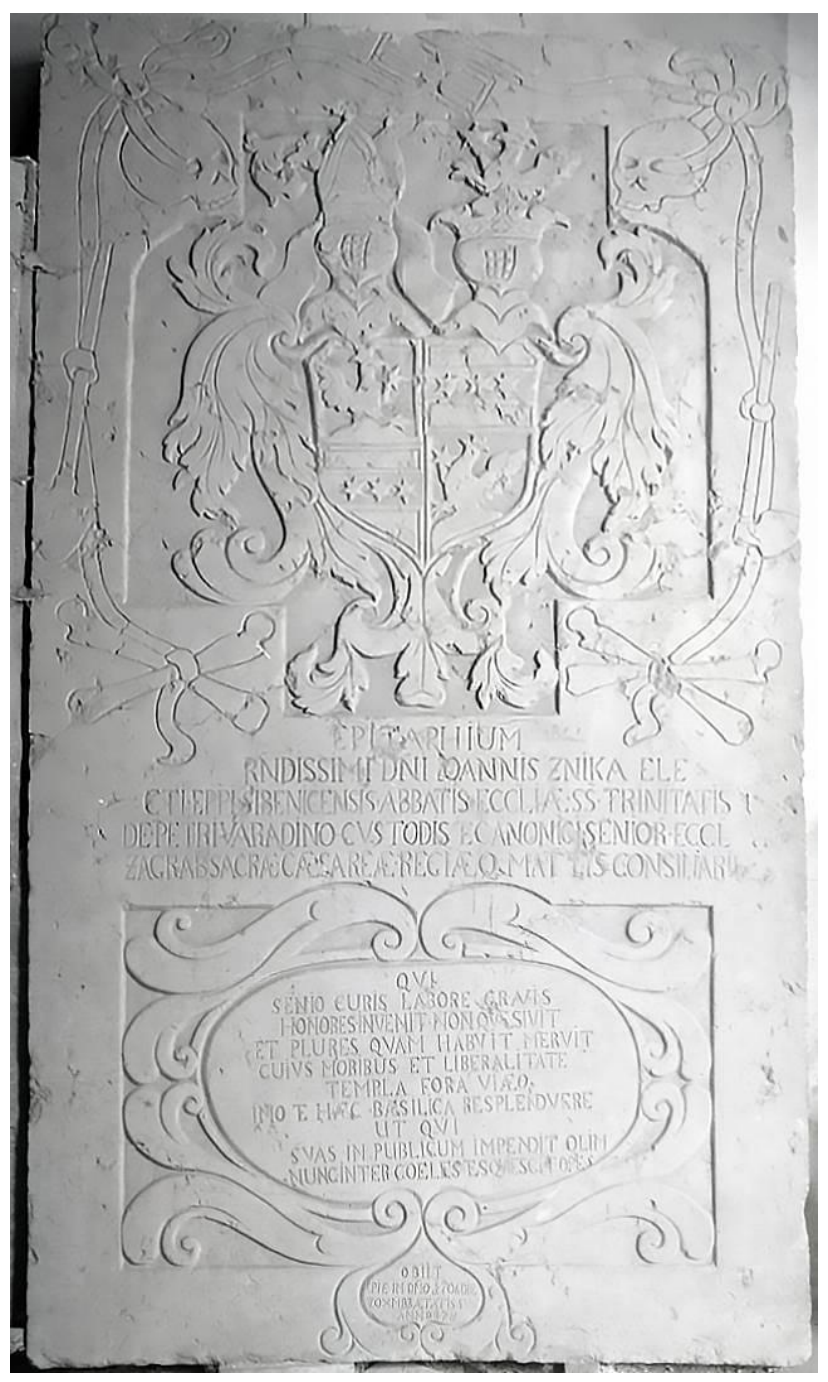

Slika 147. Nadgrobna ploča Ivana Znike (†1706.), Zagreb, Muzej grada Zagreba

pokopan u blizini grobnice kanonika Znike prema vlastitoj oporučnoj želji. ${ }^{539}$ Ploča koja je pokrivala njegov grob nije sačuvana, a najvjerojatnije je odstranjena u obnovi prvostolnice 1880. godine. ${ }^{540}$ Prema Ivanu Kukuljeviću Sakcinskome (1856., 1891.), sadržavala je pokojnikov grb (moguće sličan onome koji se nalazi na spomen-ploči postavljenoj na Kovačevićevoj kuriji na Kaptolu) te natpis o njegovim zaslugama i postignućima. ${ }^{541}$

Zagrebačka katedrala svojedobno je predstavljala najprestižnije mjesto na kojem su pripadnici plemstva i svećenstva mogli biti pokopani. Međutim, velikodostojnici su kao

\footnotetext{
${ }^{539}$ Usp. Vjekoslav Klaić, Tomo Kovačević, povjesničar hrvatski (1664.-1724.), u: Bogoslovska smotra XIII/1, Zagreb: Naklada »Katoličkog lista«, 1925., str. 69-91, 82.

${ }^{540}$ U opisu katedrale Ivana Kukuljevića Sakcinskoga iz 1856. godine, nadgrobna ploča u to se vrijeme još uvijek nalazila u crkvi. Prema opisu Ivana Krstitelja Tkalčića, godine 1885. već je bila odstranjena. Usp. Ivan Kukuljević Sakcinski, nav. dj., 1856., str. 33; Ivan Krstitelj Tkalčić, nav. dj., 1885., str. 76.

${ }^{541}$ Usp. Ivan Kukuljević Sakcinski, nav. dj., 1856., str. 33; Ivan Kukuljević Sakcinski, nav. dj., 1891., str. 349, br. 1203. Isti prijepis donijeli su Ivan Krstitelj Tkalčić (1885.) i Vjekoslav Klaić (1925.). Usp. Ivan Krstitelj Tkalčić, nav. dj., 1885., str. 76; Vjekoslav Klaić, nav. dj., 1925., str. 83.
} 
mjesto svojega posljednjeg počivališta odabirali i druge zagrebačke crkve. Jedna od njih bila je akademska crkva sv. Katarine na Gradecu. Ondje su, među ostalima, pokopani podgeneral Hrvatske i Primorske krajine Juraj IV. Frankapan Tržački (Bosiljevo?, o. 1620. - Karlovac, 1661.) i zapovjednik Vojne krajine Ivan Herbart X. Auersperg (?, 1613. - Zagreb, 1669.). Njihova tijela položena su u grobnice u svetištu crkve, a mjestā ukopa obilježena su brončanim grbovnim epitafima. Epitaf Jurja IV. Frankapana Tržačkoga (Slika 148) $)^{542}$ postavljen je na južnome, a onaj Ivana Herbarta X. Auersperga (Slika 149) ${ }^{543}$ na sjevernome zidu svetišta. Brončani nadgrobnici bili su rjeđi od onih izrađenih od kamena ili drva, a epitafi iz crkve sv. Katarine jedini su primjerci sačuvani na području Zagrebačke (nad)biskupije. Nadgrobnici dvojice vojnih časnika likovno su vrlo slično koncipirani. Vodoravno su podijeljeni na dvije polovice: u gornjoj su prikazani obiteljski grbovi, ${ }^{544}$

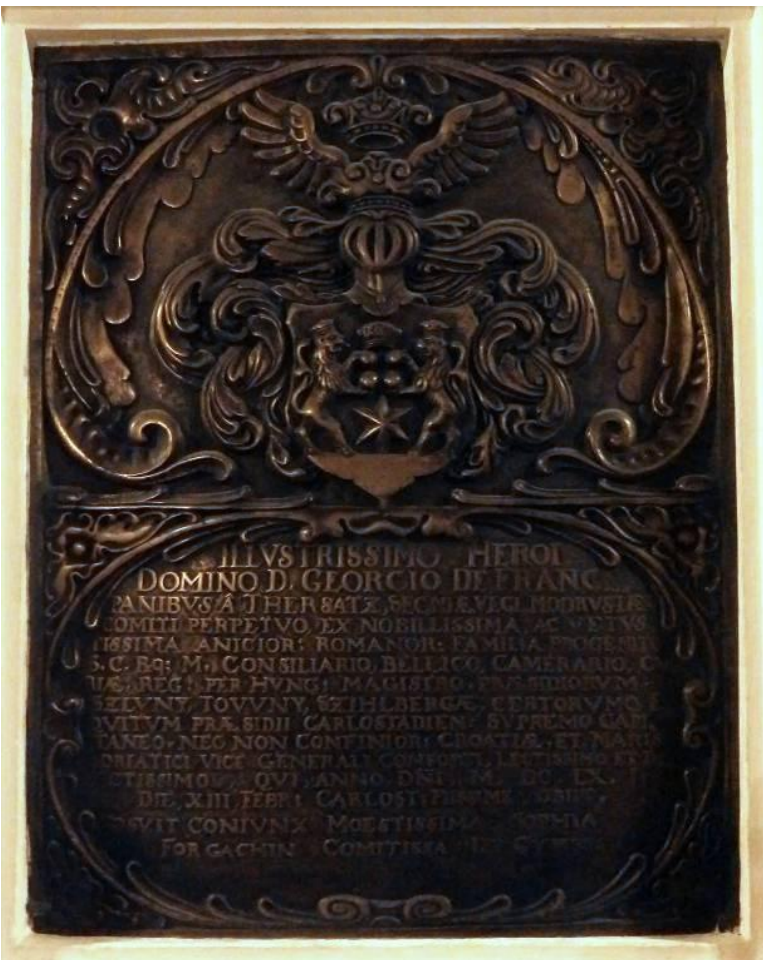

Slika 148. Epitaf Jurja IV. Frankapana Tržačkoga (†1661.), Zagreb, crkva sv. Katarine

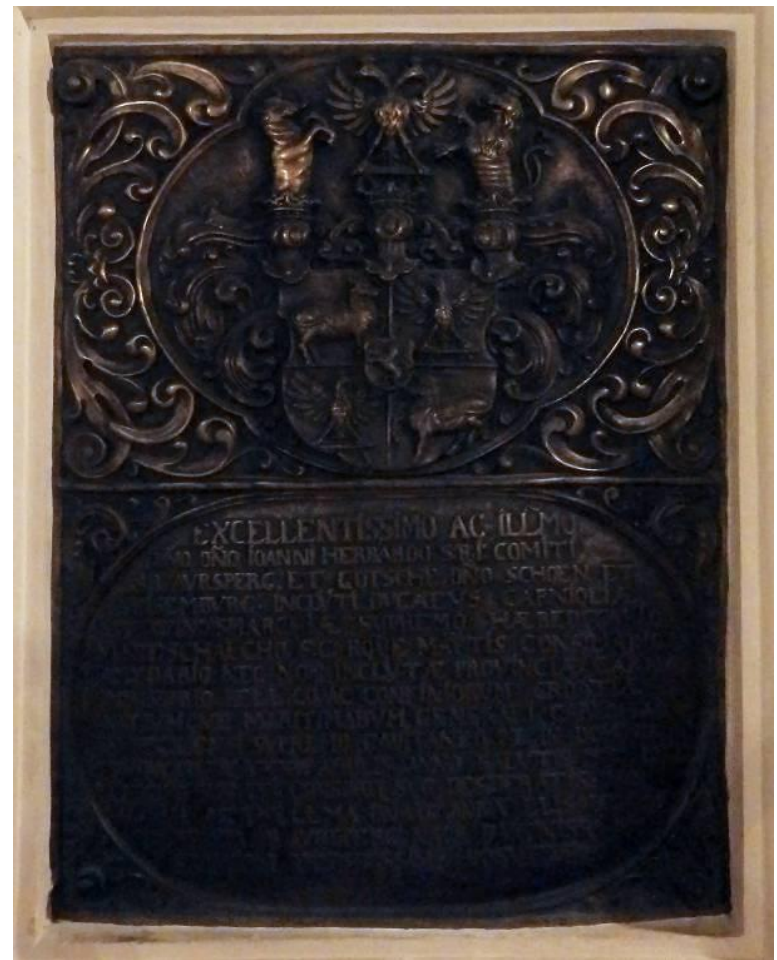

Slika 149. Epitaf Ivana Herbarta X. Auersperga (†1669.), Zagreb, crkva sv. Katarine

\footnotetext{
${ }^{542}$ Bronca, $122 \times 97 \mathrm{~cm}$, Zagreb, akademska crkva sv. Katarine. Kat. br. 47.

${ }_{543}$ Bronca, $134 \times 103 \mathrm{~cm}$, Zagreb, akademska crkva sv. Katarine. Kat. br. 48 .

${ }^{544}$ Grb obitelji Frankapan sastoji se od štita, plašta i kacige ukrašene parom krila i krunom. Na štitu je predočen par okrunjenih lavova koji u prednjim šapama drže po dvije štruce kruha. Povrh štruca nalazi se kruna, a ispod šestokraka zvijezda. Usp. Ivan von Bojničić, nav. dj., 1889., str. 48, tab. 35. Štit grba obitelji Auersperg razdijeljen je na četiri jednaka polja sa srcem štita (štitićem) u sredini. U prvome i četvrtome polju prikazano je govedo s kolutom u njušci, a u drugome i trećem okrunjeni orao na mesarskoj klupi. U srcu štita predočen je okrunjeni lav. Štit je ukrašen plaštem i trima kacigama s krunama. Iznad prve krune uzdiže se bik, iznad središnje dvoglavi okrunjeni orao, a iznad posljednje okrunjeni lav. Usp. Ivan von Bojničić, nav. dj., 1889., str. 6, tab. 5 .
} 
a u donjoj ovalne kartuše s posvetnim natpisima. Izuzev pojedinosti o životu pokojnikā, natpisi sadrže podatke o narudžbi spomenikā. U oba slučaja, nadgrobnike su dale podići supruge pokojnikā - Sofija Frankapan rođ. Forgách i Ana Elizabeta Auersperg rođ. Moscon. $\mathrm{Na}$ oba epitafa primijenjen je kasnomaniristički ornament koji se upotrebljavao u suvremenoj altaristici. Epitaf Frankapana Tržačkoga urešen je hrskavičastim cvjetovima i viticama s kralješastim elementima, ${ }^{545}$ a onaj Auersperga simetričnim prepletima vitica i manirističkom hrskavicom. ${ }^{546} \mathrm{U}$ kronici isusovačkoga reda zabilježene su posmrtne svečanosti koje su održane u crkvi u čast obojice pokojnika, a detaljnije su izložene u nastavku rada, u poglavlju posvećenom toj tematici.

Nakon što je Ivan Herbart X. Auersperg preminuo 1669. godine, na položaju karlovačkoga generala zamijenio ga je Ivan Josip Herberstein (Graz, 1633. - Graz, 1689.). Herberstein je u Karlovcu na prostoru današnjega Trga Josipa Jurja Strossmayera dao podići zgradu generalata i kapelu sv. Josipa (oko 1680.) u kojoj je pokopan prema oporučnoj želji. ${ }^{547}$ O kapeli su u početku skrbili franjevci, no nakon što je Karlovac proglašen slobodnim gradom (1778.), brigu o njoj preuzela je gradska vlast. Početkom XIX. stoljeća kapela se nalazila u vrlo lošem stanju zbog čega ju je grad odlučio srušiti (1833.), a njezin inventar prenesen je u franjevačku crkvu, uključujući nadgrobnu ploču (Slika 150) ${ }^{548}$ koja je pokrivala Herbersteinov grob. Ploča je ugrađena $u$ zid lađe na uzlazu u kapelu sv. Antuna Padovanskoga, gdje se nalazi i danas. Njezin osnovni likovni motiv je grb obitelji Herberstein $^{549}$ koji je okružen ratnim trofejima (topovima, bubnjevima, zastavama, kopljima, sabljama, oklopom i šatorom). Prema Anđeli Horvat (1975.), »u nakitu grba i popratnim ratnim rekvizitima [...] prisutno je barokno oblikovanje «. ${ }^{550}$ Ispod grba uklesan je nadgrobni

\footnotetext{
${ }^{545}$ Usp. Anđela Horvat, nav. dj., 1975., str. 343; Zorislav Horvat, nav. dj., 2002., str. 51. Sličan ornament upotrijebljen je, primjerice, na oltaru sv. Wolfganga (o. 1650.) iz kapele istoimenoga sveca u Vukovoju, oltaru sv. Marije (o. 1670.) iz kapele sv. Duha u Prigorcu ili oltaru sv. Barbare (1675.) iz kapele istoimene svetice u Brestu Pokupskom. Usp. Martina Wolff Zubović, nav. dj., sv. 2, 2017., str. 215-217, 239-240, 245-246.

${ }^{546} \mathrm{U}$ literaturi se često navodi da ornament primijenjen na Auerspergovu epitafu ima oblike ranoga baroka. Usp. Anđela Horvat, nav. dj., 1975., str. 343. Sličan ornament simetričnih vitica upotrijebljen je na glavnome oltaru (1660.) kapele Uznesenja Blažene Djevice Marije u Gornjemu Tkalcu ili oltaru sv. Fabijana i Sebastijana (1661.) iz kapele posvećene dvama svecima u Slanome Potoku. Usp. Martina Wolff Zubović, nav. dj., sv. 2, 2017., str. 225-229.

${ }^{547}$ Usp. Radoslav Lopašić, Karlovac: poviest i mjestopis grada i okolice, Karlovac: Matica hrvatska, 1879., str. 206.

${ }_{548}$ Kamen, $168 \times 84 \times 12 \mathrm{~cm}$, Karlovac, crkva Presvetoga Trojstva, izvorno u kapeli sv. Josipa. Kat. br. 5 .

${ }^{549}$ Grb se sastoji od štita, plašta izvedenoga u obliku voluta i krune. Štit je okomito razdijeljen jednom, a vodoravno dva puta, sa srcem štita (štitićem) u sredini. U prvom i četvrom polju prikazan je vuk. Drugo i peto polje dodatno su podijeljena na lijevu i desnu polovicu. Na heraldički desnoj polovici prikazana je kula, a lijevoj poprečna greda. U trećem i šestom polju predočena je konjska orma. Srce štita razdijeljeno je rožnikom (okrenutim slovom V). Usp. Ivan von Bojničić, nav. dj., 1889., str. 61, tab. 45; Vlasta Brajković, nav. dj., 1976., str. 33 .

${ }_{550}$ Anđela Horvat, nav. dj., 1975., str. 344. Autorica je pogreškom navela da je nadgrobnik izrađen u bronci, a ne kamenu.
} 
natpis koji zauzima dvije trećine spomenika, što svjedoči o porastu važnosti pisane riječi. Natpis sadrži podatak da je nadgrobnik dao izraditi pokojnikov nećak, feldmaršal Ivan Ferdinand Josip Herberstein (?, 1663. - Graz, 1721.).

U XVII. stoljeću počeo se primjenjivati novi oblik epitafa koji je koncipiran kao edikula odnosno tabernakul, a nastao je pod utjecajem renesansne arhitekture. Isti se oblik primjenjivao i u umjetničkom obrtu, posebice u izradi okvira za slike. ${ }^{551}$ Jedan od najstarijih primjeraka sačuvanih na području povijesne Zagrebačke biskupije jest epitaf Nikole (Miklósa) Istvánffyja (Kisasszonyfalva kod Pečuha, 1524. - Vinica, 1615.) i njegove supruge Elizabete rođ. Both de Bajna (? - ?, 1597.) (Slika 151 $)^{552}$ koji se nalazi u crkvi sv. Marka evanđelista u Vinici. Istvánffy je bio ugarski državnik, povjesničar i gorljiv zagovornik

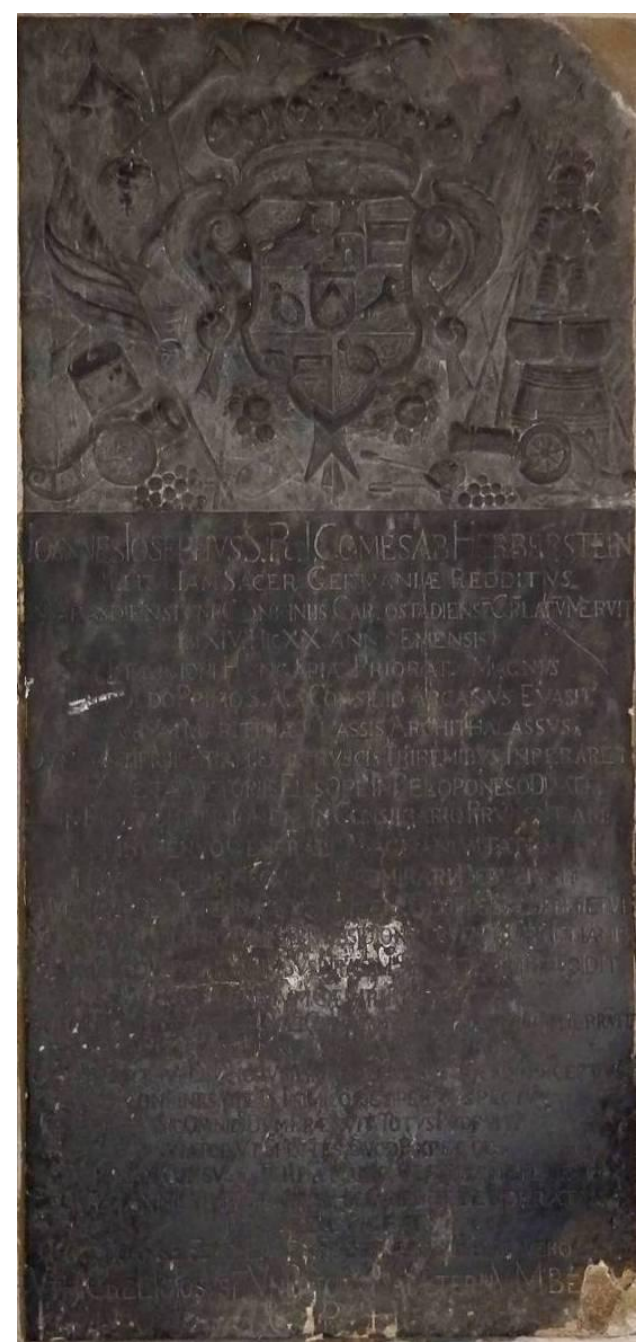

Slika 150. Nadgrobna ploča Ivana Josipa Herbersteina (†1689.), Karlovac, crkva Presvetoga Trojstva

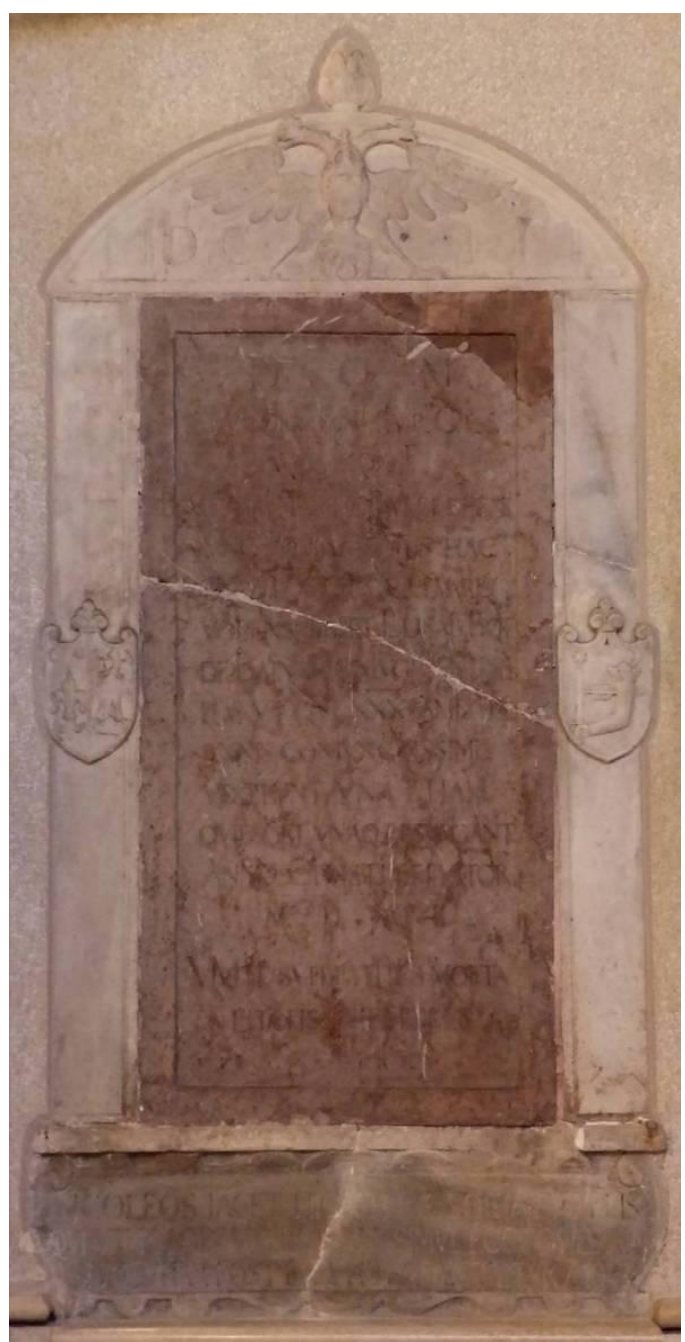

Slika 151. Epitaf Nikole Istvánffyja $i$ Elizabete rod. Both de Bajna, 1603., Vinica, crkva sv. Marka evanđelista

\footnotetext{
${ }^{551}$ Usp. D. Gene Karraker, Looking at European Frames: A Guide to Terms, Style, and Techniques, Los Angeles: J. Paul Getty Museum, 2009., str. 78.

${ }^{552}$ Mramor, $325 \times 135 \mathrm{~cm}$, Vinica, crkva sv. Marka Evanđelista. Kat. br. 71.
} 
Katoličke obnove koji je sudjelovao u bitkama protiv Osmanlija kod Sigeta (1566.) i Petrinje (1594.). ${ }^{553}$ Poznije godine života proveo je na viničkome posjedu koji je naslijedio od majke Hedvige Gyulay, gdje je naposljetku i preminuo. Pokopan je u staroj župnoj crkvi u kapeli sv. Andrije, a njegovo je tijelo položeno u obiteljsku grobnicu. ${ }^{554}$ Prije nego što je stara crkva porušena (1808.), epitaf je izvađen te je izgradnjom nove crkve ugrađen u sjeverni zid svetišta kod ulaza u sakristiju. Središnje polje edikule i njezino podnožje ispunjeni su natpisom koji sadrži podatak da je epitaf podignuo sam Istvánffy za preminulu suprugu i sebe »želeći poštedjeti potomke te brige« (HAC CVRA POSTEROS LEVARE VOLENS). ${ }^{555}$ Godina nastanka spomenika (1603.) uklesana je u luneti koja sadrži simbol obitelji Istvánffy dvoglavoga okrunjenog orla. Grbovi obitelji Istvánffy ${ }^{556}$ i Both de Bajna ${ }^{557}$ nalaze se na nosačima edikule, a prikazani su na štitovima ukrašenima volutama i ljiljanom.

Na području Hrvatskoga zagorja sačuvana su još dva nadgrobnika iz XVII. stoljeća koja su oblikovana kao edikule. Prvi od njih je epitaf Gašpara Bedekovića (? - ?, 1656.) (Slika 152) $)^{558}$ koji je pokopan u franjevačkoj crkvi sv. Katarine u Krapini. Prema natpisu, nadgrobnik je podignuo njegov brat Melkior, a postavljen je na sjevernome zidu broda crkve. Izveden je u obliku edikule postavljene na volutne konzole, koja je zaključena parom voluta. U središnjem dijelu uklesana je polukružno zaključena niša unutar koje se nalazi grb obitelji Bedeković $^{559}$ i nadgrobni natpis ispisan u distisima.

Drugi epitaf podignut je za baruna Ivana Petheőa de Gerse (? - ?, 1671.) (Slika 153), ${ }^{560}$ gospodara belsko-ivanečkoga vlastelinstva, koji je pokopan 1672. godine u svetištu nekadašnje pavlinske crkve u Lepoglavi. ${ }^{561}$ Nadgrobnik je naručila pokojnikova supruga Judita rođ. Balagović de Japra, ${ }^{562}$ a postavljen je na sjevernome zidu svetišta, iznad

\footnotetext{
${ }^{553}$ Njegovo djelo Historiarum de rebus Ungaricis libri XXXIV, ab anno 1490 ad annum 1605 (1622.) jedan je od glavnih izvora za istraživanje povijest Hrvatsko-Ugarskoga Kraljevstva u XVI. stoljeću. Usp. Božidar Brezinščak Bagola, Ivan Cesarec i Mladen Klemenčić (ur.), Enciklopedija Hrvatskoga zagorja, Zagreb: Leksikografski zavod »Miroslav Krleža«, 2017., sub voce Istvánffy, Nikola (Miklós), str. 327 [Krešimir Regan]. ${ }^{554}$ Usp. Anđelko Košćak, nav. dj., 2013., str. 42; Milan Pelc, nav. dj., 2006., str. 75.

${ }_{555}$ Za puni prijepis natpisa vidi kat. br. 71. Godina Istvánffyjeve smrti najvjerojatnije je naknadno uklesana.

556 Śtit je raskoljen na lijevu i desnu polovicu. Na heraldički desnoj polovici prikazan je ljiljan povrh kojeg se nalaze polumjesec i šestokraka zvijezda. U podnožju lijeve polovice predočena je kruna povrh koje se nalazi orao raširenih krila. Usp. Ivan von Bojničić, nav. dj., 1889., str. 73, tabl. 52.

${ }^{557} \mathrm{Na}$ štitu je prikazana oklopljena ruka probodena strijelom koja drži mač. Vrh ruke zaključen je krunom. Povrh krune nalaze se šesterokraka zvijezda i polumjesec. Usp. Ivan von Bojničić, nav. dj., 1889., str. 20, tab. 15.

${ }^{558}$ Kamen, dimenzije neznane, Krapina, crkva sv. Katarine. Kat. br. 7.

${ }^{559}$ Grb se sastoji od štita, plašta, kacige i krune s ukrasom. U podnožju štita prikazana je gornja polovica kotača s pet žbica. Povrh kotača nalazi se oklopljena ruka koja drži sablju. Isti motivi kotača i ruke sa sabljom ponovljeni su u ukrasu krune. Usp. Ivan von Bojničić, nav. dj., 1889., str. 13, tab. 10.

${ }^{560}$ Mramor, pozlata, $285 \times 120 \mathrm{~cm}$, Lepoglava, crkva Bezgrješnog začeća Blažene Djevice Marije. Kat. br. 55.

${ }^{561}$ Usp. Kamilo Dočkal, nav. dj., 2014., str. 269.

562 Ovi podatci poznati su iz natpisa na epitafu. Za puni prijepis vidi kat. br. 55. Nakon suprugove smrti, Judita Petheő de Gerse obilno je darovala crkvu lepoglavskih pavlina. Godine 1672. dala je sagraditi oltar Blažene
} 


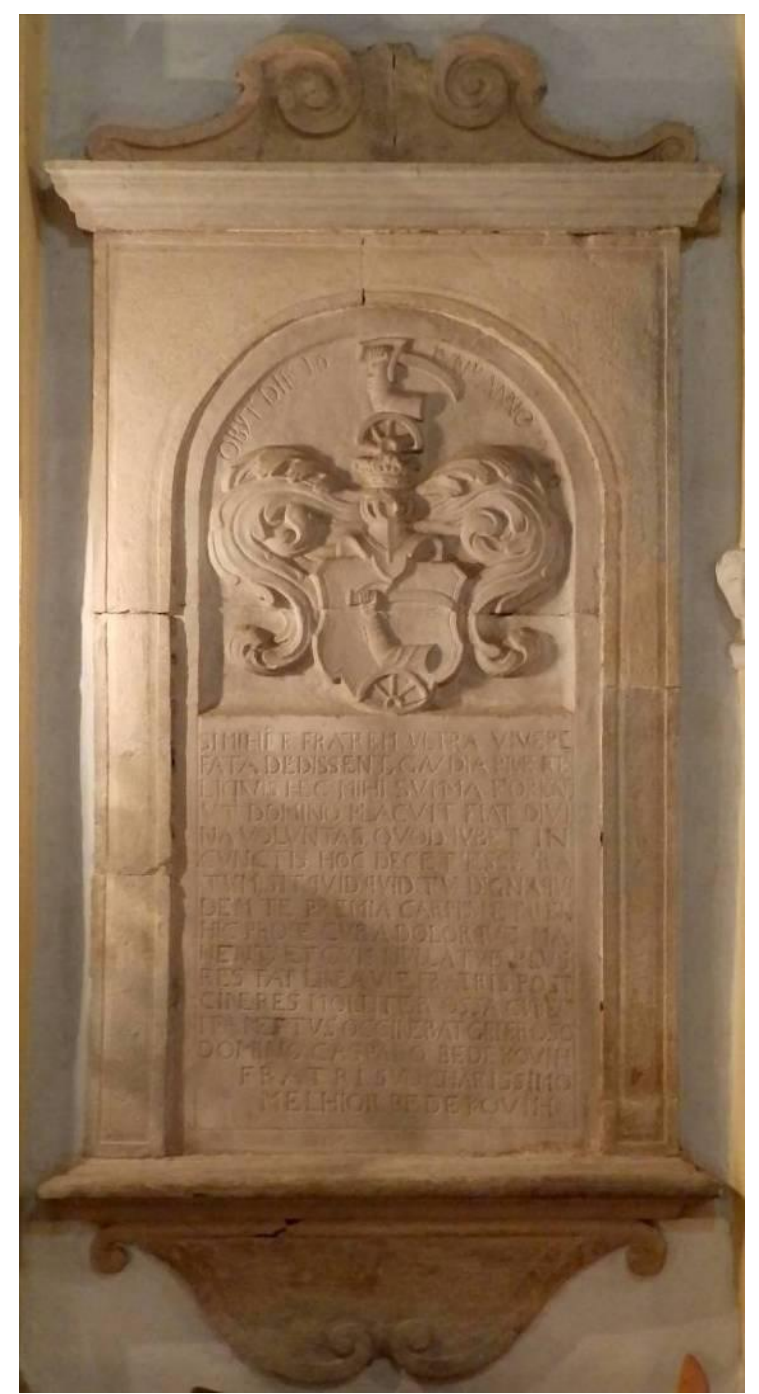

Slika 152. Epitaf Gašpara Bedekovića (†1656.), Krapina, crkva sv. Katarine

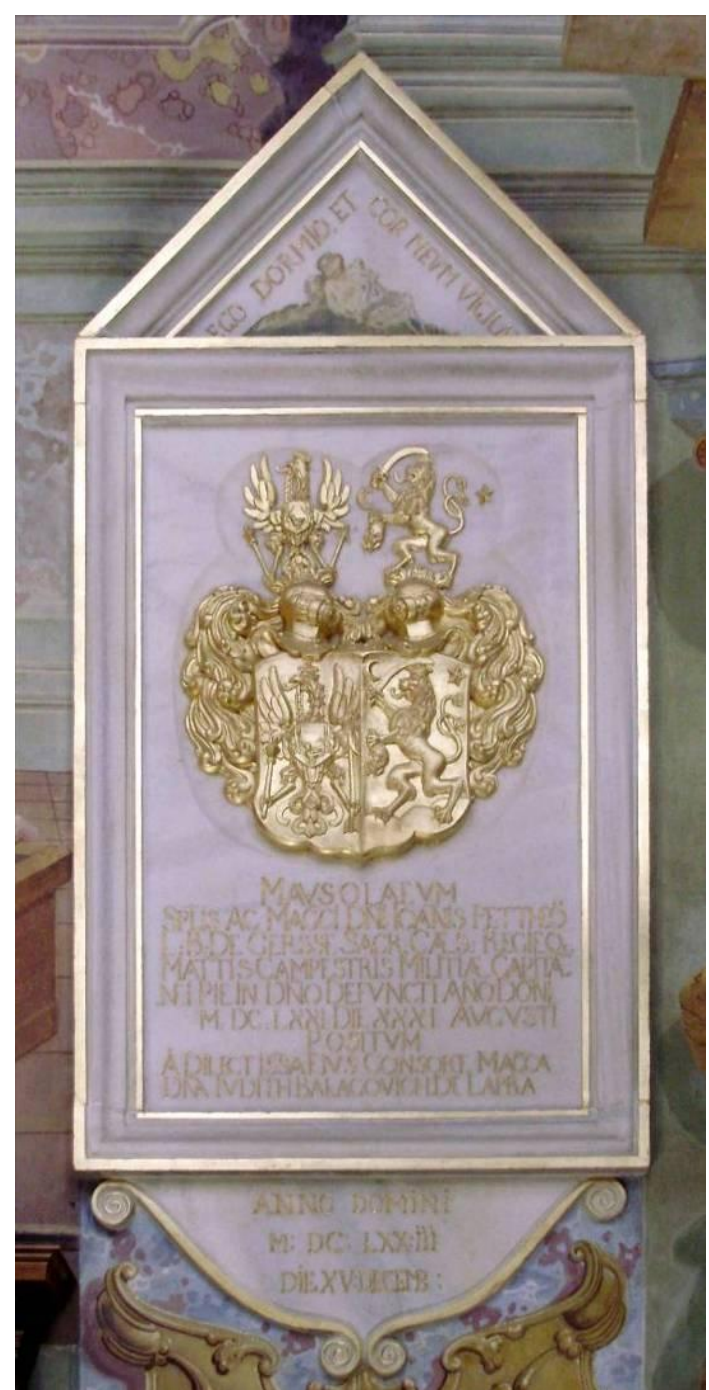

Slika 153. Epitaf Ivana Petheöa de Gerse, 1673., Lepoglava, crkva Bezgrješnoga začeća Blažene Djevice Marije

nekadašnjega ulaza u sakristiju. Oblikovan je kao stilizirana edikula, a sastoji se od središnjega pravokutnog polja postavljenoga na volutnu konzolu, koje je zaključeno jednostavnim zabatom. U središnjem dijelu nalazi se združeni grb obitelji Petheő de Gerse i Balagović $^{563}$ ispod kojega je ispisan posvetni natpis. U zabatu je predočen usnuli lik muškarca iznad kojega je citat iz Salomonove Pjesme nad pjesmama: »EGO DORMIO, ET COR

Djevice Marije Čenstohovske (nije sačuvan), a godine 1673. podigla je bočnu kapelu Muke Kristove (nazivane i Kapela mrtvih) koju je opremila oltarom Žalosne Marije (1676.). Redu je podarila i misno ruho ukrašeno dragocjenim kamenjem. Usp. Kamilo Dočkal, nav. dj., 2014., str. 206, 209, 253.

${ }^{563}$ Grb se sastoji od štita koji je ukrašen plaštem i dvama kacigama s nakitom. Štit je okomito razdijeljen na dva polja. U prvome se nalazi simbol obitelji Petheö de Gerse - okrunjeni orao raširenih krila koji u desnoj kandži drži žezlo, u lijevoj strijelu, a na prsima nosi štit s patkom između dva šaša. Usp. Ivan von Bojničić, nav. dj., 1889., str. 145, tab. 104. U drugome polju prikazan je simbol obitelji Balagović - polumjesec, zvijezda i lav koji u desnoj šapi drži sablju, a u lijevoj odrubljenu ljudsku glavu. Usp. Ivan von Bojničić, nav. dj., 1889., str. 9, tab. 7. Nakit kaciga izveden je u obliku ponovljenih motiva sa štita. 
MEVM VIGILAT.« (Ja spavam, ali srce moje bdi. Pj 5,1 $)^{564}$ Nadgrobnik je izveden u bijelome kamenu, a rubovi arhitektonskih elemenata, grb i natpis su pozlaćeni.

Iz XVIII. stoljeća sačuvan je skromniji broj grbovnih nadgrobnika u odnosu na prethodno razdoblje. U pravilu, nastavljaju se primjenjivati ista likovna rješenja koja su se upotrebljavala dotad. Najjednostavnije je ono koje sadrži detaljno izveden obiteljski grb i nadgrobni natpis, kao na nadgrobnoj ploči Ljudevita I. Erdődyja (?, 1694. - ?, 1753.) (Slika 154). ${ }^{565}$ Edődy je bio banski namjesnik, general-major i veliki župan Požeške županije, a pokopan je u franjevačkoj crkvi sv. Leonarda u Kotarima u lađi crkve. ${ }^{566}$ Iznad njegova groba postavljena je ploča i jedna je od rijetkih koja se još uvijek nalazi in situ. Osnovni likovni motiv je reljefno izveden grb obitelj Erdődy koji se sastoji od štita i tri kacige s ukrasom, ${ }^{567}$ a dodatno je urešen pojednostavljenim viticama.

U Hrvatskome povijesnome muzeju pohranjena je nadgrobna ploča Dimitrija Mihalovića (?, 1758. - ?, 1763.) (Slika 155), ${ }^{568}$ petogodišnjega dječaka iz plemićke obitelji Mihalović koja je posjedovala vlastelinstvo Orahovica-Feričanci i Čepin. Izvorno pravoslavci srpskoga podrijetla, Mihajlovići su u prvoj polovini XVIII. stoljeća prihvatili rimokatoličku vjeru i promijenili prezime. ${ }^{569}$ Poznato je da je ploča dopremljena iz Orahovice, no ne i iz koje crkve. ${ }^{570} \mathrm{~S}$ obzirom na vrijeme smrti, Dimitrij je mogao biti pokopan u župnoj crkvi Našašća Svetoga Križa ili crkvi sv. Lovre u Crkvarima. Na nadgrobniku, obiteljski grb ${ }^{571}$

\footnotetext{
${ }^{564}$ Opisujući spomenik, Gjuro Szabo zapisao je da su »u zabatu u relijefu [sic] prikazane dvije spojene ruke«. Usp. Gjuro Szabo, nav. dj., 1919., str. 36. Sličan opis donio je i Ivan Kukuljević Sakcinski. Usp. Ivan Kukuljević Sakcinski, nav. dj., 1891., str. 124, br. 413.

${ }^{565}$ Kamen, $140 \times 115 \mathrm{~cm}$, Kotari, crkva sv. Leonarda. Kat. br. 6 .

${ }^{566}$ Erdődyjevi su bili utemeljitelji i pokrovitelji kotarskih franjevaca. Franjevci su sagradili samostansku crkvu (1733. - 1735.) na mjestu drvene zavjetne kapele sv. Leonarda koju je Petar I. Erdődy (?, 1463. -?, 1547.) podignuo nakon što mu se svetac ukazao u šumi. Usp. Đurđica Cvitanović, Arhitektura franjevačke provincije hrvatsko-kranjske Sv. Križa, u: Mir i dobro: umjetničko i kulturno naslijeđe Hrvatske franjevačke provincije sv. Ćirila i Metoda o proslavi stote obljetnice utemeljenja, Zagreb: Galerija Klovićevi dvori, 2000., str. 193-204, 199. Uredili Marija Mirković i Franjo Emanuel Hoško; Gordana Remussini, Samostan i crkva svetog Leonarda u Kotarima, u: Zbornik 2010.11. Ogranak Matice hrvatske u Samoboru, Samobor: Ogranak Matice hrvatske u Samoboru, 2010., str. 24-30, 24-25. Uredio Milan Žegarac Peharnik.

567 Štit grba razdijeljen je na četiri jednaka polja, sa srcem štita (štitićem) smještenim u sredini. U prvome polju predočen je okrunjeni orao, u drugome i trećemu dvije šestokrake zvijezde omeđene dvjema valovitim gredama, a u četvrtome kula s grudobranom. U srcu štita nalazi se stari grb obitelji Bakač s jelenom i kotačem. Štit je ukrašen trima kacigama s nakitom. Iznad bočnih kaciga uzdižu se oklopljene ruke s mačevima, a iznad središnje orao. Usp. Ivan von Bojničić, nav. dj., 1889., str. 44, tab. 33.

${ }^{568}$ Vapnenačka breča, $100 \times 79 \times 16 \mathrm{~cm}$, Zagreb, Hrvatski povijesni muzej, izvorno postavljena u Orahovici (nepoznato u kojoj crkvi). Kat. br. 83.

${ }^{569}$ Usp. Mirko Valentić, nav. dj., 1969., str. 104; Mirko Valentić i Lada Prister, nav. dj., 2002., str. 65.

${ }^{570}$ Isto.

${ }^{571}$ Grb se sastoji od obiteljskoga simbola - konjanika, plašta i krune ukrašene dvorepim lavom koji u šapi drži sablju. Usp. Ivan von Bojničić, nav. dj., 1889., str. 119, tab. 85.
} 


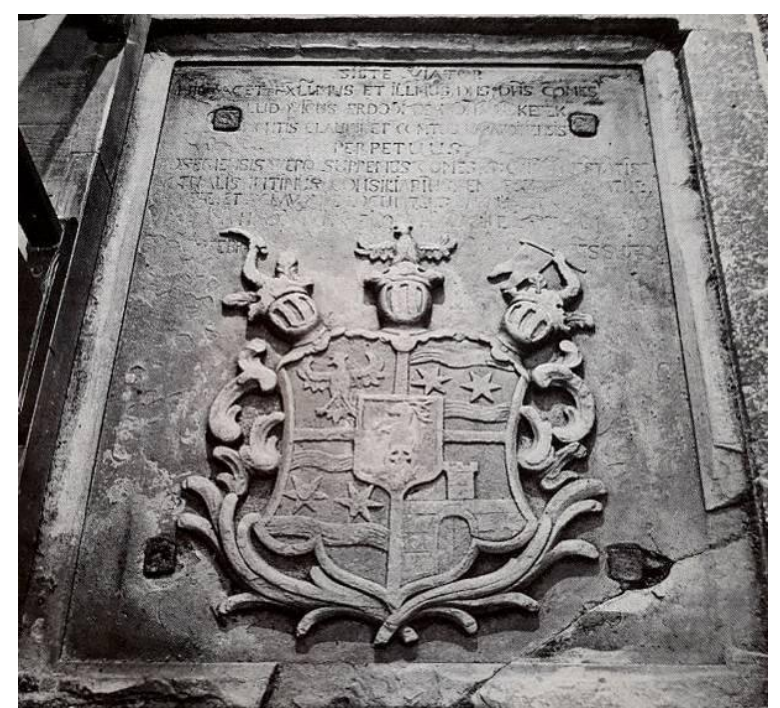

Slika 154. Nadgrobna ploča Ljudevita I.

Erdödyja (†1753.), Kotari, crkva sv. Leonarda

(desno) Slika 155. Nadgrobna ploča Dimitrija Mihalovića (†1763.), Zagreb, Hrvatski povijesni muzej

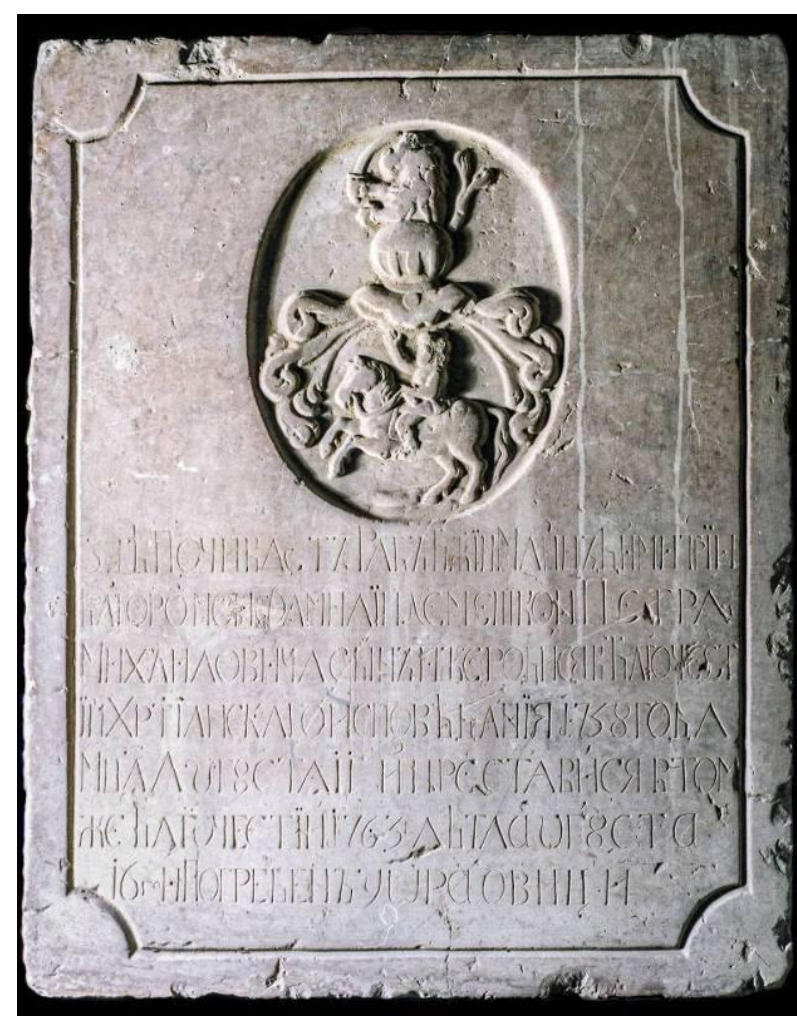

predočen je unutar ovala, a ispod njega ispisan je natpis na ćirilici, što ploču čini jedinim nadgrobnikom očuvanim na području povijesne Zagrebačke biskupije koji je pisan na ćiriličkom pismu, a izvorno se nalazio u rimokatoličkoj crkvi. ${ }^{572}$

U sakristiji župne crkve Uznesenja Blažene Djevice Marije u Stenjevcu nalazi se nadgrobna ploča potpukovnika Vuka Jelačića $\left(?-\right.$ ?, 1770.) (Slika 156) ${ }^{573}$ koja je nekoć pokrivala njegov grob u lađi crkve. ${ }^{574} \mathrm{~S}$ izvornoga mjesta odstranjena je u popravcima građevine koji su uslijedili nakon potresa 1880. godine. ${ }^{575}$ Ploča sadrži grb obitelji Jelačić ${ }^{576}$ koji je ukrašen volutnim viticama i flankiran geslom: »Vivit Post / Funera Virtus« (Krepost živi $i$ nakon smrti). Prema natpisu ispisanom ispod grba, spomenik je podigla pokojnikova obitelj sedam godina nakon njegove smrti (1777.). ${ }^{577}$

Među grbovnim nadgrobnicima XVIII. stoljeća, kvalitetom izvedbe ističe se epitaf isusovačkoga teologa i povjesničara Franje Ksavera Pejačevića (Osijek, 1707. - Požega,

\footnotetext{
${ }^{572}$ Usp. Mirko Valentić, nav. dj., 1969., str. 104; Mirko Valentić i Lada Prister, nav. dj., 2002., str. 65.

${ }_{574}^{573}$ Kamen, $142 \times 83$ cm, Stenjevec, crkva Uznesenja Blažene Djevice Marije. Kat. br. 26.

574 Prema kanonskim vizitacijama, u crkvi je postojalo pet kripti. Jedna se nalazila u svetištu i ondje su se pokapali župnici, a preostale su bile smještene u lađi crkve. Usp. Anđela Horvat, nav. dj., 1985.a, str. 98.

575 Detaljnije o radovima vidi: Anđela Horvat, nav. dj., 1985.a, str. 104.

${ }^{576}$ Grb se sastoji od štita, plašta te kacige s krunom i ukrasom. Na štitu su prikazana dva okrunjena lava koji u prednjim šapama drže mač na koji je nabijena odsječena osmanska glava. U nakitu kacige nalazi se okrunjeni lav s krilima koji drži sablju i kraljevsku jabuku. Usp. Ivan von Bojničić, nav. dj., 1889., str. 83, tab. 55.

${ }^{577}$ U natpisu su navedeni pokojnikova supruga, sinovi, kćeri i zetovi (»MONUMENTUM HOC IN / Perpetuam Meomoriam Marito Con / jux, IV. Fily et V. Filia Patri, II. Gen / eri Socero Hoc loco quiescenti posu / ere Ao Dni MDCCLXXVII«). Za puni prijepis natpisa vidi kat. br. 26.
} 
1781.) (Slika 157). ${ }^{578}$ Pejačević je pokopan u nekadašnjoj isusovačkoj crkvi sv. Lovre u Požegi, u grobnici namijenjenoj ukopu članova Družbe Isusove koja se nalazila ispod lauretanske kapele prigrađene (1725. - 1726.) uz sjeverni zid bočnoga broda crkve. ${ }^{579}$ Nadgrobnik je najvjerojatnije bio postavljen u blizini ulaska u grobnicu. Nakon što je kapela porušena između 1834. i 1839. godine u sklopu radova kojima je samostanski sklop prenamijenjen u nadbiskupijsko sirotište, ${ }^{580}$ epitaf je ugrađen u zid desno od oltara Blažene Djevice Marije koji se nalazio u bočnome brodu. ${ }^{581}$ Tijekom restauracije crkve osamdesetih i devedesetih godina XX. stoljeća, nadgrobnik je privremeno pohranjen u Muzej Požeške kotline (danas Gradski muzej Požega), a nakon završetka radova vraćen je i ugrađen u zid lijevo od ulaza u crkvu. ${ }^{582} \mathrm{Na}$ njemu je predočen grb obitelji Pejačević u pročišćenoj,

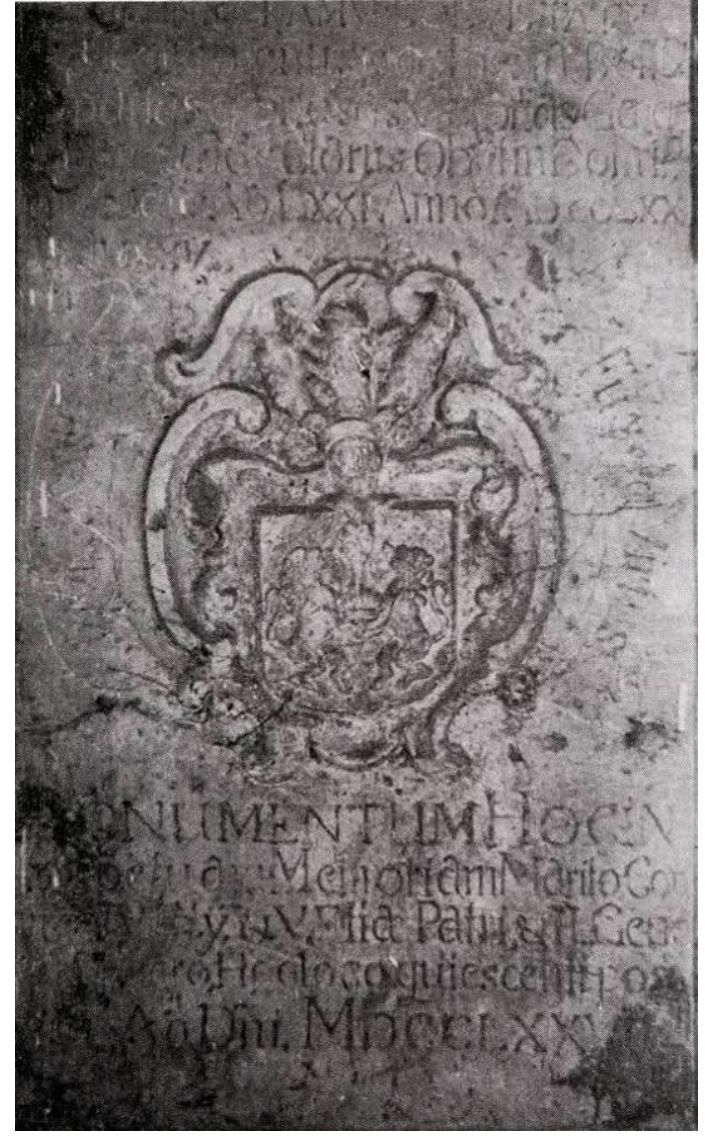

Slika 156. Nadgrobna ploča Vuka Jelačića, 1777., Stenjevec, crkva crkva Uznesenja Blažene Djevice Marije

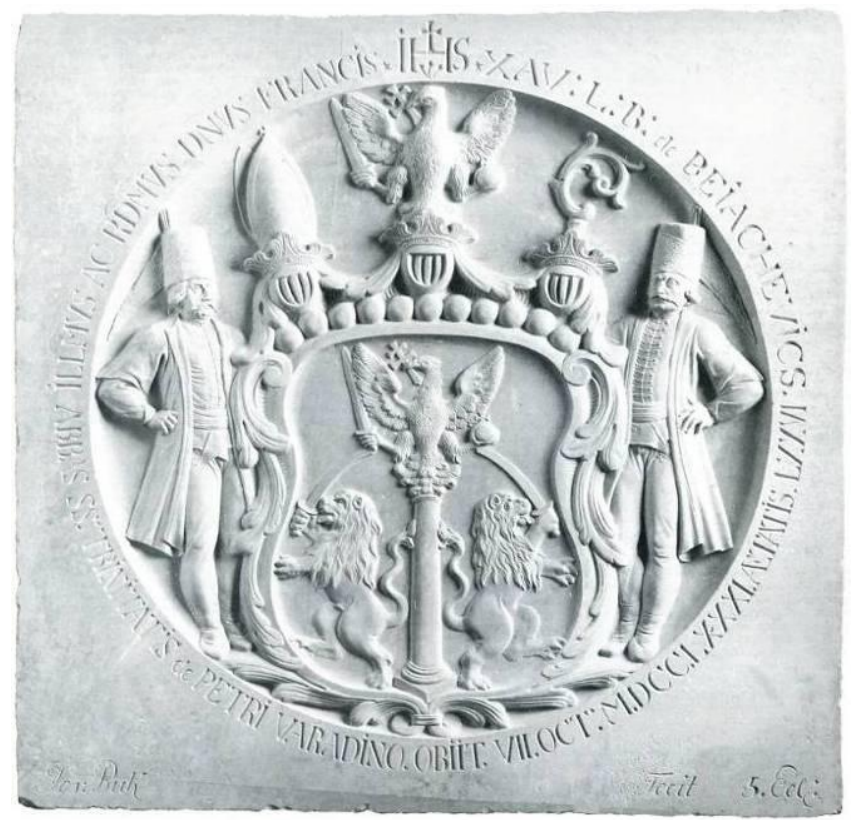

Slika 157. Josip Buk, Epitaf Franje Ksavera Pejačevića (†1781.), Požega, crkva sv. Lovre

\footnotetext{
${ }^{578}$ Kamen, $62 \times 62 \mathrm{~cm}$, Požega, crkva sv. Lovre. Kat. br. 85 .

${ }^{579}$ Usp. Ivan Srša, Požega, crkva sv. Lovre, Zagreb: Ministarstvo kulture, Uprava za zaštitu kulturne baštine, 2005., str. 61.

${ }^{580}$ Usp. Ivan Srša, nav. dj., 2005., str. 64-65.

${ }^{581}$ Usp. Julije Kempf, nav. dj., 1910., str. 527.

${ }^{582} \mathrm{Na}$ ovim podatcima zahvaljujem kustosici Odjela povijesti umjetnosti Gradskoga muzeja Požega, muzejskoj savjetnici Lidiji Španiček.
} 
klasicizirajućoj formi. Grb se sastoji od štita, točenice, kaciga s ukrasima i čuvara u liku muškaraca odjevenih u suvremenu odjeću. ${ }^{583}$ Reljefno je izveden unutar okrugloga polja oko kojeg je ispisan posvetni natpis. Uz donji rub epitafa uklesano je ime kipara koji ga je izradio (»Jos: Buk / Fecit«), što ga - uz nadgrobnu ploču Luke de Szegeda (Slika 25) - čini jednim od dva nadgrobnika s područja povijesne Zagrebačke biskupije koji sadrže potpis autora. Izuzev imena, zasad nisu poznati drugi podatci o životu i radu majstora Josipa Buka. ${ }^{584}$

Osim nadgrobnika na kojima je primijenjeno jednostavno grbovno rješenje, u XVIII. stoljeću nastavili su se upotrebljavali epitafi izvedeni u obliku stiliziranih edikula. Jedan od njih je epitaf baruna Baltazara III. Patačića (Vidovec, 1663. - Zagreb, 1719.) i njegove supruge Terezije rođ. Gereczy (?, 1675. - Rakovec, 1722.) (Slika 158). ${ }^{585}$ Postavljen je u kapeli sv. Antuna Padovanskoga koju je bračni par podignuo kao obiteljsku grobnu kapelu uz nekadašnju franjevačku, danas župnu crkvu Kraljice Svete Krunice u Remetincu kod Novoga Marofa. ${ }^{586}$ Ulaz u kriptu pokriven je jednostavnom nadgrobnom pločom (Slika 159) ${ }^{587} \mathrm{~s}$ grbom obitelji Patačić i kronogramom koji daje 1697. godinu. ${ }^{588}$ Epitaf koji je ugrađen u istočni zid kapele dao je postaviti njihov sin Aleksandar Antun Marija Patačić (Remetinec, 1697. - Beč, 1747.) neposredno nakon majčine smrti. ${ }^{589}$ Središnji dio edikule izveden je kao jednostavan profilirani okvir koji je položen na konzolu ukrašenu volutama, a zaključen je konveksno oblikovanom lunetom. Unutar lunete prikazan je obiteljski grb ukrašen plaštem i krunom. ${ }^{590}$ Poljā središnjega dijela i konzole ispunjeni su natpisom koji sadrži detalje života

\footnotetext{
${ }^{583} \mathrm{Na}$ štitu grba predočen je stup na kojem stoji orao. U kljunu drži dvostruki križ, a u kandžama mač i kraljevsku jabuku. Stup je flankiran dvama lavovima koji u prednjim šapama drže sablju. Na štit naliježe točenica, a na nju tri kacige. Bočne kacige ukrašene su biskupskim simbolima (lijeva mitrom, desna pastoralom), a središnja kaciga ponovljenim motivom orla koji u kandžama drži mač i jabuku, a u kljunu dvostruki križ. Usp. Ivan von Bojničić, nav. dj., 1889., str. 142, tab. 103.

${ }^{584}$ Usp. Doris Baričević, Barokno kiparstvo u isusovačkim crkvama u Hrvatskoj, u: Isusovačka baština u Hrvata: u povodu 450-te obljetnice osnutka Družbe Isusove i 500-te obljetnice rođenja Ignacija Loyole, Zagreb: Muzejsko galerijski centar, 1993., str. 99-112, 313-321, 318. Uredila Biserka Rauter.

${ }^{585}$ Kamen, $258 \times 109,5 \times 7$ cm, Remetinec, crkva Kraljice Svete Krunice. Kat. br. 63.

${ }^{586}$ Usp. Paškal Cvekan, Franjevci u Remetincu: Povijesno-kulturni prikaz, Virovitica: P. Cvekan, 1995.b, str. 29-30; Gjuro Szabo, nav. dj., 1912., str. 246-247.

${ }^{587}$ Kamen, $115 \times 80 \mathrm{~cm}$, Remetinec, crkva Kraljice Svete Krunice. Kat. br. 62.

${ }^{588}$ Godina kronograma upućuje na vrijeme kada je kapela građena. Iz pisanih izvora poznato je da je kapela posvećena 1704. godine, stoga možemo zaključiti da je kapela građena na prijelazu iz XVII. u XVIII. stoljeće, točnije između 1697. i 1704. godine.

589 Okolnosti narudžbe poznate su iz natpisa uklesanoga na spomeniku. Iako je Terezija Patačić umrla u Vrbovcu, njezino je tijelo preneseno u Remetinec gdje je, prema baruničinoj oporučnoj želji, položeno u obiteljsku grobnicu u kapeli sv. Antuna Padovanskoga. Usp. Pavao Maček, Rodoslovlje grofovskog ogranka Patačića od Zajezde, u: Patačići od Zajezde i crkva u Remetincu: Zbornik radova znanstvenog skupa »Tristota obljetnica Patačićeve kapele sv. Antuna u Remetincu« i drugih radova, Remetinec, 23. listopada 2004. godine, Zagreb: Društvo za povjesnicu Zagrebačke nadbiskupije »Tkalčić«, Remetinec: Župa Blažene Djevice Marije Kraljice sv. Krunice, Novi Marof: Grad Novi Marof, 2006., str. 9-45, 19. Uredio Anđelko Košćak.

590 Stit grba razdijeljen je okomito i vodoravno na četiri jednaka polja, a u sredini se nalazi srce štita (štitić). U prvom i četvrtom polju prikazan je orao, a u drugom i trećem lav koji se postavio na stražnje noge. U srcu štita predočena je djeva ogrnuta velom koja stoji na sidru. Usp. Ivan von Bojničić, nav. dj., 1889., str. 140-141, tab. 102.
} 


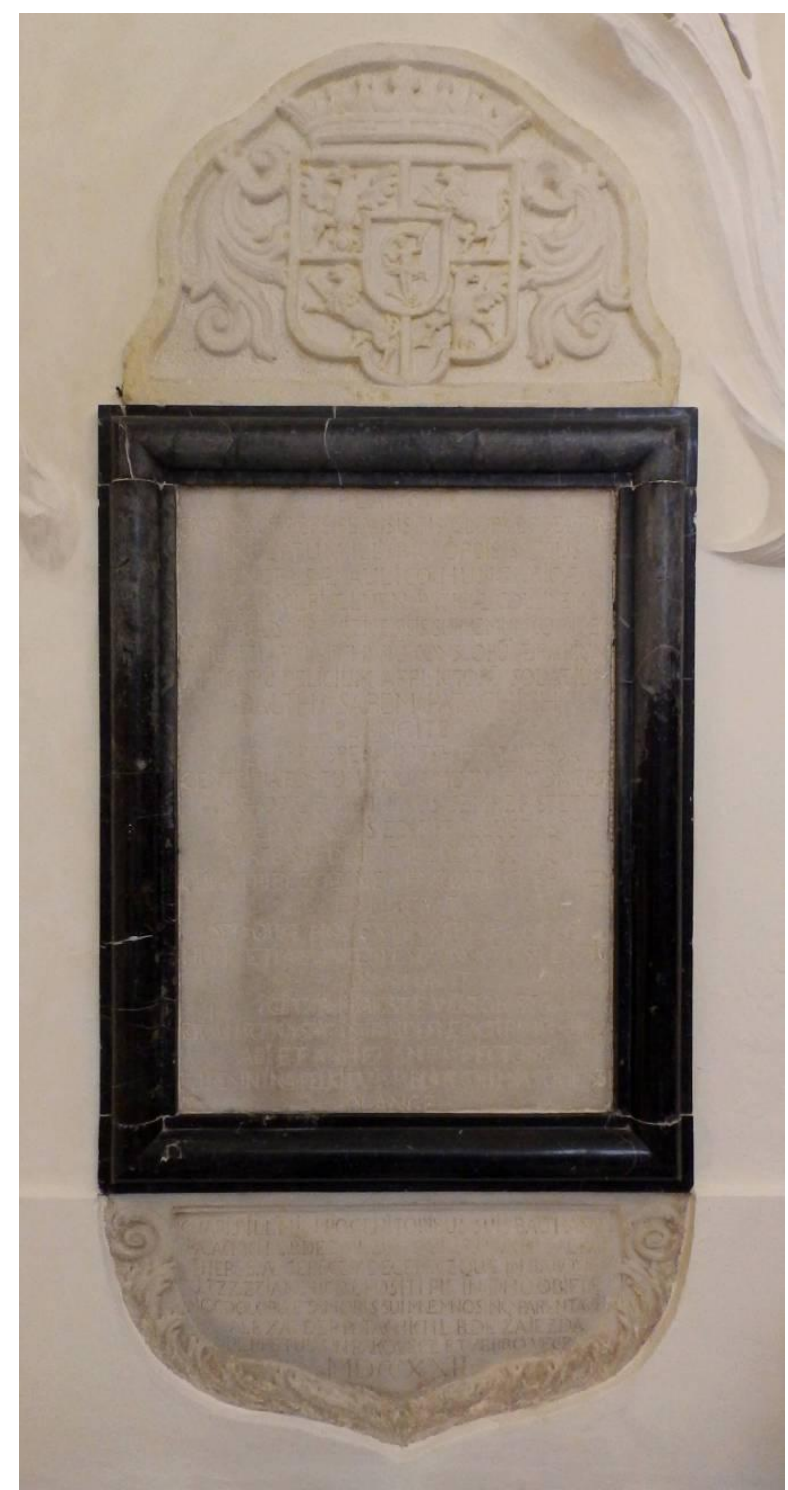

(gore lijevo) Slika 158. Epitaf Baltazara III.

Patačića i Terezije rođ. Gereczy, 1722., Remetinec, crkva Kraljice Svete Krunice

(gore desno) Slika 159. Nadgrobna ploča Baltazara III. Patačića, 1697., Remetinec, crkva Kraljice Svete Krunice

(dolje desno) Slika 160. Epitaf Bartolomeja Patačića, 1817., Remetinec, crkva Kraljice Svete Krunice
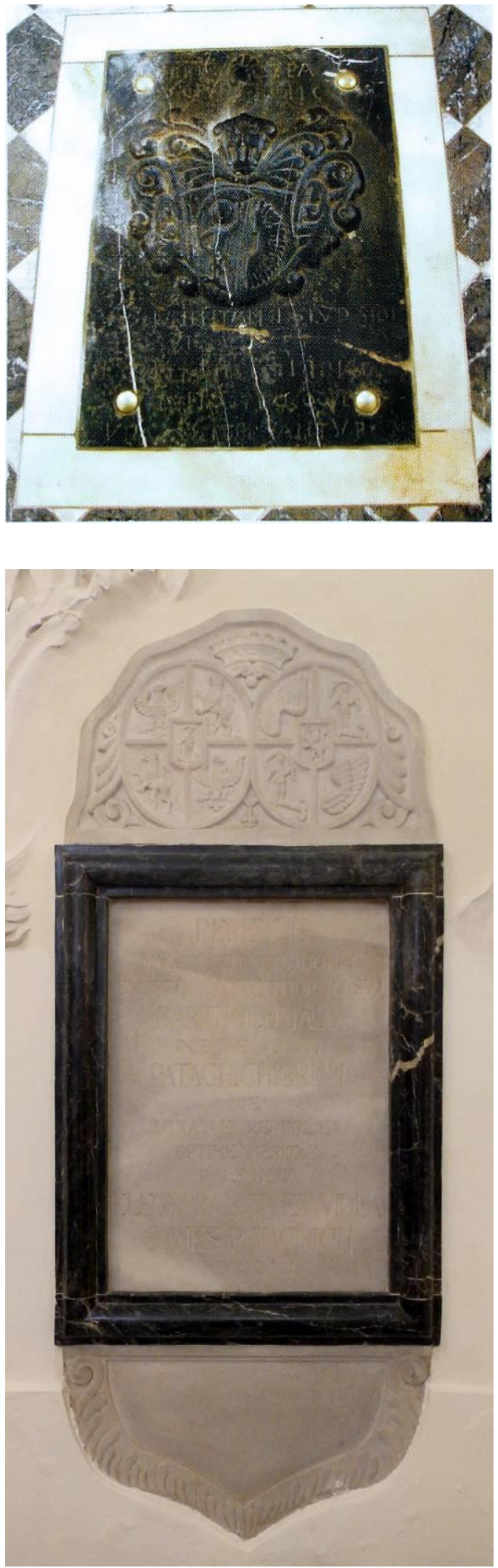
pokojnikā i posvetu njihovoga sina. Vrlo sličnoga oblikovanja je i nešto mlađi, devetnaestostoljetni epitaf grofa Bartolomeja Patačića (Graz, 1766. - Martijanec, 1817.) (Slika 160) koji je postavljen na zapadnome zidu kapele, nasuprot epitafu Baltazara II. i Terezije Patačić. U luneti je prikazan dvostruki grb obitelji Patačić ukrašen plaštem i krunom, ${ }^{591}$ a središnji okvir sadrži natpis prema kojem je epitaf dala postaviti pokojnikova supruga Eleonora Patačić.

U nekadašnjoj pavlinskoj samostanskoj crkvi u Lepoglavi nalazi se epitaf koji je vremenski blizak i kompozicijski srodan onome supružnika Patačić iz Remetinca. Riječ je o epitafu kraljevskoga komornika i pukovnika Đurđevačke krajine Sigismunda Ratkaja (?, 1660. - ?, 1702.) (Slika 161 $)^{592}$ koji je postavljen u kapeli sv. Josipa. ${ }^{593}$ Prema natpisu na spomeniku, podignuo ga je Sigismundov sin Karlo Josip čak dva desetljeća nakon očeve smrti (1722.). Nalik onome u Remetincu, Ratkajev epitaf sastoji se od središnjega pravokutnog okvira s natpisnom pločom koji je postavljen na polukružnu konzolu ukrašenu volutama i viticama, a zaključen je lunetom. U središtu lunete predočen je simbol obitelji Ratkaj, zidani bunar flankiran viticama akanta koji pridržavaju krunu, ${ }^{594}$ a njezin luk ukrašen je motivima ratnih trofeja (bubnjevima, topovima, barjacima, kacigama i kopljima). Na luneti su vidljivi tragovi polikromije: grbovni simboli i ratni trofeji obojeni su žutom i plavom bojom.

Vremenski posljednji i izvedbeno najuspješnijih epitaf oblikovan kao edikula jest onaj posvećen zagrebačkome kanoniku Nikoli Gotalu od Gotalovca $\left(?-?, 1723\right.$.) (Slika 162). ${ }^{595}$ Postavljen je na sjevernome zidu sjevernoga broda zagrebačke katedrale, iznad ulaza u riznicu. Izveden je u raznobojnom mramoru, polikromiran i pozlaćen, a sastoji se od središnje natpisne ploče izlomljenih stranica koja je zaključena segmentom koveksno oblikovanoga gređa i baldahinom čiji se nabori spuštaju s obje strane spomenika. U zoni gređa nalazi se grb obitelji Gotal ${ }^{596}$ koji nosi oznake svjetovnoga ali i crkvenoga grba - štit je ukrašen kacigom s

\footnotetext{
${ }^{591}$ U luneti je prikazan dvostruki grb obitelji Patačić ukrašen plaštem i krunom. Štitovi oba grba razdijeljeni su okomito i vodoravno na četiri jednaka polja sa srcem štita (štitićem) smještenim u sredini. Prvi štit istovjetan je onome s epitafa Baltaraza II. Patačića i njegove supruge Terezije rođ. Gereczy. U prvom i četvrtom polju prikazan je orao, a u drugom i trećem lav koji se postavio na stražnje noge. U srcu štita predočena je djeva ogrnuta velom koja stoji na sidru. U prvome i četvrtome polju drugoga štita prikazano je krilo, a u drugom i trećem djeva ogrnuta velom koja stoji na sidru. U srcu štita predočen je mač koji u šapi drži sablju. Usp. Ivan von Bojničić, nav. dj., 1889., str. 140-141, tab. 102.

${ }^{592}$ Kamen, polikromija, $276 \times 106 \times 4$ cm, Lepoglava, crkva Bezgrješnoga začeća Blažene Djevice Marije. Kat. br. 59.

${ }^{593}$ Prije Sigismunda, članovi obitelji Ratkaj pokapali su se u grobnici koja se nalazila u svetištu crkve. Kapelu sv. Josipa u kojoj je Sigismund pokopan podigla je njegova supruga Sofija Rozina rođ. Geizrug. Usp. Kamilo Dočkal, nav. dj., 2014., str. 11-12.

${ }^{594}$ Usp. Ivan von Bojničić, nav. dj., 1889., str. 157, tab. 113.

595 Mramor, dimenzije nepoznate autorici, Zagreb, katedrala Uznesenja Blažene Djevice Marije i sv. Stjepana i Ladislava. Kat. br. 43.

${ }^{596}$ Pri dnu štita predočen je brijeg s tri vrha, a na svakom vrhu nalazi se po jedna kruna. Iznad lijeve i desne krune uzdižu se dva okrunjena lava koji prednjim šapama pridržavaju još jednu, veću krunu. Iznad krune
} 


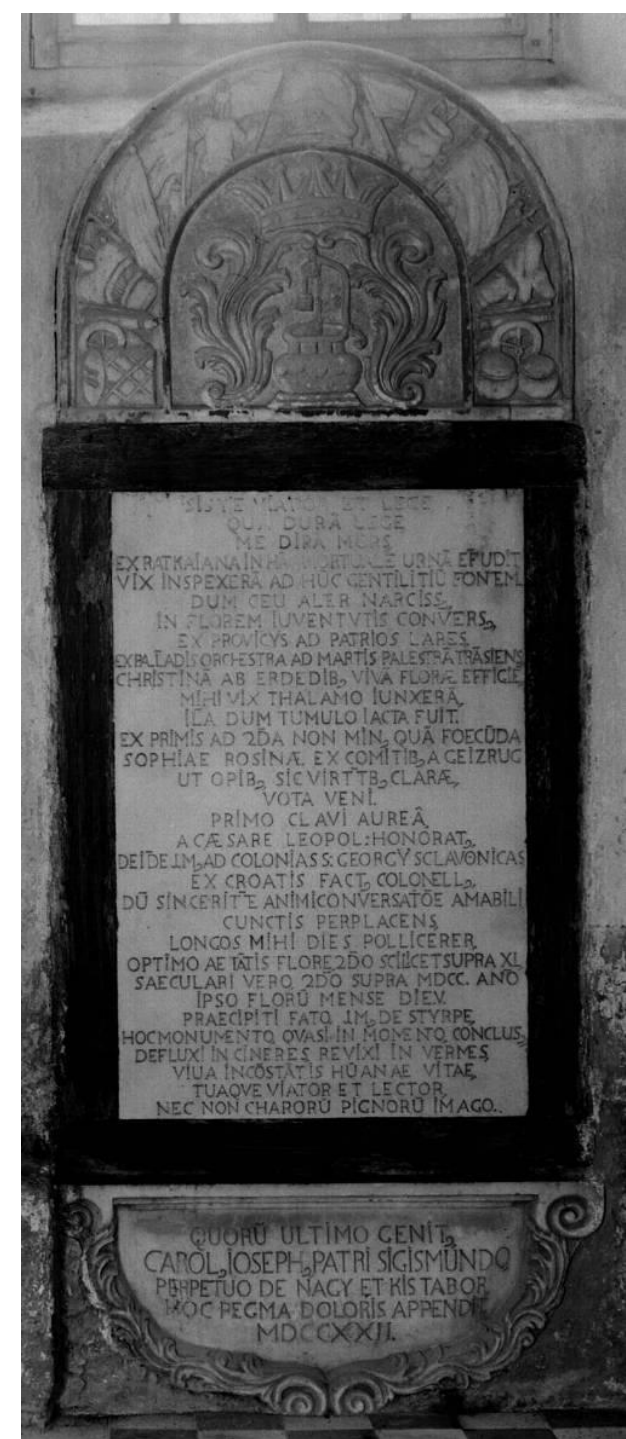

Slika 161. Lepoglava, Crkva Majke Božje, Škrinja i ploča Karla Ivana Rattkaya, 1938., foto: Ljudevit

Griesbach, HAZU, Strossmayerova galerija starih majstora, Schneiderov fotografijski arhiv

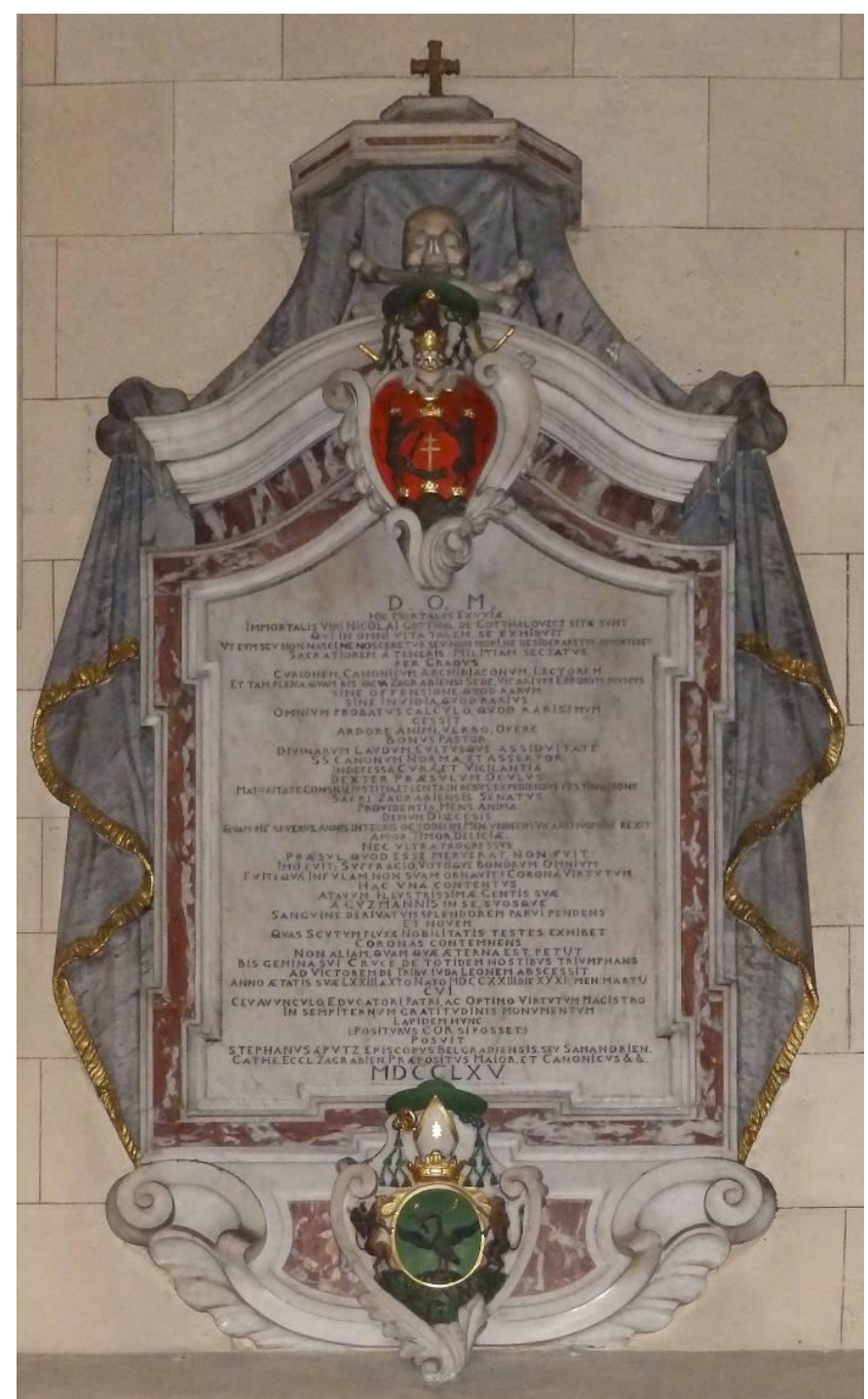

Slika 162. Epitaf Nikole Gotala od Gotalovca, 1765. Zagreb, katedrala Uznesenja Blažene Djevice Marije i sv. Stjepana i Ladislava

krunom i nakitom povrh kojih se nalazi galero šešir. Zanimljivo je uočiti da je galero zelene boje i ukrašen sa šest kićanki. Boja i broj kićanki upućuju na to da je nositelj grba bio biskup, što u slučaju Nikole Gotala nije točno. Naime, Gotal jest pretendirao na mjesto zagrebačkoga biskupa 1723. godine, no na tu poziciju odabran je Juraj Branjug. Pri dnu natpisne ploče nalazi se grb naručitelja, ${ }^{597}$ zagrebačkoga prepošta i beogradsko-smederevskoga biskupa

postavljene na središnjem vrhu brijega nalazi se ruka koja drži pero i dvostruki (biskupski) križ. Usp. Ivan von Bojničić, nav. dj., 1889., str. 55, tab. 40.

${ }^{597} \mathrm{Na}$ štitu grba predočena je ptica raširenih krila koja stoji na vrhu brijega, a u kljunu drži zmiju. U gornjem (heraldički) desnom kutu štita nalazi se šestokraka zvijezda, a u lijevom polumjesec. Štit s lijeve strane pridržava grifon, a s desne lav. Na njega naliježe kruna iznad koje se nadvisuje biskupska mitra, a iznad mitre nalazi se biskupski šešir s dva para šest kićanki. Usp. Ivan von Bojničić, nav. dj., 1889., str. 232, tab. 170. 
Stjepana Puca (?, 1700. - Zagreb, 1771.). Puc je bio Nikolin nećak koji je nakon smrti posljednjega muškoga člana obitelji Gotal, Emerika Gabrijela (†1740.), htio odati počast Gotalima kao njihov posljednji odvjetak po ženskoj lozi. ${ }^{598}$ To je učinio obnavljanjem kapele sv. Petra u Gotalovcu (1755. - 1758.), koju je obitelj koristila kao dvorsku i grobnu kapelu, ${ }^{599}$ te postavljanjem epitafa za Nikolu Gotala (1765.) u zagrebačkoj prvostolnici, više od četrdeset godina nakon njegove smrti. Potonji podatak zabilježen je i na samome epitafu.

$$
* * *
$$

Posebnu skupinu unutar ovoga dijela korpusa čine nadgrobne ploče koje pokrivaju ili su nekoć pokrivale - zajedničke kripte pripadnika samostanskih redova, a urešene su grbom pripadajuće redovničke obitelji kao simbolom zajednice kojoj su pokojnici pripadali. Kripte namijenjene ukopu redovnika u pravilu su se nalazile u svetištu samostanskih crkava, kao što se, primjerice, nalazi u franjevačkoj crkvi sv. Ivana Krstitelja u Varaždinu. Kripta je smještena ispred glavnoga oltara, a pokrivena je nadgrobnom pločom jednostavne izvedbe (Slika 163). ${ }^{600}$ U središnjoj osi ploče uklesan je grb franjevačkoga samostanskog reda ${ }^{601}$ koji je ukrašen stiliziranim rokajem. Podno njega nalazi se krilatica »HODIE MIHI / CRAS TIBI« i motiv mrtvačke lubanje s ukriženim kostima. U gornjim kutovima ploče uklesane su znamenke jedan i sedam, koje označuju da je ploča postavljena u XVIII. stoljeću. Brojke koje su se nalazile u donja dva kuta u potpunosti su istrošene, stoga ne znamo u kojem je točno desetljeću nadgrobnik izrađen. Međutim, na osnovi rokaja koji se počeo primjenjivati kao dekorativni element u likovnoj i graditeljskoj umjetnosti kontinentalne Hrvatske sredinom XVIII. stoljeća, ${ }^{602}$ možemo zaključiti da ploča nastala u drugoj polovini settecenta.

U nekadašnjoj pavlinskoj - danas župnoj - crkvi u Remetama nalazi se nadgrobna ploča (Slika 164) ${ }^{603}$ koja je nekoć pokrivala ulaz u grobnicu namijenjenu ukopu braće pavlina. Ploča je danas izložena u klaustru samostana, no izvorno se nalazila u svetištu crkve ispred glavnoga oltara, o čemu svjedoče povijesni izvori ${ }^{604}$ i fotografijski snimak Ljudevita

\footnotetext{
598 Stjepan je bio sin Nikoline i Emerikove sestre Barbare Puc rođ. Gotal. Usp. Trpimir Macan (ur.), nav. dj., 2002., sub voce Gotal [Tatjana Radauš].

${ }^{599}$ Biskup je opremio kapelu trima oltarima i propovjedaonicom. U kontekstu funeralne ikonografije, zanimljiva je skulptura koja zaključuje atiku glavnoga oltara posvećenoga sv. Petru. Riječ je o kosturu koji rukama razdire grb obitelji Gotal, simbolizirajući gašenje loze. Usp. Ivanka Reberski (ur.), nav. dj., 2008., sub voce Gotalovec. Kapela sv. Petra: Oprema crkve. Oltari, kipovi, str. 113-114 [Doris Baričević].

${ }^{600}$ Kamen, $110 \times 80 \mathrm{~cm}$, Varaždin, crkva sv. Ivana Krstitelja. Kat. br. 69.

${ }^{601}$ Grb sačinjava križ ispred kojeg je ukrižen par ruku sa stigmama. Jedna ruka je gola i predstavlja ruku Isusa Krista, a druga je odjevena u rukav habita i predstavlja ruku sv. Franje Asiškoga.

${ }^{602}$ Usp. Martina Wolff Zubović, nav. dj., sv. 1, 2017., str. 142.

${ }^{603}$ Kamen, $130 \times 84 \times 9$ cm, Remete, crkva Uznesenja Blažene Djevice Marije. Kat. br. 21.

${ }^{604}$ Usp. Janko Barlé, nav. dj., 1914., str. 82.
} 

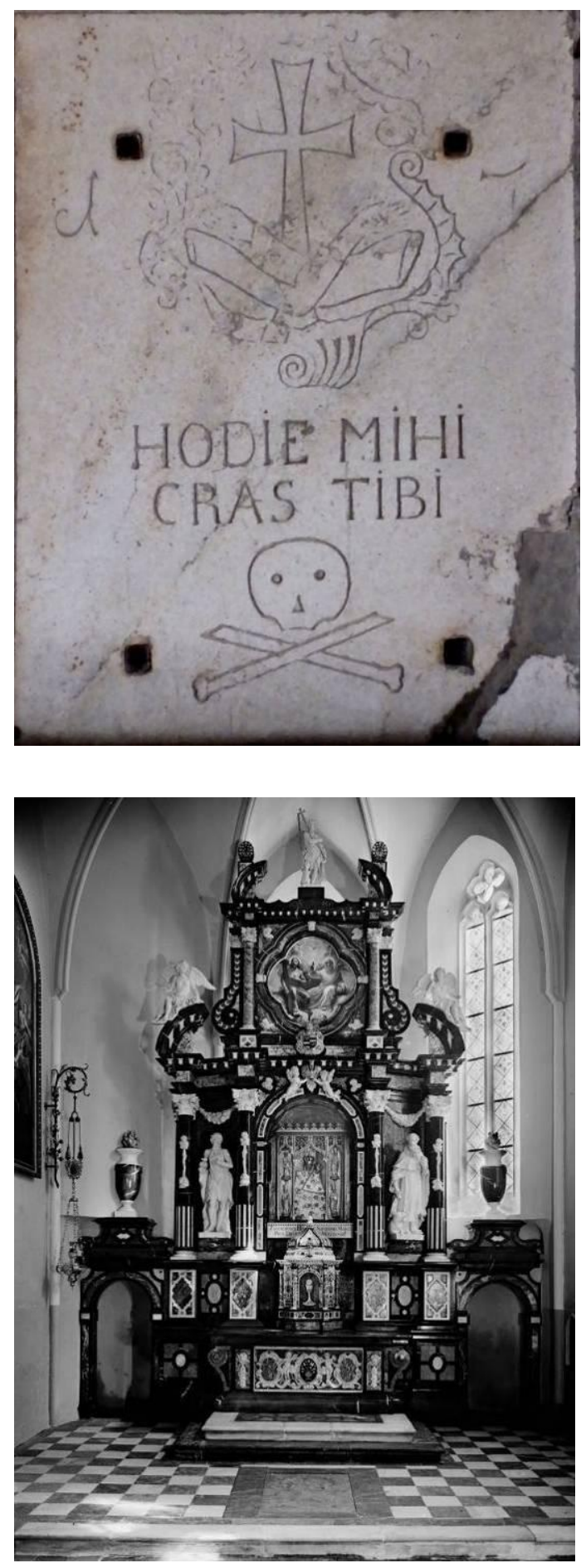

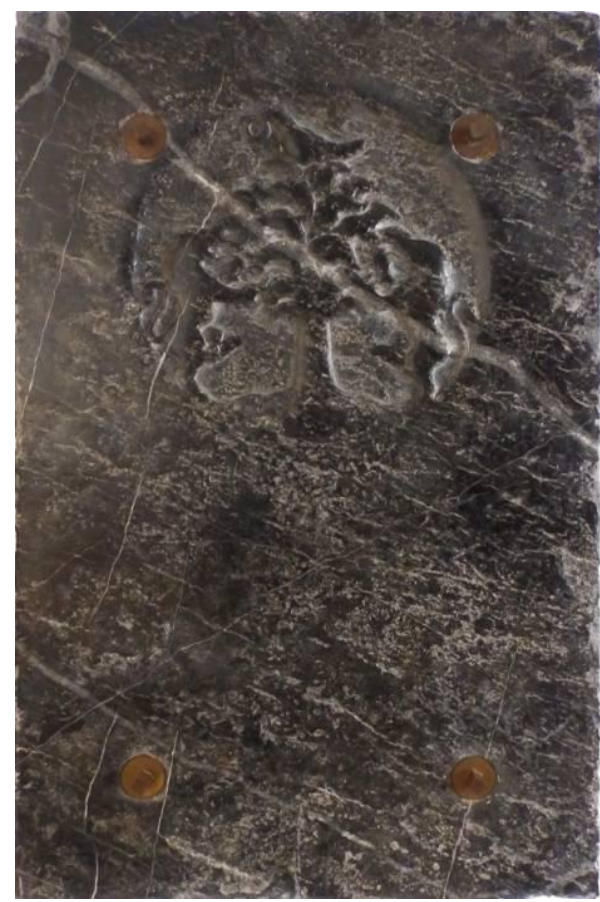

(gore lijevo) Slika 163. Nadgrobna ploča franjevačkoga reda, II. pol. XVIII. stoljeća, Varaždin, crkva sv. Ivana Krstitelja

(gore desno) Slika 164. Nadgrobna ploča pavlinskoga reda, kraj XVIII. stoljeća (?), Remete, crkva Uznesenja Blažene Djevice Marije

(dolje lijevo) Slika 165. Remete, Crkva sv. Marije, Glavni oltar, 1937., foto: Ljudevit Griesbach, HAZU, Strossmayerova galerija starih majstora, Schneiderov fotografijski arhiv

Griesbacha iz 1937. godine (Slika 165). U gornjem dijelu nadgrobnika reljefno je izveden grb pavlinskoga reda koji je pomalo dotrajao. ${ }^{605}$ Ostatak je ploče prazan, no postoji mogućnost da

\footnotetext{
${ }^{605}$ Grb pavlinskoga reda čini stablo datulje na čijem se vrhu nalazi gavran koji u kljunu drži kruh i par lavova koji flankiraju stablo. Navedeni motivi povezani su sa životom osnivatelja reda, sv. Pavlom Pustinjakom. Prema legendi, nakon što je car Decije (Budalija, o. 200. - kraj Rasgrada, 251.) prognao kršćane, sv. Pavao sklonio se u pustinju, gdje je živio u pećini nedaleko koje je raslo drvo datulje. Tijekom devedeset i osam godina koje je proveo ondje, gavran mu je svaki dan donosio polovicu kruha. U pustopoljini ga je pronašao sv. Antun opat koji ostao živjeti s njime. Nakon što je sv. Pavao preminuo, dva lava pristigla su pomoći sv. Antunu iskopati svečev grob. Usp. Anđelko Badurina (ur.), nav. dj., 1990. [1979.], sub voce Pavao pustinjak, str. 454 [Marijan Grgić].
} 
je izvorno sadržavao neki natpis koji se slijedom godinā istrošio. Nije poznato kada je nadgrobnik izrađen, no budući da je 1786. godine mijenjano popločenje crkve, ${ }^{606}$ možemo pretpostaviti da datira s kraja XVIII. stoljeća.

\subsection{NADGROBNICI S MOTIVIMA FUNERALNE IKONOGRAFIJE}

Posljednju, treću likovnu skupinu nadgrobnih spomenika koji su sačuvani na prostoru povijesne Zagrebačke biskupije čine nadgrobnici na kojima su zastupljeni motivi funeralne ikonografije. Potrebno je naglasiti da se takvi motivi javljaju i nadgrobnicima koji pripadaju drugim dvjema likovnim skupinama - spomenicima s likom pokojnika i obiteljskim grbom no samo kao ikonografska pratnja. Na nadgrobnicima koji su opisani u narednim odlomcima, funeralni motivi glavni su nosioci likovnoga značenja na spomenicima i iz toga su razloga izdvojeni u zasebnu cjelinu.

Najčešći motivi funeralne ikonografije koji se javljaju na nadgrobnim spomenicima Zagrebačke (nad)biskupije su ljudska lubanja odnosno kostur i pješčani sat (klepsidra, pješčanik). Prikazi kostura kao personifikacije smrti zastupljeni su u likovnoj umjetnosti od kasnoga srednjeg vijeka nadalje, a nastali su pod utjecajem teoloških tekstova, propovijedi i suvremene književnosti. ${ }^{607}$ Smrt je prikazivana kao kostur ili napola raspadnut mrtvac koji u rukama drži neki od svojih prepoznatljivih atributa: kosu ili srp (oruđe kojim žanje živuće); strijelu, luk ili mač (ubojito oružje kojim oduzima život); te pješčani sat ili ljudsku lubanju (simbole prolaznosti vremena). ${ }^{608}$ Svrha takvih prikaza bila je upozoriti promatrača na prolaznost ovozemaljskoga života i neizbježnost smrti pred kojom su svi ljudi jednaki te usmjeriti ga na ono što je uistinu važno - brigu o vlastitoj duši. Tema ništavnosti zemaljskoga života bila je posebno popularna u nizozemskoj i flamanskoj umjetnosti XVI. i XVII. stoljeća koja je iznjedrila prikaze mrtve prirode s voćem, cvijećem i drugim motivima koji su nosili poruku memento mori, poput ljudske lubanje, pješčanoga sata ili upaljenoga svijećnjaka. ${ }^{609}$ Isti motivi primjenjivali su se i na nadgrobnim spomenicima noseći isto upozorenje: »Morate biti spremni na smrt, koja može doći svaki trenutak; molite Boga za [svoju] duš[u].« ${ }^{610}$

\footnotetext{
${ }^{606}$ Usp. Ivan Krstitelj Krapac, nav. dj., 1870., str. 28.

${ }^{607}$ Usp. Anđelko Badurina (ur.), nav. dj., 1990. [1979.], sub voce smrt, str. 537 [Branko Fučić]; Marina VinceljaMatijašić, Imago mortis u srednjovjekovnoj umjetnosti Zapadne Europe, u: Communio: međunarodni katolički časopis XXXVIII/114, Zagreb: Kršćanska sadašnjost, 2012., str. 96-112, 101-103.

${ }^{608}$ Usp. James Hall, nav. dj., 1998., sub voce smrt, str. 310; Marina Vincelja-Matijašić, nav. dj., 2012., str. 102.

${ }^{609}$ Usp. James Hall, nav. dj., 1998., sub voce mrtva priroda, str. 211; Slavko Šterk i Boris Mašić, nav. dj., 2014., str. 54; Marina Vincelja-Matijašić, nav. dj., 2012., str. 111.

${ }^{610}$ Marina Vincelja-Matijašić, nav. dj., 2012., str. 103. Riječ je o rečenici koju jedan od trojice mrtvaca upućuje trojici mladih muškaraca (lovcu, plemiću i kralju) u trinaestostoljetnoj moralizatorskoj priči Tri živa i tri mrtva.
} 
Najjednostavnije likovno rješenje koje je zastupljeno u ovome dijelu spomeničkoga korpusa su nadgrobnici na kojima je uz natpis uklesan motiv lubanje i para ukriženih kostiju. Jedan takav primjer predstavlja nadgrobna ploča Barbare Zaboky rođ. Gereczy (? - ?, 1678.) (Slika 166), ${ }^{611}$ udovice gospodara zabočkoga imanja i podžupana varaždinske županije Baltazara Zabokyja. ${ }^{612}$ Plemkinja je prema vlastitoj želji pokopana u nekadašnjoj pavlinskoj crkvi u Lepoglavi, u grobnici ispod kapele Muke Gospodnje (nazivana i kapelom mrtvih) koju je podignula barunica Judita Petheő de Gerse rođ. Balagović od Japre s južne strane pjevališta (1675.). ${ }^{613}$ Likovni motiv i natpis danas su teško vidljivi, no potonji je moguće rekonstruirati na osnovi povijesnih izvora. ${ }^{614}$

Druga ploča sličnoga likovnog rješenja nalazi se u kapeli sv. Križa na gradskome groblju u Bjelovaru. Kapela je podignuta 1779. godine zaslugama Varaždinskoga generalata i mještana, a ispod nje nalazi se kripta u kojoj su se nekoć pokapali građani. ${ }^{615}$ Kripta je danas preuređena u spremište, a ploče koje su zatvarale ćelije izvađene su (najvjerojatnije 1907. godine kada je izvršena temeljita obnova kapele $)^{616}$ i ugrađene u unutrašnje $i$ vanjske zidove kapele. Jedina ploča koja odgovara definiranim kriterijima - datira između XV. i XVIII. stoljeća i sadrži likovni motiv - jest ploča Ivane Bajalić (?, 1735. - ?, 1781.) (Slika 167) $)^{617}$

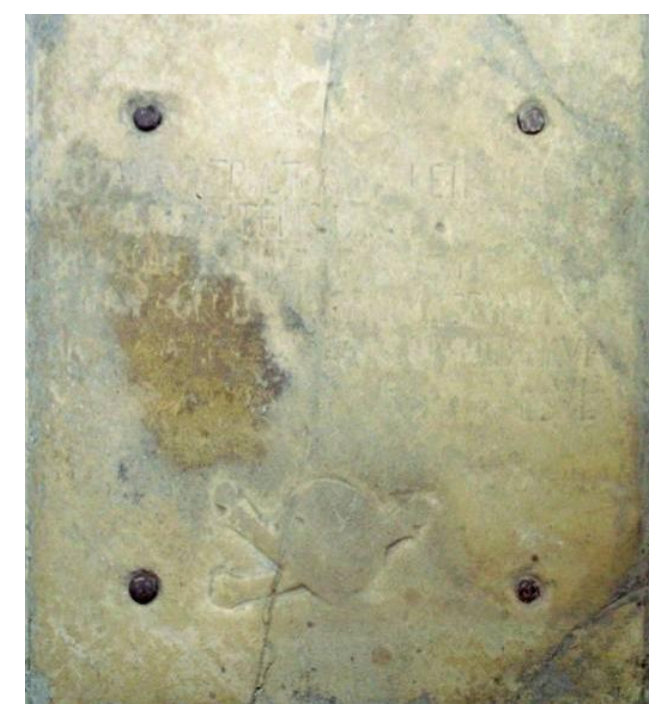

Slika 166. Nadgrobna ploča Barbare Zaboky (†1678.), Lepoglava, crkva Bezgrješnoga Začeća Blažene Djevice Marije

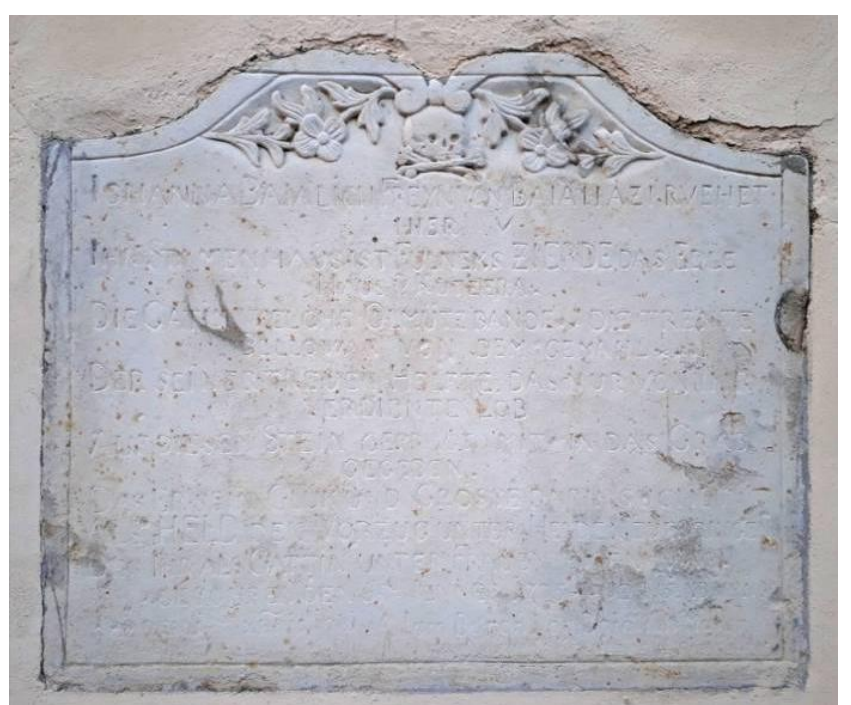

Slika 167. Ploča Ivane Bajalić (†1781.), Bjelovar, kapela sv. Križa

\footnotetext{
${ }^{611}$ Kamen, $115 \times 102$ cm, Lepoglava, crkva Bezgrješnog Začeća Blažene Djevice Marije. Kat. br. 56.

${ }^{612}$ Usp. Kamilo Dočkal, nav. dj., 2014., str. 271.

${ }^{613}$ Usp. Kamilo Dočkal, nav. dj., 2014., str. 209. Judita Balagović od Japre (? - ?, 1700.) bila je supruga Ivana Petheőa de Gerse koji je pokopan u svetištu crkve i kojem je ondje podigla epitaf (Slika 155).

${ }^{614}$ Isto.

${ }^{615}$ Usp. Stjepan Kožul, Sakralna umjetnost bjelovarskoga kraja, Zagreb: Prometej, 1999., str. 528-529.

${ }^{616}$ Usp. Stjepan Kožul, nav. dj., 1999., str. 530.

${ }^{617}$ Kamen, 60,5 × 69,5 cm, Bjelovar, kapela sv. Križa. Kat. br. 74.
} 
uzidana u začelni zid kapele. Riječ je o jednostavnoj, pravokutnoj ploči koja je većim dijelom ispunjena posvetnim natpisom. Gornja stranica ploče konveksno je oblikovana dvjema volutama, a luk ispod njih ukrašen je viticama s cvijećem i lubanjom koja počiva na ukriženim kostima. Prema natpisu, ploču je dao izraditi Ivanin suprug, barun Adam Bajalić (Bajalich, Baialich; Segedin, 1734. - Karlovac, 1800.), koji je bio podmaršal u austrijskoj vojsci.

Na nadgrobnim spomenicima u Lepoglavi i Bjelovaru motivi funeralne ikonografije prikazani su samostalno, no na pojedinim nadgrobnicima uklopljeni su u složeniji prikaz kao atributi u rukama anđela. Sličnu situaciju nalazimo na epitafu Stjepana Patačića od Zajezde $\left(?, 1576\right.$. - ?, 1636.) i njegove supruge Barbare rođ. Beković (? - ?) (Slika 168) ${ }^{618}$ koji su pokopani u crkvi sv. Vida u Vidovcu. Epitaf je izveden u obliku kartuše s posvetnim natpisom koja je flankirana anđelima podbočenih glava. Lakat lijevoga počiva na lubanji, a desnoga na pješčanome satu. Ovakvi prikazi anđelā pomalo sjetnoga izgleda, glavā oslonjenih na dlanove, bili su vrlo popularni u vrijeme manirizma. ${ }^{619}$ Pri vrhu kartuše predočen je Raspeti sa stihom iz Psalma: »IN TE DOMINE / SPERAVI NON CON / FVNDAR IN ÆTERNVM« (Tebi se, Gospodine, utječem, o da se ne postidim nikada. Ps, 31, 2). Prema natpisu unutar kartuše, supružnici Patačić postavili su epitaf još za života (1629.), za sebe i svoje potomstvo (»MONVMENTVM G[ene]ROSI D[omi]NI STEPHANI PATATHICH DE ZAIEZDA [...] NEC NON GE[ne]R[osae] D[omi]N $~$ BARBAR $~$ BEKOVYCH $\quad[\ldots]$ AC POSTERIT[at]I[bu]S IPSOR[um] QVOD VIVI POSVERVNT «). ${ }^{620}$ Nije poznato gdje se nadgrobnik nalazio u staroj župnoj crkvi, ${ }^{621}$ no izgradnjom nove $(1820 .-1829$.) ugrađen je u južni zid svetišta, ${ }^{622}$ gdje se nalazi i danas.

U obližnjem Varaždinu nalazi se spomenik na kojemu je primijenjeno najsloženije likovno rješenje unutar ove skupine spomenika. Riječ je epitafu varaždinskoga građanina $i$ trgovca Danijela Praunspergera (?, 1635. - ?, 1692.) (Slika 169) ${ }^{623}$ koji je pokopan u kapeli sv. Josipa franjevačke crkve sv. Ivana Krstitelja. Kapela je smještena sa sjeverne strane svetišta, a redovnici su njezin prostor prethodno upotrebljavali kao spremište ljekarne. Praunsperger je preuredio prostoriju između 1687. i 1689. godine u obiteljsku grobnu kapelu

\footnotetext{
${ }^{618}$ Kamen, pozlata, $77 \times 90 \mathrm{~cm}$, Vidovec, crkva sv. Vida. Kat. br. 70 .

${ }^{619}$ Usp. Emilijan Cevc, nav. dj., 1981., str. 131.

${ }^{620} \mathrm{Za}$ puni prijepis natpisa vidi kat. br. 70 .

${ }^{621}$ O izgledu stare župne crkve vidi: Iva Potočnik, Nestala barokna crkva Sv. Vida u Vidovcu, u: Radovi Zavoda za znanstveni rad Varaždin 24, Varaždin: Zavod za znanstveni rad, 2013., str. 479-488.

${ }^{622}$ Usp. Ivan Kukuljević Sakcinski, nav. dj., 1891., str. 307, br. 1049.

${ }^{623}$ Štuk, pozlata, širina 150 cm, Varaždin, crkva sv. Ivana Krstitelja. Kat. br. 68.
} 


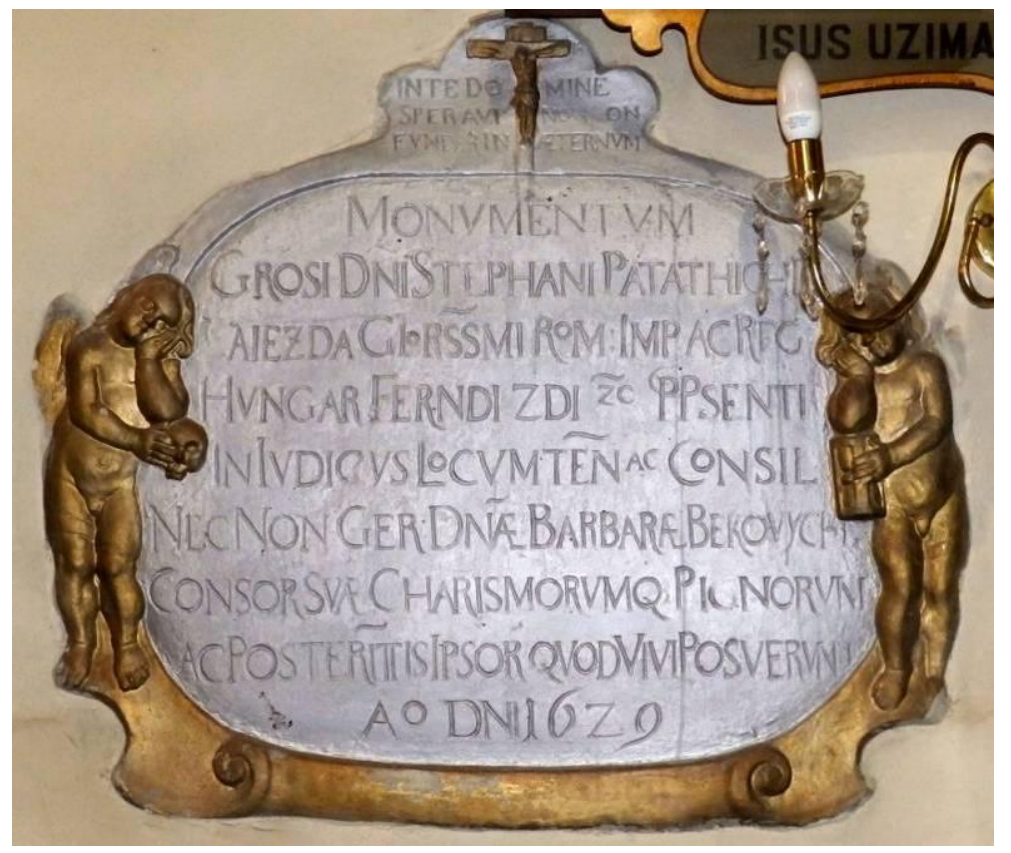

(lijevo) Slika 168. Epitaf

Stjepana Patačića od Zajezde

i Barbare rođ. Beković, 1629.,

Vidovec, crkva sv. Vida

(dolje) Slika 169. Epitaf

Danijela Praunspergera

$(† 1692$.$) , Varaždin, crkva sv.$

Ivana Krstitelja

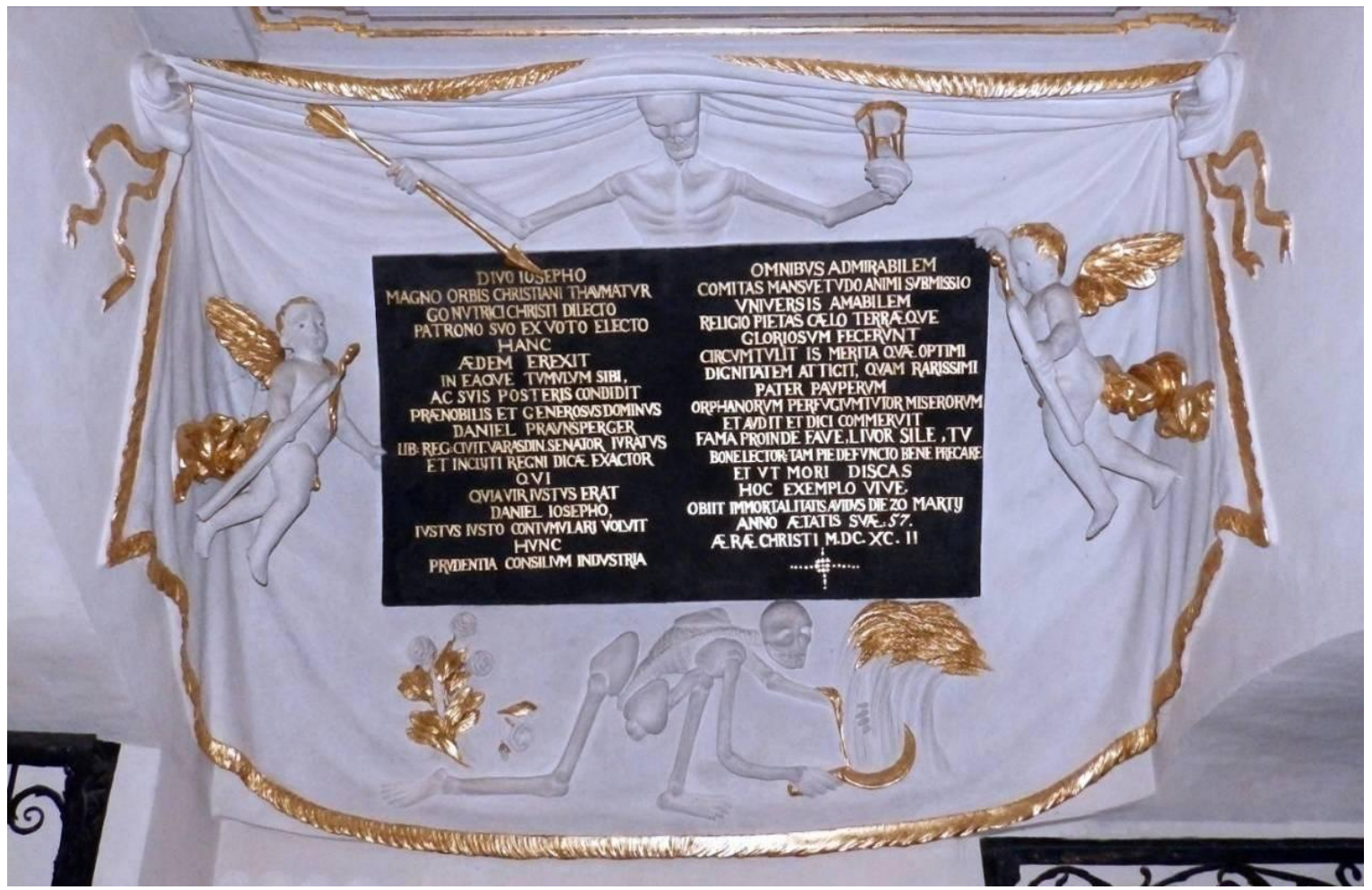

opremivši je oltarom sv. Obitelji, zidnim i štafelajnim slikama te štuko-dekoracijom. ${ }^{624}$

Posvetio ju je sv. Josipu, zagovorniku sretne i blage smrti (lat. refugium agonizantium) čija je

${ }^{624}$ Usp. Paškal Cvekan, Djelovanje franjevaca u Varaždinu: Povijesno-kulturni prikaz sedamsto godišnje prisutnosti Franjevaca u gradu Varaždinu, Varaždin: vlast. nakl., 1978., str. 89; Krešimir Filić, Franjevci u Varaždinu: Poviest franjevačke crkve i samostana. O 700-godišnjici dolazka franjevaca u Varaždin, Varaždin: vlast. nakl., 1944., str. 108. Za detaljnu oblikovno-ikonografsku analizu kapele vidi: Ana Kaniški, Kapela sv. Josipa u franjevačkoj crkvi u Varaždinu: Ikonografija i naručitelj, u: Tkalčić: godišnjak Društva za povjesnicu Zagrebačke nadbiskupije = annales Societatis historicae archiepiscopatus Zagrabiensis XVI, Zagreb: Društvo za povjesnicu Zagrebačke nadbiskupije »Tkalčić«, 2012., str. 303-412. 
teološka i liturgijska popularnosti porasla u poslijetridentskim stoljećima. ${ }^{625} \mathrm{U}$ kapeli je pokopana Praunspergerova druga supruga Ivana Kordula rođ. Hailek (1689.) i sām Praunsperger (1692.). ${ }^{626}$ Njegov epitaf nalazi se na zapadnome zidu kapele, a izveden je u tehnici štuka u obliku razastrtoga zastora koji simbolizira mrtvački pokrov kojim se pokriva tijelo pokojnika odnosno lijes u kojem je ono položeno. U sredini zastora smještena je crna ploča na kojoj je zlatnim slovima zabilježeno kako je Praunsperger uredio kapelu kao zavjet svome nebeskome zaštitniku, sv. Josipu, ali i kao obiteljsku grobnicu za sebe i svoje potomke (»DIVO IOSEPHO / [...] PATRONO SVO EX VOTO ELECTO / HANC / ÆDEM EREXIT / IN EAQVE TVMVLVM SIBI, / AC SVIS POSTERIS CONDIDIT «). ${ }^{627}$ Povrh i ispod ploče predočene su dvije alegorijske figure smrti u liku kostura. Gornji kostur u rukama drži strijelu i pješčani sat, a donji srpom siječe snop žita. Kao što je prethodno objašnjeno, strijela predstavlja ubojito oružje koje oduzima život, pješčanik prolaznost vremena, a srp ubiranje odnosno žetvu ljudskih duša. ${ }^{628}$ Natpisna ploča flankirana je dvama anđelima koji u rukama drže upaljenu svijeću, još jedan simbol kratkovječnosti ovozemaljskoga života. ${ }^{629}$ Uz figuru Smrti kao žeteoca predočen je grm rascvjetalih ruža. Prema tumačenju sv. Ambrozija, ruža je dobila trnje tek nakon što su Adam i Eva prognani iz raja, stoga ružin »miomiris i ljepota neprestance čovjeka sjećaju rajskih slasti« kojima se svaki vjernik nada vratiti. ${ }^{630}$

Kostur kao personifikacija smrti uobičajen je motiv sepulkralne umjetnosti, posebno nakon baroknih remek-djela u središtu Katoličke crkve, u Rimu. Dva od najmonumentalnijih nadgrobnika na kojima je primijenjen su papinske grobnice Urbana VIII. Barberinija (Firenca, 1568. - Rim, 1644.) i Aleksandra VII. Chigija (Siena, 1599. - Rim, 1667.) iz bazilike sv. Petra koje je izradio vodeći barokni kipar Gian Lorenzo Bernini (Napulj, 1598. - Rim, 1680.). Na grobnici Urbana VIII. (1628. - 1647.), Bernini je predočio papu kako sjedi i trajno udjeljuje blagoslov. Pri dnu postolja sjedi Smrt okrenuta promatraču leđima, a u rukama drži Knjigu smrti (Liber mortis) u koju zlatnim slovima upisuje papino ime, prenoseći poruku da slava Urbanova imena i djelā nadilazi samu smrt, što naznačuje i dostojanstvo geste blagoslova u kojoj je papa prikazan. ${ }^{631} \mathrm{Na}$ grobnici Aleksandra VII. (1671. -1678.) (Slika 170), jednim od Berninijevih posljednjih djela, majstor je promijenio pristup kiparskome zadatku. Papa više ne sjedi na prijestolju, nego kleči i moli u gesti trajne

\footnotetext{
${ }^{625}$ Usp. Sanja Cvetnić, nav. dj., 2007., str. 198.

${ }^{626}$ Usp. Paškal Cvekan, nav. dj., 1978., str. 89; Krešimir Filić, nav. dj., 1944., str. 108-111.

${ }^{627} \mathrm{Za}$ ostatak prijepisa vidi kat. br. 68.

${ }^{628}$ Usp. Anđelko Badurina (ur.), nav. dj., 1990. [1979.], sub voce smrt, str. 537 [Branko Fučić]; James Hall, nav. dj., 1998., sub voce smrt, str. 310; Marina Vincelja-Matijašić, nav. dj., 2012., str. 102.

${ }^{629}$ Usp. James Hall, nav. dj., 1998., sub voce svijeća, str. 323.

${ }^{630}$ Anđelko Badurina (ur.), nav. dj., 1990. [1979.], sub voce ruža, str. 516 [Marijan Grgić].

${ }^{631}$ Usp. Erwin Panofsky, nav. dj., 1992. [1964.], str. 94-95.
} 


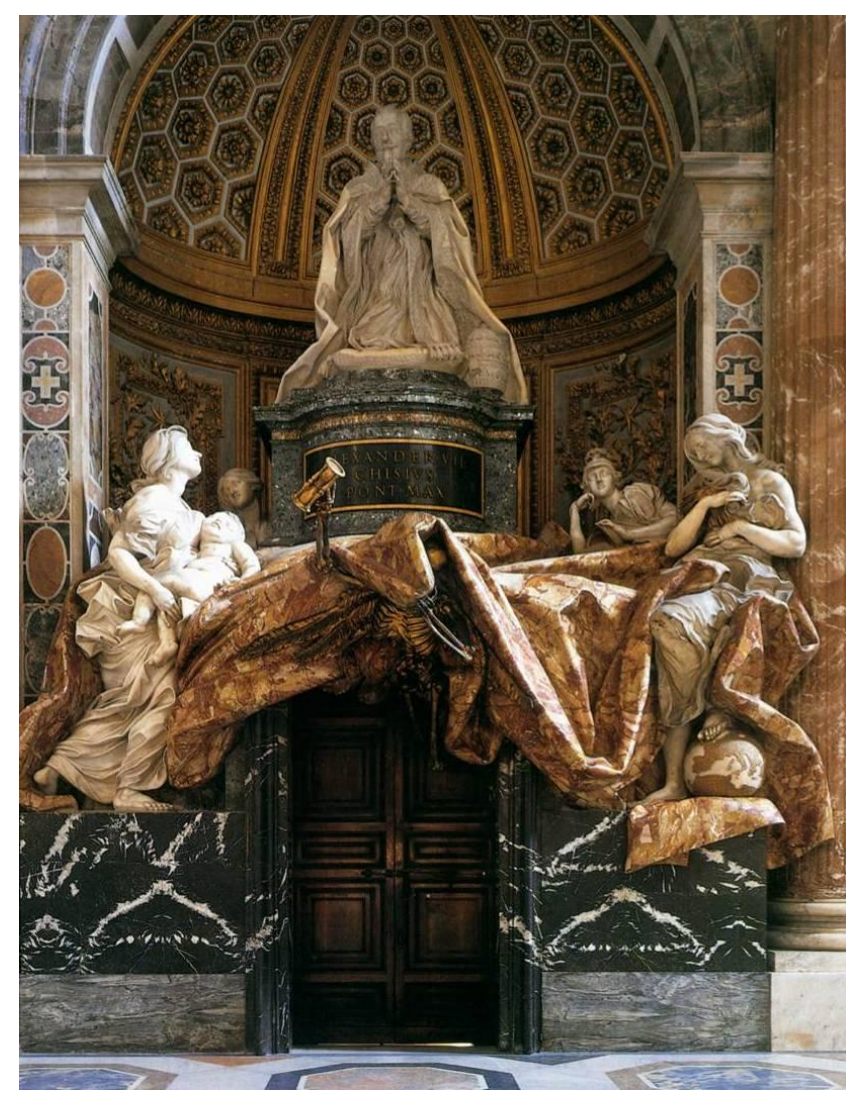

Slika 170. Gian Lorenzo Bernini, Grobnica pape Aleksandra VII., 1671. - 1678., Rim, bazilika sv. Petra

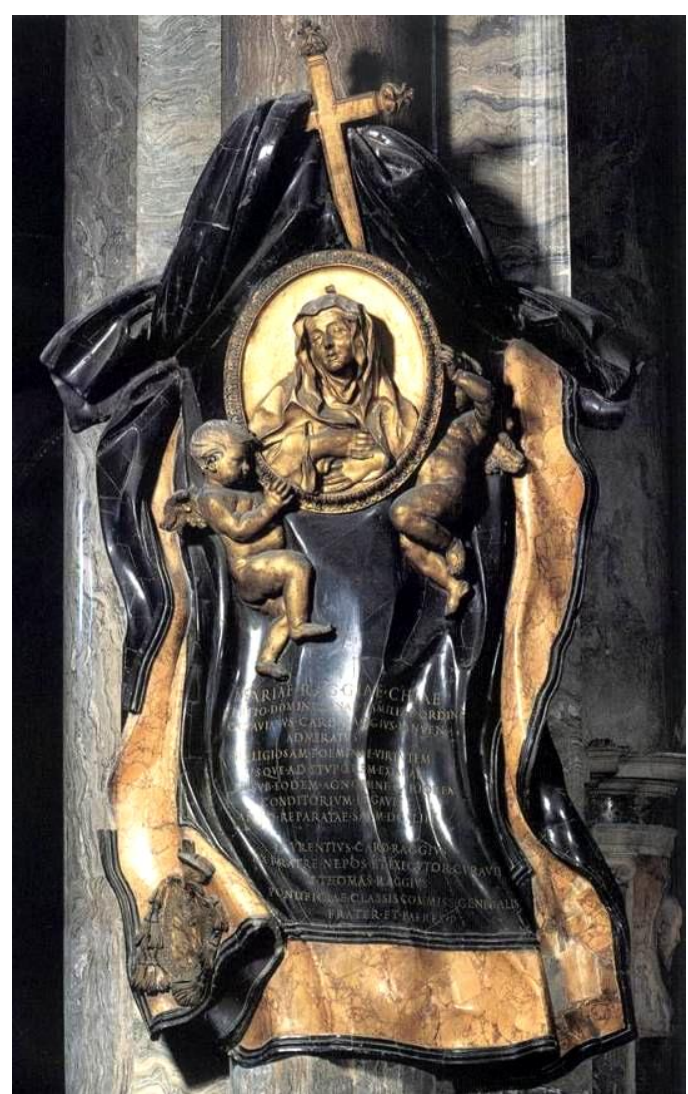

Slika 171. Gian Lorenzo Bernini, Kenotaf redovnice Marije Raggi, 1647. - 1653., Rim, bazilika S. Maria sopra Minerva

pobožnosti, a Smrt lebdi ispred ulaza u kriptu lica zakrivena draperijom, podižući u ruci pješčani sat. ${ }^{632}$ Personifikacija smrti s grobnice Urbana VIII. tako prestaje biti sredstvom glorifikacije pokojnika i postaje nositeljem upozorenja da je čovjekovo vrijeme na ovome svijetu ograničeno. Bernini je izrađivao i skromnije nadgrobnike za manje utjecajne naručitelje. Najčešće ih je oblikovao kao edikule koje su sadržavale portret pokojnika, no ponekad je kao ujedinjujući element umjesto arhitektonskoga okvira koristio viseći zastor, kao na kenotafu Alessandra Valtrinija (1639.) iz bazilike San Lorenzo in Damaso ili onome redovnice Marije Raggi (1647. - 1653.) (Slika 171) iz bazilike Santa Maria sopra Minerva. ${ }^{633}$ Sličan koncept osnovnoga oblikovanja primijenjen je i na prethodno opisanome epitafu Danijela Praunspergera (Slika 169).

Motiv zastora primijenjen je i na nadgrobnoj ploči kanonika Ivana Antolkovića (? ?, 1682.) (Slika 173), ${ }^{634}$ no ne kao kompozicijski određujuće, nego kao scenografski prigušeno i plitko izvedeno pomoćno rješenje. Draperiju na kojoj je ispisan nadgrobni natpis

\footnotetext{
${ }^{632}$ Isto.

${ }^{633}$ Usp. Erwin Panofsky, nav. dj., 1992. [1964.], str. 93.

${ }^{634}$ Vapnenac, $176 \times 94 \times 18 \mathrm{~cm}$, Zagreb, Muzej grada Zagreba, izvorno u katedrali Uznesenja Blažene Djevice Marije i sv. Stjepana i Ladislava u Zagrebu (?). Kat. br. 41.
} 
drži par plačućih anđela koji slobodnom rukom brišu suze, svjedočeći o sklonosti barokne umjetnosti prema izražavanju i isticanju emocija. Između anđela nalazi se kerubin povrh kojega je predočen kalež s Presvetim. Budući da kalež smiju dirati samo svećenici, on predstavlja simbol svećenstva, a u liturgijskim knjigama često je nazivan »novim grobom Kristova tijela« (corporis Christi novum sepulcrum). ${ }^{635}$ Prema natpisu na ploči, Ivan Antolković bio je kanonik i prepošt zagrebačke katedrale. Nije poznato gdje se ploča izvorno nalazila (danas je pohranjena u Muzeju grada Zagreba), no s obzirom na pokojnikovu službu pretpostavlja se da je bila postavljena u zagrebačkoj prvostolnici te da je odande odstranjena 1791. godine prilikom mijenjanja popločenja crkve. ${ }^{636}$

U crkvi Presvetoga Trojstva u Radoboju nedaleko Krapine sačuvan je nadgrobnik na kojem je također upotrijebljen motiv kaleža kao oznake pokojnikove službe. Riječ je o nadgrobnoj ploči župnika Jurja Habijančića $\left(?-\right.$ ?, 1621.) (Slika 174) ${ }^{637}$ koja je ukrašena

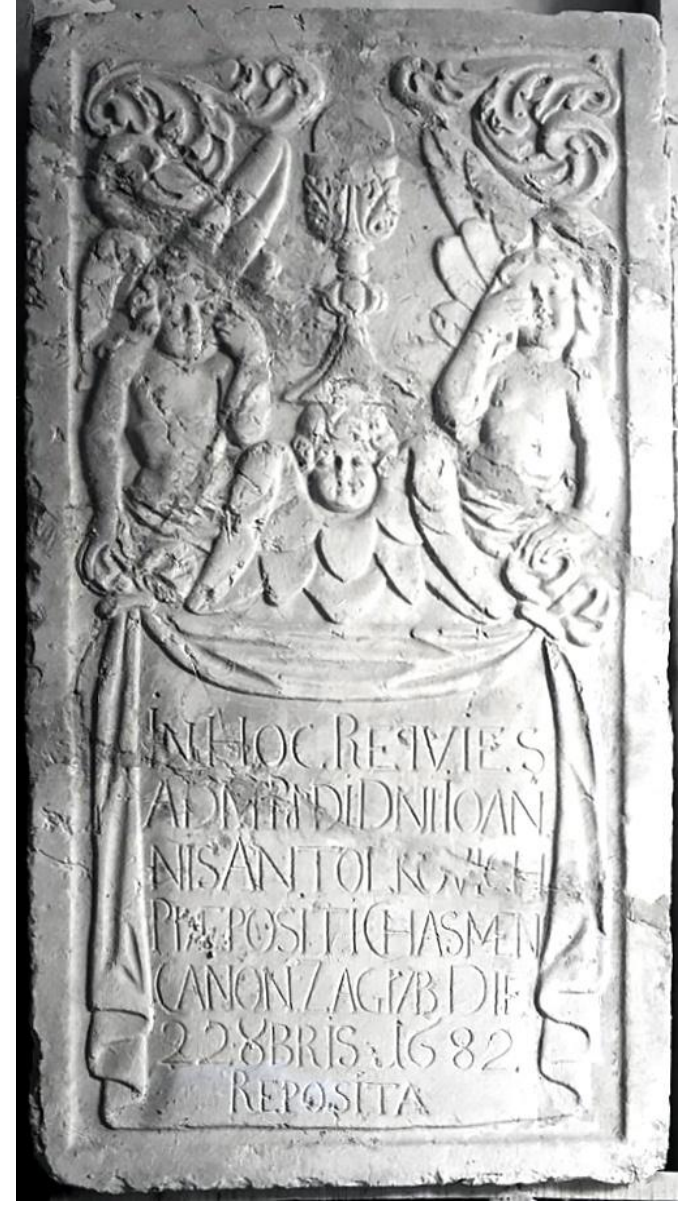

Slika 172. Nadgrobna ploča Ivana Antolkovića (†1682.), Zagreb, Muzej grada Zagreba

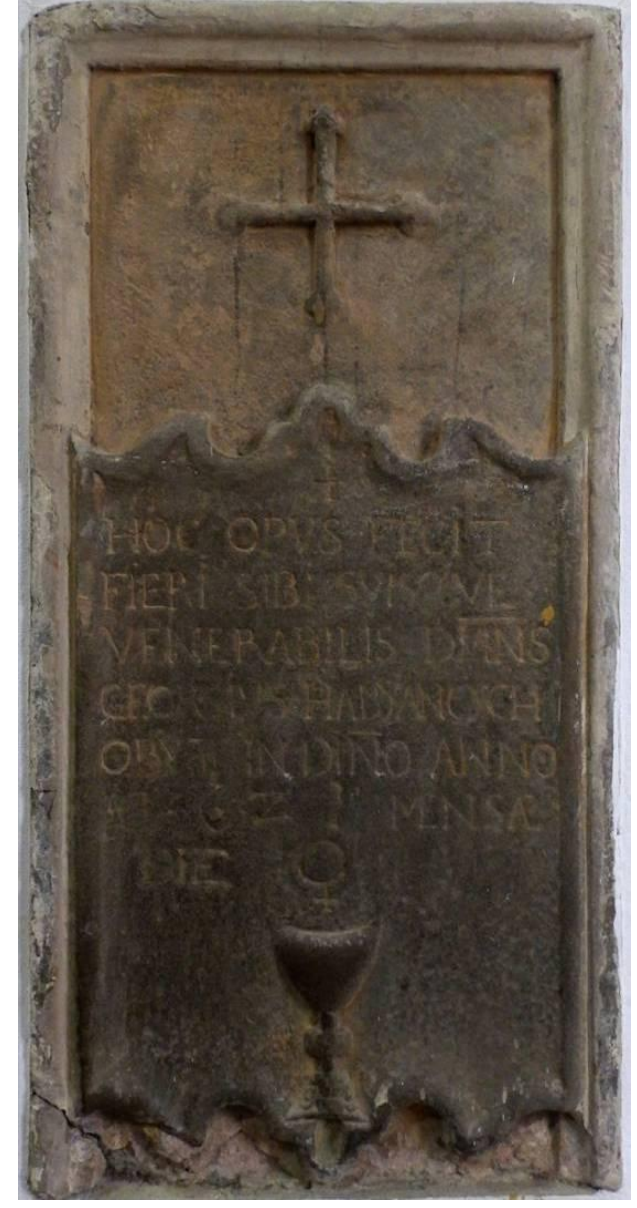

Slika 173. Nadgrobna ploča Jurja Habijančića (†1621.), Radoboj, crkva Presvetoga Trojstva

\footnotetext{
${ }^{635}$ Andreas Zajic, nav. dj., 2004., str. 168.

${ }^{636}$ Podatci preuzeti iz opisa nadgrobne ploče u stalnome postavu Muzeja grada Zagreba.

${ }^{637}$ Kamen, $122 \times 61 \times 3$ cm, Radoboj, crkva Presvetoga Trojstva. Kat. br. 19 .
} 
»križ[em] s kaležom i hostijom te maniristički izveden[im] okvir[om] «. ${ }^{638}$ Donji dio ploče nedostaje te se postavlja pitanje kojim motivom je bio urešen. Nadgrobnik je ugrađen u sjeverni zid svetišta, a tamo je najvjerojatnije postavljen krajem 1750-ih godina kada se mijenjalo popločenje. ${ }^{639}$ Prema natpisu, župnik je postavio ploču za sebe i svoju svjetovnu braću (»HOC OPVS FECIT / FIERI SIBI SVISQVE«). ${ }^{640}$

Kao što je navedeno, motivi funeralne ikonografije upotrijebljeni su i na nadgrobnicima koji su obrađeni u prethodnim potpoglavljima, odnosno na spomenicima koji sadrže prikaz pokojnika ili obiteljskoga grba kao nadređenoga likovnog motiva veće sadržajne važnosti. Ako želimo dobiti što potpuniju sliku o prostornoj zastupljenosti i vremenskoj protežnosti nadgrobnika s funeralnim motivima, potrebno je sagledati spomenike iz svih triju likovnih skupina. U donjem tabličnom pregledu (Tablica 1) tako su uključeni nadgrobnici koji sadrže motive funeralne ikonografije neovisno o njihovom glavnom likovnom rješenju. U posljednjem stupcu navedeni su motivi koji su predočeni na dotičnome spomeniku, a u zagradi je naveden nadređeni likovni motiv u slučaju da je riječ o nadgrobniku s likom pokojnika ili obiteljskim grbom.

Tablica 1. Nadgrobnici s motivima funeralne ikonografije

\begin{tabular}{|c|c|c|}
\hline Nadgrobnik & Izvorni smještaj & Vrsta motiva \\
\hline \multicolumn{3}{|c|}{ XVI. STOLJEĆE } \\
\hline Epitaf Ane Purthin $(\dagger 1589)$. & $\begin{array}{l}\text { Samobor, kapela sv. Mihaela } \\
\text { na Taborcu }\end{array}$ & $\begin{array}{l}\text { lubanja, kosti } \\
\text { (Raspeće s adorantima) }\end{array}$ \\
\hline \multicolumn{3}{|c|}{ XVII. STOLJEĆE } \\
\hline $\begin{array}{l}\text { Nadgrobna ploča Jurja } \\
\text { Habijančića }(† 1621 .)\end{array}$ & $\begin{array}{l}\text { Radoboj, crkva Presvetoga } \\
\text { Trojstva }\end{array}$ & križ, kalež \\
\hline $\begin{array}{l}\text { Epitaf Tome II. Erdődyja } \\
(\dagger 1624 .)\end{array}$ & $\begin{array}{l}\text { Zagreb, katedrala Uznesenja } \\
\text { BDM i sv. Stjepana i } \\
\text { Ladislava }\end{array}$ & $\begin{array}{l}\text { lubanja } \\
\text { (Raspeće s adorantom) }\end{array}$ \\
\hline $\begin{array}{l}\text { Epitaf Stjepana Patačića od } \\
\text { Zajezde i Barbare rođ. } \\
\text { Beković, } 1629 .\end{array}$ & Vidovec, crkva sv. Vida & lubanja, pješčani sat \\
\hline $\begin{array}{l}\text { Nadgrobna ploča Barbare } \\
\text { Zaboky (†1678.) }\end{array}$ & $\begin{array}{l}\text { Lepoglava, crkva } \\
\text { Bezgrješnoga začeća BDM }\end{array}$ & lubanja, kosti \\
\hline $\begin{array}{l}\text { Epitaf Jurja Gorupa } \\
\text { (†o. 1680.) }\end{array}$ & $\begin{array}{l}\text { Pregrada, crkva Uznesenja } \\
\text { Blažene Djevice Marije }\end{array}$ & $\begin{array}{l}\text { lubanja, kosti } \\
\text { (Presveto Trojstvo) }\end{array}$ \\
\hline
\end{tabular}

\footnotetext{
${ }^{638}$ Anđela Horvat, O spomenicima kulture općine Krapina, u: Kaj: časopis za književnost, umjetnost $i$ kulturu 1 , Zagreb: Kajkavsko spravišće, 1982.c, str. 87-142, 111.

${ }^{639}$ Usp. Drago Kozina, Općina Radoboj, Radoboj: Općina Radoboj, 2007., str. 138.

${ }^{640}$ Za puni prijepis natpisa vidi kat. br. 19.
} 


\begin{tabular}{|c|c|c|}
\hline Nadgrobnik & Izvorni smještaj & Vrsta motiva \\
\hline $\begin{array}{l}\text { Nadgrobna ploča Ivana } \\
\text { Antolkovića (†1682.) }\end{array}$ & $\begin{array}{l}\text { Zagreb, katedrala Uznesenja } \\
\text { BDM i sv. Stjepana i } \\
\text { Ladislava }\end{array}$ & zastor, kalež \\
\hline $\begin{array}{l}\text { Nadgrobna ploča Jurja } \\
\text { Orehovačkoga }(\dagger 1687 .)\end{array}$ & $\begin{array}{l}\text { Zagreb, katedrala Uznesenja } \\
\text { BDM i sv. Stjepana i } \\
\text { Ladislava }\end{array}$ & $\begin{array}{l}\text { lubanja, pješčani sat } \\
\text { (obiteljski grb) }\end{array}$ \\
\hline $\begin{array}{l}\text { Epitaf Danijela Praunspergera } \\
(\dagger 1692 .)\end{array}$ & $\begin{array}{l}\text { Varaždin, crkva sv. Ivana } \\
\text { Krstitelja }\end{array}$ & $\begin{array}{l}\text { kosturi, strijela, pješčani sat, } \\
\text { srp, žito, svijeće, zastor }\end{array}$ \\
\hline \multicolumn{3}{|c|}{ XVIII. STOLJEĆE } \\
\hline $\begin{array}{l}\text { Nadgrobna ploča grobnice } \\
\text { franjevačkoga reda (17??.) }\end{array}$ & $\begin{array}{l}\text { Varaždin, crkva sv. Ivana } \\
\text { Krstitelja }\end{array}$ & $\begin{array}{l}\text { lubanja, kosti } \\
\text { (redovnički grb) }\end{array}$ \\
\hline $\begin{array}{l}\text { Epitaf Eve rođ. Dreffel } \\
(† 1672 .) \text { i Jurja Ivana I. Hrvoja } \\
(\dagger 1704 .)\end{array}$ & Plešivica, crkva sv. Jurja & $\begin{array}{l}\text { lubanja, kosti } \\
\text { (Raspeće s adorantima) }\end{array}$ \\
\hline $\begin{array}{l}\text { Nadgrobna ploča Ivana Znike } \\
(\dagger 1706 .)\end{array}$ & $\begin{array}{l}\text { Zagreb, katedrala Uznesenja } \\
\text { BDM i sv. Stjepana i } \\
\text { Ladislava }\end{array}$ & $\begin{array}{l}\text { lubanja, kosti, pješčani sat, } \\
\text { lopata, motika } \\
\text { (obiteljski grb) }\end{array}$ \\
\hline Epitaf obitelji Češković, 1711. & $\begin{array}{l}\text { Lepoglava, crkva } \\
\text { Bezgrješnoga začeća BDM }\end{array}$ & $\begin{array}{l}\text { baklja } \\
\text { (lik pokojnika) }\end{array}$ \\
\hline $\begin{array}{l}\text { Epitaf Nikole Gotala od } \\
\text { Gotalovca, } 1765 .\end{array}$ & $\begin{array}{l}\text { Zagreb, katedrala Uznesenja } \\
\text { BDM i sv. Stjepana i } \\
\text { Ladislava }\end{array}$ & $\begin{array}{l}\text { lubanja, kosti } \\
\text { (obitelji grb) }\end{array}$ \\
\hline $\begin{array}{l}\text { Epitaf Petra Troila Sermagea } \\
\text { od Susedgrada, o. } 1773 .\end{array}$ & $\begin{array}{l}\text { Stenjevec, crkva Uznesenja } \\
\text { BDM }\end{array}$ & $\begin{array}{l}\text { lubanja } \\
\text { (lik pokojnika) }\end{array}$ \\
\hline Ploča Ivane Bajalić (†1781.) & Bjelovar, kapela sv. Križa & lubanja, kosti \\
\hline
\end{tabular}

Na osnovi tabličnoga pregleda možemo zaključiti da su motivi funeralne ikonografije najviše zastupljeni na nadgrobnim spomenicima XVII. i XVIII. stoljeća. Funeralni motiv pojavljuje se na samo jednom spomeniku koji datira iz XVI. stoljeća. Naravno, pritom treba imati na umu fragmentarnu očuvanost korpusa, što znači da ih je izvorno moglo postojati više. Slično drugim rješenjima korpusa, najveća koncentracija ovih nadgrobnika nalazi se na prostoru Hrvatskoga zagorja (Lepoglava, Pregrada, Radoboj), grada Zagreba (Kaptol, Stenjevec) i Prigorja (Varaždin, Vidovec), a pojedini primjerci zastupljeni su i na prostoru Žumberačkoga gorja (Plešivica, Samobor) te grada Bjelovara. 


\section{POKOJNICI, NARUČITELJI I UMJETNICI}

Prilikom razmatranja okolnosti narudžaba nadgrobnih spomenika, važno je sagledati sljedeća pitanja: tko podiže spomenike, kada i s kojom namjerom. Postavljena pitanja međusobno su povezana i neizostavna za potpunu interpretaciju i kontekstualizaciju nadgrobnikā kao materijalnih svjedočanstava želja i težnji pokojnikā odnosno njihovih baštinikā. Tražene odgovore pokušali smo pronaći u pisanim izvorima kao i na samim spomenicima.

Među povijesnim izvorima, glavna pozornost usmjerena je na istraživanje kanonskih vizitacija, župnih spomenica i pojedinačnih oporuka pokojnika. U kanonskim vizitacijama, koje su ponovno uvedene nakon Tridentskoga sabora (1544. - 1563.), od najveće su važnosti bili zapisnici o izgledu crkava i njihovom unutrašnjem uređenju. Ako se u crkvi nalazila kripta odnosno podzemna grobnica, vizitatori su bili dužni zabilježiti njezin smještaj. Poneki su znali zapisati je li grobnica bila namijenjena pokapanju župnikā, kolatorā ili mještanā te kolika je bila cijena ukopa. Međutim, tek su rijetki naveli je li neko grobno mjesto bilo obilježeno nadgrobnikom, poput vizitatora Petra Završkoga koji je prilikom posjeta crkvi sv. Marka evanđelista u Vinici (1726.) naveo da se u crkvi nalazi spomenik obitelji Istvánffy (Slika 151). ${ }^{641}$ Ti su zapisi vrlo kratki i bilježe samo postojanje spomenika, no ne i njegov izgled.

U većini župnih spomenica najraniji zabilježeni podatci odnose se na vrijeme nakon smrti pokojnika i postavljanja nadgrobnoga spomenika. Ako u njima i postoji zapis o postojećem spomeniku, on uglavnom sadrži sažeti opis nadgrobnika, podatak o njegovom smještaju i prijepis uklesanoga natpisa. Podatci o samoj narudžbi na žalost izostaju. Jedna od župnih spomenica koja sadrži informacije o nadgrobnicima koji se nalaze u crkvi je Spomenica lepoglavske župe (Liber Memorabilium Parochiae Lepoglavensis ab Anno 1401 usque $1789{ }^{u m}$ ). Izuzev pisanih opisa, spomenica sadrži i crteže nadgrobnih spomenika koji dokumentiraju njihov izgled s relativnom točnošću. ${ }^{642}$

Oporuke pokojnikā, osim uobičajenih stavki kojima sastavljač određuje na koji će se način razdijeliti njegova imovina i drugih pojedinosti koje želi da se provedu nakon njegove smrti, ponekad sadrže podatak o mjestu odnosno crkvi u kojoj pokojnik želi biti pokopan. Stjepan IV. (III.) Frankapan Ozaljski (†1577.) tako je, primjerice, u svojoj oporuci izrazio

\footnotetext{
${ }^{641}$ Usp. NAZ, KV, Prot. 167/VIII (1726.), str. 262.

${ }^{642}$ Usp. Lib. Mem., Arhiv HAZU, sign. IV. d. 77., fol. 1v-5r.
} 
želju da bude sahranjen u kapeli Blažene Djevice Marije na Smolčevu vrhu, koja je poznata pod imenom Svetice:

»Pokop y pokoy wykowychny thela nassega Izbyramo v czrykwy Blasene Dywe Marie na Zmolcha warhu, ka ze zowe Zwetycza, Da ze onde pokopa, y pokopano da cheka onoga pozlydnyega dne, na ky chye wzaky polag zwoga Dela plachw prygety, kako ky Bwde zazlusyl. « ${ }^{643}$

Međutim, u oporuci nema spomena o nadgrobnome spomeniku (Slika 119) kojim je naposljetku obilježen njegov grob.

Osnovni izvor koji sadrži pojedinosti o tome tko je i kada postavio neki nadgrobnik su sami spomenici odnosno natpisi uklesani na njima. Naravno, ne sadrži svaki nadgrobnik i pripadajući mu natpis tražene podatke. Od osamdeset i pet nadgrobnih spomenika s likovnim motivom koji su sačuvani ili dokumentirani na području povijesne Zagrebačke biskupije, njih trideset i četiri sadrži potankosti o tome tko ih je dao postaviti, uz dva spomenika o čijim okolnostima narudžbe znamo na osnovi sačuvanih ugovora s majstorima (Tablica 2). Iako u konačnici raspolažemo podatcima o manjem dijelu nadgrobnika (oko 42\%), oni su dostatni da dobijemo opći uvid u mehanizme naručivanja. Najveći broj podataka poznat je o nadgrobnicima iz XVII. i XVIII. stoljeća, što možemo objasniti činjenicom da su natpisi na spomenicima slijedom stoljećā postajali sve duži te su sve učestalije sadržavali podatke o tome tko ih je dao izraditi.

Tablica 2. Pojedinosti o okolnostima narudžbe pojedinih nadgrobnih spomenika

\begin{tabular}{|c|c|c|c|}
\hline Nadgrobnik & Izvorni smještaj & Naručitelj & $\begin{array}{l}\text { Godina } \\
\text { postavljanja } \\
\text { nadgrobnika }\end{array}$ \\
\hline \multicolumn{4}{|c|}{ XV. STOLJEĆE } \\
\hline $\begin{array}{l}\text { Nadgrobna ploča } \\
\text { granešinskoga župnika } \\
\text { Matije }(\dagger 1472 .)\end{array}$ & $\begin{array}{l}\text { Zagreb, crkva sv. } \\
\text { Marka }\end{array}$ & pokojnik za sebe & \\
\hline $\begin{array}{l}\text { Nadgrobna ploča } \\
\text { kanonikā Ivana i Blaža } \\
(† 1495 .) \text { iz Moravča }\end{array}$ & $\begin{array}{l}\text { Zagreb, katedrala } \\
\text { Uznesenja BDM i sv. } \\
\text { Stjepana i Ladislava }\end{array}$ & $\begin{array}{l}\text { pokojnik za sebe i } \\
\text { svojega brata }\end{array}$ & \\
\hline \multicolumn{4}{|c|}{ XVI. STOLJEĆE } \\
\hline $\begin{array}{l}\text { Nadgrobna ploča } \\
\text { Ivaniša Korvina } \\
(† 1504 .)\end{array}$ & $\begin{array}{l}\text { Lepoglava, crkva } \\
\text { Bezgrješnoga začeća } \\
\text { BDM }\end{array}$ & $\begin{array}{l}\text { prijatelj i bliski } \\
\text { suradnik, Ivan Gyulay }\end{array}$ & 1505. \\
\hline
\end{tabular}

${ }^{643}$ Prijepis Frankapanove oporuke objavio je: Ivan Kukuljević Sakcinski, Acta Croatica = Listine Hrvatske, Zagreb: Brzotiskom Narodne tiskarnice dra. Ljudevita Gaja, 1863., str. 266-269, 266. 


\begin{tabular}{|c|c|c|c|}
\hline Nadgrobnik & Izvorni smještaj & Naručitelj & $\begin{array}{l}\text { Godina } \\
\text { postavljanja } \\
\text { nadgrobnika }\end{array}$ \\
\hline $\begin{array}{l}\text { Nadgrobnik Ivana } \\
\text { Karlovića }(† 1531 .)\end{array}$ & $\begin{array}{l}\text { Remete, crkva } \\
\text { Uznesenja BDM }\end{array}$ & $\begin{array}{l}\text { supruga Jelena Karlović } \\
\text { rođ. Zrinski }\end{array}$ & \\
\hline $\begin{array}{l}\text { Nadgrobna ploča Franje } \\
\text { I. Frankapana } \\
\text { Slunjskoga }(\dagger 1572 .)\end{array}$ & $\begin{array}{l}\text { Zagreb, katedrala } \\
\text { Uznesenja BDM i sv. } \\
\text { Stjepana i Ladislava }\end{array}$ & $\begin{array}{l}\text { sestra Ana Frankapan } \\
\text { ud. Császár de Lanser }\end{array}$ & \\
\hline $\begin{array}{l}\text { Epitaf Nikole IV. } \\
\text { Zrinskoga }(\dagger 1566 .)\end{array}$ & $\begin{array}{l}\text { Šenkovec, crkva sv. } \\
\text { Jelene }\end{array}$ & sin Juraj IV. Zrinski ${ }^{*}$ & 1574. \\
\hline $\begin{array}{l}\text { Nadgrobna ploča } \\
\text { Mojsija Humskoga } \\
(\dagger 1584 .)\end{array}$ & $\begin{array}{l}\text { Mače, crkva } \\
\text { Bezgrješnoga začeća } \\
\text { BDM }\end{array}$ & pokojnik za sebe & $\begin{array}{l}\text { (oporučno } \\
\text { post mortem) }\end{array}$ \\
\hline $\begin{array}{l}\text { Epitaf Ane Purthin } \\
(\dagger 1589 .)\end{array}$ & $\begin{array}{l}\text { Samobor, kapela sv. } \\
\text { Mihaela na Taborcu }\end{array}$ & suprug (ime nepoznato) & \\
\hline $\begin{array}{l}\text { Nadgrobna ploča } \\
\text { Gašpara I. Draškoviča } \\
(† 1591 .) \text { i Katarine rođ. } \\
\text { Székely de Kevend } \\
(† 1587 .)\end{array}$ & $\begin{array}{l}\text { Bednja, crkva sv. } \\
\text { Marije Magdalene }\end{array}$ & $\begin{array}{l}\text { sinovi Ivan II. i Petar } \\
\text { Drašković }\end{array}$ & \\
\hline \multicolumn{4}{|c|}{ XVII. STOLJEĆE } \\
\hline $\begin{array}{l}\text { Epitaf Nikole } \\
\text { Istvánffyja }(\dagger 1615 .) \text { i } \\
\text { Elizabete rođ. Both de } \\
\text { Bajna }(\dagger 1597 .)\end{array}$ & $\begin{array}{l}\text { Vinica, crkva sv. } \\
\text { Marka evanđelista }\end{array}$ & $\begin{array}{l}\text { pokojnik za sebe i svoju } \\
\text { preminulu suprugu }\end{array}$ & $\begin{array}{l}1603 . \\
\text { (za života) }\end{array}$ \\
\hline $\begin{array}{l}\text { Epitaf Baltazara I. } \\
\text { Patačića }(\dagger 1616 .)\end{array}$ & $\begin{array}{l}\text { Zajezda, crkva } \\
\text { Uznesenja BDM }\end{array}$ & $\begin{array}{l}\text { supruga Margareta } \\
\text { Patačić rođ. Babonožić }\end{array}$ & \\
\hline $\begin{array}{l}\text { Nadgrobna ploča } \\
\text { Elizabete Sudić }\end{array}$ & $\begin{array}{l}\text { Krapina, crkva sv. } \\
\text { Nikole }\end{array}$ & suprug Ivan Logmagi & 1620. \\
\hline $\begin{array}{l}\text { Nadgrobna ploča } \\
\text { župnika Jurja } \\
\text { Habijančića (†1621.) }\end{array}$ & $\begin{array}{l}\text { Radoboj, crkva } \\
\text { Presvetoga Trojstva }\end{array}$ & $\begin{array}{l}\text { pokojnik za sebe i svoju } \\
\text { obitelj }\end{array}$ & \\
\hline $\begin{array}{l}\text { Epitaf Stjepana } \\
\text { Patačića od Zajezde } \\
(† 1636 .) \text { i Barbare rođ. } \\
\text { Beković }\end{array}$ & $\begin{array}{l}\text { Vidovec, crkva sv. } \\
\text { Vida }\end{array}$ & $\begin{array}{l}\text { pokojnik za sebe i svoju } \\
\text { obitelj }\end{array}$ & $\begin{array}{l}1626 . \\
\text { (za života) }\end{array}$ \\
\hline $\begin{array}{l}\text { Nadgrobna ploča } \\
\text { biskupa Ivana II. } \\
\text { Erdődyja (†1626.) }\end{array}$ & $\begin{array}{l}\text { Zagreb, katedrala } \\
\text { Uznesenja BDM i sv. } \\
\text { Stjepana i Ladislava }\end{array}$ & $\begin{array}{l}\text { kanonik i prijatelj } \\
\text { Gašpar Vrbanović }\end{array}$ & \\
\hline $\begin{array}{l}\text { Epitaf Franje Keczera } \\
\text { od } \operatorname{Rad}(\mathbf{o}) \mathbf{v a n a} \\
(\dagger \text { nakon } 1631 .)\end{array}$ & $\begin{array}{l}\text { Vinica, crkva sv. } \\
\text { Marka evanđelista }\end{array}$ & $\begin{array}{l}\text { pokojnik za sebe i svoju } \\
\text { obitelj }\end{array}$ & $\begin{array}{l}1629 . \\
\text { (za života) }\end{array}$ \\
\hline
\end{tabular}




\begin{tabular}{|c|c|c|c|}
\hline Nadgrobnik & Izvorni smještaj & Naručitelj & $\begin{array}{l}\text { Godina } \\
\text { postavljanja } \\
\text { nadgrobnika }\end{array}$ \\
\hline $\begin{array}{l}\text { Nadgrobna ploča Ivana } \\
\text { Horvata Radića }\end{array}$ & $\begin{array}{l}\text { Mihovljan, crkva sv. } \\
\text { Mihovila arkanđela }\end{array}$ & $\begin{array}{l}\text { pokojnik za sebe i svoju } \\
\text { obitelj }\end{array}$ & 1630. \\
\hline $\begin{array}{l}\text { Epitaf Gašpara } \\
\text { Bedekovića }(\dagger 1656 .)\end{array}$ & $\begin{array}{l}\text { Krapina, crkva sv. } \\
\text { Katarine }\end{array}$ & brat Melkior Bedeković & \\
\hline $\begin{array}{l}\text { Epitaf Jurja IV. } \\
\text { Frankapana Tržačkoga } \\
(† 1661 .)\end{array}$ & $\begin{array}{l}\text { Zagreb, crkva sv. } \\
\text { Katarine }\end{array}$ & $\begin{array}{l}\text { supruga Sofija } \\
\text { Frankapan rođ. Forgách }\end{array}$ & \\
\hline $\begin{array}{l}\text { Epitaf Ivana Herbarta } \\
\text { X. Auersperga }(\dagger 1669 .)\end{array}$ & $\begin{array}{l}\text { Zagreb, crkva sv. } \\
\text { Katarine }\end{array}$ & $\begin{array}{l}\text { supruga Ana Elizabeta } \\
\text { Auersperg rođ. Moscon }\end{array}$ & \\
\hline $\begin{array}{l}\text { Epitaf Ivana Petheőa de } \\
\text { Gerse }(\dagger 1671 .)\end{array}$ & $\begin{array}{l}\text { Lepoglava, crkva } \\
\text { Bezgrješnoga začeća } \\
\text { BDM }\end{array}$ & $\begin{array}{l}\text { supruga Judita Petheő } \\
\text { de Gerse rođ. Balagović } \\
\text { de Japra }\end{array}$ & 1673. \\
\hline $\begin{array}{l}\text { Epitaf Martina } \\
\text { Mogorića }(† 1643 .)\end{array}$ & $\begin{array}{l}\text { Marija Gorica, crkva } \\
\text { Pohoda BDM }\end{array}$ & zet Mihael Vernić & 1675. \\
\hline $\begin{array}{l}\text { Epitaf Jurja Gorupa od } \\
\text { Bežanca (†o. 1680.) }\end{array}$ & $\begin{array}{l}\text { Pregrada, crkva } \\
\text { Uznesenja BDM }\end{array}$ & $\begin{array}{l}\text { supruga Ana Gorup rođ. } \\
\text { Oršić od Slavetića }\end{array}$ & \\
\hline $\begin{array}{l}\text { Nadgrobna ploča } \\
\text { župnika Grgura Zebeca } \\
(† 1684 .)\end{array}$ & $\begin{array}{l}\text { Mihovljan, crkva sv. } \\
\text { Mihovila arkanđela }\end{array}$ & brat Franjo Zebec & 1684. \\
\hline $\begin{array}{l}\text { Epitaf Ivana Josipa } \\
\text { Herbersteina }(\dagger 1689 .)\end{array}$ & $\begin{array}{l}\text { Karlovac, kapela sv. } \\
\text { Josipa }\end{array}$ & $\begin{array}{l}\text { nećak Ivan Ferdinand } \\
\text { Josip Herberstein }\end{array}$ & \\
\hline $\begin{array}{l}\text { Epitaf Danijela } \\
\text { Praunspergera }(† 1692 .)\end{array}$ & $\begin{array}{l}\text { Varaždin, crkva sv. } \\
\text { Ivana Krstitelja }\end{array}$ & $\begin{array}{l}\text { pokojnik za sebe i svoju } \\
\text { obitelj }\end{array}$ & \\
\hline $\begin{array}{l}\text { Epitaf Nikole III. } \\
\text { Erdődyja (†1693.) }\end{array}$ & $\begin{array}{l}\text { Zagreb, katedrala } \\
\text { Uznesenja BDM i sv. } \\
\text { Stjepana i Ladislava }\end{array}$ & $\begin{array}{l}\text { kanonik Ivan Josip } \\
\text { Babić }^{*}\end{array}$ & 1693. \\
\hline \multicolumn{4}{|c|}{ XVIII. STOLJEĆE } \\
\hline $\begin{array}{l}\text { Epitaf Eve rođ. Dreffel } \\
(† 1672 .) \text { i Jurja Ivana I. } \\
\text { Hrvoja }(\dagger 1704 .)\end{array}$ & $\begin{array}{l}\text { Plešivica, crkva sv. } \\
\text { Jurja }\end{array}$ & $\begin{array}{l}\text { pokojnik za sebe i svoju } \\
\text { suprugu }\end{array}$ & \\
\hline $\begin{array}{l}\text { Nadgrobna ploča } \\
\text { biskupa Nikole III. } \\
\text { Ogramića Olovčića } \\
(\dagger 1701 .)\end{array}$ & $\begin{array}{l}\text { Našice, crkva sv. } \\
\text { Antuna Padovanskoga }\end{array}$ & nećak Erazmo Ogramić & 1701. \\
\hline $\begin{array}{l}\text { Epitaf Ladislava III. } \\
\text { Patačića od Zajezde } \\
(† 1705 .)\end{array}$ & $\begin{array}{l}\text { Lepoglava, crkva } \\
\text { Bezgrješnoga začeća } \\
\text { BDM }\end{array}$ & $\begin{array}{l}\text { supruga Barbara Patačić } \\
\text { rođ. Vragović }\end{array}$ & 1710. \\
\hline
\end{tabular}




\begin{tabular}{|c|c|c|c|}
\hline Nadgrobnik & Izvorni smještaj & Naručitelj & $\begin{array}{l}\text { Godina } \\
\text { postavljanja } \\
\text { nadgrobnika }\end{array}$ \\
\hline $\begin{array}{l}\text { Epitaf Pavla starijega } \\
(\dagger 1666 .) \text { i Katarine } \\
\text { Češković te njihovoga } \\
\text { sina Pavla mlađega } \\
(† 1709 .)\end{array}$ & $\begin{array}{l}\text { Lepoglava, crkva } \\
\text { Bezgrješnoga začeća } \\
\text { BDM }\end{array}$ & $\begin{array}{l}\text { sin odnosno brat Pavao } \\
\text { Antun Češković }\end{array}$ & 1711. \\
\hline $\begin{array}{l}\text { Epitaf Sigismunda } \\
\text { Ratkaja (†1702.) }\end{array}$ & $\begin{array}{l}\text { Lepoglava, crkva } \\
\text { Bezgrješnoga začeća } \\
\text { BDM }\end{array}$ & sin Karlo Josip Ratkaj & 1722. \\
\hline $\begin{array}{l}\text { Epitaf Baltazara II. } \\
\text { Patačića }(\dagger 1719 .) \text { i } \\
\text { Terezije rođ. Gereczy } \\
(\dagger 1722 .)\end{array}$ & $\begin{array}{l}\text { Remetinec, crkva } \\
\text { Kraljice Svete } \\
\text { Krunice }\end{array}$ & $\begin{array}{l}\text { sin Aleksandar Antun } \\
\text { Marija Patačić }\end{array}$ & 1722. \\
\hline $\begin{array}{l}\text { Epitaf kanonika Nikole } \\
\text { Gotala od Gotalovca } \\
(† 1723 .)\end{array}$ & $\begin{array}{l}\text { Zagreb, katedrala } \\
\text { Uznesenja BDM i sv. } \\
\text { Stjepana i Ladislava }\end{array}$ & nećak Stjepan Puc & 1765. \\
\hline $\begin{array}{l}\text { Nadgrobna ploča Vuka } \\
\text { Jelačića }(† 1770 .)\end{array}$ & $\begin{array}{l}\text { Stenjevec, crkva } \\
\text { Uznesenja BDM }\end{array}$ & supruga, sinovi i kćeri & 1777. \\
\hline $\begin{array}{l}\text { Ploča Ivane Bajalić } \\
(\dagger 1781 .)\end{array}$ & $\begin{array}{l}\text { Bjelovar, kapela sv. } \\
\text { Križa }\end{array}$ & suprug Adam Bajalić & \\
\hline
\end{tabular}

* Podatci poznati iz sačuvanih ugovora.

U pravilu, nadgrobne spomenike najčešće su podizali članovi obitelji nakon pokojnikove smrti - supružnici za preminule bračne drugove, djeca za roditelje, braća za braću. U rjeđim slučajevima nadgrobnike su postavljali članovi šire obitelji, poput nećaka ili zetova. Braća i nećaci najčešće su podizali spomenike za pojedince koji zbog službe (crkvene ili vojne) odnosno spleta životnih okolnosti nisu imali vlastitu obitelj. Primjerice, knez Franjo I. Frankapan Slunjski (†1572.) tragično je preminuo od posljedica nestručnoga liječničkog zahvata na putu za grad Mikulov (današnja Češka), gdje se trebao oženiti Juditom Krečin. S obzirom na to da je umro neženja, brigu o kneževom pogrebu u zagrebačkoj prvostolnici preuzela je njegova sestra Ana ud. Császár de Lanser, koja mu je ondje i postavila spomenik. ${ }^{644} \mathrm{U}$ tek iznimnim slučajevima nadgrobnike su naručile osobe koje nisu bile u krvnome srodstvu s pokojnicima, nego su s njima bile povezane prijateljskom i/ili suradničkom vezom. Tako je, primjerice, kustos i kanonik Gašpar Vrbanović dao obilježiti grob biskupa Ivana II. Erődyja (†1626.) nadgrobnom pločom (Slika 139) »iz ljubavi«

\footnotetext{
${ }^{644}$ Nadgrobnik na žalost nije očuvan. Za poznate detalje vidi kat. br. 35 .
} 
(AMORIS ERGO) prema biskupu s kojim je prijateljevao. ${ }^{645}$ Pokojnici su ponekad sami platili postavljanje nadgrobnika u želji da - kao što piše na epitafu Nikole Istvánffyja (†1615.) "poštede potomke te brige« (HAC CVRA POSTEROS LEVARE), ${ }^{646}$ ali i osiguraju se da će njihovo grobno mjesto biti obilježeno spomenikom prema njihovom ukusu. U takvim slučajevima, nadgrobnici su najčešće postavljeni još za pokojnikova života, a dio natpisa koji se odnosio na godinu njihove smrti uklesan je naknadno.

Kao što je objašnjeno u početnom dijelu disertacije, nadgrobni spomenici imali su trostruku ulogu: služili su očuvanju uspomene na pokojnika (komemorativna funkcija), ukazivali su na njegov društveni status (reprezentativna funkcija) i zrcalili su vjeru u uskrsnuće duše (eshatološka funkcija). Sjećanje na preminuloga, ali i obitelj kojoj je pripadao tijekom ovozemaljskoga života, prenosilo se tekstom odnosno uklesanim natpisom te likovnim jezikom - (pseudo)portretom i/ili obiteljskim grbom. Potreba za očuvanjem osobne i obiteljske memorije bila je toliko postojana da u slučajevima kada je smrću pokojnika izumrla obiteljska loza ili jedan od njezinih ogranaka, ulogu naručitelja preuzimala je najbliža živuća rodbina. Primjerice, nakon smrti posljednjega muškoga člana obitelji Gotal, zagrebački prepošt i beogradsko-smederevski biskup Stjepan Puc odlučio je odati počast Gotalovima kao njihov posljednji odvjetak po ženskoj lozi obnovivši obiteljsku grobnu kapelu u Gotalovcu (1755. - 1758.) i postavivši epitaf za jednoga od istaknutih članova obitelji, kanonika Nikolu Gotala (†1723.) (Slika 162), u zagrebačkoj katedrali čak četrdeset i dvije godine nakon kanonikove smrti (1765.). ${ }^{647}$ Upisivanjem vlastitoga imena uz ono pokojnika, naručitelji su htjeli osigurati da njihova zasluga za podizanje spomenika ne ostane nezabilježena, ali i posvjedočiti o rodbinskoj, prijateljskoj ili suradničkoj vezi s preminulim. Što je pokojnik bio utjecajniji i ugledniji, to je motivacija naručiteljā za postavljanjem nadgrobnika bila veća jer su na taj način ujedno podizali i učvršćivali vlastiti ugled. Već je naveden primjer Mihaela Vernića, člana bogate no u to vrijeme još uvijek mlade plemićke obitelji, koji je postavio epitaf svojem puncu, ogulinskome kapetanu Martinu Mogoriću (†1643.) (Slika 106), tri desetljeća nakon njegove smrti. Tim činom Vernić je osnažio svoju vezu s jednom od najstarijih hrvatskih plemićkih obitelji i doprinio potvrdi legitimiteta novostečene plemićke titule za svoju obitelj.

Tekstualnim i likovnim sadržajem, složenošću forme te kvalitetom izvedbe nadgrobni spomenici ukazivali su na društveno-ekonomski položaj pokojnika. Titule, postignuća,

\footnotetext{
${ }^{645}$ Za puni prijepis natpisa s nadgrobne ploče Ivana II. Erdődyja vidi kat. br. 39.

${ }^{646} \mathrm{Za}$ puni prijepis natpisa s epitafa Nikole Istvánffyja vidi kat. br. 71.

${ }^{647}$ Usp. Ivanka Reberski (ur.), nav. dj., 2008., sub voce Gotalovec. Kapela sv. Petra: Oprema crkve. Oltari, kipovi, str. 113-114 [Doris Baričević].
} 
zasluge i vrline zabilježeni u natpisu služili su prezentaciji i glorifikaciji preminuloga. Opisne sintagme poput »najveća nada i zvijezda dobroga savjeta» (MAXIMA SPES RERVM CONSILIO IVBAR) $)^{648}$ ili »otac i zaštitnik prijateljske naravi te sveti čovjek velike pobožnosti« (PATER ATQ[UE] PATRONVS AMICIS / MORIBVS ET SANCTA VIR PIETATE GRAVIS $)^{649}$ podjednako su krasile spomenike plemića i crkvenih velikodostojnika. Sama činjenica da su pokojnici pokopani unutar crkvenoga prostora i da je njihovo grobno mjesto obilježeno nadgrobnim spomenikom značila je da su novcem mogli zagrobno produljiti svoj zemaljski ugled i svjetovnu moć. Materijal iz kojega je nadgrobnik izrađen (drvo, štuk, kamen, mramor, bronca), njegova veličina i kompleksnost likovnoga rješenja također su služili kao posredni pokazatelj financijskih mogućnosti pokojnikā odnosno njihovih baštinikā. Naravno, pritom uvijek treba uzeti u obzir mogućnost da su se pokojnici odlučili za jednostavniji spomenik kao iskaz skromnosti i poniznosti. Biskup Martin Borković (†1687.) zatražio je u oporuci da se iznad njegova groba postavi »jednostavna ploča, bez riječi hvale« (lat. simplicis lapidis, sine aliqua laude) jer je smatrao da ih nije zaslužio. ${ }^{650}$ Borkovićeva nadgrobna ploča na žalost nije sačuvana, stoga ne možemo provjeriti je li biskupova želja ispoštovana. Međutim, njegov zahtjev ukazuje na raspon i način razmišljanja koji su naručitelji primjenjivali prilikom narudžbe nadgrobnih spomenika.

Uz komemorativnu i reprezentativnu funkciju koje su svjetovnoga karaktera, nadgrobni spomenici imali su i eshatološku namjenu. Odabirom određenoga likovnoga prikaza i/ili natpisa, pokojnici su iskazivali svoju vjeru u nastavak života nakon smrti i uskrsnuće duše. Kao što je objašnjeno u prethodnome poglavlju, nadgrobnici sa samostalnim likom pokojnika mogu se razmatrati kao »portreti za vječnost«, no u mislima ranonovovjekovnih vjernika oni su predstavljali blaženike koji iščekuju drugi dolazak Krista. ${ }^{651}$ Prikazi pokojnika-adoranta koji mole i kleče pred Raspetim su pak simbolizirali vjeru u otkupljenje grijeha i spasenje putem Kristove žrtve. ${ }^{652}$ Čak i nadgrobnici koji sadrže samo motiv obiteljskoga grba često su popraćeni tekstom koji odražava vjeru u vječni život, poput nadgrobne ploče ivanečkoga kapetana Kristofora Spišića (†1614.) (Slika 128) koji će, prema natpisu, »na posljednji dan ustati iz mrtvih u vječno blaženstvo« (IN NOVISSIMO DIE,

\footnotetext{
${ }^{648}$ Riječ je o dijelu natpisa koji je uklesan na nadgrobnoj ploči Petra II. Ratkaja (†1586.) iz crkve sv. Jurja u Desiniću. Za puni prijepis natpisa vidi kat. br. 1.

${ }^{649}$ Riječ je o dijelu natpisa koji je uklesan na nadgrobnoj ploči Jurja Orehovačkoga (†1687.) koja se izvorno nalazila u zagrebačkoj prvostolnici. Za puni prijepis natpisa vidi kat. br. 42 .

${ }^{650}$ Metod Hrg, nav. dj., 1986., str. 71.

${ }^{651}$ Usp. Philippe Ariès, nav. dj., 1981., str. 241-242, 245; Emilijan Cevc, nav. dj., 1981., str. 307, bilj. 72; Željko Demo, nav. dj., 2007., str. 50-51; Gerhard Winkler, nav. dj., 1974., str. 214.

${ }^{652}$ Usp. Philippe Ariès, nav. dj., 1981., str. 214.
} 
A MORTE AETE / RNAM BEATITVDINEM EXCITABIT). ${ }^{653}$ Stoga komemorativnoreprezentativnu i eshatološku funkciju nadgrobnika ne treba sagledavati kao međusobno isključive nego komplementarne sastavnice koje su naručitelji imali na umu prilikom narudžbe nadgrobnih spomenika.

$$
* * *
$$

Znatno je manje podataka poznato o majstorima koje su naručitelji angažirali. Imenom su poznata samo četvorica: Johannes Fiorentinus (aktivnost radionice: o. 1495. - o. 1525.), majstor ostrogonske kiparske radionice koji je izradio nadgrobnu ploču zagrebačkoga biskupa Luke de Szegeda (Slika 25); Adriaen van Conflans (Bruxelles, 1535. - Amsterdam, 1607.), bečki dvorski slikar flandrijskoga podrijetla koji je osmislio i izradio drveni epitaf za bana Nikolu IV. Zrinskoga (nije očuvan); Ivan Komersteiner (?, pol. XVII. st. - Zagreb, 1694./95.), vodeći zagrebački barokni drvorezbar i kipar koji je izradio nadgrobne ploče biskupa Martina Borkovića (nije očuvana) i Jurja Orehovačkoga (Slika 140) te drveni epitaf bana Nikole III. Erdődyja (Slika 146); te Josip Buk (? - ?), manje poznati majstor koji je izradio epitaf Franje Ksavera Pejačevića (Slika 157). Imena Johannesa Fiorentinusa i Josipa Buka uklesana su na samim spomenicima, a ona Adriaena van Conflansa i Ivana Komersteinera poznata su iz arhivskih izvora. Navedeni nadgrobnici predstavljaju kvalitetna kiparska i drvorezbarska djela koja odgovaraju položaju osoba za koje su izrađeni - biskupe, banove i kanonike. Epitaf Nikole IV. Zrinskoga (†1566.) na žalost nije sačuvan, no iz arhivskih izvora poznato je da su troškovi njegove izrade iznosili 250 talira, što je - kako smo već napomenuli - više od pola godišnje plaće glavnoga rizničara odnosno kraljevskoga tavernika (400 talira). ${ }^{654}$ Mogući izgled spomenika te vrsnoća njegove izvedbe još i danas golicaju maštu istraživača zbog pozamašne svote koja je isplaćena majstoru. Ivan Komersteiner primio je pak 73 rajnskih forinti za klesanje nadgrobne ploče Martina Borkovića. ${ }^{655}$ Ploča na žalost nije očuvana, stoga ne znamo koliko je bila likovno složena. Daleko je to od 650 rajnskih forinti koje su isplaćene majstoru za izradu oltara sv. Ladislava u zagrebačkoj prvostolnici, ${ }^{656}$ no ipak je riječ o značajnijem iznosu. Kao dodatnu usporedbu možemo navesti podatak da je Komersteiner za izradu glavnoga oltara kapelice sv. Martina u Vlaškoj ulici primio 20 rajnskih forinti

\footnotetext{
${ }^{653}$ Za puni prijepis natpisa vidi kat. br. 76 .

${ }^{654}$ Usp. Ivan Bach, nav. dj., 1957., str. 199-200; János Kapossy, nav. dj., 1948., str. 180.

${ }^{655}$ Usp. Metod Hrg, nav. dj., 1986., str. 83.

${ }^{656}$ Usp. Ivan Kukuljević Sakcinski, nav. dj., 1856., str. 23; Ivan Krstitelj Tkalčić, nav. dj., 1885., str. 61; Martina Wolff Zubović, nav. dj., sv. 1, 2017., str. 66.
} 
(vrijednost mu je isplaćena u žitu), ${ }^{657}$ više nego trostruko manje za Borkovićevu nadgrobnu ploču.

Postoji još kvalitetnih nadgrobnika koji zasad nisu pripisani nekome majstoru ili radionici, poput nadgrobne ploče supružnika Drašković (Slika 37) iz Bednje, epitafa supružnika Hrvoj (Slika 100) iz Plešivice ili epitafa Tome II. Erdődyja (Slika 102) iz zagrebačke prvostolnice, da imenujemo samo neke. Međutim, velik dio nadgrobnih spomenika ipak je nešto skromnije izvedbe, a za njihovu izradu angažirani su neznani majstori odnosno klesarske radionice. U pokušaju da se rasvijetle okolnosti nastanka čim većega dijela spomeničkoga korpusa, pojedini nadgrobnici komparativnom su analizom pripisani radionicama koje su imenovane prema mjestu njihovoga djelovanja ili najranijem atribuiranom radu. Nadgrobna ploča Nikole III. Zrinskoga (Slika 114) iz Zrina i nadgrobna ploča iz Borovca (Slika 115) tako su pripisane bihaćkoj klesarskoj radionici, a epitafi Petra II. i Šimuna Keglevića (Slika 77) iz Pregrade radionici Majstora Hassova epitafa koja je djelovala na području Maribora, Ptuja i njihove okolice. Najveći broj nadgrobnika s prostora povijesne Zagrebačke biskupije atribuiran je radionici Majstora Trantnerova epitafa, još jednoj slovenskoj klesarskoj radionici koja je prvo bila smještena $\mathrm{u}$ Ptuju, potom $\mathrm{u}$ Slovenskim Konjicama, a svojim je radovima opskrbljivala slovensku Štajersku i - dodali bismo - sjeverozapadnu Hrvatsku. S ovih prostora pripisane su joj nadgrobna ploča Benedikta Thurőczyja Ludbreškoga (Slika 50) i epitaf Franje Keczera od Rad(o)vana (Slika 93) iz Vinice, nadgrobne ploče Elizabete Sudić (Slika 123) i obitelji Keglević (Slika 124) iz Krapine, nadgrobna ploča Kristofora Spišića (Slika 128) iz Kloštar Ivanića, nadgrobna ploča Ivana Horvata Radića (Slika 129) iz Mihovljana te epitaf Baltazara I. Patačića (Slika 131) iz Zajezde.

Iz navedenoga možemo zaključiti da su se naručitelji podjednako obraćali domaćim odnosno udomaćenim umjetnicima kao i onima koji su radili izvan granica tadašnjega Hrvatskoga Kraljevstva. Izvrsnost angažiranoga majstora kao i složenost izvedbe spomenika varirali su u skladu s društvenim položajem i ekonomskim mogućnostima naručiteljā, ali i njihovim osobnim htijenjem.

\footnotetext{
${ }^{657} \mathrm{Na}$ istome oltaru radili su i slikari Ivan Eisenhardt (izradio dvije pale) i Bernardno Bobić (načinio pozlatu), koji su oboje primili istu svotu novca za svoj rad. Usp. Metod Hrg, nav. dj., 1986., str. 85.
} 


\section{STILSKE ZNAČAJKE NADGROBNIH SPOMENIKA}

Nadgrobni spomenici pripadaju grani skulpturalne umjetnosti koja je obilježena konvencijama, arhaizmima i tradicijom. Kao što je izneseno u pregledu, na novovjekovnim nadgrobnicima primijenjena su likovno-ikonografska rješenja koja su preuzeta iz srednjega vijeka te koja su se nastavila primjenjivati u više-manje neizmijenjenom obliku tijekom naredna četiri stoljeća. Potrebno je naglasiti da dugo preživljavanje likovnih rješenja i njihova ustrajna primjena nisu svojstveni samo hrvatskoj umjetnosti. Slovenski i mađarski istraživači ustvrdili su iste razvojne značajke u nadgrobnoj plastici na području Slovenije i Ugarske, odakle je kontinentalna Hrvatska najčešće primala likovne poticaje i razmjenjivala ih. ${ }^{658}$ Emilijan Cevc (1981.) objasnio je spomenut oblikovni konzervativizam htijenjem naručiteljā kojima »nije bilo stalo - ili tek u rijetkim slučajevima - do obogaćivanja umjetničke baštine, nego do manifestacije vlastite važnosti«. ${ }^{659}$ Međutim, iako nadgrobnici u mnogim segmentima ostaju gotovo istovjetni, na njima se mogu uočiti stilske promjene sukladne drugim skulptorskim zadatcima. Naravno, te promjene $-\mathrm{u}$ oblikovanju volumena, odabiru ornamenata i njihovoj ulozi, razumijevanju značenja svjetlosti u kompoziciji i opisu, obradi površine, da spomenemo samo najočitije - nisu se javljale kao gotova i čvrsta stilska formacija, nego kao dotok pojedinih značajki koje je bilo moguće prihvatiti, a da se ne naruši dostojanstvo svečanoga i tradicionalnoga zadatka. U narednim odlomcima iznesena su opažanja o značajkama stilova koje su potvrđene kroz stilski slijed oblikovanja nadgrobnih spomenika tijekom četiri stoljeća. U tom razdoblju i za korpus koji je ovdje obrađen najznačajnija je pojava »dugoga trajanja« stilskih oblika, a s tim u vezi i odstupanja u odnosu na suvremena stilska kretanja, potom svjesno vraćanje starijim rješenjima i stilski hibridne pojave na istome spomeniku.

Nadgrobni spomenici koji su sačuvani iz XV. stoljeća (Slika 174) još uvijek imaju pretežito gotička obilježja. Na nadgrobnicima koji uključuju lik pokojnika, preminuli su prikazani u strogom frontalnom stavu u statičnoj pozi. Njihova draperija oblikovana je plošno i dekorativno, ne ocrtavajući volumen tijela koje se krije ispod nje. Likovni motivi (lik pokojnika, grb, natpis, jastuk) raspoređeni su na takav način da ispunjavaju sav slobodan prostor i istiskuju ga. Natpisi su ispisani gotičkom minuskulom te teku uz rubove ploče, a obiteljski grbovi najčešće su svedeni na osnovu - štit s grbovnim simbolom.

\footnotetext{
${ }^{658}$ Usp. Emilijan Cevc, nav. dj., 1981., str. 97; Géza Galavics, nav. dj., 1987., str. 245-247; Sergej Vrišer, nav. dj., 1965., str. 202.

659 »Plemiškim naročnikom ni šlo - ali le zelo redko - za bogatenje umetnostne razgledanosti, pač pa za manifestacijo lastne pomembnosti.« Emilijan Cevc, nav. dj., 1981., str. 97. Prijevod autoričin.
} 
U XVI. stoljeću (Slika 175) spomenici zadobivaju renesansne značajke. Impostacija likova opušta se iz ukočene, krute poze u blagi kontrapost. Način na koji pokojnici pridržavaju atribute - posebice na viteškim nadgrobnicima - daje im određenu dozu živosti, iako su njihove oči sklopljene u smrtnome snu. Na pojedinim spomenicima lica pokojnika imaju portretne karakteristike, no većina ih je ipak još uvijek tipizirana. Izraženijim stupnjevanjem reljefa i perspektivnim skraćenjima dijelova tijela postignut je dojam dubine i punoće volumena. Odbačena je suvišna dekorativnost, a horror vacui ustupio je mjesto pročišćenoj formi koja je svedena na osnovne likovne elemente i čistu pozadinu. Natpisi su isklesani u humanističkoj majuskuli u blokovima koji su smješteni iznad ili ispod figuralnih prikaza. Obiteljski grbovi postupno se obogaćuju dodatnim ukrasnim elementima poput kaciga, plašteva, kruna i čuvara.

Sedamnaesto stoljeće, iz kojega je sačuvan najveći broj nadgrobnika, donosi najviše noviteta i različitosti (Slike 176 i 177). To je razdoblje ispreplitanja značajki kasne renesanse, manirizma i ranoga baroka. Likovi pokojnika zakrenuti su iz frontalnoga stava odnosno profila u poluprofil ili tričetvrt profil, čime je pospješen privid volumena tijela i dojam prostornosti. Kontrapost, koji je u prethodnom stoljeću bio tek naznačen, razvija se u punokrvnu pozu. Na epitafima koji sadrže prikaz Raspetoga i pokojnika-adoranata zamjetan je prijelaz iz simetrične u asimetričnu kompoziciju u kojoj je križ izmaknut u stranu, a pokojnici su prikazani u obrnutoj ikonografskoj perspektivi s njegove lijeve ili desne strane. Budući da pokojnici pogledom održavaju vezu s Raspetim, prostorni odnosi između likova postaju nejasni i teže čitljivi, što je svojstveno manirizmu. Na spomenicima se primijenjuju maniristički motivi poput hrskavice, maskerona i putta sa simbolima prolaznosti, a u posljednjoj četvrtini stoljeća prvi se put javlja akant kao nagovještaj baroknoga stila. U XVII. stoljeću ujedno je razvidan utjecaj suvremene likovne umjetnosti i arhitekture na nadgrobnu skulpturu. Javljaju se epitafi oblikovani poput retabla odnosno edikula, a figure pokojnika na nadgrobnim pločama smještene su ispod polukružnih lukova ukrašenih kerubinima. Premda se na nadgrobnim pločama žena i djece još uvijek primjenjuje tradicionalno rješenje gisanta, nadgrobnici podignuti za plemiće odmiču od ustaljenih likovno-ikonografskih rješenja. Odbacivanjem elemenata gisanta, mijenjanjem impostacije figure pokojnika i dodavanjem elementa postamenta s kacigom približavaju se rješenjima suvremenoga portretnog slikarstva i grafike.

Na nadgrobnim spomenicima iz XVIII. stoljeća (Slika 178) prevladavaju punokrvne barokne značajke. One su razvidne u naglašavanju dijagonalnosti kompozicije, primjeni motiva akanta, svrdlastoj obradi površine i novom dopojasnom načinu kadriranja. Spomenici 
su često načinjeni od višebojnoga kamena ili sadrže inkrustacije u svrhu pospješivanja vizualnoga efekta. Nastavljaju se primjenjivati epitafi izvedeni u obliku retablā i edikulā, a obiteljski grbovi uvijek su izvedeni u njihovom složenijem, ukrašenom obliku.

Opisane stilske promjene na nadgrobnim spomenicima $\mathrm{u}$ osnovi prate promjene $\mathrm{u}$ likovnoj i graditeljskoj umjetnosti na području kontinentalne Hrvatske općenito. U XV. stoljeću u umjetnosti kontinentalnoga dijela Hrvatske još uvijek prevladava kasna gotika, a renesansa počinje prodirati tek na prijelazu u XVI. stoljeće posredništvom panonske regije i kruga umjetnika okupljenih na dvoru kralja Matije Korvina. ${ }^{660} \mathrm{U}$ drugoj četvrtini XVI. stoljeća hrvatski se prostori okreću utjecaju srednjoeuropskoga kulturnoga kruga i sjevernjačke renesanse. Sedamnaesto stoljeće obilježeno je pluralizmom stilova u kojem se prepliću značajke kasne renesanse, manirizma i ranoga baroka. Iako se barok »svojim duhovnim manifestacijama jav[io] oko g. 1600«, u potpunosti je zaživio tek krajem XVII. i u XVIII. stoljeću. ${ }^{661} \mathrm{~S}$ prethodno navedenim specifičnostima kiparskoga zadatka, stilske promjene na nadgrobnim spomenicima posve se uklapaju u stilsku putanju cjelokupne baštine u kontinentalnoj Hrvatskoj, kako ju je ocrtao Ljubo Karman (1963.):

»Umjetnost u kontinentalnoj Hrvatskoj, kako je poznato, primala je bitne i temeljne pobude za svoj razvoj stoljećima iz svog srednjoevropskog susjedstva na sjeverozapadu. To se očituje ne samo u stilu pojedinih spomenika nego i u općim linijama njezina razvoja. Činjenica je da umjetnost u kontinentalnoj Hrvatskoj ima iste razvojne značajke kao i Slovenija i austrijske provincije: malobrojnost spomenika iz ranog srednjeg vijeka i romanike, relativno kasni nastup gotike u drugoj polovini 13. stoljeća i dugotrajno njezino održavanje do 16. stoljeća, a u pojedinim pojavama do 17. stoljeća, oskudnu afirmaciju renesanse, tako da domaće snage uglavnom od gotike prelaze ravno baroku, bogat cvat zrelog baroka u 18. stoljeću s prelaženjem na postbarokni rokoko i 'zopfstil' u drugoj polovini stoljeća. ${ }^{662}$

\footnotetext{
${ }^{660}$ Usp. Anđela Horvat, $n a v . d j ., 1975 .$, str. 449-452.

${ }^{661}$ Anđela Horvat, nav. dj., 1975., str. 451.

${ }^{662}$ Ljubo Karaman, $O$ djelovanju domaće sredine u umjetnosti hrvatskih krajeva / Über die Einwirkung des einheimischen Milieus auf die Entwicklung der Kunst in den kroatischen Ländern, Zagreb: Društvo historičara umjetnosti NR Hrvatske, 1963., str. 71.
} 

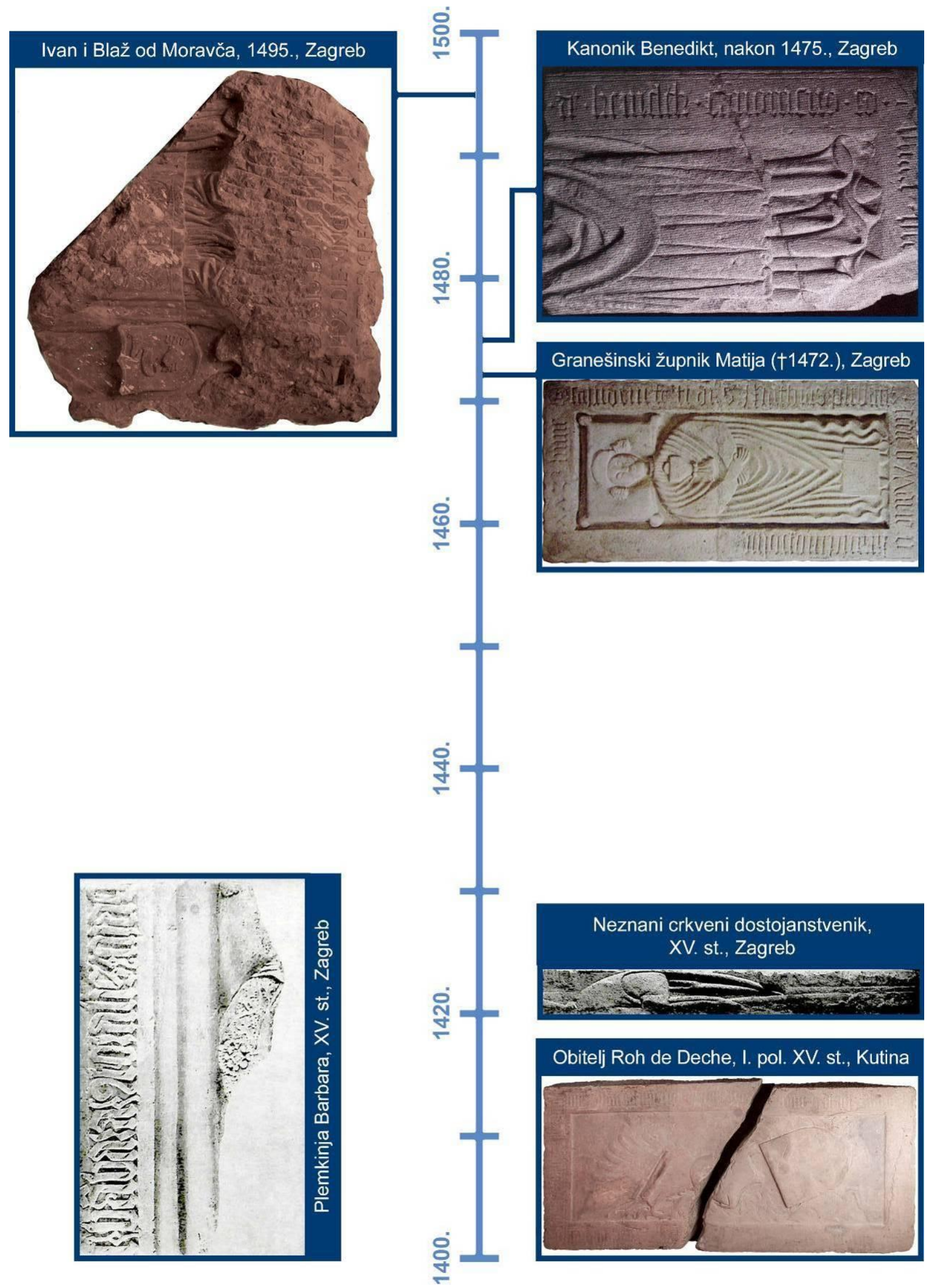

Slika 174. Nadgrobni spomenici (izbor) iz XV. stoljeća 

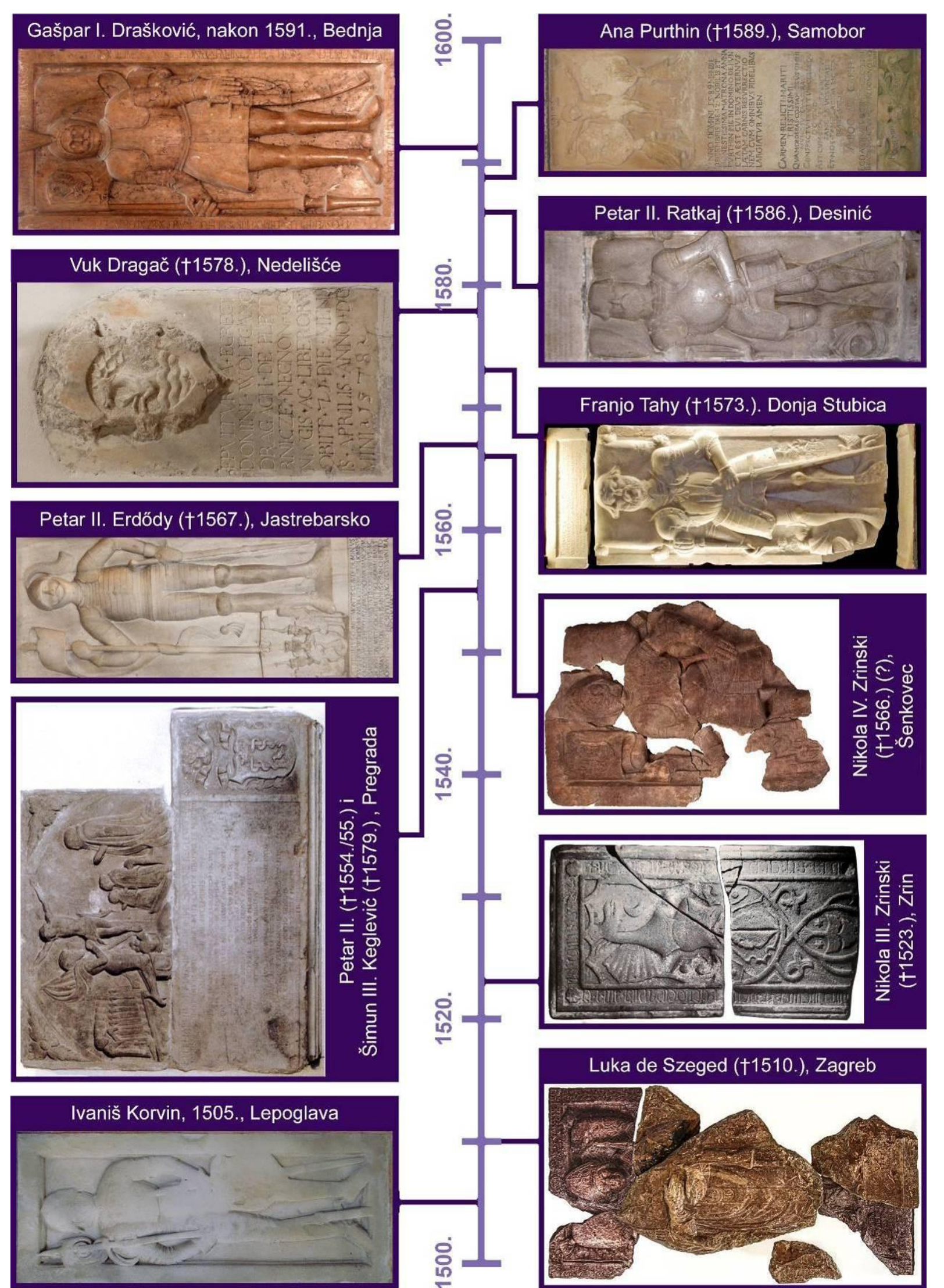

$\stackrel{\text { L }}{\leftarrow}$ Luka de Szeged (†1510.), Zagreb

Slika 175. Nadgrobni spomenici (izbor) iz XVI. stoljeća 

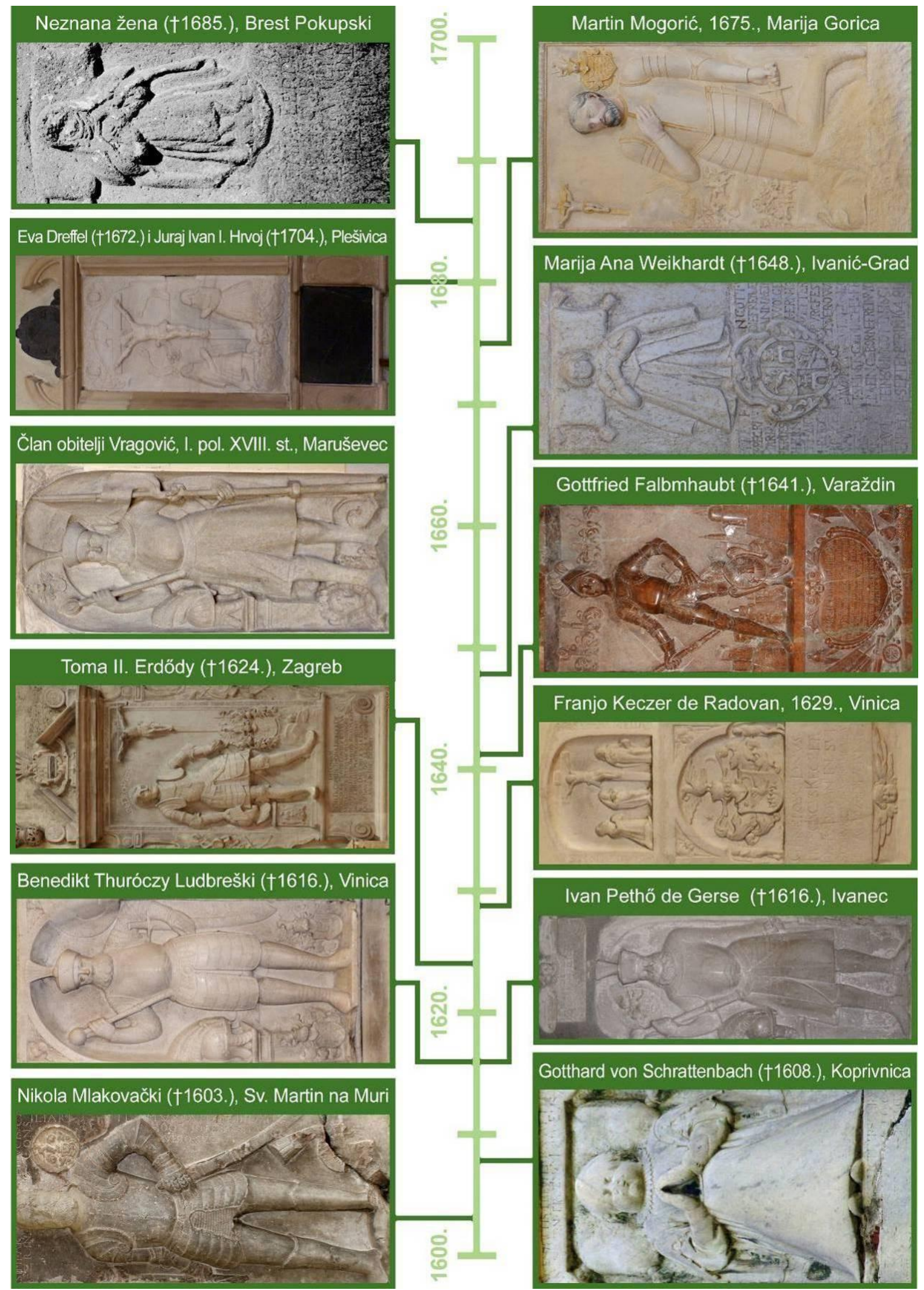

Slika 176. Nadgrobni spomenici s likom pokojnika iz XVII. stoljećea 

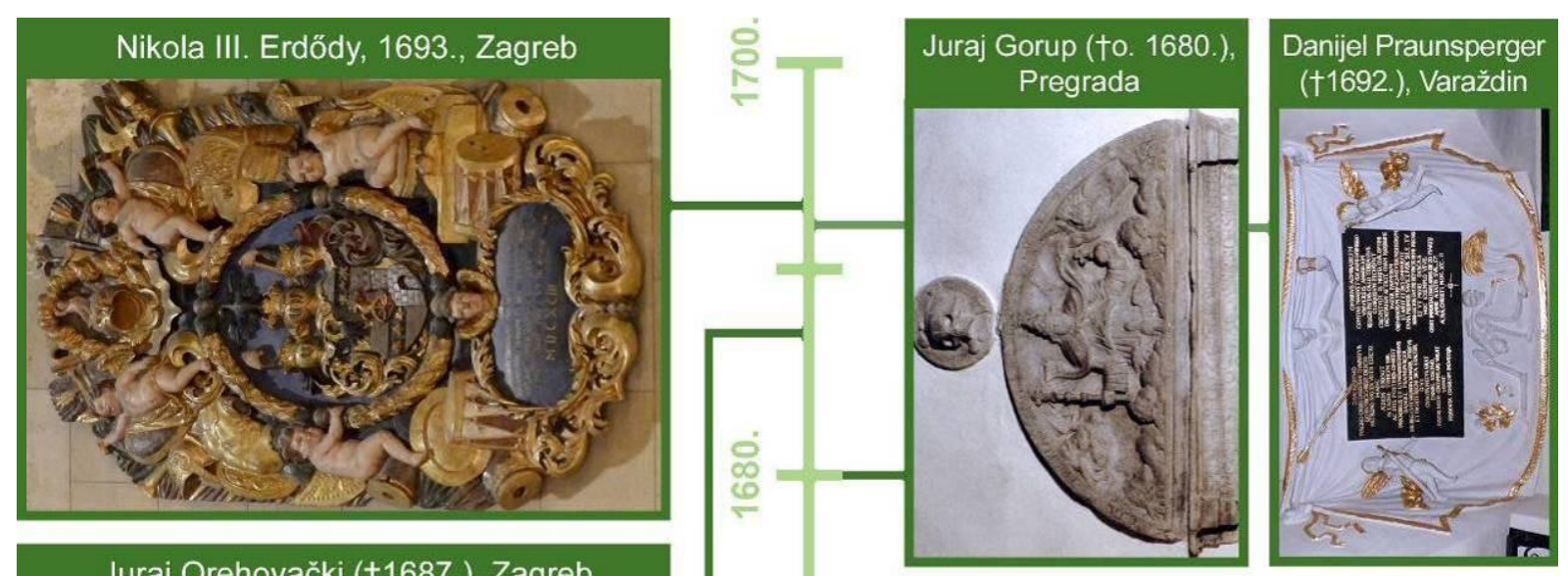

Juraj Orehovački (†1687.), Zagreb
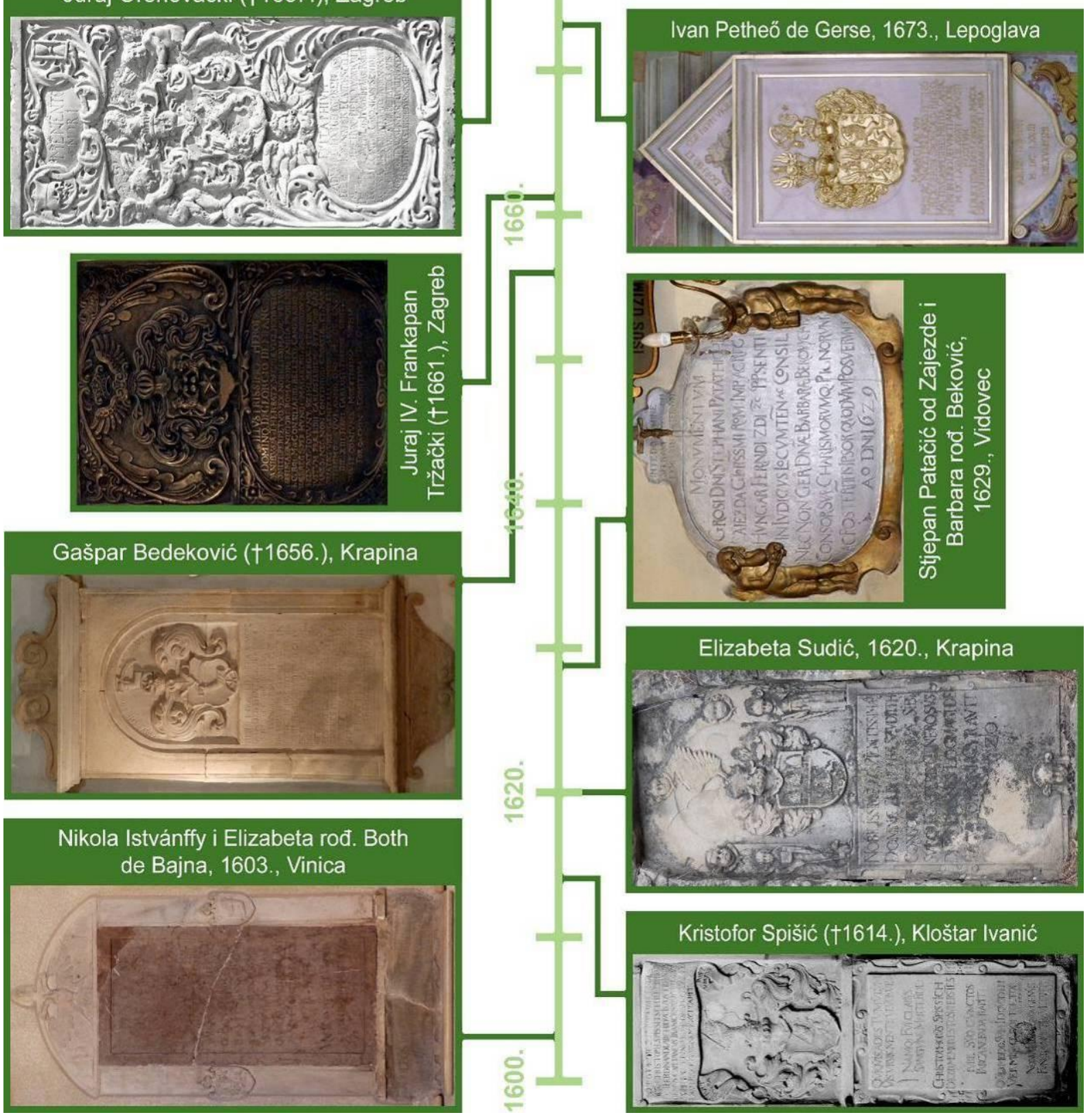

Slika 177. Nadgrobni spomenici (izbor) iz XVII. stoljeća 

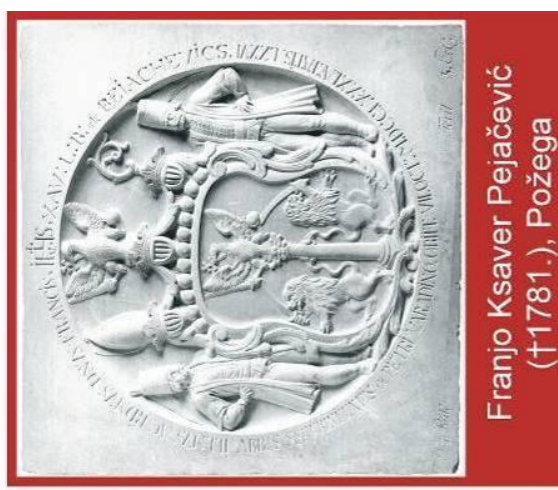

Petar Troilo Sermage, o. 1773., Stenjevec

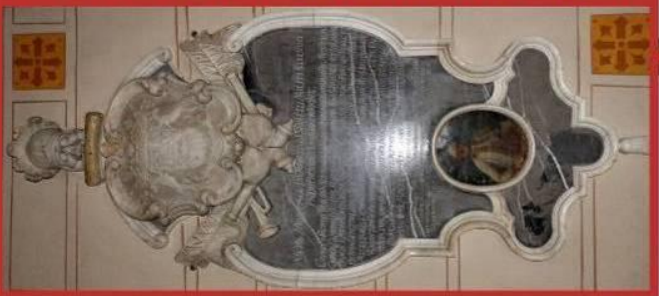

Baltazar III. Patačić i Terezija rođ. Gereczy, 1722., Remetinec

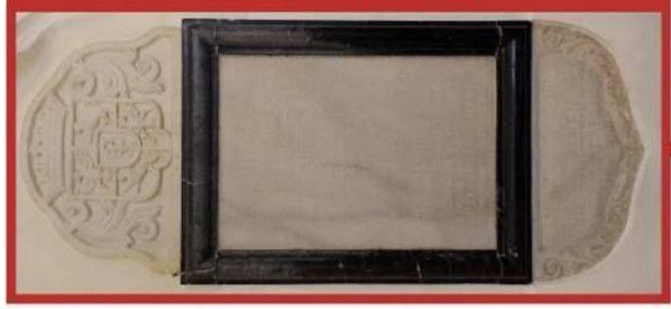

Obitelji Češković, 1711., Lepoglava

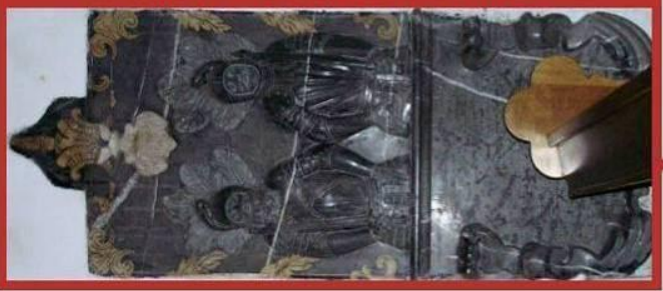

Nikola Ogramić Olovčić (†1701.), Našice

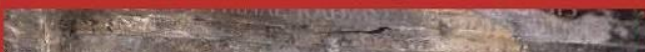

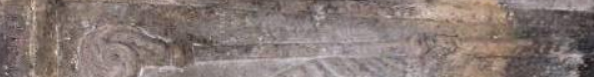

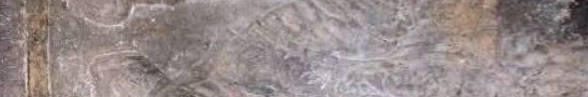

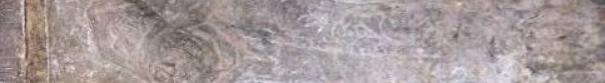

1. $\frac{253}{3}$

(1) $10 \mathrm{es}^{3}$

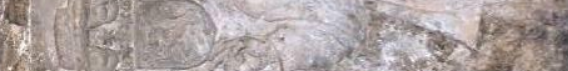

6
7
3

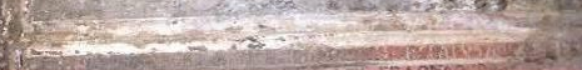

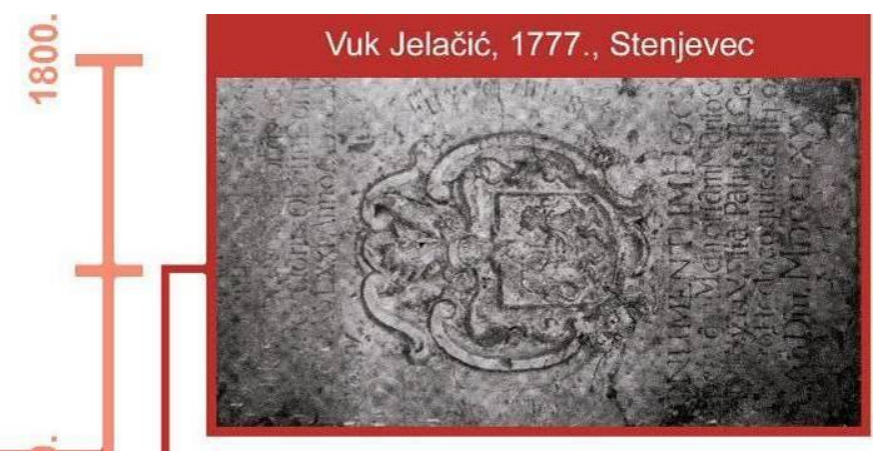

Nikola Gotal od Gotalovca, 1765., Zagreb

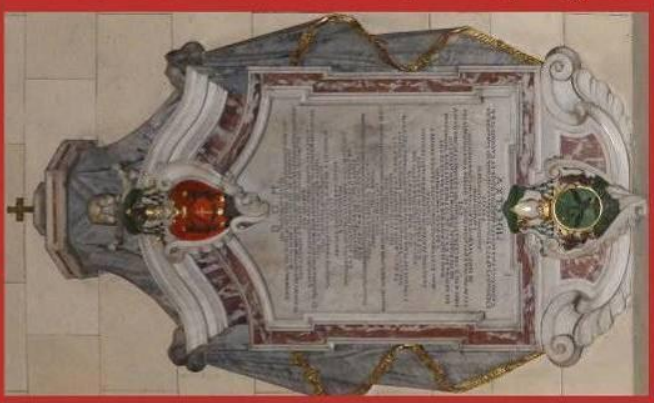

Sigismund Ratkaj, 1722., Lepoglava

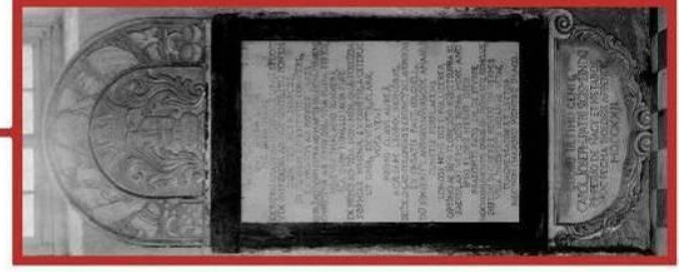

Ladislav III. Patačić, 1710., Lepoglava

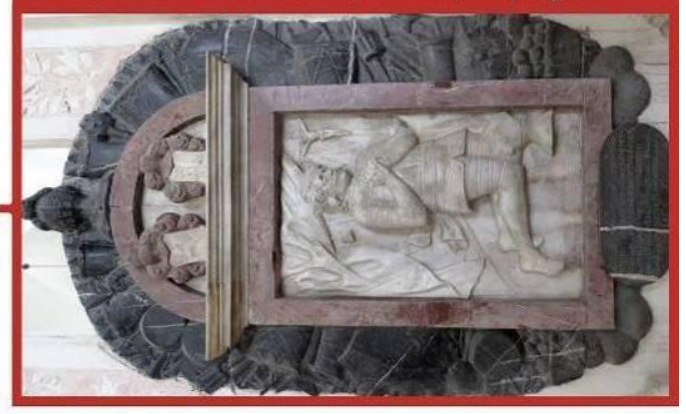

Ivan Znika (†1706.), Zagreb

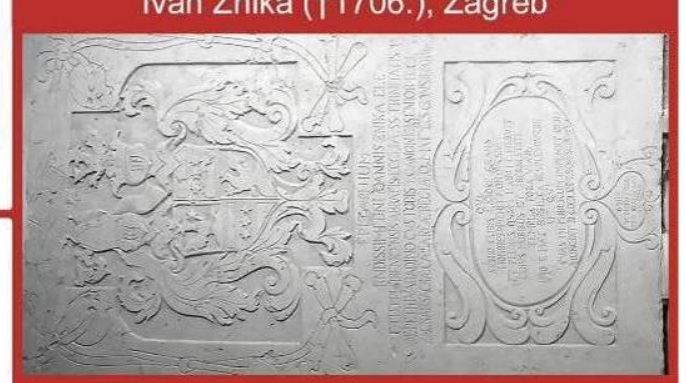

Slika 178. Nadgrobni spomenici (izbor) iz XVIII. stoljeća 


\section{GROBNE KAPELE}

Pojava novovjekovnih obiteljskih grobnih kapela koje su prigrađene uz samostanske i župne crkve ili su podignute kao slobodnostojeće građevine na području povijesne Zagrebačke biskupije zavrjeđuje zaseban osvrt zbog njihovoga broja i uloge u funeralnoj kulturi i umjetnosti općenito. Potrebno je naglasiti da pregled ne uključuje detaljnu analizu svih grobnih kapela, nego je njegova namjera objasniti njihovu pojavnost i funkciju te predstaviti najvažnije primjere.

Tradicija podizanja grobnih kapela seže u XIII. stoljeće, a jedan od prvih primjera je kapela prigrađena uz južni transept donje bazilike sv. Franje Asiškoga u Assisiju koju je podignuo kardinal Napoleone Orsini za ukop svojega brata Giovannija Orsinija $(† 1294.) .{ }^{663}$ Feudalne obitelji prve su zamijenile ukop ad sanctos onime u bočnim kapelama crkava jer su im odvojene kapele davale određenu razinu privatnosti. Međutim, njihova funkcija bila je višestruka: osim što su služile osobnoj molitvi i kontemplaciji, grobne kapele bile su mjesto potvrđivanja obiteljskoga identiteta i održavanja njezine memorije. ${ }^{664}$

Najveći broj grobnih kapela sagrađen je na području Zagrebačke (nad)biskupije između XVI. i prve polovine XIX. stoljeća, a podizali su ih članovi plemićkih obitelji. Prigrađivali su ih uz crkve nad kojima su imali patronat, ali i uz crkve samostanskih redova. Sahranjivanjem u samostanskim crkvama obitelji pokojnikā pokušavale su osigurati što dulju skrb o grobu i duši preminuloga, a najčešće su odabirali crkve propovjedničkih ili prosjačkih redova (franjevaca, dominikanaca i karmelićana). ${ }^{665} \mathrm{Na}$ području povijesne Zagrebačke biskupije pripadnici plemstva poglavito su se pokapali u crkvama franjevačkoga i isusovačkoga reda. Erdődyji su, primjerice, kao svoje posljednje počivalište odabrali franjevačku crkvu Navještenja Blažene Djevice Marije u Klanjcu, Keglevići franjevačku crkvu sv. Katarine u Krapini, Patačići franjevačku crkvu Blažene Djevice Marije Kraljice Svete krunice u Remetincu, Frankapani i Auerspergi isusovačku crkvu sv. Katarine u Zagrebu, a Draškovići isusovačku crkvu Uznesenja Blažene Djevice Marije u Varaždinu.

Izuzev franjevačkih i isusovačkih sklopova, hrvatski velikaši pokapali su se i u pavlinskim crkvama prije ukinuća reda 1786. godine. Najveći i najvažniji pavlinski samostan na području Hrvatske nalazio se u Lepoglavi. U njemu su stolovali generali reda (od 1573.), a kasnije i provincijali osamostaljene Hrvatske pavlinske provincije (od 1701.). ${ }^{666}$ Lepoglavska

\footnotetext{
${ }^{663}$ Usp. Howard Colvin, nav. dj., 1991., str. 190.

${ }^{664}$ Usp. Philippe Ariès, nav. dj., 1981., str. 289-290; Howard Colvin, nav. dj., 1991., str. 190-191.

${ }^{665}$ Usp. Philippe Ariès, nav. dj., 1981., str. 83; Howard Colvin, nav. dj., 1991., str. 191.

${ }^{666}$ Usp. Kamilo Dočkal, nav. dj., 2014., str. 141-142.
} 
crkva Blažene Djevice Marije svojevremeno je predstavljala campo santo hrvatskih velikaša. Nakon što je u svetištu sahranjen Ivaniš Korvin (Budim, 1473. - Krapina, 1504.), nezakoniti sin hrvatsko-ugarskoga kralja Matije Korvina (vladao 1458. - 1490.), u Lepoglavi su se počeli pokapati pripadnici brojnih uglednih obitelji. Njihova tijela polagana su u kripte smještene u svetištu (Benedikt Ratkaj, Gašpar i Ivan Petheő de Gerse) i brodu crkve (obitelji Češković i Orehovečki) te obiteljskim kapelama prigrađenima s obje strane broda (Slika 179) ${ }^{667}$ Prvu kapelu posvećenu Muci Gospodnjoj podignula je barunica Judita Balagović Japranska 1675. godine s južne strane pjevališta, a u njoj je prema vlastitoj želji pokopana Barbara Zaboky rođ. Gereczy (? - ?, 1678.), udovica gospodara zabočkoga imanja i podžupana varaždinske županije Baltazara Zabokyja. ${ }^{668}$ Nasuprot kapele Muke Gospodnje nalazi se Lauretanska kapela koju je 1692. godine počeo graditi podmaršal Ivan IV. Drašković (?, o. 1630. Lockenhaus, 1692.). Budući da je Ivan ubrzo preminuo, kapelu je dovršila njegova supruga Marija Magdalena rođ. Nádasdy (?, 1647. - ?, 1699.), a u njoj su pokopana dva člana šire obitelji Drašković - Petar Keglević mlađi (†1747.), sin Marije Ane Keglević rođ. Drašković i požeškoga župana Petra Keglevića starijega, te grofica Marija Katarina Drašković rođ. Brandis (?, 1680. - ?, 1751.), supruga hrvatsko-dalmatinsko-slavonskoga bana Ivana V. Draškovića. ${ }^{669}$ Prvu kapelu do svetišta posvećenu sv. Josipu podigla je Sofija Rozina Ratkaj 1702. godine, u kojoj je iste godine pokopan njezin suprug Sigismund Ratkaj (?, 1660. - ?, 1702.), kraljevski komornik i pukovnik Đurđevačke krajine. ${ }^{670}$ Godine 1705 . između kapele

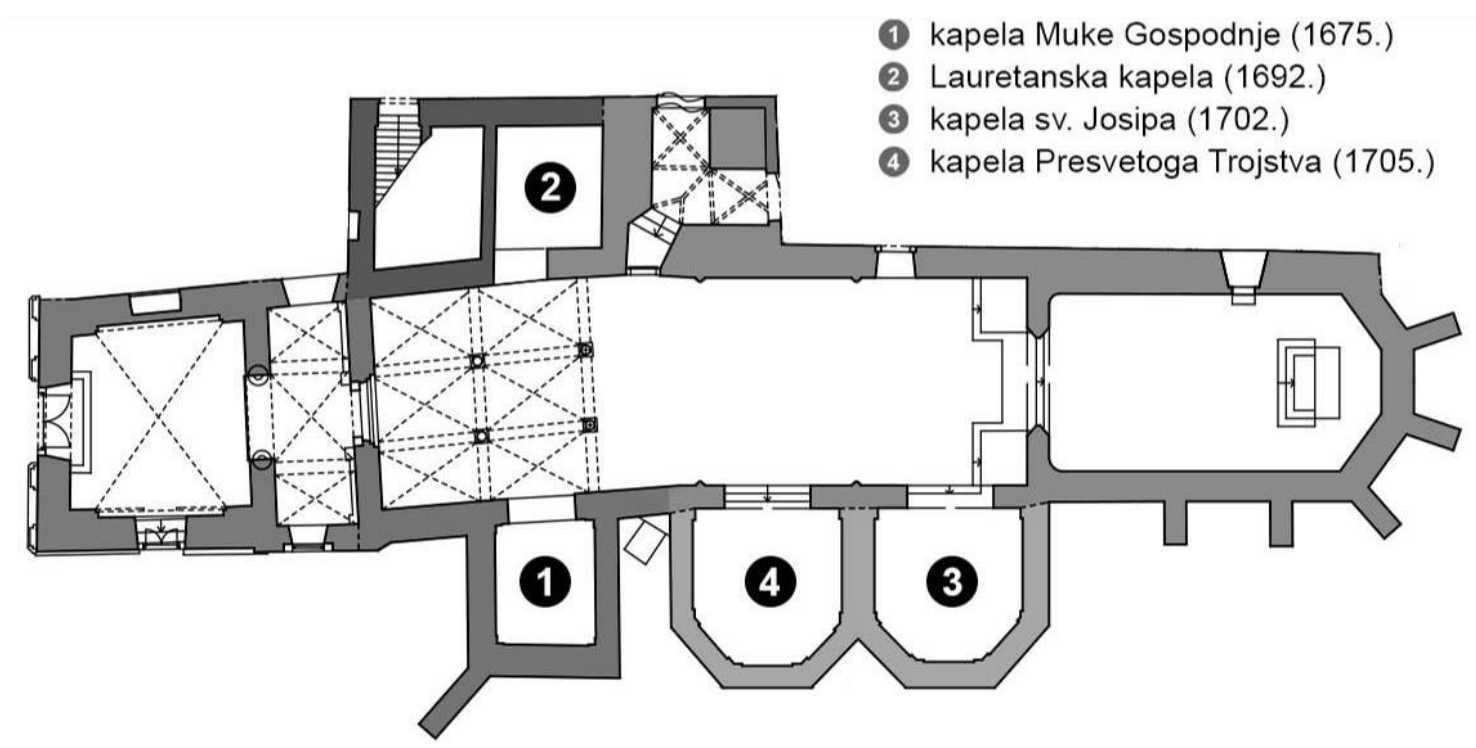

Slika 179. Grobne kapele crkve Blažene Djevice Marije u Lepoglavi i redoslijed njihove prigradnje

\footnotetext{
${ }^{667}$ Usp. Kamilo Dočkal, nav. dj., 2014., str. 265-307.

${ }^{668}$ Usp. Kamilo Dočkal, nav. dj., 2014., str. 209-210, 270-271; Gjuro Szabo, nav. dj., 1919., str. 29.

${ }^{669}$ Usp. Kamilo Dočkal, nav. dj., 2014., str. 210, 303; Gjuro Szabo, nav. dj., 1919., str. 29.

${ }^{670}$ Usp. Kamilo Dočkal, nav. dj., 2014., str. 210-211, 272-274; Gjuro Szabo, nav. dj., 1919., str. 29.
} 
sv. Josipa i kapele Muke Gospodnje podignuta je posljednja grobna kapela posvećena Presvetome Trojstvu. Podigli su je Ladislav III. Patačić (?, 1651. - Celje, 1705.), potpukovnik križevačke Krajine, i njegova supruga Barbara rođ. Vragović (? - ?, 1715.), koji su oboje ondje pokopani. ${ }^{671}$ Važnost lepoglavskoga samostana i ukop osobe kraljevskoga roda djelovali su kao snažan i dugotrajan poticaj velikaškim obiteljima da kao mjesto svojega posljednjega počivališta odaberu upravo pavlinsku crkvu u Lepoglavi.

Najsjeverniji pavlinski samostan u Hrvatskoj nalazio se u Šenkovcu, naselju nedaleko Čakovca (Slika 180). Od nekadašnjega samostanskog sklopa sačuvalo se samo svetište crkve, koje je u XIX. stoljeću preuređeno u kapelu, i temelji grobne kapele obitelji Zrinski. Postojeće stanje otkriva da je kapela bila šesterokutnoga tlocrta te da je podignuta s južne strane traveja najbližega svetištu (Slika 181). Stručnjaci se spore u vezi pitanja kada je točno sagrađena. Jedni smatraju da je podignuta za potrebe pogreba Jurja V. Zrinskoga (Čakovec, 1599. Požun, 1626.) na osnovi navoda iz dokumenta koji su 27. siječnja 1627. godine sastavili skrbnici Jurjevih sinova Nikole VII. i Petra IV. (»[...] Capellae pro sepultura praefati Comitis [Georgii a Zrinio], successorum que ejusdem noviter erectae [...]«). ${ }^{672}$ Drugi su pak mišljenja da je kapelu podignuo Nikola IV. Zrinski (Zrin, 1058. - Siget, 1566.) oko 1561. godine za ukop supruge Ane Katarine rođ. Frankapan (Ozalj, o. 1525. - ?, 1561.). ${ }^{673}$ Svoju tezu temelje na istovjetnome podatku koji je donio Josip Bedeković u knjizi Natale solum magni ecclesiae doctoris sancti Hieronymi... (Bečko Novo Mjesto, 1752.) ${ }^{674}$ te objašnjavaju da je kapela za ukop Jurja V. tek temeljito obnovljena. Sudbina grobne kapele manje je neizvjesna od rasprava o njezinome podrijetlu. Nakon velikoga požara koji je oštetio samostan i crkvu 1695. godine, pavlini su preuredili takozvani mauzolej Zrinskih u kapelu sv. Antuna odstranivši iz njega sve predmete obitelji Zrinski, uključujući nadgrobnu ploču Nikole IV. (Slika 46). ${ }^{675}$ Nakon ukinuća pavlinskoga reda, šenkovečki posjed došao je u vlasništvo obitelji Knežević

\footnotetext{
${ }^{671}$ Usp. Kamilo Dočkal, nav. dj., 2014., str. 211-213, 276-280; Gjuro Szabo, nav. dj., 1919., str. 29.

${ }^{672}$ Citirano u: Kamilo Dočkal, Povijest pavlinskog samostana sv. Jelene u Čakovcu, Zagreb, rukopis, 1951. Arhiv Hrvatske akademije znanosti i umjetnosti, XVI 29b.7, str. 56. Usporedi dalje: Marijana Korunek, nav. $d j$., 2014., str. 66; Tajana Pleše, nav. dj., 2013., str. 7.

${ }^{673}$ Usp. Anđela Horvat, nav. dj., 1956., str. 50; Anđela Horvat, nav. dj., 1975., str. 71; Viktor Kučinić, Zaboravljena grobnica Zrinjskih u Svetoj Jeleni kraj Čakovca. Rasute mrtvačke kosti kao turistička atrakcija. Čudna osakaćena crkvica posred polja kukuruza i zelja. Ostatak svetišta i mauzoleja Zrinjskih iz 16 stoljeća, u: Novosti XXXIV/188, Zagreb: [Jugoslavenska štampa], 10. VII. 1940., str. 11; Vladimir Kalšan, nav. dj., 2008., str. 51; Emilij Laszowski, nav. dj., 1928., str. 245-245; Ksenija Petrić i Tatjana Lolić, Sveta Jelena kod Čakovca. Konzervatorska studija za projekt prezentacije lokaliteta Sveta Jelena kod Čakovca, Zagreb: Konzervatorski odjel, 2005., elaborat, str. 6; Ivan Srša, nav. dj., 1998., str. 125.

${ }^{674}$ Usp. Josip Bedeković, Natale solum magni ecclesiae doctoris sancti Hieronymi in ruderibus Stridonis occultatum [...], Neostadii Austriae: Ex Typographeo Muelleriano, [1752.], str. 222.

${ }^{675}$ Usp. Josip Bedeković, nav. dj., 1752., str. 276; Kamilo Dočkal, nav. dj., 1951., str. 96-98; Vladimir Kalšan, nav. dj., 2008., str. 51-52; Emilij Laszowski, nav. dj., 1928., str. 248-249; Ivan Srša, nav. dj., 1998., str. 129; Tajana Pleše, nav. dj., 2013., str. 8-10.
} 
koja je 1822. godine porušila brod crkve, grobnu kapelu i dio samostana (preostali dio porušen je nakon potresa 1880. godine), a svetište crkve preuredila je u dvorsku kapelu posvećenu sv. Jeleni Križarici. ${ }^{676}$

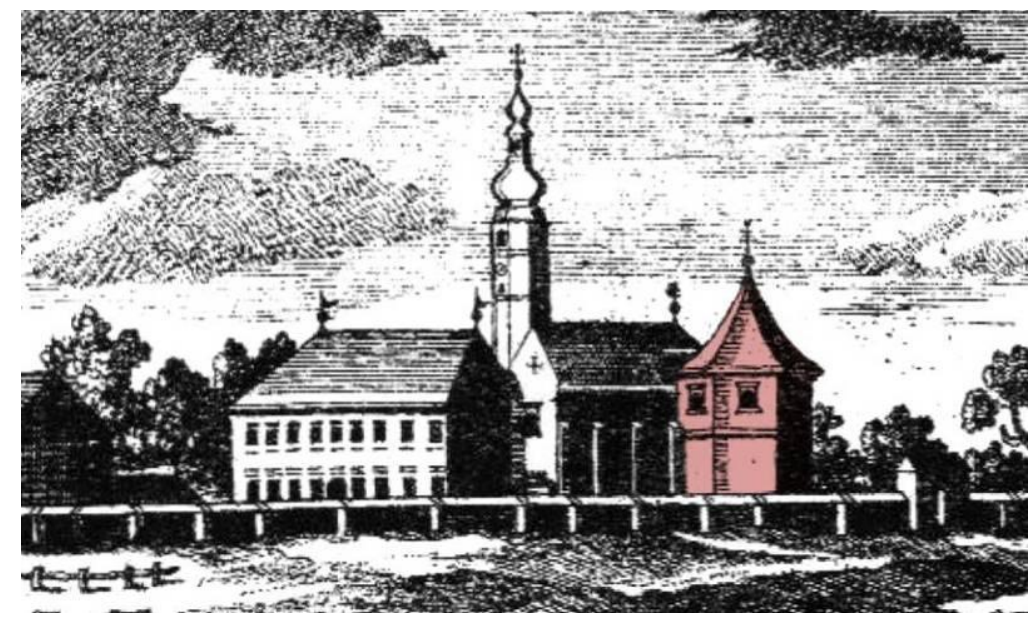

(gore) Slika 180. Detalj vedute šenkovečkoga pavlinskog sklopa s označenom grobnom kapelom Zrinskih, iz knjige Josipa Bedekovića »Natale solum...«, Bečko Novo Mjesto, 1752.

(desno) Slika 181. Tlocrt šenkovečke pavlinske crkve i očuvanih temelja grobne kapele Zrinskih, iz elaborata Ksenije Petrić i Tatjane Lolić »Sveta Jelena kod Čakovca...«, Zagreb, 2005.

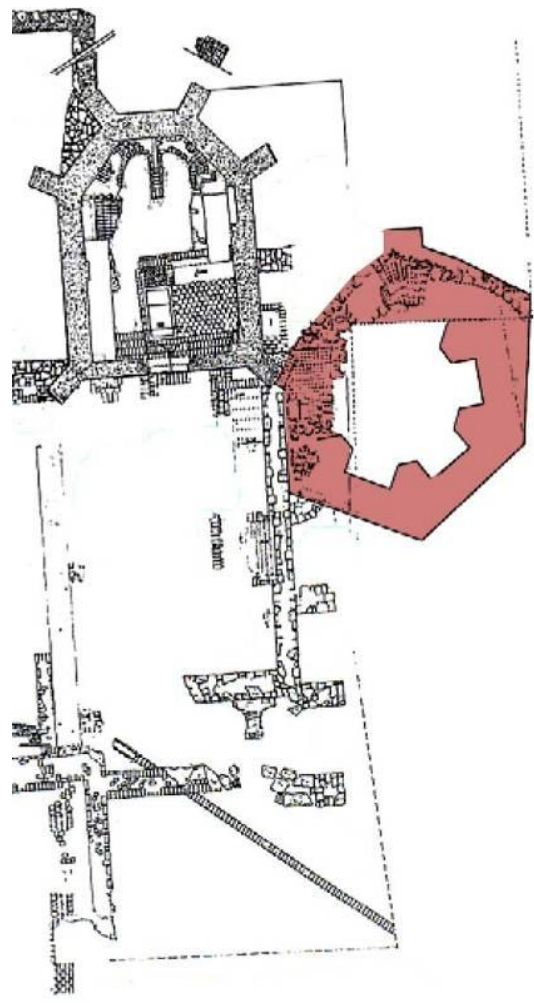

Postoji još jedan primjer grobne kapele centralnoga tlocrta koja je podignuta na prostoru povijesne Zagrebačke biskupije tijekom ranoga novog vijeka. Riječ je o kapeli koja je nekoć bila prigrađena župnoj crkvi Presvetoga Trojstva u Donjoj Stubici, a za koju se pretpostavlja da je pripadala obitelji Tahy. Najstariji dio donjostubičke crkve predstavlja poligonalno, svođeno svetište na koje se u XV. stoljeću nadovezivao brod s tabulatom (Slika 182). ${ }^{677}$ Crkva je tijekom XVI. stoljeća znatno nadograđena: u osi broda podignut je zvonik, sa sjeverne strane lađe prigrađena je kružna kapela i bočni brod, a s južne strane sakristija. ${ }^{678}$ Barokizacijom crkve (1740. - 1745.) kapela, sjeverni brod i sakristija su porušeni, a podignuti su južni i novi sjeverni brod na koji se nadovezivala nova sakristija. ${ }^{679}$ Prilikom obnove crkve krajem prošloga stoljeća, u krajnjem istočnom dijelu sjevernoga broda, na mjestu gdje se nekoć nalazila kružna kapela, pronađena je svođena kripta, koja ukazuje na

\footnotetext{
${ }^{676}$ Usp. Kamilo Dočkal, nav. dj., 1951., str. 197-198; Vladimir Kalšan, nav. dj., 2008., str. 53; Marijana Korunek, nav. dj., 2014., str. 70; Ksenija Petrić i Tatjana Lolić, nav. dj., 2005., str. 7; Ivan Srša, nav. dj., 1998., str. $125,130$.

${ }^{677}$ Usp. Katarina Horvat Levaj, Župna crkva Presvetog Trojstva u Donjoj Stubici, u: Peristil 38, Zagreb: Društvo povjesničara umjetnosti Hrvatske, 1995., str. 73-82, 74.

${ }^{678}$ Usp. Katarina Horvat, nav. dj., 1995., str. 76.

${ }^{679}$ Usp. Katarina Horvat, nav. dj., 1995., str. 78.
} 
mogućnost da je kapela imala grobnu funkciju. ${ }^{680}$ Budući da se u tome dijelu crkve nalazila nadgrobna ploča Franje Tahyja (Slika 40) (nadgrobnik je bio sekundarno ugrađen u naknadno probijen luk između krajnjega dijela sjevernoga broda i svetišta), pretpostavlja se da je kapela služila kao mauzolej obitelji Tahy. ${ }^{681}$

15. st.

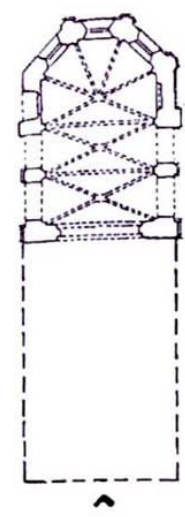

16/17. st.

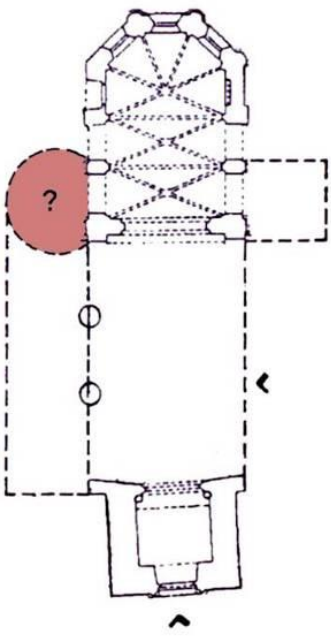

18. st.

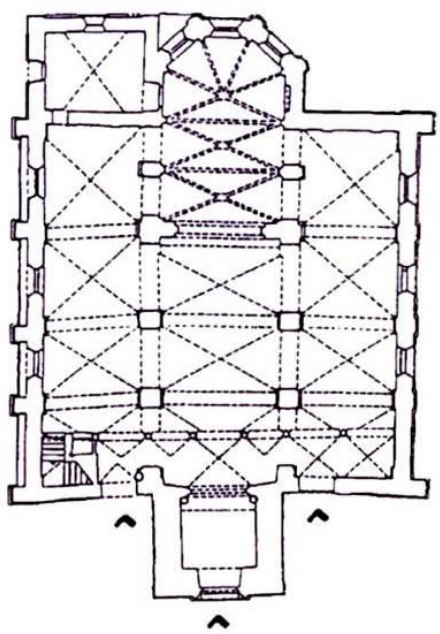

19. st.

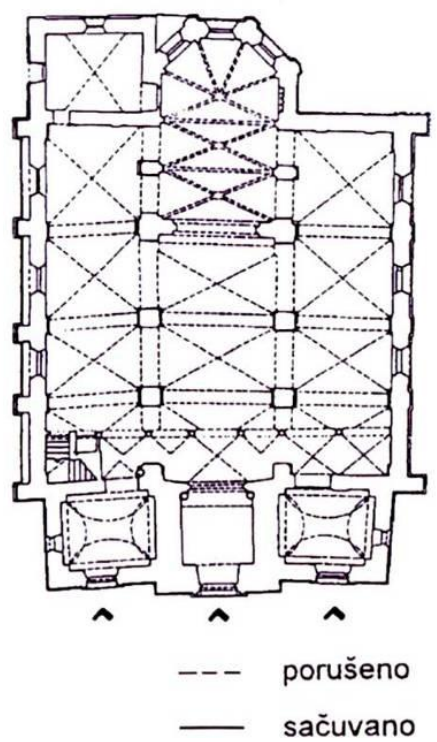

Slika 182. Razvojne faze donjostubičke crkve od XV. do XIX. stoljeća s označenom grobnom kapelom obitelji Tahy, iz članka Katarine Horvat Levaj »Župna crkva Presvetoga Trojstva...», Peristil, 1995.

Grobne kapele obitelji Zrinski i Tahy predstavljaju rijedak primjer kapela koje su bile centralnoga tlocrta. Većina kapela prigrađenih samostanskim i župnim crkvama od XVI. stoljeća nadalje pravokutnoga su tlocrta te su ravno ili poligonalno zaključene, poput onih prigrađenih nekadašnjoj pavlinskoj crkvi u Lepoglavi. Primjena centralnoga tlocrta u izgradnji obiteljskih kapela povezana je sa širenjem renesansnoga tipa mauzoleja, all' antica. Inspirirani antičkom arhitekturom i traktatima, brojni renesansni arhitekti bili su zaintrigirani idejom primjene centralnoga tlocrta u sakralnoj arhitekturi, pokušavajući osmisliti crkvu čiji bi se tlocrt temeljio na jednom od savršenih geometrijskih likova (krugu, poligonu, kvadratu ili grčkom križu). ${ }^{682}$ Doduše, crkve centralnoga tlocrta rijetko su podizane jer su imale snažnu pogansku konotaciju i nisu bile liturgijski prikladne poput onih longitudinalnih. Ono što nisu

\footnotetext{
${ }^{680}$ Usp. Katarina Horvat, nav. dj., 1995., str. 76.

${ }^{681}$ Usp. Goranka Horjan, Sakralni spomenici stubičkog kraja, u: Osam stoljeća Stubice, Gornja Stubica: Muzeji Hrvatskog zagorja, Muzej seljačkih buna; Donja Stubica: Grad Donja Stubica, 2009., str. 112-137, 117. Uredila Goranka Horjan; Katarina Horvat Levaj, nav. dj., 1995., str. 76; Milan Pelc, nav. dj., 2007., str. 257.

${ }^{682}$ Usp. Dubravka Botica, Barokne četverolisne crkve u sjeverozapadnoj Hrvatskoj: Prilog istraživanju tipologije sakralne arhitekture 18. stoljeća, Zagreb: Školska knjiga, 2015., str. 97-98; Howard Colvin, nav. dj., 1991., str. 201.
} 
mogli ostvariti u izgradnji crkava, arhitekti su primjenjivali u podizanju manjih zdanja poput sakristija, kapitularnih dvorana te obiteljskih i grobnih kapela. ${ }^{683}$ Prve grobne kapele centralnoga tlocrta podignute su na prostoru Italije, a njihovi projektanti pronalazili su inspiraciju i uzore u znamenitim antičkim i ranokršćanskim mauzolejima poput Hadrijanova mauzoleja (135. - 139.) u Rimu, Teodorikova mauzoleja (520.) u Raveni ili rotunde bazilike Svetoga groba (335.) u Jeruzalemu. ${ }^{684}$ Neki od najpoznatijih primjera su stara (projektant Filippo Brunelleschi, izgrađena 1421. - 1428.) i nova sakristija crkve San Lorenzo (projektant Michelangelo Buonarroti, izgrađena 1520. - 1534.) te kapela portugalskoga kardinala u crkvi San Miniato al Monte u Firenci (projektant Antonio Manetti, izgrađena 1461. - 1466.), kapela Piccolomini u crkvi Sant'Anna dei Lombardi u Napulju (projektanti Antonio Rossellino i Benedetto da Maiano, izgrađena 1475. -1490.) te kapela Chigi u crkvi Santa Maria del Popolo u Rimu (projektant Raffaello Sanzio, izgrađena 1513. - 1516.). ${ }^{655}$ Model podizanja grobnih kapela centralnoga tlocrta ubrzo se proširio i središnjom Europom. Dva značajnija i Hrvatskoj bliža primjera predstavljaju kapela Tome Bakača koju je kancelar Ugarskoga Kraljevstva i upravitelj Zagrebačke biskupije dao prigraditi uz ostrogonsku katedralu između 1506. i 1521. godine $^{686}$ te mauzolej cara Ferdinanda II. (izgrađen 1615. - 1638.) u crkvi sv. Katarine Aleksandrijske u Grazu koji je projektirao carev službeni arhitekt Giovanni Pietro de Pomis (Lodi, 1569./70. - Graz, 1633.). ${ }^{687}$ Ovim srednjoeuropskim primjerima tako možemo pribrojiti i grobne kapele obitelji Zrinski i Tahy koje dokazuju da su hrvatski plemići išli u korak sa suvremenim idejama renesansnih i manirističkih arhitekata.

Posebno mjesto u korpusu barokne grobne arhitekture kontinentalne Hrvatske zauzima crkva sv. Josipa u Karlovcu. Nalazila se na današnjem Trgu Josipa Jurja Strossmayera u središtu grada, a dao ju je podići karlovački general Ivan Josip Herberstein (Graz, 1633. Graz, 1689.) oko 1680. godine kao svoju grobnu crkvu. ${ }^{688}$ Nakon generalove smrti, njegovo tijelo položeno je u kriptu čiji je ulaz pokriven nadgrobnom pločom s grbom obitelji Herberstein i ratnim emblemima (Slika 150). O crkvi su prvo skrbili karlovački franjevci, a

\footnotetext{
${ }^{683}$ Usp. Howard Colvin, nav. dj., 1991., str. 202.

${ }^{684}$ Usp. Howard Colvin, nav. dj., 1991., str. 203, 232; Slavko Šterk i Boris Mašić, nav. dj., 2014., str. 50.

${ }^{685}$ Usp. Howard Colvin, nav. dj., 1991., str. 203-205.

${ }^{686}$ Usp. Jolán Balogh, nav. dj., 1982., str. 96; Howard Colvin, nav. dj., 1991., str. 205; Milan Pelc, nav. dj., 2007., str. 258.

${ }^{687}$ Usp. Ehrenfried Kluckert, Baroque Architecture in Germany, Switzerland, Austria, and Eastern Europe, u: Baroque: Architecture, Sculpture, Painting, Potsdam: Ullman Koenemann, 2010., str. 152-161, 246. Uredio Rolf Toman.

${ }^{688}$ Usp. Đurđica Cvitanović, nav. dj., 1985., str. 100-101, 255, 311; Milan Kruhek, Graditeljska baština karlovačkog Pokuplja, Karlovac: Matica hrvatska, Ogranak Karlovac, 1993., str. 96-97; Radoslav Lopašić, nav. dj., 1879., str. 123; Rudolf Strohal, Grad Karlovac opisan i orisan, Karlovac: n.n., 1906., str. 44.
} 
nakon što je Karlovac proglašen slobodnim gradom (1778.) karlovačka gradska vlast. ${ }^{689}$ Početkom XIX. stoljeća građevina se nalazila u vrlo lošem stanju zbog čega ju je gradska uprava odlučila srušiti (1833.). Srećom sačuvani su temelji (Slika 183) koji ukazuju da je crkva bila kružnoga tlocrta te da je s vanjske strane bila ojačana konkavnim kontraforima koji su opisivali oblik malteškoga križa (Ivan Josip Herberstein bio je prior Malteškoga reda za Ugarsku i Hrvatsku). Prema grafičkoj veduti grada Karlovca s početka XIX. stoljeća (Slika 184) i pisanim izvorima, crkva je bila nadsvođena kupolom zaključenom lanternom, a njezino pročelje bilo je oslikano prikazom borbe Maltežana protiv Osmanlija. ${ }^{690}$
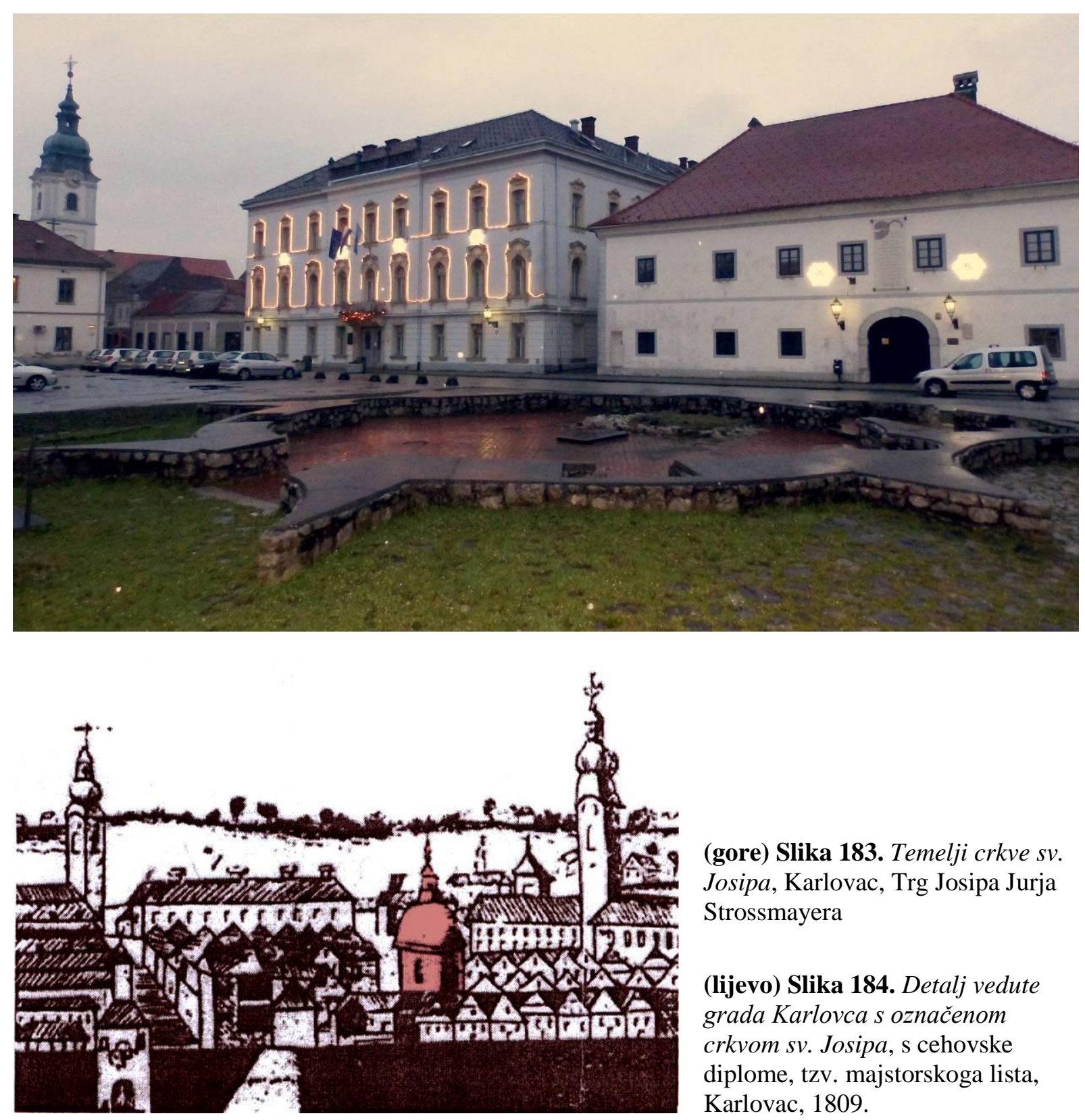

(gore) Slika 183. Temelji crkve sv. Josipa, Karlovac, Trg Josipa Jurja Strossmayera

(lijevo) Slika 184. Detalj vedute grada Karlovca s označenom crkvom sv. Josipa, s cehovske diplome, tzv. majstorskoga lista, Karlovac, 1809.

\footnotetext{
${ }^{689}$ Isto.

${ }^{690}$ Usp. Đurđica Cvitanović, nav. dj., 1985., str. 100-101, 255; Radoslav Lopašić, nav. dj., 1879., str. 123.
} 
Tijekom druge polovine XVIII. stoljeća grobne kapele postupno se prestaju prigrađivati crkvama. Jedan od razloga bila je službena odluka Josipa II. (1781.) kojom je car, iz zdravstvenih razloga, zabranio da se pokojnici sahranjuju unutar crkava i na župnim grobljima te naredio da se otvore nova, javna groblja izvan naselja. ${ }^{691}$ Unatoč carevoj odredbi, vjernici su se nastavili pokapati u crkvama i na obližnjim grobljima gotovo do sredine XIX. stoljeća. Međutim, grobne kapele koje su prethodno bile uklopljene u korpus tijelā crkvenih građevina počele su se izdvajati u zasebnu arhitektonsku cjelinu - slobodnostojeći mauzolej odnosno grobnu kapelu. Pripadnici velikaških i imućnih građanskih obitelji počeli su ih podizati na vlastitim posjedima ili novootvorenim javnim grobljima izvan naselja. Jedan od primjera predstavlja grobna kapela obitelji Drašković u Križančiji koju je Ivan Drašković sagradio 1731. godine na mjestu stare drvene kapele Pohoda Blažene Djevice Marije, na obiteljskome posjedu. ${ }^{692}$ Broj mauzoleja i slobodnostojećih grobnih kapela znatno je porastao u drugoj polovini XIX. stoljeća kada je naposljetku u potpunosti zabranjeno pokapanje unutar crkava, no time izlazimo izvan vremenskoga okvira razmatranoga u ovome radu.

\footnotetext{
${ }^{691}$ Usp. Siniša Krznar, nav. dj., 2012., str. 23; Antun Vujić (ur.), Hrvatski leksikon. I. svezak, A - K, Zagreb: Naklada leksikon d.o.o., 1996., str. 417.

${ }^{692}$ Usp. Katarina Horvat-Levaj, Barokna arhitektura, u: Hrvatska umjetnost: povijest i spomenici, Zagreb: Institut za povijest umjetnosti, Školska knjiga, 2010., str. 249-288, 271-272. Uredio Milan Pelc.
} 


\section{POSMRTNE SVEČANOSTI}

Posljednji dio disertacije čini prikaz posmrtnih svečanosti koje su uslijedile nakon smrti pojedinca i trajale su do polaganja njegovoga tijela u grob jer predstavljaju svojevrsnu sponu između smrti i čina podizanja nadgrobnika kao posljednjega materijalnog svjedočanstva o pokojnikovu životu. Posmrtne svečanosti imale su sličnu, dvojaku funkciju kao i nadgrobni spomenici. S jedne strane, sprovodni obredi trebali su osigurati da pokojnik »bude očišćen od svojih grijeha i njihovih posljedica te bude pripušten vazmenoj punini stola u Kraljevstvu«. ${ }^{693} \mathrm{~S}$ druge strane, neliturgijski dio svečanosti pružao je - poput drugih vrsta slavlja kao vjenčanja, ustoličenja i slično - priliku za (samo)prezentaciju pokojnika i njegove obitelji, koja je najčešće imala ulogu naručitelja. ${ }^{694}$ Budući da posmrtne svečanosti obuhvaćaju širok spektar aktivnosti čijom bismo detaljnom analizom izašli izvan okvira ovoga istraživanja, u narednim odlomcima tek je u osnovnim crtama prikazana novovjekovna funeralna kultura s naglaskom na likovnu smjelost privremenih scenografija, teatralni dojam svečanosti i predmete koji su se u njima upotrebljavali kao materijalnim svjedočanstvima istih.

Kao što je navedeno, sve je započinjalo smrću pojedinca, čije se tijelo moralo pripremiti za pogreb. To je zaduženje najčešće povjereno ženama koje su pokojnika oprale, premazale uljima i odjenule sukladno njegovom društvenom položaju i/ili službi. ${ }^{695}$ Tijelo je potom položeno u lijes, a lijes je postavljen na jednostavan odar unutar kuće u kojoj je osoba preminula. Nakon nekoliko noći probdjevenih u molitvi, pokojnikovo tijelo preneseno je u svečanoj povorci do mjesta ukopa (crkve, kapele ili groblja). Broj dana koji je protekao između smrti i prijenosa tijela ovisio je o tome koliko je vremena bilo potrebno da se organizira sprovod. Većina je priprema bila gotova za tri dana, no u slučaju raskošnih sprovoda crkvenih i svjetovnih velikodostojnika ponekad je znalo proteći mjesec dana ili više. ${ }^{696}$ Pripreme za sprovod bana Tome II. Bakača (†1624.) trajale su, primjerice, još dulje čak pola godine. ${ }^{697}$

\footnotetext{
${ }^{693}$ AA.VV., Katekizam katoličke crkve, Zagreb: Glas Koncila, 2016., br. 1689, str. 454.

${ }^{694}$ Usp. Minou Schraven, nav. dj., 2014., str. 6.

${ }^{695}$ Usp. Philippe Ariès, nav. dj., 1981., str. 168; Željko Demo, nav. dj., 2007., str. 51; Siniša Krznar, nav. dj., 2012., str. 30.

${ }^{696}$ Usp. Bruce Boucher, Italian Baroque Sculpture, London, New York: Thames and Hudson, 1998., str. 151; Mark Hengerer, The Funeral of the Habsburg Emperors in the Eighteenth Century, u: Monarchy and Religion: The Transformation of Royal Culture in Eighteenth-Century Europe, Oxford: University Press, 2007., str. 367394, 382. Uredio Michael Schaich.

${ }^{697}$ Usp. Velimir Deželić, Historijski grobovi u Zagrebu, u: Prosvjeta: časopis za pouku i zabavu XIV/21, Zagreb: Antun Scholz, 1906.a, str. 660-667, 662; Juraj Rattkay, nav. dj., 2001., str. 230.
} 
Do XIII. stoljeća u pogrebnim povorkama sudjelovali su samo članovi obitelji i prijatelji, no snažnijom vjerskom aproprijacijom sprovodnih obreda u kasnom srednjem vijeku njima su počeli prisustvovati i župnici, mjesno svećenstvo, prosjački (propovjednički) redovi, bratovštine, siromašni i siročad. ${ }^{698}$ Siromasi i potrebiti sudjelovali su kao primatelji milodara koji su pokojnici oporučno darovali zajednici. Milodar je bio znak njihove osobne darežljivosti, ali je ujedno služio kao zagovor pred božanskim sudom. ${ }^{699}$ Broj osoba koje su bile uključene u povorku svjedočio je o ugledu koji je pokojnik uživao tijekom života - što je broj sudionika bio veći, to je osoba bila značajnija. Redoslijed grupa koje su se kretale u koloni nije bio strogo propisan, no u pravilu su prvo išli svećenici, potom pokojnikovi bližnji, lijes s tijelom, a zatim preostali sudionici. ${ }^{700} \mathrm{U}$ slučajevima kada je preminuo vojni zapovjednik ili pripadnik visokoga plemstva koji se istaknuo ratnim podvizima, povorkama su često prisustvovali konjanici, vojnici pješaci, trubači i bubnjari (Slika 185). ${ }^{701}$

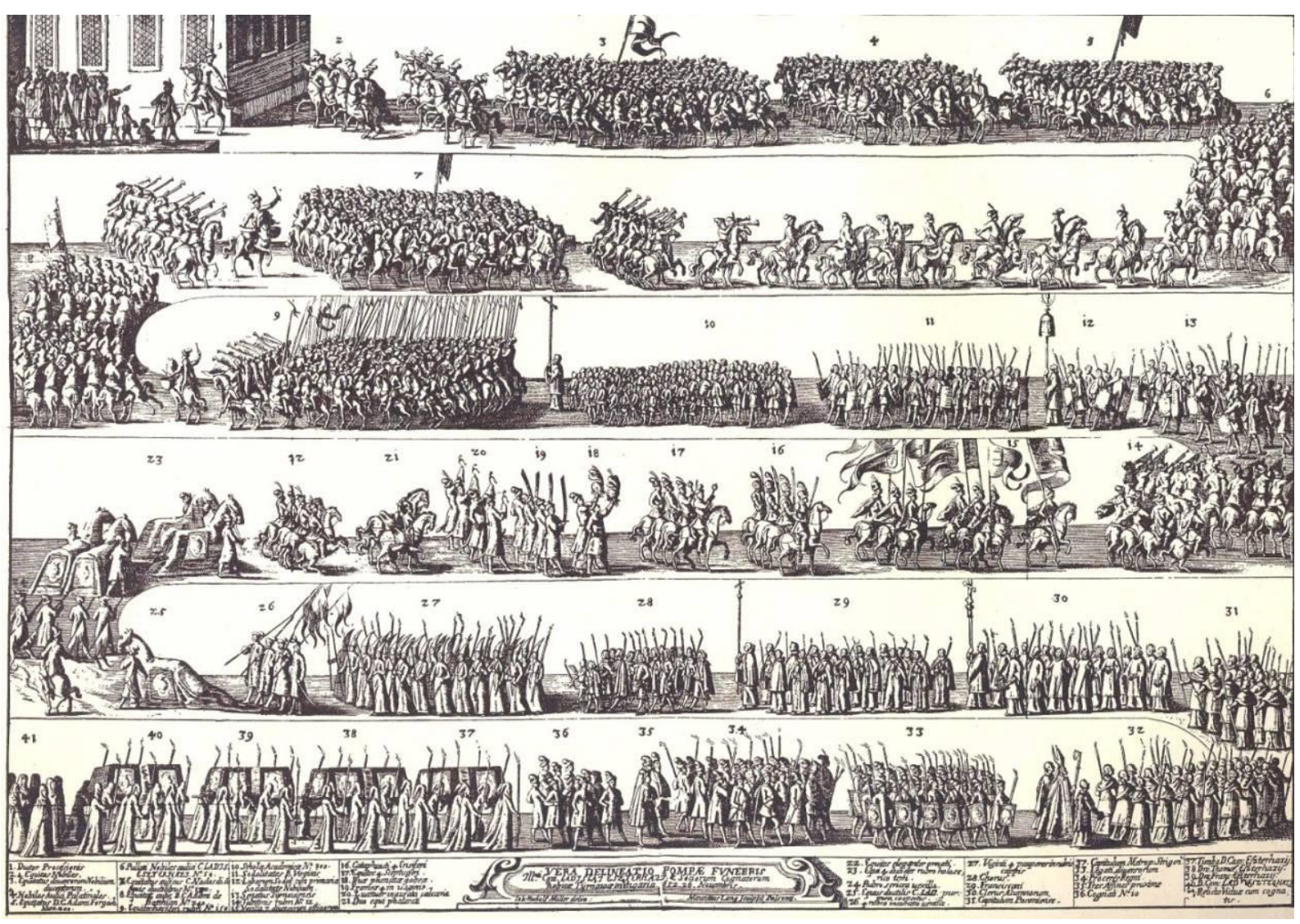

Slika 185. Moritz Lang, Pogrebna povorka Lászla, Ferenca, Támasa i Gáspára Esterházyja u Trnavi (prema crtežu Hansa Rudolfa Millera), iz knjige Tamása Pálffyja »In exequiis illustrissimi comitis ac domini, domino Ladislai Eszterhazi de Galanta...«, Beč, 1653.

\footnotetext{
${ }^{698}$ Usp. Philippe Ariès, nav. dj., 1981., str. 165-166.

${ }^{699}$ Usp. Philippe Ariès, nav. dj., 1981., str. 168.

${ }^{700}$ Usp. Željko Demo, nav. dj., 2007., str. 52.

${ }^{701}$ Usp. Géza Pálffy, nav. dj., 2005., str. 498.
} 
Važnu ulogu u povorkama imali su i predmeti koji su se u njima nosili. Neizostavan rekvizit bile su upaljene svijeće i baklje koje su simbolizirale vječno svjetlo i Kristovu žrtvu. ${ }^{702}$ Nosili su se i predmeti koji su ukazivali na društveni položaj pokojnika, poput obiteljskih grbova i zastava s likovima svetaca-zaštitnika, posvetnim natpisima ili čak čitavim oproštajnim pjesmama. Ako je preminuli pripadao nekoj od vjerskih ili svjetovnih bratovština, nosilo se znakovlje pripadajućega udruženja, ali i simboli koji su predstavljali pokojnikova osobna postignuća. U slučaju hrvatskih i ugarskih državnih velikodostojnika, ti su simboli najčešće bili povezani s borbom protiv Osmanlija, a uključivali su mačeve, sablje, kacige, oklope i mamuze. ${ }^{703}$ Primjerice, u pogrebnoj povorci bana Nikole VII. Zrinskoga (Čakovec, 1620. - Kuršanec, 1664.) na crnim su jastucima nošeni banova zapovjednička palica, zlatne mamuze, jednobridni mač (takozvani paloš) i kaciga ukrašena nojevim perom. ${ }^{704}$

Jedna od najbolje dokumentiranih pogrebnih svečanosti koje su održane na području povijesne Zagrebačke biskupije jest ona koja je priređena za bana Tomu II. Erdődyja $(\dagger 1624$.). S obzirom na to da je ban preminuo u Krapini, njegovo je tijelo bilo potrebno prenijeti u Zagreb. U povorci koja je išla iz Krapine preko Samobora sudjelovalo je tristo konjanika odjevenih u crnu odjeću i naoružanih kopljima iza kojih su koračali banovi sinovi i plemstvo. $^{705}$ Kada je povorka stigla u Zagreb, banov je lijes privremeno izložen na odru podignutom u crkvi sv. Marka. Sljedeći dan povorka je krenula iz gradečke crkve prema katedrali, a predvodio ju je par barjaktara koji su nosili dva umjetnički izrađena grba obitelji Erdődy. ${ }^{706}$ Iza njih išao je plemić koji je na grimiznom jastuku nosio viteški vojni orden Reda Otkupitelja (»insigne Ordinis equestris titulo Redemptoris, an. MDCVIII a Duce Vincentio maxima celebritate instituti, aut restitutiti $)^{707}$ kojim je pokojnik odlikovan za pobjedu nad Osmanlijama kod Siska (1593.). Njega je slijedilo nekoliko konja zaogrnutih u crni baršun o koje su bile ovješene slike banovih predaka, a iza konjā koračali su pokojnikova rodbina, plemići i građanstvo u redovima po dvije osobe. Potom je išao zagrebački biskup Petar Domitrović (? - Varaždin, 1628.; biskupovao 1611. -1628.) u pratnji svećenika, a iza njih šest konja zaogrnutih u crno ruho vuklo je kola s lijesom koja su pratila banova djeca. Opisana

\footnotetext{
${ }^{702}$ Usp. Slavko Šterk i Boris Mašić, nav. dj., 2014., str. 32.

${ }^{703}$ Usp. Géza Pálffy, nav. dj., 2005., str. 498-499.

${ }^{704}$ Usp. Károly Zrínyi, Monografija grada Čakovca. Povijest dvorca i grada. Popis stanovništva iz 1901., Čakovec: Povijesno društvo Međimurske županije, 2005., str. 65. Prevela Isabella Brzak.

${ }^{705}$ Usp. Velimir Deželić, nav. dj., 1906.a, str. 662; Juraj Rattkay, nav. dj., 2001., str. 230.

706 Isto.

${ }^{707}$ Tako njegovu povijest ukratko opisuje Acta Sanctorum u životopisu svetoga člana obitelji osnivača, sv. Alojzija Gonzage. ACTA SANCTORUM JUNII, Ex Latinis \& Grocis aliarumque gentium Monumentis, servata primigenia veterum Scriptorum phrasi COLLECTA, DIGESTA, Commentariisque \& Observationisbus illustrata A Godefrido Henschenio P. M. Daniele Papebrochio, Francisco Baertio, Conrado Janningo, E Societate JESU Presbyteris Theologis Tomus IV. [...], Venetiis, MDCCXLIII, Apud Jo: Baptistam Albirzzi Hieron. Fil. et Sebastanum Coleti., str. 864.
} 
povorka navodno je bila toliko duga da kad su prvi stjegonoše ušli u katedralu, dio povorke na Trgu svetoga Marka jedva se pomaknuo s mjesta. ${ }^{708}$

Još veći broj ljudi prisustvovao je pogrebnoj povorci zapovjednika Vojne krajine Ivana Herbarta X. Auersperga $(\dagger 1669.) .{ }^{709} \mathrm{Na}$ čelu kolone koja je vodila prema zagrebačkoj crkvi sv. Katarine, gdje je pokojnik sahranjen, koračali su gimnazijalci nižih razreda koji nisu bili članovi Marijine kongregacije. Njih je slijedilo tristo konjanika odjevenih u crne odore koji su nosili koplja sa šiljastim zastavicama te četiristo graničara pod vodstvom satnikā. Iza četa išli su pripadnici građanske i đačke Marijine kongregacije koji su nosili pogrebne zastave, a slijedilo ih je svećenstvo - dvjesto franjevačkih i pavlinskih opata koji su pristigli iz okolnih samostana i Kranjske, svećenici i župnici iz svih krajeva Hrvatskoga Kraljevstva te zagrebački biskup Martin Borković (Jastrebarsko, 1597. - Zagreb, 1687.; biskupovao 1667. 1687.) u pratnji kanonika. Iza biskupa išli su pokojnikovi konji ukrašeni zlatom i dragim kamenjem te oklopnici koji su nosili zastave i obiteljske grbove. Slijedili su ih generalova četiri sina te mnoštvo hrvatskih i kranjskih velikaša, koji su koračali ispred kola s lijesom. Pokojnikovo tijelo pratila je njegova supruga zajedno s drugim plemkinjama.

Crkve u kojima se odvijala liturgija za dušu pokojnika bile su posebno ukrašene za tu prigodu. Crkveni zidovi zastirali su se crnom tkaninom te ukrašavali obiteljskim grbovima, motivima funeralne ikonografije i/ili alegorijskim figurama poput smrti, vrlina i razdoblja ljudskoga života (Slika 186). Oltari i propovjedaonice također su se prekrivali crnom tkaninom (najčešće svilom), a unutrašnjost je bila osvijetljena mnoštvom baklja, svijeća i voštanica. ${ }^{710}$ Prigodom održavanja posmrtnih svečanosti za vojnike koji su poginuli u boju, dominantna boja u uređenju crkve nije bila crna nego crvena jer je simbolizirala žrtvu koju su pokojnici podnijeli za spas svoje domovine. ${ }^{711}$ Ponekad su se ukrašavala i pročelja crkava zastirana su draperijom i ukrašavana efemernim uresima nalik onima u unutrašnjosti hrama (Slika 187). ${ }^{712}$ Središnji dio pogrebne scenografije (tal. apparato funebre) bio je katafalk, odar podignut u glavnome brodu na koji se polagao lijes s pokojnikovim tijelom. Katafalci su se razvili iz srednjovjekovne chapelle ardente (lat. domus ardens, „goruća kapela«), a bili su iznimno popularni u XVI. i XVII. stoljeću diljem cijele Europe. ${ }^{713}$ Prvi katafalci pojavili su se

\footnotetext{
${ }^{708}$ Usp. Velimir Deželić, nav. dj., 1906.a, str. 662; Juraj Rattkay, nav. dj., 2001., str. 230.

${ }^{709}$ Usp. Artur Schneider, Iz staroga Zagreba: Svečani sprovod Herbarta X Auersperga 1669., u: Hrvatski narod: glasilo Hrvatskog ustaškog pokreta VI/957, Zagreb: Ustaški nakladni zavod, 1944., str. 5; Miroslav Vanino, nav. dj., 1969., str. 466.

${ }^{710}$ Usp. Minou Schraven, nav. dj., 2014., str. 1, 9.

${ }^{711}$ Usp. Géza Pálffy, nav. dj., 2005., str. 500.

${ }^{712}$ Usp. Minou Schraven, nav. dj., 2014., str. 92-93.

${ }^{713}$ Usp. Mark Hengerer, nav. dj., 2007., str 385; Artur Schneider, Sitna građa za kulturnu povijest grada Zagreba, u: Narodna starina IX/24, Zagreb: Josip Matasović, 1930., str. 462-465, 465; Minou Schraven, nav. dj., 2014., str. 2, 15.
} 


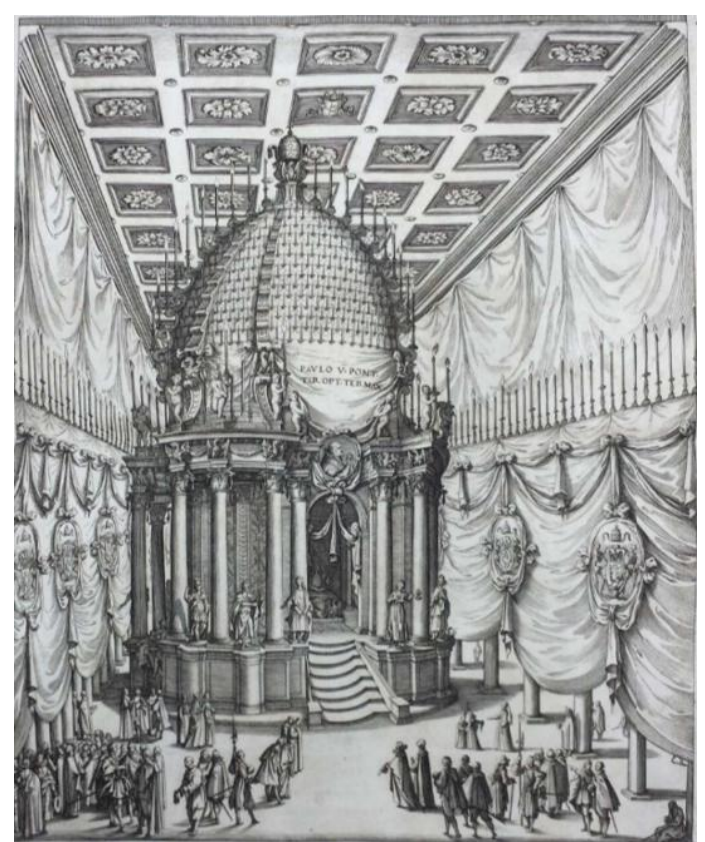

Slika 186. Theodor Krüger, Unutrašnjost bazilike Santa Maria Maggiore u Rimu opremljene za posmrtnu svečanost pape Pavla V. (kopija prema Sergiju Venturiju), 1622./23., London, The British Museum

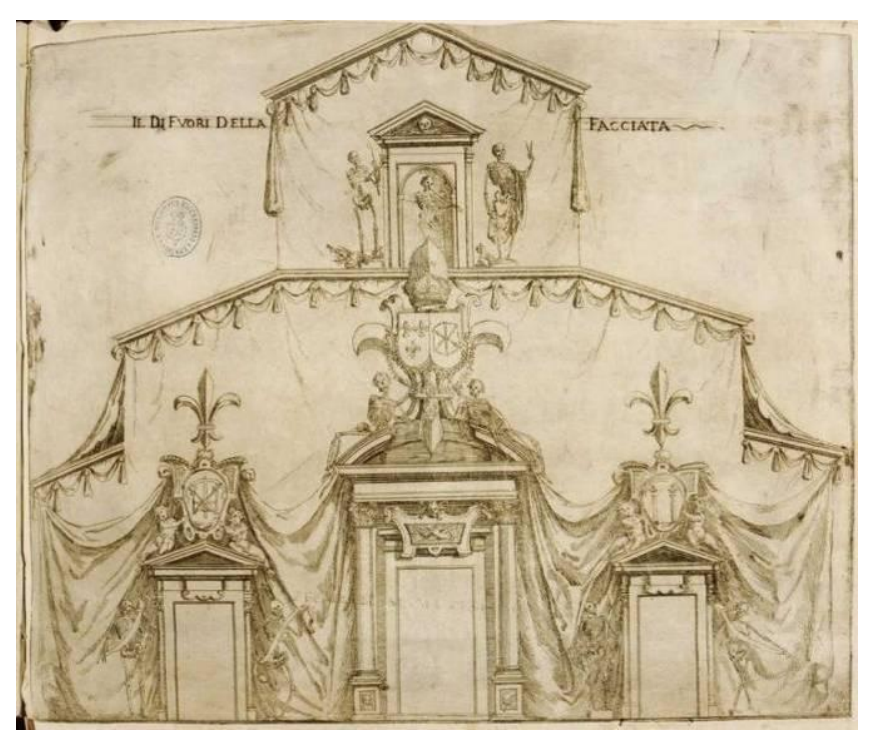

Slika 187. Krug Giulija Parigija, Pročelje crkve San Lorenzo u Firenci ukrašeno za posmrtnu svečanost kralja Henrika IV., 1610., Firenca, Biblioteca

Riccardiana

na prostoru Hrvatsko-Ugarskoga Kraljevstva početkom XVII. stoljeća, a već su sredinom istoga stoljeća postali neizostavan dio pogrebnih svečanosti hrvatskih i ugarskih velikodostojnika. ${ }^{714}$ Izgledom su najčešće nalikovali ciboriju ili tempiettu, a imali su razrađen ikonografski program. Osim obiteljskih grbova, ukrašavani su skulpturama, slikama i emblemima koji su veličali vrline i postignuća preminuloga. ${ }^{715}$ Izrađivali su se od potrošnih materijala (drva, kartona, papier-mâchéa, tkanine, gipsa itd.) koji su izgledom oponašali skupocjene materijale poput mramora ili zlata. ${ }^{716}$ Njihove nacrte najčešće su izrađivali arhitekti, a u izradi su sudjelovali slikari, kipari i obrtnici različitih zanata. Katafalci podizani za znamenite osobe isticali su se monumentalnošću i raskošnošću. Simbolično su nazivani »dvorima boli« (lat. castrum doloris), a svojom su veličinom često ispunjavali punu visinu $\mathrm{i}$ širinu broda (Slika 186).

U pisanim izvorima sačuvani su opisi raznovrsnih katafalka koji su podignuti diljem povijesne Zagrebačke biskupije za svjetovne i crkvene velikodostojnike. Poznato je, primjerice, da je svečani odar bana Tome II. Erdődyja (†1624.) u zagrebačkoj prvostolnici bio izveden »u obliku krova«, da je visinom gotovo dosezao svod te je bio ukrašen raznobojnim

\footnotetext{
${ }^{714}$ Usp. Géza Pálffy, nav. dj., 2005., str. 500.

${ }^{715}$ Usp. Minou Schraven, nav. dj., 2014., str. 15, 54, 167-168.

716 Usp. Daniel Premerl, The Meaning of Emperor Francis I's Funeral in Bologna, u: Ikon: Ćasopis za ikonografske studije 4, Rijeka: Filozofski fakultet Sveučilišta u Rijeci, 2011., str. 243-256, 243, 249.
} 
vitrajima. $^{717}$ Katafalk podgenerala Hrvatske i Primorske krajine Jurja IV. Frankapana Tržačkoga (†1662.) u crkvi sv. Katarine u Zagrebu počivao je pak na šest stupova, a bio je okružen kipovima dvanaestorice znamenitih Frankapana izrađenih u nadnaravnoj veličini. ${ }^{718}$ (Za cjelovit opis pogrebnih svečanosti održanih za Jurja IV. Frankapana vidi Prilog 1.)

Zasad najpoznatiji vizualni izvor koji bilježi izgled ranonovovjekovnoga katafalka podignutoga na razmatranome području jest bakrorez Johanna Caspara Mannassera (Graz, 1640. - Graz, 1684.) koji prikazuje svečani odar postavljen za Ivana Herbarta X. Auersperga (†1669.) (Slika 188) u zagrebačkoj Svetoj Katarini. ${ }^{719}$ Prema bakrorezu, katafalk je bio

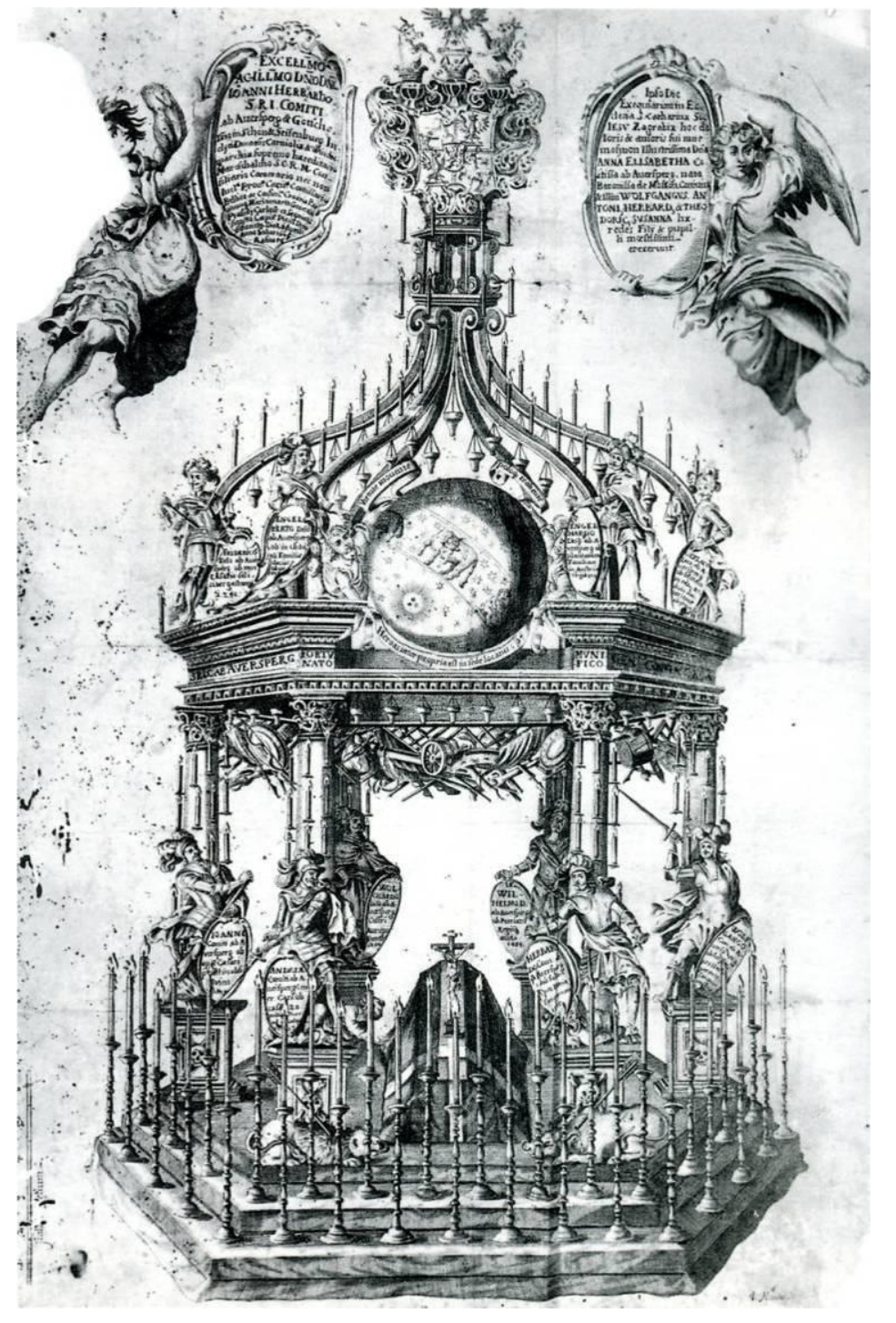

Slika 188. Johann Caspar Mannasser, Katafalk Ivana Herbarta X. Auersperga, 1669., Zagreb, Metropolitanska knjižnica, Valvasorova grafička zbirka

\footnotetext{
${ }^{717}$ Juraj Rattkay, nav. dj., 2001., str. 231. Usporedi dalje: Velimir Deželić, nav. dj., 1906.a, str. 662.

${ }^{718}$ Usp. Emilij Laszowski, nav. dj., 1939., str. 17; Miroslav Vanino, nav. dj., 1969., str. 459.

${ }^{719}$ Johann Caspar Mannasser, Katafalk Ivana Herbarta X. Auersperga, 1669., bakrorez, $598 \times 406$ mm, Zagreb, Metropolitanska knjižnica, Valvasorova grafička zbirka. Bakrorez je prvi znanstveno obradio Artur Schneider. Vidi: Artur Schneider, Sitna građa za kulturnu povijest grada Zagreba, u: Narodna starina IX/24, Zagreb: Josip Matasović, 1930., str. 462-465; Artur Schneider nav. dj., 1944., str. 5. Kasnije su o njemu pisali: Miroslav Vanino, nav. dj., 1969., str. 466-467; Anđela Horvat, nav. dj., 1975., str. 206, 211; Ivan Kampuš i Ljubo Karaman, nav. dj., 1994., str. 148.
} 
izveden u obliku ciborija sa šest stupova koji su nosili gređe i lukovičastu kupolu. Pri dnu svakoga stupa i na vijencu bili su postavljeni kipovi vojnika naoružani mačevima koji su predstavljali znamenite članove obitelji Auersperg. Njihova imena i dostignuća bila su ispisana na štitovima koje su držali u rukama. $\mathrm{S}$ arhitrava su između stupova visjeli ratni trofeji poput sablji, štitova, bubnjeva i zastava. U središtu katafalka, na vrhu triju stuba osvijetljenih kandelabrima, nalazio se lijes s pokojnikovim tijelom. Iznad lijesa visjela je kugla sa znakovima zodijaka koja je žicama bila pričvršćena za pokrov, dajući dojam da lebdi u zraku. ${ }^{720}$ Oko kugle nalazio se svitak s natpisom kojim je pokojnik smješten rame uz rame sa svojim slavnim predcima: »Heroas inter propria est in sede locatus« (Među herojima smješten je na svojem mjestu). Vrh kupole bio je zaključen lanternom i raskošno izvedenim grbom obitelji Auersperg. Prema natpisu ispisanom u gornjem desnom kutu bakroreza (unutar štita koji drži anđeo), katafalk su dali podići pokojnikova supruga Ana Elizabeta rođ. Moscon i njihova djeca Vuk, Antun, Herbart, Teodorik i Suzana. ${ }^{721}$

Prema protokolarnom slijedu, nakon što je lijes s tijelom unesen u crkvu i položen na odar, započinjala je služba za pokojnika (lat. officium defunctorum) koja se sastojala od dva dijela. ${ }^{722}$ Prvi dio činile su molitve za preminulu osobu koje su započinjale u kasno poslijepodne ili predvečerje i nastavljale se sljedeći dan ujutro. Između večernjih i jutarnjih molitava održano je bdjenje u prisutnosti svećenika i tugujuće rodbine. Nakon jutarnjih molitvi započinjao je drugi dio službe koji je činila misa zadušnica (lat. requiem). Po završetku mise, odabrani govornik uspeo se na propovjedaonicu i održao pogrebni govor (lat. oratio funebris) kojim su se veličale osobine pokojnika i njegova djela. $\mathrm{Na}$ području Hrvatskoga Kraljevstva često su se držala dva govora - jedan na latinskome, a drugi na hrvatskome jeziku. ${ }^{723}$ Po njihovome završetku, misnik je skinuo misnicu (kazulu) i naručnik (manipul), odjenuo je crni plašt (pluvijal) te se spustio iz svetišta do odra gdje je pokojniku udijelio oprost grijeha. Lijes je potom prenesen do groba i spušten u njega.

U slučajevima kada je preminula osoba koja je zadužila zajednicu, čin spuštanja pokojnikova tijela u grob dodatno je obogaćen kratkim inscenacijama. Primjerice, kada je umro plemić koji je aktivno služio u vojsci, angažiran je glumac koji je odjeven u viteški oklop dojahao u crkvu držeći u rukama barjak s grbom obitelji kojoj je pokojnik pripadao. Kada je došao do lijesa, slomio je zastavu i bacio se s konja, simbolično predstavljajući

\footnotetext{
${ }^{720}$ Usp. Miroslav Vanino, nav. dj., 1969., str. 466.

${ }^{721}$ Usp. Artur Schneider, nav. dj., 1944., str. 5.

${ }^{722}$ Usp. Željko Demo, nav. dj., 2007., str. 52; Sinišar Krznar, nav. dj., 2012., str. 30; Minou Schraven, nav. dj., 2014., str. 9-10.

${ }^{723}$ Dvojni govori održali su se, primjerice, na pogrebu grofa Jurja IV. Frankapana Tržačkoga koji je održan u crkvi sv. Katarine u Zagrebu 1662. godine. Usp. Miroslav Vanino, nav. dj., 1969., str. 459.
} 
gubitak koji je zajednica pretrpjela smrću preminuloga. ${ }^{724} \mathrm{Na}$ sprovodima Tome II. Erdődyja $(\dagger 1624 .)^{725}$ i Jurja IV. Frankapana Tržačkoga $(\dagger 1662 .)^{726}$ stotine prisutnih vojnika na sličan su način slomile svoja koplja o zidove crkve u trenutku kada je lijes spušten u grob. U slučajevima kada je smrću pokojnika izumrla obitelj ili neka od njezinih loza, na pogrebu je uništen grb dotične obitelji kao znak njezina zatiranja. ${ }^{727}$

Za ukop imućnih članova društva često su se koristili dvostruki lijesovi. Tijekom posmrtnih svečanosti pokojnikovo je tijelo bilo pohranjeno u jednostavnom drvenom sanduku. No prije nego što je ono spušteno u grob, položeno je - zajedno s drvenim lijesom u raskošnije izveden sarkofag koji je bio izliven u metalu (kositru, bakru ili bronci). Iz povijesnih izvora poznato je, primjerice, da je drveni sanduk s tijelom Jurja IV. Frankapana Tržačkoga položen »u drugi lijes izrađen od engleskoga kositra i urešen reljefima i natpisima« prije nego što je spušten u kriptu u svetištu crkve sv. Katarine. ${ }^{728}$

U franjevačkom samostanu Navještenja Blažene Djevice Marije u Klanjcu sačuvani su sarkofazi triju članova obitelji Erdődy, koji su odabrali klanječku crkvu kao jedno od svojih tradicionalnih mjesta ukopa. Najstariji od njih je sarkofag hrvatsko-dalmatinsko-slavonskoga bana Žigmunda I. Erdődyja (?, 1596. - ?, 1639.) (Slika 189), ${ }^{729}$ velikoga dobrotvora crvenih redova i jednoga od utemeljitelja klanječkoga samostana (1629.). Žigmund je sahranjen u kripti ispod svetišta u sarkofagu izlivenom od kositra. ${ }^{730}$ Sarkofag je izveden u obliku lijesa sa skošenim bočnim stranicama, a stoji na nogama urešenima manirističkom hrskavicom. Ukrašen je reljefno izvedenim i pozlaćenim motivima (rubovi stranica urešeni su palmetama, kutevi poklopca anđeoskim glavama, uzglavlje i uznožje lavljim glavama s karikama, a bočne stranice lišćem s plodovima) te ugraviranim florealnim detaljima. Na poklopcu je urezan natpis koji sadrži pojedinosti o pokojniku te grb obitelji Erdődy. Na osnovi stilske analize i usporedbe sa sarkofazima dinastije Habsburg koji su pohranjeni u kripti kapucinske crkve u Beču, Anđela Horvat (1892.) pripisala je sarkofag radionici bečkoga kositara Zaharije Lauffera, a kasniji istraživači prihvatili su njezinu atribuciju. ${ }^{731}$

\footnotetext{
${ }^{724}$ Usp. Bartłomiej Łyczak, nav. dj., 2011., str. 235.

${ }^{725}$ Usp. Velimir Deželić, nav. dj., 1906., str. 662; Juraj Rattkay, nav. dj., 2001., str. 231

${ }^{726}$ Usp. Emilij Laszowski, nav. dj., 1939., str. 17; Miroslav Vanino, nav. dj., 1969., str. 459.

${ }^{727}$ Usp. Bartłomiej Łyczak, nav. dj., 2011., str. 235; Gerhard Winkler, nav. dj., 1974., str. 216.

${ }^{728}$ Miroslav Vanino, nav. dj., 1969., str. 460.

${ }^{729}$ Kositar, pozlata, $97 \times 90 \times 229 \mathrm{~cm}$, Klanjec, crkva Navještenja Blažene Djevice Marije. Usp. Anđela Horvat, Pregled spomenika s područja općine Klanjec, u: Kaj: časopis za književnost, umjetnost i kulturu 3, Zagreb: Kajkavsko spravišće, 1979.b, str. 15-70, 25; Anđela Horvat, O metalnim sarkofazima u Klanjcu, u: Peristil 25, Zagreb: Društvo povjesničara umjetnosti SR Hrvatske, 1982.b, str. 97-106, 98 101-102; Ivan Kukuljević Sakcinski, nav. dj., 1891., str. 89, br. 287; Gjuro Szabo, nav. dj., 1912., str. 238; Gjuro Szabo, nav. dj., 1939., str. 28; Maja Velicogna-Novoselac, Vapaj za pomoć kositrenih sarkofaga obitelji Erdödy iz Klanjca, u: Anali Galerije Antuna Augustinčića 12, Klanjec: Galerija Antuna Augustinčića, 1992., str. 34-48, 34, 42-43.

${ }^{730}$ Usp. Anđela Horvat, nav. dj., 1982.b, str. 98; Maja Velicogna-Novoselac, nav. dj., 1992., str. 34.

${ }^{731}$ Usp. Anđela Horvat, nav. dj., 1982.b, str. 101-102; Maja Velicogna-Novoselac, nav. dj., 1992., str. 35.
} 


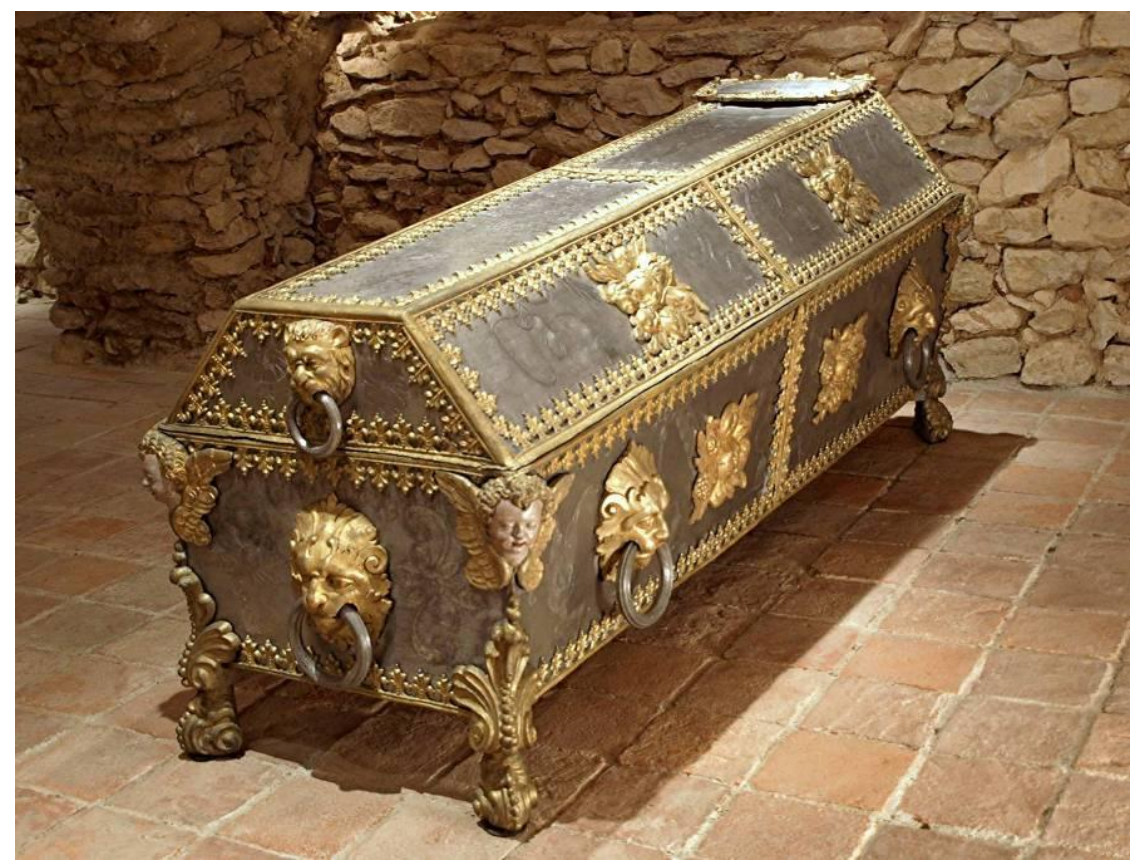

Slika 189. Zaharija

Lauffer, Sarkofag Žigmunda I. Erdödyja $(† 1639$.), Klanjec, samostan Navještenja Blažene Djevice Marije

Još raskošniji je sarkofag Mirka I. Erdődyja (?, 1620. - Cesargrad, 1690.) (Slika 190), ${ }^{732}$ Žigmundova nećaka koji je bio pokrovitelj klanječkih franjevaca, ali i onih u Jastrebarskom te zagrebačkih isusovaca i lepoglavskih pavlina. ${ }^{733}$ Pokopan je ispod kapele sv. Antuna Padovanskoga u sarkofagu načinjenome od legure kositra i olova. ${ }^{734}$ Nalik Žigmundovom, Mirkov sarkofag ima oblik lijesa skošenih stranica, a počiva na figurama ležećih jelena (po jedan na svakome uglu) i orlova raširenih krila (po jedan u sredini bočnih stranica). Primjena motiva jelena i orla može se protumačiti na dva načina. Prema katoličkome nauku, obje životinje imaju simbolično značenje: jelen simbolizira čistoću i pobožnost, a orao uskrsnuće. ${ }^{735}$ Međutim, jelen i orao ujedno predstavljaju simbole obitelji Erdődy te se nalaze na njihovome grbu. ${ }^{736}$ Stranice sarkofaga ukrašene su reljefno izvedenim motivima karakterističnima za funeralnu ikonografiju: mrtvačkim lubanjama s ukriženim kostima, lavljim glavama, kartušama s posvetnim natpisima, prikazom Raspetoga te cvijećem i raznovrsnim plodovima. Posebno je zanimljiv prikaz koji se nalazi na čeonoj strani sarkofaga (Slika 191). Na poklopcu je predočen ležeći putto koji se laktom jedne ruke oslanja na lubanju, a u drugoj drži pješčani sat. Uz njega se nalazi još jedan simbol prolaznosti -

\footnotetext{
${ }^{732}$ Kositar, olovo, $98 \times 132 \times 280 \mathrm{~cm}$, sarkofag $72 \times 90 \times 225 \mathrm{~cm}$, Klanjec, crkva Navještenja Blažene Djevice Marije. Usp. Anđela Horvat, nav. dj., 1979.b, str. 25; Anđela Horvat, nav. dj., 1982.a, str. 266; Anđela Horvat, nav. dj., 1982.b, str. 98-99, 103-104; Ivan Kukuljević Sakcinski, nav. dj., 1891., str. 90, br. 289; Maja Velicogna-Novoselac, nav. dj., 1992., str. 35-36, 44-46.

${ }^{733}$ Usp. Trpimir Macan (ur.), nav. dj., 1998., sub voce Erdődy [Tatjana Radauš].

${ }^{734}$ Usp. Maja Velicogna-Novoselac, nav. dj., 1992., str. 44.

${ }^{735}$ Usp. Anđelko Badurina (ur.), nav. dj., 1990. [1979.], sub voce Jelen, str. 296 [Marijan Grgić], sub voce Orao, str. 440-441 [Marijan Grgić].

${ }^{736}$ Usp. Ivan von Bojničić, nav. dj., 1889., str. 44, tab. 33.
} 

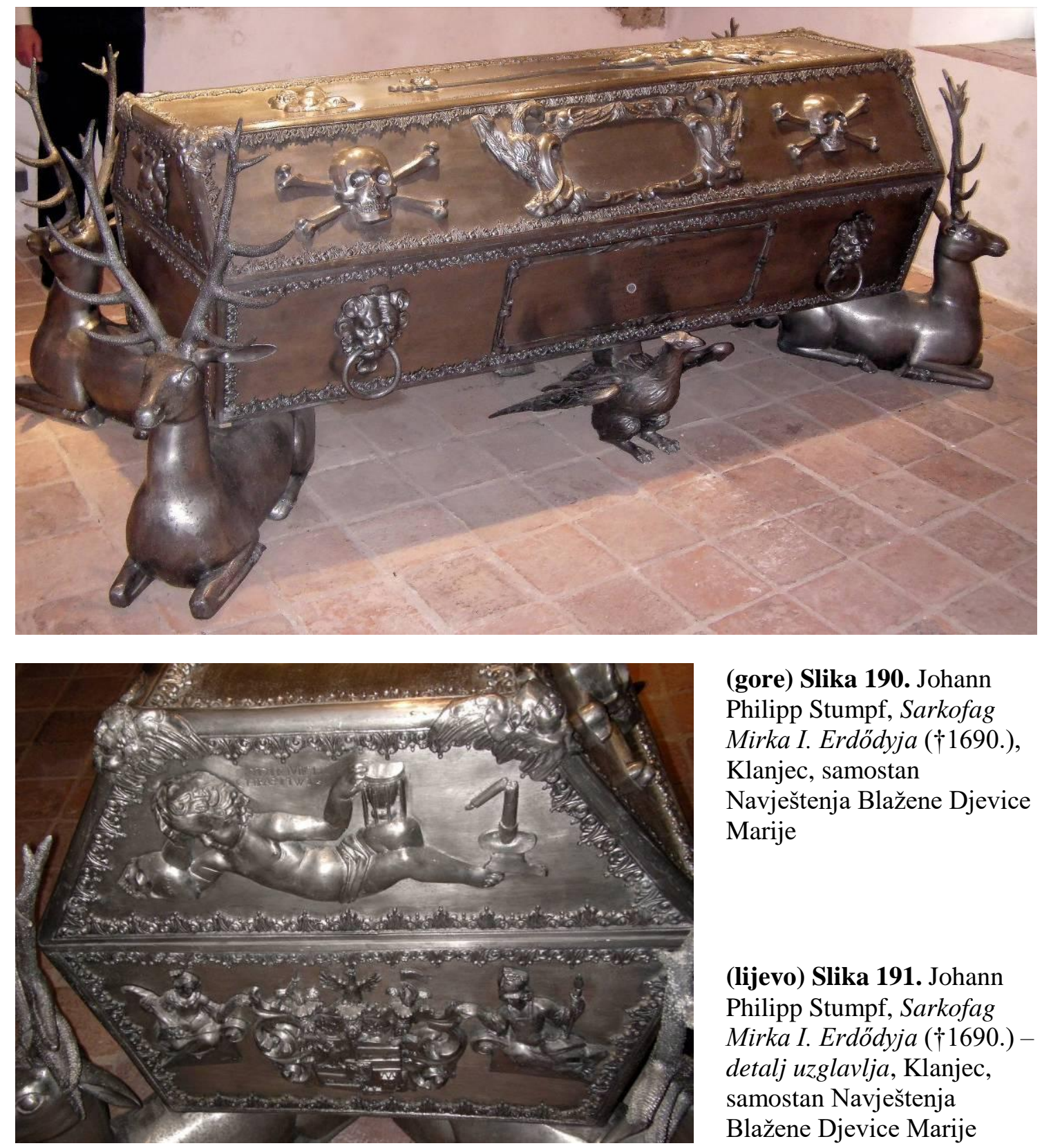

(gore) Slika 190. Johann Philipp Stumpf, Sarkofag Mirka I. Erdödyja (†1690.), Klanjec, samostan Navještenja Blažene Djevice Marije

(lijevo) Slika 191. Johann Philipp Stumpf, Sarkofag Mirka I. Erdödyja (†1690.) detalj uzglavlja, Klanjec, samostan Navještenja Blažene Djevice Marije

prelomljena svijeća. Poruka likovnih motiva o kratkotrajnosti ovozemaljskoga života upotpunjena je uzrečicom »HODIE MICHI / CHRAS TIWI« koja je ugravirana iznad anđela. $\mathrm{Na}$ čeonoj strani sanduka predočen je pak raskošan grb obitelji Erdődy koji je flankiran personifikacijama izobilja i mudrosti. ${ }^{737} \mathrm{U}$ grobnoj plastici Izobilje predstavlja djela dobročinstva koje je pokojnik učinio za svojega života, ${ }^{738}$ a u slučaju Mirka I. Erdődyja najvjerojatnije se odnosi na njegovo pomaganje klanječkih franjevaca, ali i drugih crkvenih redova. Na tragu zaključka Anđele Horvat (1982.) da je sarkofag vjerojatno izradio netko iz

\footnotetext{
${ }^{737}$ Izobilje je prepoznatljivo po kornukopiji (rogu izobilja) koju drži u rukama, a mudrost po oklopu, kacigi i koplju. Usp. James Hall, nav. dj., 1998., sub voce izobilje, str. 129-130, sub voce mudrost, str. 212.

${ }^{738}$ Usp. James Hall, nav. dj., 1998., sub voce izobilje, str. 129.
} 
krugova bečkih kositara, ${ }^{739}$ Josef Ziegler (1992.) pripisao ga je Johannu Philippu Stumpfu, salzburškome majstoru koji je izradio sarkofag nadvojvotkinje Eleonore Marije Habsburg (Regensburg, 1653. - Beč, 1697.). ${ }^{740}$

Posljednji, najmlađi sačuvani sarkofag pripada Elizabeti Erdődy rođ. Rakoczi (?, 1655. - ?, 1707.) (Slika 192) ${ }^{741}$ i jednostavnije je izvedbe od prethodna dva. Elizabeta je bila Mirkova snaga, a pokopana je u kripti ispod svetišta uz Žigmunda I. ${ }^{742}$ Izrađen od bakra, njezin sarkofag ima ponovljen oblik lijesa sa skošenim stranicama, a počiva na kuglama. Stranice poklopca jednostavno su profilirane, a one sanduka ukrašene su lisnatim ornamentom i mrtvačkim lubanjama s ukriženim kostima. Mirkov i Žigmundov sarkofag restaurirani su u radionici Josepha Zieglera u Beču (prvi od 1999. do 2001., drugi od 2002. do 2004. godine), a po povratku u Hrvatsku izloženi su u podrumu franjevačkoga samostana. Elizabetin sarkofag, s druge strane, još uvijek čeka na restauraciju i nije dostupan javnosti.

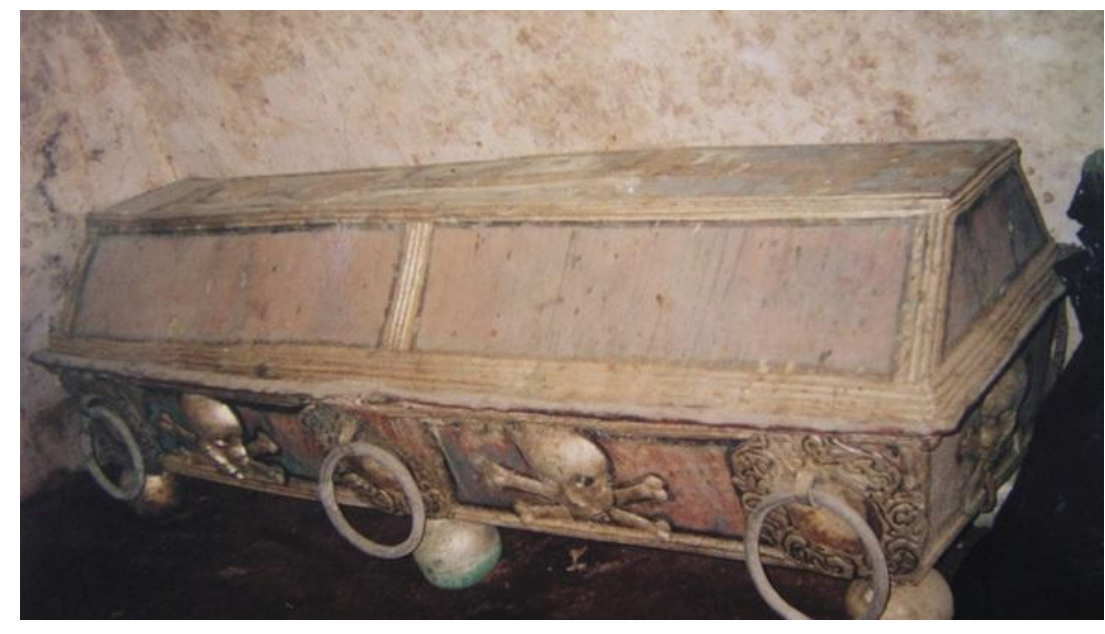

Slika 192. Sarkofag

Elizabete Erdödy rođ. Rakoczi (†1707.), Klanjec, crkva Navještenja Blažene Djevice Marije

Posmrtne svečanosti nisu se održavale samo u crkvama u kojima su pokojnici bili sahranjeni, posebice ako je bila riječ o istaknutoj osobi koja je zadužila neku crkvenu ili svjetovnu zajednicu. U znak zahvalnosti na dobročinstvu, dotična zajednica upriličila bi za pokojnika »počasnu« posmrtnu svečanost koja je nalikovala uobičajenoj. Unutrašnjost crkve ukrasila se tkaninom i emblemima, u sredini broda postavio se svečani odar, a misa zadušnica i pogrebni govor održali su se bez prisutnosti tijela preminuloga (lat. absente corpore). Srijemski biskup Stjepan I. Erdődy (?, 1585. - ?, 1638.) pokopan je, primjerice, u

\footnotetext{
${ }^{739}$ Usp. Anđela Horvat, nav. dj., 1982.b, str. 102-103, 106.

${ }^{740}$ Citirano u: Maja Velicogna-Novoselac, nav. dj., 1992., str. 36.

${ }^{741}$ Bakar, dimenzije nepoznate autorici, Klanjec, crkva Navještenja Blažene Djevice Marije. Usp. Anđela Horvat, nav. dj., 1982.b, str. 99, 105.

${ }^{742}$ Usp. Anđela Horvat, nav. dj., 1982.b, str. 99. U članku Pregled spomenika kulture s područja Općine Klanjec (1979.), Anđela Horvat navela pogrešan podatak da je riječ o sarkofagu Žigmundova sina Nikole IV. (†1706.). Usp. Anđela Horvat, nav. dj., u: Kaj: časopis za kulturu i prosvjetu XI/3, Zagreb: Kajkavsko spravišće, 1979.b, str. $15-70,25$.
} 
franjevačkoj crkvi na Kaptolu, no gradečki isusovački kolegij, želeći zahvaliti biskupu na njegovom pokroviteljstvu i prijateljstvu, uresio je crkvu sv. Katarine »pjesničkim emblemima i postavio lijep odar, a jedan je otac održao posmrtnu besjedu na latinskom jeziku na veliko zadovoljstvo velikaša i predstavnika svih staleža, koji su iz Hrvatske i Ugarske dohrlili na sprovod toga poštenjaka staroga kova . $^{743}$

Nakon završetka sprovoda, uresi korišteni u svečanostima uklanjani su iz unutrašnjosti crkava. Jedan od načina na koji su naručitelji mogli održati spomen na održani pogreb jest tiskanjem knjižica (tal. avviso) koje su sadržavale opis svečanosti, a ponekad i grafike ukrašenih crkvenih interijera i eksterijera. ${ }^{744}$ Kolanje takvih knjižica znatno je pridonijelo širenju trenda raskošnih apparati funebri koji su bili popularni u XVI. i XVII. stoljeću.

Pojedini predmeti koji su se koristili u svečanostima ostajali su u crkvama. Jedan od njih su posmrtni grbovi (njem. Totenschild, eng. funerary hatchment, mađ. halotti címer) koji su se nosili u pogrebnoj povorci, a nakon završetka sprovoda položeni su s lijesom u grob ili su izloženi u blizini grobnice kao podsjetnik na pokojnika i poziv promatraču da moli za njegovu dušu (Slika 193). ${ }^{745}$ Izrađivani su od drva (obojenoga i pozlaćenoga) ili metala

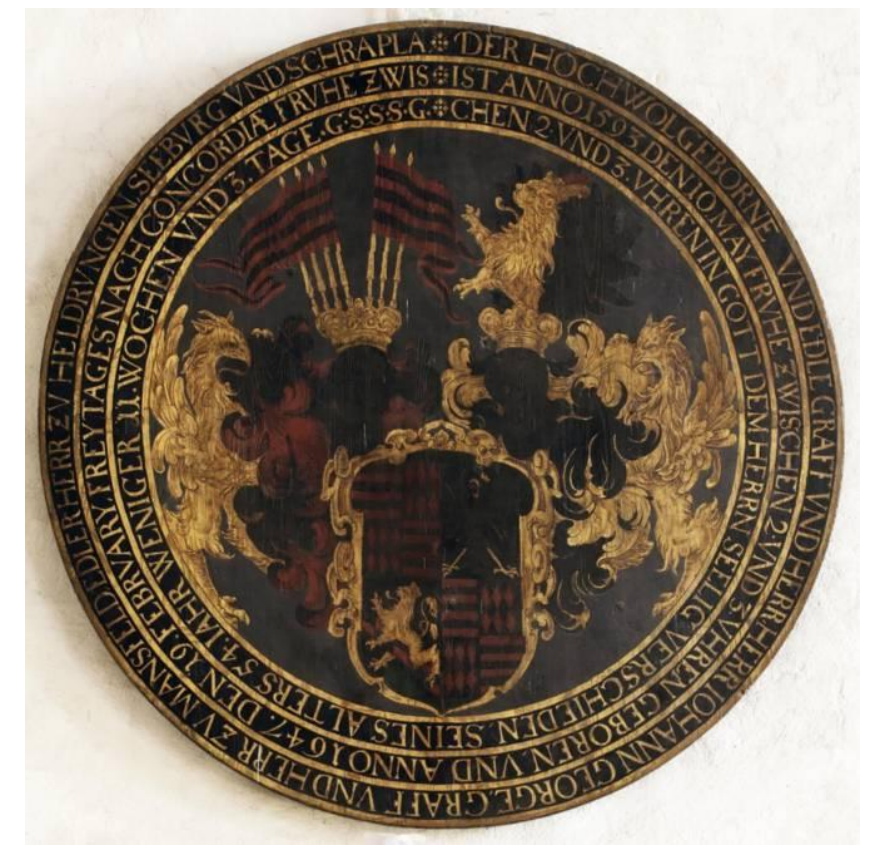

Slika 193. Posmrtni grb grofa Johanna Georga II. von MansfeldEislebena, 1647., Mansfeld, dvorska crkva sv. Jurja i Marije

\footnotetext{
${ }^{743}$ Miroslav Vanino, nav. dj., 1969., str. 451.

${ }^{744}$ Usp. Minour Schraven, nav. dj., 2014., str. 2.

${ }^{745}$ Usp. Lászlo Baják, A halotti címerek, u: Numizmatika és társtudományok III, Nyíregyháza: Jósa András Múzeum, 1999., str. 55-63, 55; Júlia Bara, „Regnavit Alexander et mortuus est." The Funeral Ceremony of Sándor Károlyi in 1744 and its Art Historical Aspects, u: Hungary in Context: Studies on Art and Architecture, Budapest: CentrArt Egyesület, 2012., str. 79-100, 86; Silvija Lučevnjak, Posmrtni grbovi u arhivskom gradivu valpovačkih vlastelina, u: Valpovački vlastelini Prandau-Norman, Osijek: Državni arhiv u Osijeku [et al.], 2018., str. 54-59, 58; Lilla Tompos, Totenwappen im Museum für Kunstgewerbe, u: Ars decorativa 6, Budapest: Iparmüvészeti Múzeum, Hopp Ferenc Kelet-ázsiai Mủvészeti Múzeum, 1979., str. 145-156, 145; Gerhard Winkler, nav. dj., 1974., str. 216; Andreas Zajic, nav. dj., 2004., str. 180-182.
} 
(bronce, srebra, bakra). Najčešće su bili ovalnoga ili osmerokutnoga oblika, a razlikovali su se od »običnih« grbova po tome što su bili upotpunjeni natpisom koji je sadržavao podatke o pokojniku, njegovome položaju, službi, častima, ponekad obitelji te godini rođenja i smrti. ${ }^{746}$ Budući da su najčešće bili izrađeni od drva, koje je trošni materijal, te da su - poput nadgrobnih spomenika - često odstranjivani iz unutrašnjosti crkava prilikom obnova, posmrtni grbovi rijetko su očuvani. Dokaze o njihovom postojanju možemo, doduše, pronaći u pisanim izvorima. Ivan Kukuljević Sakcinski (1891.) tako je zabilježio da se u crkvi sv. Franje u Zagrebu na zidu lijevo od glavnoga oltara nalazila »drven[a] pozlaćen[a] dask[a] urešen[a] grbom plemićah Orehovačkih «. ${ }^{747} \mathrm{Na}$ daski su - najvjerojatnije iznad i ispod grba bile ispisane titule Gašpara Orehovečkoga (?, o. 1600. - ?, 1672.), hrvatskoga podbana (1647. - 1670.) te zagrebačkoga i križevačkoga župana, ${ }^{748}$ a grb je bio flankiran natpisom »TAMEN VIVET GASPAR MELIORE PS[...]«.

Posmrtni grbovi izrađivali su se i u obliku letaka. Bili su nacrtani na svili ili papiru te su - nalik njihovim reljefno izvedenim pandanima - bili upotpunjeni natpisom s pojedinostima o životu pokojnika. ${ }^{749}$ Njima se obilježavala kuća preminuloga, dijelili su se sudionicima pogrebne povorke (svileni su bili namijenjeni uglednijim članovima društva, a papirnati puku) te su služili ukrašavanju unutrašnjosti crkve u kojoj se održavao pogreb (pričvršćivali su se na lijes, propovjedaonicu, oltar i katafalk). U Hrvatskom povijesnom muzeju u Zagrebu pohranjeno je nekoliko posmrtnih grbova naslikanih na svili. Jedan od njih izrađen je za pogreb zagrebačkoga biskupa Mirka Esterházyja (Nové Mesto nad Váhom, 1665. - Požun, 1745.; biskupovao 1708. - 1722.) (Slika 194), ${ }^{750}$ a drugi za sprovod njegovoga nasljednika Jurja Branjuga (Zagorska Sela, 1677. - Zagreb, 1748.; biskupovao 1723. - 1748.) (Slika 195). ${ }^{751}$

Osim obiteljskih grbova, u blizini grobova često su ostali izloženi i drugi predmeti koji su se nosili u pogrebnoj povorci poput posmrtnih zastava ili pokojnikovih osobnih predmeta. Poznato je da je u lepoglavskoj crkvi Blažene Djevice Marije iznad epitafa Ivana Petheőa de

\footnotetext{
${ }^{746}$ Isto.

${ }^{747}$ Ivan Kukuljević Sakcinski, nav. dj., 1891., str. 337, br. 1158.

${ }^{748}$ Natpis je glasio: »SCEPTABILIS AC MAGNIFICVS DOMINVS D $\overline{N V S}$ GASPAR ORAHOCZY DE / ORAHOVICZA. REGNOR. DALMATIAE CROATIAE ET SCLAVONIAE VICEBANVS. / COMITATVVM ZAGRABIENSIS ET CRISIENSIS SVPREMVS COMES SACR. CAES. / REGIAEQVE MATTIS CONSILIARIVS ET PRAESIDII BREZT SVPREMVS CAPITANEVS / OBIIT DIE 2. SEPTEMBRIS 1672.«

${ }^{749}$ Usp. Lászlo Baják, nav. dj., 1999., str. 55; Júlia Bara, nav. dj., 2012., str. 86; Silvija Lučevnjak, nav. dj., 2018., str. 58; Lilla Tompos, nav. dj., 1979., str. 145.

${ }^{750}$ Posmrtni grb Mirka Esterházyja, 1745., akvarel, svila, $720 \times 540 \mathrm{~mm}$, Zagreb, Hrvatski povijesni muzej. Usp. Vlasta Brajković, nav. dj., 1995. [1976.], str. 74-75.

${ }^{751}$ Posmrtni grb Jurja Branjuga, 1748., akvarel, svila, $620 \times 495 \mathrm{~mm}$, Zagreb, Hrvatski povijesni muzej. Usp. Vlasta Brajković, nav. dj., 1995. [1976.]., str. 65-66; D[ubravka] P[eić], Grb zagrebačkog biskupa biskupa Jurja pl. Branjuga, u: Od svagdana do blagdana: barok u Hrvatskoj = From everyday to holidays: baroque in Croatia, katalog izložbe, Zagreb: Muzej za umjetnost i obrt, 1993., str. 412, br. 460. Uredio Vladimir Maleković.
} 


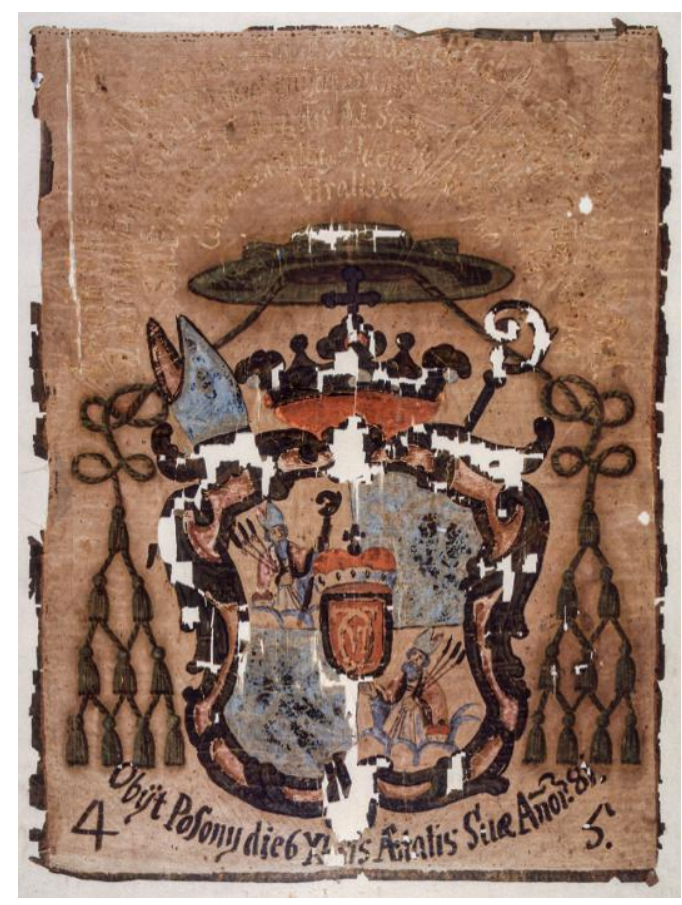

Slika 194. Posmrtni grb biskupa Mirka Esterházyja, 1745., Zagreb, Hrvatski povijesni muzej

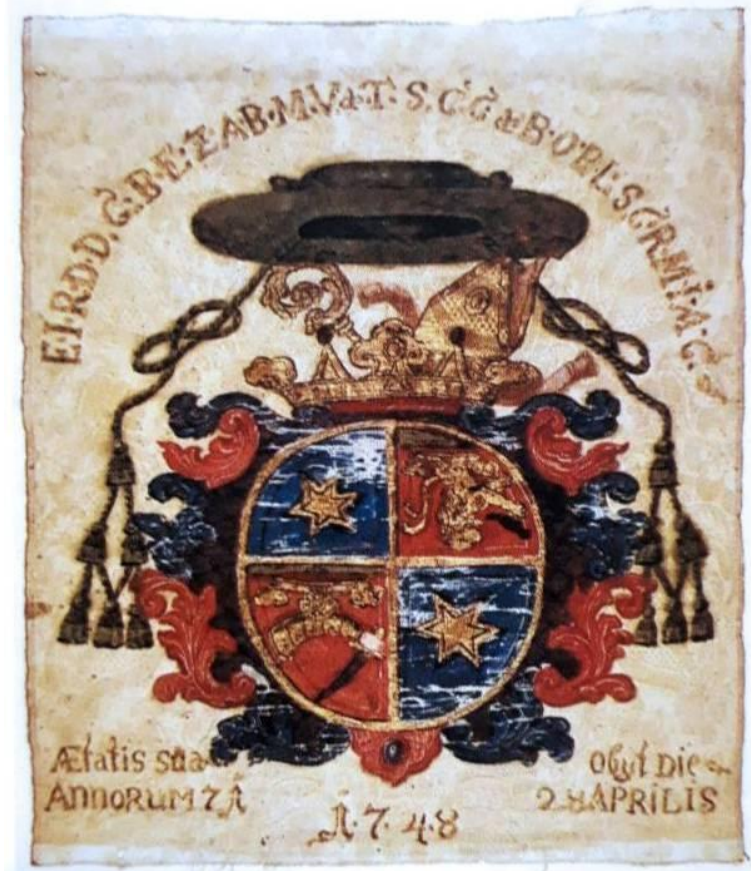

Slika 195. Posmrtni grb biskupa Jurja Branjuga, 1748., Zagreb, Hrvatski povijesni muzej

Gerse (? - ?, 1671.) (Slika 153) nekoć bila izložena crna zastava na kojoj je zlatnim slovima bio ispisan natpis koji je veličao pokojnika: »COELITIBVS, REGI, PATRIAE, THOROQUE IOANNES PROMISSAM STABILI FOVIT AMORA FIDEM. ACTA LICET BELLIS, TITVLIS ET HONORIBVS AVCTA. NON HABVIT MACVLAM LAVS PETHEANA SVAM. EXEQVIAE 18. IAN. 1671. « ${ }^{752}$ U opisu epitafa Nikole III. Erdődyja (?, 1630. Aranyosmarót, 1693.) (Slika 146) već je navedeno da su ispod spomenika bili izloženi banovi prsni oklop, kaciga, mač, bansko žezlo i zastava, koji su danas pohranjeni u riznici katedrale. $^{753}$

\footnotetext{
752 Kamilo Dočkal, nav. dj., 2014., str. 269. Citirano i u: Ivan Kukuljević Sakcinski, nav. dj., 1891., str. 125, br. 413; Gjuro Szabo, nav. dj., 1919., str. 36-37.

${ }^{753}$ Usp. Ivan Kukuljević Sakcinski, nav. dj., 1856., str. 31-32; Ivan Krstitelj Tkalčić, nav. dj., 1885., str. 72; Zdenka Munk, Tekstil, katalog T, u: Riznica zagrebačke katedrale = The Treasury of Zagreb Cathedral, katalog izložbe, Zagreb: MTM, 1987. [1983.], str. 137-148, 140 (reprodukcija na str. 87). Uredila Zdenka Munk.
} 


\section{Prilog 1.}

Opis posmrtnih svečanosti održanih za Jurja Frankapana Tržačkoga (Bosiljevo?, o. 1620. Karlovac, 1661.) i njegovoga sina Nikolu (†1659.) u zagrebačkoj crkvi sv. Katarine.

Izvor: Miroslav Vanino, Isusovci i hrvatski narod I: Rad u XVI stoljeću, Zagrebački kolegij, Zagreb: Filozofsko-teološki institut Družbe Isusove u Zagrebu, 1969., str. 459-460.

Dvije godine kasnije bogoljubnog i junačkog grofa pokosi nemila smrt u Karlovcu 13. veljače 1661. [...] Na godišnjicu smrti g. 1662. dopremljeno mu je tijelo iz Karlovca, gdje je počivalo godinu dana, u Zagreb i položeno za noć u katedralu, a sutradan doneseno je u crkvu sv. Katarine s kraljevskim sjajem, kakova dotad Zagreb pri sprovodu nije vidio. Odar dostojan kneza počivao je na šest omašnih stupova, sav je sjao u svjetlu svijeća i svjetiljaka, a okruživaše ga 12 kipova znamenitijih Frankopana u naravnoj veličini, koji su dostojanstvom $i$ ljepotom izradbe privlačili svačije oči. Posred tih kipova, na povišem podiju s nekoliko stuba, ležalo je mrtvo tijelo u lijesu koji se sjao od srebra i zlata. Zidovi crkve bijahu opstrti crnom tkaninom, a ukrašeni frankopanskim grbovima, s kojih su sjali lavovi od srebra, a natpisima u slavu tolikog muža. U crkvenom trijemu stajaše stotina crno odjevenih konjanika s kopljima. Posmrtni govor na latinskom jeziku izrekao je profesor Retorike Ferdo Ellwanger, dok je hrvatsku besjedu održao o. Baltazar Milovec, Cicero Croatiae, koji je cijelu žalobnu svečanost i opisao. Nakon zadušnica lijes s mrtvim tijelom položen je u drugi lijes izrađen od engleskoga kositra $i$ urešen reljefima $i$ natpisima, te unesen u raku uz zvukove trubalja, prasak pušaka (pred crkvom) i lomljenje kopalja. [...] Kolegijski kroničar upozorava da su s mrtvim ostancima u lijesu bile zatvorene dragocjenosti od čistog zlata $i$ dragog kamenja vrijedne 800 forinti. [...] Četrnaesti dan po pogrebu dovezeno je iz Brežica kasno navečer mrtvo tijelo jedinog grofovog sinčića Nikole, koji bijaše umro unatrag dvije godine. Lijes s mrtvim ostancima bi unesen u crkvu sv. Katarine i položen na isti sjajni odar: sprovod je pratila duga povorka malih dječaka odjevenih poput anđela. Sutradan nakon otpjevane mise o anđelima sahranjeno je uz oca tjelešce nevinoga djeteta, koje su s bijelim svijećama pratili anđelčići kao pri dočeku. 



\section{ZAKLJUČAK}

Umjetnost kontinentalne Hrvatske ranoga novog vijeka - koje svjedoči pojavi stilskih značajki nekoliko razdoblja - usko je povezana s društveno-političkim događanjima. U turbulentno vrijeme početnih dvaju stoljeća navedenoga razdoblja, mnoštvo spomenika uništeno je i izgubljeno u ratovanjima protiv Osmanskoga Carstva. Ista sudbina zatekla je i one nadgrobne, posebice podignute na područjima koja su potpala pod osmansku vlast. Na fragmentarnu očuvanost spomeničkoga korpusa utjecala je još jedna, dodatno otežavajuća okolnost, a to je da su nadgrobnici nerijetko uklanjani iz unutrašnjosti crkava u kojima su se nalazili prilikom preuređenja i obnova građevina. U takvim slučajevima najgore su prolazile nadgrobne ploče koje su se često preokretale i koristile za novo popločenje ili su jednostavno bacane. Sretnije sudbine bile su ploče čija je kulturno-povijesna vrijednost pravovremeno prepoznata te su ugrađene u zidove crkava i tako sačuvane. Pritom je potrebno naglasiti da likovna složenost i umješnost izvedbe nisu nužno utjecali na odluku hoće li nadgrobnik biti sačuvan ili ne. Dokaz za to su, primjerice, nadgrobne ploče biskupa Luke de Szegeda $(† 1510$.) i bana Nikole IV. Zrinskoga ( $\dagger$ 1566.) koje su unatoč visokom stupnju umjetničke vrijednosti razlomljene i upotrijebljene kao sekundarni građevinski materijal. Zbog opisane fragmentarne očuvanosti korpusa, sve zaključke koji se tiču pregleda građe potrebno je uzeti s određenom zadrškom jer, unatoč nastojanjima za što obuhvatnijom rekonstrukcijom, još uvijek nije poznato u kojoj su mjeri spomenici sačuvani, odnosno koliki ih je broj izgubljen.

Među likovnim djelima XV. i XVI. stoljeća, nadgrobne ploče i epitafi predstavljaju neka od najvažnijih kiparskih ostvarenja u kamenu. Izuzev arhitektonske plastike i svetohraništā, ostatak skulpture u to je vrijeme većinom rezbaren u drvu. To će, zapravo, ostati pravilo do posljednje četvrtine XVII. stoljeća kada se kamen prvi puta javlja u crkvenoj opremi zagrebačkih crkava, a potom i drugih sakralnih građevina unutar biskupije. ${ }^{754}$ Odabir materijala svjedoči o važnosti koju su nadgrobni spomenici imali za naručitelje. Budući da su nadgrobnici predstavljali posljednji materijalni dokaz o pokojnikovom ovozemaljskom životu i morali su očuvati uspomenu na njega, naručitelji su najčešće odabirali kamen kao materijal koji je bio dugotrajniji, ali time i skuplji. Likovno-ikonografska rješenja koja su primijenjena na petnaestostoljetnim i šesnaestostoljetnim spomenicima (nadgrobnici s likom ležećega pokojnika odnosno pokojnika-adoranta i grbovni spomenici) nastavljaju se na srednjovjekovnu tradiciju. Oblikovne promjene koje su zamjetne na njima nikad ne zadiru

\footnotetext{
${ }^{754}$ Usp. Nela Tarbuk, Kiparstvo 17. i 18. stoljeća u sjevernoj Hrvatskoj, u: Od svagdana do blagdana: barok u Hrvatskoj = From everyday to holidays: baroque in Croatia, katalog izložbe, Zagreb: Muzej za umjetnost i obrt, 1993., str. 122-131, 124.
} 
dublje u kompoziciju ili sadržaj, nego ostaju na razini izmjene pojedinih formalnih značajki, poput načina oblikovanja volumena, obradi površine, odabiru ornamenta i slično. Na osnovi tih značajki mogu se iščitati odrednice stila i pratiti njihov razvoj. Nalik stilskom slijedu cjelokupne spomeničke baštine kontinentalne Hrvatske, u nadgrobnoj skulpturi XV. stoljeća još uvijek prevladava kasna gotika, a renesansa se javlja u narednom, XVI. stoljeću posredništvom ugarskoga i subalpskoga područja. Najviše poticaja pristizalo je iz Ostrogona i slovenske Štajerske, o čemu svjedoče djela koja su odotamo uvezena (nadgrobnu ploču biskupa Luke de Szegeda izradila je ostrogonska radionica majstora Johannesa Fiorentinusa) ili pokazuju oblikovne sličnosti s djelima radionica aktivnih na tim prostorima (epitafi Petra II. Keglevića i Ane Purthin povezani su sa slovenskom radionicom Majstora Hassova epitafa i njegovoga suradnika, a nadgrobne ploče Franje Tahyja i Petra II. Ratkaja srodne su viteškom nadgrobniku iz Vurberka). Najreprezentativnija djela unutar ovoga dijela korpusa predstavljaju nadgrobne ploče s likom pokojnika koje su izrađene za biskupe i kanonike pokopane u zagrebačkoj prvostolnici te feudalne gospodare koji su posljednje počivalište pronašli u crkvama smještenima nedaleko svojih posjeda, a nad kojima su imali patronat. Iako ti spomenici nisu dostigli stupanj likovne složenosti nadgrobnikā koji su podizani u srednjoeuropskim kulturnim žarištima, oni svjedoče o vrsnoj umjetničkoj obradi i vještini angažiranih umjetnika.

Sedamnaesto i posebice osamnaesto stoljeće donijeli su mirnija vremena u kojima se Hrvatsko Kraljevstvo moglo posvetiti obnovi. Stabilnija gospodarsko-politička situacija pozitivno se odrazila na umjetničku aktivnost i produkciju, što se može uočiti i u nadgrobnoj plastici - najveći broj nadgrobnika sačuvan je upravo iz ovoga razdoblja. Na spomenicima se još uvijek primjenjuju ista ikonografsko-tipološka rješenja kao i tijekom prethodna dva stoljeća, no pojedini nadgrobnici sadrže kompozicijske promjene i novitete koji svoje uporište imaju u suvremenoj umjetnosti. Primjenom kontraposta i elementa postolja s odloženom kacigom te dopojasnim kadriranjem, viteški nadgrobnici (poput nadgrobnih ploča Benedikta Thuróczyja Ludbreškoga i Ivana Pethőa de Gersse ili epitafa obitelji Češković) približavaju se djelima suvremene portretistike. Pod utjecajem arhitekture i altaristike javljaju se epitafi oblikovani kao edikule (primjerice, epitafi obitelji Istvánffy-Both de Bajna, Gašpara Bedekovića ili Nikole Gotala od Gotalovca) odnosno epitafi čiji su središnji reljefni prikazi uklopljeni unutar arhitektonskoga okvira koji nalikuje oltarnim retablima (epitafi Tome II. Erdődyja, obitelji Dreffel-Hrvoj i Jurja Gorupa). Spomenici XVII. stoljeća pokazuju stilske odlike kasne renesanse, manirizma i ranoga baroka, s time da pojedini predstavljaju djela mješovitoga stilskog karaktera. Barokni stil u potpunosti se učvrstio tek u XVIII. stoljeću, 
kako u nadgrobnoj plastici, tako i u likovnoj umjetnosti i arhitekturi kontinentalne Hrvatske općenito. Tijekom navedena dva stoljeća, nadgrobna skulptura najviše je poticaja primala iz srednje Europe - iz Požuna i slovenske Štajerske. Budući da nije bila u žarištu umjetničke i naručiteljske aktivnosti poput crkvene umjetnosti, nikad nije dosegla razinu bogatstva i razvedenosti suvremenih oltara ili propovjedaonica kojima je opremana unutrašnjost crkava. Štoviše, velik je broj nadgrobnika skromnije likovne složenosti i tehničke izvedbe. Ipak, u tom razdoblju nastala su vrijedna kiparska ostvarenja, poput epitafa Tome II. i Nikole III. Erdődyja, obitelj Dreffel-Hrvoj ili Ladislava III. Patačića, koja svjedoče o visokim dometima umjetničkoga stvaralaštva unutar te grane skulpturalne djelatnosti.

Zbog njihove komemorativno-reprezentativne funkcije, nadgrobni spomenici nerazdvojivi su u razmatranju od osoba za koje su podizani. Naručitelji su im sami pokojnici (dakako, za života) ili - češće - članovi njihovih obitelji, a pripadali su svim slojevima društva. Riječ je o visokim crkvenim dostojanstvenicima (biskupima i kanonicima), imućnim feudalcima (obitelji Zrinski, Frankapan, Erdődy, Drašković, Ratkaj, Patačić, Keglević itd.), nižem plemstvu (Bedeković, Češković, Dragač, Gorup, Hrvoj, Humski, Keczer, Petheő de Gerse, Vragović, Zmajlović itd.), građanima (Ana Purthin, Danijel Praunsperger) i seoskim župnicima (Matija iz Granešine, Juraj Habijančić, Grgur Zebec). Ukop u crkvi i podizanje nadgrobnika zahtijevali su znatan novčani izdatak. U teškim političkim, gospodarskim i društvenim prilikama koje su vladale, posebice u prva dva stoljeća ranoga novog vijeka, njega su si najlakše mogli priuštiti crkveni i svjetovni velikodostojnici, čijih nadgrobnika ima brojčano najviše, a potom pripadnici nižeg plemstva. Građani i seoski župnici zastupljeni su sa svega nekoliko nadgrobnih spomenika, što svjedoči o njihovoj smanjenoj gospodarskoj moći. Novčana mogućnost naručitelja izravno je utjecala na različite aspekte spomenika, poput materijala od kojega će biti izrađen, njegove veličine, složenosti likovne kompozicije i izvrsnosti izvedbe odnosno vještine angažiranoga umjetnika. Naravno, u svemu treba razmatrati i želju naručitelja, koja je mogla biti usmjerena prema što raskošnijim, ali i skromnijim oblicima. U skladu sa svojim mogućnostima i htijenjima, naručitelji su se obraćali domaćim (udomaćenim) i stranim umjetnicima, manje i više vrsnim majstorima klesarima i drvorezbarima. Naručiteljima koji su raspolagali skromnijim novčanim sredstvima važnije je bilo obilježiti ukopno mjesto i održati memoriju na pokojnika, nego stvarati vrhunska umjetnička djela. Međutim, naručitelji koji su se nalazili na vrhu društvene ljestvice svojim su narudžbama pokušavali - i uspijevali - pratiti suvremena stilska i općenito kulturnoumjetnička zbivanja, a njihovi spomenici mogu se uvrstiti među kvalitetnija ostvarenja ranonovovjekovnoga kiparstva na području povijesne Zagrebačke biskupije. 



\section{KATALOG}

Katalogom su obuhvaćeni nadgrobni spomenici koji su podignuti unutar granica povijesne Zagrebačke biskupije od XV. do XVIII. stoljeća i sadrže neki likovni motiv. Uključeni su i nadgrobnici koji nisu sačuvani, no čiji je načelan izgled moguće rekonstruirati na osnovi pisanih ili vizualnih izvora. Radi lakšega snalaženja, katalog je podijeljen prema današnjim teritorijalno-upravnim jedinicama Katoličke crkve na pet cjelina: I) Zagrebačku nadbiskupiju, II) Varaždinsku biskupiju, III) Bjelovarsko-križevačku biskupiju, IV) Sisačku biskupiju i V) Požešku biskupiju. U pokušaju da se rekonstruira izvorno stanje, nadgrobnici unutar svake (nad)biskupije svrstani su prema njihovome prvobitnome smještaju odnosno prema crkvi ili kapeli u kojoj su početno postavljeni. Ako je nadgrobnik izmješten, njegova trenutačna lokacija navedena je u kataloškoj jedinici. Lokaliteti unutar biskupija navedeni su abecednim redom. Ako se više spomenika nalazi u istoj crkvi, navedeni su kronološkim redoslijedom od starijega prema mlađemu.

S obzirom na to da su većinu nadgrobnika izradili neznani majstori, autori spomenikā navedeni su samo u slučajevima kada je njihovo ime poznato ili istraživanja ukazuju na moguću atribuciju. Točna godina podizanja nadgrobnika podjednako je češće nepoznata nego poznata, stoga je kao orijentir u dataciji navedena godina smrti pokojnika koja - podsjećamo - ne mora nužno odgovarati godini postavljanja spomenika.

Budući da su svi nadgrobnici stilsko-ikonografski analizirani u raspravi, u katalogu je iznesen samo njihov sažeti opis. Uz nadgrobnike koji nisu sačuvani no za koje je poznato iz povijesnih izvora da su sadržavali grb obitelji pokojnika, kao slikovni prilog priložene su reprodukcije obiteljskih grbova iz grbovnika Ivana von Bojničića Der Adel von Kroatien und Slavonien (Nürnberg, 1889.).

U prijepisu natpisā, dijelovi teksta koji su oštećeni ili istrošeni, no moguće ih je rekonstruirati na osnovi pisanih ili vizualnih izvora napisani su unutar oblih zagrada. Veći dijelovi teksta koji nedostaju ili ih je nemoguće rekonstruirati naznačeni su trotočkom u uglatim zagradama [...]. Natpisi su prepisani u obliku u kojem su uklesani na spomeniku, sa skraćenicama i mogućim gramatičkim odnosno pravopisnim greškama. Crte iznad slova označuju da je taj dio riječi skraćen, odnosno da su određena slova izostavljena. Neke od

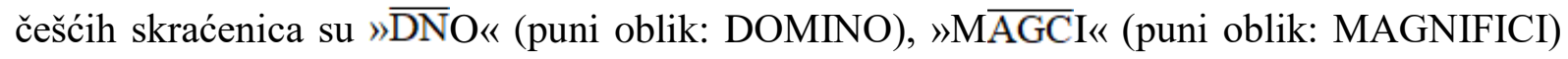
ili »ILLMI« (puni oblik: ILLUSTRISSIMI). Također napominjemo da je brojka devet ponekad upotrijebljena umjesto morfema -us, a slovo y umjesto dvostrukoga slova $i$. 


\section{ZAGREBAČKA NADBISKUPIJA}

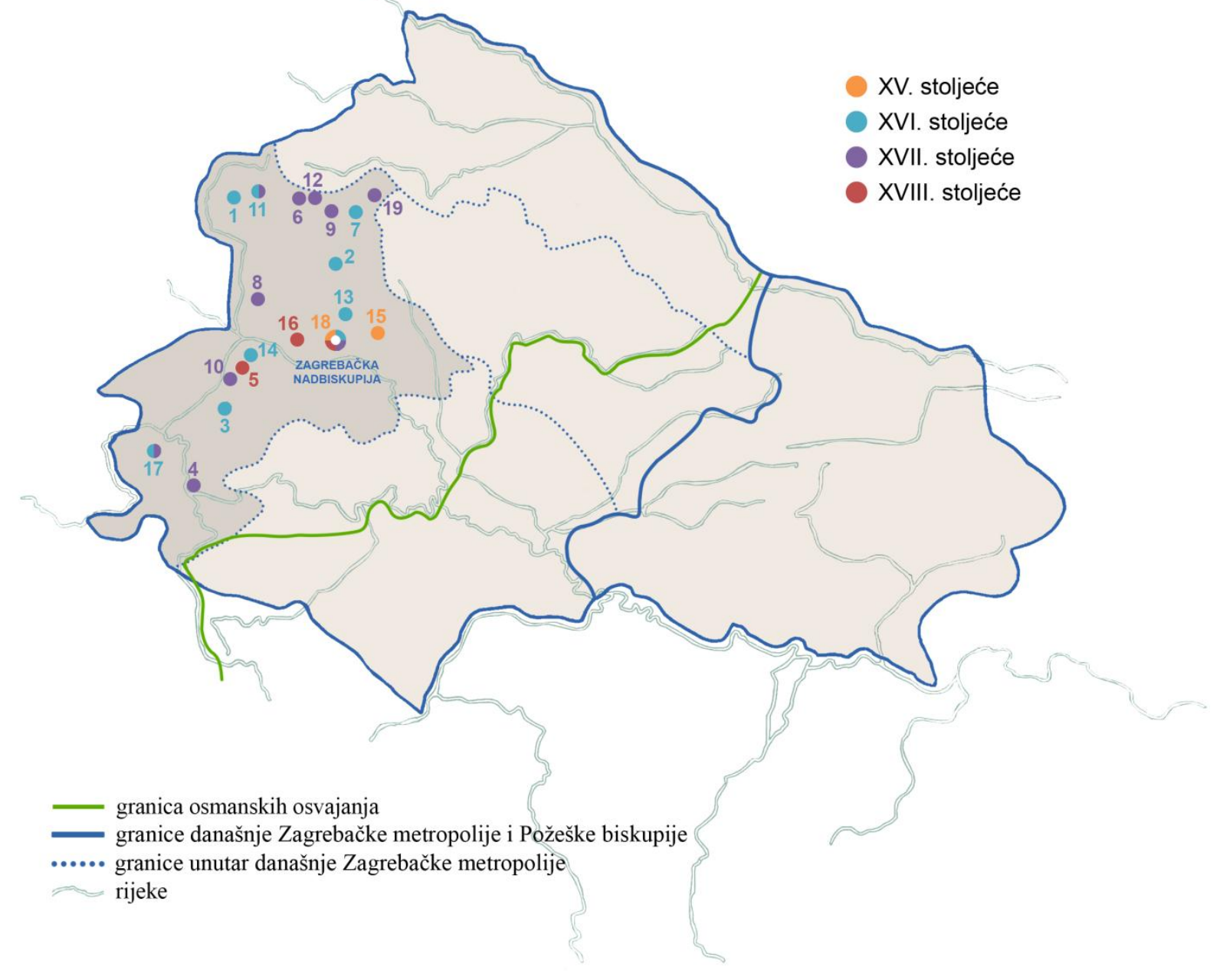

\section{O K A L I T E T I}

1. Desinić, crkva sv. Jurja

2. Donja Stubica, crkva Presvetoga Trojstva

3. Jastrebarsko, crkva sv. Nikole

4. Karlovac, kapela sv. Josipa (porušena)

5. Kotari, crkva sv. Leonarda

6. Krapina, crkva sv. Katarine - crkva sv. Nikole

7. Mače, crkva Bezgrješnoga Začeća Blažene Djevice Marije

8. Marija Gorica, crkva Pohoda Blažene Djevice Marije

9. Mihovljan, crkva sv. Mihaela arkanđela

10. Plešivica, crkva sv. Jurja

11. Pregrada, crkva Uznesenja Blažene Djevice Marije
12. Radoboj, crkva Presvetoga Trojstva

13. Remete, crkva Uznesenja Blažene Djevice Marije

14. Samobor, kapela sv. Mihovila na Taborcu

15. Sesvete, crkva Svih Svetih

16. Stenjevec, crkva Uznesenja Blažene Djevice Marije

17. Svetice, crkva Rođenja Blažene Djevice Marije

18. Zagreb, katedrala Uznesenja Blažene Djevice Marije i sv. Stjepana i Ladislava

- crkva sv. Katarine

- crkva sv. Marka

19. Zajezda, crkva Uznesenja Blažene Djevice Marije 


\section{DESINIĆ, crkva sv. Jurja}

- Kat. br. 1 -
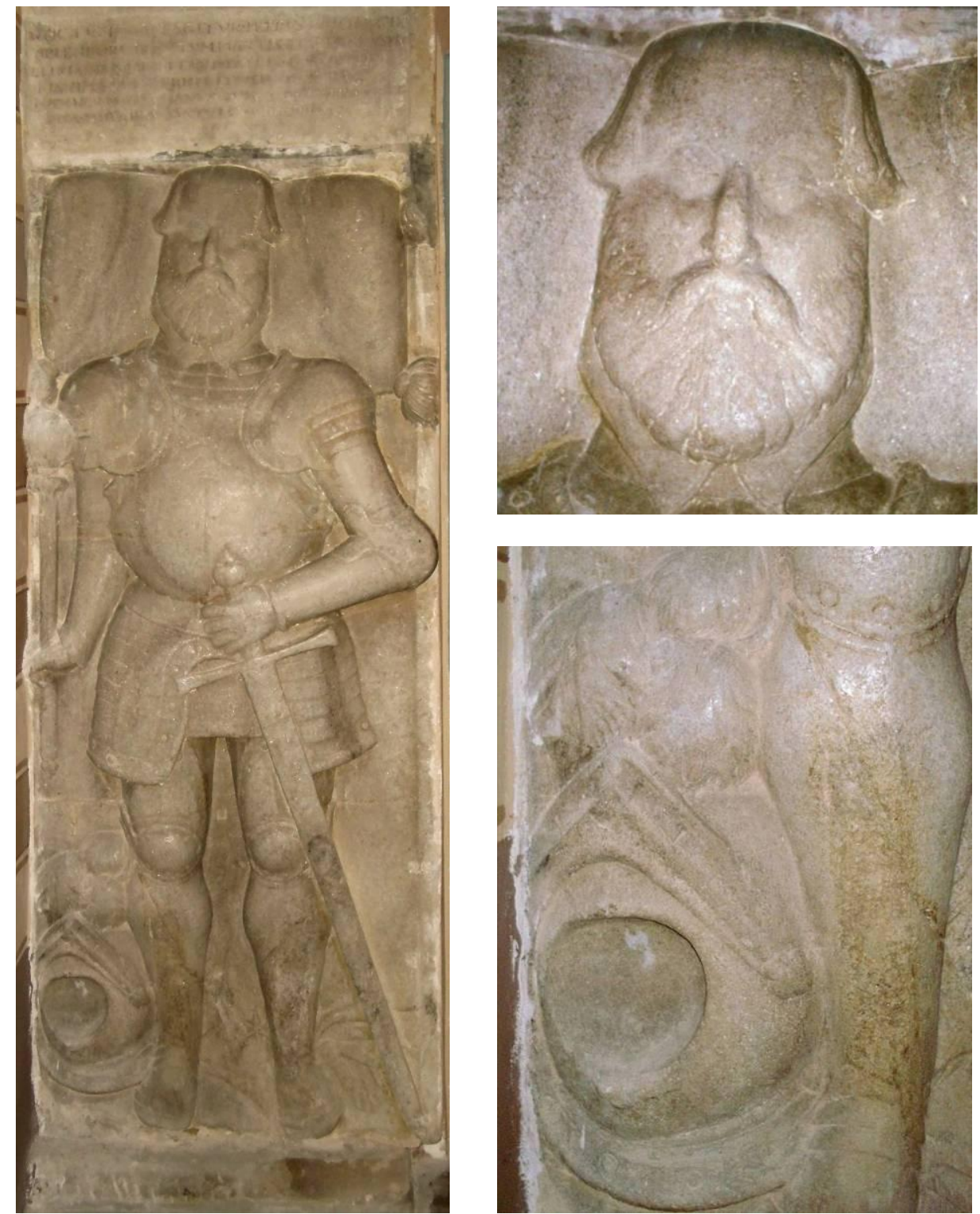

Nadgrobna ploča Petra II. Ratkaja Velikotaborskoga (? - ?, 1586.)

Kamen, $232 \times 76 \mathrm{~cm} \times[\text { uzidana }]^{755}$

Natpis: "HOC · TVMVLO · TEGITVR · PETRVS · RATCHAIVS · HEROS / SPLENDOR · VIRTVTVM · MARTIS · ET ALMVS · HONOR / ILLIRIAE · SVBLIME · DECVS · PATRIE · Q · RVENTIS · / MAXIMA · SPES · RERVM · CONSILIIQ · IVBAR / QVEM · NON · MAGNA - MANVS - TVRCÆ $\cdot$ CRVDELIS $\cdot$ ET · ATRI / VITA · PRIVARVN · SVSTVLIT $\cdot$ VNA $\cdot$ DIES $\cdot \lll$

\footnotetext{
${ }^{755}$ Dubinu nije bilo moguće izmjeriti u slučajevima kada su nadgrobne ploče uzidane ili stavljene u novi okvir, no naznaka dubine zadržana je kao podsjetnik da je riječ o trodimenzionalnim djelima.
} 


\section{Opis spomenika:}

Nadgrobna ploča formata okomito postavljena pravokutnika s likom viteza-pokojnika glave oslonjene na jastuk. Pokojnik je prikazan en face. U desnoj ruci drži topuz, a u lijevoj mač. Na lijevoj strani do pokojnikovih nogu položena je kaciga, a na desnoj viteške rukavice. Iznad figure pokojnika nalazi se ploča s posvetnim natpisom.

\section{Literatura:}

Danijel Crnić, Župa Desinić, drugo izdanje, Desinić: Župni ured Desinić, 2008., str. 29, 37.

Anđela Horvat, Između gotike i baroka: umjetnost kontinentalnog dijela Hrvatske od oko 1500. do oko 1700., Zagreb: Društvo povjesničara umjetnosti SR Hrvatske, 1975., str. 350.

Anđela Horvat, Pregled spomenika kulture općine Pregrada, u: Kaj: časopis za književnost, umjetnost i kulturu 2-3, Zagreb: Kajkavsko spravišće, 1985., str. 167-208, 204-205.

Ljubo Karaman, $O$ umjetnosti srednjega vijeka, u: Historijski zbornik III/1-4, Zagreb: Društvo za hrvatsku povjesnicu, 1950., str. 125-174, 167, bilj. 72.

Marina Krpan, Hrvatski Ratkaji, u: Kaj: časopis za književnost, umjetnost i kulturu XXV/12, Zagreb: Kajkavsko spravišče, 1992., str. 77-88, 81.

Ivan Kukuljević Sakcinski, Nadpisi sredovječni i novovjeki na crkvah, javnih i privatnih sgradah itd. u Hrvatskoj $i$ Slavoniji, Zagreb: Knjižara Jugoslavenske akademije, Knjižara Dioničke tiskare, 1891., str. 33-34, br. 110.

Milan Pelc, Renesansa, Zagreb: Naklada Ljevak, 2007., str. 315.

Milan Pelc, Renesansa, u: Hrvatska umjetnost: povijest $i$ spomenici, Zagreb: Institut za povijest umjetnosti, Školska knjiga, 2010., str. 197-247, 236. Uredio Milan Pelc.

Marijana Schneider, Odraz seljačke bune 1573. godine u likovnoj umjetnosti, u: Radovi Zavoda za hrvatsku povijest 5, Zagreb: Institut za hrvatsku povijest Sveučilišta u Zagrebu, 1973., str. 271-286, 277.

Gjuro Szabo, Izvještaj o radu zemaljskoga povjerenstva za očuvanje umjetnih $i$ historičkih spomenika u kraljevinama Hrvatskoj i Slavoniji u godini 1911., u: Vjesnik Hrvatskoga arheološkog društva XII/1, Zagreb: Hrvatsko arheološko društvo, 1912., str. 202-259, $231,238$.

Gjuro Szabo, Ljudi iz kamena, u: Jutarnji list, Zagreb: Tipografija, 24. XII. 1938., str. 5-6, 5. 
- Kat. br. 2 -

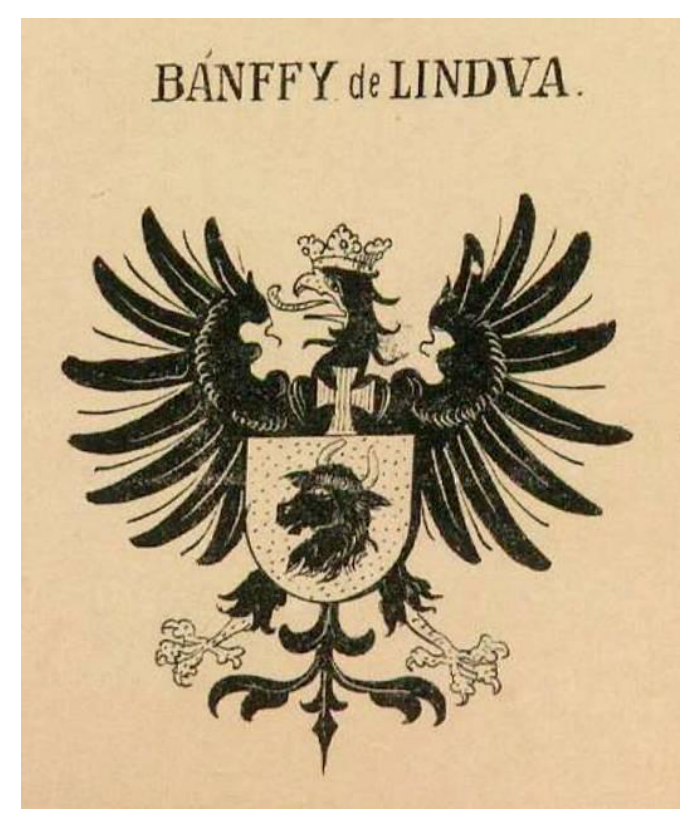

Nadgrobna ploča Ane Désházy rođ. Bánffy de Alsólendva (? - Susedgrad, 1533.)

Ploča nije sačuvana, ali je dokumentirana u pisanim izvorima.

Natpis: „HIC IACET MAGNIFICA DOMINA ANNA. FILIA M $\overline{A G C I}$ QUONDAM

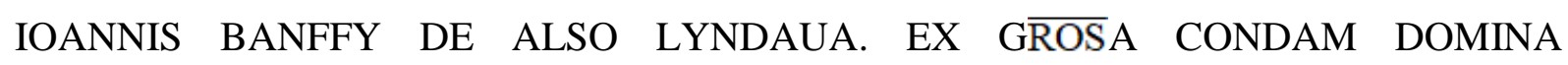
MARGARETHA FILIA OLIM DOMINI IOANNIS HENNIGH DE SZOMSZEDUARA PROCREATA. CONSORS VERO MAGCI. DNI. STEPHANI DEESHAZY. COMITIS PERPETUI DE DICTA SZOMSZEDUARA NEPOTIS QUONDAM MAGCI LADISLAY SZILAGY DE HOROGHSZEGH. GENITORIS DOMINAE ELISABETHAE. MATRIS INVISTISSIMI PRINCIPIS REGIS MATHIAE. OBIIT AVTEM IN DICTA SZOMSZED. ANNO 1533. IN DIE PARASCEVES. HORA DECIMA « ${ }^{756}$

\section{Opis spomenika:}

Prema povijesnim izvorima, nadgrobna ploča sadržavala je grb obitelji Bánffy de Alsólendva i gore navedeni natpis.

\section{Literatura:}

Ivanka Reberski (ur.), Krapinsko-zagorska županija: sakralna arhitektura s inventarom, feudalna arhitektura, spomen-obilježja, Zagreb: Institut za povijest umjetnosti, Školska

\footnotetext{
${ }^{756}$ Prijepis preuzet iz: Ivan Kukuljević Sakcinski, nav. dj., 1891., str. 262, br. 877.
} 
knjiga, 2008., sub voce Donja Stubica. Župna crkva Presvetog Trojstva, str. 155, 166 [Katarina Horvat Levaj].

Katarina Horvat Levaj, Župna crkva Presvetog Trojstva u Donjoj Stubici, u: Peristil 38, Zagreb: Društvo povjesničara umjetnosti Hrvatske, 1995., str. 73-82, 76.

Ivan Kukuljević Sakcinski, Nadpisi sredovječni i novovjeki na crkvah, javnih i privatnih sgradah itd. u Hrvatskoj $i$ Slavoniji, Zagreb: Knjižara Jugoslavenske akademije, Knjižara Dioničke tiskare, 1891., str. 262, br. 877.

Emilij Laszowski, Službeni prijepis grobnog natpisa Ane Deshazy sastavljen god. 1678., u: Vitezović: mjesečnik za genealogiju, biografiju, heraldiku i sfragistiku I/11-12, Zagreb: Tiskara C. Albrecht, lipanj 1904., str. 181.

Gjuro Szabo, Kroz Hrvatsko zagorje, Zagreb: Vasić i Horvat, 1939., str. 170. 
- Kat. br. 3 -
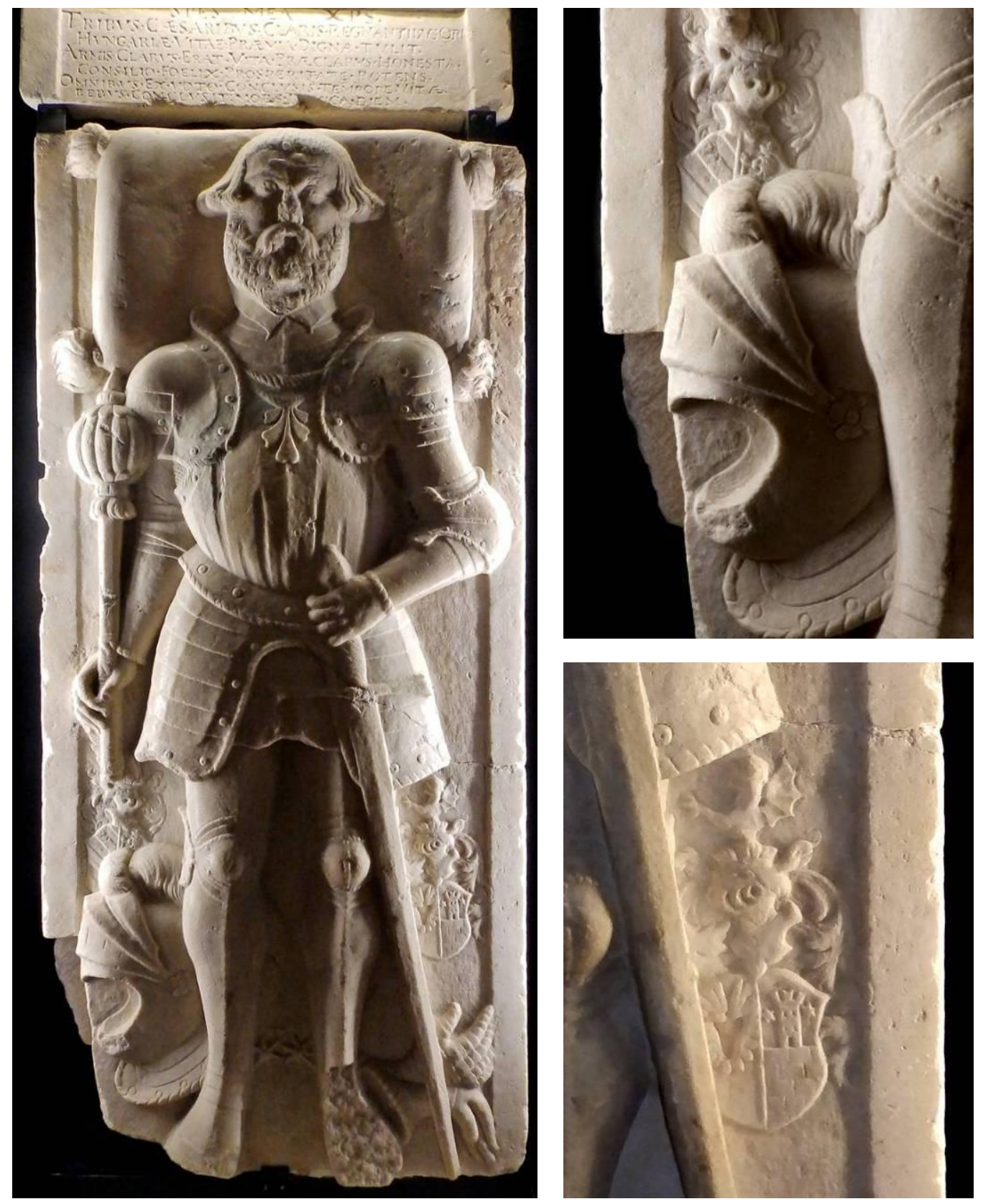

Nadgrobna ploča Franje Tahyja (?, 1526. - Susedgrad, 1573.)

Mramor, gornja natpisna ploča: $27 \times 86 \times 12 \mathrm{~cm}$, ploča s likom pokojnika: $183 \times 86 \times 12 \mathrm{~cm}$, donja natpisna ploča: $26,5 \times 86 \times 12 \mathrm{~cm}$

Ploča je danas pohranjena u Muzeju seljačkih buna u Gornjoj Stubici.

Natpis na gornjoj ploči: „SPES MEA XPS. / TRIBVS - CÆSARIBVS · CLARIS · REGNANTIBVS · ORI · / HUNGARIÆ · VITAE · PRÆMIA · DIGNA · TVLIT · / ARMIS · CLARVS · ERAT · VITA · PRÆCLARVS • HONESTA • / CONSILIO • FOELIX . PROSPERITATE · POTENS · / OMNIBVS · EX · VOTO - CONCLVSIS · TEMPORE · VITÆ · / REBVS · CONCLVSIT: MORS · I(NIM)ICA · DIEM«. Natpis na donjoj ploči: 
"AMBIG(VA TE) CVM · FOR(TASS)IS · MENTE REVOLVES / QVEM · PROCERVM · TENEANT · HÆC · MONVMENTA · VIRVM / FRANCISCVM · TAHIVM - CHARÆ · CVM · CONIVGIS · OSSIS · / HELENAE · ZRINI · MARMORE · TVMBA · TEGIT · / QVARTA · DIE · MENSIS · AVGVSTI. / ANNO · M · D · LXXIII •«

\section{Opis spomenika:}

Nadgrobna ploča formata okomito postavljena pravokutnika s likom viteza-pokojnika glave oslonjene na jastuk. Pokojnik je prikazan en face. U desnoj ruci drži topuz, a u lijevoj mač. Na lijevoj strani do pokojnikovih nogu položena je kaciga, a na desnoj viteške rukavice. Iznad kacige predočen je grb obitelji Tahy, a iznad rukavica grb obitelji Zrinski. Povrh i podno figure pokojnika nalaze se ploče s posvetnim natpisom.

\section{Literatura:}

Branko Čičko, Nemirno 16. stoljeće: Seljačka buna 1573. i raspad vlastelinstva, u: Osam stoljeća Stubice, Gornja Stubica: Muzeji Hrvatskog zagorja, Muzej seljačkih buna; Donja Stubica: Grad Donja Stubica, 2009., str. 58-75, 73. Uredila Goranka Horjan.

Igor Fisković, Renesansno kiparstvo, u: Tisuću godina hrvatskog kiparstva, Zagreb: Muzejsko galerijski centar, 1997., str. 155-219, 207. Uredio Igor Fisković.

Goranka Horjan, Sakralni spomenici stubičkog kraja, u: Osam stoljeća Stubice, Gornja Stubica: Muzeji Hrvatskog zagorja, Muzej seljačkih buna; Donja Stubica: Grad Donja Stubica, 2009., str. 112-137, 117. Uredila Goranka Horjan.

Anđela Horvat, Između gotike i baroka: umjetnost kontinentalnog dijela Hrvatske od oko 1500. do oko 1700., Zagreb: Društvo povjesničara umjetnosti SR Hrvatske, 1975., str. 350.

Katarina Horvat-Levaj, Župna crkva Presvetog Trojstva u Donjoj Stubici, u: Peristil 38, Zagreb: Društvo povjesničara umjetnosti Hrvatske, 1995., str. 73-82, 76.

Ivanka Reberski (ur.), Krapinsko-zagorska županija: sakralna arhitektura s inventarom, feudalna arhitektura, spomen-obilježja, Zagreb: Institut za povijest umjetnosti, Školska knjiga, 2008., sub voce Donja Stubica. Župna crkva Presvetog Trojstva, str. 155, 166 [Katarina Horvat Levaj].

Ljubo Karaman, O umjetnosti srednjega vijeka, u: Historijski zbornik III/1-4, Zagreb: Društvo za hrvatsku povjesnicu, 1950., str. 125-174, 167. 
Ivan Kukuljević Sakcinski, Nadpisi sredovječni i novovjeki na crkvah, javnih i privatnih sgradah itd. u Hrvatskoj $i$ Slavoniji, Zagreb: Knjižara Jugoslavenske akademije, Knjižara Dioničke tiskare, 1891., str. 262-263, br. 878.

Milan Pelc, Renesansa, Zagreb: Naklada Ljevak, 2007., str. 257, 315.

Milan Pelc, Renesansa, u: Hrvatska umjetnost: povijest $i$ spomenici, Zagreb: Institut za povijest umjetnosti, Školska knjiga, 2010., str. 197-247, 247. Uredio Milan Pelc.

Milan Pelc, Povijest umjetnosti u Hrvatskoj, Zagreb: Naklada Ljevak, 2012., str. 236.

Marijana Schneider, Odraz seljačke bune 1573. godine u likovnoj umjetnosti, u: Radovi Zavoda za hrvatsku povijest 5, Zagreb: Institut za hrvatsku povijest Sveučilišta u Zagrebu, 1973., str. 271-286, 276-277.

Gjuro Szabo, Ljudi iz kamena, u: Jutarnji list, Zagreb: Tipografija, 24. XII. 1938., str. 5-6, 5.

Gjuro Szabo, Kroz Hrvatsko zagorje, Zagreb: Vasić i Horvat, 1939., str. 171-172. 


\section{JASTREBARSKO, crkva sv. Nikole}
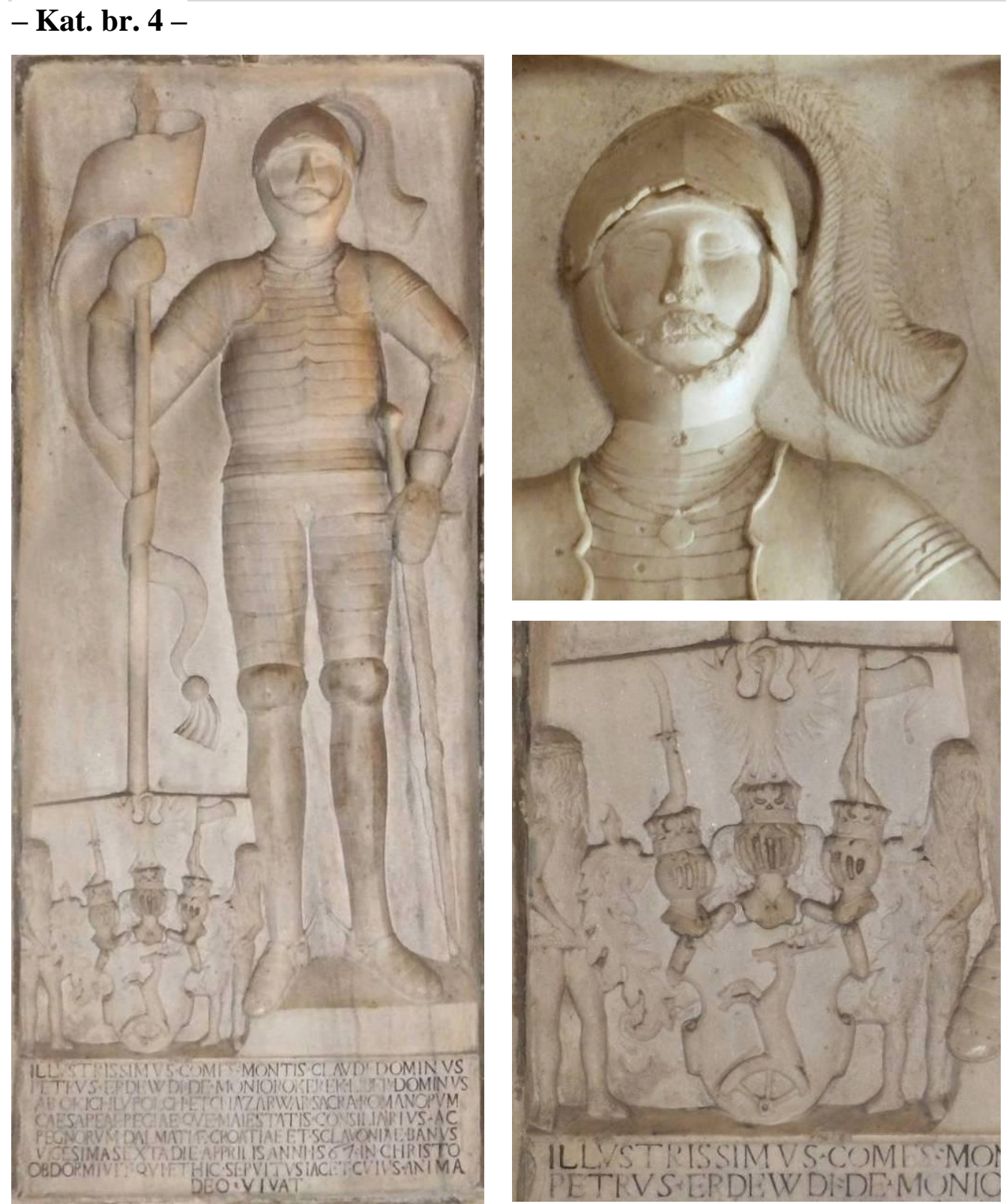

Nadgrobna ploča bana Petra II. Erdödyja (?, o. 1504. - Jastrebarsko, 1567.)

Kamen, $222 \times 90 \mathrm{~cm} \times$ [uzidana]

Natpis: "ILLVSTISSIMVS - COMES: MONTIS - CLAVDI - DOMINVS / PETRVS · ERDEWDI: DE · MONIOROKEREK - LIBEP: DOMINVS / AB: OKICH LVPOLCH · ET · CI - IAZARWAR: SACRA - ROMANORVM / CAESAREAE · REGIAE: QVE · MAIESTATIS · CONSILIARIVS · AC / PEGNORVM: DALMATIÆ • CROATIAE ET • SCLAVONIAE - BANVS / VIGESSIMA SEXTA · DIE APPRILIS ANNI - 1 - 567: IN · CHRISTO / OBDORMIVIT · QVI · ET · HIC · SEPVITVS IACET · CVIVS · ANIMA / DEO $\cdot$ VIVAT $«$ 


\section{Opis spomenika:}

Nadgrobna ploča formata okomito postavljena pravokutnika s likom pokojnika odjevena $\mathrm{u}$ viteški oklop i kacigu. Pokojnik je prikazan en face. U desnoj ruci drži barjak, a lijevom pridržava mač. Ispod stijega nalazi se grb obitelji Erdődy s čuvarima izvedenima u liku muškaraca duge kose i brade. Ispod figuralnoga prikaza uklesan je nadgrobni natpis $\mathrm{u}$ klasičnoj majuskuli.

\section{Literatura:}

Neven Brandić, Sakralna graditeljska baština Jastrebarskog i okolice, u: Jastrebarsko: 1249. - 1999.: 750 godina grada, Jastrebarsko: Naklada Slap, Gradsko poglavarstvo, 2001., str. 225-278, 230, 241-242. Uredili Filip Potrebica i Krunoslav Matešić.

Emilijan Cevc, Kiparstvo na Slovenskem med gotiko in barokom, Ljubljana: Slovenska matica, 1981., str. 137.

Đurđica Cvitanović, Crkveno graditeljstvo, u: Skriveno blago: iz riznice umjetničkih znamenitosti jastrebarskog kraja. Kulturni i prirodni spomenici Hrvatske: zbirka vodiča časopisa Kaj 8, Zagreb: Zagrebačko spravišče, 1975., str. 1-28, 1-2.

Đurđica Cvitanović, Sakralna arhitektura baroknog razdoblja. Knjiga I. Gorički i gorskodubički arhiđakonat, Zagreb: Društvo povjesničara umjetnosti SR Hrvatske, 1985., str. 83, 234.

Anđela Horvat, Između gotike i baroka: umjetnost kontinentalnog dijela Hrvatske od oko 1500. do oko 1700., Zagreb: Društvo povjesničara umjetnosti SR Hrvatske, 1975., str. 156,350 .

Milan Kruhek, Graditeljska baština karlovačkog Pokuplja, Karlovac: Matica hrvatska, Ogranak Karlovac, 1993., str. 173.

Emilij Laszowski, Epitafij bana Petra Erdöda, u: Vjestnik Kr. Hrvatsko-slavonskodalmatinskog zemaljskog arkiva I/1, Zagreb: Kralj. zemaljska tiskara, 1899., str. 200201.

Emilij Laszowski, Grobnica bana Petra Erdöda u Jastrebarskom, u: Novosti XX/35, Zagreb: [Jugoslavenska štampa], 1926., str. 11.

Emilije Laszowski, Jastrebarsko, u: Narodna starina 35, Zagreb: Josip Matasović, 1935., str. 101.

Radoslav Lopašić, Jastrebarsko, u: Vienac: zabavi i pouci, XIII/23, Zagreb: Matica hrvatska, 1881., str. 358-361, 360 . 
Dragutin Nežić, Povijest župa i crkvi Jastrebarskog dekanata, Jastrebarsko: Odbor za euharistijski kongres, 1939., str. 9-10.

Milan Pelc, Renesansa, Zagreb: Naklada Ljevak, 2007., str. 315.

Juraj Rattkay, Spomen na kraljeve i banove kraljevstava Dalmacije, Hrvatske i Slavonije od njihovih početaka, pa sve do ove 1652. godine koji je sastavio Juraj Rattkay od Velikog Tabora, zagrebački kanonik i lektor, Zagreb: Hrvatski institut za povijest, 2001., str. 218. Prevela Zrinka Blažević et al. 


\section{KARLOVAC, kapela sv. Josipa (porušena)}

- Kat. br. 5 -
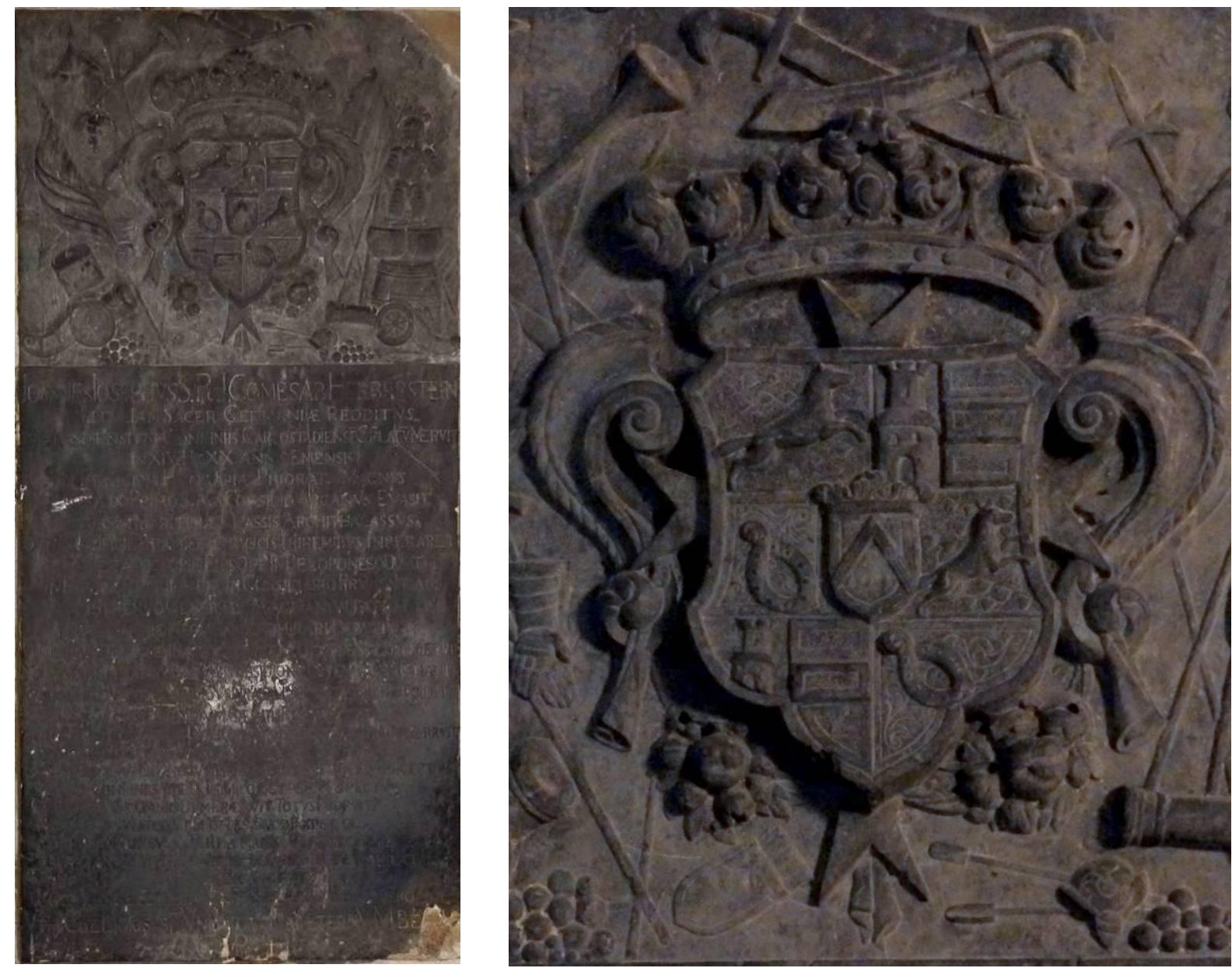

Nadgrobna ploča Ivana Josipa Herbersteina (Graz, 1633. - Graz, 1689.)

Kamen, $168 \times 84 \times 12 \mathrm{~cm}$

Ploča je danas pohranjena u franjevačkoj crkvi Presvetoga Trojstva u Karlovcu.

Natpis: »IOANNES IOSEPHVS S. R. I. COMES AB HERBERSTEIN / MELITÆ IAM SACER GERMANIÆ REDDITVS / IN VARASDINENSIVM CONFINIIS CARLOSTADIENS $\bar{E}$ GRLATV MERVIT / IBI XIV: HIC XX: ANNIS EMENSIS / RELIGIONI HVNGARIE PRIORATV MAGNVS / LEOPOLDO PRIMO S. A. A CONSILIO ARCANVS EVASIT. / SVORVM MARITIMÆ CLASSIS ARCHITHALASSVS, / DVM PONTIFICIIS ETIAM, ET ETRVSCIS TRIREMIBVS IMPERARET / VENETA VICTORIIS EIVS OPE IN PELOPONESO DITATI, / IN EQVITE EELIGIONEM IN CONSILIARIO PRVDENTIAM: / IN STRENVO GENERALI MAGNANIMITATEM / QVIA CAPERE NEQUIBANT ADMIRARI DEBVERANT. / D. MARCVM DEBITOREM NACT, VT ET FEEN GLORIÆ SVÆ DEBERETVR. / NEOCASTRVM PYRATARV BIMESTRIS OBSIDIONE CRVENTA CHRISTIANIS: / 
ADRIATICO VERO SINVI DIV SVSPIRATAM SECVRITATEM REDDIDIT / POST

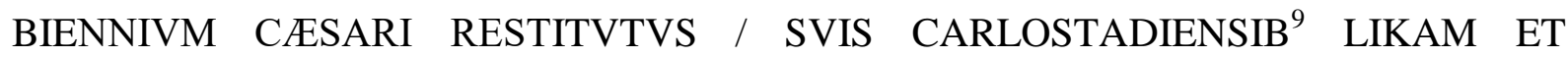
CORBAVIAM FERRO IGNEO, PRIMVM TERRVIT: / DEIN LEOPOLDO INVICTISSIMO VICTAM SVBDIDIT / QVÆRI NESCIENS, DIVINORVM AMANS, DEO CHAR $^{9}$, CÆSARI ACCEPTVS / CONFINIIS VTILIS, INIMICO SEMPER SVSPECTVS / SIC OMNIB ${ }^{9}$ DVM PRÆFVIT, TOTVS PROFVIT / VIATOR, VT SPECTES, QVOD EXPECTAS, / FAMAM CONSVLE, TERRA MARIQ VESTIGIA REPETE / QVI LVI ANNIS VIXIT GRATVS, HIC QVIESCIT DESIDERATVS / TV NE ABEAS INGRATVS / DIC CVM IOANNE FERD ${ }^{\text {DO }}$ EIVS EX FRATRE NEPOTE, RELIG ${ }^{\text {NE }}$ VERO CONFRAT / VT HIC RELIGIOSVS FVNDATOR VIVAT ÆTERNVM BEATVS. / C. P.«

\section{Opis spomenika:}

U gornjem dijelu nadgrobne ploče formata okomito postavljena pravokutnika reljefno je izveden grb obitelji Herberstein okružen ratnim trofejima (topovima, bubnjevima, zastavama, kopljima, sabljama, oklopom i šatorom). Preostale dvije trećine nadgrobnika ispunjene su nadgrobnim natpisom.

\section{Literatura:}

Đurđica Cvitanović, Sakralna arhitektura baroknog razdoblja. Knjiga I. Gorički i gorskodubički arhiđakonat, Zagreb: Društvo povjesničara umjetnosti SR Hrvatske, 1985., str. 254.

Anđela Horvat, $O$ arhitekturi centralnog trga u Karlovcu, u: Bulletin Zavoda za likovne umjetnosti Jugoslavenske akademije znanosti $i$ umjetnosti XI/1-2, Zagreb: Jugoslavenska akademija znanosti i umjetnosti, 1963., str. 75-86, 79.

Anđela Horvat, Presjek razvoja umjetnosti u karlovačkom Pokuplju, u: Zbornik Gradskog muzeja Karlovac 1, Karlovac: Gradski muzej, 1964., str. 24-64, 34.

Anđela Horvat, Između gotike i baroka: umjetnost kontinentalnog dijela Hrvatske od oko 1500. do oko 1700., Zagreb: Društvo povjesničara umjetnosti SR Hrvatske, 1975., str. $344,346$. 


\section{KOTARI, crkva sv. Leonarda}

- Kat. br. 6 -

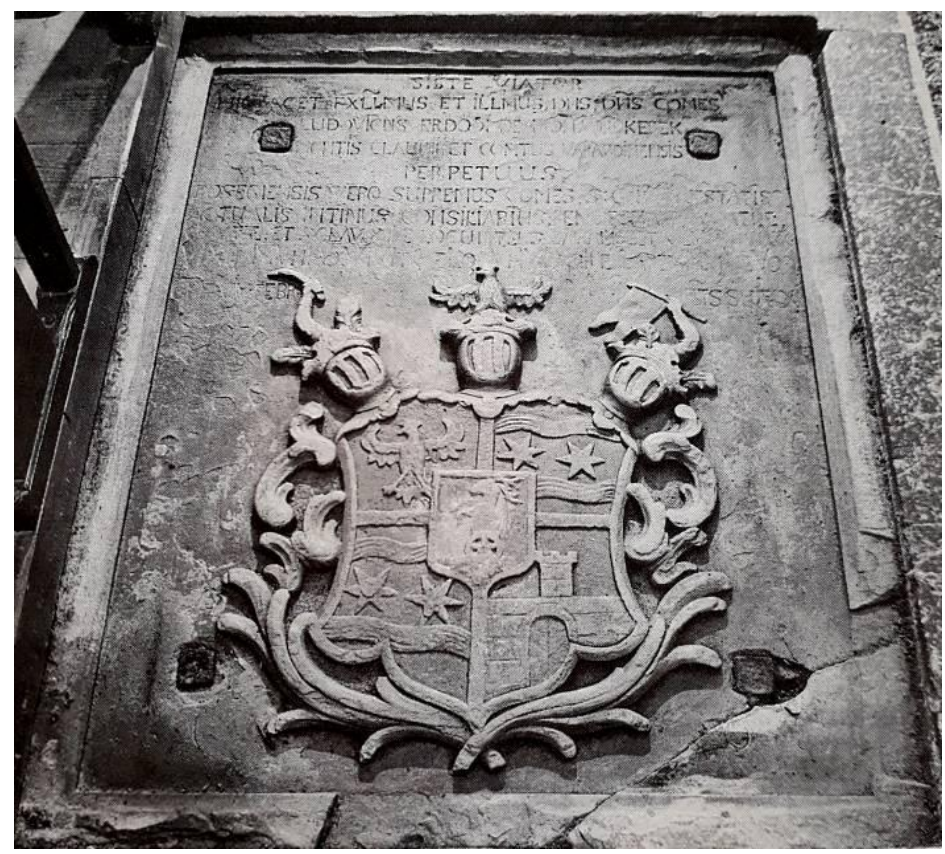

Nadgrobna ploča Ljudevita I. Erdödyja (?, 1694. - ?, 1753.)

Kamen, $140 \times 115 \mathrm{~cm} \times$ [postavljena u pod]

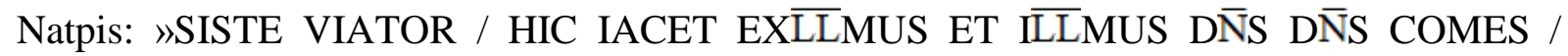
LUDOVICUS ERDODY DE MONYOROKEREK / MONTIS CLAUDII ET COMTUS VARASDIENSIS / PERPETUUS / POSEGIENSIS VERO SUPREMUS COMES, S. C. R. MAIESTATIS / ACTUALIS INTIMUS CONSILIARIUS PER REGNA DALMATIAE / CROATIAE ET SLAVONIAE LOCUMTENENS BANALIS. CAMERARIUS ET C. / VIXIT MVNDO. VIVIT COELO. VIVIT SINE LACHRI / OBIIT XIV FEBR. AETS. SVAE LXI.«

\section{Opis spomenika:}

U donjem dijelu nadgrobne ploče formata okomito postavljena pravokutnika reljefno je izveden grb obitelji Erdődy ukrašen trima kacigama s nakitom i pojednostavljenim viticama. Iznad grba uklesan je posvetni natpis.

\section{Literatura:}

Đurđica Cvitanović, Arhitektura franjevačke provincije hrvatsko-kranjske Sv. Križa, u: Mir i dobro: umjetničko i kulturno naslijeđe Hrvatske franjevačke provincije sv. Cirila $i$ 
Metoda o proslavi stote obljetnice utemeljenja, Zagreb: 2000., str. 193-204, 200. Uredili Marija Mirković i Franjo Emanuel Hoško.

Ivan Kukuljević Sakcinski, Nadpisi sredovječni i novovjeki na crkvah, javnih i privatnih sgradah itd. u Hrvatskoj $i$ Slavoniji, Zagreb: Knjižara Jugoslavenske akademije, Knjižara Dioničke tiskare, 1891., str. 234, br. 779. 


\section{KRAPINA, crkva sv. Katarine}

- Kat. br. 7 -
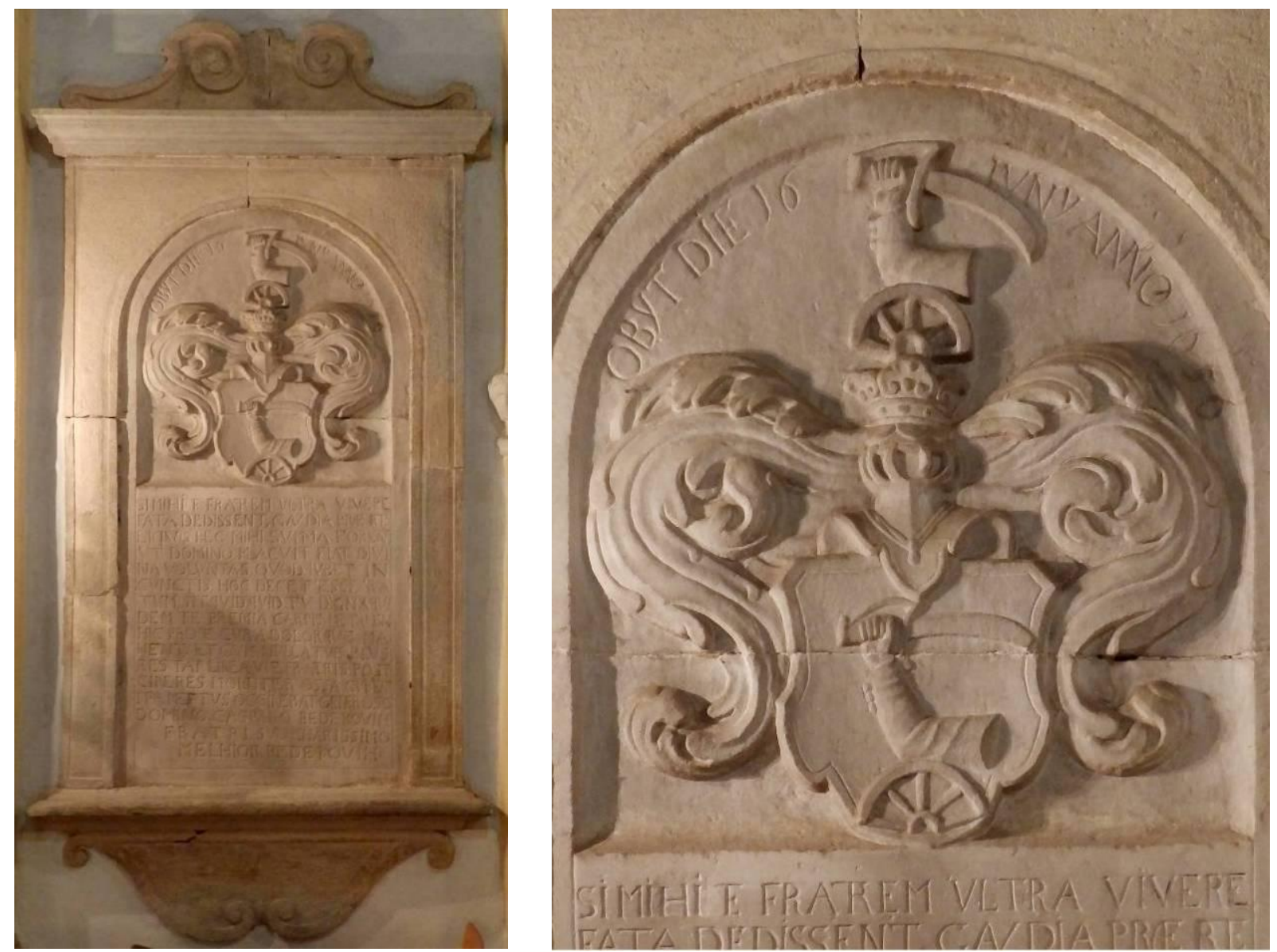

Epitaf Gašpara Bedekovića (? - ?, 1656.)

Kamen, dimenzije neznane autorici ${ }^{757}$

Natpis uz luk niše: „OBYT DIE 16. IVNY 1656«. Natpis ispod grba: »SI MIHI TE FRATREM VLTRA VIVERE / FATA DEDISSENT, GAVDIA PRÆ RE / LIQVIS HÆC MIHI SVMMA FORENT, / VT DOMINO PLACVIT FIAT DIVI / NA VOLVNTAS, QVOD IVBET IN / CVNCTIS HOC DECET ESSE RA / TVM; SIT QVID QVID TV DIGNA QVI / DEM TE PAREMIA CARPIS, ME TAMEN / HIC PRO TE CVRA DOLORQVE MA / NENT, ET CVM NVLLA TVÆ PLVS / RESTAT LINEA VITÆ, FRATRIS POST / CINERES MOLLITER OSSA CVBENT / ITA MESTVS OCCINEBAT GENEROSO / DOMINO CASPARO BEDEKOVIH / FRATRI SVO CHARISSIMO / MELCHIOR BEDEKOVIH«

\footnotetext{
${ }^{757}$ Epitaf je postavljen previsoko na zidu crkve da bi se mogao izmjeriti.
} 


\section{Opis spomenika:}

Epitaf je izveden u obliku pojednostavljene edikule, a sastoji se od volutne konzole, središnjega dijela i atičkoga zaključka ukrašenoga volutama. U središnjem dijelu uklesana je plitka, polukružno zaključena niša unutar koje se nalazi grb obitelji Bedeković i nadgrobni natpis.

\section{Literatura:}

Paškal Cvekan, Krapinski franjevci: Povijesno-kulturni prikaz djelovanja Franjevaca u Krapini prigodom 340. obljetnice njihova dolaska $u$ »Stolicu Zagorja«, Krapina: [vlastita naklada], 1980., str. 71.

Anđela Horvat, O spomenicima kulture općine Krapina, u: Kaj: časopis za književnost, umjetnost i kulturu 1, Zagreb: Kajkavsko spravišće, 1982., str. 87-142, 127.

Ivan Kukuljević Sakcinski, Nadpisi sredovječni i novovjeki na crkvah, javnih i privatnih sgradah itd. $u$ Hrvatskoj $i$ Slavoniji, Zagreb: Knjižara Jugoslavenske akademije, Knjižara Dioničke tiskare, 1891., str. 100-101, br. 327.

Stjepan Ortner, Povjest gradine i trgovišta Krapine, Zagreb: Tisak F. Bogovića, 1899., str. 156.

Gjuro Szabo, Spomenici kotara Krapina i Zlatar, u: Vjesnik Hrvatskoga arheološkog društva XIII/1, Zagreb: Hrvatsko arheološko društvo, 1914., str. 103-204, 138, 158-159. 


\section{crkva sv. Nikole}

- Kat. br. 8 -
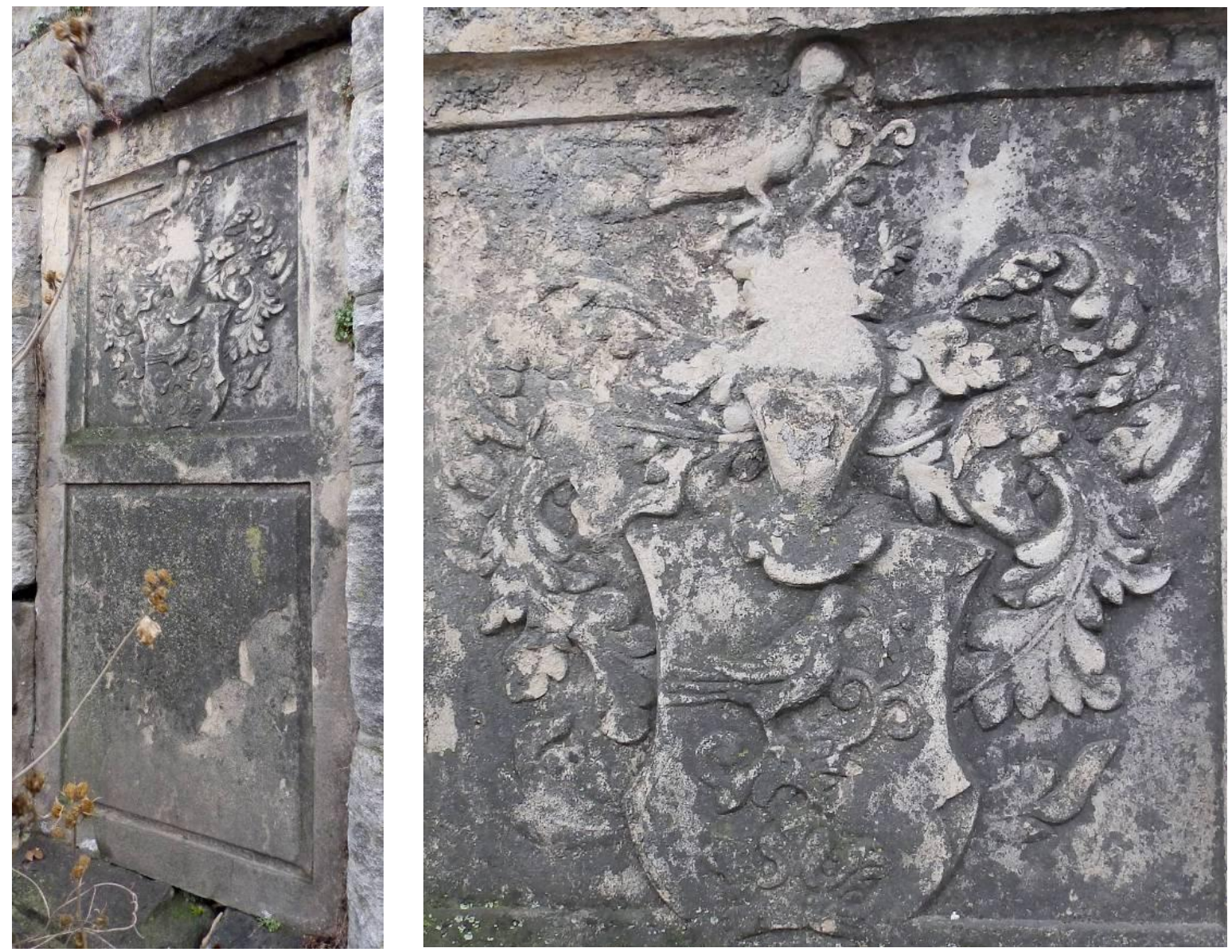

\section{Nadgrobna ploča člana neznane obitelji, XVII. stoljeće (?)}

Kamen, $173 \times 85 \mathrm{~cm} \times$ [uzidana]

Natpis je nečitljiv zbog istrošenosti ploče.

\section{Opis spomenika:}

Nadgrobna ploča izvedena je u obliku okomito postavljena pravokutnika. Vodoravno je podijeljena na dva podjednaka polja nalik kasetama. U gornjem polju nalazi se grb sa simbolom obitelji pokojnika - krunom i razlistanom granom na kojoj stoji ptica. U donjem polju nekoć je bio uklesan nadgrobni natpis koji je danas u potpunosti istrošen.

\section{Literatura:}

Dubravka Peić Čaldarović, Osnove krapinskog grbovnika, u: Krapina: grad povijesti $i$ kulture, Krapina: Grad Krapina, 2004., str. 130-138, 136. Uredila Agneza Szabo.

Gjuro Szabo, Spomenici kotara Krapina i Zlatar, u: Vjesnik Hrvatskoga arheološkog društva XIII/1, Zagreb: Hrvatsko arheološko društvo, 1914., str. 103-204, 155. 
- Kat. br. 9 -
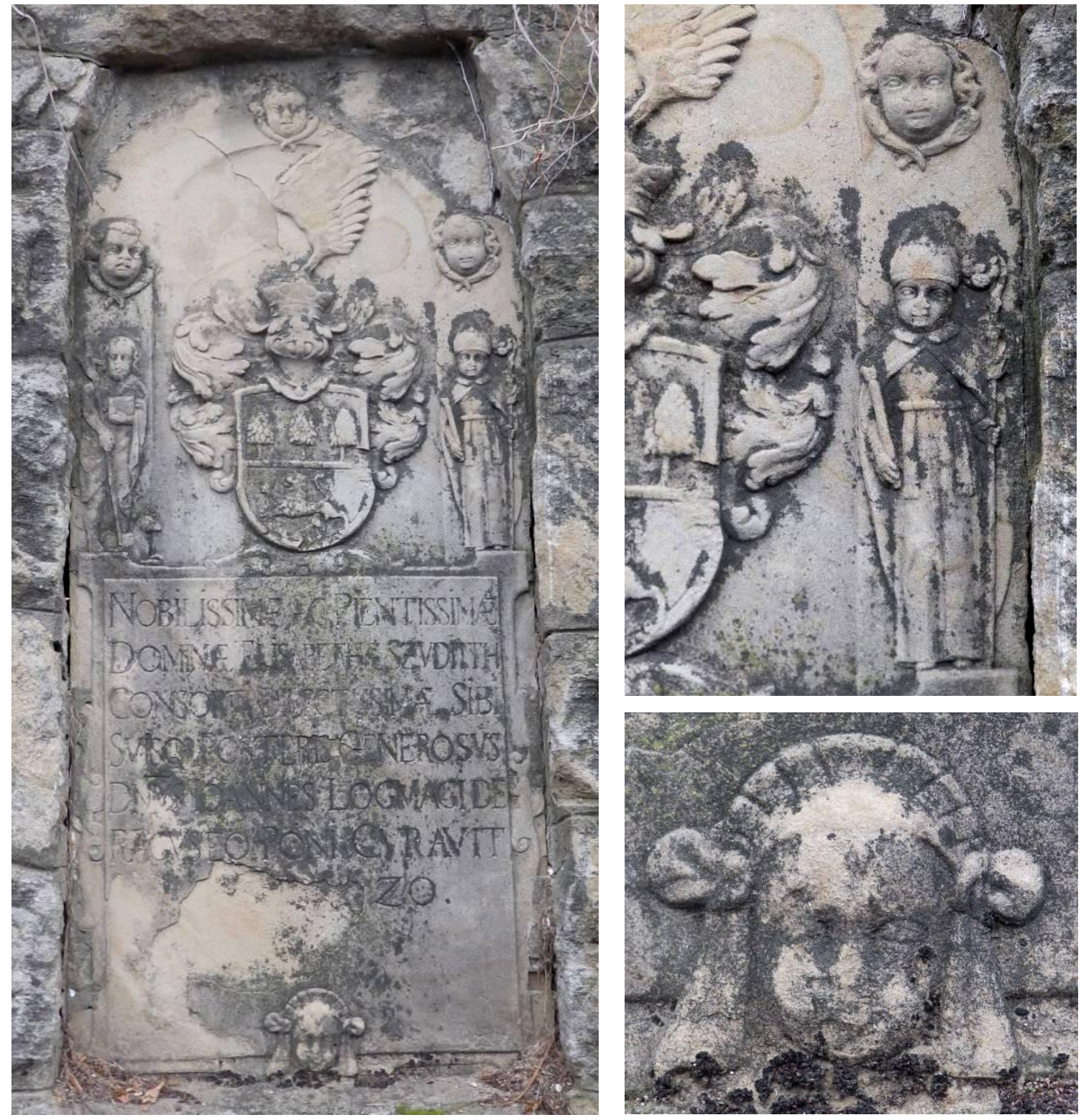

Radionica Majstora Trantnerova epitafa (?), Nadgrobna ploča Elizabete Sudić (? - ?, 1620.?), 1620.

Kamen, $174 \times 77 \mathrm{~cm} \times$ [uzidana]

Natpis: „NOBILISSIMÆ AC PIENTISSIMÆ / DOMINÆ ELISABETHÆ SZVDITTH / CONSORTI DILECTISSIMÆ SIBI / SVISQ POSTERIS GENEROSVS / DNVTS IOANNES LOGMAGI DE / RAGVSEO PONI CVRAVIT / (ANN)O 1620«

\section{Opis spomenika:}

Nadgrobna ploča izvedena je u obliku okomito postavljena pravokutnika. Vodoravno je podijeljena na dva podjednaka dijela. U gornjoj polovici predočen je grb obitelji Sudić unutar 
plitke polukružne niše. Luk niše ukrašen je trima kerubinima (dvama u petama i jednim u tjemenu luka), a njezin otvor flankiran je figurama sv. Ivana Krstitelja (lijevo) i sv. Blaža (desno). Donju polovicu ispunjava ukrasni okvir konkavno oblikovanih stranica urešenih volutama koji sadrži nadgrobni natpis. Pri dnu okvira nalazi se motiv ženske maske $s$ draperijom i ukrasom za glavu.

\section{Literatura:}

Anđela Horvat, O spomenicima kulture općine Krapina, u: Kaj: časopis za književnost, umjetnost i kulturu 1, Zagreb: Kajkavsko spravišće, 1982., str. 87-142, 121.

Ljubo Karaman, O umjetnosti srednjega vijeka, u: Historijski zbornik III/1-4, Zagreb: Društvo za hrvatsku povjesnicu, 1950., str. 125-174, 168, bilj. 73.

Dubravka Peić Čaldarović, Osnove krapinskog grbovnika, u: Krapina: grad povijesti $i$ kulture, Krapina: Grad Krapina, 2004., str. 130-138, 135-136. Uredila Agneza Szabo.

Gjuro Szabo, Spomenici kotara Krapina i Zlatar, u: Vjesnik Hrvatskoga arheološkog društva XIII/1, Zagreb: Hrvatsko arheološko društvo, 1914., str. 103-204, 154. 
- Kat. br. 10 -
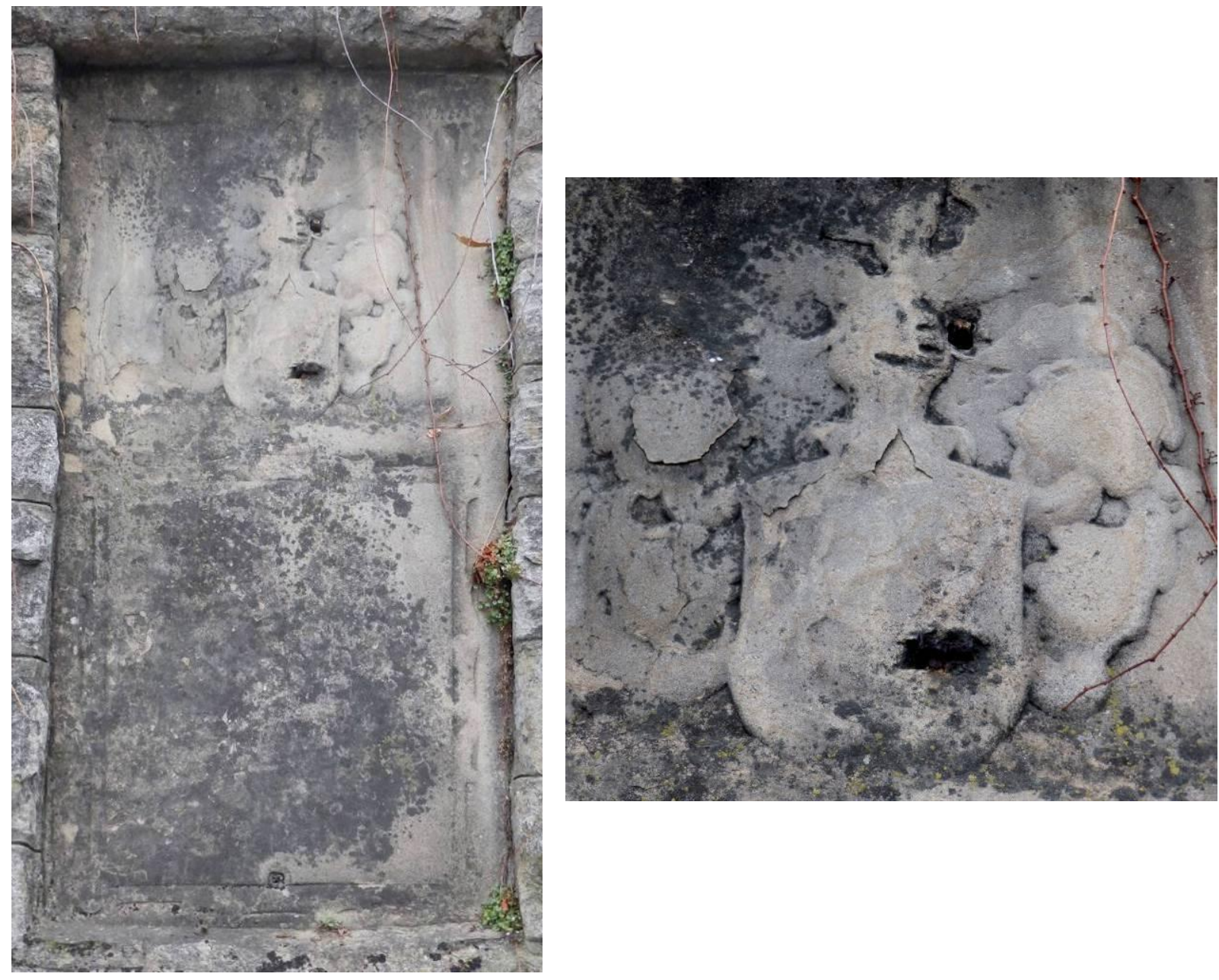

Radionica Majstora Trantnerova epitafa (?), Nadgrobna ploča obitelji Keglević, 1620.

Kamen, $186 \times 97 \mathrm{~cm} \times$ [uzidana]

Natpis je nečitljiv zbog istrošenosti ploče. Prema Gjuri Szabi (1914.), sadržavao je godinu "MDCXX". ${ }^{758}$

\section{Opis spomenika:}

Nadgrobna ploča izvedena je u obliku okomito postavljena pravokutnika. Vodoravno je podijeljena na dva podjednaka dijela. U gornjoj polovici nalazi se štit s plaštem i kacigom koji je, prema povijesnim izvorima, sadržavao grbovni simbol obitelji Keglević - lava. Donju polovicu nadgrobnika ispunjava ukrasni okvir konkavno oblikovanih stranica koji je nekoć sadržavao nadgrobni natpis (danas u potpunosti istrošen).

\footnotetext{
${ }^{758}$ Usp. Gjuro Szabo, nav. dj., 1914., str. 155.
} 


\section{Literatura:}

Anđela Horvat, O spomenicima kulture općine Krapina, u: Kaj: časopis za književnost, umjetnost i kulturu 1, Zagreb: Kajkavsko spravišće, 1982., str. 87-142, 121.

Dubravka Peić Čaldarović, Osnove krapinskog grbovnika, u: Krapina: grad povijesti $i$ kulture, Krapina: Grad Krapina, 2004., str. 130-138, 135. Uredila Agneza Szabo.

Gjuro Szabo, Spomenici kotara Krapina i Zlatar, u: Vjesnik Hrvatskoga arheološkog društva XIII/1, Zagreb: Hrvatsko arheološko društvo, 1914., str. 103-204, 155. 
- Kat. br. 11 -

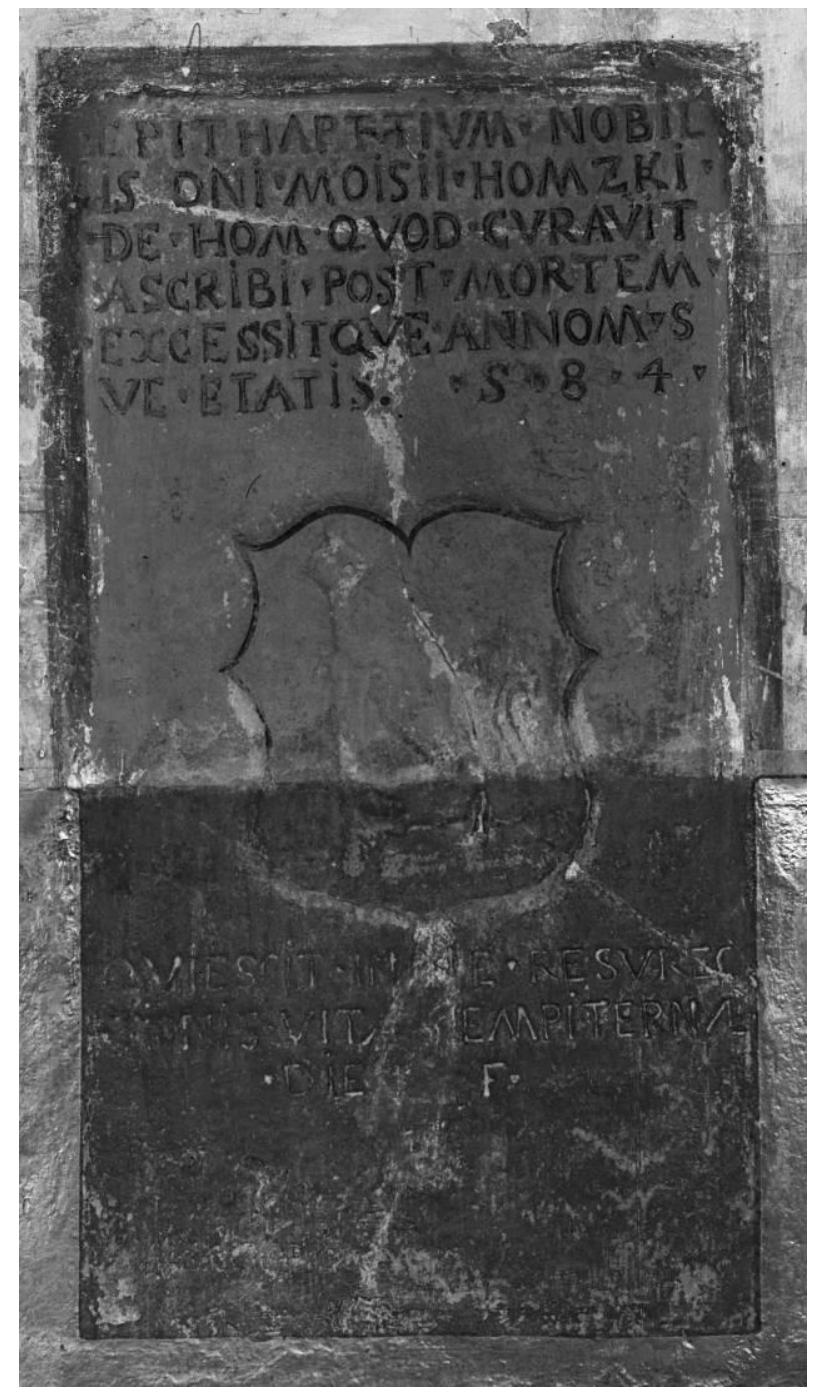

Nadgrobna ploča Mojsija Humskoga (? - ?, 1548.)

Kamen, $124 \times 71 \mathrm{~cm} \times$ [uzidana]

Natpis iznad grba: „EPITHAPHIVM NOBIL / IS DNI MOISII HOMZKI / DE HOM QVOD CVRAVIT / ASCRIBI POST MORTEM / EXCESSITQVE ANNOM S / VE ETATIS. 58 4«. Natpis ispod grba: »QVIESCIT IN PACE RESVREC / TIONIS VITÆ SEMPITERNÆ / DIE(M) F«

\section{Opis spomenika:}

Jednostavna nadgrobna ploča izvedena u obliku okomito postavljena pravokutnika. Sadrži grb obitelji Humski izveden u uleknutome reljefu, iznad i ispod kojega je uklesan posvetni natpis. 


\section{Literatura:}

Ljubo Karaman, $O$ umjetnosti srednjega vijeka, u: Historijski zbornik III/1-4, Zagreb: Društvo za hrvatsku povjesnicu, 1950., str. 125-174, 168, bilj. 73.

Ivan Kukuljević Sakcinski, Nadpisi sredovječni i novovjeki na crkvah, javnih i privatnih sgradah itd. u Hrvatskoj $i$ Slavoniji, Zagreb: Knjižara Jugoslavenske akademije, Knjižara Dioničke tiskare, 1891., str. 136, br. 452.

Vjekoslav Noršić, Mače, u: Tkalčić: Godišnjak Društva za povjesnicu Zagrebačke nadbiskupije VIII, Zagreb: Društvo za povjesnicu Zagrebačke nadbiskupije »Tkalčić«, 2004., str. 259-278, 261. Rukopis priredio Stjepan Razum.

Gjuro Szabo, Spomenici kotara Krapina i Zlatar, u: Vjesnik Hrvatskoga arheološkog društva XIII/1, Zagreb: Hrvatsko arheološko društvo, 1914., str. 103-204, 173.

Gjuro Szabo, Kroz Hrvatsko zagorje, Zagreb: Vasić i Horvat, 1939., str. 63. 


\section{MARIJA GORICA, crkva Pohoda Blažene Djevice Marije}

- Kat. br. 12 -
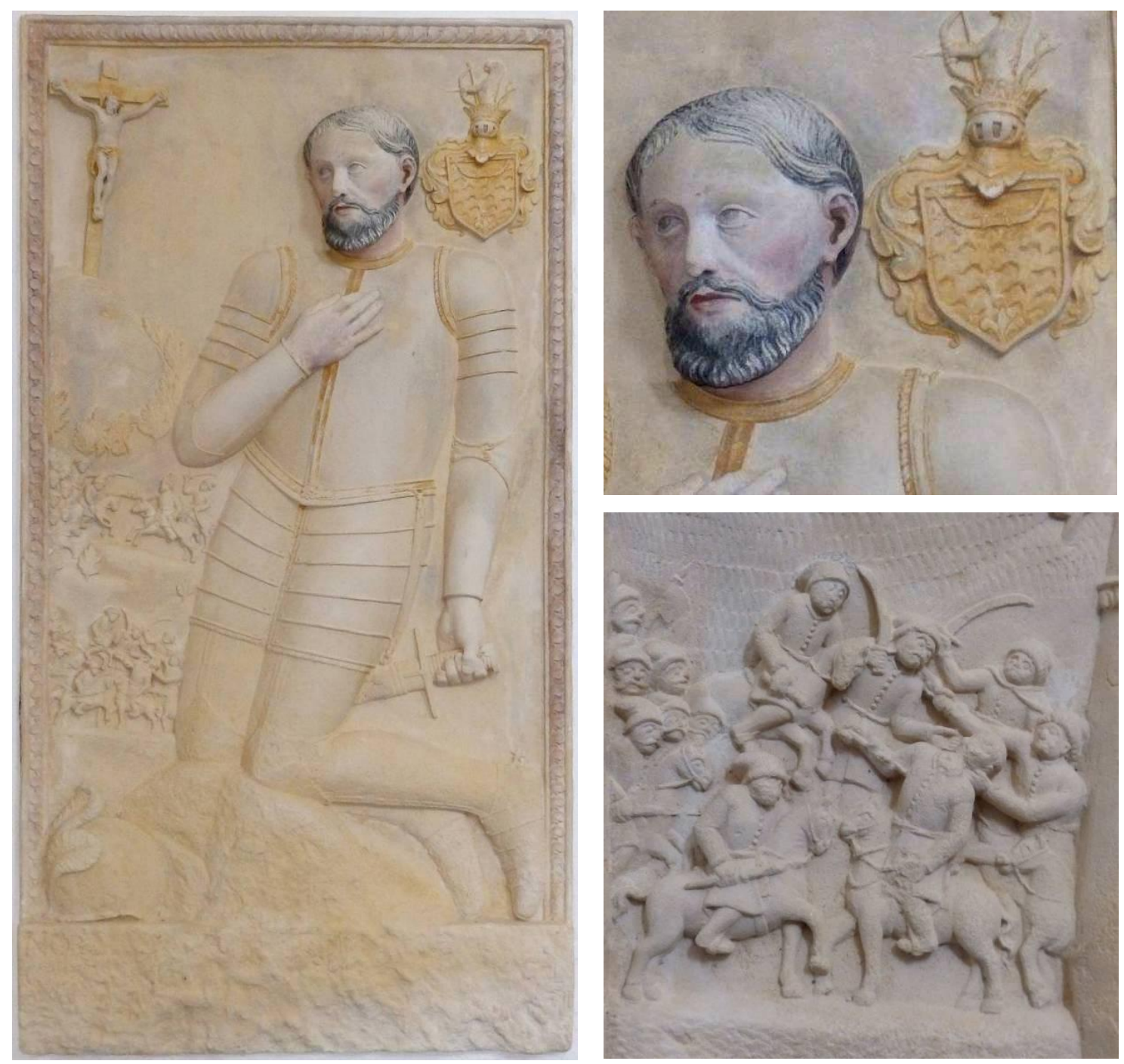

Epitaf Martina Mogorića (? - Perjasica, 1643.), 1675.

Kamen, vapnenački pješčenjak, polikromija, 154,5 × $82 \times 22 \mathrm{~cm}$

Natpis: "NOB ${ }^{\mathrm{LI}}$ : (ET GEN ${ }^{\mathrm{SO}}$ : DNO MARTINO MOGORICH AV) / GVS(TISSIMI CAESA $^{\text {IS }}$ : FERDINANDI III PRAESID O)GVL / (CAPITANEO FORTIS ${ }^{\mathrm{MO}}$ HEROI SVB MONTE PEROVICZA DE CA ${ }^{\mathrm{PI}} \mathrm{TA}^{\mathrm{TO}} \mathrm{I} / \mathrm{R}$ SVVS EG ${ }^{\mathrm{R}} \mathrm{M}^{\mathrm{IC}} \mathrm{H} Æ L$ VERNICH FIE ${ }^{\mathrm{RI}} \mathrm{FE}^{\mathrm{CIT}} 10$ OCTO $\left.^{\mathrm{RIS}} 1675\right) \lll$

\section{Opis spomenika:}

Epitaf je izveden u obliku okomito postavljena pravokutnika. Na njemu je prikazan pokojnikadorant koji kleči i moli pred Raspetim. Pokojnik je predočen u lijevom tričetvrt profilu. Odjeven je u viteški oklop, a kacigu je odložio sa strane do nogu. Desnu ruku prinio je na prsa, a u lijevoj ruci drži mač. Pogledom je usmjeren prema Kristu na križu, koji je podignut 
na vrhu brda prikazanom uz lijevi rub reljefa. U podnožju brda u dva se vodoravna pojasa odvija bitka između krajiške i osmanske konjice u kojoj je pokojnik izgubio život. U gornjem nizu sukobljene strane jurišaju jedna protiv druge, a u donjem pokojnik je opkoljen neprijateljskim konjanicima koji mu odsijecaju glavu. U gornjem desnom kutu reljefa predočen je grb obitelji Mogorić, a nadgrobni natpis uklesan je ispod figuralnoga prikaza. $\mathrm{Na}$ spomeniku su vidljivi ostaci polikromije.

\section{Literatura:}

Branimir Brgles, Franjevački samostan i crkva Blažene Djevice Marije od Pohođenja u Mariji Gorici, u: Kaj: časopis za književnost, umjetnost, kulturu XLIV/5, Zagreb: Kajkavsko spravišče, 2011., str. 45-56, 48.

Paškal Cvekan, Crkva Majke Božje od Pohođenja u Mariji Gorici, II. dio, u: Zaprešićki godišnjak 5, Zaprešić: Matica hrvatska Zaprešić, 1995., str. 30-50, 49-50.

Đurđica Cvitanović, Župna crkva sv. Marije od Pohoda u Mariji Gorici. Nekad franjevački samostan i Gospino proštenište, u: Kaj: časopis za književnost, umjetnost i kulturu XXV/3, Zagreb: Kajkavsko spravišče, 1992., str. 75-88, 75.

Anđela Horvat, Između gotike i baroka: umjetnost kontinentalnog dijela Hrvatske od oko 1500. do oko 1700., Zagreb: Društvo povjesničara umjetnosti SR Hrvatske, 1975., str. $156,351,353$.

Ljubo Karaman, O umjetnosti srednjega vijeka, u: Historijski zbornik III/1-4, Zagreb: Društvo za hrvatsku povjesnicu, 1950., str. 125-174, 167.

Emilije Laszowski, Grb plemena Mogorovića, u: Vjesnik Hrvatskoga arheološkoga društva (N.S.) II/1, Zagreb: Hrvatsko arheološko društvo, 1897., str. 21-25, 24.

Ivan Kukuljević Sakcinski, Nadpisi sredovječni i novovjeki na crkvah, javnih i privatnih sgradah itd. u Hrvatskoj $i$ Slavoniji, Zagreb: Knjižara Jugoslavenske akademije, Knjižara Dioničke tiskare, 1891., str. 41, br. 134.

Krasenka Majer Jurišić, Marija Gorica: Nadgrobna ploča Martina Mogorića. Konzervatorsko-restauratorska istraživanja $i$ prijedlog radova, Zagreb: Hrvatski restauratorski zavod, 2013.

Marijana Schneider, O epitafiju Ivana Hrvoja i Eve Dreffell u Plešivici, u: Bulletin Instituta za likovne umjetnosti Jugoslavenske akademije znanosti i umjetnosti VII/3, Zagreb, Jugoslavenska akademija znanosti i umjetnosti, 1959., str. 177-182, 181.

Gjuro Szabo, Ljudi iz kamena, u: Jutarnji list, Zagreb: Tipografija, 24. XII. 1938., str. 5-6, 6. Gjuro Szabo, Kroz Hrvatsko zagorje, Zagreb: Vasić i Horvat, 1939., str. 25-26. 
- Kat. br. 13 -
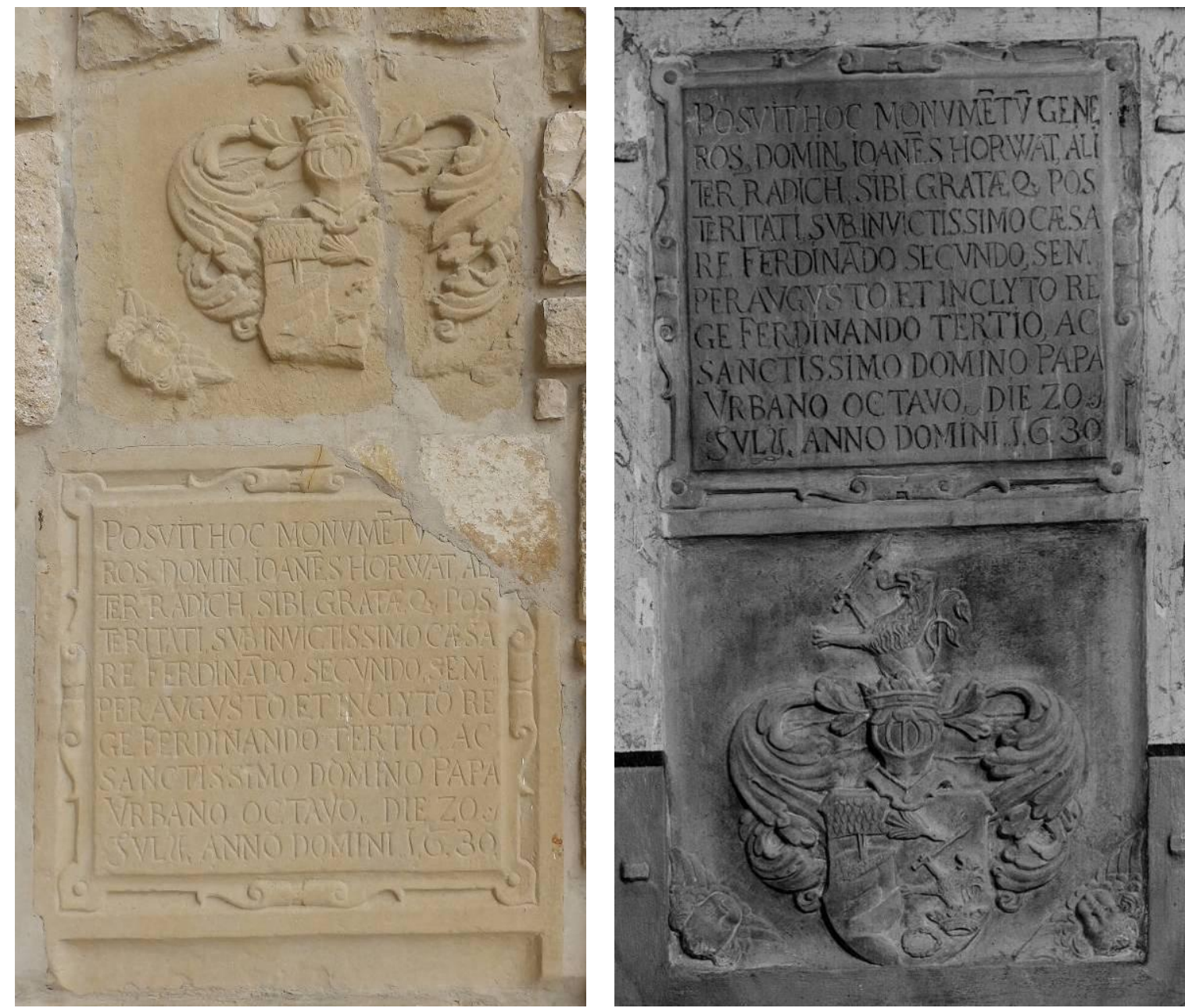

Radionica Majstora Trantnerova epitafa (?), Nadgrobna ploča Ivana Horvata Radića (? ?, o. 1630.), 1630 .

Kamen pješčenjak, $142 \times 77 \times 2,5 \mathrm{~cm}$ (dubina reljefa)

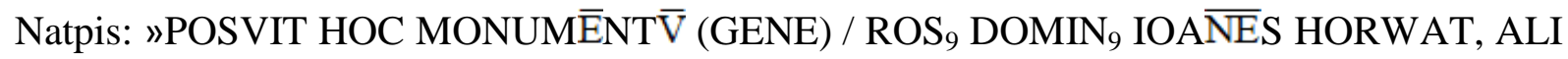
/ TER RADICH, SIBI GRATÆQ POS / TERITATI, SVB INVICTISSIMO CÆSA / RE FERDINĀDO SECVNDO, SEM / PER AVGVSTO, ET INCLYTO RE / GE FERDINANDO TERTIO, AC / SANCTISSIMO DOMINO PAPA / VRBANO OCTAVO DIE 20 / IVLY ANNO DOMINI 1.6.30.«

\section{Opis spomenika:}

Nadgrobna ploča izvedena je u obliku okomito postavljena pravokutnika. Vodoravno je podijeljena na dva podjednaka dijela. Izvorno gornju (danas donju) polovicu ispunjava ukrasni okvir konkavno oblikovanih stranica urešenih volutama koji sadrži nadgrobni natpis. 
U donjem (danas gornjem) dijelu predočen je grb obitelji Horvat Radić. Donji kutevi polja ukrašeni su kerubinima.

\section{Literatura:}

Ljubo Karaman, $O$ umjetnosti srednjega vijeka, u: Historijski zbornik III/1-4, Zagreb: Društvo za hrvatsku povjesnicu, 1950., str. 125-174, 168, bilj. 73.

Ivan Kukuljević Sakcinski, Nadpisi sredovječni i novovjeki na crkvah, javnih i privatnih sgradah itd. $u$ Hrvatskoj $i$ Slavoniji, Zagreb: Knjižara Jugoslavenske akademije, Knjižara Dioničke tiskare, 1891., str. 139-140, br. 467.

Gjuro Szabo, Spomenici kotara Krapina i Zlatar, u: Vjesnik Hrvatskoga arheološkog društva XIII/1, Zagreb: Hrvatsko arheološko društvo, 1914., str. 103-204, 175. 
- Kat. br. $14-$
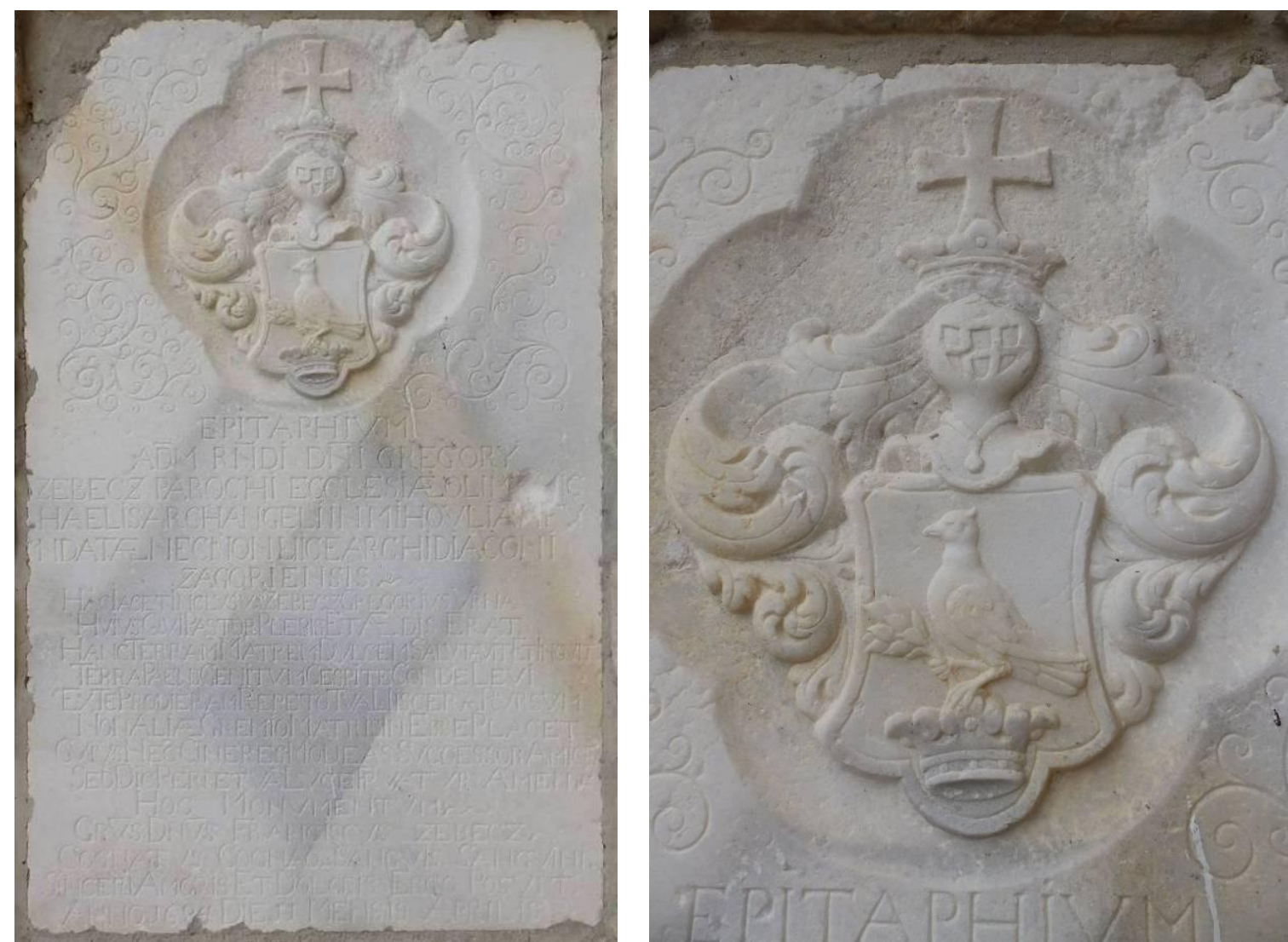

Nadgrobna ploča župnika Grgura Zebeca (?, o. 1611. - ?, 1684.), 1684.

Kamen, $136 \times 87 \times 1,5 \mathrm{~cm}$ (dubina reljefa)

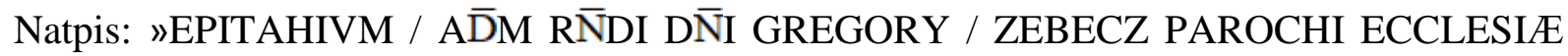
OLIM S: MIC / HAELIS ARCHANGELI IN MIHOVLIAN FV / NDATÆ NEC NON LIICEARCHIDICAONI / ZAGORIENSIS / HAC IACET INCLVSVS ZEBECZ GREGORIVS VRNA / HVIVS QVI PASTOR PLEBIS ET ÆDIS ERAT. / HANC TERRAM MATREM DVLCEM SALVTAVIT ET INQVIT / TERRA PARENS GENITVM CESPITE CONDE LEVI / EX TE PRODIERAM REPETO TVA LIISCERA RVRSVM / NON ALIÆ GREMIO MATRIS IN ESSE PLACET / CVIVS NEC CINERES MOLIEAS SVCCESSOR AMICE. / SED DIC PERPETVA LVCE FRVATVR AMEN / HOC MONUMENTVM GRV̄S DNV̄S FRANCISCVS ZEBECZ / COGNATVS COGNAO SANGVIS SANGVINI / SINCERI AMORIS ET DOLORIS ERGO POSVIT / ANNO 1684 DIE 11 MENSIS APRILIS $«$

\section{Opis spomenika:}

Jednostavna nadgrobna ploča izvedena je u obliku okomito postavljena pravokutnika. U gornjem dijelu predočen je grb obitelji Zebec unutar četverolista, a ispod njega uklesan je 
posvetni natpis. Prostor oko četverolista ukrašen je stiliziranim viticama.

\section{Literatura:}

Ivan Kukuljević Sakcinski, Nadpisi sredovječni i novovjeki na crkvah, javnih i privatnih sgradah itd. u Hrvatskoj $i$ Slavoniji, Zagreb: Knjižara Jugoslavenske akademije, Knjižara Dioničke tiskare, 1891., str. 140, br. 468.

Gjuro Szabo, Spomenici kotara Krapina i Zlatar, u: Vjesnik Hrvatskoga arheološkog društva XIII/1, Zagreb: Hrvatsko arheološko društvo, 1914., str. 103-204, 175-176.

Gjuro Szabo, Kroz Hrvatsko zagorje, Zagreb: Vasić i Horvat, 1939., str. 60-61. 


\section{PLEŠIVICA, crkva sv. Jurja}

- Kat. br. 15 -
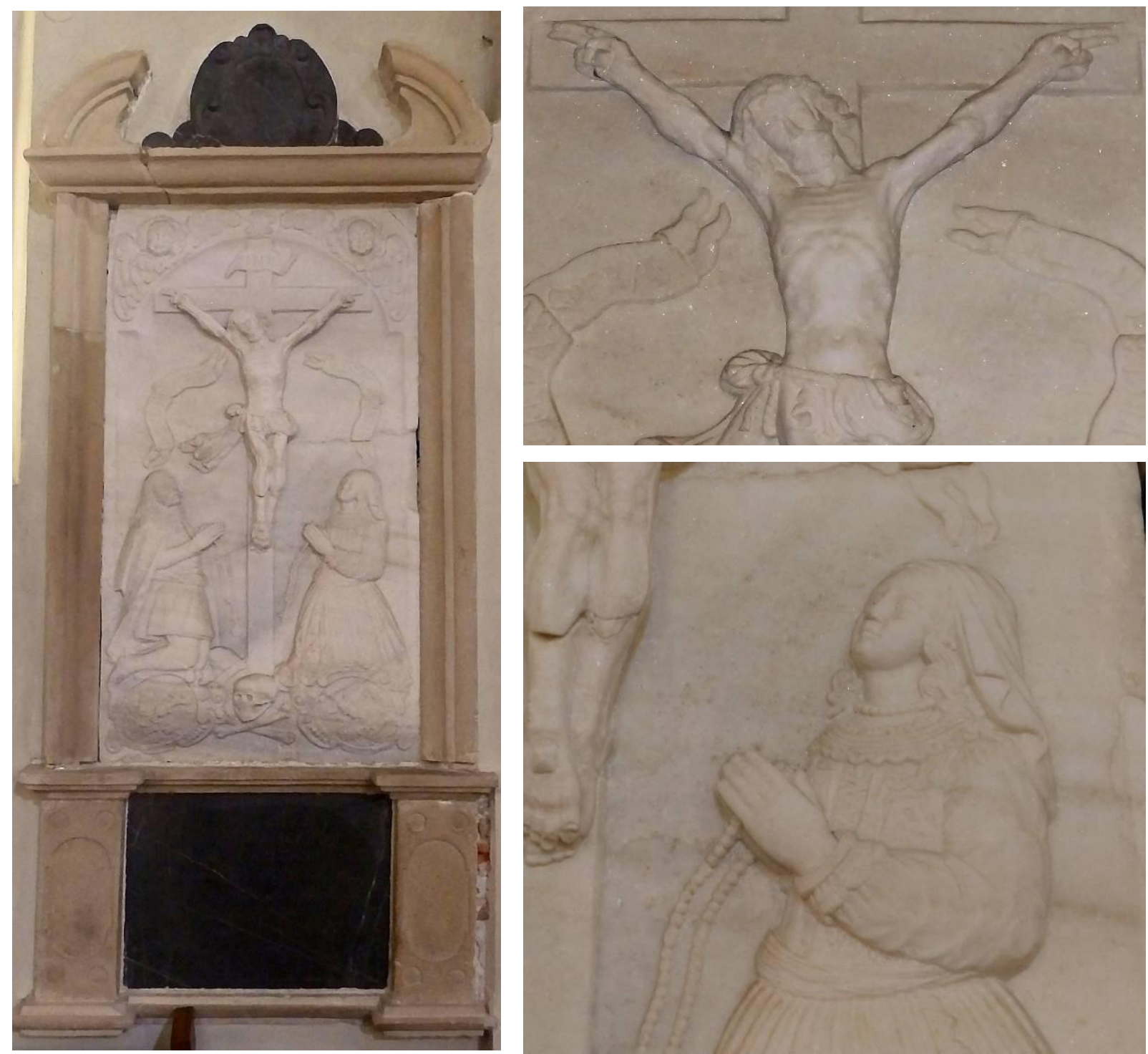

Epitaf Eve Hrvoj rođ. Dreffel (? - ?, 1672.) i Jurja Ivana I. Hrvoja (? - ?, 1704.)

Mramor, kamen pješčenjak, $247 \times 108 \times 9 \mathrm{~cm}$

Natpis na svitku iznad lika pokojnika: »IN TE DN̄E SPERAVI«. Natpis na svitku iznad lika

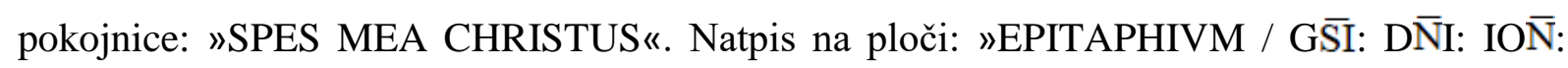
HERVOI: / OLIM: VICE CAPITANEI SIHEL / BERGENSIS: AC EIVSDEM: CHARISSIMÆ / CONSORTIS: EVÆ: RIN̄Æ DREFFELL: / QVÆ: OBYT: DIE: 9 / FEBRVARY: 1672: ÆTATIS: / SVÆ: 32 ILLE VERO POST: / ANNO: 1704 DIE 30 / XBRIS: AN: 77« 


\section{Opis spomenika:}

Epitaf je izveden u obliku oltarnoga retabla. Sastoji se od pravokutnoga postolja s natpisnom pločom, središnjega dijela i segmentnoga zabata s Kristovim monogramom. Središnji reljef sadrži prikaz pokojnikā koji kleče i mole pred Raspetim. U središtu kompozicije nalazi se Krist razapet na križu koji gestom udjeljuje blagoslov. Iznad njega nadvija se polukružni istak čija su ugaona polja ukrašena kerubinima. Podno križa nalazi se lubanja s parom ukriženih kostiju. S Kristove lijeve i desne strane kleče pokojnici ruku sklopljenih u molitvi. Prikazani su u skladu s ikonografskom perspektivom: pokojnik se nalazi zdesna, a pokojnica slijeva Kristu. Odjeveni su u velikašku odjeću, a kleče na kartušama unutar kojih su predočeni grbovi njihovih kuća. Iznad njihovih glava isklesani su svitci s citatima iz Staroga zavjeta i Rimskoga misala. Spomenik je izveden u kombinaciji kamena (arhitektonski elementi) te crnoga (natpisna ploča, Kristov monogram) i bijeloga mramora (središnji reljef).

\section{Literatura:}

Neven Brandić, Sakralna graditeljska baština Jastrebarskog i okolice, u: Jastrebarsko: 1249. - 1999.: 750 godina grada, Jastrebarsko: Naklada Slap, Gradsko poglavarstvo, 2001., str. 225-278, 254. Uredili Filip Potrebica i Krunoslav Matešić.

Đurđica Cvitanović, Crkveno graditeljstvo, u: Skriveno blago: iz riznice umjetničkih znamenitosti jastrebarskog kraja. Kulturni i prirodni spomenici Hrvatske: zbirka vodiča časopisa Kaj 8, Zagreb: Zagrebačko spravišče, 1975., str. 1-28, 13.

Đurđica Cvitanović, Sakralna arhitektura baroknog razdoblja. Knjiga I. Gorički i gorskodubički arhiđakonat, Zagreb: Društvo povjesničara umjetnosti SR Hrvatske, 1985., str. $52,241$.

Anđela Horvat, Između gotike i baroka: umjetnost kontinentalnog dijela Hrvatske od oko 1500. do oko 1700., Zagreb: Društvo povjesničara umjetnosti SR Hrvatske, 1975., str. $350,352-353$.

Ivan Kukuljević Sakcinski, Nadpisi sredovječni i novovjeki na crkvah, javnih i privatnih sgradah itd. u Hrvatskoj $i$ Slavoniji, Zagreb: Knjižara Jugoslavenske akademije, Knjižara Dioničke tiskare, 1891., str. 185, br. 613.

Dragutin Nežić, Povijest župa i crkvi Jastrebarskog dekanata, Jastrebarsko: Odbor za euharistijski kongres, 1939., str. 16.

Marijana Schneider, O epitafiju Ivana Hrvoja i Eve Dreffell u Plešivici, u: Bulletin Instituta za likovne umjetnosti Jugoslavenske akademije znanosti $i$ umjetnosti VII/3, Zagreb, Jugoslavenska akademija znanosti i umjetnosti, 1959., str. 177-182. 


\section{PREGRADA, crkva Uznesenja Blažene Djevice Marije}

- Kat. br. 16 -

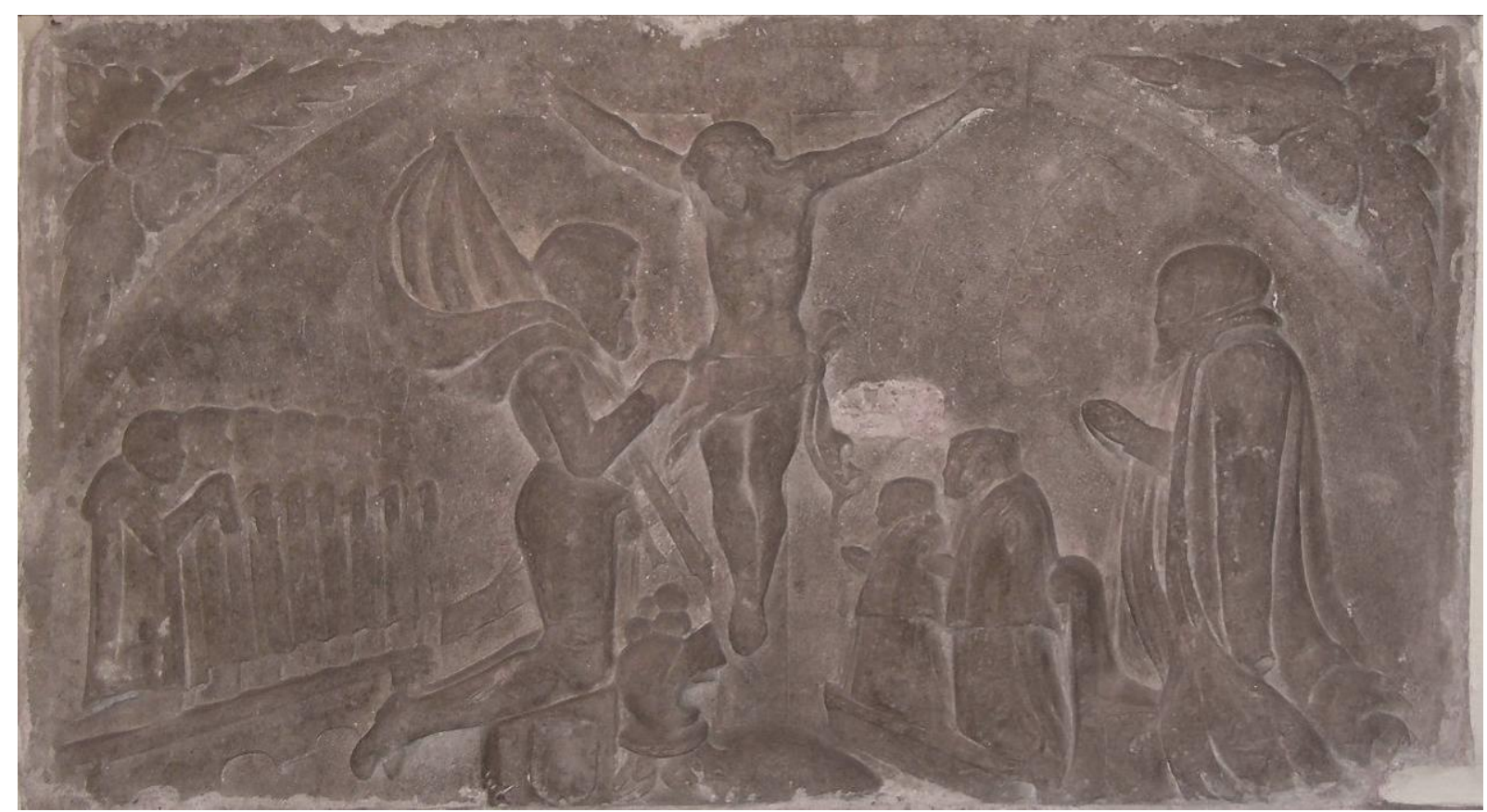

Majstor Hassova epitafa (?), Epitaf bana Petra II. Keglevića (?, o. 1485. - ?, 1554. ili 1555.)

Kamen, $62 \times 113 \times 5 \mathrm{~cm}$ (dubina reljefa)

Natpisi na svitcima iznad likova: „IOANNES / PETRVS / GASPARVS / GEORGIVS / FRANCISCVS / NICOLAVS / SIMEON / ANNA / SVSANA“

\section{Opis spomenika:}

Epitaf je izveden u obliku vodoravno položenoga pravokutnika. Sadrži prikaz pokojnika i njegove obitelji koji kleče na klecalima i mole pred Raspetim. U središtu kompozicije nalazi se Krist razapet na križu. Predočen je en face, a pogledom je usmjeren prema pokojniku koji mu se nalazi zdesna. Prikazan u poluprofilu, pokojnik je odjeven u viteški oklop, a na desnom ramenu nosi barjak. Pri dnu njegova klecala nalazi se štit sa simbolom obitelji Keglević (danas teško vidljiv) i viteška kaciga. Iza pokojnika predočeno je sedam njegovih sinova. S Kristove lijeve strane prikazane su pokojnikova supruga i njihove dvije kćeri. Nalik sinovima, odjevene su u suvremenu odjeću. Iznad glava djece uklesani su svitci koji sadrže njihova imena. 


\section{Literatura:}

Ivan Filipčić, Župa Pregrada: mala monografija o župi Naše Gospe od Kunagore, Zagreb: Kršćanska sadašnjost, Pregrada: ŽU, 1983., str. 20, 27-28, 40, 95.

Anđela Horvat, Između gotike i baroka: umjetnost kontinentalnog dijela Hrvatske od oko 1500. do oko 1700., Zagreb: Društvo povjesničara umjetnosti SR Hrvatske, 1975., str. 352.

Anđela Horvat, Pregled spomenika kulture općine Pregrada, u: Kaj: časopis za književnost, umjetnost i kulturu 2-3, Zagreb: Kajkavsko spravišće, 1985., str. 167-208, 199.

Ljubo Karaman, $O$ umjetnosti srednjega vijeka, u: Historijski zbornik III/1-4, Zagreb: Društvo za hrvatsku povjesnicu, 1950., str. 125-174, 167-168.

Ivan Kukuljević Sakcinski, Nadpisi sredovječni i novovjeki na crkvah, javnih i privatnih sgradah itd. u Hrvatskoj $i$ Slavoniji, Zagreb: Knjižara Jugoslavenske akademije, Knjižara Dioničke tiskare, 1891., str. 188-189, br. 620.

Ivanka Reberski (ur.), Krapinsko-zagorska županija: sakralna arhitektura s inventarom, feudalna arhitektura, spomen-obilježja, Zagreb: Institut za povijest umjetnosti, Školska knjiga, 2008., sub voce Pregrada. Župna crkva Uznesenja Bl. Dj. Marije, str. 512 [Dubravka Botica].

Marijana Schneider, O epitafiju Ivana Hrvoja i Eve Dreffell u Plešivici, u: Bulletin Instituta za likovne umjetnosti Jugoslavenske akademije znanosti $i$ umjetnosti VII/3, Zagreb, Jugoslavenska akademija znanosti i umjetnosti, 1959., str. 177-182, 177.

Gjuro Szabo, Izvještaj o radu zemaljskoga povjerenstva za očuvanje umjetnih $i$ historičkih spomenika u kraljevinama Hrvatskoj i Slavoniji u godini 1911., u: Vjesnik Hrvatskoga arheološkog društva XII/1, Zagreb: Hrvatsko arheološko društvo, 1912., str. 202-259, $237-238$.

Diana Vukičević-Samaržija, Umjetnost renesanse, u: Sveti trag. Devetsto godina umjetnosti Zagrebačke nadbiskupije 1094.-1994., MGC - Muzej Mimara, Zagreb, 10. rujna - 31. prosinca 1994., Zagreb: Zagrebačka nadbiskupija, Institut za povijest umjetnosti, Muzejsko-galerijski centar, 1994., str. 175-188, 183. Uredili Tugomir Lukšić i Ivanka Reberski. 
- Kat. br. 17 -

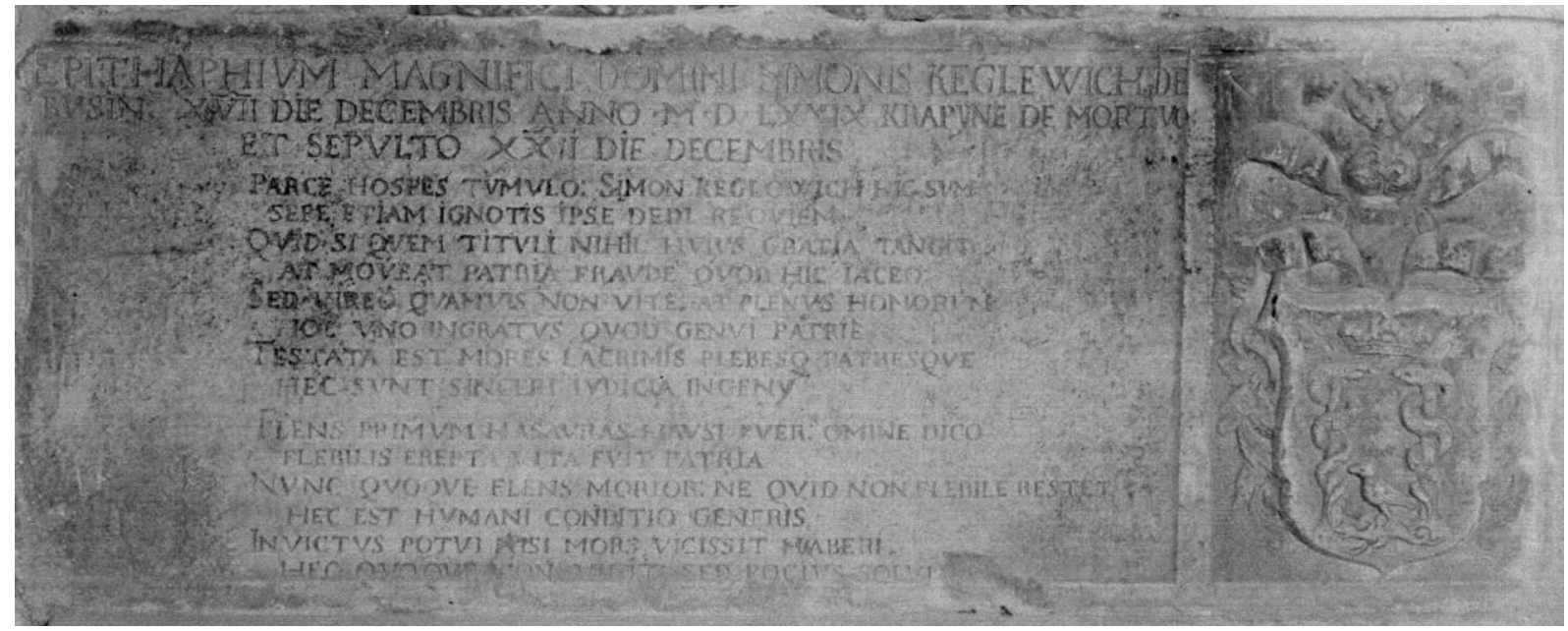

Epitaf Šimuna Keglevića (? - Krapina, 1579.)

Kamen, $60 \times 140 \times 5 \mathrm{~cm}$ (dubina reljefa)

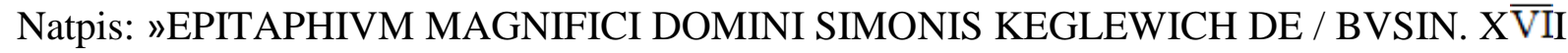
DIE DECEMBRIS ANNO - M · D · LXXIX KRAPYNE DE MORTVO: / ET SEPVLTO

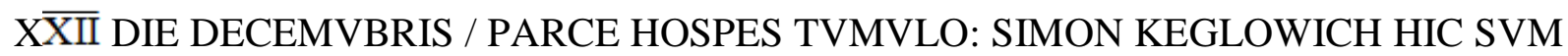
/ SEPE ETIAM IGNOTIS IPSE DEDI REQVIEM / QVID SI QVEM TITVLI NIHIL HVIVS GRATIA TANGIT / AT MOVEAT PATRIA FRAVDE QVOD HIC IACEO / SED VIREO QVAMVIS NON VITE AT PLENVS HONORVM / HOC VNO INGRATVS QVOD GENVI PATRIE / TESTATA EST MORES LACRIMIS PLEBESQ PATRESQVE / HEC SVNT SINCERI IVDICIA INGENY / FLENS PRIMVM HASAVRAS HAVSI PVER: OMINE DICO / FLEBILIS EREPTA VITA FVIT PATRIA / NVNC QVOQVE FLENS MORIOR: NE QVID NON FLEBILE RESTET. / HEC EST HVMANI CONDITIO GENERIS / INVICTVS POTVI NISI MORS, VICISSIT HABERI / NEC QVOQVE NON VICIT SED POCIVS SOLVIT«

\section{Opis spomenika:}

Epitaf je izveden u obliku vodoravno položenoga pravokutnika. Veći dio sačinjava natpisna ploča kojoj je zdesna pridruženo polje s grbom neznane obitelji. Na štitu je predočen par stabala oko kojih je ovijena po jedna zmija. U podnožju drvā nalazi se vrana, a povrh krošanja kruna. Iznad štita nalazi se lavlja glava s vrpcom u zubima. 


\section{Literatura:}

Ivan Filipčić, Župa Pregrada: mala monografija o župi Naše Gospe od Kunagore, Zagreb: Kršćanska sadašnjost, Pregrada: ŽU, 1983., str. 27-28, 40.

Ivan Kukuljević Sakcinski, Nadpisi sredovječni i novovjeki na crkvah, javnih i privatnih sgradah itd. u Hrvatskoj $i$ Slavoniji, Zagreb: Knjižara Jugoslavenske akademije, Knjižara Dioničke tiskare, 1891., str. 188-189, br. 620.

Han Lamers, Michele Marullo and the Epitaph of Šimun Keglević (1579): A note on the use and function of Latin inscriptions in Croatia, u: Bibliothèque d'Humanisme et Renaissance LXXVII/2, Geneve: Librairie Droz, 2015., str. 411-421.

Milan Pelc, Renesansa, Zagreb: Naklada Ljevak, str. 318.

Ivanka Reberski (ur.), Krapinsko-zagorska županija: sakralna arhitektura s inventarom, feudalna arhitektura, spomen-obilježja, Zagreb: Institut za povijest umjetnosti, Školska knjiga, 2008., sub voce Pregrada. Župna crkva Uznesenja Bl. Dj. Marije, str. 512 [Dubravka Botica].

Gjuro Szabo, Izvještaj o radu zemaljskoga povjerenstva za očuvanje umjetnih i historičkih spomenika u kraljevinama Hrvatskoj i Slavoniji u godini 1911., u: Vjesnik Hrvatskoga arheološkog društva XII/1, Zagreb: Hrvatsko arheološko društvo, 1912., str. 202-259, 237-238.

Diana Vukičević-Samaržija, Umjetnost renesanse, u: Sveti trag. Devetsto godina umjetnosti Zagrebačke nadbiskupije 1094.-1994., MGC - Muzej Mimara, Zagreb, 10. rujna - 31. prosinca 1994., Zagreb: Zagrebačka nadbiskupija, Institut za povijest umjetnosti, Muzejsko-galerijski centar, 1994., str. 175-188, 183. Uredili Tugomir Lukšić i Ivanka Reberski. 
Kat. br. 18

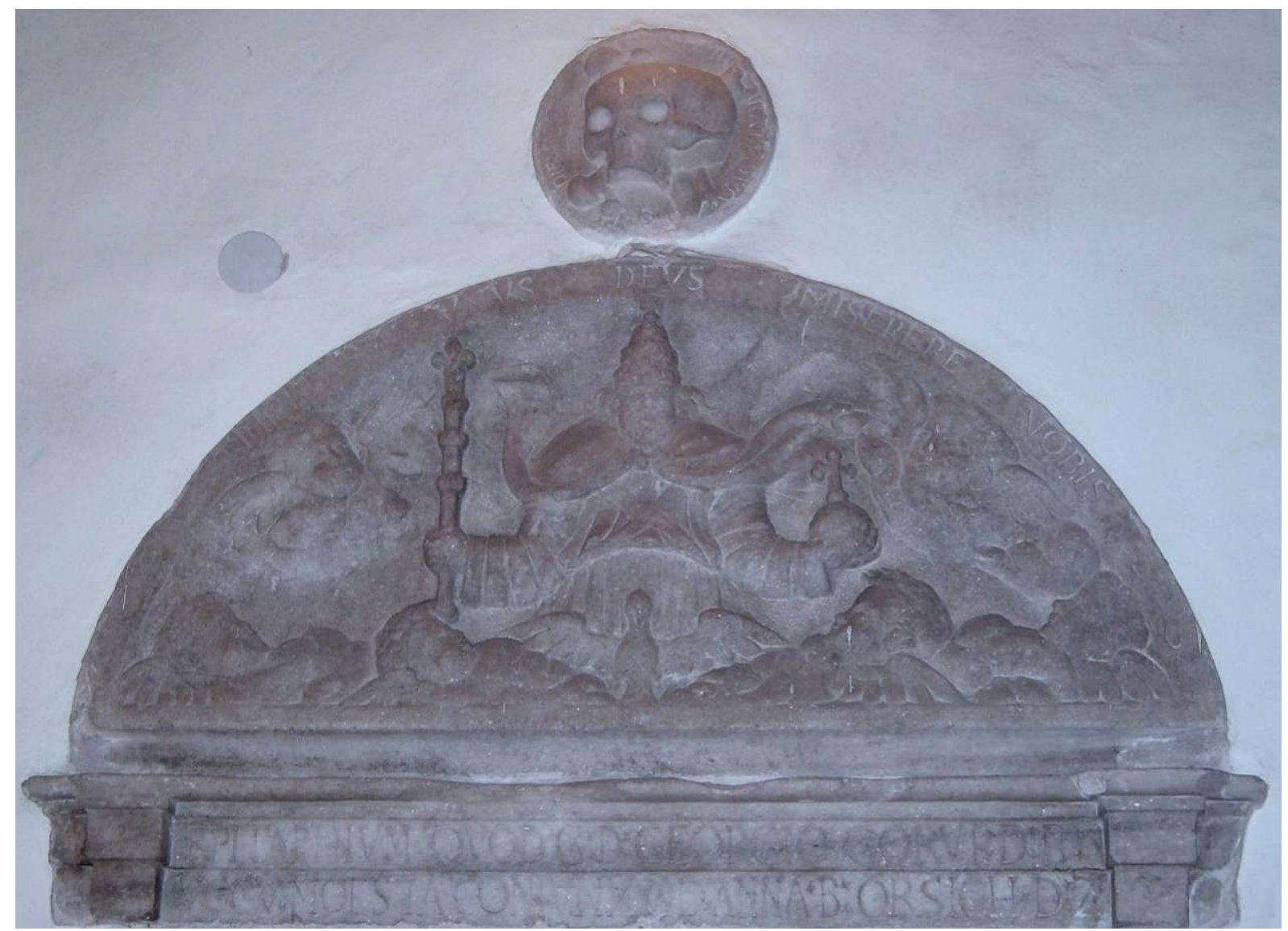

Epitaf Jurja Gorupa (? - ?, o. 1680.)

Kamen, $106 \times 135 \times 5 \mathrm{~cm}$ (dubina reljefa)

Natpis oko medaljona s lubanjom: „ESTOTE PARATI QVIA NESCITIS DIEM NEQVE HORAM«. Natpis uz rub lunete: „SANCTA TRINITAS VNVS DEVS MISERERE NOBIS «. Natpis na arhitravu: «EPITAPHIVM QVOD G: D: GEORGIO GORVP D: B: / VCCV: MOESTA / CONJVNX G: D: ANNA B: ORSICH: D: Z:«

\section{Opis spomenika:}

Sačuvan je gornji dio epitafa koji se sastoji od arhitrava, lunete i medaljona s motivom mrtvačke lubanje. U luneti su prikazani Otac i Duh Sveti okruženi kerubinima. Otac je predočen kao nebeski vladar s atributima najviše crkvene i zemaljske vlasti (tijarom, žezlom i kraljevskom jabukom), a Duh Sveti kao golubica. Posvetni natpis uklesan je na arhitravu.

\section{Literatura:}

Ivan Filipčić, Župa Pregrada: mala monografija o župi Naše Gospe od Kunagore, Zagreb: Kršćanska sadašnjost, Pregrada: ŽU, 1983., str. 40, 96. 
Anđela Horvat, Pregled spomenika kulture općine Pregrada, u: Kaj: časopis za književnost, umjetnost i kulturu 2-3, Zagreb: Kajkavsko spravišće, 1985., str. 167-208, 199.

Ljubo Karaman, O umjetnosti srednjega vijeka, u: Historijski zbornik III/1-4, Zagreb: Društvo za hrvatsku povjesnicu, 1950., str. 125-174, 167-168.

Ivan Kukuljević Sakcinski, Nadpisi sredovječni i novovjeki na crkvah, javnih i privatnih sgradah itd. u Hrvatskoj $i$ Slavoniji, Zagreb: Knjižara Jugoslavenske akademije, Knjižara Dioničke tiskare, 1891., str. 189, br. 621.

Milan Pelc, Renesansa, Zagreb: Naklada Ljevak, str. 318.

Ivanka Reberski (ur.), Krapinsko-zagorska županija: sakralna arhitektura s inventarom, feudalna arhitektura, spomen-obilježja, Zagreb: Institut za povijest umjetnosti, Školska knjiga, 2008., sub voce Pregrada. Župna crkva Uznesenja Bl. Dj. Marije, str. 512 [Dubravka Botica].

Gjuro Szabo, Izvještaj o radu zemaljskoga povjerenstva za očuvanje umjetnih i historičkih spomenika u kraljevinama Hrvatskoj i Slavoniji u godini 1911., u: Vjesnik Hrvatskoga arheološkog društva XII/1, Zagreb: Hrvatsko arheološko društvo, 1912., str. 202-259, 237-238.

Diana Vukičević-Samaržija, Umjetnost renesanse, u: Sveti trag. Devetsto godina umjetnosti Zagrebačke nadbiskupije 1094.-1994., MGC - Muzej Mimara, Zagreb, 10. rujna - 31. prosinca 1994., Zagreb: Zagrebačka nadbiskupija, Institut za povijest umjetnosti, Muzejsko-galerijski centar, 1994., str. 175-188, 183. Uredili Tugomir Lukšić i Ivanka Reberski. 


\section{RADOBOJ, crkva Presvetoga Trojstva}

- Kat. br. 19 -

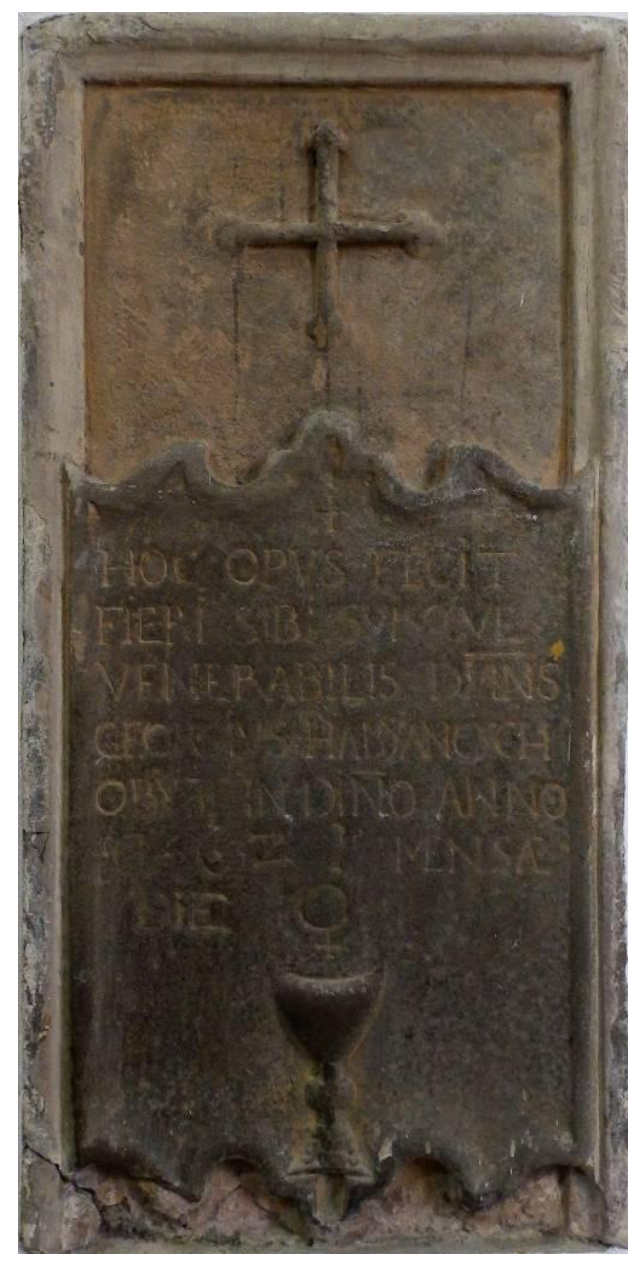

Nadgrobna ploča župnika Jurja Habijančića $(?-?, 1621$.

Kamen, $122 \times 61 \times 3 \mathrm{~cm}$ (dubina reljefa)

Natpis: »HOC OPVS FECIT / FIERI SIBI SVISQVE / VENERABILIS D $\overline{M N S}$ / GEORGIVS

HABYANCYCH / OBYT IN DIN̄O ANNO / 1621 MENSÆ / DIE«

\section{Opis spomenika:}

Jednostavna nadgrobna ploča izvedena u obliku okomito postavljena pravokutnika. Vodoravno je podijeljena na tri dijela vitičastim okvirom (donji dio nedostaje). U gornjem dijelu predočen je grčki križ, a u središnjem nadgrobni natpis koji je zaključen reljefno izvedenim motivom kaleža.

\section{Literatura:}

Anđela Horvat, O spomenicima kulture općine Krapina, u: Kaj: časopis za književnost, umjetnost i kulturu 1, Zagreb: Kajkavsko spravišće, 1982., str. 87-142, 111. 
Drago Kozina, Općina Radoboj, Radoboj: Općina Radoboj, 2007., str. 138.

Ivan Kukuljević Sakcinski, Nadpisi sredovječni i novovjeki na crkvah, javnih i privatnih sgradah itd. u Hrvatskoj $i$ Slavoniji, Zagreb: Knjižara Jugoslavenske akademije, Knjižara Dioničke tiskare, 1891., str. 194, br. 641. 
- Kat. br. 20 -

\section{CORBAVIA (KRBAVA)C.)}

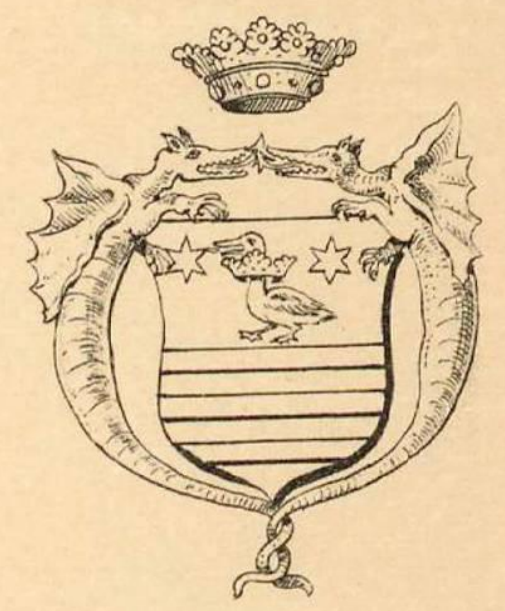

Nadgrobna ploča bana Ivana Karlovića (Udbina, 1485. - Medvedgrad, 1531.)

Ploča nije sačuvana, ali je dokumentirana u pisanim izvorima.

Natpis iznad grba: „SCIO QUOD REDEMPTOR MEUS VIVIT. Natpis ispod grba: SEPULTUS GENERE SPECTABILIS MILITIAQUE PRAEDITUS, MAGNIFICUS D. TORQUATUS COMES CORBAVIAE, REGNORUMQUE DALMATIÆ, CROATIÆ \& SLAVONIÆ BANUS, MOLE SUB HAC TEGITUR. ANNO M. D. XXXI ${ }^{759}$

\section{Opis spomenika:}

Prema Zdelarovu opisu (1737.), nadgrobna ploča sadržavala je grb obitelji Karlović i gore navedeni natpis. Grb se sastojao od štita i čuvara u obliku krokodila. Na štitu su se nalazile tri vodoravne grede povrh kojih je bio predočen labud s tri krune. Jedna kruna bila je postavljena labudu na glavi, druga oko vrata, a treća oko nogu. Opisani grb u manjoj se mjeri razlikuje od onoga objavljenoga u grbovniku Ivana von Bojničića Der Adel von Kroatien und Slavonien (Nürnberg, 1889.) (reprodukcija gore).

\section{Literatura:}

Janko Bárle, Remete: povjesni podaci o samostanu, crkvi i župi, Zagreb: Marko Mileusnić, 1914., str. 25.

\footnotetext{
${ }^{759}$ Prijepis preuzet iz: Ivan Franjo Zdelar, nav. dj., 1737., str. 108.
} 
Ivan Krstitelj Krapac, Samostan remetski: Historička crta, u: Zagrebački katolički list: crkveno-bogoslovni časopis XXI/4, Zagreb: Tiskom Dragutina Albrechta, 27. siječnja 1870., str. 25-28, 26.

Ivan Kukuljević Sakcinski, Nadpisi sredovječni i novovjeki na crkvah, javnih i privatnih sgradah itd. u Hrvatskoj $i$ Slavoniji, Zagreb: Knjižara Jugoslavenske akademije, Knjižara Dioničke tiskare, 1891., str. 198, br. 659.

Ivan Franjo Zdelar, Series banorum Dalmatiae, Croatiae et Slavoniae sub regibus Croatiae, Ungariae et Hungariae-Austriacis, Tyrnaviae: typis Academicis, per. Leopoldum Berger, 1737., str. 108. 
- Kat. br. 21 -
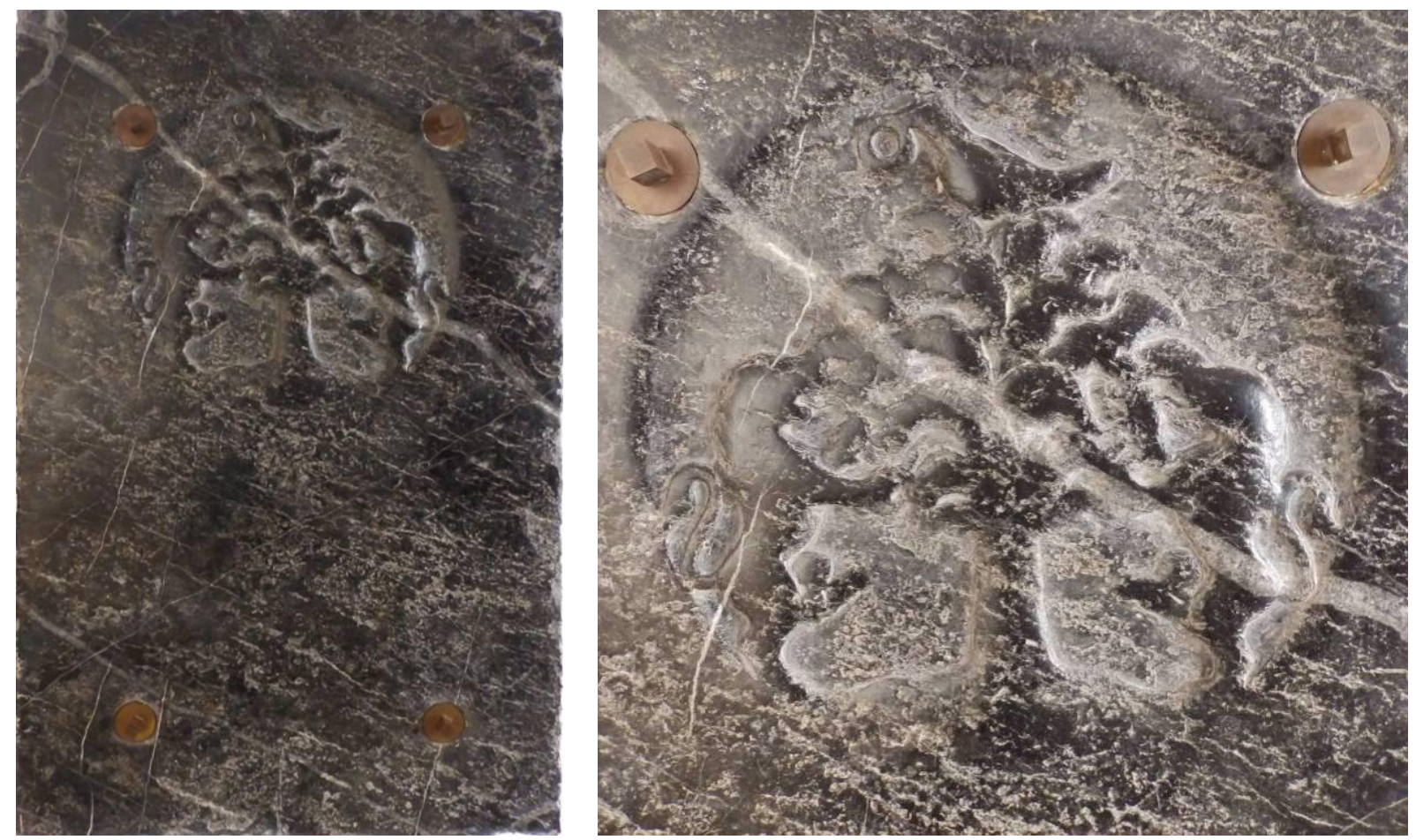

Nadgrobna ploča pavlinske grobnice, kraj XVIII. st. (?)

Kamen, $130 \times 84 \times 9 \mathrm{~cm}$

\section{Opis spomenika:}

U gornjem dijelu ploče reljefno je izveden grb pavlinskoga reda (stablo datulje na čijem vrhu sjedi gavran s komadom kruha u kljunu i par lavova koji flankiraju stablo). Ostatak je ploče prazan.

\section{Literatura:}

Janko Bárle, Remete: povjesni podaci o samostanu, crkvi i župi, Zagreb: Marko Mileusnić, 1914., str. 83. 
- Kat. br. 22 -
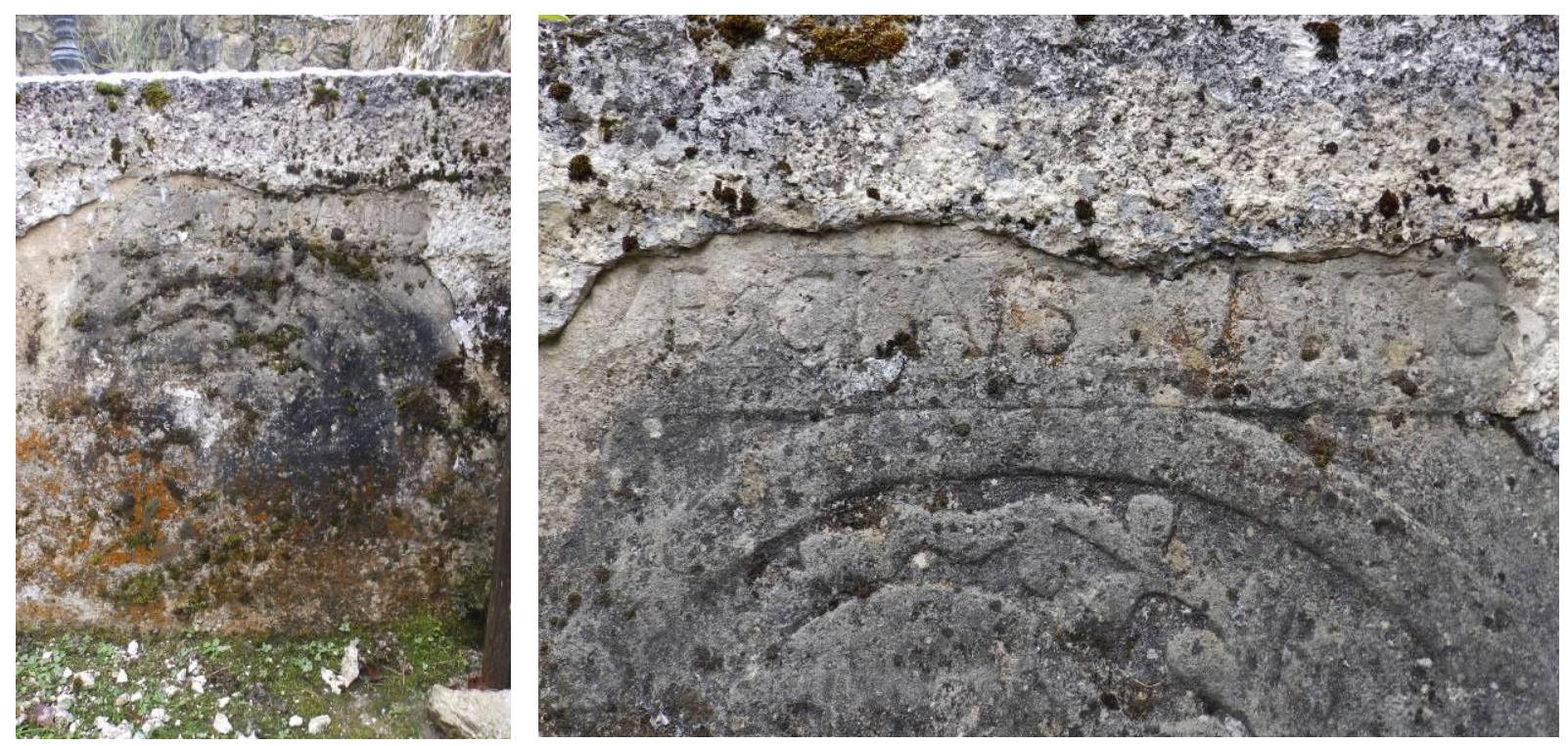

Nadgrobna ploča Leonarda Grubera (? - ?, 1536.)

Kamen, $40 \times 70 \mathrm{~cm} \times$ [uzidana]

Natpis: $»(\dagger$ HOC SVB GRAMINE [...] / LEONHARDVS [...] VE [...] / DE SAMOBOR QVI DIES / VITE SVE) CLAVSIT / ANNO (D. MDXXXVI)«

\section{Opis spomenika:}

Prema povijesnim izvorima, nadgrobna ploča izvorno je sadržavala natpis koji je tekao uz rubove ploče i grb obitelji Gruber. Danas je vidljivo tek nekoliko riječi natpisa i obrisi likovnoga motiva za koji možemo pretpostaviti da predstavlja dio obiteljskoga grba.

\section{Literatura:}

Ivan Kukuljević Sakcinski, Nadpisi sredovječni i novovjeki na crkvah, javnih i privatnih sgradah itd. u Hrvatskoj $i$ Slavoniji, Zagreb: Knjižara Jugoslavenske akademije, Knjižara Dioničke tiskare, 1891., str. 225, br. 746.

Vjekoslav Noršić, Povijest župe sv. Anastazije u Samoboru, Zagreb: Društvo za povjesnicu Zagrebačke nadbiskupije »Tkalčić«, 2005., str. 300-301. 
- Kat. br. 23 -
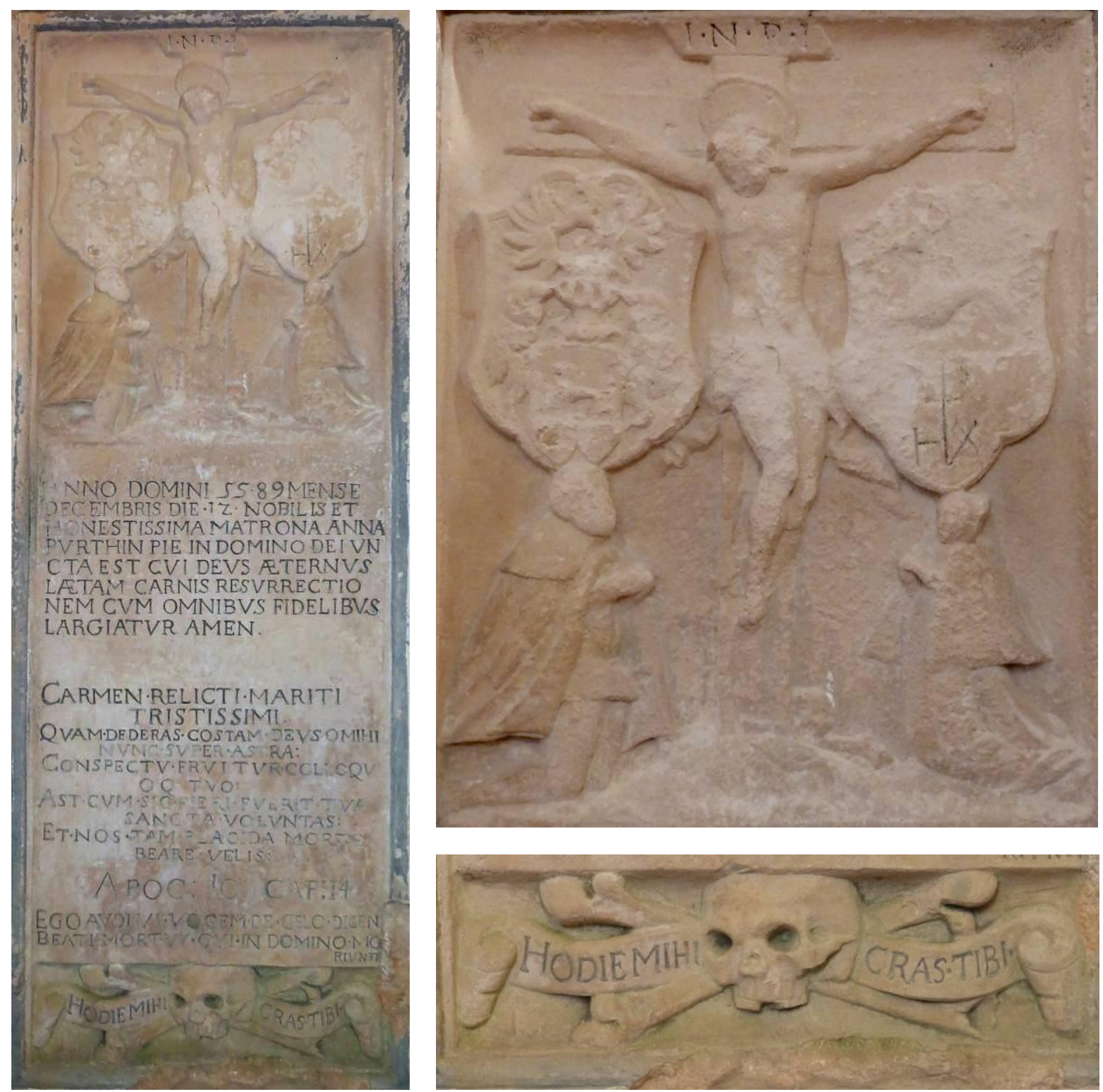

Suradnik Majstora Hassova epitafa (?), Epitaf Ane Purthin (? - ?, 1589.)

Kamen, $212 \times 75,5 \times 7,5 \mathrm{~cm}$ (dubina reljefa)

Natpis ispod figuralnoga prikaza: "ANNO DOMINI $15 \cdot 89$ MENSE / DECEMBRIS DIE ·

12 · NOBILIS ET / HONESTISSIMA MATRONA ANNA / PVRTHIN PIE IN DOMINO DEI VN / CTA EST CVI DEVS ÆTERNVS / LÆTAM CARNIS RESVRRESTIO / NEM CVM OMNIBVS FIDELIBVS / LARGIATVR AMEN. / CARMEN · RELICTI · MARITI / TRISTISSIMI. / QVAM · DEDERAS · COSTAM · DEVS · OMIHI / NVNC · SVPER · ASTRA: / CONSPECTV · FRVITVR · COLLOQV / OQ TVO: / AST · QVM · SIC · FIERI · FVERIT · TVA / SANCTA · VOLVNTAS: / ET · NOS · TAM · PLACIDA · MORTE / BEARE · VELIS / APOC: IO: CAP. 14 · / EGO AVDIVI · VOCEM · DE · CELO · DICEN / 
BEATI MORTVV · QVI · IN DOMINO · MO / RIVNTI«. Natpis na svitku uz lubanju: »HODIE MIHI / CRAS TIBI«

\section{Opis spomenika:}

Epitaf je izveden u obliku okomito postavljena pravokutnika. Sadrži prikaz pokojnikā koji kleče i mole pred Raspetim, podno kojega je uklesan nadgrobni natpis. Natpis je zaključen lubanjom s parom ukriženih kostiju i svitkom na kojem je ispisana krilatica »HODIE MIHI, CRAS TIBI«. U središtu kompozicije figuralnoga prikaza nalazi se Krist razapet na križu. Predočen je en face, a s njegove lijeve i desne strane kleče pokojnici ruku sklopljenih u molitvi. Pokojnici su prikazani u tričetvrt profilu u skladu s ikonografskom perspektivom: pokojnik se nalazi zdesna, a pokojnica slijeva Kristu. Odjeveni su u suvremenu velikašu odjeću, a iznad njihovih glava nalaze se štitovi sa simbolima obitelji kojima su pripadali tijekom ovozemaljskoga života.

\section{Literatura:}

Đurđica Cvitanović, Crkve grada Samobora, u: Kaj: časopis za književnost, umjetnost $i$ kulturu XXX/1, Zagreb: Kajkavsko spravišče, 1997., str. 27-53, 42.

Anđela Horvat, Između gotike i baroka: umjetnost kontinentalnog dijela Hrvatske od oko 1500. do oko 1700., Zagreb: Društvo povjesničara umjetnosti SR Hrvatske, 1975., str. $349-350,352$.

Ljubo Karaman, O umjetnosti srednjega vijeka, u: Historijski zbornik III/1-4, Zagreb: Društvo za hrvatsku povjesnicu, 1950., str. 125-174, 167-168.

Ivan Kukuljević Sakcinski, Nadpisi sredovječni i novovjeki na crkvah, javnih i privatnih sgradah itd. u Hrvatskoj $i$ Slavoniji, Zagreb: Knjižara Jugoslavenske akademije, Knjižara Dioničke tiskare, 1891., str. 225-226, br. 747.

Vjekoslav Noršić, Povijest župe sv. Anastazije u Samoboru, Zagreb: Društvo za povjesnicu Zagrebačke nadbiskupije »Tkalčić«, 2005., str. 302-303.

Milan Pelc, Renesansa, Zagreb: Naklada Ljevak, str. 317-318.

Marijana Schneider, O epitafiju Ivana Hrvoja i Eve Dreffell u Plešivici, u: Bulletin Instituta za likovne umjetnosti Jugoslavenske akademije znanosti $i$ umjetnosti VII/3, Zagreb, Jugoslavenska akademija znanosti i umjetnosti, 1959., str. 177-182, 177. 
Petra Somek i Dragutin Feletar, Važniji objekti graditeljske baštine grada Samobora (Od romanike do kasne secesije), u: Samobor: zemljopisno-povijesna monografija, Knjiga 2, Samobor: Meridijani, 2011., str. 537-647, 608, 610.

Diana Vukičević-Samaržija, Umjetnost renesanse, u: Sveti trag. Devetsto godina umjetnosti Zagrebačke nadbiskupije 1094.-1994., MGC - Muzej Mimara, Zagreb, 10. rujna - 31. prosinca 1994., Zagreb: Zagrebačka nadbiskupija, Institut za povijest umjetnosti, Muzejsko-galerijski centar, 1994., str. 175-188, 183. Uredili Tugomir Lukšić i Ivanka Reberski. 
- Kat. br. 24 -

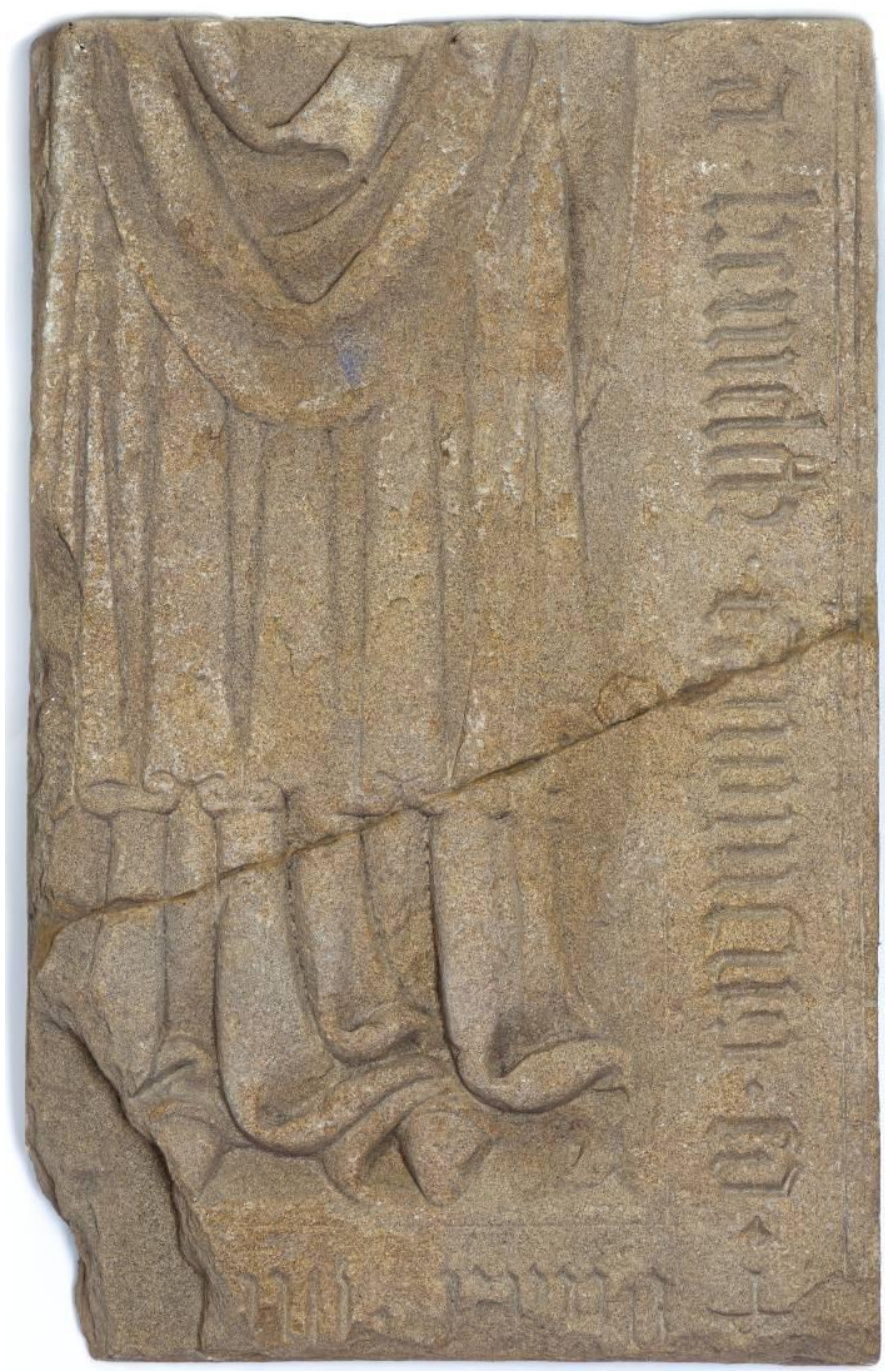

Nadgrobna ploča kanonika Benedikta, II. pol. XV. stoljeća

Kamen pješčenjak, 85 x 50 x $10 \mathrm{~cm}$

Ploča je danas pohranjena u Hrvatskom povijesnom muzeju u Zagrebu.

Natpis: »[...] a $\cdot$ Benidit $\cdot$ canonicus $\cdot[\ldots] \lll$

\section{Opis spomenika:}

Sačuvana je donja polovica nadgrobne ploče na kojoj je prikazan pokojnik odjeven u misno ruho. Draperija pada u plošnim, linijski izvedenim naborima. Uz rubove nadgrobnika uklesan je na natpis u gotičkoj minuskuli. 


\section{Literatura:}

Anđela Horvat, U povodu dilema o crkvi u Sesvetama, u: Iz starog i novog Zagreba V, Zagreb: Muzej grada Zagreba, 1974., str. 97-102, 99.

Anđela Horvat, Dva epitafa u Iloku, u: Zbornik za likovne umetnosti 15, Novi Sad: Matica srpska, Odelenje za likovne umetnosti, 1979., str. 307-315, 310

Lada Prister, Zbirka kamenih spomenika, u: Museum 1846.-1996., katalog izložbe, Zagreb: Hrvatski povijesni muzej, 1996. str. 20-25, 22. Uredila Maja Škiljan.

Mirko Valentić i Lada Prister, Zbirka kamenih spomenika, II. dopunjeno izdanje, Zagreb: Hrvatski povijesni muzej, 2002., str. 51. 
STENJEVEC, crkva Uznesenja Blažene Djevice Marije

- Kat. br. 25 -
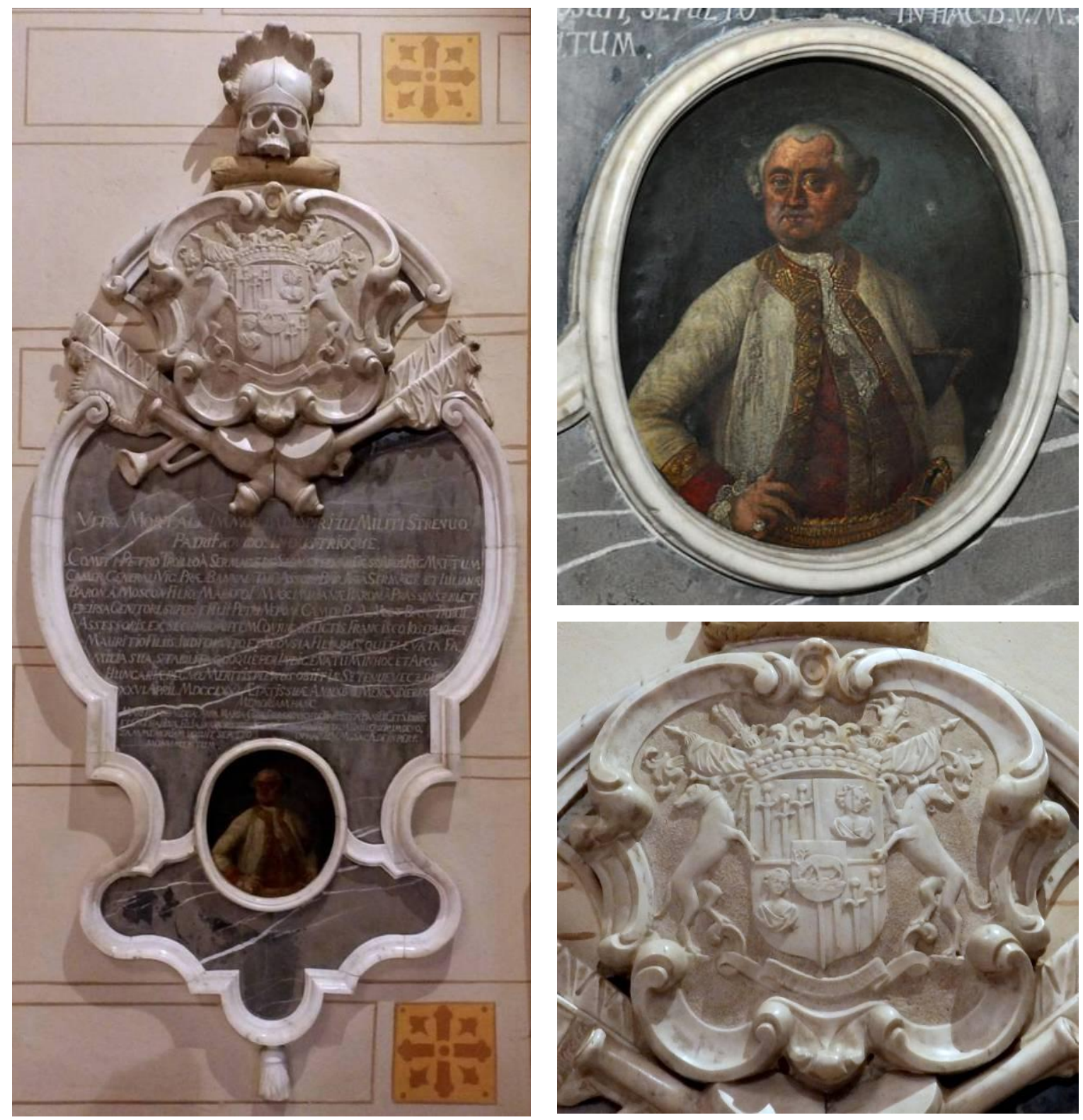

Epitaf Petra Troila Sermagea (Brdovec, 1722. - Stenjevec, 1771.)

Mramor, $215 \times 94 \times 8 \mathrm{~cm}$

Michael Milluz, Portret Petra Troila Sermagea od Susedgrada, 1773.

Ulje na bakrenoj ploči, uključujući profilirani okvir: $33 \times 29 \mathrm{~cm}$, bez okvira: $29 \times 25 \mathrm{~cm}$

Natpis: „VITA MORTALI, IMMORTALI SPIRITU, MILITI STRENUO, / PATRI PROVIDO: INDUSTRIOQUE. / COMITI PETRO TROILLO A SERMAGE DE SZOMSZEDVAR, CÆ. SS. APOS. REG. MATTUM / CAMER: GENERALI VIC. PRÆ. BANNAL. TAB. ASSORI. BAR. JOS. A SERMAGE, ET IULIANÆ / BARON A MOSCON FILIO, MARITOI MAXIMILIANÆ BARON. A PRASSINSZKI, ET / EX IPSA GENITORI SUPERST. FILII PETRI NEPOM. CAMER. R. A. M. ET BAN. TABUL / ASSESSORIS, 
EX SECUNDO AUTEM CONJUG. RELICTIS FRANCISCO, IOSEPHO, ET / MAURITIO FILIIS, IUDITH VERO ET ALOYSIA FILIABUS, QUI ELEVATA FA / MILIA SUA, STABILITA QUOQUE PER INDIGENATUM IN HOC ET APOS. / HUNGARIÆ REGNO, MERITIS PLENUS OBIIT IN SZTENYEVECZ DIE / XXVI. APRIL MDCCLXXI ÆTATIS SUÆ ANN. XLVIII. MENS. XI DIERUM / MEMORIAM HANC / MARITO SUO VIDUA, ANNA MARIA COM. DRASKOVICH DE TRAKOSTEIN, BANI D. C. ET S. IOANNIS, / ET CATHARINÆ FILIA, IN AMORIS SUI PIETATISQUE, AD HÆREDUM UNIUERSORUM DEVO / TAM MEMORIAM, POSUIT, SEPULTO IN HAC B. V. M. SAC. ÆDE IN PERP. / MONUMENTUM.«

\section{Opis spomenika:}

Epitaf je izveden u obliku kartuše profiliranoga okvira koja sadrži posvetni natpis i portret pokojnika izveden u tehnici ulja na bakrenoj ploči. Pokojnik je prikazan do razine pojasa, tijela okrenuta u lijevi, a glave u desni tričetvrt profil. Odjeven je u suvremenu vojničku odoru: bijeli kaput sa zlatnim obrubom, crveni prsluk i košulju s čipkastim orukvicama. $\mathrm{Na}$ glavi nosi bijelu periku, a ispod lijeve ruke drži trorogi šešir. U gornjem dijelu kartuše nalazi se druga, manja kartuša s grbom obitelji Sermage. Povrh grba nalazi se lubanja s kacigom urešenom perjanicom, a ispod ratni trofeji (par ukriženih barjaka s bojnim bubnjevima i trubama).

\section{Literatura:}

Anđela Horvat, Barok u kontinentalnoj Hrvatskoj, u: Barok u Hrvatskoj, Zagreb: Sveučilišna naklada Liber, Odjel za povijest umjetnosti Centra za povijesne znanosti, Društvo povjesničara umjetnosti, 1982., str. 3-381, 265. Napisali Anđela Horvat, Radmila Matejčić i Kruno Prijatelj.

Anđela Horvat, Crkva Uznesenja Blažene Djevice Marije u Stenjevcu, u: Župa Uznesenja Marijina Stenjevec: u povodu 650. obljetnice prvog spomena župe (1334-1984) i 730. obljetnice gradnje crkve Bl. Dj. Marije (1257-1987), Zagreb, Stenjevec: Rkt župa Stenjevec, 1985., str. 83-141, 98, 131, 136-137. Uredili Ivan Buhin i Anđelko Mijatović.

Milan Pelc, Povijest umjetnosti u Hrvatskoj, Zagreb: Naklada Ljevak, 2012., str. 332.

Nela Tarbuk, Kiparstvo 17. i 18. stoljeća u sjevernoj Hrvatskoj, u: Od svagdana do blagdana: barok u Hrvatskoj = From everyday to holidays: baroque in Croatia, katalog izložbe, Zagreb: Muzej za umjetnost i obrt, 1993., str. 122-131, 128. 
- Kat. br. $26-$

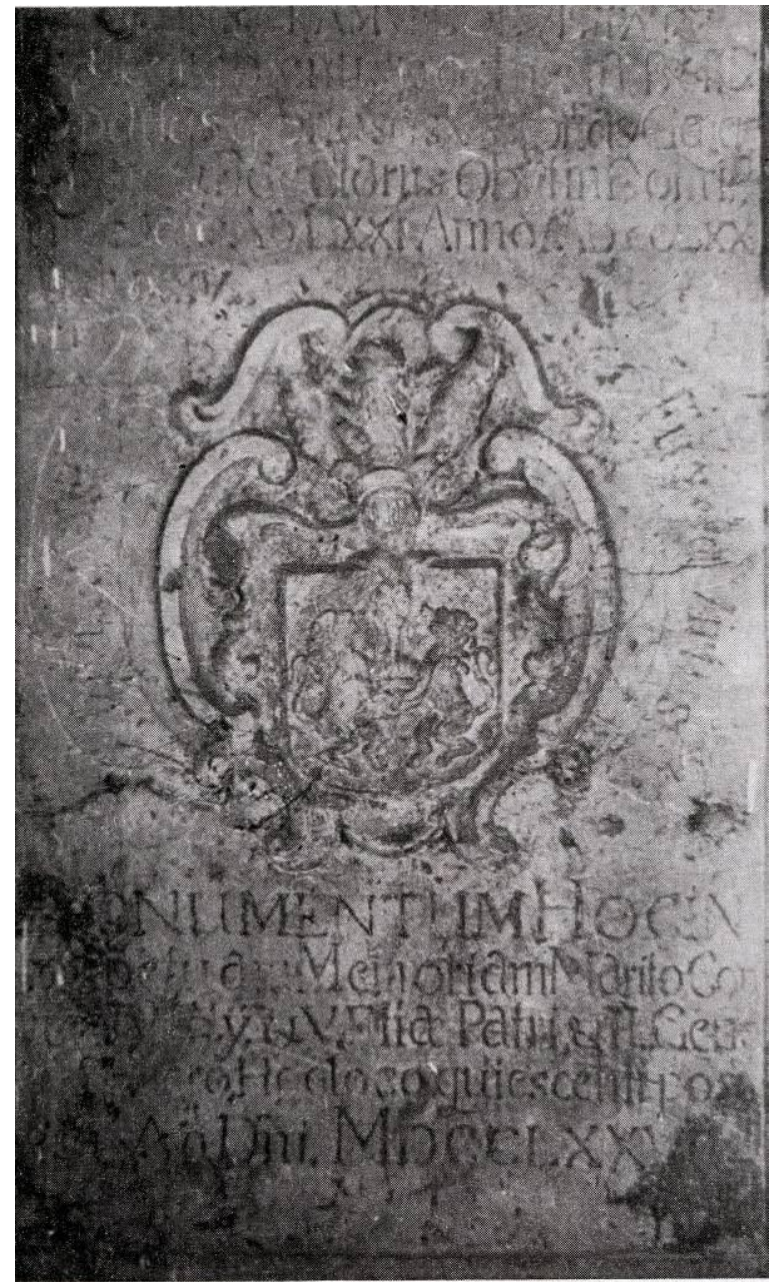

Nadgrobna ploča Vuka Jelačića (? - ?, 1770.), 1777.

Kamen, $142 \times 83 \mathrm{~cm} \times$ [uzidana].

Natpis iznad grba: »GENEROSUS DOMINUS WOLFGANGUS JELACHICH DE BUZIN SACRAE CAESAREAE REGIAE APOSTOLICAE MAJESTATIS VICE COLONELUS AERARE ET MERITIS PLENUS POST GESTA BELLA ET PARTAS GLORIOSAS VICTORIAS, GENERE, MARTE ET FIDE CLARUS, OBIIT IN DOMINO AETATIS ANNO LXXI. ANNO MDCCLXX. JULII XXV«. Natpis s lijeve i desne strane grba: „Vivit Post / Funera Virtus«. Natpis ispod grba: "MONUMENTUM HOC IN PERPETUAM MEMORIAM MARITO CONJUX, IV. FILII ET V. FILIAE PATRI ET II. GENERI SOCERO HOC LOCO QUIESCENTI POSUERE ANNO DOMINI MDCCLXXVII « ${ }^{760}$

\footnotetext{
${ }^{760}$ Natpis je preuzet iz literature jer je nadgrobna ploča danas gotovo u potpunosti zakrivena velikim sakristijskim ormarom. Usp. Anđela Horvat, nav. dj., 1985., str. 137, bilj. 118.
} 


\section{Opis spomenika:}

Nadgrobna ploča izvedena je $\mathrm{u}$ obliku okomito postavljena pravokutnika. U središtu je predočen grb obitelji Jelačić koji je ukrašen volutnim viticama i flankiran geslom »Vivit Post Funera Virtus«. Iznad i ispod grba uklesan je posvetni natpis.

\section{Literatura:}

Anđela Horvat, Crkva Uznesenja Blažene Djevice Marije u Stenjevcu, u: Župa Uznesenja Marijina Stenjevec: u povodu 650. obljetnice prvog spomena župe (1334-1984) i 730. obljetnice gradnje crkve Bl. Dj. Marije (1257-1987), Zagreb, Stenjevec: Rkt župa Stenjevec, 1985., str. 83-141, 137, 140. Uredili Ivan Buhin i Anđelko Mijatović. 


\section{SVETICE, crkva Rođenja Blažene Djevice Marije}

\section{- Kat. br. 27 -}

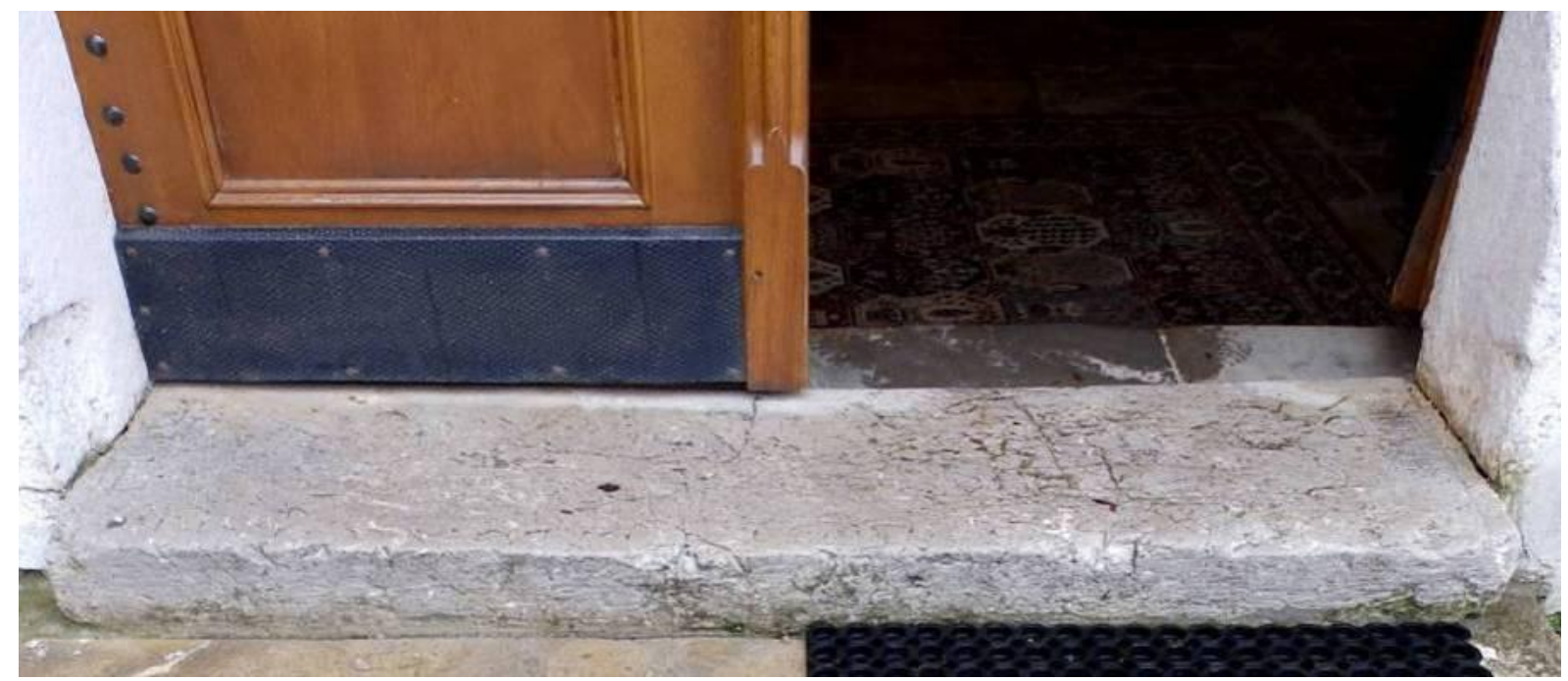

Nadgrobna ploča Stjepana IV. (III.) Frankapana Ozaljskoga (? - ?, 1577.)

Kamen, $50 \times 205 \mathrm{~cm} \times[$ postavljena u pod]

Natpis: »[...] HIC (IACET) [..]«

\section{Opis spomenika:}

Prema povijesnim izvorima, nadgrobna ploča izvorno je sadržavala grb obitelji Frankapan.

Danas je vidljiv dio natpisa koji je tekao uz rub ploče, no raspoznatljivo je tek nekoliko riječi.

\section{Literatura:}

Zorislav Horvat, Pregled sačuvanih nadgrobnih ploča Krčkih knezova Frankopana, u: Senjski zbornik: prilozi za geografiju, etnologiju, gospodarstvo, povijest i kulturu XXXII/1, Senj: Gradski muzej, Senjsko muzejsko društvo, 2005., str. 25-58, 50-51.

Zorislav Horvat, Gotička crkva na Smolčem vrhu: kasnija crkva pavlinskog samostana Svetice, u: Vjesnik Arheološkog muzeja u Zagrebu XLIII/1V, Zagreb: Arheološki muzej u Zagrebu, 2010., str. 193-204, 196.

Radoslav Lopašić, Oko Kupe $i$ Korane. Mjestopisne i povjestne crtice, Zagreb: Matica hrvatska, 1895., str. 298, bilj. 1. Dopunio Emilije Laszowski. 
- Kat. br. 28 -
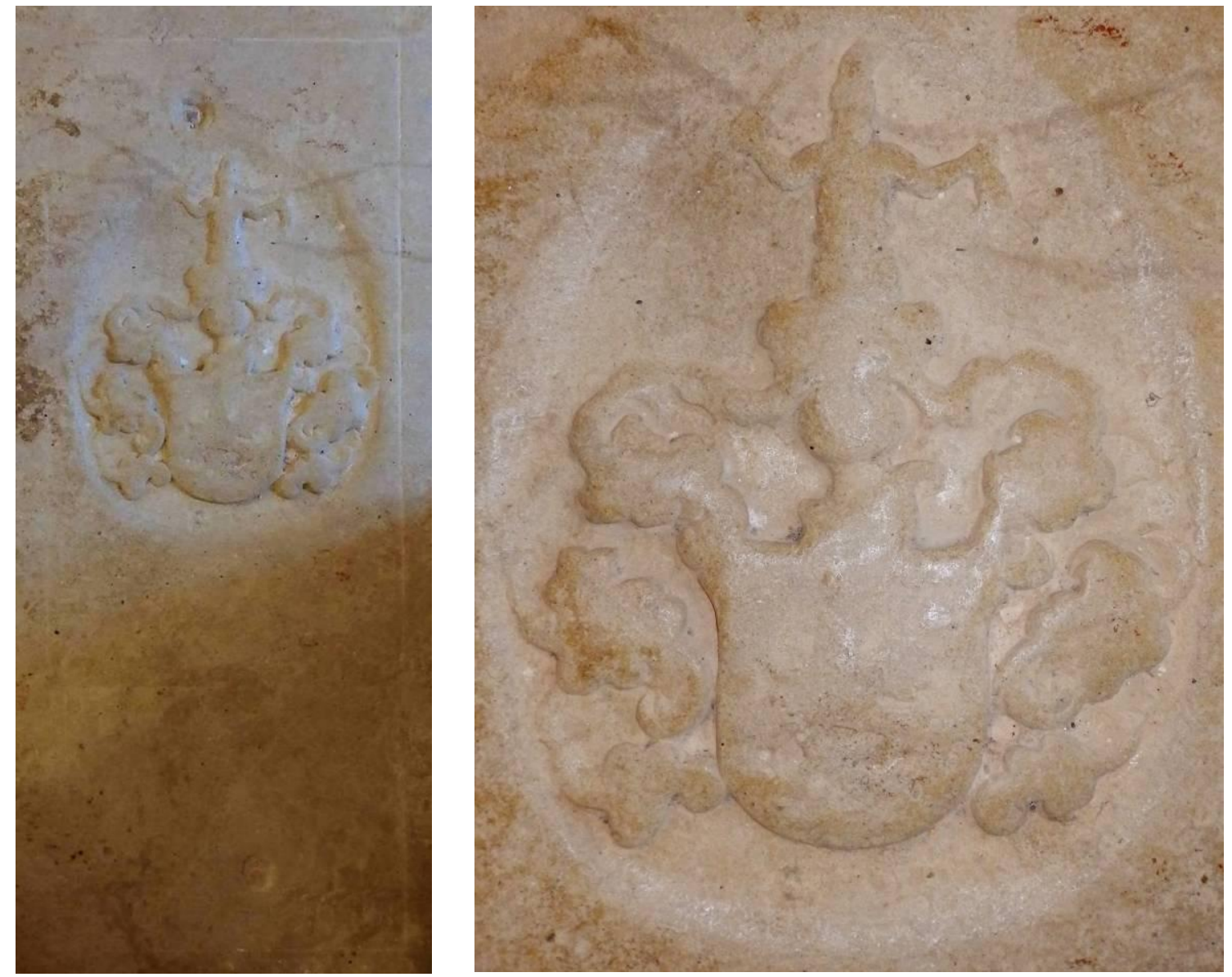

Nadgrobna ploča obitelji Zmajlović (II. pol. XVII. st.)

Kamen, $165 \times 75 \mathrm{~cm} \times$ [postavljena u pod]

Natpis: »[...] 1666«

\section{Opis spomenika:}

Jednostavna nadgrobna ploča izvedena u obliku okomito postavljena pravokutnika. Sadrži grb obitelji Zmajlović koji je uklesan u gornjem dijelu ploče unutar ovalnoga polja. Ispod grba nekoć se nalazio natpis koji je danas većim dijelom istrošen.

\section{Literatura:}

Đurđica Cvitanović, Sakralna arhitektura baroknog razdoblja. Knjiga I. Gorički i gorskodubički arhiđakonat, Zagreb: Društvo povjesničara umjetnosti SR Hrvatske, 1985., str. 265. 


\section{ZAGREB, katedrala Uznesenja Blažene Djevice Marije i sv. Stjepana i Ladislava}

\section{- Kat. br. 29 -}

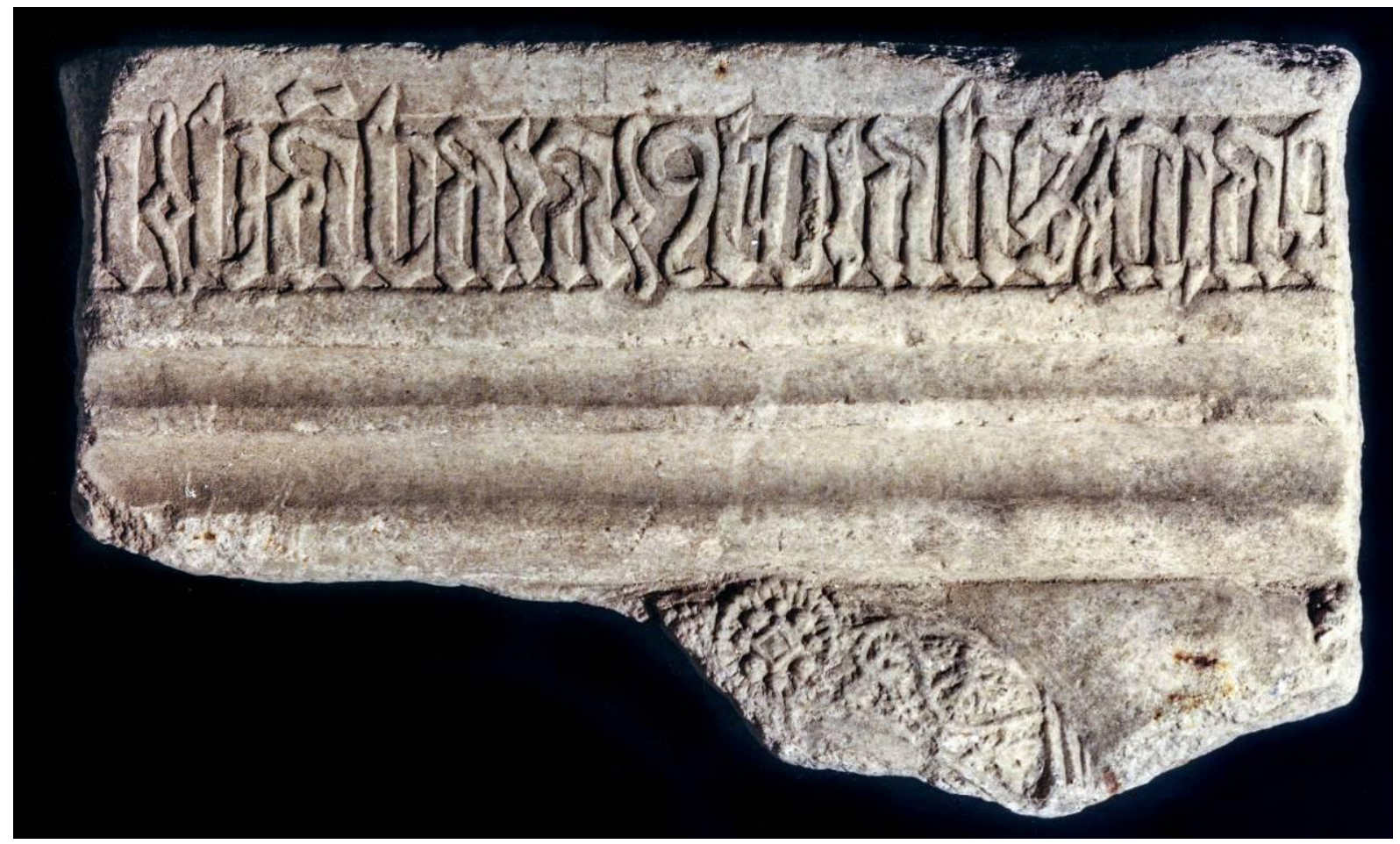

\section{Nadgrobna ploča plemkinje Barbare, XV. stoljeće}

Kristalični vapnenac, $16 \times 18 \times 6 \mathrm{~cm}$

Ploča je danas pohranjena u Hrvatskom povijesnom muzeju u Zagrebu.

Natpis: $»[\ldots] \S$ babara $\S$ ntoralis $\S \operatorname{mag}[\ldots] \ll$

\section{Opis spomenika:}

Sačuvan je gornji dio nadgrobne ploče na kojem je vidljiv dio natpisa pisanoga na gotičkoj minuskuli, profilirani okvir, jastuk i pokojničina bogato ukrašena dijadema.

\section{Literatura:}

Doris Baričević, Skulptura i slikarstvo, katalog S, u: Riznica zagrebačke katedrale $=$ The Treasury of Zagreb Cathedral, katalog izložbe, Zagreb: MTM, 1987. [1983.], str. 5564, 56. Uredila Zdenka Munk.

Josip Brunšmid, Kameni spomenici hrvatskoga narodnoga muzeja u Zagrebu. Dio II. Spomenici srednjega i novoga vijeka, u: Vjesnik Hrvatskoga arheološkog društva XII/ 1, Zagreb: Hrvatsko arheološko društvo, 1912., str. 129-197, 177.

Anđela Horvat, Dva epitafa u Iloku, u: Zbornik za likovne umetnosti 15, Novi Sad: Matica srpska, Odelenje za likovne umetnosti, 1979., str. 307-315, 309. 
Ljubo Karaman, O umjetnosti srednjega vijeka, u: Historijski zbornik III/1-4, Zagreb: Društvo za hrvatsku povjesnicu, 1950., str. 125-174, 147.

Mirko Valentić, Kameni spomenici Hrvatske XIII-XIX stoljeća, Zagreb: Povijesni muzej Hrvatske, 1969., str. 26-27.

Mirko Valentić i Lada Prister, Zbirka kamenih spomenika, II. dopunjeno izdanje, Zagreb: Hrvatski povijesni muzej, 2002., str. 25.

Diana Vukičević-Samaržija, Umjetnost kasnog srednjeg vijeka, u: Sveti trag. Devetsto godina umjetnosti Zagrebačke nadbiskupije 1094.-1994., MGC - Muzej Mimara, Zagreb, 10. rujna - 31. prosinca 1994., Zagreb: Zagrebačka nadbiskupija, Institut za povijest umjetnosti, Muzejsko-galerijski centar, 1994., str. 133-172, 166. Uredili Tugomir Lukšić i Ivanka Reberski. 
- Kat. br. 30 -
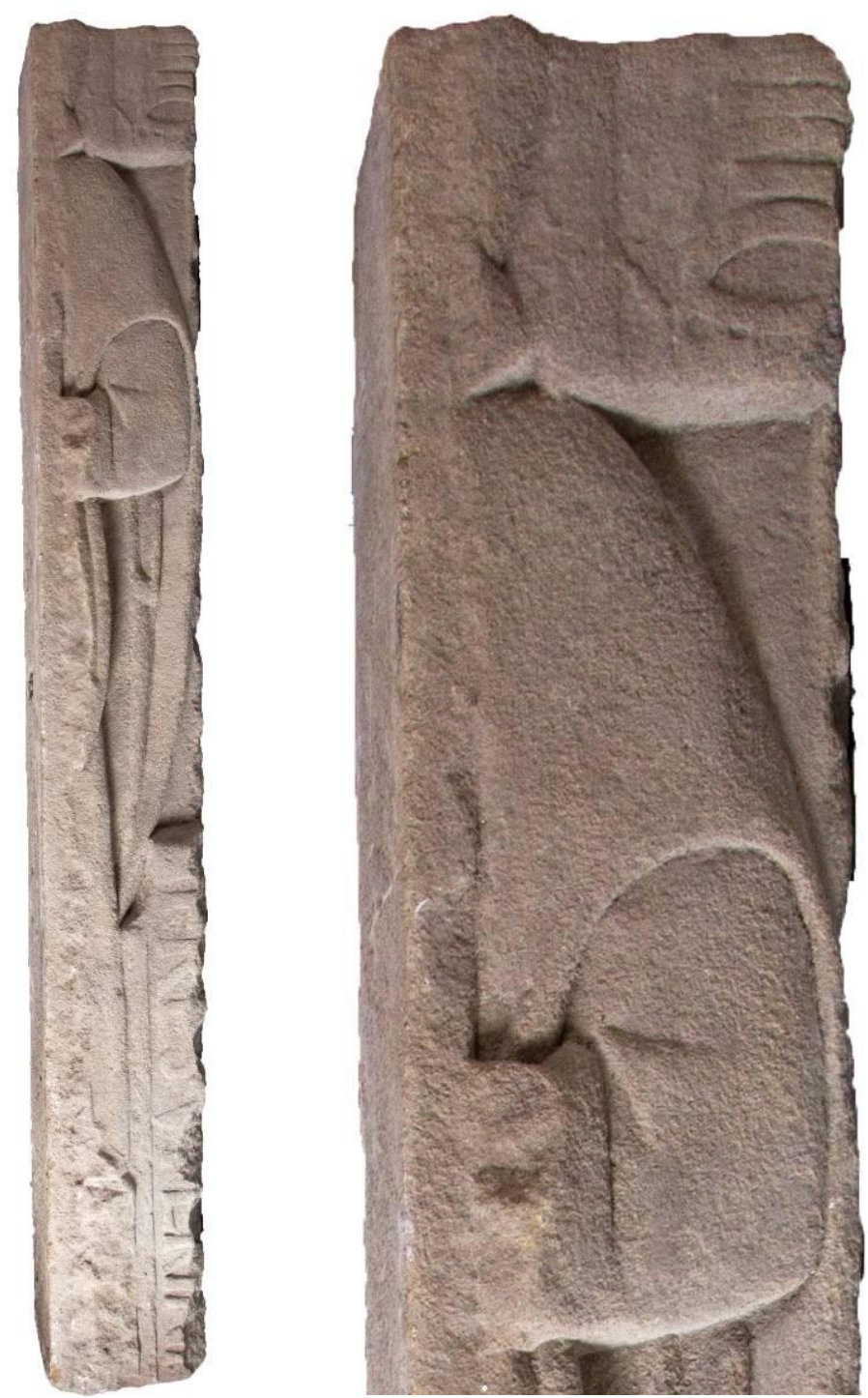

Nadgrobna ploča crkvenoga dostojanstvenika, XV. stoljeće

Kamen pješčenjak, $183 \times 23 \times 13 \mathrm{~cm}$

Ploča je danas pohranjena u Hrvatskom povijesnom muzeju u Zagrebu.

\section{Opis spomenika:}

Sačuvan je uski pojas uz desni rub nadgrobnika koji prikazuje dio tijela pokojnika odjevena u misno ruho. Vidljiv je dio jastuka s resom, stoga možemo pretpostaviti da je pokojnikova glava počivala na jastuku. Uz rub ploče očuvan je dio nadgrobnoga natpisa koji je teško rekonstruirati zbog velikoga stupnja oštećenosti. 


\section{Literatura:}

Lada Prister, Zbirka kamenih spomenika, u: Museum 1846.-1996., katalog izložbe, Zagreb: Hrvatski povijesni muzej, 1996. str. 20-25, 22. Uredila Maja Škiljan.

Mirko Valentić, Kameni spomenici Hrvatske XIII-XIX stoljeća, Zagreb: Povijesni muzej Hrvatske, 1969., str. 30.

Mirko Valentić i Lada Prister, Zbirka kamenih spomenika, II. dopunjeno izdanje, Zagreb: Hrvatski povijesni muzej, 2002., str. 25-26.

Diana Vukičević-Samaržija, Umjetnost renesanse, u: Sveti trag. Devetsto godina umjetnosti Zagrebačke nadbiskupije 1094.-1994., MGC - Muzej Mimara, Zagreb, 10. rujna - 31. prosinca 1994., Zagreb: Zagrebačka nadbiskupija, Institut za povijest umjetnosti, Muzejsko-galerijski centar, 1994., str. 175-188, 169. Uredili Tugomir Lukšić i Ivanka Reberski. 
- Kat. br. 31 -

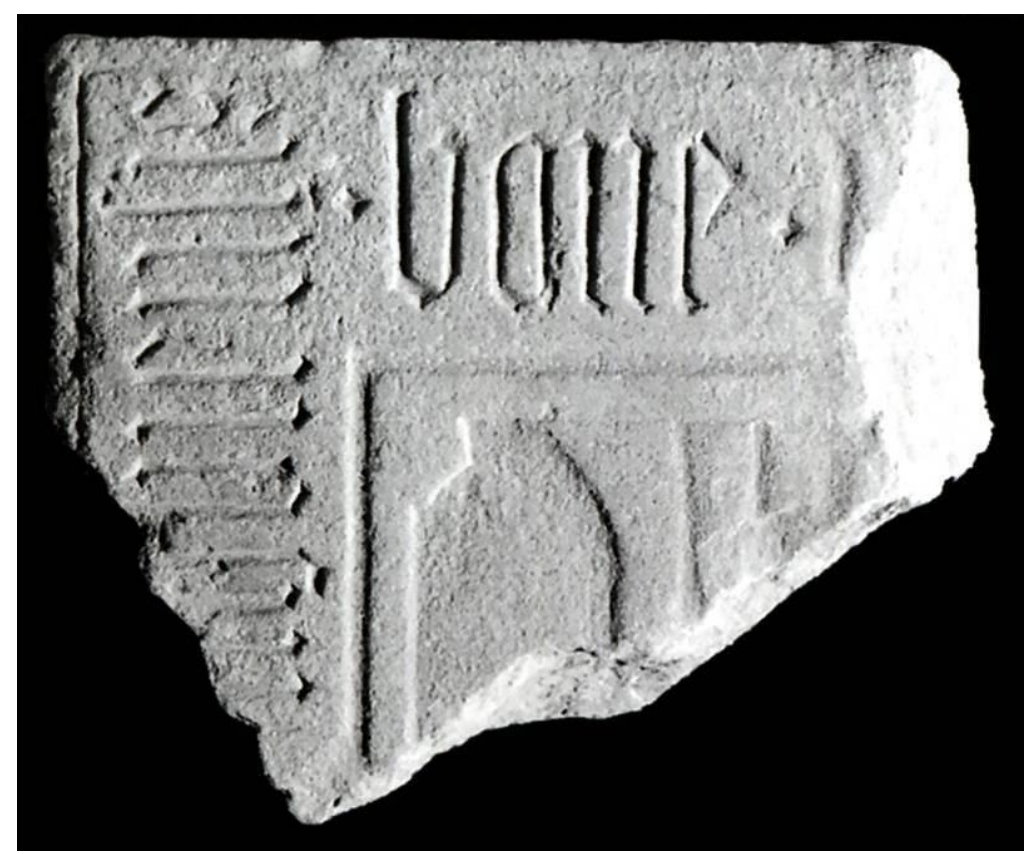

\section{Ulomak nadgrobne ploče, XV. stoljeće}

Pješčenjak, $42 \times 46 \times 15 \mathrm{~cm}$

Ploča je danas pohranjena u Hrvatskom povijesnom muzeju u Zagrebu.

Natpis: »[...] (zagra)biensis / · bone $\cdot($ memorie) $[\ldots] \lll$

\section{Opis spomenika:}

Sačuvan je gornji lijevi ulomak nadgrobne ploče na kojem je vidljiv rub plitke niše i dio natpisa na gotičkoj minuskuli koji teče uz rubove. Postoji mogućnost da je očuvani ulomak dio nadgrobne ploče s likom pokojnika odjevenoga u biskupsko ruho koja je pronađena ispod popločenja svetišta zagrebačke katedrale prilikom njezine obnove nakon potresa 1880 . godine.

\section{Literatura:}

Josip Brunšmid, Kameni spomenici hrvatskoga narodnoga muzeja u Zagrebu. Dio II. Spomenici srednjega i novoga vijeka, u: Vjesnik Hrvatskoga arheološkog društva XII/ 1, Zagreb: Hrvatsko arheološko društvo, 1912., str. 129-197, 184-185.

Ivan Krstitelj Tkalčić, Prvostolna crkva zagrebačka nekoć i sada, Zagreb: Knjigotiskara Karla Albrechta, 1885., str. 54

Mirko Valentić i Lada Prister, Zbirka kamenih spomenika, II. dopunjeno izdanje, Zagreb: Hrvatski povijesni muzej, 2002., str. 25. 


\section{THUZ de SZENTHLASZLL.}

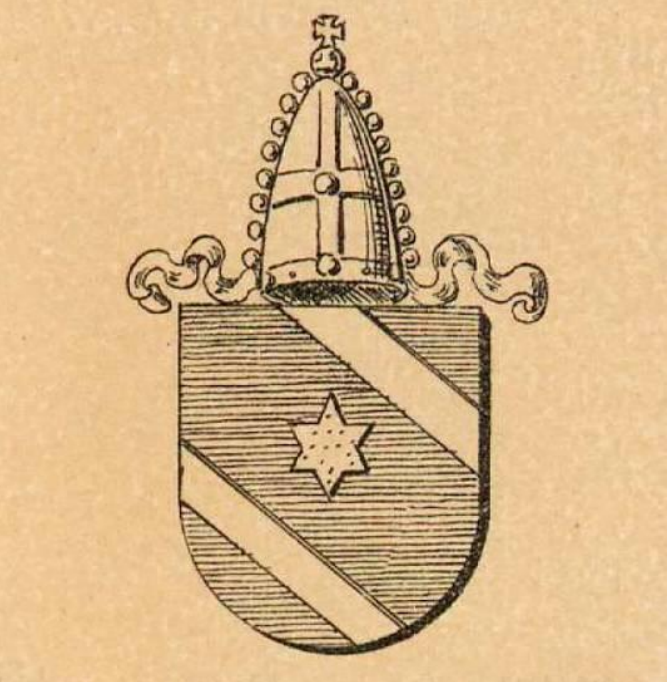

Nadgrobna ploča biskupa Osvalda Thuza od Svetoga Ladislava (?, 1438. - Čazma, 1499.)

Ploča nije sačuvana, ali je dokumentirana u pisanim izvorima.

Natpis: "ZAGRABIAE OSVALDVS MANET HIC SVB MARMORE PRAESVL. / EXEMPLVM VERAE QVI PROBITATIS ERAT. / FAMA SVVM CELEBRAT, PEREAT NE PVLVERE NOMEN. / VIRTVTVM MERITIS, SPIRITVS ASTRA TENET “761

\section{Opis spomenika:}

Prema pisanim izvorima, ploča je sadržavala lik pokojnika (najvjerojatnije odjevenoga u biskupsko ruho, s mitrom na glavi i pastoralom u ruci) i obiteljski grb.

\section{Literatura:}

Janko Barlé, Svečanosti prigodom ukopa zagrebačkoga biskupa Osvalda Thuza, u: Katolički list LXVI/32, Zagreb: Nadbiskupija zagrebačka, 1915., str. 328-330, 330.

Ivan Kukuljević Sakcinski, Prvostolna crkva zagrebačka: opisana s gledišta povjesnice, umjetnosti $i$ starinah, Zagreb: Narodna tiskara Ljudevita Gaja, 1856., str. 22.

Ivan Kukuljević Sakcinski, Nadpisi sredovječni i novovjeki na crkvah, javnih i privatnih sgradah itd. u Hrvatskoj i Slavoniji, Zagreb: Knjižara Jugoslavenske akademije, Knjižara Dioničke tiskare, 1891., str. 326, br. 1124.

Baltazar Adam Krčelić, Povijest Stolne crkve zagrebačke, Zagreb: Institut za suvremenu povijest, 1994., str. 223. Preveo Zlatko Šešelj.

\footnotetext{
${ }^{761}$ Prijepis preuzet iz: Ivan Kukuljević Sakcinski, nav. dj., 1891., str. 326, br. 1124.
} 
Milan Pelc, Spomenici potonuloga svijeta. Nadgrobne ploče s likom pokojnika u sjevernoj Hrvatskoj u pisanim i tiskanim vrelima do konca 19. st., u: Umjetnost i naručitelj. Zbornik radova znanstvenoga skupa "Dani Cvita Fiskovića" održanog 2008. godine, Zagreb: Institut za povijest umjetnosti, Odsjek za povijest umjetnosti Filozofskog fakulteta Sveučilišta u Zagrebu, 2010., str. 61-71, 65. Uredila Jasenka Gudelj.

Ivan Krstitelj Tkalčić, Prvostolna crkva zagrebačka nekoć i sada, Zagreb: Knjigotiskara Karla Albrechta, 1885., str. 55. 


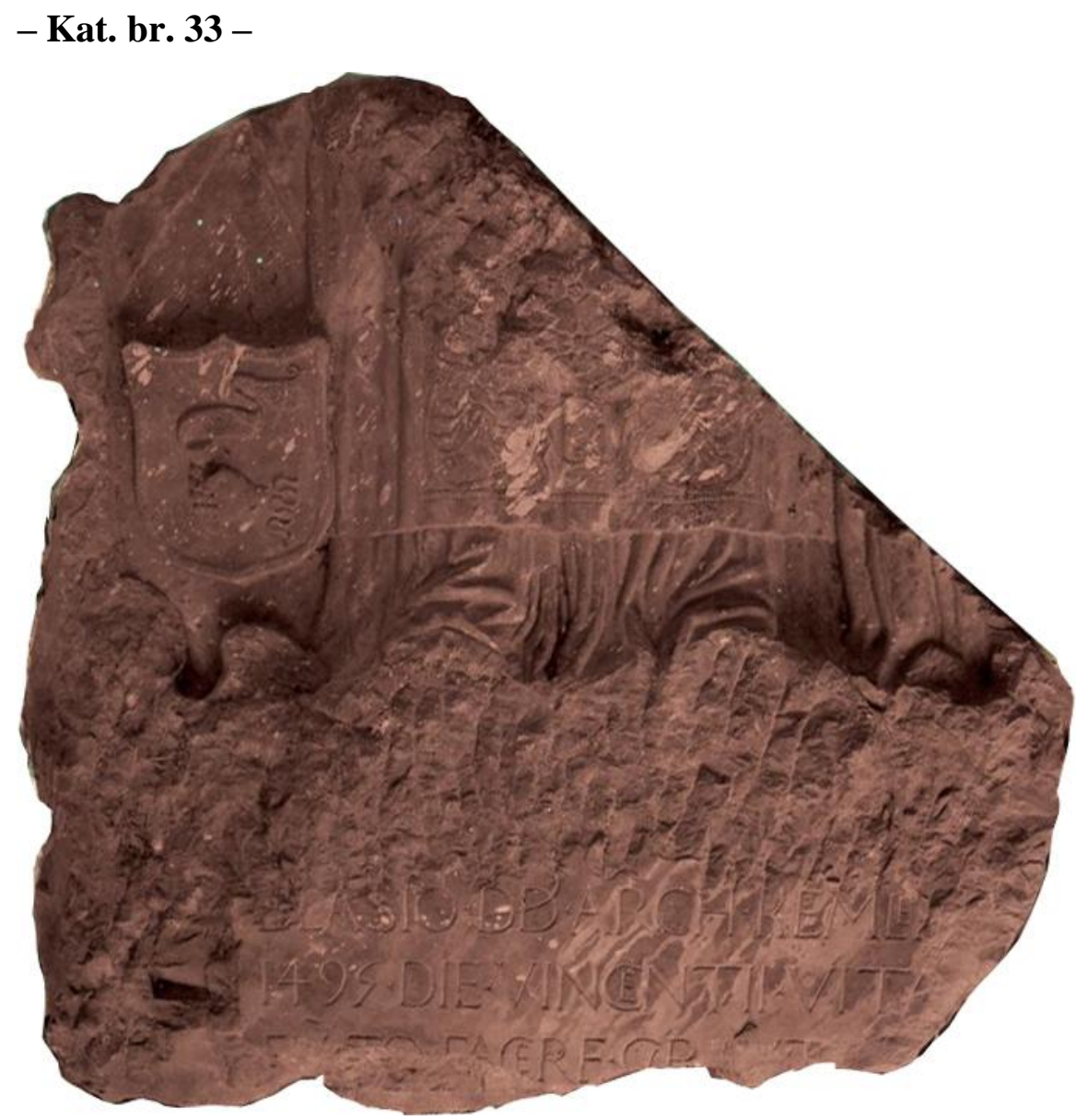

Nadgrobna ploča kanonikā Blaža i Ivana od Moravča, 1495.

Crveni vapnenac, $116 \times 99 \times 11 \mathrm{~cm}$

Ploča je danas pohranjena u Muzeju grada Zagreba u Zagrebu.

Natpis: »(IOANNES DE MAROCHA ARCHIDIACONVS GORICENSIS SIBI SVOQVE FRATRI) / BLASIO - DD · ARCH · KEMLEK / 1495 - DIE · VINCENTII · VITA / FVNCTO · FACERE · CVRAVIT«

\section{Opis spomenika:}

Sačuvan je donji dio nadgrobne ploče na kojoj je prikazan pokojnik odjeven u misno ruho. Lijevo od njegovih cjevanica predočen je štit s grbovnim simbolom obitelji Moravčanin šakom koja drži ukrasnu vrpcu. Ispod figure pokojnika uklesan je natpis u klasičnoj majuskuli.

\section{Literatura:}

Lelja Dobronić, Renesansa u Zagrebu, Zagreb: Institut za povijest umjetnosti, 1994., str. 3638. 
Anđela Horvat, Između gotike i baroka: umjetnost kontinentalnog dijela Hrvatske od oko 1500. do oko 1700., Zagreb: Društvo povjesničara umjetnosti SR Hrvatske, 1975., str. 41.

Anđela Horvat, Dva epitafa u Iloku, u: Zbornik za likovne umetnosti 15, Novi Sad: Matica srpska, Odelenje za likovne umetnosti, 1979., str. 307-315, 310.

Ljudevit Ivančan i Gjuro Szabo, Spomen-kamen kanonika Vukoslavića - nadgrobna ploča Blaža od Moravča (1495.), u: Narodna starina VIII/19, Zagreb: Josip Matasović, 1929., str. $105-107$.

Ljubo Karaman, $O$ umjetnosti srednjega vijeka, u: Historijski zbornik III/1-4, Zagreb: Društvo za hrvatsku povjesnicu, 1950., str. 125-174, 147.

Ivan Kukuljević Sakcinski, Prvostolna crkva zagrebačka: opisana s gledišta povjesnice, umjetnosti i starinah, Zagreb: Narodna tiskara Ljudevita Gaja, 1856., str. 25.

Ivan Kukuljević Sakcinski, Nadpisi sredovječni i novovjeki na crkvah, javnih i privatnih sgradah itd. u Hrvatskoj i Slavoniji, Zagreb: Knjižara Jugoslavenske akademije, Knjižara Dioničke tiskare, 1891., str. 325, br. 1120.

Vladimir Maleković (ur.), Od svagdana do blagdana: Barok u Hrvatskoj. Muzej za umjetnost i obrt, Zagreb, 25.5. - 26.9.1993. Katalog: vrijeme pobožnosti, katalog izložbe, Zagreb: Muzej za umjetnost i obrt, 1993., str. 410 [Slavko Šterk].

Milan Pelc, Spomenici potonuloga svijeta. Nadgrobne ploče s likom pokojnika u sjevernoj Hrvatskoj u pisanim i tiskanim vrelima do konca 19. st., u: Umjetnost $i$ naručitelj. Zbornik radova znanstvenoga skupa "Dani Cvita Fiskovića" održanog 2008. godine, Zagreb: Institut za povijest umjetnosti, Odsjek za povijest umjetnosti Filozofskog fakulteta Sveučilišta u Zagrebu, 2010., str. 61-71, 65-66. Uredila Jasenka Gudelj.

Ivan Krstitelj Tkalčić, Prvostolna crkva zagrebačka nekoć i sada, Zagreb: Knjigotiskara Karla Albrechta, 1885., str. 67. 
- Kat. br. 34 -
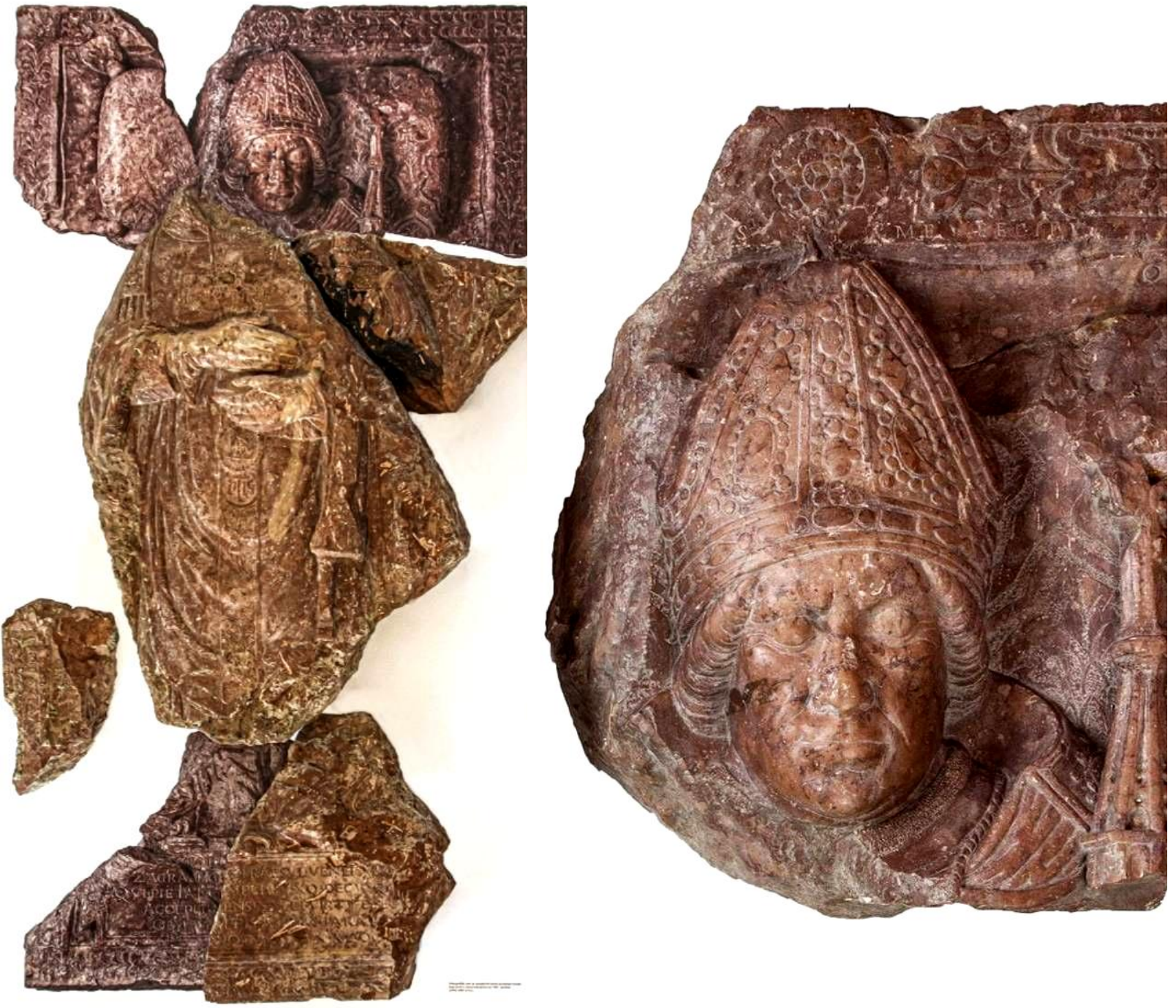

Nadgrobna ploča biskupa Luke od Szegeda (Szeged, ? - Čazma, 1510.)

Vapnenačka breča, gornji ulomci 56 × 103 x $13 \mathrm{~cm}$, donji ulomci 40 x 60 x $13 \mathrm{~cm}^{762}$

Dijelovi ploče danas su pohranjeni u Hrvatskom povijesnom muzeju u Zagrebu i Dijecezanskom muzeju Zagrebačke nadbiskupije.

Natpis na ukrasnoj traci: »IOA(NNES) [...]S ME FECIT«. Natpis ispod figure pokojnika: "HIC $\cdot$ SITUS $\cdot$ EST $\cdot$ LVCAS $\cdot$ PRAESVL $\cdot$ VENERABILIS / ZAGRABIAE · TEMPLI · LVXQVE · DECVSQVE · SACRI / QVI · PIETATE · PARENS · NVLLI · VIRTVTE · SECVNDVS / ACCEPIT $\cdot$ MERITIS $\cdot$ ASTRA $\cdot$ PARATA $\cdot$ SVIS / OBIIT $\cdot$ ANNO $\cdot$ MDX $\cdot$ KALENDIS · OCTOBRIS «

\footnotetext{
${ }^{762}$ Dostupne su samo dimenzije ulomaka pohranjenih u Hrvatskome povijesnom muzeju.
} 


\section{Opis spomenika:}

Nadgrobna ploča s likom pokojnika glave oslonjene na jastuk. Pokojnik je prikazan en face. Odjeven je u pontifikalno ruho, na glavi nosi mitru, a oko vrata pektoral. Ruke drži položene na prsima. Desna počiva na pektoralu, a u lijevoj drži patenu. Lijevom rukom ujedno pridržava pastoral koji je položen uz njegovo tijelo. Ispod figure pokojnika nalazi se tabula ansata s posvetnim natpisom. Uz rub ploče teče uska dekorativna traka ukrašena vegetabilnim motivima. Pokojnikovo tijelo položeno je na tkaninu koja je čavlićima pričvršćena uz unutarnji rub opisane dekorativne trake. Prema opisu Baltazara Adama Krčelića (1770.), nadgrobnik je sadržavao i biskupov grb (štit s grifonom koji gazi krunu) izveden u bronci.

\section{Literatura:}

Jolán Balogh, Die Kunst der Renaissance in Ungarn, u: Matthias Corvinus und die Renaissance in Ungarn 1458-1541, Schallaburg '82, 8. Mai - 1. November 1982, Megjelenés, Wien: Amt der Niederösterreichischen Landesregierung, 1982., str. 81107, 97, 101. Uredio Gottfried Stangler.

Doris Baričević, Skulptura i slikarstvo, katalog S, u: Riznica zagrebačke katedrale = The Treasury of Zagreb Cathedral, katalog izložbe, Zagreb: MTM, 1987. [1983.], str. 5564, 58. Uredila Zdenka Munk.

Josip Brunšmid, Kameni spomenici hrvatskoga narodnoga muzeja u Zagrebu. Dio II. Spomenici srednjega i novoga vijeka, u: Vjesnik Hrvatskoga arheološkog društva XII/ 1, Zagreb: Hrvatsko arheološko društvo, 1912., str. 129-197, 183-185.

Lelja Dobronić, Biskupski i kaptolski Zagreb, Zagreb: Školska knjiga, 1991., str. 34

Lelja Dobronić, Renesansa u Zagrebu, Zagreb: Institut za povijest umjetnosti, 1994., str. 74.

Igor Fisković, Renesansno kiparstvo, u: Tisuću godina hrvatskog kiparstva, Zagreb: Muzejsko galerijski centar, 1997., str. 155-219, 207. Uredio Igor Fisković.

Igor Fisković, Ulomci grobne ploče zagrebačkoga biskupa (početak XVI. st.), u: Hrvatska renesansa: katalog izložbe, Zagreb: Galerija Klovićevi dvori, 2004., str. 256, br. K. 32. Uredili Miljenko Jurković i Alain Erlande-Brandenburg.

Anđela Horvat, Između gotike i baroka: umjetnost kontinentalnog dijela Hrvatske od oko 1500. do oko 1700., Zagreb: Društvo povjesničara umjetnosti SR Hrvatske, 1975., str. $41,44-45,351$.

Anđela Horvat, Dva epitafa u Iloku, u: Zbornik za likovne umetnosti 15, Novi Sad: Matica srpska, Odelenje za likovne umetnosti, 1979., str. 307-315, 310. 
Željko Jiroušek, Pregled razvoja likovnih umjetnosti u banskoj Hrvatskoj. Od XII. do kraja XVIII. stoljeća, u: Naša domovina, svezak 2. Hrvatska kultura - politička poviest Hrvata, Zagreb: Izdanje Glavnog ustaškog stana, 1943., str. 680-697, 692.

Ivan Kampuš i Ljubo Karaman, Tisućljetni Zagreb: od davnih naselja do suvremenog grada, Zagreb: Školska knjiga, 1994., str. 84.

Ljubo Karaman, O umjetnosti srednjega vijeka u Hrvatskoj i Slavoniji, u: Historijski zbornik I/1-4, Zagreb: Društvo za hrvatsku povjesnicu, 1948., str. 103-127, 107.

Ljubo Karaman, O umjetnosti srednjega vijeka, u: Historijski zbornik III/1-4, Zagreb: Društvo za hrvatsku povjesnicu, 1950., str. 125-174, 168.

Baltazar Adam Krčelić, Povijest Stolne crkve zagrebačke, Zagreb: Institut za suvremenu povijest, 1994., str. 240. Preveo Zlatko Šešelj.

Ivan Kukuljević Sakcinski, Prvostolna crkva zagrebačka: opisana s gledišta povjesnice, umjetnosti i starinah, Zagreb: Narodna tiskara Ljudevita Gaja, 1856., str. 23.

Ivan Kukuljević Sakcinski, Nadpisi sredovječni i novovjeki na crkvah, javnih i privatnih sgradah itd. $u$ Hrvatskoj $i$ Slavoniji, Zagreb: Knjižara Jugoslavenske akademije, Knjižara Dioničke tiskare, 1891., str. 327, br. 1129.

Milan Pelc, Ugarske kiparske radionice i renesansa u sjevernoj Hrvatskoj, u: Radovi Instituta za povijest umjetnosti 30, Zagreb: Institut za povijest umjetnosti, 2006., str. 67-80, 67-71.

Milan Pelc, Renesansa, Zagreb: Naklada Ljevak, 2007., 303, 315-317.

Milan Pelc, Renesansa, u: Hrvatska umjetnost: povijest i spomenici, Zagreb: Institut za povijest umjetnosti, Školska knjiga, 2010., str. 197-247, 247.

Milan Pelc, Spomenici potonuloga svijeta. Nadgrobne ploče s likom pokojnika u sjevernoj Hrvatskoj u pisanim i tiskanim vrelima do konca 19. st., u: Umjetnost i naručitelj. Zbornik radova znanstvenoga skupa "Dani Cvita Fiskovića" održanog 2008. godine, Zagreb: Institut za povijest umjetnosti, Odsjek za povijest umjetnosti Filozofskog fakulteta Sveučilišta u Zagrebu, 2010., str. 61-71, 66. Uredila Jasenka Gudelj.

Milan Pelc, Povijest umjetnosti u Hrvatskoj, Zagreb: Naklada Ljevak, 2012., str. 236.

Kruno Prijatelj, Prinosi za monografiju o Ivanu Duknoviću, u: Anali Historijskog instituta u Dubrovniku IV/V, Dubrovnik: Historijski institut Jugoslavenske akademije znanosti i umjetnosti u Dubrovniku, 1956., str. 305-321, 316.

Kruno Prijatelj, Ivan Duknović, Zagreb: Društvo historičara umjetnosti, 1957., str. 34.

Gjuro Szabo, Ljudi iz kamena, u: Jutarnji list, Zagreb: Tipografija, 24. XII. 1938., str. 5-6, 5.

Ivan Krstitelj Tkalčić, Prvostolna crkva zagrebačka nekoć i sada, Zagreb: Knjigotiskara Karla Albrechta, 1885., str. 56. 
Mirko Valentić, Kameni spomenici Hrvatske XIII-XIX stoljeća, Zagreb: Povijesni muzej Hrvatske, 1969., 31-36.

Mirko Valentić i Lada Prister, Zbirka kamenih spomenika, II. dopunjeno izdanje, Zagreb: Hrvatski povijesni muzej, 2002., str. 26-27.

Diana Vukičević-Samaržija, Umjetnost renesanse, u: Sveti trag. Devetsto godina umjetnosti Zagrebačke nadbiskupije 1094.-1994., MGC - Muzej Mimara, Zagreb, 10. rujna - 31. prosinca 1994., Zagreb: Zagrebačka nadbiskupija, Institut za povijest umjetnosti, Muzejsko-galerijski centar, 1994., str. 175-188, 177, 186. Uredili Tugomir Lukšić i Ivanka Reberski.

Diana Vukičević-Samaržija, Likovne pojave na kraju XV. i početkom XVI. stoljeća - gotika u renesansi, u: Zagrebačka biskupija i Zagreb, 1094 - 1994. Zbornik u čast kardinala Franje Kuharića, Zagreb: Nadbiskupija zagrebačka, 1995., str. 551-558, 553-554. 
- Kat. br. 35 -

Nadgrobna ploča bana Franje I. Frankapana Slunjskoga (Slunj, 1536. - Varaždin, 1572.)

Ploča nije sačuvana, ali je dokumentirana u pisanim izvorima.

Natpis iznad lika pokojnika: »MEMORIAE SPECTAB. AC MAGNIF. D. FRANC. ZLVNY

DE FRANGEP. SEGN. VEGLIAE MODRVSIAEQVE COMITIS. DALMATIAE, CHROATIAE. SCLAV. BANI FIDELISS. ET FORTISS. ANNA SOROR RELICTA MAGN. NICOL. OLIM CZAZAR PIG. FRATRI CARISS. POSVIT. VIXIT AN. XXXVI. MORT. XI. DECEMB. MDLXXII VARASDINI«. Natpis ispod lika pokojnika: »ZLVNYA STIRPS CECIDIT FRANCISCVS MARTIS ALVMNVS. / INFESTVS RASIS, TERROR ERATQVE GETIS / EST PROAVIS CLARUS, SED DEXTRA PROMPTIOR VSQVE. / CONSILIOQVE INFERT DAMNA CRVENTA SCYTHIS. / BANVS ERAT DALMAT. SCLAVORVM TVNCQUE CROATIAE. / PROELIA COMMISIT FAVSTA, TROPHEA TVLIT. / SED QVIA PANNONIAE VIX SPES EST VLLA SALVTIS / NI DEUS ACCVRRAT, QUID SVPERESSE VELIT. / ERGO DIIS MIXTVS, POTIORI PARTE TRIVMPHAT. / OSSA TEGIT MARMOR, MENS PIA NOVIT ITER « ${ }^{763}$

\section{Opis nadgrobnika:}

Prema pisanim izvorima, ploča je bila izrađena od crvenoga mramora, a sadržavala je lik viteza-pokojnika koji kleči u molitvi.

\section{Literatura:}

Lelja Dobronić, Renesansa u Zagrebu, Zagreb: Institut za povijest umjetnosti, 1994., str. 113. Ivan Kukuljević Sakcinski, Prvostolna crkva zagrebačka: opisana s gledišta povjesnice, umjetnosti i starinah, Zagreb: Narodna tiskara Ljudevita Gaja, 1856., str. 20-21.

Ivan Kukuljević Sakcinski, Nadpisi sredovječni i novovjeki na crkvah, javnih i privatnih sgradah itd. u Hrvatskoj i Slavoniji, Zagreb: Knjižara Jugoslavenske akademije, Knjižara Dioničke tiskare, 1891., str. 328, br. 1134.

Milan Pelc, Spomenici potonuloga svijeta. Nadgrobne ploče s likom pokojnika u sjevernoj Hrvatskoj u pisanim i tiskanim vrelima do konca 19. st., u: Umjetnost $i$ naručitelj. Zbornik radova znanstvenoga skupa "Dani Cvita Fiskovića" održanog 2008. godine, Zagreb: Institut za povijest umjetnosti, Odsjek za povijest umjetnosti Filozofskog fakulteta Sveučilišta u Zagrebu, 2010., str. 61-71, 66. Uredila Jasenka Gudelj.

\footnotetext{
${ }^{763}$ Prijepis preuzet iz: Ivan Krstitelj Tkalčić, nav. dj., 1885., str. 57.
} 
Slavko Šterk i Boris Mašić, Mors porta vitae = Smrt vrata života: stara zagrebačka groblja $i$ pogrebi, Zagreb: Muzej grada Zagreba, 2014., str. 52.

Ivan Krstitelj Tkalčić, Prvostolna crkva zagrebačka nekoć i sada, Zagreb: Knjigotiskara Karla Albrechta, 1885., str. 57. 
- Kat. br. $36-$

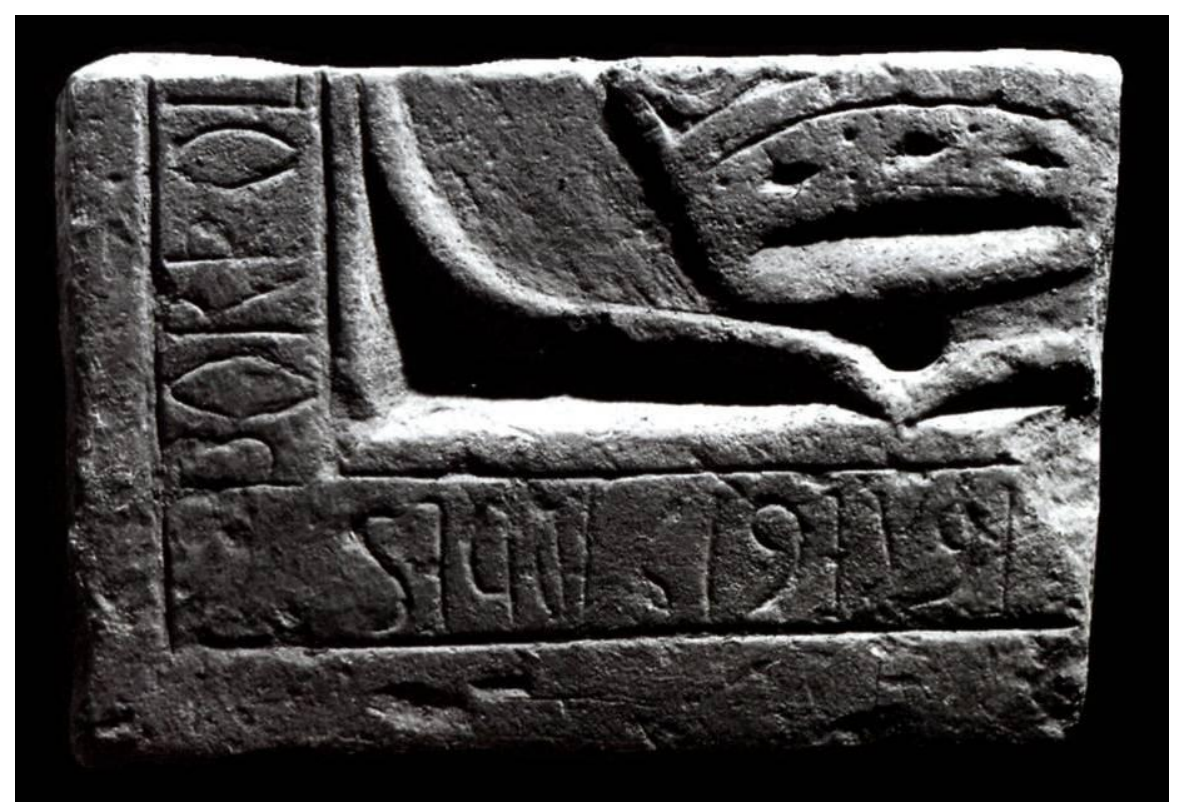

Ulomak nadgrobne ploče s grbom, 1619.

Vapnenac, $36 \times 53 \times 22 \mathrm{~cm}$

Ploča je danas pohranjena u Hrvatskome povijesnome muzeju u Zagrebu.

Natpis: »[...] E A 1619 IOHES / BORA OL [...]«

\section{Opis spomenika:}

Sačuvan je donji lijevi rub nadgrobnika na kojem je vidljiv dio središnjega polja s obiteljskim grbom (vidljiv dio štita) i natpis koji teče uz rub ploče.

\section{Literatura:}

Mirko Valentić, Kameni spomenici Hrvatske XIII-XIX stoljeća, Zagreb: Povijesni muzej Hrvatske, 1969., str. 43.

Mirko Valentić i Lada Prister, Zbirka kamenih spomenika, II. dopunjeno izdanje, Zagreb: Hrvatski povijesni muzej, 2002., str. 28. 
- Kat. br. 37 -
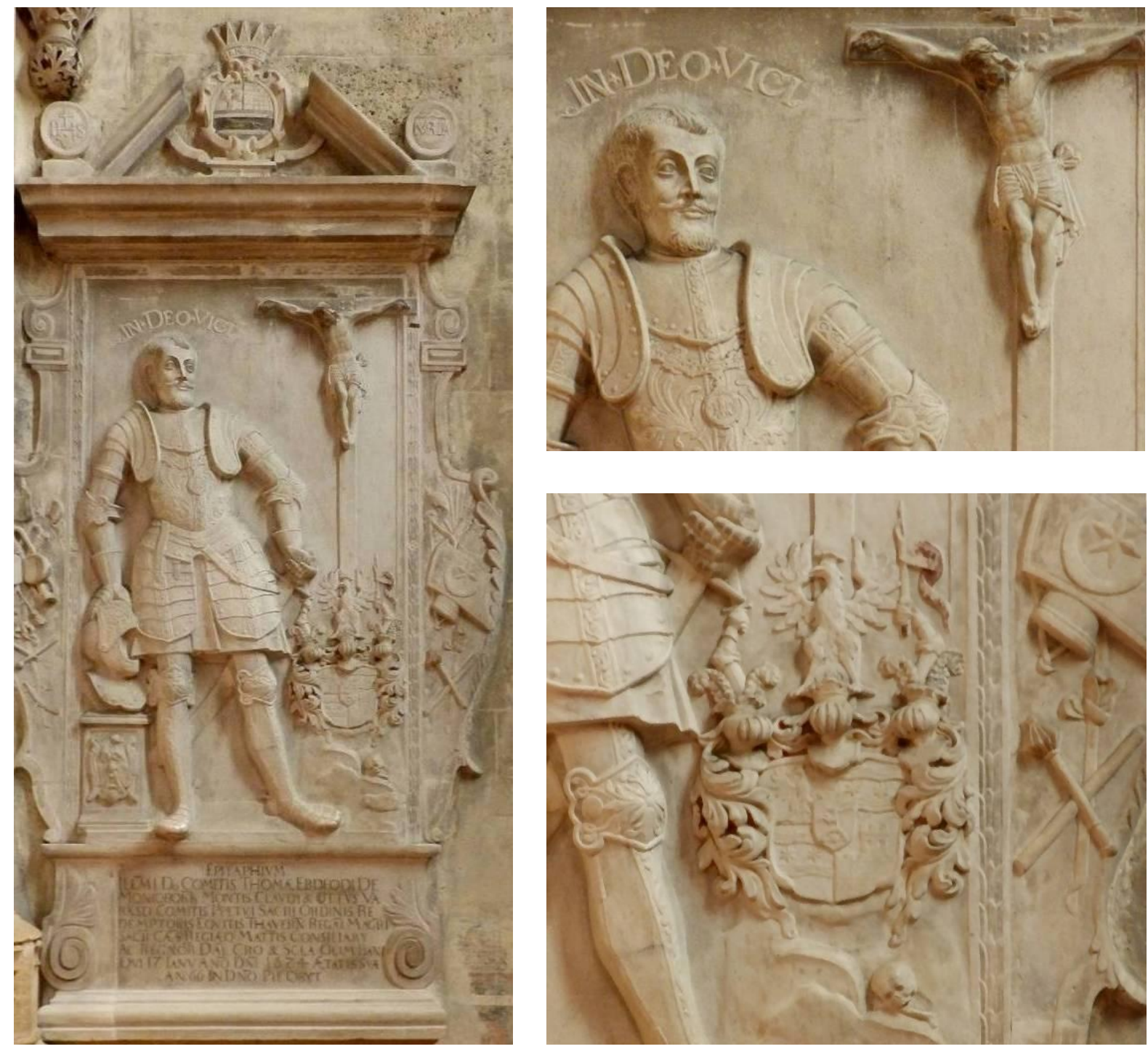

Epitaf bana Tome II. Erdödyja (?, 1558. - Krapina, 1624.)

Mramor, $340 \times 140 \times 14 \mathrm{~cm}$

Natpis iznad pokojnikove glave: »IN · DEO - VICI«. Natpis ispod figuralnoga prikaza:

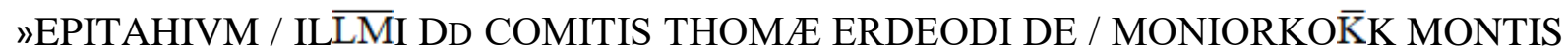
CLAVDY \& COTT̄VS VA / RASD COMITIS PिPETVI SACRI ORDINIS RE /

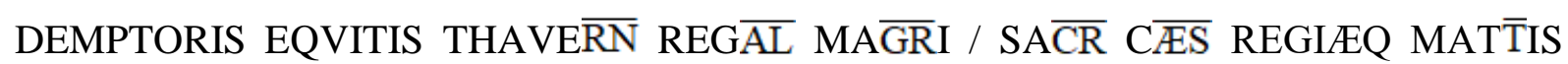

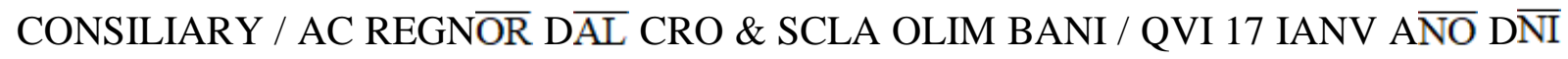
1624 ÆTATIS SVÆ / AN 66 IN DNO PIE OBYT«

\section{Opis spomenika:}

Epitaf je izveden u obliku oltarnoga retabla. Sastoji se od pravokutnoga postolja koje sadrži nadgrobni natpis, središnjega dijela s plitkim krilima koja su ukrašena ratnim trofejima $\mathrm{i}$ 
zabatnoga zaključka s akroterijima izvedenima u obliku medaljona s Marijinim i Kristovim monogramom te grbom Trojedne Kraljevine Dalmacije, Hrvatske i Slavonije (dodan u XIX. stoljeću). U središnjem dijelu predočen je pokojnik koji stoji pred Raspetim. Odjeven je u viteški oklop, a oko vrata nosi orden Reda Otkupitelja. U lijevoj ruci drži sablju, a desnom pridržava kacigu koja je odložena sa strane na postamentu ukrašenom maskeronom. Pogledom je usmjeren prema Kristu razapetom na križu, koji je postavljen na vrhu stijenja. U podnožju križa nalazi se bogato izveden grb obitelji Erdődy.

\section{Literatura:}

Zrinka Blažević i Daniel Premerl, »Christianae Reipublicae Propugnator«: Reformnokatolička mitopoetika bana Tome Erdödyja (1558-1624), u: Tridentska baština: katolička obnova i konfesionalizacija u hrvatskim zemljama. Zbornik radova sa znanstvenog skupa održanog u Zagrebu 6. i 7. prosinca 2013., Zagreb: Matica hrvatska, Katolički bogoslovni fakultet, Filozofski fakultet družbe Isusove, 2016., str. 393-408, 398-403. Uredile Zrinka Blažević i Lahorka Plejić Poje.

Orsolya Bubryák, »In Deo vici«. Kegyesség és reprezentáció Erdődy Tamás (1558-1624) horvát bán müpártolásában, u: Studia Agriensia 27. Hagyomány és megújulás: életpályák és társadalmi mobilitás a végváriak körében, Eger: Heves Megyei Múzeumi Szervezet, 2008., str. 261-283, 269-270. Uredili Mátyás Berecz i Gábor Veres.

Orsolya Bubryák, Athleta Christi. Political Propaganda in the Art Patronage of Tamás Erdödy, Ban of Croatia and Slavonia, u: Acta Historiae Artium Academiae Scientiarum Hungaricae 57, Budapest: Akademiai Kiado, 2016., str. 131-166, 148-153.

Sanja Cvetnić, Ikonografija nakon Tridentskog sabora i hrvatska likovna baština, Zagreb: FF press, 2007., str. 51-52.

Lelja Dobronić, Renesansa u Zagrebu, Zagreb: Institut za povijest umjetnosti, 1994., str. 121-122.

Géza Galavics, A magyar királyi udvar és a késő reneszáns képzőmüvészet, u: Magyar reneszánsz udvari kultúra, Budapest: Gondolat, 1987., str. 228-248, 247-248. Uredila Júlia Székely.

Anđela Horvat, Između gotike i baroka: umjetnost kontinentalnog dijela Hrvatske od oko 1500. do oko 1700., Zagreb: Društvo povjesničara umjetnosti SR Hrvatske, 1975., str. 351-353.

Ljubo Karaman, O umjetnosti srednjega vijeka, u: Historijski zbornik III/1-4, Zagreb: Društvo za hrvatsku povjesnicu, 1950., str. 125-174, 167. 
Ivan Kukuljević Sakcinski, Prvostolna crkva zagrebačka: opisana s gledišta povjesnice, umjetnosti i starinah, Zagreb: Narodna tiskara Ljudevita Gaja, 1856., str. 31.

Ivan Kukuljević Sakcinski, Nadpisi sredovječni i novovjeki na crkvah, javnih i privatnih sgradah itd. u Hrvatskoj $i$ Slavoniji, Zagreb: Knjižara Jugoslavenske akademije, Knjižara Dioničke tiskare, 1891., str. 331, br. 1143.

Árpád Mikó i Géza Pálffy, A pozsonyi Szent Márton-templom késő reneszánsz és kora barokk siremlékei (16-17. század), u: Müvészettörténeti Értesitö LI/1-2, Budapest: Akademiai Kiado, 2002., str. 107-172, 113.

Milan Pelc, Renesansa, Zagreb: Naklada Ljevak, 2007., str. 318-319.

Milan Pelc, Povijest umjetnosti u Hrvatskoj, Zagreb: Naklada Ljevak, 2012., str. 331.

Boris Prister, Hrvatski ban Toma Erdödy - vitez Reda Otkupitelja, u: Zbornik radova 2. međunarodnog numizmatičkog kongresa u Hrvatskoj, 15-17. listopada 1998., Opatija: Dobrinić \& Dobrinić, Zagreb: Hrvatsko numizmatičko društvo, 2000., str. 141-155, 142. Uredio Julijan Dobrinić.

Gjuro Szabo, Ljudi iz kamena, u: Jutarnji list, Zagreb: Tipografija, 24. XII. 1938., str. 5-6.

Gjuro Szabo, Kroz Hrvatsko zagorje, Zagreb: Vasić i Horvat, 1939., str. 28.

Nela Tarbuk, Kiparstvo 17. i 18. stoljeća u sjevernoj Hrvatskoj, u: Od svagdana do blagdana: barok u Hrvatskoj = From everyday to holidays: baroque in Croatia, katalog izložbe, Zagreb: Muzej za umjetnost i obrt, 1993., str. 122-131, 128.

Ivan Krstitelj Tkalčić, Prvostolna crkva zagrebačka nekoć i sada, Zagreb: Knjigotiskara Karla Albrechta, 1885., str. 72. 
- Kat. br. 38 -

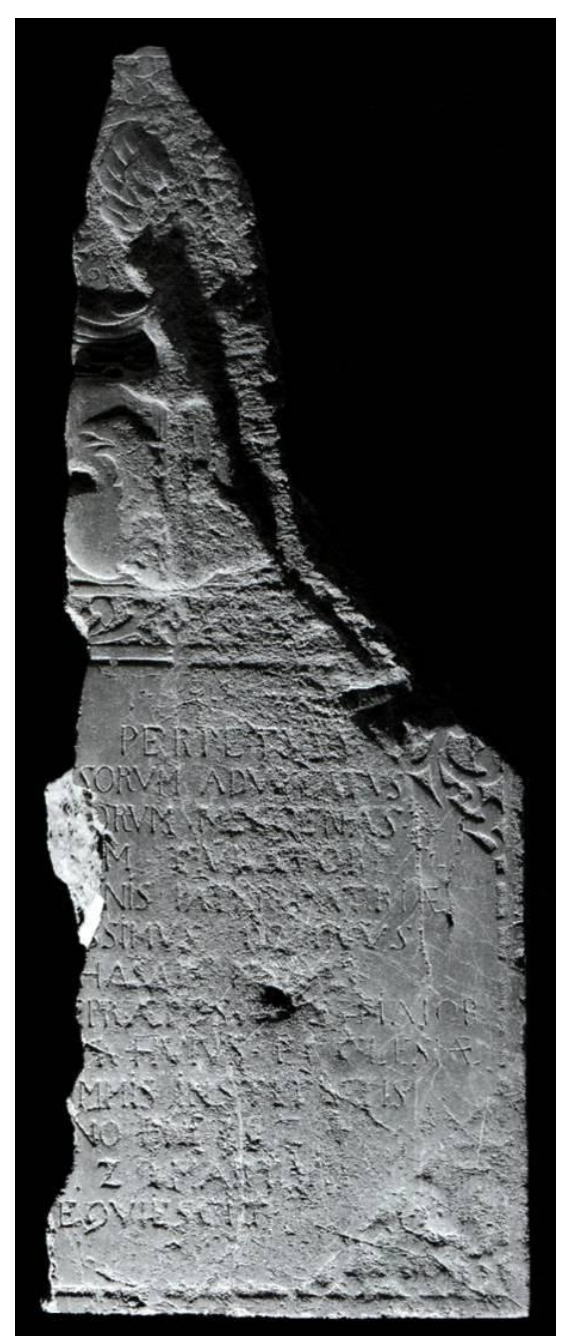

Nadgrobna ploča kanonika Baltazara Dvorničića-Napulya (Koprivnica, o. 1560. - Zagreb, 1624.)

Vapnenac, $165 \times 40 \times 15 \mathrm{~cm}$

Ploča je danas pohranjena u Hrvatskome povijesnome muzeju u Zagrebu.

Natpis: »(HIC) PERPETVVS / (RELIGIO)SORVM ADVOCATVS / (STVDI)ORVM MECOENAS / (PAVPERV)M CVRATOR / (COMMV)NIS PATER PATRIÆ / (REVERENDI)SSIMVS DOMINVS / (BALT)HASAR NAPVLI / (VICARIVS ET) PRÆPOSITVS MAIOR / (CANONICVSQV)E HVIVS ECCLESIÆ / (PIIS SV)MMIS INSTITVTIS / (AB AN)NO DOMINI 1624 / (DIE) 29 MARTY / REQVIESCIT«

\section{Opis spomenika:}

Sačuvan je donji desni kut nadgrobnika na kojem je vidljiv veći dio natpisne ploče te manji dio polja s grbom obitelji Dvorničić-Napuly. Grb i natpis međusobno su odijeljeni trakom ukrašenom motivom vitica. 


\section{Literatura:}

Ivan Kukuljević Sakcinski, Prvostolna crkva zagrebačka: opisana s gledišta povjesnice, umjetnosti $i$ starinah, Zagreb: Narodna tiskara Ljudevita Gaja, 1856., str. 38-39.

Ivan Kukuljević Sakcinski, Nadpisi sredovječni i novovjeki na crkvah, javnih i privatnih sgradah itd. u Hrvatskoj $i$ Slavoniji, Zagreb: Knjižara Jugoslavenske akademije, Knjižara Dioničke tiskare, 1891., str. 331-332, br. 1145.

Mirko Valentić, Kameni spomenici Hrvatske XIII-XIX stoljeća, Zagreb: Povijesni muzej Hrvatske, 1969., str. 47-50.

Mirko Valentić i Lada Prister, Zbirka kamenih spomenika, II. dopunjeno izdanje, Zagreb: Hrvatski povijesni muzej, 2002., str. 29-30. 


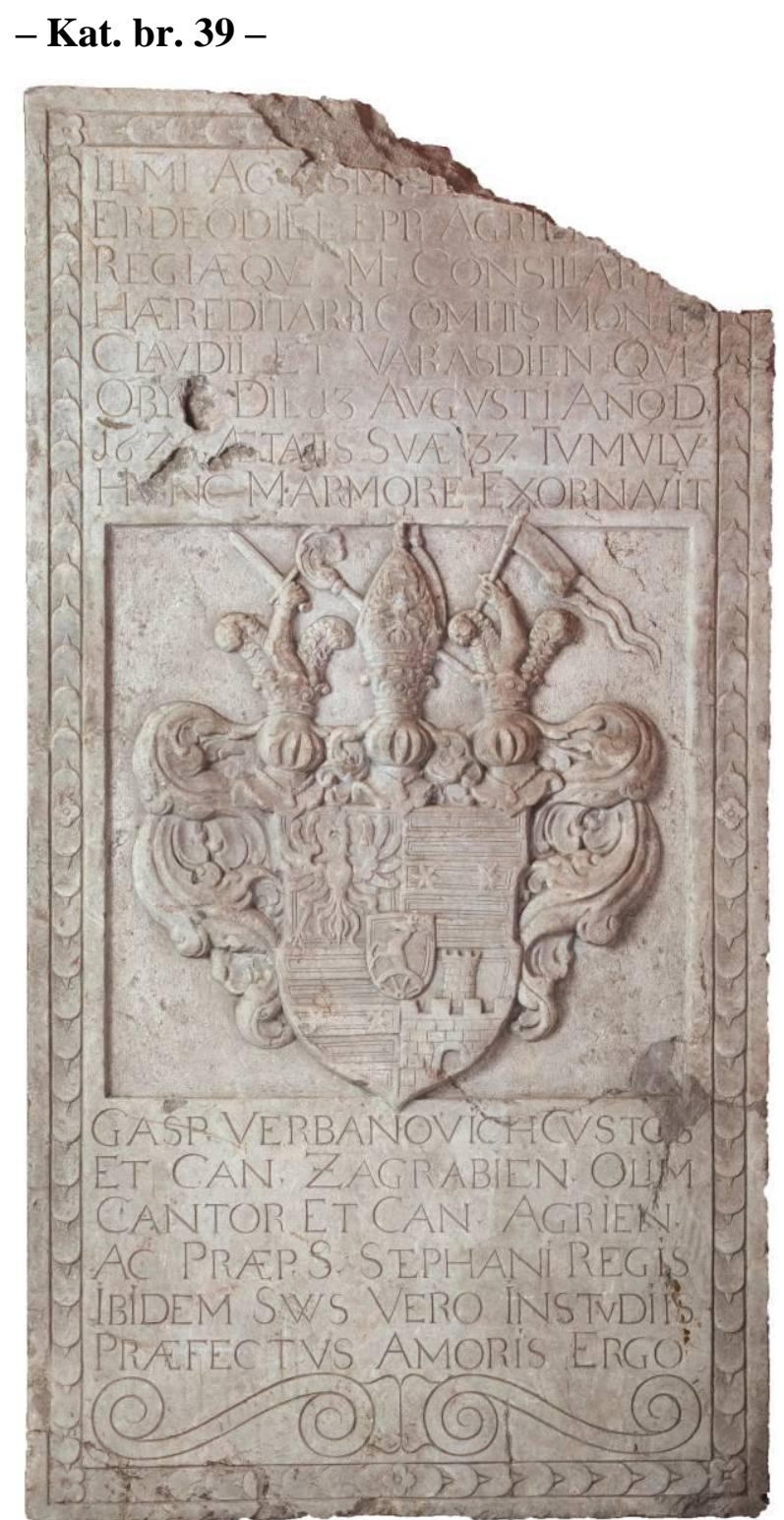

Nadgrobna ploča biskupa Ivana II. Erdödyja (?, 1589. - ?, 1626.)

Vapnenac, $161 \times 86 \times 14 \mathrm{~cm}$

Ploča je danas pohranjena u Hrvatskome povijesnome muzeju u Zagrebu.

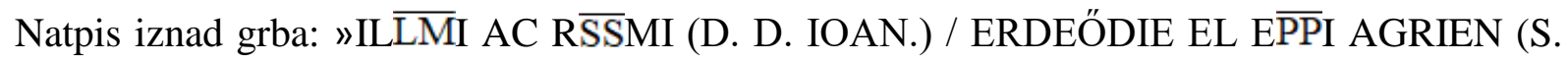
C.) / REGIÆQVE M. CONSILIAR(II) / HÆREDITARII COMITIS MONTIS / CLAVDII ET VARASDIEN QVI / OBYT DIE 13 AVGVSTI ANO D. / 1626. ÆTATIS SVÆ 37. TVMVLV / HVNC MARMORE EXORNAVIT«. Natpis ispod grba: "GASP. VERBANOVICH CVSTOS / ET CAN. ZAGRABIEN. OLIM / CANTOR ET CAN. AGRIEN. / AC PRÆP. S. STEPHANI REGIS / IBIDEM SWS VERO INSTVDIIS / PRÆFECTVS AMORIS ERGO.« 


\section{Opis spomenika:}

Nadgrobna ploča izvedena je u obliku okomito postavljena pravokutnika. Uokvirena je ornamentiranom trakom. U središtu nadgrobnika nalazi se plitko kvadratno polje unutar kojega je predočen grb obitelji Erdődy. Iznad i ispod grba uklesan je posvetni natpis. Donji natpis zaključen je parom voluta.

\section{Literatura:}

Doris Baričević, Skulptura i slikarstvo, katalog S, u: Riznica zagrebačke katedrale $=$ The Treasury of Zagreb Cathedral, katalog izložbe, Zagreb: MTM, 1987. [1983.], str. 5564, 58-59. Uredila Zdenka Munk.

Doris Baričević, Kiparstvo baroka i manirizma, u: Sveti trag. Devetsto godina umjetnosti Zagrebačke nadbiskupije 1094.-1994., MGC - Muzej Mimara, Zagreb, 10. rujna - 31. prosinca 1994., Zagreb: Zagrebačka nadbiskupija, Institut za povijest umjetnosti, Muzejsko-galerijski centar, 1994., str. 303-340, 339-340. Uredili Tugomir Lukšić i Ivanka Reberski.

Ivan Kukuljević Sakcinski, Prvostolna crkva zagrebačka: opisana s gledišta povjesnice, umjetnosti $i$ starinah, Zagreb: Narodna tiskara Ljudevita Gaja, 1856., str. 20.

Ivan Kukuljević Sakcinski, Nadpisi sredovječni i novovjeki na crkvah, javnih i privatnih sgradah itd. u Hrvatskoj $i$ Slavoniji, Zagreb: Knjižara Jugoslavenske akademije, Knjižara Dioničke tiskare, 1891., str. 332, str. 1147.

L[ada] P[rister], Nadgrobna ploča biskupa Ivana Erdödyja, u: Od svagdana do blagdana: barok u Hrvatskoj = From everyday to holidays: baroque in Croatia, katalog izložbe, Zagreb: Muzej za umjetnost i obrt, 1993., str. 407, br. 452. Uredio Vladimir Maleković.

Ivan Krstitelj Tkalčić, Prvostolna crkva zagrebačka nekoć i sada, Zagreb: Knjigotiskara Karla Albrechta, 1885., str. 54.

Mirko Valentić, Kameni spomenici Hrvatske XIII-XIX stoljeća, Zagreb: Povijesni muzej Hrvatske, 1969., str. 45-47.

Mirko Valentić i Lada Prister, Zbirka kamenih spomenika, II. dopunjeno izdanje, Zagreb: Hrvatski povijesni muzej, 2002., str. 28-29. 


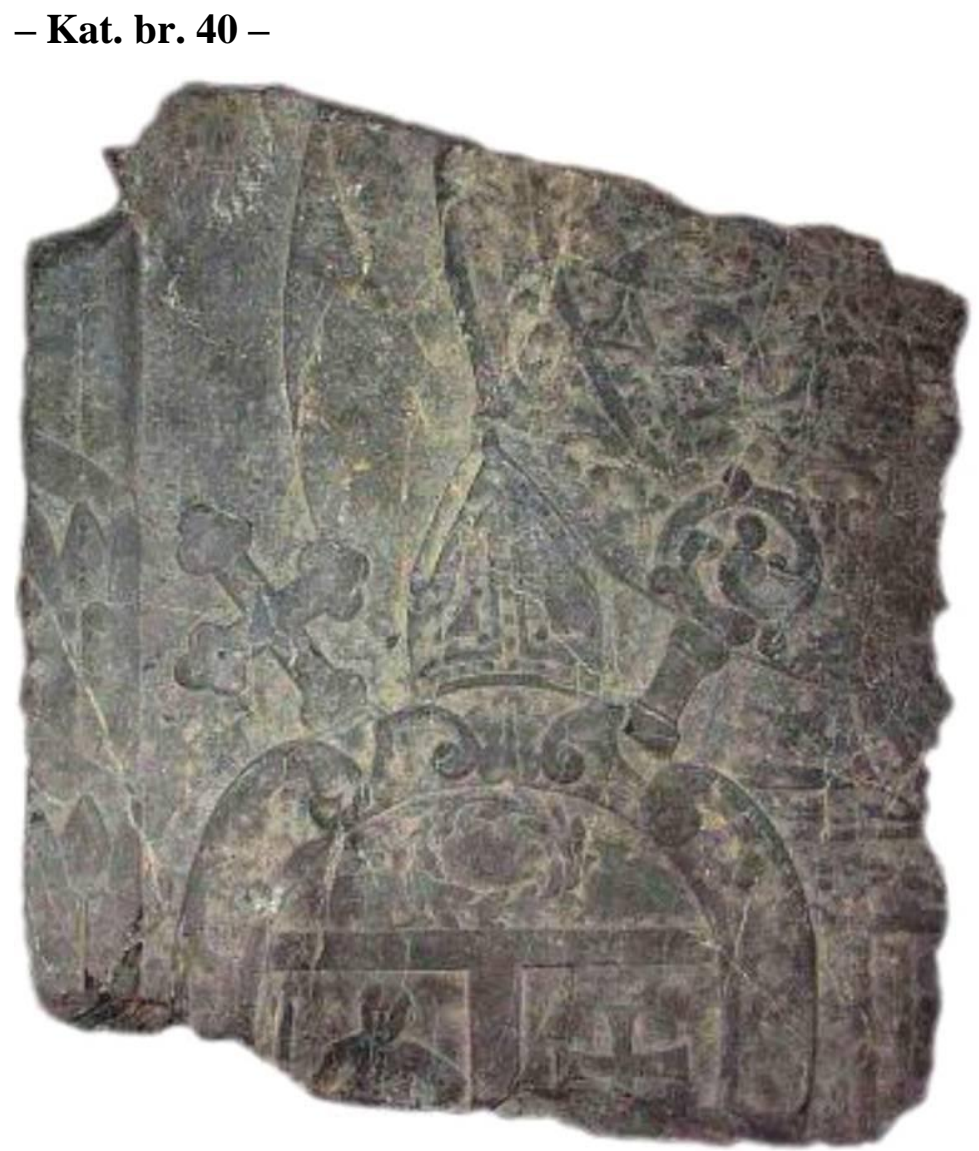

Nadgrobna ploča biskupa Petra III. Petretića (Sošice, 1604. - ?, 1667.)

Vapnenac, $56 \times 52 \times 20 \mathrm{~cm}$

Ploča je danas pohranjena u Muzeju grada Zagreba u Zagrebu.

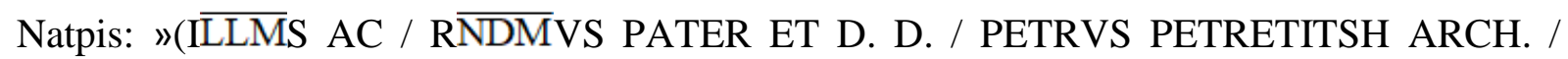

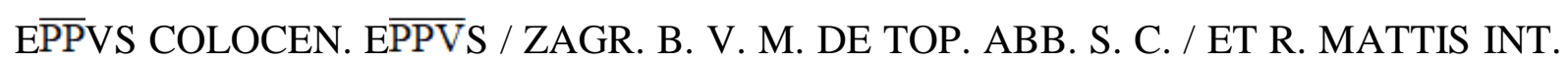
CONS. / OBYT 12. $\overline{8 B R}$. AETA. / TIS SVAE 67. / 1667) « ${ }^{764}$

\section{Opis spomenika:}

Sačuvan je dio nadgrobne ploče na kojem je vidljiv grb obitelji Petretić ukrašen križem, mitrom i pastoralom te dio ornamentiranoga ruha. Prema povijesnim izvorima, izuzev obiteljskoga grba, nadgrobnik je sadržavao i lik pokojnika.

\section{Literatura:}

Ivan Kukuljević Sakcinski, Prvostolna crkva zagrebačka: opisana s gledišta povjesnice, umjetnosti i starinah, Zagreb: Narodna tiskara Ljudevita Gaja, 1856., str. 23.

\footnotetext{
${ }^{764}$ Prijepis preuzet iz: Ivan Krstitelj Tkalčić, nav. dj., 1885., str. 58.
} 
Ivan Kukuljević Sakcinski, Nadpisi sredovječni i novovjeki na crkvah, javnih i privatnih sgradah itd. u Hrvatskoj $i$ Slavoniji, Zagreb: Knjižara Jugoslavenske akademije, Knjižara Dioničke tiskare, 1891., str. 336, br. 1156.

Milan Pelc, Spomenici potonuloga svijeta. Nadgrobne ploče s likom pokojnika u sjevernoj Hrvatskoj u pisanim i tiskanim vrelima do konca 19. st., u: Umjetnost i naručitelj. Zbornik radova znanstvenoga skupa "Dani Cvita Fiskovića održanog 2008. godine, Zagreb: Institut za povijest umjetnosti, Odsjek za povijest umjetnosti Filozofskog fakulteta Sveučilišta u Zagrebu, 2010., str. 61-71, 66. Uredila Jasenka Gudelj.

Ivan Krstitelj Tkalčić, Prvostolna crkva zagrebačka nekoć i sada, Zagreb: Knjigotiskara Karla Albrechta, 1885., str. 58. 
- Kat. br. $41-$

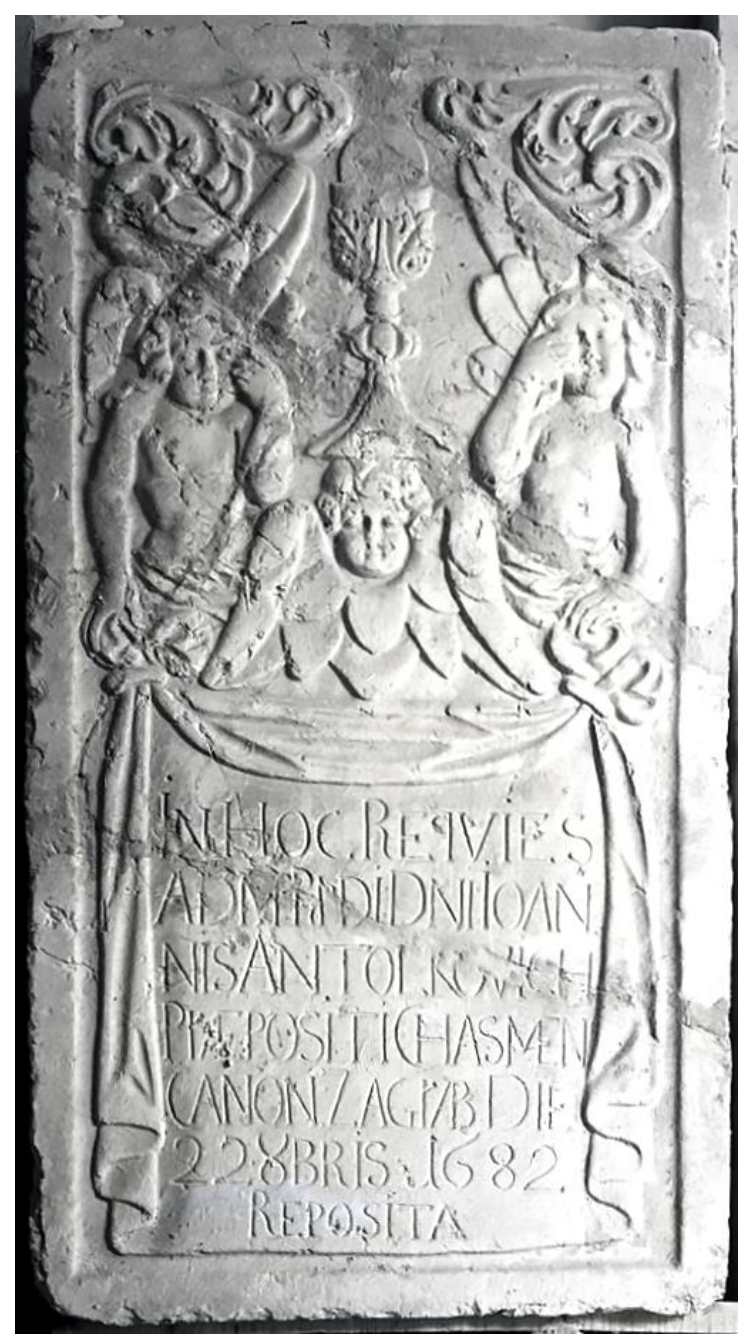

Nadgrobna ploča kanonika Ivana Antolkovića (? - ?, 1682.)

Vapnenac, $176 \times 94 \times 18 \mathrm{~cm}$

Ploča je danas pohranjena u Muzeju grada Zagreba.

Natpis: "IN HOC RESIVIES / ADM: Pd: DI: DNI: IOAN / NIS ANTOLKOVICH / PRÆPOSITI CHASMEN / CANON: ZAGRAB : DIE / 22: 8BRIS 1682 / REPOSITA«

\section{Opis spomenika:}

Na nadgrobnoj ploči formata okomito postavljena pravokutnika predočen je par plačućih anđela koji jednom rukom drže zastor, a drugom brišu suze. Na zastoru je ispisan nadgrobni natpis. Između anđela nalazi se kerubin povrh kojega je predočen kalež s Presvetim. Gornji kutevi ploče ukrašeni su motivom akanta.

\section{Literatura:}

Nadgrobnik dosad nije stručno obrađen. 


\section{- Kat. br. 42 -}

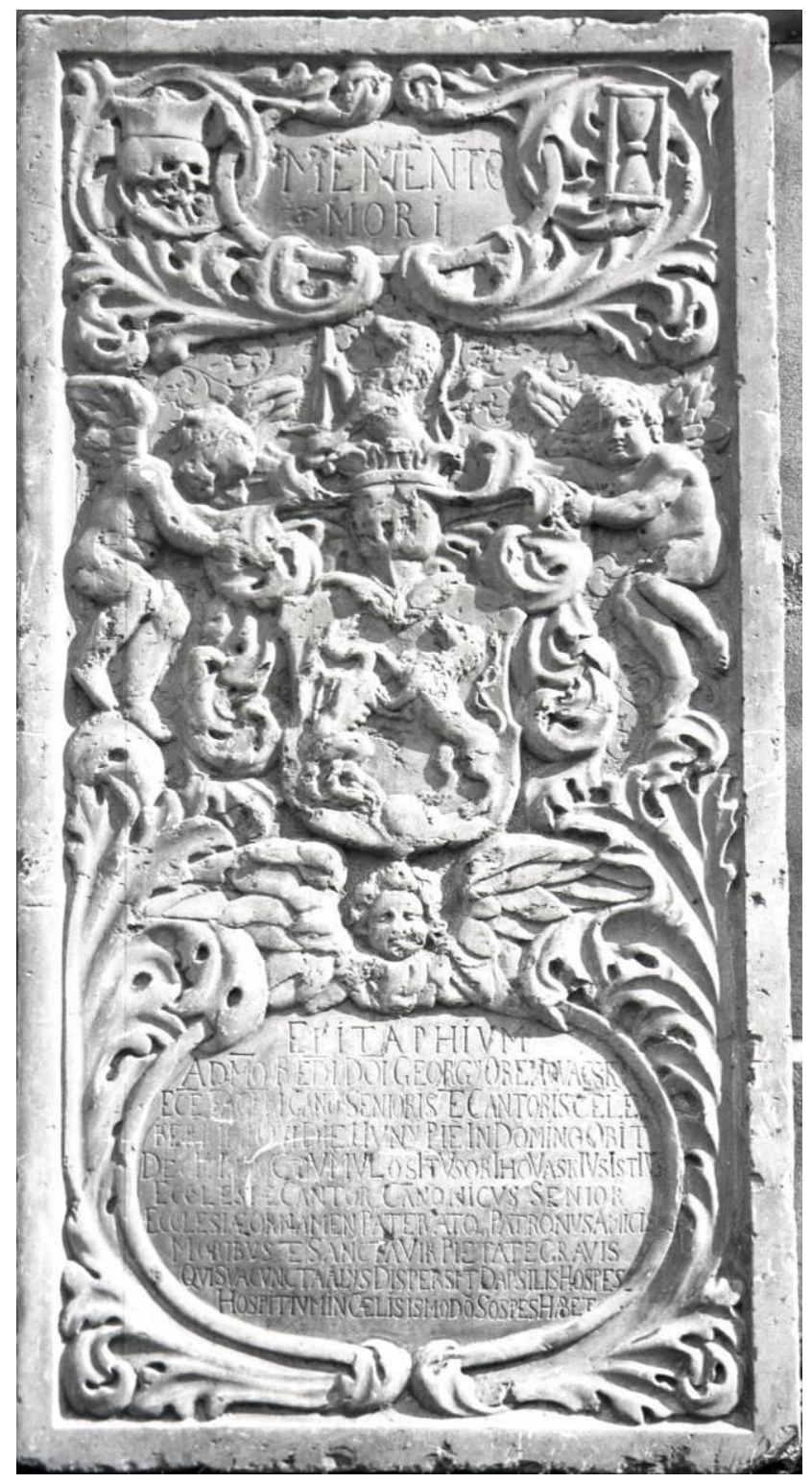

Radionica Ivana Komersteinera (?), Nadgrobna ploča kanonika Jurja Orehovačkoga (? ?, 1687.)

Vapnenac, $178 \times 94 \times 26 \mathrm{~cm}$

Ploča je danas pohranjena u Muzeju grada Zagreba u Zagrebu.

Natpisu gornjoj kartuši: „MEMENTO / MORI«. Natpis u donjoj kartuši: »EPITAHIVM /

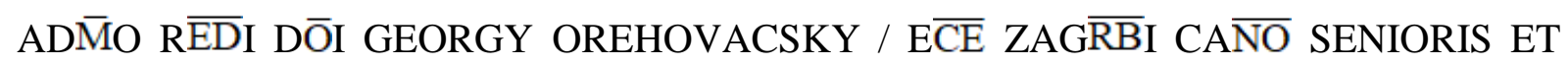
CANTORIS CELE / BERRIMI QVI DIE 1 IVNY PIE IN DOMINO OBIT / DEGIT IN HOC TVMVLO SITVS ORIHOVASKIVS ISTIVS / ECCLESIÆ CANTOR, CANONICVS SENIOR / ECCLESIÆ ORNAMEN PATER ATQ ${ }_{9}$ PATRONVS AMICIS / MORIBVS ET SANCTA VIR PIETATE GRAVIS / QVI SVA CVNCTA ALYS DISPERSIT DAPSILIS HOSPES / HOSPITIVM IN CÆLISIS MODO SOSPES HABET « 


\section{Opis spomenika:}

Nadgrobna ploča ima format okomito postavljenoga pravokutnika i jednostavan profiliran rub. U središtu nadgrobnika predočen je grb obitelji Orehovački koji pridržavaju dva anđela. Povrh grba nalazi se medaljon unutar kojega je ispisana uzrečica »MEMENTO MORI«. Medaljon je flankiran mrtvačkom lubanjom s križaticom (biretom) na lijevoj i pješčanim satom na desnoj strani. Ispod grba prikazana je kartuša s posvetnim natpisom povrh koje je predočen kerubin. Prostor između opisanih motiva ispunjen je gustim prepletom vitica i lišća akanta.

\section{Literatura:}

Ivan Kukuljević Sakcinski, Nadpisi sredovječni i novovjeki na crkvah, javnih i privatnih sgradah itd. u Hrvatskoj $i$ Slavoniji, Zagreb: Knjižara Jugoslavenske akademije, Knjižara Dioničke tiskare, 1891., str. 338, br. 1161

Ivan Krstitelj Tkalčić, Prvostolna crkva zagrebačka nekoć i sada, Zagreb: Knjigotiskara Karla Albrechta, 1885., str. 66-67. 
- Kat. br. $43-$

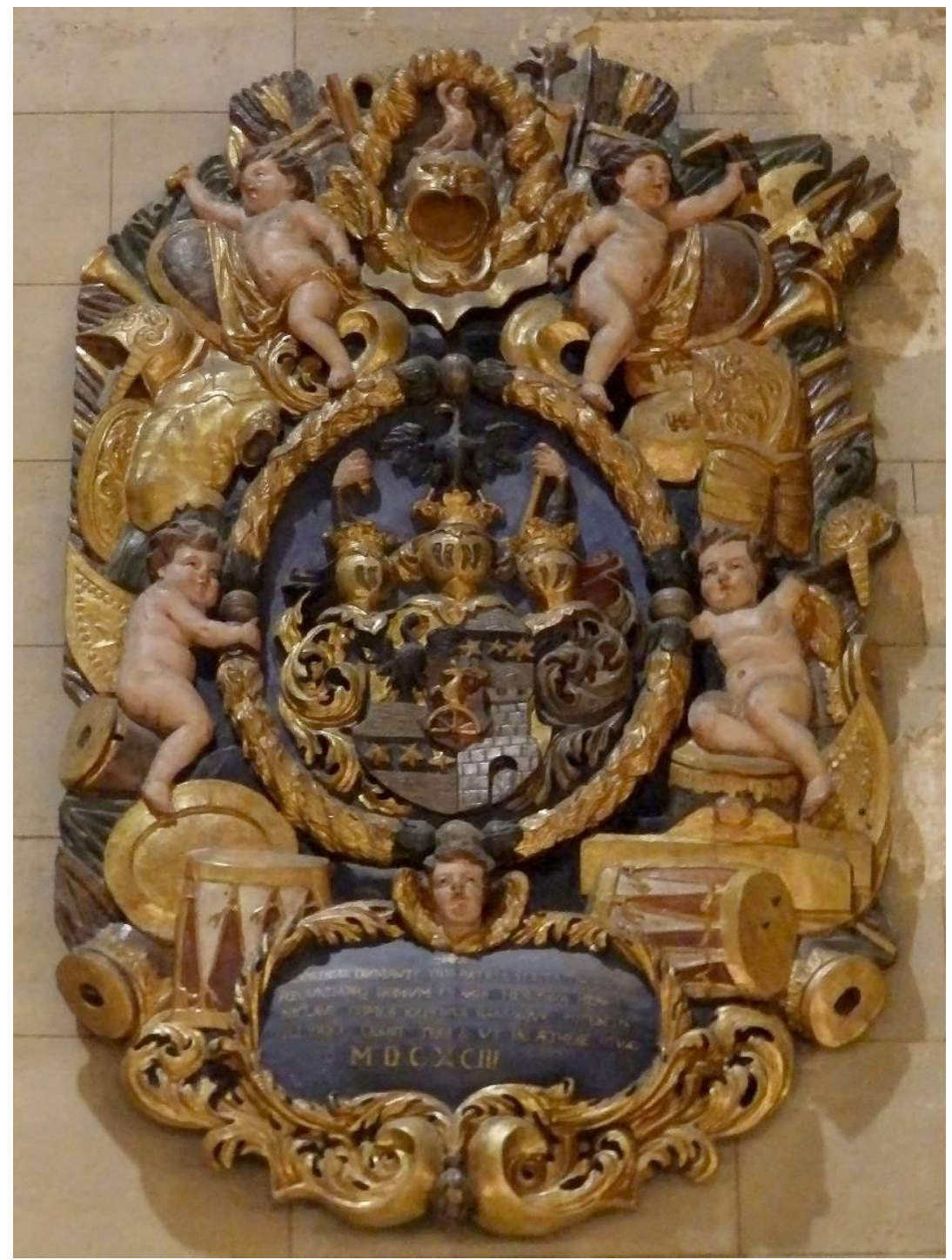

Ivan Komersteiner, Epitaf bana Nikole III. Erdödyja (?, 1630. - Aranyosmarót, 1693.), 1693.

Drvo, polikromija, pozlata, $224 \times 135 \mathrm{~cm}$

Natpis: „PLVRIBVS ORNAVIT QUI PATRIA SCUTA TRIVMPHIS, / FECUNDAMQ DOMVM CLARIS HEROIBVS HEROS, / NICLAVS COMES ERDEDIVS BANVSQUE POTENTIS / ILLYRICI, CESSIT TERRIS, VT IN ÆTHERE VIVAT. / MDCXCIII«

\section{Opis spomenika:}

U središtu epitafa ovalnoga formata nalazi se grb obitelji Erdődy okružen lovorovim vijencem koji pridržavaju dva anđela. Ispod grba nalazi se kartuša ukrašena akantom i motivom kerubina koja sadrži posvetni natpis. Lovorov vijenac okružen je ratnim trofejima (zastavama, oklopom, kacigom, oružjem i bubnjevima). Nadgrobnik je polikromiran i pozlaćen. 


\section{Literatura:}

Doris Baričević, Kiparstvo manirizma i baroka, u: Sveti trag: devetsto godina umjetnosti zagrebačke nadbiskupije, 1094. - 1994., Zagreb: Muzejsko-galerijski centar, Institut za povijest umjetnosti, Zagrebačka nadbiskupija, 1994., str. 301-340, 325. Uredili Tugomir Lukšić i Ivanka Reberski.

Ivan Kukuljević Sakcinski, Prvostolna crkva zagrebačka: opisana s gledišta povjesnice, umjetnosti i starinah, Zagreb: Narodna tiskara Ljudevita Gaja, 1856., str. 31-32.

Lina Slavica Plukavec, Obnova Ackermannovog oltara, Komersteinerovog spomenika $i$ Sickingerovih kipova u zagrebackoj prvostolnici, u: Tkalčić: godišnjak Društva za povjesnicu Zagrebačke nadbiskupije = annales Societatis historicae archiepiscopatus Zagrabiensis II, Zagreb: Društvo za povjesnicu Zagrebačke nadbiskupije »Tkalčić«, 1998., str. 165-209, 189-191.

Ivan Krstitelj Tkalčić, Prvostolna crkva zagrebačka nekoć i sada, Zagreb: Knjigotiskara Karla Albrechta, 1885., str. 72. 
- Kat. br. 44 -

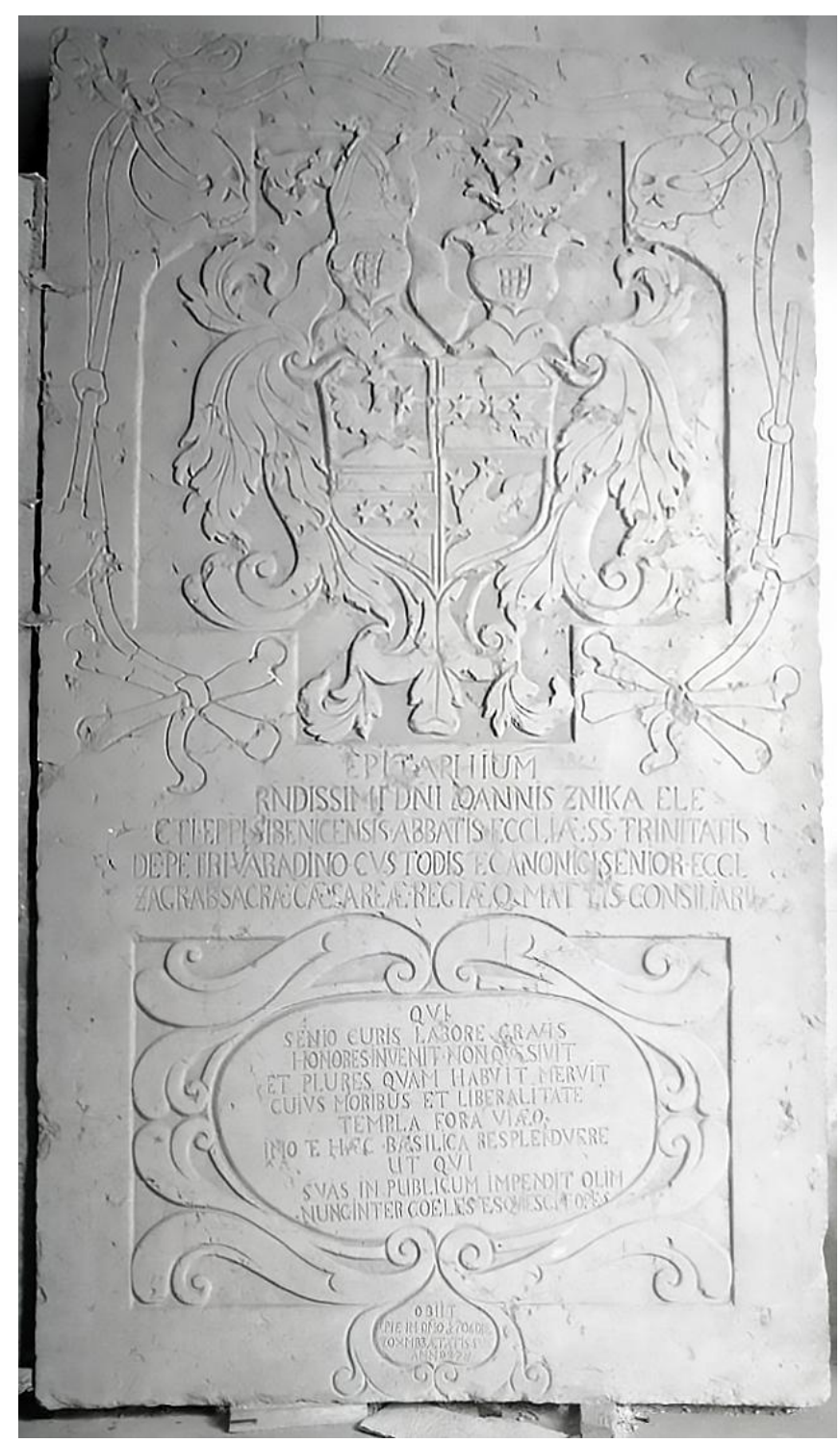

Nadgrobna ploča kanonika Ivana Znike (Matenci, 1629. - Zagreb, 1706.)

Crveni mramor, $205 \times 117 \times 11,5 \mathrm{~cm}$

Ploča je danas pohranjena u Muzeju grada Zagreba u Zagrebu.

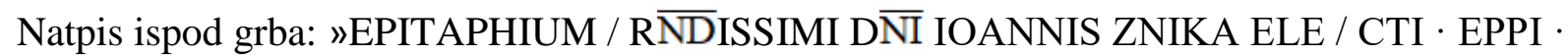
SIBENICENSIS · ABBATIS $\cdot$ EC $\overline{C L} I Æ \cdot S \bar{S} \cdot$ TRINITATIS / DE $\cdot$ PETRIVARADINO

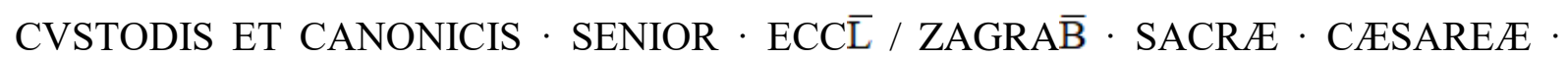
REGIÆQ · MATTIS CONSILIARII«. Natpis unutar kartuše: „QVI / SENIO CURIS LABORE GRAVIS / HONORES · INVENIT · NONQVE · SIVIT / ET PLURES QVAM HABVIT MERVIT / CUIVS MORIBUS ET LIBERALITATE / TEMPLA FORA VIÆQ / IMO TE HÆC BASILICA RESPLENDVERE / UT QVI / SVAS IN PUBLICUM 
IMPENDIT OLIM / NUNCITER COELESTES QVIESCIT OPES / OBIIT / PIE IN AN̄O 1706 DIE / 20XMBR ÆTATIS SVÆ / ANNOR 78«

\section{Opis spomenika:}

Nadgrobna ploča formata okomito postavljenoga pravokutnika izvedena je u uleknutome reljefu. U gornjoj polovici predočen je grb obitelji Znika. Okružen je stiliziranom vrpcom u koju su upleteni pješčani sat, par lubanja, lopata, motika i dva para ukriženih kostiju. U donjoj polovici ploče nalazi se kartuša unutar koje je ispisan nadgrobni natpis.

\section{Literatura:}

Ivan Kukuljević Sakcinski, Prvostolna crkva zagrebačka: opisana s gledišta povjesnice, umjetnosti i starinah, Zagreb: Narodna tiskara Ljudevita Gaja, 1856., str. 32-33.

Ivan Kukuljević Sakcinski, Nadpisi sredovječni i novovjeki na crkvah, javnih i privatnih sgradah itd. u Hrvatskoj $i$ Slavoniji, Zagreb: Knjižara Jugoslavenske akademije, Knjižara Dioničke tiskare, 1891., str. 346, br. 1189.

Ivan Krstitelj Tkalčić, Prvostolna crkva zagrebačka nekoć i sada, Zagreb: Knjigotiskara Karla Albrechta, 1885., str. 75-76.

Mirko Valentić, Kameni spomenici Hrvatske XIII-XIX stoljeća, Zagreb: Povijesni muzej Hrvatske, 1969., str. 203-204. 
- Kat. br. $45-$

Nadgrobna ploča kanonika Tomasa Kovačevića (Križevci, 1664. - Zagreb, 1724.)

Ploča nije sačuvana, ali je dokumentirana u pisanim izvorima.

Natpis: »RSSIMVS D. THOMAS KOVACHEVICH / CVST. ET CAN. SEN. CATH. ECCL. ZAGRAB. / PROTONOTARIVS APOSTOLICVS / ASSIDVVS DEVOTIONIS ET / DECORIS ECCLESIAR. PROMOTOR. MINISTRORVM / SACRARII INSTITVTOR. POENITENTIARIAE / BENEFACTOR. CANTORAL. RESIDEN. PIVS FVNDA / TOR. INDEFESSVS ANTIQVITATVM COMPILA / TOR. AETAT. SVAE AN. 61. DIE. 13. MENS. IVNIJ / IN DOMINO OBIIT. SAXO HOC TECTVS RESVRGET / 1724 « ${ }^{765}$

\section{Opis spomenika:}

Prema pisanim izvorima, ploča je sadržava pokojnikov obiteljski grb i gore navedeni natpis.

\section{Literatura:}

Vjekoslav Klaić, Tomo Kovačević, povjesničar hrvatski (1664.-1724.), u: Bogoslovska smotra XIII/1, Zagreb: Naklada »Katoličkog lista«, str. 69-91, 83.

Ivan Kukuljević Sakcinski, Prvostolna crkva zagrebačka: opisana s gledišta povjesnice, umjetnosti $i$ starinah, Zagreb: Narodna tiskara Ljudevita Gaja, 1856., str. 33.

Ivan Kukuljević Sakcinski, Nadpisi sredovječni i novovjeki na crkvah, javnih i privatnih sgradah itd. u Hrvatskoj i Slavoniji, Zagreb: Knjižara Jugoslavenske akademije, Knjižara Dioničke tiskare, 1891., str. 349, br. 1203.

Ivan Krstitelj Tkalčić, Prvostolna crkva zagrebačka nekoć i sada, Zagreb: Knjigotiskara Karla Albrechta, 1885., str. 76.

\footnotetext{
$\overline{765}$ Prijepis preuzet iz: Ivan Kukuljević Sakcinski, nav. dj., 1891., str. 349, br. 1203. Kronogram u predzadnjemu retku daje 1722. godinu, koja se ne poklapa s godinom pokojnikove smrti (1724.). Moguće je da su slova $i$ u riječi »obiit« također bila napisana u majuskuli.
} 
- Kat. br. $46-$
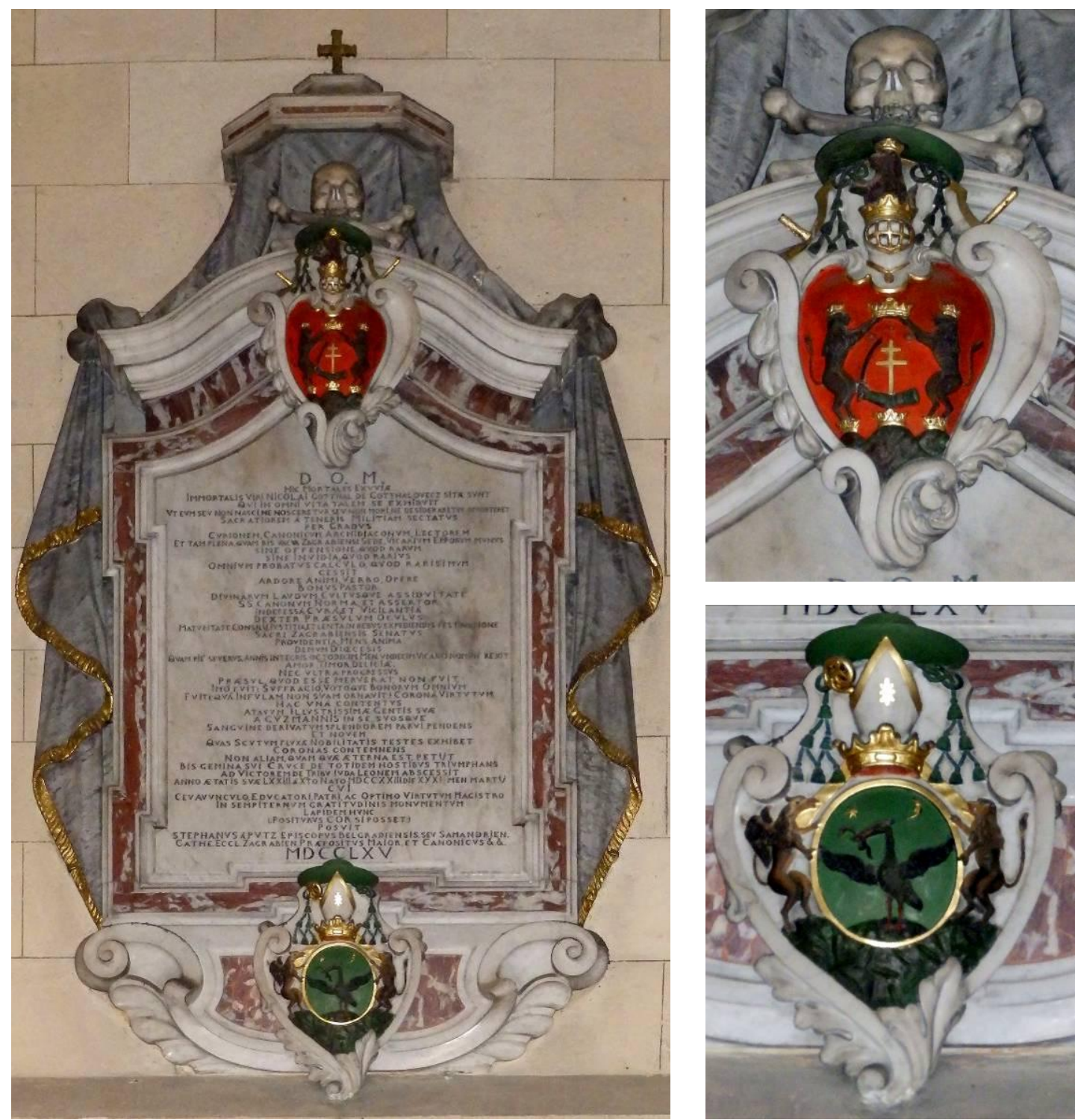

Epitaf kanonika Nikole Gotala od Gotalovca (? - ?, 1723.), 1765.

Mramor, dimenzije nepoznate autorici ${ }^{766}$

Natpis: »D. O. M. / HIC MORTALES EXVVIÆ / IMMORTALIS VIRI NICOLAI GOTTHAL DE GOTTHALOVECZ SITÆ SVNT / QVI IN OMNI VITA TALEM SE EXHIBVIT / VT EVM SEV NON NASCI, NE NOSCERETVR, SEV NON MORI, NE DESIDERARETVR, OPPORTERET / SACRATIOREM A TENERIS MILITIAM SECTATVS / PER GRADVS / CVRIONEM, CANONICVM, ARCHIDIACONVM, LECTOREM / ET TAM PLENA QVAM BIS VACVA ZAGRABIENSI SEDE, VICARIVM EDPPORVM MVNVS / SINE OFFENSIONE, QVOD RARVM / SINE INVIDIA, QVOD RARIVS / OMNIVM PROBATVS CALCVLO, QVOD RARISSIMVM / CESSIT / ARDORE ANIMI, VERBO, OPERE / BONVS PASTOR. / DIVINARVM LAVDVM,

\footnotetext{
${ }^{766}$ Epitaf je postavljen previsoko na zidu crkve da bi se mogao izmjeriti.
} 
CVLTVSQVE ASSIDVITATE / SS. CANONVM NORMA ET ASSERTOR. / INDEFESSA CVRA ET VIGILANTIA / DEXTER PRÆSVLVM OCVLVS / MATVRITATE CONSILY, IVSTITIA, ET LENTA IN REBVS EXPEDIENDIS FESTINATIONE / SACRI ZAGRABIENSIS SENATVS / PROVIDENTIA, MENS, ANIMA. / DEMVM DIECESIS / QVAM PIE SEVERVS, ANNIS INTEGRIS OCTODECIM, MEN. VNDECIM VICARIO NOMINE REXIT / AMOR, TIMOR, DELICIÆ. / NEC VLTRA PROGRESSVS / PRÆSVL, QVOD ESSE MERVERAT, NON FVIT, / IMO FVIT: SVFFRAGIO, VOTOQVE BONORVM OMNIVM / FVIT (:QVA INFVLAM NON SVAM ORNAVIT:) CORONA VIRTVTVM/ HAC VNA CONTENTVS / ATAVVM ILLVSTRISSIMÆ GENTIS SVÆ / A GVZMANNIS IN SE, SVOSQVE / SANGVINE DERIVATVM SPLENDOREM PARVIPENDENS / ET NOVEM / QVAS SCVTVM FLVXÆ NOBILITATIS TESTEM EXHIBET / CORONAS CONTEMNENS / NON ALIAM, QVAM QVÆ ÆTERNA EST, PETIIT / BIS GEMINA SVI CRVCE DE TOTIDEM HOSTIBVS TRIVMPHANS / AD VICTOREM DE TRIBV IVDA LEONEM ABSCESSIT / ANNO ÆTATIS SVÆ LXXIII A XTO NATO MDCCXXIII DIE XXXI MEN. MARTII / CVI / CEV AVVNCVLO, EDVCATORI, PATRI, AC OPTIMO VIRTVTVM MAGISTRO / IN SEMPITERNVM GRATITVDINIS MONVMENTVM / LAPIDEM HVNC / (:POSITVRVS COR SI POSSET:) / POSVIT / STEPHANVS A PVTZ EPISCOPVS BELGRADENSIS, SEV SAMANDRIEN. / CATHE. ECCL. ZAGRABIEN. PRAPOSITVS MAIOR, ET CANONICVS \&. \&. / MDCCLXV«

\section{Opis spomenika:}

Epitaf je izveden u obliku edikule. Sastoji se od središnje natpisne ploče izlomljenih stranica koja počiva na polukružnoj konzoli ukrašenoj volutama, a zaključena je konveksno oblikovanim gređem i baldahinom čiji se nabori spuštaju s obje strane spomenika. U zoni gređa nalazi se grb obitelji Gotal, a u konzolnom polju grb naručitelja Stjepana Puca.

\section{Literatura:}

Ivan Kukuljević Sakcinski, Prvostolna crkva zagrebačka: opisana s gledišta povjesnice, umjetnosti $i$ starinah, Zagreb: Narodna tiskara Ljudevita Gaja, 1856., str. 26-27.

Ivan Kukuljević Sakcinski, Nadpisi sredovječni i novovjeki na crkvah, javnih i privatnih sgradah itd. u Hrvatskoj $i$ Slavoniji, Zagreb: Knjižara Jugoslavenske akademije, Knjižara Dioničke tiskare, 1891., str. 357-359, br. 1234.

Ivan Krstitelj Tkalčić, Prvostolna crkva zagrebačka nekoć i sada, Zagreb: Knjigotiskara Karla Albrechta, 1885., str. 63-65. 


\section{Crkva sv. Katarine}

- Kat. br. 47 -

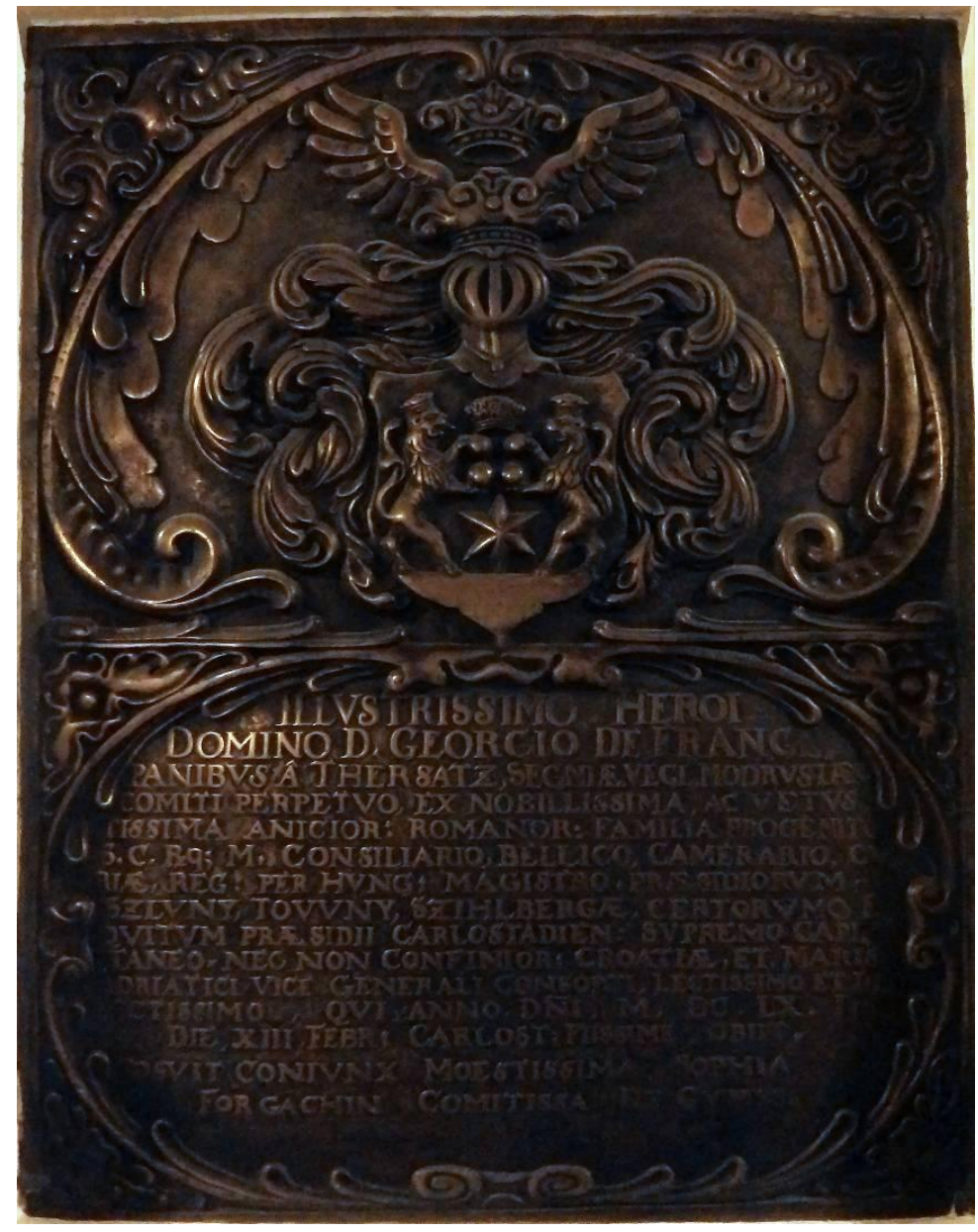

Epitaf Jurja IV. Frankapana Tržačkoga (Bosiljevo?, o. 1620. - Karlovac, 1661.)

Bronca, $122 \times 97 \mathrm{~cm} \times$ [uzidan]

Natpis: »ILLVSTRISSIMO HEROI / DOMINO D. GEORGIO DE FRANGE, / PANIBVS Â THERSATZ, SEGNIÆ. VEGL. MODRVSSIAEQ / COMITI PERPETVO, EX NOBILISSIMA, AC VETVS / TISSIMA ANCINIOR: ROMANOR: FAMILIA PROGENITO. / S. C. RQ; M. CONSILIARIO, BELLICO, CAMERARIO, CV / RIÆ, REG: PER HVNG: MAGISTRO. PRÆSIDIORVM. / SZLVNY, TOVVNY, SZHILBERGÆ, CERTORVMQE / QVITVM PRÆSIDII CARLOSTADIEN: SVPREMO CAPI. / TANEO, NEC NON CONFINIOR: CROATIÆ, ET, MARIS / ADRIATICI VICE GENERALI CONSORTI, LECTISSIMO ET DI / LECTISSIMO, QVI, ANNO DN̄I M. DC. LX. I. / DIE XIII. FEBR: CARLOST: PIISSIME OBIIT. / POSVIT CONIVNX MOESTISSIMA SOPHIA / FORGACHIN COMITISSA DE GYMES.« 


\section{Opis spomenika:}

Epitaf je izveden u obliku okomito postavljena pravokutnika. Vodoravno je podijeljen na dva podjednaka dijela. U gornjoj polovici predočen je grb obitelji Frankapan, a u donjoj kartuša s posvetnim natpisom. Ugaona polja obaju dijelova ukrašena su hrskavičastim cvjetovima i viticama s kralješastim elementima.

\section{Literatura:}

Lelja Dobronić, Crkva sv. Katarine u Zagrebu i hrvatsko plemstvo: vodič po starinama, u: Tkalčić: godišnjak Društva za povjesnicu Zagrebačke nadbiskupije = annales Societatis historicae archiepiscopatus Zagrabiensis IV, Zagreb: Društvo za povjesnicu Zagrebačke nadbiskupije »Tkalčić«, 2000., str. 389-424, 398-399.

Zorislav Horvat, Pregled sačuvanih nadgrobnih ploča Krčkih knezova Frankopana, u: Senjski zbornik: prilozi za geografiju, etnologiju, gospodarstvo, povijest $i$ kulturu XXXII/1, Senj: Gradski muzej, Senjsko muzejsko društvo, 2005., str. 25-58, 51-53.

Ivan Kukuljević Sakcinski, Nadpisi sredovječni i novovjeki na crkvah, javnih i privatnih sgradah itd. u Hrvatskoj $i$ Slavoniji, Zagreb: Knjižara Jugoslavenske akademije, Knjižara Dioničke tiskare, 1891., str. 335, br. 1154.

Mirjana Repanić-Braun, Slikarstvo, štukature i djela umjetničkoga obrta, u: Akademska crkva sv. Katarine u Zagrebu, Zagreb: Institut za povijest umjetnosti, 2011., str. 203309, 285. Napisale Katarina Horvat-Levaj, Doris Baričević, Marijana Repanić-Braun.

Marijana Schneider, Zrinski i Frankopani u likovnoj umjetnosti, u: Historijski zbornik 25-26, Zagreb: Povijesno društvo Hrvatske, 1972.-1973., str. 251-271, 258. 
- Kat. br. 48 -

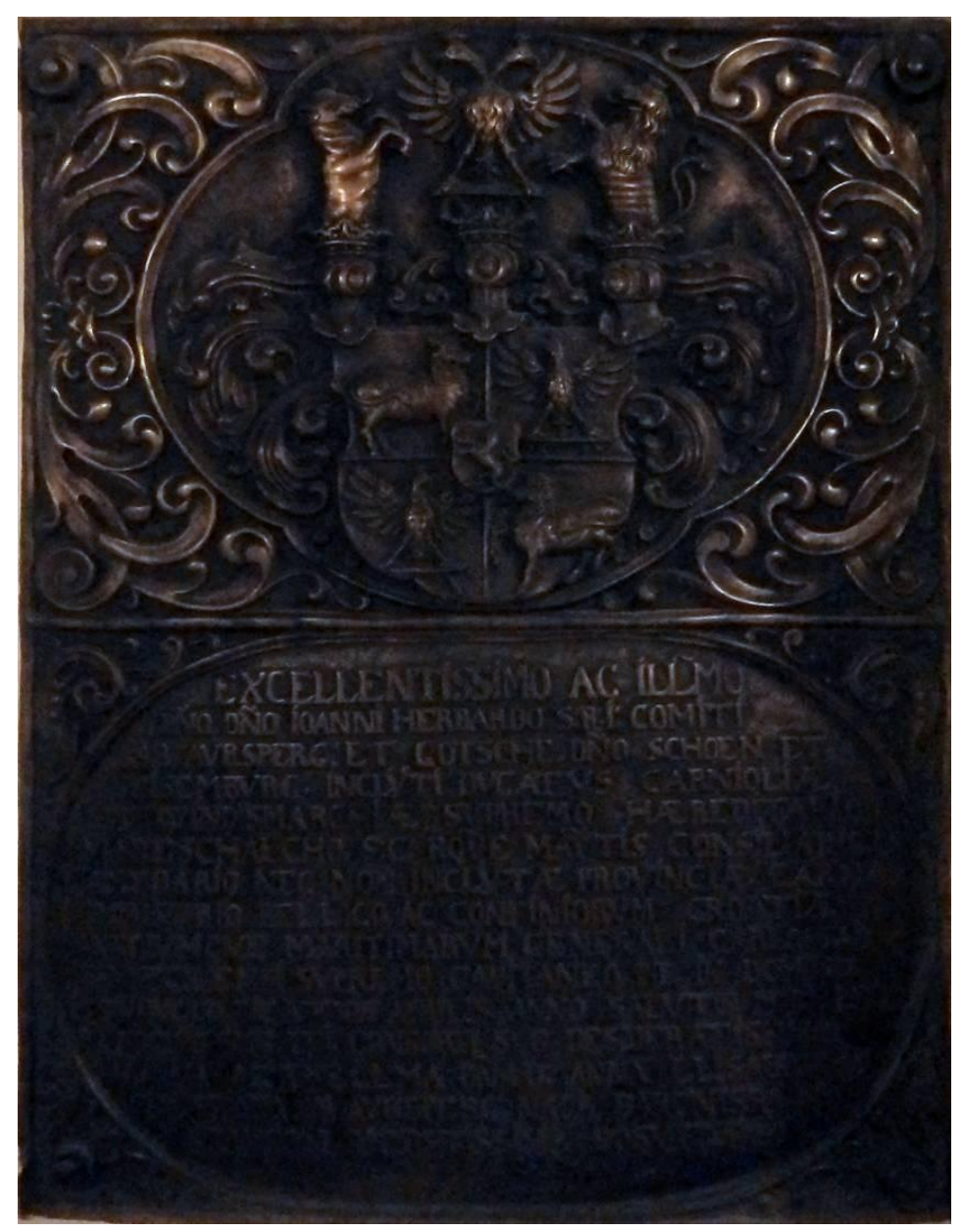

Epitaf Ivana Herbarta X. Auersperga (?, 1613. - Zagreb, 1669.)

Bronca, $134 \times 103 \mathrm{~cm} \times$ [uzidan]

Natpis: „EXCELLENTISSIMO AC ILLMO / DN̄O, DN̄O IOANNI HERBARDO S:R:I: COMITI / AB AVRSPERG, ET GOTSCHE, DN̄O SCHOEN ET / SEISEMBVRG. INCLYTI DVCATVS CARNIOLIÆ / ET WINDISHMARCHIÆ SVPREMO HÆREDITARIO /

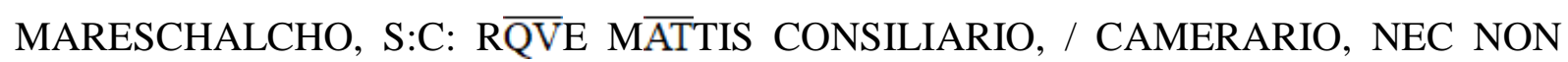

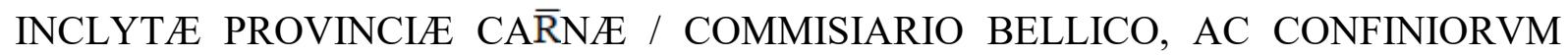
CROATIÆ / PARTIVMQVE MARITIMARVM GENERALI CARLOSTAD / ET SEGNIENSI SVPREMO CAPITANEO, PIE IN DOMINO / DEFVNCTO DIE XXVIII APRILIS ANNO SALVTIS MDCLXIX / ÆTATIS SVÆ LVI, CONSORTI SVO DESIDERATISSIMO, / IL $\bar{L} M A$ AC EXĒLLMA DN̄A D. ELISABETHA / COMITISSA AB AVRSPERG, NATA BARONISSA DE / MOSKON MOESTISSIMA POSVIT«

\section{Opis spomenika:}

Epitaf je izveden u obliku okomito postavljena pravokutnika. Vodoravno je podijeljen na 
dva podjednaka dijela. U gornjoj polovici, unutar četverolista predočen je grb obitelji Auersperg. Prostor oko četverolista ispunjen je simetričnim prepletima vitica. U donjoj polovici nalazi se ovalna kartuša s posvetnim natpisom. Ugaona polja urešena su manirističkom hrskavicom.

\section{Literatura:}

Lelja Dobronić, Crkva sv. Katarine u Zagrebu i hrvatsko plemstvo: vodič po starinama, u: Tkalčić: godišnjak Društva za povjesnicu Zagrebačke nadbiskupije = annales Societatis historicae archiepiscopatus Zagrabiensis IV, Zagreb: Društvo za povjesnicu Zagrebačke nadbiskupije »Tkalčić«, 2000., str. 389-424, 399-400.

Mirjana Repanić-Braun, Slikarstvo, štukature i djela umjetničkoga obrta, u: Akademska crkva sv. Katarine u Zagrebu, Zagreb: Institut za povijest umjetnosti, 2011., str. 203 309, 285. Napisale Katarina Horvat-Levaj, Doris Baričević, Marijana Repanić-Braun.

Ivan Kukuljević Sakcinski, Nadpisi sredovječni i novovjeki na crkvah, javnih i privatnih sgradah itd. u Hrvatskoj $i$ Slavoniji, Zagreb: Knjižara Jugoslavenske akademije, Knjižara Dioničke tiskare, 1891., str. 337, br. 1157.

Artur Schneider, Sitna građa za kulturnu povijest grada Zagreba, u: Narodna starina IX/24, Zagreb: Josip Matasović, 1930., str. 462-465. 
- Kat. br. 49 -

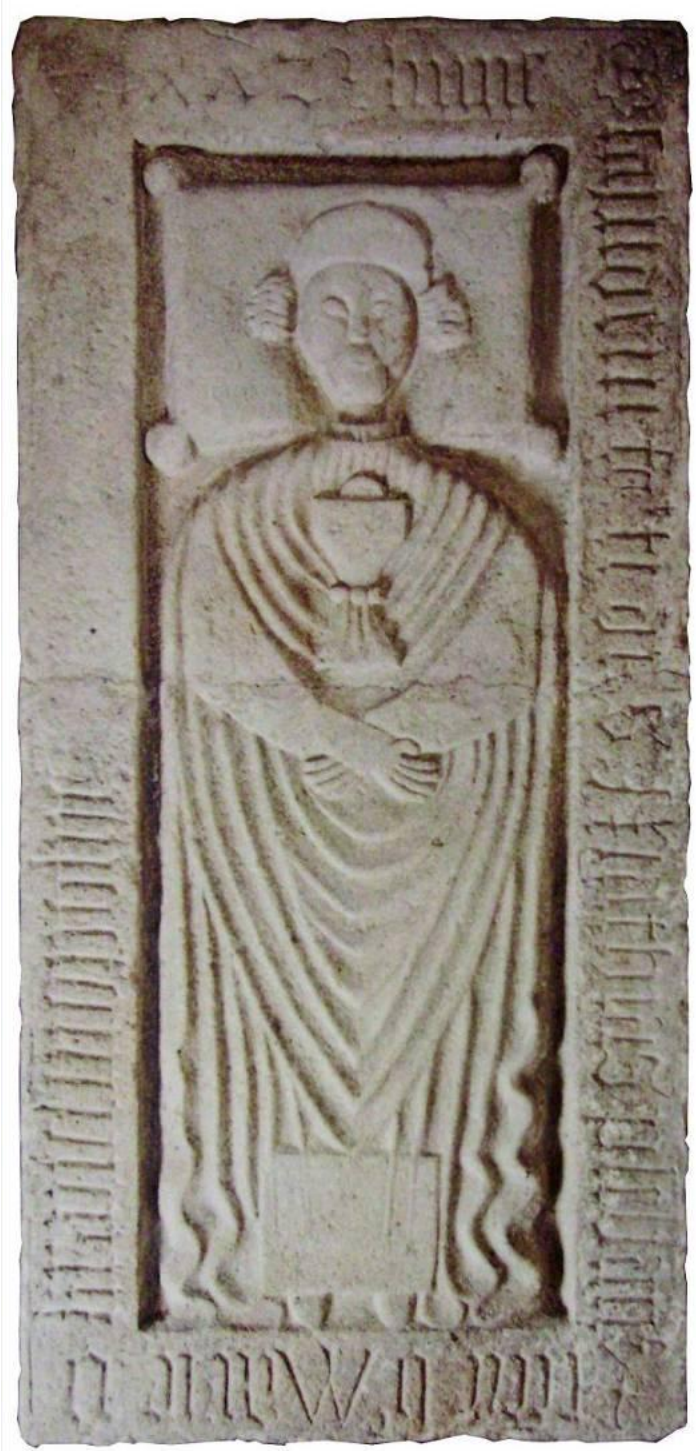

Nadgrobna ploča granešinskoga župnika Matije, 1472.

Kamen vapnenac, $198 \times 95 \times 19 \mathrm{~cm}$

Ploča je danas pohranjena u Muzeju grada Zagreba u Zagrebu.

Natpis: $" \uparrow 1472$ - Hunc / lapidem fe fi dns Mathias pleban / eccie be Marie v / Kranesinopolye [...]«

\section{Opis spomenika:}

Nadgrobna ploča formata okomito postavljena pravokutnika s likom pokojnika glave oslonjene na jastuk. Pokojnik je prikazan en face. Odjeven je u misno ruho plitko oblikovanih i shematiziranih nabora, a na glavi nosi baretu. Ruke drži prekrižene na trbuhu. Na njegovim 
prsima položen je kalež s Presvetim, a na cjevanicama knjiga. U rub ploče uklesan je natpis u gotičkoj minuskuli.

\section{Literatura:}

Josip Brunšmid, Kameni spomenici hrvatskoga narodnoga muzeja u Zagrebu. Dio II. Spomenici srednjega i novoga vijeka, u: Vjesnik Hrvatskoga arheološkog društva XII/1, Zagreb: Hrvatsko arheološko društvo, 1912., str. 129-197, 180-182.

Anđela Horvat, Dva epitafa u Iloku, u: Zbornik za likovne umetnosti 15, Novi Sad: Matica srpska, Odelenje za likovne umetnosti, 1979., str. 307-315, 310.

Zorislav Horvat, Srednjovjekovna crkva sv. Marka, u: Crkva sv. Marka u Zagrebu: arhitektura, povijest, obnova, Zagreb: Hrvatski restauratorski zavod, 2013., str. 11-36, 31. Uredio Petar Puhmajer.

Ivan Kampuš i Ljubo Karaman, Tisućljetni Zagreb: od davnih naselja do suvremenog grada, Zagreb: Školska knjiga, 1994., str. 38.

Ljubo Karaman, O umjetnosti srednjega vijeka u Hrvatskoj i Slavoniji, u: Historijski zbornik I/1-4, Zagreb: Društvo za hrvatsku povjesnicu, 1948., str. 103-127, 107.

Ljubo Karaman, O umjetnosti srednjega vijeka, u: Historijski zbornik III/1-4, Zagreb: Društvo za hrvatsku povjesnicu, 1950., str. 125-174, 146.

Ivan Kukuljević Sakcinski, Nadpisi sredovječni i novovjeki na crkvah, javnih i privatnih sgradah itd. u Hrvatskoj $i$ Slavoniji, Zagreb: Knjižara Jugoslavenske akademije, Knjižara Dioničke tiskare, 1891., str. 323, br. 1112.

Milan Pelc, Spomenici potonuloga svijeta. Nadgrobne ploče s likom pokojnika u sjevernoj Hrvatskoj u pisanim i tiskanim vrelima do konca 19. st., u: Umjetnost $i$ naručitelj. Zbornik radova znanstvenoga skupa "Dani Cvita Fiskovića održanog 2008. godine, Zagreb: Institut za povijest umjetnosti, Odsjek za povijest umjetnosti Filozofskog fakulteta Sveučilišta u Zagrebu, 2010., str. 61-71, 61-62. Uredila Jasenka Gudelj.

Gjuro Szabo, O starom misnom ruhu u našim crkvama, u: Narodna starina VIII/17, Zagreb: Josip Matasović, 1928., str. 145-153, 146.

Slavko Šterk i Boris Mašić, Mors porta vitae = Smrt vrata života: stara zagrebačka groblja $i$ pogrebi, Zagreb: Muzej grada Zagreba, 2014., str. 105.

Mirko Valentić, Kameni spomenici Hrvatske XIII-XIX stoljeća, Zagreb: Povijesni muzej Hrvatske, 1969., str. 201. 


\section{ZAJEZDA, crkva Uznesenja Blažene Djevice Marije}

- Kat. br. 50 -

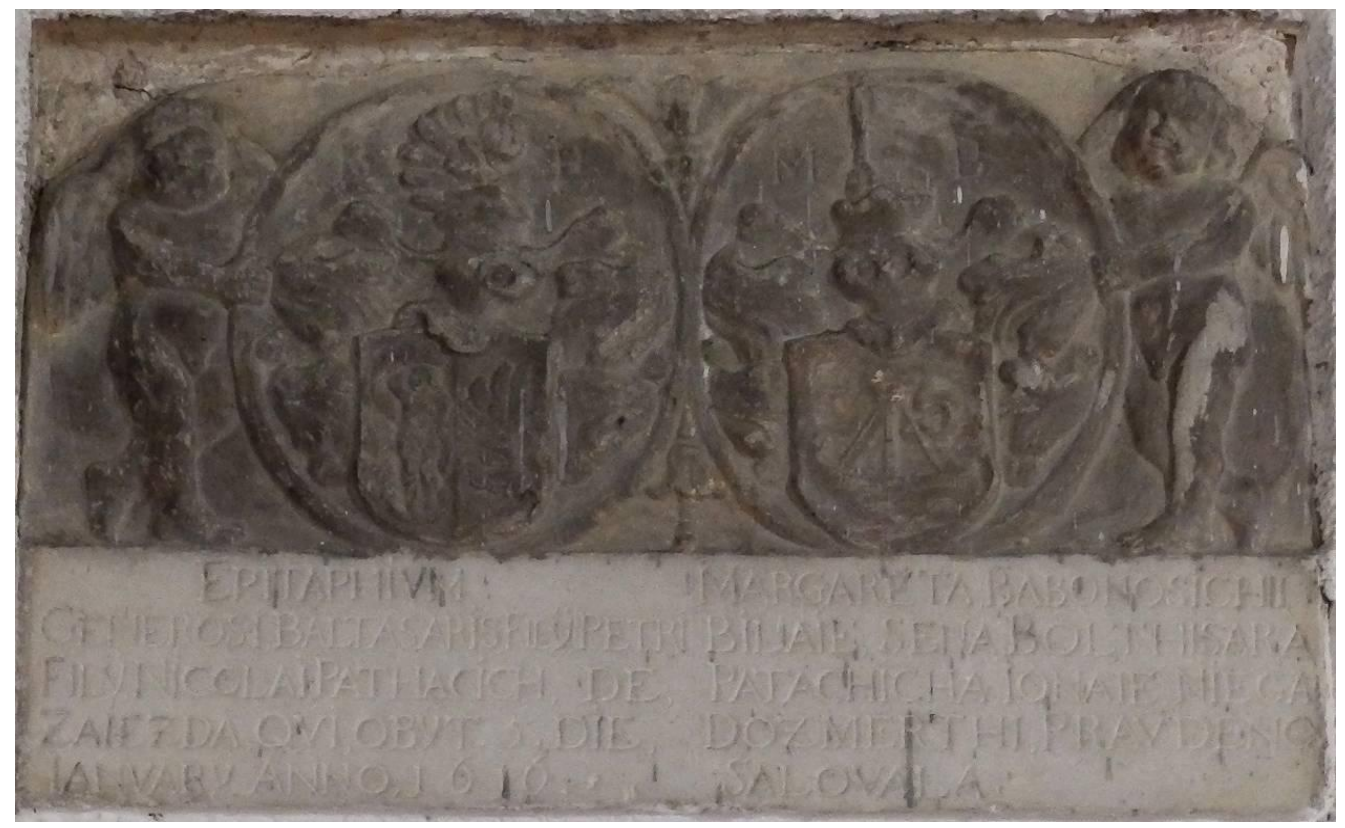

Radionica Majstora Trantnerova epitafa (?), Epitaf Baltazara Patačića (?, 1564. Zajezda, 1616.)

Kamen, $49 \times 72 \mathrm{~cm}$ [uzidan]

Natpis (lijevi stupac): „EPITAHIVM / GENEROSI BALTASARIS FILY PETRI / FILY NICOLAI PATHACICH DE / ZAIZEDA QVI OBYT 5 DIE / IANVARY ANNO 1616.« Desni stupac: "MARGARETA BABONOSICHI / BILA IE SENA BOLTHSARA / PATACHICHA, I ONA IE NIEGA / DO ZMERTHI PRAVDENO / SALOVALA«

\section{Opis spomenika:}

Epitaf je izveden u obliku vodoravno položenoga pravokutnika. U gornjem dijelu predočen je par kartuša s grbovima obitelji Patačić i Babonožić koje pridržavaju dva putta. U donjem dijelu nadgrobnika nalazi se nadgrobni natpis podijeljen na dva stupca. Lijevi stupac pisan je na latinskom, a desni na hrvatskome jeziku.

\section{Literatura:}

Emilijan Cevc, Kiparstvo na Slovenskem med gotiko in barokom, Ljubljana: Slovenska matica, 1981., str. 197.

Anđela Horvat, Između gotike i baroka: umjetnost kontinentalnog dijela Hrvatske od oko 1500. do oko 1700., Zagreb: Društvo povjesničara umjetnosti SR Hrvatske, 1975., str. $341,343$. 
Ljubo Karaman, O umjetnosti srednjega vijeka, u: Historijski zbornik III/1-4, Zagreb: Društvo za hrvatsku povjesnicu, 1950., str. 125-174, 168, bilj. 73.

Ivan Kukuljević Sakcinski, Nadpisi sredovječni i novovjeki na crkvah, javnih i privatnih sgradah itd. u Hrvatskoj $i$ Slavoniji, Zagreb: Knjižara Jugoslavenske akademije, Knjižara Dioničke tiskare, 1891., str. 375, br. 1292.

Vjekoslav Noršić, Zajezda, u: Tkalčić: godišnjak Društva za povjesnicu Zagrebačke nadbiskupije = annales Societatis historicae archiepiscopatus Zagrabiensis XIV, Zagreb: Društvo za povjesnicu Zagrebačke nadbiskupije »Tkalčić«, 2010., str. 345-384, 383. Rukopis priredio Stjepan Razum.

Ivanka Reberski (ur.), Krapinsko-zagorska županija: sakralna arhitektura s inventarom, feudalna arhitektura, spomen-obilježja, Zagreb: Institut za povijest umjetnosti, Školska knjiga, 2008., sub voce Zajezda. Župna crkva Uznesenja Bl. Dj. Marije, str. 123 [Diana Vukičević-Samaržija].

Gjuro Szabo, Spomenici kotara Krapina i Zlatar, u: Vjesnik Hrvatskoga arheološkog društva XIII/1, Zagreb: Hrvatsko arheološko društvo, 1914., str. 103-204, 130, 138, 192.

Gjuro Szabo, Kroz Hrvatsko zagorje, Zagreb: Vasić i Horvat, 1939., str. 90. 


\section{VARAŽDINSKA BISKUPIJA}

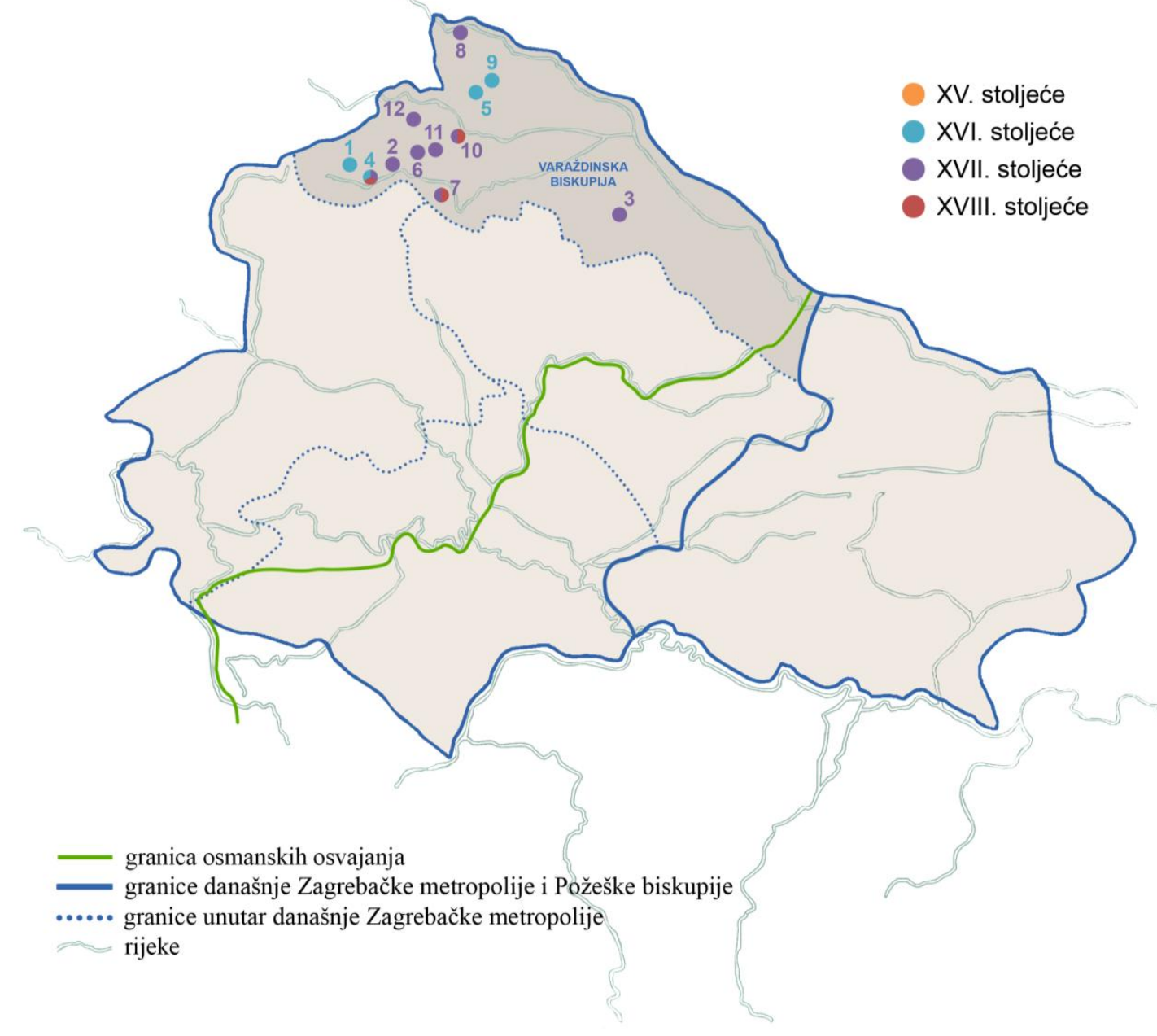

\section{O K A L I T E T I}

1. Bednja, crkva Uznesenja Blažene Djevice Marije

2. Ivanec, kapela sv. Ivana Krstitelja

3. Koprivnica, crkva sv. Nikole

4. Lepoglava, crkva Bezgrješnoga začeća Blažene Djevice Marije

5. Nedelišće, crkva Presvetoga Trojstva

6. Maruševec, crkva sv. Jurja
7. Remetinec, crkva Kraljice Svete Krunice

8. Sveti Martin na Muri, crkva sv. Martina

9. Šenkovec, crkva sv. Jelene

10. Varaždin, crkva sv. Ivana Krstitelja

11. Vidovec, crkva sv. Vida

12. Vinica, crkva sv. Marka evanđelista 


\section{BEDNJA, crkva Uznesenja Blažene Djevice Marije}

- Kat. br. 51 -
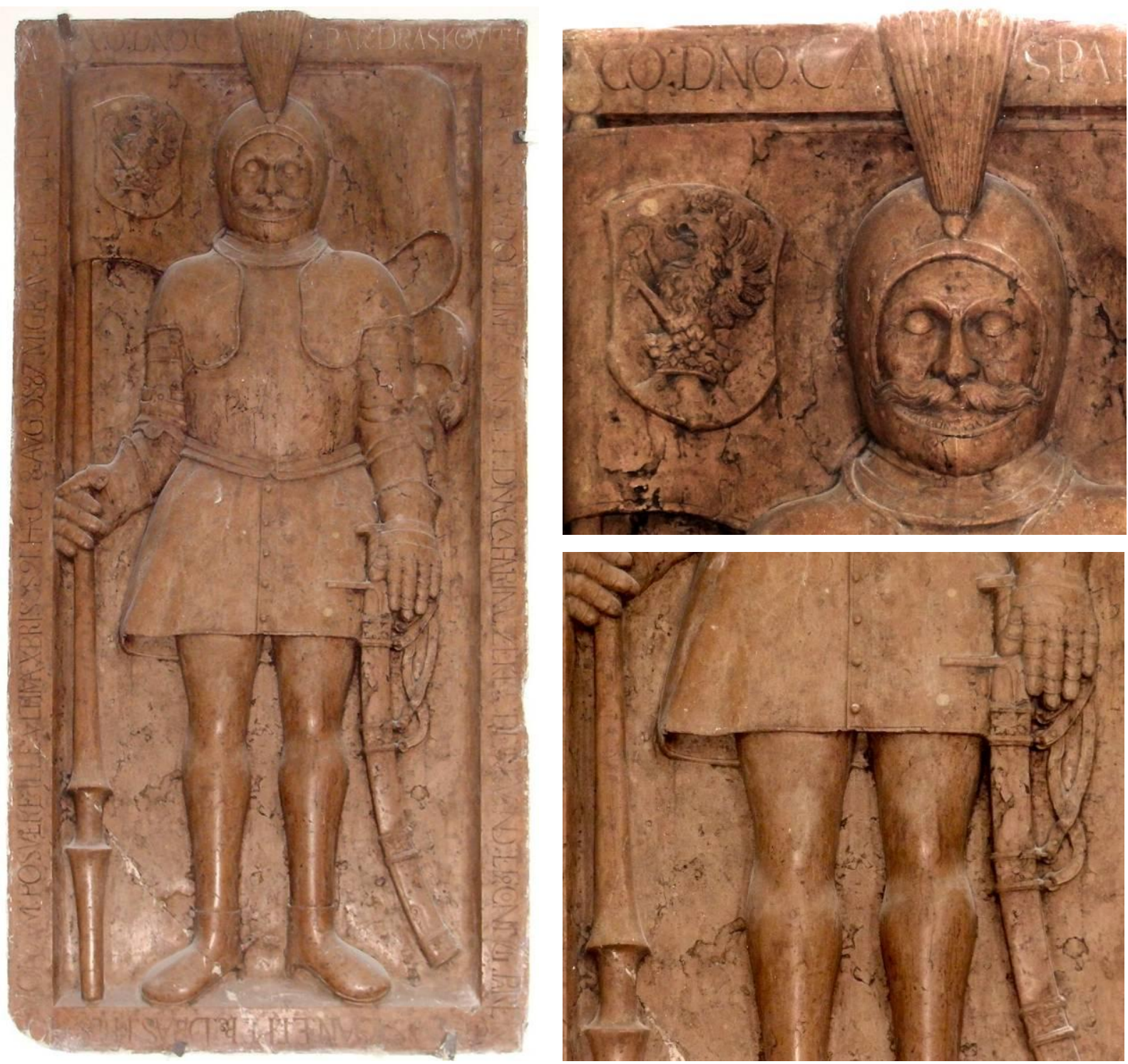

Nadgrobna ploča Gašpara Draškovića (?, 1530. - Trakošćan, 1591.) i Katarine Drašković rođ. Székely de Kevend (Ormož, 1535. - ?, 1587.)

Vapnenačka breča, $225 \times 109 \mathrm{~cm} \times$ [uzidana]

Natpis: "MAGCO: DNOE: CASPAR: DRASCOVITH / DE: TRAKOST: RVDOL: II. IMP: CONS: ET $\overline{\mathrm{DN}} \nRightarrow$ CATHARINÆ ZEKEL DE KEVEND: EI 9 CONIVG. PARENT: /

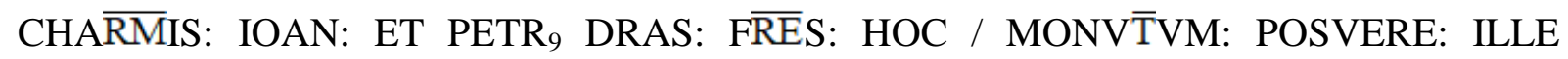
VLTIMA: XBRIS 1591: HÆC 8. AVG: 1587. MIGRAVERE AD DNVM« 


\section{Opis spomenika:}

Nadgrobna ploča formata okomito postavljenoga pravokutnika s likom pokojnika odjevena $\mathrm{u}$ viteški oklop i kacigu. Pokojnik je prikazan en face. U desnoj ruci drži barjak, a lijevom pridržava sablju. Na barjaku se nalazi grb obitelji Drašković, a platno se prostire iza pokojnikove glave u punoj širini spomenika. Uz rubove ploče uklesan je nadgrobni natpis.

\section{Literatura:}

Anđela Horvat, Između gotike i baroka: umjetnost kontinentalnog dijela Hrvatske od oko 1500. do oko 1700., Zagreb: Društvo povjesničara umjetnosti SR Hrvatske, 1975., str. $350-351$.

Ljubo Karaman, O umjetnosti srednjega vijeka, u: Historijski zbornik III/1-4, Zagreb: Društvo za hrvatsku povjesnicu, 1950., str. 125-174, 167, bilj. 72.

Ivan Kukuljević Sakcinski, Glasoviti Hrvati prošlih vjekova. Niz životopisa, Zagreb: Matica hrvatska, 1886., str. 167, 261.

Ivan Kukuljević Sakcinski, Nadpisi sredovječni i novovjeki na crkvah, javnih i privatnih sgradah itd. u Hrvatskoj i Slavoniji, Zagreb: Knjižara Jugoslavenske akademije, Knjižara Dioničke tiskare, 1891., str. 4-5, br. 12.

Vjekoslav Noršić, Bednja, u: Tkalčić: godišnjak Društva za povjesnicu Zagrebačke nadbiskupije = annales Societatis historicae archiepiscopatus Zagrabiensis XIV, Zagreb: Društvo za povjesnicu Zagrebačke nadbiskupije »Tkalčić«, 2010., str. 195-240, 207-208. Rukopis priredio Stjepan Razum.

Milan Pelc, Renesansa, Zagreb: Naklada Ljevak, 2007., str. 315.

Milan Pelc, Povijest umjetnosti u Hrvatskoj, Zagreb: Naklada Ljevak, 2012., str. 236.

Gjuro Szabo, Spomenici kotara Ivanec, u: Vjesnik Hrvatskoga arheološkog društva XIV/1, Zagreb: Hrvatsko arheološko društvo, 1919., str. 22-97, str. 70.

Gjuro Szabo, Kroz Hrvatsko zagorje, Zagreb: Vasić i Horvat, 1939., str. 106. 
- Kat. br. 52 -
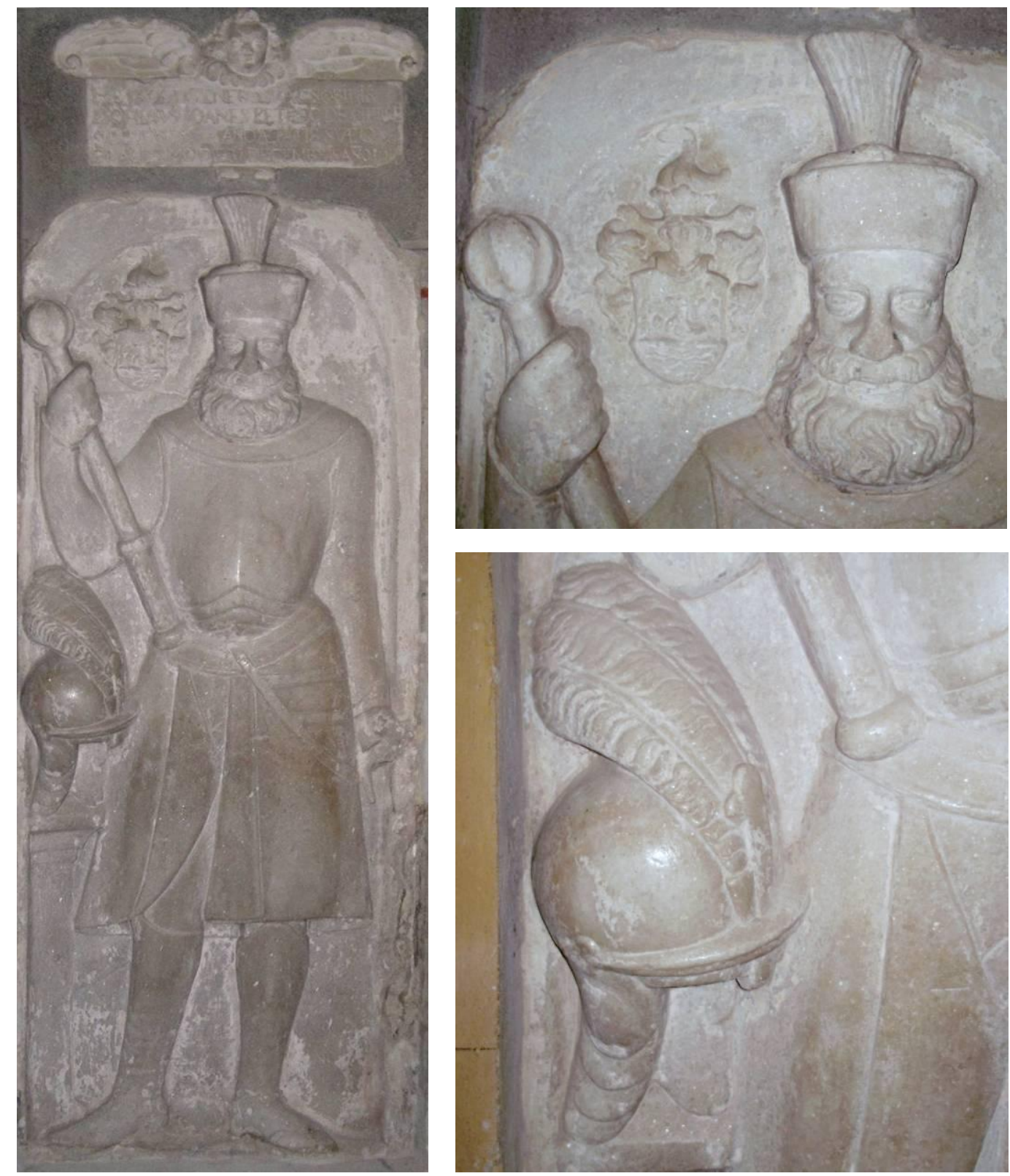

Nadgrobna ploča Ivana Petheö de Gerse (?, 1576. - ?, 1616.)

Kamen, $221 \times 74 \times 13 \mathrm{~cm}$ (dubina reljefa)

Ploča se danas nalazi u crkvi sv. Marije Magdalene u Ivancu.

Natpis: "HIC IACET GENEROSV AC NOBILIS / DOMINVS IOANES PETHEO DE GERSE / OCCUBVIT ANO ÆTATIS SVÆ QVA / DRAGESIMO DIE 31 DECEMBRIS ANO 1616« 


\section{Opis spomenika:}

Nadgrobna ploča formata okomito postavljenoga pravokutnika s likom pokojnika odjevena $\mathrm{u}$ viteški oklop koji stoji ispod polukružnoga luka. Pokojnik je prikazan u lijevom tričetvrt profilu. U desnoj ruci drži topuz, a lijevom pridržava mač opasan oko pojasa. Na glavi nosi kalpak, a kaciga je odložena na postamentu prikazanom uz lijevi rub nadgrobnika. Grb obitelji Pethő de Gerse predočen je s desne strane pokojnikova lica. Iznad figuralnoga prikaza nalazi se natpisna ploča koja je zaključena motivom kerubina.

\section{Literatura:}

Anđela Horvat, Između gotike i baroka: umjetnost kontinentalnog dijela Hrvatske od oko 1500. do oko 1700., Zagreb: Društvo povjesničara umjetnosti SR Hrvatske, 1975., str. $351-352$.

Ljubo Karaman, O umjetnosti srednjega vijeka, u: Historijski zbornik III/1-4, Zagreb: Društvo za hrvatsku povjesnicu, 1950., str. 125-174, 167, bilj. 72.

Miroslav Klemm, Umjetnički spomenici Općine Ivanec, u: Zbornik 600 godina Ivanca, Varaždin: Hrvatska akademija znanosti i umjetnosti, Zavod za znanstveni rad, Grad Ivanec, 1997., str. 287-296, 288. Uredio Adre Mohorovičić.

Anđelko Košćak, Župa sv. Marka Evanđelista - Vinica, Zagreb: Društvo za povjesnicu Zagrebačke nadbiskupije »Tkalčić«, Vinica: Župa Sv. Marka Evanđelista, 2013., str. 40.

Marijan Kraš, Ivanec: prilozi povijesti Ivanca do 1940. godine: Ivancu za šest stotu obljetnicu povodom prvoga pisanoga spomena Ivanca 1396.-1996., Varaždin: Zlati Ajngel, 1996., str. 44, 52, 54-55.

Ivan Kukuljević Sakcinski, Nadpisi sredovječni i novovjeki na crkvah, javnih i privatnih sgradah itd. u Hrvatskoj $i$ Slavoniji, Zagreb: Knjižara Jugoslavenske akademije, Knjižara Dioničke tiskare, 1891., str. 64, br. 205.

Marijana Schneider, Zrinski i Frankopani u likovnoj umjetnosti, u: Historijski zbornik 25-26, Zagreb: Povijesno društvo Hrvatske, 1972.-1973., str. 251-271, 258-259.

Gjuro Szabo, Spomenici kotara Ivanec, u: Vjesnik Hrvatskoga arheološkog društva XIV/1, Zagreb: Hrvatsko arheološko društvo, 1919., str. 22-97, 75.

Gjuro Szabo, Ljudi iz kamena, u: Jutarnji list, Zagreb: Tipografija, 24. XII. 1938., str. 5-6, 6. Gjuro Szabo, Kroz Hrvatsko zagorje, Zagreb: Vasić i Horvat, 1939., str. 114. 


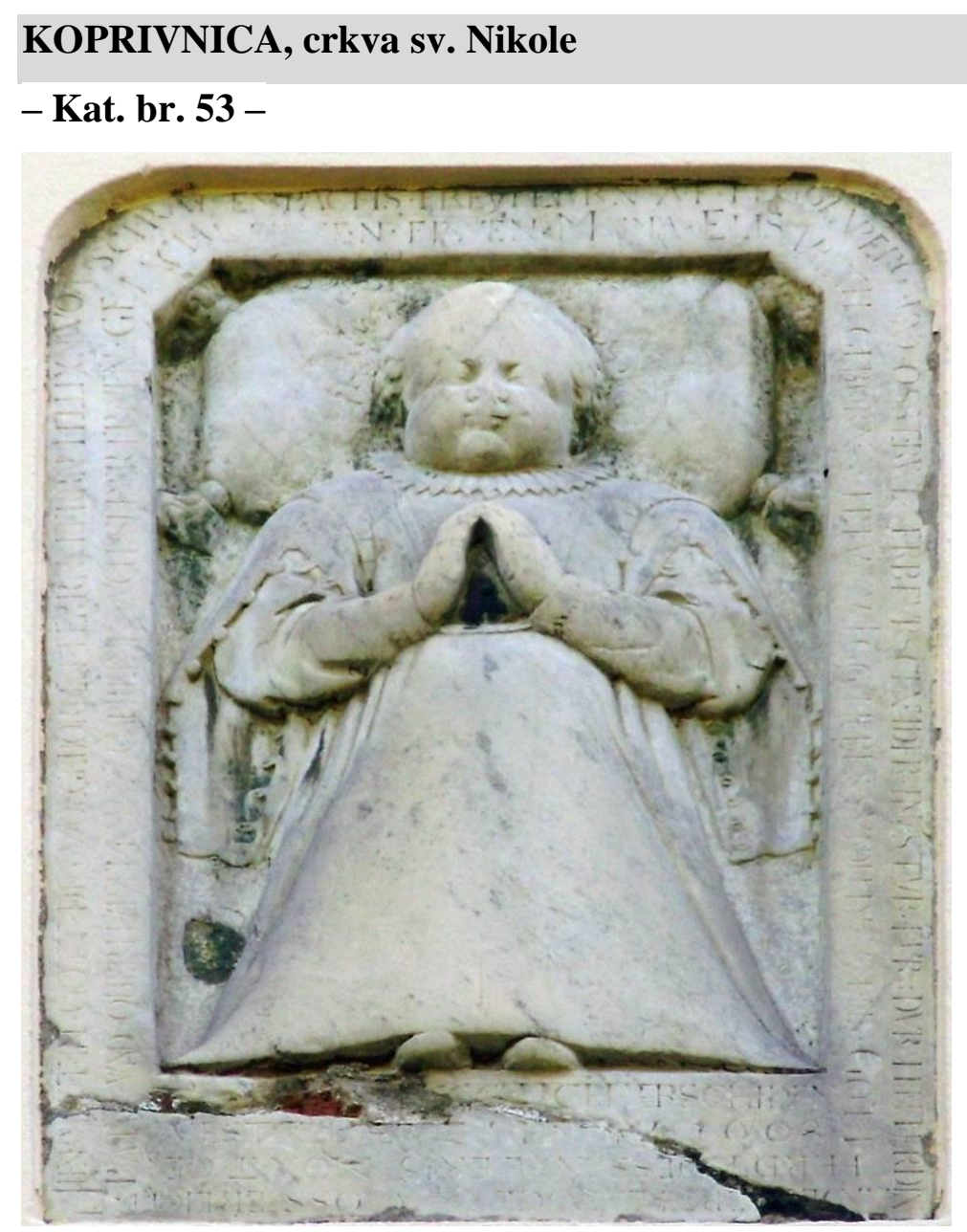

Nadgrobna ploča Gottharda von Schratenpachsa (†1608.)

Kamen pješčenjak, $100 \times 61 \mathrm{~cm} \times$ [uzidana]

Ploča je danas ugrađena u vanjski zid župnoga dvora.

Natpis: »HIER · RVHT · IN · GOTT · DES · WOHLGEBORNEN · HERRN · HERRN · FELLIXIN · / VON · SCHRATENPACHS · FREVHERRN · AVF · HEGGENPERG · / VND · OSSTERWITZ ERBFURSCHNEIDER IN STYR(ISCHE). FÜR(STENTHUMS). DURH(LAUCHT). H. N. FERDINAND E[...] ERZHERZOGEN ZU OSSTEREICH / RATH · VND · OBERHAVPTMAN · ZV · COPREINITZ · AVCH · SEINER · FRAUEN GE / MAHL $\cdot$ FRAVEN $\cdot$ FRAVEN $\cdot$ MARIA $\cdot$ ELISABETH / GEBORNE $\cdot$ V(IE) $\cdot$ FREV $\cdot$ ZV · EGG · LIEBES · SVNDLEIN · NAMENS · GOTT / HARDT · DESSEN · ALTER · 5 · MONAT GE / WEST · WELICHER · 21 · IANVAR 1608 / [ ...] IST · VERSCHIEDEN«

\section{Opis spomenika:}

Nadgrobna ploča formata okomito postavljenoga pravokutnika s likom pokojnika glave oslonjene na jastuk. Pokojnik je prikazan en face, ruku sklopljenih na prsima u molitvi. 
Odjeven je u haljinu zvonolika oblika ispod koje nosi košulju s nabranim ovratnikom i čipkastim orukvicama, a povrh nje gornju haljinu s razrezanim rukavima na kopčanje. Oko rubova ploče uklesan je posvetni natpis.

\section{Literatura:}

Leander Brozović, Građa za povijest Koprivnice, Koprivnica: Muzej grada Koprivnice, 1978., str. 69.

Dragutin Feletar, Spomenici kulture i povijesti u općini Koprivnica, Koprivnica: Muzej grada Koprivnice, 1992., str. 54.

Ljubo Karaman, O umjetnosti srednjega vijeka, u: Historijski zbornik III/1-4, Zagreb: Društvo za hrvatsku povjesnicu, 1950., str. 125-174, 167, bilj. 72.

Ivan Kukuljević Sakcinski, Nadpisi sredovječni i novovjeki na crkvah, javnih i privatnih sgradah itd. u Hrvatskoj i Slavoniji, Zagreb: Knjižara Jugoslavenske akademije, Knjižara Dioničke tiskare, 1891., str. 98, br. 318.

Andrija Lukinović, Župa Ivanić-grad, Zagreb: Glas Koncila, 2007., str. 134.

Marijana Schneider, Dva dječja kostima s nadgrobnih ploča iz Vojne krajine (s pregledom dječje nošnje u zapadnoj Evropi od 1600. do 1650.), u: Spomenica Josipa Matasovića (1892-1962.), Zagreb: Povijesno društvo Hrvatske, 1972., str. 181-199, 182-185, 198199. Uredio Igor Karaman. 


\section{LEPOGLAVA, crkva Bezgrješnoga začeća Blažene Djevice Marije}

\section{- Kat. br. 54 -}

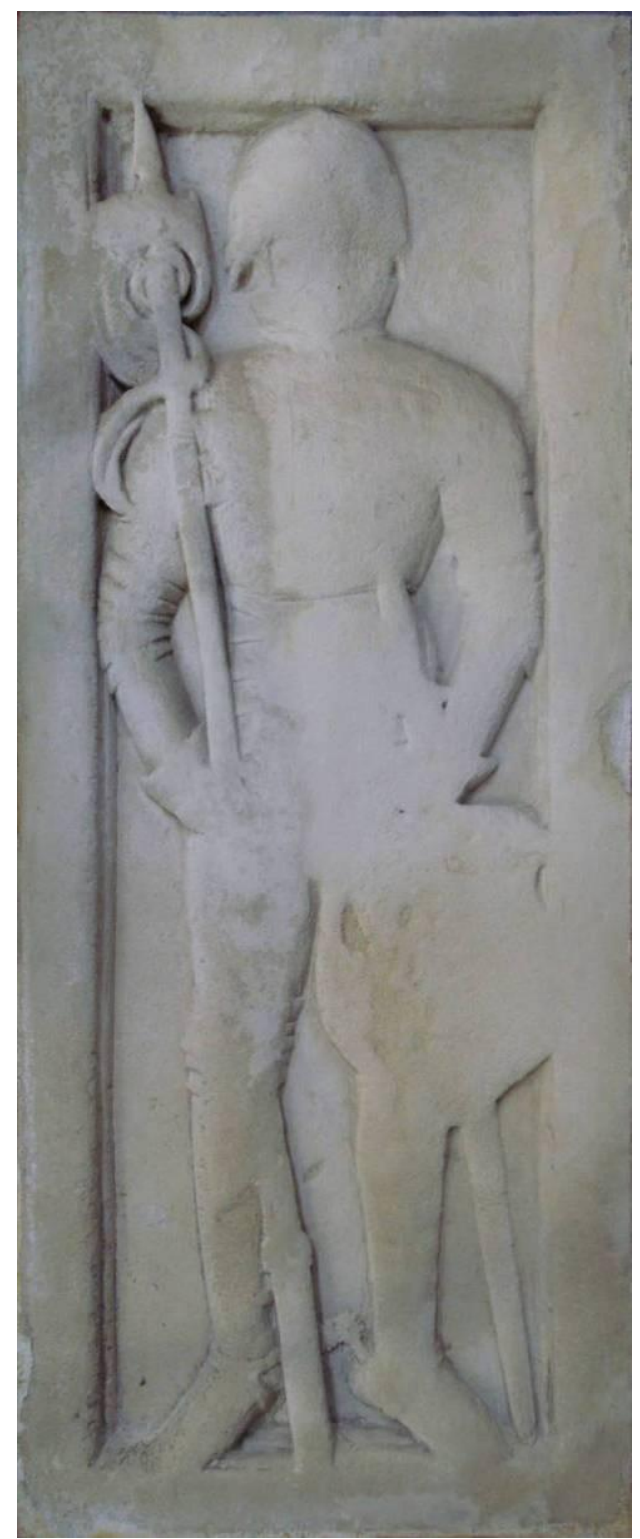

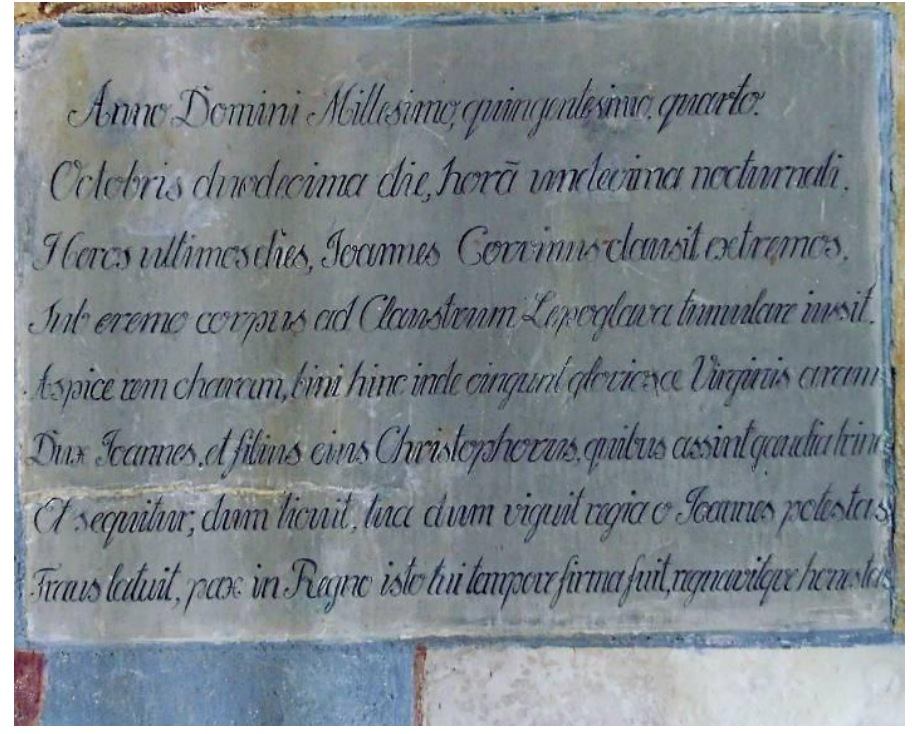

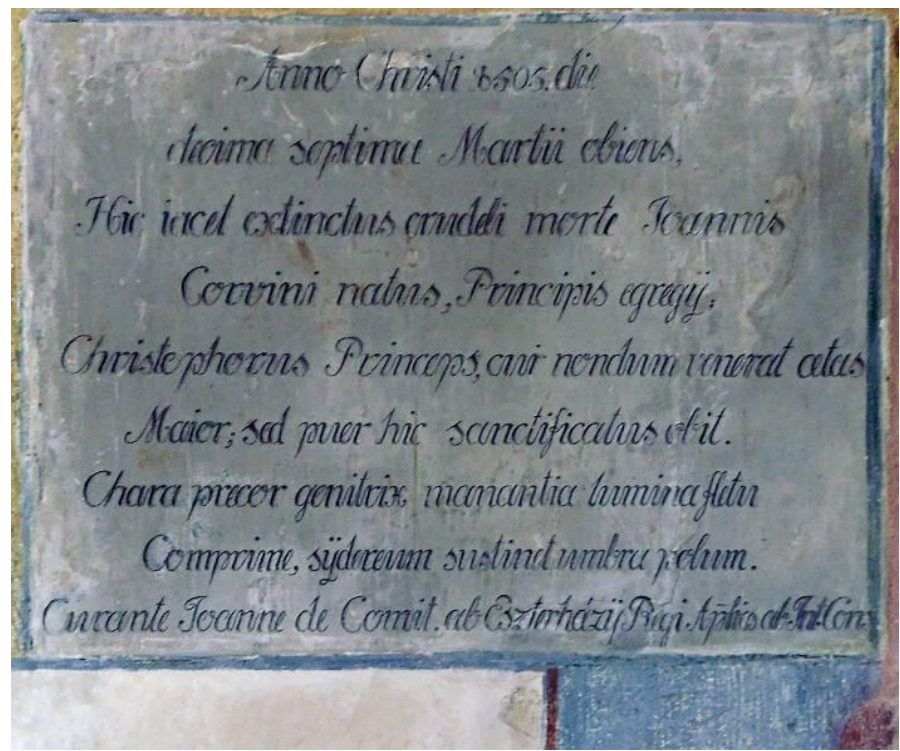

Nadgrobna ploča hercega Ivaniša Korvina (Wrocław, Poljska, 1473. - Krapina, 1504.), 1505.

Kamen, $190 \times 79 \times 4 \mathrm{~cm}$ (dubina reljefa)

Izvorna natpisna ploča (uništena): »HAEC TENET ARCTA DVCEM TVMBA IOANNEM, / MATHIAE QVI STIRPS INCLYTA REGIS ERAT / STRNVVS HIC ARMIS, PARTAQVE MVNDO TRIUMPHA / PLVRIMA POST VICTOR, DIEM CLAVSIT EXTREMVM / ANNO CHRISTI TERQVINGENTESIMO QVARTO / DIE OCTOBRIS 12. IOANNES DE GYULA FIERI FECIT ${ }^{767}$

\footnotetext{
${ }^{767}$ Prijepis preuzet iz: Kamilo Dočkal, nav. dj., 2014., str. 84.
} 
Današnje natpisne ploče: (Lijeva) »Anno Domini Millesimo, quingentisimo quarto / Octobris duodecima die, horā undecima nocturnali, / Heros ultimos dies, Ioannes Corvinus clausit extremos, / Sub eremo corpus ad Claustrum Lepoglava tumulare iussit. / Aspice rem charam, bini hinc inde cingunt gloriosæ Virginis aram / Dux Ioannes et filius eius Christophorus, quibus assint gaudia trina. / Et sequitur; dum licuit, tua dum viguit regia o Ioannes potestas, / Fraus latuit, pax in Regno isto tui tempore firma fuit, regnavitque honestas«. (Desna) »Anno Christi 1505. die / decima septima Martii obiens / Hic iacet extinctus crudeli morte Ioannis / Corvini natus, Principis egregy; / Christophorus Princeps, cui nondum venerat ætas / Maior; sed puer hic sanctificatus obit. / Chara precor genetrix manantia lumina fletu / Comprime, sydereum sustinet umbra polum. / Curante Ioanne de Comit. ab Esterházy Regi Aplico ab Int. Cons«

\section{Opis spomenika:}

Nadgrobna ploča formata okomito postavljenoga pravokutnika s likom pokojnika odjevena u viteški oklop i kacigu. Pokojnik je prikazan en face. U desnoj ruci drži barjak, a lijevom pridržava mač opasan oko pojasa. Ispod njegove lijeve ruke nalazi se štit na kojem je nekoć bio simbol obitelji Korvin - vrana koja u kljunu drži prsten. Prema povijesnim izvorima, nadgrobnik je bio upotpunjen natpisnom pločom. Nakon što je podignut s poda i ugrađen $u$ zidnu masu, stara natpisna ploča zamijenjena je dvjema novima.

\section{Literatura:}

Jolán Balogh, Die Kunst der Renaissance in Ungarn, u: Matthias Corvinus und die Renaissance in Ungarn 1458-1541, Schallaburg '82, 8. Mai - 1. November 1982, Megjelenés, Wien: Amt der Niederösterreichischen Landesregierung, 1982., str. 81107, 101. Uredio Gottfried Stangler.

Kamilo Dočkal, Povijest pavlinskog samostana Blažene Djevice Marije u Lepoglavi, Zagreb: Glas koncila, 2014., str. 83-86.

Igor Fisković, Renesansno kiparstvo, u: Tisuću godina hrvatskog kiparstva, Zagreb: Muzejsko galerijski centar, 1997., str. 155-219, 207. Uredio Igor Fisković.

Anđela Horvat, Između gotike i baroka: umjetnost kontinentalnog dijela Hrvatske od oko 1500. do oko 1700., Zagreb: Društvo povjesničara umjetnosti SR Hrvatske, 1975., str. 75,350 .

Anđela Horvat, Dva epitafa u Iloku, u: Zbornik za likovne umetnosti 15, Novi Sad: Matica srpska, Odelenje za likovne umetnosti, 1979., str. 307-315, 309. 
Ljubo Karaman, O umjetnosti srednjega vijeka, u: Historijski zbornik III/1-4, Zagreb: Društvo za hrvatsku povjesnicu, 1950., str. 125-174, 167.

Ivan Kukuljević Sakcinski, Nadpisi sredovječni i novovjeki na crkvah, javnih i privatnih sgradah itd. u Hrvatskoj $i$ Slavoniji, Zagreb: Knjižara Jugoslavenske akademije, Knjižara Dioničke tiskare, 1891., str. 120-121, br. 406.

Ivo Lentić, Pavlinski samostan i crkva sv. Marije u doba baroka, u: Kaj: časopis za kulturu i prosvjetu XV/5, Zagreb: Kajkavsko spravišče, 1982., str. 36-63, 50, 52, 54.

Milan Pelc, Renesansa, Zagreb: Naklada Ljevak, 2007., str. 314-315.

Juraj Rattkay, Spomen na kraljeve i banove kraljevstava Dalmacije, Hrvatske i Slavonije od njihovih početaka, pa sve do ove 1652. godine koji je sastavio Juraj Rattkay od Velikog Tabora, zagrebački kanonik i lektor, Zagreb: Hrvatski institut za povijest, 2001., str. 198-199. Prevela Zrinka Blažević et al.

Agneza Szabo, Ban Ivaniš Korvin u hrvatskoj povijesti i kulturi (u povodu 500. obljetnice smrti), u: Gazophylacium: časopis za znanost, umjetnost, gospodarstvo i politiku IX/34, Zagreb: Pinta - Udruga za očuvanje, obnovu i korištenje kulturnog blaga Hrvatske, 2004., str. 5-13, 12.

Gjuro Szabo, Spomenici kotara Ivanec, u: Vjesnik Hrvatskoga arheološkog društva XIV/1, Zagreb: Hrvatsko arheološko društvo, 1919., str. 22-97, 35-36.

Gjuro Szabo, Kroz Hrvatsko zagorje, Zagreb: Vasić i Horvat, 1939., str. 101.

Diana Vukičević-Samaržija, Umjetnost renesanse, u: Sveti trag. Devetsto godina umjetnosti Zagrebačke nadbiskupije 1094.-1994., MGC - Muzej Mimara, Zagreb, 10. rujna - 31. prosinca 1994., Zagreb: Zagrebačka nadbiskupija, Institut za povijest umjetnosti, Muzejsko-galerijski centar, 1994., str. 175-188, 182-183. Uredili Tugomir Lukšić i Ivanka Reberski. 
- Kat. br. $55-$
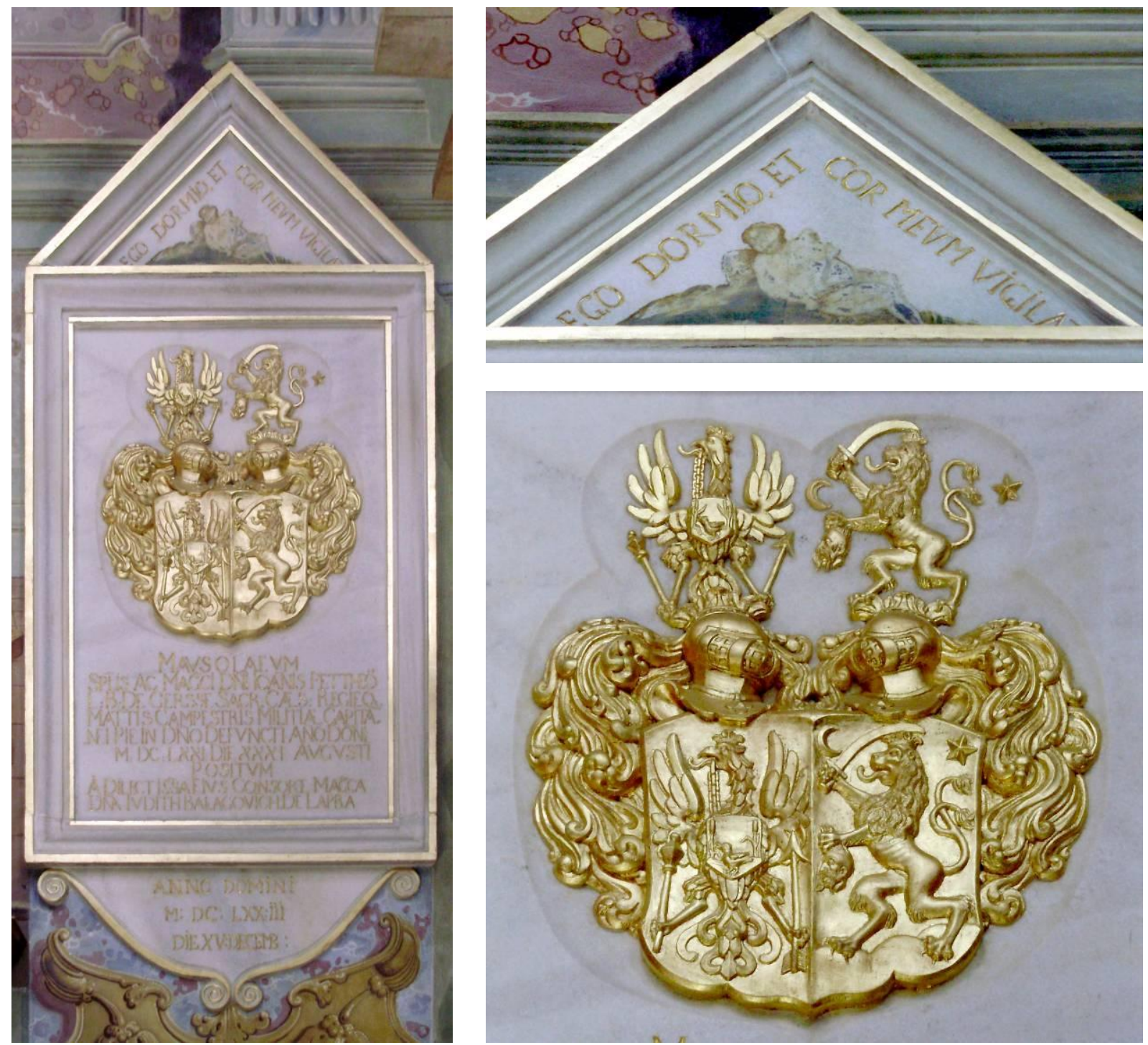

Epitaf Ivana Petheő́a de Gerse (? - ?, 1671.), 1673.

Mramor, pozlata, boja, $285 \times 120 \mathrm{~cm} \times$ [uzidan]

Natpis unutar zabata: "EGO DORMIO ET / COR MEVM VIGILAT«. Natpis ispod grbova:

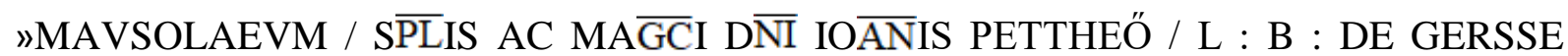
SACR : CÆS : REGIEQ, / MATTIS CAMPESTRIS MILITIÆ CAPITA. / NEI PIE IN $\overline{\mathrm{DNO}}$ DEFVNCTI AN̄O DŌNI / M: DC: LXXI: DIE XXXI AVGVSTI / POSITVM / A DILECTISSA EIVS CONSORTE MA $\overline{G C} A$ / DNA IVDITH BALAGOVICH DE LAPRA«. Natpis na konzoli: »ANNO DOMINI / M : DC : LXX : III / DIE XV : DECEMB :«

\section{Opis spomenika:}

Epitaf je izveden u obliku stilizirane edikule. Sastoji se od središnjega dijela koji je postavljen na volutnu konzolu, a zaključen je jednostavnim zabatom. U središnjem dijelu nalazi se 
združeni grb pokojnikove obitelji, Petheő de Gerse, i one njegove supruge, obitelji Balagović. Ispod grba i unutar konzole ispisan je posvetni natpis. $U$ zabatu je naslikan lik usnuloga muškarca iznad kojega je ispisano: "EGO DORMIO, ET COR MEVM VIGILAT«. Spomenik je izveden u bijelome mramoru, a rubovi arhitektonskih elemenata, grbovi i natpisi su pozlaćeni.

\section{Literatura:}

Kamilo Dočkal, Povijest pavlinskog samostana Blažene Djevice Marije u Lepoglavi, Zagreb: Glas koncila, 2014., str. 269-270.

Ivan Kukuljević Sakcinski, Nadpisi sredovječni i novovjeki na crkvah, javnih i privatnih sgradah itd. u Hrvatskoj $i$ Slavoniji, Zagreb: Knjižara Jugoslavenske akademije, Knjižara Dioničke tiskare, 1891., str. 124-125, br. 413.

Ivo Lentić, Pavlinski samostan i crkva sv. Marije u doba baroka, u: Kaj: časopis za kulturu i prosvjetu XV/5, Zagreb: Kajkavsko spravišče, 1982., str. 36-63, 38, 54.

Gjuro Szabo, Spomenici kotara Ivanec, u: Vjesnik Hrvatskoga arheološkog društva XIV/1, Zagreb: Hrvatsko arheološko društvo, 1919., str. 22-97, 36-37.

Gjuro Szabo, Kroz Hrvatsko zagorje, Zagreb: Vasić i Horvat, 1939., str. 101. 
- Kat. br. $56-$

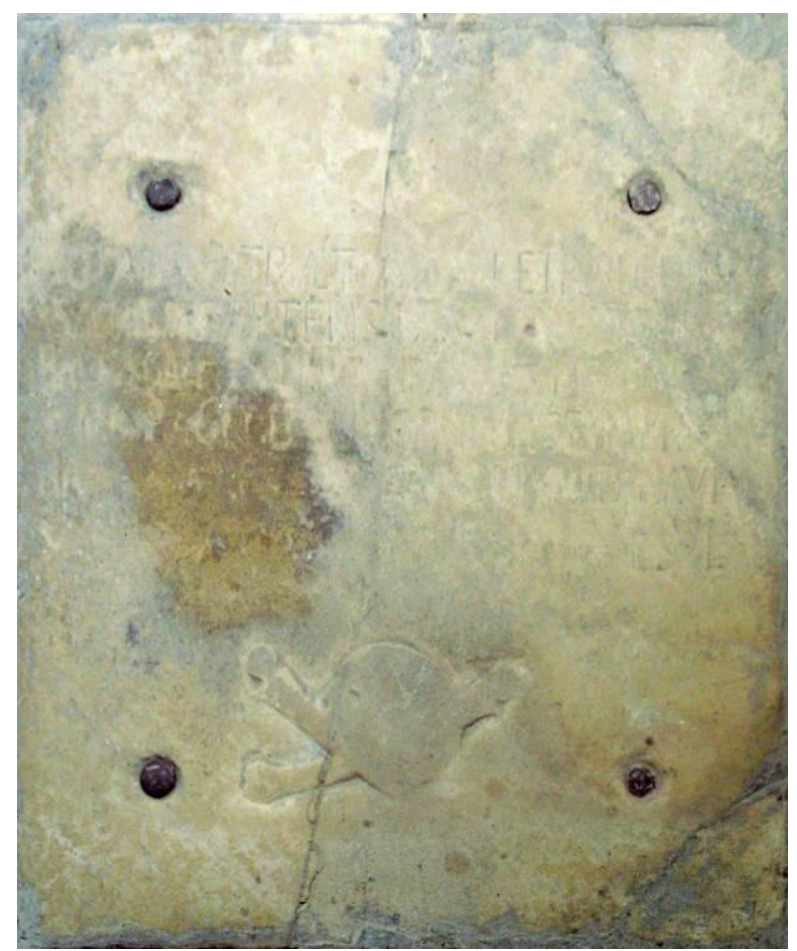

Nadgrobna ploča Barbare Gereczi, 1678.

Kamen, $115 \times 102 \mathrm{~cm} \times$ [postavljena u pod]

Natpis: "NOTA DEO PATRIÆ TO(TI, SIM)VL ET PEREGRINIS / SACRIS PRESBYTERIS. PAVPE(RIBVSQVE VIRIS) / BALTHASARIS ZABOKY QVONDA(M CARISSIMA CONJVX) / BARBARA GERECZI HIC PRIMA SEPVLTA (IACET) / NA(M QVAE CONFRATRES SVMM)E DVM VIXIT AMAVIT / (HAEC QVOQVE VVLT OBIENS FIDA MANER)E SVIS«

\section{Opis spomenika:}

Jednostavna nadgrobna ploča izvedena u obliku okomito postavljena pravokutnika. Sadrži nadgrobni natpis i motiv mrtvačke lubanje s parom ukriženih kostiju.

\section{Literatura:}

Kamilo Dočkal, Povijest pavlinskog samostana Blažene Djevice Marije u Lepoglavi, Zagreb: Glas koncila, 2014., str. 270-271.

Ivan Kukuljević Sakcinski, Nadpisi sredovječni i novovjeki na crkvah, javnih i privatnih sgradah itd. u Hrvatskoj i Slavoniji, Zagreb: Knjižara Jugoslavenske akademije, Knjižara Dioničke tiskare, 1891., str. 125, br. 415. 
Gjuro Szabo, Spomenici kotara Ivanec, u: Vjesnik Hrvatskoga arheološkog društva XIV/1, Zagreb: Hrvatsko arheološko društvo, 1919., str. 22-97, 41.

Gjuro Szabo, Kroz Hrvatsko zagorje, Zagreb: Vasić i Horvat, 1939., str. 101-102. 
- Kat. br. 57 -
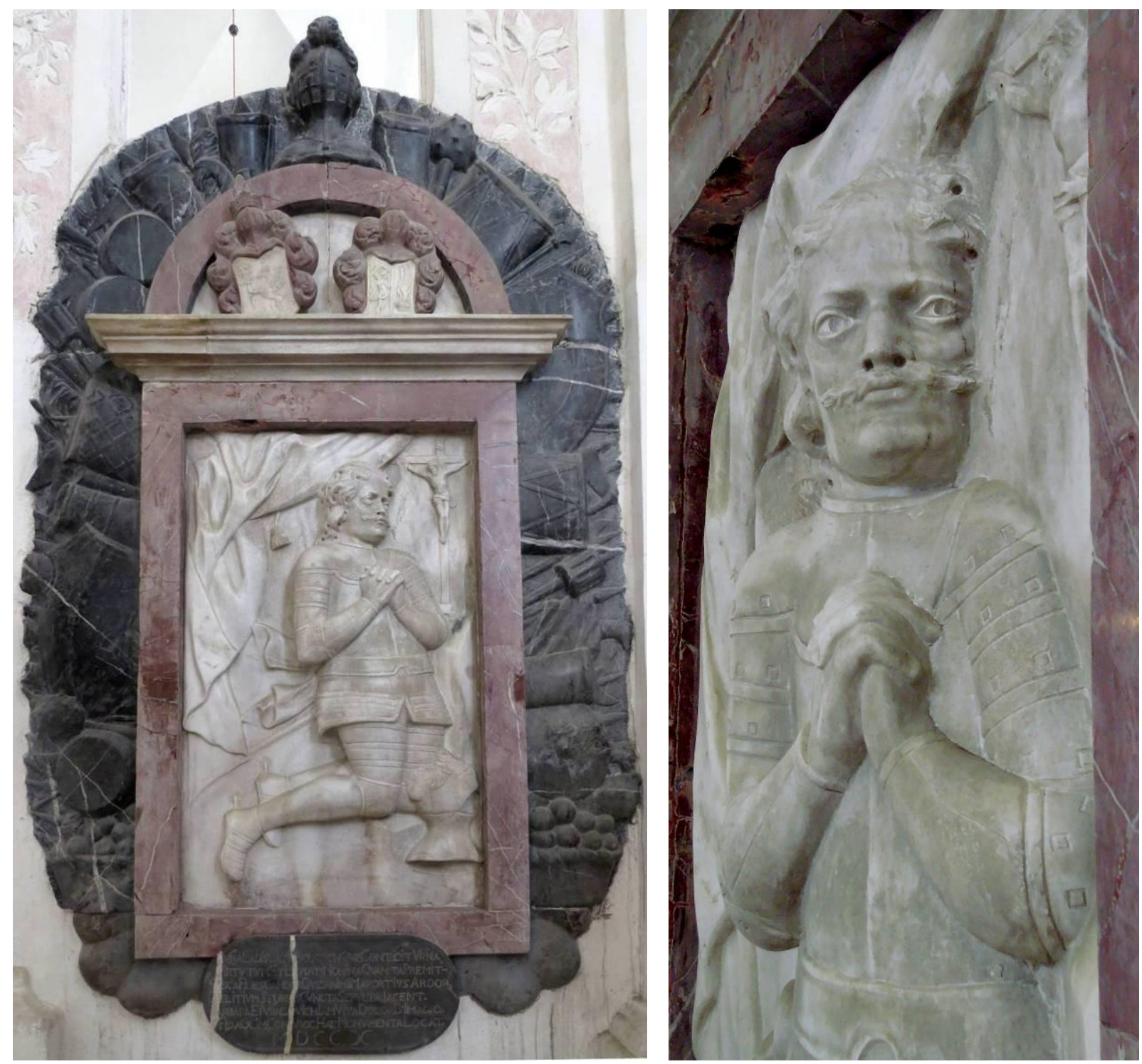

Epitaf Ladislava III. Patačića (?, 1651. - ?, 1705.), 1710.

Mramor, $302 \times 180 \times 8 \mathrm{~cm}$ (dubina reljefa)

Natpis: »VNA LADISLAVM PATATICH QVÆ CONTEIGIT VRNA, / VIRTVTVM ET LAVDVM NOMINA QVANTA PREMIT / PRISCA FIDES CANDOR QVE ANIMI MARORTIVS ARDOR / DELITIVM STYRPIS CVNCTA SEPVLTA IACENT. / BARBARA EI VRAGOVICH IAM VIVA DOLORIS IMAGO / FIDA OLIM CONIVVX HÆC MONVMENTA LOCAT. / MDCCX.«

\section{Opis spomenika:}

Epitaf je izveden u obliku stilizirane edikule zaključene polukružnim zabatom koja je okružena ratnim trofejima. U središnjem dijelu edikule prikazan je pokojnik-adorant koji kleči 
i moli pred Raspetim. Odjeven je u viteški oklop, a kaciga je odložena sa strane do njegovih nogu. Predočen je u desnom tričetvrt profilu, a pogledom je usmjeren prema Kristu na križu. Raspeti je prikazan u znatno manjem mjerilu nego pokojnik, čime više nalikuje raspelu. S pokojnikove desne strane zastrta je uskovitlana draperija. Unutar polukružnoga zabata nalaze se grbovi obitelji Patačić i Vragović kojom se pokojnik orodio. Ispod središnjega prikaza nalazi se ovalna ploča s nadgrobnim natpisom. Spomenik je izveden u kombinaciji crnoga (natpisna ploča, ratni trofeji), crvenoga (okvir središnjega prikaza, luk zabata, grbovni ukrasi) i bijeloga mramora (središnji reljefni prikaz, pozadina zabata, grbovni štitovi).

\section{Literatura:}

Kamilo Dočkal, Povijest pavlinskog samostana Blažene Djevice Marije u Lepoglavi, Zagreb: Glas koncila, 2014., str. 277-279.

Anđela Horvat, Barok u kontinentalnoj Hrvatskoj, u: Barok u Hrvatskoj, Zagreb: Sveučilišna naklada Liber, Odjel za povijest umjetnosti Centra za povijesne znanosti, Društvo povjesničara umjetnosti, 1982., str. 3-381, 266. Napisali Anđela Horvat, Radmila Matejčić i Kruno Prijatelj.

Ljubo Karaman, O umjetnosti srednjega vijeka, u: Historijski zbornik III/1-4, Zagreb: Društvo za hrvatsku povjesnicu, 1950., str. 125-174, 167, bilj. 72.

Ivan Kukuljević Sakcinski, Nadpisi sredovječni i novovjeki na crkvah, javnih i privatnih sgradah itd. u Hrvatskoj $i$ Slavoniji, Zagreb: Knjižara Jugoslavenske akademije, Knjižara Dioničke tiskare, 1891., str. 128-129, br. 419.

Ivo Lentić, Pavlinski samostan i crkva sv. Marije u doba baroka, u: Kaj: časopis za kulturu $i$ prosvjetu XV/5, Zagreb: Kajkavsko spravišče, 1982., str. 36-63, 40, 55-56.

Pavao Maček, Rod Patačića od Zajezde - pregled rodoslovlja, u: Gazophylacium: časopis za znanost, umjetnost, gospodarstvo i politiku IX/1-2, Zagreb: Pinta - Udruga za očuvanje, obnovu i korištenje kulturnog blaga Hrvatske, 2004., str. 113-117, 115.

Milan Pelc, Povijest umjetnosti u Hrvatskoj, Zagreb: Naklada Ljevak, 2012., str. 331-332.

Gjuro Szabo, Spomenici kotara Ivanec, u: Vjesnik Hrvatskoga arheološkog društva XIV/1, Zagreb: Hrvatsko arheološko društvo, 1919., str. 22-97, 40.

Gjuro Szabo, Ljudi iz kamena, u: Jutarnji list, Zagreb: Tipografija, 24. XII. 1938., str. 5-6, 6. Gjuro Szabo, Kroz Hrvatsko zagorje, Zagreb: Vasić i Horvat, 1939., str. 91. 
- Kat. br. 58 -
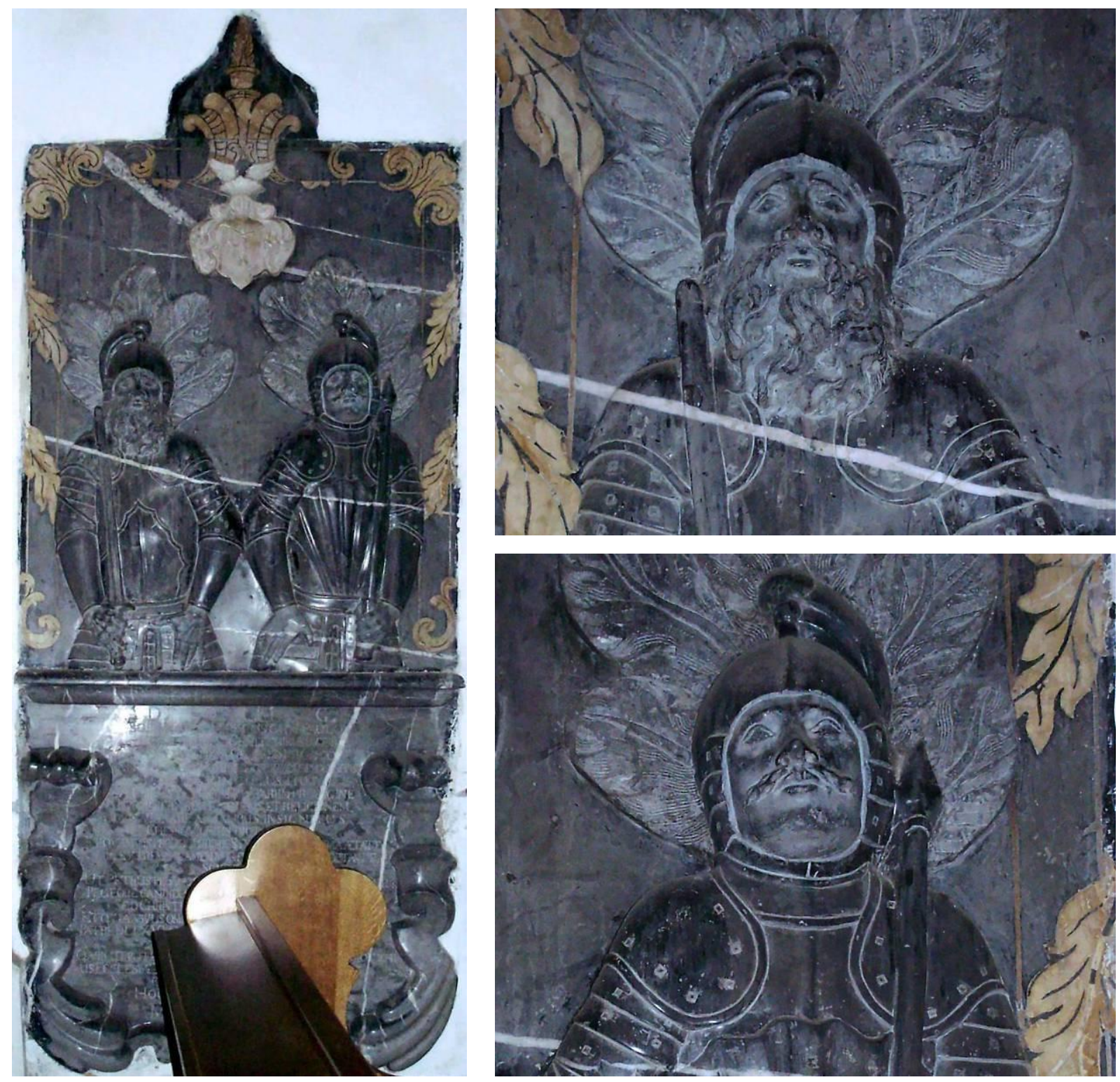

\section{Epitaf obitelji Češković, 1711.}

Mramor, $255 \times 109 \times 12 \mathrm{~cm}$ (dubina reljefa)

Natpis: »D. O. M. G. / SUB HAC PETRA PETRUS CUM PAULO / ET CATHARINA GENITORIBUS IACET. / ILLE Ă LUPO, HIC Ă GEORGIO PROAVO / ANTIQUO COGNOMINE DONIR DICTO PROGENITIS, / QUI IAM TUNC ILLUSTRIS / Ă CHEHIS VETUSTĂ CROATARUM PROPAGINE / PROPTER FIDEM FUGIENS, ET RELIGIONEM, / NOVIS Ă CÆSARE ARMALIBUS INSIGNITUS / CHESKOVICHIUS DICTUS FUIT / ET QVAMVIS PROH DOLOR. HIC STYRPIS ULTIM 9 OPTIMĂ ÆTATE / IN EXTREMIS TAMEN, MORTEM PRÆ VITA PRÆOPTAVIT. / SCILICET, / UT

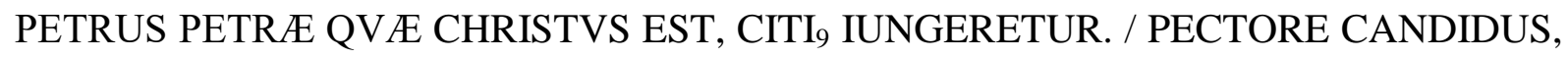

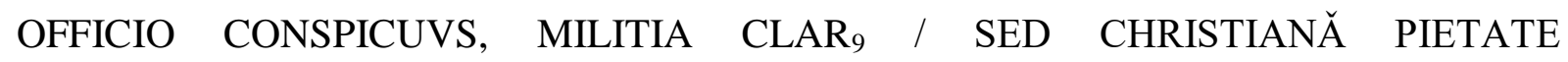


CLARISSIMUS. / ET QVIA VIVUS OMNIUM AMOREM MORTU 9 MOEROREM MERUIT. / PATRE DCLXVI FILIO DCCIX SUPRA MILLESIMUM, / VITĂ FUNCTIS. / QVIB $_{9}$ UTPOTE GENITORI, ET GERMANO, PAULUS CHESKOVICHIUS ECCLESIÆ ZAGRABIENSIS MAIOR PRAEPOSITUS. / CUM DOLORE MAXIMO, / HOC MONUMENTO PARENTAT. / MDC CXI.«

\section{Opis spomenika:}

Epitaf je vodoravno podijeljen na dva dijela gotovo jednake visine. U gornjem dijelu unutar okvira ukrašenoga vegetabilnim motivima i antefiksom u obliku baklje (izvedeni $u$ inkrustaciji žutoga kamena) predočen je par vitezova do razine pojasa. Lijevi je portretiran kao stariji muškarac duge brade i brkova koji u desnoj ruci drži mač. Desni vitez prikazan je kao mlađi muškarac gustih brkova, a u lijevoj ruci drži zapovjedničku palicu. Pozadina iza njihovih glava ukrašena je dvama lisnatim motivima, a iznad njih nalazi se grb obitelji Češković izveden u inkrustaciji bijeloga kamena. U donjem dijelu epitafa nalazi se posvetni natpis čiji su rubovi ukrašeni volutama.

\section{Literatura:}

Anđela Horvat, Barok u kontinentalnoj Hrvatskoj, u: Barok u Hrvatskoj, Zagreb: Sveučilišna naklada Liber, Odjel za povijest umjetnosti Centra za povijesne znanosti, Društvo povjesničara umjetnosti, 1982., str. 3-381, 266. Napisali Anđela Horvat, Radmila Matejčić i Kruno Prijatelj.

Ivan Kukuljević Sakcinski, Nadpisi sredovječni i novovjeki na crkvah, javnih i privatnih sgradah itd. u Hrvatskoj i Slavoniji, Zagreb: Knjižara Jugoslavenske akademije, Knjižara Dioničke tiskare, 1891., str. 123-124, br. 412.

Ivo Lentić, Pavlinski samostan i crkva sv. Marije u doba baroka, u: Kaj: časopis za kulturu i prosvjetu XV/5, Zagreb: Kajkavsko spravišče, 1982., str. 36-63, 54.

Gjuro Szabo, Spomenici kotara Ivanec, u: Vjesnik Hrvatskoga arheološkog društva XIV/1, Zagreb: Hrvatsko arheološko društvo, 1919., str. 22-97, 38.

Gjuro Szabo, Kroz Hrvatsko zagorje, Zagreb: Vasić i Horvat, 1939., str. 101. 
- Kat. br. 59 -
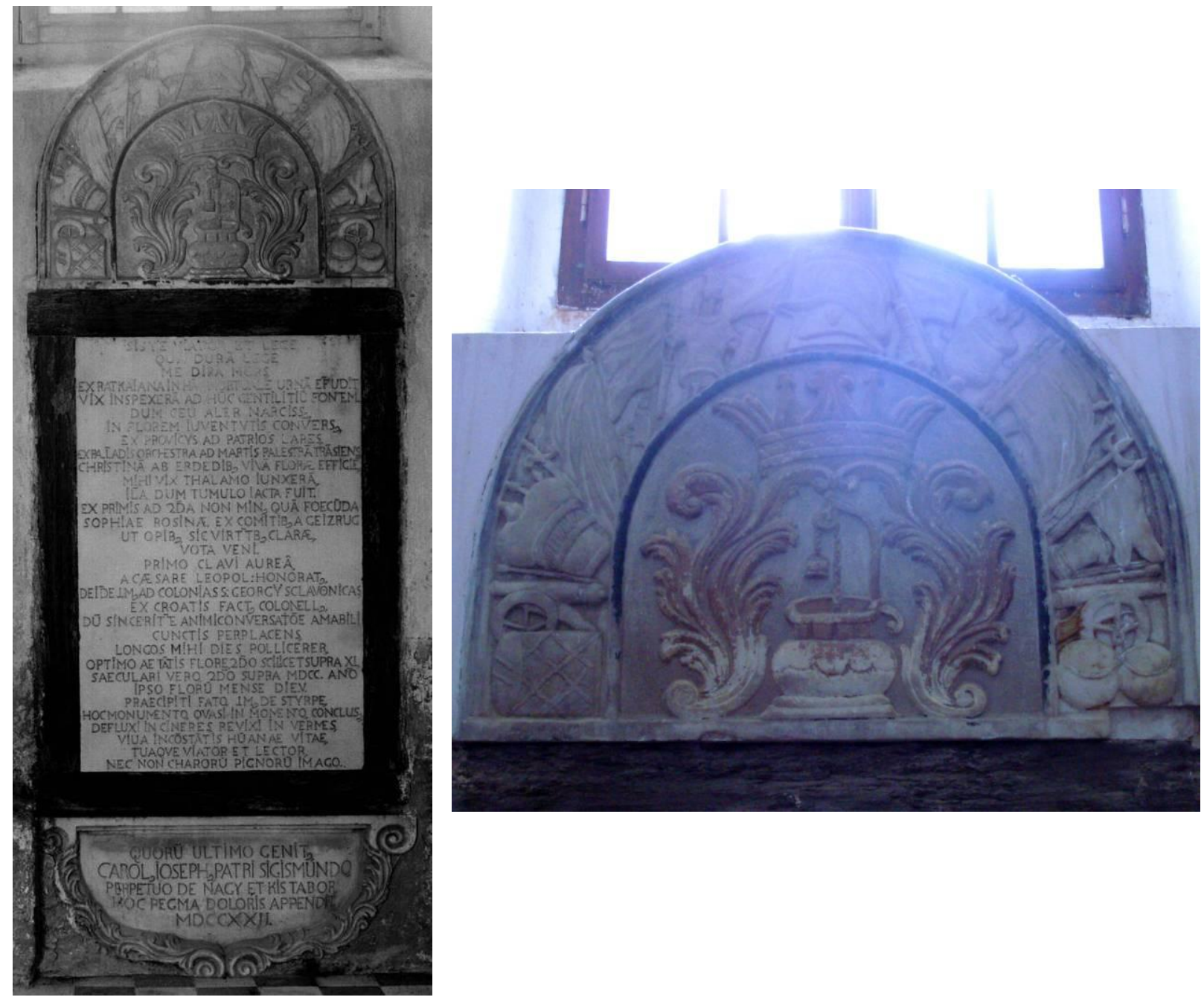

Epitaf Sigismunda Ratkaja (?, 1660. - ?, 1702.), 1722.

Kamen, polikromija, $276 \times 106 \times 4 \mathrm{~cm}$ (dubina reljefa)

Natpis u središnjem polju: »SISTE VIATOR ET LEGE, / QUĀ DURÂ LEGE, / ME DIRA

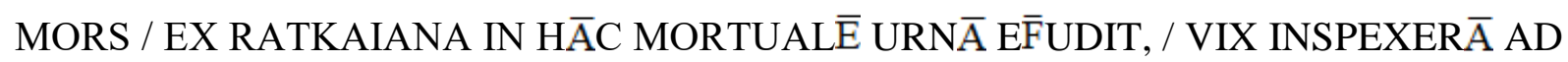

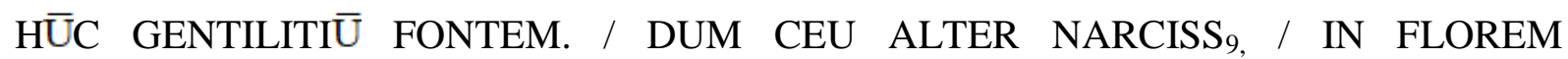

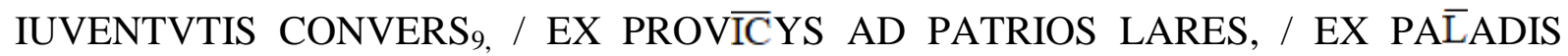

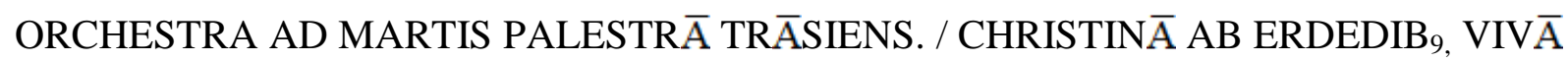

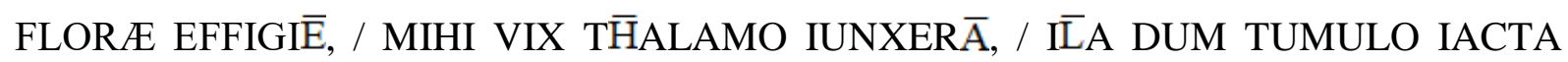
FUIT. / EX PRIMIS AD 2DA NON MIN 9 QUA FOECŪDA, / SOPHIAE ROSINÆ EX

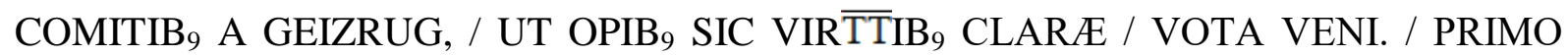
CLAVI AUREÂ, / A CÆSARE LEOPOL: HONORAT 9 , / DED̄DE IM 9 AD COLONIAS S.

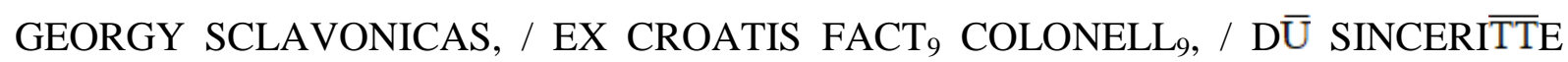
ANIMI CONVERSATOE AMABILI, / CUNCTIS PERPLACENS, / LONGOS MIHI DIES 


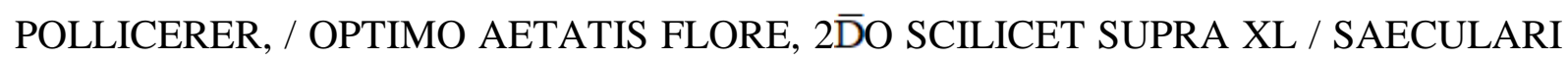

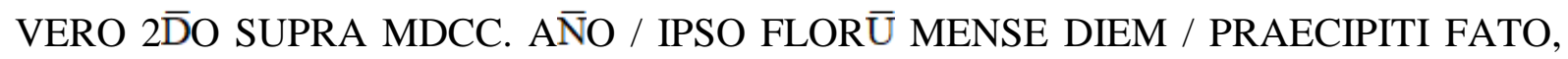
$\mathrm{IM}_{9}$ DE STYRPE, / HOC MONUMENTO QVASI IN MOMENTO, CONCLUS 9 / DEFLUXI IN CINERES, REVIXI IN VERMES, / VIUA INCONSTĀTIS HŪANAE VITAE, /

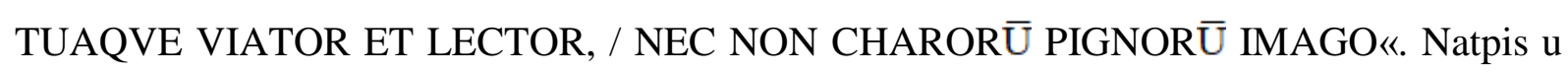

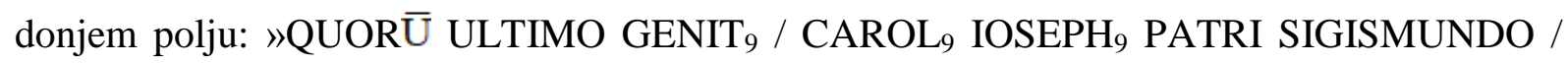
PERPETUO DE NAGY ET KIS TABOR, / HOC PEGMA DOLORIS APPENDIT. / MDCCXXII.«

\section{Opis spomenika:}

Epitaf je izveden u obliku stilizirane edikule. Sastoji se od središnjega dijela omeđenoga jednostavnim okvirom koji je postavljen na polukružnu konzolu ukrašenu volutama i viticama, a zaključen je lunetom. Luk lunete ukrašen je ratnim trofejima (bubnjevima, topovima, barjacima, kacigama i kopljima), a ispod njega nalazi se grbovni simbol obitelji Ratkaj - zidani bunar. Poljā središnjega dijela i konzole ispunjena su nadgrobnim natpisom. Na spomeniku su vidljivi ostaci polikromacije.

\section{Literatura:}

Kamilo Dočkal, Povijest pavlinskog samostana Blažene Djevice Marije u Lepoglavi, Zagreb: Glas koncila, 2014., str. 272-274.

Marina Krpan, Hrvatski Ratkaji, u: Kaj: časopis za književnost, umjetnost i kulturu XXV/12, Zagreb: Kajkavsko spravišče, 1992., str. 77-88, 88.

Ivan Kukuljević Sakcinski, Nadpisi sredovječni i novovjeki na crkvah, javnih i privatnih sgradah itd. u Hrvatskoj $i$ Slavoniji, Zagreb: Knjižara Jugoslavenske akademije, Knjižara Dioničke tiskare, 1891., str. 126-127, br. 417.

Ivo Lentić, Pavlinski samostan i crkva sv. Marije u doba baroka, u: Kaj: časopis za kulturu i prosvjetu XV/5, Zagreb: Kajkavsko spravišče, 1982., str. 36-63, 40, 55.

Gjuro Szabo, Spomenici kotara Ivanec, u: Vjesnik Hrvatskoga arheološkog društva XIV/1, Zagreb: Hrvatsko arheološko društvo, 1919., str. 22-97, 38-39.

Gjuro Szabo, Kroz Hrvatsko zagorje, Zagreb: Vasić i Horvat, 1939., str. 33. 


\section{MARUŠEVEC, crkva sv. Jurja}

\section{- Kat. br. 60 -}
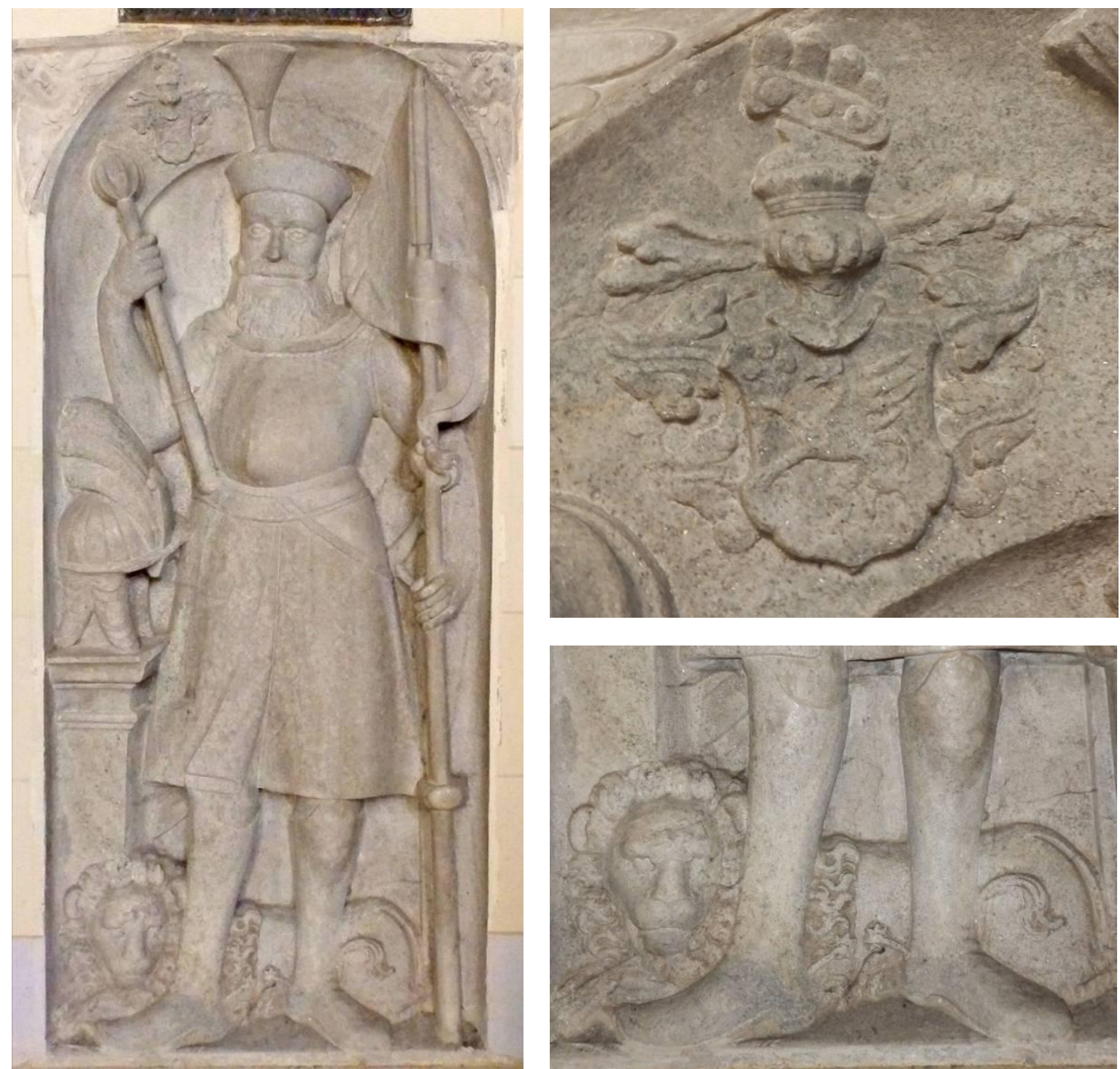

\section{Nadgrobna ploča člana obitelji Vragović, I. polovina XVII. stoljeća}

Kamen, $118 \times 100 \times 11 \mathrm{~cm}($ dubina reljefa $)$

\section{Opis spomenika:}

Nadgrobna ploča formata okomito postavljenoga pravokutnika s likom pokojnika odjevena u viteški oklop. Pokojnik stoji ispod polukružnoga luka koji je ukrašen grbom obitelji Vragović. Ugaona polja luka urešena su dvama kerubinima. Pokojnik u desnoj ruci drži topuz, a lijevom pridržava koplje barjaka. Na glavi nosi kalpak, a kaciga je odložena na postamentu prikazanom uz lijevi rub nadgrobnika. Iza pokojnikovih nogu leži lav. 


\section{Literatura:}

Ivan Čerpinko, Maruševec, Varaždin: Tiskara Varaždin, Maruševec: Općina Maruševec, 2002., str. 32-33.

Anđela Horvat, Između gotike i baroka: umjetnost kontinentalnog dijela Hrvatske od oko 1500. do oko 1700., Zagreb: Društvo povjesničara umjetnosti SR Hrvatske, 1975., str. $351-352$.

Ljubo Karaman, $O$ umjetnosti srednjega vijeka, u: Historijski zbornik III/1-4, Zagreb: Društvo za hrvatsku povjesnicu, 1950., str. 125-174, 167, bilj. 72.

Anđelko Košćak, Župa sv. Marka Evanđelista - Vinica, Zagreb: Društvo za povjesnicu Zagrebačke nadbiskupije »Tkalčić«, Vinica: Župa Sv. Marka Evanđelista, 2013., str. 40. Marijana Schneider, O epitafiju Ivana Hrvoja i Eve Dreffell u Plešivici, u: Bulletin Instituta za likovne umjetnosti Jugoslavenske akademije znanosti $i$ umjetnosti VII/3, Zagreb, Jugoslavenska akademija znanosti i umjetnosti, 1959., str. 177-182, 180.

Marijana Schneider, Zrinski i Frankopani u likovnoj umjetnosti, u: Historijski zbornik 25-26, Zagreb: Povijesno društvo Hrvatske, 1972.-1973., str. 251-271, 258-259.

Gjuro Szabo, Spomenici kotara Ivanec, u: Vjesnik Hrvatskoga arheološkog društva XIV/1, Zagreb: Hrvatsko arheološko društvo, 1919., str. 22-97, 89.

Gjuro Szabo, Ljudi iz kamena, u: Jutarnji list, Zagreb: Tipografija, 24. XII. 1938., str. 5-6, 6. Gjuro Szabo, Kroz Hrvatsko zagorje, Zagreb: Vasić i Horvat, 1939., str. 113. 
Kat. br. 61
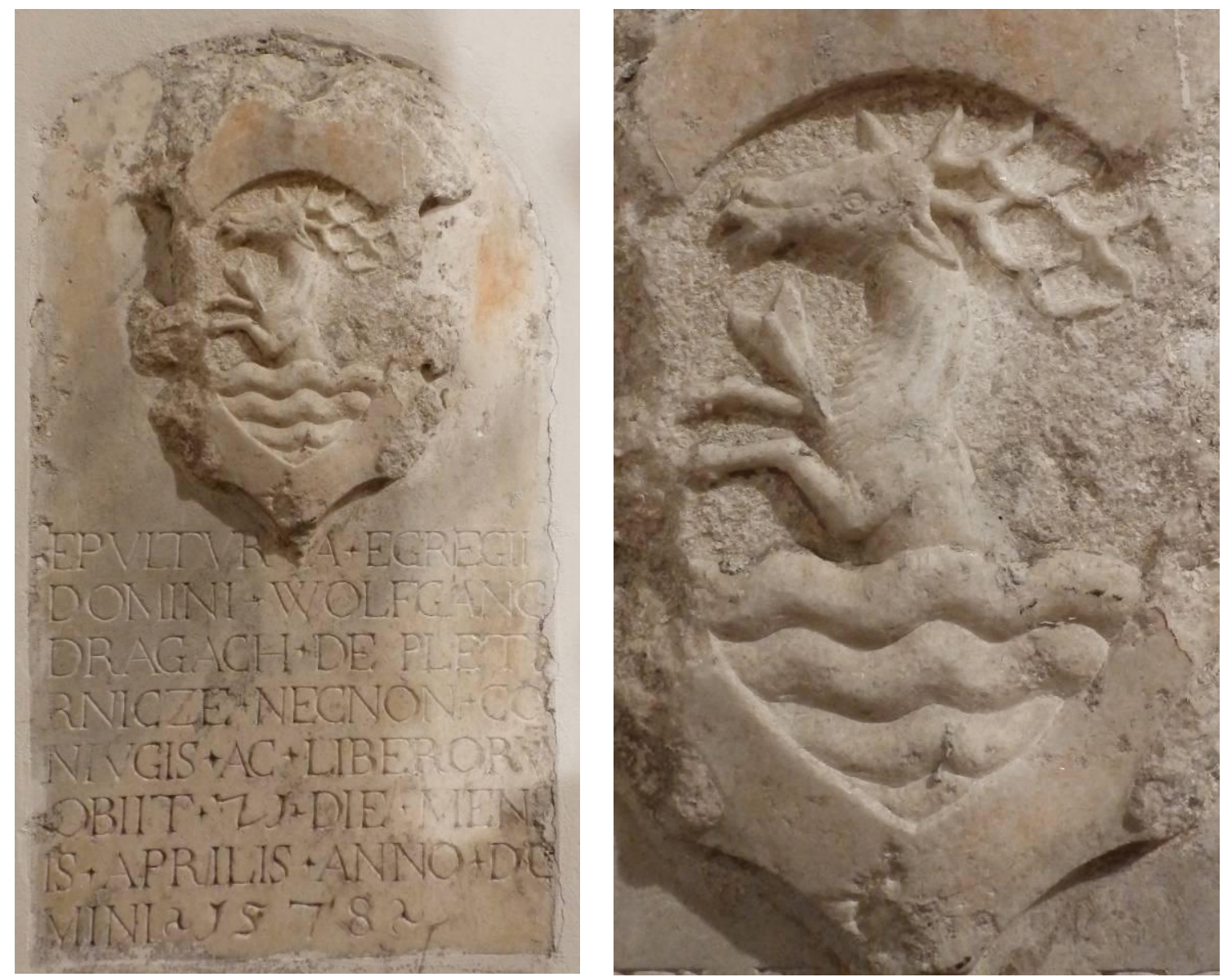

Nadgrobna ploča Vuka Dragača (? - ?, 1578.)

Kamen, $89 \times 51 \times 3 \mathrm{~cm}($ dubina reljefa)

Natpis: "SEPVLTVRA · EGREGII / DOMINI - WOLFGANG / DRAGACH · DE PLETE / RNICZE · NECNON · CO / NIVGIS · AC · LIBERORVM / OBIIT · $21 \cdot$ DIE · MENS / IS · APRILIS $\cdot$ ANNO $\cdot$ DO / MINI $\cdot 1578 \cdot \lll$

\section{Opis spomenika:}

Jednostavna nadgrobna ploča izvedena u obliku okomito postavljena pravokutnika. Sadrži reljefno izveden grb obitelji Dragač ispod kojega je ispisan nadgrobni natpis.

\section{Literatura:}

Anđela Horvat, Spomenici arhitekture $i$ likovnih umjetnosti u Međimurju, Zagreb: [Konzervatorski zavod], 1956., str. 70. 
Ljubo Karaman, O umjetnosti srednjega vijeka, u: Historijski zbornik III/1-4, Zagreb: Društvo za hrvatsku povjesnicu, 1950., str. 125-174, 168, bilj. 73.

Julije Kempf, Požega: zemljopisne bilješke iz okoline i prilozi za povijest Slob. kr. grada Požege i Požeške županije, Požega: Štamparija »Hrvatske tiskare i knjižare», 1910., str. 129.

Ivan Kukuljević Sakcinski, Nadpisi sredovječni i novovjeki na crkvah, javnih i privatnih sgradah itd. $u$ Hrvatskoj $i$ Slavoniji, Zagreb: Knjižara Jugoslavenske akademije, Knjižara Dioničke tiskare, 1891., str. 387, br. 1330. 


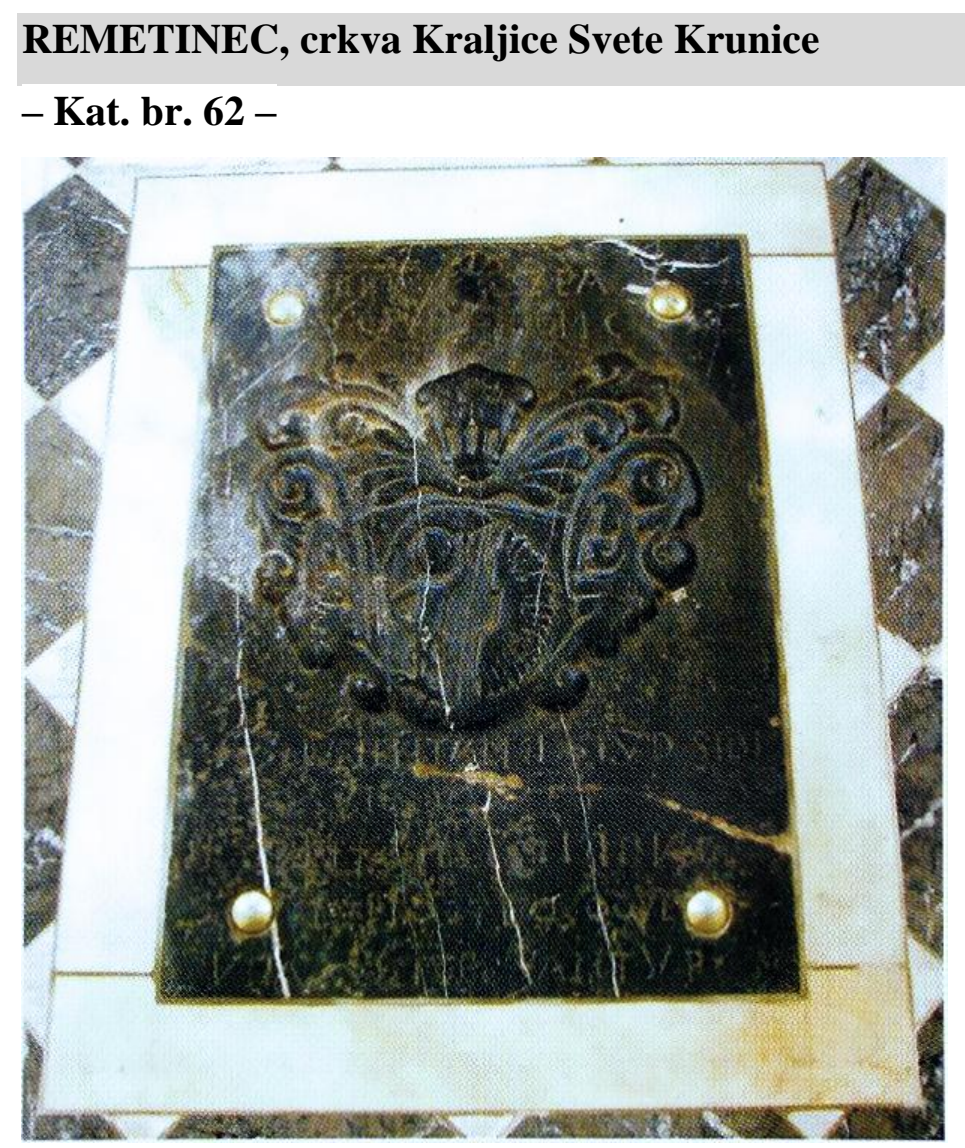

Nadgrobna ploča Baltazara III. Patačića (Vidovec, 1663. - Zagreb, 1719.), 1697.

Kamen, $115 \times 80 \mathrm{~cm} \times$ [postavljena u pod]

Natpis iznad grba: »B.P.D. Z.E.A. / S.C.R. Q.M.C.«. Natpis ispod grba: »MONVMENTVM ISTVD SIBI / ET SVIS F. F. / VT ITA DILECTI IN VITA / IN MORTE QVOQVE / VNA QEVITE FRVANTVR « ${ }^{768}$

\section{Opis spomenika:}

Jednostavna nadgrobna ploča izvedena u obliku okomito postavljena pravokutnika. Sadrži reljefno izveden grb obitelji Patačić iznad kojega su uklesani ime i titule pokojnika, a ispod ostatak nadgrobnoga natpisa.

\section{Literatura:}

Anđelko Košćak, Remetinec i Oštrice pod okriljem čudotvorne Majke Božje Čiselske, Zagreb, Remetinec: Župni ured Remetinec, 1998., str. 66-67.

\footnotetext{
${ }^{768}$ Puni oblik početnih dvaju redaka je: B[althasar] $\mathrm{P}$ [atachich] D[e] Z[aiezda] E[ques] A[ureus] / S[acrae] C[aesareae] R[egia] Q[ue] M[aiestatis] C[onsiliarius]. Usp. Pavao Maček, nav. dj., 2006., str. 13.
} 
Ivan Kukuljević Sakcinski, Nadpisi sredovječni i novovjeki na crkvah, javnih i privatnih sgradah itd. u Hrvatskoj $i$ Slavoniji, Zagreb: Knjižara Jugoslavenske akademije, Knjižara Dioničke tiskare, 1891., str. 200, br. 668.

Pavao Maček, Rodoslovlje grofovskog ogranka Patačića od Zajezde, u: Patačići od Zajezde i crkva u Remetincu: Zbornik radova znanstvenog skupa "Tristota obljetnica Patačićeve kapele sv. Antuna u Remetincu« $i$ drugih radova, Remetinec, 23. listopada 2004. godine, Zagreb: Društvo za povjesnicu Zagrebačke nadbiskupije »Tkalčić«, Remetinec: Župa Blažene Djevice Marije Kraljice sv. Krunice, Novi Marof: Grad Novi Marof, 2006., str. 9-45, 13. Uredio Anđelko Košćak.

Marija Mirković, Kapela sv. Antuna Padovanskog u Remetincu, u: Patačići od Zajezde i crkva u Remetincu: Zbornik radova znanstvenog skupa "Tristota obljetnica Patačićeve kapele sv. Antuna u Remetincu« $i$ drugih radova, Remetinec, 23. listopada 2004. godine, Zagreb: Društvo za povjesnicu Zagrebačke nadbiskupije »Tkalčić«, Remetinec: Župa Blažene Djevice Marije Kraljice sv. Krunice, Novi Marof: Grad Novi Marof, 2006., str. 47-67, 48. Uredio Anđelko Košćak. 
- Kat. br. 63 -
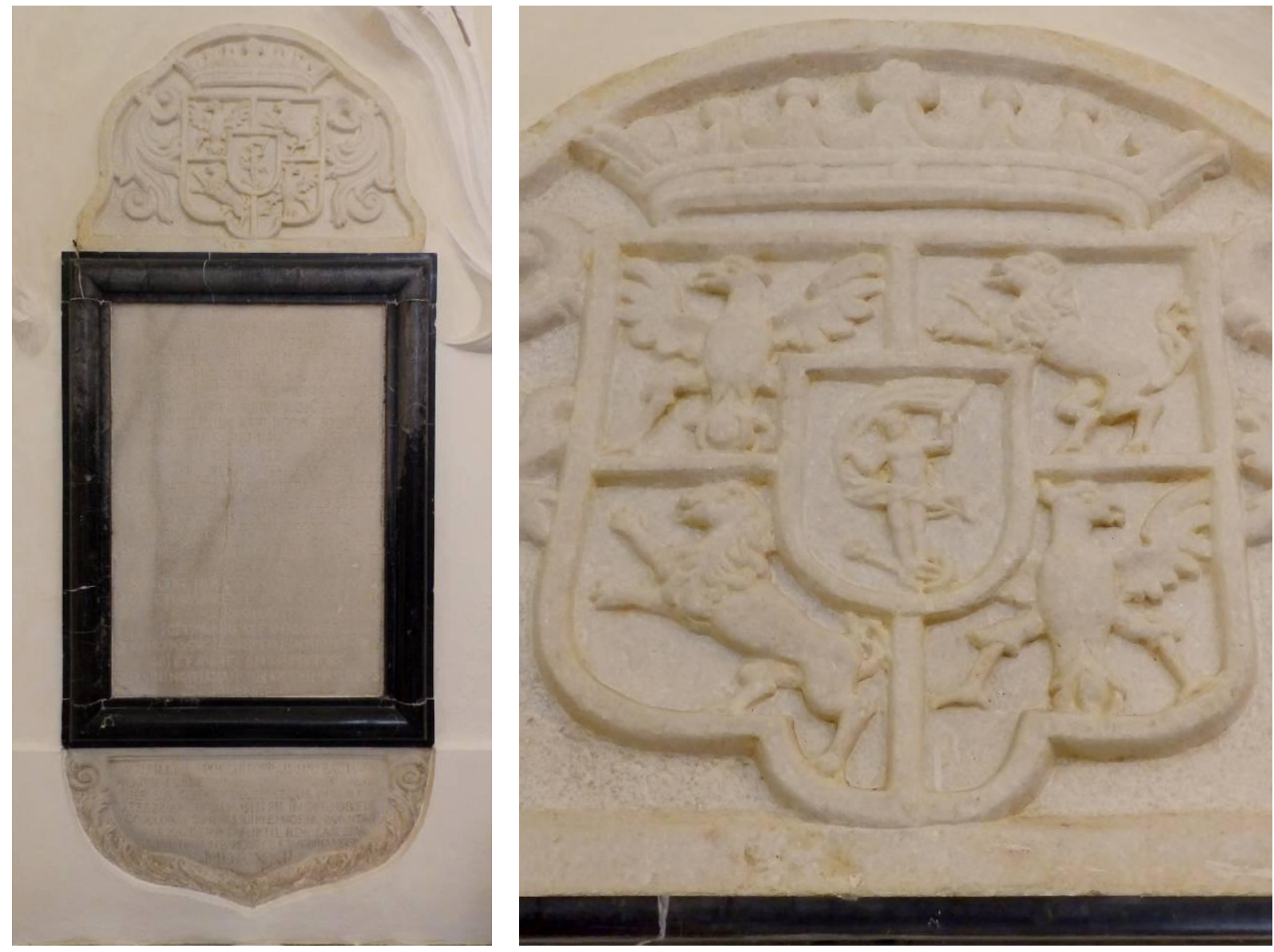

Epitaf Baltazara III. Patačića (Vidovec, 1663. - Zagreb, 1719.) i Terezije Patačić rođ. Gereczy (?, 1675. - Rakovec, 1722.), 1722.

Kamen, $258 \times 109,5 \times 7 \mathrm{~cm}$ (dubina reljefa)

Natpis u središnjem polju: »PLANGITE / QVOTQVOT SÆPE PLAUSISTIS GLORIÆ THEATRA / INCLYTUM ILLYRICI ORBIS SYDUS / EXCELSÆ AULICO: HUNGARIC $Æ ~ / ~ C A N \overline{C L} \overline{\mathrm{I}} Æ$ LŪEN PATRIÆ COLUMEN / COMITATUS

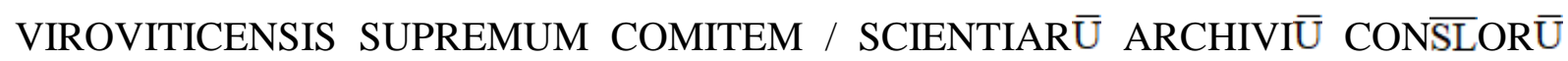

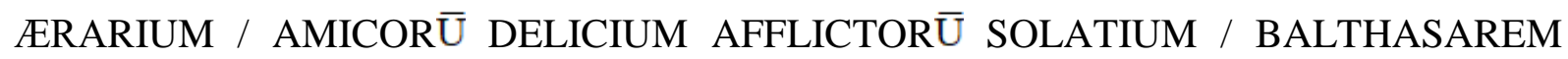
PATACHICH / PLAGINTE / QUEM PROSPERA INTER ET ADVERSA / GENTILITIA FORTUNA NON MUTAVIT IN DIVERSA / ANCHORÆ ENIM INTIXUS SEMPER STETIT / QUEM SANGVIS EDIDIT ILLUSTREM / VIRTUS REDDIDIT ILLUSTRISSIMUM / QUIA VERITATE CATONEM FACUNDIA CICERONEM / EXHIBEBAT / SED QUÆ HOS EXTINXIT DIRA MORS / HUNC ETIAM INTEMPEST $Æ$ NOCTIS SILENTIO / ASSASINAVIT / IGITUR MOESTE VIATOR STA / ET OCULIS GENAS RIGANTIBUS DEFLEIACTURAM PUBLICAM / ABI ET ANHELANTE 
PECTORE / PLURES IN UNA FELICITATIS PUBLICAÆ COLUMNAS CECIDISSE /

PLANGE«. Natpis u donjemu polju: »CHARISILLMIS PROGENITORIBUS SUIS BALTHASARI / PATACHICH L. B. DE ZAIEZDA QUI 1719. 9 X $\bar{B} R$. ZAGRAB. / THERESIÆ GERECZY DE GERECZ QUÆ IN RAKOVECZ / 1722. 27. IAN. HIC DEPOSITI PIE IN DN̄O OBIERE / HOC DOLORIS ET AMORIS SUI MNEMNOSINO PARENTAVIT / ALEXANDER PATACHICH L. B. DE ZAIEZDA / PERPETUUS IN RAKOVECZ ET VERBOVECZ / MDCCXXII «

\section{Opis spomenika:}

Epitaf je izveden u obliku stilizirane edikule. Sastoji se od središnjega dijela omeđenoga jednostavnim profiliranim okvirom koji je postavljen na konzolu ukrašenu volutama, a zaključen je konveksno oblikovanom lunetom. Unutar lunete reljefno je izveden grb obitelji Patačić. Poljā središnjega dijela i konzole ispunjena su nadgrobnim natpisom.

\section{Literatura:}

Anđelko Košćak, Remetinec i Oštrice pod okriljem čudotvorne Majke Božje Čiselske, Zagreb, Remetinec: Župni ured Remetinec, 1998., str. 66-67.

Ivan Kukuljević Sakcinski, Nadpisi sredovječni i novovjeki na crkvah, javnih i privatnih sgradah itd. u Hrvatskoj $i$ Slavoniji, Zagreb: Knjižara Jugoslavenske akademije, Knjižara Dioničke tiskare, 1891., str. 200, br. 668.

Pavao Maček, Rodoslovlje grofovskog ogranka Patačića od Zajezde, u: Patačići od Zajezde i crkva u Remetincu: Zbornik radova znanstvenog skupa »Tristota obljetnica Patačićeve kapele sv. Antuna u Remetincu« $i$ drugih radova, Remetinec, 23. listopada 2004. godine, Zagreb: Društvo za povjesnicu Zagrebačke nadbiskupije »Tkalčić«, Remetinec: Župa Blažene Djevice Marije Kraljice sv. Krunice, Novi Marof: Grad Novi Marof, 2006., str. 9-45, 13. Uredio Anđelko Košćak.

Marija Mirković, Kapela sv. Antuna Padovanskog u Remetincu, u: Patačići od Zajezde $i$ crkva u Remetincu: Zbornik radova znanstvenog skupa »Tristota obljetnica Patačićeve kapele sv. Antuna u Remetincu« $i$ drugih radova, Remetinec, 23. listopada 2004. godine, Zagreb: Društvo za povjesnicu Zagrebačke nadbiskupije »Tkalčić«, Remetinec: Župa Blažene Djevice Marije Kraljice sv. Krunice, Novi Marof: Grad Novi Marof, 2006., str. 47-67, 48. Uredio Anđelko Košćak. 
- Kat. br. 64 -
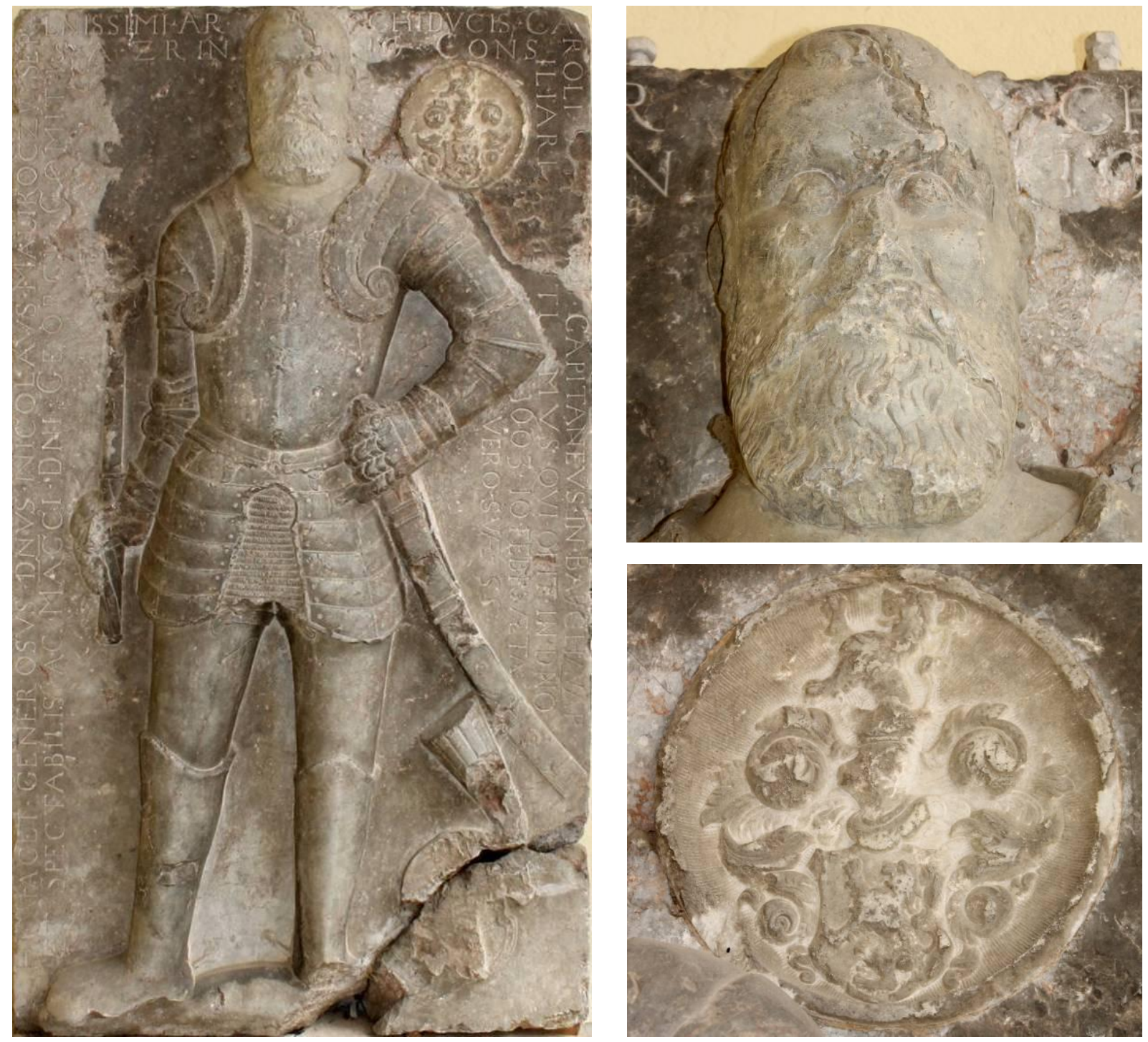

Nadgrobna ploča Nikole I. Mlakovačkoga (?, 1547. - Lapšina, 1603.)

Mramor, $200 \times 115 \times 29,5 \mathrm{~cm}$

Ploča je danas pohranjena u Muzeju Međimurja Čakovec.

Natpis: »HIC · IACET - GENEROSVS · DNVS · NICOLAVS · MALIKOCZY · SER / ENISSIMI · AR CHIDVCIS · CA / ROLI - SV(PREMVS) · CAPITANEVS · IN · BAYCHAVAR $\cdot /$ ET $\cdot$ SPECTABILIS $\cdot$ AC $\cdot$ MAGCI $\cdot$ DNI $\cdot$ GEORGY $\cdot$ COMITI / S · A $\cdot$ ZRIN IO $\cdot$ CONS / ILIARI $\cdot(\mathrm{IN}) \mathrm{TI} \mathrm{MVS} \cdot \mathrm{QVI} \cdot \mathrm{OBIT} \cdot \mathrm{IN} \cdot \mathrm{DN} O / 1603 \cdot 10 \cdot \mathrm{FEBR} \cdot$ ÆTA / VERO $\cdot \mathrm{SV} Æ \cdot 55 \lll$ 


\section{Opis spomenika:}

Nadgrobna ploča formata okomito postavljenoga pravokutnika s likom pokojnika odjevena $\mathrm{u}$ viteški oklop. Pokojnik u desnoj ruci drži topuz, a lijevom pridržava sablju opasanu oko pojasa. U donjem desnom kutu ploče predočeni su kaciga i signalni rog, a u gornjem desnom kutu grb obitelji Mlakovački izveden u inkrustaciji bijeloga mramora. Nadgrobni natpis uklesan je uz lijevi, gornji i desni rub ploče.

\section{Literatura:}

Anđela Horvat, Spomenici arhitekture $i$ likovnih umjetnosti u Međimurju, Zagreb: [Konzervatorski zavod], 1956., str. 67.

Anđela Horvat, Između gotike i baroka: umjetnost kontinentalnog dijela Hrvatske od oko 1500. do oko 1700., Zagreb: Društvo povjesničara umjetnosti SR Hrvatske, 1975., str. 191, 351, 353.

Ljubo Karaman, O umjetnosti srednjega vijeka, u: Historijski zbornik III/1-4, Zagreb: Društvo za hrvatsku povjesnicu, 1950., str. 125-174, 167, bilj. 72.

Juraj Kolarić, Blaž Tota i Stanko Jelić, Sveti Martin na Muri, Zagreb: Nova misao, 1996., str. 62.

Milan Pelc, Renesansa, Zagreb: Naklada Ljevak, 2007., str. 315.

Ljubica Ramušćak, Lapidarij. Muzej Međimurja Čakovec, Čakovec: Muzej Međimurja, 1996., str. 1, 5.

Ivan Kukuljević Sakcinski, Nadpisi sredovječni i novovjeki na crkvah, javnih i privatnih sgradah itd. $u$ Hrvatskoj $i$ Slavoniji, Zagreb: Knjižara Jugoslavenske akademije, Knjižara Dioničke tiskare, 1891., str. 389, br. 1335.

Marijana Schneider, Zrinski i Frankopani u likovnoj umjetnosti, u: Historijski zbornik 25-26, Zagreb: Povijesno društvo Hrvatske, 1972.-1973., str. 251-271, 258-259.

Marijana Schneider, Odraz seljačke bune 1573. godine u likovnoj umjetnosti, u: Radovi Zavoda za hrvatsku povijest 5, Zagreb: Institut za hrvatsku povijest Sveučilišta u Zagrebu, 1973., str. 271-286, 277. 


\section{ŠENKOVEC, crkva sv. Jelene}

- Kat. br. 65 -
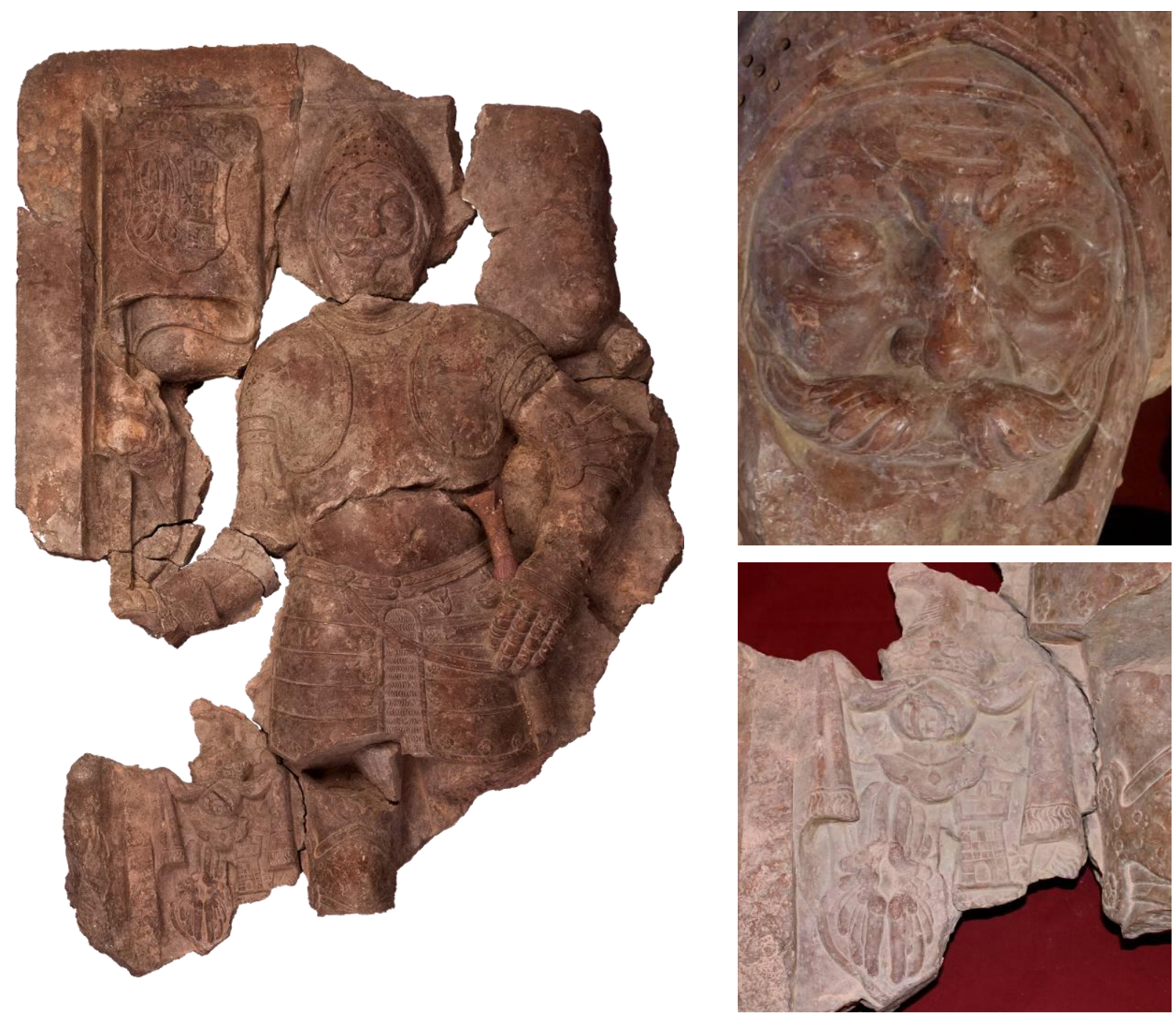

Nadgrobna ploča bana Nikole IV. Zrinskoga (?) (Zrin ?, o. 1508. - Siget, 1566.)

Mramor, $162 \times 115 \times 22,5 \mathrm{~cm}$

Ploča je danas pohranjena u Muzeju Međimurja Čakovec.

\section{Opis spomenika:}

Nadgrobna ploča s likom viteza-pokojnika glave oslonjene na jastuk. Pokojnik je prikazan en face. U desnoj ruci drži barjak s grbom obitelji Zrinski, a lijevom pridržava mač opasan oko pojasa. Grb pokojnikove obitelji prikazan je još jednom, lijevo od pokojnikova bedra. Donji dio spomenika (ispod razine vitezovih koljena) nedostaje. 


\section{Literatura:}

Igor Fisković, Renesansno kiparstvo, u: Tisuću godina hrvatskog kiparstva, Zagreb: Muzejsko galerijski centar, 1997., str. 155-219, 207. Uredio Igor Fisković.

Anđela Horvat, Spomenici arhitekture $i$ likovnih umjetnosti u Međimurju, Zagreb: [Konzervatorski zavod], 1956., str. 51-52.

Anđela Horvat, Između gotike i baroka: umjetnost kontinentalnog dijela Hrvatske od oko 1500. do oko 1700., Zagreb: Društvo povjesničara umjetnosti SR Hrvatske, 1975., str. $351-352$.

Vladimir Kalšan, Općina Šekovec, Šenkovec: Poglavarstvo Općine Šenkovec, 2008., str. 62-63.

Marijana Korunek, Pavlinski samostan u Šenkovcu i grofovi Zrinski, u: Croatica Christiana periodica XXXVIII/73, Zagreb: Katolički bogoslovni fakultet, 2014., str. 51-70, 67-69.

Emilije Laszowski, Spomenik bana grofa Nikole Zrinskoga († 1664.), u: Jutarnji list, Zagreb: Tipografija, 12. X. 1924., str. 20.

Emilije Laszowski, Zrinski mauzolej u sv. Jeleni kod Čakovca, u: Hrvatsko kolo: književnonaučni zbornik IX/15, Zagreb: Matica hrvatska, 1928., str. 244-259, 257-259.

Milan Pelc, Renesansa, Zagreb: Naklada Ljevak, 2007., str. 315.

Milan Pelc, Povijest umjetnosti u Hrvatskoj, Zagreb: Naklada Ljevak, str. 236.

Marijana Schneider, Jedan se spomenik vratio kući..., u: Vijesti Društva muzejskokonzervatorskih radnika NR Hrvatske VII/4, Zagreb: Društvo muzejskokonzervatorskih radnika NR Hrvatske, 1958., str. 108-110.

Marijana Schneider, Zrinski i Frankopani u likovnoj umjetnosti, u: Historijski zbornik 25-26, Zagreb: Povijesno društvo Hrvatske, 1972.-1973., str. 251-271, 258-259.

Diana Vukičević-Samaržija, Umjetnost renesanse, u: Sveti trag. Devetsto godina umjetnosti Zagrebačke nadbiskupije 1094.-1994., MGC - Muzej Mimara, Zagreb, 10. rujna - 31. prosinca 1994., Zagreb: Zagrebačka nadbiskupija, Institut za povijest umjetnosti, Muzejsko-galerijski centar, 1994., str. 175-188, 187. Uredili Tugomir Lukšić i Ivanka Reberski. 
- Kat. br. $66-$

Adriaen van Conflans, Epitaf Nikole IV. Zrinskoga, 1566.-1574.

Drvo, uljena boja, polikromija, pozlata

Epitaf nije sačuvan, no dokumentiran je u povijesnim izvorima.

\section{Opis spomenika:}

Na osnovi sačuvanih slikanih djelā koja su nekoć pripadala obitelji Zrinski i njeguju obiteljski kult, istraživači pretpostavljaju da je epitaf sadržavao dva likovna prikaza pokojnika: njegov posmrtni portret i prikaz gdje u molitvi kleči pred Raspetim.

\section{Literatura:}

Ivan Bach, Tri rada stranih umjetnika u Hrvatskoj, u: Peristil: zbornik radova za povijest umjetnosti II/1, Zagreb: Društvo povjesničara umjetnosti Hrvatske, 1957., str. 199-203, 199-200.

Enikő Buzási, Zrínyi és a későreneszánsz vitézi allegória: a szigetvári hös festett apoteózisa, u: Collectanea Tiburtiana: Tanulmányok Klaniczay Tibor tiszteletére, Szeged: JATE, 1990., str. 431-442, 433-434. Uredili Géza Galavics, János Herner i Bálint Keserü.

Enikő Buzási, Az egykori Zrínyi-epitáfi um és a Zrínyi-kultusz mint a 16. század végi családi reprezentáció forrása, u: Történelem-Kép, Szemelvények múlt és müvészet kapcsolatáról Magyarországon, katalog izložbe, Budapest: MNG, 2000., str. 399-402, 399. Uredili Árpád Mikó i Katalin Sinkó.

János Kapossy, Adriaen van Conflans a Zrínyi epitáfium mestere, u: Magyar Müvészet XV/4, Budapest: Szinyei Merse Pál Tár saság, 1948., str. 180. 


\section{VARAŽDIN, crkva sv. Ivana Krstitelja}

\section{- Kat. br. 67 -}
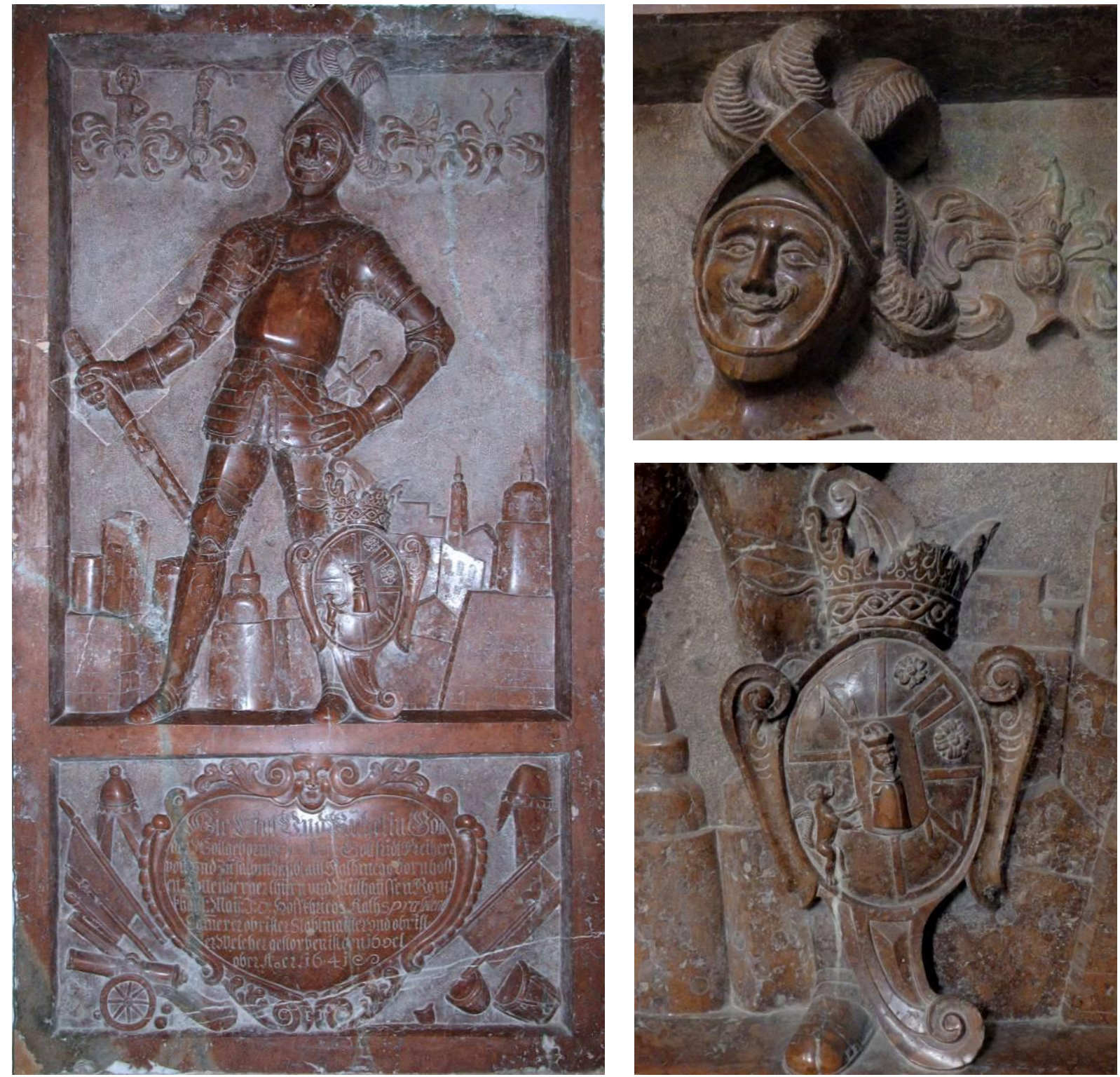

Epitaf Gottfrieda Falmhaubta (? - Varaždin?, 1641.)

Mramor, $192 \times 104,5 \times 9 \mathrm{~cm}$

Natpis: "Hie Ligt Vnd Ruhet in Gott / der Wollgeborne Herr herr Gottfridt Freiherr / von vnd zu Falbmhaübt aüf Falbmegg / dornhoff / en Rottenberger thurn vnd Müllhaüssen Rom: / khays: May: I: O: Hoffkriegs Raths præsident / Cā̄erer obrister Stablmaister vnd obrist / er Welcher gestorben ist den 16 oct / ober Ao cr. $16 \cdot 41$ «

\section{Opis spomenika:}

Epitaf je izveden u obliku okomito postavljena pravokutnika koji je vodoravno podijeljen na dva polja. U gornjem polju predočen je pokojnik odjeven u viteški oklop i kacigu. Prikazan je 
u lijevom tričetvrt profilu. U desnoj ruci nosi zapovjedniku palicu, a lijevu drži oslonjenu o bok. Uz pokojnikovu lijevu nogu nalazi se štit ukrašen volutama i krunom na kojem su prikazani simboli obitelji Falmbhaubt. Obiteljski grbovni simboli ponovljeni su uz gornji rub epitafa kao nakit kaciga ukrašenih plaštevima i krunama. Iza pokojnika prikazan je capriccio nebeskoga Jeruzalema. U donjem polju nadgrobnika nalazi se kartuša s nadgrobnim natpisom koja je ukrašena maskeronom, viticama repovlja i hrskavicom. Oko kartuše predočeni su ratni trofeji (bubnjevi, barjaci, topovi, vojni šatori).

\section{Literatura:}

Paškal Cvekan, Djelovanje franjevaca u Varaždinu. Povijesno-kulturni prikaz sedamsto godišnje prisutnosti franjevaca u gradu Varaždinu, Varaždin: Paškal Cvekan, 1978., str. 95.

Krešimir Filić, Franjevci u Varaždinu. Poviest franjevačke crkve i samostana. O 700godišnjici dolazaka franjevaca u Varaždin, Varaždin: Krešimir Filić, 1944., str. 106, 126.

Anđela Horvat, Između gotike i baroka: umjetnost kontinentalnog dijela Hrvatske od oko 1500. do oko 1700., Zagreb: Društvo povjesničara umjetnosti SR Hrvatske, 1975., str. $351,353$.

Anđela Horvat, Barok u kontinentalnoj Hrvatskoj, u: Barok u Hrvatskoj, Zagreb: Sveučilišna naklada Liber, Odjel za povijest umjetnosti Centra za povijesne znanosti, Društvo povjesničara umjetnosti, 1982., str. 3-381, 265. Napisali Anđela Horvat, Radmila Matejčić i Kruno Prijatelj.

Marijana Schneider, Zrinski i Frankopani u likovnoj umjetnosti, u: Historijski zbornik 25-26, Zagreb: Povijesno društvo Hrvatske, 1972.-1973., str. 251-271, 259.

Gjuro Szabo, Kroz Hrvatsko zagorje, Zagreb: Vasić i Horvat, 1939., str. 154. 
- Kat. br. 68 -

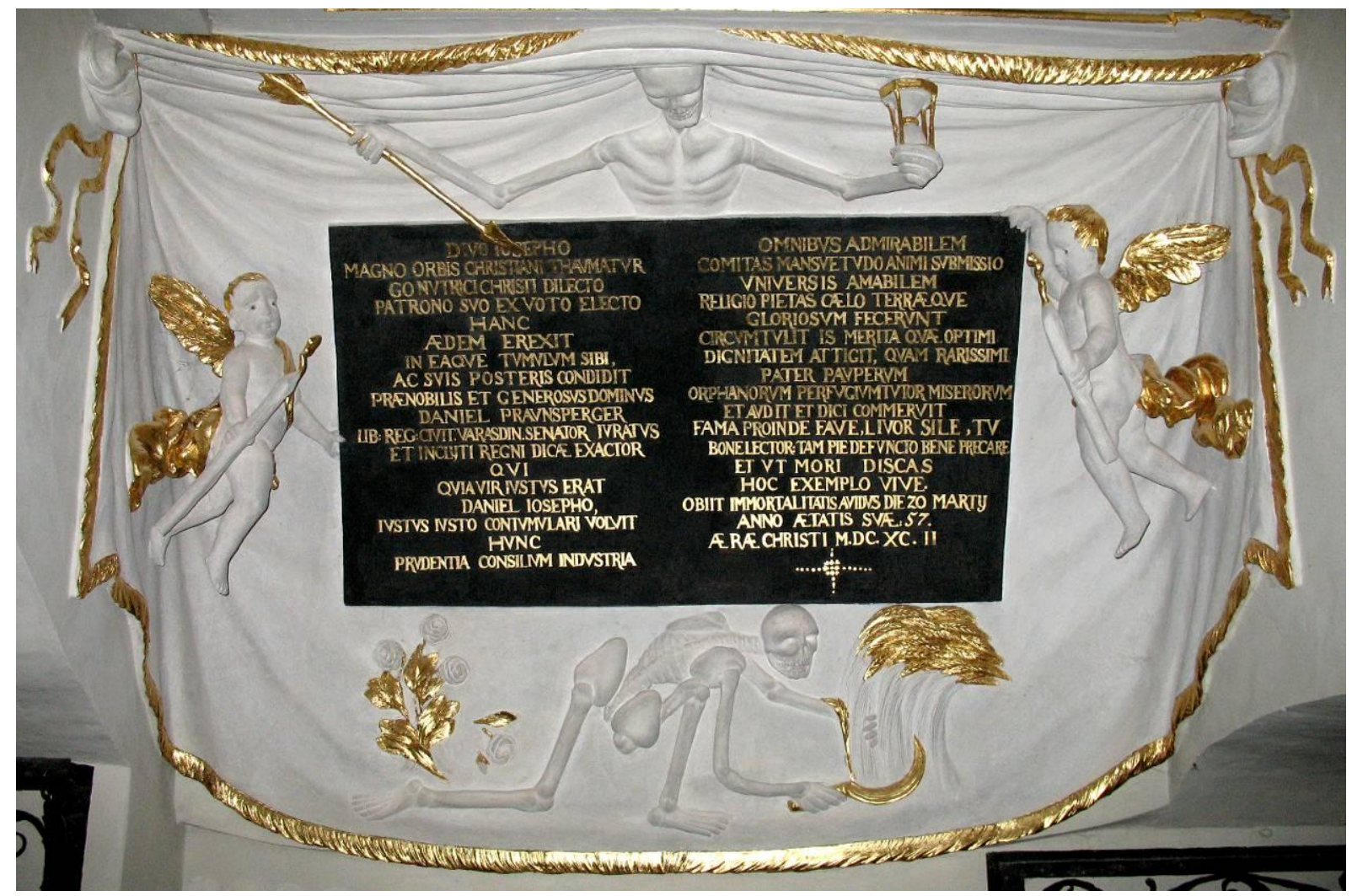

Epitaf Danijela Praunspergera (?, 1635. - ?, 1692.)

Štuk, pozlata, širina $150 \mathrm{~cm}$

Natpis (lijevi stupac): „DIVO IOSEPHO / MAGNO ORBIS CHRISTIANI THAVMATVR / GO NVTRICI CHRISTI DILECTO / PATRONO SVU EX VOTO ELECTO / HANC / ÆDEM EREXIT / IN EAQVE TVMVLVM SIBI, / AC SVIS POSTERIS CONDIDIT / PRÆNOBILIS ET GENEROSVS DOMINVS / DANIEL PRAVNSPERGER / LIB: REG: CIVIT. VARASDIN. SENATOR IVRATVS / ET INCLYTI REGNI DICÆ EXACTOR / QVI / QVIA VIR IVSTVS ERAT / DANIEL IOSEPHO, / IVSTVS IVSTO CONTVMVLATI VOLVIT / HNVC / PRVDENTIA CONSILIVM INDUSTRIA«. Desni stupac: „OMNIBVS ADMIRABILEM / COMITAS MANSVETVDO ANIMI SVBMISSIO / VNIVERSIS AMABILEM / RELIGIO PIETAS CÆLO TERRAEQVE / GLORIOSVM FECERVNT / CIRCVMTVLIT IS MERITA QVÆ OPTIMI / DIGNITATEM ATTIGIT, QVAM RARISSIMI / PATER PAVPERVM / ORPHANORVM PERFVGIVMTVIOR MISERORVM / ET AVDIT ET DICI COMMERVIT / FAMA PROINDE FAVE, LIVOR SILE, TV / BONELECTOR: TAM PIE DEFVNCTO BENE PRECARE / ET VT MORI DISCAS / HOC EXEMPLO VIVE. / OBIIT IMMORTALITATIS AVIDVS DIE 20 MARTY / ANNO ÆTATIS SVÆ: 57. / ÆRÆ CHRISTI M.D.XC.II“ 


\section{Opis spomenika:}

Epitaf je izveden u obliku razastrtoga zastora koji služi kao pozadina za reljefno oblikovane figure. U sredini zastora smještena je crna ploča $s$ nadgrobnim natpisom koji je ispisan zlatnim slovima. Povrh ploče predočen je kostur koji drži strijelu i pješčani sat, a ispod ploče kostur koji srpom siječe snop žita. Uz potonji je predočen grm rascvjetalih ruža. Natpisna ploča flankirana je dvama anđelima koji u rukama drže upaljenu svijeću. Pojedini dijelovi epitafa su pozlaćeni (rub zastora, kosa i krila anđela, njihova draperija, plamen svijeća, strijela, pješčani sat, stabljike ruža, srp, klasje žita).

\section{Literatura:}

Paškal Cvekan, Djelovanje franjevaca u Varaždinu. Povijesno-kulturni prikaz sedamsto godišnje prisutnosti franjevaca u gradu Varaždinu, Varaždin: Paškal Cvekan, 1978., str. 89-90.

Krešimir Filić, Franjevci u Varaždinu. Poviest franjevačke crkve i samostana. O 700godišnjici dolazaka franjevaca u Varaždin, Varaždin: Krešimir Filić, 1944., str. 109112.

Ana Kaniški, Kapela sv. Josipa u franjevačkoj crkvi u Varaždinu: Ikonografija i naručitelj, u: Tkalčić: godišnjak Društva za povjesnicu Zagrebačke nadbiskupije = annales Societatis historicae archiepiscopatus Zagrabiensis XVI, Zagreb: Društvo za povjesnicu Zagrebačke nadbiskupije »Tkalčić«, 2012., str. 303-412, 305-307. 
- Kat. br. 69 -

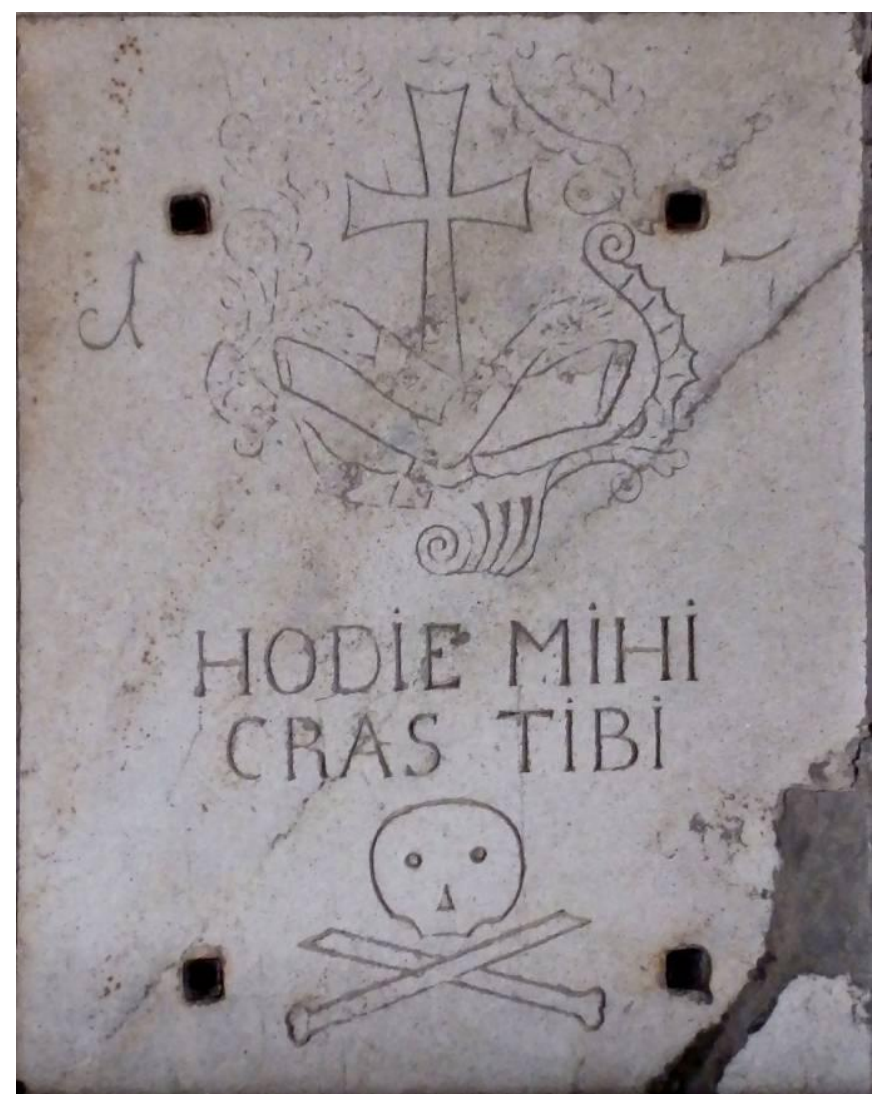

Nadgrobna ploča franjevačke grobnice, II. polovina XVIII. stoljeća

Kamen, $110 \times 80 \mathrm{~cm} \times[$ postavljena u pod]

Natpis u kutevima ploče: $\gg 1 / 7$ / [preostale dvije brojke istrošene]《. Natpis u donjem dijelu ploče: »HODIE MIHI / CRAS TIBI«

\section{Opis spomenika:}

Jednostavna nadgrobna ploča izvedena u obliku okomito postavljena pravokutnika. Sadrži grb franjevačkoga reda koji je ukrašen stiliziranim rokajem. Ispod grba uklesana je krilatica »HODIE MIHI, CRAS TIBI« i motiv lubanje s parom ukriženih kostiju. U kutevima ploče uklesana je godina njezina postavljanja (donje dvije znamenke nisu vidljive zbog istrošenosti nadgrobnika).

\section{Literatura:}

Nadgrobnik dosad nije stručno obrađen. 


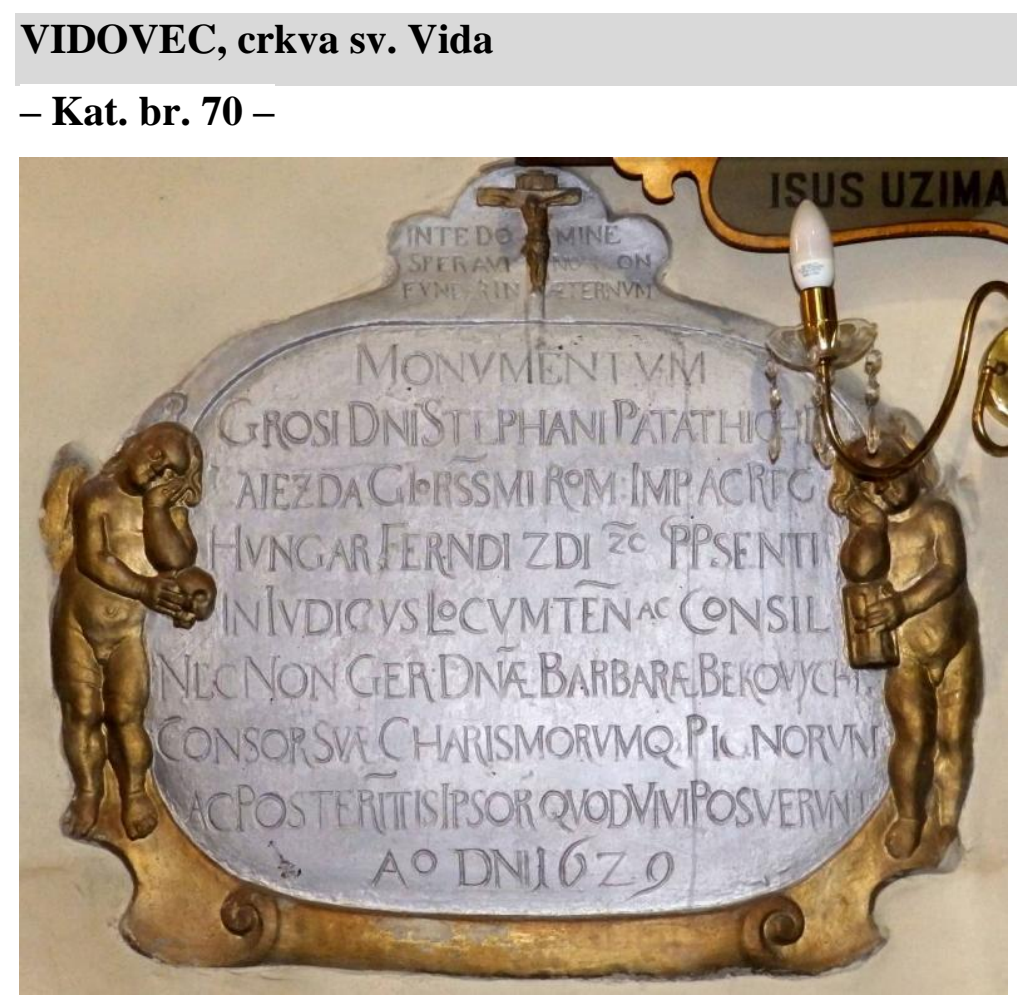

Epitaf Stjepana Patačića (?, 1576. - ?, 1636.) i Barbare Patačić rođ. Bedeković (? - ?), 1629. Kamen, pozlata, $77 \times 90 \mathrm{~cm}$

Natpis uz prikaz Raspetoga: «IN TE DOMINE / SPERAVI NON CON / FVNDAR IN

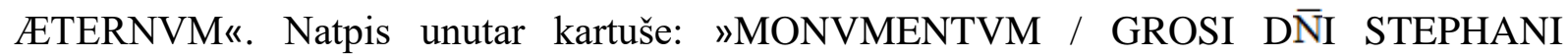
PATATHICH DE / ZAIEZDA GLORSSMI ROM: IMP AC REG / HVNGAR FERNDI ZDI $\overline{\mathrm{ZC}}$ PPSENTI / IN IVDICVS LOCVMTEN AC CONSIL / NEC NON GER D $\overline{\mathrm{NA}}$ BARBARÆ BEKOVYCH / CONSOR SVÆ CHARISMORVMQ PIGNORVM / AC POSTERITTIS IPSOR QVOD VIVI POSVERVNT / AO DNI 1629«

\section{Opis spomenika:}

Epitaf je izveden u obliku kartuše s posvetnim natpisom koja je flankirana anđelima podbočenih glava. Lakat lijevoga anđela počiva na lubanji, a desnoga na pješčanome satu. Pri vrhu kartuše predočen je Raspeti flankiran stihom iz Psalma: »IN TE, DOMINE, SPERAVI, NON CONFVNDAR IN ÆTERNVM.« Lik Krista na križu, anđeli i donji dio kartuše su pozlaćeni.

\section{Literatura:}

Ivan Kukuljević Sakcinski, Nadpisi sredovječni i novovjeki na crkvah, javnih i privatnih sgradah itd. u Hrvatskoj $i$ Slavoniji, Zagreb: Knjižara Jugoslavenske akademije, Knjižara Dioničke tiskare, 1891., str. 307, br. 1049.

Gjuro Szabo, Kroz Hrvatsko zagorje, Zagreb: Vasić i Horvat, 1939., str. 127. 


\section{VINICA, crkva sv. Marka evanđelista}

- Kat. br. 71 -
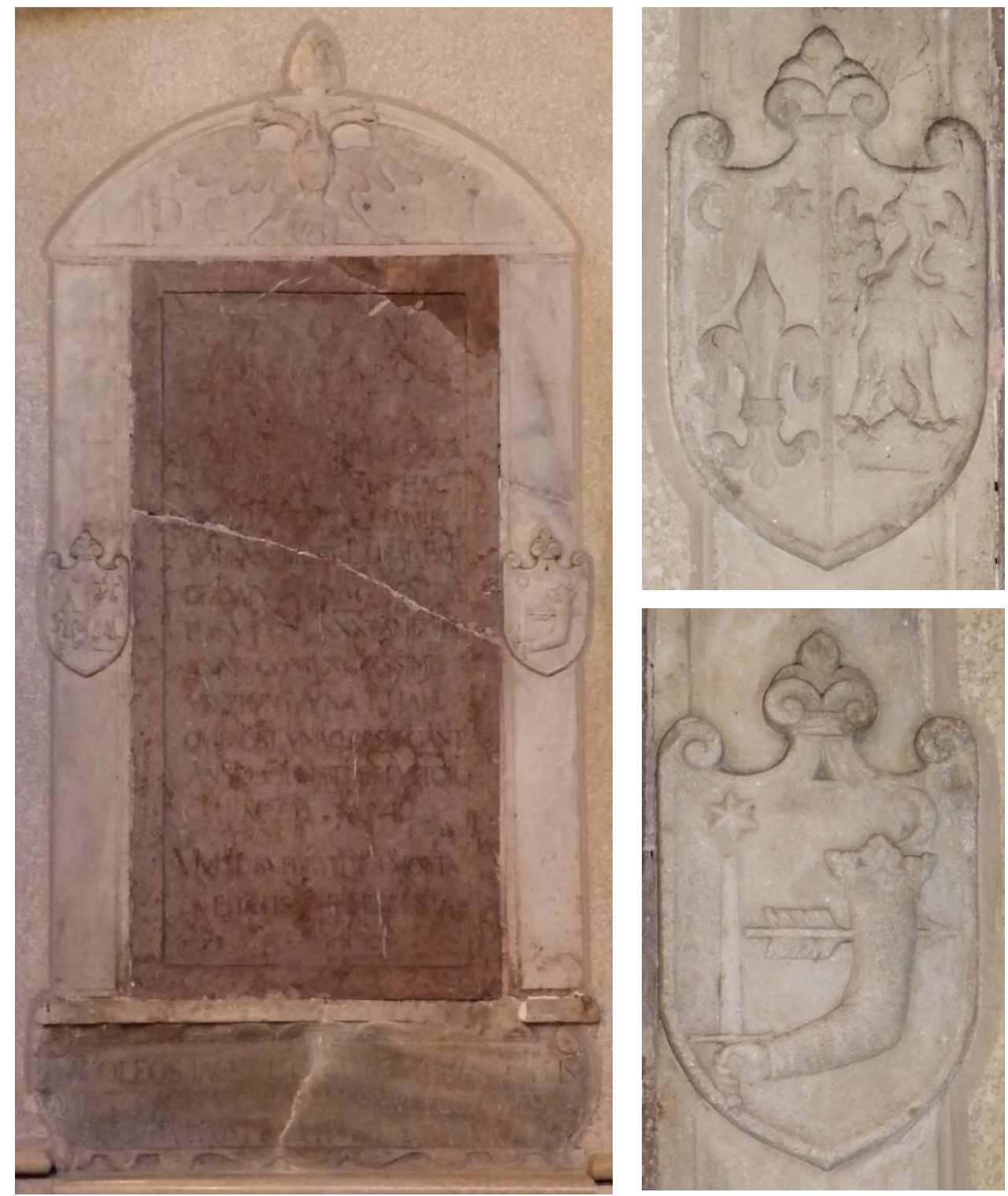

Epitaf Nikole Istvánffyja (Kisasszonyfalva kod Pečuha, 1524. - Vinica, 1615.) i Elizabete Istvánffy rođ. Both de Bajna (? - ?, 1597.), 1603.

Mramor, 32,5 × $135 \mathrm{~cm} \times$ [uzidan]

Natpis u luneti: »MDC III«. Natpis u središnjem polju: »D. O. M. / RVDOLPHO II. IMP. CÆS. / AVG. PIO. F. / NICOI. ISTVANFI PAVLI F. REGNI / VNG PROPALATINVS HAC / CVRA POSTEROS LEVARE / VOLENS SIBI ET ELISAB BOT / DE BAINA CONIVGI PIENTISS. / POS. VT QVI XXXV. AMPLIVS / ANNIS CONIVNCTISSIME / VIXERVNT. VNA ETIAM / QVIESCAT. VNAQ RESVRGANT. / ANNO CHRISTI SERVATOR / M . D . XCVII . / VIVITE SVPERSTITES MORTA / LITATIS MEMORES «. Natpis u donjem polju: »NICOLEOS IACET HIC CHARAE SOCIATVS ELISÆ / QVI VT 
PLACIDE VIXERE SIMVL, SIMVL ECCE QVIESCVNT. / SEQVE ETIAM POST FATA PIO AMPLECTVNTVR AMORE«

\section{Opis spomenika:}

Epitaf je izveden u obliku stilizirane edikule, a sastoji se od postolja, središnjega dijela i lunete zaključene antefiksom. U luneti se nalaze simbol obitelji Istvánffy (dvoglavi okrunjeni orao) i godina podizanja spomenika (1603.). Na nosačima središnjega dijela predočeni su grbovi obitelji Istvánffy i Both de Bajna. Samo središnje polje i postolje ispunjeni su nadgrobnim natpisom. Spomenik je izveden u kombinaciji sivoga (postolje), crvenoga (središnje polje) i bijeloga mramora (nosači, luneta).

\section{Literatura:}

Tomislav Đurić, Prilozi za povijest Vinice, u: Muzejski vjesnik: Glasilo muzeja sjeverozapadne Hrvatske II/2, [Varaždin]: Muzejsko društvo sjeverozapadne Hrvatske, 1979., str. 24-27, 26.

Anđelko Košćak, Župa sv. Marka Evanđelista - Vinica, Zagreb: Društvo za povjesnicu Zagrebačke nadbiskupije »Tkalčić«, Vinica: Župa Sv. Marka Evanđelista, 2013., str. 43-44, 81, 133.

Ivan Kukuljević Sakcinski, Nadpisi sredovječni i novovjeki na crkvah, javnih i privatnih sgradah itd. u Hrvatskoj $i$ Slavoniji, Zagreb: Knjižara Jugoslavenske akademije, Knjižara Dioničke tiskare, 1891., str. 309, br. 1056.

Milan Pelc, Renesansa, Zagreb: Naklada Ljevak, 2007., str. 75.

Gjuro Szabo, Kroz Hrvatsko zagorje, Zagreb: Vasić i Horvat, 1939., str. 121-122.

Biserka Vlahović, Općina Vinica, Vinica: Poglavarstvo općine Vinica, 1997., str. 44.

Diana Vukičević-Samaržija, Gotičke crkve Hrvatskog zagorja, Zagreb: Institut za povijest umjetnosti, 1993., str. 226. 
- Kat. br. 72 -
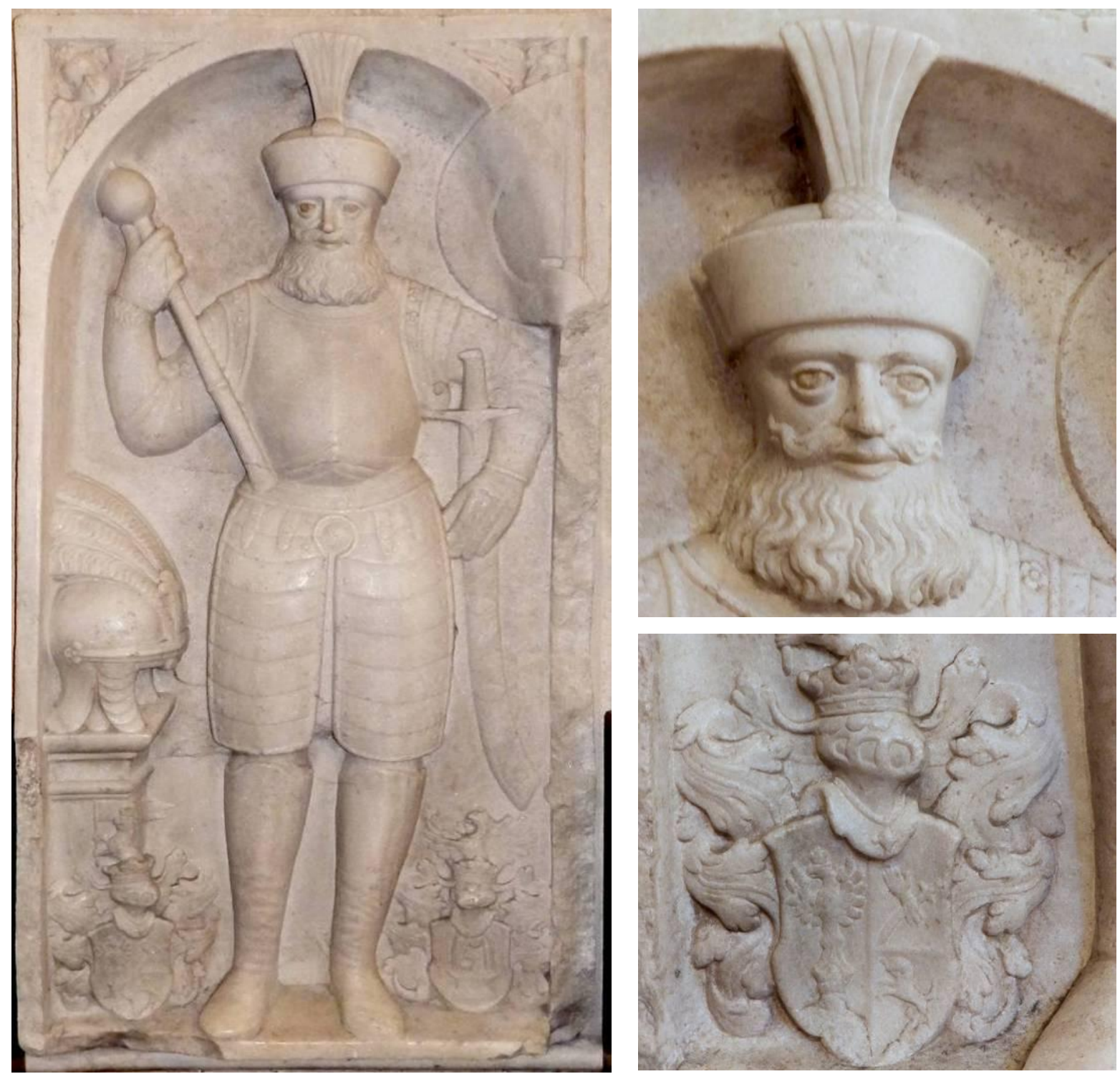

Radionica Majstora Trantnerova epitafa (?), Nadgrobna ploča bana Benedikta Thuróczyja Ludbreškoga (? - Vinica, 1616.)

Mramor, $181 \times 95,5 \times 11,5 \mathrm{~cm}$

Natpisna ploča (uništena): »REGNORVM TVTELA TRIVM BANVSQVE POTENTIS / ILLYRII ET PATRIAE HIC CVRA SALVSQVE IACET. / CVIVS SI POSSET COMPLECTI SAXEA MOLES / VIRTVTES, PVLCHER QVAM FORET ISTE LAPIS « ${ }^{769}$

\section{Opis spomenika:}

Nadgrobna ploča formata okomito postavljenoga pravokutnika s likom pokojnika odjevena u viteški oklop. Pokojnik stoji ispod polukružnoga luka, čija su ugaona polja ukrašena

\footnotetext{
${ }^{769}$ Prijepis preuzet iz: Ivan Kukuljević Sakcinski, nav. dj., 1891., str. 310, br. 1058.
} 
kerubinima. U desnoj ruci drži topuz, a lijevom pridržava sablju. Na glavi nosi kalpak, a kaciga je odložena na postamentu prikazanom uz lijevi rub nadgrobnika. Uz desni rub ploče nalazi se barjak. Grbovi pokojnikove obitelji i one njegove supruge, Suzane rođ. Ratkaj de Nagy Tabor, predočeni su pri dnu nadgrobnika, s lijeve i desne strane pokojnikovih nogu. Prema povijesnim izvorima, ispod figuralnoga prikaza nalazila se natpisna ploča, koja je danas uništena.

\section{Literatura:}

Emilijan Cevc, Kiparstvo na Slovenskem med gotiko in barokom, Ljubljana: Slovenska matica, 1981., str. 197.

Anđela Horvat, Između gotike i baroka: umjetnost kontinentalnog dijela Hrvatske od oko 1500. do oko 1700., Zagreb: Društvo povjesničara umjetnosti SR Hrvatske, 1975., str. $351-352$.

Ljubo Karaman, O umjetnosti srednjega vijeka, u: Historijski zbornik III/1-4, Zagreb: Društvo za hrvatsku povjesnicu, 1950., str. 125-174, 167, bilj. 72.

Anđelko Košćak, Župa sv. Marka Evanđelista - Vinica, Zagreb: Društvo za povjesnicu Zagrebačke nadbiskupije »Tkalčić«, Vinica: Župa Sv. Marka Evanđelista, 2013., str. 40, $81,133$.

Ivan Kukuljević Sakcinski, Nadpisi sredovječni i novovjeki na crkvah, javnih i privatnih sgradah itd. u Hrvatskoj i Slavoniji, Zagreb: Knjižara Jugoslavenske akademije, Knjižara Dioničke tiskare, 1891., str. 310, br. 1058.

Milan Pelc, Ugarske kiparske radionice i renesansa u sjevernoj Hrvatskoj, u: Radovi Instituta za povijest umjetnosti 30, Zagreb: Institut za povijest umjetnosti, 2006., str. 67-80, 75.

Milan Pelc, Renesansa, Zagreb: Naklada Ljevak, 2007., str. 315.

Milan Pelc, Renesansa, u: Hrvatska umjetnost: povijest $i$ spomenici, Zagreb: Institut za povijest umjetnosti, Školska knjiga, 2010., str. 197-247, 247. Uredio Milan Pelc.

Milan Pelc, Povijest umjetnosti u Hrvatskoj, Zagreb: Naklada Ljevak, 2012., str. 236.

Juraj Rattkay, Spomen na kraljeve i banove kraljevstava Dalmacije, Hrvatske i Slavonije od njihovih početaka, pa sve do ove 1652. godine koji je sastavio Juraj Rattkay od Velikog Tabora, zagrebački kanonik i lektor, Zagreb: Hrvatski institut za povijest, 2001., str. 247. Prevela Zrinka Blažević et al.

Marijana Schneider, O epitafiju Ivana Hrvoja i Eve Dreffell u Plešivici, u: Bulletin Instituta za likovne umjetnosti Jugoslavenske akademije znanosti $i$ umjetnosti VII/3, Zagreb, Jugoslavenska akademija znanosti i umjetnosti, 1959., str. 177-182, 180. 
Marijana Schneider, Zrinski i Frankopani u likovnoj umjetnosti, u: Historijski zbornik 25-26, Zagreb: Povijesno društvo Hrvatske, 1972.-1973., str. 251-271, 258-259.

Gjuro Szabo, Spomenici kotara Ivanec, u: Vjesnik Hrvatskoga arheološkog društva XIV/1, Zagreb: Hrvatsko arheološko društvo, 1919., str. 22-97, 89.

Gjuro Szabo, Ljudi iz kamena, u: Jutarnji list, Zagreb: Tipografija, 24. XII. 1938., str. 5-6, 6. Gjuro Szabo, Kroz Hrvatsko zagorje, Zagreb: Vasić i Horvat, 1939., str. 119.

Biserka Vlahović, Općina Vinica, Vinica: Poglavarstvo općine Vinica, 1997., str. 43.

Diana Vukičević-Samaržija, Gotičke crkve Hrvatskog zagorja, Zagreb: Institut za povijest umjetnosti, 1993., str. 226. 
- Kat. br. $73-$
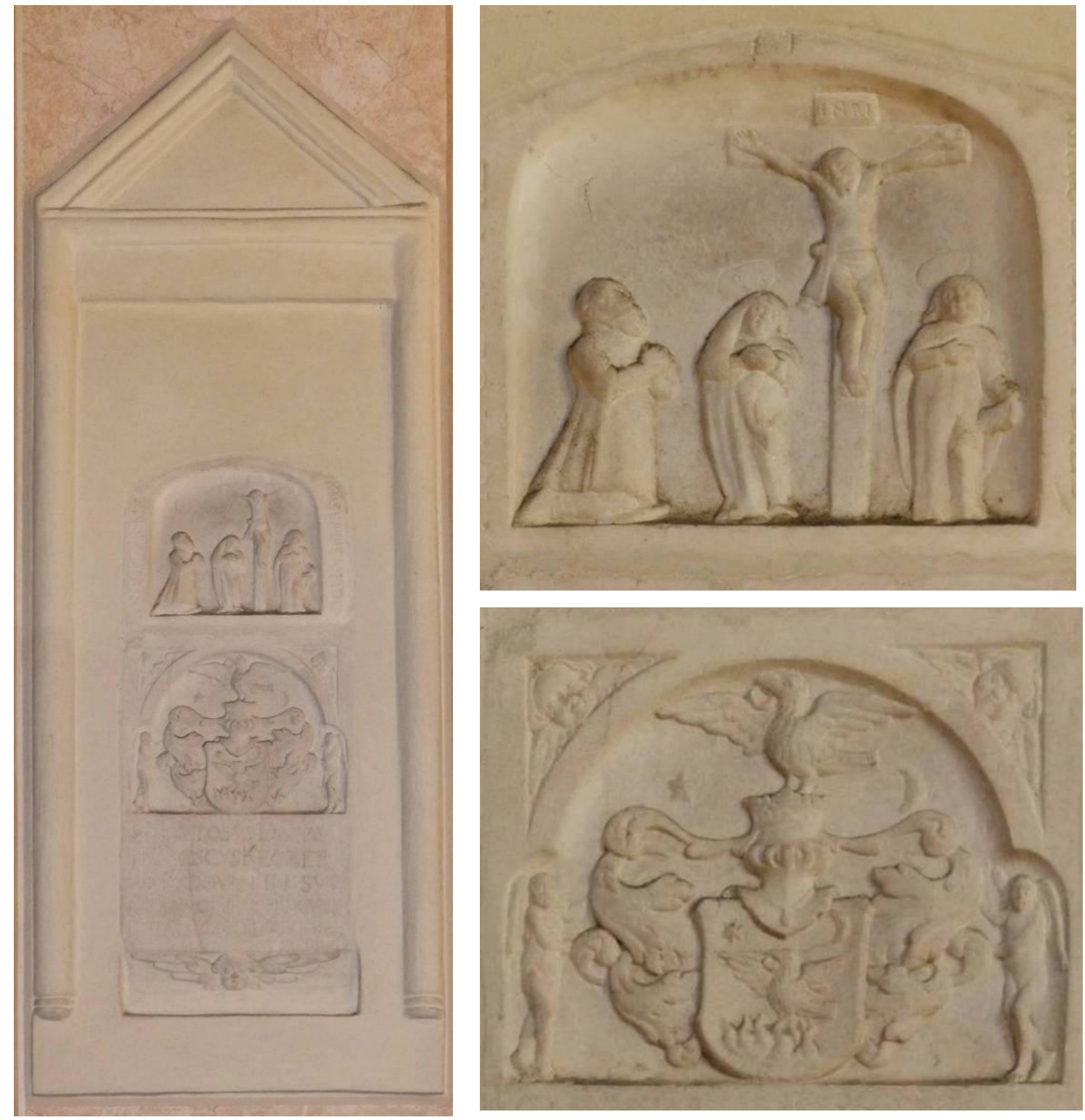

Epitaf Franje Keczera od Rad(o)vana (? - ?, poslije 1631.), 1629.

Kamen, širina edikule $78 \mathrm{~cm}$, središnji dio $104 \times 43 \times 2,5 \mathrm{~cm}$ (dubina reljefa)

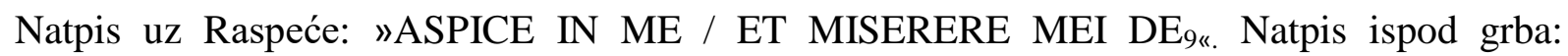
"GENEROSVS DNNS / FRANCISCVS KECZER / DE RADOVAN IN SVI / SVORVMQ 9 MEMORIAM CVRAVIT / FIERI $\overline{A O}$ 1629. DIE 7. IVLY «

\section{Opis spomenika:}

Epitaf je izveden u obliku okomito postavljena pravokutnika, a naknadno je ugrađen unutar jednostavne profilirane edikule (u XIX. stoljeću). Sastoji se od prikaza Raspeća s pokojnikom-adorantom podno kojeg se nalazi trolisna niša s grbom obitelji Keczer i natpisna ploča zaključena motivom kerubina. Bogorodica je prikazana zdesna Kristu, obiju ruku 
prislonjenih na prsa, a pogleda usmjerena prema svome sinu. Sveti Ivan evanđelist stoji s Kristove lijeve strane, u lijevoj ruci drži knjigu, a desnu je - nalik Bogorodici - privio na prsa. Do Marije kleči pokojnik odjeven u suvremenu odjeću, a njegov je lik nešto veći u odnosu na ostale. Ugaona polja trolisne niše koja sadrži grb Keczerovih ukrašena su ponovljenim motivom kerubina.

\section{Literatura:}

Anđelko Košćak, Župa sv. Marka Evanđelista - Vinica, Zagreb: Društvo za povjesnicu Zagrebačke nadbiskupije »Tkalčić«, Vinica: Župa Sv. Marka Evanđelista, 2013., str. $44-45$.

Ivan Kukuljević Sakcinski, Nadpisi sredovječni i novovjeki na crkvah, javnih i privatnih sgradah itd. u Hrvatskoj $i$ Slavoniji, Zagreb: Knjižara Jugoslavenske akademije, Knjižara Dioničke tiskare, 1891., str. 310, br. 1059.

Marijana Schneider, O epitafiju Ivana Hrvoja i Eve Dreffell u Plešivici, u: Bulletin Instituta za likovne umjetnosti Jugoslavenske akademije znanosti $i$ umjetnosti VII/3, Zagreb, Jugoslavenska akademija znanosti i umjetnosti, 1959., str. 177-182, 180.

Gjuro Szabo, Kroz Hrvatsko zagorje, Zagreb: Vasić i Horvat, 1939., str. 119.

Biserka Vlahović, Općina Vinica, Vinica: Poglavarstvo općine Vinica, 1997., str. 44.

Diana Vukičević-Samaržija, Gotičke crkve Hrvatskog zagorja, Zagreb: Institut za povijest umjetnosti, 1993., str. 226. 


\section{BJELOVARSKO-KRIŽEVAČKA BISKUPIJA}

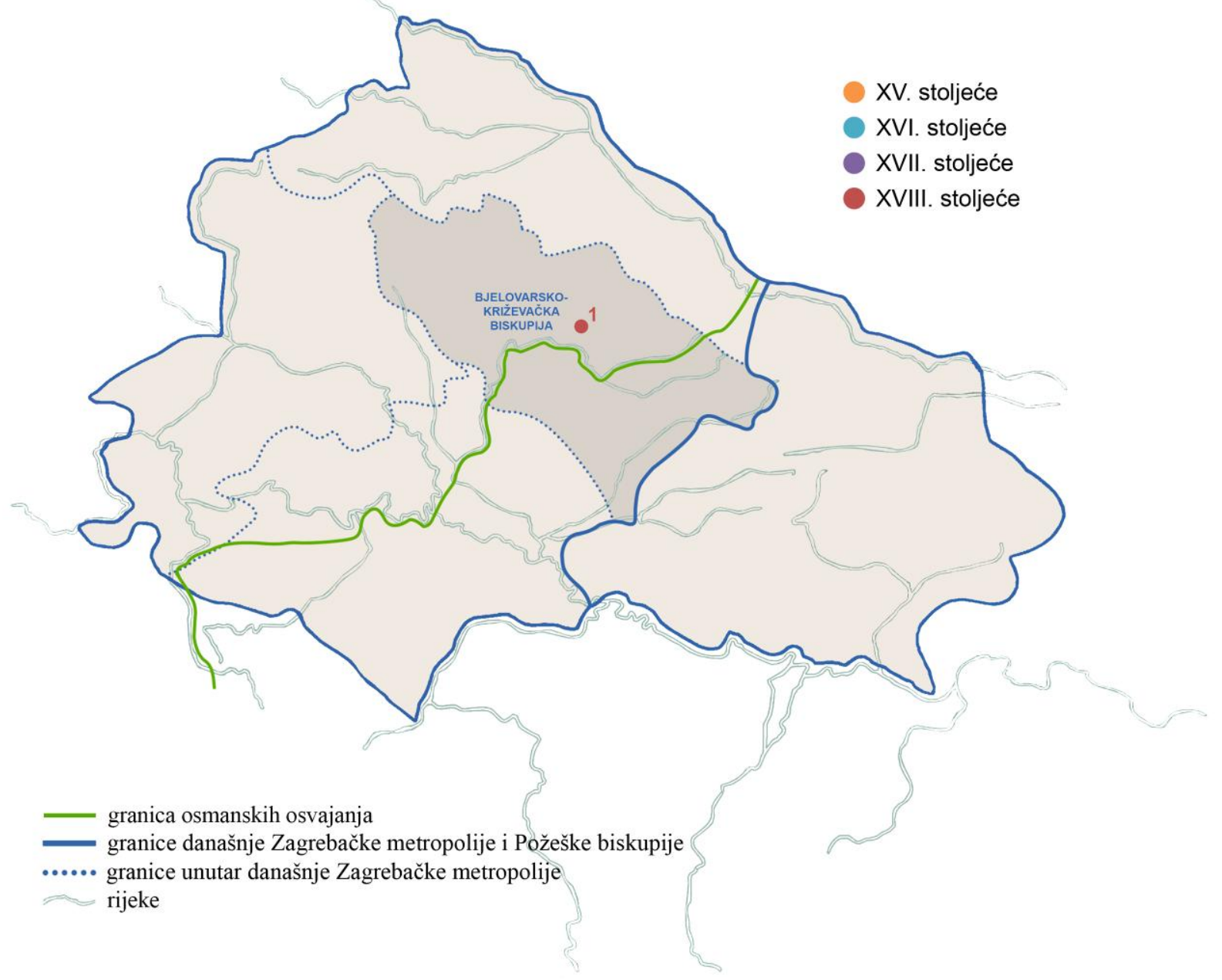

\section{O K A L I T E T}

1. Bjelovar, kapela sv. Križa (sv. Andrije) 
- Kat. br. 74 -

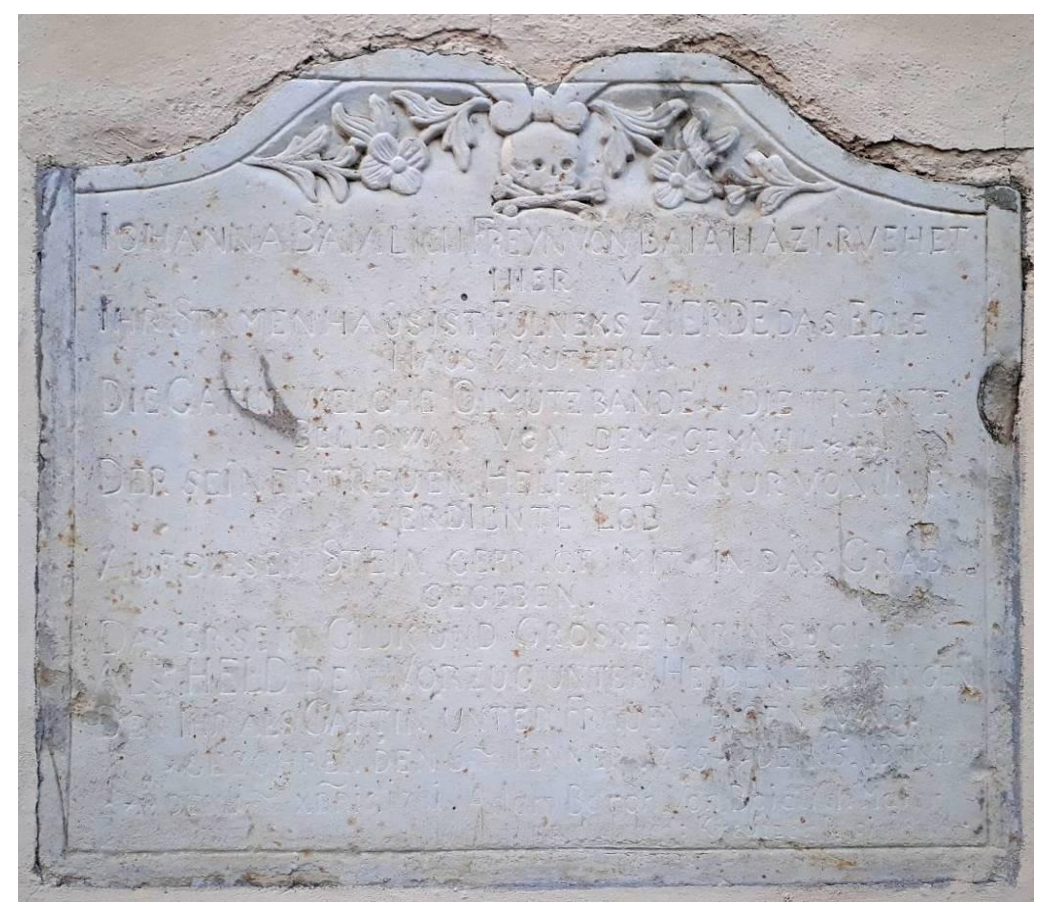

Ploča Ivane Bajalič (?, 1735. - ?, 1781.), 1781.

Kamen, 60,5 × 69,5 cm $\times$ [uzidana]

Natpis: »IOHANNA BAIALICH FREYN VON BAIAHAZI RVEHET / HIER V / IHR STAMEN HAUS IST FULNEKS ZIERDE DAS EDLE / HAUS V KUTZERA / DIE GATIN WELCHE OLMUTZ BANDE * DIE TRENTE / BELLOWAR VON DEM GEMAHL * / DER SEINER TREUEN HELFTE, DAS MUR VON IHR / VERDIENTE LOB / AUF DIESEM STEIN GEPRAGT MIT IN DAS GRAB / GEGEBEN. / DAS ER SEIN GLUK UND GROSSE DARIN SUCHET / ALS HELD DEN VORZUG UNTER HELDEN ZUEBRINGEN / DER IHR ALS GATTIN UNTER FRAUEN ELGEN WAR / * GEBOHREN DEN 6 IENNER $1735 *$ DEN 15 XBRISI / * DENI(?) XBRIS 1781 Adam Baron Von Baialich Meter / (?) Krevizer«

\section{Opis spomenika:}

Epitaf je izveden u obliku vodoravno položenoga pravokutnika koji je većim dijelom ispunjen natpisom. Gornja stranica konveksno je oblikovana dvjema volutama. Luk ispod luneta ukrašen je viticama cvijeća i lubanjom koja počiva na ukriženim kostima.

\section{Literatura:}

Stjepan Kožul, Sakralna umjetnost bjelovarskoga kraja, Zagreb: Prometej, 1999., str. 528. 


\section{SISAČKA BISKUPIJA}

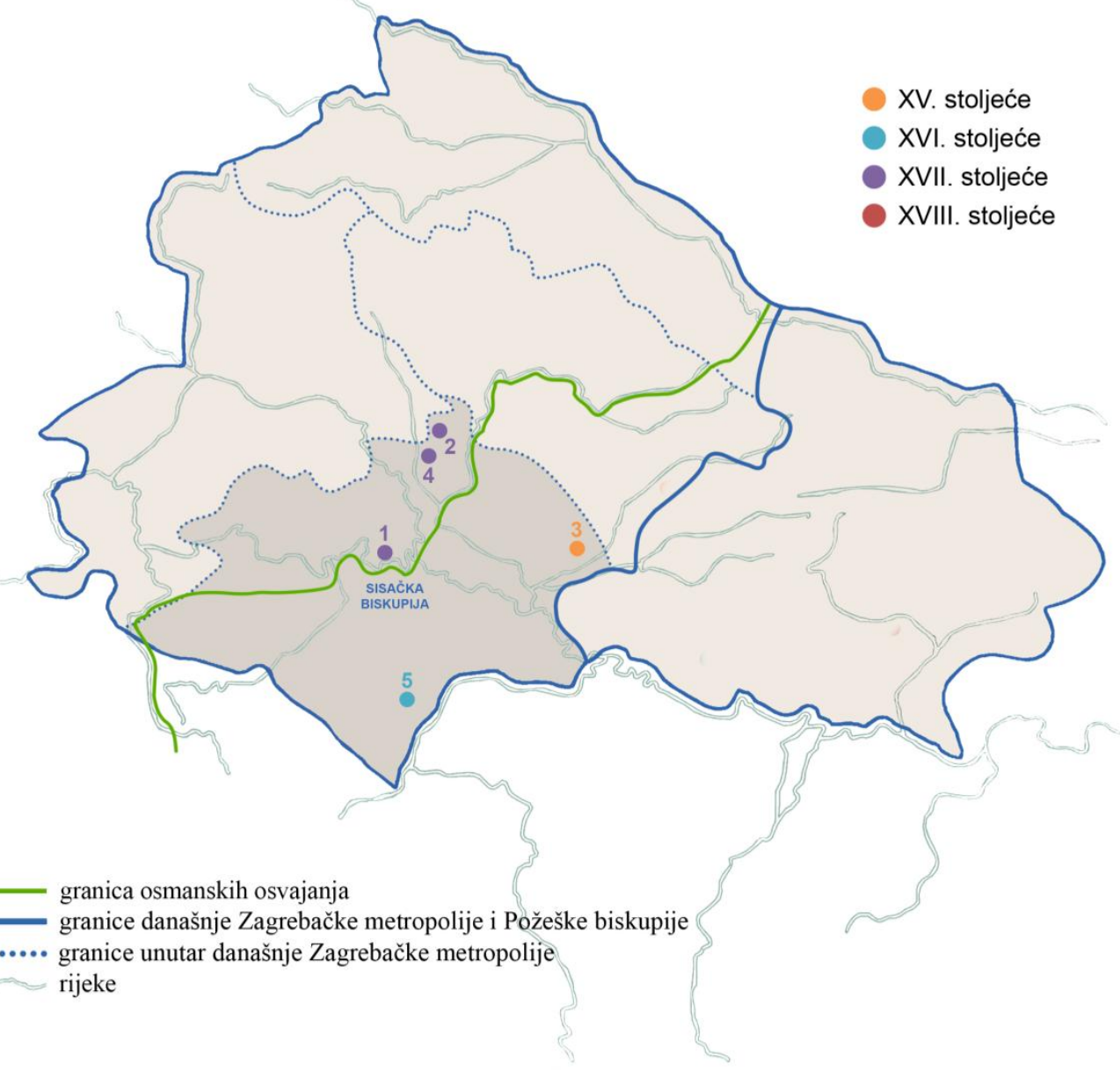

\section{O K A L I T E T I}

1. Brest Pokupski, kapela sv. Barbare

2. Kloštar Ivanić, crkva sv. Ivana Krstitelja

3. Kutina, crkva sv. Marije Snježne

4. Poljana (Ivanić Grad), kapela sv. Jakova Starijega

5. Zrin, crkva sv. Marije Magdalene 


\section{BREST POKUPSKI, kapela sv. Barbare}

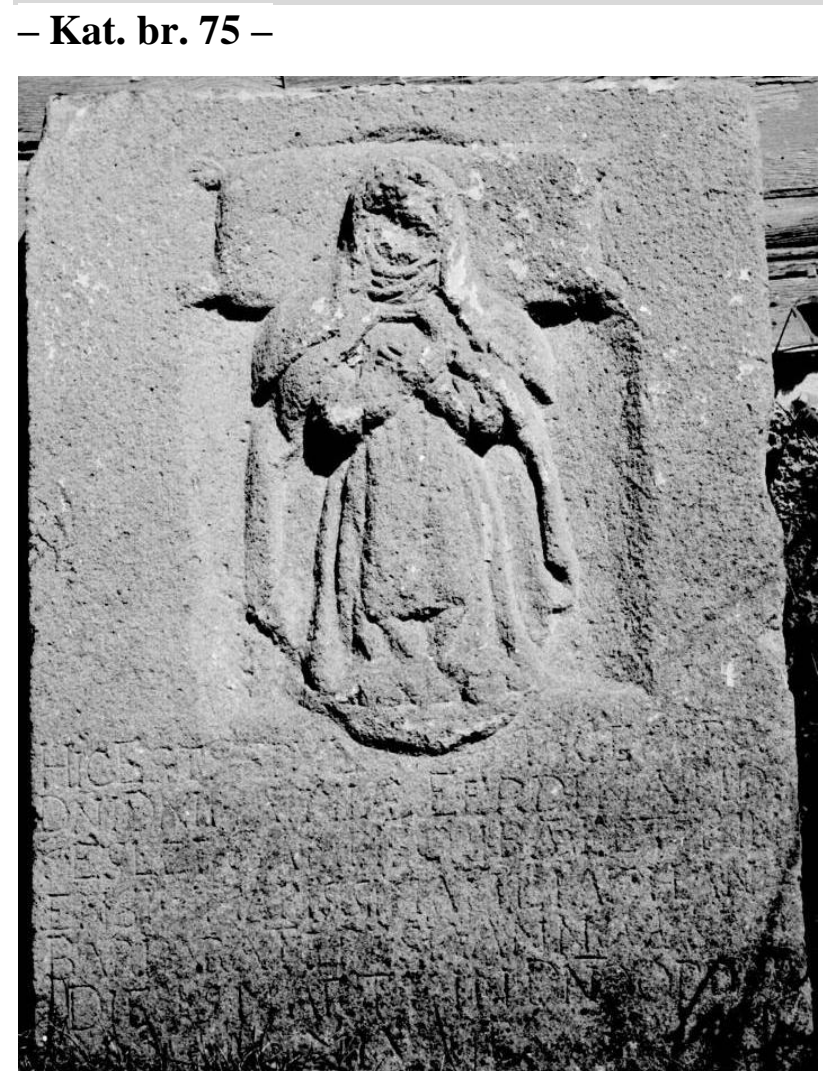

\section{Nadgrobna ploča neznane žene, 1685.}

Ploča nije sačuvana, ali je fotografijski dokumentirana.

Natpis: "HIC EST SEPVLTA GENEROS / DNI DNI NATALA FERDINANDI [...] / SESLE [...] / ENST CHARISSIMA [...] / BARBARA [...] / DIE 19 MART IN DNO [...]«

\section{Opis spomenika:}

Nadgrobna ploča formata okomito postavljenoga pravokutnika s likom pokojnice glave oslonjene na jastuk. Prikazana je en face, ruku položenih na prsima. Odjevena je u haljinu i ogrtač, a preko glave nosi ubradaču. Ispod figuralnoga prikaza uklesan je natpis koji se može djelomično pročitati.

\section{Literatura:}

Anđela Horvat, Između gotike i baroka: umjetnost kontinentalnog dijela Hrvatske od oko 1500. do oko 1700., Zagreb: Društvo povjesničara umjetnosti SR Hrvatske, 1975., str. 350,352 .

Artur Schneider, Popisivanje i fotografijsko snimanje umjetničkih spomenika godine 1939., u: Ljetopis Jugoslavenske akademije znanosti $i$ umjetnosti za godinu 1938/39. Svezak 52, Zagreb: Jugoslavenska akademija znanosti i umjetnosti, 1940., str. 172-186, 174. 


\section{KLOŠTAR IVANIĆ, crkva sv. Ivana Krstitelja}

- Kat. br. 76 -
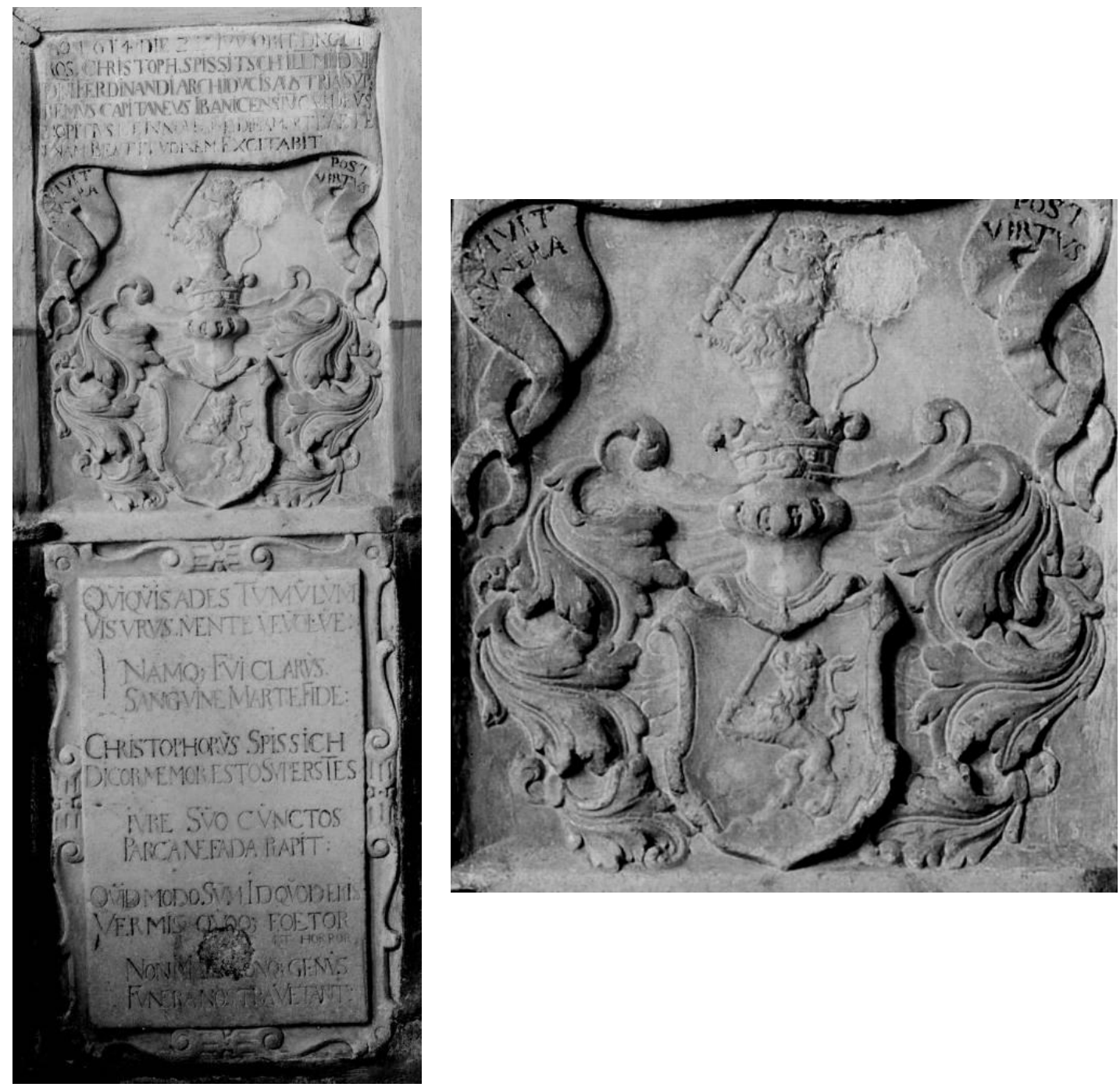

Nadgrobna ploča Kristofora Spišića (? - ?, 1614.)

Kamen, dimenzije nepoznate autorici

Natpis na svitku: "Ā̄ 1614 DIE 22 IVV OBIT DNO GIN / EROS CHRISTOPH: SPISSITSCH I ILLMI $\overline{\mathrm{DNI}}$ / $\overline{\mathrm{DN}} \mathrm{I}$ FERDINANDI ARCHIDVCIS AVSTRIA SVP / REMVS CAPITANEVS IBANICENSIV CVI DEVS / PROPITIVS ET IN NOVISSIMO DIE A MORTE AETE / RNAM BEATITVDINEM EXCITABIT. Natpis na okrajcima svitka: VIVIT / FVNERA / POST / VIRTVS«. Natpis ispod grba: „QVIQVIS ADES TVMVLVM / VIS VRVS MENTE VEVOLVE. / NAMQ 9 FVI CLARVS. / SANGVINE MARTE FIDE: / CHRISTOPHORVS SPISSICH / DICOR, MEMOR ESTO SVPERSTES / IVRE SVO CVNCTOS / PARCA NEFADA RAPIT: / QVID MODO SVM ID QVOD ERIS / VERMIS QVOD; FOETOR / ET HORROR. / NON M[...]NQ9 GENVS / FVNERA NOSTRA VETANT:« 


\section{Opis spomenika:}

Nadgrobna ploča izvedena je u obliku okomito postavljena pravokutnika koji je vodoravno podijeljen na dva podjednaka dijela. U gornjoj polovici predočen je grb obitelji Spišić povrh kojeg se nalazi svitak rascijepljenih krajeva koji sadrži natpis za koga je spomenik podignut. Donju polovicu ispunjava ukrasni okvir konkavno oblikovanih stranica urešenih volutama koji sadrži ostatak nadgrobnoga natpisa.

\section{Literatura:}

Paškal Cvekan, Franjevci u Ivaniću, Kloštar Ivanić: Franjevački samostan, 2008. [1979.], str. 64.

Anđela Horvat, Između gotike i baroka: umjetnost kontinentalnog dijela Hrvatske od oko 1500. do oko 1700., Zagreb: Društvo povjesničara umjetnosti SR Hrvatske, 1975., str. 343-344.

Ivan Kukuljević Sakcinski, Nadpisi sredovječni i novovjeki na crkvah, javnih i privatnih sgradah itd. u Hrvatskoj i Slavoniji, Zagreb: Knjižara Jugoslavenske akademije, Knjižara Dioničke tiskare, 1891., str. 70-71, br. 224.

Krasanka Majer Jurišić i Edita Šurina, Schneiderov fotografijski album - svjedok izgubljenog izgleda crkve sv. Ivana Krstitelja u Kloštar Ivaniću, u: Zbornik radova znanstveno-stručnog skupa »Hrvatski povjesničari umjetnosti. Artur Schneider (1879.1946.)«, Zagreb: Društvo povjesničara umjetnosti Hrvatske, 2016. str. 225-242, 233, 237. Uredila Ljerka Dulibić.

Nela Tarbuk, Kiparstvo 17. i 18. stoljeća u sjevernoj Hrvatskoj, u: Od svagdana do blagdana: barok u Hrvatskoj = From everyday to holidays: baroque in Croatia, katalog izložbe, Zagreb: Muzej za umjetnost i obrt, 1993., str. 122-131, 128. 


\section{KUTINA, crkva sv. Marije Snježne}

- Kat. br. 77 -

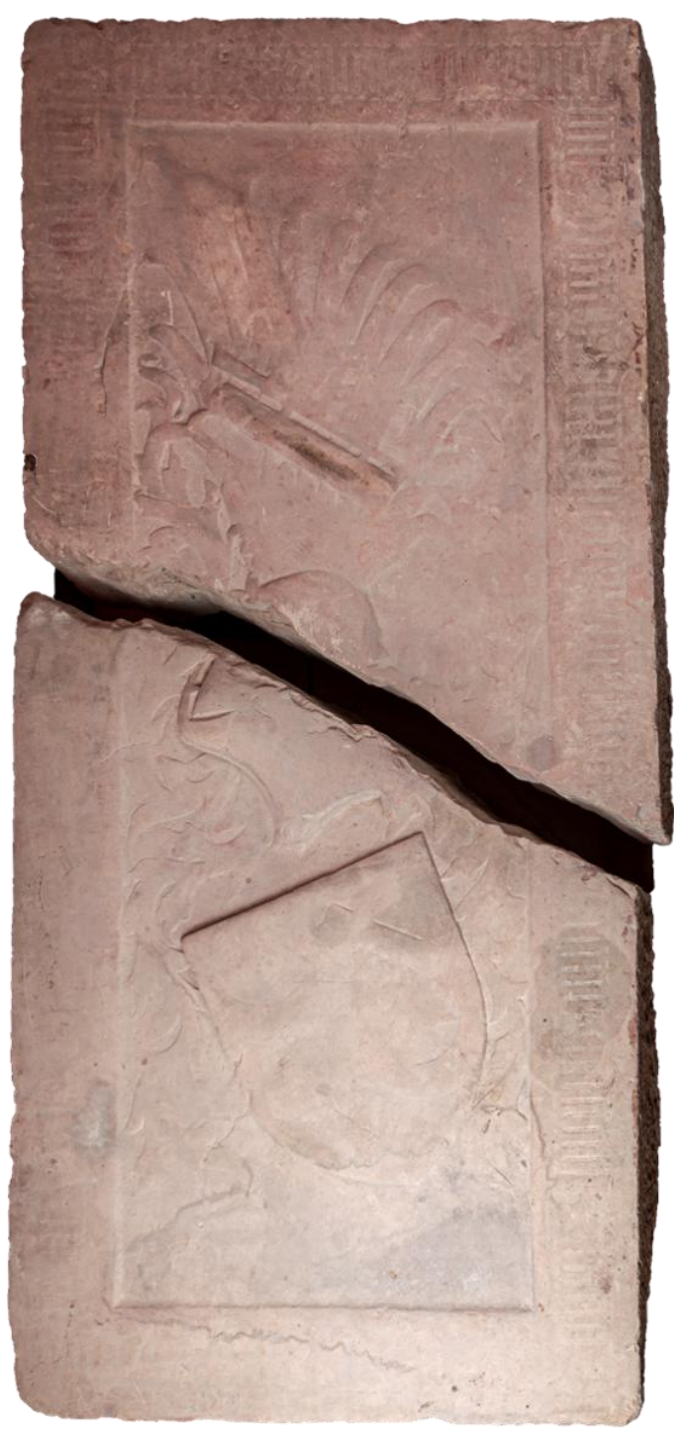

Nadgrobna ploča obitelji Roh de Deche, I. pol. XV. stoljeća

Brčkoliki vapnenac, $210 \times 110 \times 20 \mathrm{~cm}$

Ploča je danas pohranjena u Hrvatskom povijesnom muzeju u Zagrebu.

Natpis: »hic $\S$ est $\S$ sepultus $\S$ egregius $\S /$ vir $\S$ Johnes $\S$ filiu 9 stpni $\S$ filii $\S$ codam $\S$ roche $\S \mathrm{d} \S$ decche $\S$ anno / d $\bar{n} \mathrm{i} \S \mathrm{m} \S \operatorname{cccc} \S$ uigentesimo / in $\S$ die $[\ldots]$ e $\S$ ugi ${ }^{770}$

\section{Opis spomenika:}

Nadgrobna ploča izvedena je u obliku okomito postavljena pravokutnika. Kompozicijski je podijeljena na središnje polje koje sadrži grb obitelji Roh de Deche (štit s grbovnim

\footnotetext{
${ }^{770}$ Slova su zbog istrošenosti teško čitljiva. Prijepis je preuzet iz: Pál Engel i Pál Lővei, nav. dj., 1991., str. 47.
} 
simbolima, kaciga s nakitom i plašt) i natpis koji teče uz rubove nadgrobnika. Natpis je pisan gotičkom minuskulom.

\section{Literatura:}

Vlasta Brajković, Grbovi, grbovnice, rodoslovlja: katalog zbirke grbova, grbovnica $i$ rodoslovlja, Zagreb: Hrvatski povijesni muzej, 1995. [1976.]., str. 140. Rukopis uredila Dubravka Peić Čaldarović.

Pál Engel i Pál Lővei, A gerecsei vörösmárvány használata Zágrábban és környékén a középkorban, u: A Magyar Nemzeti Galéria Évkönyve IX/47-48, Budapest: Magyar Nemzeti Galéria, 1991., str. 47-51.

Zorislav Horvat, $O$ nekim osobinama gotičkih nadgrobnih ploča s grbovima u kontinentalnom dijelu SR Hrvatske, u: Bulletin Razreda za likovne umjetnosti Jugoslavenske akademije znanosti $i$ umjetnosti LIX/1, Zagreb: Jugoslavenska akademija znanosti i umjetnosti, 1988., str. 41-68, 49-50, 52-55.

Zorislav Horvat, Heraldički štitovi gotičke arhitekture kontinentalne Hrvatske, Zagreb: Društvo povjesničara umjetnosti Hrvatske, 1996., str. 39-40.

Dražen Kovačević, Đuro Szabo - o starinama u Moslavini, u: Zbornik Moslavine IV, Kutina: Muzej Moslavine, 1998., str. 99-110, 106. Uredila Ana Bobovec.

Mirko Valentić, Kameni spomenici Hrvatske XIII-XIX stoljeća, Zagreb: Povijesni muzej Hrvatske, 1969., str. 27-28.

Mirko Valentić i Lada Prister, Zbirka kamenih spomenika, II. dopunjeno izdanje, Zagreb: Hrvatski povijesni muzej, 2002., str. 63. 


\section{POLJANA, kapela sv. Jakoba Starijega}

- Kat. br. 78 -
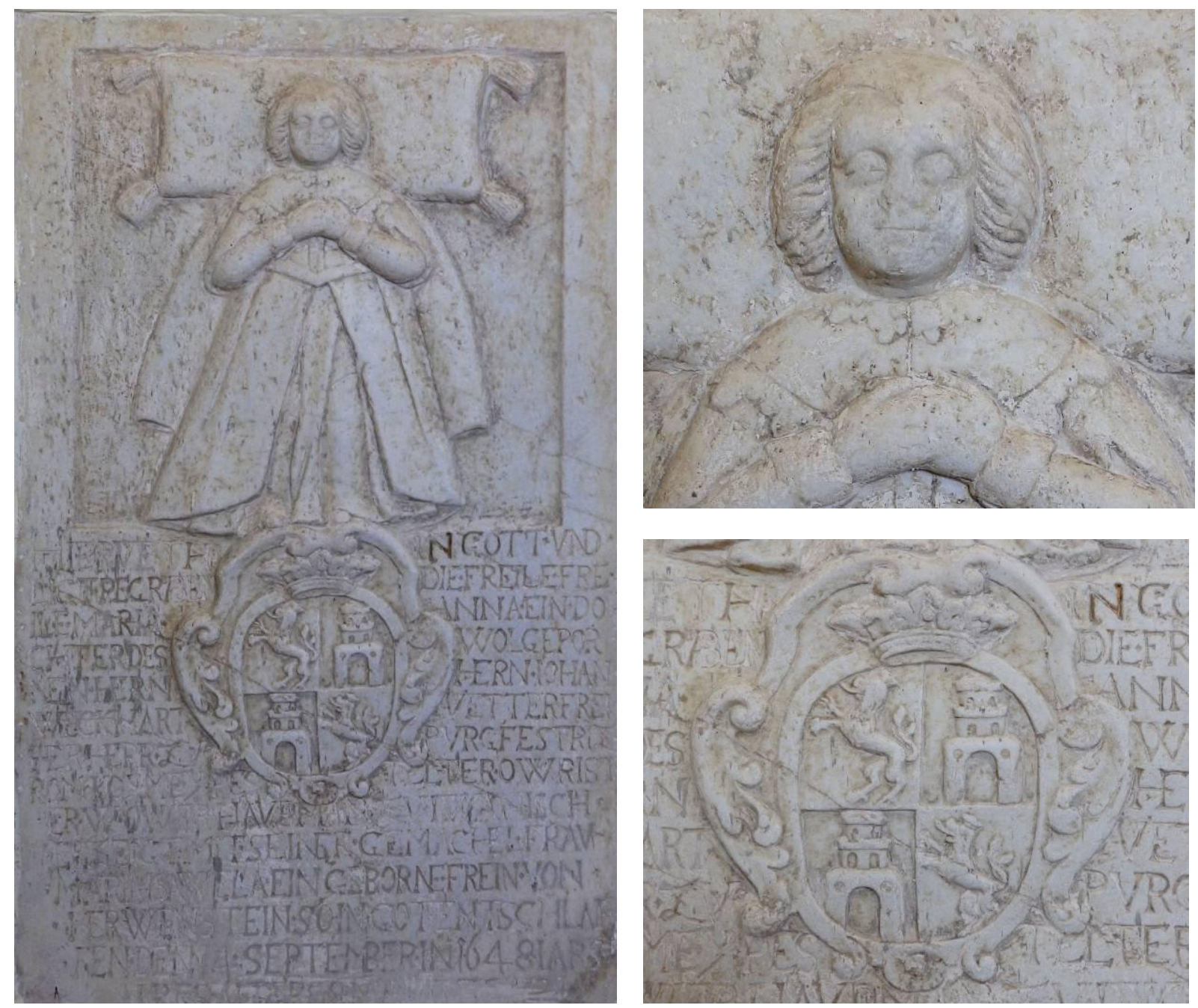

Nadgrobna ploča Marije Ane Weikhard (†1648.)

Kamen, $128 \times 77 \mathrm{~cm} \times$ [uzidana]

Natpis: »HIE $\cdot$ RVETH $\cdot$ IN $\cdot$ GOTT $\cdot$ VND $\cdot /$ LIGT $\cdot$ PEGRABEN DIE $\cdot$ FREILE $\cdot$ FRE · / ILE · MARIA · ANNA · EIN · DO · / CHTER DES WOLGEPOR / EN · HERN · HERN IOHAN / WECKHART · VETTER · FREI / HER · HERR · ZV · PVRG FESTRITZ / ROM · KOY · MEYAES · PELTER · OWRIST / ER · W · OWER · HAVBMAN · ZV · IWANISCH · / ERZEIGT · MIT · SEINER · GEMACHEL $\cdot$ FRAV / · MARIA · ISAWELA · EIN GEBORNE · FREIN · VON · / HERWENSTEIN · SO · IN · GOT ENTSCHLAF / · FEN $\cdot$ DEN $\cdot 14 \cdot$ SEPTEMBER $\cdot$ IN $\cdot 1648 \cdot$ IAHRS $/$ IHRES $\cdot$ ALTERS $\cdot 8 \cdot$ MONAT $\cdot 3$ $\cdot \mathrm{TAG} \lll$ 


\section{Opis spomenika:}

Nadgrobna ploča formata okomito postavljena pravokutnika s likom pokojnice glave oslonjene na jastuk. Pokojnica je prikazana en face, ruku sklopljenih na prsima. Odjevena je u košulju s čipkastim orukvicama i širokim ovratnikom povrh koje nosi haljinu prorezanih rukava i prednjice, a na glavi nosi kapu. Ispod figuralnoga prikaza predočen je grb obitelji pokojničine majke, obitelji Herberstein, koji je okružen nadgrobnim natpisom.

\section{Literatura:}

Ivan Kukuljević Sakcinski, Nadpisi sredovječni i novovjeki na crkvah, javnih i privatnih sgradah itd. u Hrvatskoj $i$ Slavoniji, Zagreb: Knjižara Jugoslavenske akademije, Knjižara Dioničke tiskare, 1891., str. 13, br. 48 i str. 68, br. 217.

Andrija Lukinović, Župa Ivanić-grad, Zagreb: Glas Koncila, 2007., str. 130, 134.

Marijana Schneider, Dva dječja kostima s nadgrobnih ploča iz Vojne krajine (s pregledom dječje nošnje u zapadnoj Evropi od 1600. do 1650.), u: Spomenica Josipa Matasovića (1892-1962.), Zagreb: Povijesno društvo Hrvatske, 1972., str. 181-199, 185, 198-199. Uredio Igor Karaman.

Diana Vukičević-Samaržija, Umjetnost renesanse, u: Sveti trag. Devetsto godina umjetnosti Zagrebačke nadbiskupije 1094.-1994., MGC - Muzej Mimara, Zagreb, 10. rujna - 31. prosinca 1994., Zagreb: Zagrebačka nadbiskupija, Institut za povijest umjetnosti, Muzejsko-galerijski centar, 1994., str. 175-188, 183. Uredili Tugomir Lukšić i Ivanka Reberski. 
- Kat. br. 79 -

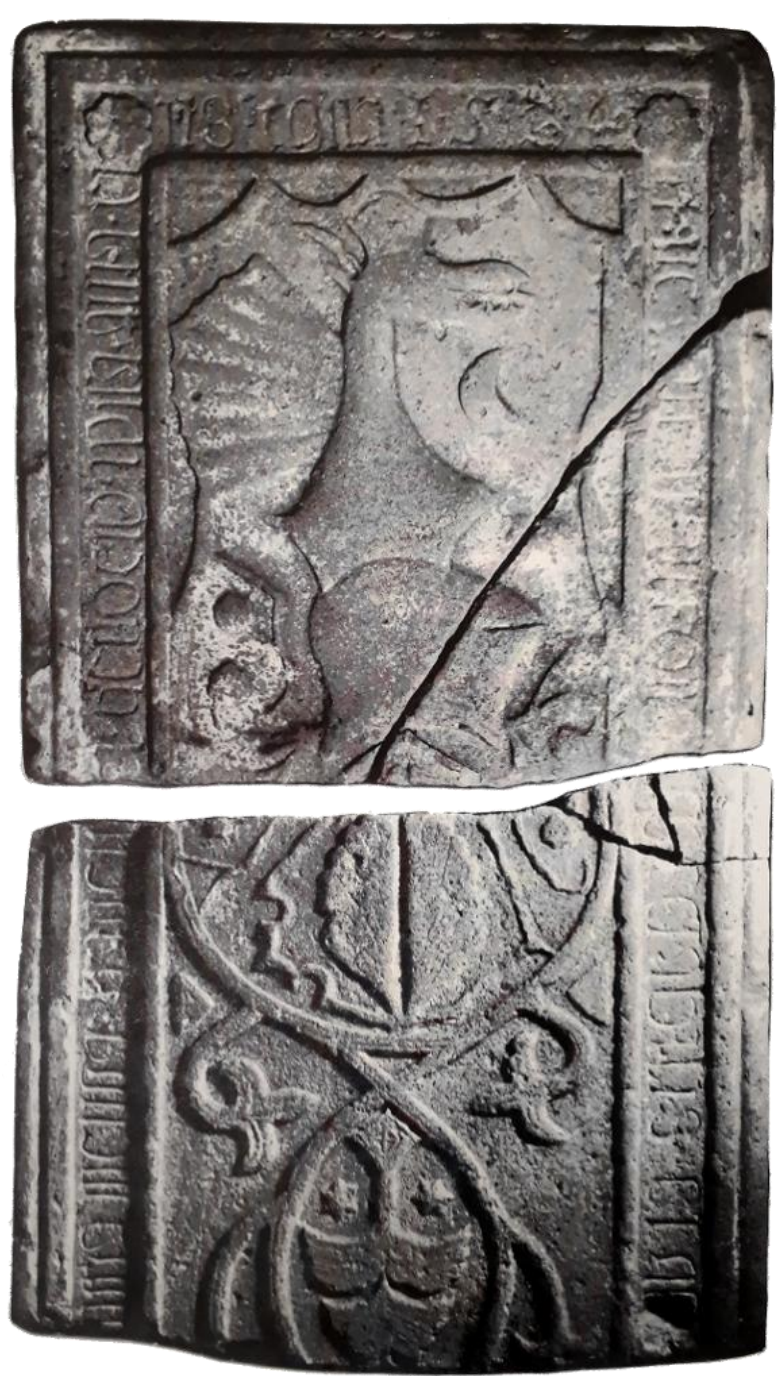

Bihaćka klesarska radionica, Nadgrobna ploča Nikole III. Zrinskoga (?, 1488./89. - Zrin, 1534.)

Kamen, $141 \times 84,5 \times 17,3 \mathrm{~cm}$

Ploča je danas pohranjena u zbirci samostana sv. Antuna Padovanskoga u Hrvatskoj Kostajnici.

Natpis: »HIC IACET IN FOSSA SPECTABILIS ET [...] / [...] MAGNIFICI INCLUSA FRANCISCI DEVOCIO IPSA ANIMA / EUIS ET OSSA 1534«

\section{Opis spomenika:}

Nadgrobna ploča izvedena je u obliku okomito postavljena pravokutnika. Kompozicijski je podijeljena na središnje polje koje sadrži grb obitelji Zrinski i natpis pisan gotičkom minuskulom koji teče uz rubove nadgrobnika. Grb - koji se sastoji od štita i kacige s ukrasom 
u obliku zmaja - predočen je unutar većega heraldičkog štita izvedenoga u obliku vitica. Vitice se pružaju ispod grba $\mathrm{i}$ isprepliću u manji medaljon s motivom topuza i parom šestokrakih zvijezda.

\section{Literatura:}

Paškal Cvekan, Kostajnica i franjevci, Kostajnica: P. Cvekan, 1982., str. 44-46.

Anđela Horvat, Između gotike i baroka: umjetnost kontinentalnog dijela Hrvatske od oko 1500. do oko 1700., Zagreb: Društvo povjesničara umjetnosti SR Hrvatske, 1975., str. 341-342.

Zorislav Horvat, $O$ nekim osobinama gotičkih nadgrobnih ploča s grbovima u kontinentalnom dijelu SR Hrvatske, u: Bulletin Razreda za likovne umjetnosti Jugoslavenske akademije znanosti $i$ umjetnosti LIX/1, Zagreb: Jugoslavenska akademija znanosti i umjetnosti, 1988., str. 47-86, 61-62, 64.

Zorislav Horvat, Heraldički štitovi gotičke arhitekture kontinentalne Hrvatske, Zagreb: Društvo povjesničara umjetnosti Hrvatske, 1996., str. 87

Zorislav Horvat, Srednjovjekovna umjetnost - arheološki stadij, u: Mir i dobro: umjetničko i kulturno naslijeđe Hrvatske franjevačke provincije sv. Ćirila i Metoda o proslavi stote obljetnice utemeljenja, katalog izložbe, Zagreb: Galerija Klovićevi dvori 2000., str. 355. Uredili Marija Mirković i Franjo Emanuel Hoško.

Ivan Kukuljević Sakcinski, Nadpisi sredovječni i novovjeki na crkvah, javnih i privatnih sgradah itd. u Hrvatskoj $i$ Slavoniji, Zagreb: Knjižara Jugoslavenske akademije, Knjižara Dioničke tiskare, 1891., str. 378, br. 1298.

Filip Škiljan, Kulturno-historijski spomenici Banije: s pregledom od prapovijesti do 1881. godine, Zagreb: Srpsko narodno vijeće, 2008., str. 152-154. 


\section{POŽEŠKA BISKUPIJA}

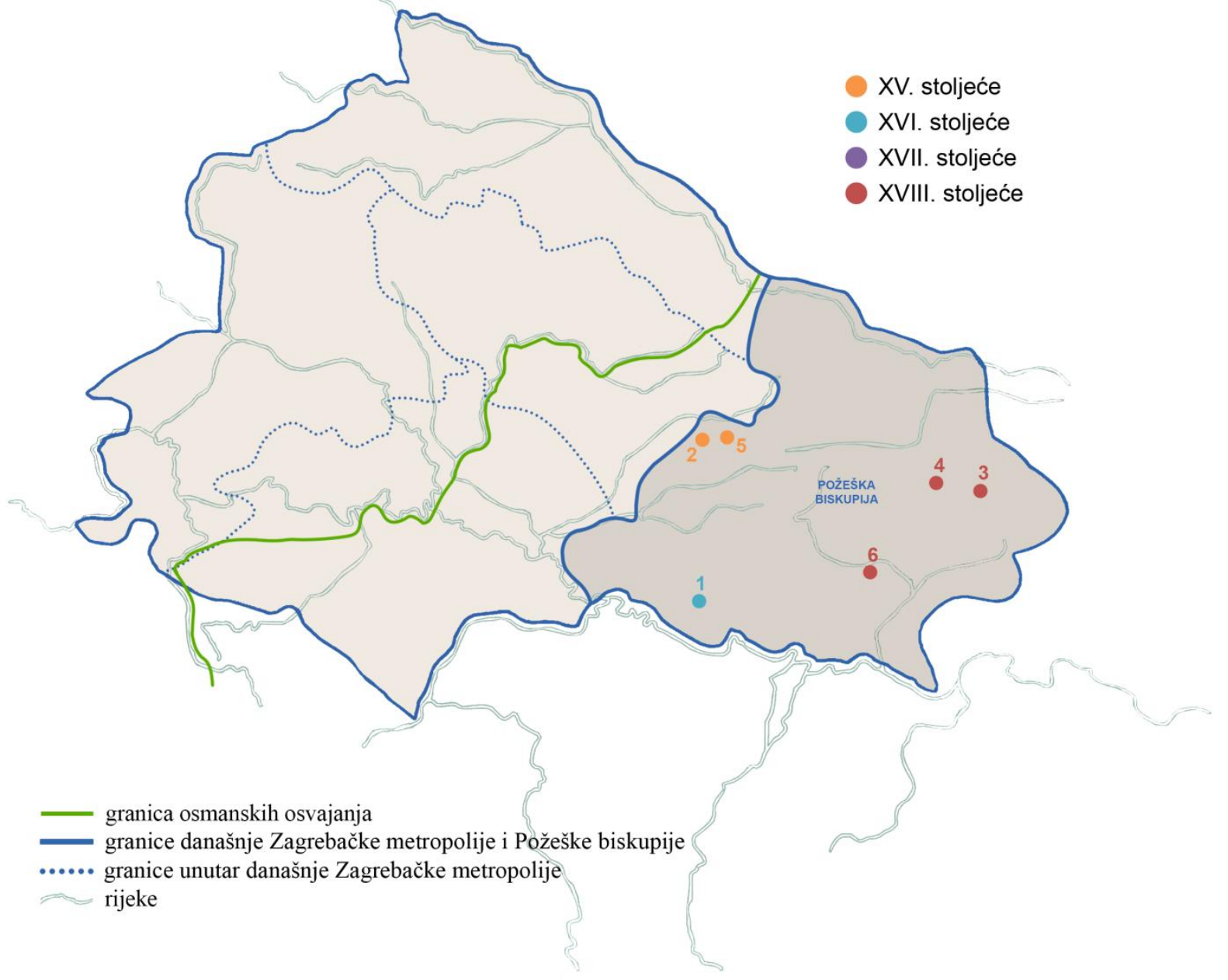

\section{O K A L I T E T I}

1. Borovac, kapela sv. Martina

2. Kreštelovac, crkva sv. Jelene

3. Našice, crkva sv. Antuna Padovanskoga

4. Orahovica

5. Podborje, crkva sv. Jelene

6. Požega, crkva sv. Lovre 
- Kat. br. 80 -

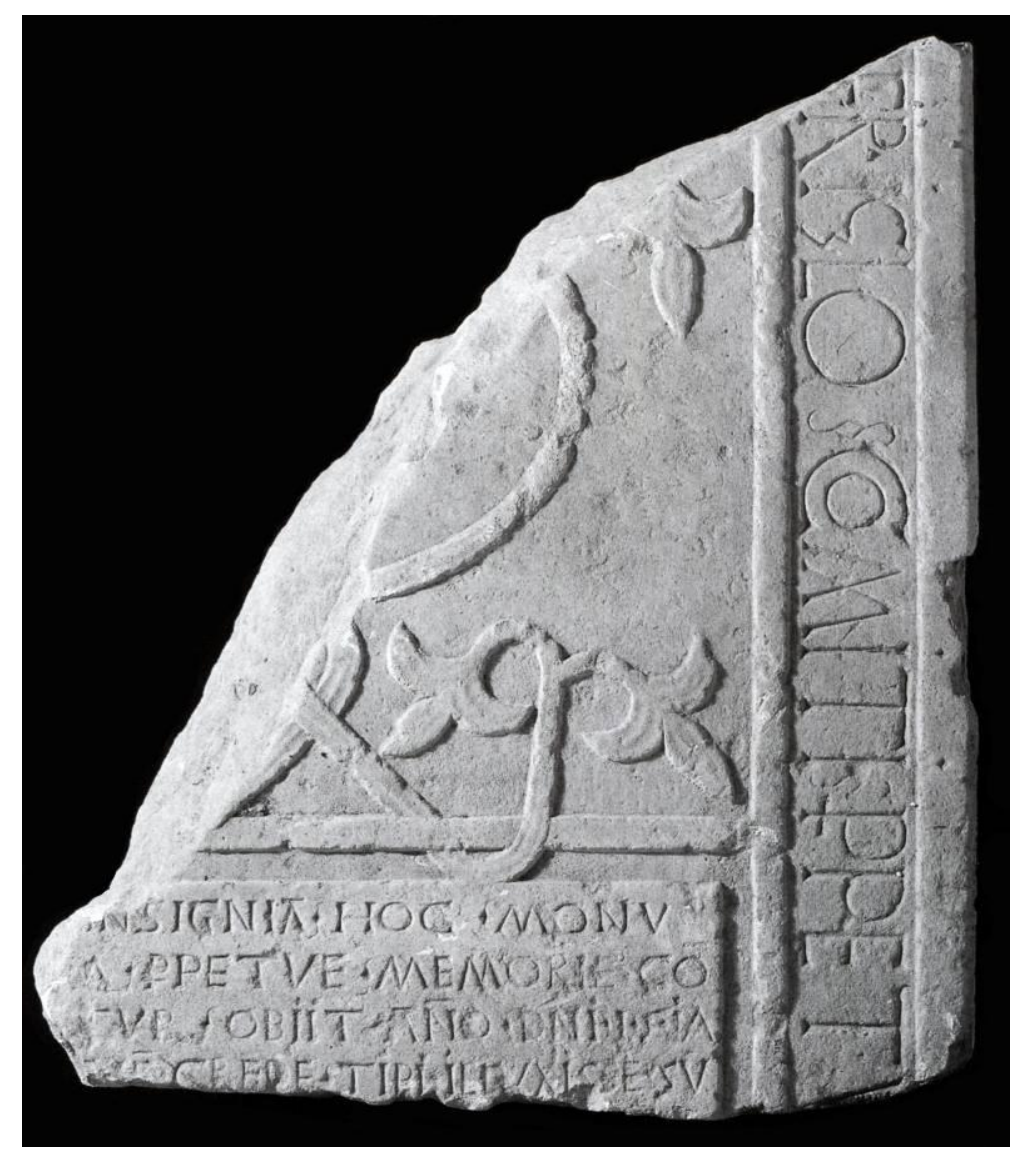

Bihaćka klesarska radionica, Nadgrobna ploča Franje Berislavića Grabarskoga (?) (? - ?, 1517.)

Vapnenac, $80 \times 67 \times 14 \mathrm{~cm}$

Ploča je danas pohranjena u Hrvatskom povijesnom muzeju u Zagrebu.

Natpis uz rubove ploče: »[...] ERSILO $\S$ COMITI PPETVI [...]«. Natpis ispod grba: »[...] INSIGNIA · HOC · MONV / (MENTUM) [...] · PPETVE · MEMORIE CO / (MITIS) [...] TVR $\cdot$ OBIIT $\cdot$ ANTO DNI $\cdot 1 \cdot 5 \cdot 1 \cdot 7 /[\ldots]$ M $\cdot$ CREDE $\cdot$ TIBI $\cdot$ ILLV $\cdot$ XIS $\cdot Æ$ E SV / $[\ldots] \ll$

\section{Opis spomenika:}

Sačuvan je donji desni kut nadgrobne ploče koji sadrži dio središnjega polja i dijelove natpisā. Središnjim poljem - koje je izvorno sadržavalo obiteljski grb - pružaju se stilizirane vitice koje završavaju motivom ljiljana. Nadgrobnik sadrži dvije vrste natpisa: jedan koji teče uz rubove ploče i drugi koji je uklesan u bloku ispod središnjega polja s viticama. 


\section{Literatura:}

Anđela Horvat, Između gotike i baroka: umjetnost kontinentalnog dijela Hrvatske od oko 1500. do oko 1700., Zagreb: Društvo povjesničara umjetnosti SR Hrvatske, 1975., str. 50.

Zorislav Horvat, $O$ nekim osobinama gotičkih nadgrobnih ploča s grbovima u kontinentalnom dijelu SR Hrvatske, u: Bulletin Razreda za likovne umjetnosti Jugoslavenske akademije znanosti i umjetnosti LIX/1, Zagreb: Jugoslavenska akademija znanosti i umjetnosti, 1988., str. 41-68, 48.

Zorislav Horvat, Heraldički štitovi gotičke arhitekture kontinentalne Hrvatske, Zagreb: Društvo povjesničara umjetnosti Hrvatske, 1996., str. 91.

Marija Šercer, Ulomak nadgrobne ploče Franje Berislavića Grabarskog, u: Informatica museologica III-IV/34, Zagreb: Muzejsko dokumentacijski centar, 2003., str. 103-106.

Lada Prister, Zbirka kamenih spomenika, u: Museum 1846.-1996., katalog izložbe, Zagreb: Hrvatski povijesni muzej, 1996. str. 20-25, 23. Uredila Maja Škiljan.

Mirko Valentić i Lada Prister, Zbirka kamenih spomenika, II. dopunjeno izdanje, Zagreb: Hrvatski povijesni muzej, 2002., str. 65.

Diana Vukičević-Samaržija, Umjetnost renesanse, u: Sveti trag. Devetsto godina umjetnosti Zagrebačke nadbiskupije 1094.-1994., MGC - Muzej Mimara, Zagreb, 10. rujna - 31. prosinca 1994., Zagreb: Zagrebačka nadbiskupija, Institut za povijest umjetnosti, Muzejsko-galerijski centar, 1994., str. 175-188, 186. Uredili Tugomir Lukšić i Ivanka Reberski. 


\section{KREŠTELOVAC, crkva sv. Jelene}

- Kat. br. 81 -

Nadgrobna ploča Ladislava Grebenskoga (? - ?, 1490.), 1489.

Ploča nije sačuvana, ali je dokumentirana u pisanim izvorima.

Natpis: »Hic jacet egregius dominus Ladislaus. Filius Hermanni de Gereben a. d. 1489. «771

\section{Opis spomenika:}

Prema Pilleru i Mitterpacheru (1783.), ploča je sadržavala grb obitelji Grebenski i gore naveden natpis. Na grbovnom štitu bio je predočen zupčanik iznad kojega korača lav.

\section{Literatura:}

Ivan Kukuljević Sakcinski, Nadpisi sredovječni i novovjeki na crkvah, javnih i privatnih sgradah itd. u Hrvatskoj $i$ Slavoniji, Zagreb: Knjižara Jugoslavenske akademije, Knjižara Dioničke tiskare, 1891., str. 33, br. 109.

Mathias Piller i Ludwig Mitterpacher, Iter per Poseganam Sclavoniae provinciam mensibus Junio et Julio anno 1782., Budae: typis regiae universitatis, 1783., str. 92.

Gjuro Szabo, Iz prošlosti Daruvara $i$ okolice, u: Narodna starina XI/28, Zagreb: Josip Matasović, 1932., str. 79-98, 89, 95.

\footnotetext{
${ }^{771}$ Prijepis preuzet iz: Gjuro Szabo, nav. dj., 1932., str. 89.
} 


\section{NAŠICE, crkva sv. Antuna Padovanskoga}

- Kat. br. 82 -
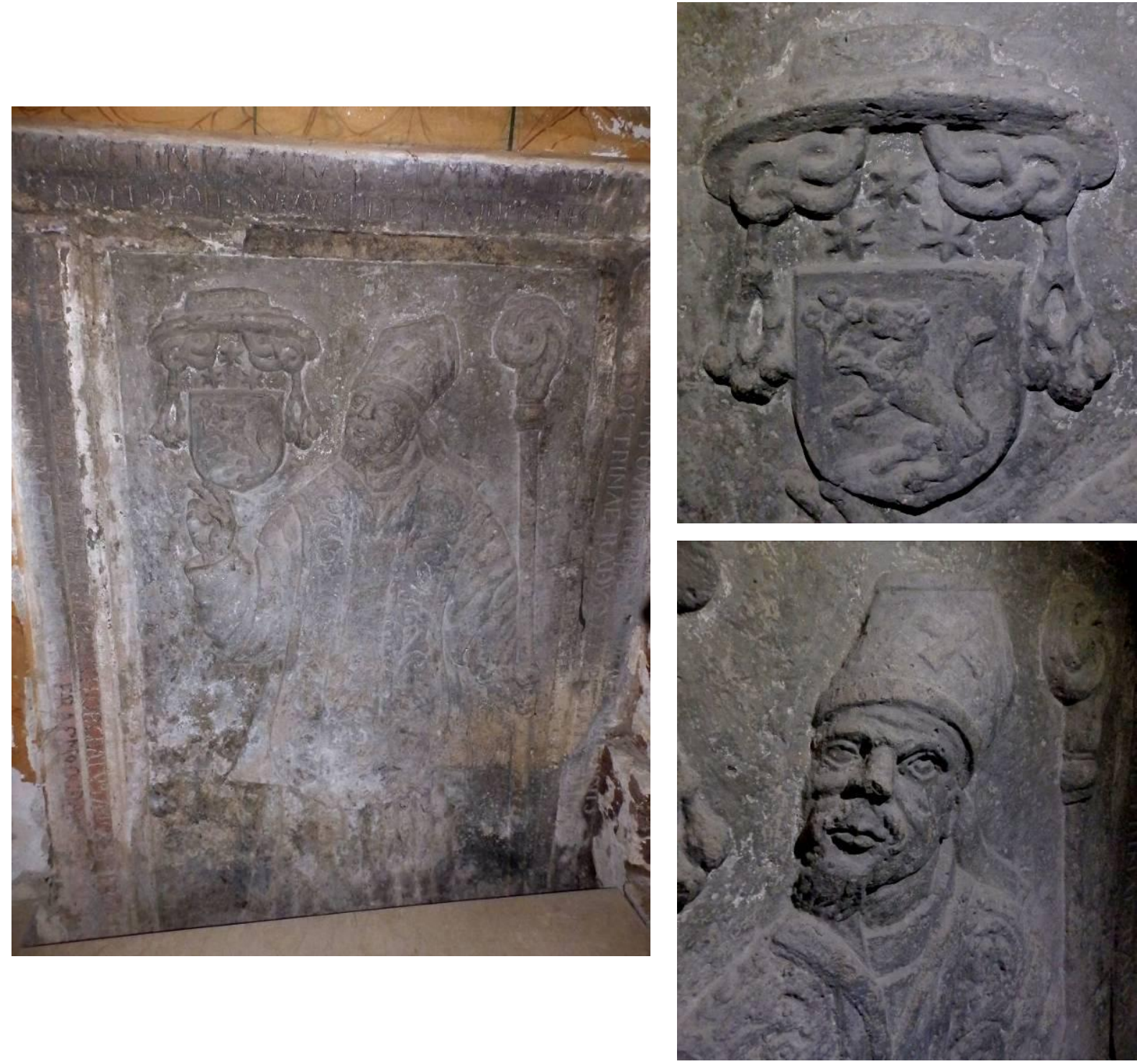

Nadgrobna ploča biskupa Nikole III. Ogramića Olovčića (Požega, 1630. - Đakovo, 1701.)

Kamen, širina o. $140 \mathrm{~cm}$

Natpis (uz gornji rub ploče): »HOC IACET IN TMLO PRÆSVL PLVMBENSIS INQVE / QVEM DEDIT INNOCVVM DEXTRA INMCA NECI «. Uz desni rub ploče: »IPSE SVIS $\mathrm{OVIB}_{9}$ TER DENS PRÆFVIT ANNIS / DOCTRINAE RADYS ET PIETATE NITENS «. Uz lijevi rub ploče: »GENTVS EX SORORE ABRAHAMI OGRAMCH · OB GRATVM AMOREM ERGA SVVM FRA(TRU) / ELLEM PRO ÆTERNA MEMORIA · FE · CVR · FR - ERASM 9 OGRAMCH A POSEGA FRATRV(ELIS EJUS)«. Uz donji rub ploče: $»$ [FRATER NICOLAUS OGRAMICH A POSSEGA EPISCOPUS DIAKOVIENSIS 
ORDINIS S. FRANCISCI OBS. PROV / IAE BOSNIAE ARGENTINAE NECATUS EST APUD SUAM CATH. DIAKOVAE DIE 14. AUGUSTI ANNO MDCCI] « ${ }^{772}$

\section{Opis spomenika:}

Nadgrobna ploča formata okomito postavljena pravokutnika s likom pokojnika. Pokojnik je prikazan u lijevom tričetvrt profilu. Odjeven je u pontifikalno ruho ukrašeno motivom akanta, a na glavi nosi mitru. U lijevoj ruci drži pastoral, a desnu je podignuo u gesti blagoslova. Pokojnik je tijelom i pogledom usmjeren prema obiteljskome grbu, koji je predočen $\mathrm{u}$ gornjem lijevom kutu nadgrobnika. Oko ruba nadgrobne ploče uklesan je natpis.

\section{Literatura:}

Stjepan Bäuerlein, Fra Nikola Ogramić-Olovčić, biskup đakovački, u: Croatia Sacra XIIIXIV/22-23, Zagreb: Hrvatska bogoslovska akademija, 1944., str. 127-160, 158-159.

Placido Belavić, Našice: povjesničke crtice, Našice: Zavičajni muzej, 1995., str. 28-29.

Paškal Cvekan, Franjevci u Abinim Našicama: Povijesno-kulturni prikaz djelovanja Franjevaca kroz 700 godina postojanja samostana i crkve Svetog Antuna u Abinim Našicama, Našice: Paškal Cvekan, 1981., str. 63, 67.

Anđela Horvat, Barok u kontinentalnoj Hrvatskoj, u: Barok u Hrvatskoj, Zagreb: Sveučilišna naklada Liber, Odjel za povijest umjetnosti Centra za povijesne znanosti, Društvo povjesničara umjetnosti, 1982., str. 3-381, 265-266. Napisali Anđela Horvat, Radmila Matejčić i Kruno Prijatelj.

Ivan Kukuljević Sakcinski, Nadpisi sredovječni i novovjeki na crkvah, javnih i privatnih sgradah itd. u Hrvatskoj i Slavoniji, Zagreb: Knjižara Jugoslavenske akademije, Knjižara Dioničke tiskare, 1891., str. 145, br. 492.

Srećko Majstorović, Našice kroz 700 godina 1229.-1929., Zagreb: Vicepostulatura, 1973., str. 70-72.

\footnotetext{
${ }^{772}$ Dio natpisa koji je uklesan uz donji rub ploče preuzet je iz literature jer je nevidljiv zbog načina na koji je ploča ugrađena u zid. Usp. Stjepan Bäuerlein, nav. dj., 1944., str. 158-159.
} 


\section{ORAHOVICA}

- Kat. br. 83 -

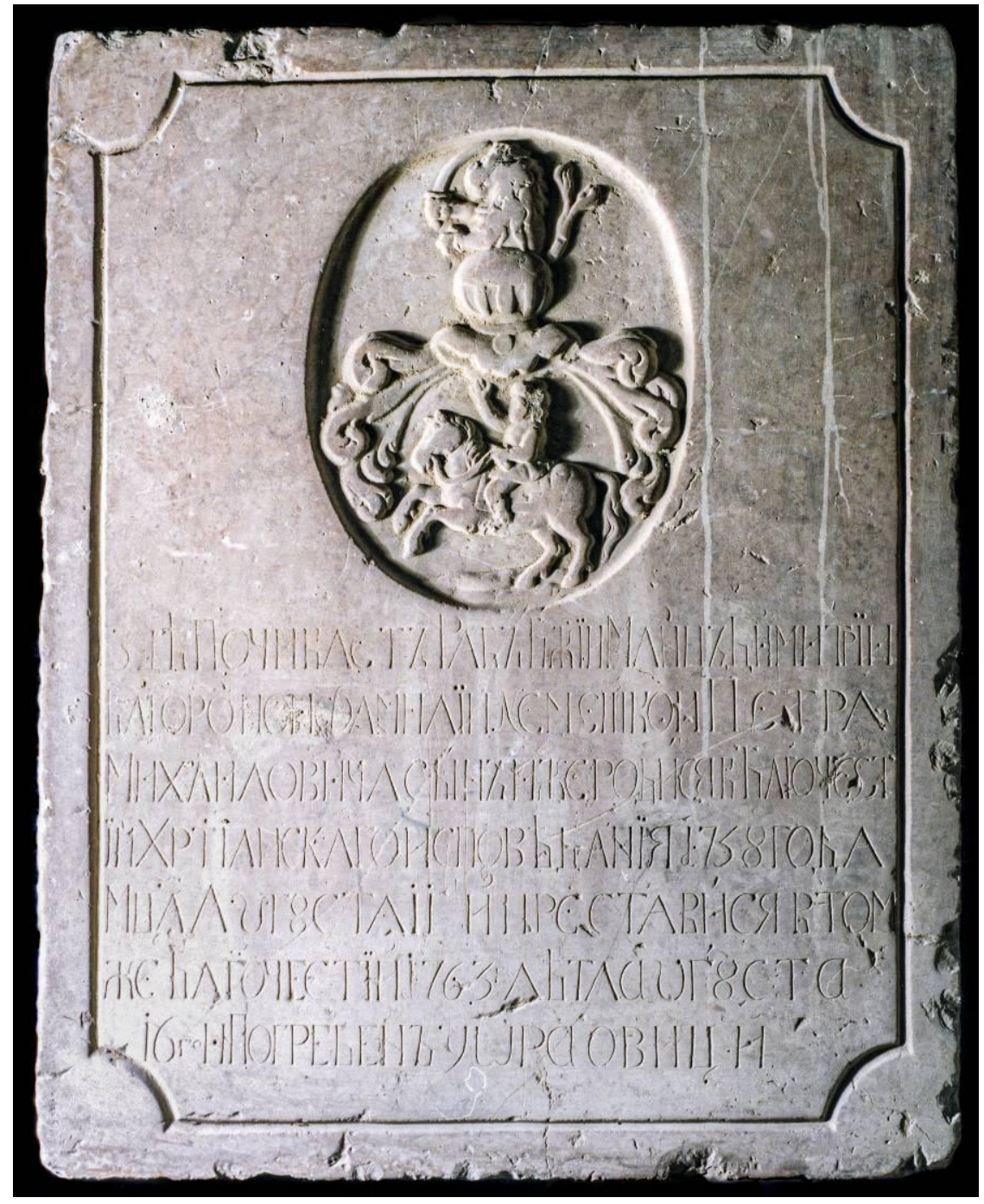

Nadgrobna ploča Dimitrija Mihalovića (?, 1758. - ?, 1763.)

Vapnenačka breča, $100 \times 79 \times 16 \mathrm{~cm}$

Ploča je danas pohranjena u Hrvatskom povijesnom muzeju u Zagrebu.

Natpis: »ЗЕЪ ПОЧИВЛЕ ТЪРАБЪ БЖЇИ МЛЙЦЪ ДИМИТРЇИ / БЛГОРОІЮИ ФАМИЛЇ ПЛЕМЕШКОИ ПЕТРА / МИХАЛОВИЧА СЫНЬ И ЖЕ РОДИСЯ В БЛГОЧЕСТ / ЇИ ХРТІАНСКА ГОИСПОВЪДАНЇЯ 1738 ГОДА / МЦА АУГ8СТА 11 И ПРЕСТАВИСЯ В ТОМ / ЖЕ БЛГОЧЕСТЇИ 1763 ЕАЂТЛ АУГ8СТА / 16ГО И ПОГРЕБЕНЬ У ФРАОВИЦИ

\section{Opis spomenika:}

Jednostavna nadgrobna ploča izvedena u obliku okomito postavljena pravokutnika. Obrubljena je jednostavnim pravokutnim okvirom kružno odsječnih kuteva. Sadrži grb 
obitelji Mihalović koji je reljefno izveden unutar ovalnoga polja. Ispod grba ispisan je nadgrobni natpis na ćirilici.

\section{Literatura:}

Mirko Valentić, Kameni spomenici Hrvatske XIII-XIX stoljeća, Zagreb: Povijesni muzej Hrvatske, 1969., str. 104-105.

Mirko Valentić i Lada Prister, Zbirka kamenih spomenika, II. dopunjeno izdanje, Zagreb: Hrvatski povijesni muzej, 2002., str. 65-66. 
PODBORJE, crkva sv. Jelene

- Kat. br. 84 -

Nadgrobna ploča Stjepana Codharyja (Roha?) de Deche (? - ?, 1462.)

Ploča nije sačuvana, ali je dokumentirana u pisanim izvorima.

Natpis: "HIC IACET SEPULTUS EGREGIUS MAGISTER STEPHANUS FILIUS IOANNIS CODHARY DE DECSA MORTVVS 1462 «773

\section{Opis spomenika:}

Prema povijesnim izvorima, ploča je sadržavala lik viteza-pokojnika i gore navedeni natpis.

\section{Literatura:}

Ivan Kukuljević Sakcinski, Nadpisi sredovječni i novovjeki na crkvah, javnih i privatnih sgradah itd. u Hrvatskoj i Slavoniji, Zagreb: Knjižara Jugoslavenske akademije, Knjižara Dioničke tiskare, 1891., str. 113, br. 376.

\footnotetext{
${ }^{773}$ Prijepis preuzet iz: Ivan Kukuljević Sakcinski, nav. dj., 1891., str. 113, br. 376.
} 


\section{POŽEGA, crkva sv. Lovre}

- Kat. br. 85 -

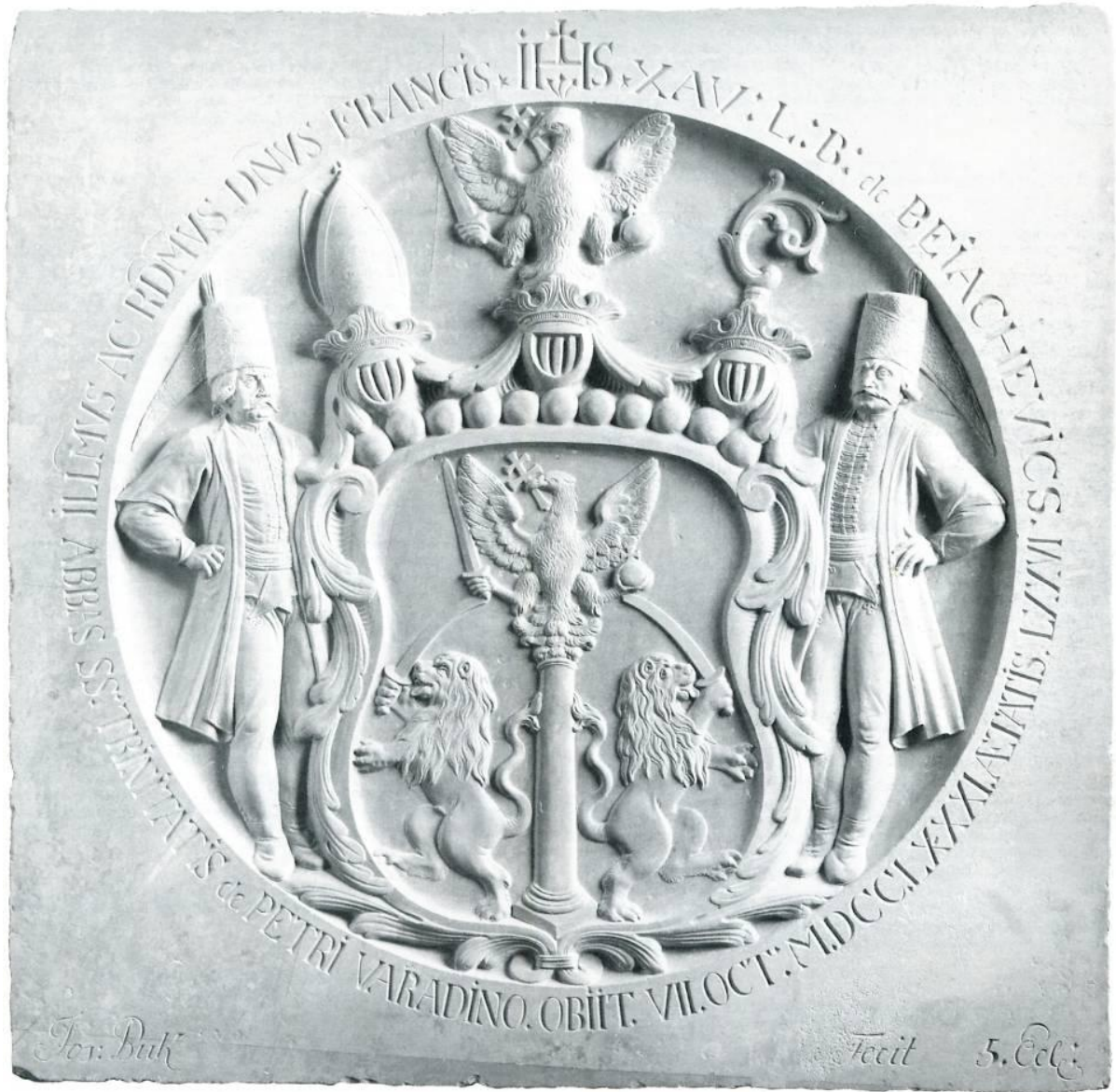

Josip Buk, Epitaf Franje Ksavera Pejačevića (Osijek, 1707. - Požega, 1781.)

Kamen, $62 \times 62 \mathrm{~cm} \times$ [uzidana]

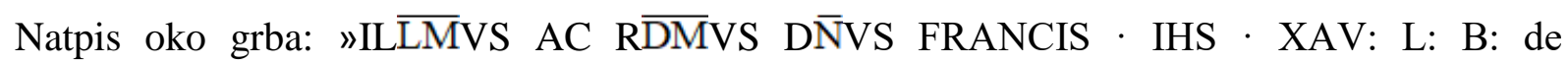
BEIACHEVICS. ABBAS SS: TRINITATIS de PETRI VARADINO. OBIIT. VII. OCT. M.DCC.LXXXI. ÆTATIS. LXXVI«. Natpis u donjem lijevom kutu: »Jos: Buk«. Natpis u donjem desnom kutu: »Fecit 5. Ecl:«

\section{Opis spomenika:}

Epitaf je izveden u obliku kvadrata u koji je upisan krug. Sadrži grb obitelji Pejačević koji je reljefno izveden unutar okrugloga polja. Štit čuvaju dva muškaraca odjevena u suvremenu odjeću. Oko grba uklesan je posvetni natpis. Uz donji rub epitafa uklesano je ime kipara (Josip Buk) koji je izradio nadgrobnik. 


\section{Literatura:}

Doris Baričević, Barokno kiparstvo u isusovačkim crkvama u Hrvatskoj, u: Isusovačka baština u Hrvata: u povodu 450-te obljetnice osnutka Družbe Isusove i 500-te obljetnice rođenja Ignacija Loyole, katalog izložbe, Zagreb: Muzejsko-galerijski centar, 1993., 99-112, 313-321, 318. Uredila Biserka Rauter Plančić.

Julije Kempf, Požega: zemljopisne bilješke iz okoline i prilozi za povijest slob. i kr. grada Požege i Požeške županije, Požega: Štamparija »Hrvatske tiskare i knjižare«, 1910., str. 527.

Ivan Srša, Požega, crkva sv. Lovre, Zagreb: Ministarstvo kulture, Uprava za zaštitu kulturne baštine, 2005., str. 63.

Zlatko Uzelac, Prilog rekonstrukciji požeškoga baroka, u: Vjesnik muzeja požeške kotline 4-5, Slavonska Požega: Muzej Požeške kotline, 1986., str. 95-104, 99. 


\section{POPIS ARHIVSKIH IZVORA I LITERATURE}

\section{ARHIVSKI IZVORI:}

\section{Arhiv Hrvatske akademije znanosti i umjetnosti}

Liber Memorabilium Parochiae Lepoglavensis ab Anno 1401 usque 1789. ${ }^{\text {um }}$, sign. IV.d. 77

Kamilo Dočkal, Povijest pavlinskog samostana sv. Jelene u Čakovcu, sign. XVI.29b. 7

Kamilo Dočkal, Samostan bl. Dj. Marije u Sveticama, sign. XVI.29c. 4

\section{Nadbiskupijski arhiv u Zagrebu}

NAZ, Kanonske vizitacije, Protokol 1/I (1620.)

NAZ, Kanonske vizitacije, Protokol 4/IV (1638.)

NAZ, Kanonske vizitacije, Protokol 22/IV (1735.)

NAZ, Kanonske vizitacije, Protokol 57/XIII (1745.)

NAZ, Kanonske vizitacije, Protokol 71/II (1698.)

NAZ, Kanonske vizitacije, Protokol 81/XII (1779.)

NAZ, Kanonske vizitacije, Protokol 96/VIII (1746., 1756.)

NAZ, Kanonske vizitacije, Protokol 97/IX (1778.)

NAZ, Kanonske vizitacije, Protokol 108/IV (1758.)

NAZ, Kanonske vizitacije, Protokol 122/V (1765.)

NAZ, Kanonske vizitacije, Protokol 162/III. (1681.)

NAZ, Kanonske vizitacije, Protokol 164/V. (1691.)

NAZ, Kanonske vizitacije, Protokol 167/VIII (1726.)

NAZ, Kanonske vizitacije, Protokol 170/XIa (1771., 1777.)

NAZ, Kanonske vizitacije, Protokol 178/II (1716.)

\section{LITERATURA:}

AA.VV., Katekizam katoličke crkve, Zagreb: Glas Koncila, 2016.

Ann Adams i Jessica Barker (ur.), Revisiting the monument: Fifty years since Panofsky's »Tomb sculpture«, London: Research Forum of the Courtauld Institute of Art, 2016.

Philippe Ariès, The Hour of Our Death, New York: Alfred A. Knopf, 1981. Prevela Helen Weaver.

Ivan Bach, Tri rada stranih umjetnika u Hrvatskoj, u: Peristil: zbornik radova za povijest umjetnosti II/1, Zagreb: Društvo povjesničara umjetnosti Hrvatske, 1957., str. 199-203. 
Anđelko Badurina (ur.), Leksikon ikonografije, liturgike i simbolike zapadnog kršćanstva, Zagreb: Kršćanska sadašnjost, 1990. [1979.].

Lászlo Baják, A halotti címerek, u: Numizmatika és társtudományok III, Nyíregyháza: Jósa András Múzeum, 1999., str. 55-63.

Jolán Balogh, Die Kunst der Renaissance in Ungarn, u: Matthias Corvinus und die Renaissance in Ungarn 1458-1541, Schallaburg '82, 8. Mai - 1. November 1982, Wien: Amt der Niederösterreichischen Landesregierung, 1982., str. 81-107. Uredio Gottfried Stangler.

Júlia Bara, »Regnavit Alexander et mortuus est." The Funeral Ceremony of Sándor Károlyi in 1744 and its Art Historical Aspects, u: Hungary in Context: Studies on Art and Architecture, Budapest: CentrArt Egyesület, 2012., str. 79-100.

Doris Baričević, Skulptura i slikarstvo, katalog S, u: Riznica zagrebačke katedrale = The Treasury of Zagreb Cathedral, katalog izložbe, Zagreb: MTM, 1987. [1983.], str. 5564. Uredila Zdenka Munk.

Doris Baričević, Barokno kiparstvo u isusovačkim crkvama u Hrvatskoj, u: Isusovačka baština u Hrvata: u povodu 450-te obljetnice osnutka Družbe Isusove i 500-te obljetnice rođenja Ignacija Loyole, Zagreb: Muzejsko galerijski centar, 1993., str. 99-112, 313321. Uredila Biserka Rauter.

Doris Baričević, Kiparstvo manirizma i baroka, u: Sveti trag: devetsto godina umjetnosti zagrebačke nadbiskupije, 1094. - 1994., Zagreb: Muzejsko-galerijski centar, Institut za povijest umjetnosti, Zagrebačka nadbiskupija, 1994., str. 301-340. Uredili Tugomir Lukšić i Ivanka Reberski.

Doris Baričević, Barokno kiparstvo sjeverne Hrvatske, Zagreb: Institut za povijest umjetnosti, Školska knjiga, 2008.

Janko Bárle, Remete: povjesni podaci o samostanu, crkvi i župi, Zagreb: Marko Mileusnić, 1914.

Stjepan Bäuerlein, Fra Nikola Ogramić-Olovčić, biskup đakovački, u: Croatia Sacra XIIIXIV/22-23, Zagreb: Hrvatska bogoslovska akademija, 1944., str. 127-160.

Josip Bedeković, Natale solum magni ecclesiae doctoris sancti Hieronymi in ruderibus Stridonis occultatum [...], Neostadii Austriae: Ex Typographeo Muelleriano, [1752.].

Placido Belavić, Našice: povjesničke crtice, Našice: Zavičajni muzej, 1995.

Josip Bilić (ur.), Likovni leksikon, Zagreb: Leksikografski zavod Miroslav Krleža, 2014.

Zrinka Blažević i Daniel Premerl, »Christianae Reipublicae Propugnator«: Reformnokatolička mitopoetika bana Tome Erdödyja (1558-1624), u: Tridentska 
baština: katolička obnova i konfesionalizacija u hrvatskim zemljama. Zbornik radova sa znanstvenog skupa održanog u Zagrebu 6. i 7. prosinca 2013., Zagreb: Matica hrvatska, Katolički bogoslovni fakultet, Filozofski fakultet družbe Isusove, 2016., str. 393-408. Uredile Zrinka Blažević i Lahorka Plejić Poje.

Ivan von Bojničić, Der Adel von Kroatien und Slavonien, Nürnberg: Verlag von Bauer und Raspe, 1889.

Dubravka Botica, Barokne četverolisne crkve u sjeverozapadnoj Hrvatskoj: Prilog istraživanju tipologije sakralne arhitekture 18. stoljeća, Zagreb: Školska knjiga, 2015.

Bruce Boucher, Italian Baroque Sculpture, London, New York: Thames and Hudson, 1998. Vlasta Brajković, Grbovi - grbovnice - rodoslovlja, Zagreb: Povijesni muzej Hrvatske, 1976.

Vlasta Brajković, Grbovi, grbovnice, rodoslovlja: katalog zbirke grbova, grbovnica $i$ rodoslovlja, Zagreb: Hrvatski povijesni muzej, 1995. [1976.]. Rukopis uredila Dubravka Peić Čaldarović.

Neven Brandić, Sakralna graditeljska baština Jastrebarskog i okolice, u: Jastrebarsko: 1249. - 1999.: 750 godina grada, Jastrebarsko: Naklada Slap, Gradsko poglavarstvo, 2001., str. 225-278. Uredili Filip Potrebica i Krunoslav Matešić.

Božidar Brezinščak Bagola, Ivan Cesarec i Mladen Klemenčić (ur.), Enciklopedija Hrvatskoga zagorja, Zagreb: Leksikografski zavod »Miroslav Krleža«, 2017.

Branimir Brgles, Franjevački samostan i crkva Blažene Djevice Marije od Pohođenja u Mariji Gorici, u: Kaj: časopis za književnost, umjetnost, kulturu XLIV/5, Zagreb: Kajkavsko spravišče, 2011., str. 45-56.

Josip Brunšmid, Kameni spomenici hrvatskoga narodnoga muzeja u Zagrebu. Dio II. Spomenici srednjega i novoga vijeka, u: Vjesnik Hrvatskoga arheološkog društva XII/ 1, Zagreb: Hrvatsko arheološko društvo, 1912., str. 129-197.

Orsolya Bubryák, »In Deo vici«. Kegyesség és reprezentáció Erdődy Tamás (1558-1624) horvát bán müpártolásában, u: Studia Agriensia 27. Hagyomány és megújulás: életpályák és társadalmi mobilitás a végváriak körében, Eger: Heves Megyei Múzeumi Szervezet, 2008., str. 261-283. Uredili Mátyás Berecz i Gábor Veres.

Orsolya Bubryák, Athleta Christi. Political Propaganda in the Art Patronage of Tamás Erdödy, Ban of Croatia and Slavonia, u: Acta Historiae Artium Academiae Scientiarum Hungaricae 57, Budapest: Akademiai Kiado, 2016., str. 131-166.

Josip Buturac, Kutina: uz 200. obljetnicu župne crkve, Zagreb: Kršćanska današnjost, 1977. 
Enikő Buzási, Zrínyi és a későreneszánsz vitézi allegória: a szigetvári hös festett apoteózisa, u: Collectanea Tiburtiana: Tanulmányok Klaniczay Tibor tiszteletére, Szeged: JATE, 1990., str. 431-442. Uredili Géza Galavics, János Herner i Bálint Keserü.

Enikő Buzási, Az egykori Zrínyi-epitáfi um és a Zrínyi-kultusz mint a 16. század végi családi reprezentáció forrása, u: Történelem-Kép, Szemelvények múlt és müvészet kapcsolatáról Magyarországon, katalog izložbe, Budapest: MNG, 2000., str. 399-402. Uredili Árpád Mikó i Katalin Sinkó.

Nenad Cambi, Antika, Zagreb: Naklada Ljevak, 2002.

Maja Cepetić, Biskupski posjedi Dubrava, Ivanić i Čazma u 12. i 13. stoljeću: teritorijalna organizacija, naselja i spomenici, doktorski rad, Zagreb: Filozofski fakultet Sveučilišta u Zagrebu, 2015.

Emilijan Cevc, Renesančna plastika na Slovenskem, u: Zbornik za umetnostno zgodovino, Nova vrsta VII, Ljubljana: Umetnostnozgodovinsko društvo SR Slovenije, 1965., str. $119-170$.

Emilijan Cevc, Kiparstvo na Slovenskem med gotiko in barokom, Ljubljana: Slovenska matica, 1981.

Howard Colvin, Architecture and the After-Life, New Haven, London: Yale University Press, 1991.

Danijel Crnić, Župa Desinić, drugo izdanje, Desinić: Župni ured Desinić, 2008.

Géza Csergheő i Ivan Bojničić, Nadgrobni kamen Radoslava Gorjanskog, u: Viestnik Hrvatskoga arkeologičkoga družtva XI/1, Zagreb: Hrvatsko arkeologičko družtvo, 1889., str. 3-8.

Paškal Cvekan, Djelovanje franjevaca u Varaždinu: Povijesno-kulturni prikaz sedamsto godišnje prisutnosti Franjevaca u gradu Varaždinu, Varaždin: vlast. nakl., 1978.

Paškal Cvekan, Franjevci u Abinim Našicama: Povijesno-kulturni prikaz djelovanja Franjevaca kroz 700 godina postojanja samostana i crkve Svetog Antuna u Abinim Našicama, Našice: Paškal Cvekan, 1981.

Paškal Cvekan, Crkva Majke Božje od Pohođenja u Mariji Gorici, II. dio, u: Zaprešićki godišnjak 5, Zaprešić: Matica hrvatska Zaprešić, 1995.a, str. 30-50.

Paškal Cvekan, Franjevci u Remetincu: Povijesno-kulturni prikaz, Virovitica: P. Cvekan, 1995.b.

Paškal Cvekan, Franjevci u Ivaniću, Kloštar Ivanić: Franjevački samostan, 2008. [1979.]. 
Paškal Cvekan, Kostajnica i franjevci, Hrvatska Kostajnica: Franjevački samostan, 2017. [1982.].

Sanja Cvetnić, Ikonografija nakon Tridentskoga sabora i hrvatska likovna baština, Zagreb: FF press, 2007.

Đurđica Cvitanović, Crkveno graditeljstvo, u: Skriveno blago: iz riznice umjetničkih znamenitosti jastrebarskog kraja. Kulturni i prirodni spomenici Hrvatske: zbirka vodiča časopisa Kaj 8, Zagreb: Zagrebačko spravišče, 1975., str. 1-28.

Đurđica Cvitanović, Sakralna arhitektura baroknog razdoblja. Knjiga I. Gorički i gorskodubički arhiđakonat, Zagreb: Društvo povjesničara umjetnosti SR Hrvatske, 1985.

Đurđica Cvitanović, Johann Fuchs projektant Župne crkve u Pregradi, u: Peristil 38, Zagreb: Društvo povjesničara umjetnosti Hrvatske, 1995., str. 121-128.

Đurđica Cvitanović, Crkve grada Samobora, u: Kaj: časopis za književnost, umjetnost $i$ kulturu XXX/1, Zagreb: Kajkavsko spravišče, 1997., str. 27-53.

Đurđica Cvitanović, Arhitektura franjevačke provincije hrvatsko-kranjske Sv. Križa, u: Mir i dobro: umjetničko $i$ kulturno naslijeđe Hrvatske franjevačke provincije sv. Cirila $i$ Metoda o proslavi stote obljetnice utemeljenja, Zagreb: Galerija Klovićevi dvori, 2000., str. 193-204. Uredili Marija Mirković i Franjo Emanuel Hoško.

Ivan Čerpinko, Maruševec, Varaždin, Maruševec: TIVA, Općina Maruševec, 2002.

Željko Demo, Opatovina: tragovi povijesti izgubljene u sadašnjosti. Rezultati arheoloških iskopavanja pred crkvom svetog Franje u Zagrebu 2002. godine, Zagreb: Arheološki muzej, 2007.

Velimir Deželić, Historijski grobovi u Zagrebu, u: Prosvjeta: časopis za pouku i zabavu XIV/21, Zagreb: Antun Scholz, 1906.a, str. 660-667.

Velimir Deželić, Historijski grobovi u Zagrebu, u: Prosvjeta: časopis za pouku i zabavu XIV/23, Zagreb: Antun Scholz, 1906.b, str. 735-740.

Lelja Dobronić, Biskupski i kaptolski Zagreb, Zagreb: Školska knjiga, 1991.

Lelja Dobronić, Renesansa u Zagrebu, Zagreb: Institut za povijest umjetnosti, 1994.

Kamilo Dočkal, Povijest pavlinskog samostana Blažene Djevice Marije u Lepoglavi, Zagreb: Glas Koncila, 2014.

Jutta Dresken-Weiland, Christian Sarcophagi from Rome, u: The Routledge Handbook of Early Christian Art, Abingdon: Routledge, 2018., str. 39-55. Uredili Robin M. Jensen i Mark D. Ellison. 
Pál Engel i Pál Lővei, A gerecsei vörösmárvány használata Zágrábban és környékén a középkorban, u: A Magyar Nemzeti Galéria Évkönyve IX/47-48, Budapest: Magyar Nemzeti Galéria, 1991., str. 47-51.

Krešimir Filić, Franjevci u Varaždinu: Poviest franjevačke crkve $i$ samostana. O 700godišnjici dolazka franjevaca u Varaždin, Varaždin: vlast. nakl., 1944.

Ivan Filipčić, Župa Pregrada: mala monografija o župi Naše Gospe od Kunagore, Zagreb: Kršćanska sadašnjost, Pregrada: ŽU, 1983.

Igor Fisković, Nadgrobna plastika humanističkog doba na našem primorju, u: Dometi: znanstveno-kulturna smotra Matice hrvatske, Ogranka u Rijeci 1-2-3, Rijeka: Izdavački centar Rijeka, 1984.a, str. 73-104.

Igor Fisković, O grobnim spomenicima u srednjovjekovnoj Dalmaciji, u: Dometi: znanstvenokulturna smotra Matice hrvatske, Ogranka u Rijeci 5, Rijeka: Izdavački centar Rijeka, 1984.b, str. 35-53.

Igor Fisković, Ulomci grobne ploče zagrebačkoga biskupa (početak XVI. st.), u: Hrvatska renesansa: katalog izložbe, Zagreb: Galerija Klovićevi dvori, 2004., str. 256, br, K. 32. Uredili Miljenko Jurković i Alain Erlande-Brandenburg.

Josip Frančišković, Crkva sv. Franje u Senju (Povjesno-liturgička razmatranja), u: Bogoslovska smotra = Ephemerides theologicae Zagrabiense XIX/4, Zagreb: Hrvatsko bogoslovska akademija, 1932., str. 411-423.

Géza Galavics, A magyar királyi udvar és a késö reneszáns képzömüvészet, u: Magyar reneszánsz udvari kultúra, Budapest: Gondolat, 1987., str. 228-248. Uredila Júlia Székely.

Géza Galavics, Kult Zrinskih i likovna prezentacija - od obiteljskog mecenatstva do novog tipa javnosti, u: Hrvatska / Mađarska / Europa. Stoljetne likovno-umjetničke veze. Simpozij povjesničara umjetnosti Hrvatske i Mađarske = Horvátország / Magyarország / Európa. Évszázados képzőmüvészeti kapcsolatok. Magyar horvát müvészettörténeti szimpozion, Zagreb: Društvo mađarskih znanstvenika i umjetnika u Hrvatskoj, 2000., str. 126-146. Uredila Jadranka Damjanov. 
Hilliard T. Goldfarb, Titian: Colore and Ingegno in the Service of Power, u: Titian and Rubens: Power, Politics, and Style, Boston: Isabella Stewart Gardner Museum, 1998., str. 1-28. Napisali Hilliard T. Goldfarb, David Freedberg i Manuela B. Mena Marqués.

Vladimir Peter Goss, Herceg Koloman i umjetnost hrvatskoga prostora, u: Prilozi povijesti umjetnosti u Dalmaciji XLV/1, Split: Književni krug Split, Konzervatorski odjel u Splitu, 2019., str. 129-143.

James Hall, Rječnik tema i simbola u umjetnosti, Zagreb: Školska knjiga, 1998. Preveo Marko Grčić.

Mark Hengerer, Zur symbolischen Dimension eines sozialen Phänomens: Adelsgräber in der Residenz (Wien im 17. Jahrhundert), u: Wien im Dreißigjährigen Krieg, Wien: Böhlau, 2001., str. 250-352. Uredio Andreas Weigl.

Mark Hengerer, Adelsgräber im Wien des 18. Jahrhunderts: Beobachtungen zu einer Archäologie des adeligen Gedächtnisses, u: Macht und Memoria. Begräbnisskultur europäischer Oberschichten in der Frühen Neuzeit, Köln: Böhlau, 2005., str. 381-420. Uredio Mark Hengerer.

Mark Hengerer, The Funeral of the Habsburg Emperors in the Eighteenth Century, u: Monarchy and Religion: The Transformation of Royal Culture in Eighteenth-Century Europe, Oxford: University Press, 2007., str. 367-394. Uredio Michael Schaich.

Goranka Horjan, Sakralni spomenici stubičkog kraja, u: Osam stoljeća Stubice, Gornja Stubica: Muzeji Hrvatskog zagorja, Muzej seljačkih buna; Donja Stubica: Grad Donja Stubica, 2009., str. 112-137. Uredila Goranka Horjan.

Anđela Horvat, Spomenici arhitekture $i$ likovnih umjetnosti u Međimurju, Zagreb: [Konzervatorski zavod], 1956.

Anđela Horvat, Ilok: ili - ne znamo dovoljno što imamo, u: Bulletin Instituta za likovne umjetnosti Jugoslavenske akademije znanosti i umjetnosti VI/1, Zagreb: Jugoslavenska akademija znanosti i umjetnosti, 1958., str. 15-21, 78.

Anđela Horvat, Između gotike i baroka: umjetnost kontinentalnog dijela Hrvatske od oko 1500. do oko 1700., Zagreb: Društvo povjesničara umjetnosti SR Hrvatske, 1975.

Anđela Horvat, Dva epitafa u Iloku, u: Zbornik za likovne umetnosti 15, Novi Sad: Matica srpska, Odelenje za likovne umetnosti, 1979.a, str. 307-315.

Anđela Horvat, Pregled spomenika s područja općine Klanjec, u: Kaj: časopis za književnost, umjetnost i kulturu 3, Zagreb: Kajkavsko spravišće, 1979.b, str. 15-70. 
Anđela Horvat, Barok u kontinentalnoj Hrvatskoj, u: Barok u Hrvatskoj, Zagreb: Sveučilišna naklada Liber, Odjel za povijest umjetnosti Centra za povijesne znanosti, Društvo povjesničara umjetnosti, 1982.a, str. 3-381. Napisali Anđela Horvat, Radmila Matejčić i Kruno Prijatelj.

Anđela Horvat, $O$ metalnim sarkofazima u Klanjcu, u: Peristil 25, Zagreb: Društvo povjesničara umjetnosti SR Hrvatske, 1982.b, str. 97-106.

Anđela Horvat, O spomenicima kulture općine Krapina, u: Kaj: časopis za književnost, umjetnost $i$ kulturu 1, Zagreb: Kajkavsko spravišće, 1982.c, str. 87-142.

Anđela Horvat, Crkva Uznesenja Blažene Djevice Marije u Stenjevcu, u: Župa Uznesenja Marijina Stenjevec: u povodu 650. obljetnice prvog spomena župe (1334-1984) i 730. obljetnice gradnje crkve Bl. Dj. Marije (1257-1987), Zagreb, Stenjevec: Rkt župa Stenjevec, 1985.a, str. 83-141. Uredili Ivan Buhin i Anđelko Mijatović.

Anđela Horvat, Pregled spomenika kulture općine Pregrada, u: Kaj: časopis za književnost, umjetnost i kulturu 2-3, Zagreb: Kajkavsko spravišće, 1985.b, str. 167-208.

Rudolf Horvat, Povijest Hrvatske: od najstarijeg doba do g. 1657. Knj. I, Zagreb: Tiskara Merkur, 1924.

Rudolf Horvat, Koprivničke crkve i kapele, u: Hrvatska prošlost, Knj. 4., Zagreb: Kulturnohistorijsko društvo »Hrvatski rodoljub«, 1943., str. 3-150. Uredio Rudolf Horvat.

Zorislav Horvat, $O$ nekim osobinama gotičkih nadgrobnih ploča s grbovima u kontinentalnom dijelu SR Hrvatske, u: Bulletin Razreda za likovne umjetnosti Jugoslavenske akademije znanosti i umjetnosti LIX/1, Zagreb: Jugoslavenska akademija znanosti i umjetnosti, 1988., str. 41-68.

Zorislav Horvat, Heraldički štitovi gotičke arhitekture kontinentalne Hrvatske, Zagreb: Društvo povjesničara umjetnosti Hrvatske, 1996.

Zorislav Horvat, Arhitektura franjevačkih samostana u dotursko doba na prostoru kontinentalne Hrvatske $i$ Slavonije (arheološki stadij), u: Mir i dobro: umjetničko $i$ kulturno naslijeđe Hrvatske franjevačke provincije sv. Cirila i Metoda o proslavi stote obljetnice utemeljenja. Katalog izložbe, Zagreb: 2000., str. 173-190. Uredili Marija Mirković i Franjo Emanuel Hoško.

Zorislav Horvat, Sačuvani nadgrobni spomenici nekih Senjana i osoba značajnih za povijest Senja - u Senju i drugdje, u: Senjski zbornik: prilozi za geografiju, etnologiju, gospodarstvo, povijest i kulturu XXIX/1, Senj: Gradski muzej, Senjsko muzejsko društvo, 2002., str. 47-86. 
Zorislav Horvat, Pregled sačuvanih nadgrobnih ploča Krčkih knezova Frankopana, u: Senjski zbornik: prilozi za geografiju, etnologiju, gospodarstvo, povijest $i$ kulturu XXXII/1, Senj: Gradski muzej, Senjsko muzejsko društvo, 2005., str. 25-58.

Zorislav Horvat, Srednjovjekovna crkva sv. Marka, u: Crkva sv. Marka u Zagrebu: arhitektura, povijest, obnova, Zagreb: Hrvatski restauratorski zavod, 2013., str. 11-36. Uredio Petar Puhmajer.

Katarina Horvat-Levaj, Župna crkva Presvetog Trojstva u Donjoj Stubici, u: Peristil 38, Zagreb: Društvo povjesničara umjetnosti Hrvatske, 1995., str. 73-82.

Katarina Horvat-Levaj, Barokna arhitektura, u: Hrvatska umjetnost: povijest i spomenici, Zagreb: Institut za povijest umjetnosti, Školska knjiga, 2010., str. 249-288. Uredio Milan Pelc.

Metod Hrg, Oporuka biskupa Martina Borkovića (1667-1687), u: Croatica Christiana periodica X/18, Zagreb: Katolički bogoslovni fakultet, 1986., str. 66-88.

Ljudevit Ivančan i Gjuro Szabo, Spomen-kamen kanonika Vukoslavića - nadgrobna ploča Blaža od Moravča (1495.), u: Narodna starina VIII/19, Zagreb: Josip Matasović, 1929., str. $105-108$.

Ratko Ivanušec, Franjevačka crkva sv. Antuna Padovanskog sa samostanom u Našicama: Konzervatorsko istraživanje i obnova, Našice: Franjevački samostan u Našicama, Zavičajni muzej Našice, 2010.

Alojz Jembrih, Iz starije povijesti župe Mihovljan, u: Hrvatsko zagorje: časopis za kulturu XVII/1-4, Donja Stubica: Kajkaviana, 2011., str. 8-36.

Željko Jiroušek, Pregled razvoja likovnih umjetnosti u banskoj Hrvatskoj. Od XII. do kraja XVIII. stoljeća, u: Naša domovina, svezak 2. Hrvatska kultura - politička poviest Hrvata, Zagreb: Izdanje Glavnog ustaškog stana, 1943., str. 680-697.

Vladimir Kalšan, Međimurska povijest, Čakovec: Vladimir Kalšan, 2006.

Vladimir Kalšan, Općina Šekovec, Šenkovec: Poglavarstvo Općine Šenkovec, 2008.

Ivan Kampuš i Ljubo Karaman, Tisućljetni Zagreb: od davnih naselja do suvremenog grada, Zagreb: Školska knjiga, 1994.

Ana Kaniški, Kapela sv. Josipa u franjevačkoj crkvi u Varaždinu: Ikonografija i naručitelj, u: Tkalčić: godišnjak Društva za povjesnicu Zagrebačke nadbiskupije = annales Societatis 
historicae archiepiscopatus Zagrabiensis XVI, Zagreb: Društvo za povjesnicu Zagrebačke nadbiskupije »Tkalčić«, 2012., str. 303-412.

János Kapossy, Adriaen van Conflans a Zrínyi epitáfium mestere, u: Magyar Müvészet XV/4, Budapest: Szinyei Merse Pál Tár saság, 1948., str. 180.

Ljubo Karaman, O umjetnosti srednjega vijeka u Hrvatskoj i Slavoniji, u: Historijski zbornik I/1-4, Zagreb: Društvo za hrvatsku povjesnicu, 1948., str. 103-127.

Ljubo Karaman, O umjetnosti srednjega vijeka, u: Historijski zbornik III/1-4, Zagreb: Društvo za hrvatsku povjesnicu, 1950., str. 125-174.

Ljubo Karaman, O djelovanju domaće sredine u umjetnosti hrvatskih krajeva / Über die Einwirkung des einheimischen Milieus auf die Entwicklung der Kunst in den kroatischen Ländern, Zagreb: Društvo historičara umjetnosti NR Hrvatske, 1963.

D. Gene Karraker, Looking at European Frames: A Guide to Terms, Style, and Techniques, Los Angeles: J. Paul Getty Museum, 2009.

Julije Kempf, Požega: zemljopisne bilješke iz okoline i prilozi za povijest Slob. kr. grada Požege i Požeške županije, Požega: Štamparija »Hrvatske tiskare i knjižare«, 1910.

Vjekoslav Klaić, Tomo Kovačević, povjesničar hrvatski (1664.-1724.), u: Bogoslovska smotra XIII/1, Zagreb: Naklada »Katoličkog lista«, 1925., str. 69-91.

Ehrenfried Kluckert, Baroque Architecture in Germany, Switzerland, Austria, and Eastern Europe, u: Baroque: Architecture, Sculpture, Painting, Potsdam: Ullman Koenemann, 2010., str. 152-161. Uredio Rolf Toman.

Renate Kohn, Zwischen standesgemäßem Repräsentationsbedürfnis und Sorge um das Seelenheil. Die Entwicklung des frühneuzeitlichen Grabdenkmals, u: Macht und Memoria. Begräbniskultur europäischer Oberschichten in der frühen Neuzeit, Köln, Weimer, Wien: Böhlau Verlag, 2005., str. 19-46. Uredio Mark Hengerer.

Mijo Korade, Petar Petretić, u: Zagrebački biskupi i nadbiskupi, Zagreb: Školska knjiga, 1995., str. 333-339. Uredio Franko Mirošević.

Marijana Korunek, Pavlinski samostan u Šenkovcu i grofovi Zrinski, u: Croatica Christiana periodica XXXVIII/73, Zagreb: Katolički bogoslovni fakultet, 2014., str. 51-70.

Anđelko Košćak, Župa sv. Marka Evanđelista - Vinica, Zagreb: Društvo za povjesnicu Zagrebačke nadbiskupije »Tkalčić«, Vinica: Župa Sv. Marka Evanđelista, 2013.

Dražen Kovačević, Đuro Szabo - o starinama u Moslavini, u: Zbornik Moslavine IV, Kutina: Muzej Moslavine, 1998., str. 99-110. Uredila Ana Bobovec.

Drago Kozina, Općina Radoboj, Radoboj: Općina Radoboj, 2007.

Stjepan Kožul, Sakralna umjetnost bjelovarskoga kraja, Zagreb: Prometej, 1999. 
Marina Krpan, Hrvatski Ratkaji, u: Kaj: časopis za književnost, umjetnost i kulturu XXV/12, Zagreb: Kajkavsko spravišče, 1992., str. 77-88.

Ivan Krstitelj Krapac, Samostan remetski: Historička crta, u: Zagrebački katolički list: crkveno-bogoslovni časopis XXI/4, Zagreb: Tiskom Dragutina Albrechta, 27. I. 1870., str. $25-28$.

Marijan Kraš, Ivanec: prilozi povijesti Ivanca do 1940. godine: Ivancu za šest stotu obljetnicu povodom prvoga pisanoga spomena Ivanca 1396.-1996., Varaždin: Zlati Ajngel, 1996.

Baltazar Adam Krčelić, Povijest Stolne crkve zagrebačke, Zagreb: Institut za suvremenu povijest, 1994. Preveo Zlatko Šešelj.

Milan Kruhek, Graditeljska baština karlovačkog Pokuplja, Karlovac: Matica hrvatska, Ogranak Karlovac, 1993.

Siniša Krznar, Arheološka slika kasnosrednjovjekovnih groblja na prostoru sjeverne Hrvatske, doktorski rad, Zagreb: Filozofski fakultet Sveučilišta u Zagrebu, 2012.

Viktor Kučinić, Zaboravljena grobnica Zrinjskih u Svetoj Jeleni kraj Čakovca. Rasute mrtvačke kosti kao turistička atrakcija. Čudna osakaćena crkvica posred polja kukuruza i zelja. Ostatak svetišta i mauzoleja Zrinjskih iz 16 stoljeća, u: Novosti XXXIV/188, Zagreb: [Jugoslavenska štampa], 10. VII. 1940., str. 11.

Ivan Kukuljević Sakcinski, Prvostolna crkva zagrebačka: opisana s gledišta povjesnice, umjetnosti i starinah, Zagreb: Narodna tiskara Ljudevita Gaja, 1856.

Ivan Kukuljević Sakcinski, Acta Croatica $=$ Listine Hrvatske, Zagreb: Brzotiskom Narodne tiskarnice dra. Ljudevita Gaja, 1863.

Ivan Kukuljević Sakcinski, Nadpisi sredovječni i novovjeki na crkvah, javnih i privatnih sgradah itd. u Hrvatskoj $i$ Slavoniji, Zagreb: Knjižara Jugoslavenske akademije, Knjižara Dioničke tiskare, 1891.

Han Lamers, Michele Marullo and the Epitaph of Šimun Keglević (1579): A note on the use and function of Latin inscriptions in Croatia, u: Bibliothèque d'Humanisme et Renaissance LXXVII/2, Geneve: Librairie Droz, 2015., str. 411-421.

Emilij Laszowski, Grb plemena Mogorovića, u: Vjesnik Hrvatskoga arheološkoga društva (N.S.) II/1, Zagreb: Hrvatsko arheološko društvo, 1897., str. 21-25.

Emilij Laszowski, Spomenik bana grofa Nikole Zrinskoga († 1664.), u: Jutarnji list, Zagreb, 12. X. 1924., str. 20. 
Emilij Laszowski, Grobnica bana Petra Erdöda u Jastrebarskom, u: Novosti XX/35, Zagreb: [Jugoslavenska štampa], 1926., str. 11.

Emilij Laszowski, Zrinski mauzolej u sv. Jeleni kod Čakovca, u: Hrvatsko kolo: književnonaučni zbornik IX/15, Zagreb: Matica hrvatska, 1928., str. 244-259.

Emilij Laszowski, Grobovi Zrinskih i Frankopana u Zagrebu i Remetama (O 268. obljetnici smrti naših hrvatskih mučenika), u: Jutarnji list XXVIII/9792, Zagreb: Tipografija, 30. IV. 1939., str. 17.

Ivo Lentić, Pavlinski samostan i crkva sv. Marije u doba baroka, u: Kaj: časopis za kulturu i prosvjetu XV/5, Zagreb: Kajkavsko spravišče, 1982., str. 36-63.

Ivy Lentić-Kugli, Kronologija i građa za povijest sakralnih objekata u Koprivnici, u: Koprivnica: grad i spomenici, Zagreb: Odjel za povijest umjetnosti Centra za povijesne znanosti Sveučilišta u Zagrebu, 1986., str. 214-225.

Radoslav Lopašić, Karlovac: poviest i mjestopis grada i okolice, Karlovac: Matica hrvatska, 1879.

Radoslav Lopašić, Jastrebarsko, u: Vienac: zabavi i pouci XIII/23, Zagreb: Matica hrvatska, 4. VI. 1881., str. 358-361.

Radoslav Lopašić, Oko Kupe $i$ Korane. Mjestopisne $i$ povjestne crtice, Zagreb: Matica hrvatska, 1895.

Silvija Lučevnjak, Posmrtni grbovi u arhivskom gradivu valpovačkih vlastelina, u: Valpovački vlastelini Prandau-Norman, Osijek: Državni arhiv u Osijeku [et al.], 2018., str. 54-59.

Andrija Lukinović, Zagreb: devetstoljetna biskupija, Zagreb: Glas Koncila, 1995.

Andrija Lukinović, Župa Ivanić-grad, Zagreb: Glas Koncila, 2007.

Bartłomiej Lyczak, The Coffin Portrait and Celebration of Death in Polish-Lithuanian Commonwealth in the Modern Period, u: Ikon: Časopis za ikonografske studije 4, Rijeka: Filozofski fakultet Sveučilišta u Rijeci, 2011., str. 233-241. Uredila Marina Vicelja-Matijašić.

Trpimir Macan (ur.), Hrvatski biografski leksikon. 4, E-Gm, Zagreb: Leksikografski zavod »Miroslav Krleža«, 1998.

Trpimir Macan (ur.), Hrvatski biografski leksikon. 5, Gn - H, Zagreb: Leksikografski zavod »Miroslav Krleža«, 2002.

Trpimir Macan (ur.), Hrvatski biografski leksikon. 7, Kam - Ko, Zagreb: Leksikografski zavod »Miroslav Krleža«, 2009. 
Pavao Maček, Rodoslovlje grofovskog ogranka Patačića od Zajezde, u: Patačići od Zajezde i crkva u Remetincu: Zbornik radova znanstvenog skupa »Tristota obljetnica Patačićeve kapele sv. Antuna u Remetincu« $i$ drugih radova, Remetinec, 23. listopada 2004. godine, Zagreb: Društvo za povjesnicu Zagrebačke nadbiskupije »Tkalčić«, Remetinec: Župa Blažene Djevice Marije Kraljice sv. Krunice, Novi Marof: Grad Novi Marof, 2006., str. 9-45. Uredio Anđelko Košćak.

Krasenka Majer Jurišić, Marija Gorica: Nadgrobna ploča Martina Mogorića. Konzervatorsko-restauratorska istraživanja $i$ prijedlog radova, Zagreb: Hrvatski restauratorski zavod, 2013.

Krasanka Majer Jurišić i Edita Šurina, Schneiderov fotografijski album - svjedok izgubljenog izgleda crkve sv. Ivana Krstitelja u Kloštar Ivaniću, u: Zbornik radova znanstveno-stručnog skupa »Hrvatski povjesničari umjetnosti. Artur Schneider (1879.1946.)«, Zagreb: Društvo povjesničara umjetnosti Hrvatske, 2016., str. 225-242. Uredila Ljerka Dulibić.

Srećko Majstorović, Našice kroz 700 godina 1229 - 1929, Zagreb: Vicepostulatura, 1973.

Vladimir Maleković (ur.), Od svagdana do blagdana: barok u Hrvatskoj = From everyday to holidays: baroque in Croatia, katalog izložbe, Zagreb: Muzej za umjetnost i obrt, 1993.

Robert Marcoux, Memory, Presence and the Medieval Tomb, u: Revisiting the monument: Fifty years since Panofsky's »Tomb sculpture«, London: Research Forum of the Courtauld Institute of Art, 2016., str. 49-67. Uredili Ann Adams i Jessica Barker.

Marjan Marlot, Celjski nadgrobniki 15. in 16. stoletja, u: Zbornik za umetnostno zgodovino VII/3-4, Ljubljana: Slovensko umetnostnozgodovinsko društvo, 1928., str. 73-85.

Ive Mažuran, Ulomak nadgrobnog spomenika iz 15. stoljeća nađen u Osijeku, u: Anali zavoda za znanstveni rad u Osijeku, Osijek: Jugoslavenska akademija znanosti i umjetnosti, 1984., str. 195-208.

Árpád Mikó, All' antica djela i njihovi stvaraoci u Budimu i Zagrebu za Matije Korvina i Jagelovića (1480-1526), u: Hrvatska / Mađarska: stoljetne književne i likovnoumjetničke veze = Horvátország / Magyarország: évszázados irodalmi és képzőmüvészeti kapcsolatok, Zagreb: Croatian Writers' Association, 1995., str. 53-60. Uredila Jadranka Damjanov.

Árpád Mikó i Géza Pálffy, A pozsonyi Szent Márton-templom késő reneszánsz és kora barokk siremlékei (16-17. század), u: Müvészettörténeti Értesitő LI/1-2, Budapest: Akademiai Kiado, 2002., str. 107-172. 
Dragutin Nežić, Povijest župa $i$ crkvi Jastrebarskog dekanata, Jastrebarsko: Odbor za euharistijski kongres, 1939.

Vjekoslav Noršić, Mače, u: Tkalčić: godišnjak Društva za povjesnicu Zagrebačke nadbiskupije = annales Societatis historicae archiepiscopatus Zagrabiensis VIII, Zagreb: Društvo za povjesnicu Zagrebačke nadbiskupije »Tkalčić«, 2004., str. 259-278. Rukopis priredio Stjepan Razum.

Vjekoslav Noršić, Povijest župe sv. Anastazije u Samoboru, Zagreb: Društvo za povjesnicu Zagrebačke nadbiskupije »Tkalčić«, 2005. Rukopis priredio Stjepan Razum.

Vjekoslav Noršić, Bednja, u: Tkalčić: godišnjak Društva za povjesnicu Zagrebačke nadbiskupije = annales Societatis historicae archiepiscopatus Zagrabiensis XIV, Zagreb: Društvo za povjesnicu Zagrebačke nadbiskupije »Tkalčić«, 2010.a, str. 195240. Rukopis priredio Stjepan Razum.

Vjekoslav Noršić, Zajezda, u: Tkalčić: godišnjak Društva za povjesnicu Zagrebačke nadbiskupije = annales Societatis historicae archiepiscopatus Zagrabiensis XIV, Zagreb: Društvo za povjesnicu Zagrebačke nadbiskupije »Tkalčić«, 2010.b, str. 345384. Rukopis priredio Stjepan Razum.

Marinko Ogorec, Povijest vojnih odora: Francuska avangarda, u: Hrvatski vojnik: prvi hrvatski vojnostručni magazin 597, mrežno izdanje. Ministarstvo obrane Republike Hrvatske, Samostalna služba za odnose s javnošću i izdavaštvo, Odjel hrvatskih vojnih glasila i izdavaštva, veljača 2020. Pristupljeno 10. 10. 2020. <https://hrvatskivojnik.hr/povijest-vojnih-odora-francuska-avangarda/>

Stjepan Ortner, Povjest gradine i trgovišta Krapine, Zagreb: Slob. kr. povelj. trgovište Krapina, 1899.

Martina Ožanić, Atektonsko građeni oltari XVIII. stoljeća na području sjeverozapadne Hrvatske, doktorski rad, Zagreb: Filozofski fakultet Sveučilišta u Zagrebu, 2017.

Tamás Pálosfalvi, The noble elite in the county of Körös (Križevci) 1400 - 1526, doktorski rad, Budimpešta: MTA Bölcsészettudományi Kutatóközpont Történettudományi Intézet, 2012.

Géza Pálffy, Die adelige Funeralkultur und Typen von Grabdenkmälern im Königreich Ungarn im 16. und 17. Jahrhundert, u: Macht und Memoria. Begräbniskultur europäischer Oberschichten in der frühen Neuzeit, Köln, Weimer, Wien: Böhlau Verlag, 2005., str. 483-513. Uredio Mark Hengerer. 
Erwin Panofsky, Tomb Sculpture: Four Lectures on Its Changing Aspects from Ancient Egypt to Bernini, London: Phaidon Press, 1992. [1964.]. Uredio H. W. Janson.

Dubravka Peić Čaldarović, Osnove krapinskog grbovnika, u: Krapina: grad povijesti $i$ kulture, Krapina: Grad Krapina, 2004., str. 130-138. Uredila Agneza Szabo.

Milan Pelc, Ugarske kiparske radionice i renesansa u sjevernoj Hrvatskoj, u: Radovi Instituta za povijest umjetnosti 30, Zagreb: Institut za povijest umjetnosti, 2006., str. 67-80.

Milan Pelc, Renesansa, Zagreb: Naklada Ljevak, 2007.

Milan Pelc, Iločki renesansni fragmenti, u: Sic ars deprenditur arte: zbornik u čast Vladimira Markovića, Zagreb: Institut za povijest umjetnosti, Odsjek za povijest umjetnosti Filozofskog fakulteta Sveučilišta u Zagrebu, 2009.a, str. 307-317. Uredili Sanja Cvetnić, Milan Pelc i Daniel Premerl.

Milan Pelc, Krhotine renesanse u Slavoniji, u: Slavonija, Baranja i Srijem: vrela europske civilizacije, sv. 2, Zagreb: Galerija Klovićevi dvori, 2009.b, str. 313-317. Uredio Božo Biškupić.

Milan Pelc, Spomenici potonuloga svijeta. Nadgrobne ploče s likom pokojnika u sjevernoj Hrvatskoj u pisanim i tiskanim vrelima do konca 19. st., u: Umjetnost i naručitelj. Zbornik radova znanstvenoga skupa "Dani Cvita Fiskovića" održanog 2008. godine, Zagreb: Institut za povijest umjetnosti, Odsjek za povijest umjetnosti Filozofskog fakulteta Sveučilišta u Zagrebu, 2010., str. 61-71. Uredila Jasenka Gudelj.

Milan Pelc, Povijest umjetnosti u Hrvatskoj, Zagreb: Naklada Ljevak, 2012.

Gergely Pethő, Rövid magyar kronika. Sok rendbéli fö historiás Könyvekböl nagy szorgalmatossággal egybe szedettetet és irattatot Petthö Gergelytül, Cassán: Az Akademiai Betükkel Frauenbeim Henrik János által, 1753.

Ksenija Petrić i Tatjana Lolić, Sveta Jelena kod Čakovca. Konzervatorska studija za projekt prezentacije lokaliteta Sveta Jelena kod Čakovca, Zagreb: Konzervatorski odjel, 2005., elaborat.

Tajana Pleše, Izvještaj o provedenim revizijskim arheološkim istraživanjima pavlinskog samostana Blažene Djevice Marije i Svih Svetih u Šenkovcu tijekom 2012. godine, Zagreb: Hrvatski restauratorski zavod, 2013.

Lina Slavica Plukavec, Obnova Ackermannovog oltara, Komersteinerovog spomenika $i$ Sickingerovih kipova u zagrebackoj prvostolnici, u: Tkalčić: godišnjak Društva za povjesnicu Zagrebačke nadbiskupije = annales Societatis historicae archiepiscopatus Zagrabiensis II, Zagreb: Društvo za povjesnicu Zagrebačke nadbiskupije »Tkalčić«, 1998., str. 165-209. 
Iva Potočnik, Nestala barokna crkva Sv. Vida u Vidovcu, u: Radovi Zavoda za znanstveni rad Varaždin 24, Varaždin: Zavod za znanstveni rad, 2013., str. 479-488.

Daniel Premerl, The Meaning of Emperor Francis I's Funeral in Bologna, u: Ikon: Časopis za ikonografske studije 4, Rijeka: Filozofski fakultet Sveučilišta u Rijeci, 2011., str. $243-256$.

Kruno Prijatelj, Prinosi za monografiju o Ivanu Duknoviću, u: Anali Historijskog instituta u Dubrovniku IV/V, Dubrovnik: Historijski institut Jugoslavenske akademije znanosti i umjetnosti u Dubrovniku, 1956., str. 305-321.

Boris Prister, Hrvatski ban Toma Erdödy - vitez Reda Otkupitelja, u: Zbornik radova 2. međunarodnog numizmatičkog kongresa u Hrvatskoj, 15-17. listopada 1998., Opatija: Dobrinić \& Dobrinić, Zagreb: Hrvatsko numizmatičko društvo, 2000., str. 141-155. Uredio Julijan Dobrinić.

Lada Prister, Zbirka kamenih spomenika, u: Museum 1846.-1996., katalog izložbe, Zagreb: Hrvatski povijesni muzej, 1996., str. 20-25. Uredila Maja Škiljan.

Juraj Rattkay, Spomen na kraljeve i banove kraljevstava Dalmacije, Hrvatske i Slavonije od njihovih početaka, pa sve do ove 1652. godine koji je sastavio Juraj Rattkay od Velikog Tabora, zagrebački kanonik i lektor, Zagreb: Hrvatski institut za povijest, 2001. Prevela Zrinka Blažević et al.

Ivanka Reberski (ur.), Krapinsko-zagorska županija: sakralna arhitektura s inventarom, feudalna arhitektura, spomen-obilježja, Zagreb: Institut za povijest umjetnosti, Školska knjiga, 2008.

Gordana Remussini, Samostan i crkva svetog Leonarda u Kotarima, u: Zbornik 2010.11. Ogranak Matice hrvatske u Samoboru, Samobor: Ogranak Matice hrvatske u Samoboru, 2010., str. 24-30. Uredio Milan Žegarac Peharnik.

Zsuzsanna van Ruyven-Zeman i Marjolein Leesberg, Hollsteins's Dutch \& Flamish Etchings, Engravings and Woodcuts 1450-1700, Volume LX. The Wierix Family: Part II, Rotterdam: Sound \& Vision Publishers, Amsterdam: Rijskprentenkabinet, 2003.

Zsuzsanna van Ruyven-Zeman i Marjolein Leesberg, Hollsteins's Dutch \& Flamish Etchings, Engravings and Woodcuts 1450-1700, Volume LXIX. The Wierix Family: Introduction and Guide to the Catalogue, Rotterdam: Sound \& Vision Publishers, Amsterdam: Rijskprentenkabinet, 2004. 
M. S., Obnova rimokatoličke župne crkve u Desiniću, u: Viesti Družtva inžinira i arhitekata u Hrvatskoj i Slavoniji XXIV/4, Zagreb, 1903., str. 49-55.

Artur Schneider, O nekim manje poznatim portretima Nikole Zrinskog, u: Narodna starina II/5, Zagreb: Josip Matasović, 1923., str. 161-164.

Artur Schneider, Sitna građa za kulturnu povijest grada Zagreba, u: Narodna starina IX/24, Zagreb: Josip Matasović, 1930., str. 462-465.

Artur Schneider, Popisivanje i fotografijsko snimanje umjetničkih spomenika godine 1938,. u: Ljetopis Jugoslavenske akademije znanosti i umjetnosti za godinu 1937/38. Svezak 51, Zagreb: Jugoslavenska akademija znanosti i umjetnosti, 1939., str. 168-180.

Artur Schneider, Popisivanje i fotografijsko snimanje umjetničkih spomenika godine 1939., u: Ljetopis Jugoslavenske akademije znanosti $i$ umjetnosti za godinu 1938/39. Svezak 52, Zagreb: Jugoslavenska akademija znanosti i umjetnosti, 1940., str. 172-186.

Artur Schneider, Popisivanje i fotografijsko snimanje umjetničkih spomenika godine 1940., u: Ljetopis Jugoslavenske akademije znanosti i umjetnosti za godinu 1939/40. Svezak 53, Zagreb: Jugoslavenska akademija znanosti i umjetnosti, 1941., str. 176-184.

Artur Schneider, Iz staroga Zagreba: Svečani sprovod Herbarta X Auersperga 1669., u: Hrvatski narod: glasilo Hrvatskog ustaškog pokreta VI/957, Zagreb: Ustaški nakladni zavod, 1944., str. 5.

Marijana Schneider, Jedan se spomenik vratio kući..., u: Vijesti Društva muzejskokonzervatorskih radnika NR Hrvatske VII/4, Zagreb: Društvo muzejskokonzervatorskih radnika NR Hrvatske, 1958., str. 108-110.

Marijana Schneider, O epitafiju Ivana Hrvoja i Eve Dreffell u Plešivici, u: Bulletin Instituta za likovne umjetnosti Jugoslavenske akademije znanosti $i$ umjetnosti VII/3, Zagreb, Jugoslavenska akademija znanosti i umjetnosti, 1959., str. 177-182.

Marijana Schneider, Dva dječja kostima s nadgrobnih ploča iz Vojne krajine (s pregledom dječje nošnje u zapadnoj Evropi od 1600. do 1650.), u: Spomenica Josipa Matasovića (1892-1962.), Zagreb: Povijesno društvo Hrvatske, 1972., str. 181-199. Uredio Igor Karaman.

Marijana Schneider, Zrinski i Frankopani u likovnoj umjetnosti, u: Historijski zbornik 25-26, Zagreb: Povijesno društvo Hrvatske, 1972.-1973., str. 251-271.

Marijana Schneider, Odraz seljačke bune 1573. godine u likovnoj umjetnosti, u: Radovi Zavoda za hrvatsku povijest 5, Zagreb: Institut za hrvatsku povijest Sveučilišta u Zagrebu, 1973., str. 271-286. 
Minou Schraven, Festive Funerals in Early Modern Italy: The Art and Culture of Conspicuous Commemoration, Surrey: Ashgate Publishing Limited; Burlington: Ashgate Publishing Company, 2014.

Sena Sekulić Gvozdanović, Izgradnja, opis i analiza projekta obnove tvrđave Nehaju u Senju, u: Senjski zbornik: prilozi za geografiju, etnologiju, gospodarstvo, povijest $i$ kulturu IV/1, Senj: Gradski muzej Senj, Senjsko muzejsko društvo, 1970., str. 241-261. Johann Siebmacher, Das erneuerte und vermehrte Teutsche Wappenbuch: in welchem deß $H$. Römischen Reiches hohe Potentaten ... Wappen, Schilde, Helm, Kleinodien ... zu ersehen: Des Neuen Wappenbuchs Fünffter und Letzter Theil, Nürnberg: Fürst, [o. 1665.].

Stjepan Sirovec, Sveti Križ Začretje: monografija: 1334. - 2004., Sveti Križ Začretje: Župa Svetog Križa, 2005.

Ivan Srša, Rezultati konzervatorskih istraživanja u kapeli svete Jelene u Šenkovcu kraj Čakovca, u: Nepek a Mura Mentén = Völker an der Mur =Ljudi uz Muru =Ljudje ob Muri. Sv. 2, A Nagykanizsan 1997. Majus 15-17. kozott megrendezett nemzetkozi konferencia eloadasai, Zalaegerszeg: Gocseji Muzeum, 1998., str. 123-150. Uredila Katalin H. Simon.

Ivan Srša, Požega, crkva sv. Lovre, Zagreb: Ministarstvo kulture, Uprava za zaštitu kulturne baštine, 2005.

Rudolf Strohal, Grad Karlovac opisan i orisan, Karlovac: n.n., 1906.

Agneza Szabo, Grofovi Erdödy, u: Jastrebarsko: 1249. - 1999.: 750 godina grada, Jastrebarsko: Naklada Slap, Gradsko poglavarstvo, 2001., str. 315-323. Uredili Filip Potrebica i Krunoslav Matešić.

Agneza Szabo, Jastrebarska grana grofova Erdödy (Erdedi), u: Gazophylacium: časopis za znanost, umjetnost, gospodarstvo i politiku XIV/1-2, Zagreb: Pinta - Udruga za očuvanje, obnovu i korištenje kulturnog blaga Hrvatske, 2009., str. 99-11.

Gjuro Szabo, Izvještaj o radu zemaljskoga povjerenstva za očuvanje umjetnih $i$ historičkih spomenika u kraljevinama Hrvatskoj i Slavoniji u godini 1911., u: Vjesnik Hrvatskoga arheološkog društva XII/ 1, Zagreb: Hrvatsko arheološko društvo, 1912., str. 202-259 (Poglavlje III. Spomenici kotara Klanjec i Pregrada, 207-259).

Gjuro Szabo, Spomenici kotara Krapina i Zlatar, u: Vjesnik Hrvatskoga arheološkog društva XIII/1, Zagreb: Hrvatsko arheološko društvo, 1914., str. 103-204.

Gjuro Szabo, Spomenici kotara Ivanec, u: Vjesnik Hrvatskoga arheološkog društva XIV/1, Zagreb: Hrvatsko arheološko društvo, 1919., str. 22-97. 
Gjuro Szabo, Iz prošlosti Daruvara $i$ okolice, u: Narodna starina XI/28, Zagreb: Josip Matasović, 1932., str. 79-98.

Gjuro Szabo, Ljudi iz kamena, u: Jutarnji list XXVII/9668, Zagreb: Tipografija, 24. XII. 1938., str. 5.

Gjuro Szabo, Kroz Hrvatsko zagorje, Zagreb: Vasić i Horvat, 1939.

Károly Széchy, Gróf Zrínyi Miklós 1620-1664, Knjiga 1, Poglavlje 1. Családi hagyományok és vérbeli öröklések, Budimpešta: Magyar Történelmi Társulat, 1902.

Marija Šercer, Ulomak nadgrobne ploče Franje Berislavića Grabarskog, u: Informatica museologica III-IV/34, Zagreb: Muzejsko dokumentacijski centar, 2003., str. 103-106.

Marija Šercer, Nadgrobna ploča Stjepana II. Frankopana, u: Modruški zbornik 2, Modruš: Katedra Čakavskog sabora Modruše, 2008., str. 37-52.

Marija Šercer, Žene Frankopanke, u: Modruški zbornik 4-5, Modruš: Katedra Čakavskog sabora Modruše, 2011., str. 21-81.

Ljerka Šimunić, Vjera, ufanje, ljubav, u: Vjera, ufanje, ljubav, katalog izložbe, Varaždin: Gradski muzej Varaždin, 2013., str. 6-19. Napisale Ljerka Albus, Ljerka Šimunić i Spomenka Težak.

Ante Škrobonja, Sveti od zdravlja: Ilustrirani leksikon svetaca zaštitnika, Zagreb: Kršćanska sadašnjost, 2004.

Danko Šourek, Donatorska i naručiteljska djelatnost zagrebačkoga kanonika Ivana Znike, u: Tkalčić: godišnjak Društva za povjesnicu Zagrebačke nadbiskupije = annales Societatis historicae archiepiscopatus Zagrabiensis IX, Zagreb: Društvo za povjesnicu Zagrebačke nadbiskupije »Tkalčić«, 2005., str. 327-410.

Slavko Šterk i Boris Mašić, Mors porta vitae = Smrt vrata života: stara zagrebačka groblja $i$ pogrebi, Zagreb: Muzej grada Zagreba, 2014.

Ivana Šupljika, Gospodari Križovljan-grada: povijest obitelji s posebnim naglaskom na posljednjeg člana Kristofora i njegov posjed u Križovljanju (1724. - 1725.), u: Podravina: časopis za multidisciplinarna istraživanja XIII/25, Samobor: Meridijani, 2014., str. 173-196.

Nela Tarbuk, Kiparstvo 17. i 18. stoljeća u sjevernoj Hrvatskoj, u: Od svagdana do blagdana: barok u Hrvatskoj = From everyday to holidays: baroque in Croatia, katalog izložbe, Zagreb: Muzej za umjetnost i obrt, 1993., str. 122-131. 
Ivan Tašev, Izniman nalaza u svetištu nakon potresa: Nadgrobna ploča biskupa Luke Baratina - nositelja razvoja renesanse, u: Glas Koncila 23, mrežno izdanje. Nadbiskupski duhovni stol, 2020. Pristupljeno 18. 8. 2020. https://www.glaskoncila.hr/izniman-nalaz-u-svetistu-katedrale-nakon-potresa-nadgrobna-ploca-biskupaluke-baratina-nositelja-razvoja-renesanse/

Ivan Krstitelj Tkalčić, Povjestni spomenici slob. kralj. grada Zagreba priestolnice kraljevine Dalmatinsko-Hrvatsko-Slavonske, Svezak drugi, U Zagrebu: Brzotiskom K. Albrechta, 1894.

Ivan Krstitelj Tkalčić, Prvostolna crkva zagrebačka nekoć i sada, Zagreb: Knjigotiskara Karla Albrechta, 1885.

Leopold Toifl, Baj csavar története stájer levéltári források alapján, u: Weitschawar Bajcsa-vár. Egy stájer erőditmény Magyarországon a 16. század második felében, Zalaegerszeg: Zala Megyei Múzeumok Igazgatósága, 2002., str. 27-40. Uredila Csilla Köfalvi.

Lilla Tompos, Totenwappen im Museum für Kunstgewerbe, u: Ars decorativa 6, Budapest: Iparművészeti Múzeum, Hopp Ferenc Kelet-ázsiai Művészeti Múzeum, 1979., str. 145156.

Bálint Ugry i Maja Žvorc, The Čakovec Stone Bust Collection: New Identifications, Possible Dating and the Identity of its Commissioner, u: Radovi Instituta za povijest umjetnosti 43, Zagreb: Institut za povijest umjetnosti, 2019., str. 123-138.

Zlatko Uzelac i Marko Ambroš, Srednjovjekovna župna crkva sv. Trojstva u Osijeku, u: Radovi Instituta za povijest umjetnosti 38, Zagreb: Institut za povijest umjetnosti, 2014., str. 51-62.

Mirko Valentić, Kameni spomenici Hrvatske XIII-XIX stoljeća, Zagreb: Povijesni muzej Hrvatske, 1969.

Mirko Valentić i Lada Prister, Zbirka kamenih spomenika, II. dopunjeno izdanje, Zagreb: Hrvatski povijesni muzej, 2002.

Miroslav Vanino, Isusovci i hrvatski narod I: Rad u XVI stoljeću, Zagrebački kolegij, Zagreb: Filozofsko-teološki institut Družbe Isusove u Zagrebu, 1969.

Maja Velicogna-Novoselac, Vapaj za pomoć kositrenih sarkofaga obitelji Erdödy iz Klanjca, u: Anali Galerije Antuna Augustinčića 12, Klanjec: Galerija Antuna Augustinčića, 1992., str. 34-48. 
Marina Vincelja-Matijašić, Imago mortis u srednjovjekovnoj umjetnosti Zapadne Europe, u: Communio: međunarodni katolički časopis XXXVIII/114, Zagreb: Kršćanska sadašnjost, 2012., str. 96-112.

Biserka Vlahović, Općina Vinica, Vinica: Poglavarstvo općine Vinica, 1997.

Diana Vukičević-Samaržija, Gotičke crkve Hrvatskog zagorja, Zagreb: Institut za povijest umjetnosti, 1993.

Diana Vukičević-Samaržija, Likovne pojave na kraju XV. i početkom XVI. stoljeća - gotika u renesansi, u: Zagrebačka biskupija i Zagreb, 1094 - 1994. Zbornik u čast kardinala Franje Kuharića, Zagreb: Nadbiskupija zagrebačka, 1995., str. 551-558.

Sergej Vrišer, Renesančni viteški nadgrobniki v Sloveniji, u: Zbornik za umetnostno zgodovino VII, Ljubljana: Slovensko umetnostnozgodovinsko društvo, Filozofska fakulteta Univerze v Ljubljani, 1965., str. 195-204.

Gerhard Winkler, Zur Typologie und Ikonographie der sepulkralen Kunst des 16. Jahrhunderts in Österreich, u: Renaissance in Österreich: Geschichte - Wissenschaft Kunst, Horn: Verlag Ferdinand Berger \& Söhne, 1974., str. 213-222. Uredio Rupert Feuchtmüller.

Martina Wolff Zubović, Tipologija i podrijetlo ornamentike na drvenim oltarima XVII. $i$ XVIII. stoljeća na području sjeverozapadne Hrvatske - recepcija, primjena i razvoj motiva, doktorski rad, Zagreb: Filozofski fakultet Sveučilišta u Zagrebu, 2017.

Andreas Zajic, »Zu ewiger gedächtnis aufgericht«. Grabdenkmäler als Quelle für Memoria und Repräsentation von Adel und Bürgertum im Spätmittelalter und in der Frühen Neuzeit. Das Beispiel Niederösterreich, Wien, München: Oldenbourg, 2004.

Ivan Franjo Zdelar, Series banorum Dalmatiae, Croatiae et Slavoniae sub regibus Croatiae, Ungariae et Hungariae-Austriacis, Tyrnaviae: typis Academicis, per. Leopoldum Berger, 1737.

Károly Zrínyi, Monografija grada Čakovca. Povijest dvorca i grada. Popis stanovništva iz 1901., Čakovec: Povijesno društvo Međimurske županije, 2005. Prevela Isabella Brzak. 



\section{POPIS SLIKOVNIH PRILOGA I NJIHOVIH IZVORĀ}

Slika 1. Granice Zagrebačke biskupije u XV. stoljeću

Slika 2. Granice Zagrebačke biskupije u XVI. stoljeću

Slika 3. Granice Zagrebačke biskupije u XVII. stoljeću

Slika 4. Granice Zagrebačke biskupije krajem XVIII. stoljeća

Slika 5. Bernardo Rossellino, Nadgrobni spomenik Leonarda Brunija, 1444. - 1447., Firenca, crkva Santa Croce

Slika 6. Nadgrobna ploča Rudolfa Švapskoga, o. 1080. - 1084., Merseburg, katedrala sv. Ivana Krstitelja i sv. Lovre

Slika 7. Tumbe Karla Smjeloga (†1477.) i njegove kćeri Marije od Burgundije (†1482.), Brugge, crkva Naše Gospe

Slika 8. Nadgrobni spomenik Luja XII. i Ane Bretonske, 1515. - 1531., St. Denis, opatijska crkva

Slika 9. Epitaf Johannesa Cuspinianusa (†1529.), Beč, katedrala sv. Stjepana

Slika 10. Hans Klintzsch, Epitaf Wernera von Plothowa, 1590. - 1591., Magdeburg, katedrala sv. Katarine i sv. Mauricija

Slika 11. Nikola Firentinac, Nadgrobni spomenik Ivana Sobote (Subotića), 1469., Trogir, crkva sv. Dominika

Slika 12. Nadgrobni spomenik Nikole Iločkoga (†1477.), Ilok, crkva sv. Ivana Kapistrana

Slika 13. Prostorna rasprostranjenost nadgrobnika od XV. do XVIII. stoljeća na području povijesne Zagrebačke biskupije

Slika 14. Područja povijesne Zagrebačke biskupije u sastavu Vojne krajine (osjenčano)

Slika 15. Lokaliteti nadgrobnih spomenika iz XV. stoljeća

Slika 16. Lokaliteti nadgrobnih spomenika iz XVI. stoljeća

Slika 17. Lokaliteti nadgrobnih spomenika iz XVII. stoljeća

Slika 18. Lokaliteti nadgrobnih spomenika iz XVIII. stoljeća

Slika 19. Nadgrobni spomenici Henrika II. (†1189.) i Eleonore Akvitanske (†1204.), Fontevrault, benediktinska opatija

Slika 20. Nadgrobna ploča granešinskoga župnika Matije (†1472.), Zagreb, Muzej grada Zagreba

Slika 21. Nadgrobna ploča kanonika Benedikta, nakon 1475., Zagreb, Hrvatski povijesni muzej

Slika 22. Nadgrobna ploča crkvenoga dostojanstvenika, XV. st., Zagreb, Hrvatski povijesni muzej

Slika 23. Nadgrobna ploča Ivana i Blaža iz Moravča, 1495., Zagreb, Muzej grada Zagreba

Slika 24. Spomen-ploča kanonika Ljudevita Vukoslavića, 1673., Zagreb, Muzej grada Zagreba 
Slika 25. Johannes Fiorentinus (?), Nadgrobna ploča biskupa Luke de Szegeda (†1510.), Zagreb, Hrvatski povijesni muzej i i Dijecezanski muzej Zagrebačke nadbiskupije

Slika 26. Johannes Fiorentinus (?), Nadgrobna ploča biskupa Luke de Szegeda (†1510.) gornji ulomak, Zagreb, Hrvatski povijesni muzej

Slika 27. Nadgrobna ploča biskupa Petra III. Petretića (†1667.), Zagreb, Muzej grada Zagreba

Slika 28. Ulomak nadgrobne ploče, XV. st., Zagreb, Hrvatski povijesni muzej

Slika 29. Nadgrobna ploča biskupa Nikole III. Ogramića Olovčića (†1701.), Našice, crkva sv. Antuna Padovanskoga

Slika 30. Nadgrobna ploča plemkinje Barbare, XV. st., Zagreb, Hrvatski povijesni muzej

Slika 31. Nadgrobna ploča Elizabete Frankapan rođ. Petheö de Gerse (†1513.), Rijeka, crkva Majke Božje Trsatske

Slika 32. Pokupski Brest, Kapela sv. Barbare, Grobna ploča, 1939., foto: Đuro Griesbach, HAZU, Strossmayerova galerija starih majstora, Schneiderov fotografijski arhiv

Slika 33. Nadgrobna ploča Gottharda von Schrattenbacha (†1608.), Koprivnica, župni dvor

Slika 34. Nadgrobna ploča Marije Ane Weikhardt (†1648.), Poljana, Ivanić-Grad, kapela sv. Jakova Starijega

Slika 35. Nadgrobna ploča Ivaniša Korvina, 1505., Lepoglava, crkva Bezgrješnoga Začeća Blažene Djevice Marije

Slika 36. Nadgrobna ploča Petra II. Erdődyja (†1567.), Jastrebarsko, crkva sv. Nikole

Slika 37. Nadgrobna ploča Gašpara I. Draškovića i Katarine rođ. Székely de Kevend, nakon 1591., Bednja, crkva sv. Marije Magdalene

Slika 38. Majstor G. S., Nadgrobna ploča Ivana Lenkovića (†1569.), Novo Mesto, franjevački samostan sv. Leonarda

Slika 39. Središnji dio epitafa Georga von Liechtensteina (†1548.), Beč, crkva sv. Mihaela

Slika 40. Nadgrobna ploča Franje Tahyja (†1573.), Gornja Stubica, Muzej seljačkih buna

Slika 41. Nadgrobna ploča Petra II. Ratkaja Velikotaborskoga (†1586.), Desinić, crkva sv. Jurja

Slika 42. Desinić, Župna crkva, Nadgrobni spomenik Petra II. Rattkay, 1938., foto: Ljudevit Griesbach, HAZU, Strossmayerova galerija starih majstora, Schneiderov fotografijski arhiv

Slika 43. Viteški nadgrobnik, 1580-e, Vurberk, crkva Uznesenja Blažene Djevice Marije

Slika 44. Detalj lica nadgrobne ploče Franje Tahyja (†1573.), Gornja Stubica, Muzej seljačkih buna 
Slika 45. Detalj lica nadgrobne ploče Petra II. Ratkaja Velikotaborskoga (†1586.), Desinić, crkva sv. Jurja

Slika 46. Nadgrobna ploča Nikole IV. Zrinskoga (?) (†1566.), Čakovec, Muzej Međimurja

Slika 47. Nadgrobna ploča Jánosa II. Thuróczyja, oko 1558., Levoča, crkva sv. Jakova

Slika 48. Poklopac tumbe Marka (Horvata) Mišljenovića od Kamičca (†1508.), Nagyvázsony, dvorac Kinizsi

Slika 49. Nadgrobna ploča Nikole I. Mlakovečkoga (†1603.), Čakovec, Muzej Međimurja

Slika 50. Radionica majstora Trantnerova epitafa (?), Nadgrobna ploča Benedikta Thuróczyja Ludbreškoga (†1616.), Vinica, crkva sv. Marka Evanđelista

Slika 51. Nadgrobna ploča Ivana IV. Petheöa de Gerse (†1616.), Ivanec, crkva sv. Marije Magdalene

Slika 52. Nadgrobna ploča člana obitelji Vragović, I. polovina XVII. stoljeća, Maruševec, crkva sv. Jurja

Slika 53. Radionica majstora Trantnerova epitafa, Epitaf Georga Trantnera (†1612.), Ptuj, crkva sv. Jurja

Slika 54. Radionica majstora Trantnerova epitafa, Epitaf Anne Zakklin rođ. Keglević (†1616.), Ptuj, crkva sv. Jurja

Slika 55. Radionica majstora Trantnerova epitafa (?), Nadgrobna ploča Benedikta Thuróczyja Ludbreškoga (†1616.) - detalji kerubina i grbova, Vinica, crkva sv. Marka Evanđelista

Slika 56. Franz Alt, Unutrašnjost svetišta požunske katedrale sv. Martina, 1848., Beč, Österreichische Nationalbibliothek

Slika 57. Caspar Menneler, Nadgrobni spomenik Nikole II. Pálffyja od Erdőda, 1601., Bratislava, katedrala sv. Martina

Slika 58. Nadgrobnik Petera von Mollarda (†1570.), Beč, crkva sv. Mihaela

Slika 59. Epitaf Ivana II. Draškovića (†1613.), Bratislava, katedrala sv. Martina

Slika 60. Detalj lica nadgrobne ploče Nikole IV. Zrinskoga (?) (†1566.), Čakovec, Muzej Međimurja

Slika 61. Detalj lica nadgrobne ploče Gašpara I. Draškovića (†1591.), Bednja, crkva sv. Marije Magdalene

Slika 62. Detalji lica s nadgrobnih ploča (redom): Benedikta Thuróczyja Ludbreškoga (†1616.) iz Vinice, Ivana IV. Petheöa de Gerse (†1616.) iz Ivanca i Vragovića iz Maruševca

Slika 63. Portret Jurja V. Zrinskoga, bakrorez iz knjige Franza Christopha Khevenhüllera »Conterfet Kupfferstich... deren jenigen regierenden grossen Herren«, Leipzig, 1722. 
Slika 64. Portret Nikole IV. Zrinskoga, drvorez iz knjige Johanna Sommera »Vita Jacobi despotae Moldavorum reguli«, Wittenberg, 1587.

Slika 65. Epitaf Gottfrieda Falmhaubta (†1641.), Varaždin, crkva sv. Ivana Krstitelja

Slika 66. Epitaf obitelji Češković, 1711., Lepoglava, crkva Bezgrješnoga Začeća Blažene Djevice Marije

Slika 67. Epitaf Petra Troila Sermagea od Susedgrada, o. 1773., Stenjevec, crkva Uznesenja Blažene Djevice Marije

Slika 68. Michael Milluz, Portret Petra Troila Sermagea od Susedgrada, 1773., Stenjevec, crkva Uznesenja Blažene Djevice Marije

Slika 69. Primjena kontraposta u portretnom slikarstvu i nadgrobnoj plastici

69.1. Andrea del Castagno, Slavne osobe: Farinata degli Uberti, o. 1450., Firenca, Galleria degli Uffizi

69.2. Nadgrobna ploča Ivaniša Korvina, 1505., Lepoglava, crkva Bezgrješnoga Začeća Blažene Djevice Marije

69.3. Nadgrobna ploča Nikole I. Mlakovečkoga (†1603.), Čakovec, Muzej Međimurja

Slika 70. Tiziano Vecellio, Portret Francesca Marije I. della Rovere, 1536. - 1538., Firenca, Galleria degli Uffizi

Slika 71. Tiziano Vecellio, Portret Filipa II. u oklopu, 1550. - 1551., Madrid, Museo del Prado

Slika 72. Portret Tamása (Tome) I. Nádasdyja, 17. st., Budimpešta, Magyar Nemzeti Múzeum

Slika 73. Portret Nikole VII. Zrinskoga, 17. st., Budimpešta, Magyar Nemzeti Múzeum

Slika 74. Portret Nikole IV. Zrinskoga, iz knjige Johanna Sommera »Vita Jacobi despotae Moldavorum reguli«, Wittenberg, 1587.

Slika 75. Giovanni Battista Fontana i Dominicus Custos, Portret Nikole IV. Zrinskoga, iz knjige »Augustissimorum Imperatorum«, Innsbruck, 1601.

Slika 76. Aegedius II. Sadeler, Portret kralja Matije Korvina, iz knjige »Mausoleum«, Nürnberg, 1664.

Slika 77. Epitaf Petra II. (†1554./55.) i Šimuna III. Keglevića (†1579.) te Jurja Gorupa (†o. 1680.), Pregrada, crkva Uznesenja Blažene Djevice Marije

Slika 78. Majstor Hassova epitafa (?), Epitaf Petra II. Keglevića (†1554./55.), Pregrada, crkva Uznesenja Blažene Djevice Marije

Slika 79. Zavjetna slika obitelji Petheö de Gerse i Choron de Devecser, sredina XVI. stoljeća, Varaždin, Gradski muzej 
Slika 80. Majstor Hassova epitafa, Detalj epitafa Mateja Hassa (†1587.), Ptuj, crkva sv. Jurja

Slika 81. Majstor Hassova epitafa, Detalj epitafa Veita Heineggera (†1581.), Maribor, crkva sv. Ivana Krstitelja

Slika 82. Pregrada, Crkva Uzašašća Bogorodičina, Nadgrobna ploča Jurja Gorupa $i$

Keglevića (detalj), 1938., foto: Ljudevit Griesbach, HAZU, Strossmayerova galerija starih majstora, Schneiderov fotografijski arhiv

Slika 83. Detalj grba s epitafa Šimuna III. Keglevića (†1579.), Pregrada, župna crkva Uznesenja Blažene Djevice Marije

Slika 84. Grbovi obitelji Keglević i Petheö de Gerse, iz grbovnika Ivana von Bojničića »Der Adel von Kroatien und Slavonien«, 1889.

Slika 85. Majstor Hassova epitafa, Epitaf Andreja Karnerainda (†1590.) s detaljem lavljih konzola, Ptuj, crkva sv. Jurja

Slika 86. Epitaf Jurja Gorupa (†o. 1680.), Pregrada, crkva Uznesenja Blažene Djevice Marije

Slika 87. Vincentus Cumini, Epitaf Reichardta pl. Lichtensteina, 1596., Ljutomer, crkva sv. Ivana Krstitelja

Slika 88. »Oltarna« kompozicija, kraj XVI./poč. XVII. st., Malečnik, crkva sv. Petra

Slika 89. Suradnik majstora Hassova epitafa (?), Epitaf Ane Purthin (†1589.), Samobor, Taborec, kapela sv. Mihaela

Slika 90. Suradnik majstora Hassova epitafa (?), Detalj epitafa Ane Purthin (†1589.), Samobor, Taborec, kapela sv. Mihaela

Slika 91. Hieronymus Wierix, Krist na križu (kopija po Martenu de Vosu), 1584., Beč, Graphische Sammlung Albertina

Slika 92. Suradnik majstora Hassova epitafa, Detalj epitafa Andreja Praunfalcha $(\dagger 1600$.$) ,$ Ptuj, crkva sv. Jurja

Slika 93. Radionica majstora Trantnerova epitafa (?), Epitaf Franje Keczera od Rad(o)vana, 1629., Vinica, crkva sv. Marka Evanđelista

Slika 94. Radionica majstora Trantnerova epitafa (?), Epitaf Franje Keczera od Rad(o)vanadetalj Raspeća, 1629., Vinica, crkva sv. Marka Evanđelista

Slika 95. Krist na križu (kopija po Antoniusu II. Wierixu), prije 1604., New York, Metropolitan Museum of Art, Department of Prints and Photographs

Slika 96. Radionica Majstora Trantnerova epitafa (?), Epitaf Franje Keczera od Rad(o)vanadetalj grba i natpisa, 1629., Vinica, crkva sv. Marka evanđelista

Slika 97. Radionica Majstora Trantnerova epitafa, Epitaf Georga Gambsisa (†1631.), Rogatec, crkva sv. Jerneja (Bartolomeja) 
Slika 98. Radionica Majstora Trantnerova epitafa, Epitaf Christopha von Tattenbacha (†1627.) - detalj središnjega reljefa, Slovenske konjice, crkva sv. Ane

Slika 99. Radionica Majstora Trantnerova epitafa, Nadgrobna ploča Ane Katarine Wechsler rođ. Haslinger (†1629.), Vurberk, crkva sv. Ane

Slika 100. Epitaf Eve rođ. Dreffel (†1672.) i Jurja Ivana I. Hrvoja (†1704.), Plešivica, crkva sv. Jurja

Slika 101. Detalj epitafa Eve rođ. Dreffel (†1672.) i Jurja Ivana I. Hrvoja (†1704.), Plešivica, crkva sv. Jurja

Slika 102. Epitaf Tome II. Erdödyja (†1624.), Zagreb, katedrala Uznesenja Blažene Djevice Marije i sv. Stjepana i Ladislava

Slika 103. Detalj epitafa Tome II. Erdődyja (†1624.), Zagreb, katedrala Uznesenja Blažene Djevice Marije i sv. Stjepana i Ladislava

Slika 104. Johan I. Sadeler, Krist na križu, 1589., San Francisco, Fine Arts Museums of San Francisco

Slika 105. Zavjetnika slika Tome II. Erdödyja, 1620., Bojnice, Slovenské národné múzeum Múzeum Bojnice

Slika 106. Epitaf Martina Mogorića, 1675., Marija Gorica, crkva Pohoda Blažene Djevice Marije

Slika 107. Epitaf Ladislava III. Patačića od Zajezde, 1710., Lepoglava, crkva Bezgrješnoga Začeća Blažene Djevice Marije

Slika 108. Oltar sv. Doroteje, poč. XVIII. stoljeća, Logorište, kapela sv. Doroteje

Slika 109. Apoteoza sigetskoga junaka Nikole Zrinskoga, kraj XVI. st., Budimpešta, Magyar Nemzeti Galéria

Slika 110. Adriaen van Conflans, Posmrtni portret Nikole Zrinskoga, 1566.-1574., Budimpešta, Magyar Nemzeti Múzeum

Slika 111. Nadgrobna ploča gorjanskoga plemića Radoslava, XIII./XIV. stoljeće, Zagreb, kapela sv. Martina

Slika 112. Nadgrobna ploča obitelj Roh de Deche, I. pol. XV. st., Zagreb, Hrvatski povijesni muzej

Slika 113. Nadgrobna ploča Filipa IV. Korođskoga (†1394.), Osijek, crkva Svetoga Križa

Slika 114. Bihaćka klesarska radionica, Nadgrobna ploča Nikole III. Zrinskoga (†1523.), Hrvatska Kostajnica, Zbirka franjevačkoga samostana

Slika 115. Bihaćka klesarska radionica, Nadgrobna ploča iz Borovca (†1517.), Zagreb, Povijesni muzej Hrvatske 
Slika 116. Mače (Zlatar), Crkva Bezgrešnoga začeća Blažene Djevice Marije, Grobna ploča Mojsija Humskoga, 1940., foto: Đuro Griesbach, HAZU, Strossmayerova galerija starih majstora, Schneiderov fotografijski arhiv

Slika 117. Nadgrobna ploča Vuka Dragača $(† 1578$.), Nedelišće, crkva Presvetoga Trojstva

Slika 118. Nadgrobna poča Leonarda Grubera (†1536.), Samobor, kapela sv. Mihovila na Taborcu

Slika 119. Ulomak nadgrobne ploče Stjepana IV. (III.) Frankapana Ozaljskoga (†1577.), Svetice, crkva rođenja Blažene Djevice Marije

Slika 120. Nadgrobne ploče ugrađene u potporni zid platoa župne crkve sv. Nikole, Krapina

Slika 121. Nadgrobna ploča neznane obitelji, XVII. st., Krapina, crkva sv. Nikole

Slika 122. Nadgrobna ploča neznane obitelji - detalj grba, XVII. st., Krapina, crkva sv. Nikole

Slika 123. Radionica majstora Trantnerova epitafa (?), Nadgrobna ploča Elizabete Sudić, 1620., Krapina, crkva sv. Nikole

Slika 124. Radionica majstora Trantnerova epitafa (?), Nadgrobna ploča obitelji Keglević, 1620-e, Krapina, crkva sv. Nikole

Slika 125. Radionica majstora Trantnerova epitafa, Epitaf obitelji Stopper, 1626., Mozirje, crkva sv. Jurja

Slika 126. Radionica majstora Trantnerova epitafa, Epitaf obitelji Stopper-detalj kerubina $i$ sv. Jakova, 1626., Mozirje, crkva sv. Jurja

Slika 127. Radionica majstora Trantnerova epitafa (?), Nadgrobna ploča Elizabete Sudić detalj kerubina i sv. Blaža, 1620., Krapina, crkva sv. Nikole

Slika 128. Ivanić Kloštar, Crkva sv. Ivana Krstitelja, Grobna ploča ivanićkog kapetana Kristofora Spišića, 1939., foto: Đuro Griesbach, HAZU, Strossmayerova galerija starih majstora, Schneiderov fotografijski arhiv

Slika 129. Radionica majstora Trantnerova epitafa (?), Nadgrobna ploča Ivana Horvata Radića, 1630., Mihovljan, crkva sv. Mihovila arkanđela

Slika 130. Mihovljan, Crkva sv. Mihajla, Grobna ploča Ivana Horvata Radića, 1940., foto: Đuro Griesbach, HAZU, Strossmayerova galerija starih majstora, Schneiderov fotografijski arhiv

Slika 131. Radionica majstora Trantnerova epitafa (?), Epitaf Baltazara Patačića (†1616.), Zajezda, crkva Uznesenja Blažene Djevice Marije

Slika 132. Radionica majstora Trantnerova epitafa, Epitaf Barbare Haas - detalj para putta $s$ grbom, 1631., Maribor, katedrala sv. Ivana Krsitelja 
Slika 133. Usporedba izvedbe obiteljskih grbova na nadgrobnim spomenicima

133.1. Nadgrobna ploča Anne Zakklin rođ. Keglević (†1616.), Ptuj, crkva sv. Jurja

133.2. Nadgrobna ploča Benedikta Thuróczyja Ludbreškoga (†1616.), Vinica, crkva sv. Marka Evanđelista

133.3. Epitaf Franje Keczera od Rad(o)vana, 1629., Vinica, crkva sv. Marka Evanđelista

133.4. Nadgrobna ploča Elizabete Sudić, 1620., Krapina, crkva sv. Nikole

133.5. Nadgrobna ploča obitelji Keglević, 1620-e, Krapina, crkva sv. Nikole

133.6. Nadgrobna ploča Kristofora Spišića (†1616.), Kloštar Ivanić, crkva sv.

133.7. Nadgrobna ploča Ivana Horvata Radića, 1630., Mihovljan, crkva sv. Mihovila arkanđela

133.8. Epitaf Baltazara Patačića (†1616.), Zajezda, crkva Uznesenja Blažene Djevice Marije

Slika 134. Nadgrobna ploča Grgura Zebeca, 1684., Mihovljan, crkva sv. Mihovila arkanđela

Slika 135. Nadgrobna ploča obitelji Zmajlović, II. pol. XVII. stoljeća, Svetice, crkva rođenja Blažene Djevice Marije

Slika 136. Grb obitelji Zmajlović, iz grbovnika Ivana von Bojničića »Der Adel von Kroatien und Slavonien«, 1889.

Slika 137. Ulomak nadgrobne ploče s grbom, 1619., Zagreb, Hrvatski povijesni muzej

Slika 138. Nadgrobna ploča Baltazara Dvorničića-Napulya (†1624.), Zagreb, Hrvatski povijesni muzej

Slika 139. Nadgrobna ploča Ivana II. Erdődyja (†1626.), Zagreb, Hrvatski povijesni muzej

Slika 140. Radionica Ivana Komersteinera (?), Nadgrobna ploča Jurja Orehovačkoga $(\dagger 1687$.$) , Zagreb, Muzej grada Zagreba$

Slika 141. Ivan Komersteiner, Oltar sv. Franje Borgie - detalj krila, 1680. - 1684., Zagreb, crkva sv. Katarine

Slika 142. Radionica Ivana Komersteinera (?), Nadgrobna ploča Jurja Orehovačkoga $(† 1687$.$) - detalj, Zagreb, Muzej grada Zagreba$

Slika 143. Radionica Ivana Komersteinera (?), Nadgrobna ploča Jurja Orehovačkoga $(† 1687$.$) - detalj anđela s grbom pokojnika, Zagreb, Muzej grada Zagreba$

Slika 144. Ivan Komersteiner, Putti s grbom donatora Nikole Ratkaja i Sofije Rosine Gaiszrugh na atici oltara sv. Franje Borgije, 1680. - 1684., Zagreb, crkva sv. Katarine

Slika 145. Ivan Komersteiner, Spomen-ploča biskupa Mikulića s kaptolske knjižnice, 1692., Zagreb, Hrvatski povijesni muzej 
Slika 146. Ivan Komersteiner, Epitaf Nikole III. Erdődyja, 1693., Zagreb, katedrala Uznesenja Blažene Djevice Marije i sv. Stjepana i Ladislava

Slika 147. Nadgrobna ploča Ivana Znike (†1706.), Zagreb, Muzej grada Zagreba

Slika 148. Epitaf Jurja IV. Frankapana Tržačkoga (†1661.), Zagreb, crkva sv. Katarine

Slika 149. Epitaf Ivana Herbarta X. Auersperga (†1669.), Zagreb, crkva sv. Katarine

Slika 150. Nadgrobna ploča Ivana Josipa Herbersteina (†1689.), Karlovac, crkva Presvetoga Trojstva

Slika 151. Epitaf Nikole Istvánffyja i Elizabete rođ. Both de Bajna, 1603., Vinica, crkva sv. Marka Evanđelista

Slika 152. Epitaf Gašpara Bedekovića (†1656.), Krapina, crkva sv. Katarine

Slika 153. Epitaf Ivana Petheöa de Gerse, 1673., Lepoglava, crkva Bezgrješnoga začeća Blažene Djevice Marije

Slika 154. Nadgrobna ploča Ljudevita I. Erdődyja (†1753.), Kotari, crkva sv. Leonarda

Slika 155. Nadgrobna ploča Dimitrija Mihalovića (†1763.), Zagreb, Hrvatski povijesni muzej

Slika 156. Nadgrobna ploča Vuka Jelačića, 1777., Stenjevec, crkva crkva Uznesenja Blažene Djevice Marije

Slika 157. Josip Buk, Epitaf Franje Ksavera Pejačevića (†1781.), Požega, crkva sv. Lovre

Slika 158. Epitaf Baltazara III. Patačića i Terezije rođ. Gereczy, 1722., Remetinec, crkva Kraljice Svete Krunice

Slika 159. Nadgrobna ploča obitelji Patačić, 1697., Remetinec, crkva Kraljice Svete Krunice

Slika 160. Epitaf Bartolomeja Patačića, 1817., Remetinec, crkva Kraljice Svete Krunice

Slika 161. Lepoglava, Crkva Majke Božje, Škrinja i ploča Karla Ivana Rattkaya, 1938., foto: Ljudevit Griesbach, HAZU, Strossmayerova galerija starih majstora, Schneiderov fotografijski arhiv

Slika 162. Epitaf Nikole Gotala od Gotalovca, 1765., Zagreb, katedrala Uznesenja Blažene Djevice Marije i sv. Stjepana i Ladislava

Slika 163. Nadgrobna ploča franjevačkoga reda, XVIII. stoljeće, Varaždin, crkva sv. Ivana Krstitelja

Slika 164. Nadgrobna ploča pavlinskoga reda, XVIII. stoljeće (?), Remete, crkva Uznesenja Blažene Djevice Marije

Slika 165. Remete, Crkva sv. Marije, Glavni oltar, 1937., foto: Ljudevit Griesbach, HAZU, Strossmayerova galerija starih majstora, Schneiderov fotografijski arhiv

Slika 166. Nadgrobna ploča Barbare Zaboky (†1678.), Lepoglava, crkva Bezgrješnoga Začeća Blažene Djevice Marije 
Slika 167. Ploča Ivane Bajalić (†1781.), Bjelovar, kapela sv. Križa

Slika 168. Epitaf Stjepana Patačića od Zajezde i Barbare rođ. Beković, 1629., Vidovec, crkva sv. Vida

Slika 169. Epitaf Danijela Praunspergera (†1692.), Varaždin, crkva sv. Ivana Krstitelja

Slika 170. Gian Lorenzo Bernini, Grobnica pape Aleksandra VII., 1671. - 1678., Rim, bazilika sv. Petra

Slika 171. Gian Lorenzo Bernini, Kenotaf redovnice Marije Raggi, 1647. - 1653., Rim, bazilika S. Maria sopra Minerva

Slika 172. Nadgrobna ploča Ivana Antolkovića (†1682.), Zagreb, Muzej grada Zagreba

Slika 173. Nadgrobna ploča Jurja Habijančića (†1621.), Radoboj, crkva Presvetoga Trojstva

Slika 174. Nadgrobni spomenici (izbor) iz XV. stoljeća

Slika 175. Nadgrobni spomenici (izbor) iz XVI. stoljeća

Slika 176. Nadgrobni spomenici s likom pokojnika iz XVII. stoljećea

Slika 177. Nadgrobni spomenici (izbor) iz XVII. stoljeća

Slika 178. Nadgrobni spomenici (izbor) iz XVIII. stoljeća

Slika 179. Grobne kapele crkve Blažene Djevice Marije u Lepoglavi i redoslijed njihove prigradnje

Slika 180. Detalj vedute šenkovečkoga pavlinskog sklopa s označenom grobnom kapelom Zrinskih, iz knjige Josipa Bedekovića »Natale solum...«, Bečko Novo Mjesto, 1752.

Slika 181. Tlocrt šenkovečke pavlinske crkve i očuvanih temelja grobne kapele Zrinskih, iz elaborata Ksenije Petrić i Tatjane Lolić »Sveta Jelena kod Čakovca...«, Zagreb, 2005.

Slika 182. Razvojne faze donjostubičke crkve od XV. do XIX. stoljeća s označenom grobnom kapelom obitelji Tahy, iz članka Katarine Horvat Levaj »Župna crkva Presvetoga Trojstva...«, Peristil, 1995.

Slika 183. Temelji crkve sv. Josipa, Karlovac, Trg Josipa Jurja Strossmayera

Slika 184. Detalj vedute grada Karlovca s označenom crkvom sv. Josipa, s cehovske diplome, tzv. majstorskoga lista, Karlovac, 1809.

Slika 185. Moritz Lang, Pogrebna povorka Lászla, Ferenca, Támasa i Gáspára Esterházyja u Trnavi (prema crtežu Hansa Rudolfa Millera), iz knjige Tamása Pálffyja »In exequiis illustrissimi comitis ac domini, domino Ladislai Eszterhazi de Galanta...«, Beč, 1653.

Slika 186. Theodor Krüger, Unutrašnjost bazilike Santa Maria Maggiore u Rimu opremljene za posmrtnu svečanost pape Pavla V. (kopija prema Sergiju Venturiju), 1622./23., London, The British Museum 
Slika 187. Krug Giulija Parigija, Pročelje crkve San Lorenzo u Firenci ukrašeno za posmrtnu svečanost kralja Henrika IV., 1610., Firenca, Biblioteca Riccardiana

Slika 188. Johann Caspar Mannasser, Katafalk Ivana Herbarta X. Auersperga, 1669., Zagreb, Metropolitanska knjižnica, Valvasorova grafička zbirka

Slika 189. Zaharija Lauffer, Sarkofag Žigmunda I. Erdődyja (†1639.), Klanjec, samostan Navještenja Blažene Djevice Marije

Slika 190. Johann Philipp Stumpf, Sarkofag Mirka I. Erdődyja (†1690.), Klanjec, samostan Navještenja Blažene Djevice Marije

Slika 191. Johann Philipp Stumpf, Sarkofag Mirka I. Erdödyja (†1690.) - detalj uzglavlja, Klanjec, samostan Navještenja Blažene Djevice Marije

Slika 192. Sarkofag Elizabete Erdödy rođ. Rakoczi (†1707.), Klanjec, crkva Navještenja Blažene Djevice Marije

Slika 193. Posmrtni grb grofa Johanna Georga II. von Mansfeld-Eislebena, 1647., Mansfeld, dvorska crkva sv. Jurja i Marije

Slika 194. Posmrtni grb biskupa Mirka Esterházyja, 1745., Zagreb, Hrvatski povijesni muzej

Slika 195. Posmrtni grb biskupa Jurja Branjuga, 1748., Zagreb, Hrvatski povijesni muzej

\section{POPIS TABLICA}

Tablica 1. Nadgrobnici s motivima funeralne ikonografije

Tablica 2. Pojedinosti o okolnostima narudžbe pojedinih nadgrobnih spomenika

\section{AUTORI I IZVORI SLIKOVNIH PRILOGA:}

Bačić, Živko: 11

Braun, Mario: 113

Brünig, Harald (brunnenturmfigur.de): 10

Križnik, Darko: 97

Macek, Patrik (Pixsell): 25

Šourek, Danko: 107, 111

Wolff Zubović, Martina: 141

Beč, Österreichische Nationalbibliothek: 56

Beč, Graphische Sammlung Albertina: 91

Bildarchiv Foto Marburg: 193

Bojnice, Slovenské národné múzeum - Múzeum Bojnice: 105

Budimpešta, Magyar Nemzeti Galéria: 109 
Budimpešta, Magyar Nemzeti Múzeum: 72-73, 110

Čakovec, Muzej Međimurja: 46

Firenca, Bibliotheca Riccardiana: 187

Firenca, Galleria degli Uffizi: 69.1, 70

Kliska, Jovan: 31, 77

London, The British Museum: 186

Ljubljana, Znanstveno istraživački centar Slovenske akademije znanosti i umjetnosti: 125-126

Madrid, Museo del Prado: 71

Magyar müvelődéstörténet, Magyar Elektronikus Könyvtár: 185

New York, Metropolitan Museum of Art: 95

Petrić, Katarina; Valjato Vrus, Ivana: 182

San Francisco, Fine Arts Museums of San Francisco: 104

Šućur, Ivo: 192

Varaždin, Gradski muzej: 79

Visegrád, Mátyás Király Múzeum: 48

Web Gallery of Art: 5, 6, 8, 19, 170-171

Wikimedia Commons: 38-39, 47, 58

Zagreb, Hrvatski povijesni muzej: 21, 22, 26, 28, 30, 112, 115, 137-139, 145, 155, 194-195

Zagreb, Institut za povijest umjetnosti: 12, 108, 114, 144, 154

Zagreb, Konzervatorski zavod: 181

Zagreb, Metropolitanska knjižnica Zagrebačke nadbiskupije: 188

Zagreb, Muzej grada Zagreba: 20, 23, 24, 27, 140, 142-143, 147, 172

Zagreb, Schneiderov fotografijski arhiv Hrvatske akademije znanosti i umjetnosti: 32, 42, 82, $116,128,130,133.6,161,165$

Snimci i presnimci autorice: 1-4, 7, 9, 13-18, 29, 33-37, 40 (uz dozvolu Muzeja seljačkih buna), 41, 43-45, 49 (uz dozvolu Muzeja Međimurja Čakovec), 50-55, 57, 59, 60 (uz dozvolu Muzeja Međimurja Čakovec), 61-68, 69.2-69.3, 74-76, 78, 80-81, 83-90, 9294, 96, 98-103, 106, 117-124, 127, 129, 131-137 (osim 133.6), 146, 148-153, 157158, 160, 162-164, 166-169, 173-180, 183-184, 189-191 


\section{VI. ŽIVOTOPIS I POPIS OBJAVLJENIH RADOVA AUTORICE}

Maja Žvorc rođena je u Čakovcu (1987.), gdje je završila osnovnu i srednju školu. Godine 2006. upisala je studij povijesti umjetnosti i engleskoga jezika i književnosti na Filozofskome fakultetu Sveučilišta u Zagrebu, na kojem je diplomirala 2012. godine. Tijekom studija sudjelovala je na projektu Multidisciplinarna istraživanja kompleksa dvorca Brezovice na matičnome odsjeku pod vodstvom dr. sc. Dubravke Botica. Godine 2012. upisala je poslijediplomski doktorski studij povijesti umjetnosti. Od 2013. do 2015. godine radila je kao kustosica na Kulturno-povijesnom odjelu Muzeja Međimurja Čakovec. Sudjelovala je na istraživačkome projektu Likovna umjetnost i komunikacija moći u razdoblju ranoga novoga vijeka (1450.-1800.): povijesne hrvatske regije na razmeđi Srednje Europe i Mediterana koji se provodio od 2014. do 2018. godine na Institutu za povijest umjetnosti pod vodstvom dr. sc. Milana Pelca. Od 2017. godine zaposlena je kao nastavnica engleskoga jezika u Srednjoj školi Čakovec, a od 2019. godine povremeno surađuje s Centrom za kulturu Čakovec kao vanjska suradnica na poslovima kustosa.

Bibliografija:

Koautorstvo s Bálintom Ugryjem, The Čakovec Stone Bust Collection: New Identifications, Possible Dating and the Identity of its Commissioner, u: Radovi Instituta za povijest umjetnosti 43, Zagreb: Institut za povijest umjetnosti, 2019., str. 123-138.

Muzej Međimurja Čakovec i obitelj Zrinski: problemi i izazovi prezentacije raznesene materijalne baštine, u: Institucije povijesti umjetnosti: zbornik 4. kongresa hrvatskih povjesničara umjetnosti, Zagreb: Društvo povjesničara umjetnosti Hrvatske, Institut za povijest umjetnosti, 2019., str. 73-79. Uredile Ivana Mance, Martina Petrinović i Tanja Trška.

"Ars aut historia" - Szabin pogled na nadgrobnike kontinentalne Hrvatske, u: Gjuro Szabo: 1875.-1943.: zbornik radova znanstveno-stručnog skupa »Hrvatski povjesničari umjetnost «, Zagreb: Društvo povjesničara umjetnosti Hrvatske, 2018., str. str. 145-162. Uredio Marko Špikić.

Herculean Allegory at the Čakovec Old Castle: Commissioner and Context, u: Radovi Instituta za povijest umjetnosti 41, Zagreb: Institut za povijest umjetnosti, 2017., str. 83-96. 
Groblja i nadgrobni spomenici, u: Enciklopedija Hrvatskoga Zagorja, Zagreb: Leksikografski zavod »Miroslav Krleža«, 2017., str. 261-262, 601. Uredili Božidar Brezinščak Bagola, Ivan Cesarec i Mladen Klemenčić.

Crtě̌ katafalka cara Franje II. podignutog u zagrebačkoj katedrali, u: Klasicizam u Hrvatskoj: zbornik radova znanstvenog skupa, Zagreb: Institut za povijest umjetnosti, 2016., str. 333-347. Uredila Irena Kraševac.

»Memento monumenti« - nadgrobni spomenici u istraživanjima Artura Schneidera, u: Artur Schneider: 1879.-1946.: zbornik radova znanstveno-stručnog skupa »Hrvatski povjesničari umjetnosti«, Zagreb: Društvo povjesničara umjetnosti Hrvatske, 2016., str. 261-275. Uredila Ljerka Dulibić.

Društveni i kulturni život u Čakovcu između 1880. i 1914. godine, u: Večernji »soirée« - »Fin de siècle u Čakovcu«: izložba u sklopu projekta pHisCulture: Upoznajmo zajedničku povijest u kulturnoj suradnji za budućnost, Čakovec: Muzej Međimurja, 2015., str. 6481.

Moda i kultura odijevanja na prijelazu stoljeća, u: Večernji »soirée» - »Fin de siècle u Čakovcu«: izložba u sklopu projekta pHisCulture: Upoznajmo zajedničku povijest u kulturnoj suradnji za budućnost, Čakovec: Muzej Međimurja, 2015., str. 106-121.

Lepoglavska crkva Bezgrješnog Začeća Djevice Marije kao »campo santo« hrvatskih velikaša, u: Kamilo Dočkal, Povijest pavlinskog samostana Blažene Djevice Marije u Lepoglavi, Zagreb: Glas Koncila, 2014., str. 25-30.

Portretna poprsja iz Muzeja Međimurja Čakovec, Zagreb: Društvo povjesničara umjetnosti Hrvatske, 2014. 